DOE/PC/93253-T1

(DE94016053)

\title{
A STUDY OF TOXIC EMISSIONS FROM A COAL-FIRED POWER PLANT
} UTILIZING AN ESP WHILE DEMONSTRATING THE ICCT CT-121 FGD PROJECT

Final Report

June 1994

Work Performed Under Contract No. AC22-93PC93253

For

U.S. Department of Energy

Pittsburgh Energy Technology Center

Pittsburgh, Pennsylvania

By

Radian Corporation

Austin, Texas 


\section{DISCLAIMER}

This report was prepared as an account of work sponsored by an agency of the United States Government. Neither the United States Government nor any agency thereof, nor any of their employees, makes any warranty, express or implied, or assumes any legal liability or responsibility for the accuracy, completeness, or usefulness of any information, apparatus, product, or process disclosed, or represents that its use would not infringe privately owned rights. Reference herein to any specific commercial product, process, or service by trade name, trademark, manufacturer, or otherwise does not necessarily constitute or imply its endorsement, recommendation, or favoring by the United States Government or any agency thereof. The views and opinions of authors expressed herein do not necessarily state or reflect those of the United States Government or any agency thereof.

This report has been reproduced directly from the best available copy.

Available to DOE and DOE contractors from the Office of Scientific and Technical Information, P.O. Box 62, Oak Ridge, TN 37831; prices available from (615) 576-8401.

Available to the public from the U.S. Department of Commerce, Technology Administration, National Technical Information Service, Springfield, VA 22161, (703) $487-4650$. 


\section{DISCLAIMER}

Portions of this document may be illegible in electronic image products. Images are produced from the best available original document. 


\section{A Study of Toxic Emissions from a Coal- Fired Power Plant Utilizing an ESP While Demonstrating the ICCT CT-121 FGD Project}

Contract No. DE-AC22-93PC93253

DCN 93-643-004-03

Final Report, 16 June 1994

Prepared by

Radian Corporation

8501 North Mopac Boulevard

P.O. Box 201088

Austin, Texas $78720-1088$

Prepared for

U.S. Department of Energy

Pittsburgh Energy Technology Center

P.O. Box 10940

Pittsburgh, Pennsylvania 15236

[U.S. DOE patent clearance is not required prior to the publication of this document.] 


\section{CONTENTS}

Section $\quad$ Page

Executive Summary $\ldots \ldots \ldots \ldots \ldots \ldots \ldots \ldots \ldots \ldots$ ES-1

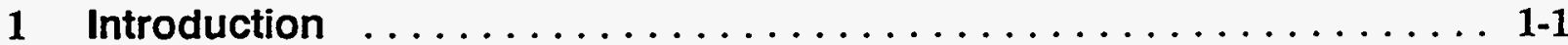

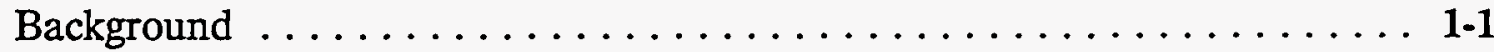

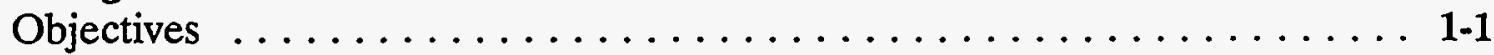

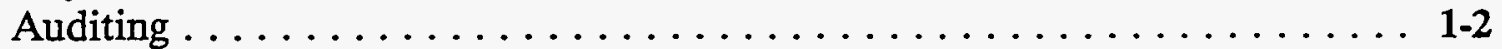

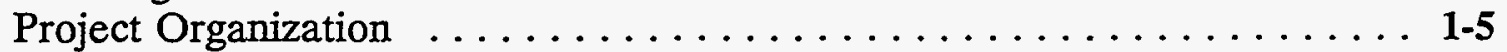

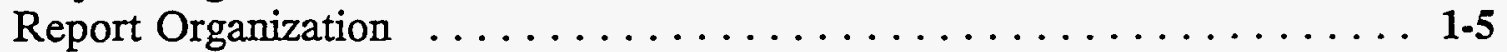

2 Site Description $\ldots \ldots \ldots \ldots \ldots \ldots \ldots \ldots \ldots \ldots \ldots \ldots \ldots \ldots$

Power Plant Configuration . . . . . . . . . . . . . . . . 2-1

Process Description: Major Process Streams ............... 2-1

CT-121 Wet FGD System . . . . . . . . . . . . . . . . 2-1

Ash and Cooling System . . . . . . . . . . . . . . . 2-4

ESP Design ............................ 2-4

Process Description: Sampling Locations . . . . . . . . . . . . . 2-4

Flue Gas Sample Streams . . . . . . . . . . . . . . . . . 2-8

Solid Sample Streams . . . . . . . . . . . . . . . . . . . . 2-8

Liquid Sample Streams . . . . . . . . . . . . . . . . . . . . 2-9

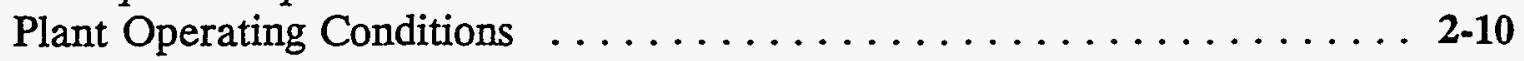

Problems ............................... 2-19

Deviations from Sampling Plan . . . . . . . . . . . . . . . 2-19

References ................................ 2-19

3 Sample Collection $\ldots \ldots \ldots \ldots \ldots \ldots \ldots \ldots \ldots \ldots \ldots \ldots \ldots \ldots \ldots$

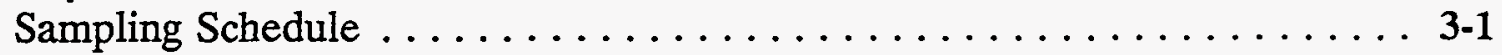

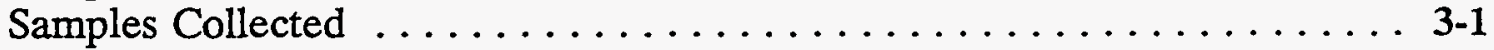

Gas Samples ................................ 3-4

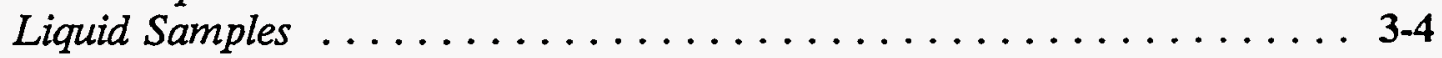

Solid Samples ............................ 3-4

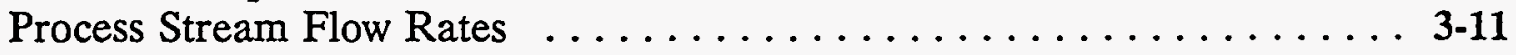

References ............................ 3-11 
4 Sample Preparation and Analysis Methods $\ldots \ldots \ldots \ldots \ldots \ldots \ldots$ 4-1

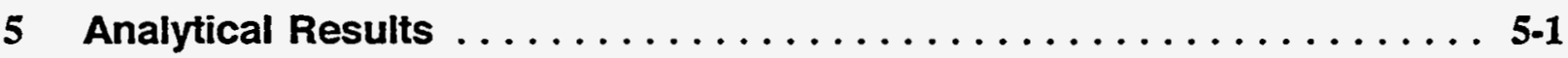

Gases ............................. 5-1

Flue Gas Particle Size Distribution Results ............... 5-12

ESP Hopper Particle Size Distribution Results $\ldots \ldots \ldots \ldots \ldots \ldots \ldots \ldots$ 5-12

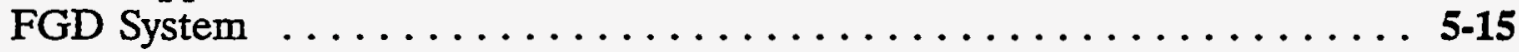

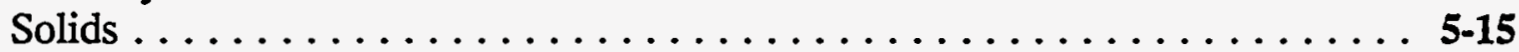

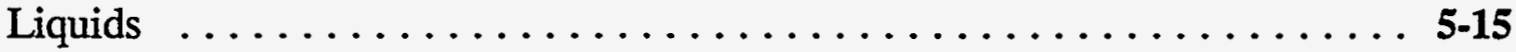

6 Data Evaluation and Analysis .................... 6-1

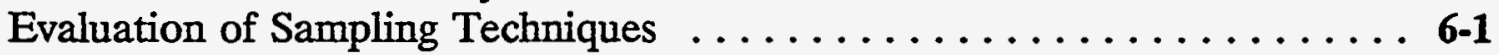

Evaluation of Analytical Techniques . . . . . . . .

Semivolatile Organics ........................6.3

Volatile Organics ..........................6.3

Aldehydes ........................6.

Metals ...........................6.

Anions . . . . . . . . .

Cyanide, Ammonia, and Phosphate ................6.5

Evaluation of Process Operation . . . . . . . . . . . . . . . . 6-5

Data Analysis: Mass Balances, Removal Efficiencies, and Emission

Factors . . . . . . . . . . .

Mass Balances .......................... 6.13

Emission Factors ............................ 6-19

Removal Efficiencies .......................... 6-19

Organic Compound Results ......................6-19

7 Comparison of Vapor and Particulate Composition $\ldots \ldots \ldots \ldots \ldots$ 7-1

8 Distribution of HAPs As a Function of Particle Size in the Flue Gas and the Particle Size Distribution of the ESP $\ldots \ldots \ldots \ldots \ldots \ldots \ldots$ 8-1

Collection and Analytical Methods . . . . . . . . . . . . . . . 8-1

Particle Size Distribution and Fractional Efficiency ............ 8-2

Predicted ESP Performance . . . . . . . . . . . . . . . . . . 8-7

Metals Removal Across ESP ..................... 8-11

Four Metals with Higher Penetration than the Average $\ldots \ldots \ldots \ldots \ldots$ 8-15

Hopper Distribution . . . . . . . . . . .

References .......................... 8-22

9 Mercury Methods Comparison and Speciation Determinations ...... 9-1

Sample Collection and Analysis .................... 9-1

Methods and Conditions ...................... 9-1

Samples Collected ............................ 9.3

Data Analysis . . . . . . . . . . . . .

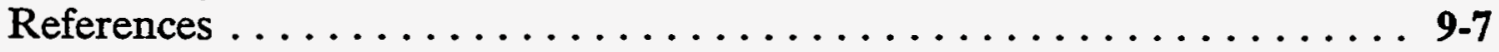


10 Hexavalent Chromium Determinations $\ldots \ldots \ldots \ldots \ldots \ldots \ldots \ldots$ 10-1

Introduction ...................... 10.1

Sample Collection and Analysis $\ldots \ldots \ldots \ldots \ldots \ldots \ldots \ldots \ldots \ldots$ 10-1

Data Analysis . . . . . . . . . . . 10.2

References ...................... 10.2

11 Determinations of Toxics on Particle Surfaces . . . . . . . . . . . 11-1

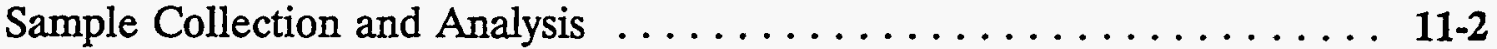

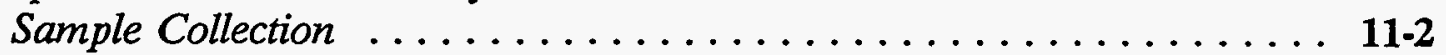

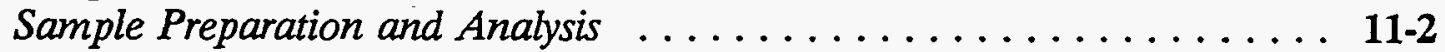

Data Analysis ............................ 11-6

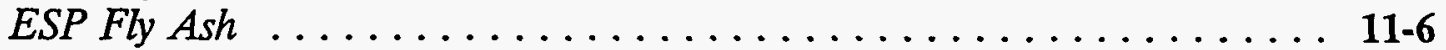

Stack Gas Particulate Matter ..................... 11-9

References ............................. 11-12

Appendix A: Quality Assurance Audits $\ldots \ldots \ldots \ldots \ldots \ldots \ldots \ldots$ A-1

Appendix B: Sampling Protocol $\ldots \ldots \ldots \ldots \ldots \ldots \ldots \ldots \ldots$ B-1

Appendix C: Sample Calculations $\ldots \ldots \ldots \ldots \ldots \ldots \ldots \ldots \ldots \ldots$ C-1

Appendix D: Quality Assurance/Quality Control $\ldots \ldots \ldots \ldots \ldots$ D-1

Appendix E: Analytical Protocol $\ldots \ldots \ldots \ldots \ldots \ldots \ldots \ldots \ldots \ldots \ldots \ldots \ldots$

Appendix F: Error Propagation and Uncertainty Calculations $\ldots \ldots \ldots$ F-1

Appendix G: Treatment of Nondetects, Values Outside of the

Calibration Range, and Blanks ............... G.1

Appendix H: Detailed Analytical Results $\ldots \ldots \ldots \ldots \ldots \ldots \ldots \ldots$ H-1

Appendix I: Development of Mass Balance Equations and Example

Calculations .................... I-1 


\section{LIST OF ILLUSTRATIONS}

Figure

Page

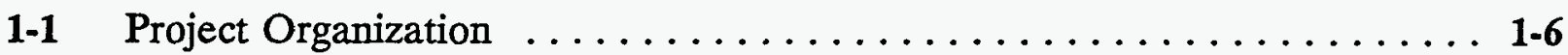

2-1 Simplified Process Flow Diagram Illustrating Sampling Locations and Flue Gas Flow . . . . . . . . . . . .

2-2 Plan View Plant Yates ESP Unit \#1 $\ldots \ldots \ldots \ldots \ldots \ldots \ldots \ldots \ldots$ 2-6

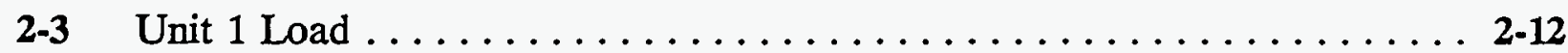

2-4 Furnace Gas Oxygen $\ldots \ldots \ldots \ldots \ldots \ldots \ldots \ldots \ldots \ldots \ldots \ldots \ldots \ldots \ldots \ldots .2-13$

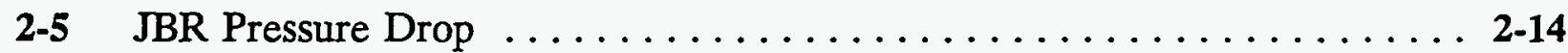

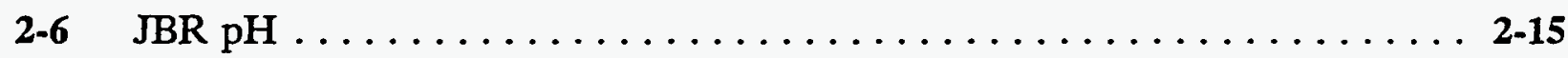

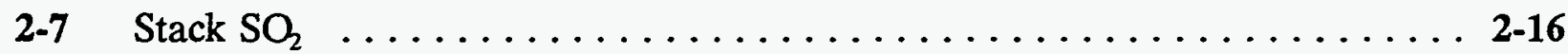

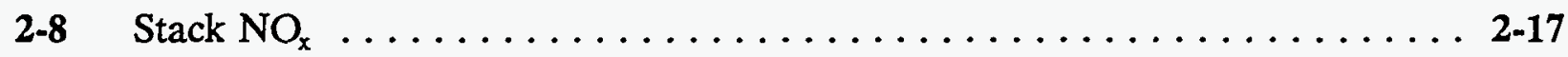

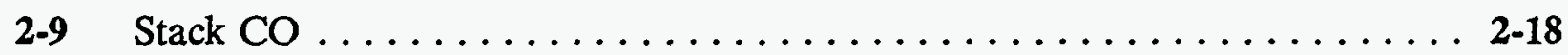

3-1 Sample Collection Schedule for June $21-24,1993 \ldots \ldots \ldots \ldots \ldots \ldots$ 3-2

3-2 Sample Collection Schedule for June $25-28,1993 \ldots \ldots \ldots \ldots \ldots$ 3-3

4-1 Gas Particulate Sample Preparation and Analysis Plan for Metals .... . . 4-2

4-2 Flue Gas Impinger Sample Preparation and Analysis Plan for Metals .... 4-3

4-3 Flue Gas Impinger Sample Preparation and Analysis Plan for Mercury . . . 4-4

4-4 Gas Particulate Sample Preparation and Analysis Plan for Anions .... . 4-5 
4-5 Flue Gas Impinger Sample Preparation and Analysis Plan for Anions . . . 4 4-6

4-6 Flue Gas Impinger Sample Preparation and Analysis Plan for Ammonia and Cyanide ..........................

4-7 Flue Gas Impinger Sample Preparation and Analysis Plan for Formaldehyde

4-8 VOST Sorbent Sample Preparation and Analysis Plan for Volatile Organic Compounds .

4-9 Flue Gas Sample Preparation and Analysis Plan for Semivolatile Organic Compounds ........................ 4-10

4-10 Flue Gas Sample Preparation and Analysis Plan for Dioxins and Furans ... 4-11

4-11 Gas Particulate Sample Preparation and Analysis Plan for Extractable Metals ............................... 4-12

4-12 Size-Fractionated Particulate Sample Preparation and Analysis Plan for Metals

4-13 Liquid Sample Preparation and Analysis Plan .............. 4-14

4-14 Coal Sample Preparation and Analysis Plan .............. 4-15

4-15 Ash Sample Preparation and Analysis Plan ............... 4-17

4-16 Limestone and FGD Solids Sample Preparation and Analysis Plan ... . . 4-18

6-1 Mass Balance Boundaries $\ldots \ldots \ldots \ldots \ldots \ldots \ldots \ldots \ldots \ldots \ldots \ldots \ldots$ 6-16

8-1 Cumulative Particle Size Distribution, Yates ESP Inlet $\ldots \ldots \ldots \ldots \ldots$ 8-3

8-2 Differential Particle Size Distribution, Yates ESP Inlet $\ldots \ldots \ldots \ldots \ldots$ 8-4

8-3 Cumulative Particle Size Distribution, Yates ESP Outlet $\ldots \ldots \ldots \ldots$ 8-5

8-4 Outlet Differential Particle Size Distribution $\ldots \ldots \ldots \ldots \ldots \ldots$ 8-6

8-5 Particle Resistivity $\ldots \ldots \ldots \ldots \ldots \ldots \ldots \ldots \ldots \ldots \ldots$ 8.9

8-6 Voltage Current Curves $\ldots \ldots \ldots \ldots \ldots \ldots \ldots \ldots \ldots \ldots \ldots$ 8-10

8-7 Opacity $\ldots \ldots \ldots \ldots \ldots \ldots \ldots \ldots \ldots \ldots \ldots \ldots \ldots \ldots \ldots .6 .12$

8-8 ESP Fractional Penetration $\ldots \ldots \ldots \ldots \ldots \ldots \ldots \ldots \ldots \ldots \ldots$ 8-13 viii 
8-9 Distribution of Metals According to Particle Size at the ESP Inlet . . . . 8-14

8-10 Distribution of Metals According to Particle Size at the ESP Outlet . . . . 8-17

8-11 Total Metals Collection in Hopper . . . . . . . . . . . . . . . 8-19

8-12 Elemental Relationship Between Outlet/Inlet Enrichment and Fine/ Coarse Enrichment . . . . . . . . . . . . . . . . . . . . 8.20

11-1 Gas Particulate Sample Preparation and Analysis Plan for Extractable Metals ............................. 11-3 



\section{LIST OF TABLES}

Table

Page

1-1 Target Analytes . . . . . . .

1.2 Report Organization $\ldots \ldots \ldots \ldots \ldots \ldots \ldots \ldots \ldots \ldots \ldots \ldots \ldots \ldots \ldots \ldots$

2-1 Summary of Design Data on the Yates Unit \#1 ESP $\ldots \ldots \ldots \ldots .2-5$

2-2 ESP Rapping Schedule, Plant Yates Unit \#1 $\ldots \ldots \ldots \ldots \ldots \ldots . . \ldots .7$

2-3 Summary of Process Monitoring Data $\ldots \ldots \ldots \ldots \ldots \ldots \ldots \ldots . \ldots \ldots .11$

3-1 Gaseous Sampling Summary $\ldots \ldots \ldots \ldots \ldots \ldots \ldots \ldots \ldots \ldots \ldots \ldots$

3-2 Number and Type of Gas Sample Analyses Plant Yates ......... 3-6

3-3 Liquids Sampling Summary $\ldots \ldots \ldots \ldots \ldots \ldots \ldots \ldots \ldots . . \ldots \ldots$

3-4 Liquid Stream QA/QC Samples $\ldots \ldots \ldots \ldots \ldots \ldots \ldots \ldots \ldots \ldots$ 3-8

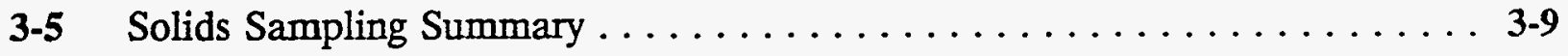

3-6 Solid Stream QA/QC Samples $\ldots \ldots \ldots \ldots \ldots \ldots \ldots \ldots \ldots \ldots \ldots$ 3-10

3-7 Process Flow Rates During Phase II of Testing . . . . . . . . .

3-8 Flow Rate Calculations $\ldots \ldots \ldots \ldots \ldots \ldots \ldots \ldots \ldots \ldots \ldots \ldots \ldots \ldots .13$

4-1 Summary of Coal Analytical Methods . . . . . . . . . . . . 4-16

5-1 Filter Substrate Data Comparison .................. 5 5-2

5-2 Gas Process Stream Data Summary $\ldots \ldots \ldots \ldots \ldots \ldots \ldots . . \ldots .6$.

5-3 Flue Gas Particle Size Distribution ... . . . . . . . . . . . 5-11 
5.4 ESP Fields 1 and 2 Hopper Composite Catches $\ldots \ldots \ldots \ldots \ldots \ldots$ 5-12

5-5 FGD System Summary $\ldots \ldots \ldots \ldots \ldots \ldots \ldots \ldots \ldots \ldots . \ldots \ldots$ 5-14

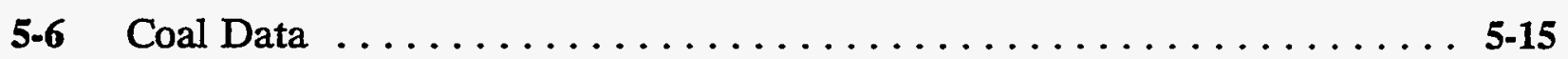

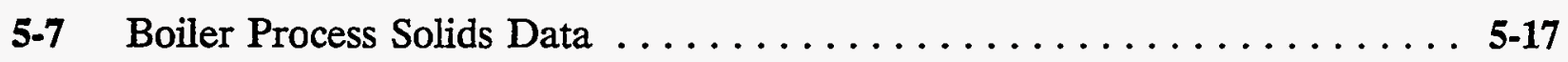

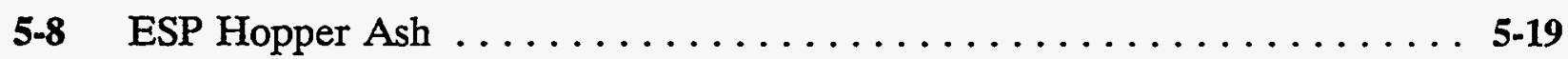

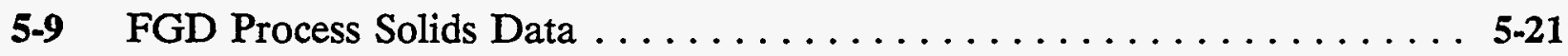

5-10 Liquid Ash Sluice System Data Summary $\ldots \ldots \ldots \ldots \ldots \ldots . \ldots .23$

5-11 Liquid FGD Process Stream Data Summary . . . . . . . . . $\ldots$ 5-25

5-12 Liquid Ancillary Stream Data Summary $\ldots \ldots \ldots \ldots \ldots \ldots \ldots \ldots . . \ldots \ldots$

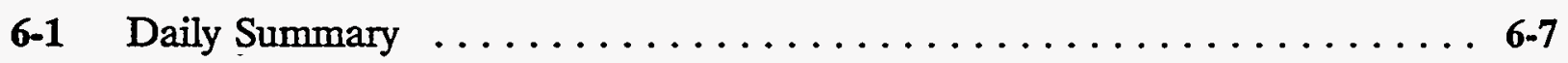

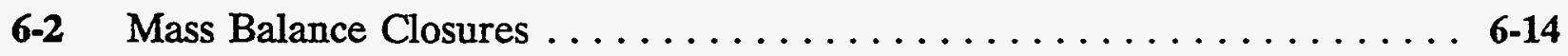

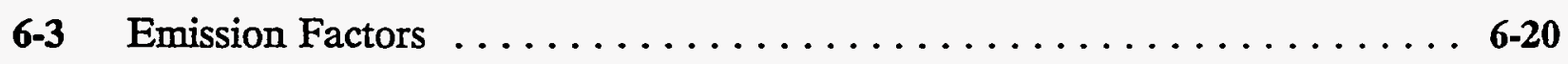

6-4 Removal Efficiencies (Includes Particulate and Vapor Phase) $\ldots \ldots \ldots$ 6-22

7-1 Vapor and Particulate-Phase Distribution at ESP Inlet $\ldots \ldots \ldots \ldots \ldots$ 7-2

7-2 Vapor and Particulate-Phase Distribution at ESP Outlet $\ldots \ldots \ldots \ldots$ 7-3

7-3 Vapor and Particulate-Phase Distribution at Stack $\ldots \ldots \ldots \ldots \ldots$ 7-4

7-4 Stack Field Blank Versus Vapor Concentration $\ldots \ldots \ldots \ldots \ldots \ldots$ 7-6

8-1 Measured Particle Size and Fractional Efficiency $\ldots \ldots \ldots \ldots \ldots \ldots$ 8-7

8-2 Comparison of Predicted and Measured ESP Performance $\ldots \ldots \ldots \ldots$ 8-15

8-3 ESP Particulate-Phase Metals Collection Efficiency ............ 8-16

8-4 Enrichment of Streams in Inorganic Elements $\ldots \ldots \ldots \ldots \ldots \ldots \ldots$ 8-21

9-1 Mercury Concentrations in Flue Gas $\ldots \ldots \ldots \ldots \ldots \ldots \ldots . . .4$

9-2 Summary of Blank Results $\ldots \ldots \ldots \ldots \ldots \ldots \ldots \ldots .9 . \ldots \ldots$

9-3 Summary of Spike and Audit Sample Recoveries $\ldots \ldots \ldots \ldots \ldots$ 9-6 xii 
10-1 Results for Hexavalent Chromium and Total Chromium . . . . . . . . 10-2

11-1 Extractable Composition of ESP Inlet Gas Particulate Matter . . . . . . . 11-7

11-2 Extractable Composition of ESP Outlet Gas Particulate Matter ... . . 11-8

11-3 Extractability of Elements in Fly Ash $\ldots \ldots \ldots \ldots \ldots \ldots \ldots$

11-4 Extractable Composition of Stack Gas Particulate Matter .......... 11-11 



\section{GLOSSARY}

\begin{tabular}{|c|c|}
\hline acfm & Actual Cubic Foot (Feet) per Minute \\
\hline AAS & Atomic Absorption Spectrophotometry \\
\hline $\mathrm{ADA}$ & ADA Technologies, Inc. \\
\hline AP -42 & $\begin{array}{l}\text { Publication number of the principal emission factor document } \\
\text { published by EPA. }\end{array}$ \\
\hline APH & Air Preheater \\
\hline ASTM & American Society for Testing and Materials \\
\hline B & Data Flag (value has been blank corrected) \\
\hline Btu & British Thermal Unit \\
\hline $\mathrm{C}$ & $\begin{array}{l}\text { Data Flag (with blank correction, value was below detection limit, } \\
\text { detection limit reported) }\end{array}$ \\
\hline $\mathrm{CE}$ & Combustion-Engineering, Inc. \\
\hline CEM & Continuous Emission Monitor \\
\hline CEMS & Continuous Emission Monitoring System \\
\hline Chicago OPC & Chicago Office of Patent Counsel (U.S. DOE) \\
\hline $\mathrm{CI}$ & Confidence Interval \\
\hline $\mathrm{C}_{\mathrm{p}}$ & Pitot Tube Coefficient \\
\hline CT-121 & $\begin{array}{l}\text { Chiyoda Thoroughbred-121 (a second-generation flue gas } \\
\text { desulfurization process) }\end{array}$ \\
\hline CT\&E & Commercial Testing \& Engineering \\
\hline CVAA & Cold Vapor Atomic Absorption \\
\hline CVAFS & Cold Vapor Atomic Fluorescence Spectrometry \\
\hline DAS & Data Acquisition System \\
\hline$\Delta \mathbf{P}$ & $\begin{array}{l}\text { "Delta P"; Pressure Drop; Pressure Difference (measured in } \\
\text { inches of water column) }\end{array}$ \\
\hline DL & Detection Limit \\
\hline
\end{tabular}


DNPH Dinitrophenylhydrazine

DQO Data Quality Objective

dscfm Dry Standard Cubic Foot (Feet) per Minute

$\mathrm{E}$

Data Flag (analyte concentration exceeded calibration range)

EPA U.S. Environmental Protection Agency

EPRI Electric Power Research Institute

ESP Electrostatic Precipitator

FGD Flue Gas Desulfurization

$\mathrm{f} / \mathrm{sec} \quad$ Foot (Feet) per Second

g

Gram(s)

GC/MS Gas Chromatography/Mass Spectrometry

GDMS Glow Discharge Mass Spectrometry

g-mole Gram-Mole (weight of a mole of a substance expressed in grams)

GPC Georgia Power Company

HAP Hazardous Air Pollutant

HHV Higher Heating Value

HPLC High Performance Liquid Chromatography

IC Ion Chromatography

ICCT Innovative Clean Coal Technology (a U.S. DOE program)

ICP-AES Inductively Coupled Plasma-Atomic Emission Spectroscopy

ICP-MS Inductively Coupled Plasma-Mass Spectrometry

INAA Instrumental Neutron Activation Analysis

J

Data Flag (below the lower detection limit)

JBR Jet Bubbling Reactor (the absorber design used in the CT-121 process)

kg Kilogram(s)

L Liter

m Meter

$\mathrm{mL} \quad$ Milliliter

MM5 Modified Method 5 


\begin{tabular}{|c|c|}
\hline$\mu \mathrm{g}$ & Microgram(s) \\
\hline$\mu \mathrm{L}$ & Microliter \\
\hline$\mu \mathrm{m}$ & Micrometer; $1 \times 10^{6}$ meter \\
\hline NA & Not Applicable \\
\hline ND & Not Detected \\
\hline $\mathrm{Nm}^{3}$ & $\begin{array}{l}\text { Normal Cubic Meter(s): } 1 \mathrm{~m}^{3} @ 0^{\circ} \mathrm{C} \text { and } 1.0 \mathrm{~atm} \text { (equivalent to } \\
\left.37.44 \mathrm{ft}^{3} @ 68^{\circ} \mathrm{F} \text { and } 1.0 \mathrm{~atm}\right)\end{array}$ \\
\hline Orsat & Method of Fixed-Gas $\left(\mathrm{O}_{2}, \mathrm{CO}_{2}, \mathrm{CO}\right)$ Analysis \\
\hline PAH & Polycyclic Aromatic Hydrocarbon \\
\hline PCDD & Polychlorinated Dibenzodioxin \\
\hline PCDF & Polychlorinated Dibenzofuran \\
\hline PNR & Probe and Nozzle Rinse \\
\hline POM & Polycyclic Organic Matter \\
\hline RPD & Relative Percent Difference \\
\hline PSD & Particle Size Distribution \\
\hline RSF & Relative Sensitivity Factor (used in mass spectrometry) \\
\hline RTI & Research Triangle Institute \\
\hline scf & $\begin{array}{l}\text { Standard Cubic Foot (feet): } 1 \mathrm{ft}^{3} @ 68^{\circ} \mathrm{F} \text { and } 1.0 \text { atm (equivalent } \\
\text { to } 0.02671 \mathrm{~m}^{3} @ 0^{\circ} \mathrm{C} \text { and } 1.0 \mathrm{~atm} \text { ) }\end{array}$ \\
\hline $\operatorname{scfm}$ & Standard Cubic Foot (Feet) per Minute \\
\hline SCS & Southern Company Services, Inc. \\
\hline SIE & Specific Ion Electrode \\
\hline SW-846 & Publication number of "Test Methods for Evaluating Solid Waste" \\
\hline TCLP & Toxicity Characteristic Leaching Procedure \\
\hline Tenax & An organic resin used for sample collection \\
\hline UV-Vis & Ultraviolet-Visible \\
\hline OC & Volatile Organic Compound; Volatile Organic Chemical \\
\hline OST & Volatile Organic Sampling Train \\
\hline
\end{tabular}




\section{EXECUTIVE SUMMARY}

The U.S. Department of Energy is performing comprehensive assessments of toxic emissions from eight selected coal-fired electric utility units. This program responds to the Clean Air Act Amendments of 1990, which require the U.S. Environmental Protection Agency (EPA) to evaluate emissions of hazardous air pollutants (HAPs) from electric utility power plants for potential health risks. The resulting data will be furnished to EPA for emissions factor and health risk determinations.

The assessment of emissions involves the collection and analysis of samples from the major input, process, and output streams of each of the eight power plants for selected hazardous pollutants identified in Title III of the Clean Air Act. Additional goals are to determine the removal efficiencies of pollution control subsystems for these selected pollutants and the concentrations associated with the particulate fraction of the flue gas stream as a function of particle size. Material balances are being performed for selected pollutants around the entire power plant and several subsystems to identify the fate of hazardous substances in each utility system.

Radian Corporation was selected to perform a toxics assessment at a plant demonstrating an Innovative Clean Coal Technology (ICCT) Project. The site selected is Plant Yates Unit No. 1 of Georgia Power Company, which includes a Chiyoda Thoroughbred-121 demonstration project.

\section{Site Description}

Plant Yates Unit No. 1 is a bituminous coal-fired steam electricity-generating unit with a net generating capacity of 100 megawatts. Located in Newnan, Georgia, the station is owned and operated by Georgia Power Company. The station uses a tangentially fired $\mathrm{CE}$ boiler that burns a $2.5 \%$-sulfur blend of Illinois No. 5 and Illinois No. 6 bituminous coals. It uses an electrostatic precipitator to control particulate matter, and the Chiyoda Thoroughbred-121 process controls sulfur dioxide emissions from the entire flue gas stream.

\section{Process Description}

The Chiyoda Thoroughbred-121 is a second-generation FGD process employing a unique absorber design, called a jet bubbling reactor, to combine conventional $\mathrm{SO}_{2}$ absorption, neutralization, sulfite oxidation, and gypsum crystallization in one reaction vessel. The process is designed to operate in a $\mathrm{pH}$ range of 3 to 5 , where the driving force for limestone dissolution is high, resulting in nearly complete reagent utilization. Oxidation of sulfite to sulfate is also promoted at the lower $\mathrm{pH}$ because of the increased solubility of innate 
oxidation catalysts such as iron. Because all the absorbed $\mathrm{SO}_{2}$ is oxidized, there is sufficient surface area for gypsum crystal growth to prevent the slurry from becoming significantly supersaturated with respect to calcium sulfate. This significantly reduces the potential for gypsum scaling.

\section{Sampling Locations}

Three flue gas stream locations were identified for testing: the ESP inlet, the ESP outlet (FGD inlet), and the stack. The solid streams sampled were raw coal, pulverized feed coal, pulverizer rejects, individual ESP hopper ash, and raw limestone. Samples collected as slurried or sluiced streams include the bottom ash, the combined ESP hopper ash, limestone, and FGD slurry solids. The following liquid streams were sampled: ash pond water, gypsum pond water, ash sluice water (from the bottom ash and fly ash), FGD slurry blowdown filtrate, limestone slurry filtrate, coal pile run-off, and cooling water at the condenser inlet.

\section{Sample Collection}

Radian's approach to meeting the test objectives utilized established sampling methods (where possible) and a sampling strategy consistent with that of the EPRI-sponsored Field Chemical Emissions Monitoring (FCEM) program. ${ }^{1}$ Samples were collected with the boiler operating within $10 \%$ of full load, at steady-state conditions, and in triplicate over two periods of three days each: June 21-23 and June 25-27, 1993.

\section{Detection Limits}

Detection limits for the gaseous phase target metals of interest are presented in Table ES- 1 . These numbers were derived from instrument method detection limits, the volume of gas sampled, and the amount of solid sample that was analyzed. Data are presented for detection limits derived from gas samples collected from the stack. This location was chosen to illustrate typical detection limits, as it represents the highest level of particulate detection limits, due to the low particulate loading at this location. Loading at the stack averaged $0.0145 \mathrm{~g} / \mathrm{Nm}^{3}$, and the numbers presented in the table represent the analysis of approximately $35 \mathrm{mg}$ of particulate collected from a nominal $3 \mathrm{~m}^{3}$ sample size.

\section{Quality Assurance and Quality Control}

During sample collection, quality assurance audits were conducted by Radian's internal QA auditor and by Research Triangle Institute, under contract with EPA. Radian's auditor also conducted a performance evaluation audit by submitting "double-blind" (identity and composition unknown) samples to the analytical laboratories. Quality control procedures involved the evaluation of results for field and laboratory blank samples, duplicate field samples, matrix-spiked and surrogate-spiked samples, and laboratory control samples.

Overall, QA/QC data associated with this program indicate that measurement data are acceptable and defensible. The QA/QC data indicate that the quality control mechanisms 
Table ES-1

Detection Limits for Gaseous Phase Target Metals

\begin{tabular}{|c|c|c|c|}
\hline \multirow[b]{2}{*}{ Specie } & \multirow[b]{2}{*}{ Method } & \multicolumn{2}{|c|}{ Detection Limits, $\mu \mathrm{g} / \mathrm{Nm}^{3}$} \\
\hline & & Vapor & Solids \\
\hline Antimony & ICP-MS & 0.004 & 0.0008 \\
\hline Arsenic & GF-AAS & 0.2 & 0.04 \\
\hline Barium & ICP-ÄES & 0.16 & 0.09 \\
\hline Beryllium & ICP-AES & 0.17 & 0.03 \\
\hline Boron & ICP-AES & 4.6 & $\mathrm{NA}$ \\
\hline Cadmium & GF-AAS & 0.07 & 0.17 \\
\hline Chromium & ICP-AES & 0.76 & 0.44 \\
\hline Cobalt & ICP-AES & 1.0 & 0.59 \\
\hline Copper & ICP-AES & 1.2 & 0.44 \\
\hline Lead & GF-AAS & 0.25 & 0.04 \\
\hline Manganese & ICP-AES & 0.12 & 0.46 \\
\hline Mercury & CV-AAS & 0.13 & 0.01 \\
\hline Molybdenum & ICP-AES & 1.4 & 0.15 \\
\hline Nickel & ICP-AES & 3.0 & 1.0 \\
\hline Selenium & GF-AAS & 0.26 & 0.12 \\
\hline Vanadium & ICP-AES & 0.72 & 0.66 \\
\hline
\end{tabular}

NA = Not analyzed, insufficient sample size. 
were effective in ensuring measurement data reliability within the expected limits of sampling and analytical error.

\section{Plant Operating Conditions}

During sample collection, operating conditions were continuously monitored using a computerized data acquisition system which logged process information as 15-minute averages. In addition, boiler operating data were logged hourly by control room operators. Overall, all processes were very stable, and the key operating parameters were within the targeted range during the entire test period.

Three continuous emission monitors were operated during the test period, providing data for sulfur dioxide, nitrogen oxides, and carbon monoxide. ESP characteristics were monitored by ADA Technologies, Inc.

\section{Analytical Results}

Samples were analyzed for trace elements, minor and major elements; volatile organic compounds, and semivolatile organic compounds. Analytical results have been tabulated in detail with $95 \%$ confidence intervals and detection limit ratios.

Procedures were provided by DOE for results below the detection limit, values outside the calibration range, and blanks. In the detailed data tabulations, some data have been flagged; for example, some background contamination was encountered.

\section{Data Analysis: Màss Balances, Removal Efficiencies, and Emission Factors}

Emission factors, removal efficiencies, and other results rely on measurement data that are near the limit of detection or below it for many of the substances of interest. For that reason, uncertainty analyses and the calculation of confidence intervals were performed as part of this program.

Following are observations as a result of the data analysis:

- Material balances were calculated for 27 elements. Sixty-percent of these met the target closure objectives of $70-130 \%$ for balance around the plant. Eight-five percent met a closure criteria of 50-150 percent.

- Removal efficiencies for non-volatile particulate metals averaged greater than $98 \%$ across the ESP. The JBR was also effective in further reducing the emission of several metals, due primarily to its effectiveness as a particulate control device.

- Emission factors have been calculated for the target trace elements and are presented in Table ES-2. Thirteen of these elements have emission rates of less than 10 pounds per billion Biu of coal. 
Table ES-2

Emission Factors

$\mathrm{lb} / 10^{12} \mathrm{Btu} \quad 95 \% \mathrm{CI}$

\section{Anions}

Chloride

742

647

Fluoride

122

67

Selected Elements ${ }^{\text {a }}$

\begin{tabular}{|c|c|c|}
\hline Antimony & 0.06 & 0.01 \\
\hline Arsenic & 1.2 & 0.2 \\
\hline Barium & 2.8 & 9.9 \\
\hline Beryllium & 0.1 & 0.1 \\
\hline Cadmium & 0.6 & 2.1 \\
\hline Chromium & 5.3 & 49.5 \\
\hline Cobalt & 0.7 & 0.8 \\
\hline Copper & 2.0 & 2.3 \\
\hline Lead & 0.6 & 0.6 \\
\hline Manganese & 7.2 & 48 \\
\hline Mercury & 3.0 & 0.3 \\
\hline Molybdenum & 1.5 & 2.6 \\
\hline Nickel & 40.1 & 435 \\
\hline Selenium & 26.5 & 58 \\
\hline Vanadium & 2.1 & 0.5 \\
\hline \multicolumn{3}{|l|}{ Ildehydes } \\
\hline Acetaldehyde & 8.6 & 9.2 \\
\hline Formaldehyde & 24 & 36 \\
\hline \multicolumn{3}{|l|}{ Volatile Organics ${ }^{b, c}$} \\
\hline Benzene & 1.3 & 0.3 \\
\hline Carbon Disulfide & 2.2 & 1.2 \\
\hline Toluene & 2.0 & 1.0 \\
\hline
\end{tabular}


Table ES-2 (Continued)

\begin{tabular}{lcc} 
& $\mathbf{l b} / \mathbf{1 0}^{\mathbf{1 2}} \mathbf{B t u}$ & $\mathbf{9 5 \%} \mathbf{C I}$ \\
\cline { 2 - 3 } Semivolatile Organics $^{\mathbf{d}}$ & & \\
2-Methylphenol (0-cresol) & 2.9 & 3.8 \\
4-Methylphenol (p-cresol) & 0.95 & 1.9 \\
Acetophenone & 3.2 & 0.7 \\
Benzoic Acid & 120 & 7 \\
Benzyl Alcohol & 2.8 & 12 \\
Naphthalene & 1.5 & 1.0 \\
Phenol & 9.2 & 8.8
\end{tabular}

${ }^{2}$ Run 1 particulate-phase data were invalidated for all elements included here except arsenic, selenium, and vanadium due to the filter background comprising $20 \%$ or greater of the measured concentration.

${ }^{b}$ Only those compourds with an average concentration above the detection limit are included.

- Methylene chloride, acetone, and other halogenated hydrocarbons are not included because their presence is strongly suspected to be the result of contamination.

d Phthalate esters are not included because their presence is suspected to be the results of contamination. 
The method used to determine uncertainties in calculated results is based on "Measurement Uncertainty" 2 and is consistent with the approach to handling data used in the FCEM program.

\section{Comparison of Vapor and Particulate Composition}

Most of the substances measured at Plant Yates are distributed between the flue gas (vapor) and the particulate matter associated with bottom ash, collected ESP ash, ash removed in the FGD system, or emitted ash which exits with the flue gas through the stack. (The sampling and analytical techniques used for organic compounds did not quantify distribution between particulate and vapor phases.)

At ESP inlet conditions, more than $99 \%$ of most of the substances of interest are in the particulate phase. Exceptions are chloride, fluoride, selenium, and mercury. With these same exceptions, the particulate phase is the predominant phase at the ESP outlet and stack.

\section{Distribution of HAPs as a Function of Particle Size in the Flue Gas and the Particle Size Distribution of the ESP}

Most of the metals are removed across the ESP at a rate that is approximately the same as that of the total particulate. Exceptions are arsenic, cadmium, phosphorus, and selenium. Arsenic, cadmium, and phosphorus penetration could be due to low concentrations or to association with particles in the range of 0.5 to $2 \mu \mathrm{m}$. The selenium penetration is thought to be due to sampling or analytical error.

\section{Mercury Methods Comparison and Speciation Determinations}

Two different methods were used to measure mercury concentrations in the flue gas. The Bloom mercury speciation train ${ }^{3}$ was used to measure the concentrations of individual vaporphase mercury species: ionic mercury, elemental mercury, and methyl mercury. Total mercury, particulate and vapor phases, was measured using a multi-metals train. ${ }^{4}$

Ionic mercury appears to be the predominant species in the ESP inlet and ESP outlet gas streams, but ionic mercury is more efficiently removed by the scrubber. Methyl mercury concentrations also appear to decrease across the scrubber.

\section{Hexavalent Chromium Determinations}

Hexavalent chromium as well as total chromium were nondetectable in the samples collected after appropriate blank correction had been applied. Although samples were collected as specified by the published method, ${ }^{5}$ it should be noted that the collection procedure for obtaining $\mathrm{Cr}^{6+}$ samples from a flue gas matrix containing $\mathrm{SO}_{2}$ has not been validated. 


\section{Determinations of Toxics on Particle Surfaces}

Because of the health and environmental importance of toxic substances that are found on the surfaces of particles and because these substances are more available to biological and ecological systems, a comparison between bulk composition and surface leachability was performed. Results have been tabulated, and some conclusions can be drawn for individual elements, but no overall trends are clearly evident.

\section{Recommendations and Considerations}

Some technical issues have been identified during this study that may warrant further consideration. Among these are the following sampling, analytical and/or process related issues:

- Selenium sampling and analysis;

- Mercury partitioning and speciation; and

- Fly ash penetration of the FGD process.

\section{Selenium}

Selenium could not be accurately quantified throughout the process. Apparent problems were associated with both the collection and the analysis of selenium. Further directed study of selenium is recommended. Problems associated with the quantification of selenium are discussed in Section 8.

\section{Mercury}

Mercury was collected and analyzed by both Method $29^{6}$ and by the Bloom method ${ }^{7}$ which uses charcoal tubes for the absorption and speciation of mercury. Results obtained from these two methods are presented in Section 9. One of the phenomena observed is an apparent increase in the elemental mercury concentration across the FGD system. Another anomaly is the apparent enrichment in fly ash particles of mercuiry when collected from the flue gas via filtration. These two items warrant further study and investigation.

\section{Fly Ash Penetration of FGD System}

The link between particle size, surface orientation of trace elements, and the penetration of fine particles cannot be demonstrated by comparing the extractable and total metal concentrations of the particulate emissions from the FGD system. Fly ash penetration, the mass contribution from sulfuric acid mist and scrubber mist soluble salts (gypsum) add additional variables to the assessment of air toxic emissions as a function of surface orientation. The following penetration mechanisms can potentially impact the analysis of the particulate emissions from wet scrubbers: 
- Direct penetration of the fly ash;

- Capture of the ash particles in the scrubber liquor and re-entrainment during recycle;

- Entrainment of scrubber-generated solids;

- Evaporation and penetration of scrubber mist as soluble salts; and

- Condensation and recovery of sulfuric acid mist as particulate.

Controlled condensation test methods should be used in future test efforts for measuring sulfuric acid emissions apart from gypsum, and $\mathrm{SO}_{2}$ artifacts. The analysis of tracer elements associated only with the coal ash may be warranted to determine ash penetration and dilution from scrubber solids. Analysis of size-fractionated particulate emissions could potentially identify the predominant size ranges associated with individual components.

Test efforts to quantify the relative contribution of each phenomenon to particulate emissions may be of interest to those considering wet scrubbers for the control of air toxics as well as $\mathrm{SO}_{2}$. This data would provide a basis of comparison between the surface extractability of the dry ash entering an FGD system and the particulate emissions downstream.

\section{References}

1. Electric Power Research Institute. Field Chemical Emissions Monitoring (FCEM) Generic Sampling and Analytical Plan. Draft Report. Palo Alto, CA (May 1994).

2. American Society of Mechanical Engineers. Measurement Uncertainty: Instruments and Apparatus. PTC 19.1-1985 (reaffirmed 1990), pp 1-65. United Engineering Center, New York, NY. Published by the American National Standards Institute.

3. Nicolas S. Bloom, Eric M. Prestbo, and Vesna L. Miklavicic, "Fluegas Mercury Emissions and Speciations from Fossil Fuel Combustion." Published in the proceedings of the Second International Conference on Managing Hazardous Air Pollutants (sponsored by the Electric Power Research Institute) Washington, D.C. (July 1993).

4. 40 CFR 266, Subpart H, "Method 29: Determination of Metals Emissions in Exhaust Gases from Hazardous Waste Incineration and Similar Combustion Processes: Proposed Method."

5. 40 CFR 266, Appendix IX: Methods Manual for Compliance with the BIF Regulations. "Determination of Hexavalent Chromium Emissions from Stationary Sources (Method $\left.\mathrm{Cr}^{+6}\right)$."

6. 40 CFR 266, Subpart H, "Method 29: Determination of Metals Emissions in Exhaust Gases from Hazardous Waste Incineration and Similar Combustion Processes: Proposed Method." 
7. Nicolas S. Bloom, Eric M. Prestbo, and Vesna L. Miklavicic, "Fluegas Mercury Emissions and Speciations from Fossil Fuel Combustion." Published in the proceedings of the Second International Conference on Managing Hazardous Air Pollutants (sponsored by the Electric Power Research Institute) Washington, D.C. (July 1993). 


\section{INTRODUCTION}

\section{Background}

The U.S. Department of Energy is performing comprehensive assessments of toxic emissions from eight selected coal-fired electric utility units. These data are being collected in response to the Clean Air Act Amendments of 1990, which require that EPA conduct a study of the emissions of hazardous air pollutants (HAPs) from electric utility power plants, and these emissions be evaluated for potential health risks. The data will be compiled and combined with similar data that are being collected as part of the Field Chemical Emissions Monitoring program ${ }^{1}$ sponsored by the Electric Power Research Institute (EPRI) and will then be furnished to the U.S. Environmental Protection Agency for emissions factor and health risk determinations.

The assessments of emissions involve the collection and analysis of samples from the major input and output streams of each of the eight power plants for selected hazardous pollutants contained in Title III of the Clean Air Act. Additional goals of these assessments are to collect data from the selected plants that may be helpful in characterizing removal efficiencies of pollution control subsystems for these selected pollutants and to determine the concentrations associated with the particulate fraction of the flue gas stream as a function of particle size. Material balances will be performed for selected pollutants around the entire power plant and various subsystems to determine the fate of hazardous substances in each utility system.

Radian Corporation was selected to perform one toxics assessment at a plant demonstrating an Innovative Clean Coal Technology (ICCT) Project. The selected site is the Plant Yates Unit No. 1 of Georgia Power Company, which includes the ICCT CT-121 demonstration project.

\section{Objectives}

The specific objectives of this project are:

- To collect and subsequently analyze representative solid, liquid, and gas samples of all specified input and output streams of the Plant Yates, Unit No. 1, including the CT-121 flue gas desulfurization system, for selected hazardous air pollutants that are contained in Title III of the 1990 Clean Air Act Amendments and to assess the potential level of release (concentration) of these pollutants; 
- To determine the removal efficiencies of specified pollution control subsystems for selected pollutants at Plant Yates Unit No. 1;

- To determine material balances for selected pollutants in specified subsystems of the power plant and an overall material balance for the power plant;

- To determine the concentration as a function of particle size of the respective pollutants associated with the particulate fraction of the flue gas stream of Plant Yates Unit No. 1;

- To determine the concentration of the respective pollutants associated with the particulate and vapor-phase fractions of the specified flue gas streams of Plant Yates Unit No. 1;

- To determine the concentrations of toxic substances on the surfaces of fly ash particles;

- To provide data for EPA for use in risk assessments and in updating publication AP- $42^{2}$;

- To determine hexavalent chromium stack emissions; and

- To compare Method $29^{3}$ vapor-phase mercury results with those obtained via charcoal absorption.

Table 1-1 lists the chemical substances analyzed during this project.

Emission factors, removal efficiencies, and other results rely on measurement data that vary and/or may be near the limit of detection or below it for many of the substances of interest. This report includes uncertainty analysis and confidence intervals in order to assess the quality of the data.

\section{Auditing}

During the field sampling program conducted at Plant Yates in June 1993, quality assurance audits were conducted by Radian Corporation's internal QA auditor as well as by Research Triangle Institute, under contract with the U.S. Environmental Protection Agency.

Radian's audit was conducted with the purpose of providing an objective, independent assessment of the sampling effort, ensuring that the sampling procedures, data generating, data gathering, and measurement activities produce reliable and useful results. The audit provided a review of calibration documentation, documentation of QC data, completeness of data forms and notebooks, data review/validation procedures, sample logging procedures, and others. 
Table 1-1

Target Analytes

\section{Trace Elements}

Antimony

Arsenic

Barium

Beryllium

Boron

Cadmium

Chromium, total

Cobalt

\section{Radionuclides}

\section{Hexavalent Chromium}

\section{Mercury Speciation/Comparison}

\section{Anions}

Chloride ( $\mathrm{HCl})$

Fluoride (HF)

Sulfates

Phosphates

\section{Reduced Species}

\section{Ammonia}

Cyanide

\section{Organics}

Formaldehyde

Dioxins

Furans

\section{Volatile Organics}

Benzene

Bromoform

Carbon Disulfide

Carbon Tetrachloride

Chlorobenzene

Chloroform

1,4-Dichlorobenzene

cis-1,3-Dichloropropene

trans-1,3-Dichloropropene

Ethyl Benzene

Ethyl Chloride (Chloroethane)

Ethylene Dichloride (1,2-Dichloroethane)

Ethylidene Dichloride (1,1-Dichloroethane)

Methyl Bromide (Bromomethane)

Methyl Chloride (Chloromethane)

$\begin{array}{ll}\text { Copper } & \text { Molybdenum } \\ \text { Lead } & \text { Nickel } \\ \text { Manganese } & \text { Selenium } \\ \text { Mercury } & \text { Vanadium }\end{array}$

Molybdenum

Selenium

Mercury Vanadium
Methyl Chloroform (1,1,1-Trichloroethane)

Methyl Ethyl Ketone (2-Butanone)

Methylene Chloride (Dichloromethane)

Propylene Dichloride (1,2-Dichloropropane)

Styrene

1,1,2,2-Tetrachloroethane

Tetrachloroethene

Toluene

1,1,2-Trichloroethane

Trichloroethene

Vinyl Acetate

Vinyl Chloride

Vinylidene Chloride (1,1-Dichloroethene)

m,p-Xylene

o-Xylene 


\section{Table 1-1 (Continued)}

\section{Semivolatile Organics}

\author{
Acenaphthene \\ Acenaphthylene \\ Acetophenone \\ 4-Aminobiphenyl \\ Aniline \\ Anthracene \\ Benzidine \\ Benzo(a)anthracene \\ Benzo(a)pyrene \\ Benzo(b)fluoranthene \\ $\operatorname{Benzo}(\mathrm{g}, \mathrm{h}, \mathbf{i})$ perylene \\ Benzo(k)fluoranthene \\ Benzoic Acid \\ Benzyl Alcohol \\ 4-Bromophenyl Phenyl Ether \\ Butylbenzylphthalate \\ 4-Chloro-3-Methylphenol \\ p-Chloraniline \\ bis(2-Chloroethoxy)methane \\ bis(2-Chloroethyl)ether \\ bis(2-Chloroisopropyl)ether \\ 1-Chloronaphthalene \\ 2-Chloronaphthalene \\ 2-Chlorophenol \\ 4-Chlorophenyl Phenyl Ether \\ Chrysene \\ bis(2-Ethylhexyl)phthalate \\ Fluoranthene \\ Fluorene \\ Hexachlorobenzene \\ Hexachlorobutadiene \\ Hexachlorocyclopentadiene \\ Hexachloroethane
}

\section{Additional Elements}

$\begin{array}{ll}\text { Aluminum } & \text { Magnesium } \\ \text { Calcium } & \text { Potassium } \\ \text { Iron } & \text { Sodium }\end{array}$

Indeno(1,2,3-cd)pyrene

Isophorone

Methyl Methanesulfonate

3-Methylchlolanthrene

2-Methylnaphthalene

2-Methylphenol (o-cresol)

4-Methylphenol (p-cresol)

N-Nitroso-di-n-butylamine

$\mathrm{N}$-Nitrosodimethylamine

$\mathrm{N}-\mathrm{Nitrosodiphenylamine}$

$\mathrm{N}$-Nitrosopropylamine

$\mathrm{N}$-Nitrosopiperidine

Naphthalene

1-Naphthylamine

2-Naphthylamine

2-Nitroaniline

3-Nitroaniline

4-Nitroaniline

Nitrobenzene

Di-n-octylphthalate.

Dibenz $(a, h)$ anthracene

Dibenz $(a, j)$ acridine

Dibenzofuran

Dibutylphthalate

1,2-Dichlorobenzene

1,3-Dichlorobenzene

1,4-Dichlorobenzene

3,3'-Dichlorobenzidine

2,4-Dichlorophenol

2,6-Dichlorophenol

2,6-Dichlorophenol

Diethylphthalate

p-Dimethylaminoazobenzene
7,12-Dimethylbenz(a)anthracene

Dimethylphenethylamine

2,4-Dimethylphenol

Dimethylphthalate

4,6-Dinitro-2-methylphenol

2,4-Dinitrophenol

2,4-Dinitrotoluene

2,6-Dinitrotoluene

Diphenylamine

1,2-Diphenylhydrazine

Ethyl Methanesulfonate

2-Nitrophenol

4-Nitrophenol

Pentachlorobenzene

Pentachloronitrobenzene

Pentachlorophenol

Phenacetin

Phenanthrene

Phenol

2-Picoline

Pronamide

Pyrene

Pyridine

1,2,4,5-Tetrachlorobenzene

2,3,4,6-Tetrachlorophenol

1,2,24-Trichlorobenzene

2,4,5-Trichlorophenol

2,4,6-Trichlorophenol

2-Fluorobiphenyl

2-Fluorophenol

Nitrobenzene-d5

Phenol-d5

Terphenyl-d14

2,4,6-Tribromophenol
Silicon

Strontium

Titanium
Zinc

Uranium (coal only)

Thorium (coal only) 
The completeness of the quality assurance data was reviewed to judge whether the quality of the measurement data could be evaluated with the available information. In general, the results of the QC checks available indicate that the samples are well characterized. An evaluation of the accuracy, precision, and bias of the data, even if only on a qualitative level, is considered to be an important part of the data evaluation. A full discussion of each of these components can be found in Appendix D.

RTI was on site during the field sampling program to conduct a systems audit and a performance audit. These audits addressed the Radian sampling program. Results of the RTI audit are presented in Appendix A.

\section{Project Organization}

Figure 1-1 shows the organization of this project.

\section{Report Organization}

Table 1-2 lists the contents of the major sections and appendices of this final report.

\section{References}

1. Electric Power Research Institute. Field Chemical Emissions Monitoring (FCEM) Generic Sampling and Analytical Plan. Draft Report. Palo Alto, CA (May 1994).

2. U.S. Environmental Protection Agency, Office of Air and Radiation, Office of Air Quality Planning and Standards. Compilation of Air Pollutant Emission Factors, Vol. 1: Stationary Point and Area Sources. AP 42, 4th ed., Research Triangle Park, NC (September 1985 with periodic updates).

3. 40 CFR 266, Subpart H, "Method 29: Determination of Metals Emissions in Exhaust Gases from Hazardous Waste Incineration and Similar Combustion Processes: Proposed Method." 


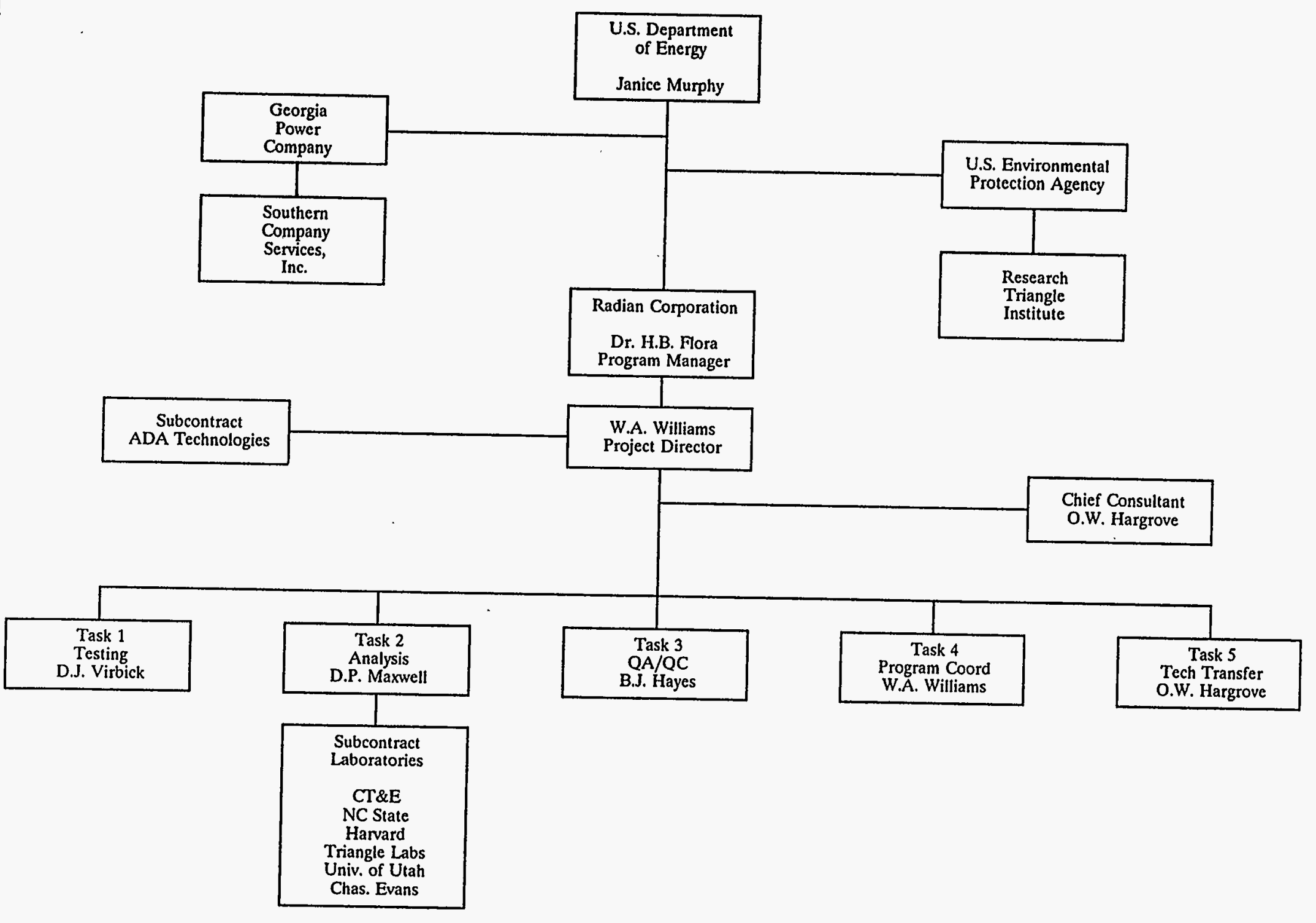


Table 1-2

Report Organization

Section

Glossary

Executive Summary

Introduction (p. 1-1)

Auditing (p. A-1, App. A)

Site Description (p. 2-1)

Sample Collection (p. 3-1)

Sampling Protocol (p. B-1, App. B)

Sample Preparation and Analysis Methods (p. 4-1)

Analytical Protocol (p. E-1, App. E)

Analytical Results (p. 5-1)

Sampling Data Sheets (p. C-1, App. C)

Data Analysis and Interpretation (p. 6-1)

Quality Assurance/Quality Control (p. D-1, App. D)

\section{Contents}

Acronyms, abbreviations, and definitions.

Stand-alone summary of the document.

Background, objectives, auditing, contractor organization, and report organization.

Information on audits conducted by RTI.

Power plant configuration, process description, sampling locations, and plant operating conditions.

Sampling schedule, test matrix, samples collected, sample handling, sample presentation, sample compositing.

Method descriptions, sample train disassembly, sample preparation for transportation, and storage.

Preparation procedures and chemical analysis methods for gases, liquids, and solids.

Method descriptions, deviations, and modifications.

Tabulated analytical information for gases, liquids, and solids.

Data for gas samples, including calculations for samples at the stack outlet.

An evaluation of the overall quality of the data, material balances, trace species removal efficiencies, and emission factor determinations.

Radian systems and performance audits: precision, accuracy, and completeness in the areas of sample collection, analysis, and DQOs. Detailed QA/QC results in tabular form. 
Table 1-2 (Continued)

Section

Contents

Uncertainty Analysis (p. F-1, App. Description of how the error propagation analysis F) was performed on calculated results.

Treatment of Non-Detects, Information provided by DOE.

Values Outside of the Calibration Range, and Blanks (P. G-1, App. G) 


\section{SITE DESCRIPTION}

\section{Power Plant Configuration}

The Plant Yates Unit No. 1 is a bituminous coal-fired steam electricity-generating unit with a net generating capacity of 100 megawatts. Located in Newnan, Georgia, the station is owned and operated by Georgia Power Company. Unit 1 includes a tangentially fired CE boiler that burns a $2.5 \%$ sulfur blend of Illinois No. 5 and Illinois No. 6 bituminous coals, an electrostatic precipitator for particulate control, and the CT-121 flue gas desulfurization system for sulfur dioxide $\left(\mathrm{SO}_{2}\right)$ emissions control during the ICCT demonstration. ${ }^{1}$

A process flow diagram of the Plant Yates facility that includes sampling locations is presented in Figure 2-1. Flue gas flows through a single duct into the ESP, which is four chambers wide and three rows of chambers deep; however, only the first two rows of chambers are energized. The ESP has a separate row of hoppers to collect the fly ash from each field, i.e., one row of hoppers per field. After the ESP, the flue gas flows through a single ID fan and then to the CT-121 system. The flue gas exiting the CT-121 unit is vented to the atmosphere through a 250-foot exhaust stack. No other units at the station use this stack.

\section{Process Description: Major Process Streams}

\section{CT-121 Wet FGD System}

The CT-121 is a second-generation FGD process which employs a unique absorber design, called a jet bubbling reactor (JBR), to combine conventional $\mathrm{SO}_{2}$ absorption, neutralization, sulfite oxidation, and gypsum crystallization in one reaction vessel. The process is designed to operate in a $\mathrm{pH}$ range ( 3 to 5 ) where the driving force for limestone dissolution is high, resulting in nearly complete reagent utilization. Oxidation of sulfite to sulfate is also promoted at the lower $\mathrm{pH}$ because of the increased solubility of innate oxidation catalysts such as iron $(\mathrm{Fe})$. Because all of the absorbed $\mathrm{SO}_{2}$ is oxidized, there is sufficient surface area for gypsum crystal growth to prevent the slurry from becoming significantly supersaturated with respect to calcium sulfate. This significantly reduces the potential for gypsum scaling, a problem that frequently occurs in natural-oxidation FGD systems. Since much of the crystal attrition and secondary nucleation associated with the large centrifugal pumps in conventional FGD systems is also eliminated in the CT-121 design, large, easily dewatered gypsum crystals can be produced. 


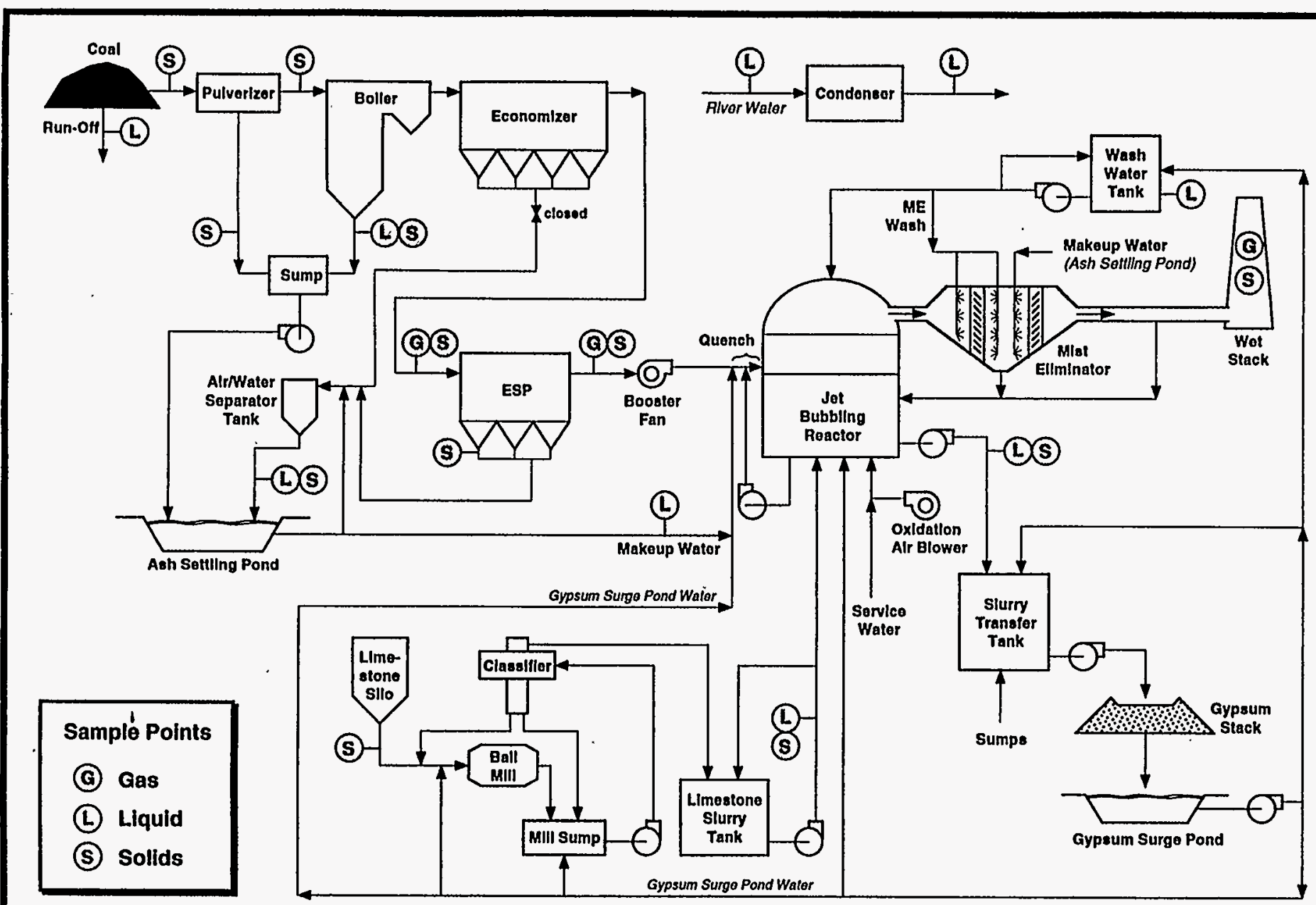


Gas Cooling Section. Flue gas from the boiler passes through the ESP and is pressurized by the Unit 1 I.D. fan. From the fan, the flue gas enters the gas cooling section. Here the flue gas is cooled and saturated with a mixture of JBR slurry, makeup water, and pond water. The quench slurry is sprayed into the gas at a liquid-to-gas ratio of about $10 \mathrm{gal} / 1000$ acf at full boiler load using two centrifugal gas cooling pumps. The suction for the gas cooling pumps is located near the bottom of the JBR.

JBR. From the gas cooling section, the flue gas enters the JBR. The JBR is the central feature of the CT-121 process. The gas enters an enclosed plenum chamber formed by an upper deck plate and a lower deck plate. Sparger tube openings in the lower deck plate force the gas into the slurry contained in the jet bubbling (froth) zone of the JBR vessel. After bubbling through the slurry, the gas flows upward through gas risers which pass through both the lower and upper deck plates. Entrained liquor in the gas disengages in a second plenum above the upper deck plate, and the cleaned gas passes to the mist eliminator.

The slurry in the JBR can be divided into two zones: the jet bubbling or froth zone and the reaction zone. $\mathrm{SO}_{2}$ absorption occurs in the froth zone, while neutralization, sulfite oxidation, and crystal growth occur in both the froth and reaction zones.

The froth zone is formed when the untreated gas is accelerated through the sparger tubes in the lower deck and bubbled beneath the surface of the slurry at a depth of 6 to 16 inches. The froth zone provides the gas-liquid interfacial area for $\mathrm{SO}_{2}$ mass transfer to the slurry. The bubbles in the froth zone are continually collapsing and reforming to generate new and fresh interfacial areas and to transport reaction products away from the froth zone to the reaction zone. The amount of interfacial area can be varied by changing the level in the $\mathrm{JBR}$, and consequently, the injection depth of flue gas. The deeper the gas is injected into the slurry, the greater the interfacial area for mass transfer and the greater the $\mathrm{SO}_{2}$ removal. In addition, at deeper sparger depths, there is an increase in the gas-phase residence time. $\mathrm{SO}_{2}$ removal can also be increased by increasing the $\mathrm{pH}$ of the slurry in the froth zone, since a higher $\mathrm{pH}$ results in higher slurry alkalinity. The $\mathrm{pH}$ is controlled by the amount of limestone fed to the reaction zone of the JBR.

The solids concentration in the JBR is maintained at a constant level by removing a slurry stream from the bottom of the reaction zone and pumping this stream to a holding tank (gypsum slurry transfer tank), where it is diluted with pond water before being pumped to the gypsum stack. This is done to keep the velocity high over a range of operating conditions.

The oxygen which reacts with absorbed $\mathrm{SO}_{2}$ to produce sulfate is provided to some extent by oxygen diffusion from the flue gas, but the predominant source is air bubbled into the reaction zone of the JBR. The oxidation air lines enter through the very top of the JBR vessel, penetrate the upper and lower deck plates, and introduce the air near the bottom of the JBR. Oxygen diffuses from the air into the slurry as the bubbles rise to the froth zone of the JBR. Excess air mixes with the flue gas and exits the JBR to the mist eliminator. Before the oxidation air enters the JBR, it is saturated with service water to prevent a wetdry interface at the discharge of the oxidation air lines. 
Site Description

\section{Ash and Cooling System}

Plant Yates uses an ash settling and storage area consisting of one ash-settling pond. Bottom ash from the boiler and pyrites from the pulverizers are sluiced together and are disposed of in the ash-settling pond. The ESP ash, economizer ash, and air preheater ash are also sluiced together and disposed of in the same ash-settling pond. Water from the Chattahoochee River is used for cooling water in a once-through type steam condenser.

\section{ESP Design}

The ESP is a conventional weighted wire configuration typical of many of the older ESPs found on coal-fired utility boilers in the Midwest and Eastern parts of the United States. Details of the ESP are provided in Table 2-1. The specific collection area (SCA) is $210 \mathrm{ft}^{2} / \mathrm{kacfm}$ at full load. This size is representative of the ESPs built during the 1970 s to provide collection efficiencies of 95 to 99 percent. The plate-to-plate spacing is 9 inches, which is typical for this vintage ESP. Current ESP design standards use 12- to 16-inch spacing to reduce the impact of plate or wire misalignment which can cause sparking at lower voltages. The velocity is somewhat lower than many of the older ESPs which often operate at velocities of 6 or $7 \mathrm{ft} / \mathrm{sec}$. The average ESP velocity of $4.4 \mathrm{ft} / \mathrm{sec}$ is more characteristic of modern design practices.

Figure 2-2 shows a schematic layout of the ESP. The ESP is configured with three mechani$\mathrm{cal}$ sections and four electrical sections. As shown in the schematic, the arrangement is somewhat unusual in that the mechanical sections are not aligned with the electrical sections. This provided some minor difficulties in modeling the performance of the ESP, as described in Section 8.

Figure 2-2 also identifies the rapping components. The Plant Yates ESP uses a Forry Rapper Control System programmed to operate vibrators on the high voltage wire frames and electromechanical rappers on the collector plate assemblies. Table 2-2 presents a detailed breakdown of the rapping frequencies. The high-voltage wire frame vibrators are on a 12 minute repeat cycle and have 2 second on-times. The collector plate rappers have a 30 minute repeat cycle and are energized to lift the 20-pound solenoids nominally four inches before releasing them. The rapping cycles are offset so that only one section of the plates is rapped at any single period of time. This rapping procedure results in smaller but more frequent spikes in opacity.

\section{Process Description: Sampling Locations}

Samples were collected from streams representing three types of matrices: gases, solids, and liquids. Gaseous samples were collected from the inlet and outlet of the ESP and from the stack. Solids were collected of the coal feed, bottom and fly ashes, limestone, 
Table 2-1

Summary of Design Data on the Yates Unit \#1 ESP

Manufacturer

Housing

Mechanical Sections

Electrical Sections

Gas Flow Passages

Collector Electrodes

Plate Spacing

Plate Height

Total Plate Length

Length of Sections

Total Plate Area

Total Cross Section Area

Gas Conditions

Gas Flow at Full Load

Gas Velocity at Full Load

Residence Time at Full Load

SCA at Full Load

Emitter Design

Design

Diameter

Spacing

Number

Total Wire Length
Buell

1 ESP Box

3

4

82

9 inches

$30 \mathrm{ft}$

$21 \mathrm{ft}$

$9 \mathrm{ft}$ Section 1, $6 \mathrm{ft}$ for Sections $2 \& 3$ $103,320 \mathrm{ft}^{2}$

$1845 \mathrm{ft}^{2}$

$491,000 \mathrm{acfm}$

$4.4 \mathrm{ft} /$ second

4.7 seconds

$210 \mathrm{ft}^{2} / \mathrm{kacfm}$

Weighted Wire

0.110 inches

8 inches

2,296

$68,880 \mathrm{ft}$ 
$61^{\prime}-6$

ESP INLET

SECTIOTN 1

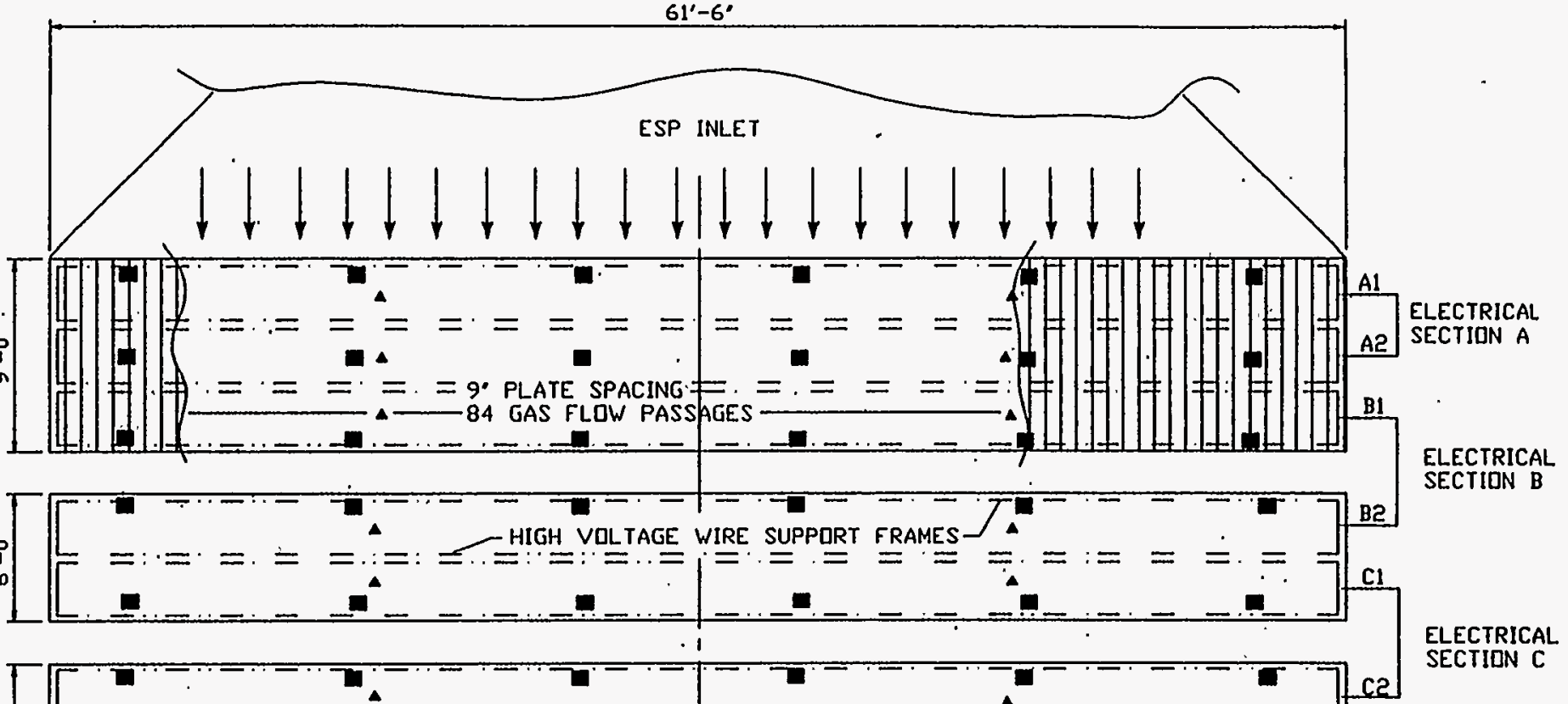

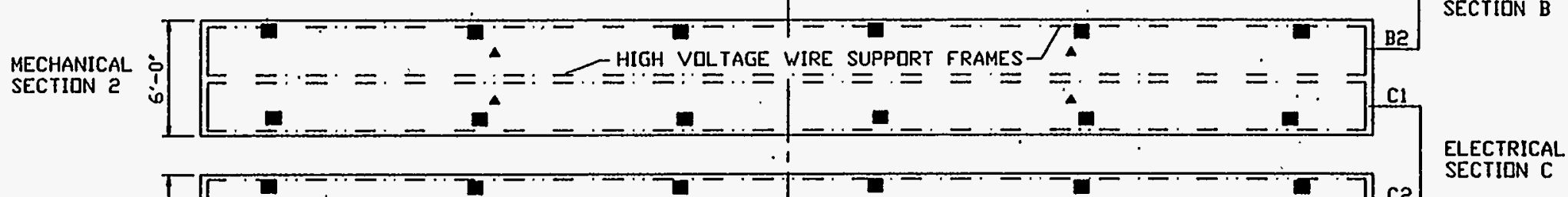

- high Voltage frake vibrator

w collector plate rapPer 
Table 2-2

ESP Rapping Schedule

Plant Yates Unit \#1

\begin{tabular}{|c|c|c|c|c|}
\hline $\begin{array}{c}\text { Mechanical } \\
\text { Section }\end{array}$ & Rapper Type & $\begin{array}{c}\text { Cycle } \\
\text { Repeat Time }\end{array}$ & $\begin{array}{c}\text { Rapper } \\
\text { Identification }\end{array}$ & $\begin{array}{c}\text { Activated } \\
\text { (minutes into cycle) }\end{array}$ \\
\hline 1 & $\begin{array}{l}\text { HV Vibrator } \\
\text { (1 vibrator per } \\
\text { frame) }\end{array}$ & 12 minutes & $\begin{array}{l}\text { HV: A1 } \\
\text { HV: A2 } \\
\text { HV: B1 }\end{array}$ & $\begin{array}{c}4 \\
8 \\
12\end{array}$ \\
\hline 2 & HV Vibrator & 12 minutes & $\begin{array}{l}\mathrm{HV}: \mathrm{B} 2 \\
\mathrm{HV}: \mathrm{C} 1\end{array}$ & $\begin{array}{c}5 \\
10\end{array}$ \\
\hline 3 & HV Vibrator & 12 minutes & $\begin{array}{l}\mathrm{HV}: \mathrm{C} 2 \\
\mathrm{HV}: \mathrm{D}\end{array}$ & $\begin{array}{c}6 \\
12\end{array}$ \\
\hline 1 & $\begin{array}{l}\text { Plate Rapper } \\
\text { (1 rapper per } \\
\text { plate support) }\end{array}$ & 30 minutes & $\begin{array}{l}\text { Plate: A1-1 } \\
\text { Plate: A1-2 } \\
\text { Plate: A1-3 }\end{array}$ & $\begin{array}{c}4 \\
8 \\
12\end{array}$ \\
\hline 1 & Plate Rapper & 30 minutes & $\begin{array}{l}\text { Plate: A2-1 } \\
\text { Plate: A2-2 } \\
\text { Plate: A2-3 }\end{array}$ & $\begin{array}{c}5 \\
10 \\
15\end{array}$ \\
\hline 1 & Plate Rapper & 30 minutes & $\begin{array}{l}\text { Plate: B1-1 } \\
\text { Plate: B1-1 } \\
\text { Plate: B1-3 }\end{array}$ & $\begin{array}{c}6 \\
12 \\
18\end{array}$ \\
\hline 2 & Plate Rapper & 30 minutes & $\begin{array}{l}\text { Plate: B2-1 } \\
\text { Plate: B2-2 } \\
\text { Plate: B2-3 }\end{array}$ & $\begin{array}{c}7 \\
14 \\
21\end{array}$ \\
\hline 2 & Plate Rapper & 30 minutes & $\begin{array}{l}\text { Plate: C1-1 } \\
\text { Plate: C1-2 } \\
\text { Plate: C1-3 }\end{array}$ & $\begin{array}{c}8 \\
16 \\
24\end{array}$ \\
\hline 3 & Plate Rapper & 30 minutes & $\begin{array}{l}\text { Plate: C2-1 } \\
\text { Plate: C2-2 } \\
\text { Plate: C2-3 }\end{array}$ & $\begin{array}{c}9 \\
18 \\
27\end{array}$ \\
\hline 3 & Plate Rapper & 30 minutes & $\begin{array}{l}\text { Plate: D-1 } \\
\text { Plate: D-2 } \\
\text { Plate: D-3 }\end{array}$ & $\begin{array}{l}10 \\
20 \\
30\end{array}$ \\
\hline
\end{tabular}

Note: Rapping frequency and cycles are duplicated for each side of the ESP. 
and FGD slurry. Liquids included the makeup waters, sluice waters associated with the ash steams, and filtrate from the limestone and FGD slurry streams, cooling water, and coal pile runoff. Figure 2-1 illustrates the sampling locations which are described in detail in the following sections.

\section{Flue Gas Sample Streams}

Three flue gas stream locations were identified for testing:

- ESP inlet;

- ESP outlet (FGD inlet); and

- Stack.

The ESP inlet sampling location is located at ground level. Sixteen four-inch ports are located horizontally just downstream of where two ducts which exit the air preheater are combined.

The ESP outlet location is located approximately 60 feet above ground level. Six four-inch ports are located vertically across the duct.

The stack sampling location is approximately 120 feet above ground level and has four fourinch ports, equally spaced at 90 degrees.

\section{Solid Sample Streams}

Solid streams sampled were the following:

- Raw coal;

- Pulverized feed coal;

- Pulverizer rejects;

- Bottom ash;

- ESP fly ash;

- Raw limestone;

- Limestone slurry solids; and

- FGD slurry solids. 
Solid samples were collected concurrent with the gas stream testing and are considered to be representative of process operation.

Coal Samples. The sample locations for collecting coal samples are located around each of the four coal pulverizers serving Unit 1. Samples of raw coal were collected from each pulverizer feed chute after the weigh belt. Feed coal samples were collected at the exit of each pulverizer, just prior to the boiler feed, and the pulverizer rejects were collected at the inlet to each reject hopper.

Ash Samples. Bottom ash samples were collected wet at the bottom ash sluice water sump upstream of the bottom ash sluice pumps. Bottom ash was separated from the sluice water by allowing the solids to settle and siphoning off the sluice water. ESP fly ash was collected dry from the clean-out ports of the two energized banks of ESP hoppers, and sluiced ESP fly ash was also collected at the sluice water discharge to the ash pond.

Limestone. Limestone samples were collected from two sampling locations. Raw limestone was collected off the weigh belt feed to the grinding mill, and limestone slurry was collected from a sample tap on the recirculating limestone slurry feed line to the JBR. Slurry samples were filtered to obtain the solids.

FGD Solids. FGD solids were sampled from a sample tap at the discharge of the JBR underflow slurry pumps. The solids were filtered through a filter press to separate the solid and liquid phases at the time of collection.

\section{Liquid Sample Streams}

The following liquid streams were sampled:

- Ash pond water;

- Gypsum pond water;

- Ash sluice water (bottom ash and fly ash);

- FGD slurry blowdown filtrate;

- Limestone slurry filtrate;

- Coal pile run-off; and

- Cooling water at the condenser inlet.

Liquid samples were collected concurrent with the gas-phase testing and are considered to be representative of process operation during that time period. 
Site Description

Pond Waters. Ash and gypsum pond water were sampled from sample taps. The ash pond water sample tap is located near the limestone slurry tank containment area where ash pond water is used in limestone slurry preparation. Gypsum pond water was collected from a sample tap located on the mist eliminator wash water tank.

Ash Sluice Water. Bottom ash and ESP fly ash sluice water samples were obtained by siphoning the aqueous phase of the ash/water sluice mixture from the solid phase after allowing approximately 2 hours for the solids to settle. The collection points for the ash sluice samples are described in the section on solid sample streams.

Limestone and FGD Filtrates. The aqueous phases of the limestone slurry and JBR underflow slurry were obtained from filtration of the collected solids samples described earlier. Limestone slurry and all FGD filtrates for organic compound analyses were sampled from a filter press at the point of collection to avoid loss of organics and to prevent further reactions in the FGD slurry matrix.

Coal Pile Run-off. Coal pile run-off collection was performed after a rain storm. Samples were collected from shallow trenches leading from the coal pile to the run-off collection pond.

Condenser Water Samples. Cooling water samples at the inlet of the turbine steam condenser were collected from a sample tap located at the discharge of the cooling water pumps.

\section{Plant Operating Conditions}

Operating conditions were continuously monitored via a computerized data acquisition system (DAS) which logged process information as 15 minute averages. In addition, boiler operating data were logged hourly by the control room operators. Of the total amount of data collected, key parameters have been summarized and are presented in Table 2-3. These data reflect the general stability of the process. Unit load and furnace gas oxygen concentrations are shown graphically in Figures 2-3 and 2-4. The dashed lines represent the bounds of what is considered normal operation. Also, the grey shaded areas represent the periods during which testing was being performed. Key operating parameters for the CT-121 process are shown in Figures 2-5 and 2-6. Overall, all processes were very stable and the key operating parameters were within the targeted range during the entire test period.

Three continuous emission monitors were operated during the test period. Sulfur dioxide and nitrogen oxides were monitored continuously by existing Plant Yates instrumentation.

Carbon monoxide was monitored using an instrument supplied by Radian. The results of the CEM monitoring are presented in Figures 2-7, 2-8, and 2-9. 


\section{Table 2-3}

Summary of Process Monitoring Data

\begin{tabular}{|c|c|c|c|c|c|c|}
\hline Parameter & $6 / 21$ & $6 / 22$ & $6 / 23$ & $6 / 25$ & $6 / 26$ & $6 / 27$ \\
\hline \multicolumn{7}{|l|}{ Boiler: } \\
\hline Load (MW) & 101 & 101 & 101 & 100 & 100 & 101 \\
\hline Coal Flow $(1,000 \mathrm{lb} / \mathrm{hr}$, wet $)$ & 89 & 88 & 89 & 90 & 91 & 92 \\
\hline Furnace $\mathrm{O}_{2}(\%)$ & 3.5 & 3.6 & 3.5 & 3.3 & 3.3 & 3.4 \\
\hline Burners in Service & 16 & 16 & 16 & 16 & 16 & 16 \\
\hline \multicolumn{7}{|l|}{ ESP: } \\
\hline Opacity (\%) & 15.0 & 14.4 & 16.0 & 17.1 & 17.7 & 18.6 \\
\hline \multicolumn{7}{|l|}{ JBR: } \\
\hline $\mathrm{SO}_{2}$ Temoval $^{\mathrm{b}}(\%)$ & 93.0 & 91.6 & 90.7 & 88.8 & $-{ }^{c}$ & $--^{\infty}$ \\
\hline Scrubber $\mathrm{pH}$ & 4.6 & 4.5 & 4.5 & 4.5 & 4.5 & 4.5 \\
\hline JBR $\Delta \mathrm{P}\left(\right.$ Inches $\mathrm{H}_{2} \mathrm{O}$ ) & 14.1 & 14.1 & 14.1 & 14.1 & 14.1 & 14.1 \\
\hline \multicolumn{7}{|l|}{ Stack: } \\
\hline $\mathrm{O}_{2}(\%, \mathrm{dry})$ & 8.2 & 8.0 & 7.9 & 7.7 & 7.7 & 7.6 \\
\hline $\mathrm{SO}_{2} \quad$ (ppmv, dry) & 160 & 181 & 202 & 236 & 182 & 186 \\
\hline $\mathrm{NO}_{x}$ (ppmv, dry) & 430 & 490 & 470 & 430 & 420 & 320 \\
\hline CO (ppmv, dry) & 3.5 & $-{ }^{d}$ & 2.6 & 2.6 & 2.0 & 5.7 \\
\hline
\end{tabular}

- Daily averages.

${ }^{b}$ Based upon $\mathrm{SO}_{2}$ corrected to $3 \% \mathrm{O}_{2}$.

- Inlet $\mathrm{O}_{2}$ monitor not functioning properly.

d $\mathrm{CO}$ monitor not functioning properly. 


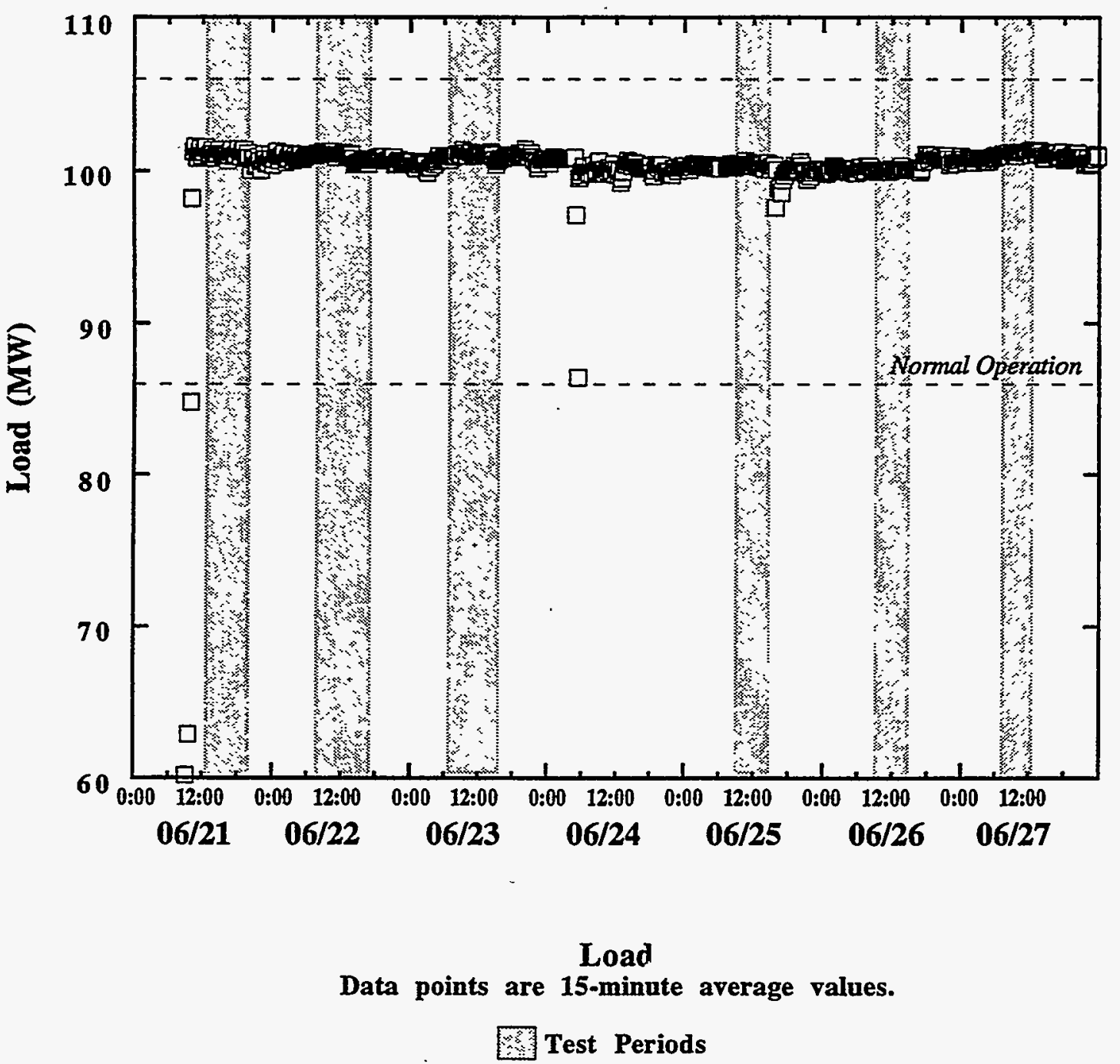

Figure 2-3

Unit 1 Load 


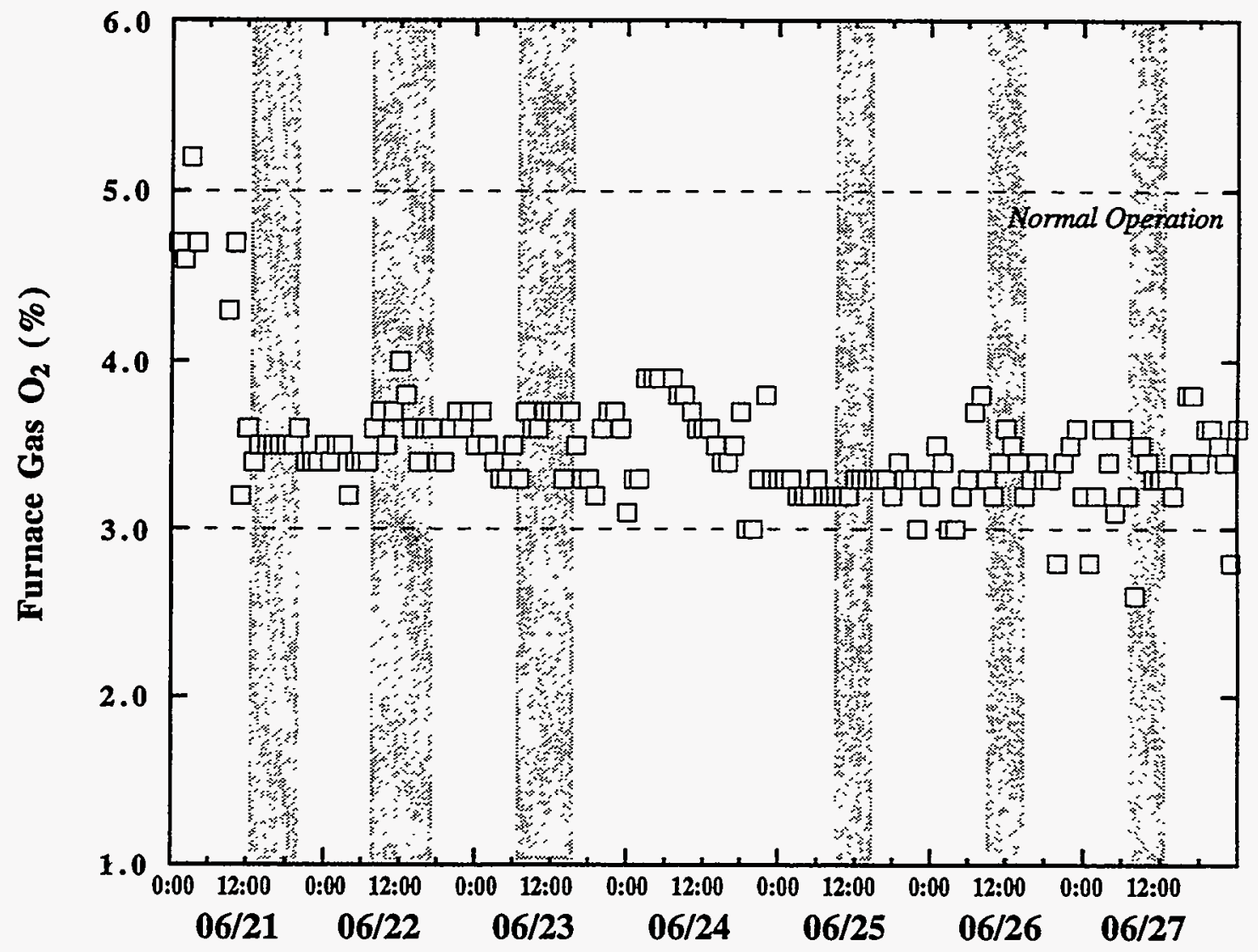

Furnace Gas $\mathbf{O}_{2}$

Data points are hourly values.

Test Periods

Figure 2-4

Furnace Gas Oxygen 


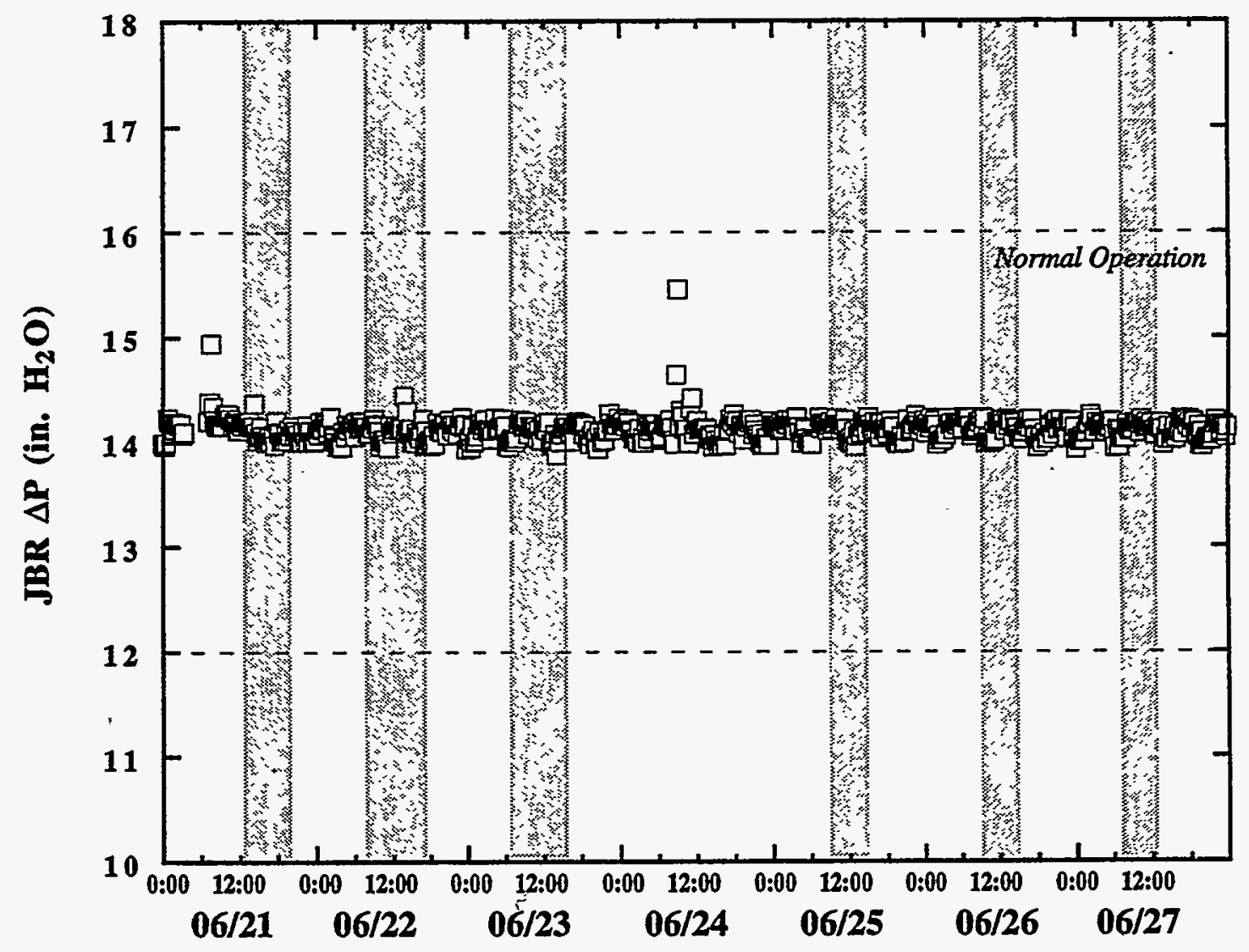

JBR Deck $\Delta \mathbf{P}$

Data points are 15-minute average values.

Test Periods

Figure 2-5

JBR Pressure Drop 


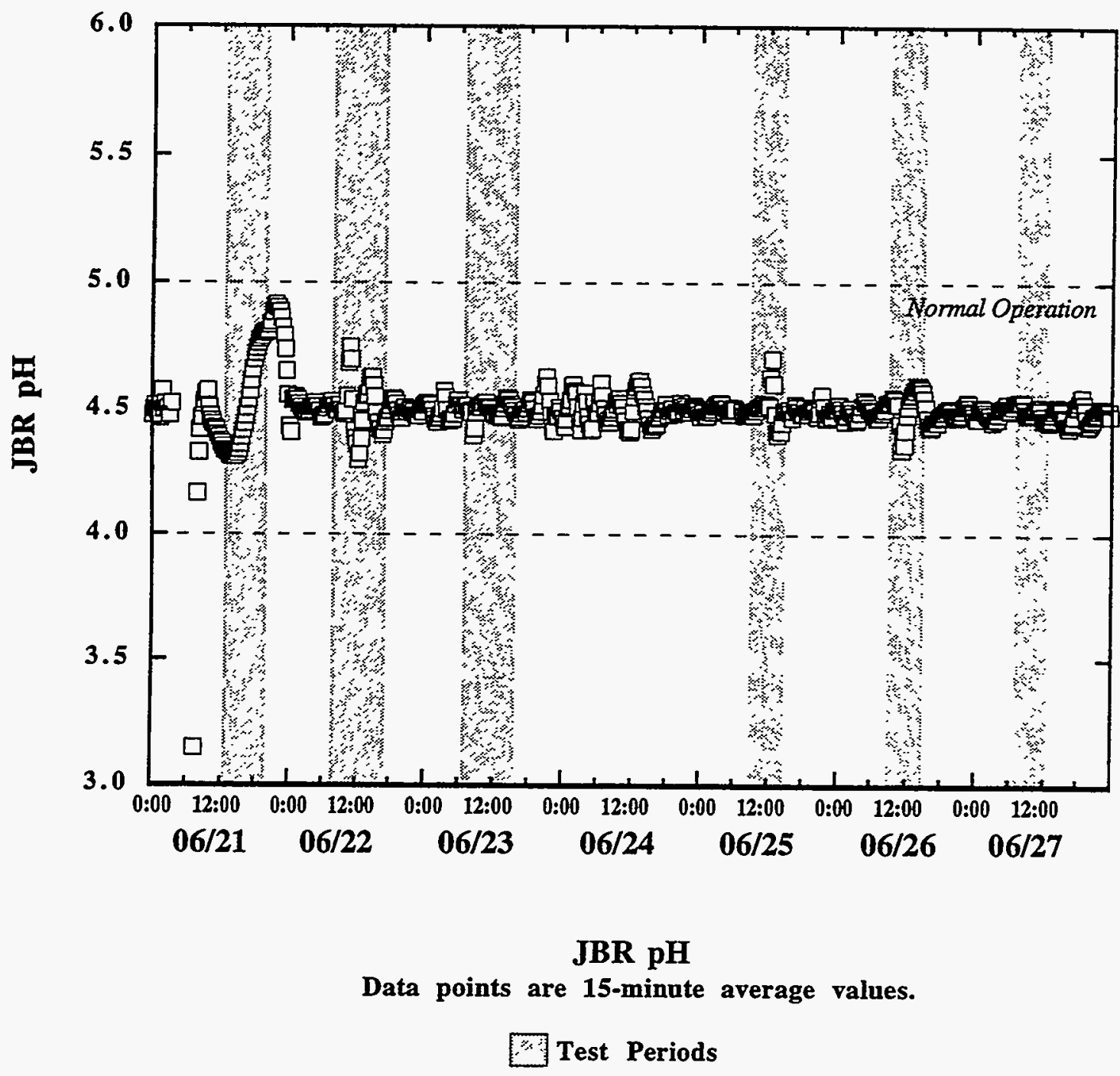

Figure 2-6

JBR pH 


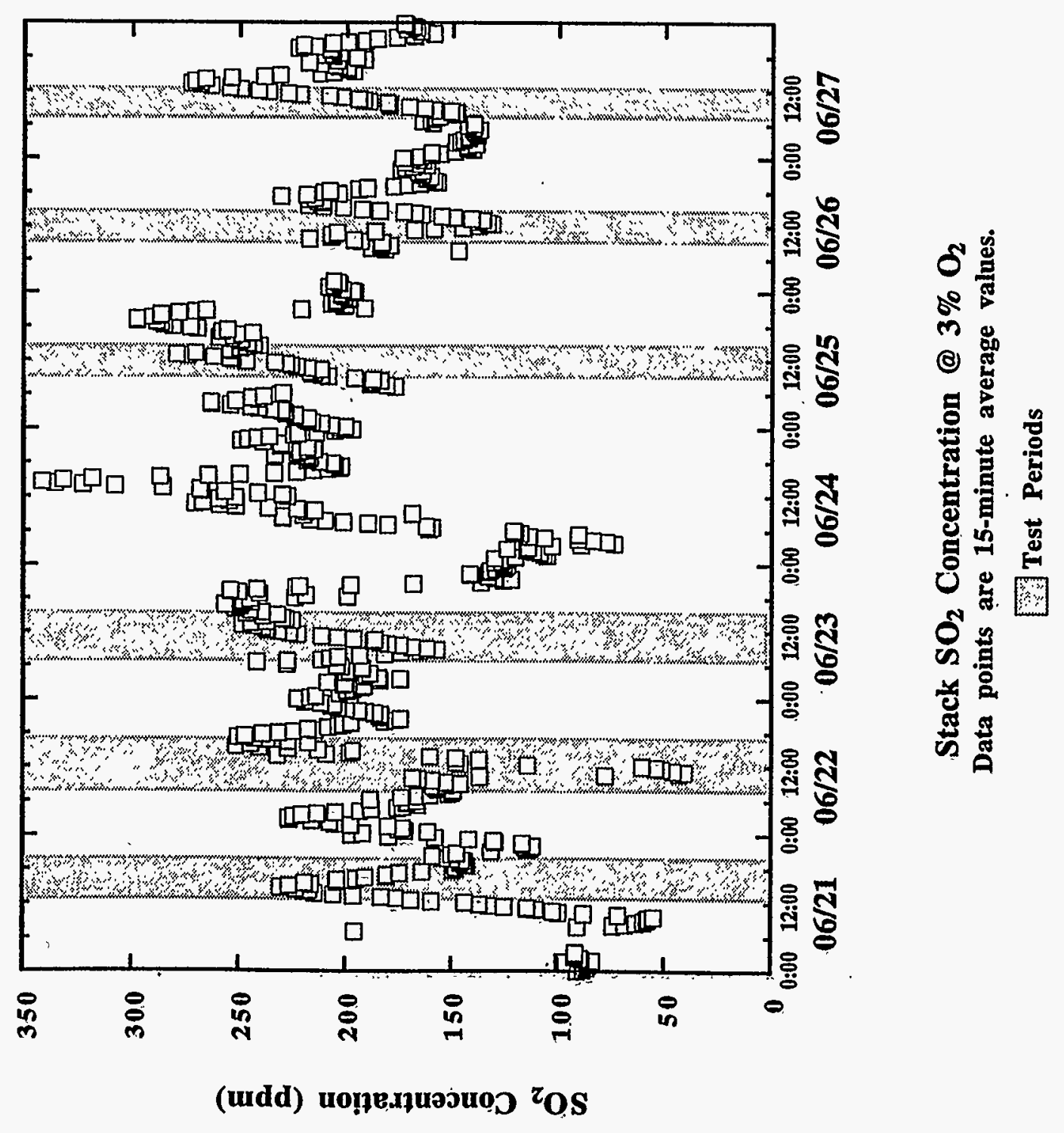

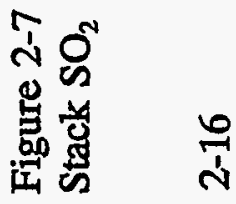




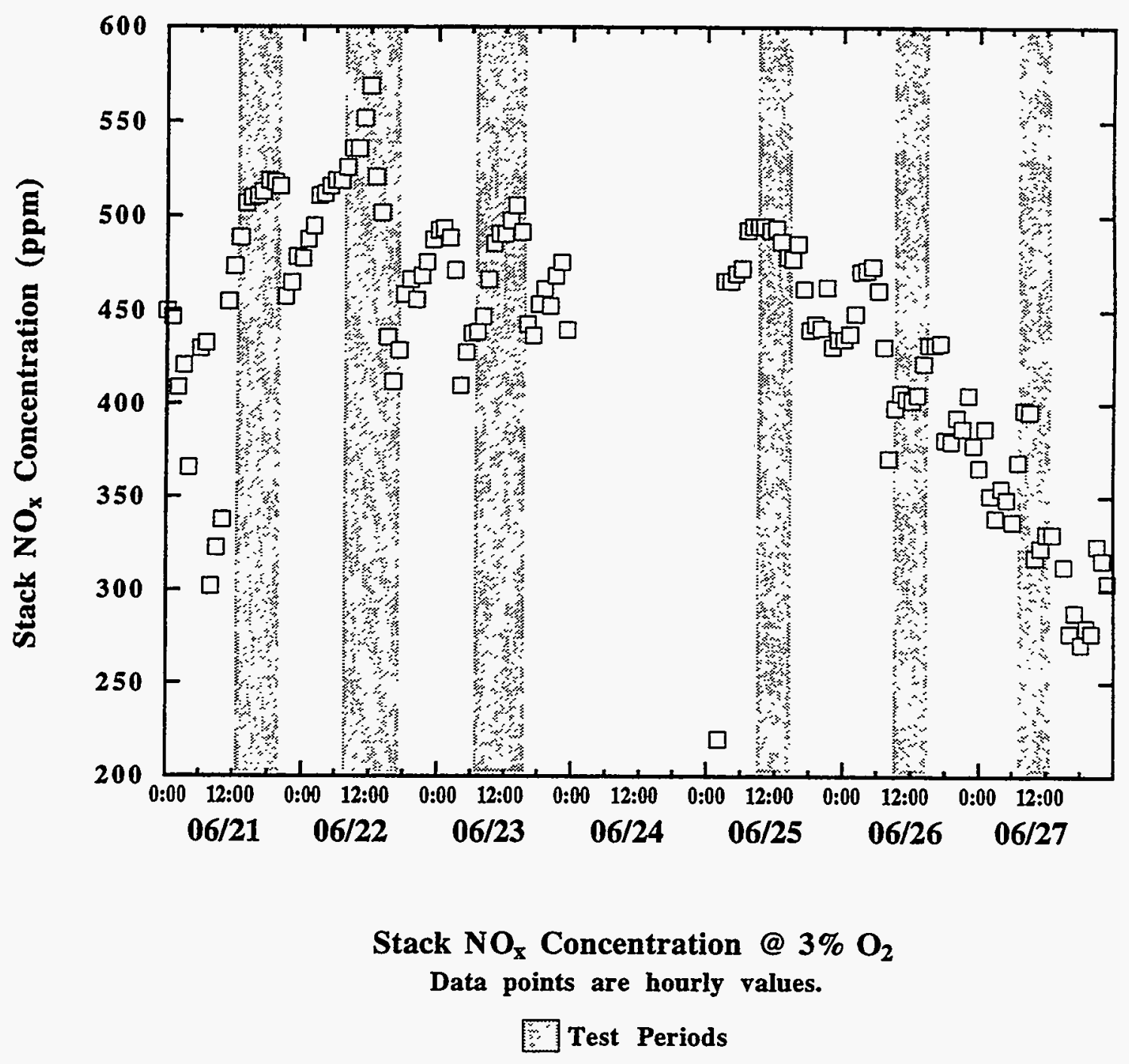

Figure 2-8

Stack $\mathrm{NO}_{\mathbf{x}}$ 


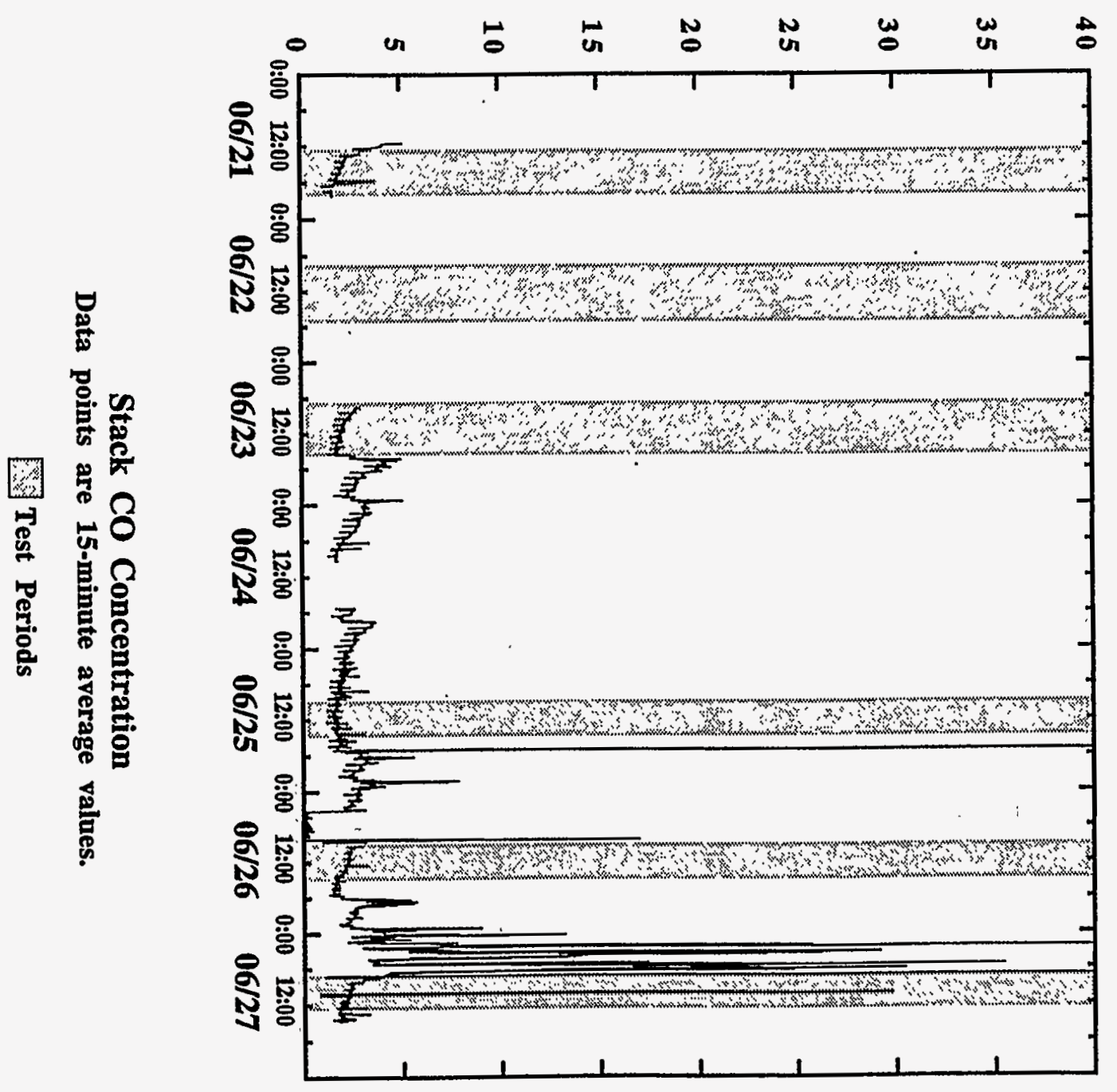




\section{Problems}

Only slight operational problems were encountered during the test effort. On the first day of testing, a steam leak was detected and, although the leak was minor, plant personnel opted to bring the plant down to fix the leak, rather than run the risk of having a major problem occur while the testing was in progress. Repairing the leak resulted in a six-hour delay in the start of the testing activities on day one.

The average $\mathrm{JBR} \mathrm{SO}_{2}$ removal efficiency dropped below $90 \%$ on June 25 . A change in the JBR piping is believed to have resulted in a high bias in the $\mathrm{pH}$ indicators. For this reason, $\mathrm{SO}_{2}$ removal was generally lower than expected. However, with respect to the range of $\mathrm{SO}_{2}$ removal achieved over the previous four days, the $88.8 \%$ removal is within normal operating limits and had no effect on the test results.

\section{Deviations from Sampling Plan}

The sampling approach was defined with soot blowing confined to the evening shifts and no testing was to be performed during soot blowing events (with the exception of round-theclock sample collection for PSD at the stack and bulk particulate collection at the stack and ESP Outlet). However, during the second day of the material balance period a high pressure drop was encountered across the air pre-heater (APH). Sampling was delayed for two hours while the APH soot-blowers were activated. A full pressure drop reduction could not be achieved and the decision was made to continue testing with the APH soot blowers activated continuously. Testing on the third day was also done with the APH soot blowers activated. This approach provided consistent process operation for the testing. Soot blowing at all other boiler locations was not performed until after the testing was completed each day. A post-test inspection of boiler operator logs indicated that APH soot-blowing was probably done continuously during the first day of the material balance period also. Although boiler control room instructions were for "no soot blowing," the post-test inspection revealed a steadily decreasing pressure drop across the APH on Day 1 of the material balance period. Typically, this only happens if the APH soot blowers are on. There was, however, no way to confirm this after the fact. The impact of the APH soot blowing is currently judged not to have an impact on the data quality or the overall test results.

\section{References}

1. David P. Burford, Oliver W. Hargrove, and Harry J. Ritz, "Demonstration of Innovative Applications of Technology for the CT-121 FGD Process." Published in the proceedings of the First Annual Clean Coal Technology Conference (sponsored by the U.S. Department of Energy), Cleveland, OH (September 1992). 


\section{SAMPLE COLLECTION}

Radian used established sampling. methods (where possible) and a sampling strategy consistent with that of the EPRI-sponsored Field Chemical Emissions Monitoring (FCEM) program $^{1}$ to accomplish the project goals. Samples were collected with Plant Yates operating within $10 \%$ of full load, at steady-state conditions, and in triplicate over two three-day periods.

\section{Sampling Schedule}

Radian performed the test program at the Yates facility in two discrete three-day sampling periods. During the first three-day period (Phase I), samples were collected for the characterization of organic species and particle size distribution, and ADA Technologies performed an assessment of the ESP operating characteristics. The second three-day sampling period (Phase II) was a "material balance period," during which samples were collected for analysis of inorganic components.

Figures 3-1 and 3-2 illustrate the sampling periods for each sample stream. Field blank samples were collected June 20, 1993 for the organic-phase test parameters and field blank samples were collected for the "material balance" parameters on June 24, 1993.

\section{Samples Collected}

All sampling was performed according to the procedures detailed in the Management Plan for the Plant Yates CT-121 FGD Project.

Only two deviations were noted from the specifications provided in the Management Plan.

The first involves the collection of dry ash from the ESP ash hoppers. The management plan specified for the collection of samples from three rows of hoppers; however, after arrival on site, it was discovered that only the first two rows were energized. The sampling approach was modified to limit the sampling to just the first two rows of hoppers. These first two rows (four hoppers per row) of hoppers were to be sampled individually; however, only seven of the eight hoppers could be sampled. A valve stuck open on hopper number 7 , and the system could not be isolated from the sluice system.

The second deviation concerned the collection of condenser water. No condenser outlet samples could be collected, as the two valves located at the condenser outlet were not operational. 


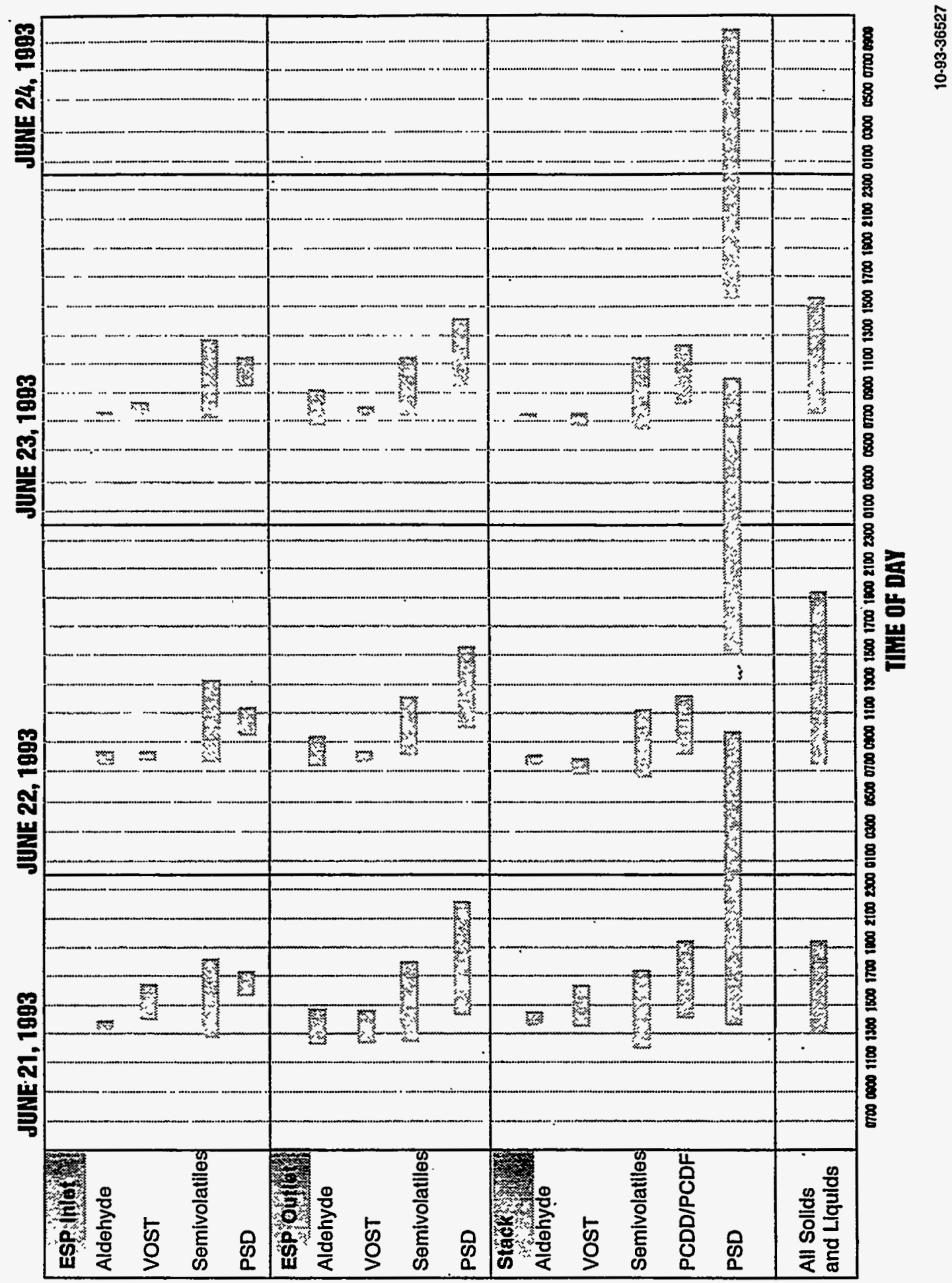

Figure 3-1

Sample Collection Schedule for June 21-24, 1993 


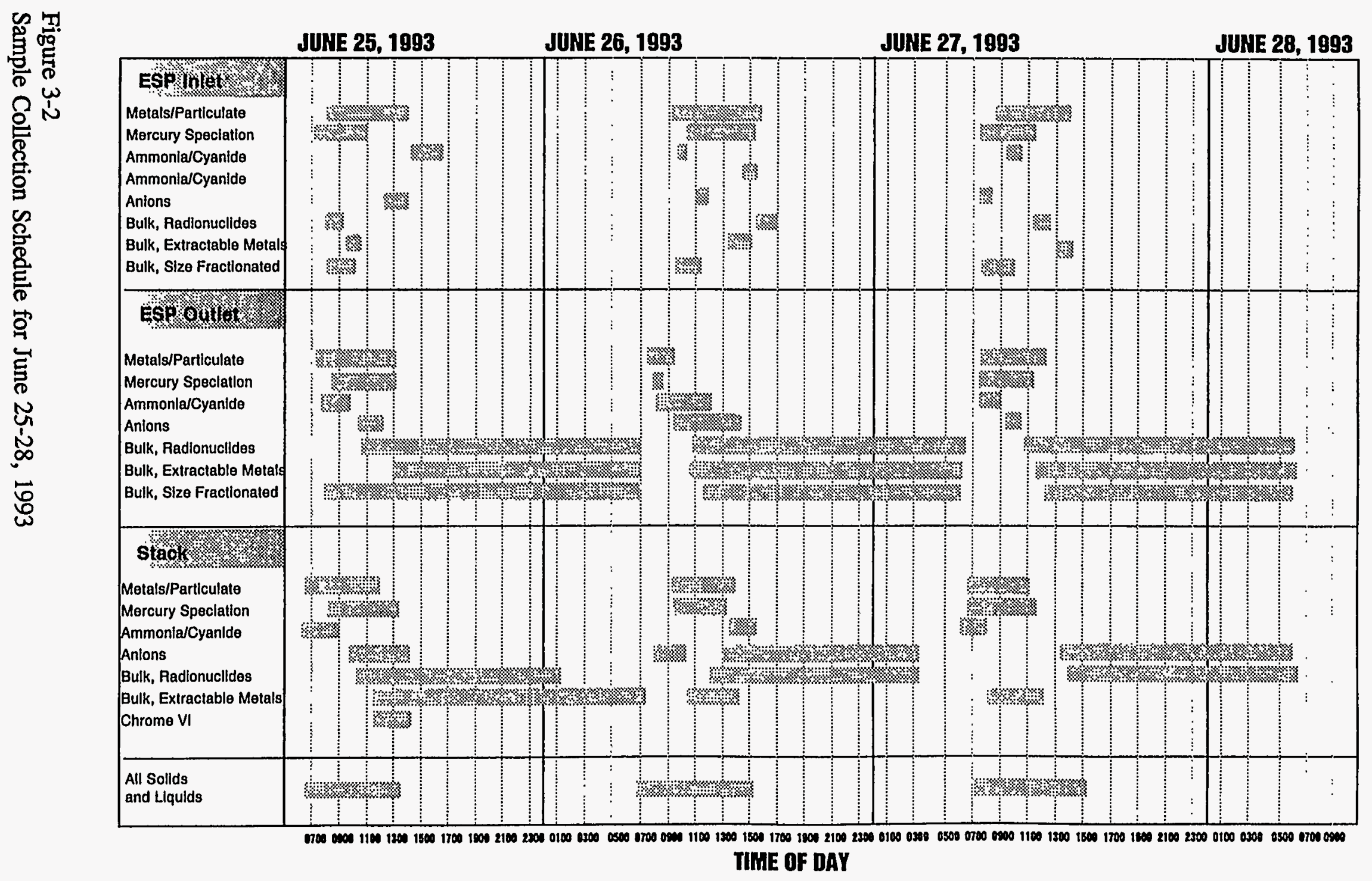

10-83-36527 


\section{Gas Samples}

Samples were collected from three separate gas locations during the toxics emission study, namely the ESP inlet, the ESP outlet, and the stack. Sampling was performed concurrently at each location with specific run times varying due to effluent conditions.

A summary of the samples collected from the gaseous locations is presented in Table 3-1. The summary identifies the sample type, collection method, the number of samples collected and analyzed from each location, and the sample preservation techniques. Samples collected as part of the QA/QC program for gaseous samples are identified in Table 3-2.

Gas sampling data sheets are available in Appendix C. Data presented in Appendix C include the sample run times and sample volumes. In addition to the summarized field data, the calculations used for data reduction are also presented.

\section{Liquid Samples}

Liquid samples were collected concurrently with the gaseous sampling. The primary liquid collection technique was grab sampling. Table 3-3 identifies each of the streams sampled as well as the collection method, number of samples collected and analyzed, and the sample preservation techniques. Table 3-4 lists the liquid samples which were collected and/or analyzed as part of the $\mathrm{QA} / \mathrm{QC}$ program.

Liquid samples were composited daily during each test run with the exception of the aldehydes and volatile organic compound (VOC) samples which were collected as single grab samples. The sluices and slurry filtrates were also collected as composite samples during each test run and the solids removed either by settling and decantation, or direct filtration from the process sample point. Detailed descriptions of the sampling techniques are presented in Appendix B.

\section{Solid Samples}

Solid samples were collected concurrently with the gaseous and liquid sampling. Sampling was performed by compositing grab samples that were collected at regular intervals during the gas sampling period. In addition to the grab sampling, solids were also collected during sluicing operations of the bottom ash and ESP ash. These samples were collected by grab sampling techniques through the duration of the sluicing and composited into one sample per test run.

Detailed descriptions of the solids sampling techniques are presented in Appendix B. Table 3-5 summarizes the solid sampling effort during this program. The table identifies the sample location or sample type, the collection method, the number of samples collected and analyzed, and the sample preservation techniques. Samples collected or submitted to support the QA/QC program for the solids are listed in Table 3-6. 
Table 3-1

Gaseous Sampling Summary

\begin{tabular}{|c|c|c|c|c|c|c|c|c|}
\hline \multirow[b]{2}{*}{ Test Parameter } & \multirow[b]{2}{*}{$\begin{array}{l}\text { Collection } \\
\text { Method" }\end{array}$} & \multicolumn{2}{|c|}{ ESP Inlet } & \multicolumn{2}{|c|}{ ESP Outlet } & \multicolumn{2}{|c|}{ Stack } & \multirow[b]{2}{*}{$\begin{array}{l}\text { Sample Handling } \\
\text { and Preservation }\end{array}$} \\
\hline & & $\begin{array}{l}\text { Samples } \\
\text { Collected }\end{array}$ & $\begin{array}{c}\text { Samples } \\
\text { Analyzed }\end{array}$ & $\begin{array}{l}\text { Samples } \\
\text { Collocted }\end{array}$ & $\begin{array}{c}\text { Samples } \\
\text { Analyzed }\end{array}$ & $\begin{array}{l}\text { Samples } \\
\text { Collected }\end{array}$ & $\begin{array}{l}\text { Samples } \\
\text { Analyzed }\end{array}$ & \\
\hline Aldehyde & EPA Method 0011 & 3 & 3 & 3 & 3 & 3 & 3 & Cooled to $<4{ }^{\circ} \mathrm{C}$ prior to analysis \\
\hline Volatile Organics & vost & 9 & 9 & 9 & 9 & 10 & 9 & Cooled to $<4^{\circ} \mathrm{C}$ prior to analysis \\
\hline Semivolatile Organics & Modified Method 5 & 3 & 3 & 3 & 3 & 3 & 3 & Cooled to $<4^{\circ} \mathrm{C}$ prior to analysis \\
\hline PCDD/PCDF & Method 23 & - & - & - & - & 3 & 3 & Cooled to $<4{ }^{\circ} \mathrm{C}$ prior to analysis \\
\hline Particle Size Distribution & Method 17 & 3 & 3 & 3 & 3 & 3 & 3 & No special handling \\
\hline Particulate Loading and Metals & Method 5/Method 29 & 3 & 3 & 3 & 3 & 3 & 3 & No special handling \\
\hline Mercury Speciation & Nick Bloom Method & 3 & 3 & 3 & 3 & 3 & 3 & No special handling \\
\hline Anions & Method 5 (Modified) & 3 & 3 & 3 & 3 & 3 & 3 & No special handling \\
\hline Ammonia/Cyanide & Method 5 (Modified) & 4 & 3 & 3 & 3 & 3 & 3 & Cooled to $<4^{\circ} \mathrm{C}$ prior to analysis \\
\hline Radionuclides & Method 5/17 & 3 & 3 & 3 & 3 & 3 & 3 & No special handling \\
\hline Extractable Metals & Method 5/17 & 3 & 3 & 3 & 3 & 3 & 3 & No special handling \\
\hline Size Fractionated Particulate - Metals & Method 17 & 3 & 3 & 3 & 3 & - & - & No special handling \\
\hline Chromium VI & Method $\mathrm{Cr}^{+6}$ & - & - & - & - & 3 & 3 & Analyzed on-site \\
\hline
\end{tabular}

- Detailed references are shown in Appendix B. 
Table 3-2

Number and Type of Gas Sample Analyses Plant Yates

\begin{tabular}{|c|c|c|c|c|c|c|}
\hline Parameter & $\begin{array}{c}\text { Field } \\
\text { Samples }\end{array}$ & $\begin{array}{l}\text { Matrix } \\
\text { Spike }\end{array}$ & $\begin{array}{c}\text { Audit } \\
\text { Samples }\end{array}$ & $\begin{array}{l}\text { Field } \\
\text { Blanks }\end{array}$ & $\underset{\text { Trip }}{\text { Blanks }}$ & $\begin{array}{c}\text { Total } \\
\text { Samples }\end{array}$ \\
\hline Moisture & 9 & - & - & - & - & 9 \\
\hline Particulate Loading & 9 & - & - & 3 & 1 & 13 \\
\hline Particle Size Distribution & 9 & - & - & - & - & 9 \\
\hline Chloride (Particulate) & 9 & 1 & - & 1 & - & 11 \\
\hline Fluoride (Particulate) & 9 & 1 & - & 1 & - & 11 \\
\hline Sulfate (Particulate) & 9 & 1 & - & 1 & - & 11 \\
\hline ICP Screen (Particulate) & 9 & 1 & 1 & 3 & 1 & 15 \\
\hline GFAAS Metals (Particulate) & 9 & 1 & 1 & 3 & 1 & 15 \\
\hline Mercury (Particulate) & 9 & 1 & 1 & 3 & 1 & 15 \\
\hline $\begin{array}{l}\text { Semivolatiles (Particulate \& Flue } \\
\text { Gas) }\end{array}$ & 9 & 2 & - & 3 & 1 & 15 \\
\hline PCDD/PCFD (Particulate) & 3 & - & - & 1 & 1 & 5 \\
\hline Radioactivity (Particulate) & 9 & - & - & 1 & - & 12 \\
\hline Ammonia (Flue gas) & 9 & 1 & 1 & 1 & - & 12 \\
\hline Cyanide (Flue gas) & 9 & 1 & .1 & 1 & - & 12 \\
\hline Chloride (Flue gas) & 9 & 1 & 1 & 1 & - & 12 \\
\hline Fluoride (Flue gas) & 9 & 1 & 1 & 1 & - & 12 \\
\hline Sulfate (Flue gas) & 9 & 1 & 1 & 1 & - & 12 \\
\hline ICP Screen (Flue gas) & 9 & 1 & 1 & 3 & 1 & 15 \\
\hline GFAAS Metals (Flue gas) & 9 & 1 & 1 & 3 & 1 & 15 \\
\hline Mercury (Flue gas) & 9 & 1 & 1 & 3 & 1 & 15 \\
\hline Aldehydes (Flue gas) & 9 & 2 & - & 3 & 2 & 16 \\
\hline Volatile Organics (Flue gas) & 27 & - & - & 9 & 1 & 37 \\
\hline PCDD/PCDF (Flue gas) & 3 & - & - & 1 & 1 & 5 \\
\hline
\end{tabular}

- GFAAS metals include As, $\mathrm{Cd}, \mathrm{Pb}$, and Se. 
Table 3-3

Liquids Sampling Summary

\begin{tabular}{|c|c|c|c|c|c|c|c|c|c|c|c|c|c|c|c|}
\hline \multirow[b]{2}{*}{ Tex Parameter } & \multirow{2}{*}{$\begin{array}{c}\text { Colloction } \\
\text { Method }\end{array}$} & \multicolumn{2}{|c|}{ Ash Pond } & \multicolumn{2}{|c|}{$\begin{array}{l}\text { Gypoum } \\
\text { Pond Wafer }\end{array}$} & \multicolumn{2}{|c|}{$\begin{array}{l}\text { Aeh Sluice } \\
\text { Filtrates }\end{array}$} & \multicolumn{2}{|c|}{$\begin{array}{l}\text { JBR } \\
\text { Slurry }\end{array}$} & \multicolumn{2}{|c|}{$\begin{array}{l}\text { Limextone Slurry } \\
\text { Filtrate }\end{array}$} & \multicolumn{2}{|c|}{$\begin{array}{l}\text { Cool Pile } \\
\text { Run-Off }\end{array}$} & \multicolumn{2}{|c|}{$\begin{array}{l}\text { Condeaser } \\
\text { Inlet }\end{array}$} \\
\hline & & Collected & Anslyzed & Collected & Analyzed & Collected & Analyzed & Collected & Anslyzed & Collected & Analyzed & Collected & Analyzed & Collocted & Analyzed \\
\hline Formaldehyde & Grab & 3 & 3 & 3 & 3 & 6 & 6 & 3 & 3 & 3 & 3 & 2 & 2 & 3 & 3 \\
\hline Volatile Organics & Grab & 3 & 3 & 3 & 2 & 6 & 6 & 3 & 3 & 3 & 3 & 2 & 1 & 3 & 3 \\
\hline Semivolatile Organics & Grab & 3 & 3 & 3 & 2 & 8 & 6 & 4 & 3 & 4 & 3 & 2 & 1 & 4 & 3 \\
\hline Metals, Soluble & Grab & 3 & 3 & 3 & 3 & 6 & 6 & 3 & 3 & 3 & 3 & - & - & 3 & 3 \\
\hline Anions & Grab & 3 & 3 & 3 & 3 & 6 & 6 & 3 & 3 & 3 & 3 & - & - & 3 & 3 \\
\hline Ammonia & Grab & 3 & 3 & 3 & 3 & 6 & 6 & 3 & 3 & 3 & 3 & - & - & 3 & 3 \\
\hline Cyanido & Grab & 3 & 3 & 3 & 3 & 6 & 6 & 3 & 3 & 3 & 3 & - & - & 3 & 3 \\
\hline
\end{tabular}


Table 3-4

Liquid Stream QA/QC Samples

\begin{tabular}{lcccccc}
\multicolumn{1}{c}{ Parameter } & $\begin{array}{c}\text { Field } \\
\text { Samples }\end{array}$ & $\begin{array}{c}\text { Field } \\
\text { Dups }\end{array}$ & $\begin{array}{c}\text { Matrix } \\
\text { Spike }\end{array}$ & $\begin{array}{c}\text { Audit } \\
\text { Samples }\end{array}$ & $\begin{array}{c}\text { Trip } \\
\text { Blanks }\end{array}$ & $\begin{array}{c}\text { Total } \\
\text { Samples }\end{array}$ \\
\hline Chloride & 21 & 7 & 3 & 1 & - & 32 \\
Fluoride & 21 & 7 & 3 & 1 & -- & 32 \\
Phosphate & 21 & 7 & 3 & 1 & -- & 32 \\
Sulfate & 21 & 7 & 3 & 1 & -- & 32 \\
Sulfite & 3 & 1 & - & -- & -- & 4 \\
Ammonia & 21 & 7 & 3 & 1 & -- & 32 \\
Cyanide & 21 & 7 & 3 & 1 & -- & 32 \\
ICP Screen (Soluble) & 30 & 10 & 4 & 2 & -- & 46 \\
Arsenic & 30 & 10 & 4 & 2 & -- & 46 \\
Cadmium & 30 & 10 & 4 & 2 & -- & 46 \\
Lead & 30 & 10 & 4 & 2 & -- & 46 \\
Mercury & 30 & 10 & 4 & 2 & -- & 46 \\
Selenium & 30 & 10 & 4 & 2 & - & 46 \\
Aldehydes & 23 & 7 & 6 & - & - & 36 \\
Semivolatile Organics & 22 & 7 & 6 & - & - & 35 \\
Volatile Organics & 22 & 7 & - & - & 1 & 30
\end{tabular}




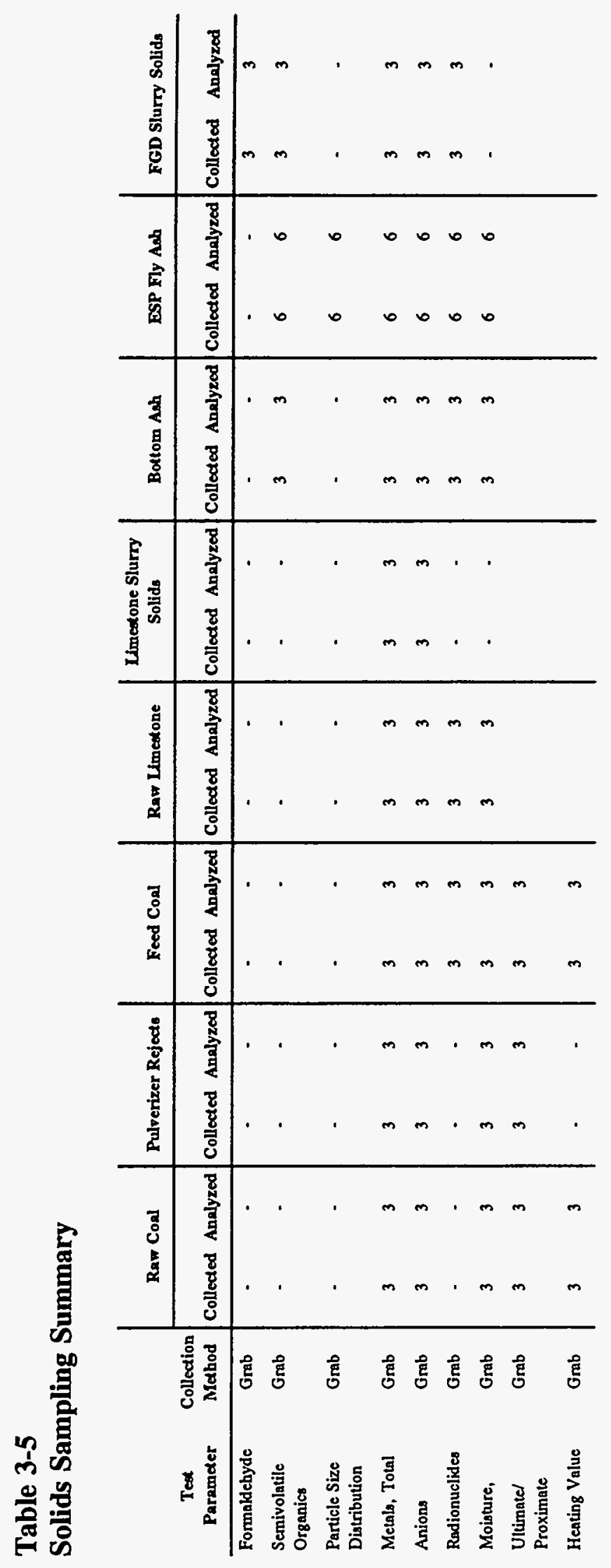




\section{Table 3-6}

Solid Stream QA/QC Samples

\begin{tabular}{|c|c|c|c|c|c|}
\hline Parameter & $\begin{array}{c}\text { Field } \\
\text { Samples }\end{array}$ & $\begin{array}{l}\text { Field } \\
\text { Dups }\end{array}$ & $\begin{array}{r}\text { Matrix } \\
\text { Spike }\end{array}$ & $\begin{array}{c}\text { Audit } \\
\text { Samples }\end{array}$ & $\begin{array}{c}\text { Total } \\
\text { Samples }\end{array}$ \\
\hline Moisture & 12 & 4 & - & -- & 16 \\
\hline Particle Size Distribution & 6 & 2 & - & - & 8 \\
\hline Ultimate/Proximate & 9 & 3 & - & 1 & 13 \\
\hline Carbon & 12 & 4 & -- & - & 16 \\
\hline Sulfur & 9 & 3 & - & -- & 12 \\
\hline Heating Value & 6 & 2 & -- & 1 & 9 \\
\hline Chloride & 30 & 10 & 4 & 2 & 46 \\
\hline Fluoride & 30 & 10 & 4 & 2 & 46 \\
\hline Phosphate (Phosphorus) & 30 & 10 & 4 & 2 & 46 \\
\hline Sulfate/Sulfite & 3 & 1 & 1 & - & 5 \\
\hline ICP Screen & 30 & 10 & 4 & 2 & 46 \\
\hline Metals & 9 & 3 & - & 1 & 13 \\
\hline Arsenic & 30 & 10 & 4 & 2 & 46 \\
\hline Cadmium & 30 & 10 & 4 & 2 & 46 \\
\hline Lead & 30 & 10 & 4 & 2 & 46 \\
\hline Mercury & 30 & 10 & 4 & 2 & 46 \\
\hline Selenium & 30 & 10 & 4 & 2 & 46 \\
\hline Aldehydes & 3 & 1 & 2 & - & 6 \\
\hline Semivolatile Organics & 12 & 4 & 4 & - & 20 \\
\hline Radioactivity & 15 & 4 & - & - & 19 \\
\hline
\end{tabular}




\section{Process Stream Flow Rates}

Table 3-7 presents average process stream flow rates for Phase II of the testing. The methods used to measure and equations used to calculate these flow rates are described in Table 3-8. These flow rates were used in the material balance calculations, described in Section 6.2. Those flow rates measured directly are presented on a run-by-run basis. Others are presented as Phase II test period averages, since they are calculated from averaged data; i.e., the dry feed coal flow rate is calculated from the average wet raw coal flow rate and average water content. Gaseous flow rates were measured at three different locations at the site: ESP inlet, outlet, and the stack. The actual measurements from these locations averaged 293,000 dscfm $\pm<3 \%$, well within the expected limits of the measurement technique. However, given the various physical properties of the three locations, engineering judgment would indicate that the measurements from the stack were the most accurate of the three and, since the stack measurements also reflect ultimate emissions, the measurements from this location should be the reference point for consistency in the treatment of data and determination of internal mass flow rates. An average of 4,000 scfm of oxidation air was added to the flue gas as it passes through the JBR. Therefore, the rate of gas that enters and exits the ESP is that amount measured at the stack minus (-) the oxidation air added at the JBR. The stack flow rate was $288,000 \mathrm{dscfm}-4,000 \mathrm{dscfm}$ (oxidation air) $=284,000$ dscfm as the flow rate for the INLET AND OUTLET of the ESP. The ESP operates at negative pressure; therefore, these numbers represent maximum rates, since any inleakage of gas would be measured at the stack.

Coal flow rates were determined from data obtained from the boiler control room. Raw coal is loaded into buckets which hold nominally 500 pounds of coal and a counter records each time a bucket is dumped. These readings, obtained over a 24-hour period, provide the basis for the coal feed rate. The dry feed coal rate was determined from the raw coal rate (corrected for moisture) less the pulverizer rejects. This method yields an average feed coal rate for the material balance period of $80,200 \mathrm{lb} / \mathrm{hr}$. As a consistency check, the full-load unit heat rate was used to calculate a coal feed rate of $86,000 \mathrm{lb} / \mathrm{hr}$, approximately $7 \%$ higher than measured. The calculated coal feed rate falls within the $95 \%$ confidence interval of the measured coal rate shown in Table 3-7. The bottom ash flow rate was determined by subtracting the ash flow rate measured at the ESP inlet from the ash contained in the feed coal.

Other flow rates used in mass balance calculations were measured by process instrumentation and are discussed in Section 6. Uncertainties for these calculated flow rates, expressed as $95 \%$ confidence intervals, were calculated using the method detailed in Appendix F.

\section{References}

1. Electric Power Research Institute. Field Chemical Emissions Monitoring (FCEM) Generic Sampling and Analytical Plan. Draft Report. Palo Alto, CA (May 1994). 
Sample Collection

Table 3-7

Process Flow Rates During Phase $\mathbf{I}$ of Testing

\begin{tabular}{|c|c|c|c|c|c|}
\hline & $\begin{array}{l}\text { Run 1 } \\
6 / 25 / 93\end{array}$ & $\begin{array}{c}\text { Run } 2 \\
6 / 26 / 93\end{array}$ & $\begin{array}{l}\text { Run 3 } \\
6 / 27 / 93\end{array}$ & Mean & $\begin{array}{l}\text { Std. } \\
\text { Dev. }\end{array}$ \\
\hline Raw Coal Moisture (\%) & 12.7 & 11.2 & 11.2 & 11.7 & 0.9 \\
\hline Feed Coal Ash (\%, dry) & 10.5 & 11.3 & 11.6 & 11.1 & 0.6 \\
\hline \multicolumn{6}{|c|}{ Measured Flow Rates and Grain Loadings: } \\
\hline Raw Coal (lb/hr, wet) & 90,200 & 90,700 & 92,000 & 91,000 & $3,200^{4}$ \\
\hline Coal Pulverizer Rejects $(\mathrm{lb} / \mathrm{hr})$ & 110 & 130 & 110 & 120 & $15^{b}$ \\
\hline ESP Ińlet Loäđing (gr/dscf) & 3.38 & 3.67 & 3.88 & 3.64 & 0.25 \\
\hline ESP Outlet Loading, (gr/dscf) & 0.0598 & 0.0489 & 0.0644 & 0.0577 & 0.0080 \\
\hline Stack Gas (dscfm) & 290,000 & 287,000 & 285,000 & 288,000 & 2,500 \\
\hline Stack Loading (gr/dscf) & 0.0078 & 0.0048 & 0.0051 & 0.0059 & 0.0017 \\
\hline Calculated Flow Rates: & & & . & & $95 \%$ CI \\
\hline Feed Coal (lb/hr, dry) & - & - & - & 80,200 & 8,200 \\
\hline ESP Inlet Gas (dscfm) ${ }^{c}$ & - & - & - & 284,000 & 6,200 \\
\hline ESP Outlet Gas (dscfin) ${ }^{c}$ & - & - & - & 284,000 & 6,200 \\
\hline ESP Inlet Ash, $(\mathrm{lb} / \mathrm{hr})^{\mathrm{d}}$ & - & - & - & 8,870 & 1,500 \\
\hline ESP Oùtlet Ash, (lb/hr) & - & - & - & 140 & 49 \\
\hline ESP Collected Ash (lb/hr) & - & - & - & 8,730 & 2,500 \\
\hline Bottom Ash $(\mathrm{lb} / \mathrm{hr})^{e}$ & - & - & - & 440 & 1,100 \\
\hline \multicolumn{6}{|l|}{ Particulate Emissions: } \\
\hline Emissions $(\mathrm{lb} / \mathrm{hr})$ & - & - & - & 14.6 & 10.4 \\
\hline Emissions $\left(\mathrm{lb} / 10^{6} \mathrm{Btu}\right)$ & - & - & - & 0.014 & 0.009 \\
\hline
\end{tabular}

- Standard deviation calculated from 71 hourly values measured over the three days of testing.

${ }^{b}$ Standard deviation calculated from 9 values measured over the three days of testing.

- The stack gas flow rate was considered to be the most accurate measurement of the gas flow rate; the ESP inlet and outlet flow rates were assumed equal to the stack gas less the JBR oxidation air (4,100 scfm).

${ }^{d}$ Includes $4.5 \%$ unburned carbon.

' Includes $2.3 \%$ unburned carbon. 


\section{Table 3-8}

Flow Rate Calculations

\section{Raw Coal:}

Counting of $500 \mathrm{lb}$ (nominal) buckets

\section{Pulverizer Rejects:}

Measured by bucket-and-stopwatch method

\section{Stack Gas:}

Measured by Pitot tube traverse

Feed Coal, dry basis:

$91,000 \mathrm{lb} / \mathrm{hr}$ Raw Coal $-91,000 \mathrm{lb} / \mathrm{hr} * 0.117 \mathrm{lb}$ Water/lb coal $-120 \mathrm{lb} / \mathrm{hr}$ Rejects $=$ $80,200 \mathrm{lb} / \mathrm{hr}$

\section{ESP Inlet and ESP Outlet Flue Gas:}

$288,000 \mathrm{dscfm}$ Stack Gas - 4,100 scfm Oxidation Air $=284,000 \mathrm{dscfm}$

\section{ESP Inlet Ash:}

$284,000 \mathrm{dscfm} * 3.64 \mathrm{gr} / \mathrm{dscf} * 0.000143 \mathrm{lb} / \mathrm{gr} * 60 \mathrm{~m} / \mathrm{hr}=8,870 \mathrm{lb} / \mathrm{hr}$

\section{ESP Outlet Ash:}

$284,000 \mathrm{dscfm} * 0.0577 \mathrm{gr} / \mathrm{dscf} * 0.000143 \mathrm{lb} / \mathrm{gr} * 60 \mathrm{~m} / \mathrm{hr}=140 \mathrm{lb} / \mathrm{hr}$

\section{ESP Collected Ash:}

8,870 lb/hr ESP Inlet Ash - $140 \mathrm{lb} / \mathrm{hr}$ ESP Outlet Ash = 8,730 lb/hr

\section{Bottom Ash:}

$[80,200 \mathrm{lb} / \mathrm{hr}$ Dry Feed Coal * $0.111 \mathrm{lb}$ ash/lb coal - $(8,870 \mathrm{lb} / \mathrm{hr}$ ESP Inlet Ash- 8,870 lb/hr $* 0.045 \mathrm{lb}$ Carbon/1b Ash]/(1-0.023) lb Carbon-Free Bottom Ash/lb Bottom Ash $=440 \mathrm{lb} / \mathrm{hr}$

\section{Stack Emissions:}

$288,000 \mathrm{dscfm}$ Stack Gas * $0.0059 \mathrm{gr} / \mathrm{dscf} * 0.000143 \mathrm{lb} / \mathrm{gr} * 60 \mathrm{~m} / \mathrm{hr}=14.6 \mathrm{lb} / \mathrm{hr}$

Stack Emission Factor:

$14.6 \mathrm{lb} / \mathrm{hr} /(80,200 \mathrm{lb} / \mathrm{hr}$ Feed coal $* 12,700 \mathrm{Btu} / \mathrm{lb}) * 1,000,000=0.014 \mathrm{lb} / 10^{6} \mathrm{Btu}$ 


\section{4}

\section{SAMPLE PREPARATION AND ANALYSIS METHODS}

Preparation procedures and chemical analysis methods for gases are shown in Figures 4-1 through 4-12.

Procedures for liquid sample preparation and analysis are shown in Figure 4-13. Procedures for coal are shown in Figure 4-14 and Table 4-1. Procedures for ash are in Figure 4-15. Procedures for limestone and FGD solids are shown in Figure 4-16.

Appendix E of this technical note contains descriptions of and references for the methods used for this project. 


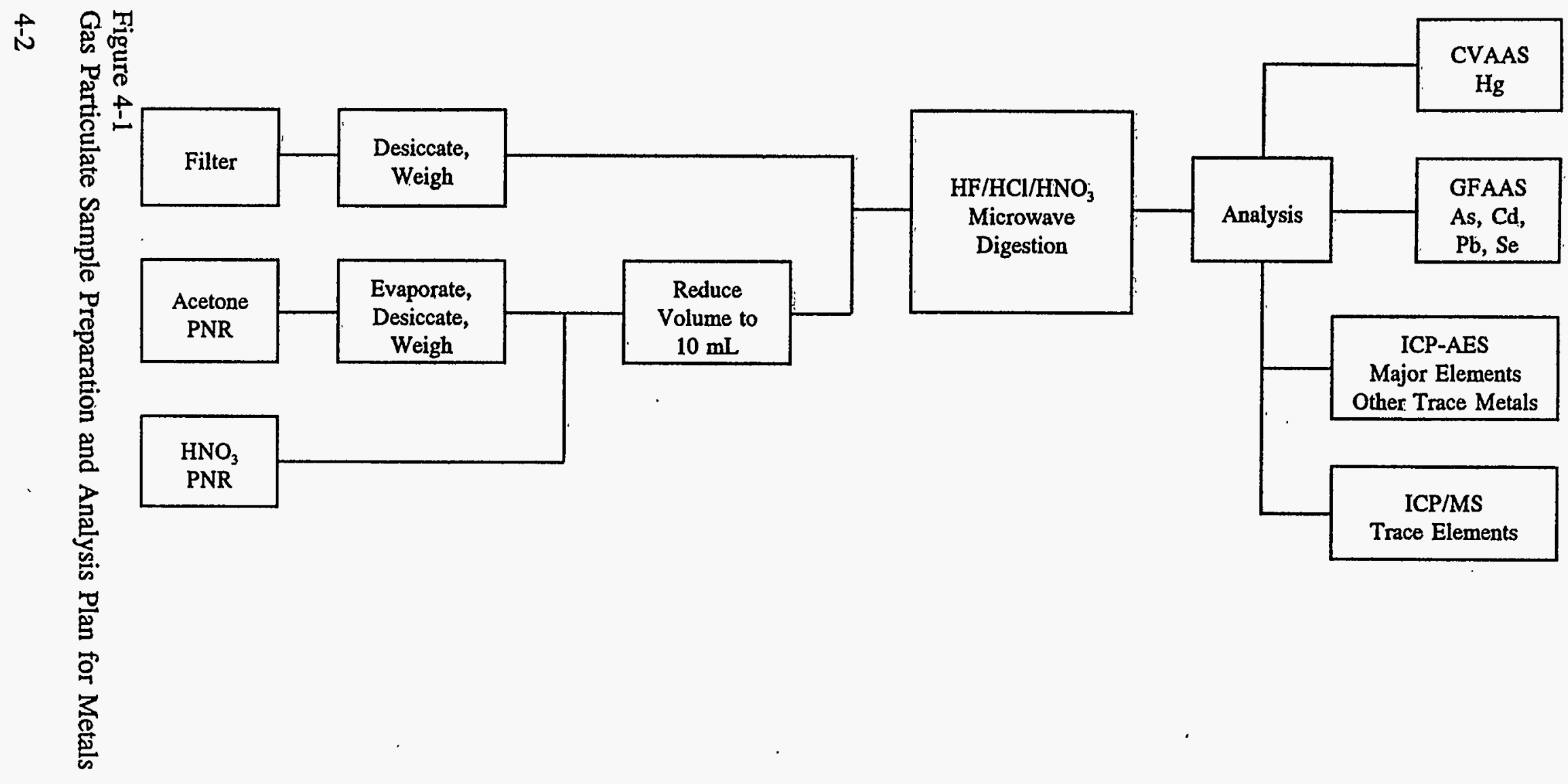




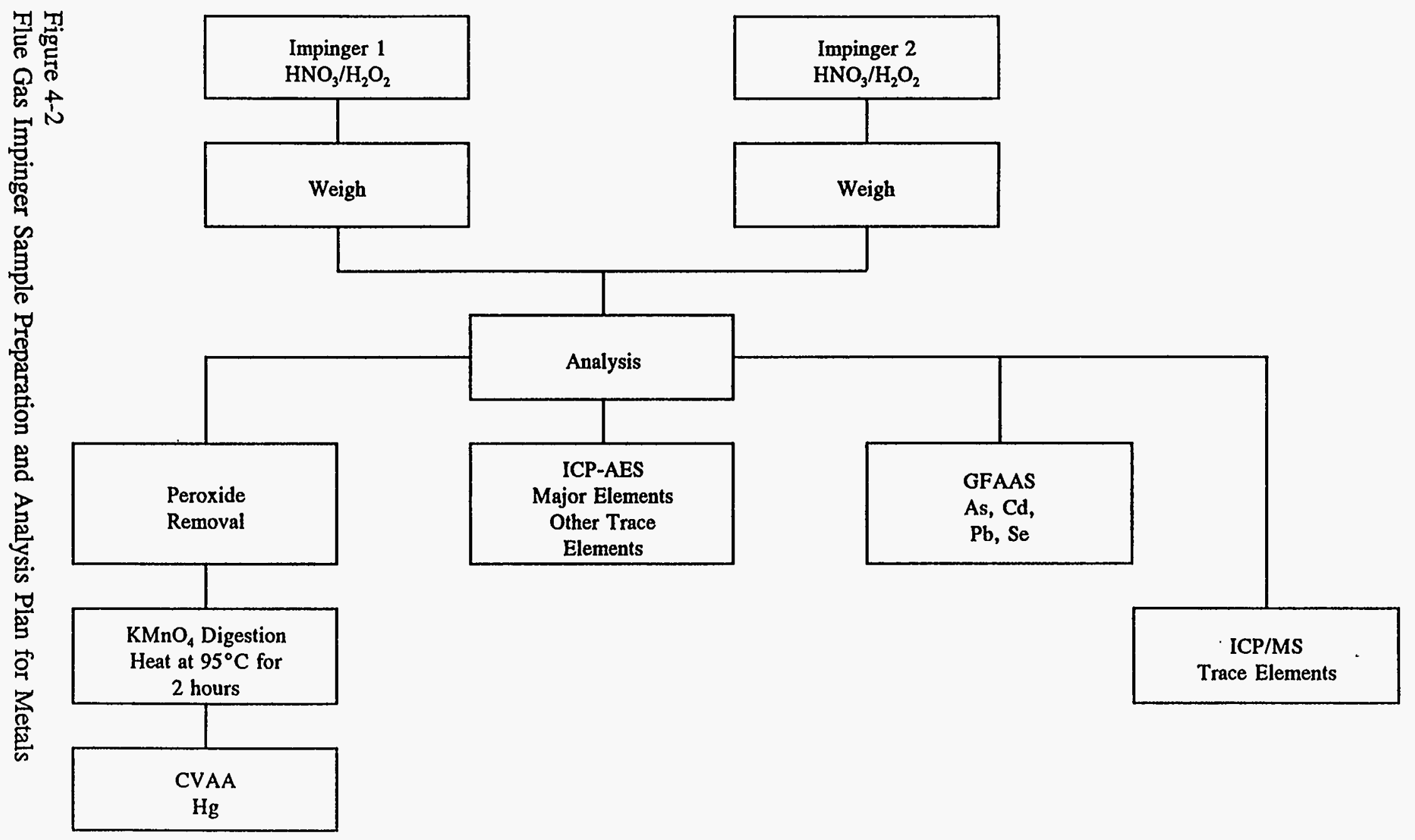




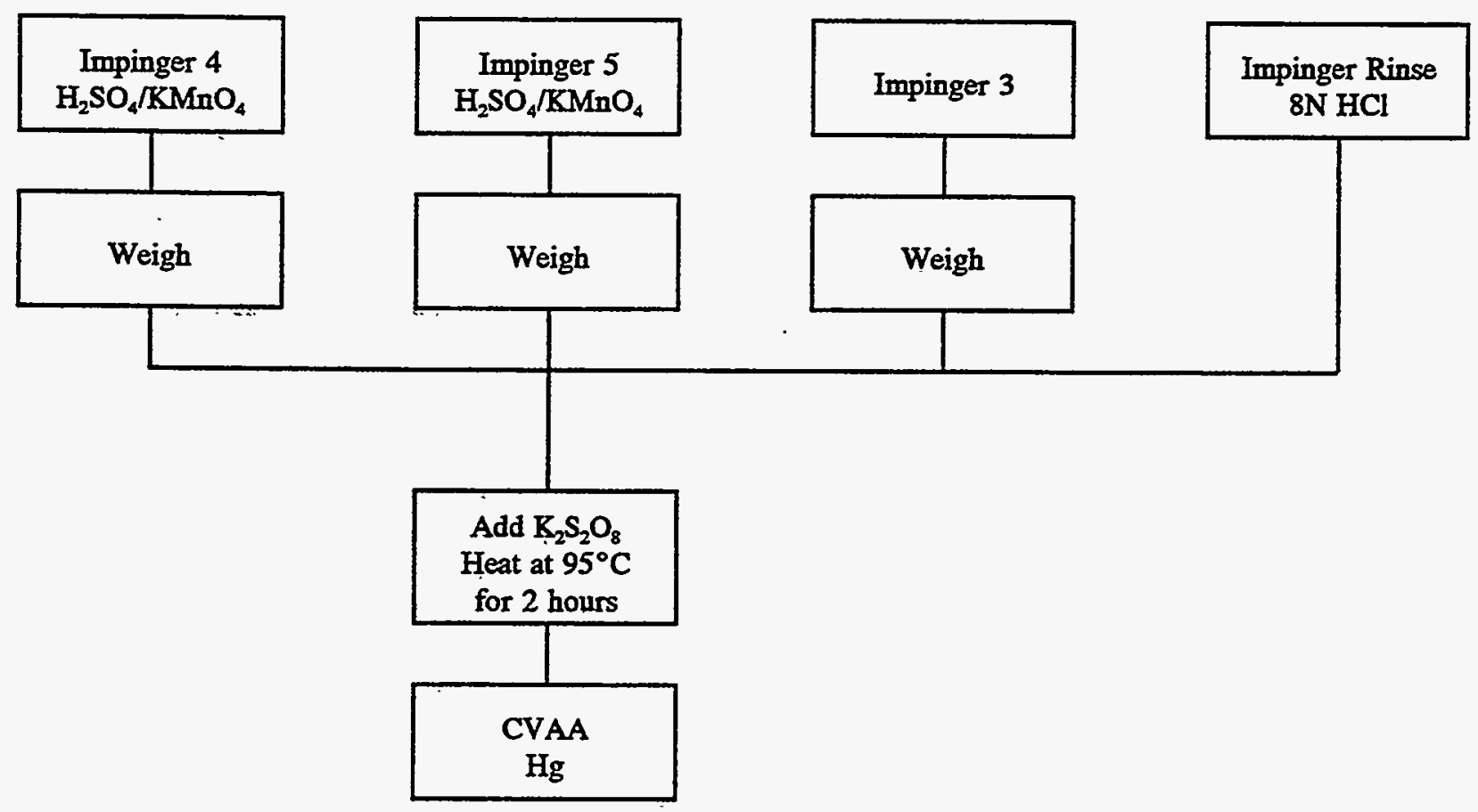

Figure 4-3

Flue Gas Impinger Sample Preparation and Analysis Plan for Mercury 


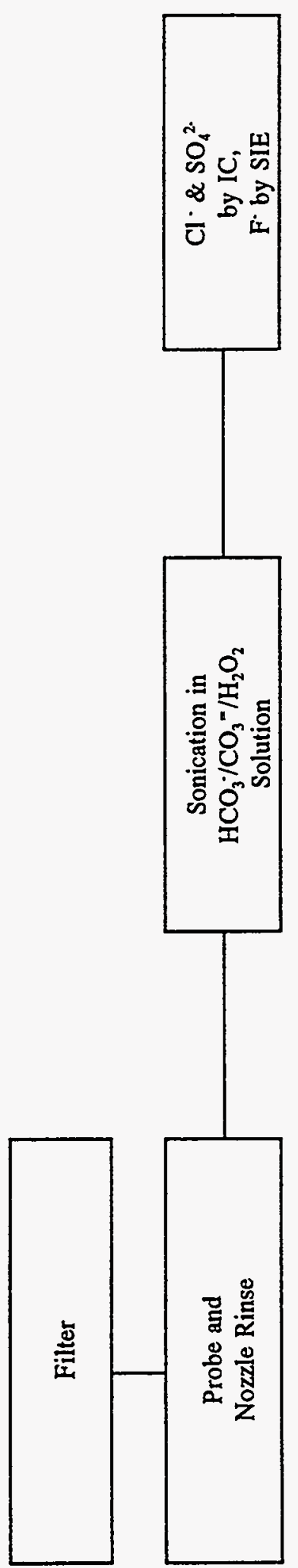

Figure 4-4

Gas Particulate Sample Preparation and Analysis Plan for Anions 


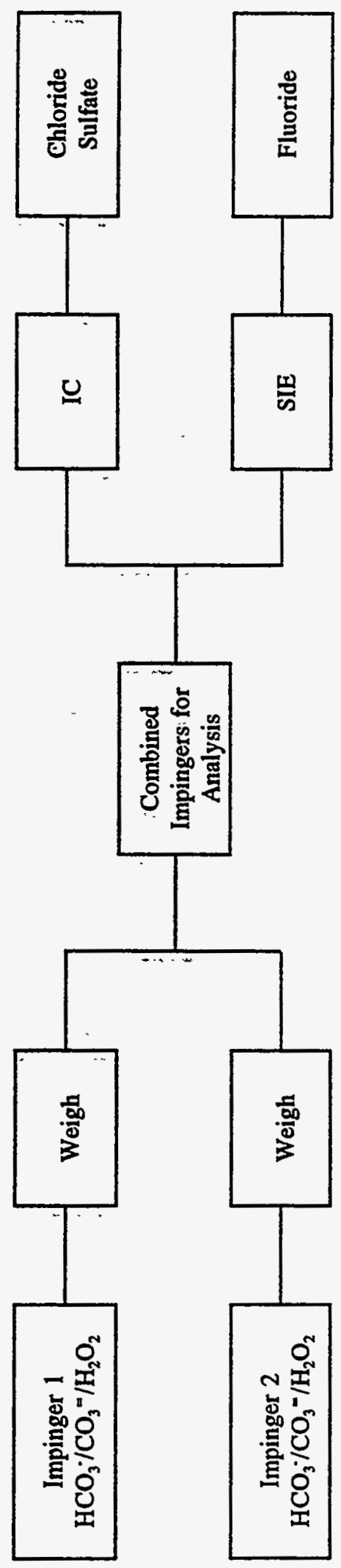

Figure 4-5

Flue Gas Impinger Sample Preparation and Analysis Plan for Anions 


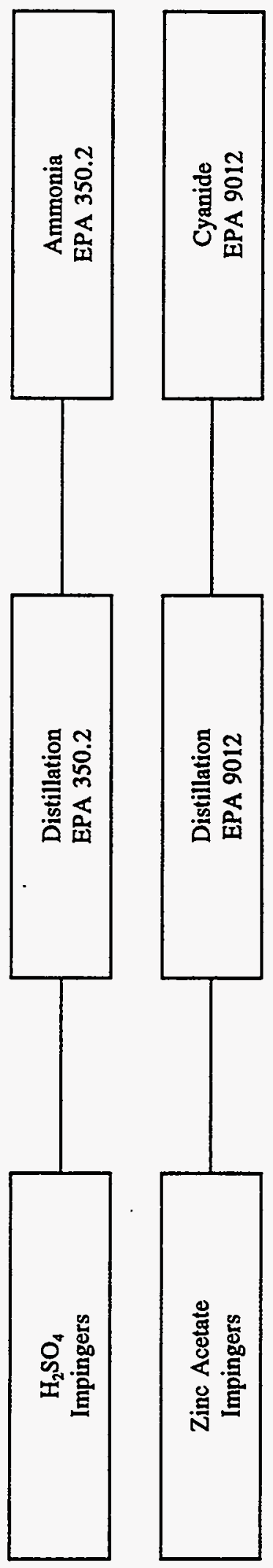

Figure 4-6

Flue Gas Impinger Sample Preparation and Analysis Plan for Ammonia and Cyanide 


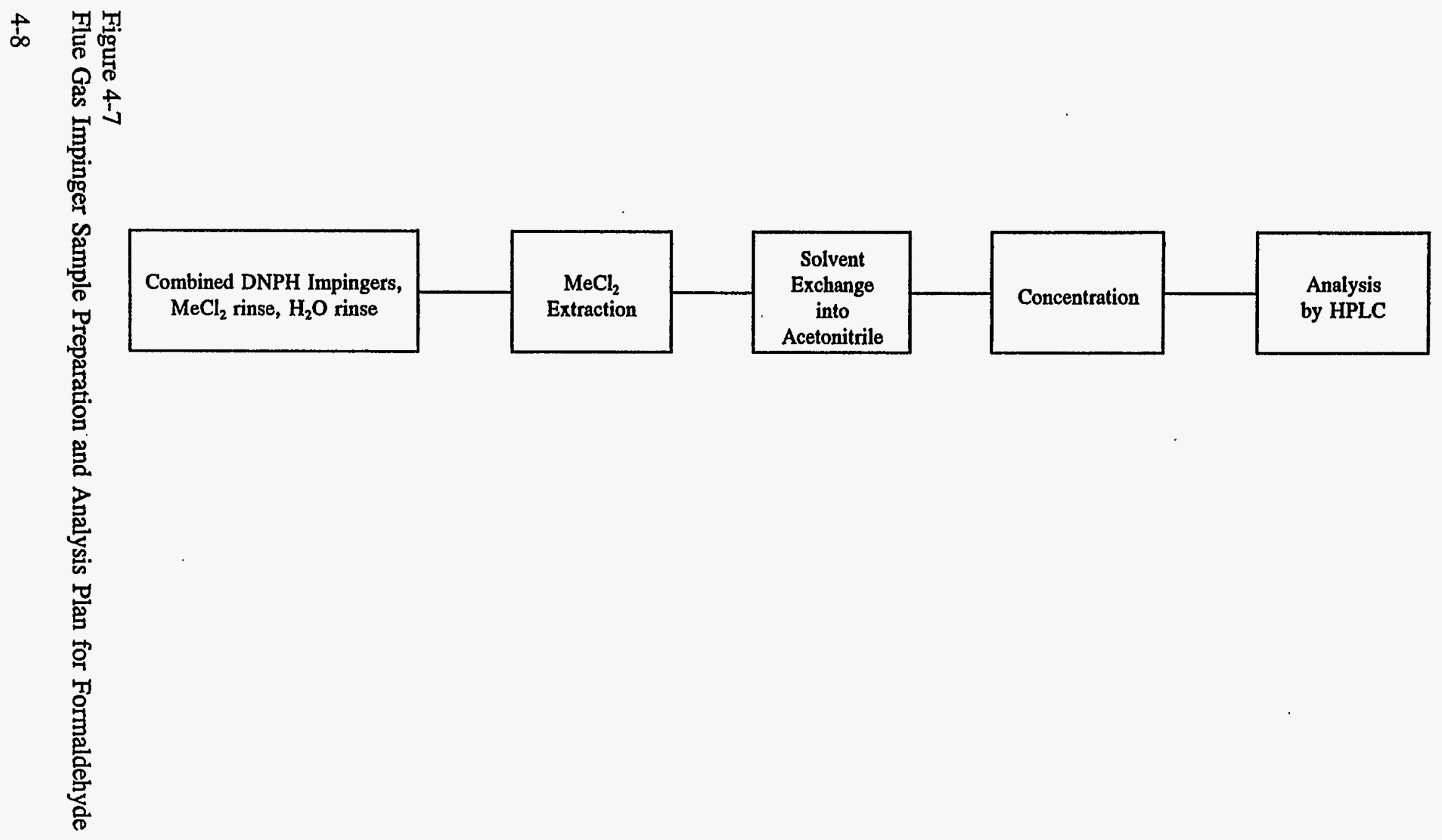




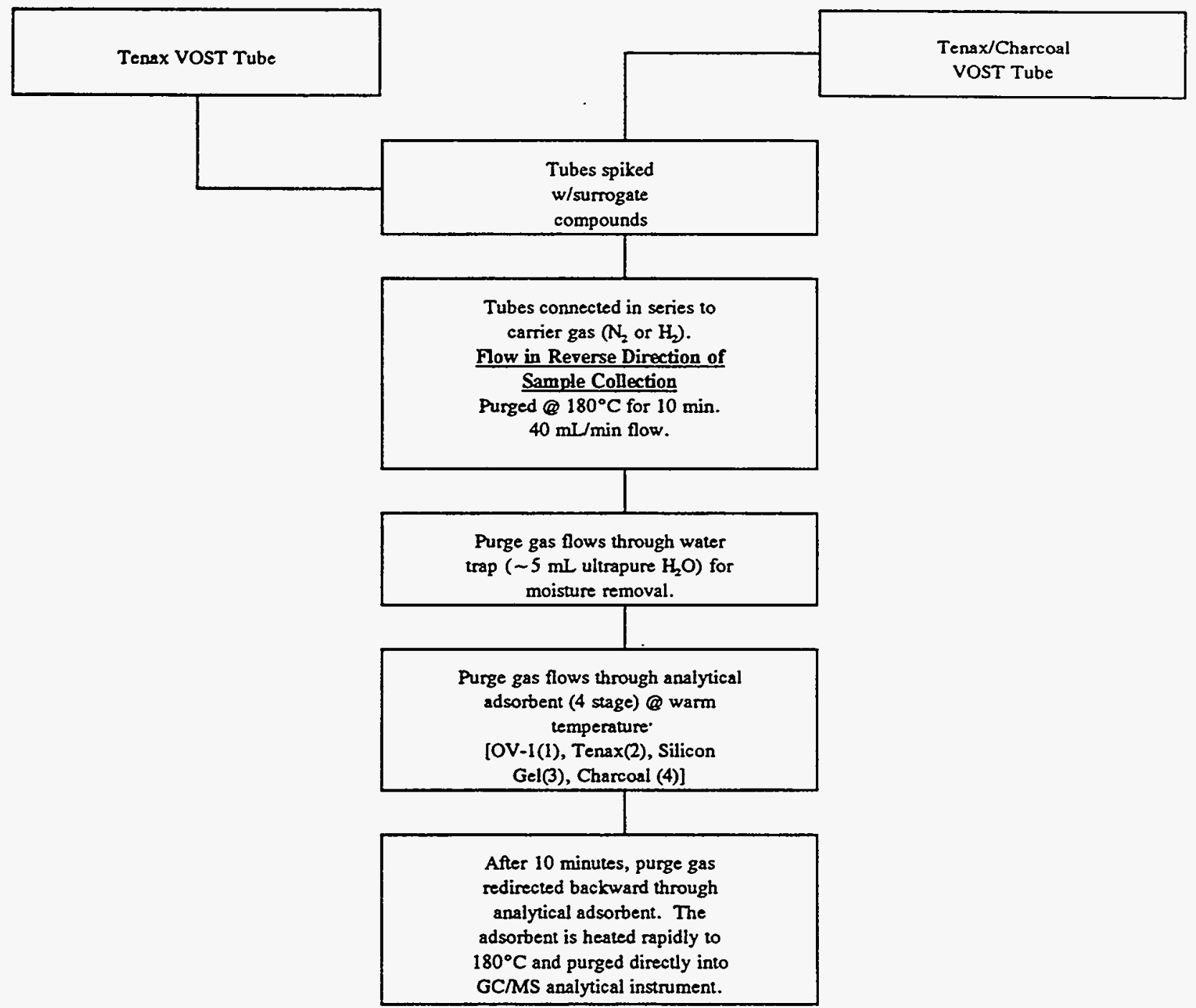

Figure 4-8

VOST Sorbent Sample Preparation and Analysis Plan for Volatile Organic Compounds 


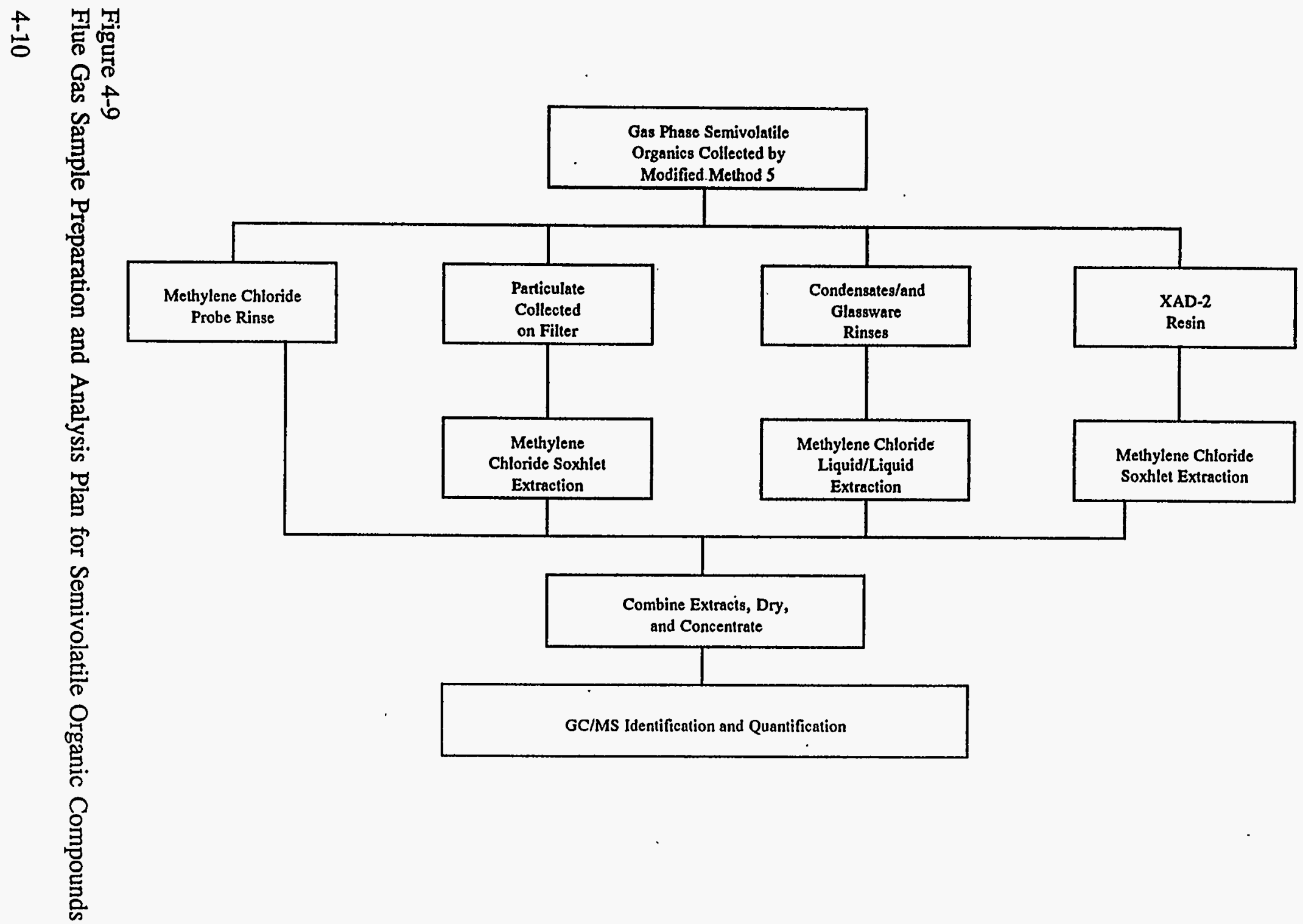




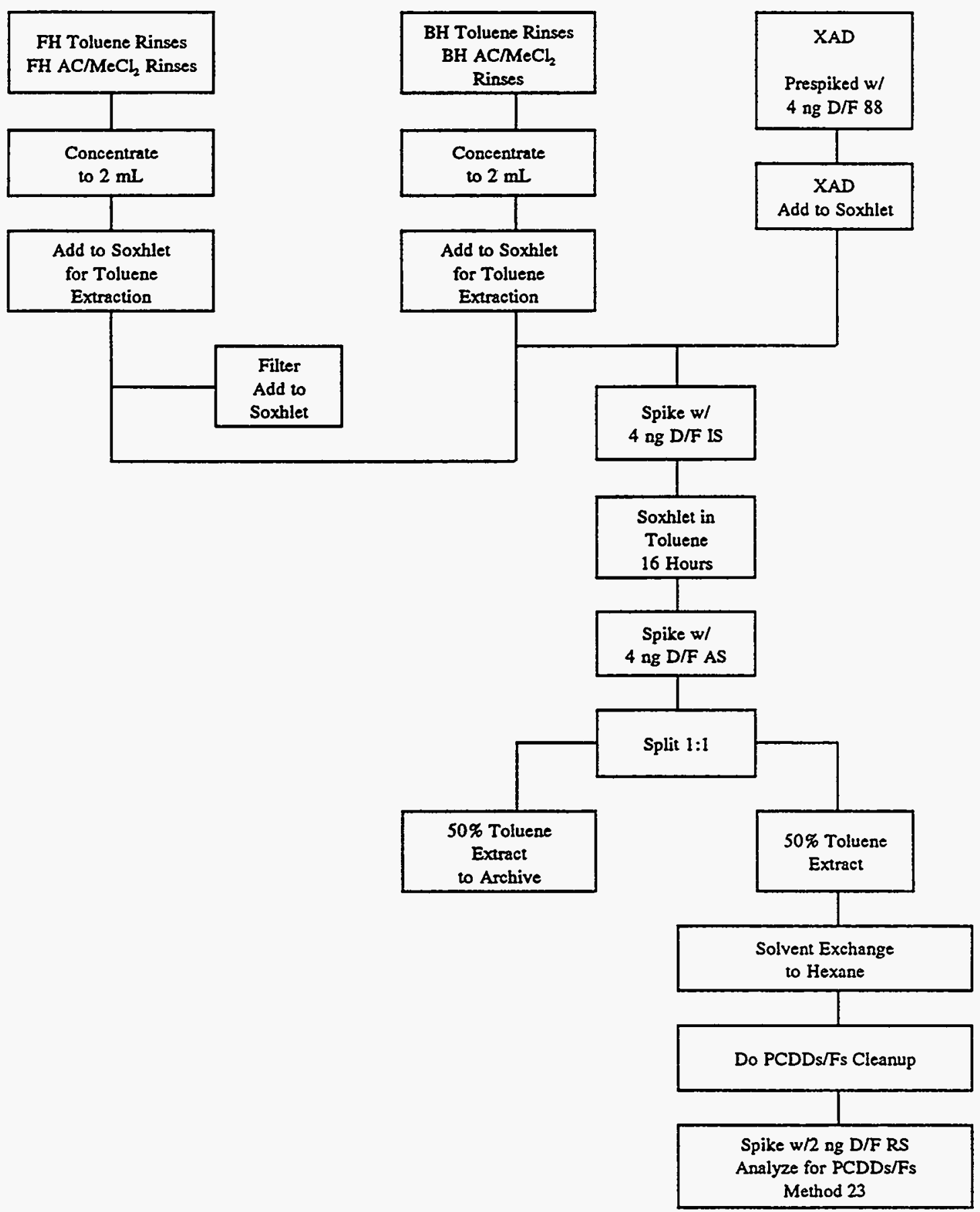

Figure 4-10

Flue Gas Sample Preparation and Analysis Plan for Dioxins and Furans 


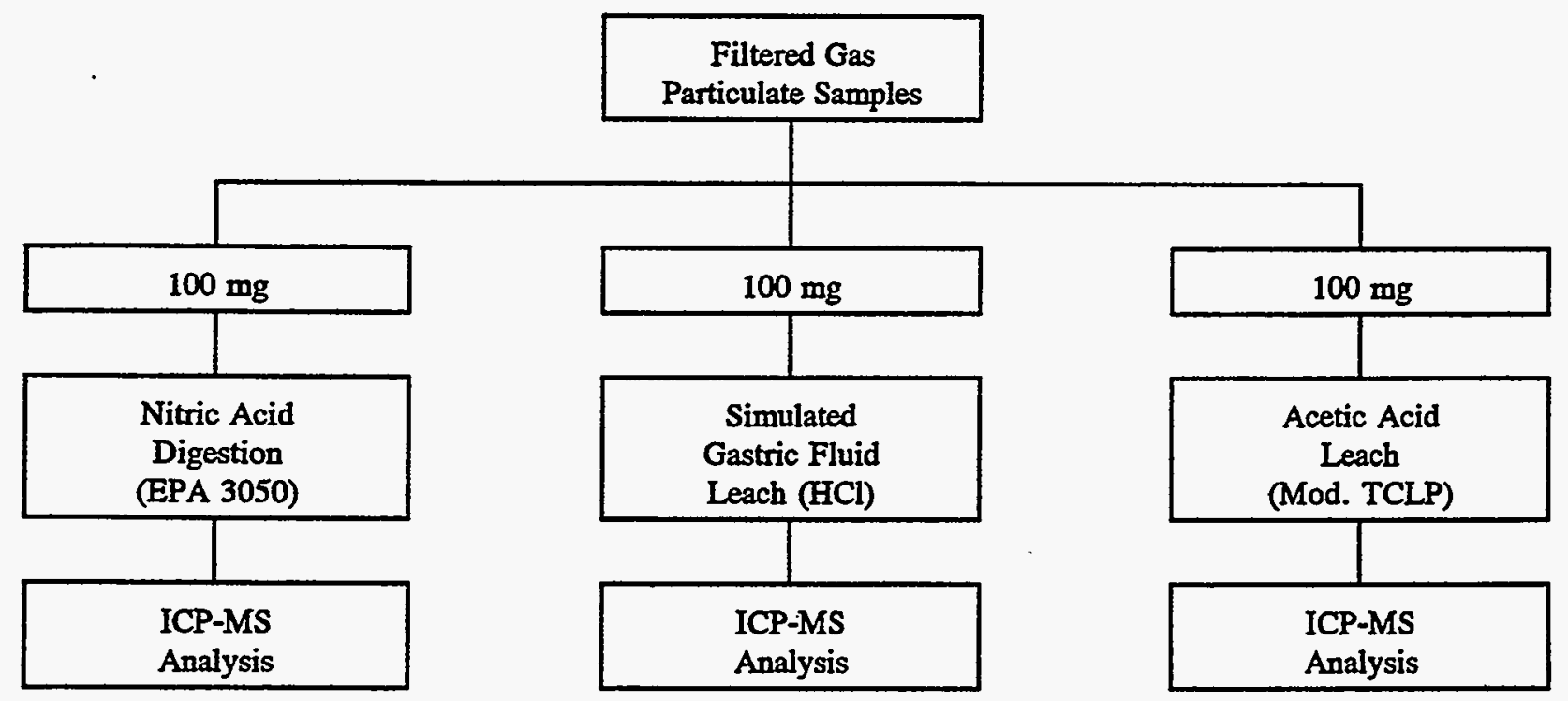

Figure 4-11

Gas Particulate Sample Preparation and Analysis Plan for Extractable Metals 


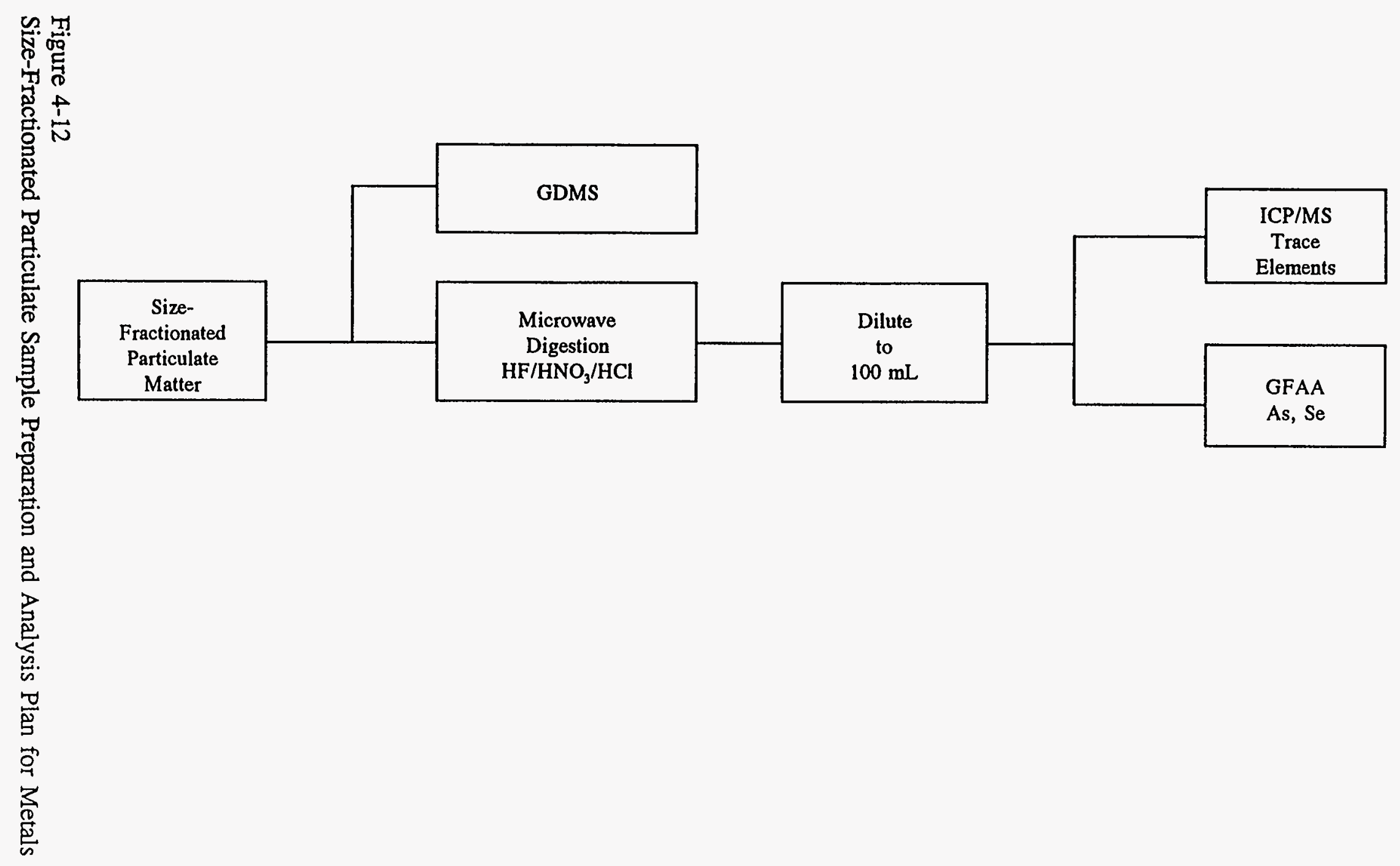

$\stackrel{f}{\stackrel{\vec{\omega}}{*}}$ 


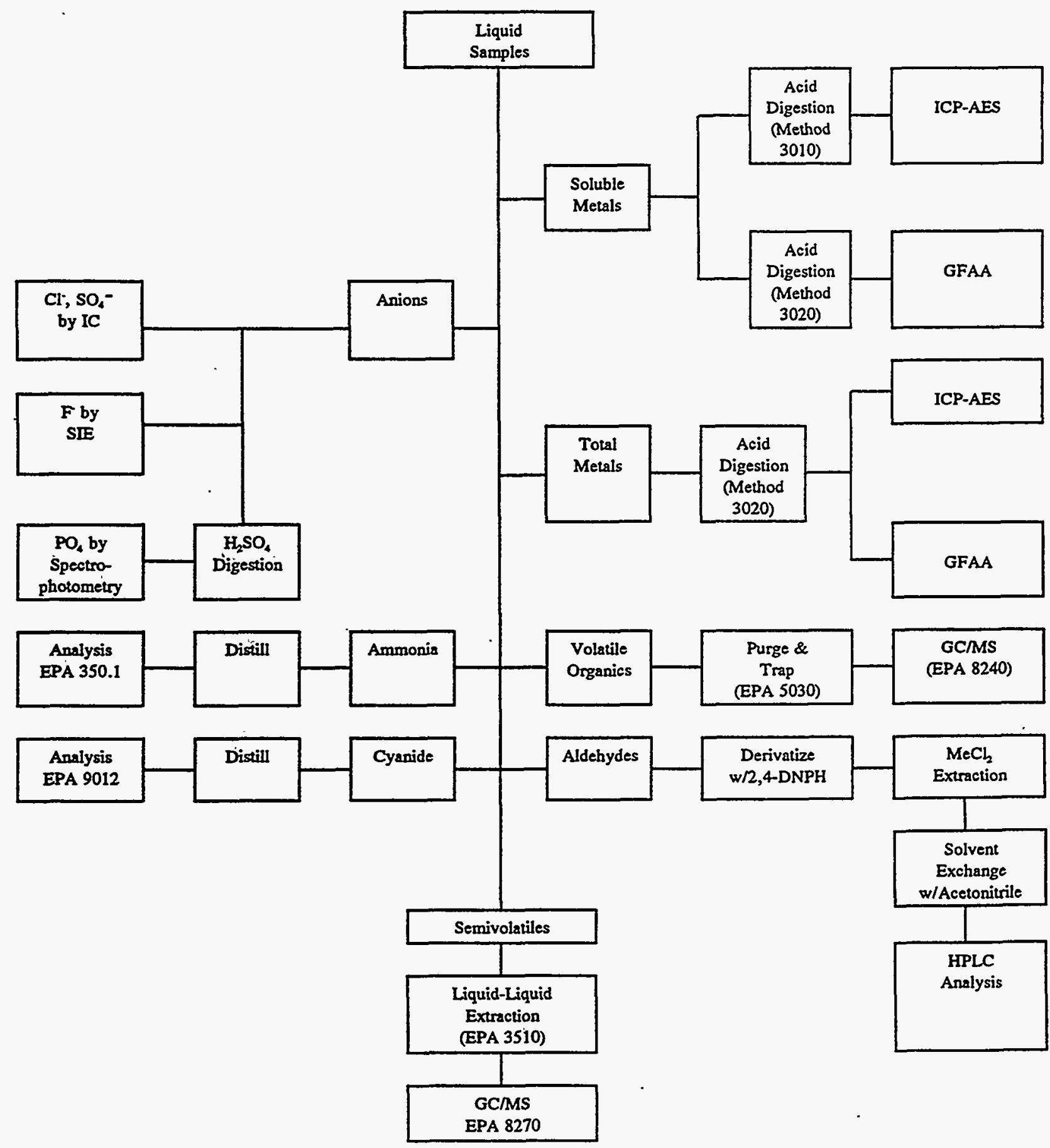

Figure 4-13

Liquid Sample Preparation and Analysis Plan 


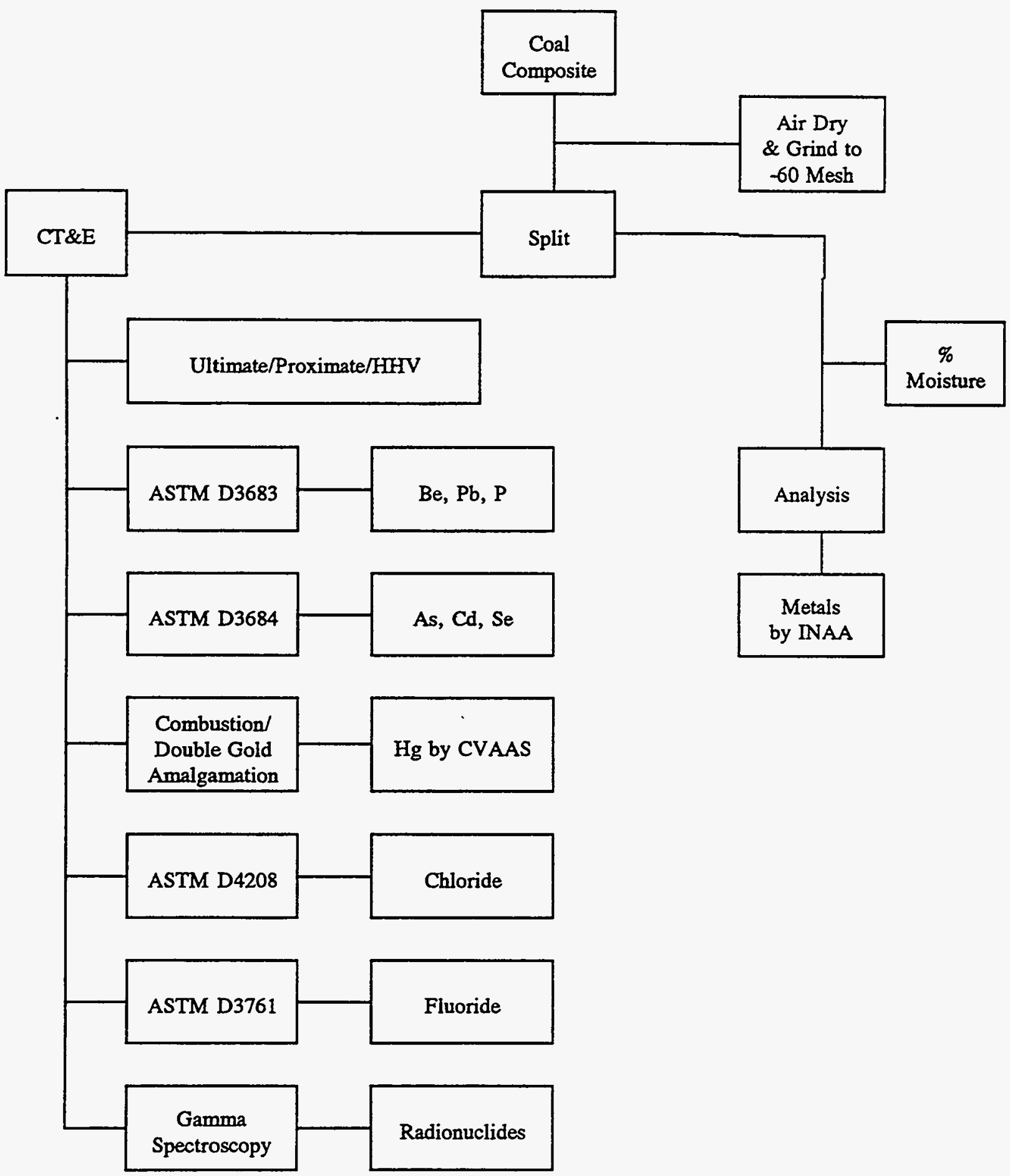

Figure 4-14

Coal Sample Preparation and Analysis Plan 
Table 4-1

Summary of Coal Analytical Methods

\section{Chemical Substance}

Ultimate/Proximate/Higher Heating Value

Moisture

Ash

Carbon, Hydrogen, Nitrogen

Sulfur

Volatile Matter

Heating Value

Chlorine in Coal

Fluorine in Coal

Radionuclides
Analytical Method

ASTM D3173

ASTM D3174

ASTM D5373

ASTM D4239

ASTM D3175

ASTM D2015

ASTM D4208

ASTM D3761

Gamma Emission Spectroscopy

ASTM $=$ American Society for Testing and Materials. 


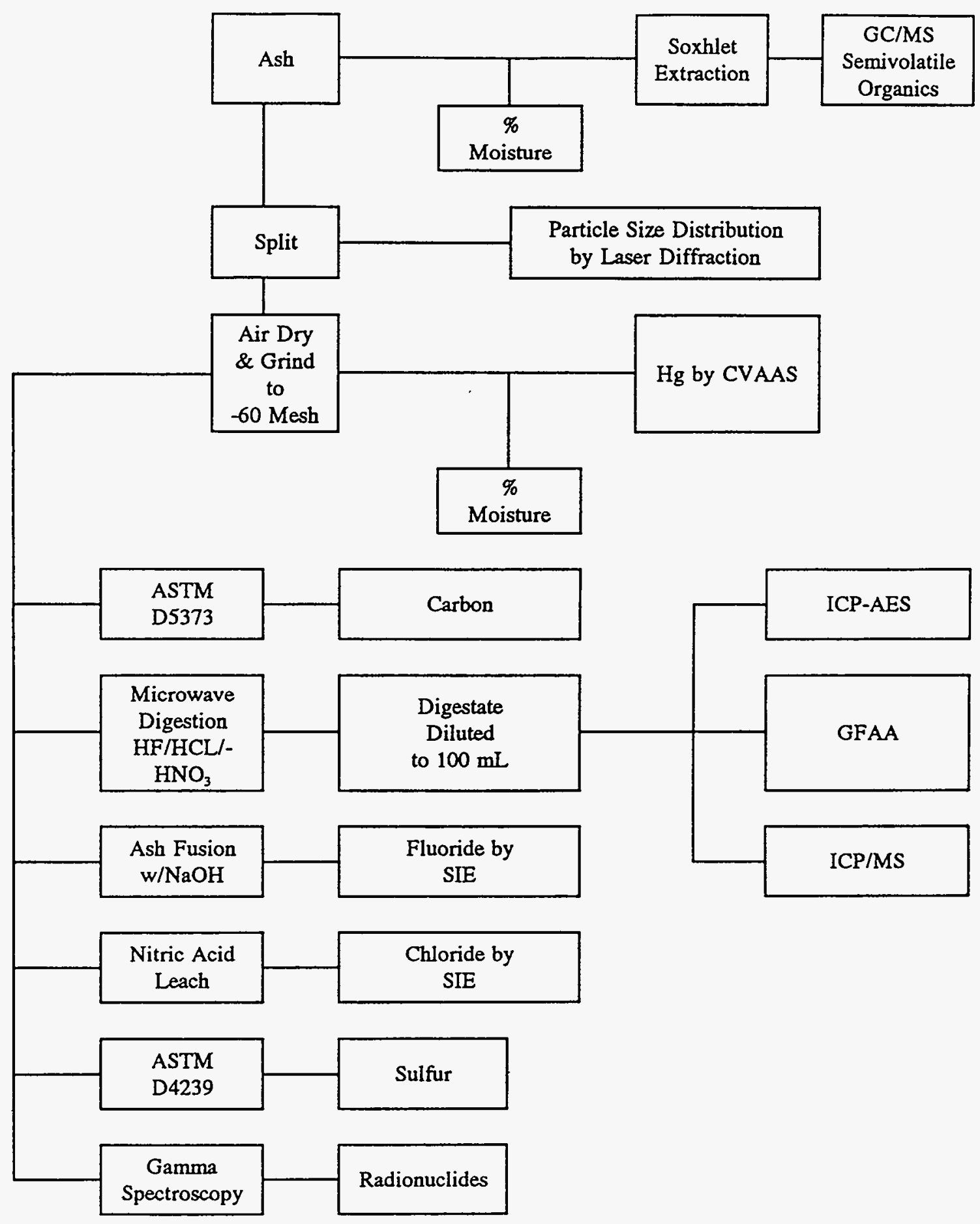

Figure 4-15

Ash Sample Preparation and Analysis Plan 


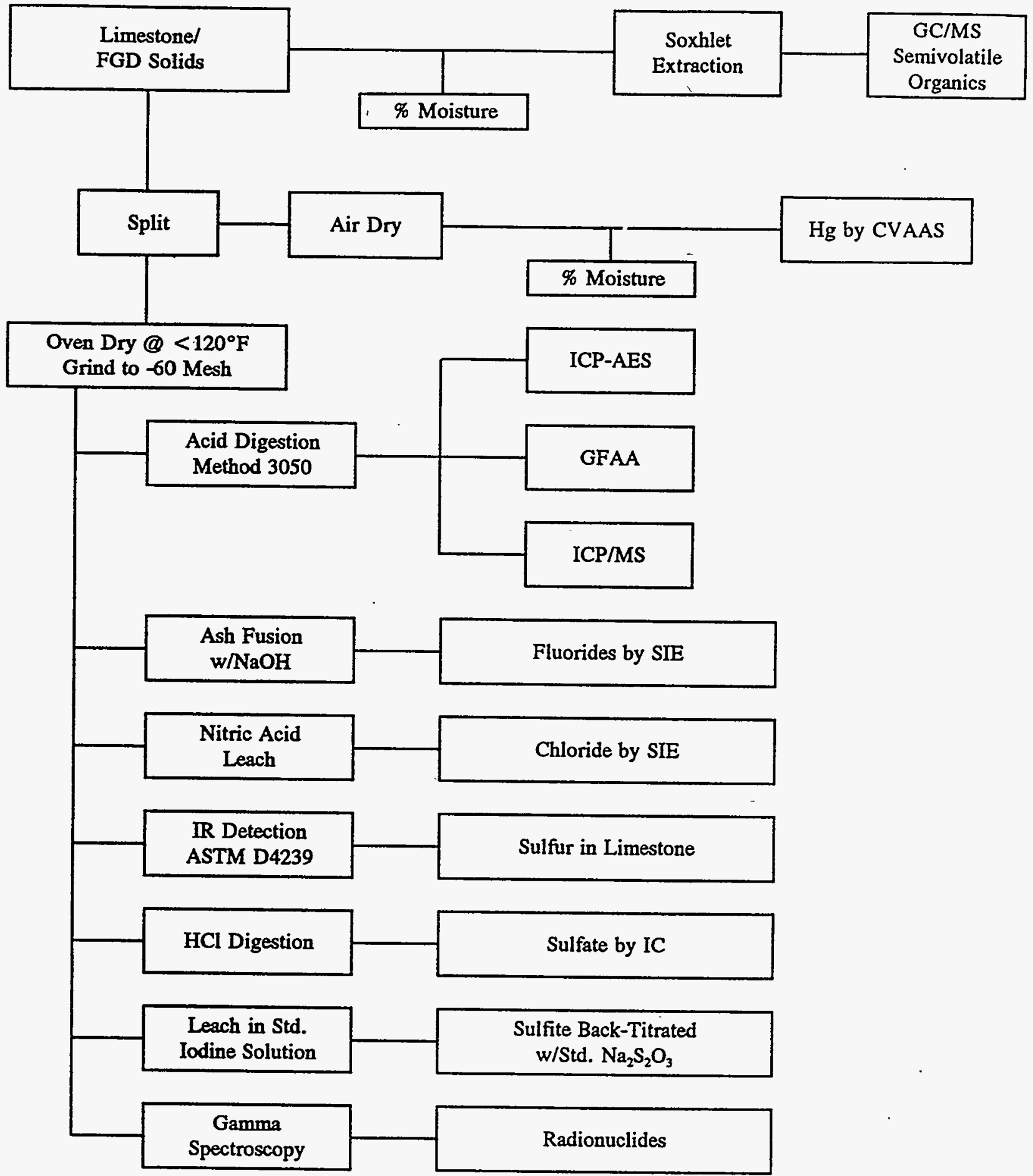

Figure 4-16

Limestone and FGD Solids Sample Preparation and Analysis Plan 


\section{5}

\section{Analytical Results}

The results of the analyses performed on samples collected during the emissions test program are presented in this section. The results are reported by stream matrix, i.e., gaseous, solid, or liquid, and are presented as averages for individual process streams along with the $95 \%$ confidence interval (CD) and the detection limit (DL) ratio. The detection limit ratio represents the percentage of the average value that is contributed by data which were below the detection limit. The analytical results for organic species reported in the following tables have been limited to only those compounds which were detected in any of the three test runs. Complete details of the analytical results may be found in Appendix $\mathrm{H}$. Appendix $\mathrm{H}$ contains results on a per run basis, the analytical method used for each analysis, appropriate data flags for each value, additional analytical results for compounds which were not part of the scope of work but which information was obtained by virtue of the particular analytical method used, along with the averages of Runs 1-3, 95\% CI, and DL ratios. Treatment of values that were less than the method detection limit are explained in Appendix G. Confidence intervals and error propagation are described in Appendix F.

Some data in Appendix $\mathrm{H}$ have been flagged. These data (which have been shaded) are suspect due to extremely high background contamination and have been excluded from the mean and CI calculations. High background contamination was encountered in gaseous particulate samples obtained from three of the multi-metals runs performed at the ESP outlet and the stack. This problem arose from the misidentification (during the field prep phase) of three glass fiber filter substrates. These glass fiber substrates were prepped, labelled and treated as quartz filters. The error was discovered during analysis when very high levels of barium and zinc were identified. The glass fiber substrates were used in Runs 1 and 3 at the ESP outlet and in Run 1 at the stack. Table 5-1 shows results for a blank analysis of a quartz and glass fiber filter. Background results are similar for $\mathrm{Sb}, \mathrm{As}, \mathrm{Se}$, and $\mathrm{V}$. All other species (except Mo) are substantially higher in the glass fiber matrix. Again, shaded data have been invalidated and are not included in the reported mean values.

\section{Gases}

The particulate loading and analytical results for the ESP inlet, ESP outlet and the stack are presented in Table 5-2. Concentration of trace elements as a function of particle size is given for three approximate size ranges; less than $3 \mu \mathrm{m}, 3-10 \mu \mathrm{m}$, and greater than $10 \mu \mathrm{m}$ on an aerodynamic basis. The analysis of boron and silicon in the fly ash samples filtered from the flue gas streams was not performed due to the limited quantity of sample and the limitations of the sampling and sample preparation techniques. For gas particulate samples, the filtered solids are prepared for analysis by digesting the entire filter with a mixed acid solution containing hydrochloric, nitric, and hydrofluoric acids. 
Analytical Results

Table 5-1

Filter Substrate Data Comparison

\begin{tabular}{|c|c|c|}
\hline Specie & $\begin{array}{c}\text { Quartz } \\
(\mu g)\end{array}$ & $\begin{array}{c}\text { Glass Fiber } \\
(\mu \mathrm{g})\end{array}$ \\
\hline Aluminum & 122 & 36,500 \\
\hline Antimony & $<9$ & $<9$ \\
\hline Arsenic & 0.14 & $<0.12$ \\
\hline Barium & 8.6 & 57,600 \\
\hline Beryllium & 0.08 & 6 \\
\hline Cadmium & $<0.13$ & 4 \\
\hline Calcium & 101 & 15,500 \\
\hline Chromium & 1.4 & 21 \\
\hline Cobalt. & 0.25 & 22 \\
\hline Copper & 0.57 & 4 \\
\hline Iron & 15 & 312 \\
\hline Lead & $<0.13$ & 35 \\
\hline Magnesium & 14 & 2,700 \\
\hline Manganese & 0.60 & 15 \\
\hline Mercury & 0.07 & 0.1 \\
\hline Molybdenum & 19 & 2 \\
\hline Nickel & 2.6 & 8 \\
\hline Phosphorus & $<7.5$ & 144 \\
\hline Potassium & $<205$ & 30,000 \\
\hline Selenium & 0.06 & $<0.09$ \\
\hline Sodium & 224 & 88,800 \\
\hline Strontium & 0.80 & 664 \\
\hline Titanium & 8.2 & 78 \\
\hline Vanadium & 0.65 & 0.15 \\
\hline Zinc & 6.3 & 39,900 \\
\hline
\end{tabular}


Analytical Results

Table 5-2

Gas Process Stream Data Summary

\begin{tabular}{|c|c|c|c|c|c|c|c|c|c|c|}
\hline \multirow{2}{*}{$\begin{array}{c}\text { Analyte Group/ } \\
\text { Specie }\end{array}$} & \multirow[b]{2}{*}{ Units } & \multicolumn{3}{|c|}{ ESP Inlet } & \multicolumn{3}{|c|}{ ESP Outlet } & \multicolumn{3}{|c|}{ Stack } \\
\hline & & Average & $\begin{array}{c}95 \% \\
\mathrm{CI}\end{array}$ & $\begin{array}{c}\text { DL } \\
\text { Ratio }\end{array}$ & Average & $\begin{array}{c}95 \% \\
\text { CI }\end{array}$ & $\begin{array}{c}\text { DL } \\
\text { Ratio }\end{array}$ & Average & $\begin{array}{c}95 \% \\
\mathrm{CI}\end{array}$ & $\begin{array}{c}\text { DL } \\
\text { Ratio }\end{array}$ \\
\hline Particulate Loading & $\mathrm{g} / \mathrm{Nm}^{3}$ & 8.95 & 1.5 & - & 0.142 & 0.05 & - & 0.0145 & 0.010 & - \\
\hline \multicolumn{11}{|l|}{ Reduced Species } \\
\hline Ammonia as $\mathrm{N}$ & $\mu \mathrm{g} / \mathrm{Nm}^{3}$ & 29.0 & 7.4 & -- & 27 & 16 & - & 11 & 17 & - \\
\hline Hydrogen Cyanide & $\mu \mathrm{g} / \mathrm{Nm}^{3}$ & 0.15 & 0.24 & - & 0.90 & 1.7 & -. & 28 & 94 & - \\
\hline \multicolumn{11}{|l|}{ Anions-Vapor } \\
\hline Chloride & $\mu \mathrm{g} / \mathrm{Nm}^{3}$ & 112,000 & 34,300 & - & 136,000 & 67,000 & - & 540 & 820 & - \\
\hline Fluoride & $\mu \mathrm{g} / \mathrm{Nm}^{3}$ & 8,300 & 1,400 & -- & 7,900 & 3,200 & - & 124 & 66 & - \\
\hline Sulfate & $\mu \mathrm{g} / \mathrm{Nm}^{3}$ & $7,460,000$ & 432,000 & -- & $6,900,000$ & $1,500,000$ & -- & 680,000 & 160,000 & -. \\
\hline \multicolumn{11}{|l|}{ Anions-Particulate } \\
\hline Chloride & $\mu \mathrm{g} / \mathrm{Nm}^{3}$ & 6,100 & 9,100 & - & 45 & 94 & - & 210 & 310 & -. \\
\hline Fluoride & $\mu g / \mathrm{Nm}^{3}$ & 1.3 & 2.4 & - & 0.12 & 0.21 & - & 0.051 & 0.041 & - \\
\hline Sulfate & $\mu \mathrm{g} / \mathrm{Nm}^{3}$ & 79,000 & 98,000 & -- & 4,200 & 760 & - & 5,900 & 8,700 & - \\
\hline \multicolumn{11}{|l|}{ Anions-Total } \\
\hline Chloride & $\mu \mathrm{g} / \mathrm{Nm}^{3}$ & 118,000 & 31,000 & -- & 136,000 & 67,000 & -- & 750 & 800 & - \\
\hline Fluoride & $\mu \mathrm{g} / \mathrm{Nm}^{3}$ & 8,300 & 1,400 & - & 7,900 & 3,200 & -- & 124 & 66 & - \\
\hline Sulfate & $\mu \mathrm{g} / \mathrm{Nm}^{3}$ & $7,500,000$ & 417,000 & - & $6,900,000$ & $1,500,000$ & -- & 690,000 & 170,000 & - \\
\hline \multicolumn{11}{|l|}{ Radionuclides } \\
\hline Actinium-228@338 KeV & $\mathrm{pCi} / \mathrm{g}$ & 25 & 36 & $11 \%$ & & & & & & \\
\hline Actinium-228@911 KeV & $\mathrm{pCi} / \mathrm{g}$ & 20 & 15 & -- & & & & & & \\
\hline Actinium-228@968 KeV & $\mathrm{pCi} / \mathrm{g}$ & 29 & 41 & $13 \%$ & & & & & & \\
\hline Bismuth-212@ $727 \mathrm{KeV}$ & $\mathrm{pCi} / \mathrm{g}$ & $<39$ & - & $100 \%$ & & & & & & \\
\hline Bismuth-214@1120.4 KeV & $\mathrm{pCi} / \mathrm{g}$ & $<24$ & -- & $100 \%$ & & & & & & \\
\hline Bismuth-214@1764.7 KeV & $\mathrm{pCi} / \mathrm{g}$ & 49 & 71 & $12 \%$ & & & & & & \\
\hline Bismuth-214@609.4 KeV & $\mathrm{pCi} / \mathrm{g}$ & 28 & 17 & -- & & & & & & \\
\hline $\mathrm{K}-40 @ 1460 \mathrm{KeV}$ & $\mathrm{pCi} / \mathrm{g}$ & 230 & 317 & - & 73 & 31 & -- & $<56$ & -- & $48 \%$ \\
\hline Lead-210@46 KeV & $\mathrm{pCi} / \mathrm{g}$ & 79 & 33 & -- & & & & & & \\
\hline Lead-212@238 KeV & $\mathrm{pCi} / \mathrm{g}$ & 19 & 19 & -- & & & & & & \\
\hline Lead-214@295.2 KeV & $\mathrm{pCi} / \mathrm{g}$ & 24 & 20 & -- & & & & & & \\
\hline Lead-214@352.0 KeV & $\mathrm{pCi} / \mathrm{g}$ & 25 & 8.0 & -- & & & & & & \\
\hline Radium-226@186.0 KeV & $\mathrm{pCi} / \mathrm{g}$ & 130 & 50 & - & & & & & & \\
\hline Thallium-208@583 KeV & $\mathrm{pCi} / \mathrm{g}$ & 17 & 11 & - & & & & & & \\
\hline Thallium-208@860 KeV & $\mathrm{pCi} / \mathrm{g}$ & $<67$ & -. & $100 \%$ & & & & & & \\
\hline Thorium-234@1001 KeV & $\mathrm{pCi} / \mathrm{g}$ & 79 & 35 & - & & & & & & \\
\hline Thorium-234@63.3 KeV & $\mathrm{pCi} / \mathrm{g}$ & 69 & 43 & - & & & & & & \\
\hline Uranium-235@143 KeV & $\mathrm{pCi} / \mathrm{g}$ & 69 & 43 & - & & & & & & \\
\hline \multicolumn{11}{|l|}{ Part Metals by Wt. } \\
\hline Aluminum & $\mu g / g$ & 97,000 & 11,000 & -- & 101,000 & - & -- & 13,800 & 7,300 & - \\
\hline Antimony & $\mu \mathrm{g} / \mathrm{g}$ & 3.6 & 2.4 & - & 2.7 & 0.65 & -- & 3.8 & 5.7 & - \\
\hline Arsenic & $\mu \mathrm{g} / \mathrm{g}$ & 45 & 12 & -- & 117 & 48 & - & 81 & 71 & -- \\
\hline Barium & $\mu g / g$ & 490 & 106 & -- & 620 & - & - & 210 & 1,100 & - \\
\hline Beryllium & $\mu \mathrm{g} / \mathrm{g}$ & 10 & 0.57 & - & 14 & - & - & 2.9 & 2.1 & - \\
\hline Cadmium & $\mu \mathrm{g} / \mathrm{g}$ & 2.70 & 1.4 & - & 8.9 & -- & - & 41 & 79 & - \\
\hline Calcium & $\mu g / g$ & 18,100 & 3,900 & -- & 14,800 & - & - & 18,600 & 31,000 & - \\
\hline Chromium & $\mu g / g$ & 320 & 500 & -- & 190 & - & -- & 330 & 3,000 & - \\
\hline Cobalt & $\mu g / g$ & 31 & 0.83 & -- & 37 & - & - & $<150$ & - & $52 \%$ \\
\hline
\end{tabular}




\section{Table 5-2 (Continued)}

\begin{tabular}{|c|c|c|c|c|c|c|c|c|c|c|}
\hline \multirow[b]{2}{*}{$\begin{array}{l}\text { Analyte Group/ } \\
\text { Specie }\end{array}$} & \multirow[b]{2}{*}{ Units } & \multicolumn{3}{|c|}{ ESP Inlet } & \multicolumn{3}{|c|}{ ESP Outlet } & \multicolumn{3}{|c|}{ Stack } \\
\hline & & Average & $\begin{array}{c}95 \% \\
\text { CI } \\
\end{array}$ & $\begin{array}{c}\text { DL } \\
\text { Ratio }\end{array}$ & Average & $\begin{array}{c}95 \% \\
\text { CI }\end{array}$ & $\begin{array}{c}\text { DL } \\
\text { Ratio }\end{array}$ & Average & $\begin{array}{c}95 \% \\
\mathrm{CI} \\
\end{array}$ & $\begin{array}{c}\text { DL } \\
\text { Ratio }\end{array}$ \\
\hline Copper & $\mu \mathrm{g} / \mathrm{g}$ & 86 & 2.6 & - & 116 & 35 & - & 56 & 49 & $\overline{-}$ \\
\hline Iron & $\mu g / g$ & 91,000 & 27,000 & - & 61,000 & 14,000 & - & 11,700 & 22,000 & - \\
\hline Lead & $\mu \mathrm{g} / \mathrm{g}$ & 79 & $19^{\circ}$ & - & 153 & - & - & 36 & 20 & - \\
\hline Magnesium & $\mu \mathrm{g} / \mathrm{g}$ & 4,690 & 480 & - & 5,500 & - & - & 2,800 & 10,700 & - \\
\hline Manganese & $\mu g / g$ & 237 & 32 & - & 243 & 68 & - & 490 & 2,600 & - \\
\hline Mercury & $\mu g / g$ & 0.79 & 0.59 & - & 0.90 & 0.3 & - & 0.57 & 5.2 & $14 \%$ \\
\hline Molybdenum & $\mu \mathrm{g} / \mathrm{g}$ & 35 & 39 & - & 58 & 31 & - & 73 & 120 & - \\
\hline Nickel & $\mu \mathrm{g} / \mathrm{g}$ & 230 & 250 & - & 157 & 25 & - & 2,500 & 27,000 & - \\
\hline Phosphorus & $\mu \mathrm{g} / \mathrm{g}$ & 230 & 150 & - & 830 & - & - & $<220$ & - & $100 \%$ \\
\hline Potassium & $\mu g / g$ & 17,500 & 1,900 & - & 17,900 & - & - & 2,900 & 1,600 & - \\
\hline Selenium & $\mu \mathrm{g} / \mathrm{g}$ & 15 & 7.0 & - & 570 & 860 & -- & 1,700 & 3,500 & - \\
\hline Sodium & $\mu g / g$ & 5,120 & 190 & - & 6,700 & - & - & 4,200 & 1,900 & - \\
\hline Strontium & $\mu g / g$ & 324 & 12 & - & 360 & - & - & 106 & 53 & - \\
\hline Titanium & $\mu g / g$ & 6,140 & 790 & - & 5,400 & 1,600 & - & 910 & 1,700 & - \\
\hline Vanadium & $\mu \mathrm{g} / \mathrm{g}$ & 308 & 5.7 & - & 381 & 93 & - & 112 & 46 & - \\
\hline \multicolumn{11}{|l|}{ Part Metals by Vol } \\
\hline Aluminum & $\mu \mathrm{g} / \mathrm{Nm}^{3}$ & 870,000 & 240,000 & - & 12,100 & - & - & 190 & 260 & - \\
\hline Antimony & $\mu \mathrm{g} / \mathrm{Nm}^{3}$ & 33 & 26 & - & 0.39 & 0.11 & - & 0.052 & 0.019 & - \\
\hline Arsenic & $\mu \mathrm{g} / \mathrm{Nm}^{3}$ & 400 & 170 & - & 16 & 6.6 & - & 1.1 & 0.24 & - \\
\hline Barium & $\mu \mathrm{g} / \mathrm{Nm}^{3}$ & 4,400 & 1,700 & - & 74 & - & - & 2.8 & 10 & - \\
\hline Beryllium & $\mu \mathrm{g} / \mathrm{Nm}^{3}$ & 93 & 16 & - & 1.7 & - & - & 0.041 & 0.047 & - \\
\hline Cadmium & $\mu \mathrm{g} / \mathrm{Nm}^{3}$ & 24 & 15 & - & 1.1 & - & - & 0.59 & 2.2 & - \\
\hline Calcium & $\mu \mathrm{g} / \mathrm{Nm}^{3}$ & 161,300 & 7,200 & - & 1,800 & - & - & 270 & 920 & - \\
\hline Chromium & $\mu \mathrm{g} / \mathrm{Nm}^{3}$ & 2,900 & 4,600 & - & 23 & - & - & 5.1 & 50 & - \\
\hline Cobalt & $\mu \mathrm{g} / \mathrm{Nm}^{3}$ & 275 & 48 & - & 4.5 & - & - & $<0.6$ & - & $59 \%$ \\
\hline Copper & $\mu \mathrm{g} / \mathrm{Nm}^{3}$ & 770 & 130 & - & 16 & 1.2 & - & 0.77 & 0.76 & - \\
\hline Iron & $\mu \mathrm{g} / \mathrm{Nm}^{3}$ & 808,000 & 99,000 & - & 8,500 & 1,100 & - & 170 & 600 & -- \\
\hline Lead & $\mu \mathrm{g} / \mathrm{Nm}^{3}$ & 710 & 290 & - & 18 & - & - & 0.50 & 0.64 & - \\
\hline Magnesium & $\mu \mathrm{g} / \mathrm{Nm}^{3}$ & 42,000 & 11,000 & - & 660 & - & - & 41 & 220 & - \\
\hline Manganese & $\mu \mathrm{g} / \mathrm{Nm}^{3}$ & 2,120 & 120 & - & 34 & 3.7 & - & 7.2 & 49 & - \\
\hline Mercury & $\mu \mathrm{g} / \mathrm{Nm}^{3}$ & 7.1 & 5.6 & - & 0.126 & 0.037 & - & 0.0071 & 0.057 & $18 \%$ \\
\hline Molybdenum & $\mu \mathrm{g} / \mathrm{Nm}^{3}$ & 320 & 390 & - & 8.1 & 1.3 & - & 1.4 & 2.6 & - \\
\hline Nickel & $\mu \mathrm{g} / \mathrm{Nm}^{3}$ & 2,000 & 2,300 & - & 22 & 5.7 . & - & 39 & 440 & - \\
\hline Phosphorus & $\mu \mathrm{g} / \mathrm{Nm}^{3}$ & 2,100 & 1,600 & - & 100 & - & - & $<2.6$ & - & $100 \%$ \\
\hline Potassium & $\mu \mathrm{g} / \mathrm{Nm}^{3}$ & 157,000 & 43,000 & - & 2,150 & - & $\cdots$ & 40 & 53 & - \\
\hline Selenium & $\mu \mathrm{g} / \mathrm{Nm}^{3}$ & 133 & 73 & - & 82 & 130 & - & 26 & 58 & - \\
\hline Sodium & $\mu \mathrm{g} / \mathrm{Nm}^{3}$ & 45,800 & 6,200 & - & 800 & - & - & 59 & 140 & - \\
\hline Strontium & $\mu \mathrm{g} / \mathrm{Nm}^{3}$ & 2,910 & 570 & - & 43 & - & - & 1.5 & 3.5 & - \\
\hline Titanium & $\mu \mathrm{g} / \mathrm{Nm}^{3}$ & 55,000 & 16,000 & - & 760 & 230 & - & 12.5 & 0.59 & - \\
\hline Vanadium & $\mu \mathrm{g} / \mathrm{Nm}^{3}$ & 2,760 & 430 & - & 54 & 11 & - & 1.6 & 0.47 & - \\
\hline \multicolumn{11}{|l|}{ Metals, Vapor } \\
\hline Aluminum & $\mu \mathrm{g} / \mathrm{Nm}^{3}$ & 150 & 940 & - & 58 & 48 & - & $<8.7$ & - & $50 \%$ \\
\hline Antimony & $\mu \mathrm{g} / \mathrm{Nm}^{3}$ & 0.56 & 6.5 & - & 0.021 & 0.0096 & - & 0.012 & 0.0019 & - \\
\hline Arsenic & $\mu \mathrm{g} / \mathrm{Nm}^{3}$ & $<0.17$ & - & $100 \%$ & $<0.18$ & - & $100 \%$ & $<0.18$ & - & $100 \%$ \\
\hline Barium & $\mu \mathrm{g} / \mathrm{Nm}^{3}$ & 1.5 & 7.9 & - & 1.0 & 1.1 & - & $<0.14$ & - & $54 \%$ \\
\hline Beryllium & $\mu \mathrm{g} / \mathrm{Nm}^{3}$ & 0.06 & 0.25 & - & $<0.16$ & - & $57 \%$ & $<0.17$ & - & $82 \%$ \\
\hline
\end{tabular}


Analytical Results

Table 5-2 (Continued)

\begin{tabular}{|c|c|c|c|c|c|c|c|c|c|c|}
\hline \multirow[b]{2}{*}{$\begin{array}{l}\text { Analyte Group/ } \\
\text { Specie }\end{array}$} & \multirow[b]{2}{*}{ Units } & \multicolumn{3}{|c|}{ ESP Inlet } & \multicolumn{3}{|c|}{ ESP Outlet } & \multicolumn{3}{|c|}{ Stack } \\
\hline & & Average & $\begin{array}{c}95 \% \\
\mathrm{CI}\end{array}$ & $\begin{array}{c}\text { DL } \\
\text { Ratio }\end{array}$ & Average & $\begin{array}{c}95 \% \\
\text { CI }\end{array}$ & $\begin{array}{c}\text { DL } \\
\text { Ratio }\end{array}$ & Average & $\begin{array}{c}95 \% \\
\text { CI }\end{array}$ & $\begin{array}{c}\text { DL } \\
\text { Ratio }\end{array}$ \\
\hline Boron & $\mu \mathrm{g} / \mathrm{Nm}^{3}$ & 6,400 & 12,000 & - & 6,900 & 1,200 & - & 440 & 70 & - \\
\hline Cadmium & $\mu \mathrm{g} / \mathrm{Nm}^{3}$ & 0.11 & 0.93 & $16 \%$ & 0.10 & 0.31 & $21 \%$ & $<0.064$ & - & $100 \%$ \\
\hline Calcium & $\mu g / \mathrm{Nm}^{3}$ & 300 & 110 & - & 184 & 87 & - & $<40$ & - & $52 \%$ \\
\hline Chromium & $\mu \mathrm{g} / \mathrm{Nm}^{3}$ & 11 & 140 & - & $<0.73$ & - & $42 \%$ & $<0.67$ & - & $100 \%$ \\
\hline Cobalt & $\mu \mathrm{g} / \mathrm{Nm}^{3}$ & $<0.74$ & - & $55 \%$ & $<1.0$ & - & $31 \%$ & 0.39 & 0.77 & - \\
\hline Copper & $\mu \mathrm{g} / \mathrm{Nm}^{3}$ & 1.1 & 1.6 & - & 1.1 & 1.2 & $16 \%$ & 1.2 & 2.4 & $14 \%$ \\
\hline Iron & $\mu \mathrm{g} / \mathrm{Nm}^{3}$ & 140 & 120 & - & 50 & 78 & - & $<1.8$ & - & $50 \%$ \\
\hline Lead & $\mu \mathrm{g} / \mathrm{Nm}^{3}$ & $<0.21$ & -- & $100 \%$ & 0.40 & 1.1 & $20 \%$ & $<0.22$ & - & $100 \%$ \\
\hline Magnesium & $\mu \mathrm{g} / \mathrm{Nm}^{3}$ & 20 & 18 & - & 12 & 6.4 & - & $<7.0$ & - & $24 \%$ \\
\hline Manganese & $\mu \mathrm{g} / \mathrm{Nm}^{3}$ & $<0.10$ & -- & $100 \%$ & $<0.11$ & - & $100 \%$ & $<0.11$ & - & $100 \%$ \\
\hline Mercury & $\mu \mathrm{g} / \mathrm{Nm}^{3}$ & 5.5 & 5.6 & -- & 5.6 & 1.1 & - & 3.0 & 0.27 & -- \\
\hline Molybdenum & $\mu \mathrm{g} / \mathrm{Nm}^{3}$ & $<1.4$ & -- & $52 \%$ & $<1.4$ & - & $37 \%$ & 0.12 & 0.048 & - \\
\hline Nickel & $\mu \mathrm{g} / \mathrm{Nm}^{3}$ & 7 & $7 \%$ & $8 \%$ & $<2.9$ & - & $59 \%$ & $<2.6$ & - & $46 \%$ \\
\hline Phosphorus & $\mu \mathrm{g} / \mathrm{Nm}^{3}$ & $<16$ & -- & $100 \%$ & $<17$ & - & $100 \%$ & $<16$ & -- & $100 \%$ \\
\hline Potassium & $\mu \mathrm{g} / \mathrm{Nm}^{3}$ & 10 & 130 & $2 \%$ & 20 & 100 & $1 \%$ & 37 & 96 & $0.4 \%$ \\
\hline Selenium & $\mu \mathrm{g} / \mathrm{Nm}^{3}$ & $<0.22$ & - & $100 \%$ & $<0.23$ & - & $100 \%$ & 0.80 & 1.6 & - \\
\hline Sodium & $\mu \mathrm{g} / \mathrm{Nm}^{3}$ & 240 & 360 & -- & 290 & 280 & - & $<11$ & -- & $100 \%$ \\
\hline Strontium & $\mu \mathrm{g} / \mathrm{Nm}^{3}$ & 2 & 4 & - & 1.4 & 0.28 & - & $<0.045$ & - & $100 \%$ \\
\hline Titanium & $\mu \mathrm{g} / \mathrm{Nm}^{3}$ & 9 & 71 & - & 2.5 & 3.4 & -- & $<0.27$ & - & $58 \%$ \\
\hline Vanadium & $\mu \mathrm{g} / \mathrm{Nm}^{3}$ & 1.2 & 3 & - & 1.0 & 1.3 & $12 \%$ & 0.55 & 0.57 & - \\
\hline \multicolumn{11}{|l|}{ Total Metals } \\
\hline Aluminum & $\mu \mathrm{g} / \mathrm{Nm}^{3}$ & 870,000 & 240,000 & - & 12,200 & - & - & 200 & 250 & - \\
\hline Antimony & $\mu \mathrm{g} / \mathrm{Nm}^{3}$ & 33 & 25 & - & 0.41 & 0.12 & - & 0.065 & 0.026 & -- \\
\hline Arsenic & $\mu \mathrm{g} / \mathrm{Nm}^{3}$ & 410 & 170 & - & 17 & 6.6 & - & 1.2 & 0.24 & - \\
\hline Barium & $\mu \mathrm{g} / \mathrm{Nm}^{3}$ & 4,400 & 1,700 & - & 75 & - & - & 2.9 & 10 & - \\
\hline Beryllium & $\mu \mathrm{g} / \mathrm{Nm}^{3}$ & 93 & 16 & - & 1.7 & - & - & 0.099 & 0.29 & - \\
\hline Boron (vapor only) & $\mu \mathrm{g} / \mathrm{Nm}^{3}$ & 6,600 & 2,500 & - & 6,900 & 1,200 & - & 440 & 70 & - \\
\hline Cadmium & $\mu \mathrm{g} / \mathrm{Nm}^{3}$ & 24 & 15 & - & 1.3 & - & - & 0.63 & 2.2 & - \\
\hline Calcium & $\mu \mathrm{g} / \mathrm{Nm}^{3}$ & 163,300 & 6,200 & - & 1,900 & - & - & 290 & 830 & - \\
\hline Chromium & $\mu \mathrm{g} / \mathrm{Nm}^{3}$ & 2,900 & 4,700 & - & 23 & - & - & 5.4 & 50 & - \\
\hline Cobalt & $\mu \mathrm{g} / \mathrm{Nm}^{3}$ & 276 & 48 & -- & 5 & - & - & 0.74 & 4 & - \\
\hline Copper & $\mu \mathrm{g} / \mathrm{Nm}^{3}$ & 770 & 130 & - & 17 & 1.9 & - & 2.0 & 1.8 & - \\
\hline Iron & $\mu \mathrm{g} / \mathrm{Nm}^{3}$ & 809,000 & 98,000 & - & 8,600 & 1,100 & - & 170 & 600 & - \\
\hline Lead & $\mu \mathrm{g} / \mathrm{Nm}^{3}$ & 710 & 290 & - & 19 & - & - & 0.61 & 0.54 & - \\
\hline Magnesium & $\mu \mathrm{g} / \mathrm{Nm}^{3}$ & 42,000 & 11,200 & - & 670 & - & - & 45 & 230 & - \\
\hline Manganese & $\mu \mathrm{g} / \mathrm{Nm}^{3}$ & 2,120 & 130 & - & 34 & 3.7 & - & 7.3 & 49 & - \\
\hline Mercury & $\mu \mathrm{g} / \mathrm{Nm}^{3}$ & 13 & 5.6 & - & 5.7 & 1.1 & - & 3.1 & 0.44 & - \\
\hline Molybdenum & $\mu \mathrm{g} / \mathrm{Nm}^{3}$ & 320 & 390 & - & 8.7 & 1.4 & - & 1.5 & 2.4 & - \\
\hline Nickel & $\mu \mathrm{g} / \mathrm{Nm}^{3}$ & 2,100 & 2,300 & - & 24 & 6.3 & - & 41 & 430 & - \\
\hline Phosphorus & $\mu \mathrm{g} / \mathrm{Nm}^{3}$ & 2,100 & 1,600 & - & 110 & -- & - & $<10$ & - & $100 \%$ \\
\hline Potassium & $\mu \mathrm{g} / \mathrm{Nm}^{3}$ & 157,000 & 43,000 & - & 2,200 & -- & - & 79 & 540 & - \\
\hline Selenium & $\mu \mathrm{g} / \mathrm{Nm}^{3}$ & 133 & 73 & - & 80 & 130 & - & 27 & 57 & - \\
\hline Sodium & $\mu \mathrm{g} / \mathrm{Nm}^{3}$ & 46,100 & 6,200 & - & 1,000 & - & - & 65 & 130 & - \\
\hline Strontium & $\mu \mathrm{g} / \mathrm{Nm}^{3}$ & 2,920 & 580 & - & 45 & - & -- & 1.5 & 3.5 & - \\
\hline
\end{tabular}


Table 5-2 (Continued)

\begin{tabular}{|c|c|c|c|c|c|c|c|c|c|c|}
\hline \multirow[b]{2}{*}{$\begin{array}{l}\text { Analyte Group/ } \\
\text { Specie }\end{array}$} & \multirow[b]{2}{*}{ Units } & \multicolumn{3}{|c|}{ ESP Inlet } & \multicolumn{3}{|c|}{ ESP Outlet } & \multicolumn{3}{|c|}{ Stack } \\
\hline & & Average & $\begin{array}{c}95 \% \\
\text { CI }\end{array}$ & $\begin{array}{c}\text { DL } \\
\text { Ratio }\end{array}$ & Average & $\begin{array}{c}95 \% \\
\text { CI }\end{array}$ & $\begin{array}{c}\text { DL } \\
\text { Ratio }\end{array}$ & Average & $\begin{array}{c}95 \% \\
\text { CI }\end{array}$ & $\begin{array}{c}\text { DL } \\
\text { Ratio }\end{array}$ \\
\hline Titanium & $\mu \mathrm{g} / \mathrm{Nm}^{3}$ & 55,000 & 16,000 & - & 760 & 230 & $\overline{-}$ & 13 & 0.26 & - \\
\hline Vanadium & $\mu \mathrm{g} / \mathrm{Nm}^{3}$ & 2,770 & 440 & - & 55 & 10 & - & 2.2 & 1 & - \\
\hline \multicolumn{11}{|l|}{ Hg Vapor, Bloom } \\
\hline Mercury, Elemental & $\mu \mathrm{g} / \mathrm{Nm}^{3}$ & 2.0 & 1.8 & - & 2.5 & 0.28 & - & 2.8 & 1.1 & - \\
\hline Mercury II & $\mu \mathrm{g} / \mathrm{Nm}^{3}$ & 4.1 & 1.4 & - & .4 .2 & 2 & - & 0.47 & 0.33 & - \\
\hline Mercury, Methyl & $\mu \mathrm{g} / \mathrm{Nm}^{3}$ & 0.31 & 0.59 & - & 0.63 & 0.45 & - & 0.044 & 0.041 & - \\
\hline Mercury, Total & $\mu \mathrm{g} / \mathrm{Nm}^{3}$ & 6.4 & 1.1 & - & 7.3 & 2.4 & - & 3.3 & 0.88 & - \\
\hline \multicolumn{11}{|l|}{ Hexavalent Chromium } \\
\hline Chromium VI & $\mu \mathrm{g} / \mathrm{Nm}^{3}$ & & & & & & & $<0.190$ & - & $100 \%$ \\
\hline Total Chromium & $\mu \mathrm{g} / \mathrm{Nm}^{3}$ & & & & & & & $<0.560$ & - & $100 \%$ \\
\hline \multicolumn{11}{|l|}{ Extract Metals, Nitric } \\
\hline Antimony & $\mu \mathrm{g} / \mathrm{g}$ & 2.7 & 1 & - & 3.2 & 3.4 & - & 5.8 & - & - \\
\hline Arsenic & $\mu g / g$ & 43 & 45 & -- & 98 & 40 & -- & 160 & - & -- \\
\hline Barium & $\mu \mathrm{g} / \mathrm{g}$ & 220 & 145 & -- & 318 & 8.4 & - & 350 & -- & - \\
\hline Beryllium & $\mu \mathrm{g} / \mathrm{g}$ & 4.1 & 2.3 & - & 5.4 & 5.8 & - & 10 & -- & - \\
\hline Boron & $\mu g / g$ & 1,520 & 857 & - & 1,900 & 1,200 & -- & $<15$ & - & $100 \%$ \\
\hline Cadmium & $\mu g / g$ & 2.2 & 5 & $5 \%$ & 10 & 18 & - & 67 & - & - \\
\hline Chromium & $\mu g / g$ & 29 & 30 & - & 64 & 61 & - & 44 & - & - \\
\hline Cobalt & $\mu \mathrm{g} / \mathrm{g}$ & 5.0 & 10 & - & 17 & 3.8 & - & $<0.90$ & - & $100 \%$ \\
\hline Copper & $\mu g / g$ & 32 & 36 & - & 98 & 32 & - & 120 & - & - \\
\hline Lead & $\mu g / g$ & 39 & 52 & - & 116 & 31 & - & 91 & - & - \\
\hline Manganese & $\mu g / g$ & 120 & 87 & - & 1000 & 3,500 & - & 330 & - & - \\
\hline Mercury & $\mu g / g$ & 80 & 230 & $0.4 \%$ & 4.0 & 11 & $8.1 \%$ & $<7.0$ & - & $100 \%$ \\
\hline Molybdenum & $\mu \mathrm{g} / \mathrm{g}$ & 43 & 59 & - & 72 & 21 & - & 51 & - & - \\
\hline Nickel & $\mu \mathrm{g} / \mathrm{g}$ & 45 & 30 & - & 84 & 46 & - & 390 & - & - \\
\hline Selenium & $\mu g / g$ & $<23$ & - & $100 \%$ & $<23$ & - & $100 \%$ & $<87$ & - & $100 \%$ \\
\hline Vanadium & $\mu \mathrm{g} / \mathrm{g}$ & 150 & 160 & - & 270 & 260 & - & 390 & - & - \\
\hline \multicolumn{11}{|l|}{ Extract Metals, Gastric } \\
\hline Antimony & $\mu \mathrm{g} / \mathrm{g}$ & 0.71 & 0.095 & - & 1.0 & 0.4 & - & 3.4 & -- & -- \\
\hline Arsenic & $\mu \mathrm{g} / \mathrm{g}$ & $<0.68$ & - & $100 \%$ & $<0.66$ & - & $100 \%$ & $<2.5$ & - & $100 \%$ \\
\hline Barium & $\mu \mathrm{g} / \mathrm{g}$ & 103 & 55 & - & 125 & 22 & - & 210 & - & - \\
\hline Beryllium & $\mu g / g$ & 1.1 & 0.61 & - & 2.7 & 0.66 & - & 4.2 & - & - \\
\hline Boron & $\mu \mathrm{g} / \mathrm{g}$ & 698 & 4.6 & - & 822 & 88 & - & 150 & - & - \\
\hline Cadmium & $\mu g / g$ & 1.8 & 3.0 & - & 5.9 & 3.2 & - & 12 & - & - \\
\hline Chromium & $\mu g / g$ & 27 & 13 & - & 54 & 18 & - & 85 & - & - \\
\hline Cobalt & $\mu \mathrm{g} / \mathrm{g}$ & 1.8 & 1.4 & - & 5.5 & 2 & - & 11 & - & - \\
\hline Copper & $\mu \mathrm{g} / \dot{\mathrm{g}}$ & 10 & 5.3 & - & 33 & 9.3 & - & 51 & - & - \\
\hline Lead & $\mu \mathrm{g} / \mathrm{g}$ & 9.4 & 9.6 & - & 33 & 7.1 & - & 66 & - & - \\
\hline Manganese & $\mu \mathrm{g} / \mathrm{g}$ & 60 & 65 & - & 46 & 11 & - & 350 & - & - \\
\hline Mercury & $\mu \mathrm{g} / \mathrm{g}$ & 1.9 & 3.0 & - & 0.38 & 0.22 & -- & $<0.15$ & - & $100 \%$ \\
\hline Molybdenum & $\mu g / g$ & 29 & 22 & - & 61 & 12 & -- & 49 & - & - \\
\hline Nickel & $\mu \mathrm{g} / \mathrm{g}$ & 10 & 21 & - & 38 & 22 & - & 170 & - & - \\
\hline Selenium & $\mu \mathrm{g} / \mathrm{g}$ & $<0.88$ & - & $100 \%$ & 18 & 6.8 & -- & 140 & - & - \\
\hline Vanadium & $\mu \mathrm{g} / \mathrm{g}$ & $<0.36$ & - & $100 \%$ & 122 & 79 & -- & $<1.3$ & - & $100 \%$ \\
\hline
\end{tabular}


Analytical Results

Table 5-2 (Continued)

\begin{tabular}{|c|c|c|c|c|c|c|c|c|c|c|}
\hline \multirow[b]{2}{*}{$\begin{array}{c}\text { Analyte Group/ } \\
\text { Specie }\end{array}$} & \multirow[b]{2}{*}{ Units } & \multicolumn{3}{|c|}{ ESP Inlet } & \multicolumn{3}{|c|}{ ESP Outlet } & \multicolumn{3}{|c|}{ Stack } \\
\hline & & Average & $\begin{array}{c}95 \% \\
\mathrm{CI}\end{array}$ & $\begin{array}{c}\text { DL } \\
\text { Ratio }\end{array}$ & Average & $\begin{array}{c}95 \% \\
\text { CI }\end{array}$ & $\begin{array}{c}\text { DL } \\
\text { Ratio }\end{array}$ & Average & $\begin{array}{c}95 \% \\
\mathrm{CI}\end{array}$ & $\begin{array}{c}\text { DL } \\
\text { Ratio }\end{array}$ \\
\hline \multicolumn{11}{|l|}{ Extract Metals, Acetic } \\
\hline Antimony & $\mu g / g$ & 0.80 & 1.1 & - & 0.88 & 0.38 & - & $<0.03$ & - & $100 \%$ \\
\hline Arsenic & $\mu g / g$ & 1.0 & 0.63 & - & 3.4 & 3.9 & - & $<0.5$ & -. & $100 \%$ \\
\hline Barium & $\mu \mathrm{g} / \mathrm{g}$ & 48 & 30 & - & 44 & 13 & - & 17 & -- & -- \\
\hline Beryllium & $\mu \mathrm{g} / \mathrm{g}$ & 0.32 & 0.54 & - & 0.98 & 0.53 & -- & 2.9 & - & - \\
\hline Boron & $\mu g / g$ & 1,010 & 240 & - & 910 & 280 & -- & $<0.82$ & - & $100 \%$ \\
\hline Cadmium & $\mu \mathrm{g} / \mathrm{g}$ & 1.6 & 2.9 & -- & 10 & 27 & -- & 5.9 & - & -- \\
\hline Chromium & $\mu \mathrm{g} / \mathrm{g}$ & 7.4 & 1 & -- & 19 & 7.2 & - & 36 & -- & .. \\
\hline Cobalt & $\mu \mathrm{g} / \mathrm{g}$ & 1.5 & 0.87 & -- & 6.0 & 7.4 & - & 7.5 & - & - \\
\hline Copper & $\mu \mathrm{g} / \mathrm{g}$ & 11 & 14 & - & 18 & 4.9 & - & 64 & -- & -- \\
\hline Lead & $\mu \mathrm{g} / \mathrm{g}$ & 0.21 & 0.35 & -- & 1.5 & 0.98 & - & 20 & - & - \\
\hline Manganese & $\mu \mathrm{g} / \mathrm{g}$ & 51 & 52 & -- & 39 & 8.5 & - & 470 & -- & - \\
\hline Mercury & $\mu g / g$ & 0.70 & 1.9 & - & 0.13 & 0.38 & - & $<0.38$ & - & $100 \%$ \\
\hline Molybdenum & $\mu g / g$ & 1.5 & 5.3 & - & 4.0 & 12 & - & 3.5 & - & -- \\
\hline Nickel & $\mu g / g$ & 8.6 & 5.6 & -- & 23 & 1.0 & - & 66 & - & -- \\
\hline Selenium & $\mu g / g$ & $<0.54$ & - & $41 \%$ & 4.1 & 3.3 & - & 61 & -- & -- \\
\hline Vanadium & $\mu \mathrm{g} / \mathrm{g}$ & 1.5 & 1.0 & -- & 5.0 & 10 & - & $<0.19$ & -- & $100 \%$ \\
\hline \multicolumn{11}{|l|}{ Metals by Size, $>10 \mu \mathrm{m}$} \\
\hline Percent of Total Mass & $\%$ & 57 & & & 16 & & & & & \\
\hline Aluminum & $\mu g / g$ & 109,000 & 35,000 & - & 72,000 & 16,000 & - & & & \\
\hline Antimony & $\mu g / g$ & 2.0 & 1.1 & - & 3.2 & 1.0 & -- & & & \\
\hline Arsenic & $\mu g / g$ & 26 & 8.4 & - & 49 & 21 & - & & & \\
\hline Barium & $\mu g / g$ & 520 & 130 & - & 390 & 100 & -- & & & \\
\hline Beryllium & $\mu \mathrm{g} / \mathrm{g}$ & 10 & 5.6 & - & 10 & 18 & - & & & \\
\hline Cadmium & $\mu \mathrm{g} / \mathrm{g}$ & 1.7 & 0.88 & - & 3.6 & 1.8 & - & & & \\
\hline Calcium & $\mu g / g$ & 22,100 & 10,000 & - & 14,000 & 3,900 & - & & & \\
\hline Chromium & $\mu \mathrm{g} / \mathrm{g}$ & 184 & 4.3 & - & 213 & 35 & -- & & & \\
\hline Cobalt & $\mu g / g$ & 32 & 4.4 & - & 32 & 18 & - & & & \\
\hline Copper & $\mu g / g$ & 87 & 23 & - & 102 & 33 & - & & & \\
\hline Iron & $\mu \mathrm{g} / \mathrm{g}$ & 102,000 & 2,500 & - & 160,000 & 140,000 & - & & & \\
\hline Lead & $\mu g / g$ & 51 & 19 & - & 72 & 31 & - & & & \\
\hline Magnesium & $\mu g / g$ & 5,400 & 2,000 & - & 3,700 & 1,600 & - & & & \\
\hline Manganese & $\mu g / g$ & 238 & 17 & - & 700 & 1,100 & -- & & & \\
\hline Mercury & $\mu g / g$ & 0.50 & 0.47 & - & 0.55 & 0.21 & - & & & \\
\hline Molybdenum & $\mu g / g$ & 16 & 20 & - & 43 & 13 & - & & & \\
\hline Nickel & $\mu g / g$ & 121 & 34 & - & 129 & 96 & - & & & \\
\hline Phosphorus & $\mu g / g$ & $<72$ & - & $100 \%$ & $<71$ & -- & $100 \%$ & & & \\
\hline Potassium & $\mu \mathrm{g} / \mathrm{g}$ & 18,500 & 2,700 & - & 14,600 & 2,900 & - & & & \\
\hline Selenium & $\mu g / g$ & 11 & 1 & - & 160 & 210 & - & & & \\
\hline Silicon & $\mu g / g$ & 218,000 & 20,000 & - & 175,000 & 77,000 & -- & & & \\
\hline Sodium & $\mu \mathrm{g} / \mathrm{g}$ & 4,600 & 1,900 & - & 5,500 & 4,000 & - & & & \\
\hline Strontium & $\mu \mathrm{g} / \mathrm{g}$ & 357 & 97 & - & 294 & 58 & - & & & \\
\hline Titanium & $\mu \mathrm{g} / \mathrm{g}$ & 6,150 & 560 & - & 5,300 & 2,000 & - & & & \\
\hline Vanadium & $\mu \mathrm{g} / \mathrm{g}$ & 293 & 45 & - & 290 & 120 & -- & & & \\
\hline
\end{tabular}


Table 5-2 (Continued)

\begin{tabular}{|c|c|c|c|c|c|c|c|c|c|c|}
\hline \multirow[b]{2}{*}{$\begin{array}{c}\text { Analyte Group/ } \\
\text { Specie }\end{array}$} & \multirow[b]{2}{*}{ Units } & \multicolumn{3}{|c|}{ ESP Inlet } & \multicolumn{3}{|c|}{ ESP Outlet } & \multicolumn{3}{|c|}{ Stack } \\
\hline & & Average & $\begin{array}{c}95 \% \\
\mathrm{CI}\end{array}$ & $\begin{array}{c}\text { DL } \\
\text { Ratio }\end{array}$ & Average & $\begin{array}{c}95 \% \\
\mathrm{CI}\end{array}$ & $\begin{array}{c}\text { DL } \\
\text { Ratio }\end{array}$ & Average & $\begin{array}{c}95 \% \\
\mathrm{CI}\end{array}$ & $\begin{array}{c}\text { DL } \\
\text { Ratio }\end{array}$ \\
\hline \multicolumn{11}{|l|}{ Metals by Size, $3-10 \mu \mathrm{m}$} \\
\hline Percent of Total Mass & $\%$ & 27 & & & 44 & & & & & \\
\hline Aluminum & $\mu \mathrm{g} / \mathrm{g}$ & 118,000 & 23,000 & -- & 105,000 & 63,000 & -- & & & \\
\hline Antimony & $\mu g / g$ & 4.8 & 2.7 & - & 8.6 & 1.1 & - & & & \\
\hline Arsenic & $\mu \mathrm{g} / \mathrm{g}$ & 71 & 31 & - & 127 & 11 & - & & & \\
\hline Barium & $\mu g / g$ & 630 & 250 & - & 629 & 85 & - & & & \\
\hline Beryllium & $\mu \mathrm{g} / \mathrm{g}$ & 13 & 8.1 & - & 18 & 15 & -- & & & \\
\hline Cadmium & $\mu \mathrm{g} / \mathrm{g}$ & 5.8 & 3.6 & - & 11 & 2.4 & -- & & & \\
\hline Calcium & $\mu \mathrm{g} / \mathrm{g}$ & 19,000 & 17,000 & - & 14,000 & 1,600 & -- & & & \\
\hline Chromium & $\mu \mathrm{g} / \mathrm{g}$ & 218 & 16 & -- & 275 & 65 & -- & & & \\
\hline Cobalt & $\mu g / g$ & 43 & 5.6 & - & 51 & 10 & -- & & & \\
\hline Copper & $\mu \mathrm{g} / \mathrm{g}$ & 142 & 22 & -- & 170 & 39 & -- & & & \\
\hline Iron & $\mu \mathrm{g} / \mathrm{g}$ & 64,000 & 19,000 & - & 63,000 & 14,000 & -- & & & \\
\hline Lead & $\mu \mathrm{g} / \mathrm{g}$ & 119 & 82 & -- & 191 & 5.2 & -- & & & \\
\hline Magnesium & $\mu \mathrm{g} / \mathrm{g}$ & 6,350 & 520 & - & 5,000 & 4,200 & -- & & & \\
\hline Manganese & $\mu g / g$ & 226 & 34 & - & 280 & 110 & - & & & \\
\hline Mercury & $\mu \mathrm{g} / \mathrm{g}$ & 0.47 & 0.54 & - & $<0.48$ & - & $18 \%$ & & & \\
\hline Molybdenum & $\mu \mathrm{g} / \mathrm{g}$ & 46 & 34 & - & 80 & 25 & - & & & \\
\hline Nickel & $\mu g / g$ & 152 & 69 & - & 211 & 73 & - & & & \\
\hline Phosphorus & $\mu \mathrm{g} / \mathrm{g}$ & $<73$ & - & $100 \%$ & 228 & 100 & - & & & \\
\hline Potassium & $\mu \dot{g} / g$ & 21,800 & 3,300 & - & 21,300 & 7,200 & - & & & \\
\hline Selenium & $\mu g / g$ & 3.1 & 7.3 & $6 \%$ & 45 & 33 & - & & & \\
\hline Silicon & $\mu \mathrm{g} / \mathrm{g}$ & 231,000 & 14,000 & - & 218,000 & 20,000 & -- & & & \\
\hline Sodium & $\mu \mathrm{g} / \mathrm{g}$ & 6,700 & 2,600 & - & 7,900 & 1,500 & -- & & & \\
\hline Strontium & $\mu g / g$ & 384 & 11 & - & 370 & 120 & -- & & & \\
\hline Titanium & $\mu g / g$ & 6,830 & 960 & - & 6,860 & 850 & - & & & \\
\hline Vanadium & $\mu g / g$ & 390 & 190 & - & 509 & 91 & - & & & \\
\hline \multicolumn{11}{|l|}{ Metals by Size, <3 $\mu \mathrm{m}$} \\
\hline Percent of Total Mass & $\%$ & 16 & & & 40 & & & & & \\
\hline Aluminum & $\mu \mathrm{g} / \mathrm{g}$ & 135,000 & 18,000 & - & 122,000 & 10,000 & - & & & \\
\hline Antimony & $\mu \mathrm{g} / \mathrm{g}$ & 10 & 5.7 & -- & 13 & 0.94 & $\cdots$ & & & \\
\hline Arsenic & $\mu \mathrm{g} / \mathrm{g}$ & 160 & 110 & - & 202 & 54 & - & & & \\
\hline Barium & $\mu g / g$ & 780 & 400 & - & 758 & 85 & - & & & \\
\hline Beryllium & $\mu \mathrm{g} / \mathrm{g}$ & 17 & 9.8 & - & 15 & 5.0 & -- & & & \\
\hline Cadmium & $\mu \mathrm{g} / \mathrm{g}$ & 15 & 12 & - & 21 & 8.0 & - & & & \\
\hline Calcium & $\mu \mathrm{g} / \mathrm{g}$ & 19,000 & 13,000 & - & 16,200 & 2,100 & -- & & & \\
\hline Chromium & $\mu \mathrm{g} / \mathrm{g}$ & 246 & 65 & - & 290 & 84 & - & & & \\
\hline Cobalt & $\mu \mathrm{g} / \mathrm{g}$ & 63 & 28 & - & $\because 64$ & 15 & -- & & & \\
\hline Copper & $\mu g / g$ & 195 & 52 & - & 250 & 180 & -- & & & \\
\hline Iron & $\mu g / g$ & 58,600 & 4,700 & - & 67,900 & 5,100 & -- & & & \\
\hline Lead & $\mu \mathrm{g} / \mathrm{g}$ & 180 & 120 & - & 220 & 230 & -- & & & \\
\hline Magnesium & $\mu \mathrm{g} / \mathrm{g}$ & 7,500 & 1,500 & - & 6,700 & 3,500 & - & & & \\
\hline Manganese & $\mu \mathrm{g} / \mathrm{g}$ & 267 & 79 & - & 319 & 29 & - & & & \\
\hline Mercury & $\mu \mathrm{g} / \mathrm{g}$ & 0.63 & 0.25 & - & 0.39 & 0.15 & -- & & & \\
\hline Molybdenum & $\mu g / g$ & 103 & 72 & - & 118 & 49 & -- & & & \\
\hline Nickel & $\mu g / g$ & 202 & 49 & - & 235 & 52 & -- & & & \\
\hline
\end{tabular}




\section{Table 5-2 (Continued)}

\begin{tabular}{|c|c|c|c|c|c|c|c|c|c|c|}
\hline \multirow[b]{2}{*}{$\begin{array}{l}\text { Analyte Group/ } \\
\text { Specie }\end{array}$} & \multirow[b]{2}{*}{ Units } & \multicolumn{3}{|c|}{ ESP Inlet } & \multicolumn{3}{|c|}{ ESP Outlet } & \multicolumn{3}{|c|}{ Stack } \\
\hline & & Average & $\begin{array}{c}95 \% \\
\text { CI }\end{array}$ & $\begin{array}{c}\text { DL } \\
\text { Ratio }\end{array}$ & Average & $\begin{array}{c}95 \% \\
\mathrm{CI}\end{array}$ & $\begin{array}{c}\text { DL } \\
\text { Ratio }\end{array}$ & Average & $\begin{array}{c}95 \% \\
\text { CI }\end{array}$ & $\begin{array}{c}\mathrm{DL} \\
\text { Ratio }\end{array}$ \\
\hline Phosphorus & $\mu \mathrm{g} / \mathrm{g}$ & $<499$ & -- & $35 \%$ & 820 & 790 & -- & & & \\
\hline Potassium & $\mu g / g$ & 24,500 & 2,600 & -- & 22,700 & 5,700 & - & & & \\
\hline Selenium & $\mu \mathrm{g} / \mathrm{g}$ & $<8.0$ & - & $36 \%$ & 60 & 43 & - & & & \\
\hline Silicon & $\mu g / g$ & 223,000 & 38,000 & -- & 207,000 & 18,000 & - & & & \\
\hline Sodium & $\mu \mathrm{g} / \mathrm{g}$ & 8,000 & 2,300 & -- & 8,300 & 2,800 & -- & & & \\
\hline Strontium & $\mu g / g$ & 430 & 120 & -- & 429 & 91 & -- & & & \\
\hline Titanium & $\mu g / g$ & 6,970 & 480 & -- & 6,890 & 170 & -- & & & \\
\hline Vanadium & $\mu g / g$ & 2,700 & 9,100 & -- & 770 & 230 & -- & & & \\
\hline \multicolumn{11}{|l|}{ Organics, Aldehydes } \\
\hline Acetaldehyde & $\mu \mathrm{g} / \mathrm{Nm}^{3}$ & 130 & 170 & - & 1.2 & 2.8 & - & 8.7 & 9.2 & \\
\hline Formaldehyde & $\mu \mathrm{g} / \mathrm{Nm}^{3}$ & 61 & 56 & - & 0.50 & 1.1 & -- & 24 & 35 & \\
\hline \multicolumn{11}{|l|}{ Organics, Semivolatile } \\
\hline 2-Methylphenol(o-cresol) & $\mathrm{ng} / \mathrm{Nm}^{3}$ & 1,500 & 4,500 & $1 \%$ & 5,000 & 11,000 & -- & 3,000 & 3,700 & -- \\
\hline 4-Methylphenol(p-cresol) & $\mathrm{ng} / \mathrm{Nm}^{3}$ & 1,100 & 2,700 & $3 \%$ & 1,730 & 780 & -- & 960 & 2,000 & $3 \%$ \\
\hline Acetophenone & $\mathrm{ng} / \mathrm{Nm}^{3}$ & 2,400 & 5,000 & $1 \%$ & 3,260 & 750 & -- & 3,300 & 710 & -. \\
\hline Benzoic acid & $\mathrm{ng} / \mathrm{Nm}^{3}$ & 140,000 & 100,000 & -- & 130,000 & 70,000 & -- & 119,000 & 5,000 & -- \\
\hline Benzyl alcohol & $\mathrm{ng} / \mathrm{Nm}^{3}$ & 2,300 & 9,100 & $4 \%$ & 4,000 & 18,000 & $2 \%$ & 2,800 & 1,100 & $3 \%$ \\
\hline Butylbenzylphthalate & $\mathrm{ng} / \mathrm{Nm}^{3}$ & $<230$ & -- & $39 \%$ & 340 & 170 & -- & 300 & 130 & $\cdots$ \\
\hline Dibutylphthalate & $\mathrm{ng} / \mathrm{Nm}^{3}$ & 2,600 & 10,000 & -- & $<160$ & -- & $39 \%$ & 170 & 260 & -- \\
\hline Diethylphthalate & $\mathrm{ng} / \mathrm{Nm}^{3}$ & 260 & 360 & $12 \%$ & 190 & 530 & $24 \%$ & 240 & 140 & -. \\
\hline Dimethylphthalate & $\mathrm{ag} / \mathrm{Nm}^{3}$ & $<110$ & -- & $100 \%$ & $<96$ & -- & $100 \%$ & 180 & 560 & $18 \%$ \\
\hline Naphthalene & $\mathrm{ng} / \mathrm{Nm}^{3}$ & 900 & 460 & -- & 1,100 & 1,000 & - & 1,500 & 980 & -- \\
\hline Phenol & $\mathrm{ng} / \mathrm{Nm}^{3}$ & 8,000 & 11,000 & - & 9,000 & 15,000 & -- & 9,300 & 8,700 & -- \\
\hline bis(2-Ethylhexyl)phthalate & $\mathrm{ng} / \mathrm{Nm}^{3}$ & 1,400 & 1,700 & - & 15,000 & 41,000 & - & 1,400 & 1,400 & -- \\
\hline \multicolumn{11}{|l|}{ Organics, Volatile } \\
\hline 1,1,1-Trichloroethane & $\mathrm{ng} / \mathrm{Nm}^{3}$ & 700 & 270 & - & 690 & 190 & - & 640 & 810 & $14 \%$ \\
\hline Acetone & $\mathrm{ng} / \mathrm{Nm}^{3}$ & 16,000 & 63,000 & $6 \%$ & $<2,600$ & -- & $100 \%$ & 3,600 & 6,300 & $13 \%$ \\
\hline Benzene & $\mathrm{ng} / \mathrm{Nm}^{3}$ & 1,100 & 680 & - & 1,470 & 240 & -- & 1,310 & 360 & -- \\
\hline Carbon Disulfide & $\mathrm{ng} / \mathrm{Nm}^{3}$ & 7,000 & 25,000 & & 3,400 & 7,700 & & 2,300 & 1.200 & \\
\hline Chloromethane & $\mathrm{ng} / \mathrm{Nm}^{3}$ & $<460$ & -- & $100 \%$ & $<530$ & -- & $100 \%$ & 6,000 & 13.000 & $1 \%$ \\
\hline Methylene Chloride & $\mathrm{ng} / \mathrm{Nm}^{3}$ & 170,000 & 540,000 & - & 33,000 & 37,000 & -- & 130,000 & 280,000 & - \\
\hline Tetrachloroethene & $\mathrm{ng} / \mathrm{Nm}^{3}$ & 1,000 & 800 & -- & 820 & 470 & -- & 1,500 & 2,300 & -- \\
\hline Toluene & $\mathrm{ng} / \mathrm{Nm}^{3}$ & 1,200 & 2,000 & -- & 1,200 & 1,100 & -- & 2,000 & 1,000 & - \\
\hline Trichlorofluoromethane & $\mathrm{ng} / \mathrm{Nm}^{3}$ & 9,000 & 27,000 & -- & $<540$ &.- & $44 \%$ & 1.100 & 1,700 & -- \\
\hline $\mathrm{m}, \mathrm{p}$-Xylene & $\mathrm{ng} / \mathrm{Nm}^{3}$ & & & & $<540$ & -- & $40 \%$ & & & \\
\hline \multicolumn{11}{|l|}{ Dioxins/Furans } \\
\hline Total TCDD & $\mathrm{ng} / \mathrm{Nm}^{3}$ & & & & & & & 0.0067 & 0.008 & $16 \%$ \\
\hline
\end{tabular}


Boric acid is added to dissolve the insoluble metal fluorides that are produced during digestion. This addition of boric acid makes the quantification of boron in the sample impossible. Silicon in the gas particulate sample cannot be isolated due to the overwhelming contribution of silicon from the filter media.

The results presented in the data tables in this section of the report have been corrected for significant figures and may vary slightly from the detailed data summary presented in Appendix $\mathrm{H}$. The number of significant figures reported is directly related to the order of magnitude of the $95 \% \mathrm{CI}$. Therefore, numbers with a small degree of variability will contain more significant figures than those whose $\mathrm{CI}$ is extremely broad.

Detection limit ratios are presented where the mean value is derived in some part from results that are below the method detection limit. If all values used in determining the mean value were above the detection limit, then no DL ratio was calculated and is represented by "-.."

\section{Flue Gas Particle Size Distribution Results}

Flue gas particle size distributions were measured in three runs at the ESP inlet, ESP outlet, and the stack. All of these measurements were performed with inertial sizing devices. The Andersen High Capacity Source Sampler was used at the ESP inlet. This device has two impaction stages, a cyclone, and a final filter. The University of Washington Mark V cascade impactor was used at the ESP outlet and at the stack. This impactor was equipped with a right angle pre-cutter, eleven impaction stages, and a final filter. Because the cutpoint of the pre-cutter was close to the cutpoints of the first two stages, the weights of the precutter and first two impaction stages were combined for the size distribution calculations.

Since these particle sizing devices are inertial sizing devices, the particle cutpoints are reported from the field in aerodynamic micrometers. Conversion of aerodynamic diameter to physical diameter will be described and used in Section 8. Table 5-3 gives the average cumulative particle size distributions for the ESP inlet, ESP outlet, and stack in terms of aerodynamic particle size for the three runs. As an example of how to read the tables, Table $5-3$ shows that at the ESP outlet, $15.5 \%$ of the particulate mass was found in particles with aerodynamic diameters less than 2.1 aero $\mu \mathrm{m}$.

\section{ESP Hopper Particle Size Distribution Results}

The particle size distributions of ESP hopper catches were also measured. ESP hopper catches were collected once during Runs 1 and 2 and twice during Run 3. Field 1 and Field 2 hopper catch composites were made and analyzed by Microtracs laser diffraction. This method measures particle volumes as a function of physical particle diameter. Table 5-4 shows the average cumulative percent particle volumes as a function of physical particle diameter for the ESP Field 1 composites and the ESP Field 2 composites, respectively. These results are discussed in Section 8. 
Table 5-3

Flue Gas Particle Size Distribution

\begin{tabular}{|c|c|c|}
\hline & $\begin{array}{l}\text { Aerodynamic Particle } \\
\text { Diameter (Aero } \mu \mathrm{m})\end{array}$ & $\begin{array}{l}\text { Average Mass Percent Less } \\
\text { than Indicated Diameter }\end{array}$ \\
\hline \multirow[t]{3}{*}{ ESP Inlet } & 12.0 & 32.6 \\
\hline & 6.5 & 20.3 \\
\hline & 1.8 & 3.8 \\
\hline \multirow[t]{10}{*}{ ESP Outlet } & 10.1 & 66.3 \\
\hline & 4.3 & 35.0 \\
\hline & 2.1 & 15.5 \\
\hline & 1.14 & 7.4 \\
\hline & 0.74 & 4.1 \\
\hline & 0.57 & 3.1 \\
\hline & 0.43 & 2.1 \\
\hline & 0.33 & 1.4 \\
\hline & 0.27 & 0.7 \\
\hline & 0.16 & 0.7 \\
\hline \multirow[t]{10}{*}{ Stack } & 10.7 & 60.8 \\
\hline & 4.6 & 52.6 \\
\hline & 2.3 & 43.2 \\
\hline & 1.26 & 30.0 \\
\hline & 0.85 & 17.7 \\
\hline & 0.67 & 11.7 \\
\hline & 0.52 & 7.3 \\
\hline & 0.41 & 3.7 \\
\hline & 0.34 & 0.6 \\
\hline & 0.21 & 0.6 \\
\hline
\end{tabular}


Analytical Results

Table 5-4

ESP Fields 1 and 2 Hopper Composite Catches

\begin{tabular}{cc|cc}
\multicolumn{2}{c|}{ Hopper 1 } & \multicolumn{2}{c}{ Hopper 2 } \\
\hline $\begin{array}{c}\text { Physical Particle } \\
\text { Diameter } \\
\text { (physical } \mu \mathrm{m} \text { ) }\end{array}$ & $\begin{array}{c}\text { Average Volume } \\
\text { Percent Less than } \\
\text { Indicated Diameter }\end{array}$ & $\begin{array}{c}\text { Physical Particle } \\
\text { Diameter } \\
\text { (physical } \boldsymbol{\mu m} \text { ) }\end{array}$ & $\begin{array}{c}\text { Average Volume } \\
\text { Percent Less than } \\
\text { Indicated Diameter }\end{array}$ \\
\hline 106 & 100.0 & 42 & 100.0 \\
75 & 90.6 & 30 & 93.4 \\
53 & 76.6 & 21 & 83.9 \\
38 & 67.7 & 15 & 72.5 \\
27 & 57.3 & 10.6 & 60.5 \\
19 & 46.4 & 7.5 & 47.9 \\
13 & 38.4 & 5.3 & 34.6 \\
9.4 & 30.5 & 3.7 & 24.5 \\
6.6 & 21.2 & 2.6 & 17.2 \\
4.7 & 15.0 & 1.7 & 11.1 \\
3.3 & 8.2 & 1.01 & 6.0 \\
2.4 & 3.5 & 0.66 & 2.7 \\
1.7 & 2.1 & 0.43 & 0.8 \\
1.0 & 0.7 & 0.34 & 0.3 \\
0.66 & 0.1 & 0.24 & 0.1
\end{tabular}




\section{FGD System}

Analytical results for influent and effluent streams associated with the JBR have been compiled and are presented in Table 5-5. Mean results are presented for the limestone slurry, the JBR underflow slurry and the inlet and outlet gaseous streams. These data are also presented elsewhere in this section with $95 \% \mathrm{CI}$ and $\mathrm{DL}$ ratios.

\section{Solids}

Data for the solid streams have been summarized and are presented in Tables 5-6 to 5-9. Table 5-6 contains data representing the coal feed section of the process. Table 5-7 represents the primary ash streams exiting the boiler, Table 5-8 contains ESP hopper ash data and Table 5-9 contains data from the JBR/FGD removal process.

\section{Liquids}

Liquid streams data have been summarized and are presented in Tables 5-10 to 5-12. Table 5-10 contains data from the ash sluice system. Table 5-11 presents the FGD process stream data and ancillary streams such as the cooling water and coal pile run-off are in Table 5-12. As with the gaseous results, the only organic results that are presented are for those species which were detected. Detailed results are contained in Appendix H. 
Table 5-5

FGD System Summary

\begin{tabular}{|c|c|c|c|c|c|c|}
\hline \multirow[b]{2}{*}{ Specie } & \multicolumn{2}{|c|}{$\begin{array}{c}\text { Limestone } \\
\text { Slurry }\end{array}$} & \multicolumn{2}{|c|}{$\begin{array}{l}\text { JBR Underflow } \\
\text { Slurry }\end{array}$} & \multirow{2}{*}{$\begin{array}{c}\begin{array}{c}\text { ESP } \\
\text { Outlet }\end{array} \\
\begin{array}{c}\text { Total } \\
\left(\mu \mathrm{g} / \mathrm{Nm}^{3}\right)\end{array}\end{array}$} & \multirow{2}{*}{$\frac{\text { Stack }}{\begin{array}{c}\text { Total } \\
\left(\mu \mathrm{g} / \mathrm{Nm}^{3}\right)\end{array}}$} \\
\hline & $\begin{array}{l}\text { Aqueous } \\
(\mu \mathrm{g} / \mathrm{mL})\end{array}$ & $\begin{array}{l}\text { Solids } \\
(\mu \mathrm{g} / \mathrm{g})\end{array}$ & $\begin{array}{l}\text { Aqueous } \\
(\mu \mathrm{g} / \mathrm{mL})\end{array}$ & $\begin{array}{l}\text { Solids } \\
(\mu \mathrm{g} / \mathrm{g})\end{array}$ & & \\
\hline Aluminum & 0.26 & 760 & 12.3 & 1,100 & 12,200 & 200 \\
\hline Antimony & $<0.24$ & 0.019 & $<0.19$ & 0.073 & 0.53 & 0.41 \\
\hline Arsenic & 0.07 & $<0.33$ & 0.20 . & $<0.41$ & 17 & 1.9 \\
\hline Barium & 4 & 5.39 & 3.39 & 4.02 & 75 & 3.2 \\
\hline Beryllium & $<0.0055$ & 0.143 & 0.0069 & 0.129 & 2.4 & 0.43 \\
\hline Boron & 1,400 & 202 & 1,400 & 425 & 6,900 & 440 \\
\hline Cadmium & 0.0067 & 0.608 & 0.456 & 0.247 & 1.3 & 1.2 \\
\hline Calcium & 7,070 & 392,000 & 17,000 & $255,-$ & 1,900 & 300 \\
\hline Chromium & 0.063 & 13.4 & 0.07 & 000 & 24 & 6.4 \\
\hline & & & & 11.3 & & \\
\hline Cobalt & 0.09 & 1.48 & 0.304 & 0.99 & 6.0 & 0.74 \\
\hline Copper & 0.04 & 3.71 & 0.239 & 2.73 & 18 & 2.0 \\
\hline Iron & $<0.06$ & 2,510 & $<0.048$ & 2,190 & 8,600 & 170 \\
\hline Lead & 0.0017 & 0.98 & 0.013 & 0.84 & 19 & 1.3 \\
\hline Magnesium & 1,900 & 1,390 & 1,800 & 810 & 670 & 47 \\
\hline Manganese & 40 & 429 & 307 & 103 & 35 & 7.9 \\
\hline Mercury & 0.00006 & $<0.012$ & 0.001 & 0.178 & 5.7 & 3.1 \\
\hline Molybdenum & 0.21 & 0.23 & 0.064 & 1.48 & 9.1 & 1.5 \\
\hline Nickel & 0.8 & 4.0 & 1.52 & 2.8 & 25 & 42 \\
\hline Phosphorus & 0.16 & 110 & 0.720 & 88 & 120 & $<19$ \\
\hline Potassium & 140 & 338 & 123 & 310 & 2,200 & 80 \\
\hline Selenium & 0.128 & 8.4 & 0.50 & 25.5 & 80 & 27 \\
\hline Silicon & 7 & 370 & 42.4 & 447 & & \\
\hline Sodium & 290 & 55 & 244 & 84.1 & 1,000 & 71 \\
\hline Strontium & 40 & 112 & 32.9 & 73.8 & 45 & 2.1 \\
\hline Titanium & 0.5 & $<0.16$ & 0.82 & 20.9 & 760 & 13 \\
\hline Vanadium & 0.19 & 6.7 & 0.24 & 9.9 & 55 & 2.2 \\
\hline
\end{tabular}


Table 5-6

Coal Data

\begin{tabular}{|c|c|c|c|c|c|c|c|c|c|c|c|}
\hline \multirow[b]{2}{*}{$\begin{array}{l}\text { Analyte } \\
\text { Group }\end{array}$} & \multirow[b]{2}{*}{ Specie } & \multirow[b]{2}{*}{ Units } & \multicolumn{3}{|c|}{ Feed Coal } & \multicolumn{3}{|c|}{ Raw Coal } & \multicolumn{3}{|c|}{ Pulverizer Rejects } \\
\hline & & & Average & $\begin{array}{c}95 \% \\
\mathrm{CI}\end{array}$ & $\begin{array}{c}\text { DL } \\
\text { Ratio }\end{array}$ & Average & $\begin{array}{c}95 \% \\
\mathrm{CI}\end{array}$ & $\begin{array}{c}\mathrm{DL} \\
\text { Ratio }\end{array}$ & Average & $\begin{array}{c}95 \% \\
\mathrm{CI}\end{array}$ & $\begin{array}{c}\text { DL } \\
\text { Ratio }\end{array}$ \\
\hline \multirow[t]{2}{*}{ Anions } & Chloride & $\mu \mathrm{g} / \mathrm{g}$ & 1,400 & 90 & & 1,350 & 220 & & 510 & 100 & \\
\hline & Fluoride & $\mu g / g$ & 100 & 0 & & 123 & 38 & & 323 & 29 & \\
\hline \multirow[t]{30}{*}{ Metals } & Aluminum & $\mu \mathrm{g} / \mathrm{g}$ & 14,500 & 1,400 & & 14,300 & 3,100 & & 27.200 & 9.600 & \\
\hline & Antimony & $\mu g / g$ & 0.61 & 0.16 & & 0.62 & 0.33 & & 1.2 & 0.45 & \\
\hline & Arsenic & $\mu \mathrm{g} / \mathrm{g}$ & 2.3 & 1.4 & & 3.0 & 0 & & 47 & 45 & \\
\hline & Barium & $\mu \mathrm{g} / \mathrm{g}$ & 80 & 51 & & 112 & 19 & & 330 & 520 & \\
\hline & Beryllium & $\mu g / g$ & 1.1 & 0 & & 1.13 & 0.14 & & 1.5 & 1.9 & \\
\hline & Boron & $\mu g / g$ & 100 & 0 & & 110 & 25 & & 120 & 120 & \\
\hline & Bromine & $\mu \mathrm{g} / \mathrm{g}$ & 7.44 & 0.53 & & 7.4 & 1 & & 4.3 & 1.5 & \\
\hline & Cadmium & $\mu g / g$ & 0.30 & 0 & & 0.53 & 0.72 & & 4.1 & 8.6 & \\
\hline & Calcium & $\mu \mathrm{g} / \mathrm{g}$ & 2,100 & 1,300 & & 3,000 & 1,300 & & 12.700 & 6.500 & \\
\hline & Chlorine & $\mu \mathrm{g} / \mathrm{g}$ & 1,240 & 100 & & 1,210 & 140 & & 590 & 130 & \\
\hline & Chromium & $\mu \mathrm{g} / \mathrm{g}$ & 24.8 & 2.9 & & 25.8 & 0.37 & & 64 & 14 & \\
\hline & Cobalt & $\mu \mathrm{g} / \mathrm{g}$ & 3.5 & 1.9 & & 4.08 & 0.19 & & 7.8 & 0.8 & \\
\hline & Copper & $\mu g / g$ & 36 & 62 & & 42 & 50 & & 68 & 85 & $14 \%$ \\
\hline & Iron & $\mu \mathrm{g} / \mathrm{g}$ & 11,400 & 1,100 & & 12,800 & 1,700 & & 127.000 & 17.000 & \\
\hline & Lead & $\mu g / g$ & 8.0 & 2.5 & & 9.0 & 4.3 & & 37 & 32 & \\
\hline & Magnesium & $\mu g / g$ & 570 & 170 & & 660 & 58 & & 1,370 & 320 & \\
\hline & Manganese & $\mu g / g$ & 23.4 & 3.3 & & 24.4 & 5.9 & & 99 & 53 & \\
\hline & Mercury & $\mu \mathrm{g} / \mathrm{g}$ & 0.077 & 0.029 & & 0.043 & 0.014 & & 0.13 & 0.29 & \\
\hline & Molybdenum & $\mu g / g$ & 22.3 & 6.1 & & 18 & 11 & & 13 & 20 & \\
\hline & Nickel & $\mu \mathrm{g} / \mathrm{g}$ & 30.0 & 6.4 & & 40 & 14 & & $<120$ & - & $66 \%$ \\
\hline & Phosphorus & $\mu g / g$ & 84 & 16 & & 100 & 120 & & 1.500 & 2,200 & \\
\hline & Potassium & $\mu \mathrm{g} / \mathrm{g}$ & 3,300 & 720 & & 3,100 & 2,300 & & 2.700 & 6.600 & \\
\hline & Selenium & $\mu g / g$ & 2.3 & 1.4 & & 2.3 & 1.4 & & 8.7 & 3.8 & \\
\hline & Silver & $\mu \mathrm{g} / \mathrm{g}$ & $<0.52$ & - & $100 \%$ & $<0.41$ & - & $100 \%$ & $<1.9$ & - & $59 \%$ \\
\hline & Sodium & $\mu \mathrm{g} / \mathrm{g}$ & 631 & 82 & & 679 & 89 & & 1.110 & 240 & \\
\hline & Strontium & $\mu g / g$ & 74.9 & 9.3 & & 88 & 14 & & 450 & 460 & \\
\hline & Tin & $\mu g / g$ & $<16$ & - & $100 \%$ & $<17$ & - & $100 \%$ & $<31$ & - & $49 \%$ \\
\hline & Titanium & $\mu g / g$ & 890 & 170 & & 850 & 170 & & 1,980 & 110 & \\
\hline & Uranium & $\mu g / g$ & 1.8 & 0.6 & & 1.60 & 0.37 & & 4.1 & 1.9 & \\
\hline & Vanadium & $\mu \mathrm{g} / \mathrm{g}$ & 39.4 & 1.2 & & 37.7 & 6.3 & & 59.8 & 8.2 & \\
\hline \multirow[t]{11}{*}{ Ultimate/Proximate } & \% Ash & $\%$ & 11.1 & 1.4 & & 12.2 & 2.5 & & & & \\
\hline & \% Carbon & $\%$ & 72.0 & 0.52 & & 70.8 & 1.2 & & 38.5 & 4.2 & \\
\hline & \% Hydrogen & $\%$ & 4.83 & 0.014 & & 4.76 & 0.17 & & & & \\
\hline & \% Moisture & $\%$ & & & & 11.7 & 2.2 & & & & \\
\hline & $\%$ Nitrogen & $\%$ & 1.52 & 0.14 & & 1.45 & 0.052 & & & & \\
\hline & \% Oxygen (diff.) & $\mathscr{0}$ & 7.74 & 0.62 & & 7.92 & 0.93 & & & & \\
\hline & \% Sulfur & $\%$ & 2.74 & 0.29 & & 2.90 & 0.36 & & 16.0 & 2.3 & \\
\hline & Fixed Carbon & $\%$ & 50.8 & 2.5 & & 50.7 & 0.74 & & & & \\
\hline & $\begin{array}{l}\text { Higher Heating } \\
\text { Value }\end{array}$ & $\mathrm{Btu} / \mathrm{lb}$ & 12,697 & 64 & & 12,590 & 270 & & & & \\
\hline & $\begin{array}{l}\text { Heating Value } \\
\text { (MAF) }\end{array}$ & MAF Btu & 14,290 & 160 & & 14,330 & 150 & & & & \\
\hline & Volatile Matter & $\%$ & 37.0 & 2.7 & & 37.1 & 1.9 & & & & \\
\hline
\end{tabular}


Table 5-6 (Continued)

\begin{tabular}{|c|c|c|c|c|c|c|c|c|c|c|c|}
\hline \multirow[b]{2}{*}{$\begin{array}{l}\text { Analyte } \\
\text { Group }\end{array}$} & \multirow[b]{2}{*}{ Specie } & \multirow[b]{2}{*}{ Units } & \multicolumn{3}{|c|}{ Feed Coal } & \multicolumn{3}{|c|}{ Raw Coal } & \multicolumn{3}{|c|}{ Pulverizer Rejects } \\
\hline & & & Average & $\begin{array}{c}95 \% \\
\mathrm{CI}\end{array}$ & $\begin{array}{c}\text { DL } \\
\text { Ratio }\end{array}$ & Average & $\begin{array}{l}95 \% \\
\text { CI }\end{array}$ & $\begin{array}{c}\text { DL } \\
\text { Ratio }\end{array}$ & Average & $\begin{array}{c}95 \% \\
\text { CI }\end{array}$ & $\begin{array}{c}\text { DL } \\
\text { Ratio }\end{array}$ \\
\hline \multirow[t]{18}{*}{ Radionuclides } & $\begin{array}{l}\text { Actinium-228 @ } \\
338 \mathrm{KeV}\end{array}$ & $\mathrm{pCi} / \mathrm{g}$ & 0.33 & 0.29 & & & & & & & \\
\hline & $\begin{array}{l}\text { Actinium-228 @ } \\
911 \mathrm{KeV}\end{array}$ & $\mathrm{pCi} / \mathrm{g}$ & 0.33 & 0.14 & & & & & & & \\
\hline & $\begin{array}{l}\text { Actinium-228 @ } \\
968 \mathrm{KeV}\end{array}$ & $\mathrm{pCi} / \mathrm{g}$ & 0.07 & 0.29 & & & & & & & \\
\hline & $\begin{array}{l}\text { Bismuth-212 @ } \\
727 \mathrm{KeV}\end{array}$ & $\mathrm{pCi} / \mathrm{g}$ & ND & - & & & & & & & \\
\hline & $\begin{array}{l}\text { Bismuth-214 @ } \\
1120.4 \mathrm{KeV}\end{array}$ & $\mathrm{pCi} / \mathrm{g}$ & 0.93 & 0.38 & & & & & & & \\
\hline & $\begin{array}{l}\text { Bismuth-214 @ } \\
1764.7 \mathrm{KeV}\end{array}$ & $\mathrm{pCi} / \mathrm{g}$ & 0.10 & 0.43 & & & & & & & . \\
\hline & $\begin{array}{l}\text { Bismuth-214@ } \\
609.4 \mathrm{KeV}\end{array}$ & $\mathrm{pCi} / \mathrm{g}$ & 0.67 & 0.14 & & & & & & & \\
\hline & $\begin{array}{l}\mathrm{K}-40 @ 1460 \\
\mathrm{KeV}\end{array}$ & $\mathrm{pCi} / \mathrm{g}$ & 1.4 & 3.6 & & & & & & & \\
\hline & $\begin{array}{l}\text { Lead-210@ } 46 \\
\mathrm{KeV}\end{array}$ & $\mathrm{pCi} / \mathrm{g}$ & 1.3 & 0.9 & & & & & & & \\
\hline & $\begin{array}{l}\text { Lead-212@ } 238 \\
\mathrm{KeV}\end{array}$ & $\mathrm{pCi} / \mathrm{g}$ & 0.20 & 0 & & & & & & & \\
\hline & $\begin{array}{l}\text { Lead-214@ } \\
295.2 \mathrm{KeV}\end{array}$ & $\mathrm{pCi} / \mathrm{g}$ & 0.63 & 0.14 & & & & & & & \\
\hline & $\begin{array}{l}\text { Lead-214@ } 352.0 \\
\mathrm{KeV}\end{array}$ & $\mathrm{pCi} / \mathrm{g}$ & 0.63 & 0.14 & & & & & & & \\
\hline & $\begin{array}{l}\text { Radium-226@ } \\
186.0 \mathrm{KeV}\end{array}$ & $\mathrm{pCi} / \mathrm{g}$ & 1.17 & 0.72 & & & & & & & \\
\hline & $\begin{array}{l}\text { Thallium-208 @ } \\
583 \mathrm{KeV}\end{array}$ & $\mathrm{pCi} / \mathrm{g}$ & 0.30 & 0.25 & & & & & & & \\
\hline & $\begin{array}{l}\text { Thallium-208 @ } \\
860 \mathrm{KeV}\end{array}$ & $\mathrm{pCi} / \mathrm{g}$ & ND & - & & & & & & & \\
\hline & $\begin{array}{l}\text { Thorium-234@ } \\
63.3 \mathrm{KeV}\end{array}$ & $\mathrm{pCi} / \mathrm{g}$ & 1.0 & 1.4 & & & & & & & \\
\hline & $\begin{array}{l}\text { Thorium-234 @ } \\
92.6 \mathrm{KeV}\end{array}$ & $\mathrm{pCi} / \mathrm{g}$ & 0.67 & 0.38 & & & & & & & \\
\hline & $\begin{array}{l}\text { Uranium-235 @ } \\
143 \mathrm{KeV}\end{array}$ & $\mathrm{pCi} / \mathrm{g}$ & 0.07 & 0.29 & & & & & & & \\
\hline
\end{tabular}


Table 5-7

Boiler Process Solids Data

\begin{tabular}{|c|c|c|c|c|c|c|c|c|}
\hline \multirow[b]{2}{*}{$\begin{array}{l}\text { Analyte } \\
\text { Group }\end{array}$} & \multirow[b]{2}{*}{ Specie } & \multirow[b]{2}{*}{ Units } & \multicolumn{3}{|c|}{ Bottom Ash } & \multicolumn{3}{|c|}{ Sluiced Fly Ash } \\
\hline & & & Average & $\begin{array}{c}95 \% \\
\mathrm{CI}\end{array}$ & $\begin{array}{c}\text { DL } \\
\text { Ratio }\end{array}$ & Average & $\begin{array}{c}95 \% \\
\mathrm{CI}\end{array}$ & $\begin{array}{c}\text { DL } \\
\text { Ratio }\end{array}$ \\
\hline \multirow[t]{2}{*}{ Anions } & Chloride & $\mu \mathrm{g} / \mathrm{g}$ & 130 & 170 & $13 \%$ & $<100$ & - & $100 \%$ \\
\hline & Fluoride & $\mu \mathrm{g} / \mathrm{g}$ & 32 & 26 & & 99 & 67 & \\
\hline \multirow[t]{26}{*}{ Metals } & Aluminum & $\mu \mathrm{g} / \mathrm{g}$ & 76,000 & 11,000 & & 98,000 & 8,000 & \\
\hline & Antimony & $\mu \mathrm{g} / \mathrm{g}$ & 1.14 & 0.20 & & 339 & 2.04 & \\
\hline & Arsenic & $\mu \mathrm{g} / \mathrm{g}$ & 7.2 & 6.2 & & 61 & 37 & \\
\hline & Barium & $\mu \mathrm{g} / \mathrm{g}$ & 457 & 66 & & 496 & 87 & \\
\hline & Beryllium & $\mu \mathrm{g} / \mathrm{g}$ & 7.7 & 2.9 & & I1.I & 3.1 & \\
\hline & Boron & $\mu \mathrm{g} / \mathrm{g}$ & 280 & 170 & & 470 & 230 & \\
\hline & Cadmium & $\mu g / g$ & 0.32 & 0.39 & & 4.10 & 3 & \\
\hline & Calcium & $\mu \mathrm{g} / \mathrm{g}$ & 20,300 & 3,400 & & 13,800 & 2,000 & \\
\hline & Chromium & $\mu g / g$ & 192 & 18 & & 185 & 21 & \\
\hline & Cobalt & $\mu g / g$ & 31.6 & 4.3 & & 36.9 & 5.8 & \\
\hline & Copper & $\mu \mathrm{g} / \mathrm{g}$ & 77 & 18 & & 104 & 23 & \\
\hline & Iron & $\mu g / g$ & 130,000 & 31,000 & & 89,000 & 22,000 & \\
\hline & Lead & $\mu g / g$ & 20 & 3.8 & & 83 & 40 & \\
\hline & Magnesium & $\mu g / g$ & 3610 & 820 & & 4,880 & 350 & \\
\hline & Manganese & $\mu \mathrm{g} / \mathrm{g}$ & 270 & 56 & & 245 & 46 & \\
\hline & Mercury & $\mu g / g$ & $<0.011$ & - & $70 \%$ & 0.150 & 0.12 & \\
\hline & Molybdenum & $\mu g / g$ & $<3.0$ & - & $39 \%$ & $<14$ & - & $29 \%$ \\
\hline & Nickel & $\mu \mathrm{g} / \mathrm{g}$ & 131 & 15 & & 143 & 32 & \\
\hline & Phosphorus & $\mu \mathrm{g} / \mathrm{g}$ & 400 & 210 & & 70 & 140 & \\
\hline & Potassium & $\mu g / g$ & 14,200 & 1,100 & & 18,210 & 1,000 & \\
\hline & Selenium & $\mu \mathrm{g} / \mathrm{g}$ & $<1$ & - & $100 \%$ & 12 & 11 & \\
\hline & Silicon & $\mu \mathrm{g} / \mathrm{g}$ & 213,000 & 11,000 & & 219,000 & 7,600 & \\
\hline & Sodium & $\mu g / g$ & 36,10 & 580 & & 5,100 & 1,200 & \\
\hline & Strontium & $\mu g / g$ & 280 & 41 & & 322 & 30 & \\
\hline & Titanium & $\mu \mathrm{g} / \mathrm{g}$ & 5,550 & 560 & & 6,330 & 750 & \\
\hline & Vanadium & $\mu g / g$ & 277 & 29 & & 327 & 58 & \\
\hline \multirow[t]{2}{*}{ Ultimate/Proximate } & \% Carbon & 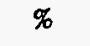 & 2.3 & 4.2 & & 4.50 & 2.7 & \\
\hline & \% Sulfur & $\%$ & 0.15 & 0.41 & & 0.134 & 0.041 & \\
\hline \multirow[t]{10}{*}{ Radionuclides } & Actinium-228@ @ $338 \mathrm{KeV}$ & $\mathrm{pCi} / \mathrm{g}$ & 2.1 & 0 & & 2.37 & 0.14 & \\
\hline & Actinium-228@911 KeV & $\mathrm{pCi} / \mathrm{g}$ & 2.20 & 0.25 & & 2.33 & 0.14 & \\
\hline & Actinium-228@968 KeV & $\mathrm{pCi} / \mathrm{g}$ & 2.2 & 1 & & 2.50 & 0.25 & \\
\hline & Bismuth-212@ $727 \mathrm{KeV}$ & $\mathrm{pCi} / \mathrm{g}$ & 3.0 & 1.2 & & 2.60 & 0.99 & \\
\hline & Bismuth-214@1120.4 KeV & $\mathrm{pCi} / \mathrm{g}$ & 7.4 & 1.3 & & 6.50 & 2.4 & \\
\hline & Bismuth-214@1764.7 KeV & $\mathrm{pCi} / \mathrm{g}$ & 6.8 & 2.2 & & 5.90 & 1.8 & \\
\hline & Bismuth-214@609.4 KeV & $\mathrm{pCi} / \mathrm{g}$ & 7.1 & 1.5 & & 6.50 & 1.4 & \\
\hline & $\mathrm{K}-40 @ 1460 \mathrm{KeV}$ & $\mathrm{pCi} / \mathrm{g}$ & 16.7 & 2.9 & & 18.0 & 2.5 & \\
\hline & Lead-210@ $@ 46 \mathrm{KeV}$ & $\mathrm{pCi} / \mathrm{g}$ & 1.37 & 0.52 & & 6.40 & 2.7 & \\
\hline & Lead-212@238 KeV & $\mathrm{pCi} / \mathrm{g}$ & 2.03 & 0.72 & & 2.20 & 0.25 & \\
\hline
\end{tabular}


Table 5-7 (Continued)

\begin{tabular}{|c|c|c|c|c|c|c|c|c|}
\hline \multirow[b]{2}{*}{$\begin{array}{l}\text { Analyte } \\
\text { Group }\end{array}$} & \multirow[b]{2}{*}{ Specie } & \multirow[b]{2}{*}{ Units } & \multicolumn{3}{|c|}{ Bottom Ash } & \multicolumn{3}{|c|}{ Sluiced Fly Ash } \\
\hline & & & Average & $\begin{array}{c}95 \% \\
\text { CI }\end{array}$ & $\begin{array}{c}\text { DL } \\
\text { Ratio }\end{array}$ & Average & $\begin{array}{c}95 \% \\
\mathrm{CI}\end{array}$ & $\begin{array}{c}\text { DL } \\
\text { Ratio }\end{array}$ \\
\hline \multirow[t]{8}{*}{ Radionuclides (Cont'd) } & Lead-214@295.2 KeV & $\mathrm{pCi} / \mathrm{g}$ & 7.3 & 1.9 & & 6.50 & 1.4 & \\
\hline & Lead-214@352.0 KeV & $\mathrm{pCi} / \mathrm{g}$ & 7.6 & 1.8 & & 6.60 & 1.3 & \\
\hline & Radium-226@186.0 KeV & $\mathrm{pCi} / \mathrm{g}$ & 10.3 & 1.5 & & 9.9 & 2.9 & \\
\hline & Thallium-208@583 KeV & $\mathrm{pCi} / \mathrm{g}$ & 2.20 & 0.43 & & 2.23 & 0.29 & \\
\hline & Thallium-208@860 KeV & $\mathrm{pCi} / \mathrm{g}$ & 1.9 & 4.2 & & 2.97 & 0.14 & \\
\hline & Thorium-234@63.3 KeV & $\mathrm{pCi} / \mathrm{g}$ & 5.77 & 0.76 & & 6.60 & 4.3 & \\
\hline & Thorium-234@ $92.6 \mathrm{KeV}$ & $\mathrm{pCi} / \mathrm{g}$ & 5.0 & 1.3 & & 5.00 & 2.2 & \\
\hline & Uranium-235@143 KeV & $\mathrm{pCi} / \mathrm{g}$ & 0.31 & 0.16 & & 0.220 & 0.15 & \\
\hline \multirow[t]{2}{*}{ Organics, Semivolatile } & 2-Methylnaphthalene & $\mathrm{ng} / \mathrm{g}$ & 34 & 97 & $22 \%$ & $<26$ & - & $100 \%$ \\
\hline & bis(2-Ethylhexyl)phthalate & $\mathrm{ng} / \mathrm{g}$ & $<86$ & - & $26 \%$ & 230 & 520 & $2 \%$ \\
\hline
\end{tabular}


Table 5-8

ESP Hopper Ash

\begin{tabular}{|c|c|c|c|c|c|c|c|c|}
\hline \multirow[b]{2}{*}{$\begin{array}{l}\text { Analyte } \\
\text { Group }\end{array}$} & \multirow[b]{2}{*}{ Specie } & \multirow[b]{2}{*}{ Units } & \multicolumn{3}{|c|}{ ESP Hopper Ash-Field 1} & \multicolumn{3}{|c|}{ ESP Hopper Ash-Field 2} \\
\hline & & & Average & $\begin{array}{c}95 \% \\
\mathrm{CI} \\
\end{array}$ & $\begin{array}{c}\text { DL } \\
\text { Ratio }\end{array}$ & Average & $\begin{array}{c}95 \% \\
\mathrm{CI}\end{array}$ & $\begin{array}{c}\text { DL } \\
\text { Ratio }\end{array}$ \\
\hline \multirow[t]{2}{*}{ Anions } & Chioride & $\mu \mathrm{g} / \mathrm{g}$ & 350 & 650 & $5 \%$ & $<100$ & - & $100 \%$ \\
\hline & Fluoride & $\mu g / g$ & 90 & 49 & & 125 & 91 & \\
\hline \multirow[t]{25}{*}{ Metals } & Aiuminum & $\mu \mathrm{g} / \mathrm{g}$ & 97,000 & 51,000 & & 89,000 & 11,000 & \\
\hline & Antimony & $\mu \mathrm{g} / \mathrm{g}$ & 2.99 & 1.01 & & 4.19 & 1.38 & \\
\hline & Arsenic & $\mu \mathrm{g} / \mathrm{g}$ & 46 & 11 & & 71.9 & 9.8 & \\
\hline & Barium & $\mu \mathrm{g} / \mathrm{g}$ & 490 & 150 & & 493 & 98 & \\
\hline & Beryilium & $\mu g / g$ & 10.9 & 3.3 & & 17.2 & 3.4 & \\
\hline & Cadmium & $\mu g / g$ & 3.26 & 0.72 & & 5.42 & 0.69 & \\
\hline & Calcium & $\mu g / g$ & 17,900 & 6,400 & & 15,640 & 960 & \\
\hline & Chromium & $\mu \mathrm{g} / \mathrm{g}$ & 183 & 31 & & 220 & 110 & \\
\hline & Cobalt & $\mu \mathrm{g} / \mathrm{g}$ & 34.0 & 4.1 & & 42 & 6 & \\
\hline & Copper & $\mu g / g$ & 98 & 26 & & 150 & 150 & \\
\hline & Iron & $\mu g / g$ & 90,000 & 17,000 & & 80.000 & 8,600 & \\
\hline & Lead & $\mu g / g$ & 72 & 11 & & 96 & 20 & \\
\hline & Magnesium & $\mu g / g$ & 4,600 & 2,700 & & 4,100 & 1,000 & \\
\hline & Manganese & $\mu g / g$ & 219 & 52 & & 216 & 25 & \\
\hline & Mercury & $\mu \mathrm{g} / \mathrm{g}$ & 0.119 & 0.087 & & 0.18 & 0.18 & \\
\hline & Molybdenum & $\mu g / g$ & 25 & 19 & & 49 & 32 & \\
\hline & Nickel & $\mu g / g$ & 127 & 28 & & 158 & 31 & \\
\hline & Phosphorus & $\mu \mathrm{g} / \mathrm{g}$ & 100 & 140 & $12 \%$ & $<72$ & - & $100 \%$ \\
\hline & Potassium & $\mu \mathrm{g} / \mathrm{g}$ & 17,400 & 3,100 & & 18,100 & 1,100 & \\
\hline & Selenium & $\mu g / g$ & 9.3 & 4.7 & & 16.6 & 3.3 & \\
\hline & Silicon & $\mu g / g$ & 223,000 & 35,000 & & 215,000 & 15,000 & \\
\hline & Sodium & $\mu g / g$ & 5,200 & 1,200 & & 6,000 & 1,400 & \\
\hline & Strontium & $\mu g / g$ & 320 & 120 & & 327 & 41 & \\
\hline & Titanium & $\mu \mathrm{g} / \mathrm{g}$ & 6,120 & 190 & & 6,450 & 290 & \\
\hline & Vanadium & $\mu g / g$ & 305 & 37 & & 357 & 55 & \\
\hline \multirow[t]{13}{*}{ Radionuclides } & Actinium-228@338 KeV & $\mathrm{pCi} / \mathrm{g}$ & 2.13 & 0.38 & & 2.17 & 0.38 & \\
\hline & Actinium-228@ @ $911 \mathrm{KeV}$ & $\mathrm{pCi} / \mathrm{g}$ & 2.10 & 0.43 & & 2.2 & 0.5 & \\
\hline & Actinium-228@968 KeV & $\mathrm{pCi} / \mathrm{g}$ & 2.43 & 0.87 & & 2.63 & 0.14 & \\
\hline & Bismuth-212@ $0727 \mathrm{KeV}$ & $\mathrm{pCi} / \mathrm{g}$ & 2.8 & 1.6 & & 2.8 & 1.3 & \\
\hline & $\begin{array}{l}\text { Bismuth-214@ } 1120.4 \\
\mathrm{KeV}\end{array}$ & $\mathrm{pCi} / \mathrm{g}$ & 6.1 & 2.6 & & 6.27 & 0.76 & \\
\hline & $\begin{array}{l}\text { Bismuth-214 @ } 1764.7 \\
\mathrm{KeV}\end{array}$ & $\mathrm{pCi} / \mathrm{g}$ & 5.9 & 2.3 & & 5.7 & 0.9 & \\
\hline & Bismuth-214@609.4 KeV & $\mathrm{pCi} / \mathrm{g}$ & 6.2 & 2.1 & & 6.0 & 1.9 & \\
\hline & $\mathrm{K}-40 @ 1460 \mathrm{KeV}$ & $\mathrm{pCi} / \mathrm{g}$ & 17.0 & 4.3 & & 17.3 & 1.4 & \\
\hline & Lead-210@ $@ 6 \mathrm{KeV}$ & $\mathrm{pCi} / \mathrm{g}$ & 5.43 & 0.72 & & 7.8 & 1.4 & \\
\hline & Lead-212@238 KeV & $\mathrm{pCi} / \mathrm{g}$ & 2.10 & 0.75 & & 1.87 & 0.76 & \\
\hline & Lead-214@ $295.2 \mathrm{KeV}$ & $\mathrm{pCi} / \mathrm{g}$ & 6.1 & 1.5 & & 6.0 & 1.2 & \\
\hline & Lead-214@352.0 KeV & $\mathrm{pCi} / \mathrm{g}$ & 6.2 & 2.1 & & 6.1 & 1.1 & \\
\hline & Radium-226@186.0 KeV & $\mathrm{pCi} / \mathrm{g}$ & 9.0 & 2.2 & & 9.7 & 2.8 & \\
\hline
\end{tabular}


Analytical Results

Table 5-8 (Continued)

\begin{tabular}{|c|c|c|c|c|c|c|c|c|}
\hline \multirow[b]{2}{*}{$\begin{array}{l}\text { Analyte } \\
\text { Gronp }\end{array}$} & \multirow[b]{2}{*}{ Specie } & \multirow[b]{2}{*}{ Units } & \multicolumn{3}{|c|}{ ESP Hopper Ash-Field 1} & \multicolumn{3}{|c|}{ ESP Hopper Ash-Field 2} \\
\hline & & & Average & $\begin{array}{c}95 \% \\
\text { CI }\end{array}$ & $\begin{array}{c}\text { DL } \\
\text { Ratio }\end{array}$ & Average & $\begin{array}{c}95 \% \\
\mathrm{CI}\end{array}$ & $\begin{array}{c}\text { DL } \\
\text { Ratio }\end{array}$ \\
\hline \multicolumn{9}{|l|}{ Radionuclides (Cont'd) } \\
\hline & Thallium-208@ @ $583 \mathrm{KeV}$ & $\mathrm{pCi} / \mathrm{g}$ & 2.07 & 0.29 & & 2.17 & 0.38 & \\
\hline & Thallium-208@860 KeV & $\mathrm{pCi} / \mathrm{g}$ & 2.1 & 1.9 & & 2.2 & 4.8 & \\
\hline & Thorium-234@63.3 KeV & $\mathrm{pCi} / \mathrm{g}$ & 5.6 & 2.2 & & 5.5 & 1.6 & \\
\hline & Thorium-234@92.6 KeV & $\mathrm{pCi} / \mathrm{g}$ & 4.3 & 1.6 & & 4.8 & 1.6 & \\
\hline & Uranium-235 @ $143 \mathrm{KeV}$ & $\mathrm{pCi} / \mathrm{g}$ & 0.22 & 0.17 & & 0.9 & 2.8 & \\
\hline Organics, Semivolatile & bis(2-Ethylhexyl)phthalate & $\mathrm{ng} / \mathrm{g}$ & 190 & 780 & $3 \%$ & 200 & 590 & $2 \%$ \\
\hline
\end{tabular}


Table 5-9

FGD Process Solids Data

\begin{tabular}{|c|c|c|c|c|c|c|c|c|c|c|c|}
\hline \multirow[b]{2}{*}{$\begin{array}{l}\text { Analyte } \\
\text { Group }\end{array}$} & \multirow[b]{2}{*}{ Specie } & \multirow[b]{2}{*}{ Units } & \multicolumn{3}{|c|}{$\begin{array}{c}\text { JBR Underflow } \\
\text { Snrry Solids }\end{array}$} & \multicolumn{3}{|c|}{ Limestone Slurry Solids } & \multicolumn{3}{|c|}{ Raw Limestone } \\
\hline & & & Average & $\begin{array}{c}95 \% \\
\mathrm{CI}\end{array}$ & $\begin{array}{c}\text { DL } \\
\text { Ratio }\end{array}$ & Average & $\begin{array}{c}95 \% \\
\mathrm{CI}\end{array}$ & $\begin{array}{c}\text { DL } \\
\text { Ratio }\end{array}$ & Average & $\begin{array}{c}95 \% \\
\mathrm{CI}\end{array}$ & $\begin{array}{c}\text { DL } \\
\text { Ratio }\end{array}$ \\
\hline \multirow[t]{4}{*}{ Anions } & Chloride & $\mu g / g$ & 9,550 & 720 & & 4,100 & 2,900 & & 179 & 47 & \\
\hline & Fluoride & $\mu g / g$ & 750 & 140 & & 85.0 & 46 & & 59.0 & 19 & \\
\hline & Sulfate & $\mu g / g$ & 496,300 & 8,700 & & & & & & & \\
\hline & Sulfite & $\mu g / g$ & $<240$ & - & $100 \%$ & & & & & & \\
\hline \multirow[t]{26}{*}{ Metals } & Aluminum & $\mu \mathrm{g} / \mathrm{g}$ & 1,100 & 190 & & 760 & 320 & & 980 & 160 & \\
\hline & Antimony & $\mu g / g$ & 0.073 & 0.028 & & 0.019 & 0.003 & & 0.007 & 0.01 & \\
\hline & Arsenic & $\mu \mathrm{g} / \mathrm{g}$ & $<0.41$ & - & $100 \%$ & $<0.33$ & - & $100 \%$ & $<0.33$ & - & $100 \%$ \\
\hline & Barium & $\mu \mathrm{g} / \mathrm{g}$ & 4.02 & 0.94 & & 5.39 & 0.66 & & 4.87 & 0.59 & \\
\hline & Beryllium & $\mu \mathrm{g} / \mathrm{g}$ & 0.129 & 0.066 & & 0.143 & 0.017 & & 0.137 & 0.028 & \\
\hline & Boron & $\mu \mathrm{g} / \mathrm{g}$ & 425 & 43 & & 202 & 88 & & 3.5 & 1.3 & \\
\hline & Cadmium & $\mu g / g$ & 0.247 & 0.035 & & 0.608 & 0.042 & & 0.332 & 0.016 & \\
\hline & Calcium & $\mu g / g$ & 255,000 & 15,000 & & 392,000 & 27,000 & & 395,000 & 9,000 & \\
\hline & Chromium & $\mu \mathrm{g} / \mathrm{g}$ & 11.3 & 2.5 & & 13.4 & 2.3 & & 9.80 & 0.64 & \\
\hline & Cobalt & $\mu \mathrm{g} / \mathrm{g}$ & 0.99 & 0.43 & & 1.48 & 0.51 & & 1.30 & 0.62 & \\
\hline & Copper & $\mu g / g$ & 2.73 & 0.81 & & 3.71 & 0.48 & & 1.5 & 1.1 & \\
\hline & Iron & $\mu \mathrm{g} / \mathrm{g}$ & 2,190 & 370 & & 2,510 & 670 & & 1,787 & 57 & \\
\hline & Lead & $\mu \mathrm{g} / \mathrm{g}$ & 0.84 & 0.21 & & 0.98 & 0.11 & & 1.1 & 0.2 & \\
\hline & Magnesium & $\mu \mathrm{g} / \mathrm{g}$ & 810 & 100 & & 1,390 & 190 & & 1,233 & 29 & \\
\hline & Manganese & $\mu g / g$ & 103 & 11 & & 429 & 33 & & 207 & 6.6 & \\
\hline & Mereury & $\mu g / g$ & 0.178 & 0.055 & & $<0.012$ & - & $29 \%$ & 0.005 & 0.012 & $40 \%$ \\
\hline & Molybdenum & $\mu \mathrm{g} / \mathrm{g}$ & 1.48 & 0.56 & & 0.230 & 0.4 & & $<0.222$ & - & $50 \%$ \\
\hline & Nickel & $\mu g / g$ & 2.8 & 1.3 & & 4.00 & 2.5 & & 3.16 & 0.88 & \\
\hline & Phosphorus & $\mu g / g$ & 88 & 29 & & 110 & 10 & & 108 & 31 & \\
\hline & Potassium & $\mu \mathrm{g} / \mathrm{g}$ & 310 & 160 & & 338 & 86 & & 363 & 45 & \\
\hline & Selenium & $\mu \mathrm{g} / \mathrm{g}$ & 25.5 & 1.2 & & 8.40 & 2.8 & & 3.9 & 2 & \\
\hline & Silicon & $\mu g / g$ & 447 & 73 & & 370 & 220 & . & 440 & 110 & \\
\hline & Sodium & $\mu \mathrm{g} / \mathrm{g}$ & 84.1 & 7.8 & & 55.0 & 19 & & 20.9 & 2.5 & \\
\hline & Strontium & $\mu \mathrm{g} / \mathrm{g}$ & 73.8 & 7.4 & & 112 & 5.3 & & 108 & 2.5 & \\
\hline & Titanium & $\mu \mathrm{g} / \mathrm{g}$ & 20.9 & $7 . i$ & & $<0.16$ & - & $100 \%$ & 30 & 110 & $\begin{array}{l}0.00 \\
2 \%\end{array}$ \\
\hline & Vanadium & $\mu g / g$ & 9.9 & 2.1 & & 6.7 & 4.3 & & 8.13 & 0.41 & \\
\hline Moisture & Percent Moisture & wt\% & & & & & & & 8.7 & 1.4 & \\
\hline \multirow[t]{3}{*}{ Radionuclides } & $\begin{array}{l}\text { Actinium-228@338 } \\
\mathrm{KeV}\end{array}$ & $\mathrm{pCi} / \mathrm{g}$ & ND & - & & & & & 0.30 & 0.19 & \\
\hline & $\begin{array}{l}\text { Actinium-228@911 } \\
\mathrm{KeV}\end{array}$ & $\mathrm{pCi} / \mathrm{g}$ & 0.05 & 0.23 & & & & & 0.17 & 0.38 & \\
\hline & $\begin{array}{l}\text { Actinium-228@968 } \\
\mathrm{KeV}\end{array}$ & $\mathrm{pCi} / \mathrm{g}$ & ND & - & & & & & ND & - & \\
\hline
\end{tabular}


Table 5-9 (Continued)

\begin{tabular}{|c|c|c|c|c|c|c|c|c|c|c|c|}
\hline \multirow[b]{2}{*}{$\begin{array}{l}\text { Analyte } \\
\text { Group }\end{array}$} & \multirow[b]{2}{*}{ Specie } & \multirow[b]{2}{*}{ Units } & \multicolumn{3}{|c|}{$\begin{array}{c}\text { JBR Underflow Surry } \\
\text { Solids } \\
\end{array}$} & \multicolumn{3}{|c|}{ Limestone Surry Solids } & \multicolumn{3}{|c|}{ Raw Limestone } \\
\hline & & & Average & $\begin{array}{l}95 \% \\
\mathbf{C I}\end{array}$ & $\begin{array}{c}\text { DL } \\
\text { Ratio }\end{array}$ & Average & $\begin{array}{l}95 \% \\
\text { CI }\end{array}$ & $\begin{array}{c}\text { DL } \\
\text { Ratio }\end{array}$ & Average & $\begin{array}{c}95 \% \\
\mathrm{CI}\end{array}$ & $\begin{array}{c}\text { DL } \\
\text { Ratio }\end{array}$ \\
\hline & $\begin{array}{l}\text { Bismuth-212 @ } 727^{\circ} \\
\mathrm{KeV}\end{array}$ & $\mathrm{pCi} / \mathrm{g}$ & ND & - & & & & & ND & - & \\
\hline & $\begin{array}{l}\text { Bismuth-214 @ } \\
1120.4 \mathrm{KeV}\end{array}$ & $\mathrm{pCi} / \mathrm{g}$ & 0.25 & 0.54 & & & & & ND & - & \\
\hline & $\begin{array}{l}\text { Bismuth-214 @ } \\
1764.7 \mathrm{KeV}\end{array}$ & $\mathrm{pCi} / \mathrm{g}$ & 0.11 & 0.27 & & & & & 0.32 & 0.32 & \\
\hline & $\begin{array}{l}\text { Bismuth-214@609.4 } \\
\text { KeV }\end{array}$ & $\mathrm{pCi} / \mathrm{g}$ & 0.11 & 0.23 & & & & & 0.15 & 0.14 & \\
\hline & $\mathrm{K}-40 @ 1460 \mathrm{KeV}$ & $\mathrm{pCi} / \mathrm{g}$ & ND & - & & & & & 0.39 & 0.86 & \\
\hline & Lead-210 @ $46 \mathrm{KeV}$ & $\mathrm{pCi} / \mathrm{g}$ & 0.30 & 1.1 & & & & & 0.2 & 1.1 & \\
\hline & Lead-212@ $238 \mathrm{KeV}$ & $\mathrm{pCi} / \mathrm{g}$ & 0.09 & 0.05 & & & & & 0.113 & 0.038 & \\
\hline & $\begin{array}{l}\text { Lead-214 @ } 295.2 \\
\mathrm{KeV}\end{array}$ & pCi/g & 0.05 & 0.23 & & & & & 0.19 & 0.11 & \\
\hline & $\begin{array}{l}\text { Lead-214@352.0 } \\
\mathrm{KeV}\end{array}$ & $\mathrm{pCi} / \mathrm{g}$ & 0.140 & 0.075 & & & & & 0.193 & 0.072 & \\
\hline & $\begin{array}{l}\text { Radium-226@ } 186.0 \\
\text { KeV }\end{array}$ & $\mathrm{pCi} / \mathrm{g}$ & 0.33 & 0.72 & & & & & 0.42 & 0.91 & \\
\hline & $\begin{array}{l}\text { Thallium-208@583 } \\
\mathrm{KeV}\end{array}$ & $\mathrm{pCi} / \mathrm{g}$ & 0.20 & 0.21 & & & & & 0.07 & 0.3 & \\
\hline & $\begin{array}{l}\text { Thallium-208@860 } \\
\mathrm{KeV}\end{array}$ & $\mathrm{pCi} / \mathrm{g}$ & ND & - & & & & & ND & - & \\
\hline & $\begin{array}{l}\text { Thorium-234@63.3 } \\
\mathrm{KeV}\end{array}$ & $\mathrm{pCi} / \mathrm{g}$ & 0.19 & 0.8 & & & & & 0.12 & 0.53 & \\
\hline & $\begin{array}{l}\text { Thorium-234@92.6 } \\
\mathrm{KeV}\end{array}$ & $\mathrm{pCi} / \mathrm{g}$ & 0.20 & 0.44 & . & & & & 0.08 & 0.36 & \\
\hline & $\begin{array}{l}\text { Uranium-235 @ } 143 \\
\text { KeV }\end{array}$ & $\mathrm{pCi} / \mathrm{g}$ & ND & - & & & & & ND & - & \\
\hline \multirow[t]{2}{*}{ Aldehydes } & Acetaldehyde & $\mu \mathrm{g}$ & $<0.10$ & - & $100 \%$ & & & & & & \\
\hline & Formaldehyde & $\mu \mathrm{g}$ & $<0.10$ & - & $100 \%$ & & & & & & \\
\hline Organics, Semivolatile & $\begin{array}{l}\text { bis(2-Ethylhexyl) } \\
\text { phthalate }\end{array}$ & $\mathrm{ng} / \mathrm{g}$ & 100 & 350 & $15 \%$ & & & & & & \\
\hline
\end{tabular}


Table 5-10

Liquid Ash Sluice System Data Summary

\begin{tabular}{|c|c|c|c|c|c|c|c|c|c|c|c|}
\hline \multirow[b]{2}{*}{$\begin{array}{l}\text { Analyte } \\
\text { Group }\end{array}$} & \multirow[b]{2}{*}{ Specie } & \multirow[b]{2}{*}{ Units } & \multicolumn{3}{|c|}{ Ash Pond Water } & \multicolumn{3}{|c|}{$\begin{array}{c}\text { Bottom Ash Sluice } \\
\text { Filtrate }\end{array}$} & \multicolumn{3}{|c|}{$\begin{array}{c}\text { ESP Fly Ash Sluice } \\
\text { Filtrate }\end{array}$} \\
\hline & & & Average & $\begin{array}{l}95 \% \\
\mathrm{CI}\end{array}$ & $\begin{array}{c}\text { DL } \\
\text { Ratio }\end{array}$ & Average & $\begin{array}{c}95 \% \\
\mathrm{CI}\end{array}$ & $\begin{array}{c}\text { DL } \\
\text { Ratio }\end{array}$ & Average & $\begin{array}{c}95 \% \\
\text { CI }\end{array}$ & $\begin{array}{l}\text { DL } \\
\text { Ratio }\end{array}$ \\
\hline \multirow[t]{2}{*}{ Reduced Species } & Cyanide & $\mu g / \mathrm{mL}$ & 0.0019 & 0.0024 & - & 0.002 & 0.0011 & - & 0.0015 & 0.0016 & - \\
\hline & Ammonia as $\mathbf{N}$ & $\mu \mathrm{g} / \mathrm{mL}$ & 0.20 & 0.12 & - & 0.45 & 0.43 & -- & 0.38 & 0.08 & - \\
\hline \multirow[t]{4}{*}{ Anions } & Chloride & $\mu \mathrm{g} / \mathrm{mL}$ & 8.9 & 1.9 & - & 7.9 & 1.1 & - & 10.4 & 1.6 & - \\
\hline & Fluoride & $\mu \mathrm{g} / \mathrm{mL}$ & 0.43 & 0.11 & - & 0.281 & 0.046 & - & 0.74 & 0.57 & - \\
\hline & Phosphate & $\mu \mathrm{g} / \mathrm{mL}$ & $<0.014$ & - & $100 \%$ & 0.025 & 0.037 & $13 \%$ & 0.023 & 0.047 & $14 \%$ \\
\hline & Sulfate & $\mu \mathrm{g} / \mathrm{mL}$ & 113 & 12 & - & 81 & 34 & - & 340 & 510 & - \\
\hline \multirow[t]{27}{*}{ Metals, Soluble } & Aluminum & $\mu \mathrm{g} / \mathrm{mL}$ & 0.014 & 0.012 & - & 0.31 & 0.31 & - & 1.0 & 3.3 & - \\
\hline & Antimony & $\mu \mathrm{g} / \mathrm{mL}$ & $<0.024$ & - & $100 \%$ & $<0.024$ & - & $100 \%$ & $<0.024$ & - & $67 \%$ \\
\hline & Arsenic & $\mu \mathrm{g} / \mathrm{mL}$ & $<0.00066$ & - & $100 \%$ & 0.024 & 0.088 & - & 0.017 & 0.049 & - \\
\hline & Barium & $\mu \mathrm{g} / \mathrm{mL}$ & 0.155 & 0.028 & - & 0.102 & 0.084 & - & 0.24 & 0.16 & - \\
\hline & Beryllium & $\mu \mathrm{g} / \mathrm{mL}$ & $<0.00055$ & - & $31 \%$ & $<0.00055$ & - & $100 \%$ & $<0.00055$ & - & $100 \%$ \\
\hline & Boron & $\mu \mathrm{g} / \mathrm{mL}$ & 1.08 & 0.23 & - & 0.87 & 0.64 & - & 10 & 15 & - \\
\hline & Cadmium & $\mu \mathrm{g} / \mathrm{mL}$ & 0.0011 & 0.0010 & - & 0.0011 & 0.0021 & $4 \%$ & 0.0027 & 0.004 & - \\
\hline & Calcium & $\mu \mathrm{g} / \mathrm{mL}$ & 32.8 & 3.5 & - & 39 & 23 & -- & 140 & 170 & - \\
\hline & Chromium & $\mu \mathrm{g} / \mathrm{mL}$ & $<0.0025$ & - & $53 \%$ & 0.0031 & 0.0026 & - & 0.0480 & 0.051 & - \\
\hline & Cobalt & $\mu \mathrm{g} / \mathrm{mL}$ & $<0.0034$ & - & $60 \%$ & $<0.0034$ & - & $100 \%$ & $<0.0034$ & - & $98 \%$ \\
\hline & Copper & $\mu \mathrm{g} / \mathrm{mL}$ & 0.0044 & 0.0049 & - & 0.0180 & 0.047 & - & 0.0026 & 0.0015 & - \\
\hline & Iron & $\mu \mathrm{g} / \mathrm{mL}$ & 5.40 & 3.8 & - & 0.0280 & 0.034 & - & 0.0060 & 0.015 & - \\
\hline & Lead & $\mu \mathrm{g} / \mathrm{mL}$ & 0.008 & 0.011 & - & 0.0100 & 0.013 & - & 0.0048 & 0.0036 & - \\
\hline & Magnesium & $\mu \mathrm{g} / \mathrm{mL}$ & 3.11 & 0.17 & - & 2.3 & 1.6 & - & 4.5 & 2 & - \\
\hline & Manganese & $\mu \mathrm{g} / \mathrm{mL}$ & 0.560 & 0.21 & - & 0.05 & 0.12 & - & 0.020 & 0.045 & - \\
\hline & Mercury & $\mu \mathrm{g} / \mathrm{mL}$ & 0.00006 & 0.000043 & - & 0.00004 & 0.00007 & - & $<0.00004$ & - & $38 \%$ \\
\hline & Molybdenum & $\mu \mathrm{g} / \mathrm{mL}$ & 0.035 & 0.021 & - & 0.072 & 0.083 & - & 0.62 & 0.98 & - \\
\hline & Nickel & $\mu \mathrm{g} / \mathrm{mL}$ & 0.0197 & 0.0055 & - & 0.005 & 0.014 & - & 0.024 & 0.026 & - \\
\hline & Phosphorus & $\mu \mathrm{g} / \mathrm{mL}$ & 0.070 & 0.18 & $16 \%$ & 0.11 & 0.13 & - & 0.14 & 0.26 & $7 \%$ \\
\hline & Potassium & $\mu \mathrm{g} / \mathrm{mL}$ & 5.34 & 0.78 & - & 4.4 & 2.7 & - & 12 & 17 & - \\
\hline & Selenium & $\mu \mathrm{g} / \mathrm{mL}$ & 0.0019 & 0.0037 & - & 0.0039 & 0.0009 & - & 0.035 & 0.04 & - \\
\hline & Silicon & $\mu \mathrm{g} / \mathrm{mL}$ & 3.45 & 0.7 & - & 4.7 & 0.5 & - & 4.1 & 2.7 & - \\
\hline & Sodium & $\mu \mathrm{g} / \mathrm{mL}$ & 12.4 & 0.75 & - & 9.4 & 2.2 & - & 22 & 25 & - \\
\hline & Strontium & $\mu \mathrm{g} / \mathrm{mL}$ & 0.342 & 0.020 & - & 0.28 & 0.31 & - & 0.62 & 0.66 & - \\
\hline & Tin & $\mu \mathrm{g} / \mathrm{mL}$ & $<0.014$ & - & $84 \%$ & $<0.014$ & - & $43 \%$ & 0.0040 & 0.015 & - \\
\hline & Titanium & $\mu \mathrm{g} / \mathrm{mL}$ & $<0.0024$ & - & $62 \%$ & 0.0013 & 0.0022 & $13 \%$ & 0.016 & 0.067 & - \\
\hline & Vanadium & $\mu \mathrm{g} / \mathrm{mL}$ & 0.0050 & 0.016 & - & 0.029 & 0.049 & - & 0.07 & 0.12 & - \\
\hline \multirow[t]{6}{*}{ Metals, Total } & Aluminum & $\mu \mathrm{g} / \mathrm{mL}$ & 0.18 & 0.39 & - & & & & & & \\
\hline & Antimony & $\mu \mathrm{g} / \mathrm{mL}$ & 0.018 & 0.012 & - & & & & & & \\
\hline & Arsenic & $\mu \mathrm{g} / \mathrm{mL}$ & 0.0007 & 0.0014 & - & & & & & & \\
\hline & Barium & $\mu \mathrm{g} / \mathrm{mL}$ & 0.153 & 0.032 & - & & & & & & \\
\hline & Beryllium & $\mu \mathrm{g} / \mathrm{mL}$ & 0.00026 & 0.00064 & - & & & & & & \\
\hline & Boron & $\mu \mathrm{g} / \mathrm{mL}$ & 1.03 & 0.16 & - & & & & & & \\
\hline
\end{tabular}


Table 5-10 (Continued)

\begin{tabular}{|c|c|c|c|c|c|c|c|c|c|c|c|}
\hline \multirow[b]{2}{*}{$\begin{array}{l}\text { Analyte } \\
\text { Group }\end{array}$} & \multirow[b]{2}{*}{ Specie } & \multirow[b]{2}{*}{ Units } & \multicolumn{3}{|c|}{ Ash Pond Water } & \multicolumn{3}{|c|}{$\begin{array}{c}\text { Bottom Ash Sluice } \\
\text { Filtrate }\end{array}$} & \multicolumn{3}{|c|}{$\begin{array}{c}\text { ESP Fly Ash Sluice } \\
\text { Filtrate }\end{array}$} \\
\hline & & & Average & $\begin{array}{l}95 \% \\
\mathrm{CI}\end{array}$ & $\begin{array}{c}\text { DL } \\
\text { Ratio }\end{array}$ & Average & $\begin{array}{l}95 \% \\
\mathrm{CI}\end{array}$ & $\begin{array}{c}\text { DL } \\
\text { Ratio }\end{array}$ & Average & $\begin{array}{c}95 \% \\
\mathrm{CI}\end{array}$ & $\begin{array}{l}\text { DL } \\
\text { Ratio }\end{array}$ \\
\hline \multirow{21}{*}{$\begin{array}{l}\text { Metals, Total } \\
\text { (Cont'd) }\end{array}$} & Cadmium & $\mu \mathrm{g} / \mathrm{mL}$ & 0.0018 & 0.0039 & - & & & & & & \\
\hline & Calcium & $\mu \mathrm{g} / \mathrm{mL}$ & 33.7 & 2.7 & - & & & & & & \\
\hline & Chromium & $\mu \mathrm{g} / \mathrm{mL}$ & 0.0016 & 0.0011 & - & & & & & & \\
\hline & Cobalt & $\mu \mathrm{g} / \mathrm{mL}$ & 0.00638 & 0.00077 & - & & & & & & \\
\hline & Copper & $\mu \mathrm{g} / \mathrm{mL}$ & 0.0073 & 0.0051 & - & & & & & & \\
\hline & Iron & $\mu \mathrm{g} / \mathrm{mL}$ & 10.2 & 5.4 & - & & & & & & \\
\hline & Lead & $\mu g / m L$ & 0.017 & 0.057 & $1 \%$ & & & & & & \\
\hline & Magnesium & $\mu \mathrm{g} / \mathrm{mL}$ & 3.17 & 0.20 & - & & & & & & \\
\hline & Manganese & $\mu \mathrm{g} / \mathrm{mL}$ & 0.56 & 0.21 & - & & & & & & \\
\hline & Mercury & $\mu \mathrm{g} / \mathrm{mL}$ & 0.00005 & 0.00007 & - & & & & & & \\
\hline & Molybdenum & $\mu \mathrm{g} / \mathrm{mL}$ & 0.084 & 0.034 & - & & & & & & \\
\hline & Nickel & $\mu \mathrm{g} / \mathrm{mL}$ & 0.024 & 0.013 & - & & & & & & \\
\hline & Phosphorus & $\mu \mathrm{g} / \mathrm{mL}$ & 0.027 & 0.052 & - & & & & & & \\
\hline & Potassium & $\mu \mathrm{g} / \mathrm{mL}$ & 5.74 & 0.83 & - & & & & & & \\
\hline & Selenium & $\mu \mathrm{g} / \mathrm{mL}$ & 0.0048 & 0.0026 & - & & & & & & \\
\hline & Silicon & $\mu \mathrm{g} / \mathrm{mL}$ & 3.70 & 0.73 & - & & & & & & \\
\hline & Sodium & $\mu \mathrm{g} / \mathrm{mL}$ & 12.8 & 1.9 & - & & & & & & \\
\hline & Strontium & $\mu \mathrm{g} / \mathrm{mL}$ & 0.34 & 0.026 & - & & & & & & \\
\hline & Tin & $\mu \mathrm{g} / \mathrm{mL}$ & $<0.014$ & - & $50 \%$ & & - & & & & \\
\hline & Titanium & $\mu \mathrm{g} / \mathrm{mL}$ & 0.00068 & 0.00098 & - & & & & & & \\
\hline & Vanadium & $\mu \mathrm{g} / \mathrm{mL}$ & 0.024 & 0.011 & - & & & & & & \\
\hline \multirow[t]{2}{*}{ Aldehydes } & Acetaldehyde & $\mu \mathrm{g} / \mathrm{mL}$ & 0.08 & 0.17 & - & 0.080 & 0.16 & - & 0.04 & 0.11 & - \\
\hline & Formaldehyde & $\mu \mathrm{g} / \mathrm{mL}$ & 0.015 & 0.021 & - & 0.023 & 0.036 & - & 0.03 & 0.048 & - \\
\hline $\begin{array}{l}\text { Organics, } \\
\text { Semivolatile }\end{array}$ & Diethylphthalate & $\mu \mathrm{g} / \mathrm{L}$ & $<0.39$ & - & $100 \%$ & 0.5 & 1.3 & $24 \%$ & $<0.38$ & - & $100 \%$ \\
\hline $\begin{array}{l}\text { Organics, } \\
\text { Volatile }\end{array}$ & Methylene Chloride & $\mu \mathrm{g} / \mathrm{L}$ & $<5.0$ & - & $19 \%$ & $<5.0$ & - & $46 \%$ & 4.9 & 2.9 & - \\
\hline
\end{tabular}


Table 5-11

\section{Liquid FGD Process Stream Data Summary}

\begin{tabular}{|c|c|c|c|c|c|c|c|c|c|c|c|}
\hline \multirow[b]{2}{*}{$\begin{array}{l}\text { Analyte } \\
\text { Group }\end{array}$} & \multirow[b]{2}{*}{ Specie } & \multirow[b]{2}{*}{ Units } & \multicolumn{3}{|c|}{ Gypsum Pond Water } & \multicolumn{3}{|c|}{$\begin{array}{c}\text { JBR Underflow Slurry } \\
\text { Filtrate }\end{array}$} & \multicolumn{3}{|c|}{$\begin{array}{c}\text { Limestone Slurry } \\
\text { Filtrate }\end{array}$} \\
\hline & & & Average & $\begin{array}{c}95 \% \\
\mathrm{CI}\end{array}$ & $\begin{array}{c}\text { DL } \\
\text { Ratio }\end{array}$ & Average & $\begin{array}{c}95 \% \\
\mathrm{CI}\end{array}$ & $\begin{array}{c}\text { DL } \\
\text { Ratio }\end{array}$ & Average & $\begin{array}{l}95 \% \\
\text { CI }\end{array}$ & $\begin{array}{c}\text { DL } \\
\text { Ratio }\end{array}$ \\
\hline \multirow[t]{2}{*}{ Reduced Species } & Cyanide & $\mu g / m L$ & 0.0486 & 0.0046 & - & 0.082 & 0.1 & - & 0.050 & 0.1 & - \\
\hline & Ammonia as $\mathbf{N}$ & $\mu \mathrm{g} / \mathrm{mL}$ & 15 & 3 & - & $<40$ & - & $19 \%$ & 14.1 & 2.4 & - \\
\hline \multirow[t]{5}{*}{ Anions } & Chloride & $\mu \mathrm{g} / \mathrm{mL}$ & 16,400 & 4,100 & - & 26,100 & 4,200 & - & 13,100 & 2,100 & - \\
\hline & Fluoride & $\mu \mathrm{g} / \mathrm{mL}$ & 14.9 & 3.1 & - & 31.0 & 16 & - & 1.84 & 0.95 & - \\
\hline & Phosphate & $\mu \mathrm{g} / \mathrm{mL}$ & 0.033 & 0.021 & - & 0.050 & 0.15 & $7 \%$ & $<0.020$ & - & $100 \%$ \\
\hline & Sulfate & $\mu g / m L$ & 980 & 140 & - & 712 & 65 & - & 780 & 160 & - \\
\hline & Sulfite & $\mu g / \mathrm{mL}$ & - & & - & 0.033 & 0.038 & - & - & - & - \\
\hline \multirow[t]{27}{*}{ Metals, Soluble } & Aluminum & $\mu \mathrm{g} / \mathrm{mL}$ & 0.76 & 0.68 & - & 12.3 & 4.7 & - & 0.260 & 0.85 & - \\
\hline & Antimony & $\mu \mathrm{g} / \mathrm{mL}$ & $<0.24$ & - & $100 \%$ & $<0.19$ & - & $100 \%$ & $<0.24$ & - & $100 \%$ \\
\hline & Arsenic & $\mu \mathrm{g} / \mathrm{mL}$ & 0.127 & 0.027 & - & 0.200 & 0.26 & - & 0.070 & 0.13 & - \\
\hline & Barium & $\mu \mathrm{g} / \mathrm{mL}$ & 1.19 & 0.057 & - & 3.39 & 0.29 & - & 4.00 & 11 & - \\
\hline & Beryllium & $\mu \mathrm{g} / \mathrm{mL}$ & $<0.0055$ & - & $68 \%$ & 0.0069 & 0.0047 & - & $<0.0055$ & - & $56 \%$ \\
\hline & Boron & $\mu g / m L$ & 533 & 89 & - & 1,400 & 190 & - & 1.400 & 4,100 & - \\
\hline & Cadmium & $\mu \mathrm{g} / \mathrm{mL}$ & 0.149 & 0.035 & - & 0.456 & 0.065 & - & 0.0067 & 0.0026 & - \\
\hline & Calcium & $\mu \mathrm{g} / \mathrm{mL}$ & 8,100 & 2,100 & - & 17,000 & 10,000 & - & 7,070 & 190 & - \\
\hline & Chromium & $\mu \mathrm{g} / \mathrm{mL}$ & 0.101 & 0.03 & - & 0.070 & 0.091 & - & 0.063 & 0.047 & - \\
\hline & Cobalt & $\mu g / m L$ & 0.11 & 0.13 & - & 0.304 & 0.0029 & - & 0.090 & 0.3 & - \\
\hline & Copper & $\mu \mathrm{g} / \mathrm{mL}$ & 0.057 & 0.048 & - & 0.239 & 0.086 & - & 0.040 & 0.11 & - \\
\hline & Iron & $\mu \mathrm{g} / \mathrm{mL}$ & $<0.060$ & - & $100 \%$ & $<0.048$ & - & $100 \%$ & $<0.060$ & - & $100 \%$ \\
\hline & Lead & $\mu \mathrm{g} / \mathrm{mL}$ & 0.0022 & 0.0072 & $16 \%$ & 0.013 & 0.0089 & - & 0.0017 & 0.0013 & - \\
\hline & Magnesium & $\mu \mathrm{g} / \mathrm{mL}$ & 690 & 120 & - & 1,800 & 100 & - & 1.900 & 5.600 & - \\
\hline & Manganese & $\mu \mathrm{g} / \mathrm{mL}$ & 120 & 20 & - & 307 & 41 & - & 40 & 110 & - \\
\hline & Mercury & $\mu \mathrm{g} / \mathrm{mL}$ & 0.00024 & 0.00022 & - & 0.0010 & 0.0011 & - & 0.000057 & $1 e-05$ & - \\
\hline & Molybdenum & $\mu \mathrm{g} / \mathrm{mL}$ & 0.087 & 0.068 & - & 0.064 & 0.016 & - & 0.210 & 0.63 & - \\
\hline & Nickel & $\mu \mathrm{g} / \mathrm{mL}$ & 0.62 & 0.14 & - & 1.52 & 0.32 & - & 0.800 & 2.3 & - \\
\hline & Phosphorus & $\mu \mathrm{g} / \mathrm{mL}$ & 0.34 & 0.13 & - & 0.72 & 0.13 & - & 0.160 & 0.19 & - \\
\hline & Potassium & $\mu g / \mathrm{mL}$ & 52 & 12 & - & 123 & 8.6 & - & 140 & 420 & - \\
\hline & Selenium & $\mu \mathrm{g} / \mathrm{mL}$ & 0.36 & 0.23 & - & 0.5 & 1 & $0 \%$ & 0.128 & 0.049 & - \\
\hline & Silicon & $\mu \mathrm{g} / \mathrm{mL}$ & 15.8 & 2.7 & - & 42 & 6 & - & 7 & 21 & - \\
\hline & Sodium & $\mu \mathrm{g} / \mathrm{mL}$ & 97 & 16 & - & 244 & 5 & - & 290 & 860 & - \\
\hline & Strontium & $\mu \mathrm{g} / \mathrm{mL}$ & 13.2 & 2.1 & - & 32.9 & 4.3 & - & 40 & 110 & - \\
\hline & Tin & $\mu \mathrm{g} / \mathrm{mL}$ & 0.18 & 0.6 & $13 \%$ & $<0.14$ & - & $100 \%$ & $<0.14$ & - & $95 \%$ \\
\hline & Titanium & $\mu \mathrm{g} / \mathrm{mL}$ & 2.19 & 0.45 & - & 0.82 & 0.13 & - & 0.5 & 1 & $0.3 \%$ \\
\hline & Vanadium & $\mu \mathrm{g} / \mathrm{mL}$ & 0.322 & 0.065 & - & 0.24 & 0.22 & - & 0.19 & 0.23 & - \\
\hline \multirow[t]{6}{*}{ Metals, Total } & Aluminum & $\mu \mathrm{g} / \mathrm{mL}$ & 2.04 & 0.69 & - & & & & & & \\
\hline & Antimony & $\mu \mathrm{g} / \mathrm{mL}$ & $<0.14$ & - & $100 \%$ & & & & & & \\
\hline & Arsenic & $\mu \mathrm{g} / \mathrm{mL}$ & 0.127 & 0.031 & - & & & & & & \\
\hline & Barium & $\mu \mathrm{g} / \mathrm{mL}$ & 1.19 & 0.25 & - & & & & & & \\
\hline & Beryllium & $\mu \mathrm{g} / \mathrm{mL}$ & $<0.0055$ & - & $35 \%$ & & & & & & \\
\hline & Boron & $\mu \mathrm{g} / \mathrm{mL}$ & 540 & 150 & - & & & & & & \\
\hline
\end{tabular}


Table 5-11 (Continued)

\begin{tabular}{|c|c|c|c|c|c|c|c|c|c|c|c|}
\hline \multirow[b]{2}{*}{$\begin{array}{l}\text { Analyte } \\
\text { Group }\end{array}$} & \multirow[b]{2}{*}{ Specie } & \multirow[b]{2}{*}{ Units } & \multicolumn{3}{|c|}{ Gypsum Pond Water } & \multicolumn{3}{|c|}{$\begin{array}{c}\text { JBR Underflow Slurry } \\
\text { Filtrate } \\
\end{array}$} & \multicolumn{3}{|c|}{$\begin{array}{l}\text { Limestone Slurry } \\
\text { Filtrate } \\
\end{array}$} \\
\hline & & & Average & $\begin{array}{c}95 \% \\
\text { CI }\end{array}$ & $\begin{array}{c}\text { DL } \\
\text { Ratio }\end{array}$ & Average & $\begin{array}{c}95 \% \\
\text { CI }\end{array}$ & $\begin{array}{c}\text { DL } \\
\text { Ratio }\end{array}$ & Average & $\begin{array}{c}95 \% \\
\mathbf{C I}\end{array}$ & $\begin{array}{c}\text { DL } \\
\text { Ratio }\end{array}$ \\
\hline \multirow{21}{*}{$\begin{array}{l}\text { Metals, Total } \\
\text { (Cont'd) }\end{array}$} & Calcium & $\mu \mathrm{g} / \mathrm{mL}$ & 9,500 & 6,000 & - & & & & & & \\
\hline & Cadmium & $\mu \mathrm{g} / \mathrm{mL}$ & 0.177 & 0.018 & - & & & & & & \\
\hline & Chromium & $\mu \mathrm{g} / \mathrm{mL}$ & 0.075 & 0.094 & - & & & & & & \\
\hline & Cobalt & $\mu \mathrm{g} / \mathrm{mL}$ & 0.143 & 0.065 & - & & & & & & \\
\hline & Copper & $\mu \mathrm{g} / \mathrm{mL}$ & 0.053 & 0.029 & - & . & & & & & \\
\hline & Iron & $\mu \mathrm{g} / \mathrm{mL}$ & 0.68 & 0.73 & - & & & & & & \\
\hline & Lead & $\mu \mathrm{g} / \mathrm{mL}$ & 0.0036 & 0.0048 & - & & & & & & \\
\hline & Magnesium & $\mu \mathrm{g} / \mathrm{mL}$ & 720 & 210 & - & & & & & & \\
\hline & Manganese & $\mu \mathrm{g} / \mathrm{mL}$ & 123 & 39 & - & & & & & & \\
\hline & Mercury & $\mu \mathrm{g} / \mathrm{mL}$ & 0.00030 & 0.00004 & - & & & & & & \\
\hline & Molybdenum & $\mu \mathrm{g} / \mathrm{mL}$ & 0.076 & 0.012 & - & & & & & & \\
\hline & Nickel & $\mu \mathrm{g} / \mathrm{mL}$ & 0.63 & 0.18 & - & & & & & & \\
\hline & Phosphorus & $\mu \mathrm{g} / \mathrm{mL}$ & 0.236 & 0.024 & - & & & & & & \\
\hline & Potassium & $\mu \mathrm{g} / \mathrm{mL}$ & 52 & 13 & - & & & & & & \\
\hline & Selenium & $\mu \mathrm{g} / \mathrm{mL}$ & 0.27 & 0.17 & - & & & & & & \\
\hline & Silicon & $\mu \mathrm{g} / \mathrm{mL}$ & 18.4 & 3.2 & - & & & & & & \\
\hline & Sodium & $\mu \mathrm{g} / \mathrm{mL}$ & 102 & 25 & - & & & & & & \\
\hline & Strontium & $\mu \mathrm{g} / \mathrm{mL}$ & 13.7 & 4.6 & - & & & & & & \\
\hline & Tin & $\mu \mathrm{g} / \mathrm{mL}$ & $<0.086$ & - & $100 \%$ & & & & & & \\
\hline & Titanium & $\mu \mathrm{g} / \mathrm{mL}$ & 1.10 & 2.8 & - & & & & & & \\
\hline & Vanadium & $\mu g / m L$ & 0.22 & 0.28 & - & & & & & & \\
\hline \multirow[t]{2}{*}{ Aldehydes } & Acetaldehyde & $\mu \mathrm{g} / \mathrm{mL}$ & 0.05 & 0.11 & - & 0.06 & 0.12 & - & 0.050 & 0.1 & - \\
\hline & Formaldehyde & $\mu \mathrm{g} / \mathrm{mL}$ & 0.023 & 0.027 & - & 0.08 & 0.26 & - & 0.021 & 0.025 & - \\
\hline \multirow{2}{*}{$\begin{array}{l}\text { Organics, } \\
\text { Semivolatile }\end{array}$} & Dimethylphthalate & $\mu g / L$ & 1.3 & 2.2 & - & 2.1 & 4.2 & $2 \%$ & $<0.36$ & - & $100 \%$ \\
\hline & bis(2-Ethylhexy)phthalate & $\mu \mathrm{g} / \mathrm{L}$ & 8.0 & 81 & - & 4.4 & 1.5 & - & 140 & 560 & - \\
\hline $\begin{array}{l}\text { Organics, } \\
\text { Volatile }\end{array}$ & Acetone & $\mu g / L$ & $<10$ & - & $26 \%$ & $<10$ & - & $60 \%$ & 22.3 & 7.2 & - \\
\hline
\end{tabular}


Table 5-12

\section{Liquid Ancillary Stream Data Summary}

\begin{tabular}{|c|c|c|c|c|c|c|c|c|}
\hline \multirow[b]{2}{*}{$\begin{array}{l}\text { Analyte } \\
\text { Group }\end{array}$} & \multirow[b]{2}{*}{ Specie } & \multirow[b]{2}{*}{ Units } & \multicolumn{3}{|c|}{ Cooling Water } & \multicolumn{3}{|c|}{ Coal Pile Rmm-off } \\
\hline & & & Average & $\begin{array}{c}95 \% \\
\mathrm{CI}\end{array}$ & $\begin{array}{c}\mathrm{DL} \\
\text { Ratio }\end{array}$ & Average & $\begin{array}{c}95 \% \\
\mathrm{CI}\end{array}$ & $\begin{array}{c}\text { DL } \\
\text { Ratio }\end{array}$ \\
\hline \multirow[t]{2}{*}{ Reduced Species } & Cyanide & $\mu \mathrm{g} / \mathrm{mL}$ & 0.00148 & 0.00091 & - & & & \\
\hline & Ammonia as $\mathrm{N}$ & $\mu \mathrm{g} / \mathrm{mL}$ & 0.047 & 0.014 & - & & & \\
\hline \multirow[t]{4}{*}{ Anions } & Chloride & $\mu \mathrm{g} / \mathrm{mL}$ & 5.7 & 1.8 & - & & & \\
\hline & Fluoride & $\mu g / m L$ & 0.134 & 0.018 & - & & & \\
\hline & Phosphate & $\mu \mathrm{g} / \mathrm{mL}$ & 0.094 & 0.07 & - & & & \\
\hline & Sulfate & $\mu \mathrm{g} / \mathrm{mL}$ & 6.3 & 1.4 & - & & & \\
\hline \multirow[t]{27}{*}{ Metals, Soluble } & Aluminum & $\mu \mathrm{g} / \mathrm{mL}$ & 0.031 & 0.047 & - & & & \\
\hline & Antimony & $\mu \mathrm{g} / \mathrm{mL}$ & $<0.024$ & - & $65 \%$ & & & \\
\hline & Arsenic & $\mu \mathrm{g} / \mathrm{mL}$ & $<0.0007$ & - & $100 \%$ & & & \\
\hline & Barium & $\mu \mathrm{g} / \mathrm{mL}$ & 0.0131 & 0.0081 & - & & & \\
\hline & Beryllium & $\mu \mathrm{g} / \mathrm{mL}$ & $<0.0006$ & - & $100 \%$ & & & \\
\hline & Boron & $\mu \mathrm{g} / \mathrm{mL}$ & 0.9 & 3.4 & - & & & \\
\hline & Cadmium & $\mu g / m L$ & 0.0020 & 0.007 & - & & & \\
\hline & Calcium & $\mu \mathrm{g} / \mathrm{mL}$ & 19 & 53 & - & & & \\
\hline & Chromium & $\mu \mathrm{g} / \mathrm{mL}$ & 0.0020 & 0.0027 & - & & & \\
\hline & Cobalt & $\mu \mathrm{g} / \mathrm{mL}$ & $<0.0034$ & - & $85 \%$ & & & \\
\hline & Copper & $\mu \mathrm{g} / \mathrm{mL}$ & 0.03 & 0.13 & - & & & \\
\hline & Iron & $\mu \mathrm{g} / \mathrm{mL}$ & 0.11 & 0.13 & - & & & \\
\hline & Lead & $\mu \mathrm{g} / \mathrm{mL}$ & 0.027 & 0.097 & - & & & \\
\hline & Magnesium & $\mu \mathrm{g} / \mathrm{mL}$ & 3.1 & 4 & - & & & \\
\hline & Manganese & $\mu g / m L$ & 0.07 & 0.25 & - & & & \\
\hline & Mercury & $\mu \mathrm{g} / \mathrm{mL}$ & 0.00005 & 0.00003 & - & & & \\
\hline & Molybdenum & $\mu \mathrm{g} / \mathrm{mL}$ & 0.00152 & 0.00069 & - & & & \\
\hline & Nickel & $\mu \mathrm{g} / \mathrm{mL}$ & 0.0021 & 0.0048 & - & & & \\
\hline & Phosphorus & $\mu \mathrm{g} / \mathrm{mL}$ & $<0.061$ & - & $21 \%$ & & & \\
\hline & Potassium & $\mu \mathrm{g} / \mathrm{mL}$ & 2.42 & 0.49 & - & & & \\
\hline & Selenium & $\mu \mathrm{g} / \mathrm{mL}$ & $<0.0014$ & - & $100 \%$ & & & \\
\hline & Silicon & $\mu \mathrm{g} / \mathrm{mL}$ & 4.6 & 4.3 & - & & & \\
\hline & Sodium & $\mu \mathrm{g} / \mathrm{mL}$ & 8 & 12 & - & & & \\
\hline & Strontium & $\mu \mathrm{g} / \mathrm{mL}$ & 0.049 & 0.08 & - & & & \\
\hline & Tin & $\mu \mathrm{g} / \mathrm{mL}$ & $<0.014$ & - & $68 \%$ & & & \\
\hline & Titanium & $\mu \mathrm{g} / \mathrm{mL}$ & 0.0011 & 0.0012 & - & & & \\
\hline & Vanadium & $\mu \mathrm{g} / \mathrm{mL}$ & 0.0027 & 0.0006 & - & & & \\
\hline \multirow[t]{6}{*}{ Metals, Total } & Aluminum & $\mu \mathrm{g} / \mathrm{mL}$ & 2.9 & 4.4 & - & & & \\
\hline & Antimony & $\mu \mathrm{g} / \mathrm{mL}$ & 0.022 & 0.034 & - & & & \\
\hline & Arsenic & $\mu \mathrm{g} / \mathrm{mL}$ & 0.007 & 0.031 & $3 \%$ & & & \\
\hline & Barium & $\mu \mathrm{g} / \mathrm{mL}$ & 0.031 & 0.028 & - & & & \\
\hline & Beryllium & $\mu \mathrm{g} / \mathrm{mL}$ & $<0.0006$ & - & $55 \%$ & & & \\
\hline & Boron & $\mu \mathrm{g} / \mathrm{mL}$ & 0.32 & 0.35 & - & & & \\
\hline
\end{tabular}


Table 5-12 (Continued)

\begin{tabular}{|c|c|c|c|c|c|c|c|c|}
\hline \multirow[b]{2}{*}{$\begin{array}{l}\text { Analyte } \\
\text { Groupp }\end{array}$} & \multirow[b]{2}{*}{ Specie } & \multirow[b]{2}{*}{ Units } & \multicolumn{3}{|c|}{ Cooling Water } & \multicolumn{3}{|c|}{ Coal Pile Rm-off } \\
\hline & & & Average & $\begin{array}{c}95 \% \\
\text { CI }\end{array}$ & $\begin{array}{c}\text { DL } \\
\text { Ratio }\end{array}$ & Average & $\begin{array}{c}95 \% \\
\mathrm{CI}\end{array}$ & $\begin{array}{c}\text { DL } \\
\text { Ratio }\end{array}$ \\
\hline \multirow{21}{*}{$\begin{array}{l}\text { Metals, Total } \\
\text { (Cont'd) }\end{array}$} & Cadmium & $\mu \mathrm{g} / \mathrm{mL}$ & 0.001 & 0.0024 & - & & & \\
\hline & Calcium & $\mu \mathrm{g} / \mathrm{mL}$ & 5.9 & 1.6 & - & & & \\
\hline & Chromium & $\mu \mathrm{g} / \mathrm{mL}$ & 0.0049 & 0.0046 & - & & & \\
\hline & Cobalt & $\mu \mathrm{g} / \mathrm{mL}$ & 0.005 & 0.004 & - & & & \\
\hline & Copper & $\mu \mathrm{g} / \mathrm{mL}$ & 0.010 & 0.0081 & - & & & \\
\hline & Iron & $\mu \mathrm{g} / \mathrm{mL}$ & 4.1 & 5.4 & - & & & \\
\hline & Lead & $\mu \mathrm{g} / \mathrm{mL}$ & 0.030 & 0.058 & - & & & \\
\hline & Magnesium & $\mu \mathrm{g} / \mathrm{mL}$ & 1.69 & 0.71 & - & & & \\
\hline & Manganese & $\mu \mathrm{g} / \mathrm{ml}$ & 0.18 & 0.17 & - & & & \\
\hline & Mercury & $\mu \mathrm{g} / \mathrm{mL}$ & 0.00004 & 0.00003 & - & & & \\
\hline & Molybdenum & $\mu \mathrm{g} / \mathrm{mL}$ & 0.0024 & 0.0015 & - & & & \\
\hline & Nickel & $\mu \mathrm{g} / \mathrm{mL}$ & $<0.0099$ & - & $34 \%$ & & & \\
\hline & Phosphorus & $\mu \mathrm{g} / \mathrm{mL}$ & 0.12 & 0.2 & $9 \%$ & & & \\
\hline & Potassium & $\mu \mathrm{g} / \mathrm{mL}$ & 2.76 & 0.97 & - & & & \\
\hline & Selenium & $\mu \mathrm{g} / \mathrm{mL}$ & 0.008 & 0.03 & $6 \%$ & & & \\
\hline & Silicon & $\mu \mathrm{g} / \mathrm{mL}$ & 6.6 & 4.8 & - & & & \\
\hline & Sodium & $\mu \mathrm{g} / \mathrm{mL}$ & 5.4 & 1.9 & - & & & \\
\hline & Strontium & $\mu \mathrm{g} / \mathrm{mL}$ & 0.0276 & 0.0076 & - & & & \\
\hline & Tin & $\mu \mathrm{g} / \mathrm{mL}$ & $<0.014$ & - & $100 \%$ & & & \\
\hline & Titanium & $\mu \mathrm{g} / \mathrm{mL}$ & 0.16 & 0.21 & - & & & \\
\hline & Vanadium & $\mu \mathrm{g} / \mathrm{mL}$ & 0.0083 & 0.0095 & - & & & \\
\hline \multirow[t]{2}{*}{ Aldehydes } & Acetaldehyde & $\mu \mathrm{g} / \mathrm{mL}$ & 0.06 & 0.12 & - & 0.09 & 0.27 & - \\
\hline & Formaldehyde & $\mu \mathrm{g} / \mathrm{mL}$ & 0.026 & 0.049 & - & 0.06 & 0.39 & - \\
\hline \multirow{2}{*}{$\begin{array}{l}\text { Organics, } \\
\text { Semivolatile }\end{array}$} & Butylbenzylphthalate & $\mu \mathrm{g} / \mathrm{L}$ & $<0.45$ & - & $100 \%$ & 0.54 & - & - \\
\hline & bis(2-Ethylhexyl)phthalate & $\mu \mathrm{g} / \mathrm{L}$ & 3.5 & 7.2 & $3 \%$ & 3.3 & - & - \\
\hline Onganics, Volatile & Acetone & $\mu g / L$ & $<10$ & - & $45 \%$ & 40 & 250 & - \\
\hline
\end{tabular}




\section{6}

\section{DATA EVALUATION AND ANALYSIS}

This section presents an evaluation of data presented in Section 5. In evaluating these data, the following question is fundamental:

- Are the measured concentration data representative?

Since there is insufficient information to address this question directly, statistics, along with engineering and scientific judgment, must be used to answer this question. This is done by addressing related topics which can be evaluated quantitatively:

- Were analytical techniques accurate and precise?

- Were sampling techniques accurate and precise?

- Was process operation steady and representative?

If the answer to each of the above questions is "yes," then the measurements are considered representative and no qualifications made to their use. If analysis turns up potential problems with one or more of the above areas for certain data, caution must be exercised in using these data, since there is a good chance that they are not representative.

Assessment of sampling and analytical techniques is the purview of the QA/QC program. Detailed QA/QC results are presented in Appendix D, and these results are summarized below. An evaluation of process operation and a discussion of mass balance closures, which are used as an additional check on data representativeness, are also presented in this section. Finally, a discussion of the organic results concludes this section.

\section{Evaluation of Sampling Techniques}

Several factors are evaluated to determine acceptable sample collection. Key components of the sampling equipment including the Pitot tubes, thermocouples, orifice meters, dry gas meters, and sampling nozzles were calibrated in the Radian Source Sampling Laboratory before use in the field. These calibrations were also checked after the equipment was returned to the laboratory after completion of the field activities. Standard EPA methods or other acceptable sampling methods were used to collect the organic, metal, and anion samples. The sampling runs were well documented, and all gas samples were collected at rates of between 90 and $110 \%$ of the isokinetic rates. Sufficient data were collected to ensure acceptable data completeness and comparability of the measurements. 
Gas samples were collected from the ESP inlet, ESP outlet, and stack as integrated samples for most analyses over a specified time period. Solid samples of coal, limestone, bottom ash, ESP fly ash, and FGD slurry were collected at hourly intervals over each of the test runs. These individual grabs were combined to provide a single composite sample of each stream for each of the three test runs. Liquid streams were also collected as hourly grabs which were combined to provide a single composite for analysis for each test run. All sampling was conducted while the plant was operating at 85 to $100 \%$ of full load and should be representative of typical operation for Plant Yates.

Thus, the applicable QA/QC evaluation indicates that sampling techniques were acceptable and effective in providing measurement data reliability within the expected limits of sampling error.

\section{Evaluation of Analytical Techniques}

Generally, the type of quality control information obtained pertains to measurement precision, accuracy (which includes precision and bias), and blank effects that are determined using various types of replicate, spiked and blank samples. The specific characteristics evaluated depend on the type of quality control checks performed. For example, blanks may be prepared at different stages in the sampling and analysis process to isolate the source of the blank effect. Similarly, replicate samples may be generated at different stages to isolate and measure sources of variability. The QA/QC measures used as part of this program data evaluation protocol and the characteristic information obtained are provided in Appendix D.

Different QC checks provide different types of information, particularly pertaining to the sources of inaccuracy, imprecision, and blank effects. As part of this program, measurement precision and accuracy are typically being estimated from QC indicators that cover as much of the total sampling and analytical process as feasible. Precision and accuracy measurements are based primarily on the actual sample matrix. The precision and accuracy estimates obtained experimentally during the test program are compared to the data quality objectives (DQOs) established for the program as listed in the project QAPP.

Appendix D includes a presentation of the types of quality control data reported for the program and a summary of precision and accuracy estimates. Almost all of the quality control results met the project objectives.

The following potential problems were identified by the quality control data.

- Chloromethane, methylene chloride, and tetrachloroethene were found in one or more of the field blanks analyzed for volatile organics. In many cases, the same concentrations were also found in the field samples.

- A standard limestone sample (NIST 1C) was submitted blind as a performance audit sample. Aluminum, silicon, and sodium recoveries in this sample were below $50 \%$, and the recovery of potassium was greater than 200 percent. This may indicate a similar bias for these elements in the limestone process streams. 
- Selenium showed no spike recovery in the impinger solutions analyzed by GFAAS.

These and other QA/QC findings are summarized, according to major species categories, in the discussions below.

\section{Semivolatile Organics}

Precision. The precision of the semivolatile organic analyses was estimated using matrix spiked duplicate pairs. The precision objective was met for all of the gas-phase solid samples, the gas vapor-phase samples, the solid stream samples, and aqueous-phase sample streams.

Accuracy. The accuracy of the semivolatile analyses was estimated using matrix spiked duplicate samples. All of the spiked compounds analyzed in the gas solid-phase samples and the aqueous process streams were within the accuracy objectives. Matrix spikes into the solid process streams were all within the recovery objects for all analytes in the FGD solid stream and all except pyrene in the ESP ash solids. Recovery for pyrene was $51 \%$ and $56 \%$ (project objective--52-115\%) for the ESP ash sample and 48\% and 37\% for the ESP ash field duplicate.

Blank Effects. Acetophenone and benzoic acid were found in one or more of the field blanks associated with the gas-phase solids analyses. The concentrations of these compounds in the blanks, however, were not significant in comparison to the concentrations found in the samples. Several phthalates were also found in the field blanks. The concentrations found in the samples were about the same level as found in the blanks and are therefore considered an artifact of the sampling and handling process.

\section{Volatile Organics}

Precision. Precision for volatile organic analysis of the aqueous process streams was estimated using matrix spiked duplicate samples. The $50 \%$ precision objectives were met for each of the volatile analytes used for the matrix spikes.

Accuracy. Accuracy for the volatile organic analyses in the aqueous process streams was estimated using matrix spiked samples, and accuracy for the gas vapor-phase streams was estimated using surrogates spiked into each sample prior to analysis. The method specified accuracy objectives for matrix spike recoveries $(0.1-234 \%$ were met for all analytes of interest (actual recoveries ranged from $70-136 \%$ ) for the aqueous streams. Accuracy objectives for surrogate recoveries of 70 to $130 \%$ for the gas-phase streams were met for all samples except for toluene-d8 in one stack sample. Accuracy based on the analysis of two laboratory method spikes met the recovery objectives for all analytes of interest except for one acetone, chloromethane, chloroethane, and methylene chloride spike.

Blank Effects. Chloromethane, methylene chloride, and tetrachloroethene were found in one or more of the field gas vapor-phase blank samples. In most cases these compounds were found in the investigative field samples at about the same level as in the field blank or 
at lower concentrations: Chloromethane and methylene chloride were also found in one laboratory blank. The presence of these compounds in both blanks and samples merely raises the uncertainty about their presence in the flue gas.

\section{Aldehydes}

Precision. Precision for the aldehyde analyses was estimated using duplicate sample analyses. The precision objectives of $50 \%$ were met for both formaldehyde and acetaldehyde in the gas vapor-phase samples and the aqueous process stream sample analyses.

Accuracy. Accuracy for the aldehydes was estimated using matrix spiked samples. The project accuracy objectives of recoveries of $50-150 \%$ were met for the gas vapor-phase and aqueous stream sample spikes for both formaldehyde and acetaldehyde.

\section{Metals}

Precision. The precision of metals analyses by ICP-AES, GFAAS, and CVAAS was estimated for samples using matrix-spiked duplicate samples. The precision objectives (RPD $<20 \%$ ) were met for all target analytes analyzed by ICP-AES except aluminum and barium in the gas solid-phase spiked samples and boron in the process solid-spiked samples. The precision objectives for the GFAAS analyses were met except for lead in the gas vapor-phase matrix-spiked samples, selenium in the process solid matrix-spiked samples, and mercury and selenium in the aqueous process stream matrix spikes.

Accuracy. The accuracy of metals analyses was estimated for the gas solid-phase samples using standard reference material (NIST 1633a fly ash) submitted blind to the laboratory as a performance audit sample. All of the metals analyzed by ICP-AES were within the 75-125\% accuracy objectives except for beryllium (147\%) which was recovered above the objectives.

The accuracy of the metals analyses was estimated for coal samples using a standard reference coal sample (NIST 1632b) submitted blind to the laboratory. All of the metals analyzed by INAA in the reference sample were within the $75-125 \%$ accuracy objective.

The accuracy of the metals analyses was estimated for the limestone samples using a standard reference limestone (NIST Limestone 1C) submitted blind to the laboratory. The results show that the recoveries for most of the metals were outside the $75-125 \%$ accuracy objectives. Aluminum, silicon, and sodium recoveries were $50 \%$, and the recovery for potassium was greater than 200 percent. The recoveries of these analytes may show a similar bias in the limestone process streams.

The accuracy of the metals analyses for the gas vapor-phase samples and the aqueous process streams were estimated using performance audit samples prepared from EPA reference standards. The results show that the recoveries of all the metals analyzed by ICP-AES and GFAAS were within the 75-125\% accuracy objectives except $\mathrm{Ca}(368 \%)$ and $\mathrm{Sb}(127 \%), \mathrm{Ca}$ $(169 \%, 520 \%), \mathrm{Fe}(139 \%)$, and $\mathrm{Mg}(131 \%, 246 \%)$ by ICP-AES and Se (50\%) by GFAAS . The concentrations of these elements in the samples were at or near the detection limit. 
Matrix-spiked samples were also used to determine the accuracy of the metals analyses in the gas, process solids, and aqueous process matrices. Recoveries for the target analytes were within the $75-125 \%$ accuracy objectives except for selenium (0\% recovery) in the gas vaporphase matrix and mercury (35\% recovery) in the aqueous process stream matrix.

Blank Effects. Aluminum, iron, manganese, and nickel were found at concentrations above the reporting limits in the field blanks to the gas vapor-phase sampling train. These elements were also found to a lesser extent in the impinger reagent blank solutions.

\section{Anions}

Precision. Precision for the anions analyses was estimated for the gas vapor-phase samples, process solid streams, and aqueous process streams by the analysis of matrix spiked samples. The precision objectives of $20 \%$ were met for chloride, fluoride, and sulfate except for chloride and sulfate in one matrix spike pair from the stack with RPDs of $22 \%$ and $24 \%$, respectively.

Accuracy. Accuracy for the anions analyses was estimated using matrix spiked duplicate samples. The accuracy objectives of $80-120 \%$ recovery was met for all analytes and all sample matrices except for the fluoride spikes into the ESP ash solid samples with recoveries of $56 \%$ and 60 percent.

\section{Cyanide, Ammonia, and Phosphate}

Precision. Precision for the cyanide, ammonia, and phosphate analyses was estimated using matrix spiked duplicate sample analyses. The precision objectives of $20 \%$ were met for each of the analytes for both the gas vapor phase and aqueous process streams except for ammonia spikes into the JBR process liquids. The spike concentration was too low in comparison to the level found in the native process sample.

Accuracy. Accuracy for ammonia, cyanide and phosphate was estimated using both matrix spiked duplicate samples and "double blind" performance audit samples. The accuracy objectives (cyanide, 75-125\%; ammonia, 80-120\%; phosphate, 75-125\%) were met for all matrix spiked samples except for the ammonia spikes into the JBR process liquids with recoveries at 60 and 273 percent. Recoveries for the performance audit samples met the accuracy objectives for all analytes with recoveries of $88 \%$ for ammonia, $80 \%$ for cyanide, and $97 \%$ for phosphate. Recoveries for performance audit samples spiked into the gas vapor-phase impinger solutions were not as good as the aqueous spiked audit samples. The recovery for ammonia in the impinger solutions was $63 \%$ and the recovery for cyanide was 50 percent. The aqueous spikes and impinger spikes were performed using the same spiking solutions and were spiked at the same concentration levels.

\section{Evaluation of Process Operation}

Plant operating data were examined to ensure that process operation was stable and representative of normal operation during the sampling periods. Excessive scatter or significant 
trends can indicate periods where operational problems were encountered. The availability of data from the CT-121 data acquisition system allowed for a comprehensive review of process operation. Data points were logged as 15-minute averages. Plots of unit load, furnace gas $\mathrm{O}_{2}, \mathrm{JBR} \Delta \mathrm{P}, \mathrm{JBR} \mathrm{pH}$, stack $\mathrm{SO}_{2}, \mathrm{CO}$, and $\mathrm{NO}_{x}$ concentrations are located in Section 2. The range of normal operation is indicated on most of these figures. A statistical summary of process data is presented in Table 6-1. Daily average values for process parameters are presented along with the minimum and maximum values. Variability is expressed by the standard deviation. Note that high standard deviations are to be expected for some variables, such as return water flow rates, which are controlled by on/off controllers. Table 6-1 was used to identify areas of concern with process operation. A parameter with values steadily increasing or decreasing over the course of the test period may indicate a period of non-steady operation. The following paragraph summarizes the process analysis and points out areas of concern.

Analysis of the process data revealed that process operation was steady and representative during sampling periods. Problems with data quality are not likely to be the result of process variability. Some comments on process operation are as follows:

- Due to problems with the JBR inlet $\mathrm{O}_{2}$ monitor, the JBR inlet $\mathrm{SO}_{2}$ concentration, which is corrected with the $\mathrm{O}_{2}$ meter reading, is biased low on $6 / 26$ and $6 / 27$. Additionally, the stack $\mathrm{O}_{2}$ monitor calibration check showed it to be biased on $6 / 26$. However, the average stack CEM $\mathrm{O}_{2}$ data are not significantly different from the $\mathrm{O}_{2}$ concentration measured using the Orsat method.

- The average FGD makeup water was approximately twice as high on $6 / 25$ than on other days. This was revealed to be an instrument problem.

- $\mathrm{SO}_{2}$ removal was slightly lower than expected, even accounting for the bias in the inlet $\mathrm{O}_{2}$ monitor. The slightly lower $\mathrm{SO}_{2}$ removal should not raise concerns about the representativeness of the data, however, as $\mathrm{SO}_{2}$ removal was still within the range of normal operation for this type of scrubber. A possible explanation for the lower removal involves modifications made to the JBR limestone inlet piping. Modifications to the piping are suspected to have created a region of higher limestone concentration in the JBR where the $\mathrm{pH}$ indicators are located. As a result, the $\mathrm{pH}$ in this region was slightly higher than in the remainder of the reactor. Therefore, the average reactor $\mathrm{pH}$ may have been slightly lower than was indicated, resulting in lower $\mathrm{SO}_{2}$ removal.

- A brief dip in load occurred on $6 / 24$ between 1700 and 1730 . The lowest point reached is unknown since the process data are reported on 15 minute average basis, the lowest of which was $86 \mathrm{MW}$. Since testing was completed by this time on $6 / 24$, there is no effect on data representativeness.

\section{Data Analysis: Mass Balances, Removal Efficiencies, and Emission Factors}

Calculations based on measured data have two general purposes: they can be used to assess the representativeness of the measured data or to evaluate process performance. Mass 
Table 6-1

Daily Summary

Date

$\begin{array}{lllllll}6 / 21 & 6 / 22 & 6 / 23 & 6 / 24 & 6 / 25 & 6 / 26 & 6 / 27\end{array}$

\section{Gross Load, MW}

Average, daily

Sample Std. Dev.

Maximum Value

Minimum Value

Raw Coal Flow, lb/hr

- Average, daily

Sample Std. Dev.

Maximum Value

Minimum Value

Furnace Gas $\mathrm{O}_{2}$, \%

Average, daily

Sample Std. Dev.

Maximum Value

Minimum Value

Opacity, \%

Average, daily

Sample Std. Dev.

Maximum Value

Minimum Value

Stack $\mathrm{O}_{2}$, \% on Dry Basis

Average, daily

Sample Std. Dev.

Maximum Value

Minimum Value

Stack $\mathrm{SO}_{2}$, ppm at $3 \% \mathrm{O}_{2}{ }^{2}$

Average, daily

Sample Std. Dev.

Maximum Value

Minimum Value

$\begin{array}{ccccccc}100 & 100 & 100 & 100 & 100 & 100 & 100 \\ 0.5 & 0.24 & 0.32 & 1.5 & 0.44 & 0.34 & 0.22 \\ 100 & 100 & 100 & 100 & 100 & 100 & 100 \\ 98 & 100 & 100 & 86 & 98 & 100 & 100\end{array}$

$\begin{array}{ccccccc}89,000 & 88,000 & 89,000 & 88,000 & 90,000 & 91,000 & 92,000 \\ 3,000 & 3,400 & 3,300 & 3,000 & 2,400 & 2,900 & 4,000 \\ 94,000 & 94,000 & 99,000 & 95,000 & 96,000 & 98,000 & 100,000 \\ 85,000 & 82,000 & 84,000 & 81,000 & 84,000 & 85,000 & 84,000\end{array}$

$\begin{array}{ccccccc}3.5 & 3.6 & 3.5 & 3.5 & 3.3 & 3.3 & 3.4 \\ 0.062 & 0.17 & 0.19 & 0.28 & 0.078 & 0.23 & 0.3 \\ 3.6 & 4.0 & 3.7 & 3.9 & 3.4 & 3.8 & 3.8 \\ 3.4 & 3.2 & 3.1 & 3.0 & 3.0 & 2.8 & 2.6\end{array}$

$\begin{array}{ccccccc}15 & 14 & 16 & 17 & 17 & 18 & 19 \\ 3.6 & 0.96 & 1.7 & 2.5 & 1.3 & 1.3 & 1.5 \\ 31 & 18 & 27 & 33 & 23 & 22 & 23 \\ 12 & 13 & 14 & 14 & 14 & 15 & 16\end{array}$

$\begin{array}{ccccccc}8.2 & 8 & 7.9 & 8 & 7.7 & 7.7 & 7.6 \\ 0.12 & 0.23 & 0.18 & 0.22 & 0.072 & 0.18 & 0.1 \\ 8.5 & 8.6 & 8.1 & 9 & 7.9 & 9 & 7.7 \\ 7.8 & 6.6 & 6.3 & 6.7 & 7.6 & 7.5 & 7\end{array}$

$\begin{array}{ccccccc}160 & 180 & 200 & 200 & 240 & 180 & 190 \\ 38 & 47 & 37 & 65 & 31 & 25 & 38 \\ 230 & 250 & 260 & 340 & 300 & 230 & 270 \\ 88 & 41 & 120 & 74 & 180 & 130 & 140\end{array}$


Table 6-1 (Continued)

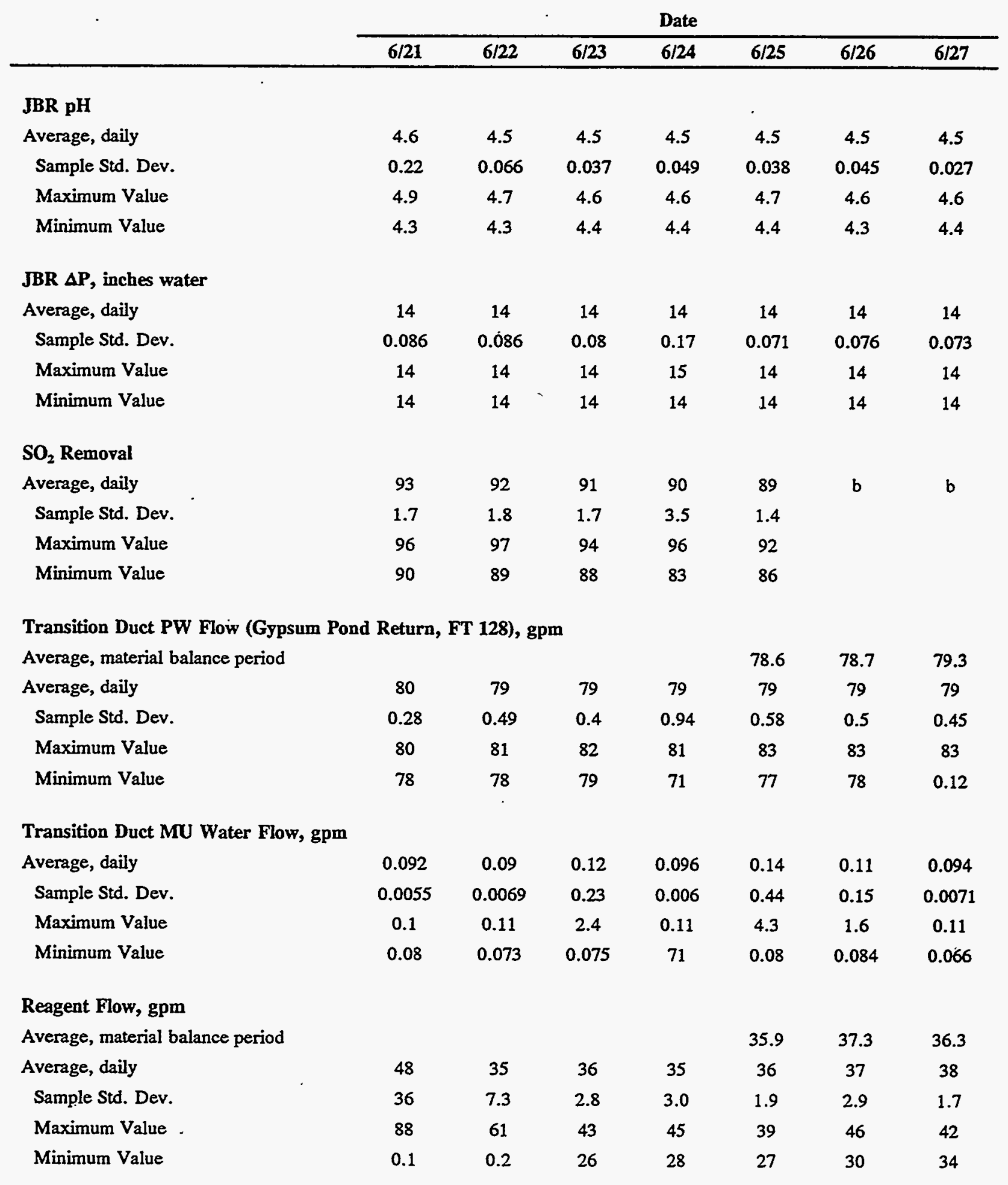


Table 6-1 (Continued)

\begin{tabular}{llllllll}
\multicolumn{10}{c}{ Date } \\
\cline { 2 - 7 } & $6 / 21$ & $6 / 22$ & $6 / 23$ & $6 / 24$ & $6 / 25$ & $6 / 26$ & $6 / 27$ \\
\hline
\end{tabular}

JBR Level, $\mathrm{ft}$

Instantaneous Values (used in accumulation calculations)

$$
\begin{aligned}
& \text { Beginning }(t-\Delta t) \\
& \text { Ending ( } t)
\end{aligned}
$$

Average, daily

Sample Std. Dev.

Maximum Value

Minimum Value

$\begin{array}{ccccccc} & & & & 14.1 & 14.1 & 14.1 \\ 14 & 14 & 14 & 14 & 14 & 14.1 & 14.1 \\ 0.011 & 0.017 & 0.022 & 0.042 & 0.026 & 0.013 & 0.014 \\ 14 & 14 & 14 & 14 & 14 & 14 & 14 \\ 14 & 14 & 14 & 14 & 14 & 14 & 14\end{array}$

JBR Density, wt\% solids

Average, material balance period

$\begin{array}{lll}22.8 & 23.0 & 23.0\end{array}$

Instantaneous Values (used in accumulation calculations)

Beginning (t- $-\Delta t)$

Ending ( $t$ )

Average, daily

Sample Std. Dev.

Maximum Value

Minimum Value

$\begin{array}{ccccccc} & & & & 22.2 & 23.7 & 22.7 \\ 23 & 23 & 23 & 23 & 23.3 & 23.3 & 23.5 \\ 0.51 & 0.55 & 0.55 & 0.52 & 0.51 & 0.56 & 0.51 \\ 24 & 24 & 24 & 24 & 24 & 24 & 24 \\ 22 & 22 & 22 & 22 & 22 & 22 & 22\end{array}$

Mist Eliminator/Deck Wash PW Flow (Ash Pond Return FT 150A), gpm $^{c}$

Average, material balance period

Average, daily

Sample Std. Dev.

Maximum Value

Minimum Value

$\begin{array}{ccccccc}25 & 25 & 28 & 28 & 25.1 & 25.5 & 28.8 \\ 29 & 28 & 32 & 35 & 30 & 26 & 26 \\ 110 & 110 & 120 & 130 & 100 & 120 & 32 \\ -0.33 & -0.33 & -0.34 & -0.37 & -0.37 & -0.37 & -0.29\end{array}$

Mist Eliminator Makeup Water Flow (FT 150B), gpm $^{c}$

Average, material balance period

Average, daily

Sample Std. Dev.

Maximum Value

Minimum Value

$\begin{array}{ccccccc}-2 & -4 & -4.1 & -4.1 & -4 & -4 & -4.2 \\ 27 & 25 & 25 & 22 & 24 & 28 & 18 \\ 180 & 240 & 240 & 210 & 230 & 260 & 140 \\ -6.9 & -7.2 & -7.5 & -7.5 & -7.3 & -7.6 & -7.6\end{array}$

JBR Level Control Line PW Flow (Ash Pond Return, FT 142), gpm

Average, material balance period

Average, daily

Sample Std. Dev.

Maximum Value

Minimum Value

$\begin{array}{ccccccc}44 & 50 & 56 & 54 & 39 & 37 & 48 \\ 56 & 84 & 86 & 79 & 68 & 66 & 72 \\ 200 & 270 & 270 & 250 & 220 & 200 & 210 \\ 0.27 & 0.27 & 0.24 & 0.24 & 0.25 & 0.26 & 0.3\end{array}$


Table 6-1 (Continued)

\begin{tabular}{|c|c|c|c|c|c|c|c|}
\hline & & & & Date & & & \\
\hline & $6 / 21$ & $6 / 22$ & $6 / 23$ & $6 / 24$ & $6 / 25$ & $6 / 26$ & $6 / 27$ \\
\hline Mist Eliminator Differential Pres & hes wate & & & & & & \\
\hline Average, daily & 0.67 & 0.65 & 0.64 & 0.64 & 0.63 & 0.65 & 0.66 \\
\hline Sample Std. Dev. & 0.014 & 0.016 & 0.017 & 0.022 & 0.013 & 0.02 & 0.013 \\
\hline Maximum Value & 0.7 & 0.68 & 0.68 & 0.7 & 0.66 & 0.7 & 0.68 \\
\hline Minimum Value & 0.62 & 0.62 & 0.61 & 0.52 & 0.6 & 0.62 & 0.64 \\
\hline Reagent Slurry Density, wt\% sol & & & & & & & \\
\hline Average, material balance period & & & & & 37.2 & 37.2 & 33.9 \\
\hline Average, daily & 33 & 30 & 33 & 37 & 37 & 37 & 34 \\
\hline Sample Std. Dev. & 0.18 & 2.9 & 2.1 & 0.15 & 0.025 & 0.045 & 2.1 \\
\hline Maximum Value & 33 & 34 & 38 & 38 & 37 & 37 & 39 \\
\hline Minimum Value & 32 & 25 & 30 & 37 & 37 & 37 & 32 \\
\hline Furnace Pressure, inches water & & & & & & & \\
\hline Average, daily & -0.21 & -0.22 & -0.22 & -0.22 & -0.22 & -0.22 & -0.22 \\
\hline Sample Std. Dev. & 0.017 & 0.013 & 0.012 & 0.016 & 0.012 & 0.0095 & 0.016 \\
\hline Maximum Value & -0.12 & -0.19 & -0.19 & -0.16 & -0.19 & -0.19 & -0.18 \\
\hline Minimum Value & -0.24 & -0.27 & -0.25 & -0.28 & -0.26 & -0.25 & -0.26 \\
\hline JBR Agitator Running ${ }^{d}$ & & & & & & & \\
\hline Average, daily & 1 & 1 & 1 & 1 & 1 & 1 & 1 \\
\hline Sample Std. Dev. & 0 & 0 & 0 & 0 & 0 & 0 & 0 \\
\hline Maximum Value & 1 & 1 & 1 & 1 & 1 & 1 & 1 \\
\hline Minimum Value & 1 & 1 & 1 & 1 & 1 & 1 & 1 \\
\hline Oxidation Air "A", scfm & & & & & & & \\
\hline Average, daily & 2,100 & 2,100 & 2,100 & 2,100 & 2,100 & 2,100 & 2,100 \\
\hline Sample Std. Dev. & 20 & 40 & 50 & 40 & 30 & 50 & 60 \\
\hline Maximum Value & 2,200 & 2,200 & 2,200 & 2,200 & 2,200 & 2,200 & 2,200 \\
\hline Minimum Value & 2,100 & 2,100 & 2,000 & 2,000 & 2,100 & 2,000 & 2,000 \\
\hline Oxidation Air "B", scfm & & & & & & & \\
\hline Average, daily & 2,100 & 2,000 & 2,000 & 2,100 & 2,100 & 2,000 & 2,000 \\
\hline Sample Std. Dev. & 20 & 30 & 50 & 40 & 30 & 40 & 50 \\
\hline Maximum Value & 2,100 & 2,100 & 2,100 & 2,100 & 2,100 & 2,100 & 2,100 \\
\hline Minimum Value & 2,000 & 2,000 & 2,000 & 2,000 & 2,000 & 2,000 & 2,000 \\
\hline
\end{tabular}


Data Evaluation and Analysis

Table 6-1 (Continued)

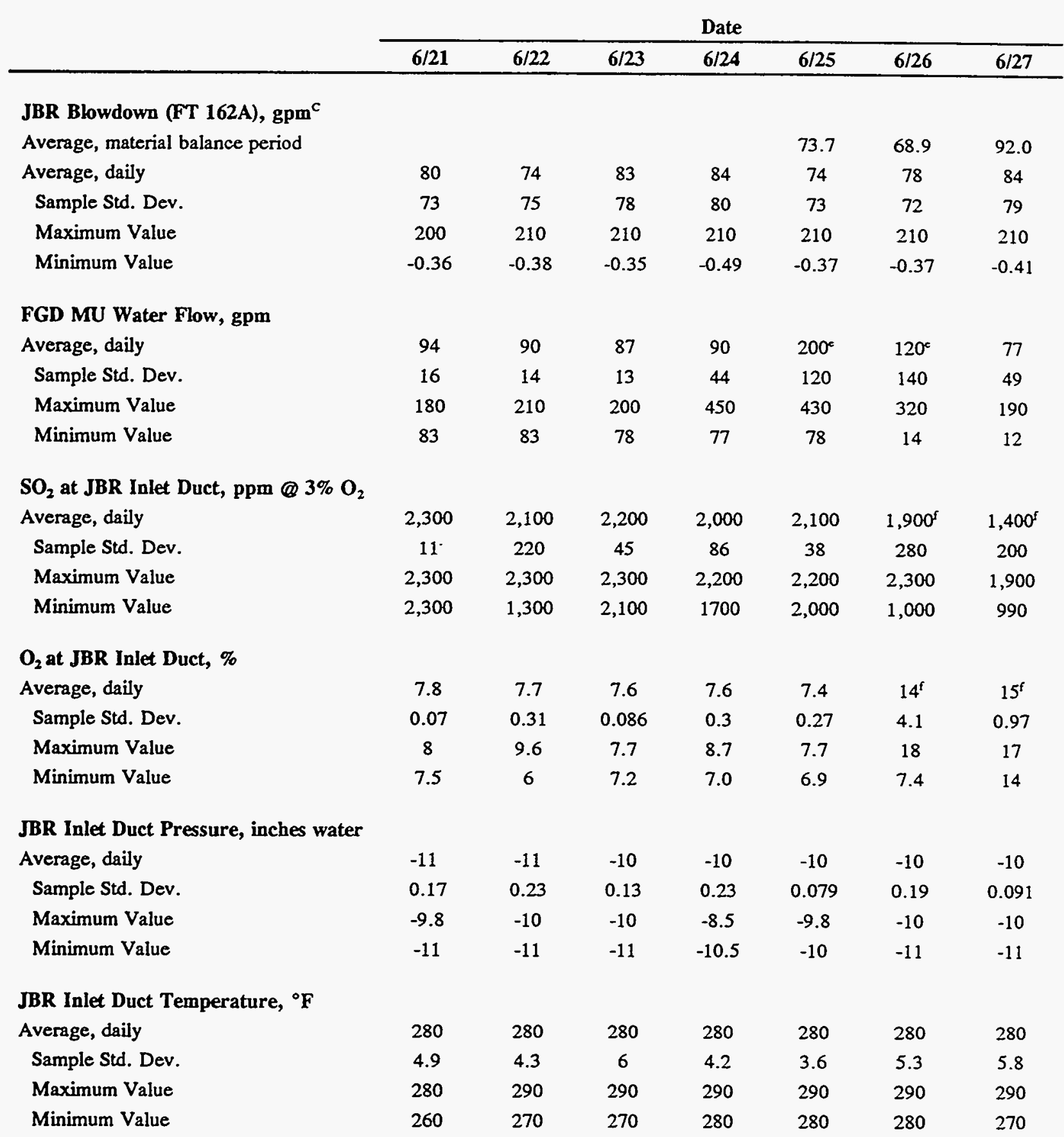

- A bias in the stack $\mathrm{O}_{2}$ monitor was found during calibration check on 6/27. However, the average CEM stack $\mathrm{O}_{2}$ concentrations are not significantly different from the stack gas $\mathrm{O}_{2}$ concentration determined using the Orsat method.

b These values not reported since they are known to be biased due to faulty inlet $\mathrm{O}_{2}$ monitor readings.

c Negative values result of instrumentation bias.

Value of 1 indicates agitator on, 0 indicates off.

- High average due to instrumentation problem.

'Problems with inlet $\mathrm{O}_{2}$ monitor have biased these values. 
balance closures were calculated as a check on data representativeness. Since the mass of trace elements must be conserved, an examination of the mass balance can provide clues to sampling and/or analytical deficiencies. Removal efficiencies and emission factors are evaluations of process performance. Removal efficiencies provide an insight into the fate of a substance in power plant processes. Emission factors express plant emissions on a unitenergy basis.

The method used to determine uncertainties in calculated results is based on the ANSI/ASME PTC 19.1-1985, "Measurement Uncertainty" and is consistent with the approach to handling data used in EPRI's Field Chemical Emission Monitoring (FCEM) program. This method, along with an example calculation, is presented in Appendix F. In statistical calculations, a distinction was made between "raw data," such as gas flow rates and concentrations, and calculated data, such as mass balance closures and emission factors. The term "raw" is in quotation marks because some calculations were necessary to obtain these data. The distinction between raw and calculated data was made based on the goal of a particular measurement, i.e., the goal of a Pitot-tube traverse is to determine a gas flow rate, so the flow rate is considered a raw data point and not the individual $\Delta \mathrm{P}$ measurements. Calculated data are determined using mean raw data. Therefore, calculated data are not presented on a daily or run basis but as mean values for the entire material balance period. Fundamental to obtaining calculated data is the assumption that the power plant processes are reasonably close to steady state. In this project, stream flow rates not directly measured, emission factors, removal efficiencies, and mass balance closures are all treated as calculated data.

Data were reviewed and justifiable eliminations and substitutions made prior to the calculation of material balance closures and removal efficiencies. The following modifications were made to the data set:

- The ESP outlet gas particulate-phase data for Runs 1 and 3 were invalidated for $\mathrm{Al}, \mathrm{Ba}$, $\mathrm{Be}, \mathrm{Cd}, \mathrm{Ca}, \mathrm{Cr}, \mathrm{Co}, \mathrm{Pb}, \mathrm{Mg}, \mathrm{P}, \mathrm{K}, \mathrm{Na}$, and $\mathrm{Sr}$ due to the filter background concentration comprising greater than $20 \%$ of the measured concentration.

- The stack gas particulate-phase data for Run 1 were invalidated for all elements except As, Se, and V due to the filter background concentration comprising greater than $20 \%$ of the. measured particulate concentration.

- The limestone slurry filtrate Run 3d was substituted for Run 3a. $46 \%$ of the detected elements in Run 3a are statistical outliers. An analytical error is suspected to have occurred for Run 3a. No further details are available.

- The ESP inlet gas vapor-phase data for Run 2 were invalidated due to particulate breakthrough into the impinger solutions. This event caused a high bias in the vapor-phase concentrations.

- No flue gas particulate-phase analyses were performed for boron, since boric acid is included in the chemicals used to digest the particulate filters. The sluiced fly ash analyses were substituted so that mass balances could be performed. 
- For As, $\mathrm{Cr}$, and $\mathrm{Hg}$, certain analyses are suspected to be biased and cause poor mass balance closures. For these elements, mass balance closures are also calculated with certain data substitutions made (see Table 6-2 for details).

\section{Mass Balances}

The results of mass balance closures, emission factors, and removal efficiencies are presented in the following sections. Following the results section are summaries of the equations used. Example calculations are presented in Appendix I.

Table 6-2 presents mass balance closures for selected elements. Mass balances were performed about the boiler, ESP, JBR, and the total plant. Figure 6-1 depicts the mass balance boundaries. Steady-state process operation was assumed for all vessels but the JBR. Due to the short test periods, significant accumulation of a substance could occur in the JBR. Small fluctuations in the JBR level and solids concentration are part of normal operation.

A general mass balance equation which applies to any system is:

$$
\left[\begin{array}{l}
\text { Accumulation of } \\
\text { Mass in System }
\end{array}\right]=\left[\begin{array}{c}
\text { Mass into } \\
\text { System }
\end{array}\right]-\left[\begin{array}{l}
\text { Mass out } \\
\text { of System }
\end{array}\right]+\left[\begin{array}{c}
\text { Mass Generated } \\
\text { in System }
\end{array}\right]
$$

Over a long period of steady operation, the accumulation in the JBR also could be considered negligible. The following general equation was used to calculate mass balance closures.

For all vessels but the JBR, the accumulation term should be negligible and was assumed to be zero. Development of specific mass balance equations is presented in Appendix I.

The mass balance closure for each element met the project objective if it was between 70 and 130 percent. Poor closures and high uncertainties have their root cause in sampling, analyti$\mathrm{cal}$, or process problems. Since an analysis of the process showed that process operation was steady and representative of normal operation, problems with mass balance closures for some substances may reflect problems with analytical or sampling techniques.

Concerns with mass balance closures fall into three categories:

- Out-of-range mass balance closure is outside target range of 70-130 percent;

- High uncertainty--uncertainty in closure exceeds \pm 50 percent; and

- Clear bias--closure \pm uncertainty does not encompass $100 \%$ closure. 
Table 6-2

Mass Balance Closures

\begin{tabular}{|c|c|c|c|c|c|c|c|c|}
\hline & \multicolumn{2}{|c|}{ Boiler } & \multicolumn{2}{|c|}{ ESP } & \multicolumn{2}{|c|}{ JBR } & \multicolumn{2}{|c|}{ Plant } \\
\hline & $\begin{array}{c}\% \\
\text { Closure }\end{array}$ & $\begin{array}{c}95 \% \\
\text { CI }\end{array}$ & $\begin{array}{c}\% \\
\text { Closure }\end{array}$ & $\begin{array}{c}95 \% \\
\mathrm{CI}\end{array}$ & $\begin{array}{c}\% \\
\text { Closure }\end{array}$ & $\begin{array}{c}95 \% \\
\mathrm{CI}\end{array}$ & $\begin{array}{c}\% \\
\text { Closure }\end{array}$ & $\begin{array}{c}95 \% \\
\mathrm{CI}\end{array}$ \\
\hline \multicolumn{9}{|l|}{ Anions } \\
\hline Chloride & 104 & 25 & 115 & 45 & 76 & 24 & 77 & 25 \\
\hline Fluoride & 103 & 16 & 105 & 30 & 97 & 33 & 104 & 39 \\
\hline \multicolumn{9}{|l|}{ Elements } \\
\hline Aluminum ${ }^{*}$ & 74 & 17 & 101 & $-{ }^{b}$ & 65 & $--^{b}$ & 75 & 6.5 \\
\hline Antimony ${ }^{c}$ & 67 & 44 & 92 & $52^{d}$ & 91 & $124^{c}$ & 65 & 26 \\
\hline Arsenic & $214(103)^{f}$ & $94(43)^{f}$ & 136 & $67^{8}$ & $38^{\mathrm{h}}$ & 28 & $270(135)^{f}$ & $142(71)^{f}$ \\
\hline Barium & 69 & 30 & 100 & - & 76 & - & 69 & 27 \\
\hline Beryllium ${ }^{\mathbf{i}}$ & 105 & 16 & 107 & - & 55 & - & 111 & 24 \\
\hline Boron & 131 & $110^{j}$ & 105 & - & 109 & - & 114 & 32 \\
\hline Cadmium ${ }^{d}$ & 100 & 63 & 155 & - & 109 & -- & 136 & 51 \\
\hline Calcium & 94 & 35 & 76 & - & 82 & - & 81 & 31 \\
\hline Chromium & $144(91)^{k}$ & $225(30)^{k}$ & $58(92)^{k}$ & - & 89 & - & 83 & 8.9 \\
\hline Cobalt & 98 & 36 & 120 & - & 80 & - & 114 & 40 \\
\hline Copper & 26 & 24 & 122 & 22 & 74 & 23 & 33 & 30 \\
\hline Iron & 89 & 18 & 99 & 21 & 77 & 26 & 87 & 17 \\
\hline Lead & 109 & 37 & 106 & - & 36 & - & 113 & 44 \\
\hline Magnesium & 92 & 22 & 104 & - & 107 & - & 103 & 21 \\
\hline Manganese & 113 & 19 & 104 & 18 & 101 & 31 & 103 & 27 \\
\hline Mercury & $205(110)^{1}$ & $84(35)^{1}$ & $55(102)^{1}$ & $18(26)^{1}$ & 88 & 13 & 101 & 30 \\
\hline Molybdenum & 18 & 20 & 23 & 27 & 111 & 39 & 4.5 & 3.6 \\
\hline Nickel & 84 & $86^{d}$ & 63 & 39 & 121 & $357^{\mathrm{d}}$ & 55 & 9.5 \\
\hline Phosphorus $^{e}$ & 31 & 19 & 34 & -- & 91 & - & 20 & 13 \\
\hline Potassium $^{c}$ & 59 & 13 & 104 & - & 84 & - & 62 & 9.6 \\
\hline Selenium ${ }^{\mathrm{d}}$ & 65 & 31 & 141 & 81 & 188 & 106 & 145 & 54 \\
\hline Sodium & 91 & 12 & 99 & - & 100 & - & 91 & 15 \\
\hline Strontium $^{e}$ & 48 & 7.9 & 99 & - & 95 & - & 59 & 7.8 \\
\hline Titanium & 77 & 18 & 103 & 23 & 31 & 10 & 78 & 12 \\
\hline Vanadium & 87 & 13 & 106 & 17 & 91 & 32 & 92 & 13 \\
\hline
\end{tabular}

- Spike recovery in ESP inlet gas-phase particulate for aluminum was $62 \%$, indicating possible analytical bias.

${ }^{b}$ Since the ESP outlet gas-phase particulate Runs 1 and 3 were invalidated, confidence intervals for the ESP and JBR mass balance closures could not be calculated for many elements. 


\section{Table 6-2 (Continued)}

c These elements are consistently enriched in the coal ash over the process stream solid-phase concentrations, suggesting that the coal analyses are biased high for these elements.

${ }^{d}$ High uncertainties for mass balance closure are caused by high variability in the gas particulate-phase concentrations.

- High uncertainty in JBR closure for antimony is the result of high detection limits in liquid-phase samples; antimony was not detected in the JBR blowdown filtrate or limestone slurry filtrate.

' Values in parentheses are those obtained when INAA coal analyses are substituted for the GFAA data.

B High uncertainty in the ESP closure for arsenic is mostly due to high variability in ESP sluiced ash concentration.

${ }^{b}$ Arsenic concentration was below detection limit in JBR blowdown solid phase.

'Spike recovery for beryllium in the performance evaluation ash sample was $147 \%$, indicating possible analytical bias.

I High variability in the boiler closure for boron is caused by high variability in the ESP inlet gas vapor-phase analyses.

* ESP inlet gas-phase particulate Run $2 \mathrm{Cr}$ concentration, at $550 \mathrm{ng} / \mathrm{g}$, is a statistical outlier. In comparison with sluiced ash, hopper ash, and size fractionated particulate data for chromium, this value is likely to be biased high. The mass balance data in parentheses are calculated with this value replaced with the Run 2 ESP sluiced ash concentration.

${ }^{1}$ ESP inlet particulate data for mercury are suspected to be biased high based on comparison with sluiced ash hopper ash analyses. This is also supported by the high boiler and low ESP mass balance closures. The mass balance data in parentheses are calculated with the ESP sluiced ash analyses substituted for the ESP inlet gasphase particulate analyses.

m Gas particulate-phase data are not available. ESP sluiced ash data were substituted for the boron particulate concentration. 


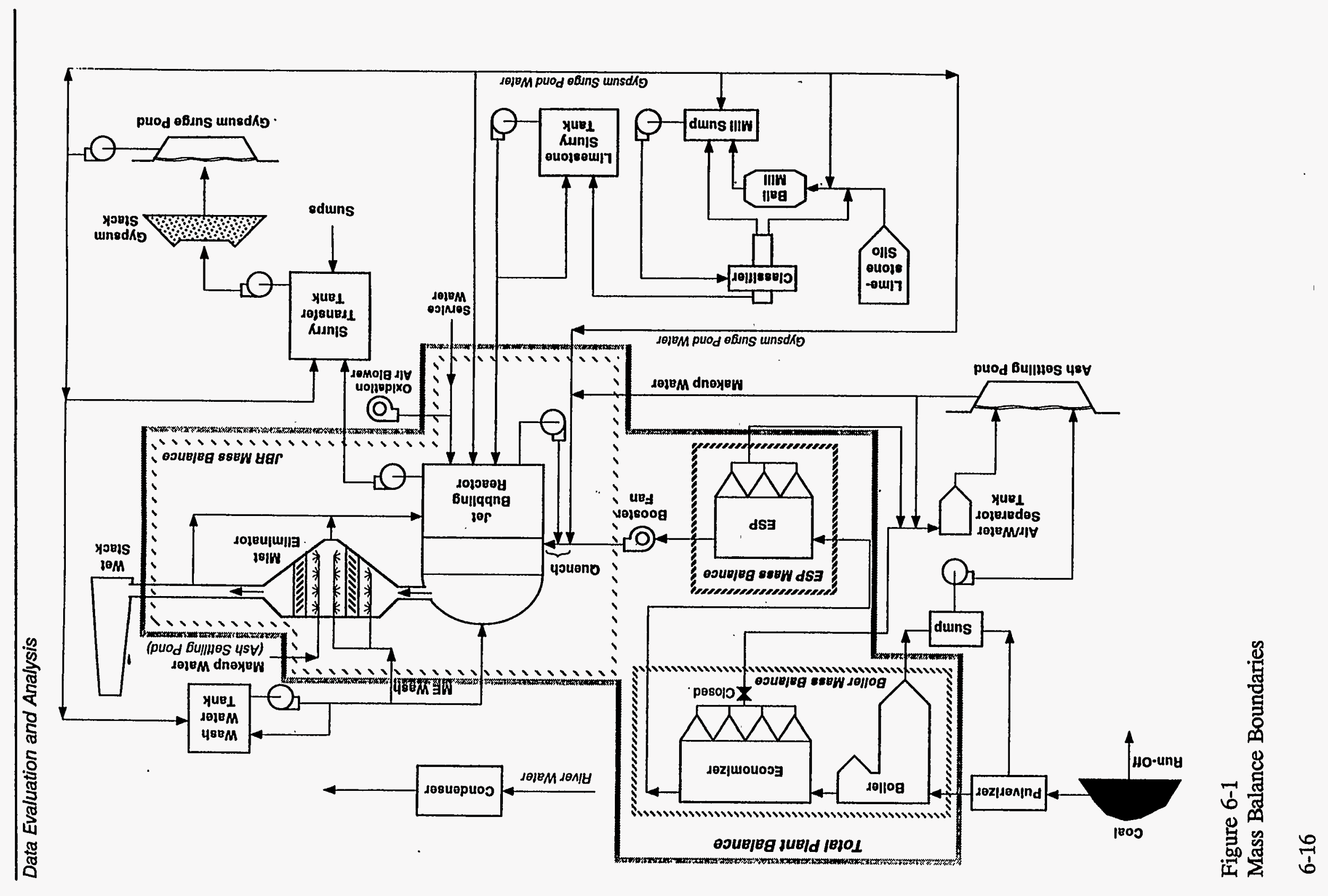




$$
\text { Mass Balance Closure (\%) }=100 *\left[1-\frac{\text { Total Mass Out }}{\text { (Mass In - Mass Accumulated) }}\right]
$$

For the boiler closure, $70 \%$ of the mass balances performed fell within the target range. The percentage within the target range for the ESP, JBR, and Total Plant were $85 \%, 78 \%$, and $59 \%$, respectively.

Confidence intervals are not presented for many elements for the ESP and JBR mass balance closures. The precision error for the ESP outlet gas, particulate-phase analyses is unknown for many elements due to the rejection of data from Runs 1 and 3. Discussion of concerns with specific substances is presented in the following paragraphs.

Substitutions. For some elements, both a review of the analytical data and initial mass balance closures suggested that some data were biased. For these elements, data substitutions were made, and the material balances were recalculated. These results are in parentheses on Table 6-2. Specific cases are discussed in the following paragraphs.

As. The arsenic coal analyses by GFAA yield mass balance closures about the boiler and plant of 214 and $270 \%$, respectively, suggesting a bias in the coal or ash analyses. When the coal concentration for each run was replaced by the corresponding analysis by INAA, the closures about the boiler and plant were 103 and $134 \%$ respectively. This suggests that the GFAA analysis performed for coal may have been biased.

Cr. The ESP inlet gas, particulate-phase Run 2 analysis for $\mathrm{Cr}$ at $550 \mu \mathrm{g} / \mathrm{g}$ is a statistical outlier when compared with all available ash analyses. This value is strongly suspected to be the result of analytical bias or non-representative sampling. This is supported by the boiler mass balance closure, at $144 \%$. When this value is replaced with the Run 2 sluiced ash concentration, the closure is $91 \%$.

Hg. The ESP inlet, particulate-phase data are suspected to be biased high, based on other ash analyses and prior experience with mercury data. This is also supported by the high mass balance closure about the boiler (205\%) and correspondingly lower closure about the ESP $(55 \%)$. When these data are replaced with the sluiced fly ash analyses, the closures are a much more reasonable $110 \%$ about the boiler and $102 \%$ about the ESP.

Out-of-Range Mass Balance Closures. Many mass balance closures lie outside the target range. For some of these, poor closure can be attributed to high variability in the concentration in one or more process streams. Other elements have closures which are clearly biased. The following paragraphs provide explanations for poor and clearly biased mass balance closures.

$S b, C u, M o, K, P, S r$. Antimony, copper, molybdenum, potassium, phosphorus, and strontium have mass balance closures well outside the target range for two or more devices. The confidence intervals for these closures indicate that a clear analytical or 
sampling bias exists or that the mass balance closure model is inadequate for these substances. Problems closing material balances for copper, molybdenum, and phosphorus have been encountered in previous work by Radian. For antimony, copper, potassium, and strontium, the boiler and plant closures are out of range, while the ESP and JBR closures are reasonable. Since the boiler and plant closures are driven by the coal analyses, this suggests a high bias in the INAA analyses for coal for these substances. All of these elements show enrichment in the coal ash over bottom ash, collected ash, and the gas particulate phase at all locations (except phosphorus in the ESP outlet). None of these elements are expected to be in the vapor phase. This pattern suggests that the coal analyses for antimony, copper, molybdenum, potassium, phosphorus, and strontium are biased high in varying degrees. See Section 8 for further details on enrichment.

$A /$ and $B e . \mathrm{Al}$ and $\mathrm{Be}$ analytical QA/QC procedures reveal a possible analytical bias in gas particulate-phase analyses for $\mathrm{Al}$. The $\mathrm{Al}$ spike recovery for this matrix was $62 \%$, indicating a possible low bias. This could explain the slight bias apparent in the mass balance closure $(74 \% \pm 17 \%)$. In addition, the spike recovery of $\mathrm{Be}$ in the performance evaluation sample for fly ash was $147 \%$. Only the JBR mass balance was outside the target range for $\mathrm{Be}$, however. In addition, $\mathrm{QA} / \mathrm{QC}$ procedures revealed possible analytical problems with some elements in the gas vapor-phase and limestone samples. For these elements, the limestone and vapor-phase concentrations have a very small effect on mass balance closures, however.

As. Arsenic was not detected in the JBR blowdown solids. This may explain the $36 \%$ mass balance closure.

$B e, P b, S e$, and $T$. These elements have poor closures about the JBR. No cause for these poor closures was determined, with the exception of the previously mentioned possibility for analytical bias for $\mathrm{Be}$ in the solid phase.

High Uncertainties in Mass Balance Closures. Some mass balance closures, both within and outside the target range, have high uncertainties. For those elements outside the target range, high variability in one or more measurements is the usual cause. The causes for high uncertainties in some elements is discussed below.

$\mathrm{Cd}, \mathrm{Ni}$, and Se. For these elements, uncertainty in the mass balance closure exceeds $50 \%$ for most devices. The cause is high uncertainty in the gas particulate-phase analyses. The Ni closure about the JBR, at $120 \pm 357 \%$, is especially high because the Run 1 stack gas particulate-phase analyses were invalidated. The cause of the high variability in particulate-phase analyses for these elements in unknown. Insufficient data. are available to make a reasonable hypothesis; however, the measurement error associated with the small sample mass collected at the stack is a likely contributor to the data variability.

Sb. The high uncertainty $(95 \% \pm 120 \%)$ in the antimony closure about the JBR is the result of high detection limits in the liquid-phase samples analyzed. Antimony was not detected in the JBR blowdown filtrate or limestone slurry filtrate. The high uncertainty 
in the boiler closure is the result of variability in the ESP inlet gas particulate-phase analyses.

B. The high uncertainty $(131 \% \pm 110 \%)$ in the boron closure about the boiler is the result of variability in the ESP inlet gas-phase analyses.

As. The high uncertainty in the ESP closure is mostly due to high variability in the ESP inlet gas vapor-phase analyses.

\section{Emission Factors}

The emission factor expresses stack emissions on an energy basis. Emission factors for elements are located in Table 6-3. The following general equation was used in calculating emission factors:

$$
\text { Emission Factor }=\frac{\text { Mass of Species in Stack Gas }}{\text { Energy of Coal Burned }}
$$

Detailed emission factor equations and an example calculation are presented in Appendix I.

\section{Removal Efficiencies}

Removal efficiencies of elements were calculated for the boiler, ESP, and JBR. Results are presented in Table 6-4. Since all elements but B, Hg, and Se should be present primarily in the solid phase, most of the removal of trace species occurs with the removal of fly ash in the ESP. The following equation defines the removal efficiency for a substance:

$$
\text { Removal Efficiency }=100 *\left(1-\frac{\text { Mass of Species in Gas Stream Exiting System }}{\text { Mass of Species in Gas Stream (or Coal) Entering System }}\right)
$$

An example calculation of a removal efficiency is provided in the Example Calculations in Appendix I.

\section{Organic Compound Results}

The organic compounds detected in the samples from all three gas streams can be grouped into three categories: plasticizers, outside source contaminants, and process 
Data Evaluation and Analysis

Table 6-3

Emission Factors

Anions

Chloride

742

647

Fluoride

122

67

Selected Elements ${ }^{\mathbf{2}}$

\begin{tabular}{|c|c|c|}
\hline Antimony & 0.06 & 0.01 \\
\hline Arsenic & 1.2 & 0.2 \\
\hline Barium & 2.8 & 9.9 \\
\hline Beryllium & 0.1 & 0.1 \\
\hline Cadmium & 0.6 & 2.1 \\
\hline Chromium & 5.3 & 49.5 \\
\hline Cobalt & 0.7 & 0.8 \\
\hline Copper & 2.0 & 2.3 \\
\hline Lead & 0.6 & 0.6 \\
\hline Manganese & 7.2 & 48 \\
\hline Mercury & 3.0 & 0.3 \\
\hline Molybdenum & 1.5 & 2.6 \\
\hline Nickel & 40.1 & 435 \\
\hline Selenium & 26.5 & 58 \\
\hline Vanadium & 2.1 & 0.5 \\
\hline \multicolumn{3}{|l|}{ Aldehydes } \\
\hline Acetaldehyde & 8.6 & 9.2 \\
\hline Formaldehyde & 24 & 36 \\
\hline \multicolumn{3}{|l|}{ Volatile Organics ${ }^{b, c}$} \\
\hline Benzene & 1.3 & 0.3 \\
\hline Carbon Disulfide & 2.2 & 1.2 \\
\hline Toluene & 2.0 & 1.0 \\
\hline
\end{tabular}


Table 6-3 (Continued)

\begin{tabular}{lcc} 
& $\mathbf{l b} / \mathbf{1 0} \mathbf{1 2}^{\mathbf{1 2}} \mathbf{B t u}$ & $\mathbf{9 5 \%} \mathbf{C I}$ \\
\cline { 2 - 3 } Semivolatile Organics & \\
2-Methylphenol (o-cresol) & 2.9 & 3.8 \\
4-Methylphenol (p-cresol) & 0.95 & 1.9 \\
Acetophenone & 3.2 & 0.7 \\
Benzoic Acid & 120 & 7 \\
Benzyl Alcohol & 2.8 & 12 \\
Naphthalene & 1.5 & 1.0 \\
Phenol & 9.2 & 8.8
\end{tabular}

- Run 1 particulate-phase data were invalidated for all elements included here except arsenic, selenium, and vanadium due to the filter background comprising $20 \%$ or greater of the measured concentration.

${ }^{b}$ Only those compounds with an average concentration above the detection limit are included.

- Methylene chloride, acetone, and other halogenated hydrocarbons are not included because their presence is strongly suspected to be the result of contamination.

d Phthalate esters are not included because their presence is suspected to be the results of contamination. 
Table 6-4

Removal Efficiencies (Includes Particulate and Vapor Phase)

\begin{tabular}{|c|c|c|c|c|c|c|}
\hline & \multicolumn{2}{|c|}{ Boiler } & \multicolumn{2}{|c|}{ ESP } & \multicolumn{2}{|c|}{ JBR } \\
\hline & \% Remoral & $95 \% \mathrm{CI}$ & \%Removal & $95 \% \mathrm{CI}$ & \% Removal & 95\% CI \\
\hline \multicolumn{7}{|l|}{ Anions } \\
\hline Chloride & -7 & 126 & -12 & 49 & 99 & 1 \\
\hline Fluoride & 1.4 & 15 & 1.6 & 37 & 98 & 1 \\
\hline \multicolumn{7}{|l|}{ Elements } \\
\hline Aluminum & 26.0 & 16.8 & 98.6 & $-b$ & 98.4 & - \\
\hline Antimony & 32.8 & 45 & 98.8 & 0.6 & 84.1 & 3.1 \\
\hline Arsenic & $-113.5(-2.4)^{c}$ & $94.7(43.6)$ & 95.9 & 1.5 & 92.7 & 2.1 \\
\hline Barium & 31.5 & 29.7 & 98.3 & - & 96.1 & - \\
\hline Beryllium & $-4.3^{\mathrm{d}}$ & 18.2 & 98.1 & - & 92.6 & - \\
\hline Boron " & -30.6 & 114.7 & 34.3 & - & 93.5 & - \\
\hline Cadmium & 0.5 & 62.9 & 95.1 & - & 46.2 & - \\
\hline Calcium & 6.9 & 44.1 & 98.8 & - & 85.3 & - \\
\hline Chromium & $-43.2(10.2)^{\circ}$ & $228.7(33.3)^{\circ}$ & 98.7 & - & 76.6 & - \\
\hline Cobalt & 3.1 & 35.2 & 98.2 & - & 85.3 & - \\
\hline Copper & 73.8 & 25.4 & 97.8 & 0.3 & 88.1 & 13.5 \\
\hline Iron & 12.5 & 10.1 & 98.9 & 0.1 & 98.0 & 7.0 \\
\hline Lead & -9.1 & 36.9 & 97.4 & - & 96.7 & - \\
\hline Magnesium & 8.5 & 24.1 & 98.4 & - & 93.3 & - \\
\hline Manganese & -11.4 & 12.8 & 98.4 & - & 78.4 & 144 \\
\hline Mercury & $-105(-10)^{2}$ & $84.1(35)^{s}$ & $55.2(16.5)^{8}$ & $14.4(20.6)^{8}$ & 45.9 & 7.4 \\
\hline Molybdenums & 82.5 & 19.9 & 97.2 & 2.2 & 82.5 & 27.2 \\
\hline Nickel & 16.4 & 88.1 & 98.8 & 0.7 & -75.5 & 1890 \\
\hline Phosphorus & 69.6 & 21.3 & 94.8 & - & 91.1 & - \\
\hline Potassium ${ }^{t}$ & 41.5 & 13.9 & 98.6 & - & 96.4 & - \\
\hline Selenium & 34.8 & 30.9 & 38.1 & 85.1 & 66.9 & 56.1 \\
\hline Sodium & 10.1 & 11.9 & 97.6 & - & 94.0 & - \\
\hline Strontium & 52.1 & 7.9 & 98.5 & - & 96.6 & - \\
\hline Titanium & 24.0 & 18.5 & 98.6 & 0.4 & 98.3 & 0.4 \\
\hline Vanadium & 13.7 & 12.4 & 98.0 & 0.3 & 96.0 & 0.9 \\
\hline
\end{tabular}

- Spike recovery in ESP inlet gas-phase particulate for A1 was 62\%, indicating possible analytical bias.

bince the ESP outlet gas-phase particulate Runs 1 and 3 were discarded, confidence intervals for the ESP and JBR removal efficiencies could not be calculated for many elements.

-Values in parentheses are those obtained when INAA coal analyses are substituted for the GFAA data.

a Spike recovery for Be in the PE ash sample was $147 \%$, indicating possible analytical bias.

- ESP inlet gas-phase particulate Run 2, at $550 \mathrm{ng} / \mathrm{g}$, is a statistical outlier. In comparison with sluiced ash, hopper ash, and size fractionated particulate data for chromium, this value is likely to be biased high. The removal efficiency data in parentheses are calculated with this value rejected.

'These elements are consistently enriched in the coal ash over the process stream solid-phase concentrations, suggesting that the coal analyses are biased high for these elements.

2 ESP inlet gas-phase particulate data are suspected to be biased high compared with sluiced ash hopper ash analyses. This is also supported by the high boiler and low ESP mass balance closures. The removal efficiency data in parentheses are calculated with the ESP sluiced ash analyses substituted for the ESP inlet gas-phase particulate analyses.

Gas particulate-phase data were unavailable. ESP sluiced ash data were substituted. 
related compounds. The phthalate esters detected in the MM5 gas samples are typical plasticizers commonly attributed to plastic bottles, bags, etc. used in the field laboratory environment. Sample and field blank concentrations are comparable; since phthalates are ubiquitous in the terrestrial environment, their presence is most likely due to contamination.

Methylene chloride and acetone are common reagents used in the field for sample recovery, and the detection of these compounds in the VOST samples is attributed to their presence in the field laboratory environment. Also detected in the VOST samples were chloromethane, trichloroethane, tetrachloroethene, and trichlorofluoromethane. These compounds were also found in the field blanks, but not in the trip blanks. Their presence is attributed to an unknown source of solvents or refrigerants in the field environment and they are not considered to be process-generated compounds.

Six semivolatile organic compounds and two volatile organic compounds detected consistently in the three gas streams are likely associated with the coal combustion process. These are benzene, toluene, phenol, 2-methylphenol (o-cresol), 4-methylphenol (p-cresol), acetophenone, naphthalene, and benzoic acid. The average measurable concentrations of these compounds across all three gas streams are less than 1 ppbv except phenol ( $2.5 \mathrm{ppbv})$, formaldehyde ( $8.2 \mathrm{ppbv})$, and benzoic acid ( $37 \mathrm{ppbv}$ ). (Note that benzoic acid is not included on the Title III list of compounds in the Clear Air Act Amendments.)

Benzene, toluene, and the phenols are known products of coal devolatilization, and their presence indicates partial oxidation of the coal or the possible presence of lower-temperature combustion zones within the boiler. The presence of naphthalene, in addition to being a process related compound, is sometimes attributed to inadequate cleanup of the XAD resin material used as the sorbent in the MM5 sampling train. At this site, however, naphthalene concentrations in the blank resin samples were less than three times the detection limit indicating a relatively clean resin matrix. The gas sample concentrations were all less than eight times the detection limit with most of the measurable naphthalene concentrations near the levels found in the blank samples. Consequently, the confidence intervals around the naphthalene concentrations are large, and any definitive conclusion about the presence of naphthalene in the flue gas is not possible from these data.

Conversely, benzoic acid is present in the flue gas samples at an average concentration of 37 ppbv, over ten times greater than any other process related compound. The presence of benzoic acid in the flue gas may be explained by at least two well known mechanisms:

- Oxidation of naphthalene followed by decarboxylation at $300^{\circ} \mathrm{C}$. This route was used commercially to produce benzoic acid until recently, when it was phased out in favor of liquid-phase oxidation of toluene. Naphthalene is oxidized to phthalic acid anhydride then decarboxylated, which takes place spontaneously at $300^{\circ} \mathrm{C}$, with about $40 \%$ conversion. It is not unreasonable to assume that a similar reaction could occur during the combustion process when naphthalene is present.

- Oxidation of toluene to benzoic acid. The catalytic oxidation of toluene to benzoic acid using $\mathrm{V}_{2} \mathrm{O}_{5}$ was also used to produce benzoic acid commercially in Germany during 
World War II. Although it has also been replaced by the liquid-phase oxidation mechanism, the fact that the process existed indicates that benzoic acid can be obtained by the oxidation of toluene. The oxidation yields benzoic acid and benzaldehyde, which can also be oxidized to benzoic acid.

Benzoic acid is not on the Clean Air Act list of 189 toxic substances, but it is noteworthy that all of the detected organic compounds are aromatic and share a common toluene or substituted-benzene structure. Although benzoic acid may be a degradation product of XAD resin, there is no evidence confirming this compound is generated as a sampling artifact. Another likely hypothesis is that the semivolatile compounds detected in the flue gas are attributed to various oxidation and substitution products of naphthalene, xylene (detected in only one sample), and toluene, with benzoic acid being the predominant product.

Similarly, the presence of acetaldehyde and formaldehyde in the flue gas may be attributed to the oxidation of ethane and methane possibly produced from the partial oxidation of coal. Gas samples were not analyzed for acetic or formic acid, which are the oxidation products of acetaldehyde and formaldehyde, respectively. The analysis of these organic acids, if detected, could provide some insight into the behavior of acetaldehyde and formaldehyde and the level of oxidation possible in the system. 


\section{COMPARISON OF VAPOR AND PARTICULATE COMPOSITION}

Most of the substances measured at Plant Yates are distributed between the flue gas (vapor) and particulate matter (bottom ash, collected ESP ash, ash removed in the FGD system, or emitted ash which exits with the flue gas through the stack). Of the organic compounds tested, the semivolatile compounds should be associated with the particulate matter, and the volatile compounds should remain in the vapor phase. (Some of the organic compounds are at least slightly soluble in water and thus may be removed from the flue gas in the wet FGD system.) The sampling and analytical techniques used in the project did not quantify the distribution of the organic compounds between the particulate and vapor phases.

EPA Proposed Method 29 was the primary method used for collecting the trace metals samples at Plant Yates. The anions train used to measure acid gas concentrations is similar to Method 29 in many respects since both are modifications to the Method 5 sampling procedure. In these methods, the particulate and vapor concentrations are analyzed and may be reported separately. However, because of the low vapor-phase concentrations and the high potential for contamination during sampling, sample handling, or analysis, the partitions between particulate and vapor phases should be used cautiously.

Most of the inorganic elements present in the flue gas downstream of the air heater should be in the particulate phase. As is discussed in Section 8, some of the metals will be enriched in the finer particulate sizes, but the vapor pressure of most elements and their compounds is too low for measurable concentrations to be expected in the vapor phase at temperatures of $300^{\circ} \mathrm{F}$ and below. Exceptions to this include mercury, hydrochloric acid, hydrofluoric acid, and selenium which may have significant vapor concentrations. Selenium may be present either as vaporous compounds such as $\mathrm{SeO}_{2}$ or as a component enriched in the finer particulate matter.

Tables 7-1, 7-2, and 7-3 show the particulate and vapor-phase distribution of the inorganic substances of interest measured at Yates in the ESP inlet, ESP outlet, and stack streams, respectively. Rather than summing the components of the sampling train, the concentrations of the particulate and vapor phases have been computed and averaged separately. For values reported from the laboratory as below the detection limit, one-half the detection limit was included in the averaging procedure. The average determined in this manner was used to calculate the particulate percentage, even if the average was less than the average detection limit of the non-detected samples. In this event, the average detection limit has also been included in the tables as a less than value in parentheses $(<D L)$. The percentage of the particulate- and vapor-phase concentrations that result from averaging values below detection limits are included in the tables. 
Table 7-1

Vapor and Particulate-Phase Distribution at ESP Inlet

\begin{tabular}{|c|c|c|c|c|c|c|}
\hline Element & $\begin{array}{c}\text { Part. Conc. } \\
\mu \mathrm{g} / \mathrm{Nm}^{3}\end{array}$ & $\begin{array}{c}\text { \% Part. } \\
\text { DL }^{2}\end{array}$ & \multicolumn{2}{|c|}{$\begin{array}{c}\text { Vapor Conc. } \\
\mu \mathrm{g} / \mathrm{Nm}^{3} \text { b }\end{array}$} & $\begin{array}{l}\text { \% Vapor } \\
\text { DLc }\end{array}$ & $\begin{array}{l}\text { \% of Element in } \\
\text { Particulate Phase }\end{array}$ \\
\hline Antimony & 33 & $0 \%$ & 0.56 & & $0 \%$ & $98.3 \%$ \\
\hline Arsenic & 400 & $0 \%$ & 0.083 & $(<0.17)$ & $100 \%$ & $100.0 \%$ \\
\hline Barium & 4,400 & $0 \%$ & 1.5 & & $0 \%$ & $100.0 \%$ \\
\hline Beryllium & 93 & $0 \%$ & 0.06 & & $0 \%$ & $99.9 \%$ \\
\hline Boron & $4,200^{d}$ & $0 \%$ & 6,390 & & $0 \%$ & $39.7 \%$ \\
\hline Cadmium & 24 & $0 \%$ & 0.11 & & $16 \%$ & $99.6 \%$ \\
\hline Chloride & 6,100 & $0 \%$ & 112,000 & & $0 \%$ & $5.2 \%$ \\
\hline Chromium & 2,900 & $0 \%$ & 11 & & $0 \%$ & $99.6 \%$ \\
\hline Cọbalt & 275 & $0 \%$ & 0.34 & $(<0.74)$ & $55 \%$ & $99.9 \%$ \\
\hline Copper & 770 & $0 \%$ & 1.1 & & $0 \%$ & $99.9 \%$ \\
\hline Fluoride & 1.3 & $0 \%$ & 8,300 & & $0 \%$ & $0.0 \%$ \\
\hline Lead & 710 & $0 \%$ & 0.103 & $(<0.21)$ & $100 \%$ & $100.0 \%$ \\
\hline Manganese & 2,120 & $0 \%$ & 0.051 & $(<0.10)$ & $100 \%$ & $100.0 \%$ \\
\hline Mercury & $1.3^{\circ}$ & $0 \%$ & 5.5 & & $0 \%$ & $19.2 \%$ \\
\hline Molybdenum & 320 & $0 \%$ & 0.66 & $(<1.4)$ & $52 \%$ & $99.8 \%$ \\
\hline Nickel & 2,000 & $0 \%$ & 7 & & $7 \%$ & $99.6 \%$ \\
\hline Phosphorus & 2,100 & $0 \%$ & 7.8 & $(<16)$ & $100 \%$ & $99.6 \%$ \\
\hline Selenium & 133 & $0 \%$ & 0.11 & $(<0.22)$ & $100 \%$ & $99.9 \%$ \\
\hline Strontium & 2,910 & $0 \%$ & 2 & & $0 \%$ & $99.9 \%$ \\
\hline Vanadium & 2,760 & $0 \%$ & 1.20 & & $0 \%$ & $100.0 \%$ \\
\hline
\end{tabular}

Note: The Hg concentration in the sluiced ash has been substituted for the ESP inlet ash Hg concentration since the latter is believed to be biased high.

- Percentage of the particulate concentration that results from using measurements below detection limits.

bote: Run 2 has been excluded from the vapor-phase average because of contamination.

- Percentage of the vapor concentration that results from using measurements below detection limits.

'Boron concentrations from the sluiced fly ash have been substituted for the gas stream particulate concentrations. Chemicals containing boron are used in the digestion procedure used for the gas stream particulate samples.

- The sluiced fly ash mercury concentration was substituted for the mercury concentration measured in the ESP inlet particulate. Material balances around the boiler, ESP, and overall plant support the hypothesis that the ESP inlet particulate mercury concentration is biased high. 
Table 7-2

Vapor and Particulate-Phase Distribution at ESP Outlet

\begin{tabular}{lcccccc}
\multicolumn{1}{c}{ Element } & $\begin{array}{c}\text { Part. Conc. } \\
\mu \mathrm{g} / \mathrm{Nm}^{3}\end{array}$ & $\begin{array}{c}\text { \% Part. } \\
\mathbf{D L}^{\mathbf{2}}\end{array}$ & $\begin{array}{c}\text { Vapor Conc. } \\
\mu \mathrm{g} / \mathrm{Nm}^{3}\end{array}$ & $\begin{array}{c}\text { \% Vapor } \\
\mathbf{N D}^{\mathbf{b}}\end{array}$ & $\begin{array}{c}\text { \% of Element in } \\
\text { Particulate Phase }\end{array}$ \\
\hline Antimony & 0.39 & $0 \%$ & 0.021 & $0 \%$ & $94.8 \%$ \\
Arsenic & 16 & $0 \%$ & 0.091 & $(<0.18)$ & $100 \%$ & $99.4 \%$ \\
Barium & 74 & $0 \%$ & 1.0 & & $0 \%$ & $98.7 \%$ \\
Beryllium & 1.7 & $0 \%$ & 0.093 & $(<0.16)$ & $57 \%$ & $94.9 \%$ \\
Cadmium & 1.1 & $0 \%$ & 0.10 & & $20 \%$ & $91.1 \%$ \\
Chloride & 45 & $0 \%$ & 136,000 & & $0 \%$ & $0.0 \%$ \\
Chromium & 23 & $0 \%$ & 0.57 & $(<0.73)$ & $42 \%$ & $97.6 \%$ \\
Cobalt & 4.5 & $0 \%$ & 0.54 & $(<1.0)$ & $31 \%$ & $89.2 \%$ \\
Copper & 16 & $0 \%$ & 1.1 & & $16 \%$ & $93.9 \%$ \\
Fluoride & 0.12 & $0 \%$ & 7,900 & & $0 \%$ & $0.0 \%$ \\
Lead & 18 & $0 \%$ & 0.37 & & $20 \%$ & $98.0 \%$ \\
Manganese & 34 & $0 \%$ & 0.055 & $(<0.11)$ & $100 \%$ & $99.8 \%$ \\
Mercury & 0.126 & $0 \%$ & 5.6 & & $0 \%$ & $2.2 \%$ \\
Molybdenum & 8.1 & $0 \%$ & 0.61 & $(<1.4)$ & $37 \%$ & $93.0 \%$ \\
Nickel & 22 & $0 \%$ & 1.54 & $(<2.9)$ & $59 \%$ & $93.6 \%$ \\
Phosphorus & 100 & $0 \%$ & 8.49 & $(<17)$ & $100 \%$ & $92.2 \%$ \\
Selenium & 82 & $0 \%$ & 0.12 & $(<0.23)$ & $100 \%$ & $99.9 \%$ \\
Strontium & 43 & $0 \%$ & 1.4 & & $0 \%$ & $96.9 \%$ \\
Vanadium & 54 & $0 \%$ & 1 & & $12 \%$ & $98.2 \%$
\end{tabular}

2 Percentage of the particulate concentration that results from using measurements below detection limits.

b Percentage of the vapor concentration that results from using measurements below detection limits. 
Table 7-3

Vapor and Particulate-Phase Distribution at Stack

\begin{tabular}{|c|c|c|c|c|c|c|c|}
\hline Elemènt & \multicolumn{2}{|c|}{$\begin{array}{c}\text { Part. Conc. } \\
\mu \mathrm{g} / \mathrm{Nm}^{3}\end{array}$} & \multirow{2}{*}{$\frac{\begin{array}{c}\% \text { Part. } \\
\text { DL }^{2}\end{array}}{0 \%}$} & \multicolumn{2}{|c|}{$\begin{array}{l}\text { Vapor Conc. } \\
\mu \mathrm{g} / \mathrm{Nm}^{3}\end{array}$} & \multirow{2}{*}{$\frac{\begin{array}{c}\% \text { Vapor } \\
\mathrm{DL}^{\mathrm{b}}\end{array}}{0 \%}$} & \multirow{2}{*}{$\begin{array}{c}\% \text { of Element in } \\
\text { Particulate Phase } \\
80.6 \%\end{array}$} \\
\hline Antimony & 0.052 & & & 0.012 & & & \\
\hline Arsenic & 1.1 & & $0 \%$ & 0.089 & $(<0.18)$ & $100 \%$ & $92.5 \%$ \\
\hline Barium & 2.8 & & $0 \%$ & 0.082 & $(<0.14)$ & $54 \%$ & $97.2 \%$ \\
\hline Beryllium & 0.041 & & $0 \%$ & 0.061 & $(<0.17)$ & $82 \%$ & $40.1 \%$ \\
\hline Cadmium & 0.59 & & $0 \%$ & 0.032 & $(<0.064)$ & $100 \%$ & $94.9 \%$ \\
\hline Chloride & 214 & & $0 \%$ & 540 & & $0 \%$ & $28.4 \%$ \\
\hline Chromium & 5.1 & & $0 \%$ & 0.34 & $(<0.67)$ & $100 \%$ & $93.8 \%$ \\
\hline Cobalt & 0.25 & $(<0.6)$ & $59 \%$ & 0.39 & & $0 \%$ & $39.3 \%$ \\
\hline Copper & 0.77 & & $0 \%$ & 1.2 & & $14 \%$ & $38.2 \%$ \\
\hline Fluoride & 0.051 & & $0 \%$ & 124 & & $0 \%$ & $0.0 \%$ \\
\hline Lead & 0.50 & & $0 \%$ & 0.11 & $(<0.22)$ & $100 \%$ & $82.1 \%$ \\
\hline Manganese & 7.2 & & $0 \%$ & 0.054 & $(<0.11)$ & $100 \%$ & $99.3 \%$ \\
\hline Mercury & 0.0071 & & $18 \%$ & 3.0 & & $0 \%$ & $0.2 \%$ \\
\hline Molybdenum & 1.4 & & $0 \%$ & 0.12 & & $0 \%$ & $92.3 \%$ \\
\hline Nickel & 39 & & $0 \%$ & 1.8 & $(<2.6)$ & $46 \%$ & $95.7 \%$ \\
\hline Phosphorus & 1.3 & $(<2.6)$ & $100 \%$ & 8.2 & $(<16)$ & $100 \%$ & $13.6 \%$ \\
\hline Selenium & 26 & & $0 \%$ & 0.8 & & $0 \%$ & $97.1 \%$ \\
\hline Strontium & 1.5 & & $0 \%$ & 0.022 & $(<0.045)$ & $100 \%$ & $98.5 \%$ \\
\hline Vanadium & 1.6 & & $0 \%$ & 0.55 & & $0 \%$ & $74.5 \%$ \\
\hline
\end{tabular}

- Percentage of the particulate concentration that results from using measurements below detection limits.

${ }^{b}$ Percentage of the vapor concentration that results from using measurements below detection limits. 
At ESP inlet conditions, more than $99 \%$ of the mass of the substances of interest were found in the particulate phase. Exceptions to this are chloride, fluoride, and mercury. Most chloride and fluoride exiting the boiler are in the acid gas form ( $\mathrm{HCl}$ and $\mathrm{HF}$.) In fact, Title III of the Clean Air Act Amendments of 1990, only lists $\mathrm{HCl}$ and $\mathrm{HF}$ and not chloride and fluoride salts which would be in the particulate form. However, the particulate measurements are included in this section for completeness.

With the exception of mercury, chloride, and fluoride, the particulate phase contains most of the mass of elements at the ESP outlet and stack as well. The percentage found in the particulate phase decreases for some elements in the stack, primarily because the particulate loading (and therefore the particulate concentration of an element on a gas-phase basis) decreases. The gas-phase concentrations of most elements are reasonably consistent at each of the sampling locations. However, these concentrations, while very low, are above those expected. Since the concentrations of the elements in the liquid impinger samples are extremely low (10 ppb level or below for most), contamination of the impinger solutions is the suspected cause.

Field blank concentrations support the hypothesis that contamination may be the cause of the higher-than-expected vapor-phase concentrations of the elements of interest. Table 7-4 compares the stack vapor measurements to the stack field blank concentrations (calculated on an average stack gas volume basis). For most of the elements, the field blank concentration equals or exceeds the measured stack concentration. Since the reagent blanks are generally much lower than the field blanks, sample handling under field conditions is the expected cause of contamination. Possible sources of contamination include incomplete rinsing of the sampling train glassware or inadvertent contact of the rinse solution with external glassware surfaces. Again, because the concentration of these elements is in the ppb range, very little material is required to cause these levels of contamination.

Mercury and fluoride are almost entirely in the vapor phase at the ESP outlet and stack. Chloride shows a substantial particulate percentage at the stack. This high level of particulate chloride is believed to be caused by a minor amount of absorber liquid being reentrained from the mist eliminator surfaces. Again, this chloride is a calcium salt which is not included on the list of elements and compounds in Title III of the Clean Air Act Amendments of 1990.

Finally, the selenium distribution at Plant Yates is worthy of note. Essentially all of the selenium was found in the particulate phase at Yates, while at most other coal-fired electric utility plants a significant fraction of the selenium has been measured in the vapor phase. (Variability in the selenium data is also high in most cases.) Although the particulate phase contains the selenium, particulate-phase selenium removal efficiency was only $40 \%$ (see Table 8-2) compared to greater than $98 \%$ removal efficiency for the total particulate matter. All other particulate-phase metals are removed at greater than $90 \%$ efficiency. These data indicate that selenium may be reacting or condensing on the particulate filter during gasphase sampling resulting in a lower-than-expected vaporous selenium concentration. Also note that the spike recovery for the selenium vapor was low, indicating a possible low bias in the vapor-phase selenium concentration. 
Table 7-4

Stack Field Blank Versus Vapor Concentration

\begin{tabular}{lrcc}
\multicolumn{1}{c}{ Element } & \multicolumn{2}{c}{$\begin{array}{c}\text { Vapor Conc. } \\
\mu \mathrm{g} / \mathrm{Nm}^{3}\end{array}$} & $\begin{array}{c}\text { Field Blank } \\
\mu \mathrm{g} / \mathrm{Nm}^{3}\end{array}$ \\
\hline Antimony & 0.012 & & 1.78 \\
Arsenic & 0.089 & $(<0.18)^{2}$ & $<0.177$ \\
Barium & 0.082 & $(<0.14)$ & 0.734 \\
Beryllium & 0.061 & $(<0.17)$ & $<0.150$ \\
Cadmium & 0.032 & $(<0.064)$ & 0.054 \\
Chromium & 0.34 & $(<0.67)$ & 3.19 \\
Cobalt & 0.39 & & 1.01 \\
Copper & 1.2 & & 1.66 \\
Lead & 0.11 & $(<0.22)$ & 1.08 \\
Manganese & 0.054 & $(<0.11)$ & 10.6 \\
Molybdenum & 0.12 & & 0.073 \\
Nickel & 1.8 & $(<2.6)$ & 3.59 \\
Phosphorus & 8.2 & $(<16)$ & $<16.5$ \\
Selenium & 0.8 & & $<0.228$ \\
Strontium & 0.022 & $(<0.045)$ & 0.513 \\
Vanadium & 0.55 & & 0.821
\end{tabular}

"The "<" symbol indicates the average D.L. for these substances. 
In Table 7-1, the mercury concentration in the sluiced fly ash has been substituted for the mercury concentration measured in the ESP inlet particulate matter because the ESP value is believed to be biased high. (The ESP inlet ash mercury concentration is significantly higher than that measured at most other coal-fired electric utility plants.) As shown in Table 6-2, material balances for mercury around the boiler $(205 \%)$ and ESP $(55 \%)$ indicate that the mercury particulate concentration may be high. The overall balance for mercury $(101 \%)$ is good. (This balance does not use the ESP inlet data.) Since the ESP sluiced ash includes most of the ash at the ESP inlet, concentrations in this stream should be reasonable estimates for the ESP inlet ash concentrations. When this substitution is made, the mercury balances around the boiler (110\%) and ESP (102\%) become more reasonable. 


\section{DISTRIBUTION OF HAPS AS A FUNCTION OF PARTICLE SIZE IN THE FLUE GAS AND THE PARTICLE SIZE DISTRIBUTION IN THE ESP}

Understanding the distribution of trace metals according to particle size is important in understanding and predicting trace metals emissions rates and removal efficiencies across control devices. For example, if an element was enriched (higher concentration than in the bulk ash) in the fine particulate matter, the removal efficiency for that element across an ESP would be expected to be less than that of the bulk particulate matter. (Theoretically, an ESP does not control the fines as well as the larger particle size fractions.)

Prior to the presentation of results from Plant Yates, expected results based on historical data will be discussed. Trace metals in coal can be grouped into three general categories:

- Elements (and compounds) that are not vaporized during the combustion process and, therefore, are assumed to be uniformly distributed in the bottom ash and fly ash. Included in this category are barium, beryllium, manganese, strontium, vanadium, and, sometimes, chromium and nickel.

- Elements that are partially or completely vaporized in the furnace and then condense as the flue gas temperature drops in cooler regions of the boiler and in downstream equipment. This condensation can occur on the surface of ash particles or by homogenous nucleation, so elements in this category tend to be enriched in the finer fly ash particles. Included here are arsenic, cadmium, copper, lead, molybdenum, and, sometimes, chromium, nickel, and selenium. Antimony and phosphorus may also fall in this category, but not much supporting data on these elements are available as yet.

- Elements that are vaporized and remain primarily in the vapor phase at flue gas temperatures in the stack. Mercury and sometimes selenium fall into this category. Selenium may be present either as vaporous compounds, such as $\mathrm{SeO}_{2}$, or as a component enriched in the finer particulate matter.

\section{Collection and Analytical Methods}

The mass particle size distributions around the ESP can be used to characterize its performance. The size distributions were determined by Anderson High Capacity Source Sampler ( 4 cuts) for the ESP inlet, by Microtracs laser diffraction for the ESP Field 1 hopper catch and the ESP Field 2 hopper catch, and by University of Washington Mark V cascade impactor (11 cuts) at the ESP outlet. 
To convert the size distributions from aerodynamic diameter to physical diameter, it is necessary to know the density of the particles. Particle density measurements were made on samples from the ESP from Plant Yates ESP Hoppers 1-4 on 6/23/93. A helium pycnometer was used to measure the porosity and volume of the ash samples. The samples were then weighed to determine the particle density. The average of three measurements was 2.41 $\mathrm{g} / \mathrm{cm}^{3}$, and it was assumed that this density was representative for all sizes of particles. This value for density was then used in the impactor data reduction to calculate the physical diameters.

\section{Particle Size Distribution and Fractional Efficiency}

Figures 8-1, 8-2, 8-3, and 8-4 show the cumulative and differential particle size distribution measured at the inlet and outlet of the ESP. Specific run data for the ESP inlet and outlet PSD tests are included in Appendix C.

The inertial sampling equipment used for these tests is described in Section 5. Sampling was conducted at a fixed, isokinetic flow rate to yield a constant stage cutpoint. The sampling train utilized is essentially a standard EPA reference Method 17 configuration. Stage cutpoints for the cascade impactors and cyclone samplers are derived from empirical calibrations based on operating flow rates, run conditions, and sampler geometry.

ESP particle size data are presented on a physical basis, rather than aerodynamic, using a measured ash density of $2.4 \mathrm{gm} / \mathrm{cm}^{3}$. The ESP inlet particle size distribution is a direct average of triplicate runs at the same cyclone stage cutpoints. The top and bottom end of the distribution are assumed to be $50 \mu \mathrm{m}$ and $0.1 \mu \mathrm{m}$, respectively. This range was selected to cover the extent of particles which are typical of coal-fired boilers. Mass median diameter and geometric standard deviation of the distribution were estimated graphically, based on the $50 \mu \mathrm{m}$ upper size limit, assuming a log-normal distribution. The resulting inlet distribution had a mass median diameter of $13 \mu \mathrm{m}$ with a standard deviation of 4.1 This represents a rather wide spread for an inlet size distribution. Since only four data points are available from the cyclones, it is difficult to discern any more details on the inlet distribution. However, the amount of space charge suppression that was observed in the first field of the ESP does indicate large concentrations of fine particles which would also reflect a large standard deviation.

Data reduction for the outlet PSD follows a standard cascade impactor $\mathrm{D}_{50}$ calculation method. ${ }^{1}$ Outlet particle size was also extrapolated to a $50 \mu \mathrm{m}$ upper endpoint. Mass fraction and differential distribution were directly averaged from the raw impactor run data, since stage $D_{50}$ cutpoints were nearly identical between runs. The resulting distribution had a mass median diameter of $4.1 \mu \mathrm{m}$ and a standard deviation of 3.1. This size is representative of the size distribution commonly measured at the outlet of an ESP.

In Figures 8-3 and 8-4, and Table 8-1, the differential mass has been normalized to the level of the Method 5/29 average measured particulate concentration. This corrects for sample fallout and loss in the particle sizing cyclones and cascade impactor. It also accounts for 


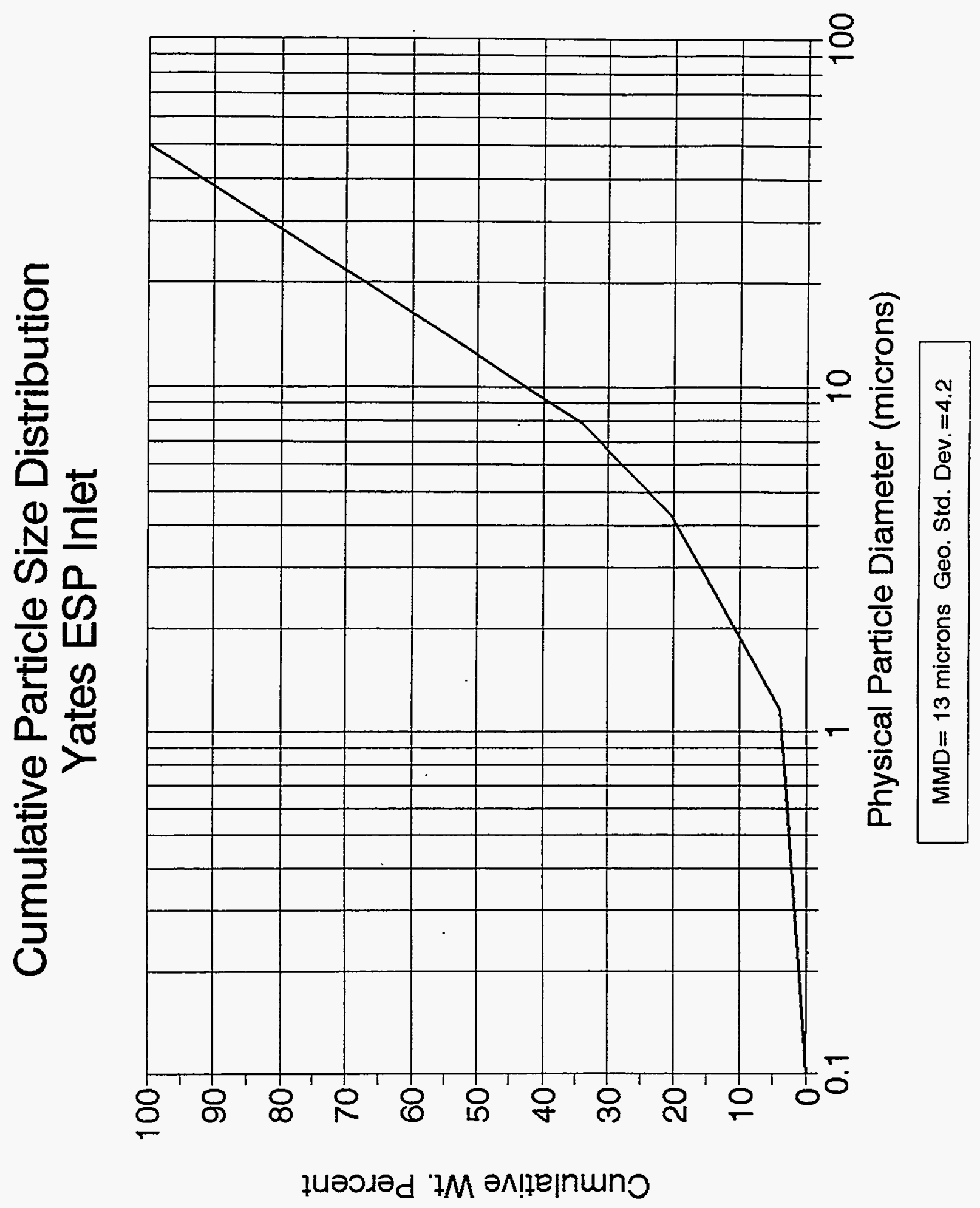

Figure 8-1

Cumulative Particle Size Distribution, Yates ESP Inlet 

Yates ESP Inlet

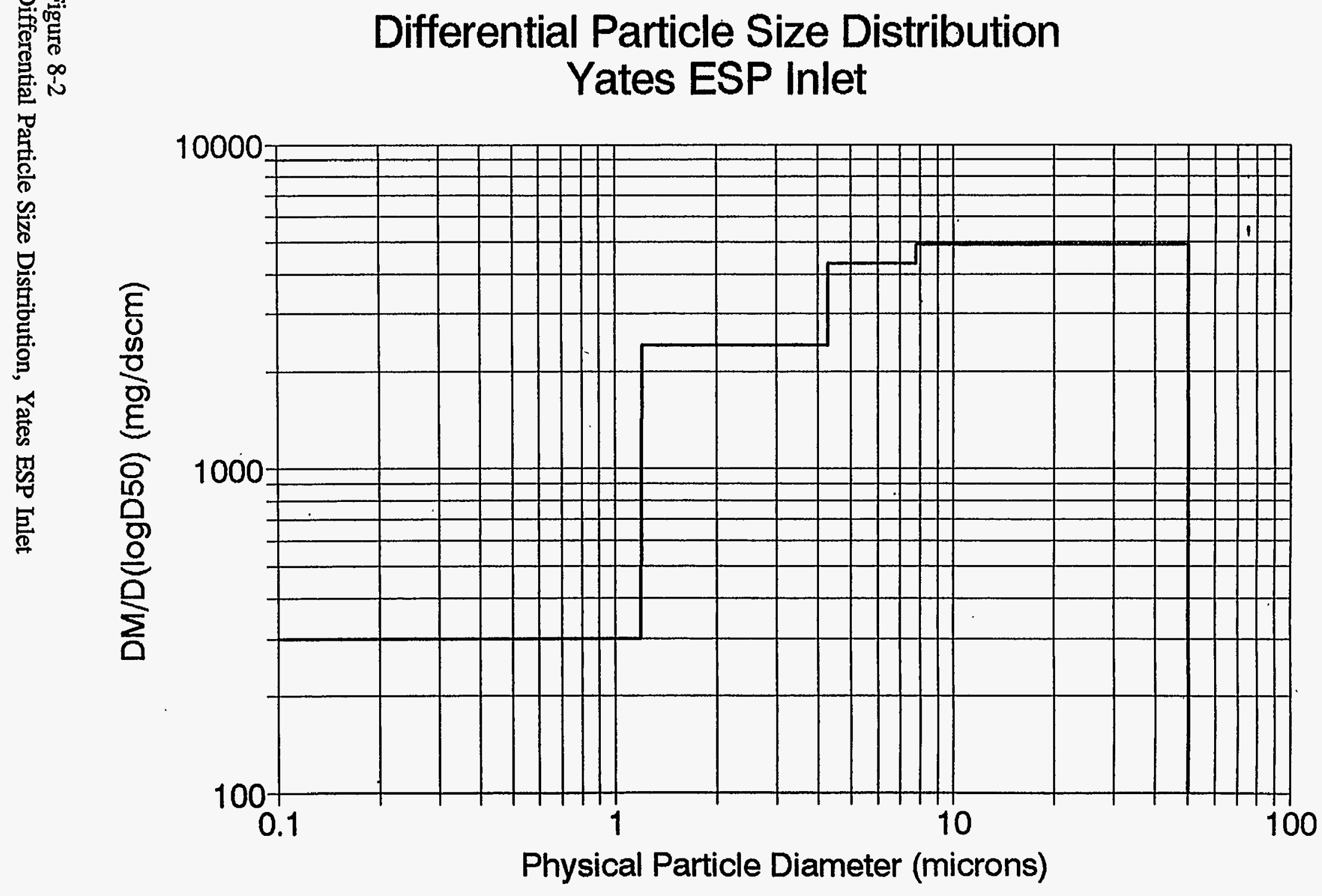




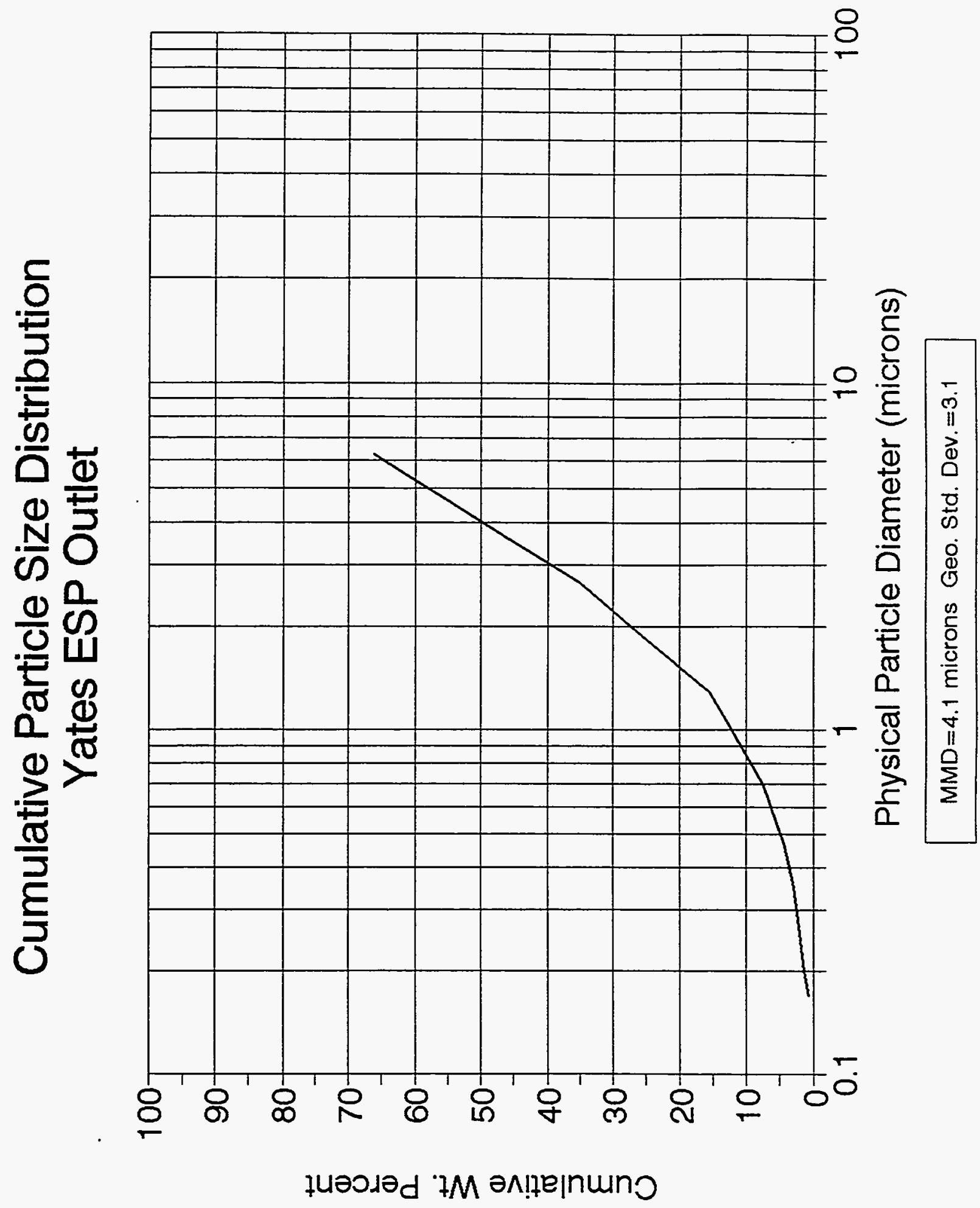

Figure 8-3

Cumulative Particle Size Distribution, Yates ESP Outlet 


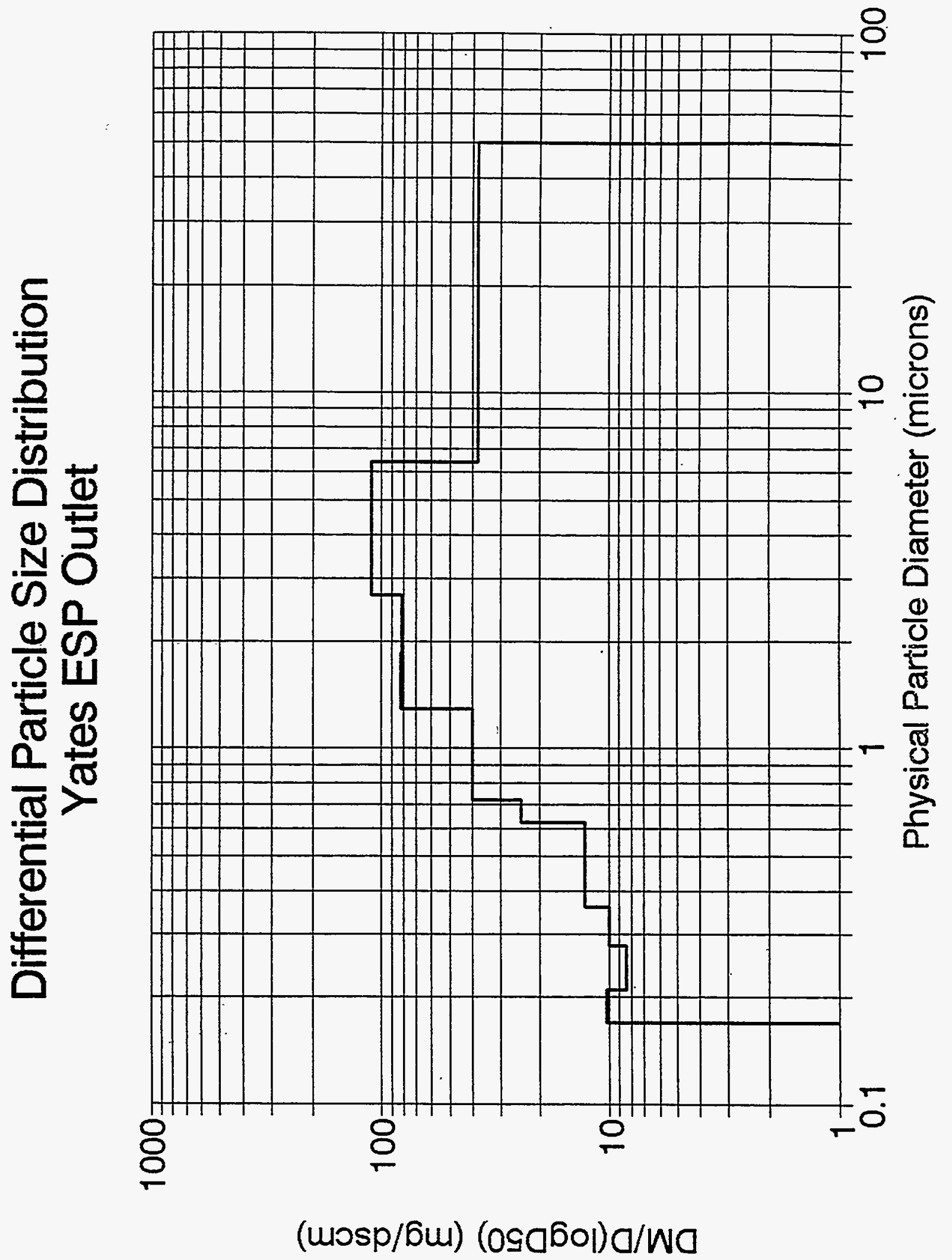

Figure 8-4

Outlet Differential Particle Size Distribution 
Table 8-1

Measured Particle Size and Fractional Efficiency

\begin{tabular}{ccccccc}
$\begin{array}{c}\text { Physical } \\
\text { Diameter } \\
\text { (microns) }\end{array}$ & $\begin{array}{c}\text { Inlet } \\
\text { Cumulative } \\
\text { Mass (\%) }\end{array}$ & $\begin{array}{c}\text { Inlet } \\
\text { DM/d (logD50) } \\
\text { (mg/dscm) }\end{array}$ & $\begin{array}{c}\text { Outlet } \\
\text { Cumulative } \\
\text { Mass (\%) }\end{array}$ & $\begin{array}{c}\text { Outlet } \\
\text { DM/d(logD50) } \\
\text { (mg/dscm) }\end{array}$ & $\begin{array}{c}\text { Fractional } \\
\text { Efficiency } \\
(\%)\end{array}$ & $\begin{array}{c}\text { Fractional } \\
\text { Penetration } \\
(\%)\end{array}$ \\
\hline $0.1-1.2$ & 3.8 & 300 & 16.0 & 17.3 & 94.2 & 5.8 \\
$1.2-4.3$ & 20.3 & 2,413 & 55.0 & 81.5 & 96.6 & 3.4 \\
$4.3-7.8$ & 33.8 & 4,309 & 78.0 & 95.5 & 97.8 & 2.2 \\
$>7.8$ & 100.0 & 4,927 & 100.0 & 51.0 & 99.0 & 1.0
\end{tabular}

Notes:

1. Fly ash density $=2.41 \mathrm{gm} / \mathrm{cm}^{3}$.

2. Inlet differential distribution normalized to average mass test concentration of $8,338 \mathrm{mg} / \mathrm{dscm}$.

3. Outlet differential distribution normalized to average mass test concentration of $131.8 \mathrm{mg} / \mathrm{dscm}$.

differences between the single-point impactor and cyclone sampler tests and the multipoint Method 5/29 measurements.

Table 8-1 shows the collection efficiency as a function of physical particle size. The overall collection efficiency for all particles was 98.4 percent. The measured collection efficiency for particles below $1.2 \mu \mathrm{m}$ was $94 \%$, while the collection efficiency for particles between $1.2-4.3$ microns was 96 percent. The mass fraction above $1 \mu \mathrm{m}$ represents the majority of particles emitted from the ESP. Although theoretical collection efficiency decreases with the particle diameter, non-ideal effects such as sneakage, gas flow distribution, and reentrainment can have a very significant effect on ESP performance for larger particle sizes. This demonstrates that an ESP can efficiently collect submicron particles and does not emit just fine particles as is commonly believed.

\section{Predicted ESP Performance}

ESP performance can be affected by several variables including particle resistivity and the electrical characteristics of the ESP. Both of these conditions can ultimately affect opacity. Each of these are discussed in the following section.

Particle Resistivity. Particle resistivity was measured at the ESP inlet using an extractive resistivity measuring device. In this device, sample collection and resistivity measurement are performed in a chamber external to the duct. The system uses an in-situ probe to isokinetically extract a sample of dust to a temperature-controlled precipitation chamber where a point-plane precipitator deposits the dust onto a disc. Once a suitable layer has been deposited, layer thickness is measured with a precision micrometer. Resistivity is measured 
in the presence of flue gas by applying increasing voltage across the dust layer. The resulting current is measured with a picoammeter until the dust layer breaks down electrically and sparkover occurs. The resistivity is then calculated using the ratio of the electric field to the current density just prior to sparkover, as described in ASME Power Test Code Number 28. Measurements are typically made over a range of temperatures for the same dust layer. This allows resistivity to be measured over a range of possible ESP operating conditions.

In addition to the in-situ measurements, resistivity was also calculated using a computer model developed by Bickelhaupt. ${ }^{2,3}$ This model predicts resistivity as a function of temperature, water vapor content, and $\mathrm{SO}_{3}$ concentration. An as-received ultimate coal analysis is required to run the Bickelhaupt model.

Figure 8-5 shows a plot of the particle resistivity. The solid triangles are in-situ measurements made during the field test program at the ESP inlet. Although the ESP temperature was steady at approximately $280^{\circ} \mathrm{F}$, it was possible to make measurements at a range of temperatures from $240^{\circ} \mathrm{F}$ to $320^{\circ} \mathrm{F}$ by varying the temperature in the resistivity chamber.

The lines shown in Figure 8-5 are the predicted values based upon the Bickelhaupt empirical model. This model uses coal and ash characteristics to predict particle resistivity. It has been documented that the weakest part of the model is predicting the gas-phase $\mathrm{SO}_{3}$ concentration. Therefore, the plot contains the predictions for four values of $\mathrm{SO}_{3}$ from 0-7 ppm.

At $280^{\circ} \mathrm{F}$, the measured resistivity was $8-10 \times 10^{10} \mathrm{ohm}-\mathrm{cm}$, which represents conditions for very good precipitation. The measured values are higher than the predicted values with greater than $1 \mathrm{ppm}$ of $\mathrm{SO}_{3}$. The predicted values with no $\mathrm{SO}_{3}$ match well with the measured values. This means that the amount of $\mathrm{SO}_{3}$ present in the flue gas was much lower than predicted. This can be caused by conditions in the boiler or by characteristics of the air preheater. Often $\mathrm{SO}_{3}$ can be scrubbed by the cold surfaces in the heat exchanger.

Another indication that the $\mathrm{SO}_{3}$ was low was the low dew point that was measured. The resistivity chamber has been modified to allow measurement of acid dew point. A window on the chamber is cooled to a point that condensation occurs on the window face exposed to the flue gas. The window is then heated externally until the mist disappears. A thermocouple attached to the inside of the window is used to determine the temperature of the glass surface. Experience with this system has shown that the dew point can be consistently measured $\pm 2^{\circ} \mathrm{F}$. During the measurements at Plant Yates, there was no detectable dew point above $220^{\circ} \mathrm{F}$. This corresponds to an $\mathrm{SO}_{3}$ concentration of approximately $0.3 \mathrm{ppm}$.

Electrical Characteristics. The electrical characteristics are shown in Figure 8-6. The voltage current (VI) characteristics are expressed in the normalized terms of electric field strength $(\mathrm{kV} / \mathrm{cm})$ and current density $\left(\mathrm{nA} / \mathrm{cm}^{2}\right)$. All the fields, except Field $\mathrm{C}$, operate at field strengths greater than $3 \mathrm{kV} / \mathrm{cm}$. Cold-side ESPs that are not experiencing problems related to high resistivity will typically operate in the range of 3.0 to $3.5 \mathrm{kV} / \mathrm{cm}$. Therefore, the VI curves shown in Figure 8-6 reflect the moderate particle resistivity levels described préviously. 


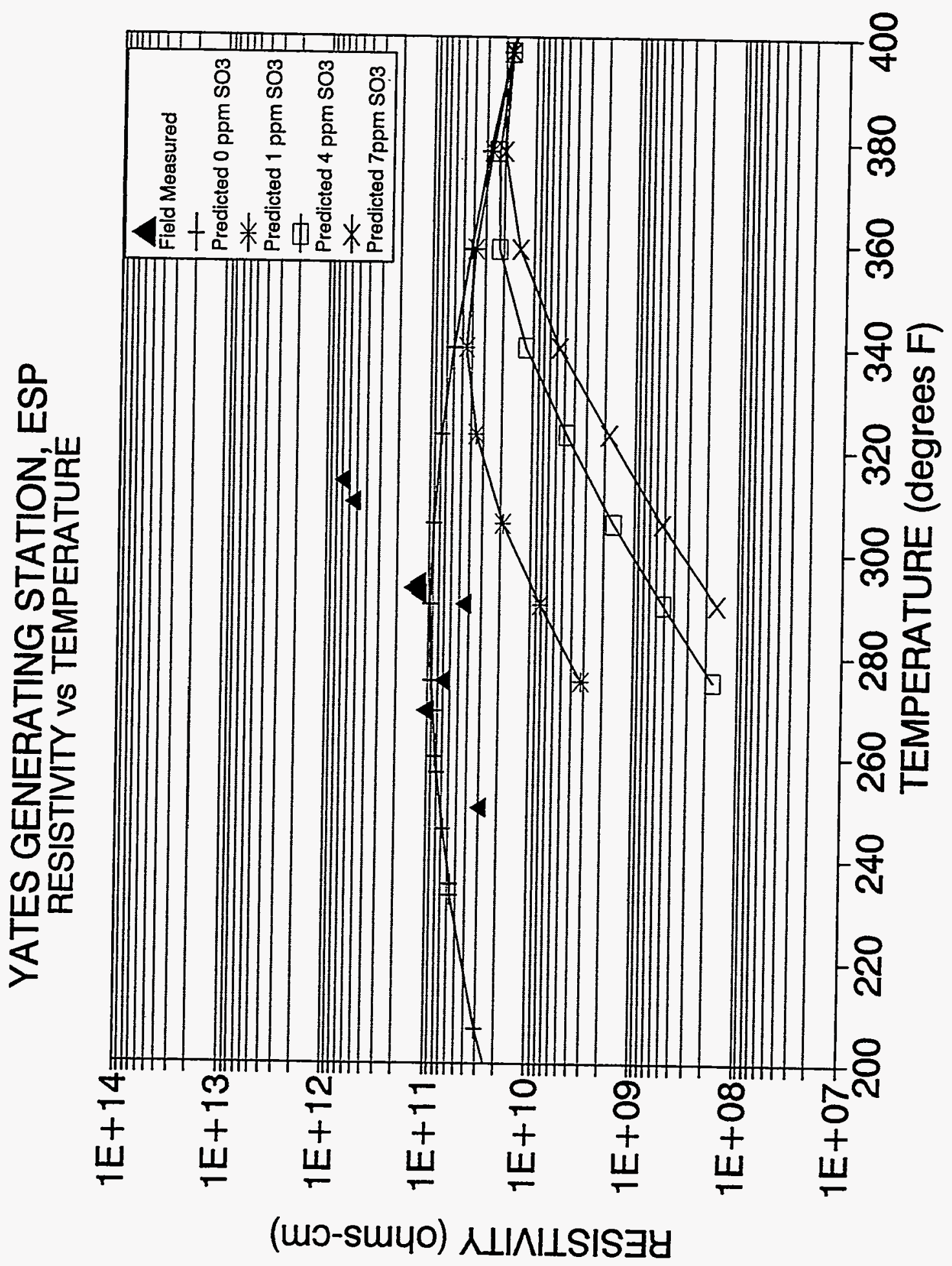

Figure 8-5

Particle Resistivity 
VOLTAGE/CURRENT CURVES 6/23/93 16:00

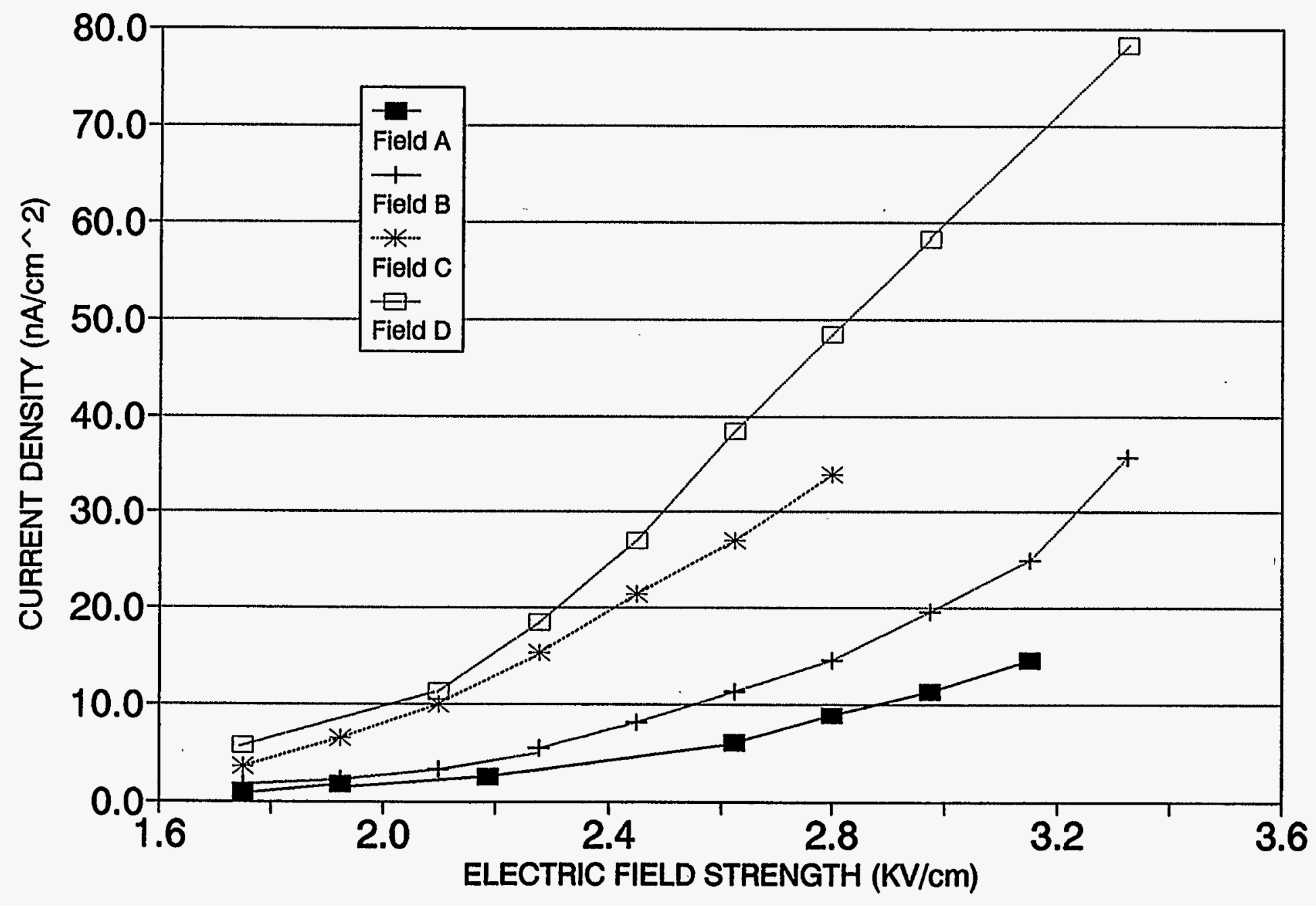


Field C is sparked at $2.8 \mathrm{kV} / \mathrm{cm}$ which is lower than the field strengths in Fields $\mathrm{B}$ and D which are upstream and downstream of Field C. Since the low voltage sparking is isolated in only one section of the ESP, the problem is probably not related to particle resistivity and is most likely due to some minor misalignment in this field.

Opacity. The opacity over a given period of time is shown in Figure 8-7 which is a plot of 6 minute averages of 15 second readings. During the time period shown in this figure, all sections should have been rapped. The lack of rapping spikes is likely due to the sampling time on the data recorder. However, it could be possible that the rapping spikes are relatively small. The holding force on the collected dust layer is proportional to the square of the particle resistivity. At the resistivity levels measured for this ash, the holding force could be strong enough to inhibit removal of the dust from the plates.

Predicted ESP Performance. The performance of the ESP was predicted using a predictive ESP computer model developed by ADA Technologies for DOE. ${ }^{4}$ The non-ideal factor for gas flow distribution (25\%) that has been recommended by EPRI for older ESPs was used in the modeling. The EPRI value for sneakage was modified for this application to take into account the fact that there were four electrical sections but only three mechanical sections.

The results of the predictions are shown in Table 8-2. As can be seen, the predicted performance of the ESP matches well with the measured performance. The model predicted $98.4 \%$ for the overall collection efficiency which agrees with the measured results from the total particulate tests. The outlet size distributions are also similar as both show a mass median diameter of approximately $4 \mu \mathrm{m}$. The opacity values are a little different, but the exact dimensions of the duct where the opacity is measured is not known. This is important for predicting opacity.

Figure 8-8 is a plot of the measured and predicted penetration as a function of particle size. The measured efficiency is much cruder because only 4 data points are available for the calculation from the inlet measurements. However, the measured and predicted efficiencies as a function of particle size are nearly identical. Both show a maximum penetration for submicron particles of 6 to 7 percent.

From the fact that there is a strong correlation between the measured and modeled performance, it is concluded that the ESP is performing as would be expected for the fly ash and flue gas conditions present. No operational or performance problems are observable.

\section{Metals Removal Across ESP}

Table 8-3 shows the removal of particulate metals across the ESP as well as the penetration of particulate metals through the ESP. The average penetration is $1.6 \%$ for all particles. As can be seen, most of the metals are removed at approximately the same rate as the total particulate. This would be expected because the metals are associated with all sizes of particles and the ESP is showing very high collection efficiency for even submicron particles. Figure 8-9 shows the distribution of metals as a function of particle size measured at the inlet 
YATES GENERATING STATION

OPACITY READINGS @ ESP OUTLET 6/22/93

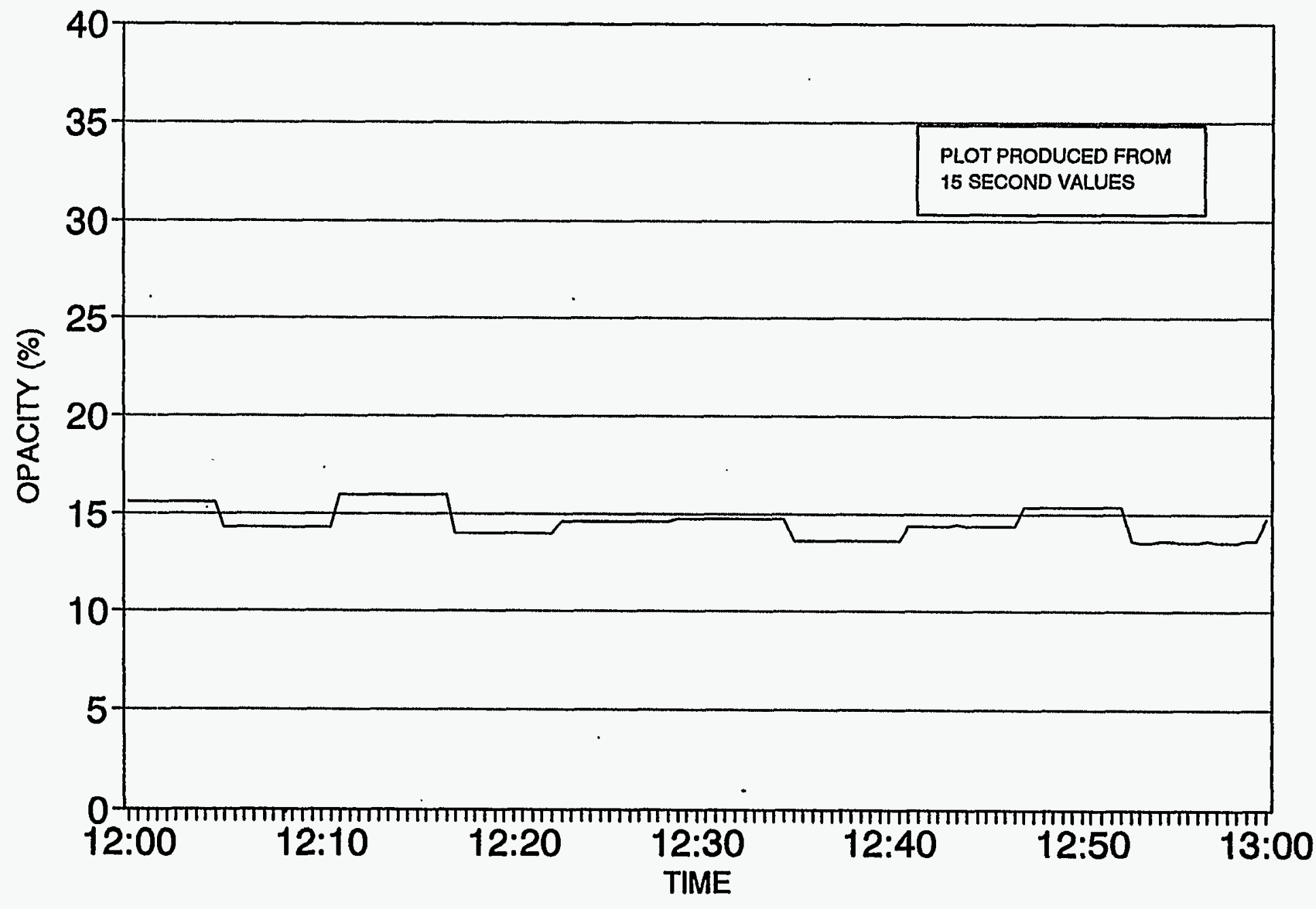




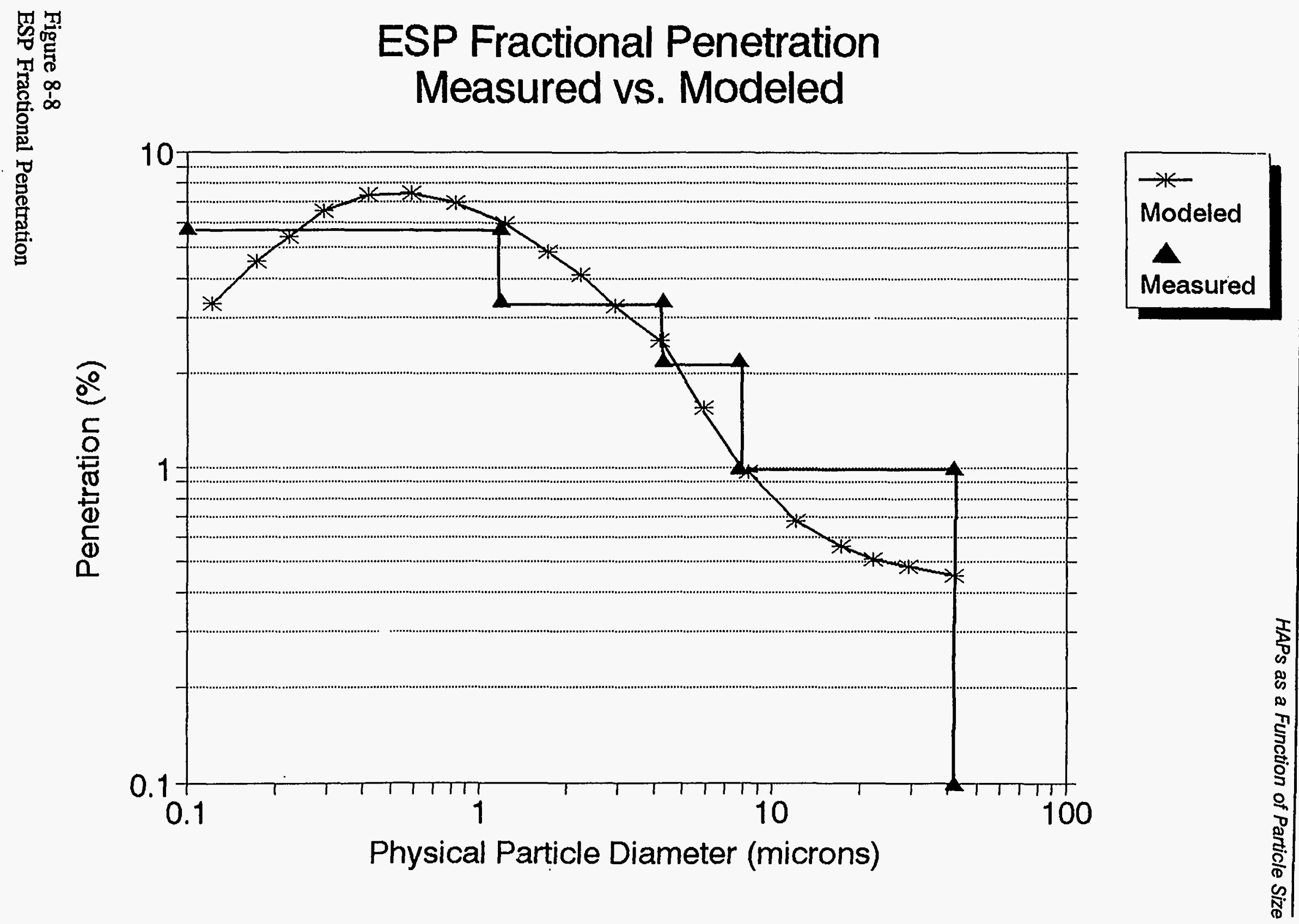


Distribution of Metals According to Particle Size at the ESP Inlet

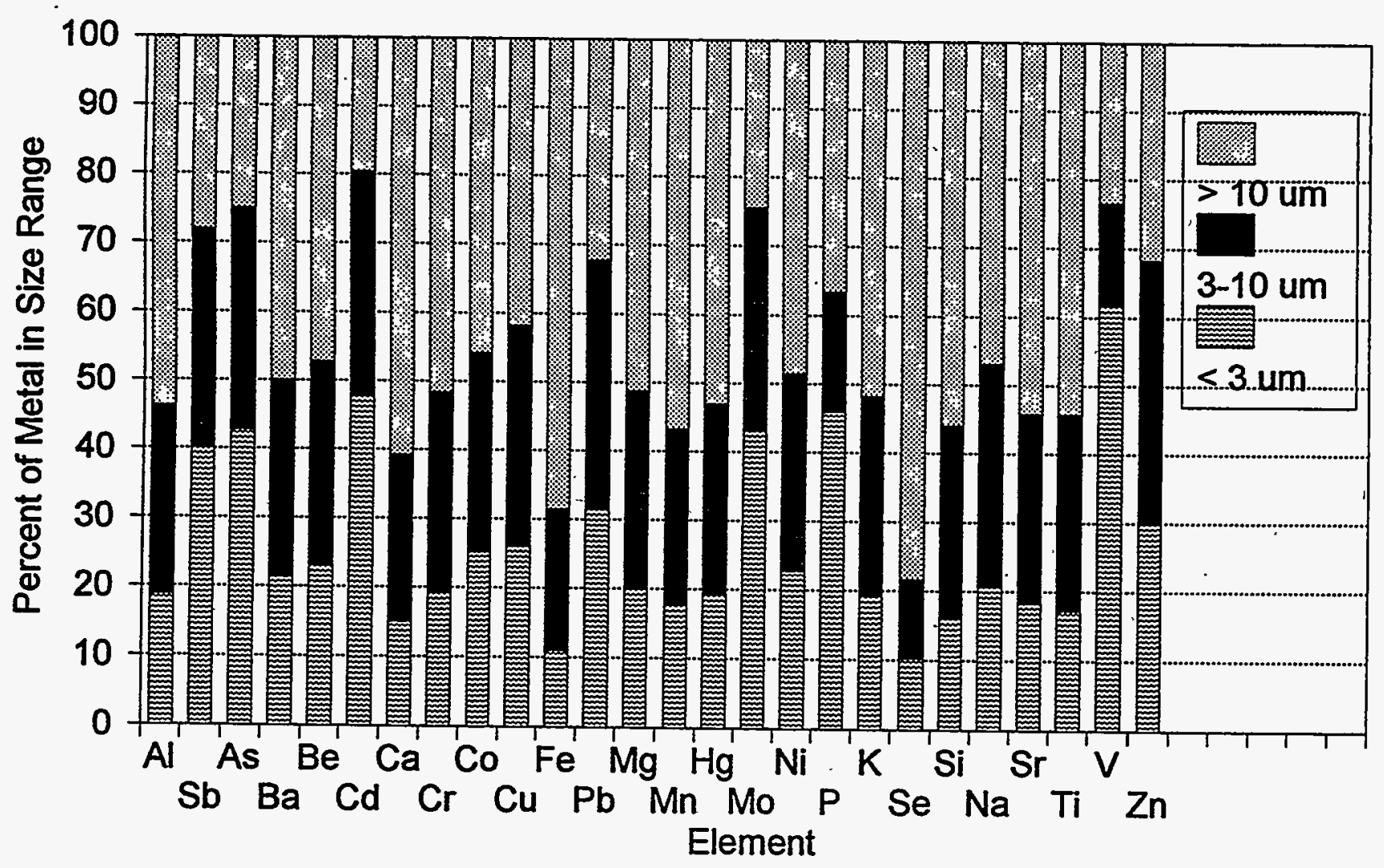

Figure 8-9

Distribution of Metals According to Particle Size at the ESP Inlet 
Table 8-2

Comparison of Predicted and Measured ESP Performance

\begin{tabular}{lcc} 
& Predicted & Measured \\
\hline Collection Efficiency & 98.4 & 98.4 \\
Outlet Size Distribution & & \\
$\quad$ Mass Median Diameter, $\mu \mathrm{m}$ & 3.9 & 4.1 \\
$\quad$ Standard Deviation & 3.3 & 3.1 \\
Opacity & $19 \%$ & $16 \%$
\end{tabular}

to the ESP. As can be seen, as much as 50 to $70 \%$ of all particles are associated with very large particles (i.e., $>10 \mu \mathrm{m}$ ).

Figure 8-10 is a similar plot of the distribution of the metals measured at the outlet. At the outlet, the highest concentration of mass is in the finest particles (i.e., $<3 \mu \mathrm{m}$ ). This is due to the fact that the efficiency of the ESP drops off slightly as a function of particle size as shown in Figure 8-8.

\section{Four Metals with Higher Penetration than the Average}

There are four metals that have penetration values at least twice that of the overall average penetration. The increased penetration in arsenic $(3.96 \%)$, cadmium $(4.46 \%)$, and phosphorus $(4.83 \%$ ) [and mercury if substitution of sluiced ash concentration for the ESP inlet is used (10.98\%)] are relatively small and could be due to either the low concentrations for arsenic and cadmium, or they could be due to the fact that they might be associated with the submicron particles. Both the measured and the predicted penetration of submicron particles was on the order of $6 \%$ so any increased enrichment of the fine particles for these particles could account for the higher penetration. The measured distribution at the outlet also points to an enrichment of the fine particles for these metals. Figure 8-10 shows that for arsenic, cadmium, and phosphorus, there is a greater percentage of the metal in the finest particles.

Selenium is the one metal which cannot be explained by the performance of the ESP. If all the selenium were associated with the most difficult to collect particles, $<1 \mu \mathrm{m}$, it would have a maximum penetration of less than 7 percent. However, the measured penetration is greater than 50 percent. In addition, Figure $8-10$ shows that nearly $50 \%$ of the selenium being emitted is associated with particles greater than $10 \mu \mathrm{m}$. This points to an error in sampling and analysis because it would not be physically possible for any particulate-phase material to penetrate the ESP at a rate of 50\%, especially very large particles. Previous testing observation indicates that vapor-phase selenium may precipitate on the active sites provided by the filter in the Method 29 train under certain conditions. If this was the case at Plant Yates, the "penetration" could actually be caused by vapor-phase selenium which has been characterized as in the particulate phase. 
HAPs as a Function of Particle Size

Table 8-3

ESP Particulate-Phase Metals Collection Efficiency

ESP Inlet ESP Outlet

\begin{tabular}{|c|c|c|c|c|c|c|}
\hline Metal & $\mu \mathrm{g} / \mathrm{Nm}^{3}$ & lbs/hr & $\mu \mathrm{g} / \mathrm{Nm}^{3}$ & $\mathrm{lbs} / \mathrm{hr}$ & $(\%)$ & (\%) \\
\hline Aluminum & 870,000 & 926 & 12,100 & 12.9 & 98.60 & 1.40 \\
\hline Antimony & 33 & 0.035 & 0.39 & 0.0004 & 98.81 & 1.19 \\
\hline Arsenic & 404 & 0.43 & $\cdot 16$ & 0.017 & 96.04 & 3.96 \\
\hline Barium & 4,440 & 4.72 & 74 & 0.079 & 99.33 & 1.67 \\
\hline Beryllium & 93 & 0.10 & 1.65 & 0.002 & 98.23 & 1.77 \\
\hline Cadmium & 24 & 0.03 & 1.07 & 0.001 & 95.54 & 4.46 \\
\hline Calcium & 161,000 & 172 & 1,777 & 1.9 & 98.90 & 1.10 \\
\hline Chromium & $2,870^{\circ}$ & 3.05 & 23 & 0.024 & 99.20 & 0.80 \\
\hline Cobalt & 275 & 0.29 & 4.45 & 0.005 & 98.38 & 1.62 \\
\hline Copper & 768 & 0.82 & 16 & 0.017 & 97.92 & 2.08 \\
\hline Iron & 808,000 & 860 & 8,537 & 9.1 & 98.94 & 1.06 \\
\hline Lead & 768 & 0.82 & 18 & 0.019 & 97.66 & 2.34 \\
\hline Magnesium & 42,100 & 45 & 657 & 0.70 & 98.44 & 1.56 \\
\hline Manganese & 2,120 & 2.3 & 34 & 0.036 & 98.39 & 1.61 \\
\hline Mercury & $(1.33)^{2}$ & 0.01 & 0.13 & 0.0002 & 90.2 & 10.98 \\
\hline Molybdenum & 315 & 0.34 & 8.09 & 0.009 & 97.43 & 2.57 \\
\hline Nickel & 2,030 & 2.16 & 22 & 0.023 & 98.92 & 1.08 \\
\hline Phosphorus & 2,070 & 2.20 & 100 & 0.11 & 95.17 & 4.83 \\
\hline Potassium & 157,000 & 167 & 2,150 & 2.3 & 98.63 & 1.37 \\
\hline Selenium & 133. & 0.14 & 82 & 0.087 & 38.35 & 61.65 \\
\hline Sodium & 45,800 & 49 & 803 & 0.85 & 98.25 & 1.75 \\
\hline Strontium & 2,906 & 3.09 & 43 & 0.046 & 98.52 & 1.48 \\
\hline Titanium & 55,100 & 57 & 757 & 0.81 & 98.63 & 1.37 \\
\hline Vanadium & 2,761 & 2.9 & 54 & 0.057 & 98.04 & 1.96 \\
\hline
\end{tabular}

2 As discussed in Sections 6 and 7, the mercury concentration ESP inlet particulate sample appears to be high. The mercury concentration from the sluiced ash sample has been substituted here.

Notes:

1. Average inlet flow rate $=284,000 \mathrm{dscfm}$.

2. Average outlet flow rate $=284,000 \mathrm{dscfm}$. 


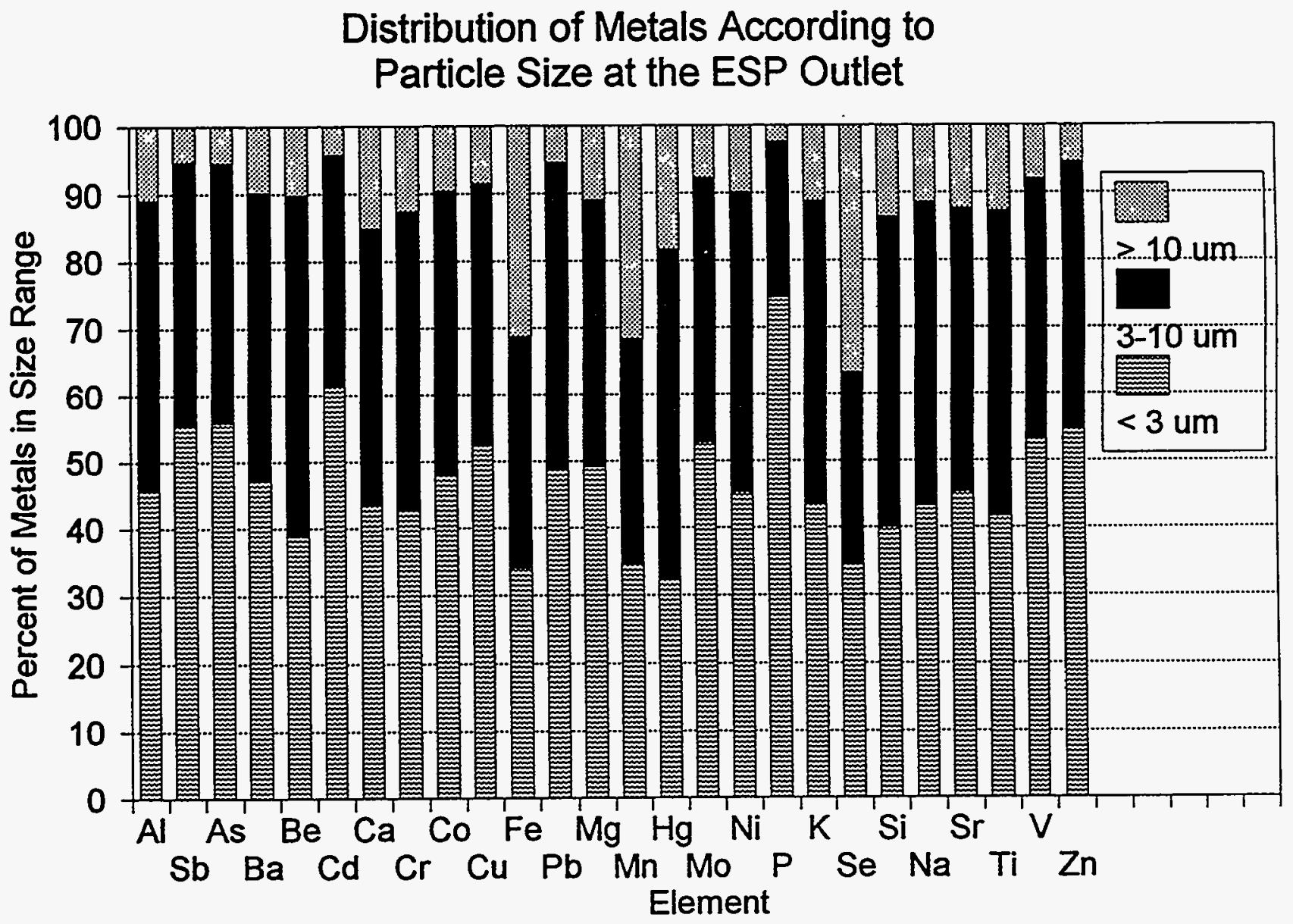

Figure 8-10

Distribution of Metals According to particle Size at the ESP Outlet 
Further confusing this issue is the fact that particulate selenium also showed up on particles collected in the cyclones. The flow in the cyclones does not provide the intimate contact between the gas and collected particles that the filter does. However, it does appear that whatever phase shift occurring in Method 29 for selenium is also occurring in the cyclones.

\section{Hopper Distribution}

The concentrations of the metals in the hopper ash were also analyzed to determine if any insight could be obtained from this information relative to the performance of the ESP and HAPs. It has been hypothesized that if the metals were concentrated in the finer particles, which are more difficult to collect, then the downstream hopper might have a higher concentration of metals. The concentrations of metals in the particulate collected in the second hopper were divided by the concentrations from the first hopper to verify this hypothesis.

These data are plotted in Figure 8-11. As shown, the metals are distributed about a ratio of 1 with most metals increasing in the downstream hopper (ratio greater than 1). This supports the hypothesis of metals concentrating in the finer particles.

Another way to visualize the interplay between elemental concentration as a function of particle size and elemental enrichment produced by the ESP is to present concentration and enrichment together. Figure 8-12 does this. The vertical scale is enrichment of elements in the particulate material from the ESP inlet to the ESP outlet. The horizontal scale is the ratio of fine particle concentration to coarse particle concentration at the ESP inlet. Note that selenium has been left off the figure. Selenium's coordinates are $(0.7,12.09)$ which puts it in the far upper left comer of the plot. This implies that selenium is enriched in the ESP outlet particulate but not in the fine fraction of the ESP inlet ash. This result is probably biased by vapor-phase selenium precipitating or reacting on the Method 29 filter as previously discussed. However, the lower selenium concentration in the finer fractions of the ESP inlet ash was also unexpected given the volatile nature of selenium.

The figure shows, with the exception of selenium, a relatively smooth relationship between the two ratios. The plot demonstrates the concept that the elements, which at the ESP inlet have higher concentrations in fine particles than in coarse particles, becomes enriched at the ESP outlet in comparison with the ESP inlet.

Table 8-4 shows enrichment of inorganic elements in the different ash streams at Plant Yates. The factors were determined by dividing the concentration of an element in an ash stream by the coal ash concentration (concentration of an element in the coal divided by the ash fraction). These data generally show the trends expected with the more volatile elements exhibiting greater enrichment ratios in the ESP outlet than in the ESP inlet. (Chloride and fluoride show very little enrichment in the ash streams since the large majority of these elements are in the vapor phase.)

Of particular note is that most elements have significantly lower enrichment ratios in the stack particulate matter than in the ESP outlet ash. Using the major species' (aluminum, 


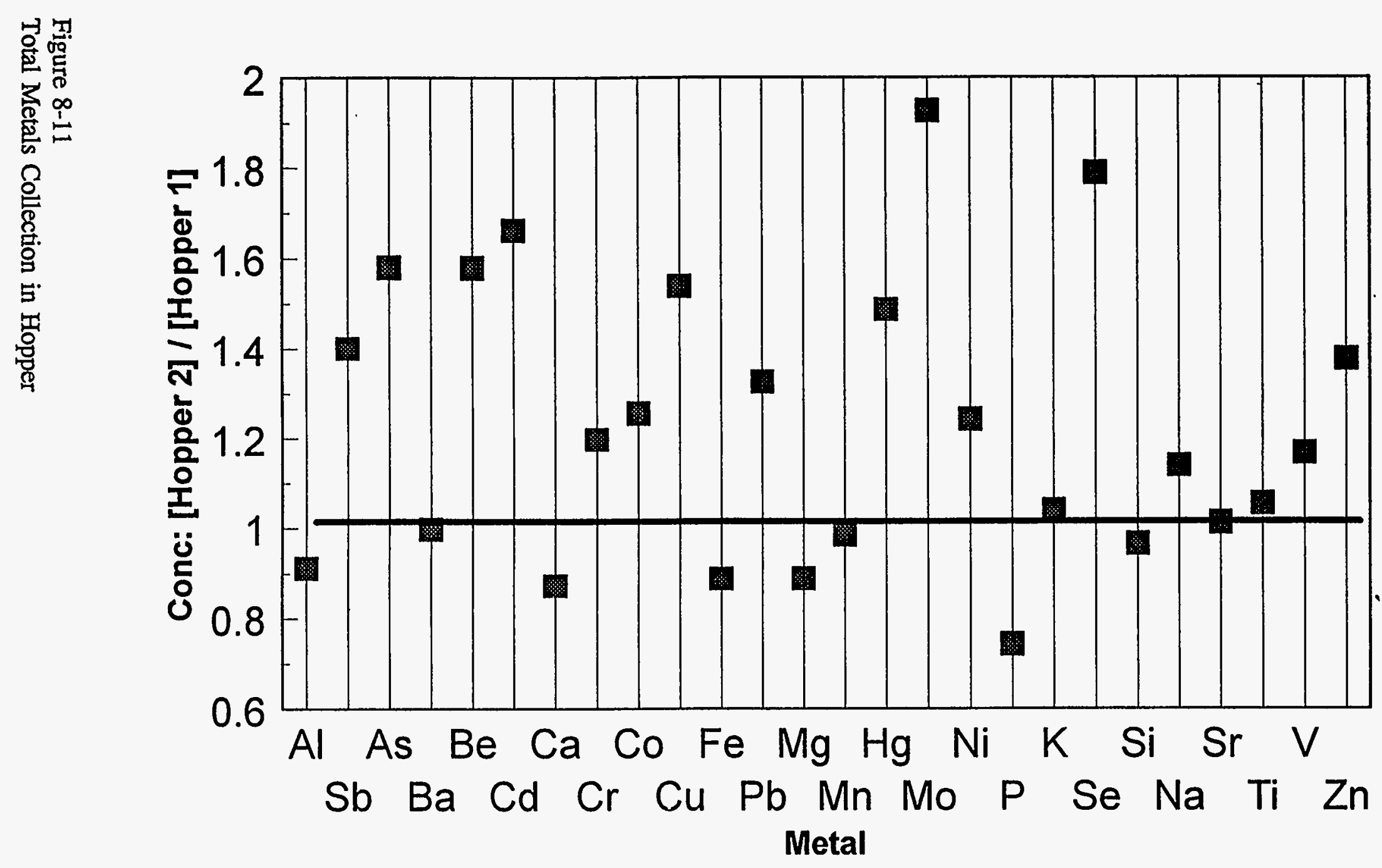




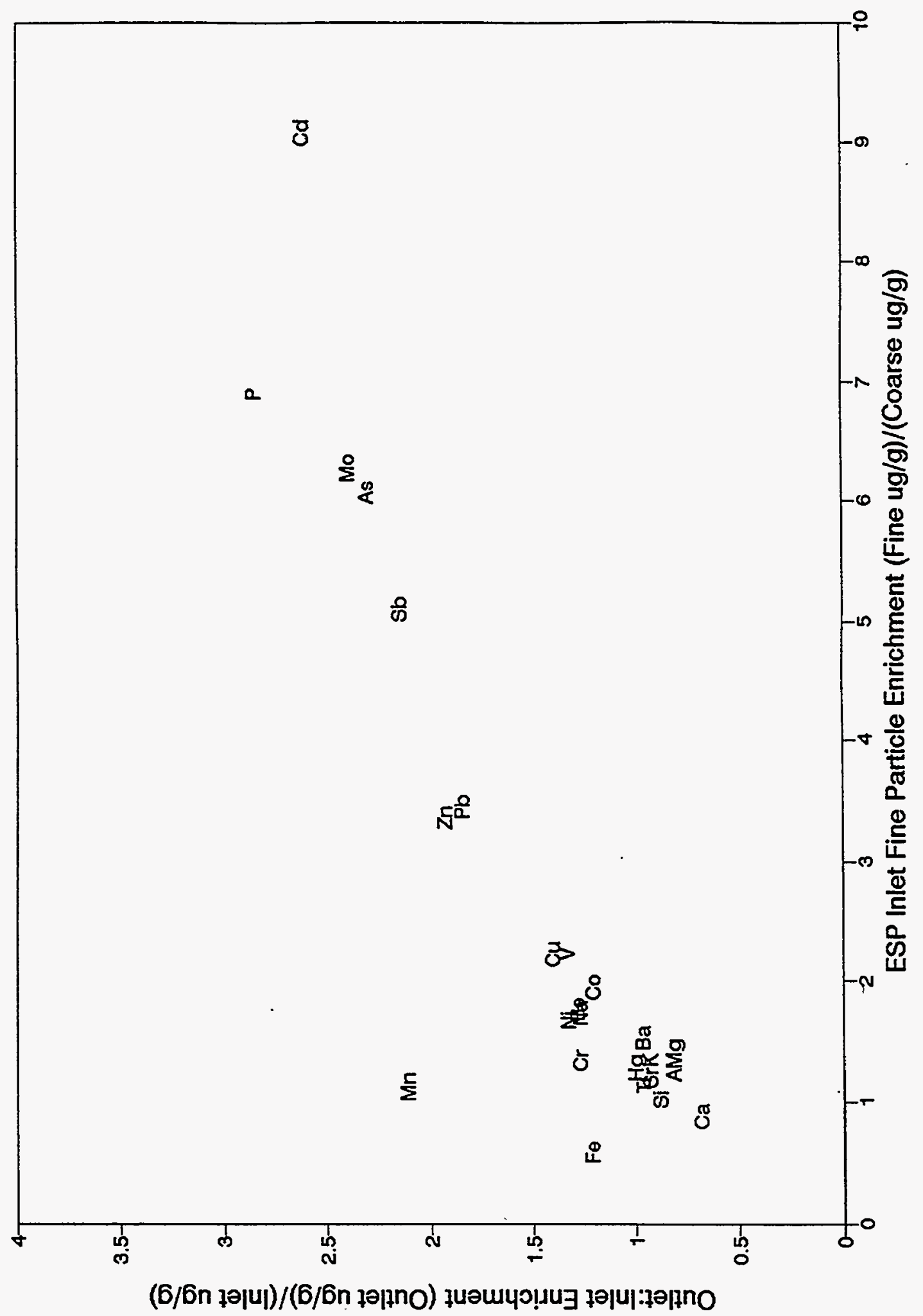

Figure 8-12

- Elemental Relationship Between Outlet/Inlet Enrichment and Fine/Coarse Enrichment 
Table 8-4

Enrichment of Streams in Inorganic Elements

\begin{tabular}{|c|c|c|c|c|c|c|c|c|c|c|c|}
\hline \multirow[b]{2}{*}{ Element } & \multirow{2}{*}{$\begin{array}{c}\text { Coal Ash } \\
(\mu \mathrm{g} / \mathrm{g})\end{array}$} & \multicolumn{2}{|c|}{ Bottom Ash } & \multicolumn{2}{|c|}{ ESP Inlet Ash } & \multicolumn{2}{|c|}{ Sluiced Ash } & \multicolumn{2}{|c|}{ ESP Outlet Ash } & \multicolumn{2}{|c|}{ Stack Particulate Matter } \\
\hline & & $(\mu \mathrm{g} / \mathrm{g})$ & Enrichment & $(\mu \mathrm{g} / \mathrm{g})$ & Enrichment & $\mu g / g$ & Enrichment & $(\mu \mathrm{g} / \mathrm{g})$ & Enrichment & $(\mu \mathrm{g} / \mathrm{g})$ & Enrichment \\
\hline Aluminum & 130,000 & 76,000 & 0.58 & 97,000 & 0.74 & 98,000 & 0.75 & 100,000 & 0.77 & 13,000 & 0.10 \\
\hline Antimony & 5.50 & 1.1 & 0.21 & 3.6 & 0.66 & 3.4 & 0.62 & 2.7 & 0.50 & 3.8 & 0.69 \\
\hline Arsenic $^{b}$ & 21.0 & 7.2 & 0.34 & 45 & 2.14 & 61 & 2.89 & 120 & 5.57 & 81 & 3.86 \\
\hline Barium & 720 & 460 & 0.63 & 490 & 0.69 & 500 & 0.69 & 620 & 0.86 & 210 & 0.30 \\
\hline Beryllium & 9.91 & 7.7 & 0.77 & 10 & 1.05 & 11 & 1.12 & 14 & 1.41 & 3 & 0.30 \\
\hline Boron & 900 & 280 & 0.31 & N/A & N/A & 470 & 0.53 & N/A & N/A & N/A & N/A \\
\hline Cadmium $^{b}$ & 2.7 & 0.32 & 0.12 & 2.7 & 0.99 & 4.1 & 1.52 & 8.9 & 3.30 & 41 & 15.17 \\
\hline Calcium & 19,000 & 20,000 & 1.05 & 18,000 & 0.94 & 14,000 & 0.71 & 15,000 & 0.77 & 19,000 & 0.97 \\
\hline Chloride $^{c}$ & 11,200 & 130 & 0.01 & 680 & 0.06 & $50^{d}$ & 0.00 & 317 & 0.03 & 15,000 & 1.34 \\
\hline Chromium $^{b}$ & 223 & 190 & 0.86 & 320 & 1.42 & 190 & 0.83 & 190 & 0.86 & 330 & 1.47 \\
\hline Cobalt & 31.6 & 32 & 1.00 & 31 & 0.98 & 37 & 1.17 & 37 & 1.17 & 19 & 0.59 \\
\hline Copper & 330 & 77 & 0.24 & 86 & 0.26 & 100 & 0.32 & 120 & 0.36 & 56 & 0.17 \\
\hline Fluoride $^{c}$ & 901 & 32 & 0.03 & 0.15 & 0.00 & 99 & 0.11 & 0.85 & 0.00 & 3.5 & 0.00 \\
\hline Iron & 100,000 & 130,000 & 1.27 & 91,000 & 0.88 & 84,000 & 0.82 & 61,000 & 0.59 & 12,000 & 0.11 \\
\hline Lead $^{b}$ & 72 & 20 & 0.28 & 79 & 1.10 & 83 & 1.15 & 150 & 2.12 & 36 & 0.50 \\
\hline Magnesium & 5,100 & 3,600 & 0.71 & 4,700 & 0.92 & 4,900 & 0.96 & 5,500 & 1.07 & 2,800 & 0.55 \\
\hline Manganese & 210 & 270 & 1.28 & 240 & 1.12 & 250 & 1.16 & 240 & 1.15 & 490 & 2.31 \\
\hline Mercury $^{c}$ & 0.72 & $0.01^{\mathrm{d}}$ & 0.01 & 0.79 & 1.10 & 0.15 & 0.20 & 0.9 & 1.25 & 0.57 & 0.79 \\
\hline Molybdenum ${ }^{6}$ & 200 & $3.0^{\mathrm{d}}$ & 0.01 & 35 & 0.17 & $7.2^{\mathrm{d}}$ & 0.04 & 58 & 0.29 & 73 & 0.36 \\
\hline Nickel $^{b}$ & 270 & 130 & 0.48 & 230 & 0.84 & 140 & 0.53 & 160 & 0.58 & 2,500 & 9.28 \\
\hline Phosphorus & 760 & 400 & 0.52 & 230 & 0.30 & 68 & 0.09 & 830 & 1.09 & 110 & 0.14 \\
\hline Potassium & 30,000 & 14,000 & 0.48 & 17,000 & 0.59 & 18,000 & 0.61 & 18,000 & 0.60 & 2,900 & 0.10 \\
\hline Selenium $^{c}$ & 21 & $0.57^{\mathrm{d}}$ & 0.03 & 15 & 0.71 & 12 & 0.57 & 570 & 27.35 & 3,500 & 166.50 \\
\hline Sodium & 5,700 & 3,600 & 0.64 & 5,100 & 0.90 & 5,100 & 0.89 & 6,700 & 1.18 & 1,900 & 0.34 \\
\hline Strontium & 670 & 280 & 0.41 & 320 & 0.48 & 320 & 0.48 & 360 & 0.53 & 110 & 0.16 \\
\hline Titanium & 8,100 & 5,600 & 0.69 & 6,100 & 0.76 & 6,300 & 0.79 & 5,400 & 0.67 & 910 & 0.11 \\
\hline Vanadium & 350 & 280 & 0.78 & 310 & 0.87 & 330 & 0.92 & 380 & 1.07 & 110 & 0.32 \\
\hline Sulfate & & 1,590 & & 8,900 & & & 3,450 & 30,000 & & 410,000 & \\
\hline
\end{tabular}

- Coal ash concentrations were calculated by using coal concentrations and dividing by the coal ash fraction.

'Denotes an element that is vaporized in the boiler and then condenses and may become enriched on fine particles. Cr \& Ni do not always show enrichment.

- Denotes an element that is vaporized and can remain in the vapor phase. Selenium can either be enriched in the fine particles or be in the gas phase.

The measured concentrations were below detection limit. Numbers shown are half of the detection limit. 
iron, magnesium, potassium, sodium, and titanium) concentrations, it appears that only about $25 \%$ of the mass in the stack particulate was fly ash. The bulk of the mass (about 65\%) can be attributed to sulfuric acid mist (based on the large increase in sulfate), while gypsum carryover accounts for about $5 \%$ and liquid chloride carryover accounts for about 3 percent. Note that these results indicate a flue gas $\mathrm{SO}_{3}$ concentration of $1-2 \mathrm{ppm}$, which is in the same low range as that measured in the flue gas in the ESP (0.3 ppm).

Elements that show enrichment in the stack particulate matter (other than calcium [from gypsum] and chloride) are selenium, nickel, manganese, chromium, and cadmium. Problems with selenium have been discussed in this section. The nickel and chromium concentrations in the stack include one high concentration which does not appear to be consistent with other ash numbers. Their enrichment ratios become much more reasonable when these values are excluded. The reason for the apparent high manganese and cadmium enrichments is not known.

\section{References}

1. M. Durham, S. Tegtmeyer, K. Yasmundt, and L. Sparks. "A Microcomputer-Based Cascade-Impactor Data-Reduction System," Third Symposium on the Transfer and Utilization of Particulate Control Technology. EPA-600/9-82-005d, 285 (July 1982).

2. R.E. Bickelhaupt and J.E. Sparks. "An Improved Model for Predicting Fly Ash Resistivity." Proceedings: EPA/EPRI Sixth Symposium on the Transfer and Utilization of Particulate Control Technology, EPRI CS-4918, p. 11-1 (November 1986).

3. R.E. Bickelhaupt. "Fly Ash Resistivity Precision Improvement with Emphasis on Sulfur Trioxide." EPA-600/7-86-010, NTIS PB 86-178126 (1986).

4. D.B. Holstein, D.E. Rugg, and M.D. Durham. "Development of an ESP Model for Dry Scrubbing Applications." EPRI Ninth Particulate Control Symposium, Williamsburg, VA (1991). 


\section{MERCURY METHODS COMPARISON AND SPECIATION DETERMINATIONS}

This section compares the results of two different methods used to determine the concentrations of total mercury and its various chemical forms in the flue gas streams. The objectives of the mercury sampling were to determine total mercury concentration and individual mercury species concentrations at each of the three flue gas sampling locations. These results will provide information on the emissions and control of mercury. In addition, the speciation results can be used to more accurately assess the possible health risks associated with mercury emissions.

Two different methods were used to measure mercury concentrations in the flue gas. The Bloom mercury speciation train ${ }^{1}$ was used to measure the concentrations of individual vaporphase mercury species: ionic mercury and elemental mercury. Total mercury, including both particulate and vapor phases, was measured using the proposed EPA Method 29 multimetals train. Although the Method 29 multi-metals train was designed to measure total concentrations of metals and not to provide speciation information, it may still provide some insight into the vapor-phase mercury species present.

\section{Sample Collection and Analysis}

This subsection describes the sampling and analytical methods used to measure mercury concentrations. The methods are described in detail in Appendix B, but the important features are discussed here. In addition, the sample collection schedule is presented.

\section{Methods and Conditions}

Bloom Speciation Train. The Bloom mercury speciation train was used to collect samples at the ESP inlet, the ESP outlet, and the stack. A quartz-lined probe was inserted into each duct, and flue gas was extracted non-isokinetically at a single point. The flue gas then passed through a series of four solid adsorbent cartridges which were used to trap the various vapor-phase mercury species. The cartridges were maintained at approximately $110^{\circ} \mathrm{C}$ in a heated jacket outside the duct. The first two cartridges contained $\mathrm{KCl}$-impregnated soda lime, which is designed to capture ionic mercury species $\left(\mathrm{Hg}^{+2}\right.$ and $\left.\mathrm{Hg}^{+}\right)$. The third and fourth cartridges contained iodated carbon, which is designed to capture elemental mercury. A glass wool plug ahead of the adsorbent cartridges prevented particulate from entering the adsorbents. This plug was not analyzed, because the single-point, nonisokinetic sampling does not provide representative particulate capture. Only vapor-phase species were determined. 
Mercury Methods Comparison and Speciation Determinations

The $\mathrm{KCl} /$ soda lime traps were dissolved in acetic acid solutions. Ionic mercury was determined by aqueous-phase ethylation, purging onto a carbotrap, cryogenic GC separation, and detection with cold vapor atomic fluorescence spectrometry (CVAFS). This method was used to quantify methyl mercury (MMHg), as methylethyl mercury, however this technique was discovered to produce artifacts (see letter from Frontier Geosciences at the end of this section) due to a reaction during the dissolution of the $\mathrm{KCl} /$ soda lime traps. All data for methyl mercury derived using this method. is considered in error and has been disregarded. Inorganic ionic mercury $\left(\mathrm{Hg}^{+2}\right)$ was determined as diethyl mercury. Elemental mercury on iodated carbon traps was determined by digesting with a mixture of $\mathrm{HNO}_{3} / \mathrm{H}_{2} \mathrm{SO}_{4}$ and $\mathrm{BrCl}$, reducing with $\mathrm{SnCl}_{2}$, purging and preconcentrating on gold, and detecting with CVAFS.

Several QA/QC procedures were used for the Bloom train. Field blanks were collected at each of the three sampling locations to assess the effects of contamination. A trip blank was also analyzed. Laboratory spikes were performed for each type of mercury species to assess analytical efficiency. In addition, the CVAFS instrument was calibrated using certified standards.

Method 29 Multi-Metals Train. The multi-metals trains were used to collect samples at the ESP inlet, the ESP outlet, and the stack. The trains used at the ESP outlet and stack were Method 5 trains, with particulate collected on a quartz filter maintained at constant temperature (approximately $250^{\circ} \mathrm{F}$ ) outside of the duct. Because of the high particulate concentrations at the ESP inlet, a Method.17 train was used, with particulate collected in an in-situ quartz thimble. At all three locations, samples were collected isokinetically while traversing the duct according to Method 1.

The impinger trains, used to collect vapor-phase metals, were identically configured at each location. The first and second impingers contained a $5 \% \mathrm{HNO}_{3} / 10 \% \mathrm{H}_{2} \mathrm{O}_{2}$ solution. The third impinger was empty, to prevent any mist carryover. The fourth and fifth impingers contained a $10 \% \mathrm{H}_{2} \mathrm{SO}_{4} / 4 \% \mathrm{KMnO}_{4}$ solution.

Particulate samples were microwave-digested in HF/aqua regia solutions and analyzed for all target metals. Mercury concentrations were determined using cold vapor atomic absorption spectrometry (CVAAS). The $\mathrm{HNO}_{3} / \mathrm{H}_{2} \mathrm{O}_{2}$ solutions were also analyzed for all target metals, with the mercury determined by CVAAS. The $\mathrm{H}_{2} \mathrm{SO}_{4} / \mathrm{KMnO}_{4}$ solutions were analyzed only for mercury using CVAAS.

The multi-metals train may provide information on mercury speciation. Ionic forms of mercury are water-soluble and should be readily captured in the $\mathrm{HNO}_{3} / \mathrm{H}_{2} \mathrm{O}_{2}$ solution. Elemental mercury, on the other hand, should pass through the $\mathrm{HNO}_{3} / \mathrm{H}_{2} \mathrm{O}_{2}$ impingers, because the solubility of elemental mercury in aqueous solutions is very low and the $\mathrm{H}_{2} \mathrm{O}_{2}$ cannot efficiently oxidize it. The elemental mercury will be oxidized and captured in the $\mathrm{H}_{2} \mathrm{SO}_{4} / \mathrm{KMnO}_{4}$ impingers.

Several QA/QC procedures were followed for the multi-metals trains. Field blanks, reagent blanks, and method blanks were analyzed to assess the effects of contamination. Matrixspiked and matrix-spiked duplicate samples were analyzed to assess recovery and precision. 
Mercury Methods Comparison and Speciation Determinations

The CVAAS instruments were calibrated using certified standards, and calibration checks were routinely performed.

\section{Samples Collected}

Figure 3-2 shows the collection schedule for the Bloom train and multi-metals train samples. Three samples were collected for each train type at each of the three sampling locations. Gas sample volumes were approximately $0.1 \mathrm{Nm}^{3}$ for the Bloom train and $3 \mathrm{Nm}^{3}$ for the multi-metals train. Field data sheet summaries are included in Appendix C.

\section{Data Analysis}

Table 9-1 shows the mercury concentrations measured with the Bloom train and the Method 29 multi-metals train. The total vapor-phase mercury concentrations measured using the two techniques are in good agreement. Using the mean multi-metals train results, it appears that approximately $99 \%$ of the particulate-phase mercury is removed by the ESP, and the removal of total mercury by the scrubber is approximately $46 \%$.

The speciation results from the two methods show similar trends. Ionic mercury is the predominant species in the ESP inlet and ESP outlet gas streams, but the ionic mercury is more efficiently removed by the scrubber, as shown by its markedly lower concentrations at the stack. The removal of ionic mercury by the scrubber can be attributed to a higher solubility in water as compared to elemental mercury.

While the overall trends in the two methods are similar, the detailed speciation results do not appear equivalent. In particular, the levels of elemental mercury measured by the two techniques do not agree well at any of the three locations, and the agreement is poor between the two techniques for ionic mercury concentrations at the stack.

Table 9-2 shows the mercury concentrations found in the blank samples and their significance relative to the actual sample concentrations. Blank contamination does not appear to be significant. Table 9-3 summarized the spike recoveries for the two techniques. All of the recoveries were within the acceptable range of 75 to 125 percent. While the QA/QC results for the two techniques indicate acceptable quality, they only address the issues of contamination and analytical accuracy. The issue of species conversion during sampling has not been addressed. Therefore, while each method can be considered to give reliable results for the total concentration of vapor-phase mercury, less confidence can be placed in the speciation results. The possibility of conversion of one species to another within the sampling equipment or in the sampling media make it less certain that the species were actually present in the flue gas at the measured levels. 
Mercury. Methods Comparison and Speciation Determinations

Table 9-1

Mercury Concentrations in Flue Gas

Concentrations, $\mu \mathrm{g} / \mathrm{Nm}^{3}$

\begin{tabular}{|c|c|c|c|c|c|c|c|}
\hline \multirow[b]{2}{*}{ Location } & \multirow[b]{2}{*}{ Component } & \multicolumn{5}{|c|}{ Concentrations, $\mu \mathrm{g} / \mathrm{Nm}^{3}$} & \multirow{2}{*}{$\begin{array}{l}\% \text { of } \\
\text { Vapor }\end{array}$} \\
\hline & & Run 1 & Run 2 & Run 3 & Mean & $95 \% \mathrm{CI}$ & \\
\hline \multicolumn{8}{|c|}{ Bloom Hg Speciation Train } \\
\hline ESP. Inlet & $\begin{array}{l}\text { Tonic } \mathrm{Hg} \\
\text { Elemental Hg } \\
\text { Total Vapor }\end{array}$ & $\begin{array}{l}4.5 \\
2.4 \\
6.9\end{array}$ & $\begin{array}{l}3.8 \\
2.4 \\
6.2\end{array}$ & $\begin{array}{l}5.0 \\
1.2 \\
6.2\end{array}$ & $\begin{array}{l}4.4 \\
2.0 \\
6.4\end{array}$ & $\begin{array}{l}1.5 \\
1.7 \\
1.0\end{array}$ & $\begin{array}{r}69 \\
31 \\
-\end{array}$ \\
\hline ESP Outlet & $\begin{array}{l}\text { Ionic Hg } \\
\text { Elemental Hg } \\
\text { Total Vapor }\end{array}$ & $\begin{array}{l}5.8 \\
2.5 \\
8.3\end{array}$ & $\begin{array}{l}4.6 \\
2.6 \\
7.2\end{array}$ & $\begin{array}{l}4.0 \\
2.4 \\
6.4\end{array}$ & $\begin{array}{l}4.8 \\
2.5 \\
7.3\end{array}$ & $\begin{array}{l}2.3 \\
0.2 \\
2.4\end{array}$ & $\begin{array}{r}66 \\
34 \\
-\end{array}$ \\
\hline Stack & $\begin{array}{l}\text { Ionic } \mathrm{Hg} \\
\text { Elemental Hg } \\
\text { Total Vapor }\end{array}$ & $\begin{array}{r}0.38 \\
3.0 \\
3.4\end{array}$ & $\begin{array}{r}0.51 \\
3.1 \\
3.6\end{array}$ & $\begin{array}{r}0.63 \\
2.3 \\
2.9\end{array}$ & $\begin{array}{r}0.47 \\
2.8 \\
3.3\end{array}$ & $\begin{array}{r}0.33 \\
1.1 \\
0.9\end{array}$ & $\begin{array}{r}15 \\
85 \\
-\end{array}$ \\
\hline \multicolumn{8}{|c|}{ Method 29 Multi-Metals Train } \\
\hline ESP Inlet & $\begin{array}{l}\text { Ionic } \mathrm{Hg}^{\mathrm{b}} \\
\text { Elemental } \mathrm{Hg}^{\mathrm{c}} \\
\text { Total Vapor } \\
\text { Solid } \\
\text { Total Vapor + Solid }\end{array}$ & $\begin{array}{r}4.6 \\
0.51 \\
5.1 \\
5.2 \\
10.3\end{array}$ & $\begin{array}{r}4.9 \\
0.31 \\
5.3 \\
9.6 \\
14.8\end{array}$ & $\begin{array}{r}5.7 \\
0.23 \\
6.0 \\
6.4 \\
12.4\end{array}$ & $\begin{array}{r}5.1 \\
0.35 \\
5.4 \\
.7 .1 \\
12.5\end{array}$ & $\begin{array}{r}1.5 \\
0.36 \\
1.2 \\
5.6 \\
5.6\end{array}$ & $\begin{array}{r}94 \\
6 \\
- \\
- \\
-\end{array}$ \\
\hline ESP Outlet & $\begin{array}{l}\text { Ionic Hg } \\
\text { Elemental Hg } \\
\text { Total Vapor } \\
\text { Solid } \\
\text { Total Vapor + Solid }\end{array}$ & $\begin{array}{r}4.8 \\
1.2 \\
6.0 \\
0.11 \\
6.1\end{array}$ & $\begin{array}{r}4.1 \\
1.1 \\
5.2 \\
0.12 \\
5.3\end{array}$ & $\begin{array}{r}4.9 \\
0.65 \\
5.5 \\
0.14 \\
5.7\end{array}$ & $\begin{array}{r}4.6 \\
0.98 \\
5.6 \\
0.13 \\
5.7\end{array}$ & $\begin{array}{r}1.1 \\
0.73 \\
1.1 \\
0.04 \\
1.1\end{array}$ & $\begin{array}{l}82 \\
18 \\
- \\
- \\
-\end{array}$ \\
\hline Stack & $\begin{array}{l}\text { Ionic } \mathrm{Hg} \\
\text { Elemental } \mathrm{Hg} \\
\text { Total Vapor } \\
\text { Solid } \\
\text { Total Vapor + Solid }\end{array}$ & $\begin{array}{r}1.1 \\
1.8 \\
2.9 \\
<0.0050 \\
2.9\end{array}$ & $\begin{array}{r}1.5 \\
1.6 \\
3.1 \\
0.0116 \\
3.1\end{array}$ & $\begin{array}{r}1.9 \\
1.2 \\
3.1 \\
<0.0051 \\
3.1\end{array}$ & $\begin{array}{r}1.5 \\
1.5 \\
3.0 \\
0.0056 \\
3.0\end{array}$ & $\begin{array}{r}0.9 \\
0.7 \\
0.3 \\
0.013 \\
0.3\end{array}$ & $\begin{array}{l}50 \\
50 \\
- \\
- \\
-\end{array}$ \\
\hline
\end{tabular}

- Although MMHg values were originally reported by Frontier Geosciences, a letter from Frontier Geosciences was issued on January 26, 1994 stating, in part, "... we now know that the MMHg we were measuring and reporting is due to an artifact. [this method] ... overestimates the amount of $\mathrm{MMHg}$. The MMHg fraction should tentatively be considered as part of the $\mathrm{Hg}$ (II) fraction of the total $\mathrm{Hg}$ in flue gas until our ongoing investigations are completed." These investigations are still in progress and, until they are completed, the presence or absence of $\mathrm{MMHg}$ in the flue gas cannot be confirmed.

${ }^{b}$ Mercury collected in the $\mathrm{HNO}_{3} / \mathrm{H}_{2} \mathrm{O}_{2}$ impingers.

c Mercury collected in the $\mathrm{H}_{2} \mathrm{SO}_{4} / \mathrm{KMnO}_{4}$ impingers. 
Table 9-2

Summary of Blank Results

\begin{tabular}{llcc} 
Blank Sample Type & $\begin{array}{l}\text { No. of } \\
\text { Blanks }\end{array}$ & $\begin{array}{c}\text { Range of } \\
\text { Blank Levels }\end{array}$ & $\begin{array}{c}\text { Max Contribution } \\
\text { to Samples }\end{array}$ \\
\hline
\end{tabular}

Bloom Train

Ionic $\mathrm{Hg}$

Field Blanks

Trip Blanks

6

2

$0.3-0.6 \mathrm{ng}$

$4 \%$

$0.5-0.8 \mathrm{ng}$

$4 \%$

Elemental $\mathrm{Hg}$

Field Blanks

Trip Blanks

6

1.3-4.6 ng

$4 \%$

$2 \quad 1.1-3.7 \mathrm{ng}$

$3 \%$

Method 29 Multi-Metals Train

$\mathrm{HNO}_{3} / \mathrm{H}_{2} \mathrm{O}_{2}$ Impingers

Field Blanks

Reagent Blanks

$<0.24 \mu \mathrm{g} / \mathrm{L}$
$<0.24 \mu \mathrm{g} / \mathrm{L}$

$<5 \%$

1

$<5 \%$

$\mathrm{H}_{2} \mathrm{SO}_{4} / \mathrm{KMnO}_{4}$ Impingers

Field Blanks

Reagent Blanks

$\begin{array}{lll}3 & <0.24 \mu \mathrm{g} / \mathrm{L} & <28 \% \\ 1 & <0.24 \mu \mathrm{g} / \mathrm{L} & <28 \%\end{array}$

" Maximum blank value as a percentage of the minimum sample result. 
Mercury Methods Comparison and Speciation Determinations

Table 9-3

Summary of Spike and Audit Sample Recoveries

\begin{tabular}{lcc} 
Sample Type & No. of Samples & Range of Recoveries \\
\hline Bloom Train & & \\
Ionic $\mathrm{Hg}$ & 2 & $102-103 \%$ \\
Elemental Hg & 2 & $100-102 \%$ \\
Method $29 \mathrm{Multi}-$ Metals Train & & $120 \%$ \\
$\mathrm{HNO}_{3} / \mathrm{H}_{2} \mathrm{O}_{2}$ Impingers & 2 & $76-78 \%$ \\
$\mathrm{H}_{2} \mathrm{SO}_{4} / \mathrm{KMnO}_{4}$ Impingers & 2 &
\end{tabular}


The Bloom train is a technique that is still being developed. ${ }^{2}$ Extensive work has been done to improve the capture efficiency of the traps, to increase the analytical efficiency, and to minimize the chance for species conversion. There are no studies that would conclusively demonstrate the validity of the method, such as the spiking of specific mercury compounds into the flue gas ahead of the sampling train. Therefore, the method can be considered unproven.

There is no published information regarding the ability of the multi-metals train to provide mercury speciation information from utility stack gases. The interpretation of the results thus far relies solely on chemical theory. In addition, the extent of species conversion within the train is unknown.

\section{References}

1. Nicolas S. Bloom, Eric M. Prestbo, and Vesna L. Miklavicic, "Fluegas Mercury Emissions and Speciations from Fossil Fuel Combustion." Published in the proceedings of the Second International Conference on Managing Hazardous Air Pollutants (sponsored by the Electric Power Research Institute) Washington, D.C. (July 1993).

2. Ibid. 


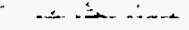




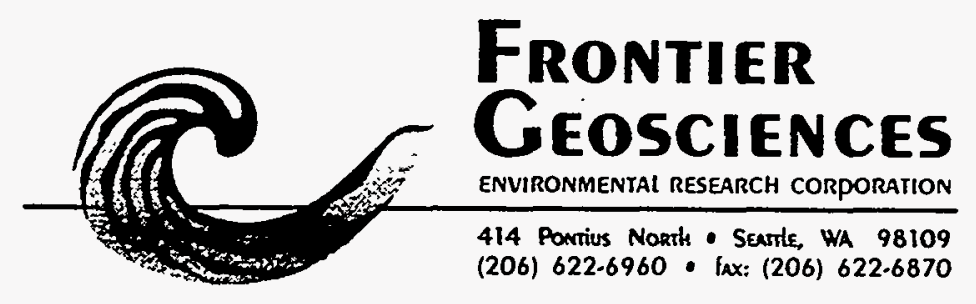

January 26, 1994

Eric M. Prestbo and Nicolas S Bloom

\section{Discovery of Methyl Mercury Artifact in the Solid Sorbent Speciation (S 3 ) method for Coal Combustion Fluegas}

We have stated in both reports and presentations (Prestbo and Bloom, 1993, Bloom et al., 1993) that monomethyl mercury $(\mathrm{MMHg})$ can be measured and is found in coal combustion flue gas in the range of $5-15 \%$ of the total $\mathrm{Hg}$. Because of very recent experiments we have completed in the laboratory, we now know that the MMHg we were measuring and reporting is due to an artifact. Only through painstaking laboratory work were we able to discover the unusual chemical reactions which produce $\mathrm{MMHg}$ in solution. We discovered that $\mathrm{Hg}(\mathrm{II})$ and S(IV) collected on the $\mathrm{KCl} /$ soda lime sorbent, when digested in $10 \%$ acetic acid solution will form $\mathrm{MMHg}$ on the high $\mathrm{pH}$ surface of the dissolving soda lime. The likely mechanism leading to this can be found (in retrospect) in a paper by Lee and Rochelle (1987). This finding was quite surprising considering that $\mathrm{SO}_{2}$ is known to be a reducing and not an oxidizing compound. The $\mathrm{MMHg}$ forms due to the release of methyl groups during the degradation of acetic acid in conjunction with the oxidation of $\mathrm{SO}_{3}=$.

What we can state convincingly is that all previous flue gas data generated by our laboratory overestimates the amount of $\mathrm{MMHg}$. The $\mathrm{MMHg}$ fraction should tentatively be considered as part of the $\mathrm{Hg}(\mathrm{II})$ fraction of the total $\mathrm{Hg}$ in fluegas until our ongoing investigations are completed. It should also be clearly stated that although the $\mathrm{MMHg}$ values are no longer valid, this is not true for $\mathrm{Hg}(\mathrm{II}), \mathrm{HgO}$ and especially total $\mathrm{Hg}$. Further, please refrain from stating that $\mathrm{MMHg}$ is not present in fluegas until we have a chance to complete some field site studies using a refined methodology.

We are actively pursuing the problem encountered. Iititialiy we will investigate non-methyl containing solutions (i.e. citric acid) for dissolving $\mathrm{KCl} /$ soda lime to avoid the artifact. Secondly, we will use several other means of collecting flue gas, including unique impinger solutions to more conclusively determine the presence or absence of $\mathrm{MMHg}$ in combustion flue gas.

As you know, speciation of trace metals, and especially mercury is difficult in any matrix. We regret that previous $\mathrm{MMHg}$ fluegas data was in error. We will continue to communicate to you any of our new findings as we have with this one.

Please don 't hesitate to call us if you have any questions or need further clarification on this issue. 


\section{References}

Bloom N.S., Prestbo E.M. and Miklavcic V.L. (1993) "Fluegas mercury emissions and speciation from fossil fuel combustion", presented at Conference on Managing Air Toxics: State of the Art, Washington D.C. July 13-15 (withdrawn from publication).

Lee Y.J. and Rochelle G.T. (1987) "Oxidative degradation of organic acid conjugated with sulfite oxidation in flue gas desulfurization: products, kinetics, and mechanism", Env. Sci. and Technol., 21:266.

Prestbo E.M. and Bloom N.S. (1993) "Recent advances in the measurement of mercury species in combustion flue gas using solid phase adsorption and cold vapor atomic fluorescence spectroscopy (CVAFS)", Presented at the AWMA 86th Annual Meeting, June 13-18, (93-TA-32.05). 


\section{0}

\section{HEXAVALENT CHROMIUM DETERMINATIONS}

\section{Introduction}

The stack gas at Plant Yates was sampled for the presence of hexavalent chromium and total chromium. Hexavalent chromium samples were analyzed on site at Plant Yates in order to provide results as quickly as possible. Radian's experience has shown that hexavalent chromium is unstable and is reduced to trivalent chromium quite rapidly during the first 24 hours after sample collection. Appropriate blanks were analyzed to minimize the possibility that any contamination would go undetected.

\section{Sample Collection and Analysis}

Hexavalent chromium samples were collected on June 25, 26, and 27, 1993. Samples were collected and analyzed using EPA's recirculating caustic solution method. ${ }^{1}$ This method uses a recirculating probe system that mixes the total gas sample (vapor and particulate) with the caustic impinger solution immediately after the sample nozzle. This provides a high $\mathrm{pH}$ environment to minimize the reduction of $\mathrm{Cr}^{6+}$. Analysis was performed on site using an ion chromatograph. However, instrument problems were encountered and no useful data could be obtained.

As a result, the samples were returned to Radian's laboratory in Austin and analyzed for hexavalent chromium as well as total chromium. In addition, QA/QC samples were analyzed as follows:

- One matrix spike;

- One performance audit sample;

- Three field blanks; and

- One trip blank (total chromium only).

Although the hexavalent sample collection method was used as specified in the published method, it should be noted that the collection procedure for obtaining $\mathrm{Cr}^{6+}$ samples from a flue gas matrix containing $\mathrm{SO}_{2}$ has not been validated. 
Hexavalent Chromium Determinations

\section{Data Analysis}

As shown in Table 10-1, hexavalent chromium and total chromium were nondetectable in the samples collected after appropriate blank correction had been applied.

Table 10-1

Results for Hexavalent Chromium and Total Chromium

\begin{tabular}{llllll}
\multicolumn{1}{c}{ Specie } & Units & Run 1 & Run 2 & Run 3 & Average \\
\hline Chromium VI & $\mu \mathrm{g} / \mathrm{Nm}^{3}$ & $<0.18 \mathrm{C}$ & $<0.19 \mathrm{C}$ & $<0.20 \mathrm{C}$ & $<0.190$ \\
Total Chromium & $\mu \mathrm{g} / \mathrm{Nm}^{3}$ & $<0.52 \mathrm{C}$ & $<0.57 \mathrm{C}$ & $<0.59 \mathrm{C}$ & $<0.560$
\end{tabular}

$C=$ Data flag; value was blank-corrected below the detection limit.

Experience has shown that measurement of hexavalent chromium can be very difficult in electric utility flue gas. A brief discussion of the technical implications of determination of chromium (VI) in stack gas and, in particular, in combustion sources and utility sources is included here.

The $\mathrm{Cr}(\mathrm{VI})$ method depends on the solubility and stability of chromium (VI) in basic aqueous solution. The method calls for the use of a strong base in a solution contained in the impingers and recycled to the probe tip for early gas contact and flushing to the probe walls. The method is theoretically sound but has some limitations when applied to combustion sources in general and utility flue gases specifically.

As mentioned above, $\mathrm{Cr}(\mathrm{VI})$ is stable in a strong alkaline solution $(\mathrm{pH}>\sim 9)$. But all combustion gas streams contain large amounts of $\mathrm{CO}_{2}(10-20 \%)$, which is an acid gas, and serves to lower the $\mathrm{pH}$ of the impinger solution. As a result, the $\mathrm{pH}$ may dip lower than desirable during sampling, or the solution must be more alkaline then specified in the method or continually monitored. As a further complication, utility flue gas contains significant levels of $\mathrm{SO}_{2}$ (100 ppm or more). $\mathrm{SO}_{2}$ is also an acid gas but is a reductant as well. So the impinger solution designed to absorb $\mathrm{Cr}(\mathrm{VI})$ also absorbs $\mathrm{CO}_{2}$ and $\mathrm{SO}_{2}$. The result of this is a lowered $\mathrm{pH}$ and a solution which contains an oxidant $[\mathrm{Cr}(\mathrm{VI})]$ and a reductant $\left(\mathrm{SO}_{2} / \mathrm{HSO}_{3}{ }^{-}\right)$. As the $\mathrm{pH}$ falls, the redox couple becomes more favorable, and any $\mathrm{Cr}(\mathrm{VI})$ present may be reduced by $\mathrm{SO}_{2} / \mathrm{HSO}_{3}^{-}$and not detected as $\mathrm{Cr}(\mathrm{VI})$.

\section{References}

1. 40 CFR 266, Subpart H, Appendix IX, "Methods Manual for Compliance with the BIF Regulations," Section 3.0, "Sampling and Analytical Methods," Subsection 3.2, "Determination of Hexavalent Chromium Emissions from Stationary Sources (Method $\mathrm{Cr}^{6+}$ )," 7-1-91 edition. 


\section{1}

\section{DETERMINATIONS OF TOXICS ON PARTICLE SURFACES}

The Clean Air Act Amendments of 1990 (CAAA) require that emissions of hazardous air pollutants (HAPs) from coal-fired power plants be evaluated for potential health risks. The 189 hazardous substances listed in the CAAA include numerous inorganic and organic species that remain volatile under the conditions present in flue gas emission control systems at coal-fired power plants. As the flue gas cools downstream of these control devices and is released into the atmosphere, it is hypothesized that many of these substances condense on the surface of the fine particulate matter not removed by the control device.

Fine-particulate emissions in the respirable size range of less than 10 microns are of particular interest in assessing health risks. The environmental and toxicological impacts resulting from these emissions are typically estimated on a "worst case" basis where the total composition of the emitted particles is considered available to biological and ecological systems. The condensed metal species found predominantly on the surface of fly ash particles are more accessible to the environment than those species trapped in the aluminasilica fly ash matrix. More appropriately, the leachability of these toxic substances and their availability relative to the total composition should be considered when assessing the health risks associated with particulate-borne HAPs.

Radian Corporation, under contract with the United States Department of Energy (DOE Contract No. DE-AC22-92PC90367), is conducting a separate test program to collect and analyze size-fractionated stack gas particulate samples for numerous inorganic HAPs. Specific goals of the program include collecting gram quantities of size-fractionated stack gas particulate matter (after a wet scrubber) and determining the relationship between particle size, bulk composition, and extractable (surface-leachable) composition.

At Plant Yates, extractable metal concentrations were determined on bulk, rather than sizefractionated samples of flue gas particulate matter. But in addition to sampling the gas from the JBR-FGD system, samples were also collected from the ESP inlet and outlet. From the data collected, the relationship between extractable metal emissions from both wet and dry particulate control devices is possible.

This section compares the analytical results for bulk composition and surface leachability of metals in flue gas particulate samples collected from the inlet and outlet of the ESP and from the outlet of the JBR-FGD system. Metal concentrations are reported for arsenic, barium, beryllium, cadmium, chromium, copper, cobalt, lead, manganese, molybdenum, nickel, selenium, and vanadium. 


\section{Sample Collection and Analysis}

The difficulty in characterizing surface species is that there are currently no standard, certified methods documented for determining the leachability of metals from the surface of micron-sized particles. In a previous study, several leaching agents and analytical techniques were applied to standard reference fly ash samples for evaluation; three were selected for use on the entrained fly ash samples collected during this project. The techniques selected for characterizing surface availability involve acid leaching and digestion of the particulate samples followed by inductively coupled plasma-mass spectrometry (ICP-MS) analysis. For comparison, the total composition was derived from the metals analysis of the size-fractionated particulate matter at the ESP inlet and outlet, and from the analysis of the stack gas multimetals train filter samples.

\section{Sample Collection}

Sample collection at the ESP inlet was performed according to EPA Reference Method $17^{1}$ (in-stack filtration). Quartz-fiber thimble filters were specified to handle the high particulate mass loading encountered upstream of the ESP and to reduce the background levels of trace elements associated with glass-fiber filters. To avoid introducing filter media into the sample and providing blank analyses for background corrections, sample material was recovered directly from the thimble filters and prepared for analysis.

EPA Reference Method $5^{2}$ was used to collect particulate matter from the ESP outlet and stack gas streams. Quartz-fiber filters were also specified; however, due to mis-identification, glass-fiber filters were inadvertently used on all extractable metals test runs at the ESP outlet and on Runs 1 and 3 at the stack location. Enough sample mass was collected on the ESP outlet filters to permit ash sample separation from the filter media; however, the small sample mass collected on the stack gas filters precluded this separation.

\section{Sample Preparation and Analysis}

Sample material recovered from the filters was split in 0.1 gram portions and prepared by the techniques described in Figure 11-1. Stack gas filters were split into three roughly equal fractions and weighed to determine each segment's percentage of the total filter mass. The particulate sample mass on each fraction was determined by multiplying this percentage by the filter weight gain representing the total sample mass. Uniform distribution of the sample mass and the mass of the filter media is assumed. Glass-fiber filter blanks were not prepared for analysis; however, a blank quartz-fiber filter was prepared and analyzed to assess the background levels of extractable metals specific to the quartz-fiber media.

An overview of the sample preparation and analysis techniques selected for the size-fractionated particulate samples is presented in Figure 11-1. Analysis of nitric acid digestates was used to represent the highest degree of surface availability for metals not bound in the alumina-silica fly ash matrix. A simulated gastric fluid and an acetic acid buffer solution were selected to extract metals representative of ingestion and ground water leaching mechanisms, respectively. ICP-MS was selected as the analytical technique over atomic 


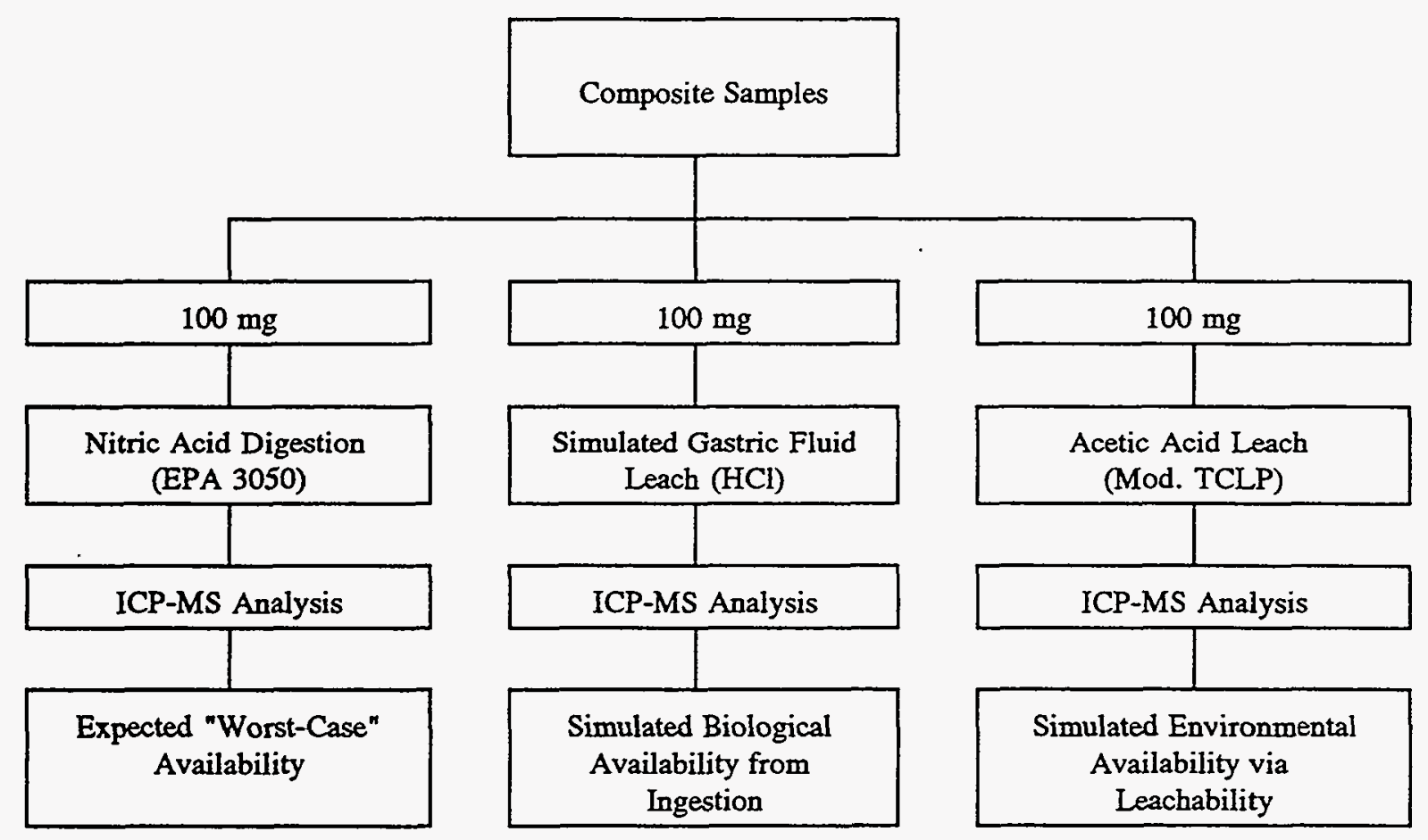

Figure 11-1

Gas Particulate Sample Preparation and Analysis Plan for Extractable Metals 
emission and graphite furnace-atomic absorption spectrophotometry since these spectrophotometric techniques failed to provide the sensitivity required to accurately detect the target elements in the low concentration ranges expected.

Total Composition. Total composition analyses were performed on both the size-fractionated particulate samples, and on the filtered particulate matter collected with the multi-metals sampling train. Reported sample results were generated by ICP-AES and GFAA analyses in most cases; ICP-MS results were selected where elemental concentrations were below ICPAES and GFAA detection limits. High background corrections, attributed to the inadvertent use of glass-fiber filters in some of the multi-metals trains invalidated many trace element results.

Therefore, the total composition of the fly ash collected from the ESP inlet and outlet ducts is represented by a composite of the size-fractionated particulate results. This substitution provided triplicate values for determining the average bulk composition for all trace elements. The resulting averages were biased universally low in these cases, so composition data from the multi-metals trains was not used. The exception is at the stack where two of the three filters used in the multi-metals train were quartz fiber, and no other metals composition data were available. The mass collected in each size fraction was determined relative to the sum, and then factored into the sum of the trace element concentrations. As a confirmation of the validity of this approach, the relative percent difference between the calculated values and the results obtained for fly ash collected from quartz-fiber filters was less than $30 \%$ for all elements except antimony, and selenium.

Nitric Acid Digestion. The strongest, most aggressive sample leaching technique performed on each particulate sample was a nitric acid digestion using EPA Method 3050. This procedure refluxes the sample in concentrated nitric acid and hydrogen peroxide. Metals present on the surface of the particle and those that may be loosely bound in the particle's matrix are digested. This technique does not totally digest the alumina-silica ash matrix and therefore may not account for some metals detected by total composition techniques.

All particulate samples were prepared by this method. Samples were digested, filtered through a 0.45 micron nitrocellulose membrane filter, and brought to a $100 \mathrm{~mL}$ final volume. Prior to analysis by ICP-MS, 1:20 dilutions were made to bring the sample into the linear range of the mass detector. To assess potential matrix interferences, one of the samples was selected as the source for a matrix spike. The sample selected was split to provide a sample for spiking, and the remaining sample was identified for duplicate analysis. The spike was prepared using a SPEX ${ }^{\otimes}$ multi-element ICP-MS calibration solution. Spike levels in the analyzed digestate were $50 \mathrm{ppb}$ for all elements except molybdenum, which was not present in the calibration solution. This spiking level was based on previous results obtained from this procedure applied to standard reference fly ash samples.

Simulated Gastric Fluid Leach. Simulated gastric fluid is a solution of $85 \mathrm{mM}$ hydrochloric acid, the enzyme pepsin, and sodium chloride. The $\mathrm{pH}$ of this solution is approximately 1.2. The leachability of metals in this matrix has a toxicological implication since some fly ash particles trapped in the mucous lining of the upper respiratory tract may be swallowed. 
The dissolution of fly ash in gastric fluid represents a likely ingestion mechanism for toxic metals into the body.

Particulate samples were placed in a covered beaker with $10 \mathrm{~mL}$ of the gastric fluid solution and stirred mechanically for a minimum of 18 hours at room temperature. Using the same recovery procedure as the nitric acid digestates, the leachate was filtered and brought to a $100 \mathrm{~mL}$ final volume with DI water. Undiluted aliquots were analyzed by ICP-MS. In addition, a matrix spike was prepared, and the sample selected for spiking was identified for duplicate analysis. Gastric fluid matrix spikes were also prepared using the SPEX ${ }^{\circledR}$ ICP-MS calibrating solution and were prepared at $69 \mathrm{ppb}$ for each of the target analytes except molybdenum. This spiking level was based on previous results obtained from this procedure applied to standard reference fly ash samples.

Because chloride ions pose adverse matrix effects for a number of the target elements analyzed by ICP-MS, calibration standards were prepared from the gastric fluid matrix to provide calibration curves with the same potential bias present in the samples. Arsenic is one of the key elements that is susceptible to mass detection interferences. Argon and chlorine, with atomic weights of 39.95 and 35.45 , respectively, tend to form the polyatomic $\mathrm{ArCl}^{+}$ion with a mass of $75.4 \mathrm{amu}$. The high chloride levels in the gastric fluid, coupled with argon plasma source, generate a signal from $\mathrm{ArCl}^{+}$that can overwhelm the arsenic signal at $74.9 \mathrm{amu}$.

Acetic Acid Leach. The weakest of the three leaching solutions is an acetic acid solution prepared according to the EPA's Toxicity Characteristic Leaching Procedure ${ }^{3}$ (TCLP). The TCLP is the regulatory standard procedure used to determine the hazardous nature of solid wastes. The protocol requires leaching of the solid waste in a buffered acetic acid solution that is maintained at a $\mathrm{pH}$ of 4.93 throughout the test. The metal concentrations determined in the acetic acid leachate are compared to regulatory standards to determine whether the material is classified as hazardous or nonhazardous.

The TCLP is designed for leaching sample quantities much larger than $100 \mathrm{mg}$, and to scale down the volumes specified in the method to accommodate the small quantity of particulate sample available was impracticable. Alternatively, $100 \mathrm{mg}$ particulate samples were placed in a covered beaker with $10 \mathrm{~mL}$ of the buffered acetic acid solution $(\mathrm{pH} 4.93)$ and stirred for a minimum of 18 hours at room temperature. During this time, no additional $\mathrm{pH}$ adjustments were made to the acetic acid solution. Sample recovery and spiking were performed in the same manner as the gastric fluid leaching. The digestate was filtered and diluted to a $100 \mathrm{~mL}$ final volume before analysis by ICP-MS, and the same matrix spike and duplicate analysis scheme was used. The $69 \mathrm{ppb}$ spiking level was also based on previous results obtained from this procedure when applied to standard reference fly ash samples. 


\section{Data Analysis}

\section{ESP Fly Ash}

The extractability of metals from the surface of fly ash and flue gas particulate matter relates to a combination of factors. Metal solubility, particle surface area, surface concentration, or other matrix effects can influence the leachability of metals from particles. Increasing extractability was generally observed along the flue gas path, and the relationship between surface area, particle size, and surface concentration is considered influential.

For example, the analytical results for the various fly ash samples collected around the ESP all indicate differences in metal concentration as a function of particle size. Specifically, that enrichment of many trace elements increases as particle size decreases. This is evident from the evaluation of size-fractionated particulate samples collected from the ESP inlet and outlet flue gas (Section 8.0). An analysis of the fly ash collected from the first and second ESP fields also indicates this relationship between increasing trace element concentration and decreasing particle size. Trace element enrichment was more prominent in particles collected from the second (downstream) ESP field where the mean particle diameter was $<10$ microns, compared to 30 microns in the first field.

Since the samples collected for extraction were filtered, and not size-fractionated, the mean particle diameter of the samples is an important consideration. It is reasonable to expect higher extractable concentrations at the ESP outlet compared to the inlet, based solely on the reduction in the mean particle diameter across the ESP. The increased surface area associated with an equivalent sample mass exposes more material to the leaching solutions. Barium and vanadium are two elements whose total fly ash concentrations remained relatively constant across the ESP. But due to the smaller mean particle diameter of the ESP outlet sample, the extractable percentage by nitric acid digestion jumped from $39-59 \%$ for barium and from $35-61 \%$ for vanadium.

All of the remaining trace elements had higher bulk concentrations in the ESP outlet samples when compared to the ESP inlet. In this case, the increase in concentration and surface area exposure should produce an increase in the extractable percentage. Except for antimony, manganese, molybdenum, and mercury, this was true for all of the trace elements. Arsenic and selenium, when detected, showed little change. Tables 11-1 and 11-2 present the extractable metal concentrations of the ESP inlet and outlet fly ash, respectively. The total trace element concentration derived from size-fractionated particulate results is also presented along with the extractable percentage under each leaching condition.

Surface availability may be estimated from the extractable percentages between elements in samples from the same stream. Elements exhibiting the highest degree of extractability are likely to be surface oriented, unbound in the particle matrix, or in a form readily dissolved by the leaching agent. However, an analytical bias in the results for any given element may also manifest itself as high (or low) extractability. 
Table 11-1

Extractable Composition of ESP Inlet Gas Particulate Matter

\begin{tabular}{lccccccc}
\multirow{2}{*}{$\begin{array}{c}\text { Trace } \\
\text { Elements }\end{array}$} & $\begin{array}{c}\text { Total } \\
\text { Composition }\end{array}$ & $\begin{array}{c}\text { Nitric Acid Digestion } \\
\text { (EPA SW 3050) }\end{array}$ & \multicolumn{2}{c}{$\begin{array}{c}\text { Simulated } \\
\text { Gastric Fluid Leach }\end{array}$} & \multicolumn{2}{c}{$\begin{array}{c}\text { Acetic Acid Leach } \\
\text { (TCLP) }\end{array}$} \\
\cline { 2 - 8 } & $(\mu \mathrm{g} / \mathrm{g})$ & $(\mu \mathrm{g} / \mathrm{g})$ & $(\%$ Extracted) & $(\mu \mathrm{g} / \mathrm{g})$ & $(\%$ Extracted) & $(\mu \mathrm{g} / \mathrm{g})$ & (\% Extracted) \\
\hline Antimony & 3.18 & 2.68 & 84.3 & 0.709 & 22.3 & 0.798 & 25.1 \\
Arsenic & 44.8 & 42.6 & 95.1 & $<0.678$ & $<1.5$ & 1.02 & 2.3 \\
Barium & 560 & 220 & 39.2 & 103 & 18.4 & 48.1 & 8.6 \\
Beryllium & 11.2 & 4.11 & 36.7 & 1.14 & 10.2 & 0.322 & 2.9 \\
Cadmium & 3.45 & 2.22 & 64.5 & 1.82 & 52.9 & 1.65 & 47.9 \\
Chromium & 197 & 29.0 & 14.7 & 27.5 & 14.0 & 7.37 & 3.7 \\
Cobalt & 36.5 & 5.03 & 13.8 & 1.80 & 4.9 & 1.48 & 4.0 \\
Copper & 108 & 32.1 & 29.8 & 9.96 & 9.2 & 10.9 & 10.2 \\
Lead & 76.4 & 39.3 & 51.4 & 9.37 & 12.3 & 0.205 & 0.3 \\
Manganese & 236 & 120 & 51.1 & 60.0 & 25.5 & 51.4 & 21.8 \\
Molybdenum & 28.5 & 42.9 & 151 & 29.3 & 103 & 1.45 & 5.1 \\
Nickel & 134 & 45.1 & 33.8 & 10.3 & 7.7 & 8.64 & 6.5 \\
Selenium & 8.51 & $<23.3$ & $<274$ & $<0.884$ & $<10.4$ & 0.221 & 2.6 \\
Vanadium & 421 & 146 & 34.6 & $<0.359$ & $<0.1$ & 1.46 & 0.3 \\
& & & & & & &
\end{tabular}


Table 11-2

Extractable Composition of ESP Outlet Gas Particulate Matter,

\begin{tabular}{lccccccc}
\multicolumn{1}{c}{$\begin{array}{c}\text { Trace } \\
\text { Elements }\end{array}$} & $\begin{array}{c}\text { Total } \\
\text { Composition }\end{array}$ & $\begin{array}{c}\text { Nitric Acid Digestion } \\
\text { (EPA SW 3050) }\end{array}$ & $\begin{array}{c}\text { Simulated } \\
\text { Gastric Fluid Leach }\end{array}$ & \multicolumn{2}{c}{$\begin{array}{c}\text { Acetic Acid } \\
\text { Leach (TCLP) }\end{array}$} \\
\cline { 2 - 8 } Antimony & $(\mu \mathrm{g} / \mathrm{g})$ & $(\mu \mathrm{g} / \mathrm{g})$ & $(\%$ Extracted) & $(\mu \mathrm{g} / \mathrm{g})$ & $(\%$ Extracted) & $(\mu \mathrm{g} / \mathrm{g})$ & (\% Extracted) \\
Arsenic & 6.79 & 3.21 & 47.4 & 0.954 & 14.1 & 0.875 & 12.9 \\
Barium & 103 & 98.4 & 95.4 & $<0.660$ & $<0.6$ & 3.38 & 3.3 \\
Beryllium & 540 & 318 & 58.8 & 125 & 23.2 & 44.1 & 8.2 \\
Cadmium & 13.7 & 5.43 & 39.6 & 2.72 & 19.8 & 0.981 & 7.1 \\
Chromium & 9.23 & 9.79 & 106 & 5.86 & 63.5 & 9.57 & 104 \\
Cobalt & 248 & 64.3 & 25.9 & 54.3 & 21.8 & 19.5 & 7.8 \\
Copper & 44.3 & 16.9 & 38.3 & 5.47 & 12.3 & 6.02 & 13.6 \\
Lead & 152 & 98.5 & 64.9 & 33.5 & 22.1 & 17.9 & 11.8 \\
Manganese & 141 & 116 & 82.3 & 32.9 & 23.4 & 1.50 & 1.1 \\
Molybdenum & 697 & 165 & 33.1 & 46.2 & 9.3 & 39.3 & 7.9 \\
Nickel & 69.1 & 72.2 & 105 & 61.4 & 88.9 & 4.43 & 6.4 \\
Selenium & 177 & 83.8 & 47.5 & 38.4 & 21.7 & 22.7 & 12.8 \\
Vanadium & 101 & $<23.3$ & $<23.1$ & 18.1 & 18.0 & 4.07 & 4.0 \\
& 448 & 272 & 60.7 & 122 & 27.3 & 4.68 & 1.0
\end{tabular}


Table 11-3 ranks the overall extractability of the target elements from fly ash in order from highest to lowest using the percent extractable results from all three leaching techniques. Elements with matrix spike recovery results outside the data quality objective range of 75$125 \%$ are identified, and as stated previously, may bias the relative extractability information.

To assess the accuracy of the extractable concentration data, matrix spikes were performed for each leachate matrix as indicators of analytical bias. A complete table of matrix spike recoveries for each of the leachate matrices is presented in Table D-2 of Appendix D. Based on the poor matrix spike and blank spike recoveries, mercury results were invalidated. QC sample results for arsenic in the gastric fluid leachates illustrate the difficulty of arsenic analysis by ICP-MS in a high chloride matrix. Molybdenum and antimony were not included in the spiking solution. Consequently, no spike recovery information is available for qualifying the accuracy of their results.

In addition to matrix spike recovery results, additional factors influencing the extractability data include bias in the bulk composition results. For example, the extractable concentrations of molybdenum reported for nitric acid and gastric fluid is above 100 percent. This element may indeed be $100 \%$ extractable from the particle surfaces or there could be an analytical bias in the total composition.

\section{Stack Gas Particulate Matter}

Particulate emissions from the FGD system were also characterized using extractability percentages to relate particle size, surface area, and surface concentration of the target elements. However, there are additional mechanisms to consider with the potential for scrubber mist carryover, (i.e., salts) and the leachability of the gas-borne particulate matter through the wet FGD system. With an average FGD slurry $\mathrm{pH}$ of 4.5 , the JBR provides a mechanism for leaching some elements from the incoming fly ash. A shift in mean particle diameter is also observed as the larger sized particles are trapped in the scrubber.

Table 11-4 presents the extractable metal concentrations, the trace element concentration derived from multi-metals train results for test Runs 2 and 3 (quartz filters used), and the extractable percentage under each leaching condition. Only the results from extractable metals test Run 2 were selected for reporting the stack concentrations since glass-fiber filters were inadvertently used to collect particulate matter from the stack gas during test Runs 1 and 3. Data for the omitted test runs are reported in the Appendix.

Several metals were detected in the leachates at concentrations higher than the equivalent total composition value. Metals extracted by nitric acid digestion at percentages greater than $120 \%$ of the bulk composition include: beryllium, vanadium, lead, copper, arsenic, barium, and cadmium. Extractable percentages greater than $120 \%$ by gastric fluid leaching are reported for lead and beryllium. Clearly a bias exists in the analysis of either the stack gas particulate matter collected by the multi-metals train, the single Run 2 sample for extractable metals, or both. 


\section{Table 11-3}

\section{Extractability of Elements in Fly Ash ${ }^{2}$}

\begin{tabular}{lccc}
$\begin{array}{c}\text { Extractability } \\
\text { (Highest - Lowest) }\end{array}$ & $\begin{array}{c}\text { Average } \\
\text { \% Extractable }\end{array}$ & $\begin{array}{c}\text { Average Matrix } \\
\text { Spike Recovery }\end{array}$ & $\begin{array}{c}\text { Spike Recovery } \\
\text { Range }\end{array}$ \\
\hline Molybdenum $^{\mathrm{c}}$ & $76 \%$ & Not Available $^{\mathrm{c}}$ & Not Available $^{\mathrm{c}}$ \\
Cadmium $^{\text {Antimonyc }}$ & $73 \%$ & $96.2 \%$ & $107 \%-88 \%$ \\
Arsenic $^{\mathrm{b}}$ & $34 \%$ & Not Available $^{\mathrm{c}}$ & Not Available $^{\mathrm{c}}$ \\
Selenium $^{\mathrm{b}}$ & $33 \%$ & $80.5 \%$ & $123 \%-0 \%^{\mathrm{b}}$ \\
Lead $^{\text {Barium }}$ & $30 \%$ & $117 \%$ & $138 \%-84 \%$ \\
Manganese $^{\mathrm{b}}$ & $29 \%$ & $87.7 \%$ & $97 \%-83 \%$ \\
Copper & $26 \%$ & $89.7 \%$ & $94 \%-85 \%$ \\
Nickel & $25 \%$ & $88.8 \%$ & $108 \%-71 \% \mathrm{~b}$ \\
Beryllium & $25 \%$ & $98.8 \%$ & $105 \%-92 \%$ \\
Vanadium $^{\mathrm{b}}$ & $22 \%$ & $95.3 \%$ & $103 \%-81 \%$ \\
Chromium & $19 \%$ & $93.1 \%$ & $108 \%-79 \%$ \\
Cobalt & $19 \%$ & $71.0 \% \mathrm{~b}$ & $109 \%-0 \%$ \\
& $15 \%$ & $97.6 \%$ & $106 \%-88 \%$ \\
& $15 \%$ & $97.7 \%$ & $100 \%-92 \%$
\end{tabular}

- Results consider average extractability of elements from fly ash samples collected from the flue gas at the inlet and outlet of the ESP.

${ }^{b}$ Indicates that the spike recovery result obtained is outside the data quality objective range of 75-125 percent. The ranking of these elements may be biased by analytical results indicating higher or lower extractable percentages.

'Antimony and molybdenum were not present in the SPEX ${ }^{\circledR}$ ICP-MS calibration solution used to prepare matrix spikes. No spike recovery information is available to determine the relative accuracy of these results. Consequently, the extractable percentages for these elements could be affected by analytical bias. 
Table 11-4

Extractable Composition of Stack Gas Particulate Matter

\begin{tabular}{lccccccc}
\multirow{2}{*}{$\begin{array}{c}\text { Trace } \\
\text { Elements }\end{array}$} & $\begin{array}{c}\text { Total } \\
\text { Composition }\end{array}$ & $\begin{array}{c}\text { Nitric Acid Digestion } \\
\text { (EPA SW 3050) }\end{array}$ & $\begin{array}{c}\text { Simulated } \\
\text { Gastric Fluid Leach }\end{array}$ & \multicolumn{2}{c}{$\begin{array}{c}\text { Acetic Acid Leach } \\
\text { (TCLP) }\end{array}$} \\
\cline { 2 - 8 } & $(\mu \mathrm{g} / \mathrm{g})$ & $(\mu \mathrm{g} / \mathrm{g})$ & $(\%$ Extracted) & $(\mu \mathrm{g} / \mathrm{g})$ & $(\%$ Extracted) & $(\mu \mathrm{g} / \mathrm{g})$ & $(\%$ Extracted) \\
\hline Antimony & 31.5 & 5.78 & 18.4 & 3.37 & 10.7 & $<0.034$ & $<0.1$ \\
Arsenic & 81.1 & 164 & 202 & $<2.46$ & $<3.0$ & $<0.497$ & $<0.6$ \\
Barium & 214 & 354 & 165 & 214 & 100 & 17.2 & 8.0 \\
Beryllium & 2.94 & 10.2 & 349 & 4.20 & 143 & 2.91 & 98.9 \\
Cadmium & 41.4 & 67.0 & 162 & 12.4 & 29.9 & 5.92 & 14.3 \\
Chromium & 329 & 43.8 & 13.3 & 84.7 & 25.7 & 36.4 & 11.1 \\
Cobalt & 18.1 & $<0.899$ & $<5.0$ & 10.9 & 60.4 & 7.47 & 41.3 \\
Copper & 55.8 & 124 & 222 & 51.3 & 91.9 & 63.8 & 114 \\
Lead & 35.7 & 90.8 & 254 & 65.8 & 184 & 20.0 & 56.1 \\
Manganese & 488 & 328 & 67.2 & 349 & 71.5 & 470 & 96.3 \\
Molybdenum & 100 & 51.4 & 51.4 & 48.6 & 48.6 & 3.45 & 3.5 \\
Nickel & 2509 & 392 & 15.6 & 169 & 6.7 & 66.2 & 2.6 \\
Selenium & 899 & $<86.9$ & $<9.7$ & 140 & 15.6 & 61.2 & 6.8 \\
Vanadium & 122 & 385 & 315 & $<1.30$ & $<1.1$ & $<0.185$ & $<0.2$ \\
& & & & & & &
\end{tabular}


Results for matrix spikes performed on the extractable metals sample collected at the ESP inlet and the multi-metals train samples are presented in Table D-2 of Appendix D. Since no QC activities were performed specific to the extractable metals Run 2 sample, data quality can only be estimated from relevant matrix and analytical spike data. In addition, the selection of only one sample result for comparison provides a high degree of uncertainty with these results.

Elements that were found in the stack gas particulate matter at concentrations greater than the ESP outlet (FGD inlet) gas are: antimony, cadmium, chromium, molybdenum, nickel, and selenium. Lower concentrations are noted for arsenic, barium, beryllium, cobalt, copper, lead, and vanadium. The concentration of manganese remained relatively constant across the FGD system.

The reduction in elemental concentrations, in spite of the reduction in mean particle diameter, across the JBR suggests that some elements may be leached from the fly ash by the FGD slurry. Some dilution of the fly ash by FGD solids low in certain trace elements may also be occurring; however, a comparison between calcium concentrations in the gas particulate-phase samples across the JBR system revealed only a slight, and statistically insignificant, increase in calcium concentration.

A comparison of trace metal concentrations between limestone slurry and JBR slurry filtrates suggests that the slurry is leaching trace elements from the fly ash. Enrichment is observed . (in order of highest to lowest enrichment) for cadmium, lead, manganese, copper, selenium, cobalt, arsenic, nickel, vanadium, beryllium, and chromium at concentration factors much greater than the 6 cycles of concentration observed for soluble silica. In addition to these elements enriched in the aqueous phase, molybdenum, selenium, vanadium, and arsenic are enriched in the JBR slurry's solid phase.

This concentration mechanism plays an important part in the study of extractable metals in gas particulate matter downstream of wet scrubbing systems. As a result, particle surface characterizations based on extractability data may not be feasible without a more thorough understanding of the enrichment and carryover mechanisms taking place in the scrubber system.

\section{References}

1. 40 CFR 60, Appendix A. Test Methods. "Method 17: Determination of Particulate Emissions from Stationary Sources (In-Stack Filtration Method)."

2. 40 CFR 60, Appendix A. Test Methods. "Method 5: Determination of Particulate Emissions from Stationary Sources."

3. 55 FR 26986 (Friday, June 29, 1990), "Toxicity Characteristic Leaching Procedure (Method 1311)." 


\section{APPENDIX A: QUALITY ASSURANCE AUDITS}

The purpose of a quality assurance audit is to provide an objective, independent assessment of a sampling or measurement effort. It ensures that the sampling procedures, data generating, data gathering, and measurement activities produce reliable and useful results. Sometimes inadequacies are identified in the sampling/measurement system and/or the quality control program. In such cases, audits provide the mechanism for implementing corrective action.

A technical systems audit (TSA) is an on-site, qualitative review of the various aspects of a total sampling and/or analytical system. It is an assessment of overall effectiveness and represents an objective evaluation of a set of interactive systems with respect to strengths, deficiencies, and potential areas of concern. The audit consists of observations and documentation of all aspects of the measurement effort.

A performance audit is an independent check to evaluate the data produced by a measurement system. Audit standards and test equipment which are traceable to acceptable reference standards are used to assess the performance of each analytical method and/or measurement device (performance audit). Performance audits are designed to provide a quantitative, pointin-time evaluation of the data quality of the sampling and analytical systems being tested. This is accomplished by addressing specific parts of the overall system. Each performance audit addresses two general measurement categories of a project:

- Chemical analysis of samples; and

- Physical measurements supporting the sampling effort.

Audit activities consist of challenging the various measurement systems with standards and test equipment traceable to accepted reference standards. Laboratories conducting the analytical work on a program are given performance audit samples prepared by spiking representative sample matrices with target analytes at representative concentration levels. Results for these audit samples are tabulated and considered in evaluating the analytical performance and data reporting protocols for each laboratory.

For this program, technical system audits and performance audits were conducted of each of the DOE contractors by Research Triangle Institute (RTI) under contract to EPA. For the 
Appendix A: Quality Assurance Audits

audits of the Radian activities, reports were prepared and subsequently distributed to Radian through DOE detailing the results of the audits. Copies of the RTI audit reports are presented as attachments to this appendix. The following subsections present the Radian response to RTI's findings.

\section{Technical Systems Audit Results}

A technical systems audit was conducted of the sampling and on-site analytical activities for this program on June 23-25, 1993. This audit was conducted by J.B. Flanagan and C.O. Whitaker of RTI. Four findings were discussed in the RTI audit report. Each of these findings and RTI recommendations are discussed in the following paragraphs.

\section{Finding 1.}

Basis due to long sampling lines from the calibration tanks to the probes and nonlinearity of the continuous monitor (CEM) system may go undetected due to infrequent multi-point calibrations. The CEM system at Plant Yates was not a designated part of the Radian effort for the DOE program and was not a negotiated activity between DOE and Georgia Power. Therefore, Radian has no control over and may not initiate any corrective actions related to, the operation of the CEM at Plant Yates.

\section{Finding 2}

Aldehyde measurements were performed in accordance with the method; however, acetone (a possible contaminant) was present in the mobile laboratory as a wash bottle under the hood. One or more of the field blanks for the aldehyde sampling trains showed varying concentrations of acetaldehyde and formaldehyde. However, these analytes were not found in the reagent blanks stored in the mobile laboratory. It is not possible with the data available to rule out possible contamination due to the wash bottle of acetone. The concentrations found in the blanks should be considered in the use of the sample data. This precaution was noted in the project QA/QC summary (see Appendix D).

\section{Finding 3}

All plant and sampling times are recorded in Central Daylight Savings Time instead of Eastern Daylight Savings Time. Radian has worked on several other Georgia Power projects and is familiar with their timekeeping procedures. In addition, since the field crew was from one of Radian's offices located in the Central Time Zone, the use of CDT was probably less confusing than working on EDT.

\section{Finding 4}

Sampling data are hand-entered from field sheets into a portable computer each day, making occasional typographical errors virtually unavoidable. The normal Radian practice is to compare the computer output with the original data sheets to ensure that the information has been input correctly. This is generally done once the field crew has returned to the office 
and the summary report of field activities is prepared. In addition, the Radian QA coordinator or his/her designee checks a percentage of the data sheets, logbooks, and calculations.

In addition to the technical systems audit, a number of performance evaluation audits were performed during the on-site effort. The greater part of the performance audit was directed toward the off-site analyses and a lesser part to the on-site activities. The results of the offsite performance audit samples are discussed in the next section. The results of the on-site performance audit are discussed in the following paragraphs.

\section{Orsat Determinations}

A duplicate analysis of oxygen was performed using a test gas supplied by RTI. The results of the analysis of test gas BLM002689 was $9.0 \%$ oxygen which calculates out to a $97.8 \%$ recovery as compared to the theoretical concentration of 9.2 percent.

\section{Source Sampling Consoles}

An audit of the dry gas meters in four source sampling consoles was performed by RTI using a standard orifice. Audit results calculated as relative percent difference between the dry gas volume measurement and the calculated volume based on the RTI orifice were within the $\pm 10 \%$ acceptance criteria for three of the four meters tested. The result for the fourth meter $(-11.7 \%)$ was just slightly below the criteria. The auditor noted that the audit data set for this meter did not include a meter run stop time. It is not known if a more exact run time would have resulted in this measurement being within the criteria.

\section{Continuous Emissions Monitors}

Audit of the continuous emissions monitors was not an negotiated activity between Georgia Power and DOE for this program. Therefore, Plant Yates would not permit RTI to audit the CEM. Any change in the frequency of the calibration approach would have to be decided between DOE and Georgia Power (The yearly calibration is actually a yearly certification or performance audit).

In the RTI audit report five recommendations are discussed. Since the majority of these recommendations were not discussed at the audit wrap-up meeting conducted at Plant Yates, limited corrective action was initiated. A summary of the RTI recommendations and the Radian corrective actions are discussed in the following paragraphs:

\section{Recommendation 1}

Due to the unusually large differences seen between the RTI standard orifice and the sampling consoles used for source testing, it is recommended that the average of the pre-and post- test calibrations be used in the emission estimates. Only one of the consoles audited by RTI was outside the acceptance criteria given. The theoretical value for this audit run is not certain because the meter run stop time was not recorded. Therefore, it is not known if the result for this console was actually outside the acceptance criteria. A QA check of the post- 
Appendix A: Quality Assurance Audits

test calibration for the consoles used on the project showed that the difference between the pre-test and post-test calibrations was less than $5 \%$ as required by the method (RPD-1.38\% \pm 1.08 , Range $0.1 \%-3.47 \%$ per Radian QA coordinator).

\section{Recommendation 2}

Mass flow rates for solids such as bottom ash and ESP ash are calculated based on coal feed rates and percentage ash in the coal obtained by proximate/ultimate analysis. One or more independent, direct methods of measuring or estimating the amount of ash produced should be attempted. The ESP collected ash flow rate was determined using the measured particulate loadings at the ESP inlet and outlet and the measured gas flow rate, not the coal feed rate and coal ash concentration. The bottom ash was calculated using the ESP inlet particulate loadings and coal feed rate and ash concentration. Radian considered obtaining representative bottom ash and ESP collected ash flow rates using the method described by RTI. However, the level of effort required, particularly for the ESP collected ash flow rate would have required additional sampling personnel and, given the physical design of the ash sluice system, additional information gained in this manner would also have a very large degree of uncertainty as to its accuracy.

\section{Recommendation 3}

Because RTI auditors were not allowed to take any completed data sheets off-site, a data audit should be conducted in which raw data sheets, computer-logged data, logbooks, validation procedures, and calculations are examined. Data quality audits of the raw data, logbooks, calculations, and computerized data are checked and counter checked by various project personnel (including the Radian QA coordinator) throughout the progress of the project. The overall project is then peer- reviewed by senior engineers and scientists at least twice prior to the final reporting process.

\section{Recommendation 4}

CEMs at Plant Yates are not scheduled for multi-point calibration until the fall of 1993 which will result in a one-year interval since the last multi-point calibration. The interval between multi-point calibrations of the CEM should be changed from yearly to every six months. This recommendation is outside of the scope of the present project and is out of the control of Radian.

\section{Recommendation 5}

The major elements for mass balance determinations should be discussed and finalized between DOE and Radian. Elements for the mass balance determinations were finalized between DOE and Radian and are presented in Section 6 of this Document. 


\section{Performance Audit Results}

At the time of the technical systems audit conducted by RTI in June 1993, a series of performance audit samples were prepared and presented to the Radian sampling team to be submitted to the various analytical laboratories along with the investigative samples. The audit samples were prepared by spiking the impinger solutions or other analytical matrices provided to the auditors by Radian.

\section{VOST}

Two sets of Tenax cartridges were spiked with 18 compounds. These were analyzed for 16 of the 18 compounds by Radian's subcontractor, Air Toxics, Limited. In the RTI audit report, the results for these analyses were compared to the wrong set of recovery objectives. Tables A-1 and A-2 show the results and the recovery objectives for volatile organics as presented in Table 9-4 (page C9-9) of the project QAPP. The QC objectives were met for 10 of the 16 analytes in sample Y194 and 9 of the 16 analytes in sample Y195. Of the analytes with recoveries outside the QC objectives, toluene, methylene chloride, 1,1,1trichloroethane, trichlorofluoromethane, benzene, chloroform, and carbon tetrachloride were recovered high in one or more of the samples and chlorobenzene was recovered low in one sample. A portion of the methylene chloride recovery may be due to contamination, since this analyte was found in varying concentrations in most of the field and laboratory blanks analyzed with the samples. The high toluene recoveries were also attributed to contamination in the RTI audit report. In this case, the contamination appears to be in the audit cylinder, since this analyte was not found in any of the field or laboratory blanks and the concentration in Y195 is approximately twice the concentration in Y194. This concentration ratio matches the relationship for the RTI theoretical concentrations for other analytes in the two samples.

\section{Semivolatile Organics}

Two XAD-2 modules, a train rinse, and a probe rinse were spiked with 16 analytes. Each module was combined with a rinse and reported as a combined sample. The analytical results for the 16 spiked compounds were within the project objectives for sample Y173-177 and 14 of the 16 spiked compounds were within the QC objectives in sample Y178-182. Anthracene, indeno(1,2,3-cd)pyrene, dibenzo(a,h)anthracene, and benzo(g,h,i)perylene results were outside the $\mathrm{QC}$ objectives. These compounds were spiked at or near the approved detection limits stated in the project QAPP.

\section{Aldehydes}

Two DNPH impinger solutions were spiked with formaldehyde. The recovery for this analyte showed recoveries above the stated project QC objectives. RTI attributed these apparent enhanced recoveries to possible contamination. Formaldehyde was found in several of the field blanks and at the detection limit in one laboratory blank but was not found in the reagent blanks. Laboratory control samples and matrix spiked samples showed good recoveries for both formaldehyde and acetaldehyde. 
Appendix A: Quality Assurance Audits

Table A-1

Analysis of Vost Sample ID Y194 by Air Toxics Limited

\begin{tabular}{lcccccc}
\multicolumn{1}{c}{ Analyte } & $\begin{array}{c}\text { Detection } \\
\text { Limit } \\
\text { (ng) }\end{array}$ & $\begin{array}{c}\text { Theoretical } \\
\text { Concentration } \\
\text { (ng) }\end{array}$ & $\begin{array}{c}\text { Analyzed } \\
\text { Concentration } \\
\text { (ng) }\end{array}$ & $\begin{array}{c}\text { \% } \\
\text { Recovery }\end{array}$ & $\begin{array}{c}\text { QC } \\
\text { Objectives } \\
\text { Rec. }\end{array}$ & $\begin{array}{c}\text { QC } \\
\text { Objectives } \\
\text { Met? }\end{array}$ \\
\hline Benzene & 10 & 63.73 & 74 & 116 & $37-151$ & yes \\
Chlorobenzene & 10 & 177.43 & 53 & 30 & $37-160$ & low \\
Ethylbenzene & 10 & 153.86 & 120 & 78 & $37-162$ & yes \\
Toluene & 10 & 151.68 & 2300 & 1520 & $47-150$ & high \\
O-Xylene & 10 & 159.30 & 71 & 45 & NS & NA \\
Bromomethane & 10 & 125.33 & 130 & 104 & D-242 & yes \\
1,3-Butadiene & NA & 25.94 & NA & - & - & NA \\
Chloroform & 10 & 87.60 & 110 & 126 & $51-138$ & yes \\
Carbon tetrachloride & 10 & 123.28 & 140 & 114 & $70-140$ & yes \\
1,2-Dichloroethane & 10 & 74.04 & 53 & 72 & $49-155$ & yes \\
1,2-Dibromoethane & NA & 300.37 & NA & - & - & NA \\
1,2-Dichloropropane & 10 & 192.00 & 160 & 83 & D-210 & yes \\
Methylene chloride & 10 & 112.98 & 5700 & 5040 & D-221 & high \\
Tetrachloroethylene & 10 & 141.40 & 120 & 85 & $46-157$ & yes \\
Trichloroethylene & 10 & 103.69 & 120 & 116 & $71-157$ & yes \\
1,1,1-Trichloroethane & 10 & 148.77 & 230 & 155 & $52-150$ & high \\
Trichlorofluoromethane & 10 & 217.11 & 470 & 216 & $17-181$ & high \\
Vinyl chloride & 10 & 40.10 & 48 & 120 & D-251 & yes
\end{tabular}


Table A-2

Analysis of Vost Sample W Y195 by Air Toxics Limited

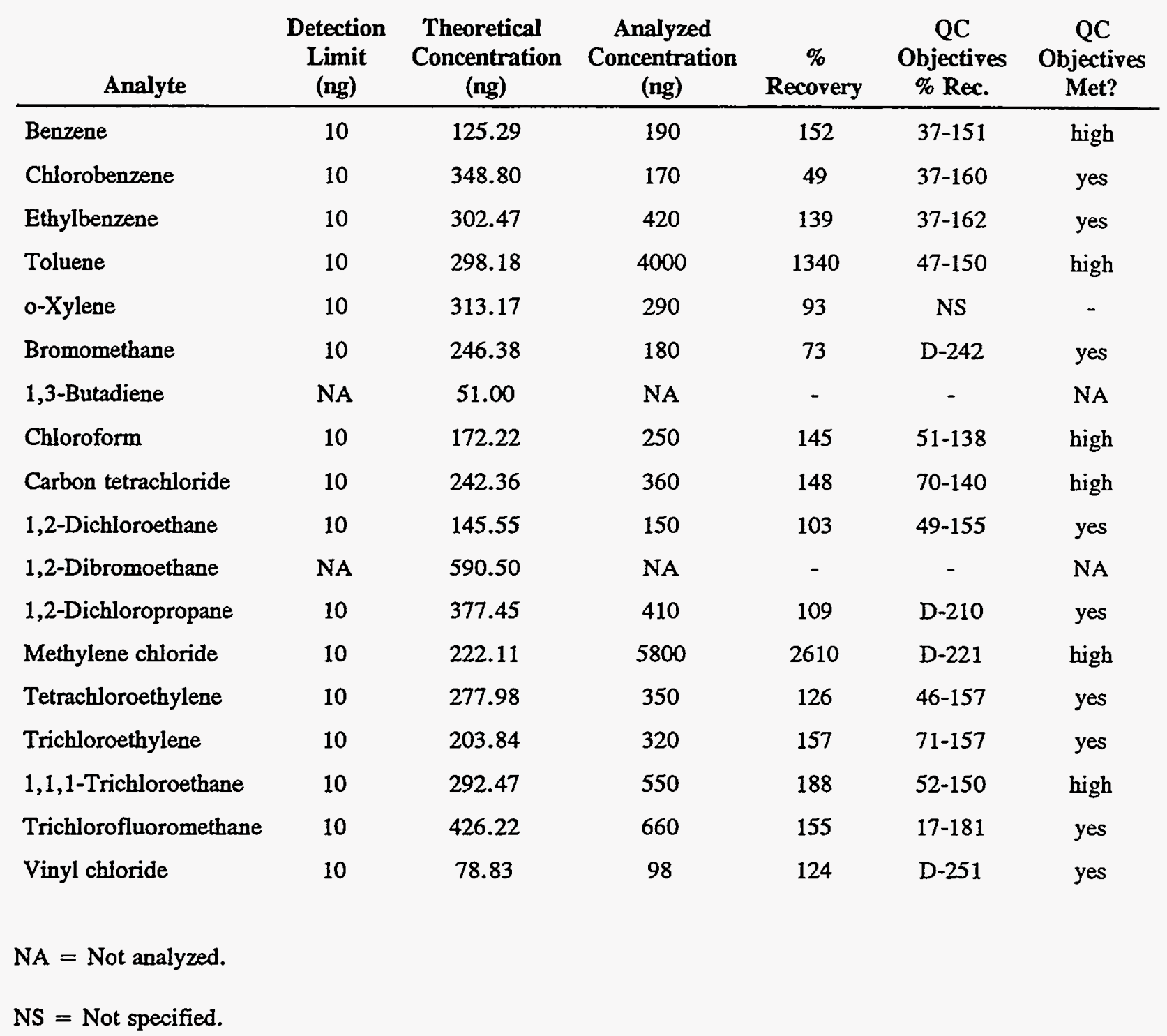


RTI analyzed the spike solution (about two months later) and found reduced recoveries based on the nominal concentration. It appears that the true concentration of the spike solution is not known. Formaldehyde standards prepared from the commercially available $37 \%$ solutions may vary since these reagents may vary in actual concentration from $36-41$ percent. Standards prepared as nominal concentrations can be analyzed by a titration procedure to obtain a known concentration for a standard. It is not known if this procedure was used by RTI to assign a theoretical concentration for the spike solution.

\section{Metals}

Performance audit samples were prepared by RTI for the filter, the nitric acid-peroxide impingers, and the permanganate impingers of the multi-metals sampling train. Arsenic, cadmium, lead, and selenium were recovered within the QC objectives in the nitric acid/peroxide impinger solutions. However, mercury showed a slightly high recovery in this solution. Metal recoveries for the two spikes onto blank filters showed good recoveries except for one arsenic spike with a high recovery and one cadmium, selenium, and mercury spike with slightly low recoveries on the other filter. Mercury spiked into the two permanganate impinger solutions showed low recoveries (21-40\%). The performance audit sample prepared by the Radian QA Coordinator also showed low. recovery $(33 \%)$ for the permanganate solution sample. 


\section{Department of Energy}

Pittsburgh Energy Technology Center

P.O. Box 10940

Pittsburgh, Pennsylvania 15236-0940

November 10, 1993

Barbara J. Hayes

Radian Corporation

8501 Mo-Pac Blvd.

P.O. Box 201088

Austin, TX 78720-1088

Dear Barbara:

Enclosed are clean copies of the Field Sampling Report and the PE Sample Analysis information prepared by Research Triangle Institute. Please include these documents in the External Audit Section of the Draft Final Report to be submitted to the DOE on December 10, 1993. In addition, provide a response to RTI's finding in the Draft Final Report.

If you have any questions, please call me at (412) 892-4691.

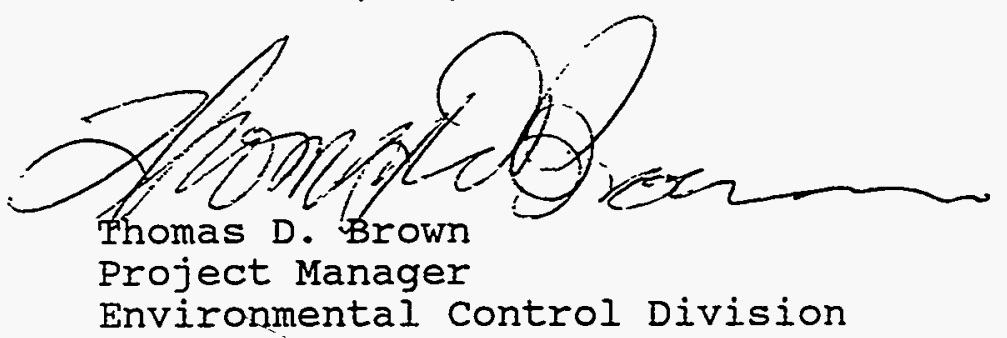

Enclosures

CC: Hollis Flora, Radian 

October 4, 1993

Mr. Tom Brown

PETC, U.S. Department of Energy

P.O. Box 10940, M.S. 922-206

Pittsburgh, PA 15236

Subject: Radian PE sample analysis during the Yates Plant Audit

Dear Tom:

Enclosed are the analysis results for 10 sets of performance evaluation (PE) samples given to Radian Corporation during the audit of the Yates plant. Of particular concern are the mercury and the formaldehyde analyses.

After encountering a serious problem with the aldehyde analysis, we recalculated the PE sample concentrations and analyzed the samples in our laboratory. In the analytical procedure, there are still some undetermined factors such as the percent conversion of aldehyde into the DNPH-derivatives. Even though the molar ratios of DNPH to aldehyde were sufficiently high to drive the conversion reaction to completion, the aldehyde analysis results are lower than expected. The further laboratory work may resolve this issue.

\section{Volatiles}

RTI spiked two sets of Tenax cartridges in a VOST train with 18 compounds. The cartridges were analyzed by Radian's subcontractor, Air Toxics, Limited. The laboratory analyzed for 16 of the 18 compounds spiked into the cartridges. Of the compounds quantitated, 10 of 16 were recovered within the data quality objectives (DQOs) set by Radian for sample Y194, and 9 of 16 were recovered within the DQOs for sample Y195. Of the compounds particularly relevant to this project (benzene, toluene, ethylbenzene, and o-xylene), recoveries were mixed. Benzene was recovered well within range on sample Y194, but slightly out of range on sample Y195. Toluene was recovered completely out of range on both samples due to apparent contamination. Ethylbenzene was recovered within range on both samples. O-xylene was recovered out of range on sample Y194, but within range on sample Y195.

\section{Semivolatiles}

RTI spiked two XAD-2 modules, a train rinse, and a probe rinse with 16 PAHs in solution. Each module was combined with a rinse and reported by Radian as a combined 
Radian PE Samples

Yates Plant Audit

Page 2 of 9

October 4, 1993

sample. Radian performed satisfactorily on 28 of the 32 analyses. One undetected analyte was spiked at below the reported detection limit. This occurred because the detection limits reported were much higher than the $1 \mathrm{ng} / \mathrm{m}^{3}$ required by DOE for the project.

Metals on Filters

Several metals were spiked onto two filters of the M-29 trains to simulate metals in the particulate catch. Radian recovered 6 of the 10 metals concentrations within the limits of their DQOs.

\section{Metals. in Impinger Solutions. $\left(\mathrm{HNO}_{3} / \mathrm{H}_{2} \mathrm{O}_{2}\right)$}

Several metals were spiked into the first impinger of the metals train. Radian recovered eight of the nine metals within the limits of their DQOs.

Metals in Impinger Solutions. (KMnO)

Mercury was spiked into two acidic $\mathrm{KMnO}_{4}$ solutions. Neither was recovered in the range of their DQOs (75 to 125\%).

\section{Formaldehyde in Impinger Solutions. (DNPH)}

RTI spiked two DNPH impinger solutions with a solution containing a nominal concentration of $0.4068 \mu \mathrm{g} / \mu \mathrm{l}$. Radian's recoveries calculated based on this concentration are higher indicating possible contamination. RTI has analyzed the spiking solution and our recovery based on the nominal value is $67.6 \%$ (average concentration of $0.275 \mu \mathrm{g} / \mu \mathrm{l}$ ). RTI is continuing verification analyses on the spiking solution.

If I can be of further assistance, please call me at 541-5919.

Sincerely,

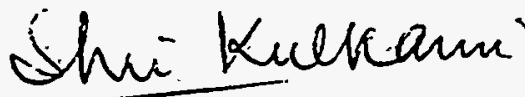

Shri Kulkami, Ph:D.

Managër, Quality Assurance and

Technology Assessment Department

SVK:dmh

cc: S.J: Wasson

J. McSorley

File: $\quad 5960-193 / 4805$

91A-04 
Radian PE Samples

Yates Plant Audit

Page 3 of 9

September 30, 1993

METALS IN IMPINGER SOLUTIONS $\left(\mathrm{HNO}_{3} / \mathrm{H}_{2} \mathrm{O}_{2}\right)$

SAMPLE ID: Y276

\begin{tabular}{|c|c|c|c|c|c||}
\hline METAL & $\begin{array}{c}\text { RTI } \\
\text { AMOUNT } \\
(\mu \mathrm{g})\end{array}$ & $\begin{array}{c}\text { RADIAN } \\
\text { AMOUNT } \\
(\boldsymbol{\mu g})\end{array}$ & $\begin{array}{c}\text { PERCENT } \\
\text { RECOVERY }\end{array}$ & $\begin{array}{c}\text { RECOVERY } \\
\text { DQO (\%) }\end{array}$ & $\begin{array}{c}\text { DQO } \\
\text { MET }\end{array}$ \\
\hline \hline As & 50 & 52.10 & 104.2 & $75-125$ & Yes \\
\hline $\mathrm{Cd}$ & 30 & 37.00 & 123.3 & $75-125$ & Yes \\
\hline $\mathrm{Pb}$ & 20 & 19.79 & 98.9 & $75-125$ & Yes \\
\hline $\mathrm{Se}$ & 40 & 41.60 & 104.0 & $75-125$ & Yes \\
\hline $\mathrm{Hg}$ & 10 & 12.68 & 126.8 & $75-125$ & No \\
\hline
\end{tabular}

METALS IN IMPINGER SOLUTIONS $\left(\mathrm{HNO}_{3} / \mathrm{H}_{2} \mathrm{O}_{2}\right)$

SAMPLE ID: Y279

\begin{tabular}{|c|c|r|r|r|c||}
\hline METAL & $\begin{array}{c}\text { RTI } \\
\text { AMOUNT } \\
(\mu \mathrm{g})\end{array}$ & $\begin{array}{c}\text { RADIAN } \\
\text { AMOUNT } \\
(\boldsymbol{\mu} \mathrm{g})\end{array}$ & $\begin{array}{c}\text { PERCENT } \\
\text { RECOVERY }\end{array}$ & $\begin{array}{c}\text { RECOVERY } \\
\text { DQO (\%) }\end{array}$ & $\begin{array}{c}\text { DQO } \\
\text { MET }\end{array}$ \\
\hline \hline $\mathrm{As}$ & 15 & 15.03 & 100.2 & $75-125$ & Yes \\
\hline $\mathrm{Cd}$ & 60 & 68.26 & 113.8 & $75-125$ & Yes \\
\hline $\mathrm{Pb}$ & 40 & 42.34 & 105.9 & $75-125$ & Yes \\
\hline $\mathrm{Se}$ & 80 & 90.72 & 113.4 & $72-125$ & Yes \\
\hline
\end{tabular}

These values are taken from Radian's QA plan (page C9-7). 
Radian PE Samples

Yates Plant Audit

Page 4 of 9

September 30, 1993

\section{METALS ON FILTERS}

SAMPLE ID: Y278, filter 966

\begin{tabular}{|c|c|c|c|c|c||}
\hline METAL & $\begin{array}{c}\text { RTI } \\
\text { AMOUNT } \\
(\mu \mathrm{g})\end{array}$ & $\begin{array}{c}\text { RADIAN } \\
\text { AMOUNT } \\
(\boldsymbol{\mu g})\end{array}$ & $\begin{array}{c}\text { PERCENT } \\
\text { RECOVERY }\end{array}$ & $\begin{array}{c}\text { RECOVERY } \\
\text { DQO (\%) }\end{array}$ & $\begin{array}{c}\text { DQ0 } \\
\text { MET }\end{array}$ \\
\hline As & 40 & 84.4 & 211.0 & $75-125$ & No \\
\hline $\mathrm{Cd}$ & 10 & 9.59 & 95.9 & $75-125$ & Yes \\
\hline $\mathrm{Pb}$ & 15 & 15.3 & 102.0 & $75-125$ & Yes \\
\hline $\mathrm{Se}$ & 25 & 22.3 & 89.2 & $75-125$ & Yes \\
\hline $\mathrm{Hg}$ & 10 & 10 & 100.0 & $75-125$ & Yes \\
\hline
\end{tabular}

\section{METALS ON FILTERS}

SAMPLE ID: Y281, filter 974

\begin{tabular}{|c|c|c|c|c|c||}
\hline METAL & $\begin{array}{c}\text { RTI } \\
\text { AMOUNT } \\
(\mu \mathrm{\mu g})\end{array}$ & $\begin{array}{c}\text { RADIAN } \\
\text { AMOUNT } \\
(\mu \mathrm{\mu g})\end{array}$ & $\begin{array}{c}\text { PERCENT } \\
\text { RECOVERY }\end{array}$ & $\begin{array}{c}\text { RECOVERY } \\
\text { DQO (\%) }\end{array}$ & $\begin{array}{c}\text { DQO } \\
\text { MET }\end{array}$ \\
\hline \hline $\mathrm{As}$ & 25 & 27.9 & 111.6 & $75-125$ & Yes \\
\hline $\mathrm{Cd}$ & 15 & 10.6 & 70.7 & $75-125$ & No \\
\hline $\mathrm{Pb}$ & 25 & 25.3 & 101.2 & $75-125$ & Yes \\
\hline $\mathrm{Se}$ & 35 & 23.4 & 66.9 & $75-125$ & No \\
\hline $\mathrm{Hg}$ & 20 & 14.6 & 73.0 & $75-125$ & No \\
\hline
\end{tabular}

1 These values are taken from Radian's QA plan (page C9-7). 
Radian PE Samples

Yates Plant Audit

Page 5 of 9

September 30, 1993

MERCURY IN IMPINGER SOLUTIONS (KMn04)

\begin{tabular}{|c|c|c|c|c|c||}
\hline SAMPLE ID & $\begin{array}{c}\text { RTI } \\
\text { AMOUNT } \\
(\mu \mathrm{g})\end{array}$ & $\begin{array}{c}\text { RADIAN } \\
\text { AMOUNT } \\
(\mu \mathrm{g})\end{array}$ & $\begin{array}{c}\text { PERCENT } \\
\text { RECOVERY }\end{array}$ & $\begin{array}{c}\text { RECOVERY } \\
\text { DQO (\%) }\end{array}$ & $\begin{array}{c}\text { DQO } \\
\text { MET }\end{array}$ \\
\hline \hline Y277 $^{1}$ & 20 & 4.18 & 20.9 & $75-125$ & No \\
\hline Y280 $^{2}$ & 50 & 19.75 & 39.5 & $75-125$ & No \\
\hline
\end{tabular}

FORMALDEHYDE IN IMPINGER SOLUTIONS (DNPH)

\begin{tabular}{|c|c|c|c|c|c||}
\hline SAMPLE ID & $\begin{array}{c}\text { RTI } \\
\text { AMOUNT } \\
(\mu \mathrm{g})\end{array}$ & $\begin{array}{c}\text { RADIAN } \\
\text { AMOUNT } \\
(\mu \mathrm{g})\end{array}$ & $\begin{array}{c}\text { PERCENT } \\
\text { RECOVERY }\end{array}$ & $\begin{array}{c}\text { RECOVERY } \\
\text { DQO (\%) }\end{array}$ & $\begin{array}{c}\text { DQO } \\
\text { MET }\end{array}$ \\
\hline \hline Y187 & 24.4 & 76 & 311 & $50-150$ & No \\
\hline Y188 & 34.2 & 90 & 263 & $50-150$ & No \\
\hline
\end{tabular}

Also spiked with $30 \mu \mathrm{g} \mathrm{Pb}$.

Also spiked with $20 \mu \mathrm{g}$ As.

These values were taken from Radian's QA plan (page C9-7).

These values were taken from Radian's QA plan (page C9-8). 
Radian PE Samples

Yates Plant Audit

Page 6 of 9

September 30, 1993

SVOC RECOVERIES FROM XAD-2 MODULES

SAMPLE ID: Y178-182 (Combined)

\begin{tabular}{||l|c|c|c|c|c||}
\hline \multicolumn{1}{|c|}{ ANALYTE } & $\begin{array}{c}\text { RTI } \\
\text { VALUE } \\
(\mathbf{\mu g})\end{array}$ & $\begin{array}{c}\text { Radian } \\
\text { VALUE } \\
(\mathbf{\mu g})\end{array}$ & $\begin{array}{c}\text { PERCENT } \\
\text { RECOVERY }\end{array}$ & $\begin{array}{c}\text { RECOVERY } \\
\text { DQO (\%) }\end{array}$ & $\begin{array}{c}\text { DQO } \\
\text { MET }\end{array}$ \\
\hline \hline Naphthalene & 10 & 9.98 & 99.8 & $21-133$ & Yes \\
\hline Acenaphthylene & 20 & 17.3 & 86.5 & $33-145$ & Yes \\
\hline Acenaphthene & 10 & 8.22 & 82.2 & $47-145$ & Yes \\
\hline Fluorene & 2 & 1.19 & 59.5 & $59-121$ & Yes \\
\hline Phenanthrene & 1 & 0.853 & 85.3 & $54-120$ & Yes \\
\hline Anthracene & 1 & $\mathrm{ND}^{2}$ & 0.0 & $27-133$ & No \\
\hline Fluoranthene & 2 & 1.44 & 72.0 & $26-137$ & Yes \\
\hline Pyrene & 1 & 0.634 & 63.4 & $52-115$ & Yes \\
\hline Chrysene & 1 & 0.844 & 84.4 & $17-168$ & Yes \\
\hline Benzo(a)anthracene & 1 & 0.694 & 69.4 & $33-143$ & Yes \\
\hline Benzo(b)fluoranthene & 2 & 1.4 & 70.0 & $24-159$ & Yes \\
\hline Benzo(k)fluoranthene & 1 & 0.713 & 71.3 & $11-162$ & Yes \\
\hline Benzo(a)pyrene & 1 & 0.484 & 48.4 & $17-163$ & Yes \\
\hline Indeno(1,2,3-cd)pyrene & 1 & $\mathrm{ND}^{2}$ & 0.0 & D-171 & No \\
\hline Dibenz(a,h)anthracene & 2 & $\mathrm{ND}^{2}$ & 0.0 & D-227 & No \\
\hline Benzo(g,h,i)perylene & 2 & $\mathrm{ND}^{2}$ & 0.0 & D-219 & No \\
\hline Other Compounds Reported & & & & & - \\
\hline Acetophenone & 0 & 0.694 & -- & - & - \\
\hline Benzoic Acid & 0 & 14.2 & - & - & - \\
\hline Diethylphthalate & 0 & 0.689 & - & - & - \\
\hline \hline
\end{tabular}

Recovery DQOs (\%) were taken from Radian's QA plan (Page C9-10).

$\mathrm{ND}=$ not detected.

This compound was spiked at a concentration below the reported detection limit of $1.33 \mu \mathrm{g}$. 
Radian PE Samples

Yates Plant Audit

Page 7 of 9

September 30, 1993

SVOC RECOVERIES FROM XAD-2 MODULES

SAMPLE ID: Y173-177 (Combined)

\begin{tabular}{||l|c|c|c|c|c||}
\hline \multicolumn{1}{|c|}{ ANALYTE } & $\begin{array}{c}\text { RTI } \\
\text { VALUE } \\
(\boldsymbol{\mu} \mathbf{g})\end{array}$ & $\begin{array}{c}\text { RADIAN } \\
\text { VALUE } \\
(\boldsymbol{\mu g})\end{array}$ & $\begin{array}{c}\text { PERCENT } \\
\text { RECOVERY }\end{array}$ & $\begin{array}{c}\text { RECOVERY } \\
\text { DQO (\%) }\end{array}$ & $\begin{array}{c}\text { DQO } \\
\text { MET }\end{array}$ \\
\hline \hline Naphthalene & 35.0 & 30.1 & 86.0 & $21-133$ & Yes \\
\hline Acenaphthylene & 70.0 & 62.8 & 89.7 & $33-145$ & Yes \\
\hline Acenaphthene & 35.0 & 28.7 & 82.0 & $47-145$ & Yes \\
\hline Fluorene & 7.0 & 4.53 & 64.7 & $59-121$ & Yes \\
\hline Phenanthrene & 3.5 & 2.54 & 72.6 & $54-120$ & Yes \\
\hline Anthracene & 3.5 & 2.5 & 71.4 & $27-133$ & Yes \\
\hline Fluoranthene & 7.0 & 4.42 & 63.1 & $26-137$ & Yes \\
\hline Pyrene & 3.5 & 2.13 & 60.8 & $52-115$ & Yes \\
\hline Chrysene & 3.5 & 1.52 & 43.4 & $17-168$ & Yes \\
\hline Benzo(a)anthracene & 3.5 & 1.65 & 47.1 & $33-143$ & Yes \\
\hline Benzo(b)fluoranthene & 7.0 & 2.82 & 40.3 & $24-159$ & Yes \\
\hline Benzo(k)fluoranthene & 3.5 & 1.62 & 46.3 & $11-162$ & Yes \\
\hline Benzo(a)pyrene & 3.5 & 1.33 & 38.0 & $17-163$ & Yes \\
\hline Indeno(1,23-cd)pyrene & 3.5 & 1.33 & 38.0 & D-171 & Yes \\
\hline Dibenz(a,h)anthracene & 7.0 & 2.14 & 30.6 & D-227 & Yes \\
\hline Benzo(g,h,i)perylene & 7.0 & 2.19 & 31.3 & D-219 & Yes \\
\hline Other Materials Recovered & & & & & - \\
\hline Benzoic Acid & 0 & 60.3 & -- & & - \\
\hline \hline
\end{tabular}

Recovery DQOs (\%) were taken from Radian's QA plan (page C9-10). 
Radian PE Samples

Yates Plant Audit

Page 8 of 9

September 30, 1993

VOLATILE ORGANICS ON TENAX (VOST)

SAMPLE ID: Y194

\begin{tabular}{|c|c|c|c|c|c|}
\hline COMPOUNDS & $\begin{array}{c}\text { RTI } \\
\text { AMOUNT } \\
\text { (ng) }\end{array}$ & $\begin{array}{c}\text { RADIAN } \\
\text { AMOUNT } \\
\text { (ng) }\end{array}$ & $\begin{array}{l}\text { PERCENT } \\
\text { RECOVERY }\end{array}$ & $\begin{array}{c}\text { RECOVERY' } \\
\text { DQO (\%) }\end{array}$ & $\begin{array}{l}\text { DQO } \\
\text { MET }\end{array}$ \\
\hline Vinyl Chloride & 40.10 & 48 & 119.7 & $50-150$ & yes \\
\hline Chloroform & 87.60 & 110 & 125.6 & $50-150$ & yes \\
\hline Carbon Tetrachloride & 123.28 & 140 & 113.6 & $50-150$ & yes \\
\hline Methylene Chloride & 112.98 & 5700 & 5045.1 & $50-150$ & no \\
\hline 1,2 Dichloroethane & 74.04 & 53 & 71.5 & $50-150$ & yes . \\
\hline Trichlorethylene & 103.69 & 120 & 115.7 & $50-150$ & yes \\
\hline Benzene & 63.73 & 74 & 116.1 & $50-150$ & yes \\
\hline Tetrachloroethylene & 141.40 & 120 & 84.9 & $50-150$ & yes \\
\hline 1,3-Butadiene ${ }^{1}$ & 25.94 & - & - & $50-150$ & - \\
\hline Bromomethane & 125.33 & 130 & 103.7 & $50-150$ & yes \\
\hline Trichlorofluoromethane & 217.11 & 470 & 216.5 & $50-150$ & no \\
\hline 1,1,1-Trichloroethane & 148.77 & 230 & 154.6 & $50-150$ & no \\
\hline 1,2-Dichloropropane & 192.00 & 160 & 83.3 & $50-150$ & yes \\
\hline 1,2-Dibromoethane ${ }^{2}$ & 300.37 & - & - & $50-150$ & - \\
\hline Toluene & 151.68 & 2300 & 1516.4 & $50-150$ & no \\
\hline Chlorobenzene & 177.43 & 53 & 29.9 & $50-150$ & no \\
\hline Ethylbenzene & 153.86 & 120 & 78.0 & $50-150$ & yes \\
\hline Ortho-Xylene & 159.30 & 71 & 44.6 & $50-150$ & no \\
\hline \multicolumn{6}{|c|}{ Other Compounds Reported } \\
\hline Acetone & 0 & 120 & -- & - & - \\
\hline
\end{tabular}

$1 \quad$ Recovery DQOs (\%) were taken from Radian's QA plan (page C9-10).

2 This compound was not identified or analyzed by Radian's subcontractor, Air Toxics Limited. 
Radian PE Samples

Yates Plant Audit

Page 9 of 9

September 30, 1993

\section{VOLATILE ORGANICS ON TENAX (VOST)}

SAMPLE ID: Y195

\begin{tabular}{|c|c|c|c|c|c|}
\hline COMPOUNDS & $\begin{array}{c}\text { RTI } \\
\text { AMOUNT } \\
\text { (ng) }\end{array}$ & $\begin{array}{c}\text { RADIAN } \\
\text { AMOUNT } \\
\text { (ng) }\end{array}$ & $\begin{array}{l}\text { PERCENT } \\
\text { RECOVERY }\end{array}$ & $\begin{array}{l}\text { RECOVERY }^{\mathbf{1}} \\
\text { DQO (\%) }\end{array}$ & $\begin{array}{l}\text { DQO } \\
\text { MET }\end{array}$ \\
\hline Vinyl Chloride & 78.83 & 98 & 124.3 & $50-150$ & yes \\
\hline Chloroform & 172.22 & 250 & 145.2 & $50-150$ & yes \\
\hline Carbon Tetrachloride & 242.36 & 360 & 148.5 & $50-150$ & yes \\
\hline Methylene Chloride & 222.11 & 5800 & 2611.3 & $50-150$ & no \\
\hline 12 Dichloroethane & 145.55 & 150 & 103.1 & $50-150$ & yes \\
\hline Trichlorethylene & 203.84 & 320 & 157.0 & $50-150$ & no \\
\hline Benzene & 125.29 & 190 & 151.6 & $50-150$ & no \\
\hline Tetrachloroethylene & 277.98 & 350 & 125.9 & $50-150$ & yes \\
\hline 1,3-Butadiene $\mathrm{I}^{\mathrm{I}}$ & 51.00 & - & - & $50-150$ & - \\
\hline Bromomethane & 246.38 & 180 & 73.1 & $50-150$ & yes \\
\hline Trichlorofluoromethane & 426.82 & 660 & 154.6 & $50-150$ & no \\
\hline 1.1.1-Trichloroethane & 292.47 & 550 & 188.1 & $50-150$ & no \\
\hline 12-Dichloropropane & 377.45 & 410 & 108.6 & $50-150$ & yes \\
\hline 1,2-Dibromoethane ${ }^{2}$ & 590.50 & - & - & $50-150$ & - \\
\hline Toluene & 298.18 & 4000 & 1341.5 & $50-150$ & no \\
\hline Chlorobenzene & 348.80 & 170 & 48.7 & $50-150$ & no \\
\hline Ethylbenzene & 302.47 & 420 & 138.9 & $50-150$ & yes \\
\hline Ortho-Xylene & 313.17 & 290 & 92.6 & $50-150$ & yes \\
\hline \multicolumn{6}{|c|}{ Other Compounds Reported } \\
\hline Acetone & 0 & 160 & - & - & - \\
\hline
\end{tabular}

Recovery DQOs (\%) were taken from Radian's QA plan (page C9-10).

This compound was not identified or analyzed by Radian's subcontractor. Air Toxics Limited. 


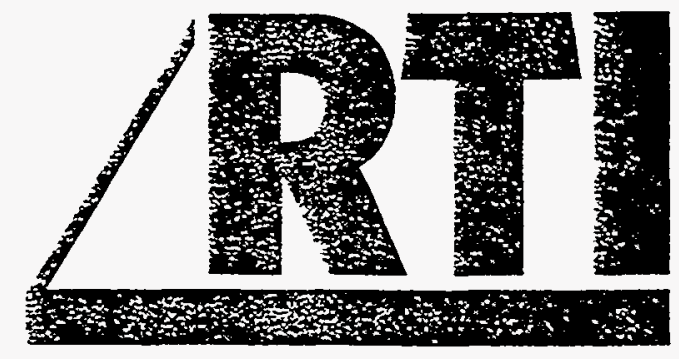

RESEARCH TRIANGLE INSTITUTE RTI/5960/193 - 04D

August 6, 1993

\section{QA/QC AUDITS ON DOE UTILITY BOILER TEST PROGRAM \\ FIELD SAMPLING AUDIT REPORT}

Site: Yates Station Unit 1, Newnan, GA

DOE Contractor: Radian Corporation

DOE Project Officer. Janice Murphy

Performed for

Joseph A. McSorley

EPA Work Assignment Manager

Office of Air Quality Planning and Standards

U.S. Environmental Protection Agency

Research Triangle Park, NC 27711

Prepared by

Research Triangle Institute

P.O. Box 12194

Research Triangle Park, NC 27709

RTI Work Assignment Leader: Shirley J. Wasson

Under EPA Contract No. 68D10009

Work Assignment No. I-193 



\title{
Field Audit of:
}

\author{
Yates Station Unit 1 \\ Georgia Power Company \\ Newnan, Georgia \\ Contractor: Radian Corporation \\ Dates: June 23-25, 1993 \\ RTI Personnel: J. B. Flanagan and C. O. Whitaker
}

\section{Introduction}

The Yates Station Unit 1 is a bituminous coal-fired steam-electricity-generating unit with a net generating capacity of 105 megawatts. The station is located near Newnan, Georgia, and is owned and operated by Georgia Power Company. Unit 1 has a tangentially fired boiler manufactured by Combustion Engineering in 1949. During this test, the unit was fueled with $2.5 \%$ sulfur blend of Illinois No. 5 and Illinois No. 6 bituminous coals. The feed coal is a 50:50 blend mined from the "Arch Captain" and "Old Ben Franklin" mines.

The plant uses electrostatic precipitators for particulate control. Unit 1 currently controls sulfur dioxide $\left(\mathrm{SO}_{2}\right)$ using a Jet Bubbling Reactor (JBR) supplied under the CT-121 demonstration project. Sampling for the hazardous air pollutants (HAP) study is being carried out by Radian Corporation, which also operates the CT-121 demonstration project in cooperation with Georgia Power and DOE. The JBR process combines conventional limestone flue gas desulfurization (FGD) chemistry, forced oxidation, and gypsum crystallization in one reaction vessel. It is designed to operate in a medium-acid solution, where limestone is completely soluble and where the sulfite resulting from $\mathrm{SO}_{2}$ absorption can be oxidized completely to sulfate. Attrition of gypsum crystals and problems of poor sludge quality and chemical scaling are also eliminated due to improvements of the second generation FGD process. The process is not specifically designed to destroy pollutants such as $\mathrm{NO}_{2}$ or organics.

\section{Findings}

1. Finding: Basis due to long sampling lines from the calibration tanks to the probes and nonlinearity of the continuous emission monitor (CEM) system may go undetected due to infrequent multipoint calibrations. Line losses and multipoint calibrations are not normally measured and multipoint calibrations are not performed during the demonstration program; the next scheduled full calibration is scheduled for the changeover to Phase II of the demonstration program some time this fall. Daily zero-span checks are conducted for all CEMs. 
Effect on Data: If there is loss of calibration gas in the 300 to 600 feet of tubing running from the cylinders to the probes, the span result will be biased. Sulfur dioxide is particularly sensitive to decomposition reactions on surfaces. The potential for nonlinearity is unknown in the absence of regularly scheduled multipoint calibrations.

2. Finding: Aldehyde measurements were performed in accordance with the method; however, acetone, (a possible contaminant) was present in the mobile laboratory as a wash bottle under the hood.

Effect on Dara: Any acetone that might be found in the samples would be suspect.

3. Finding: All plant and sampling times are recorded in Central Daylight Savings Time instead of Eastern Daylight Savings Time. The central power grid is controlled by Georgia Power's headquarters in Alabama, which is in the Central time zone. Yates plant personnel have adopted Central time to coordinate with the central operations. To avoid confusion, Radian also adopted Central time in conducting the HAP project.

Effect on Data: Radian and plant personnel were all well-aware of this situation; however, special care should be taken to cross-check data to avoid confusion in sampling times during data validation.

4. Finding: Sampling data are hand-entered from field sheets into a portable computer each day, making occasional typographical errors virtually unavoidable.

Effect on Data: Data validation procedures such as duplicate keying or $100 \%$ comparison with original sheets should be used to minimize these errors.

\section{Observations}

This section includes general observations for which no adverse effect on the data could necessarily be predicted, but which had the potential to differentiate results at this site from results at other sites.

1. Radian sent an analyst and a high performance liquid chromatography (HPLC) instrument to the site for $\mathrm{Cr}^{5 \mathrm{~V}}$ measurements. Having the analyses performed on-site provides faster results: a $1 / 2$ - to 2 -hour turnaround versus 24 hours or more when samples are sent back to an off-site laboratory. This conscientious effort to obtain more timely analyses of this unstable material should be taken into account when comparing Radian's results for $\mathrm{Cr}^{\mathrm{FV}}$ with those from other contractors. 
2. The "Nick Bloom" method for sampling vapor phase mercury differed from that of another contractor on this project in that differently sized charcoal tubes were used and different methods of analysis will be used. Radian also used a soda-ash tube in conjunction with the charcoal tube which was intended to allow discrimination between oxidation states of mercury. Results of different contractors may not be comparable if different implementations of this method are employed.

\section{Activities}

1. Meetings

Audit activities included three meetings between RTI, DOE, Georgia Power, and Radian personnel. An initial meeting was held on $6 / 22$ and an exit meeting on $6 / 24$. Additionally, there was a meeting on the afternoon of $6 / 22$ in which the Georgia Power representatives expressed concerns about data security for the JBR project and misgivings about having "EPA representatives" on-site. Dr. Flanagan called Ms. Wasson, the RTI Project Leader, to inform her of this development immediately after this meeting. Dr. Kulkarni of RTI and Mr. Brown of DOE were contacted later the same day. No further concerns were expressed, however, and the remainder of the audit proceeded normally. Mr. Roy Clarkson, a representative of Georgia Power, reviewed all data to be taken from the site at the exit meeting on $6 / 24$. This information consisted only of the auditor's logbooks and checklists and some blank data forms obtained from Radian. Mr. Al Williams, the Radian Project Manager, made the decision not to release copies of any completed data sheets requested by the auditors based on Georgia Power's concerns.

During one of the meetings with Radian personnel, it was learned that the "major" element(s) for independent mass balance determination had not been selected. This was presumably under negotiation between Radian and DOE as a change in scope.

2. Performance Evaluation Audit

a) Orsat Determination - Mr. Tom Peters of Radian was observed by Mr. Craig Whitaker of RTI while performing the Orsat procedure using test gas supplied by RTI. The audit gas concentration for tank ID number BLM002689 was $9.21 \%$ oxygen in dry nitrogen. Correct procedures appeared to be followed. The following data were taken. Acceptable agreement was found for oxygen. Neither carbon dioxide nor carbon monoxide was present in the tank, and none was found. 
Replicate

1

2

Orsat Result (mL oxvgen)

\author{
9.0
}

9.0

Average: $\quad 9.0$

Initial volume was $100 \mathrm{~mL}$

$9.0 \mathrm{~mL} / 100 \mathrm{~mL} \times 100=9.0 \%$ found by Orsat.

Percent Difference $=\frac{9.0 \%-9.2 \%}{9.2 \%} \times 100=-2.17 \%$

b) Performance Audit of Source Sampling Consoles - Mr. Whitaker provided a standardized orifice (ID number 117) to the sampling console operators. They' were instructed to set a constant flow using the orifice and to measure the volumine indicated by the console's dry gas meter during a 10- or 20-minute sampling period. Operators reported a pressure drop across the RTI orifice, dry gas meter volume, and temperature. Results are tabulated in the following table. "Calculated Volume," the fifth column in the table, was calculated by RTi based on the orifice constant and pressure drop, multiplied by the run time.

CONSOLE (DRY GAS METER VOLUME) PERFORMANCE AUDIT RESULTS*

\begin{tabular}{|c|c|c|c|c|c||}
\hline $\begin{array}{c}\text { Radian } \\
\text { console } \\
\text { serial } \\
\text { number }\end{array}$ & $\begin{array}{c}\text { Console } \\
\text { location }\end{array}$ & $\begin{array}{c}\text { Run } \\
\text { time } \\
\text { (min) }\end{array}$ & $\begin{array}{c}\text { Radian } \\
\text { console dry } \\
\text { gas meter } \\
\text { volume (scf) }\end{array}$ & $\begin{array}{c}\text { Calculated } \\
\text { volume based on } \\
\text { flow using RTI } \\
\text { orifice (scf) }\end{array}$ & $\begin{array}{c}\text { Relative } \\
\text { Percent } \\
\text { difference }\end{array}$ \\
\hline A161:362 & Stack & 20 & 13.98 & 15.450 & -9.5 \\
\hline A161394 & Stack & 21 & 16.59 & 16.404 & 1.1 \\
\hline 161364 & ESP outlet & 10 & 7.89 & 7.711 & 2.3 \\
\hline A161395** & ESP outlet & $10^{* *}$ & 7.50 & .8 .495 & -11.7 \\
\hline
\end{tabular}

* Acceptance criteria $\pm 10 \%$.

** This audit data set did not include a meter run stop time; however, runs were requested for 10 minutes and the data appear consistent with a 10-minute run time. 
c) VOST Sampling - The operator demonstrated extensive knowledge in the operation and process. Cartridges were inscribed with flow directions and encapsulated before and after use. Two sets of tenax and tenax/charcoal were exposed to measured flows of test gas supplied by RTI. Exposure periods were 10 and 20 minutes. Because analytical results must be received before these audit samples can be evaluated, the tube numbers, compounds, and concentrations will be reported in a separate memorandum.

d) Continuous Emissions Monitors (CEMs) - The facility would not allow RTI to audit the installed monitors, but the system functions were explained by the operator, Mr. Jeff Nelms. The cylinders used for daily zero and span checks were found to be Protocol No. 1 gases. Serial numbers and concentrations for these zero/span gases are provided in the following table.

CEM SPAN GAS SUMMARY

\begin{tabular}{|c|c|c|c|c|}
\hline Vendor & Cylinder & Compound & Concentration & $\begin{array}{c}\text { Expiration } \\
\text { date }\end{array}$ \\
\hline \hline Scott & AAL-13190 & $\begin{array}{c}\text { Nitric oxide } \\
\text { Sulfur dioxide } \\
\text { Nitrogen }\end{array}$ & $\begin{array}{c}360 \mathrm{ppm} \\
1791 \mathrm{ppm} \\
\text { balance }\end{array}$ & $5-18-95$ \\
\hline Scott & AAL-17497 & $\begin{array}{c}\text { Oxygen } \\
\text { Nitrogen }\end{array}$ & $\begin{array}{c}20.9 \% \\
\text { balance }\end{array}$ & $5-18-96$ \\
\hline Scott & AAL-4472 & Sulfur dioxide & $241 \mathrm{ppm}$ & $1-4-95$ \\
\hline
\end{tabular}

Two locations are being monitored by the CEMs: the ESP outlet (immediately upstream of the JBR) and the stack (downstream of the JBR). The following information is being acquired at each location:

ESP outlet (upstream of JBR):

- Temperature

- Opacity

- Oxygen

$-\mathrm{NO}_{\mathrm{x}}$

$-\mathrm{SO}_{2}$

Stack (downstream of JBR):

- Temperature

- Oxygen

$-\mathrm{SO}_{2}$ 
Because different gases are being monitored at the two locations, different span gas combinations and concentrations were used.for.the span checks. For the stack gas analyzers, cylinder AAL-4472 $\left(\mathrm{SO}_{2}\right.$ in $\left.\mathrm{N}_{2}\right)$ and cylinder AAL-17497 $\left(\mathrm{O}_{2}\right.$ in $\left.\mathrm{N}_{2}\right)$ were used. On the ESP outlet upstream of the JBR, cylinder AAL-13190 (NO and $\mathrm{SO}_{2}$ in $\mathrm{N}_{2)}$ and cylinder AAL-17497 $\left(\mathrm{O}_{2}\right.$ in $\left.\mathrm{N}_{2}\right)$ were used. Cylinders of zero air were also present for zero determination. According to site personnel, tanks are replaced at intervals of approximately 1 to 2 months. This rather rapid turnover of standard gases is due to the large volume required to fill and purge the hundreds of feet of tubing between the tank, the sampling point, and the analyzers, as described in the next paragraph.

Heated sample lines are used to carry the calibration gas to the probes. The calibration gas then flows back to the CEMs through the same lines that are used acquire gas samples. As part of the audit, the heated sample lines were traced and verified by the operator, who estimated that the fetch (one-way distance from the probe to the CEMs) was 300 to 350 feet. The fetch to the ESP outlet duct probe was estimated to be approximately 600 feet.

3. Technical Systems Audit

The following table summarizes the activities observed by the auditors.

OPERATIONS OBSERVED DURING TSA

\begin{tabular}{|c|c|c|c|}
\hline Medium & Location & Auditor & Comment \\
\hline \hline Coal, 1/4" feed & boiler building & Flanagan, Whitaker & $\begin{array}{c}\text { Periodic grab } \\
\text { samples collected } \\
\text { into plastic bucket }\end{array}$ \\
\hline Coal, pulverized & boiler building & Flanagan, Whitaker & $\begin{array}{c}\text { Cyclone used to } \\
\text { capture high- } \\
\text { pressure suspension } \\
\text { of coal powder } \\
\text { prior to burner }\end{array}$ \\
\hline Pyrite reject & boiler building & Flanagan, Whitaker & $\begin{array}{c}\text { All material caught } \\
\text { in plastic buckets }\end{array}$ \\
\hline $\begin{array}{c}\text { Boiler bottom ash } \\
\text { (slurry) }\end{array}$ & $\begin{array}{c}\text { sluice pipe outlet at } \\
\text { ash pond }\end{array}$ & Flanagan, Whitaker & $\begin{array}{c}\text { Dipper samples } \\
\text { alternately filling } \\
\text { two glass carboys }\end{array}$ \\
\hline
\end{tabular}


OPERATIONS OBSERVED DURING TSA (continued)

\begin{tabular}{|c|c|c|c|}
\hline Medium & Location & Auditor & Comment \\
\hline $\begin{array}{l}\text { Condenser water } \\
\text { inlet }\end{array}$ & boiler building & Flanagan & $\begin{array}{l}\text { From spigot }-- \text { tube } \\
\text { allowed to run } \\
\text { before sampling }\end{array}$ \\
\hline $\begin{array}{c}\text { Condenser water } \\
\text { outlet }\end{array}$ & boiler building & not being sampled & $\begin{array}{l}\text { Sample point } \\
\text { inaccessible }\end{array}$ \\
\hline Flue gas & ESP inlet & Whitaker & \\
\hline Flue gas & ESP outlet & Whitaker & \\
\hline Stack gas (JBR out) & Stack & Whitaker & \\
\hline $\begin{array}{l}\text { ESP hopper ash } \\
\text { (slurry) }\end{array}$ & $\begin{array}{l}\text { sluice pipe outlet at } \\
\text { ash pond }\end{array}$ & Flanagan & $\begin{array}{l}\text { Dipper samples } \\
\text { alternately filling } \\
\text { two glass carboys }\end{array}$ \\
\hline JBR makeup water & JBR area & Flanagan & \\
\hline JBR slurry density & $\begin{array}{l}\text { JBR area -- density } \\
\text { meter slip stream }\end{array}$ & Flanagan & $\begin{array}{l}\text { Nuclear density } \\
\text { meter out of service }\end{array}$ \\
\hline Limestone & limestone silo & not observed & \\
\hline Coal pile runoff & coal pile & not observed & $\begin{array}{c}\text { No rain during } \\
\text { audit }\end{array}$ \\
\hline $\mathrm{Cr}^{\mathrm{IV}}$ measurement & $\begin{array}{l}\text { JBR Project } \\
\text { Laboratory }\end{array}$ & Flanagan & $\begin{array}{c}\text { Actual samples not } \\
\text { seen; calibration } \\
\text { only }\end{array}$ \\
\hline $\begin{array}{l}\text { XAD-2 cartridge } \\
\text { spike for semi- } \\
\text { volatiles }\end{array}$ & laboratory trailer & Flanagan & \\
\hline Metals train spikes & laboratory trailer & Flanagan & \\
\hline VOST challenge & stack sampling area & Whitaker & \\
\hline $\begin{array}{l}\text { Orsat procedure } \\
\text { (oxygen) }\end{array}$ & laboratory trailer & Whitaker & Acceptable results. \\
\hline
\end{tabular}




\section{$\underline{\text { Recominendations }}$}

1. Unusually large differences were seen when RTI's standard orifice was used to test some of the sampling consoles used for source testing. These consoles are scheduled to be re-tested after their return to the laboratory and the results compared with the calibrations prior to the site test. Because of the discrepancies observed with the RTI orifice, the calibration results should be reported to DOE as soon as they are available. The pre- and post-test calibrations must agree within $5 \%$ or the data must be corrected. For regulatory purposes, the factor giving the higher emission estimate would be applied; however, for the research work under this project, an average of the two factors would probably be more appropriate.

2. Mass flow rates for solids such as bottom ash and ESP ash are calculated based on coal feed rates and percentage ash in the coal obtained by proximate/ultimate analysis. One or more independent, direct methods of measuring or estimating the amount of ash produced should be attempted. For example, one such method for independently calculating ash production rates would involve multiplying the ash slurry average mass concentration by the length of time the slurry flows and by the flow rate out of the pipe. Ash concentration in the slurry can be obtained by taking representative, timeproportional samples throughout the length of time the slurry flows. Flow rates can be measured at the outfall or obtained from the plant. Intercomparison of different estimates will increase the confidence in the validity of the mass balance calculations. This is a problem common to all contractors at all sites.

3. Because auditors were not allowed to take any completed Radian data sheets off-site, a data audit should be conducted in which raw data sheets, computer-logged data, logbooks, validation procedures, and calculations are examined.

4. A multi-point calibration has not been conducted on the CEMs used for the demonstration project since November 17-20, 1992. The CEMs are not scheduled for another calibration until the next phase of the JBR project, which begins in the fall. This would result in more than a year between calibrations. It is recommended that Georgia Power and Radian make provision to conduct multipoint calibrations at intervals of no more than six months for $\mathrm{SO}_{2}, \mathrm{NO}_{x}$, and $\mathrm{O}_{2}$. If possible, line losses between the span gas cylinders and the probes should also be determined at this time.

5. It is recommended that the major elements for mass balance determination be discussed and finalized between DOE and Radian, if this has not already been done. 
Personnel Present During Site Visit

$\begin{array}{lll}\text { Name } & \text { Organization } & \text { Telephone } \\ \text { Chuck Schmidt } & \text { DOE } & (412) 892-4690 \\ \text { Tim McIlvried } & \text { DOE } & \\ \text { Dave Burford } & \text { Georgia Power } & (404) 253-2111 \\ \text { Roy Clarkson } & \text { Georgia Power } & \\ \text { Jeff Nelms } & \text { Georgia Power } & \\ \text { Al Williams } & \text { Radian } & (512) 454-4797 \\ \text { Ira Pearl } & \text { Radian } & (512) 454-4797 \\ \text { Barbara Hayes } & \text { Radian } & (512) 454-4797 \\ \text { Renee Cravin } & \text { Radian } & (512) 454-4797 \\ \text { Dave Virbick } & \text { Radian } & (512) 454-4797 \\ \text { Dave Maxwell } & \text { Radian } & (512) 454-4797 \\ \text { Benji Cox } & \text { Radian } & (512) 454-4797 \\ \text { Tom Peters } & \text { Radian } & (512) 454-4797 \\ \text { Ed Zabasaija } & \text { Radian } & (512) 454-4797 \\ \text { Tom Baraga } & \text { Radian } & (512) 454-4797 \\ \text { Jim McGee } & \text { Radian } & (512) 454-4797 \\ \text { Jim Hand } & \text { Radian } & (512) 454-4797 \\ \text { Lori Rodriquez } & \text { Radian } & (512) 454-4797 \\ \text { Jim Flanagan } & \text { RTI } & (919) 541-6417 \\ \text { Craig Whitaker } & \text { RTI } & (919) 541-5988\end{array}$




\section{APPENDIX B: SAMPLING PROTOCOL}

Radian used established sampling methods, where possible, to collect representative samples from the various sampling locations within the Yates plant site. The sampling locations at Plant Yates Boiler No. 1 and the various plant processes included:

- Boiler inlet, outlet, and sluice streams;

- ESP inlet, outlet, and ash streams;

- FGD system inlet, outlet, and slurry streams; and

- Stack gas.

For most of the sources, the sampling methods used were standard methods with known performance characteristics, specific for the collection of a representative sample according to the stream matrix. These methods, summarized in Table B-1, provide data for comparisons with industry standards.

\section{Gas Streams}

The following section presents the methodology to collect samples from gaseous streams.

\section{Particulate Loading}

EPA Reference Method $5^{1}$ or EPA Reference Method $17^{2}$ was performed to determine particulate loading at the selected sampling locations at Plant Yates. Method 5 was used at the stack and ESP outlet locations and Method 17 was used at the ESP inlet sampling location. These methods provided isokinetic extraction of particulate matter on a glass fiber filter. However, since particulate loading determinations were performed in conjunction with the sampling for particulate and vapor-phase metals, quartz fiber filters were used in place of glass. The particulate mass, which included all material that condenses at or above the filtration temperature, was determined gravimetrically, after the removal of uncombined water. 
Appendix B: Sampling Protocol

\section{Table B-1}

\section{Summary of Sampling Methods}

\begin{tabular}{|c|c|c|c|}
\hline Stream Type & Parameter & Frequency & Sampling Method \\
\hline Solids & All & $\begin{array}{l}\text { Grab sample hourly to com- } \\
\text { posite per test run (time- } \\
\text { averaged composite) }\end{array}$ & $\begin{array}{l}\text { EPA Method S007 (trowel/ } \\
\text { scoop) }\end{array}$ \\
\hline Liquids & All & $\begin{array}{l}\text { Grab sample hourly to com- } \\
\text { posite per test (time-averaged } \\
\text { composite)a }\end{array}$ & $\begin{array}{l}\text { EPA Method S007 (trowel/ } \\
\text { scoop) EPA Method S004 } \\
\text { (tap) }\end{array}$ \\
\hline \multirow[t]{6}{*}{ Gases } & Volatile Organics & $\begin{array}{l}4 \text { pairs of VOST traps over } \\
2 \text {-hour time period }\end{array}$ & $\begin{array}{l}\text { VOST (SW-846 Method } \\
0030)^{5}\end{array}$ \\
\hline & Sémivolatile Organics & $\begin{array}{l}\text { Integrated sample over 4- to } \\
\text { 6-hour time period }\end{array}$ & $\begin{array}{l}\text { Modified Method } 5 \text { (SW-846) } \\
\text { Method } 0010^{6}\end{array}$ \\
\hline & $\begin{array}{l}\text { Vapor-Phase Inorganic/ } \\
\text { Organic Species }\end{array}$ & $\begin{array}{l}\text { Integrated sample over 4- to } \\
6 \text {-hour time period }\end{array}$ & $\begin{array}{l}\text { Various impinger solutions } \\
\text { sampling trains }\end{array}$ \\
\hline & Trace Elements (Metals) & $\begin{array}{l}\text { Integrated sample over } 1 \text { - to } \\
\text { 2-hour time period }\end{array}$ & Multi-metals sampling train ${ }^{7}$ \\
\hline & Particulate & $\begin{array}{l}\text { Integrated sample over } 1 \text { - to } \\
\text { 2-hour time period }\end{array}$ & $\begin{array}{l}\text { EPA Methods } 5^{8} \text { and } 17^{9} \\
\text { sampling trains }\end{array}$ \\
\hline & Particle Size Distribution & $\begin{array}{l}\text { Fixed point sample over } \\
\text { appropriate time period }\end{array}$ & In-stack cascade impactor \\
\hline
\end{tabular}

Solid and liquid samples for volatile organics analyses were sampled only once per day, per test run. 
The RM5 sampling system incorporated a calibrated glass nozzle, heated glass lined probe, heated oven (housing the filter holder and substrate), a condenser assembly, and a calibrated extraction system. The Method 17 sampling system was similar except an in-stack filtration system was used as opposed to the hot box and heated filter holder configuration of Method 5. Both systems operated under vacuum for extraction of effluent gas through leak free components. Both systems were leak checked before and after each individual test.

An extraction (sampling) rate was determined based upon preliminary measurements of temperature, flow rate, pressure, and moisture collected prior to the sampling program. The sampling rate was calculated from these variables to assist in providing and maintaining isokinetic sampling throughout the entire test period. At isokinetic conditions, the velocity of the stack gas entering the nozzle of the extraction system is equal to the effluent velocity at the sample point. The extraction system allowed manual adjustment of the sample rate when changes occurred in any of the variables that would affect isokinetic collection.

The individual stream gas velocities and the selection of the proper sample nozzle dictated the required sample time. The sampling was conducted at equal time intervals along the selected traverse points as determined by EPA Reference Method $1 .^{10}$

After each test sequence, the particulate samples were recovered. For Method 5, the collected sample included the particulate deposited inside the extraction nozzle, heated probe, and filter holder (designated as the front half probe and nozzle rinse, PNR), as well as the particulate collected on the filter substrate. The Method 17 collected sample included the particulate deposited inside the nozzle and collected on the in-stack filter.

\section{Particulate Metals and Vapor-Phase Metals}

Sampling for the collection of particulate and vapor-phase metals was performed in conjunction with Method 5 and 17 using the procedures detailed in EPA Conditional Method 29. Method 29 is similar to Method 5 with a few sample train modifications. Modifications to Method 5 included replacing the stainless steel nozzle and probe liner with glass components. Method 17 was modified to operate with a glass nozzle and a teflon coated thimble holder to reduce the possibility of metal contamination due to the sampling system. The particulate material was collected on quartz fiber substrates, replacing the standard glass fiber filters normally used with Methods 5 and 17 . Vapor-phase metals were collected in a series of impinger solutions. The first two impingers contained a dilute nitric acid and hydrogen peroxide solution. The third impinger was empty. The next two impingers contained acidic potassium permanganate solution for mercury collection. These impingers were followed by one dry impinger, and an impinger filled with silica gel. A minimum of 100 dry standard cubic feet of gas was collected isokinetically.

Sample recovery was performed in the on-site laboratory. An outline of the sample recovery procedure is detailed below: 
Appendix B: Sampling Protocol

1 - Petri dish - plastic - filter

1 - $500 \mathrm{~mL}$ glass - Acetone PNR. Rinse front half of filter holder with acetone into PNR bottle.

1 - $500 \mathrm{~mL}$ glass $-\mathrm{HNO}_{3}$ PNR. Rinse front half of filter holder into PNR bottle.

1 - $1000 \mathrm{~mL}$ plastic - 1 st \& 2nd Imp.

Rinse back half of filter holder and impingers with $0.1 \mathrm{~N} \mathrm{HNO}_{3}$ into sample bottle.

1 - $1000 \mathrm{~mL}$ glass - 3rd, 4th, \& 5th impingers. Rinse impingers with $0.1 \mathrm{~N} \mathrm{HNO}_{3}$ into sample bottle.

1 - $250 \mathrm{~mL}$ glass. Rinse 3rd, 4th \& 5th impingers with $8 \mathrm{~N} \mathrm{HCl}$.

Preservation - None

\section{Particle Size Distribution}

The particle size distribution of material in the sample gas was measured using cascade impactors. These impactors classify particulate matter with respect to aerodynamic particle size.

The impactor separated the particulate matter into seven size fractions (six impacted fractions and one fraction collected on the back-up filter). The isokinetic flow rate through the sampling nozzle was determined based on velocity data obtained during éarlier sampling (EPA Method 5). Operation of the impactor required the flow rate through the impactor be kept constant. This requirement eliminated the possibility of adjusting the flow rate if variations in stack gas velocity occurred. After sampling, the impactor was unloaded and the collected particulate material weighed. The weight gains were used to calculate the particle size distribution. The recovery outline is presented below:

10 - Petri dishes - plastic - filters

1 - $250 \mathrm{~mL}$ glass - acetone PNR. Rinse pre-cutter with acetone into PNR bottle.

Preservation - None

\section{Anions}

A Method 5-train was used to collect vapor-phase and solid-phase (particulate) acid gas species of hydrochloric, hydrofluoric, sulfuric and phosphoric acids along with sulfur dioxide and sulfur trioxide. The two sorbing impinger solutions for the acid gases were $200 \mathrm{~mL}$ of a carbonate/bicarbonate solution containing hydrogen peroxide followed by a dry impinger and an impinger filled with silica gel. The sample train was operated according to the procedures detailed in EPA Reference Method 5. 
Recovery procedures for the Anions train are presented below:

1 - Petri dish - Plastic - filter

1 - $500 \mathrm{~mL}$ plastic $-\mathrm{H}_{2} \mathrm{O}$ PNR. Rinse front half of filter holder with $\mathrm{H}_{2} \mathrm{O}$ into PNR bottle.

1 - 1,000 mL plastic - Impinger contents. Pour the contents of the first three impingers into sample bottle. Rinse back half of filter holder, connecting glassware and impingers with $\mathrm{H}_{2} \mathrm{O}$ into sample bottle.

Preservation - Keep cold $\left(<4^{\circ} \mathrm{C}\right)$

\section{Volatile Organics}

The volatile component determinations were performed using a volatile organic sampling train (VOST). ${ }^{11}$ In VOST, volatile organics were removed from the sample gas by sorbent traps maintained at $20^{\circ} \mathrm{C}$. The first resin trap contained Tenax and the second trap contained Tenax followed by petroleum-based charcoal. A dry gas meter was used to measure the volume of gas passed through the pair of traps. Sample volumes of 20 liters were collected on separate pairs of traps with a 0.5 liter per minute sampling rate. The samples were collected at a fixed point in the stack where the velocity matches the average gas velocity.

The VOST consisted of a quartz probe, water-cooled condensers, sorbent traps, and sample gas metering system. During sample collection, the Tenax traps were maintained at $20^{\circ} \mathrm{C}$. To further increase the collection efficiency, the sample gas was cooled and dried by passing it through a water-cooled condenser prior to its contact with the sorbent trap.

Before the initial assembly of the sampling train, all sample-contacting components were cleaned with non-ionic detergent, rinsed in HPLC-grade distilled water, and dried at $100^{\circ} \mathrm{C}$. The resin traps were stored in clean glass containers with Teflon-lined screw caps, the condensers and other glassware were covered with appropriate end caps prior to use.

Before use, the traps, the Teflon-filled ceramic ferules, and the hardware used in connecting the traps, were conditioned. The virgin Tenax and the charcoal were Soxhlet extracted with methanol. After the resins were dried under infrared lamps, they were placed in a vacuum oven for six hours at $50^{\circ} \mathrm{C}$. The tubes were packed individually and thermally conditioned for 12 hours at $200^{\circ} \mathrm{C}$ with organic free nitrogen at a rate of $40 \mathrm{~mL} / \mathrm{min}$. To check for emissions of volatile organic compounds, a tube from each batch was tested as a blank.

Leak checks were performed before and after collection of each pair of resin traps. After the post-collection leak check had been completed, the traps were sealed with end caps and returned to their respective glass containers for storage and transport. During storage and transportation, the traps were kept cool $\left(<4^{\circ} \mathrm{C}\right)$.

\section{Aldehydes}

Aldehydes were collected using a 2,4-dinitrophenylhydrazine (DNPH) train according to EPA Method $0011 .^{12}$ Sample collection was performed isokinetically following the procedures 
detailed in EPA Method 5. The impinger solutions were combined into one sample along with the methylene chloride glassware rinse. The solutions were sealed in amber glass containers with Teflon closures and stored at $4^{\circ} \mathrm{C}$.

\section{Semivolatile Compounds}

Semivolatile organics (SVs) determinations were performed using a Modified Method 5 $(M M 5)^{13}$ sampling train. The probe washes, filter catches, XAD sorbent traps, and aqueous condensates were extracted and analyzed for SVs according to SW-846 Method 8270 protocol. The MM5 sampling system consisted of a heated probe, heated filter, sorbent module, and pumping and metering unit. A gooseneck nozzle of an appropriate diameter to allow isokinetic sample collection was attached to the probe. S-type Pitot tube differential pressure was monitored to determine the isokinetic sampling rate.

From the heated filter, sample: gas entered the sorbent module. The sorbent module consisted of a water-cooled condenser followed by the XAD-2 resin trap. After the resin trap was a dry, modified Greenburg-Smith impinger which collected the aqueous condensate. The stem of this impinger was short to reduce carryover of collected aqueous condensate. Following the condensate trap were two water impingers that collected any mist carryover from the condensate trap, and a final impinger containing silica gel to dry the sample gas before metering. A pump and dry gas meter were used to control and monitor the sample gas flow rate.

Sampling of the stack gases was conducted in accordance with the published MM5 protocol. The sampling rate for each train was between 0.5 and $1.0 \mathrm{dscfm}$. A minimum of $106 \mathrm{dscf}$ was collected by each train over a minimum sampling period of two hours.

Sampling train preparation and sample retrieval were performed in a controlled environment to reduce the possibility of sample contamination. Prior to assembly, each component of the sampling train was thoroughly rinsed with methylene chloride.

After sample collection, the ends of the sampling train were sealed with solvent-rinsed foil and returned to the clean-up area for sample retrieval. The filter was recovered and placed in a methylene chloride-rinsed glass petri dish. Aqueous condensate collected in the first two impingers and in the sorbent trap was transferred to methylene chloride-rinsed amber glass bottles with Teflon-lined screw cap closures. All.components of the sampling train, from the nozzle through the sorbent module, including the probe, filter glassware, and impinger glassware were rinsed thoroughly with a solution of methylene chloride. The probe was cleaned using a nylon brush followed by rinsing with a methylene chloride. The probe rinse and glassware rinses were combined with the recovered condensate sample. The XAD-2 resin cartridges were sealed and transferred to the laboratory intact. The recovery procedures are outlined below:

1 - Petri dish - glass - filter

1 - $500 \mathrm{~mL}$ glass $-\mathrm{MeCl}_{2}$ PNR. Rinse front half of filter holder with $\mathrm{MeCl}_{2}$ into PNR bottle. 


\section{1 - XAD Resin Cartridge}

1 - $500 \mathrm{~mL}$ glass - Condensate. Pour the contents of the first two impingers into bottle. Discard third impinger $\mathrm{H}_{2} \mathrm{O}_{2}$ solution.

1 - $500 \mathrm{~mL}$ glass - $\mathrm{MeCl}_{2}$ Train Rinse. Rinse back half of filter holder, condenser, connecting glassware and impingers 1 and 2 with $\mathrm{MeCl}_{2}$ into sample bottle.

Preservation - Keep cold $\left(<4^{\circ} \mathrm{C}\right)$

\section{Dioxins and Furans}

Sampling for the collection of dioxins and furans present in the selected gas stream was performed using EPA Reference Method 23. ${ }^{14}$ Sample collection procedures specified in Method 23 were followed with the following exception:

- All train component rinses were performed with methylene chloride and acetone. An additional toluene rinse was then performed and added to the respective front half and back half acetone/methylene chloride rinse samples.

Sample rate, volume and procedures were identical to the MM5 procedures described above.

\section{Ammonia}

Sample collection for the determination of ammonia present in the gas streams was performed in conjunction with the anions sampling train. Similarly as with the anions sample train, gas was extracted isokinetically through a glass fiber filter then directed to an impinger train which contains the collection solution. For the collection of ammonia, dilute sulfuric acid was placed in the first two impingers of the condenser assembly. Recovery procedures for the ammonia train are presented below:

1 - 1,000 mL plastic - Impinger contents. Pour the contents of the first three impingers into sample bottle. Rinse connecting glassware and impingers with $\mathrm{H}_{2} \mathrm{O}$ into sample bottle.

\section{Hydrogen Cyanide}

Sample collection for the determination of hydrogen cyanide present in the gas streams was performed in conjunction with the ammonia sampling train. Gas was extracted isokinetically through a glass fiber filter then directed to an impinger train which contains the collection solution. For the collection of cyanide, dilute zinc acetate solution was placed in the third and fourth impingers of the ammonia train. Recovery procedures for the hydrogen cyanide portion of the train are presented below:

1 - $1,000 \mathrm{~mL}$ glass - Impinger contents. Pour the contents of the first three impingers into sample bottle. Rinse connecting glassware and impingers with $\mathrm{H}_{2} \mathrm{O}$ into sample bottle. 
Appendix B: Sampling Protocol

\section{Radionuclides}

Flue gas particulate samples for radionuclide analysis were collected using the approach defined by EPA Reference Methods 5 and 17 with one exception. The samples were collected at a single point in the duct representative of the average flue gas velocity. Filter samples were stored and transported in plastic petri dishes and thimbles were contained in plastic bottles.

\section{Extractable Metals}

Separate samples for extractable metals content were also collected using the single point isokinetic approach described for radionuclide sample collection. Quartz-fiber filter media was used to reduce the background metals contribution associated with glass fiber filters. Filter samples were stored and transported in glass petri dishes and thimbles were contained in glass bottles.

\section{Vapor-Phase Mercury by Charcoal Sorption}

Sampling for mercury speciation was performed using a sample train designed by Nicolas Bloom. ${ }^{15}$ The sampling train consists of a quartz probe, tandem pair of soda-lime traps, tandem iodated carbon traps, drierite cartridge and mass flow metering system. The sample train was assembled outside of the stack and leak checked to verify the sample integrity. The probe tip was placed at a single point in the stack that was determined to be representative of normal flow, based upon preliminary velocity measurements. The sample was extracted from the source with the sample rate adjusted to provide a 100 Liter sample collected over a minimum of two hours. At the completion of sampling, the train was leak checked and the sorbent tubes and probe liner recovered. Sorbent tubes were segregated based upon run and location and sealed in plastic bags for transport to the laboratory.

\section{Chrome VI}

Samples were collected via the BIF method for chromium (VI). ${ }^{16}$ This method used a nozzle, teflon lines, peristaltic pump for recirculating solution and impinger solutions. The impinger contained a known volume of $10 \mathrm{~N}$ potassium hydroxide. Samples were collected isokinetically from the outlet stack using the sampling procedures detailed in EPA Reference Method 5. At the completion of the sample collection period, the sample train was purged with ultrapure nitrogen prior to the recovery of the sample. The impinger solutions were recovered from the sample train, filtered, then transported to the on-site laboratory for analysis. All of the train components were rinsed with $0.1 \mathrm{~N}$ nitric acid and the rinse was retained for total chromium analysis.

\section{Solid Sampling Procedures}

Dry solid stream samples (raw coal, boiler feed coal, pulverizer rejects, limestone, and ESP hopper ash) were collected using grab sampling techniques. Individual grab samples of each stream were collected hourly throughout each test run and composited to generate a represen- 
tative, time-averaged composite sample. Composite samples of raw coal, boiler feed coal, pulverizer rejects, and raw limestone were riffled and split to produce a 1 kilogram (minimum) sample which was placed in a plastic bag and sealed for transportation to the laboratory.

Two composite samples of dry fly ash, one for each ESP field, were prepared from individual grab samples collected from ESP hoppers 1-4, and 5-8. For purposes of compositing, the mass distribution and removal efficiency were assumed to be uniform across the ESP inlet duct and across each bank of ESP ash hoppers. Consequently, the ash collected from each of the four hoppers in the same field were composited equally. Each composite sample was thoroughly mixed and stored in pre-cleaned glass bottles (for analysis of organic compounds), or in plastic bottles. Samples collected for organic compound analyses were refrigerated at $4^{\circ} \mathrm{C}$ and kept cool during transportation to the laboratory. No preservation was needed on samples for inorganic analyses.

Sluiced ash stream samples (bottom ash and ESP fly ash) were also collected using grab sampling techniques. Bottom ash, which is normally sluiced once per shift at Plant Yates, was sluiced prior to the beginning of each daily test run to remove accumulated ash material that was non-representative of the test period. Bottom ash sluicing operation was then secured immediately before, and throughout each daily test period. At the conclusion of each test period, sluicing operations were resumed while a sampler collected multiple grab samples with a polyethylene dipper. Samples were collected as long as there was visual evidence of bottom ash in the sluice water at concentrations high enough to warrant continued sampling.

These samples were composited directly into a large bucket where the ash was allowed to settle. After the ash had settled, the sluice water component was siphoned off to avoid disturbing the ash fines, and the wet ash mixed and bottled for storage and transportation to the laboratory. Samples for analysis of organic compounds were split from the composite sample and preserved in pre-cleaned, amber-glass containers by cooling to $4^{\circ} \mathrm{C}$.

Sluiced fly ash from the ESP hoppers was collected in a manner similar to bottom ash, except sluicing operations were performed continuously to avoid ash buildup in the ESP. Since the ESP ash sluicing system was combined with the sluiced economizer and air preheater ash, the systems were isolated before the start of the test run to avoid bias in the ESP ash composite. Grab samples were collected hourly from the sluice water discharge pipe to the ash pond. Like bottom ash, the fly ash was allowed to settle, and the sluice water component siphoned off to avoid disturbing the ash fines. The wet ash was mixed and bottled for storage and transportation to the laboratory. Samples for analysis of organic compounds were split from the composite sample and preserved in pre-cleaned, amber-glass containers by cooling to $4^{\circ} \mathrm{C}$.

Limestone and FGD slurry samples were collected using grab-tap sampling procedures. Sample taps were opened and allowed to purge immediately prior to collecting the process samples to insure representative sample collection. Hourly grab samples of limestone slurry were composited directly to a large container, and FGD slurry was filtered directly from the 
tap through a filter press. The limestone slurry composites were filtered after mixing. The recovered filter cakes were bottled for storage and transportation to the laboratory. Samples for analysis of organic compounds were split from the composite samples and preserved in pre-cleaned, amber-glass containers by cooling to $4^{\circ} \mathrm{C}$. Sub-samples of the FGD solids composite were also taken for the on-site analysis of sulfite and sulfate ions.

\section{Liquid Sampling Procedures}

Liquid samples were collected from both filtered and unfiltered sources. Raw, unfiltered water streams consisted of ash pond water, recycled gypsum pond water, coal pile run-off, and cooling water at the inlet of the steam condenser. Filtered streams consisted of bottom ash and fly ash sluice water, and limestone and FGD slurry filtrates.

Raw water samples were sampled by grab-tap sampling techniques. Hourly grab samples were composited into appropriate sample containers and preserved as soon as possible after sample collection. In some cases the sample was added directly to sample bottles containing the preservative in order to reduce the loss of the more volatile species (e.g. $\mathrm{NH}_{3}, \mathrm{CN}^{-}$). Table B-2 presents the liquid sample preservation techniques for specific analytes.

Filtrate samples were collected as described in the corresponding sluice water or slurry stream. Sluice water that was siphoned from the settled ash material was filtered in its entirety, split into the appropriate sample containers, and preserved according to the techniques presented in Table B-2. Slurry filtrates were also split into appropriate containers and preserved in the same manner as sluice water filtrates.

Sluice water and slurry filtrate samples collected for the analysis of volatile organic compounds and aldehydes present the only exception to the sample collection procedures described above. Due to the volatility of these analytes, bottom ash sluice water, ESP fly ash sluice water, limestone slurry, and FGD slurry samples were collected for volatile organics directly into VOA vials without filtration, and chilled to $4^{\circ} \mathrm{C}$.

\section{References}

1. 40 CFR 60, Appendix A. Test Methods. "Method 5: Determination of Particulate Emissions from Stationary Sources."

2. 40 CFR 60, Appendix A. Test Methods. "Method 17: Determination of Particulate Emissions from Stationary Sources (In-Stack Filtration Method)."

3. U.S. Environmental Protection Agency. "Method S007: Solid Grab Sample, Trowel (Scoop)," Sampling and Analysis Methods for Hazardous Waste Combustion. EPA600/8-84-002 (February 1984).

4. U.S. Environmental Protection Agency. "Method S004: Liquid Grab Sample, Tap," Sampling and Analysis Method for Hazardous Waste Combustion. EPA-600/8-84-002 (February 1984). 
5. U.S. Environmental Protection Agency. Office of Solid Waste. "Method 0030: Volatile Organic Sampling Train," Test Methods for Evaluating Solid Waste. SW-846, 3rd ed., Washington, D.C. (November 1986).

6. U.S. Environmental Protection Agency, Office of Solid Waste. "Method 0010: Modified Method 5 Sampling Train," Test Methods for Evaluating Solid Waste. SW846, 3rd. ed. Washington, D.C. (November 1986).

7. 40 CFR 266, Subpart H, "Method 29: Determination of Metals Emissions in Exhaust Gases from Hazardous Waste Incineration and Similar Combustion Processes: Proposed Method."

8. 40 CFR 60, Appendix A. Test Methods. "Method 5: Determination of Particulate Emissions from Stationary Sources."

9. 40 CFR 60, Appendix A. Test Methods. "Method 17: Determination of Particulate Emissions from Stationary Sources (In-Stack Filtration Method)."

10. 40 CFR 60, Appendix A. Test Methods. "Method 1: Sample and Velocity Traverses from Stationary Sources."

11. U.S. Environmental Protection Agency. Office of Solid Waste. "Method 0030: Volatile Organic Sampling Train," Test Methods for Evaluating Solid Waste. SW-846, 3rd ed., Washington, D.C. (November 1986).

12. 40 CFR 266, Appendix IX, Section 3.5. Methods Manual for Compliance with the BIF Regulations. "Sampling for Aldehyde and Ketone Emissions from Stationary Sources (Method 0011)."

13. U.S. Environmental Protection Agency. Office of Solid Waste. "Method 0010: Modified Method 5 Sampling Train," Test Methods for Evaluating Solid Waste. SW846, 3rd ed., Washington, D.C. (November 1986).

14. 40 CFR 266, Appendix IX: Methods Manual for Compliance with the BIF Regulations. "Determination of Polychlorinated Dibenzo-p-dioxins and Polychlorinated Dibenzofurans from Stationary Sources (Method 23)."

15. Bloom, Nicolas S., Eric M. Prestbo, and Vesna L. Miklavicic. "Fluegas Mercury Emissions and Speciations from Fossil Fuel Combustion." Published in the proceedings of the Second International Conference on Managing Hazardous Air Pollutants. Sponsored by the Electric Power Research Institute. Washington, D.C. (July 1993).

16. 40 CFR 266, Appendix IX: Methods Manual for Compliance with the BIF Regulations. "Determination of Hexavalent Chromium Emissions from Stationary Sources (Method $\left.\mathrm{Cr}^{6+}\right)$." 
Appendix B: Sampling Protocol

\section{Table B-2}

Preservation, Storage, and Holding Time Requirements for Liquid Samples

\begin{tabular}{|c|c|c|}
\hline Analytical Parameter & $\begin{array}{l}\text { Preservation and Storage } \\
\text { Requirements }\end{array}$ & $\begin{array}{l}\text { Maximum Holding } \\
\text { Time (Days) }\end{array}$ \\
\hline Volatile Organics & Cool $4^{\circ} \mathrm{C}$; amber glass VOA vial & 7 analyze \\
\hline Semivolatile Organics & Cool $4^{\circ} \mathrm{C}$; amber glass & 14 extract, 40 analyze \\
\hline Formaldehyde & Cool $4^{\circ} \mathrm{C}$; amber glass & 5 derivitize, 3 analyze \\
\hline Soluble Metals & Filter on-site; $\mathrm{HNO}_{3} \mathrm{pH}<2$ & 6 months analyze \\
\hline Total Metals & $\mathrm{HNO}_{3} \mathrm{pH}<2$; plastic & 6 months analyze $e^{2}$ \\
\hline Anions & Cool $4^{\circ} \mathrm{C}$; plastic & 28 analyze \\
\hline Phosphate & $\mathrm{Cool} 4^{\circ} \mathrm{C} ; \mathrm{H}_{2} \mathrm{SO}_{4}$ to $\mathrm{pH}<2$ & 28 analyze \\
\hline Sulfite & None; plastic & Analyze immediately \\
\hline Ammonia & $\mathrm{CoOl} 4^{\circ} \mathrm{C} ; \mathrm{H}_{2} \mathrm{SO}_{4}$ to $\mathrm{pH}<2$ & 28 analyze \\
\hline Cyanide & $\mathrm{Cool} 4^{\circ} \mathrm{C} ; \mathrm{NaOH}$ to $\mathrm{pH}>12$ & 14 analyze \\
\hline
\end{tabular}

- Maximum holding time for $\mathrm{Hg}$ is 28 days. 
Appendix C: SAMPLE CALCULATIONS

C-1 
Appendix C: Sample Calculations

\section{TABLE OF CONTENTS}

Flow Rate Determination $\ldots \ldots \ldots \ldots \ldots \ldots \ldots \ldots \ldots \ldots$ C-3

Nomenclature . . . . . . . . . . . . . . . . C-3

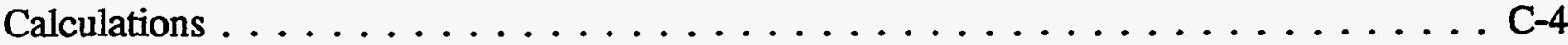

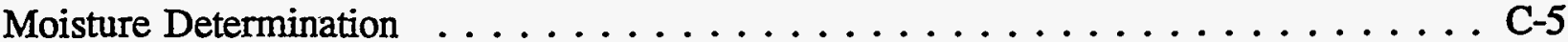

Nomenclature . . . . . . . . . . . . . . . . . C-5

Particulate Emission Determination $\ldots \ldots \ldots \ldots \ldots \ldots \ldots \ldots \ldots$ C-6

Calculations . . . . . . . . . . . . . . . . . C-7

Tables ............................ C-8

ESP Inlet/Aldehydes $\ldots \ldots \ldots \ldots \ldots \ldots \ldots \ldots \ldots \ldots \ldots$ C-8

ESP Inlet/Modified Method $5 \ldots \ldots \ldots \ldots \ldots \ldots \ldots \ldots \ldots$ C-9

ESP Inlet/PSD . . . . . . . . . . . . . . . . C-10

ESP Inlet/VOST . . . . . . . . . . . . . . . . . . C-11

ESP Inlet/Multi-Metals - Particulate . . . . . . . . . . . . . C-12

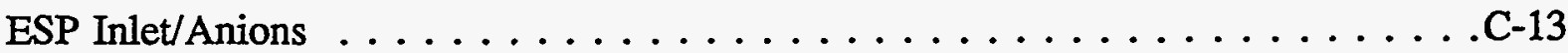

ESP Inlet/Ammonia-Cyanide . . . . . . . . . . . . . . . C-14

ESP Inlet/Radionuclides . . . . . . . . . . . . . . . . . . C-15

ESP Inlet/Size-Fractionated Particulate $\ldots \ldots \ldots \ldots \ldots \ldots \ldots \ldots \ldots$. . . . . . . . . . .

ESP Inlet/Extractable Metals . . . . . . . . . . . . . . . . C-17

ESP Outlet/Modified Method $5 \ldots \ldots \ldots \ldots \ldots \ldots \ldots \ldots \ldots$. . . . . . . . . . .

ESP Outlet/Aldehydes . . . . . . . . . . . . . . . . . . . C-19

ESP Outlet/VOST . . . . . . . . . . . . . . . . . . . C-20

ESP Outlet/PSD . . . . . . . . . . . . . . . . . . . . C-21

ESP Outlet/Multi-Metals - Particulate . . . . . . . . . . . . . . C-22

ESP Outlet/Anions . . . . . . . . . . . . . . . . . . C-23

ESP Outlet/Ammonia-Cyanide . . . . . . . . . . . . . . . . . C-24

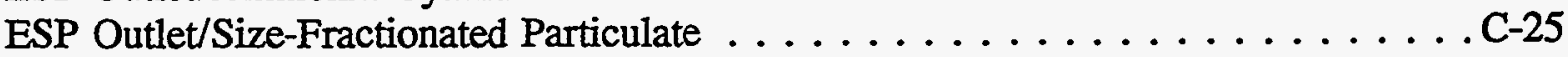

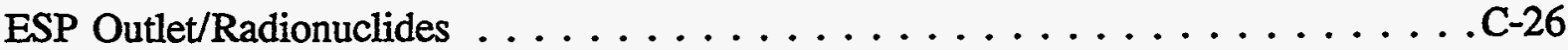

ESP Outlet/Extractable Metals . . . . . . . . . . . . . . . . C-27

Stack/Modified Method $5 \ldots \ldots \ldots \ldots \ldots \ldots \ldots \ldots \ldots \ldots$. . . . . . . . . . . .

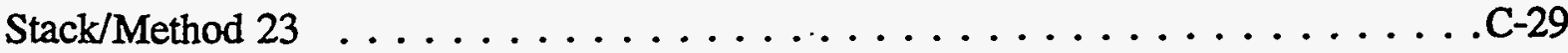

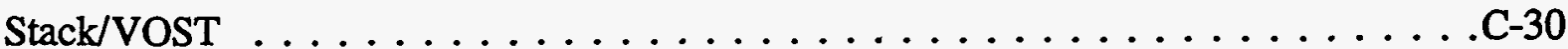

Stack/Aldehydes . . . . . . . . . . . . . . . . . . . C-31

Stack/PSD . . . . . . . . . . . . . . . . . . C-32

Stack/Multi-Metals - Particulate $\ldots \ldots \ldots \ldots \ldots \ldots \ldots \ldots \ldots$. . . . . . . . . . .

Stack/Anions . . . . . . . . . . . . . . . . . . . . . . .C-34

Stack/Ammonia-Cyanide . . . . . . . . . . . . . . . . . C-35

Stack/Radionuclides . . . . . . . . . . . . . . . . . . . . C-36

Stack/Extractable Metals . . . . . . . . . . . . . . . . . . . . C-37

Stack/Chromium VI . . . . . . . . . . . . . . C-38 
A brief discussions of the data reduction procedures required to support this program is provided below. All calculations and data reduction procedures are compiled from 40 CFR Part 60, Appendix A for the specific Reference Methods. Included with each calculation is a brief definition of terms and general nomenclature utilized in the data reduction process.

\section{Flow Rate Determination}

The average gas velocity is determined from the gas density and from measurements of the average velocity head with a Pitot tube and inclined manometer.

\section{Nomenclature}

$A=$ Cross sectional area of the stack or duct, $\left(\mathrm{ft}^{2}\right)$

$\mathrm{C}_{\mathrm{p}}=$ Pitot tube coefficient, dimensionless

$\mathrm{MW}_{\mathrm{dry}}=$ Molecular weight of gas, dry basis, lb/lb-mole

$\mathrm{MW}_{\text {wet }}=$ Molecular weight of gas, moisture corrected, $\mathrm{lb} / \mathrm{lb}-\mathrm{mole}$

$\mathrm{P}_{\mathrm{bar}}=$ Uncorrected barometric pressure at test site, " $\mathrm{Hg}$

$\mathrm{P}_{\mathrm{B}}=$ Static pressure of gas, " $\mathrm{Hg}$

$P_{s}=$ Absolute pressure of gas, " $\mathrm{Hg}$

$\mathrm{ACFM}=$ Effluent flow in actual feet per minute

SCFM = Effluent flow in standard cubic feet per minute

DSCFM = Effluent flow in dry standard cubic feet per minute

$\mathrm{T}_{\mathrm{s}}=$ Average gas temperature, ${ }^{\circ} \mathrm{F}$

Vel $=$ Average gas velocity in feet per second

$\Delta \mathrm{P}=$ Velocity Head of gas, " $\mathrm{H}_{2} \mathrm{O}$

ave $\Delta P=$ Average square root of the velocity head, " $\mathrm{H}_{2} \mathrm{O}$

$\% \mathrm{CO}_{2}=$ Percent carbon dioxide by volume, dry basis

$\% \mathrm{O}_{2}=$ Percent oxygen by volume, dry basis

$\% \mathrm{H}_{2} \mathrm{O}=$ Percent moisture of gas stream 
Appendix C: Sample Calculations

\section{Calculations}

Stack Pressure:

$$
\mathbf{P}_{\mathrm{s}}=\mathbf{P}_{\mathrm{bar}}+\left(\frac{\mathbf{P}_{\mathrm{g}}}{13.6}\right)
$$

Molecular Weight - Dry Basis:

$$
\mathrm{MW}_{\text {dry }}=0.44\left(\% \mathrm{CO}_{2}\right)+0.32\left(\% \mathrm{O}_{2}\right)+0.28\left(100-\% \mathrm{CO}_{2}-\% \mathrm{O}_{2}\right)
$$

Molecular Weight - Wet Basis:

$$
M W_{\text {wet }}=M W_{\text {dry }} \times\left[\frac{\left(1-\% \mathrm{H}_{2} \mathrm{O}\right)}{100}\right]+0.18 \times\left(\% \mathrm{H}_{2} \mathrm{O}\right)
$$

Velocity (fps):

$$
\text { VPS }=85.49 \times C_{p} \times(\text { ave } \sqrt{\Delta P}) \times \sqrt{\frac{T_{s}+460}{P_{s} \times M W_{\text {wet }}}}
$$

Flow Rate (ACFM):

$$
A C F M=(\text { VPS }) \times(A) \times 60
$$

Flow Rate (SCFM):

$$
\operatorname{SCFM}=17.64 \times\left[\frac{\mathrm{P}_{s}}{\left(\mathrm{~T}_{\mathrm{s}}+460\right)}\right] \times \mathrm{ACFM}
$$


Flow Rate (DSCFM):

$$
\operatorname{DSCFM}=17.64 \times\left[\frac{100-\% \mathrm{H}_{2} \mathrm{O}}{100}\right] \times\left[\frac{\mathrm{P}_{s}}{\left(\mathrm{~T}_{\mathrm{s}}+460\right)}\right] \times \mathrm{ACFM}
$$

\section{Moisture Determination}

A gas sample is extracted from the source and moisture is removed from the sample stream and determined gravimetrically.

\section{Nomenclature}

$\mathrm{B}_{\mathrm{wo}}=$ Water vapor in gas stream, proportion by volume

$\mathrm{P}_{\mathrm{bar}}=$ Uncorrected barometric pressure at test location, $\mathrm{Hg}$

$\mathrm{T}_{\mathrm{m}}=$ Average dry gas meter temperature, ${ }^{\circ} \mathrm{F}$

$\mathrm{V}_{\mathrm{m}}=$ Volume of gas sampled as measured by dry gas meter, acf

$\mathrm{V}_{\text {mstd }}=$ Volume of gas sampled, corrected to standard conditions, dscf

$\mathrm{V}_{\mathrm{H} 2 \mathrm{O}}=$ Volume of condensate collected in the condenser system, $(\mathrm{mL})$

$\mathrm{V}_{\mathrm{w}}=$ Volume of water vapor

$Y_{d}=$ Dry gas meter calibration factor

$\mathrm{DH}=$ Average pressure differential, $\mathrm{H}_{2} \mathrm{O}$

Volume of Water Vapor:

$$
\mathrm{V}_{\mathrm{w}}=0.04707 \times\left(\mathrm{V}_{\mathrm{H} 2 \mathrm{O}}\right)
$$

Standard Sample Volume:

$$
V_{M S T D}=17.64\left(Y_{d}\right)\left(V_{m}\right) \times\left[\frac{P_{b a r}+(\Delta H / 13.6)}{T_{m}+460}\right]
$$


Water Vapor Fraction:

$$
B_{w 0}=\frac{V_{w}}{\left(V_{w}\right)+\left(V_{\text {mstd }}\right)}
$$

Percent Moisture:

$$
\% \text { Moisture }=\mathrm{B}_{\text {wo }} \times 100
$$

\section{Particulate Emission Determination}

Particulate matter is extracted isokinetically from a source and collected on a heated substrate and condensed in the impinger train. The particulate mass is determined gravimetrically after removal of uncombined water.

$A_{n}=$ Area of nozzle $\left(\mathrm{ft}^{2}\right)$

$\mathrm{B}_{\mathrm{wo}}=$ Water vapor in gas stream, proportional by volume

$\mathrm{C}_{\mathrm{part}}=$ Particulate mass collected, $\mathrm{mg}$

$\mathrm{DH}=$ Average orifice pressure drop, $" \mathrm{H}_{2} \mathrm{O}$

DSCFM = Effluent flow, dry standard cubic feet per minute

$\mathrm{P}_{\mathrm{bar}}=$ Uncorrected barometric pressure at test location, "Hg

$P_{s}=$ Absolute pressure of gas, "Hg

$\mathrm{T}=$ Total sample time, minutes

$\mathrm{T}_{\mathrm{m}}=$ Average dry gas meter temperature, ${ }^{\circ} \mathrm{F}$

$\mathrm{T}_{\mathrm{s}}=$ Average gas temperature, ${ }^{\circ} \mathrm{F}$

$\mathrm{V}_{\mathrm{H} 2 \mathrm{O}}=$ Volume of condensate collected, $\mathrm{mL}$

$\mathrm{V}_{\mathrm{m}}=$ Volume of gas sampled as measured by dry gas meter, acf

$\mathrm{V}_{\mathrm{mstd}}=$ Volume of gas sampled, corrected to standard conditions, dscf

Vel $=$ Average duct velocity, feet per second 
$Y_{d}=$ Dry gas meter calibration factor

\% I = Isokinetic sampling rate

\section{Calculations}

Dry Gas Volume:

$$
V_{\text {MSTD }}=17.64\left(Y_{d}\right)\left(V_{m}\right) \times\left[\frac{P_{\text {bar }}+(\Delta H / 13.6)}{T_{m}+460}\right]
$$

Percent Isokinetic:

$$
\% \mathrm{I}=0.09450 \times \frac{\left[\left(\mathrm{T}_{\mathrm{s}}+460\right) \times\left(\mathrm{V}_{\text {msta }}\right)\right]}{(\mathrm{T}) \times\left(\mathrm{V}_{s}\right) \times\left(\mathrm{P}_{s}\right) \times\left(\mathrm{A}_{\mathrm{n}}\right) \times\left(1-\mathrm{B}_{\text {wo }}\right)}
$$

Particulate Concentration:

$$
\mathrm{gr} / \mathrm{dscf}=\frac{\mathrm{C} \text { (part) } \times 0.0154}{\mathrm{~V}_{\text {mstd }}}
$$

Particulate Emission:

$$
\mathrm{lb} / \mathrm{hr}=\frac{(\mathrm{gr} / \mathrm{dscf}) \times \text { DSCFM } \times 60}{7000}
$$


PLANT YATES

ESP INLET/ALDEHYDES

\begin{tabular}{|c|c|c|c|c|}
\hline $\begin{array}{l}\text { Rin No. } \\
\text { Date } \\
\text { Time Stirt } \\
\text { Time Finish } \\
\text { Operator }\end{array}$ & $\begin{array}{c}1 \\
6 / 21 / 93 \\
1310 \\
1345 \\
\text { MKO }\end{array}$ & $\begin{array}{c}2 \\
6 / 22 / 93 \\
0735 \\
0805 \\
\text { MKO }\end{array}$ & $\begin{array}{c}3 \\
6 / 23 / 93 \\
0720 \\
0750 \\
\text { MKO }\end{array}$ & $\begin{array}{c}\text { Average } \\
\text { - } \\
\text { - } \\
\text { - } \\
\text { - }\end{array}$ \\
\hline Initial Leak Rate & 0.008 & 0.008 & 0.009 & - \\
\hline Final Leak Rate & 0.009 & 0.006 & 0.007 & - \\
\hline Duct Dimensions (ft) & $8.5 \times 57$ & $8.5 \times 57$ & $8.5 \times 57$ & - \\
\hline Pitot Tube Correction Factor (Cp) & 0.84 & 0.84 & 0.84 & - \\
\hline Dry Gas Meter Calibration (Yd) & 1.009 & 1.009 & 1.009 & - \\
\hline Nozzle Diameter (inches) & 0.2750 & 0.2750 & 0.2750 & - \\
\hline Barometric Pressure ("Hg) & 29.51 & 29.40 & 29.39 & 29.43 \\
\hline Static Pressure ("B2O) & -6.4 & -6.2 & -6.0 & -6.2 \\
\hline Meter Volume (acf) & 12.281 & 10.395 & 10.275 & 10.984 \\
\hline Average square root of delta p & 0.3230 & 0.3580 & 0.3132 & 0.3314 \\
\hline Average delta H (" H2O) & 0.39 & 0.48 & 0.37 & 0.41 \\
\hline Average Stack Temperature (F) & 315 & 311 & 314 & 313 \\
\hline Áverage DGM Temp (F) & 79.9 & 76.9 & 77.7 & 78.2 \\
\hline Test Duration (minutes) & 35.0 & 30.0 & 30.0 & 31.7 \\
\hline$\% \mathrm{CO} 2$ & 10.5 & 10.2 & 10.8 & 10.5 \\
\hline$\% 02$ & 8.5 & 8.6 & 8.3 & 8.5 \\
\hline$\% \mathbf{N 2}$ & 81.0 & 81.2 & 80.9 & 81.0 \\
\hline Meter Volume (dscf) & 11.964 & 10.148 & 10.009 & 10.707 \\
\hline Flue Gas Moisture (\%) & 7.9 & 8.0 & 8.3 & 8.1 \\
\hline Gas Molecular Weight (Wet) (g/g-mole) & 29.07 & 29.02 & 29.06 & 29.05 \\
\hline Absolute Stack Pressure (" Hg) & 29.04 & 28.94 & 28.95 & 28.98 \\
\hline Absolute Stack Temperature (R) & 775 & 771 & 774 & 773 \\
\hline Average Gas Velocity (f/sec) & 22.22 & 24.63 & 21.57 & 22.81 \\
\hline Avg Flow Rate (acfm) & 645,978 & 716,039 & 627,156 & 663,058 \\
\hline Avg Flow Rate (dscfm) & 393,345 & 436,243 & 379,432 & 403,007 \\
\hline Isokinetic Sampling Rate (\%) & 102.10 & 91.10 & 103.31 & 98.83 \\
\hline
\end{tabular}




\section{ESP INLET/MODIFIED METHOD 5}

\begin{tabular}{|c|c|c|c|c|}
\hline $\begin{array}{l}\text { Run No. } \\
\text { Date } \\
\text { Time Start } \\
\text { Time Finish } \\
\text { Operator } \\
\end{array}$ & $\begin{array}{c}1 \\
6 / 21 / 93 \\
1255 \\
1815 \\
\text { JWM } \\
\end{array}$ & $\begin{array}{c}2 \\
6 / 22 / 93 \\
0729 \\
1341 \\
\text { JWM } \\
\end{array}$ & $\begin{array}{c}3 \\
6 / 23 / 93 \\
707 \\
1250 \\
\text { JWM } \\
\end{array}$ & $\begin{array}{c}\text { Average } \\
- \\
- \\
- \\
- \\
\end{array}$ \\
\hline Initial Leak Rate & 0.012 & 0.010 & 0.008 & - \\
\hline Final Leak Rate & 0.015 & 0.018 & 0.014 & $=$ \\
\hline Duct Dimensions (ft) & $8.5 \times 57$ & $8.5 \times 57$ & $8.5 \times 57$ & - \\
\hline Pitot Tube Correction Factor (Cp) & 0.84 & 0.84 & 0.84 & - \\
\hline Dry Gas Meter Calibration (Yd & 0.999 & 0.999 & 0.999 & - \\
\hline Nozzle Diameter (inches) & 0.3580 & 0.3580 & 0.3580 & - \\
\hline Barometric Pressure ("Hg) & 29.51 & 29.40 & 29.39: & 29.43 \\
\hline Static Pressure ("H2O) & -6.4 & -6.2 & -6.0 & -6.2 \\
\hline Meter Volume (acf) & 103.779 & 115.043 & 111.153 & 109.992 \\
\hline Average square root of delta p & 0.2399 & 0.2651 & 0.2470 & 0.2507 \\
\hline Average delta H (" H2O) & 0.74 & 0.85 & 0.74 & 0.78 \\
\hline Average Stack Temperature (F) & 295 & 304 & 300 & 300 \\
\hline Average DGM Temp (F) & 85.4 & 84.7 & 87.1 & 85.7 \\
\hline Test Duration (minutes) & 240.0 & 240.0 & 240.0 & 240.0 \\
\hline Condensed Water (g) & 180.8 & 202.6 & 203.5 & 195.6 \\
\hline$\% \mathrm{CO} 2$ & 10.5 & 10.2 & 10.8 & 10.5 \\
\hline & 8.5 & 8.6 & 8.3 & 8.5 \\
\hline$\% \mathrm{~N} 2$ & 81.0 & 81.2 & 80.9 & 81.0 \\
\hline Meter Volume & 99.183 & 109.693 & 105.460 & 104.779 \\
\hline Flue Gas Mois & 7.9 & 8.0 & 8.3 & 8.1 \\
\hline Gas Molecular Weight (Wet) (g/g-mole & 29.07 & 29.02 & 29.05 & 29.05 \\
\hline Absolute Stack Pressure (" Hg) & 29.04 & 28.94 & 28.95 & 28.98 \\
\hline Absolute Stack Temperature (R) & 755 & 764 & 760 & 760 \\
\hline Average Gas Velocity (f/sec) & 16.30 & 18.15 & 16.86 & 17.10 \\
\hline Avg Flow Rate (acfm) & 473,726 & 527,730 & 490,232 & 497,230 \\
\hline Avg Flow Rate (dscfm) & 295,838 & 324,601 & 301,800 & 307,413 \\
\hline Isokinetic Sampling Rate (\%) & 96.84 & 97.61 & 100.93 & 98.46 \\
\hline
\end{tabular}


PLANT YATES

ESP INLET/PSD

\begin{tabular}{|c|c|c|c|c|}
\hline \begin{tabular}{|l} 
Run No. \\
Date \\
Time Start \\
Time Finish \\
Operator \\
\end{tabular} & $\begin{array}{c}1 \\
6 / 21 / 93 \\
1555 \\
1740 \\
\text { MKO }\end{array}$ & $\begin{array}{c}2 \\
6 / 22 / 93 \\
0925 \\
1145 \\
\text { MKO }\end{array}$ & $\begin{array}{c}3 \\
6 / 23 / 93 \\
0935 \\
1130 \\
\text { MKO }\end{array}$ & $\begin{array}{c}\text { Average } \\
- \\
- \\
- \\
-\end{array}$ \\
\hline Initial Leak Rate & 0.015 & 0.018 & $\overline{0.016}$ & - \\
\hline Final Lea & NA & NA & NA & - \\
\hline Duct Dimensions (ft) & $8.5 \times 57$ & $8.5 \times 57$ & $8.5 \times 57$ & - \\
\hline Tub & 0.84 & 0.84 & 0.84 & - \\
\hline Gas ] & 0.988 & 0.988 & 0.988 & - \\
\hline de $D$ & 0.2750 & 0.2750 & 0.2750 & - \\
\hline metric Pre & 29.51 & 29.40 & 29.39 & 29.43 \\
\hline Static Pressure & -6.4 & -6.2 & -6.0 & -6.2 \\
\hline Meter Volume (act) & 30.730 & 43.462 & 40.653 & 38.282 \\
\hline age : & 0.2650 & 0.2828 & 0.2915 & 0.2798 \\
\hline rage delta H (" H2O) & 0.27 & 0.31 & 0.31 & 0.30 \\
\hline rage Stack Temperature (F) & 318 & 320 & 318 & 319 \\
\hline Average DGM Ten & 84.8 & 85.0 & 94.0 & 87.9 \\
\hline Test Duration (minutes) & 105.0 & 140.0 & 115.0 & 120.0 \\
\hline $\mathrm{CO2}$ & 10.5 & 10.2 & 10.8 & 10.5 \\
\hline \% 02 & 8.5 & 8.6 & 8.3 & 8.5 \\
\hline$\% \mathrm{~N}_{2}$ & 81.0 & 81.2 & 80.9 & 81.0 \\
\hline Meter Volume (dscf) & 29.041 & 40.910 & 37.631 & 35.861 \\
\hline Flue Gas Moisture (\%) & 7.9 & 8.0 & 8.3 & 8.1 \\
\hline Molecular Weight (Wet) (g/g-mo & 29.07 & 29.02 & 29.06 & 29.05 \\
\hline Preckure (1" Ho) & 29.04 & 28.94 & 28.95 & 28.98 \\
\hline re (R) & 778 & 780 & 778 & 779 \\
\hline age Gas Velocity ( $f / \sec )$ & 18.27 & 19.57 & 20.13 & 19.32 \\
\hline STlow & 531,075 & 568,922 & 585,210 & 561,736 \\
\hline Flow & 322,049 & 342,614 & 352,234 & 338,966 \\
\hline Isokinetic Sampling Rate (\%) & 100.90 & 100.20 & 109.14 & 103.42 \\
\hline
\end{tabular}


PLANT YATES

ESP INLET/VOST

\begin{tabular}{|c|c|c|c|c|c|c|c|c|c|c|}
\hline \begin{tabular}{|l|} 
Run No. \\
Date \\
Time Start \\
Time Finish \\
Operator \\
\end{tabular} & $\begin{array}{c}\text { IA } \\
6 / 21 / 93 \\
1400 \\
1440 \\
\text { RVW } \\
\end{array}$ & $\begin{array}{c}18 \\
6 / 21 / 93 \\
1455 \\
1535 \\
\text { RVW } \\
\end{array}$ & $\begin{array}{c}1 C \\
6 / 21 / 93 \\
1550 \\
1630 \\
\text { RVW } \\
\end{array}$ & $\begin{array}{c}2 \mathrm{~A} \\
6 / 22 / 93 \\
0742 \\
0822 \\
\mathrm{RVW} \\
\end{array}$ & $\begin{array}{c}2 B \\
6 / 22 / 93 \\
0910 \\
0950 \\
\text { RVW } \\
\end{array}$ & $\begin{array}{c}2 \mathrm{C} \\
6 / 22 / 93 \\
1001 \\
1041 \\
\text { RVW } \\
\end{array}$ & $\begin{array}{c}3 A \\
6 / 23 / 93 \\
0742 \\
0822 \\
\text { RVW } \\
\end{array}$ & $\begin{array}{c}3 \mathrm{~B} \\
6 / 23 / 93 \\
0840 \\
0920 \\
\text { RVW } \\
\end{array}$ & $\begin{array}{c}3 \mathrm{C} \\
6 / 23 / 93 \\
0932 \\
1012 \\
\text { RVW } \\
\end{array}$ & $\begin{array}{c}\text { Average } \\
- \\
- \\
- \\
- \\
\end{array}$ \\
\hline Initial Leak Rate & $0.00 @ 17^{\prime \prime}$ & $0.00 @ 15$ & $0.00 @ 18$ & $0.00 @ 17$ & $0.00 @ 16$ & $0.00 @ 15$ & $0.00 @ 16$ & $0.00 @ 15$ & $0.00 @ 18$ & - \\
\hline Final Leak Rate & $0.00 @ 16^{\prime \prime}$ & $0.00 @ 17$ & $0.00 @ 15$ & $0.00 @ 15$ & $0.00 @ 16$ & $0.00 @ 16$ & $0.00 @ 15$ & $0.00 @ 15$ & $0.00 @ 16$ & - \\
\hline Duct Dimensions ( $\mathrm{ft}$ ) & $8.5 \times 57$ & $8.5 \times 57$ & $8.5 \times 57$ & $8.5 \times 57$ & $8.5 \times 57$ & $8.5 \times 57$ & $8.5 \times 57$ & $8.5 \times 57$ & $8.5 \times 57$ & - \\
\hline Dry Gas Meter Calibration (Yd) & 1.0113 & 1.0113 & 1.0113 & 1.0113 & 1.0113 & 1.0113 & 1.0113 & 1.0113 & 1.0113 & - \\
\hline Barometric Pressure (" $\mathbf{H g}$ ) & 29.51 & 29.51 & 29.51 & 29.40 & 29.40 & 29.40 & 29.39 & 29.36 & 29.36 & 29.45 \\
\hline Static Pressure ("H2O) & -6.4 & -6.4 & -6.4 & -6.2 & -6.2 & -6.2 & -6.0 & -6.0 & -6.0 & -6.3 \\
\hline Meter Volume (aL) & 20.235 & 20.150 & 20.115 & 20.045 & 20.030 & 20.050 & 20.040 & 20.075 & 20.080 & 20.095 \\
\hline Average delta H (" H20) & 1.40 & 1.40 & 1.50 & 1.40 & 1.40 & 1.40 & 1.50 & 1.40 & 1.40 & 1.43 \\
\hline Average Stack Temperature (F) & 295 & 295 & 295 & 304 & 304 & 304 & 300 & 300 & 300 & 300 \\
\hline Average DGM Temp (C) & 26.3 & 28.5 & 29.7 & 24.0 & 26.7 & 29.3 & 25.6 & 29.4 & 31.8 & 27.2 \\
\hline Test Duration (minutes) & 40.0 & 40.0 & 40.0 & 40.0 & 40.0 & 40.0 & 40.0 & 40.0 & 40.0 & $\overline{40.0}$ \\
\hline$\% \mathrm{CO} 2$ & 10.5 & 10.5 & 10.5 & 10.2 & 10.2 & 10.2 & 10.8 & 10.8 & 10.8 & 10.4 \\
\hline$\% 02$ & 8.5 & 8.5 & 8.5 & 8.6 & 8.6 & 8.6 & 8.3 & 8.3 & 8.3 & 8.5 \\
\hline$\% \mathrm{~N} 2$ & 81.0 & 81.0 & 81.0 & 81.2 & 81.2 & 81.2 & 80.9 & 80.9 & 80.9 & 81.1 \\
\hline Meter Volume (dsL) & 19.845 & 19.615 & 19.503 & 19.731 & 19.542 & 19.391 & 19.621 & 19.400 & 19.254 & 19.607 \\
\hline Flue Gas Moisture (\%) & 7.9 & 7.9 & 7.9 & 8.0 & 8.0 & 8.0 & 8.3 & 8.3 & 8.3 & 8.0 \\
\hline Gas Molecular Weight (Wet) (g/g-mole) & 29.07 & 29.07 & 29.07 & 29.02 & 29.02 & 29.02 & 29.06 & 29.06 & 29.06 & 29.05 \\
\hline Absolute Stack Pressure (" Hg) & 29.04 & 29.04 & 29.04 & 28.94 & 28.94 & 28.94 & 28.95 & 28.92 & 28.92 & 28.99 \\
\hline Absolute Stack Temperature (R) & 755 & 755 & 755 & 764 & 764 & 764 & 760 & 760 & 760 & 760 \\
\hline
\end{tabular}


PLANT YATES

ESP INLET/MULTI-METALS - PARTICULATE

\begin{tabular}{|c|c|c|c|c|}
\hline $\begin{array}{l}\text { Run No. } \\
\text { Date } \\
\text { Time Start } \\
\text { Time Finish } \\
\text { Operator } \\
\end{array}$ & $\begin{array}{c}1 \\
6 / 25 / 93 \\
0800 \\
1405 \\
\text { JWM }\end{array}$ & $\begin{array}{c}2 \\
6 / 26 / 93 \\
0935 \\
1611 \\
\text { JWM }\end{array}$ & $\begin{array}{c}3 \\
6 / 27 / 93 \\
0848 \\
1405 \\
J W M\end{array}$ & $\begin{array}{c}\text { Average } \\
- \\
- \\
- \\
-\end{array}$ \\
\hline Initial Leak Rate & 0.014 & 0.006 & 0.017 & - \\
\hline Final Leak Rate & 0.016 & 0.012 & 0.015 & - \\
\hline Duct Dimensions (ft) & $8.5 \times 57$ & $8.5 \times 57$ & $8.5 \times 57$ & - \\
\hline Pitot Tube Correction Factor (Cp) & 0.84 & 0.84 & 0.84 & - \\
\hline Dry Gas Meter Calibration (Yd) & 0.999 & 0.999 & 0.999 & - \\
\hline Nozzle Diameter (inches) & 0.3580 & 0.3580 & 0.3580 & - \\
\hline (Barometric Pressure ("Hg) & 29.55 & 29.56 & 29.40 & 29.50 \\
\hline Static Pressure ("H2O) & -5.8 & -5.8 & -5.9 & -5.8 \\
\hline Meter Volume (acf) & 111.213 & 110.002 & 111.690 & 110.968 \\
\hline Average square root of delta p & 0.2403 & 0.2490 & 0.2524 & 0.2472 \\
\hline Average delta H (" H2O) & 0.77 & 0.74 & 0.76 & 0.76 \\
\hline Average Stack Temperature (F) & 301 & 299 & 303 & 301 \\
\hline Average DGM Temp (F) & 84.0 & 87.0 & 90.0 & 87.0 \\
\hline Test Duration (minutes) & 240.0 & 240.0 & 240.0 & 240.0 \\
\hline Condensed Water (g) & 201.0 & 244.0 & 252.2 & 232.4 \\
\hline Filter Weight Gain (g) & 21.4931 & 24.9809 & 26.2059 & 24.2266 \\
\hline PNR Weight Gain (g) & 1.8780 & & 0.3098 & 1.0939 \\
\hline$\| \% \mathrm{CO} 2$ & 10.1 & 10.5 & 11.8 & 10.8 \\
\hline$\| \% 02$ & 9.9 & 8.8 & 7.0 & 8.6 \\
\hline$\%$ N2 & 80.0 & 80.7 & 81.2 & 80.6 \\
\hline Meter Volume (dscf) & 106.704 & 104.991 & 105.454 & 105.716 \\
\hline Flue Gas Moisture (\%) & 8.2 & 9.9 & $10 . i$ & 9.4 \\
\hline Gas Molecular Weight (Wet) (g/g-mole) & 29.03 & 28.84 & 28.93 & 28.94 \\
\hline Absolute Stack Pressure (" Hg) & 29.12 & 29.13 & 28.97 & 29.07 \\
\hline Absolute Stack Temperature (R) & 761 & 759 & 763 & 761 \\
\hline Average Gas Velocity (f/sec) & 16.37 & 16.99 & 17.29 & 16.89 \\
\hline Avg Flow Rate (acfm) & 475,917 & 494,021 & 502,740 & 490,893 \\
\hline Avg Flow Rate (dscfm) & 295,051 & 301,434 & 302,524 & 299,670 \\
\hline Isokinetic Sampling Rate (\%) & 104.46 & 100.61 & 100.69 & 101.92 \\
\hline Particulate Concentration (gr/dsc) & $3.38 \mathrm{E}+00$ & $3.67 \mathrm{E}+00$ & $3.88 \mathrm{E}+00$ & $3.64 \mathrm{E}+00$ \\
\hline Ite Concentra & 4.83E-04 & $5.25 \mathrm{E}-04$ & 5.54E-04 & $5.21 E-04$ \\
\hline Particulate Emission (g & 1,077 & 1,196 & 1,268 & 1,180 \\
\hline Particulate Emission (bs/hour) & 8,550 & 9.489 & 10,064 & 9,367 \\
\hline
\end{tabular}


PLANT YATES

ESP INLET/ANIONS

\begin{tabular}{|c|c|c|c|c|}
\hline \begin{tabular}{|l|} 
Run No. \\
Date \\
Time Stárt \\
Time Finish \\
Operator \\
\end{tabular} & $\begin{array}{c}1 \\
6 / 25 / 93 \\
1225 \\
1405 \\
\text { MKO } \\
\end{array}$ & $\begin{array}{c}2 \\
6 / 26 / 93 \\
1108 \\
1213 \\
\mathrm{MKO} \\
\end{array}$ & $\begin{array}{c}3 \\
6 / 27 / 93 \\
0715 \\
0837 \\
\text { MKO } \\
\end{array}$ & $\begin{array}{c}\text { Average } \\
- \\
- \\
- \\
- \\
\end{array}$ \\
\hline Initial Leak Rate & 0.010 & 0.004 & 0.009 & - \\
\hline Final Leak Rate & 0.004 & 0.009 & 0.006 & - \\
\hline Duct Dimensions (ft) & $8.5 \times 57$ & $8.5 \times 57$ & $8.5 \times 57$ & - \\
\hline itot Tube & 0.84 & 0.84 & 0.84 & - \\
\hline Dry Gas I & 1.003 & 1.003 & 1.003 & - \\
\hline Nozzle Di & 0.3750 & 0.3750 & 0.3750 & - \\
\hline Barometric Pres & 29.55 & 29.56 & 29.40 & 29.50 \\
\hline Static Pressure & -5.8 & -5.8 & -5.4 & -5.7 \\
\hline Meter Volume (acf) & 64.816 & 44.245 & 45.140 & 51.400 \\
\hline Average square root of delta $p$ & 0.3161 & 0.3201 & 0.2783 & 0.3048 \\
\hline Average delta H (" H2O) & 1.36 & 1.41 & 0.99 & 1.25 \\
\hline Average Stack Tem & 290 & 282 & 310 & 294 \\
\hline Average DGM Te & 85.0 & 88.0 & 76.0 & 83.0 \\
\hline Test Duration (minutes) & 100.0 & 65.0 & 82.0 & 82.3 \\
\hline$\% \mathrm{CO} 2$ & 10.1 & 10.5 & 11.8 & 10.8 \\
\hline$\% 02$ & 9.9 & 8.8 & 7.0 & 8.6 \\
\hline$\% \mathbf{N 2}$ & 80.0 & 80.7 & 81.2 & 80.6 \\
\hline Meter Volume & 62.414 & 42.391 & 43.933 & 49.579 \\
\hline Flue Gas Moisture (\%) & 8.2 & 9.9 & 10.1 & 9.4 \\
\hline Gas Molecular Weight (Wet) (g/g-mole & 29.03 & 28.84 & 28.94 & 28.94 \\
\hline Absolute Stack Pressure (" Hg) & 29.12 & 29.13 & 29.00 & 29.09 \\
\hline Absolute Stack Temperature (R) & 750 & 742 & 770 & 754 \\
\hline Average Gas Velocity (f/sec) & 21.38 & 21.59 & 19.14 & 20.71 \\
\hline Avg Flow Rate (acfm) & 621,544 & 627,741 & 556,462 & 601,915 \\
\hline Avg Flow Rate (dscfm) & 390,837 & 392,000 & 332,388 & 371,741 \\
\hline Isokinetic Sampling Rate (\%) & 100.90 & 105.11 & 101.84 & 102.62 \\
\hline
\end{tabular}


PLANT YATES

ESP INLET/AMMONIA-CYANIDE

\begin{tabular}{|c|c|c|c|c|c|}
\hline \begin{tabular}{|l|} 
Run No. \\
Date \\
Time Start \\
Time Finish \\
Operator \\
\end{tabular} & $\begin{array}{c}1 \\
6 / 25 / 93 \\
1450 \\
1650 \\
\text { MKO } \\
\end{array}$ & $\begin{array}{c}2 \\
6 / 26 / 93 \\
0930 \\
1035 \\
\text { MKO }\end{array}$ & $\begin{array}{c}3 \\
6 / 26 / 93 \\
1420 \\
1520 \\
\text { MKO } \\
\end{array}$ & $\begin{array}{c}4 \\
06 / 27 / 93 \\
0920 \\
1040 \\
\text { MKO } \\
\end{array}$ & $\begin{array}{c}\text { Average } \\
- \\
- \\
- \\
- \\
\end{array}$ \\
\hline Initial Leak Rate & 0.010 & 0.009 & 0.009 & 0.006 & - \\
\hline Final Leak Rate & 0.009 & 0.006 & 0.006 & 0.004 & - \\
\hline Duct Dimensions (ft) & $8.5 \times 57$ & $8.5 \times 57$ & $8.5 \times 57$ & $8.5 \times 57$ & - \\
\hline Pitot Tube Correction Factor (Cp) & 0.84 & 0.84 & 0.84 & 0.84 & - \\
\hline Dry Gas Meter Calibration (Yd) & 1.003 & 1.003 & 1.003 & 1.003 & - \\
\hline Nozzle Diameter (inches) & 0.3750 & 0.3750 & 0.3750 & 0.3750 & - \\
\hline Barometric Pressure ("Hg) & 29.55 & 29.56 & 29.56 & 29.40 & 29.56 \\
\hline Static Pressure ("H2O) & -5.8 & -5.8 & -5.8 & -5.9 & -5.8 \\
\hline Meter Volume (acf) & 46.663 & 41.622 & 41.654 & 46.885 & 43.313 \\
\hline Average square root of delta p & 0.3122 & 0.3122 & 0.3077 & 0.2871 & 0.3107 \\
\hline Average delta $\mathrm{H}$ (" H20) & 1.33 & 1.31 & 1.34 & 1.09 & 1.33 \\
\hline Average Stack Temperature (F) & 289 & 283 & 284 & 315 & 285 \\
\hline Average DGM Temp (F) & 88.0 & 80.0 & 94.0 & 83.0 & 87.3 \\
\hline Test Duration (minutes) & 70.0 & 65.0 & 60.0 & 80.0 & 65.0 \\
\hline$\% \mathrm{CO} 2$ & 10.1 & 10.5 & 10.5 & 11.8 & 10.4 \\
\hline \% 02 & 9.9 & 8.8 & 8.8 & $\mathbf{7 . 0}$ & 9.2 \\
\hline$\%$ N2 & 80.0 & 80.7 & 80.7 & 81.2 & 80.5 \\
\hline Meter Volume (dscf) & 44.684 & 40.459 & 39.470 & 45.054 & 41.538 \\
\hline Flue Gas Moisture (\%) & 8.2 & 9.9 & 9.9 & 10.1 & 9.3 \\
\hline Gas Molecular Weight (Wet) (g/g-mole) & 29.03 & 28.84 & 28.84 & 28.94 & 28.90 \\
\hline Absolute Stack Pressure (" $\mathbf{H g}$ ) & 29.12 & 29.13 & 29.13 & 28.97 & 29.13 \\
\hline Absolute Stack Temperature (R) & 749 & 743 & 744 & 775 & 745 \\
\hline Average Gas Velocity (f/sec) & 21.10 & 21.08 & 20.79 & 19.82 & 20.99 \\
\hline Avg Flow Rate (acfm) & 613,466 & 612,867 & 604,440 & 576,283 & 610,258 \\
\hline Avg Flow Rate (dscfm) & 386,272 & 381,939 & 376,181 & 341,573 & 381,464 \\
\hline Isokinetic Sampling Rate (\%) & 104.41 & 102.97 & 110.49 & 104.17 & 105.95 \\
\hline
\end{tabular}




\section{PLANT YATES \\ ESP INLET/RADIONUCLIDES}

\begin{tabular}{|c|c|c|c|c|}
\hline \begin{tabular}{|l} 
Run No. \\
Date \\
Time Start \\
Time Finish \\
Operator \\
\end{tabular} & $\begin{array}{c}1 \\
6 / 25 / 93 \\
0745 \\
0907 \\
\text { MKO } \\
\end{array}$ & $\begin{array}{c}2 \\
6 / 26 / 93 \\
1540 \\
1700 \\
\text { MKO } \\
\end{array}$ & $\begin{array}{c}3 \\
6 / 27 / 93 \\
1120 \\
1240 \\
\text { MKO } \\
\end{array}$ & $\begin{array}{c}\text { Average } \\
- \\
- \\
- \\
- \\
\end{array}$ \\
\hline Initial Leak Rate & 0.009 & 0.010 & 0.007 & - \\
\hline Final Leak Rate & 0.006 & 0.009 & 0.004 & - \\
\hline Duct Dimensions (ft) & $8.5 \times 57$ & $8.5 \times 57$ & $8.5 \times 57$ & - \\
\hline Pitot Tube Correction Factor (Cp) & 0.84 & 0.84 & 0.84 & - \\
\hline Dry Gas Meter Calibration (Yd) & 1.009 & 1.009 & 1.003 & - \\
\hline Nozzle Diameter (inches) & 0.3750 & 0.3750 & 0.3750 & - \\
\hline Barometric Pressure ('Hg) & 29.55 & 29.56 & 29.40 & 29.50 \\
\hline Static Pressure ("H2O) & -5.8 & -5.8 & -5.9 & -5.8 \\
\hline Meter Volume (acf) & 53.605 & 45.950 & 45.096 & 48.217 \\
\hline Average square root of delta $p$ & 0.3300 & 0.2905 & 0.2737 & 0.2981 \\
\hline Average delta H (" H2O) & 1.48 & 1.10 & 0.96 & 1.18 \\
\hline Average Stack Temperature (F) & 301 & 317 & 316 & 311 \\
\hline Average DGM Temp (F) & 82.0 & 97.0 & 93.0 & 90.7 \\
\hline Test Duration (minutes) & 82.0 & 80.0 & 80.0 & 80.7 \\
\hline$\% \mathrm{CO} 2$ & 10.1 & 10.5 & 11.8 & 10.8 \\
\hline$\% 02$ & 9.9 & 8.8 & 7.0 & 8.6 \\
\hline$\%$ N2 & 80.0 & 80.7 & 81.2 & 80.6 \\
\hline Meter Volume (dscf) & 52.231 & 43.540 & 42.537 & 46.103 \\
\hline Flue Gas Moisture (\%) & 8.2 & 9.9 & 10.1 & 9.4 \\
\hline Gas Molecular Weight (Wet) (g/g-mole) & 29.03 & 28.84 & 28.94 & 28.94 \\
\hline Absolute Stack Pressure (" Hg) & 29.12 & 29.13 & 28.97 & 29.07 \\
\hline Absolute Stack Temperature (R) & 761 & 777 & 776 & 771 \\
\hline Average Gas Velocity ( $\mathrm{f} / \mathrm{sec})$ & 22.48 & 20.06 & 18.91 & 20.49 \\
\hline Avg Flow Rate (acfm) & 653,616 & 583,171 & 549,740 & 595,509 \\
\hline Avg Flow Rate (dscfm) & 405,064 & 347,529 & 325,421 & 359,338 \\
\hline Isokinetic Sampling Rate $(\%)$ & 99.35 & 98.94 & 103.23 & 100.51 \\
\hline
\end{tabular}


PLANT YATES

ESP INLET/S.F. PARTICULATE

\begin{tabular}{|c|c|c|c|c|}
\hline \begin{tabular}{|l} 
Run No. \\
Date \\
Time Start \\
Time Finish \\
Operator \\
\end{tabular} & $\begin{array}{c}1 \\
6 / 25 / 93 \\
0800 \\
1020 \\
\text { MKO } \\
\end{array}$ & $\begin{array}{c}2 . \\
6 / 26 / 93 \\
0915 \\
1125 \\
\text { MKO } \\
\end{array}$ & $\begin{array}{c}3 \\
6 / 27 / 93 \\
0740 \\
0955 \\
\text { RVW } \\
\end{array}$ & $\begin{array}{c}\text { Average } \\
- \\
- \\
- \\
\end{array}$ \\
\hline Initial Leak Rate & 0.009 & 0.017 & 0.014 & - \\
\hline Final Lea & NA & NA & NA & - \\
\hline Duct Dimensions (ft) & $8.5 \times 57$ & $8.5 \times 57$ & $8.5 \times 57$ & - \\
\hline (p) & 0.84 & 0.84 & 0.84 & - \\
\hline $\mathbf{D}$ & 0.988 & 1.009 & 1.009 & - \\
\hline No & 0.2750 & 0.2750 & 0.2750 & - \\
\hline $\mathbf{B a}$ & 29.55 & 29.56 & 29.40 & 29.50 \\
\hline Stat & -5.8 & -5.8 & -5.9 & -5.8 \\
\hline Meter Volv & 41.161 & 43.983 & 42.677 & 42.607 \\
\hline Av & 0.2826 & 0.3289 & 0.2871 & 0.2995 \\
\hline A & 0.31 & 0.41 & 0.32 & 0.35 \\
\hline rage St & 288 & 311 & 313 & 304 \\
\hline Average D & 81.0 & 83.8 & 82.0 & 82.3 \\
\hline Test Duration (minutes) & 130.0 & 120.0 & 135.0 & 128.3 \\
\hline $1 \% \mathrm{CO} 2$ & 10.1 & 10.5 & 11.8 & 10.8 \\
\hline \% 02 & 9.9 & 8.8 & 7.0 & 8.6 \\
\hline$\% \mathbf{N 2}$ & 80.0 & 80.7 & 81.2 & 80.6 \\
\hline Meter Volu & 39.229 & 42.615 & 41.253 & 41.032 \\
\hline Flue Gas & 8.2 & 9.9 & 10.1 & 9.4 \\
\hline Gas Molecular Weight (Wet) (g/g-mole & 29.03 & 28.84 & 28.94 & 28.94 \\
\hline$|A|$ & 29.12 & 29.13 & 28.97 & 29.07 \\
\hline Absolute Stack Tem & 748 & 771 & 773 & 764 \\
\hline rage Gas Velocity (f/sec) & 19.09 & 22.62 & 19.80 & 20.50 \\
\hline 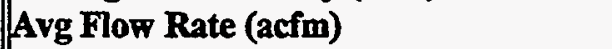 & 554,932 & 657,618 & 575,539 & 596,030 \\
\hline Avg Flow $\mathrm{F}$ & 349,883 & 395,047 & 342,015 & 362,315 \\
\hline Isokinetic Sampling Rat & 101.33 & 105.61 & 104.97 & 103.97 \\
\hline
\end{tabular}




\section{PLANT YATES \\ ESP INLET/EXTRACTABLE METALS}

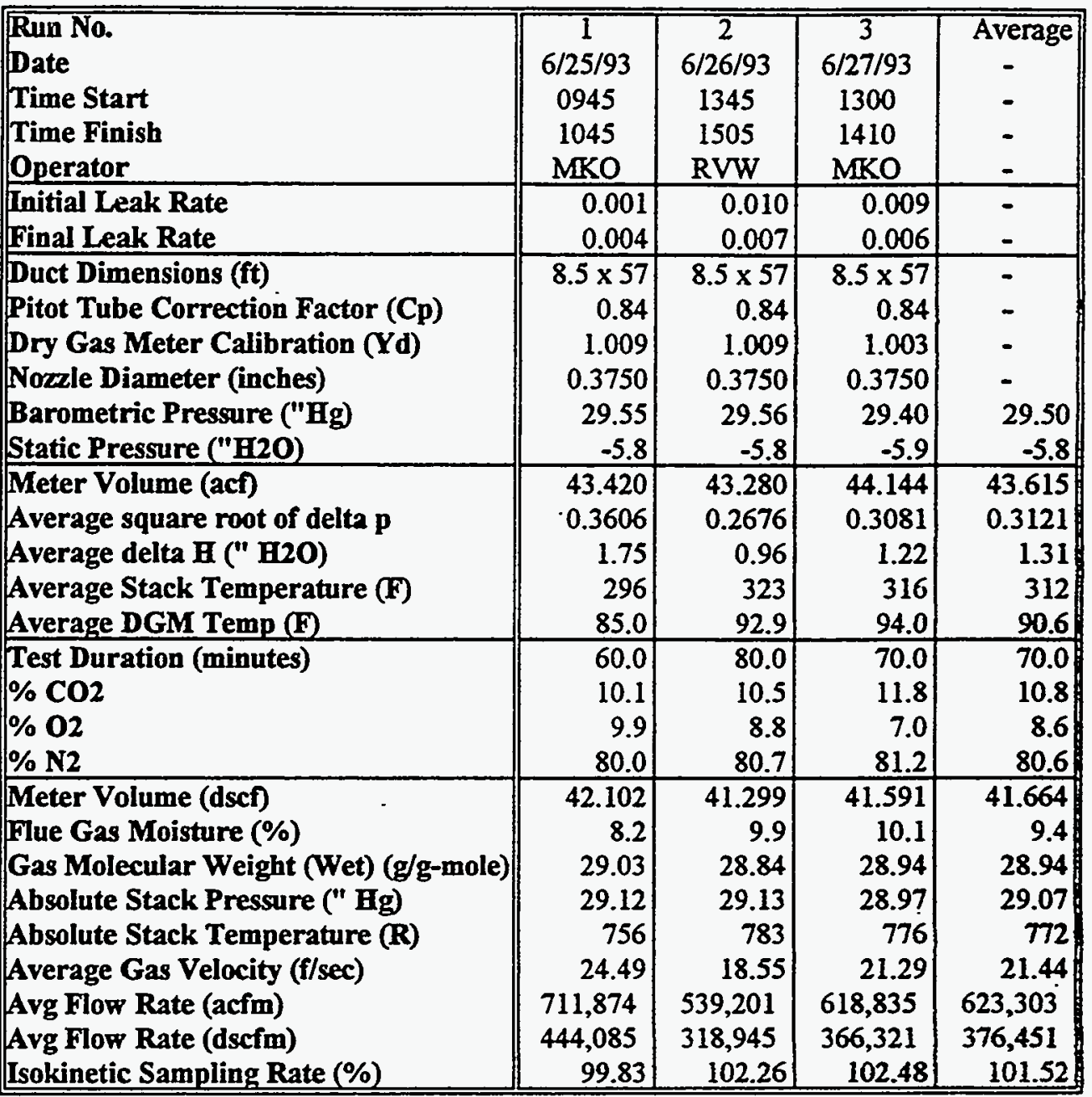


PLANT YATES

ESP OUTLET/MODIFIED METHOD 5

\begin{tabular}{|c|c|c|c|c|}
\hline \begin{tabular}{|l} 
Run No. \\
Date - \\
Time Start \\
Time Finish \\
Operator \\
\end{tabular} & $\begin{array}{c}1 \\
6 / 21 / 93 \\
1249 \\
1812 \\
\text { TJB } \\
\end{array}$ & $\begin{array}{c}2 \\
6 / 22 / 93 \\
0753 \\
1247 \\
\text { TJB } \\
\end{array}$ & $\begin{array}{c}3 \\
6 / 23 / 93 \\
0712 \\
1129 \\
\text { TJB } \\
\end{array}$ & $\begin{array}{c}\text { Average } \\
- \\
- \\
- \\
- \\
\end{array}$ \\
\hline Initial Leak Rate & 0.005 & 0.003 & 0.002 & - \\
\hline Final Leak Rate & 0.005 & 0.005 & 0.005 & - \\
\hline Duct Dimensions (ft) & $11.3 \times 11.3$ & $11.3 \times 11.3$ & $11.3 \times 11.3$ & - \\
\hline Pitot Tube Correction Factor (Cp) & 0.84 & 0.84 & 0.84 & - \\
\hline Dry Gas Meter Calibration (Yd) & 0.997 & 0.997 & 0.997 & - \\
\hline Nozzle Diameter (inches) & 0.1970 & 0.1970 & 0.1970 & - \\
\hline Barometric Pressure ("Hg) & 29.51 & 29.40 & 29.36 & 29.42 \\
\hline Static Pressure ("H20) & -11 & -11 & -11 & -11 \\
\hline Meter Volume (acf) & 126.423 & 127.680 & 118.467 & 124.190 \\
\hline Average square root of delta $p$ & 0.9096 & 0.9306 & 0.8958 & 0.9120 \\
\hline Average delta H (" H20) & 0.93 & 0.94 & 0.82 & 0.90 \\
\hline Average Stack Temperature (F) & 280 & 280 & 275 & 278 \\
\hline Average DGM Temp (F) & 86.5 & 84.6 & 83.5 & 84.9 \\
\hline Test Duration (minutes) & 240.0 & 240.0 & 240.0 & 240.0 \\
\hline Condensed Water (g) & 207.6 & 212.4 & 211.2 & 210.4 \\
\hline$\% \mathrm{CO} 2$ & 11.1 & 11.2 & 10.6 & 11.0 \\
\hline \% 02 & 8.0 & 7.9 & 8.5 & 8.1 \\
\hline$\%$ N2 & 80.9 & 80.9 & 80.9 & 80.9 \\
\hline Meter Volume (dscf) & 120.387 & 121.556 & 112.827 & 118.256 \\
\hline Flue Gas Moisture (\%) & 7.5 & 7.6 & 8.1 & 7.8 \\
\hline Gas Molecular Weight (Wet) (g/g-mole) & 29.19 & 29.19 & 29.06 & 29.14 \\
\hline Absolute Stack Pressure (" Hg) & 28.70 & 28.59 & 28.55 & 28.61 \\
\hline Absolute Stack Temperature (R) & 740 & 740 & 735 & 738 \\
\hline Average Gas Velocity (f/sec) & 61.39 & 62.93 & 60.55 & 61.62 \\
\hline Avg Flow Rate (acfm) & 470,365 & 482,150 & 463,880 & 472,132 \\
\hline Avg Flow Rate (dscfm) & 297,590 & 303,573 & 292,059 & 297,741 \\
\hline Lsokinetic Sampling Rate (\%) & 101.70 & 100.67 & 97.12 & 99.83 \\
\hline
\end{tabular}


PLANT YATES

ESP OUTLET/ALDEHYDES

\begin{tabular}{|c|c|c|c|c|}
\hline \begin{tabular}{|l} 
Run No. \\
Date \\
Time Start \\
Time Finish \\
Operator \\
\end{tabular} & $\begin{array}{c}1 \\
6 / 21 / 93 \\
1232 \\
1447 \\
\text { APE }\end{array}$ & $\begin{array}{c}2 \\
6 / 22 / 93 \\
0719 \\
0928 \\
\text { APE }\end{array}$ & $\begin{array}{c}3 \\
6 / 23 / 93 \\
0655 \\
0909 \\
\text { APE }\end{array}$ & $\begin{array}{c}\text { Average } \\
- \\
- \\
- \\
-\end{array}$ \\
\hline Tnitial Leak Rate & 0.010 & 0.002 & 0.007 & - \\
\hline Final Leak Rate & 0.005 & 0.002 & 0.005 & - \\
\hline Duct Dimensions (ft) & $11.3 \times 11.3$ & $11.3 \times 11.3$ & $11.3 \times 11.3$ & - \\
\hline Pitot Tube Correction Factor (Cp) & 0.84 & 0.84 & 0.84 & - \\
\hline Dry Gas Meter Calibration (Yd) & 0.992 & 0.992 & 0.992 & - \\
\hline Nozzle Diameter (inches) & 0.1900 & 0.1910 & 0.1910 & - \\
\hline Barometric Pressure ("Hg) & 29.51 & 29.40 & 29.36 & 29.42 \\
\hline Static Pressure ("H2O) & -11 & -11 & -11 & -11 \\
\hline Meter Volume (acf) & 66.723 & 66.100 & 67.250 & 66.691 \\
\hline Average square root of delta $p$ & 0.8750 & 0.9583 & 0.9487 & 0.9273 \\
\hline Average delta H (" H2O) & 0.78 & 0.89 & 0.81 & 0.82 \\
\hline Average Stack Temperature (F) & 280 & 275 & 270 & 275 \\
\hline Average DGM Temp (F) & 82.0 & 87.8 & 87.9 & 85.9 \\
\hline Test Duration (minutes) & 135.0 & 129.0 & 135.0 & 133.0 \\
\hline$\% \mathrm{CO} 2$ & 11.1 & 11.2 & 10.6 & 11.0 \\
\hline$\% 02$ & 8.0 & 7.9 & 8.5 & 8.1 \\
\hline$\% \mathrm{~N}_{2}$ & 80.9 & 80.9 & 80.9 & 80.9 \\
\hline Meter Volume (dscf) & 63.719 & 62.240 & 63.213 & 63.057 \\
\hline Flue Gas Moisture (\%) & 7.5 & 7.6 & 8.1 & 7.7 \\
\hline Gas Molecular Weight (Wet) (g/g-mole) & 29.19 & 29.19 & 29.06 & 29.15 \\
\hline Absolute Stack Pressure (" Hg) & 28.70 & 28.59 & 28.55 & 28.61 \\
\hline Absolute Stack Temperature (R) & 740 & 735 & 730 & 735 \\
\hline Average Gas Velocity $(\mathrm{f} / \mathrm{sec})$ & 59.06 & 64.58 & 63.90 & 62.51 \\
\hline Avg Flow Rate (acfm) & 452,448 & 494,802 & 489,582 & 478,944 \\
\hline Avg Flow Rate (dscfm) & 286,337 & 313,723 & 310,413 & 303,491 \\
\hline Isokinetic Sampling Rate (\%) & 106.92 & 98.71 & 96.82 & 100.82 \\
\hline
\end{tabular}


PLANT YATES

ESP OUTLET/VOST

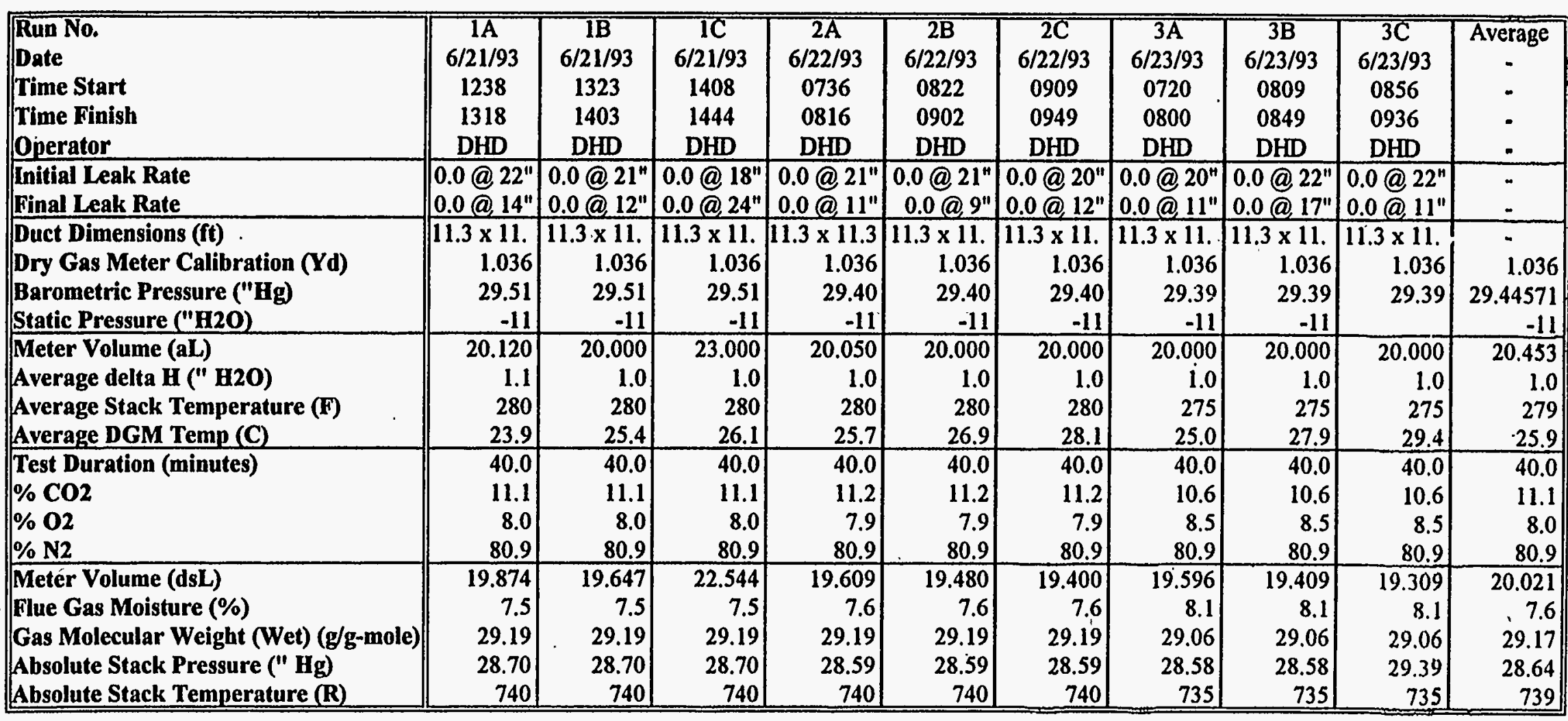




\section{PLANT YATES \\ ESP OUTLET/PSD}

\begin{tabular}{|c|c|c|c|c|}
\hline \begin{tabular}{|l} 
Run No. \\
Date \\
Time Start \\
Time Finish \\
Operator \\
\end{tabular} & $\begin{array}{c}1 \\
6 / 21 / 93 \\
1436 \\
2236 \\
\text { TJB } \\
\end{array}$ & $\begin{array}{c}2 \\
6 / 22 / 93 \\
1003 \\
1550 \\
D D\end{array}$ & $\begin{array}{c}3 \\
6 / 23 / 93 \\
0907 \\
1407 \\
\text { DD }\end{array}$ & $\begin{array}{c}\text { Average } \\
- \\
- \\
- \\
- \\
\end{array}$ \\
\hline Initial Leak Rate & 0.01 & 0.009 & 0.010 & - \\
\hline Final Leak Rate & NA & NA & NA & - \\
\hline Duct Dimensions (ft) & $11.3 \times 11.3$ & $11.3 \times 11.3$ & $11.3 \times 11.3$ & - \\
\hline Pitot Tube Correction Factor (Cp) & 0.84 & 0.84 & 0.84 & - \\
\hline Dry Gas Meter Calibration (Yd) & 1.007 & 1.007 & 1.007 & - \\
\hline Nozzle Diameter (inches) & 0.1910 & 0.1910 & 0.1910 & - \\
\hline Barometric Pressure ("Hg) & 29.51 & 29.40 & 29.36 & 29.42 \\
\hline Static Pressure ("H2O) & -11 & -11 & -11 & -11 \\
\hline Meter Volume (act) & 254.680 & 180.019 & 154.960 & 196.553 \\
\hline Average square root of delta p & 0.9920 & 0.9460 & 0.9550 & 0.9643 \\
\hline Average delta H (" H20) & 0.95 & 0.90 & 0.86 & 0.90 \\
\hline Average Stack Temperature (F) & 280 & 285 & 282 & 282 \\
\hline Average DGM Temp (F) & 84.4 & 88.4 & 93.9 & 88.9 \\
\hline Test Duration (minutes) & 480.0 & 350.0 & 300.0 & 376.7 \\
\hline$\% \mathrm{CO} 2$ & 11.1 & 11.2 & 10.6 & 11.0 \\
\hline$\% 02$ & 8.0 & 7.9 & 8.5 & 8.1 \\
\hline$\% \mathrm{~N}_{2}$ & 80.9 & 80.9 & 80.9 & 80.9 \\
\hline Meter Volume (dscf) & 245.909 & 171.888 & 146.280 & 188.026 \\
\hline Flue Gas Moisture (\%) & 7.5 & 7.6 & 8.1 & 7.7 \\
\hline Gas Molecular Weight (Wet) (g/g-mole) & 29.19 & 29.19 & 29.06 & 29.15 \\
\hline Absolute Stack Pressure (" Hg) & 28.70 & 28.59 & 28.55 & 28.61 \\
\hline Absolute Stack Temperature (R) & 740 & 745 & 742 & 742 \\
\hline Average Gas Velocity (f/sec) & 66.95 & 64.17 & 64.85 & 65.32 \\
\hline Avg Flow Rate (acfm) & 512,947 & 491,597 & 496,867 & 500,470 \\
\hline Avg Flow Rate (dscfm) & 324,624 & 307,714 & 309,938 & 314,092 \\
\hline Isokinetic Sampling Rate (\%) & 101.30 & 102.44 & 100.98 & 101.57 \\
\hline
\end{tabular}


PLANT YATES

ESP OUTLET/MULTI-METALS - PARTICULATE

\begin{tabular}{|c|c|c|c|c|}
\hline \begin{tabular}{|l} 
Run No. \\
Date \\
Time.Start \\
Time Finish \\
Operator
\end{tabular} & $\begin{array}{c}1 \\
6 / 25 / 93 \\
0758 \\
1316 \\
\text { TJB }\end{array}$ & $\begin{array}{c}2 \\
6 / 26 / 93 \\
0925 \\
1410 \\
\text { TJB }\end{array}$ & $\begin{array}{c}3 \\
6 / 27 / 93 \\
0746 \\
1210 \\
\text { TJB }\end{array}$ & \begin{tabular}{c|} 
Average \\
- \\
- \\
- \\
-
\end{tabular} \\
\hline Initial Leak Rate & 0.010 & 0.005 & 0.008 & - \\
\hline Final Leak Rate: & 0.015 & 0.007 & 0.007 & - \\
\hline Duct Dimensions (ft) & $11.3 \times 11.3$ & $11.3 \times 11.3$ & $11.3 \times 11.3$ & - \\
\hline Pitot Tube Correction Factor (Cp) & 0.84 & 0.84 & 0.84 & - \\
\hline Dry Gas Meter Calibration (Yd) & 0.997 & 0.997 & 0.997 & - \\
\hline Nozele Diameter (inches) & 0.1970 & 0.1970 & 0.1970 & - \\
\hline Barometric Pressure ('Hg) & 29.55 & 29.42 & 29.30 & 29.42 \\
\hline Static Pressure ("H20) & -11.0 & -11.0 & -11.0 & -11.0 \\
\hline Meter Volume (acf) & 118.957 & 121.053 & 125.534 & 121.848 \\
\hline Average square root of delta p & 0.8758 & 0.9165 & 0.9210 & 0.9044 \\
\hline Average delta H (" H2O) & 0.79 & 0.86 & 0.90 & 0.85 \\
\hline Average Stack Temperature (F) & 279 & 281 & 281 & 281 \\
\hline Average DGM Temp (F) & 85.8 & 88.5 & 89.8 & 88.0 \\
\hline Test Duration (minutes) & 241.0 & 240.0 & 240.0 & 240.3 \\
\hline Condensed Water (g) & 243.4 & 258.9 & 277.2 & 259.8 \\
\hline Filter Weight Gain (g) & 0.3241 & 0.2829 & 0.3586 & 0.3219 \\
\hline PNR Weight Gain (g) & 0.1157 & 0.0801 & 0.1338 & 0.1099 \\
\hline$\| \% \mathrm{CO} 2$ & 11.2 & 11.1 & 11.4 & 11.2 \\
\hline$\| \% 02$ & 7.6 & 7.5 & 7.6 & 7.6 \\
\hline$\|$ N2 & 81.2 & 81.4 & 81.0 & 81.2 \\
\hline Meter Volume (dscf) & 113.537 & 114.483 & 117.971 & 115.330 \\
\hline Flue Gas Moisture (\%) & 9.2 & 9.6 & 10.0 & 9.6 \\
\hline (G2s Molecular Weight (Wet) (g/g-mole) & 28.98 & 28.91 & 28.92 & 28.94 \\
\hline Absolute Stack Pressure (" Hg) & 28.74 & 28.61 & 28.49 & 28.61 \\
\hline Absolute Stack Temperature (R) & 739 & 741 & 741 & 741 \\
\hline Average Gas Velocity (f/sec) & 59.25 & 62.30 & 62.74 & 61.43 \\
\hline Avg Flow Rate (acfm) & 456,368 & 479,816 & 483,235 & 473,140 \\
\hline Avg Flow Rate (dscfm) & 284,170 & 295,247 & 294,874 & 291,430 \\
\hline Isokinetic Sampling Rate (\%) & 100.56 & 98.00 & 101.11 & 99.89 \\
\hline Particulate Concentration (gr/dscf) & $5.98 \mathrm{E}-02$ & $4.89 E-02$ & $6.44 \mathrm{E}-02$ & $5.77 \mathrm{E}-02$ \\
\hline Concentration (lbs/dscf) & $8.54 \mathrm{E}-06$ & $6.99 \mathrm{E}-06$ & $9.20 \mathrm{E}-06$ & $8.25 E-06$ \\
\hline Particulate Emission (grams/sec) & 18.35 & 15.61 & 20.52 & 18.16 \\
\hline Particulate Emission (bs/hour) & 145.63 & 123.85 & 162.83 & 144.11 \\
\hline
\end{tabular}


PLANT YATES

ESP OUTLET/ANIONS

\begin{tabular}{|c|c|c|c|c|}
\hline \begin{tabular}{|l} 
Run No. \\
Date \\
Time Start \\
Time Finish \\
Operator
\end{tabular} & $\begin{array}{c}1 \\
6 / 25 / 93 \\
1015 \\
1152 \\
\text { APE } \\
\end{array}$ & $\begin{array}{c}2 \\
6 / 26 / 93 \\
1113 \\
1243 \\
\text { APE } \\
\end{array}$ & $\begin{array}{c}3 \\
6 / 27 / 93 \\
0915 \\
1038 \\
\text { TJB }\end{array}$ & $\begin{array}{c}\text { Average } \\
- \\
- \\
- \\
- \\
\end{array}$ \\
\hline Initial Leak Rate & $<0.001$ & 0.005 & 0.010 & - \\
\hline Final Leak Rate & 0.007 & 0.003 & 0.004 & $=$ \\
\hline Duct Dimensions (ft) & $11.3 \times 11.3$ & $11.3 \times 11.3$ & $11.3 \times 11.3$ & - \\
\hline Pitot Tube Correction Factor (Cp) & 0.84 & 0.84 & 0.84 & - \\
\hline Dry Gas Meter Calibration (Yd) & 0.992 & 0.992 & 0.992 & - \\
\hline Nozale Diameter (inches) & 0.2230 & 0.2230 & 0.2290 & - \\
\hline Barometric Pressure ("Hg) & 29.55 & 29.42 & 29.30 & 29.42 \\
\hline Static Pressure ("H2O) & -11.0 & -11.0 & -11.0 & -11.0 \\
\hline Meter Volume (acf) & 65.200 & 62.150 & 60.611 & 62.654 \\
\hline Average square root of delt & 0.9574 & 0.9558 & 0.9327 & 0.9486 \\
\hline Average delta H (" H2O) & 1.50 & 1.53 & 1.60 & 1.54 \\
\hline Average Stack Temperature (F) & 282 & 283 & 280 & 282 \\
\hline Average DGM Temp (F) & 96.3 & 96.5 & 99.7 & 97.5 \\
\hline Test Duration (minutes) & 97.0 & 90.0 & 83.0 & 90.0 \\
\hline$\% \mathrm{CO} 2$ & 11.2 & 11.1 & 11.4 & 11.2 \\
\hline$\% 02$ & 7.6 & 7.5 & 7.6 & 7.6 \\
\hline$\% \mathbf{N 2}$ & 81.2 & 81.4 & 81.0 & 81.2 \\
\hline Meter Volume (dscf) & 60.855 & 57.738 & 55.768 & 58.121 \\
\hline |Flue Gas Moisture (\%) & 9.2 & 9.6 & 10.0 & 9.6 \\
\hline Gas Molecular Weight (Wet) (g/g-mole) & 28.98 & 28.92 & 28.92 & 28.94 \\
\hline (Absolute Stack Pressure (" Hg) & 28.74 & 28.61 & 28.49 & 28.61 \\
\hline Absolute Stack Temperature (R) & 742 & 743 & 740 & 742 \\
\hline |Average Gas Velocity ( $\mathbf{f} / \mathrm{sec}$ ) & 64.89 & 65.04 & 63.48 & 64.47 \\
\hline |Avg Flow Rate (acfm) & 499,777 & 500,985 & 488,928 & 496,563 \\
\hline Avg Flow Rate (dsefm) & 310,071 & 307,637 & 298,858 & 305,522 \\
\hline Isokinetic Sampling Rate (\%) & 95.78 & 98.72 & 100.92 & 98.47 \\
\hline
\end{tabular}




\section{PLANT YATES \\ ESP OUTLET/AMMONIA-CYANIDE}

\begin{tabular}{|c|c|c|c|c|}
\hline $\begin{array}{l}\text { Run No. } \\
\text { Date } \\
\text { Time Start } \\
\text { Time Finish } \\
\text { Operator } \\
\end{array}$ & $\begin{array}{c}1 \\
6 / 25 / 93 \\
0741 \\
0930 \\
\text { TJB } \\
\end{array}$ & $\begin{array}{c}2 \\
6 / 26 / 93 \\
0930 \\
1104 \\
\text { APE } \\
\end{array}$ & $\begin{array}{c}3 \\
6 / 27 / 93 \\
0725 \\
0856 \\
\text { TJB } \\
\end{array}$ & $\begin{array}{c}\text { Average } \\
- \\
- \\
- \\
- \\
\end{array}$ \\
\hline Initial Leak Rate & 0.010 & 0.007 & 0.010 & - \\
\hline Final Leak Rate & 0.015 & 0.006 & 0.007 & - \\
\hline Duct Dimensions (ft) & $11.3 \times 11.3$ & $11.3 \times 11.3$ & $11.3 \times 11.3$ & - \\
\hline Pitot Tube & 0.84 & 0.84 & 0.84 & - \\
\hline Dry Gas N & 0.992 & 0.992 & 0.992 & - \\
\hline Nozzle Dia & 0.2230 & 0.2230 & 0.2290 & - \\
\hline Barometric Pressure ("Hg) & 29.55 & 29.42 & 29.30 & 29.42 \\
\hline Static Pressure ("H2 & -11.0 & -11.0 & -11.0 & -11.0 \\
\hline Meter Volume (acf) & 73.525 & 64.150 & 63.443 & 67.039 \\
\hline Average sc & 0.9680 & 0.9589 & 0.9434 & 0.9568 \\
\hline Average del & 1.55 & 1.52 & 1.60 & 1.56 \\
\hline Average Stack Temperature (F) & 280 & 279 & 279 & 280 \\
\hline Average DGM.Tem & 87.3 & 88.2 & 91.5 & 89.0 \\
\hline Test Duration (minutes) & 109.0 & 95.0 & 91.0 & 98.3 \\
\hline$\% \mathrm{CO} 2$ & 11.2 & 11.1 & 11.4 & 11.2 \\
\hline$\% 02$ & 7.6 & 7.5 & 7.6 & 7.6 \\
\hline$\% \mathbf{N 2}$ & 81.2 & 81.4 & 81.0 & 81.2 \\
\hline Meter Volume (dscf) & 69.762 & 60.496 & 59.242 & 63.167 \\
\hline Flue Gas Moisture (\%) & 9.2 & 9.6 & 10.0 & 9.6 \\
\hline Gas Molecular Weight (Wet) (g/g-mole & 28.98 & 28.92 & 28.92 & 28.94 \\
\hline Absolute Stack Pressure (" H & 28.74 & 28.61 & 28.49 & 28.61 \\
\hline Absolute Stack Temperature (R) & 740 & 739 & 739 & 740 \\
\hline Average Gas Velocity (f/sec) & 65.52 & 65.10 & 64.18 & 64.93 \\
\hline vg Flow Rate (acfm) & 504,628 & 501,391 & 494,303 & 500,108 \\
\hline vg Flow $\mathrm{F}$ & 313,927 & 309,385 & 302,430 & 308,581 \\
\hline Isokinetic Sampling Rat & 96.51 & 97.43 & 96.63 & 96.86 \\
\hline
\end{tabular}




\section{ESP OUTLET/ S.F. PARTICULATE}

\begin{tabular}{|c|c|c|c|c|}
\hline \begin{tabular}{|l} 
Run No. \\
Date \\
Time Start \\
Time Finish \\
Operator \\
\end{tabular} & $\begin{array}{c}1 \\
6 / 24-6 / 25 / 93 \\
0740 \\
0700 \\
\text { DHD } \\
\end{array}$ & $\begin{array}{c}2 \\
6 / 25-6 / 26 / 93 \\
1130 \\
0636 \\
\text { DHD } \\
\end{array}$ & $\begin{array}{c}3 \\
6 / 26-6 / 27 / 93 \\
1218 \\
0627 \\
\text { DHD } \\
\end{array}$ & $\begin{array}{c}\text { Average } \\
- \\
- \\
- \\
- \\
\end{array}$ \\
\hline Initial Leak Rate & 0.012 & 0.005 & 0.005 & - \\
\hline Final Leak Rate & NA & $\mathrm{NA}$ & NA & - \\
\hline Duct Dimensions (ft) & $11.3 \times 11.3$ & $11.3 \times 11.3$ & $11.3 \times 11.3$ & - \\
\hline Pitot Tube Correction Factor (Cp) & 0.84 & 0.84 & 0.84 & - \\
\hline |Dry Gas Meter Calibration (Yd) & 1.007 & 1.007 & 1.007 & - \\
\hline Nozzle Diameter (inches) & 0.2110 & 0.2110 & 0.2110 & - \\
\hline Barometric Pressure ("Hg) & 29.53 & 29.55 & 29.42 & 29.5 \\
\hline Static Pressure ("B2O) & -11.0 & -11.0 & -11.0 & -11.0 \\
\hline Meter Volume (acf) & 852.132 & 687.620 & 711.797 & 750.516 \\
\hline re root of delta p & 0.9581 & 0.9954 & 1.0651 & 1.0062 \\
\hline Average delta H (" H2O & 1.35 & 1.42 & 1.54 & 1.43 \\
\hline Average Stack Temperature (F) & 281 & 279 & 281 & 280 \\
\hline Average DGM Temp (F) & 89.8 & 91.3 & 92.9 & 91.3 \\
\hline Test Duration (minutes) & 1375.8 & 1108.7 & 1055.5 & 1180.0 \\
\hline$\% \mathrm{CO} 2$ & 11.2 & 11.1 & 11.4 & 11.2 \\
\hline \% 02 & 7.6 & 7.5 & 7.6 & 7.6 \\
\hline$\%$ N2 & 81.2 & 81.4 & 81.0 & 81.2 \\
\hline Meter Volume (dscf) & 816.056 & 657.274 & 675.646 & 716.325 \\
\hline Flue Gas Moisture (\%) & 9.2 & 9.6 & 10.0 & 9.6 \\
\hline Gas Molecular Weight (Wet) (g/g-mole & 28.98 & 28.92 & 28.92 & 28.94 \\
\hline Absolute Stack Pressure (" Hg) & 28.72 & 28.74 & 28.61 & 28.69 \\
\hline Absolute Stack Temperature (R) & 741 & 739 & 741 & 740 \\
\hline Average Gas Velocity (f/sec) & 64.92 & 67.39 & 72.36 & 68.22 \\
\hline Avg Flow Rate (acfm) & 500,013 & 519,062 & 557,350 & 525,475 \\
\hline Avg Flow Rate (dscfm) & 310,378 & 322,050 & 341,884 & 324,771 \\
\hline Isokinetic Sampling Rate (\%) & 101.05 & 97.33 & 99.00 & 99.13 \\
\hline
\end{tabular}




\section{PLANT YATES \\ ESP OUTLET/RADIONUCLIDES}

\begin{tabular}{|c|c|c|c|c|}
\hline \begin{tabular}{|l} 
Run No. \\
Date \\
Time Start \\
Time Finish \\
Operator \\
\end{tabular} & \begin{tabular}{|c}
1 \\
$6 / 24-6 / 25 / 93$ \\
1040 \\
0700 \\
APE \\
\end{tabular} & $\begin{array}{c}2 \\
6 / 25-6 / 26 / 93 \\
1050 \\
0640 \\
\text { TJB }\end{array}$ & $\begin{array}{c}3 \\
6 / 26-6 / 27 / 93 \\
1055 \\
0619 \\
\text { DHD } \\
\end{array}$ & $\begin{array}{c}\text { Average } \\
- \\
- \\
- \\
-\end{array}$ \\
\hline $\begin{array}{l}\text { Initial Leak Rate } \\
\text { Final Leak Rate }\end{array}$ & $\begin{array}{r}<0.001 \\
0.007\end{array}$ & $\begin{array}{l}0.005 \\
0.003\end{array}$ & $\begin{array}{l}0.005 \\
0.005\end{array}$ & - \\
\hline Duct Dimensions (ft) & $11.3 \times 11.3$ & $11.3 \times 11.3$ & $11.3 \times 11.3$ & - \\
\hline Pitot Tube Cor & 0.84 & 0.84 & 0.84 & - \\
\hline Dry Gas Meter & 1.005 & 1.005 & 1.005 & - \\
\hline Nozzle Diamet & 0.1970 & 0.1970 & 0.1970 & - \\
\hline Barometric Pre & 29.53 & 29.55 & 29.42 & 29.50 \\
\hline Static Pressure ("H2 & -11.0 & -11.0 & -11.0 & -11.0 \\
\hline Meter Volume (2cf) & 718.510 & 658.079 & 667.090 & 681.226 \\
\hline rerage sq & 1.1124 & 1.0092 & 1.0217 & 1.0478 \\
\hline verage delt: & 1.27 & 1.10 & 1.20 & 1.19 \\
\hline erage Stack & 283 & 283 & 282 & 283 \\
\hline Average DGM Te & 94.7 & 93.9 & 96.9 & 95.2 \\
\hline Test Duration (minutes) & 1166.7 & 1182.4 & 1137.7 & 1162.3 \\
\hline$\% \mathrm{CO} 2$ & 11.2 & 11.1 & 11.4 & 11.2 \\
\hline \% 02 & 7.6 & 7.5 & 7.6 & 7.6 \\
\hline \%.N2 & 81.2 & 81.4 & 81.0 & 81.2 \\
\hline Meter Volume (dscf) & 680.531 & 624.352 & 626.886 & 643.923 \\
\hline Flue Gas Moist & 9.2 & 9.6 & 10.0 & 9.6 \\
\hline G2s Molecular & 28.98 & 28.92 & 28.92 & 28.94 \\
\hline Absolute Stack & 28.72 & 28.74 & 28.61 & 28.69 \\
\hline Absolute Stack & 743 & 743 & 742 & 743 \\
\hline Average Gas Ve & 75.46 & 68.51 & 69.48 & 71.15 \\
\hline Avg Flow Rate & 581,204 & 527,706 & 535,180 & 548,030 \\
\hline Avg Flow Rate & 359,951 & 325,606 & 327,622 & 337,726 \\
\hline Isokinetic Sampling Rate (\%) & 98.29 & 98.37 & 102.02 & 99.5 \\
\hline
\end{tabular}


PLANT YATES

ESP OUTLET/EXTRACTABLE METALS

\begin{tabular}{|c|c|c|c|c|}
\hline \begin{tabular}{|l} 
Run No. \\
Date \\
Time Start \\
Time Finish \\
Operator \\
\end{tabular} & \begin{tabular}{|c}
1 \\
$6 / 24-6 / 25 / 93$ \\
1300 \\
0700 \\
TJB \\
\end{tabular} & $\begin{array}{c}2 \\
6 / 25-6 / 26 / 93 \\
1040 \\
0636 \\
\text { TJB } \\
\end{array}$ & $\begin{array}{c}3 \\
6 / 26-6 / 27 / 93 \\
1137 \\
0621 \\
\text { TJB } \\
\end{array}$ & $\begin{array}{c}\text { Average } \\
- \\
- \\
- \\
- \\
\end{array}$ \\
\hline Initial Leak Rate & 0.015 & 0.009 & 0.010 & - \\
\hline Final Leak Rate & 0.014 & 0.006 & 0.010 & - \\
\hline Duct Dimensions ( $\mathrm{ft}$ ) & $11.3 \times 11.3$ & $11.3 \times 11.3$ & $11.3 \times 11.3$ & - \\
\hline Pitot Tube Correction Factor (Cp) & 0.84 & 0.84 & 0.84 & - \\
\hline Dry Gas Meter Calibration (Yd) & 0.998 & 0.998 & 0.998 & - \\
\hline Nozzle Diameter (inches) & 0.2300 & 0.2290 & 0.2290 & - \\
\hline Barometric Pressure ("Hg) & 29.53 & 29.55 & 29.42 & 29.50 \\
\hline Static Pressure ("H20) & -11.0 & -11.0 & -11.0 & -11.0 \\
\hline Meter Volume (acf) & 906.500 & 948.750 & 812.605 & 889.285 \\
\hline Ire root of delta $p$ & 1.1008 & 1.0954 & 0.9840 & 1.0601 \\
\hline Average delta H (" H2O) & 2.49 & 2.30 & 1.90 & 2.23 \\
\hline Average Stack Temperature (F) & 282 & 283 & 285 & 283 \\
\hline Average DGM Temp (F) & 90.9 & 92.6 & 94.5 & 92.7 \\
\hline Test Duration (minutes) & 1101.0 & 1103.1 & 1125.0 & 1109.7 \\
\hline$\% \mathrm{CO} 2$ & 11.2 & 11.1 & 11.4 & 11.2 \\
\hline$\%$ & 7.6 & 7.5 & 7.6 & 7.6 \\
\hline$\% \mathbf{N 2}$ & 81.2 & 81.4 & 81.0 & 81.2 \\
\hline Meter Volume (dscf) & 861.084 & 898.627 & 762.923 & $840 . \overline{8} 78$ \\
\hline Flue Gas Moisture (\%) & 9.2 & 9.6 & 10.0 & 9.6 \\
\hline Gas Molecular Weight (Wet) ( $g / g$-mole) & 28.98 & 28.92 & 28.92 & 28.94 \\
\hline Absolute Stack Pressure (" Hg) & 28.72 & 28.74 & 28.61 & 28.69 \\
\hline Absolute Stack Temperature (R) & 742 & 743 & 745 & 743 \\
\hline Average Gas Velocity (f/sec) & 74.63 & 74.35 & 67.06 & 72.01 \\
\hline Avg Flow Rate (acfm) & 574,833 & 572,664 & 516,473 & 554,657 \\
\hline Avg Flow Rate (dscfm) & 356,389 & 353,488 & 314,897 & 341,592 \\
\hline Isokinetic Sampling Rate (\%) & 97.65 & 103.45 & 96.67 & 99.26 \\
\hline
\end{tabular}


PLANT YATES

STACK/MODIFIED METHOD 5

\begin{tabular}{|c|c|c|c|c|}
\hline $\begin{array}{l}\text { Run No. } \\
\text { Date } \\
\text { Time Start } \\
\text { Time Finish } \\
\text { Operator }\end{array}$ & $\begin{array}{c}1 \\
6 / 21 / 93 \\
1240 \\
1755 \\
\text { EZ }\end{array}$ & $\begin{array}{c}2 \\
.6 / 22 / 93 \\
0655 \\
1115 \\
\text { EZ }\end{array}$ & $\begin{array}{c}3 \\
6 / 23 / 93 \\
0645 \\
1118 \\
\text { EZ }\end{array}$ & $\begin{array}{l}\text { Average } \\
- \\
- \\
- \\
-\end{array}$ \\
\hline $\begin{array}{l}\text { Initial Leak Rate } \\
\text { Final Leak Rate }\end{array}$ & $\begin{array}{l}<0.001 \\
<0.001\end{array}$ & $\begin{array}{l}<0.001 \\
<0.001\end{array}$ & $\begin{array}{r}0.002 \\
<0.001\end{array}$ & - \\
\hline Stack Diameter (ft) & 13.00 & 13.0 & 13.0 & - \\
\hline Pitot Tube Correction Factor (Cp) & 0.84 & 0.84 & 0.84 & - \\
\hline Dry Gas Meter Calibration (Yd) & 0.994 & 0.994 & 0.994 & - \\
\hline Nozzle Diameter (inches) & 0.1960 & 0.1960 & 0.1950 & - \\
\hline Barometric Pressure ("Hg) & 29.31 & 29.34 & 29.19 & 29.28 \\
\hline Static Pressure ("H20) & -0.5 & -0.5 & -0.5 & -0.5 \\
\hline Meter Volume (acf) & 121.788 & 127.049 & 125.624 & 124.820 \\
\hline Average square root of delta $p$ & 0.8230 & 0.8251 & 0.7944 & 0.8142 \\
\hline Average delta H (" H20) & 0.85 & 0.85 & 0.77 & 0.82 \\
\hline Average Stack Temperature (F) & 127 & 128 & 128 & 128 \\
\hline Average DGM Temp (F) & 89.6 & 94.7 & 94.5 & 92.9 \\
\hline Test Duration (minutes) & 240.0 & 240.0 & 240.0 & 240.0 \\
\hline Condensed Water (g) & 390.2 & 409.4 & 398.0 & 399.2 \\
\hline$\% \mathrm{CO} 2$ & 10.2 & 10.8 & 10.2 & 10.4 \\
\hline$\% 02$ & 8.8 & 8.6 & 8.5 & 8.6 \\
\hline$\%$ N2 & 81.0 & 80.6 & 81.3 & 81.0 \\
\hline Meter Volume (dscf) & 114.171 & 118.129 & 116.237 & 116.179 \\
\hline Flue Gas Moisture (\%) & 13.9 & 14.1 & 13.9 & 14.0 \\
\hline Gas Molecular Weight (Wet) (g/g-mole & 28.32 & 28.37 & 28.31 & 28.33 \\
\hline Absolute Stack Pressure (" Hg) & 29.27 & 29.30 & 29.15 & 29.24 \\
\hline Absolute Stack Temperature (R) & 587 & 588 & 588 & 588 \\
\hline Average Gas Velocity (f/sec) & 49.73 & 49.83 & 48.15 & 49.24 \\
\hline Avg Flow Rate (acfm) & 396,063 & 396,819 & 383,500 & 392,127 \\
\hline Avg Flow Rate (dscfm) & 300,017 & 299,801 & 288,743 & 296,187 \\
\hline Isokinetic Sampling Rate (\%) & 100.47 & 104.02 & 107.37 & 103.95 \\
\hline
\end{tabular}


PLANT YATES

STACK/METHOD 23

\begin{tabular}{|c|c|c|c|c|}
\hline $\begin{array}{l}\text { Run No. } \\
\text { Date } \\
\text { Time Start } \\
\text { Time Finish } \\
\text { Operator } \\
\end{array}$ & $\begin{array}{c}1 \\
6 / 21 / 93 \\
1400 \\
1933 \\
\text { DJV } \\
\end{array}$ & $\begin{array}{c}2 \\
6 / 22 / 93 \\
0812 \\
1236 \\
\text { DJV } \\
\end{array}$ & $\begin{array}{c}3 \\
6 / 23 / 93 \\
0810 \\
1249 \\
\text { DJV }\end{array}$ & $\begin{array}{c}\text { Average } \\
- \\
- \\
- \\
-\end{array}$ \\
\hline Initial Leak Rate & 0.008 & 0.001 & 0.002 & - \\
\hline Final Leak Rate & 0.001 & $<0.001$ & $<0.001$ & - \\
\hline Stack Diameter (ft) & 13.0 & 13.0 & 13.0 & - \\
\hline Pitot Tube Correction Factor (Cp) & 0.84 & 0.84 & 0.84 & - \\
\hline Dry Gas Meter Calibration (Yd) & 1.029 & 1.029 & 1.029 & - \\
\hline Nozale Diameter (inches) & 0.1950 & 0.1950 & 0.1950 & - \\
\hline Barometric Pressure ("Hg) & 29.31 & 29.34 & 29.19 & 29.28 \\
\hline Static Pressure ("H2O) & -0.5 & -0.5 & -0.5 & -0.5 \\
\hline Meter Volume (acf) & 114.442 & 118.294 & 115.263 & 116.000 \\
\hline Average square root of delta $p$ & 0.7956 & 0.8141 & 0.7932 & 0.8010 \\
\hline Average delta H (" H2O) & 0.79 & 0.82 & 0.78 & 0.80 \\
\hline Average Stack Temperature (F) & 123 & 128 & 129 & 127 \\
\hline Average DGM Temp (F) & 80.6 & 86.9 & 87.3 & 84.9 \\
\hline Test Duration (minutes) & 240.0 & 240.0 & 240.0 & 240.0 \\
\hline Condensed Water (g) & 392.0 & 390.6 & 387.5 & 390.0 \\
\hline$\% \mathrm{CO} 2$ & 10.2 & 10.8 & 10.2 & 10.4 \\
\hline$\% 02$ & 8.8 & 8.6 & 8.5 & 8.6 \\
\hline$\% \mathbf{N 2}$ & 81.0 & 80.6 & 81.3 & 81.0 \\
\hline Meter Volume (dscf) & 112.896 & 115.477 & 111.851 & 113.408 \\
\hline Flue Gas Moisture (\%) & 14.1 & 13.8 & 14.1 & 14.0 \\
\hline Gas Molecular Weight (Wet) (g/g-mo & 28.30 & 28.41 & 28.29 & 28.33 \\
\hline Absolute Stack Pressure (" Hg) & 29.27 & 29.30 & 29.15 & 29.24 \\
\hline Absolute Stack Temperature (R) & 583 & 588 & 589 & 587 \\
\hline Average Gas' Velocity (f/sec) & 47.93 & 49.13 & 48.14 & 48.40 \\
\hline Avg Flow Rate (acfm) & 381,724 & 391,287 & 383,360 & 385,457 \\
\hline Avg Flow Rate (dscfm) & 290,495 & 296,622 & 287,675 & 291,598 \\
\hline Isokinetic Sampling Rate (\%) & 103.65 & 103.83 & 103.70 & 103.73 \\
\hline
\end{tabular}




\begin{tabular}{|c|c|c|c|c|c|c|c|c|c|c|c|}
\hline 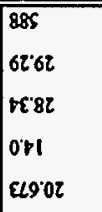 & $\begin{array}{l}885 \\
6162 \\
1 \varepsilon 82 \\
681 \\
29961\end{array}$ & $\begin{array}{l}885 \\
6162 \\
1882 \\
681 \\
29961\end{array}$ & $\begin{array}{l}885 \\
6162 \\
158 z \\
601 \\
.65161\end{array}$ & $\begin{array}{l}885 \\
8 \varepsilon 62 \\
\angle \varepsilon 82 \\
181 \\
59861\end{array}$ & $\begin{array}{l}885 \\
8 \varepsilon 6 r \\
\angle \varepsilon 8 z \\
i n t \\
z z \cdot 61\end{array}$ & $\begin{array}{l}885 \\
0 \varepsilon 6 r \\
L \varepsilon 82 \\
171 \\
199102\end{array}$ & $\begin{array}{l}285 \\
1 \varepsilon 6 z \\
z \varepsilon 8 z \\
6 \varepsilon 1 \\
\varepsilon 2161\end{array}$ & 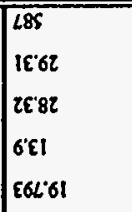 & $\begin{array}{l}85 \\
1 \varepsilon 6 z \\
z \varepsilon 8 z \\
6 \varepsilon 1 \\
199861\end{array}$ & 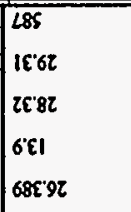 & 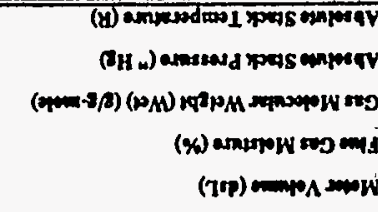 \\
\hline $6^{\prime} 08$ & $\bar{\varepsilon}+18$ & 818 & E18 & 908 & 908 & 908 & 0.18 & 0.18 & 0.18 & 0,18 & $\overline{2 N X}$ \\
\hline L8 & 58 & $\varsigma 8$ & 58 & 98 & 98 & 98 & 88 & 88 & 88 & 88 & $20 \%$ \\
\hline bor & 201 & 201 & rot & 800 & 801 & 801 & zol & 201 & 201 & 201 & $200 x$ \\
\hline 000 & oon & 0000 & 0.00 & 0.00 & 0.00 & oot & 0000 & 0000 & 0000 & 000 & 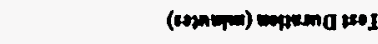 \\
\hline 0.52 & $\overline{\varepsilon 92}$ & $\overline{892}$ & 872 & $\overline{\varepsilon 62}$ & $\sqrt{0.22}$ & 802 & 598 & ह92 & $5 \sqrt{52}$ & 102 & 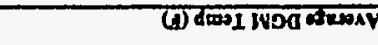 \\
\hline 821 & 8zr1 & 821 & $8 \pi$ & $82 i$ & 821 & $8 \mathrm{~s}$ & $\mid 2 \pi$ & ८zा & L2ז & L2I & (d) amperodosos 1 porg astandy \\
\hline$\varepsilon \tau$ & orz & orz & 0 ozz & $02 z$ & $02 z$ & $0 z \tau$ & ort & ori & oir & otr & 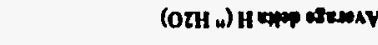 \\
\hline $190^{\circ} \mathrm{IZ}$ & oozoz & oor.0r & oor 02 & $0+99^{\circ} 02$ & otror & orror & $00 z-0 z$ & oszioz & oiroz & sspigr & (v) \\
\hline $50^{\circ}$ & sio. & 50 & $50^{\circ}$ & 50 & $50^{\circ}$ & $50^{\circ}$ & so. & $5 \%$ & 50. & 50 & 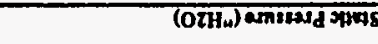 \\
\hline$\varepsilon \varepsilon \sigma \tau$ & 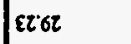 & $\varepsilon r 6 r$ & $\varepsilon 26 \tau$ & pegz & DE⿺z & regr & s5.6r & sc $6 r$ & s\&6r & s\& 62 & (BHW) annsesd onsmang \\
\hline 110.1 & 110' & $110 \%$ & 110.1 & 110.t & 1001 & $110 \%$. & $110 \%$ & 110't & $1100 \%$ & 1001 & 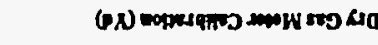 \\
\hline & | & $0 . \varepsilon$ & Oळ\& & |० & |0छा & $0 \approx 1$ & $0 \% \varepsilon$ & |O\& & | & Ooहा & (U) (U) \\
\hline$=$ & .01 .00000 & .0100000 & .5201000 & $.271 .06000^{\circ}$ &.$\Omega 208000$ & $.220600^{\circ} 0$ & .0100100 & $.510000^{\circ}$ & .02011100 & $.2200010^{\circ}$ & 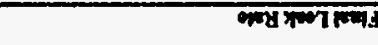 \\
\hline - & .01 04000 & $.12 \bigoplus \angle 00^{\circ} 0$ & .1200000 & .1205000 & .0202000 & .0200100 & .0202100 & $.02 \bigoplus 500 \%$ & .2202100 & .0200000 & 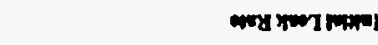 \\
\hline 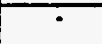 & Har & Hat & HaI & Hat & Hat & म9I & Hat & Har & Hat & Hat & $\sin 10$ \\
\hline - & 0560 & 5880 & $s \& 10$ & 0260 & $s 280$ & $O \in \angle O$ & $\$ 591$ & sssi & s\$口1 & sort & 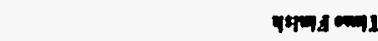 \\
\hline 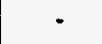 & 0160 & 5080 & $s 590$ & $0+80$ & stLO & 0590 & s191 & sIsI & sitr & sz๕! & Has mant 1 \\
\hline - & Easzrg & EดรZT) & EGEZT) & E6/27) & Egrzess & ع6r2us & E\&II" & E6/ILI & ⿷6/1/2я & E6/29 & \\
\hline ostandy & $\boldsymbol{x}$ & ac & $\mathbf{v \varepsilon}$ & $x t$ & gr & $v t$ & at & or & gl & vi & \\
\hline
\end{tabular}




\section{PLANT YATES \\ STACK/ALDEHYDES}

\begin{tabular}{|c|c|c|c|c|}
\hline $\begin{array}{l}\text { Run NQ. } \\
\text { Date } \\
\text { Time Start } \\
\text { Time Finish } \\
\text { Operator } \\
\end{array}$ & $\begin{array}{c}1 \\
6 / 21 / 93 \\
1340 \\
1408 \\
\text { DJV } \\
\end{array}$ & $\begin{array}{c}2 \\
6 / 22 / 93 \\
0715 \\
0745 \\
\text { DJV } \\
\end{array}$ & $\begin{array}{c}3 \\
6 / 23 / 93 \\
0700 \\
0730 \\
\text { DJV } \\
\end{array}$ & $\begin{array}{c}\text { Average } \\
- \\
- \\
- \\
- \\
\end{array}$ \\
\hline Initial Leak Rate & 0.001 & $<0.001$ & 0.007 & - \\
\hline Final Leak Rate & 0.001 & 0.001 & 0.002 & - \\
\hline Stack Diameter (ft) & 13.0 & 13.0 & 13.0 & - \\
\hline Pitot Tube Correction Factor $\left(C_{p}\right)$ & 0.84 & 0.84 & 0.84 & - \\
\hline Dry Gas Meter Calibration (Yd) & 1.006 & 1.006 & 1.006 & - \\
\hline Nozzle Diameter (inches) & 0.1747 & 0.1747 & 0.1747 & - \\
\hline Barometric Pressure ("Hg) & 29.31 & 29.34 & 29.19 & 29.28 \\
\hline Static Pressure ("H2O) & -0.5 & -0.5 & -0.5 & -0.5 \\
\hline Meter Volume (acf) & 10.707 & 11.086 & 10.929 & 10.907 \\
\hline Average square root of delta $p$ & 0.7680 & 0.7681 & 0.7461 & 0.7607 \\
\hline Average delta H (" H2O) & 0.46 & 0.45 & 0.43 & 0.45 \\
\hline Average Stack Temperature (F) & 127 & 133 & 131 & 130 \\
\hline Average DGM Temp (F) & 81.0 & 81.5 & 79.6 & 80.7 \\
\hline Test Duration (minutes) & 28.0 & 30.0 & 30.0 & 29.3 \\
\hline$\% \mathrm{CO} 2$ & 10.2 & 10.8 & 10.2 & 10.4 \\
\hline$\% 02$ & 8.8 & 8.6 & 8.5 & 8.6 \\
\hline$\%$ N2. & 81.0 & 80.6 & 81.3 & 81.0 \\
\hline Meter Volume (dscf) & 10.310 & 10.676 & 10.507 & 10.498 \\
\hline Flue Gas Moisture (\%) & 13.9 & 14.1 & 13.9 & 14.0 \\
\hline Gas Molecular Weight (Wet) $(g / g$-mole & 28.32 & 28.37 & 28.31 & 28.33 \\
\hline Absolute Stack Pressure (" Hg) & 29.27 & 29.30 & 29.15 & 29.24 \\
\hline Absolute Stack Temperature (R) & 587 & 593 & 591 & 590 \\
\hline Average Gas Velocity (f/sec) & 46.41 & 46.57 & 45.32 & 46.10 \\
\hline Avg Flow Rate (acfm) & 59,602 & 370,850 & 360,938 & 367,130 \\
\hline Avg Flow Rate (dscfm) & 279,942 & 277,918 & 270,646 & 276,169 \\
\hline Lsokinetic Sampling Rate (\%) & 104.90 & 102.12 & 103.21 & 103.41 \\
\hline
\end{tabular}


PLANT YATES

STACK/PSD

\begin{tabular}{|c|c|c|c|c|}
\hline $\begin{array}{l}\text { Run No. } \\
\text { Date } \\
\text { Time Start } \\
\text { Time Finish } \\
\text { Operator }\end{array}$ & \begin{tabular}{|c|}
1 \\
$6 / 21-6 / 22 / 93$ \\
1330 \\
0945 \\
DJV \\
\end{tabular} & $\begin{array}{c}2 \\
6 / 22-6 / 23 / 93 \\
1500 \\
0953 \\
\text { DJV } \\
\end{array}$ & $\begin{array}{c}3 \\
6 / 23-6 / 24 / 93 \\
1553 \\
1000 \\
\text { DJV } \\
\end{array}$ & $\begin{array}{c}\text { Average } \\
- \\
- \\
- \\
- \\
\end{array}$ \\
\hline Initial Leak Rate & 0.008 & 0.002 & 0.004 & - \\
\hline Final Leak Rate & NA & NA & NA & - \\
\hline Stack Diameter (ft) & 13.00 & 13.0 & 13.0 & - \\
\hline Pitot Tube Correction Factor (Cp) & 0.84 & 0.84 & 0.84 & - \\
\hline Dry Gas Meter Calibration (Yd) & 0.994 & 0.994 & 0.994 & - \\
\hline Nozale Diameter (inches) & 0.1960 & 0.1960 & 0.1960 & - \\
\hline Barometric Pressure ("Hg) & 29.31 & 29.34 & 29.19 & 29.28 \\
\hline Static Pressure ("H2O) & -0.5 & -0.5 & -0.5 & -0.5 \\
\hline Meter Volume (acf) & 519.949 & 609.370 & 557.093 & 562.137 \\
\hline Average square root of delta p & 0.8000 & 0.8367 & 0.8367 & 0.8245 \\
\hline Average delta H (" H2O) & 0.80 & 0.87 & 0.87 & 0.85 \\
\hline Average Stack Temperature (F) & 125 & 128 & 128 & 127 \\
\hline Average DGM Te & 96.0 & 95.7 & 94.9 & 95.5 \\
\hline Test Duration (minutes) & 987.0 & 1133.0 & 1080.0 & 1066.7 \\
\hline$\% \mathrm{CO} 2$ & 10.2 & 10.8 & 10.2 & 10.4 \\
\hline$\% 02$ & 8.8 & 8.6 & 8.5 & 8.6 \\
\hline$\% \mathbf{N}_{2}$ & 81.0 & 80.6 & 81.3 & 81.0 \\
\hline Meter Volume (dscf) & 481.761 & 565.595 & 515.177 & 520.844 \\
\hline Flue Gas Moisture (\%) & 13.9 & 14.1 & 13.9 & 14.0 \\
\hline Gas Molecular Weight (Wet) (g/g-mole) & 28.32 & 28.37 & 28.31 & 28.33 \\
\hline Absolute Stack Pressure (" Hg) & 29.27 & 29.30 & 29.15 & 29.24 \\
\hline Absolute Stack Temperature (R) & 585 & 588 & 588 & 587 \\
\hline Average Gas' Vélocity (f/sec) & 48.26 & 50.53 & 50.72 & 49.84 \\
\hline Avg Flow Rate (acfm) & 384,346 & 402,434 & 403,909 & 396,896 \\
\hline Avg Flow Rate (dscfm) & 292,105 & 303,896 & 304,155 & 300,052 \\
\hline Lsokinetic Sampling.Rate. $(\%)$ & 105.88 & 104.08 & 99.37 & 103.11 \\
\hline
\end{tabular}


PLANT YATES

STACK/MULTI-METALS - PARTICULATE

\begin{tabular}{|c|c|c|c|c|}
\hline $\begin{array}{l}\text { Run Na. } \\
\text { Date } \\
\text { Time Start } \\
\text { Time Finish } \\
\text { Operator } \\
\end{array}$ & $\begin{array}{c}1 \\
6 / 25 / 93 \\
0641 \\
1152 \\
\text { DJV } \\
\end{array}$ & $\begin{array}{c}2 \\
6 / 26 / 93 \\
0921 \\
1356 \\
\text { DJV }\end{array}$ & $\begin{array}{c}3 \\
6 / 27 / 93 \\
0653 \\
1106 \\
\text { DJV }\end{array}$ & $\begin{array}{c}\text { Average } \\
- \\
- \\
- \\
-\end{array}$ \\
\hline Initial Leak Rate & 0.002 & 0.001 & 0.001 & - \\
\hline Final Leak Rate & 0.001 & 0.002 & 0.001 & - \\
\hline Stack Diameter (ft) & 13.0 & 13.0 & 13.0 & - \\
\hline Pitot Tube Correction Factor (Cp) & 0.84 & 0.84 & 0.84 & - \\
\hline Dry Gas Meter Calibration (Yd) & 1.029 & 1.029 & 1.029 & - \\
\hline Nozzle Diameter (inches) & 0.1950 & 0.1950 & 0.1950 & - \\
\hline Barometric Pressure ("Hg) & 29.33 & 29.36 & 29.21 & 29.30 \\
\hline Static Pressure ("H2O) & -0.5 & -0.5 & -0.5 & -0.5 \\
\hline Meter Volume (acf) & 114.190 & 113.406 & 115.002 & 114.199 \\
\hline Average square root of delta $p$ & 0.8017 & 0.7958 & 0.7974 & 0.7983 \\
\hline Average delta H (" H2O) & 0.77 & 0.75 & 0.76 & 0.76 \\
\hline Average Stack Temperature (F) & 128 & 130 & 130 & 130 \\
\hline Average DGM Temp (F) & 75.1 & 83.0 & 90.4 & 82.8 \\
\hline Test Duration (minutes) & 240.0 & 240.0 & 240.0 & 240.0 \\
\hline Condensed Water (g) & 403.5 & 399.5 & 416.7 & 406.6 \\
\hline Filter Weight Gain (g) & 0.0461 & 0.0326 & $0.03 \vdots 2$ & 0.0380 \\
\hline PNR Weight Gain (g) & 0.0117 & 0.0023 & 0.0016 & 0.0052 \\
\hline$\% \mathrm{CO} 2$ & 10.9 & 11.4 & 11.6 & 11.3 \\
\hline$\% 02$ & 7.8 & 7.4 & 7.4 & 7.5 \\
\hline$\%$ N2 & 81.3 & 81.2 & 81.0 & 81.2 \\
\hline Meter Volume (dscf) & 113.874 & 111.558 & 111.039 & 112.157 \\
\hline Flue Gas Moisture (\%) & -14.3 & 14.5 & 15.0 & 14.6 \\
\hline Gas Molecular Weight (Wet) (g/g-mole & 28.33 & 28.37 & 28.32 & 28.34 \\
\hline Absolute Stack Pressure (" $\mathbf{H g}$ ) & 29.29 & 29.32 & 29.17 & 29.26 \\
\hline Absolute Stack Temperature (R) & 588 & 590 & 590 & 590 \\
\hline Average Gas Velocity ( $\mathrm{f} / \mathrm{sec}$ ) & 48.47 & 48.13 & 48.40 & 48.33 \\
\hline Avg Flow Rate (acfm) & 386,045 & 383,297 & 385,419 & 384,920 \\
\hline Avg Flow Rate (dscfm) & 290,497 & 287,454 & 285,491 & 287,814 \\
\hline Isokinetic Sampling Rate (\%) & 104.55 & 103.51 & 103.74 & 103.93 \\
\hline Particulate Concentration (gr/dscf) & $7.83 \mathrm{E}-03$ & $4.83 \mathrm{E}-03$ & $5.12 \mathrm{E}-03$ & $5.93 \mathrm{E}-03$ \\
\hline Particulate Concen & $1.12 \mathrm{E}-06$ & $6.90 \mathrm{E}-07$ & $7.31 \mathrm{E}-07$ & 8.47E-07 \\
\hline Particulate Emis & 2.46 & 1.50 & 1.58 & 1.84 \\
\hline Particulate Emission (lbs/hou & 19.51 & 11.90 & 12.52 & 14.64 \\
\hline
\end{tabular}


PLANT YATES

STACKJANIONS

\begin{tabular}{|c|c|c|c|c|}
\hline $\begin{array}{l}\text { Run No. } \\
\text { Date } \\
\text { Time Start } \\
\text { Time Finish } \\
\text { Operator } \\
\end{array}$ & $\begin{array}{c}1 \\
6 / 25 / 93 \\
0940 \\
1155 \\
\text { EBZ } \\
\end{array}$ & $\begin{array}{c}2 \\
6 / 26 / 93 \\
1325 \\
1536 \\
\text { EBZ } \\
\end{array}$ & $\begin{array}{c}3 \\
6 / 27 / 93 \\
0845 \\
1055 \\
\text { EBZ } \\
\end{array}$ & $\begin{array}{c}\text { Average } \\
- \\
- \\
- \\
- \\
\end{array}$ \\
\hline Initial Leak Rate & $<0.001$ & $<0.001$ & $<0.001$ & - \\
\hline Final Leak Rate & $<0.001$ & $<0.001$ & $<0.001$ & - \\
\hline Stack Diameter (ft) & 13.0 & 13.0 & 13.0 & - \\
\hline Pitot Tube Correction Factor (Cp) & 0.84 & 0.84 & 0.84 & - \\
\hline Dry Gas Meter Calibration (Yd) & 1.006 & 1.006 & 1.006 & - \\
\hline Nozzle Diameter (inches) & 0.1950 & 0.1950 & 0.1950 & - \\
\hline Barometric Pressure ("Hg) & 29.33 & 29.36 & 29.21 & 29.30 \\
\hline Static Pressure ("H & -0.5 & -0.5 & -0.5 & -0.5 \\
\hline Meter Volume (acf) & 62.495 & 60.363 & 61.975 & 61.611 \\
\hline Average square root of delta $p$ & 0.7874 & 0.7681 & 0.8183 & 0.7913 \\
\hline Average delta H (" H2O) & 0.72 & 0.67 & 0.74 & 0.71 \\
\hline Average Stack Temperature (F) & 132 & 133 & 133 & 133 \\
\hline Average DGM Temp (F) & $91 . \mathrm{i}$ & 104.5 & 100.3 & 98.6 \\
\hline Test Duration (minutes) & 134.0 & 131.0 & 130.0 & 131.7 \\
\hline $\mathrm{CO} 2 \%$ & 10.9 & 11.4 & 11.6 & 11.3 \\
\hline $02 \%$ & 7.8 & 7.4 & 7.4 & 7.5 \\
\hline$\% \mathbf{N}_{2}$ & $81: 3$ & 81.2 & 81.0 & 81.2 \\
\hline Meter Volume (dscf) & 59.157 & 55.834 & 57.465 & 57.486 \\
\hline Flue Gas Moisture (\%) & 14.3 & 14.5 & 15.0 & 14.6 \\
\hline Gas Molecular Weight (Wet) (g/g-mole & 28.33 & 28.36 & 28.33 & 28.34 \\
\hline Absolute Stack Pressure (" Hg & 29.29 & 29.32 & 29.17 & 29.26 \\
\hline Absolute Stack Temperature (R) & 592 & 593 & 593 & 593 \\
\hline Average Gas Velocity ( $f / s e c)$ & 47.76 & 46.57| & 49.78 & 48.04 \\
\hline Avg Flow Rate (acfm) & 380,391 & 370,917 & 396,432 & 382,580 \\
\hline Avg Flow $R$ & 284,451 & 276,630 & 292,426 & 284,503 \\
\hline Isokinetic Sampling Rate (\%) & 99.35 & 98.63 & 96.76 & 98.25 \\
\hline
\end{tabular}




\section{PLANT YATES \\ STACK/AMMONIA-CYANIDE}

\begin{tabular}{|c|c|c|c|c|}
\hline $\begin{array}{l}\text { Run No. } \\
\text { Date } \\
\text { Time Start } \\
\text { Time Finish } \\
\text { Operator }\end{array}$ & $\begin{array}{c}1 \\
6 / 25 / 93 \\
0647 \\
0904 \\
\text { EBZ } \\
\end{array}$ & $\begin{array}{c}2 \\
6 / 26 / 93 \\
1145 \\
1315 \\
\text { EBZ } \\
\end{array}$ & $\begin{array}{c}3 \\
6 / 27 / 93 \\
0639 \\
0809 \\
\text { EBZ } \\
\end{array}$ & $\begin{array}{c}\text { Average } \\
- \\
- \\
- \\
-\end{array}$ \\
\hline Initial Leak Rate & $<0.001$ & $<0.001$ & $<0.001$ & - \\
\hline Final Leak Rate & $<0.001$ & 0.001 & $<0.001$ & - \\
\hline Stack Diameter (ft) & 13.0 & 13.0 & 13.0 & - \\
\hline Pitot Tube Corre & 0.84 & 0.84 & 0.84 & - \\
\hline Dry Gas Meter Calibr & 1.006 & 1.006 & 1.006 & - \\
\hline Nozzle Diame & 0.1950 & 0.1950 & 0.1950 & - \\
\hline Baro & 29.33 & 29.36 & 29.21 & 29.30 \\
\hline Static Press & -0.5 & -0.5 & -0.5 & -0.5 \\
\hline Meter Volume (acf) & 61.781 & 41.312 & 43.505 & 48.866 \\
\hline Aver & 0.7550 & 0.7681 & 0.7874 & 0.7702 \\
\hline Average & 0.68 & 0.69 & 0.72 & 0.70 \\
\hline Average Sta & 132 & 133 & 135 & 133 \\
\hline Average DG & 86.3 & 97.4 & 85.4 & 89.7 \\
\hline Test Duration (minutes) & 137.0 & 90.0 & 94.0 & 107.0 \\
\hline$\% \mathrm{CO} 2$ & 10.9 & 11.4 & 11.6 & 11.3 \\
\hline$\% 02$ & 7.8 & 7.4 & 7.4 & 7.5 \\
\hline$\% \mathbf{N 2}$ & 81.3 & 81.2 & 81.0 & 81.2 \\
\hline Meter Volume (dscf) & 58.984 & 38.698 & 41.440 & 46.374 \\
\hline Flue Gas Moisture (\%) & 14.3 & 14.5 & 15.0 & 14.6 \\
\hline Gas Molecular Weight (Wet) (g/g-mole & 28.33 & 28.36 & 28.33 & 28.34 \\
\hline Absolute Stack Pressure (" Hg) & 29.29 & 29.32 & 29.17 & 29.26 \\
\hline Absolute Stack Temperature (R) & 592 & 593 & 595 & 593 \\
\hline Average Gas Velocity (f/sec) & 45.78 & 46.59 & 47.98 & 46.78 \\
\hline Avg Flow Rate (acfm) & 364,612 & 371,043 & 382,091 & 372,582 \\
\hline Avg Flow Rate (dscfm) & 272,827 & 276,537 & 280,900 & 276,755 \\
\hline Isokinetic Sampling Rate (\%) & 101.02 & 99.53 & 100.46 & 100.34 \\
\hline
\end{tabular}




\section{PLANT YATES \\ STACK/RADIONUCLDES}

\begin{tabular}{|c|c|c|c|c|}
\hline $\begin{array}{l}\text { Run Na. } \\
\text { Date } \\
\text { Time Start } \\
\text { Time Finish } \\
\text { Operator } \\
\end{array}$ & $\begin{array}{c}1 \\
6 / 24-6 / 25 / 93 \\
1223 \\
0153 \\
\text { JEH }\end{array}$ & $\begin{array}{c}2 \\
6 / 25-6 / 26 / 93 \\
0840 \\
0331 \\
\text { JEH }\end{array}$ & $\begin{array}{c}3 \\
6 / 26-6 / 27 / 93 \\
1357 \\
0614 \\
\text { JEH }\end{array}$ & $\begin{array}{l}\text { Average } \\
- \\
- \\
- \\
-\end{array}$ \\
\hline $\begin{array}{l}\text { Initial Leak Rate } \\
\text { Final Leak Rate }\end{array}$ & $\begin{array}{l}<0.001 \\
<0.001\end{array}$ & $\begin{array}{l}0.010 \\
0.009\end{array}$ & $\begin{array}{l}<0.001 \\
<0.001\end{array}$ & - \\
\hline Stack Diameter (ft) & 13.0 & 13.0 & 13.0 & - \\
\hline Pitot Tube Correction Factor (Cp) & 0.84 & 0.84 & 0.84 & - \\
\hline Dry Gas Meter Calibration (Yd) & 0.994 & 0.988 & 0.988 & - \\
\hline Nozzle Diameter (inches) & 0.2400 & 0.2400 & 0.2400 & - \\
\hline Barometric Pressure ("Hg) & 29.33 & 29.33 & 29.36 & 29.34 \\
\hline Static Pressure ("H2O) & -0.5 & -0.5 & -0.5 & -0.5 \\
\hline Meter Volume (acf) & 599.556 & 654.007 & 696.609 & 650.057 \\
\hline Average square root of delta $p$ & 0.8459 & 0.8370 & 0.8524 & 0.8451 \\
\hline Average delts H (" H2O) & 1.94 & 1.87 & 1.96 & 1.92 \\
\hline Average Stack Temperature (F) & 130 & 129 & 131 & 130 \\
\hline Average DGM Temp (F) & 97.3 & 93.0 & 97.7 & 96.0 \\
\hline Test Duration (minutes) & 816.0 & 893.0 & 908.0 & 872.3 \\
\hline$\% \mathrm{CO} 2$ & 10.9 & 11.4 & 11.6 & 11.3 \\
\hline$\% 02$ & 7.8 & 7.4 & 7.4 & 7.5 \\
\hline$\% \mathrm{~N}_{2}$ & 81.3 & 81.2 & 81.0 & 81.2 \\
\hline Meter Volume (dsef) & 556.184 & 607.560 & 642.493 & 602.079 \\
\hline Flue Gas Moisture (\%) & 14.3 & 14.5 & 15.0 & 14.6 \\
\hline Gas Molecular Weight (Wet) (g/g-mole) & 28.33 & 28.36 & 28.33 & 28.34 \\
\hline Absolute Stack Pressure (" Hg) & 29.29 & 29.29 & 29.32 & 29.30 \\
\hline Absolute Stack Temperature (R) & 590 & 589 & 591 & 590 \\
\hline Average Gas Velocity (f/sec) & 51.21 & 50.61 & 51.63 & 51.15 \\
\hline Avg Flow Rate (acfm) & 407,813 & 403,033 & 411,204 & 407,350 \\
\hline Avg Flow Rate (dscfm) & 306,199 & 302,339 & 305,914 & 304,817 \\
\hline Isokinetic Sampling Rate (\%) & 94.07 & 95.09 & 97.74 & 95.63 \\
\hline
\end{tabular}




\section{PLANT YATES \\ STACK/EXTRACTABLE METALS}

\begin{tabular}{|c|c|c|c|c|}
\hline $\begin{array}{l}\text { Run No. } \\
\text { Date } \\
\text { Time Start } \\
\text { Time Finish } \\
\text { Operator } \\
\end{array}$ & \begin{tabular}{|c}
1 \\
$6 / 24-6 / 25 / 93$ \\
1150 \\
0725 \\
EBZ \\
\end{tabular} & $\begin{array}{c}2 \\
6 / 25-6 / 26 / 93 \\
1246 \\
0331 \\
E B Z \\
\end{array}$ & $\begin{array}{c}3 \\
6 / 26-6 / 27 / 93 \\
1442 \\
0616 \\
\text { EBZ } \\
\end{array}$ & $\begin{array}{c}\text { Average } \\
- \\
- \\
- \\
- \\
\end{array}$ \\
\hline Initial Leak Rate & $<0.001$ & $<0.001$ & $<0.001$ & - \\
\hline Final Leal & $<0.0$ & 0.001 & $<0.001$ & - \\
\hline Stack Diameter (ft) & .0 & 13.0 & 13.0 & - \\
\hline Cp) & 0.84 & 0.84 & 0.84 & - \\
\hline Dry Gas M & 0.994 & 1.029 & 1.029 & - \\
\hline Nozele Di & 0.2400 & 0.2400 & 0.2400 & - \\
\hline Barometri & 29.33 & 29.33 & 29.36 & 29.34 \\
\hline Static Pres & -0.5 & -0.5 & -0.5 & -0.5 \\
\hline Meter Volu & 818.991 & 600.910 & 618.386 & 679.429 \\
\hline ge s & 0.7874 & 0.8000 & 0.7616 & 0.7830 \\
\hline age & 1.78 & 1.75 & 1.58 & 1.70 \\
\hline erature (F) & 129 & 125 & 126 & 127 \\
\hline rerage D & 97.6 & 89.1 & 90.6 & 92.4 \\
\hline Test Duration (minutes) & 1112.0 & 857.0 & 880.0 & 949.7 \\
\hline$\%$ & 10.9 & 11.4 & 11.6 & 11.3 \\
\hline 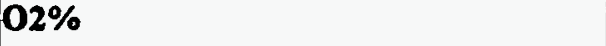 & 7.8 & 7.4 & 7.4 & 7.5 \\
\hline$\underline{-2}$ & 81.3 & 81.2 & 81.0 & 81.2 \\
\hline Meter Volume (dscf) & 759.081 & 585.462 & 601.172 & 648.572 \\
\hline Gas M & 14.3 & 14.5 & 15.0 & 14. \\
\hline Vet) $\left(g / g-m_{0}\right.$ & 28.33 & 28.36 & 28.33 & 28.34 \\
\hline ID & 29.29 & 29.29 & 29.32 & 29.30 \\
\hline ture (R) & 589 & 585 & 586 & 587 \\
\hline e Gas Velocity (f/sec) & 47.63 & 48.22 & 45.93 & 47.26 \\
\hline & 379,362 & 384,045 & & 376,407 \\
\hline $\mathbf{F}$ & 285,223 & 289,842 & 274,469 & 283,178 \\
\hline Isokinetic Sampling Rate (\%) & 101.14 & 99.60 & 105.18 & 101.97 \\
\hline
\end{tabular}


PLANT YATES

STACK/CHROME VI

\begin{tabular}{|c|c|c|c|c|}
\hline $\begin{array}{l}\text { Run No. } \\
\text { Date } \\
\text { Time Start } \\
\text { Time Finish } \\
\text { Operator. }\end{array}$ & $\begin{array}{c}1 \\
6 / 25 / 93 \\
1147 \\
1434 \\
\text { JEH } \\
\end{array}$ & $\begin{array}{c}2 \\
6 / 26 / 93 \\
1041 \\
1445 \\
\text { JEH } \\
\end{array}$ & $\begin{array}{c}3 \\
6 / 27 / 93 \\
0800 \\
1150 \\
\text { JEH }\end{array}$ & $\begin{array}{c}\text { Average } \\
- \\
- \\
- \\
- \\
\end{array}$ \\
\hline Initial Leak Rate & $<0.001$ & $<0.001$ & 0.007 & - \\
\hline Final Leak Rate & $<0.001$ & 0.002 & 0.008 & - \\
\hline Stack Diameter (ft) & 13.0 & 13.0 & 13.0 & - \\
\hline Pitot Tube Correction Factor (Cp) & 0.84 & 0.84 & 0.84 & - \\
\hline Dry Gas Meter Calibration (Yd) & 0.994 & 0.994 & 0.994 & - \\
\hline Nozzle Diameter (inches) & 0.1950 & 0.1950 & 0.1950 & - \\
\hline Barometric Pressure ("Hg) & 29.33 & 29.36 & 29.21 & 29.30 \\
\hline Static Pressure ("H2O) & -0.5 & -0.5 & -0.5 & -0.5 \\
\hline Meter Volume (acf) & 68.563 & 66.971 & 69.589 & 68.374 \\
\hline Average square root of delta $p$ & 0.7658 & 0.7689 & 0.7868 & 0.7738 \\
\hline Average delta H (" H2O) & 0.69 & 0.69 & 0.71 & 0.70 \\
\hline Average Stack Temperature (F) & 127 & 130 & 130 & 129 \\
\hline Average DGM Temp (F) & 90.5 & 90.7 & 87.5 & 89.6 \\
\hline Test Duration (minutes) & 144.0 & 144.0 & 146.0 & 144.7 \\
\hline $\mathrm{CO} 2 \%$ & 10.9 & 11.4 & 11.6 & 11.3 \\
\hline $02 \%$ & 7.8 & 7.4 & 7.4 & 7.5 \\
\hline$\%$ N2 & 81.3 & 81.2 & 81.0 & 81.2 \\
\hline Meter Volume (dscf) & 64.184 & 62.738 & 65.242 & 64.054 \\
\hline Flue Gas Moisture (\%) & 14.3 & 14.5 & 15.0 & 14.6 \\
\hline Gas Molecular Weight (Wet) (g/g-mole) & 28.33 & 28.36 & 28.33 & 28.34 \\
\hline Absolute Stack Pressure (" Hg & 29.29 & 29.32 & 29.17 & 29.26 \\
\hline Absolute Stack Temperature (R) & 587 & 590 & 590 & 589 \\
\hline Average Gas Velocity (f/sec) & 46.24 & 46.50 & 47.74 & 46.83 \\
\hline Avg Flow Rate (acfm) & 368,270 & 370,354 & 380,212 & 372,945 \\
\hline Avg Flow Rate (dscfm) & 277,922 & 277,614 & 281,887 & 279,141 \\
\hline Isokinetic Sampling Ra & 102.66 & 100.46 & 101.47 & 101.53 \\
\hline
\end{tabular}




\section{VOST FIELD DATA SHEET}

PLANT___Plant Yates Station Boiler No. 1

DATE $\quad 6 / 23193$

SAMPLING LOCATION ESP OUTLE

RUN NO. 3

OPERATOR

TEST NO.

AMBIENT TEMPERATURE

BAROMETRIC PRESSURE

29.39

BLANK TUBE NUMBERS T: $14516 A$ T/C $14516 B$
ASSUMED MOISTURE \% ?

METER BOX NO.

METER FACTOR 1.0355

PROBE HEATER SETTING 200-300

COMMENTS

\begin{tabular}{|c|c|c|c|c|c|c|c|c|c|c|c|c|c|}
\hline \multirow{2}{*}{$\begin{array}{c}\text { Tost } \\
\text { Number } \\
\end{array}$} & \multicolumn{2}{|c|}{ Leak Chock ("Hg) } & \multirow{2}{*}{$\begin{array}{l}\text { Tubo N } \\
\text { (Lab) }\end{array}$} & \multirow{2}{*}{$\begin{array}{c}\text { Sampling } \\
\text { (min) }\end{array}$} & \multirow{2}{*}{$\begin{array}{l}\text { Clock } \\
\text { Time }\end{array}$} & \multirow{2}{*}{$\begin{array}{c}\text { Gas Meter } \\
\text { Reading }\end{array}$} & \multirow{2}{*}{$\begin{array}{c}\text { Moter } \\
\text { Pressure } \\
\end{array}$} & \multirow{2}{*}{$\begin{array}{l}\text { Stack } \\
\text { Temp }\end{array}$} & \multirow{2}{*}{$\begin{array}{l}\text { DGM } \\
\text { Tomp } \\
\end{array}$} & \multirow{2}{*}{$\begin{array}{l}\text { Probo } \\
\text { Tomp } \\
\end{array}$} & \multirow{2}{*}{$\begin{array}{l}1 \text { ist Condensor } \\
\text { Outlei Temp. }\end{array}$} & \multirow{2}{*}{$\begin{array}{l}\text { 2nd Condensor } \\
\text { Oullet Temp. }\end{array}$} & \multirow{2}{*}{$\begin{array}{c}\text { Pump Vacuum } \\
\text { Femp- }\end{array}$} \\
\hline & Pro & Post & & & & & & & & & & & \\
\hline \multirow[t]{5}{*}{$3 A$} & 0@20 & 0,11 & \multirow{2}{*}{$\begin{array}{c}T \\
14520 \\
A\end{array}$} & 0 & 0120 & 0.00 & 1 & & 73 & 311 & 58 & 58 & 8 \\
\hline & & & & 10 & 0730 & 5.05 & 1 & & 75 & 324 & 55 & 56 & 8 \\
\hline & & & \multirow{2}{*}{$\begin{array}{c}T / C \\
14 \leqslant 8 \\
148\end{array}$} & 20 & 12240 & 10.0 & 1 & & 78 & 272 & 55 & $\sqrt{6}$ & 8 \\
\hline & & & & 30 & 0258 & 1505 & 1 & & 79 & 273 & 58 & 57 & 8 \\
\hline & & & & 40 & 08002 & 20.00 & 1 & & 80 & 274 & 58 & 58 & 8 \\
\hline \multirow[t]{5}{*}{$3 B$} & \multirow[t]{2}{*}{0022} & \multirow{2}{*}{ o@17 } & \multirow{2}{*}{$\begin{array}{c}T \\
14517 \\
A\end{array}$} & 0 & 0809 & 0.00 & 1 & & 81 & 220 & 59 & 59 & 5 \\
\hline & & & & 10 & 0819 & 5.0 & 1 & & 82 & 300 & 58 & 58 & 5 \\
\hline & & & \multirow{2}{*}{$\begin{array}{c}T / C \\
14517 \\
\beta\end{array}$} & 20 & 0829 & 10,02 & 1 & & 82 & 293 & 58 & 58 & 5 \\
\hline & & & & 30 & 0839 & 15.05 & 1 & & 83 & 290 & 59 & 58 & 5 \\
\hline & & & & 40 & 0849 & 20.00 & 1 & & 83 & 287 & 59 & 58 & 5 \\
\hline \multirow[t]{10}{*}{$3 c$} & $0 Q 22$ & oQ 1 & \multirow{2}{*}{$\begin{array}{c}14526 \\
A\end{array}$} & 0 & 0856 & 0.00 & 1 & & 84 & 260 & 56 & 58 & 5 \\
\hline & & & & 10 & 0906 & 5.06 & 1 & & 85 & 223 & 61 & 59 & 5 \\
\hline & & & \multirow{2}{*}{$\begin{array}{c}1458 \\
14\end{array}$} & $2 p$ & 0916 & 9.98 & 1 & & 85 & 277 & 60 & 59 & 5 \\
\hline & & & & 30 & 0926 & 1501 & 1 & & 85 & 283 & 53 & 58 & 5 \\
\hline & & & & 40 & 0936 & 20.00 & 1 & & 86 & 289 & 5 & 58 & 5 \\
\hline & & & \multirow[t]{2}{*}{$T$} & 0 & & & & & & & & & \\
\hline & & & & & & & & & & & & & \\
\hline & & & \multirow[t]{2}{*}{$T / C$} & & & & & & & & & & \\
\hline & & & & & & & & & & & & & \\
\hline & & & & & & & & & & & & & \\
\hline
\end{tabular}


PLANT_Plant Yates Station Boiler No. 1

DATE

SAMPLING LOCATION \&SP OLT

RUN NO._ 2 TEST NO

OPERATOR Noul

AMBIENT TEMPERATURE

70

BAROMETRIC PRESSURE

29.40

BLANK TUBE NUMBERS T:14533A T/C: $14533 B$ $6 / 22 / 93$

ASSUMED MOISTURE \% 7

METER BOX NO. $\sqrt{-9}$

METER FACTOR 1.0355

PROBE HEATER SETTING ' 300 COMMENTS

\begin{tabular}{|c|c|c|c|c|c|c|c|c|c|c|c|c|c|}
\hline \multirow{2}{*}{$\begin{array}{c}\text { Tost } \\
\text { Number }\end{array}$} & \multicolumn{2}{|c|}{ Loak Chock $(\mathrm{Hg})$} & \multirow{2}{*}{$\begin{array}{c}\text { Tubo N } \\
\text { (Lab) }\end{array}$} & \multirow{2}{*}{$\begin{array}{c}\text { Sampling } \\
\text { (min) }\end{array}$} & \multirow{2}{*}{$\begin{array}{l}\text { Clock } \\
\text { Timo }\end{array}$} & \multirow{2}{*}{$\begin{array}{l}\text { Gas Meter } \\
\text { Reading }\end{array}$} & \multirow{2}{*}{$\begin{array}{c}\text { Meter } \\
\text { Pressure } \\
\end{array}$} & \multirow{2}{*}{$\begin{array}{l}\text { Stack } \\
\text { Temp }\end{array}$} & \multirow{2}{*}{$\begin{array}{l}\text { DGM } \\
\text { Temp } \\
\end{array}$} & \multirow{2}{*}{$\begin{array}{l}\text { Probo } \\
\text { Temp }\end{array}$} & \multirow{2}{*}{$\begin{array}{l}\text { Ist Condensor } \\
\text { Qutlat Temp. }\end{array}$} & \multirow{2}{*}{$\begin{array}{l}\text { 2nd Condonsor } \\
\text { Outlet Tomp. }\end{array}$} & \multirow{2}{*}{ Pump Vacuum } \\
\hline & \multirow{3}{*}{ pare } & Post & & & & & & & & & & & \\
\hline $2 A$ & & \multirow{2}{*}{$0 @ 11$} & \multirow{2}{*}{$\begin{array}{c}T \\
14530 \\
A\end{array}$} & 0 & c) 136 & 0.00 & 1 & & 78 & 300 & 61 & 60 & 7 \\
\hline & & & & 10 & 0746 & 5.08 & 1 & & 78 & 304 & 63 & 61 & 7 \\
\hline & & & \multirow{2}{*}{$\mid \begin{array}{c}T / C \\
1 y / 330 \\
B\end{array}$} & 20 & 0756 & 10.13 & 1 & & 78 & 305 & 54 & 54 & 7 \\
\hline & & & & 30 & 0806 & 15.0 & 1 & & 78 & 302 & 57 & 56 & 7 \\
\hline & & & & 40 & 0816 & 20,05 & 1 & & 79 & 252 & 59 & 56 & 7 \\
\hline \multirow[t]{5}{*}{$2 B$} & $0 @ 21$ & 0@9 & \multirow{2}{*}{$4 \mathrm{~A}^{\mathrm{T}} \mathrm{T}$} & 0 & 0822 & 0.00 & 1 & & 79 & 262 & 58 & 54 & 4 \\
\hline & & & & 10 & 0832 & 5.00 & 1 & & 80 & 223 & 52 & 55 & 4 \\
\hline & & & \multirow{2}{*}{$\begin{array}{c}T / C \\
14 / 527\end{array}$} & 20 & 0842 & 9.94 & 1 & & 81 & 289 & 56 & $\sqrt{6}$ & 4 \\
\hline & & & & 30 & 0852 & 15.01 & 1 & & 81 & 262 & 55 & 55 & 4 \\
\hline & & & & 40 & 0902 & 20,00 & 1 & & 81 & 280 & 58 & 57 & 4 \\
\hline \multirow[t]{5}{*}{$2 c$} & 6020 & 0012 & \multirow{2}{*}{$\begin{array}{c}14525 \\
A\end{array}$} & 0 & 0909 & 0,00 & 1 & & 82 & 267 & 60 & 58 & 4 \\
\hline & & & & 10 & 0919 & 4.98 & 1 & & 82 & 278 & 58 & 57 & $4+1$ \\
\hline & & & \multirow{3}{*}{14525} & 20 & 0929 & 9.99 & 1 & & 83 & 285 & 57 & 56 & $4+1$ \\
\hline & & & & 30 & 0936 & 15.02 & 1 & & 83 & 292 & 58 & 56 & 5 \\
\hline & & & & 40 & 0949 & 20.00 & 1 & & 83 & 285 & 35 & 56 & 5 \\
\hline & & & \multirow[t]{2}{*}{$T$} & 0 & & & & & & & & & \\
\hline & & & & & & & & & & & & & \\
\hline & & & \multirow[t]{2}{*}{$T / C$} & & & & & & & & & & \\
\hline & & & & & & & & & & & & & \\
\hline & & & & & & & & & & & & & \\
\hline
\end{tabular}




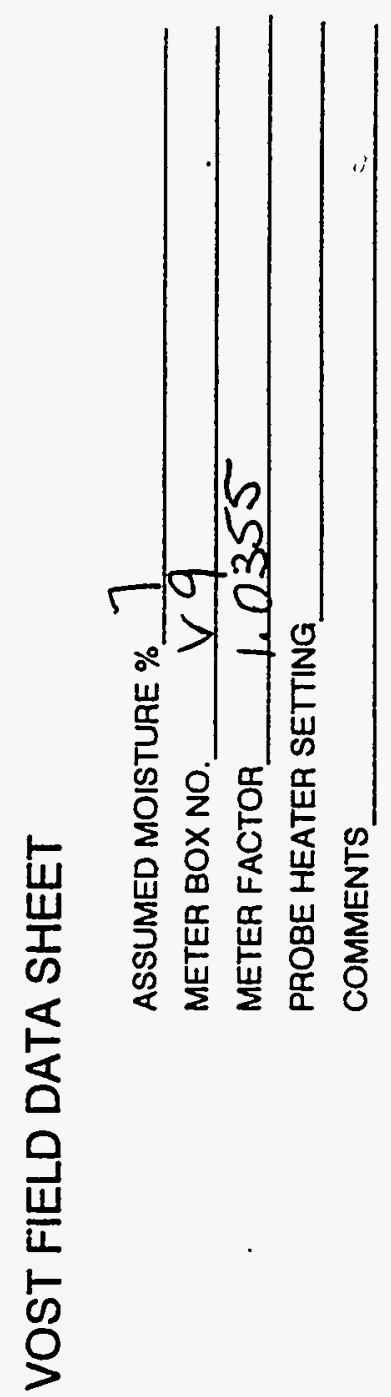

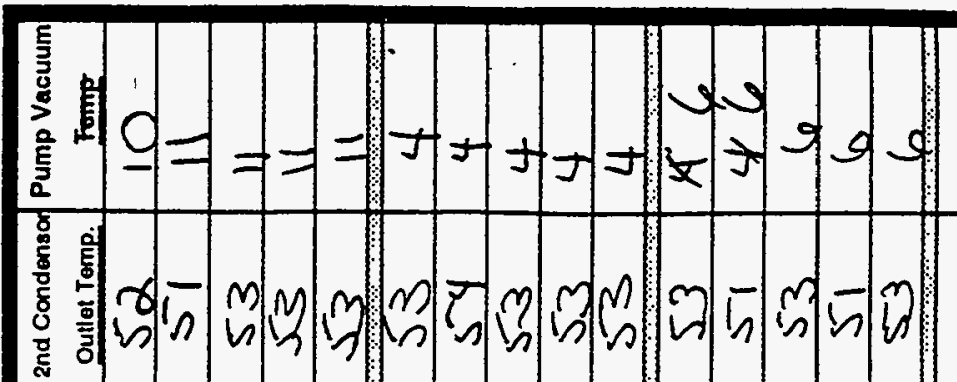

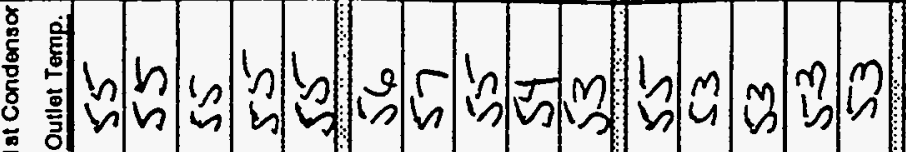

:

:

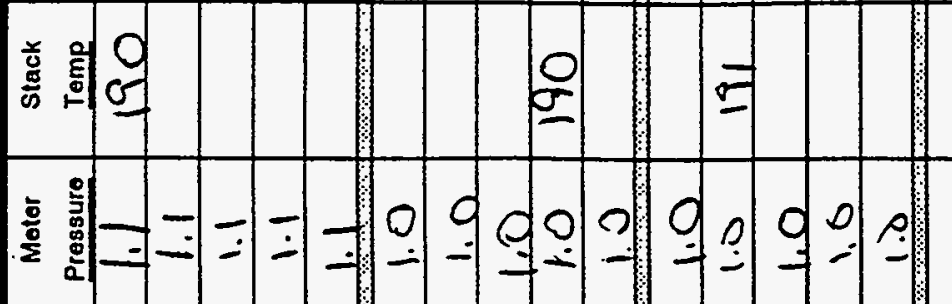

言竞

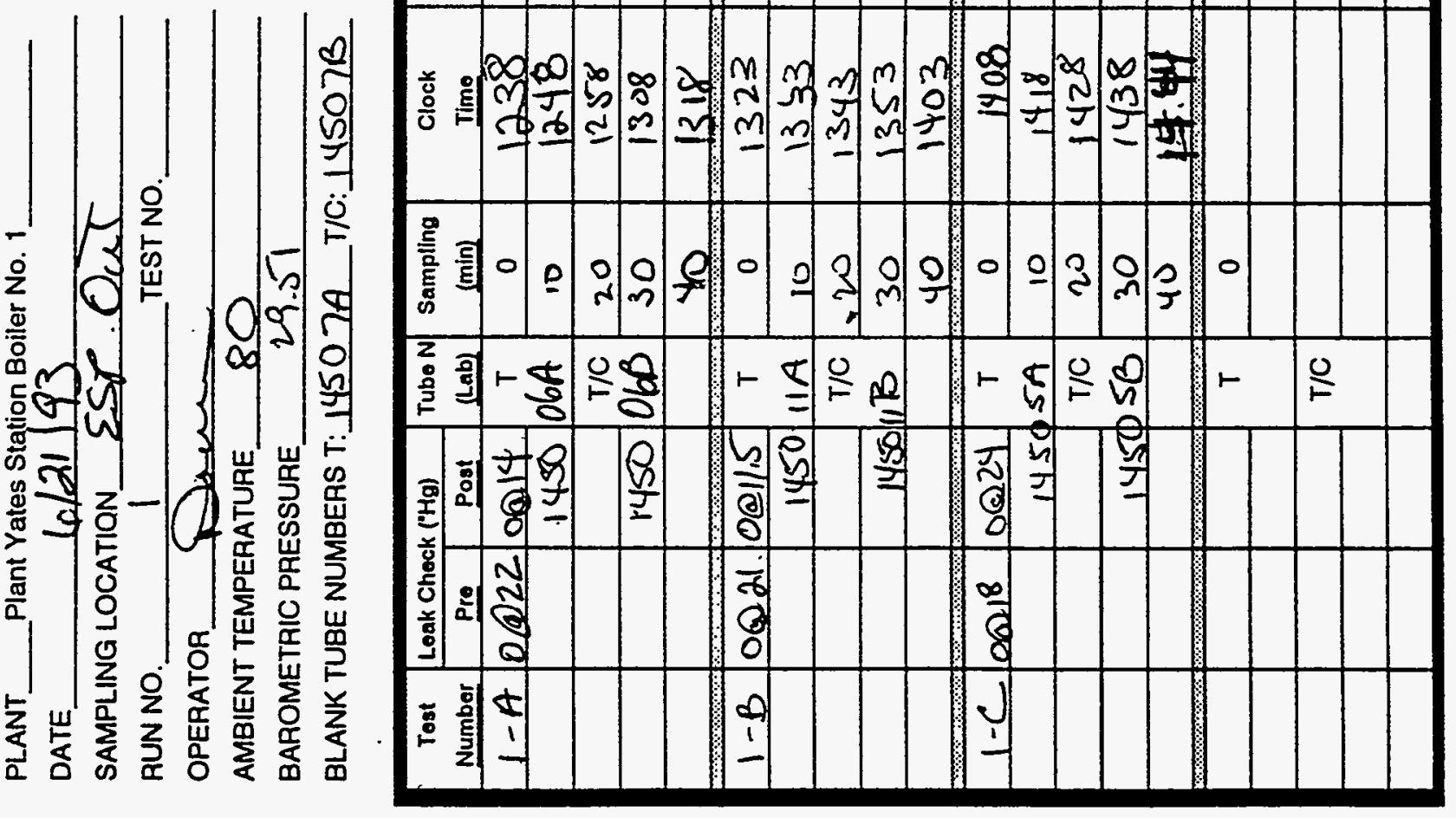


PLANT NAME Plant Yates Station Boiler No. 1

SAMPLING LQCATION OUTlet RUN NQ 1 MM-5

Page 1 of 2 DATE $621 / 93$ TIMESTART 1299 \% TIME FINISH 1812 DUCT DIMENSIONS $11.4 \frac{1}{\mathrm{x}} \pi .4$ DIAMETER PTCF .84 DGMCF $\frac{.997}{\mathrm{Hg}}$ NOZZLE DIA. .197 inches STATIC PRESS $\frac{21.51 .0}{\text { B H2O OPERATOR TJB }}$ TEST DURATION $320240 \mathrm{~min}$. INITIAL LEAK RATE .005012" $\mathrm{cm}$. FINAL LEAK RATE. $0.5 \% 10^{\prime \prime} \mathrm{cm}$

\begin{tabular}{|c|c|c|c|c|c|c|c|c|c|c|c|c|}
\hline $\begin{array}{c}\text { Traverse } \\
\text { Point }\end{array}$ & $\begin{array}{l}\text { Clock } \\
\text { Time }\end{array}$ & $\begin{array}{l}\text { Dry gas theter } \\
\text { reading fa3 }\end{array}$ & in $\mathrm{H} 2 \mathrm{O}$ & in $\mathrm{H} 2 \mathrm{O}$ & $\begin{array}{c}\text { Stack } \\
\text { Temp. } F\end{array}$ & $\frac{D_{\text {Rry gas m }}}{\text { Lnlet }}$ & $\frac{\text { er temp. }}{\text { Outlet }}$ & $\begin{array}{l}\text { Hot box } \\
\text { Temp. }\end{array}$ & $\begin{array}{l}\text { Probe } \\
\text { Temp }\end{array}$ & $\begin{array}{c}\text { Last } \\
\text { Impinger }\end{array}$ & $\begin{array}{l}\text { Vacuum } \\
\text { is. Hg }\end{array}$ & $\begin{array}{c}\text { Cond. } \\
\text { Exit } \\
\text { Temp. F }\end{array}$ \\
\hline-1 & 1249 & 3769971 & 8 & 1.1 & 187 & 75 & 70 & 254 & 254 & 61 & $\$ .0$ & 65 \\
\hline 23 & 1254 & 340.3 & .83 & 89 & 173 & 71 & 70 & 245 & 241 & 56 & 5.0 & 63 \\
\hline 3 & 1259 & 382.1 & $.6-1$ & $(4,2)$ & 192 & 73 & 70 & 249 & 255 & 46 & 5.0 & 53 \\
\hline 4 & 1304 & 384.5 & .3 & 3 & 190 & 74 & 70 & 245 & 251 & 46 & $\$ .0$ & 52 \\
\hline 5 & 1309 & 386.15 & .34 & 40 & 191 & 74 & 71 & 257 & 250 & 46 & 4.5 & 54 \\
\hline 6 & 1314 & 387.9 & .58 & .67 & 181 & 25 & 31 & 252 & 253 & 77 & 5.5 & $5 \%$ \\
\hline 7 & 1319 & 389.9 & .71 & .85 & 161 & 77 & 72 & 242 & 246 & $4 \sqrt{5}$ & 6.0 & 51 \\
\hline 8 & 1324 & 393.0 & .75 & -96 & 137 & 79 & 74 & 254 & 2050 & 45 & & 51 \\
\hline STOP & 1329 & 395.012 & Po & char & 2 & & 00 & & $10^{11}$ & & & \\
\hline $2-1$ & 1343 & 395.9 & .9 & $n 1$ & 1871 & 79 & 78 & 139 & 252 & 47 & 7.0 & 56 \\
\hline 2 & 1348 & 398.75 & .7 & .83 & 195 & 81 & 28 & 252 & 255 & 49 & c.o & 43 \\
\hline 3 & 1354 & 401.8 & -75 & .89 & 197 & 83 & 78 & 245 & 245 & 50 & 6.0 & 49 \\
\hline 4 & 1359 & 404.35 & .9 & 1.1 & 198 & 89 & 78 & 255 & 249 & 50 & 7.0 & 42 \\
\hline 5 & 1404 & 407.05 & .7 & .81 & 194 & 85 & 79 & 245 & 247 & 50 & 7.0 & 41 \\
\hline 6 & 14089 & 409.65 & 65 & .76 & 182 & 86 & 80 & 252 & 260 & 50 & 6.0 & 41 \\
\hline 7 & 1414 & 411.95 & .73 & $18.8 \times .9$ & 160 & 86 & 81 & 245 & 244 & 51 & 6.0 & 41 \\
\hline 8 & 1419 & 414.7 & .5 & .63 & 153 & 87 & 82 & 249 & 261 & 51 & 5.0 & 41 \\
\hline STOP & 1424 & 416.85 & Port & Change & Leak & $\checkmark$ & & $\rightarrow$ & & & & \\
\hline $3-1$ & 1517 & 417.9 & .54 & .56 & 280 & 782 & 82 & 253 & 246 & 53 & 5.0 & 51 \\
\hline 2 & 1522 & 420.5 & 95 & .98 & 280 & 83 & 82 & 254 & 255 & 56 & 6.5 & 51 \\
\hline 3 & 1527 & 422.6 & 1.2 & 1.25 & 280 & 84 & 82 & 249 & 249 & 55 & 6.5 & 48 \\
\hline 4 & 1532 & 425.3 & 1.3 & 1.35 & 281 & 87 & 83 & 253 & 255 & 56 & 6.5 & 43 \\
\hline 5 & 1537 & 428.20 & 1.0 & 1.05 & 279 & 89 & 84 & 254 & 246 & 56 & 7.0 & 42 \\
\hline 6 & 1532 & 431.35 & .92 & .96 & 279 & 90 & 84 & 245 & 245 & 58 & 7.0 & 45 \\
\hline 7 & 1547 & 433.91 & .73 & .76 & 278 & 90 & 84 & 255 & 263 & 60 & 7.0 & 43 \\
\hline 8 & 1552 & 436.45 & .52 & .54 & 276 & 90 & 85 & 245 & 264 & 63 & 5.0 & 42 \\
\hline stoP & 1557 & 438.56 & & & & & & & & & & \\
\hline & & & & & & & & & & & & \\
\hline & & 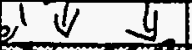 & $1 \longdiv { A p }$ & & & & & & & & & \\
\hline Avg. & & entaces & 6855 & & $1005 \%$ & 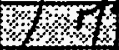 & & & & & & 4 \\
\hline heck'd & - & 50 9 & $4 \%$ & \& & $48 \%$ & 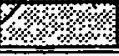 & $3 \%$ & $\% \%$ & 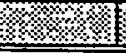 & $2 \times 1 \%$ & $>$ & 84 \\
\hline
\end{tabular}

CONSOLE \# 161364

FILTER *

AMBIENT TEMP.

PROBE LENGTH 12

LINER MATERIAL GIASS

REMARKS

Nozzle ID 111

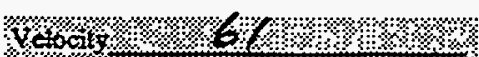

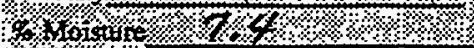

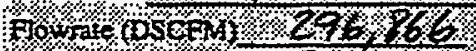

Isokintid (6)

18.10 KSTACK TEup in Error during tirst 20.95 t $\mathrm{t} / 3$ due to elee gr. Desob/sur 
:-1ODIrIED METHOD 5 FIELD FÁTA SHEET

PLANT NAME Plant Yates Stati'n Boiler No. 1

$\begin{array}{ll}\text { SAMPLING LOCATION OutLeT RUN N } \\ \text { DATE } 6 & 2,93 \text { TIMESTART }\end{array}$ DUCT DLMENSIONS DIAMETER DGMCF NOZZLE DIA.

TEST DURATION

Page $1 / 2$ of 2

PTCF

PTCF

STATIC PRESS " $\mathrm{H} 2 \mathrm{O}$

OPERATOR

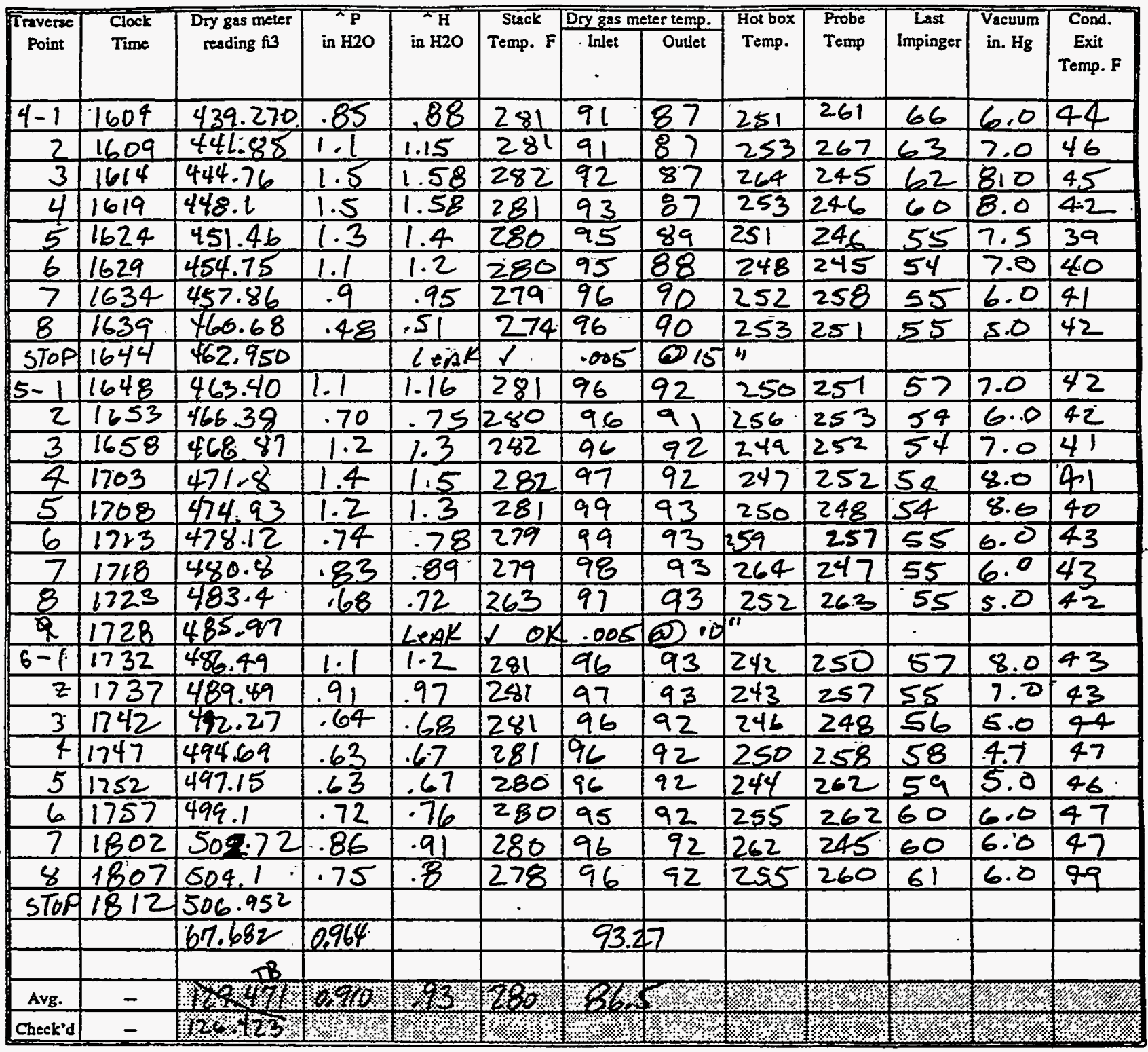

CONSOLE \#

FILTER \#

AMBIENT TEMP.

PROBE LENGTH

LINER MATERIAL

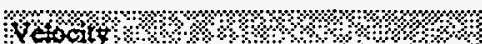

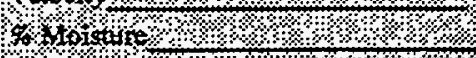

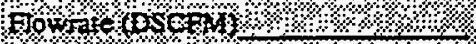

tsokncto $(\mathrm{s})$

REMARKS 


\section{MODIFIED METHOD $\subsetneq$ FIELD DATA SHEET}

PLANT NAME Plant Yates Station Boiler No. 1

.. SAMPLING LPCATION OUTLET RUN No. 2

$\therefore$ DATE $6 / 22 / 53$ TIME START 0753 JTVIME FINISH 2247 TEST DURATION 240 min.

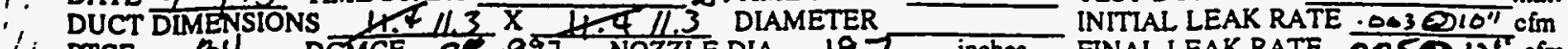

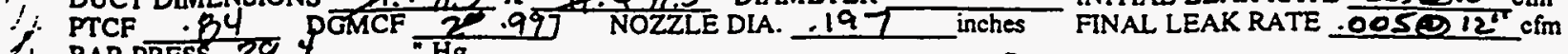

BAR PRESS 29.4
STATIC PRESS -11.0

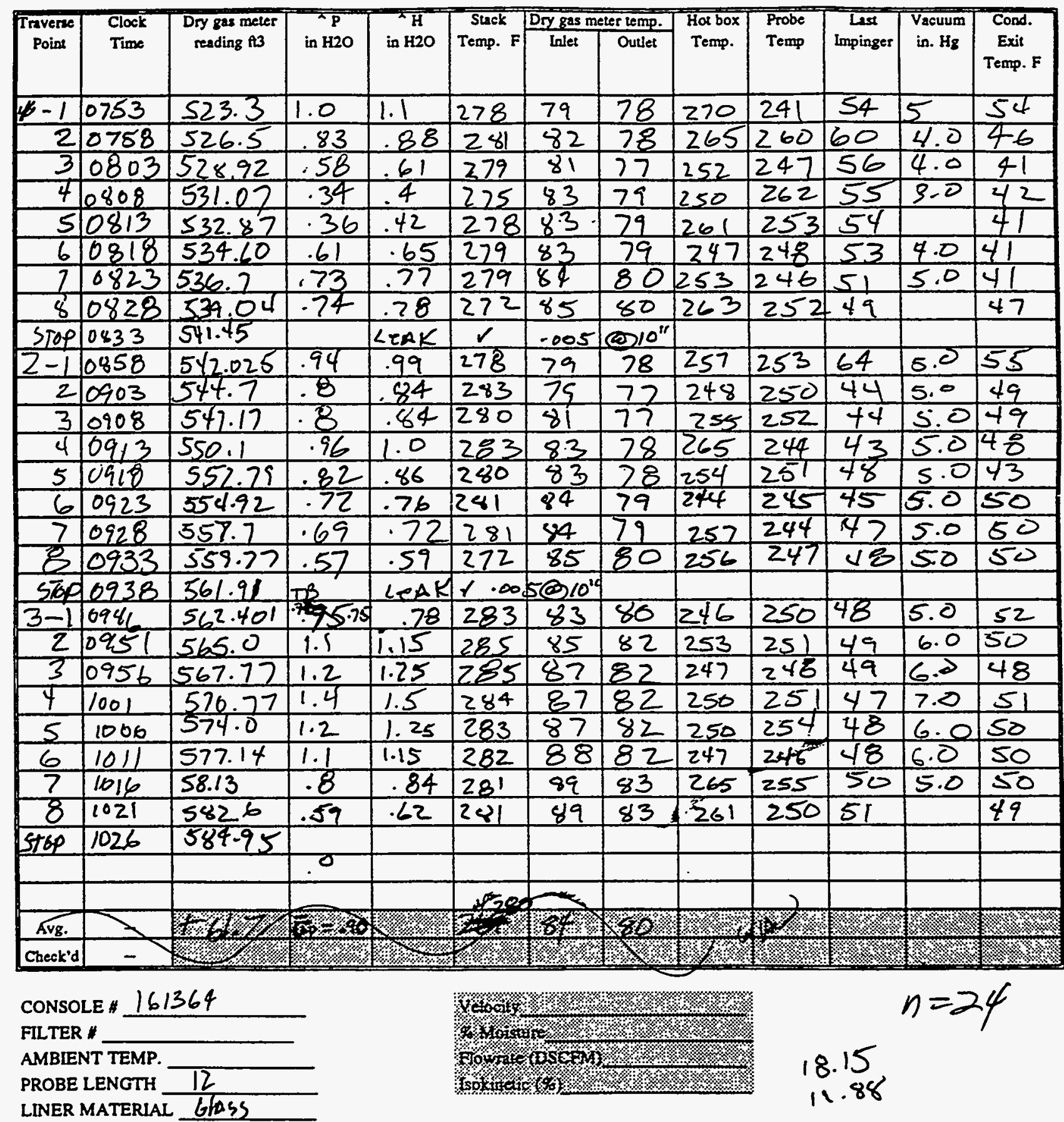

REMARKS 


\section{MODIFIED iVIETHOD 5 FIELD DATA SHEE:}

PLANT NAME Plant Yates Station Boiler No. 1 Page 2 of 2

SAMPLING LOCATION Outlet

\begin{tabular}{ll} 
SAMPLING LOCATION Outlet & RUN NO. 2 \\
DATE $6 / 22 / 83$ & TIME START \\
DUCT DIMENSIONS & TIME FINISH \\
\hline
\end{tabular}

$\mathrm{X}$ DLAMETER

10

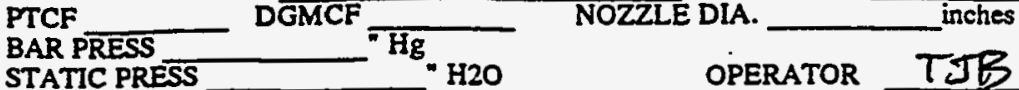

TEST DURATION

INITIAL LEAK RATE min.

FINAL LEAK RATE cfm

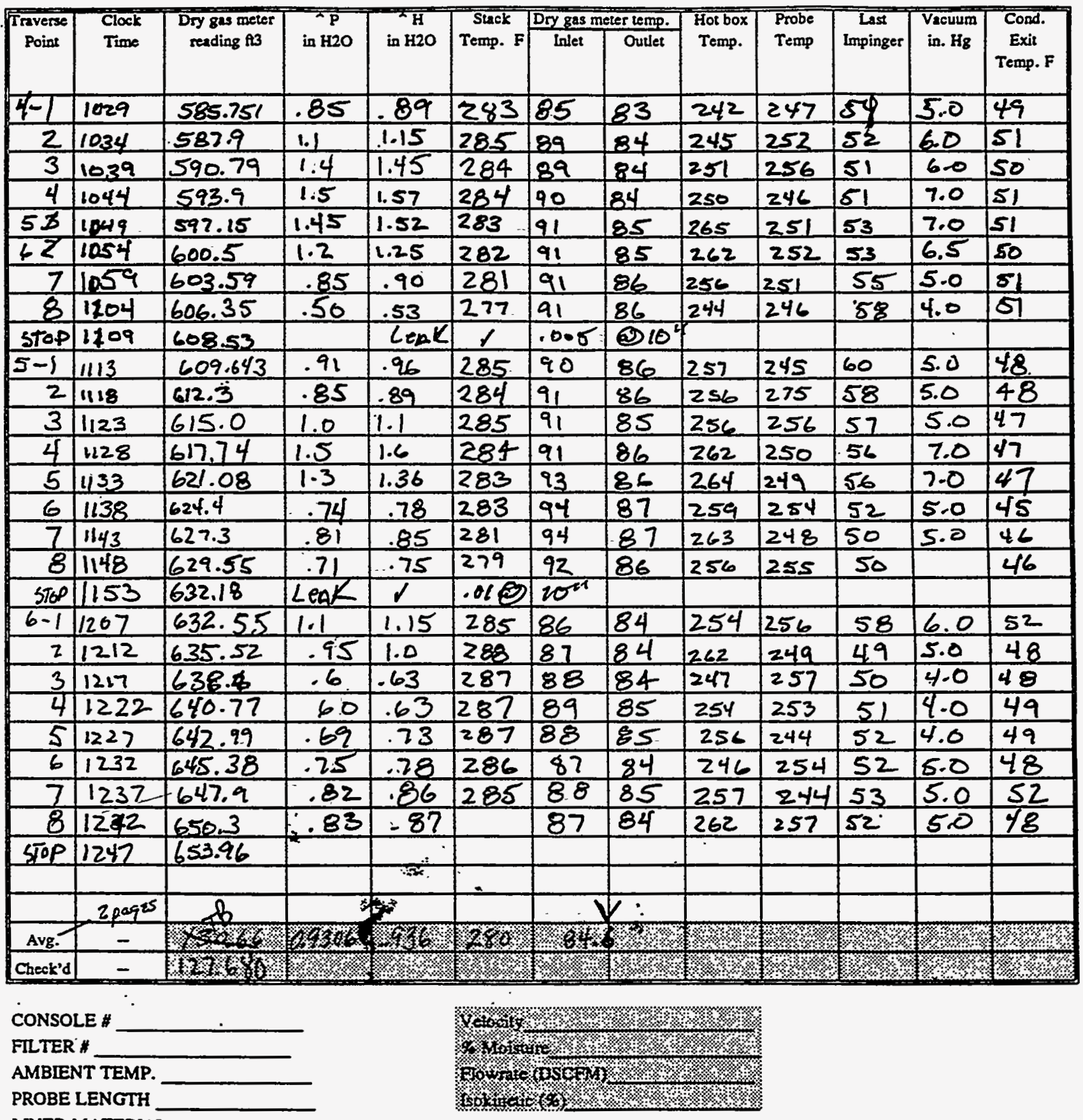

REMARKS

C-46 


\section{MIUdT̄ied METHOD 5 FIELd DATA SHEET}

PLANT NAME Plant Yates Station Boiler No. 1

SAMPLING LQCATION OUtlet RUN No. 3

Page 1 of 2 DATE $6 / 23 / 43$ TIME START $\frac{6712}{\mathrm{X} / 1.4}$ TIME FINISH 112.9 PTCF .84 DGMCF 1992 NOZZLE DIA. 197 BAR PRESS 29.36 " $\mathrm{Hg}$ inches STATIC PRESS -11.0 OPERATOR TJB

\begin{tabular}{|c|c|c|c|c|c|c|c|c|c|c|c|c|}
\hline \multirow{2}{*}{ Traverse } & \multirow{2}{*}{$\begin{array}{l}\text { Clock } \\
\text { Time }\end{array}$} & \multirow{2}{*}{$\begin{array}{l}\text { Dry ges meter } \\
\text { reading fi3 }\end{array}$} & \multirow{2}{*}{ in $\mathrm{H} 2 \mathrm{O}$} & \multirow{2}{*}{ in $\mathrm{H} 2 \mathrm{O}$} & \multirow{2}{*}{$\begin{array}{c}\text { Stack } \\
\text { Temp. } F\end{array}$} & \multicolumn{2}{|c|}{ Dry gas meler lemp. } & \multirow{2}{*}{$\begin{array}{l}\text { Hot box } \\
\text { Temp. }\end{array}$} & \multirow{2}{*}{$\begin{array}{l}\text { Probe } \\
\text { Temp }\end{array}$} & \multirow{2}{*}{$\begin{array}{c}\text { Last } \\
\text { Impinger }\end{array}$} & \multirow{2}{*}{$\begin{array}{l}\text { Vacuum } \\
\text { in. } \mathrm{Hg}\end{array}$} & \multirow{2}{*}{$\begin{array}{l}\text { Cond. } \\
\text { Exit } \\
\text { Temp. F }\end{array}$} \\
\hline & & & & & & Inlet & Outlet & & & & & \\
\hline $1-1$ & 0712 & 668.7 & .95 & .96 & 280 & 25 & 72 & 247 & 255 & 68 & 8 & 55 \\
\hline 2 & $0: 17$ & 671.5 & .80 & .80 & 275 & 77 & 73 & 242 & 253 & 59 & 6 & 41 \\
\hline 3 & 0722 & 673.83 & .51 & .56 & 274 & 81 & 75 & 259 & 245 & 56 & 5 & 43 \\
\hline 4 & 0727 & 675.97 & .35 & .35 & 272 & 84 & 27 & 246 & 256 & 55 & 4 & 45 \\
\hline 5 & 0732 & 677.65 & .33 & 33 & 274 & 84 & 72 & 246 & 244 & 56 & 4 & 50 \\
\hline 6 & 0737 & 679.15 & .60 & .60 & 274 & 83 & 78 & 246 & 255 & 58 & 6. & 51 \\
\hline 7 & 0742 & 681.17 & .64 & .64 & 273 & 85 & 79 & 253 & 244 & 51 & 6 & 48 \\
\hline 8 & 0747 & 683.50 & .75 & 75 & 269 & 85 & 79 & $25 c$ & 251 & 50 & 7 & 47 \\
\hline STOP & 0752 & 685.75 & LeAK & 1 & .003 & @) 15 & & & & & & \\
\hline $2-1$ & 0756 & 686.25 & .86 & 86 & 277 & 85 & 80 & 241 & 255 & 54 & 7 & 4.7 \\
\hline 2 & 0801 & 688.8 & 7.69 & .69 & 278 & 86 & 80 & 265 & 244 & 48 & 7 & 47 \\
\hline 3 & 0806 & 691.0 & .71 & .71 & 277 & 86 & 80 & 260 & 243 & 47 & 2 & 46 \\
\hline 4 & 0811 & 04.0 & .95 & .95 & 277 & 85 & 79 & 259 & 254 & 47 & 7 & 44 \\
\hline 5 & 0816 & 695.77 & .69 & .69 & 244 & 85 & 79 & 264 & 247 & 47 & 7 & 45 \\
\hline 6 & 0821 & 698.15 & .60 & .60 & 275 & 85 & 80 & 246 & 250 & 47 & 7 & 45 \\
\hline 7 & 0826 & 700.27 & .71 & .71 & 274 & 85 & 80 & 252 & 260 & 48 & 7 & 46 \\
\hline 8 & 0831 & 702.64 & .57 & .57 & 264 & 85 & 80 & 256 & 249 & 49 & 6 & 48 \\
\hline STOP & 0836 & 704.79 & & LeAK & $d .00$ & 50 & $15 \pi$ & & & & & \\
\hline $3-1$ & 0839 & 705.235 & .61 & .61 & 278 & 83 & 80 & 240 & 251 & 58 & 7 & 51 \\
\hline 2 & 0844 & 707.62 & .96 & .96 & 280 & 85 & 80 & 245 & 252 & 53 & 9 & 52 \\
\hline 3 & 0849 & 709.9 & 1.2 & 1.2 & 279 & 85 & 80 & 248 & 262 & 52 & 10.0 & 53 \\
\hline 4 & 0054 & 712.88 & 1.3 & 1.3 & 280 & 85 & 80 & 254 & 265 & 52 & 10.0 & so \\
\hline 5 & 0859 & 216.0 & .99 & .99 & 277 & 85 & 80 & $24^{\circ} 6$ & 254 & 56 & 9.0 & 53 \\
\hline$\frac{6}{7}$ & 0904 & 718.9 & .91 & .91 & 276 & 85 & 81 & 247 & 259 & 57 & 8.0 & 54 \\
\hline 7 & 0909 & 721.8 & 70 & .70 & 276 & 84 & 80 & 258 & 246 & 59 & 7.0 & 55 \\
\hline 8 & 0914 & 723.7 & .51 & .51 & & 85 & 81 & 246 & 254 & 59 & 6.0 & 55 \\
\hline $310 A$ & 0919 & 725.744 & & & & & & & & & & \\
\hline & & & & & & & & & & & & \\
\hline & & & & & & & & & & & & \\
\hline Avg. & $=$ & $4 \%$ & \%" & \% & 8 & 4 & $\$ \%$ & 8 & 4 & $8 \%$ & (1) & (x) \\
\hline Check'd & - & 5181 & 28 & 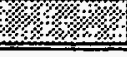 & 98 & 19 & & $1 \%$ & 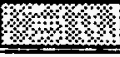 & 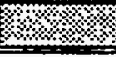 & ४ & 8 \\
\hline
\end{tabular}

CONSOLE \# 161364

FILTER \#

AMBIENT TEMP.

PROBE LENGTH $12^{\circ}$

LINER MATERIAL GTGSS

REMARKS

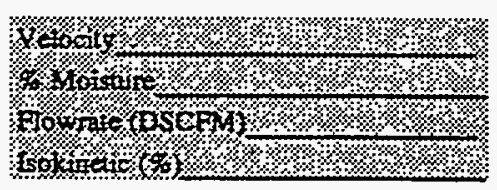

$\mathrm{CO}_{2}^{11.2} 02^{7.9} \quad 10.0 \% \mathrm{Bw}^{-9}$ 


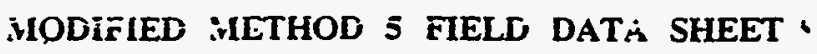

PLANT NAME Plant Yates Station Boiler No. 1

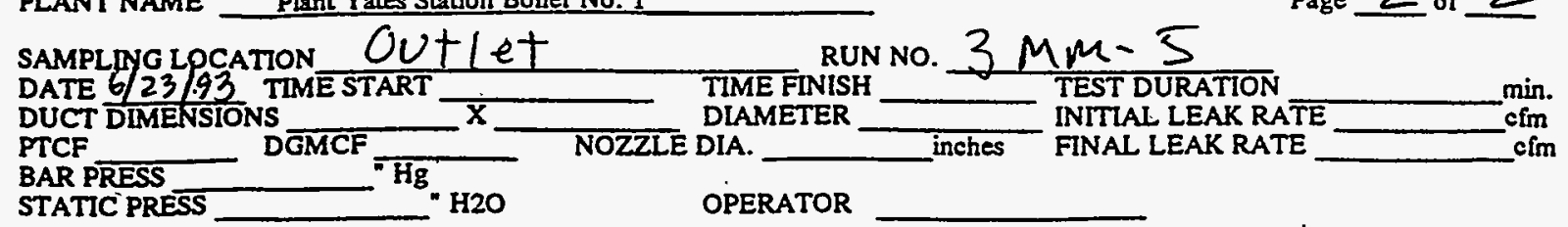

\begin{tabular}{|c|c|c|c|c|c|c|c|c|c|c|c|c|}
\hline \multirow{2}{*}{$\begin{array}{c}\text { Traverse } \\
\text { Point }\end{array}$} & \multirow{2}{*}{$\begin{array}{l}\text { Clock } \\
\text { Time }\end{array}$} & \multirow{2}{*}{$\begin{array}{l}\text { Dry gas meler } \\
\text { reading fi3 }\end{array}$} & \multirow{2}{*}{ in $F$. } & \multirow{2}{*}{ in $\mathrm{H} 2 \mathrm{O}$} & \multirow{2}{*}{$\begin{array}{c}\text { Stack } \\
\text { Temp. F }\end{array}$} & \multicolumn{2}{|c|}{ Dry gas meter temp. } & \multirow{2}{*}{$\begin{array}{l}\text { Hot box } \\
\text { Temp. }\end{array}$} & \multirow{2}{*}{$\begin{array}{l}\text { Probe } \\
\text { Temp }\end{array}$} & \multirow{2}{*}{$\begin{array}{c}\text { Last } \\
\text { Impinger }\end{array}$} & \multirow{2}{*}{$\begin{array}{l}\text { Vacuum } \\
\text { in. } \mathrm{Hg}\end{array}$} & \multirow{2}{*}{$\begin{array}{c}\text { Cond. } \\
\text { Exit } \\
\text { Temp. F }\end{array}$} \\
\hline & & & & & & Inlet & Dutlet & & & & & \\
\hline $5-1$ & 0922 & 725.92 & .85 & .85 & 280 & 84 & 8 & 256 & 251 & 55 & 8.0 & 51 \\
\hline 2 & 0927 & 728.67 & 1.0 & 1.0 & 280 & 84 & 80 & 252 & 249 & 53 & 9.0 & 31 \\
\hline 3 & 0932 & 736.44 & 1.3 & 1.3 & 281 & 84 & 80 & 243 & 260 & 51 & 10.0 & 49 \\
\hline 4 & 0937 & 734.37 & 1.3 & 1.3 & 280 & 85 & 80 & 254 & 255 & 51 & 10.0 & 51 \\
\hline 5 & 09.22 & 737.7 & 1.3 & 1.3 & 280 & 87 & 81 & 245 & 257 & 52 & 10.0 & 51 \\
\hline 6 & 0947 & 740.5 & 1.1 & 1.1 & 277 & 82 & 81 & 252 & 251 & 53 & 10.0 & 51 \\
\hline 7 & 0952 & 743.7 & .79 & .79 & 277 & 86 & 81 & 248 & 261 & 55 & 7.0 & 51 \\
\hline 8 & 09.57 & 746.05 & .48 & .48 & 277 & 86 & 81 & 252 & 249 & 56 & 7.0 & 52 \\
\hline STCP & 9002 & 748.052 & & LeAK & $\bar{d}$ & .005 & $015^{\circ}$ & & & & & \\
\hline $5-1$ & 1005 & 748.368 & .98 & .98 & 280 & 85 & 81 & 256 & 259 & 57 & 9.0 & 51. \\
\hline 2 & $10 \%$ & 750.79 & .72 & 72 & 282 & 86 & 81 & 249 & 244 & 57 & 7.0 & 53 \\
\hline 3 & 1015 & 753.3 & 1.0 & 1.0 & 282 & 86 & 82 & 261 & 254 & 57 & 9.0 & 53 \\
\hline 4 & 1020 & 15: 75648 & 1.2 & 1.2 & 282 & 87 & 82 & 257 & 253 & 57 & 9.0 & 53 \\
\hline 5 & 1025 & 758.30 & 1.2 & 1.2 & 281 & 88 & 82 & 258 & 244 & 56 & 9.0 & 52 \\
\hline 6 & 1030 & 762.3 & .71 & .71 & 280 & 89 & 83 & 254 & 258 & 57 & 8.0 & 51 \\
\hline 7 & 1035 & 764.55 & 75 & .75 & 280 & 88 & 83 & 246 & 245 & 58 & 7.5 & 52 \\
\hline 8 & 1040 & 767.3 & 68 & .68 & 1274 & 89 & 84 & 245 & 262 & 58 & & 50 \\
\hline S्र.p & 1045 & 769.243 & -88 &. & & & & & & & & \\
\hline $6-1$ & 1649 & 769.6 & 88 & .88 & 283 & 90 & 86 & 255 & 255 & 62 & 8.5 & 54 \\
\hline 2 & 1054 & 772.18 & .91 & .91 & 284 & 91 & 87 & 262 & 258 & 55 & 9.0 & 50 \\
\hline 3 & 1059 & 274.79 & .62 & .62 & 284 & 92 & 87 & 245 & 246 & 52 & 7.0 & 46 \\
\hline 4 & $1 / 04$ & 716.65 & .68 & .68 & 283 & 92 & 88 & 266 & 250 & 52 & 7.0 & 47 \\
\hline 5 & 1109 & 779.35 & .65 & .65 & 282 & 93 & 88 & 250 & 263 & 51 & 7.0 & 45 \\
\hline 6 & 1114 & .781 .64 & .67 & .67 & 281 & 91 & 88 & 245 & 255 & 50 & 7.0 & 47 \\
\hline 7 & 1119 & 784.05 & .85 & .85 & 282 & 91 & 89 & 246 & 245 & 50 & 8.0 & 44 \\
\hline 8 & 1124 & 786.5 & 82 & .82 & 283 & 91 & 89 & 251 & 251 & $4 a$ & 8.0 & 48 \\
\hline STOP & i1 29 & 748.961 & & & + & & & & & & & \\
\hline & & & & & $?$ & & & & & & & \\
\hline & & & & & & & & & & & & \\
\hline Avg. & $=$ & $16 \cos 6$ & Q.68\% & 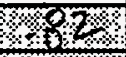 & 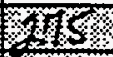 & $4 \%$ & $3 \%$ & צా & $1 \%$ & & x & \\
\hline Check'd & - & 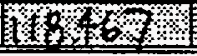 & 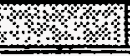 & 20 & $18 \%$ & $1 \%$ & $18 \%$ & $18 \%$ & $18 \%$ & & $4 \%$ & \\
\hline
\end{tabular}

CONSOLE \#

FILTER \#

AMBIENT TEMP.

PROBE LENGTH

LINER MATERIAL

REMARKS
Wenolls

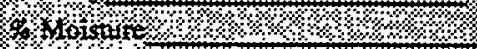

10w1 $\alpha$ rosoful

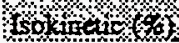

Page 2 of 2 


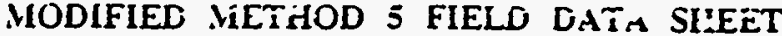

PLANT NAME Plant Yates Station Boiler No. 1

SaMPLING LOCATION ESP OUTILT

DATE 620993 TIME START $\frac{1000}{\mathrm{X}} \mathrm{H}$

PTCF . Y 4 DGMCF

BAR PRESS 29.56
STATIC गRESS -11.0
RUN No. $F B$.

TIME FINISH IO3O TEST DURATION $30 \mathrm{~m}$, $\mathrm{W} \mathrm{min}$ DLAMETER INITIAL LEAK RATE .015 DIA. 250 inches FINAL LEAK RATE $=015$ OPERATOR TJß
Page 1 of

\begin{tabular}{|c|c|c|c|c|c|c|c|c|c|c|c|c|}
\hline \multirow{2}{*}{$\begin{array}{c}\text { Truverse } \\
\text { Point }\end{array}$} & \multirow{2}{*}{$\begin{array}{l}\text { Clock } \\
\text { Time }\end{array}$} & \multirow{2}{*}{$\begin{array}{l}\text { Dry gas meter } \\
\text { reading } \mathrm{ft} 3\end{array}$} & \multirow{2}{*}{ in $\mathrm{H} 2 \mathrm{O}$} & \multirow{2}{*}{ in $\mathrm{H} 12 \mathrm{O}$} & \multirow{2}{*}{$\begin{array}{c}\text { Stack } \\
\text { Temp. F }\end{array}$} & \multicolumn{2}{|c|}{ Dry gas meter temp. } & \multirow{2}{*}{$\begin{array}{l}\text { Hot box } \\
\text { Temp. }\end{array}$} & \multirow{2}{*}{$\begin{array}{l}\text { Probe } \\
\text { Temp }\end{array}$} & \multirow{2}{*}{$\begin{array}{c}\text { Last } \\
\text { Impinger }\end{array}$} & \multirow{2}{*}{$\begin{array}{l}\text { Vacuum } \\
\text { in. } \mathrm{Hg}\end{array}$} & \multirow{2}{*}{$\begin{array}{l}\text { Cond. } \\
\text { Exit } \\
\text { Temp. F }\end{array}$} \\
\hline & & & & & & Inlet & Outles & & & & & \\
\hline & $10: 15$ & 356.3 & & & & & & & & & & \\
\hline & $10: 30$ & 357.12 & & & & & & & & & & \\
\hline & & & & - & & & & & & & & \\
\hline & & & & & & & & & & & & \\
\hline & & & & & & & & & & & & \\
\hline & & & & & & & & & & & & \\
\hline & & & & & & & & & & & & \\
\hline & & & & & & & & & & & & \\
\hline & & & & & & & & & & & & \\
\hline & & & & & & & & & & & & \\
\hline & & & & & & & & & & & & \\
\hline & & & & & & & & & & & & \\
\hline & & & & & & & & & & & & \\
\hline & & & & & & & & & & & & \\
\hline & & & & & & & & & & & & \\
\hline & & & & & & & & & & & & \\
\hline & & & & & & & & & & & & \\
\hline & & & & & & & & & & & & \\
\hline & & & & & & & & & & & & \\
\hline & & & & & & & & & & & & \\
\hline & & & & & & & & & & & & \\
\hline & & & & & & & & & & & & \\
\hline & & & & & & & & & & & & \\
\hline & & & & & & & & & & & & \\
\hline & & & & & & & & & & & & \\
\hline & & & & & & & & & & - & & \\
\hline & & & & & & & & & & & & \\
\hline & & & & & & & & & & & & \\
\hline & & & & & & & & & & & & \\
\hline Avg. & - & 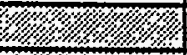 & & 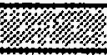 & $\% \% / 4$ & \%/ & \%/ & \%/\% & $14 \%$ & $2 \%$ & 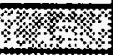 & xys \\
\hline Check'd & - & $14 \% 1 \% 1 \%$ & $4 \%$ & $1 \%$ & 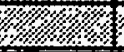 & 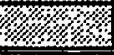 & $\% \%$ & \%, & $6 \%$ & $48 \%$ & \% 8 & 秋 \\
\hline
\end{tabular}

CONSOLE 161364

FLTER " NA.

AMBIENT TEMP.

PROBE LENGTH 12

LINER MATERIAL GHAS

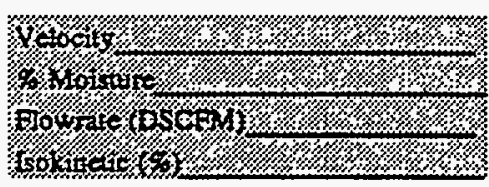

REMARKS 
Plant Name Plant Yates Station Boiler No. 1

Sampling hastion OUTLE

Date 6693 Time Start 1332

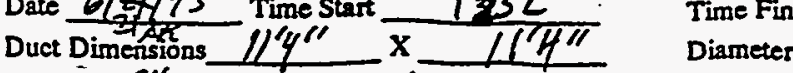
Aldehydes Run No. 1

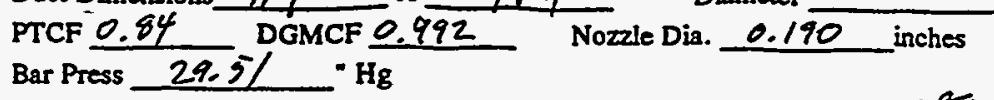
PTCF 0.84 DGMCF 0.992 Nozzle Dia. 0.190 inches Bar Press $29.5 \%=\mathrm{Hg}$

CONSOLE \# $-4 / 61403$

FILTER \#

AMBIENT TEMP.

PROBE LENGTH

LINER MATERIAL

glass

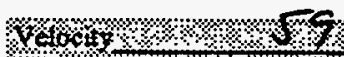

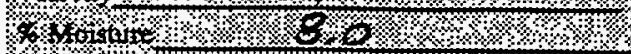

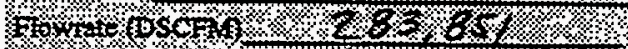

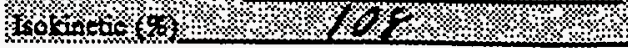

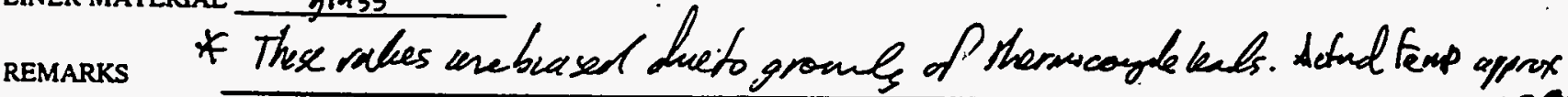




$$
\text { Page } 1 \text { of }
$$

Plant Name Plant Yates Station Boiler No. 1

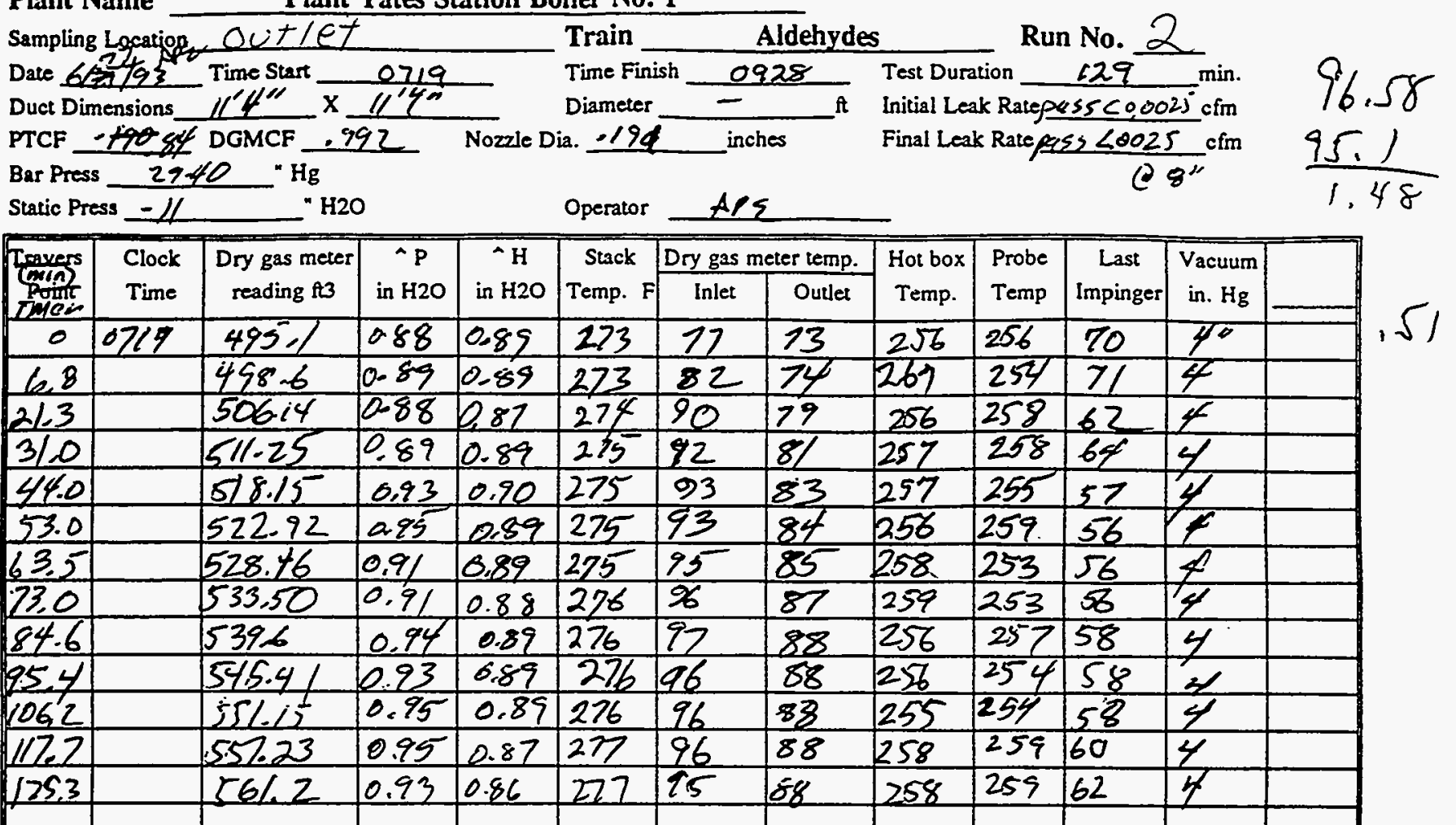


Plant Name Plant Yates Station Boiler No. 1

Sampling Location ESP OUt

Date $6 / 23 / 53$ Time Start 0664

Train

Aldehydes

Run No. 3

Duct Dimensions_1/"4" $\times 11^{\prime 4} 4^{\prime \prime} \quad$ Diameter PTCF_0.84 DGMCF,$\overline{992}$ Nozzle Dia. $: 19 \overline{\text { inches }}$ Bar Press 29.75. $\mathrm{Hg} 29.36$ or Static Press - 11 Operator

\begin{tabular}{|c|c|c|c|c|c|c|c|c|c|c|c|c|}
\hline \multirow{2}{*}{$\begin{array}{c}\text { Travers } \\
\text { Point }\end{array}$} & \multirow{2}{*}{$\begin{array}{l}\text { Clock } \\
\text { Time }\end{array}$} & \multirow{2}{*}{$\begin{array}{c}\text { Dry gas meter } \\
\text { reading ft3 }\end{array}$} & \multirow{2}{*}{\begin{tabular}{c|}
$-P$ \\
in $\mathrm{H} 2 \mathrm{O}$
\end{tabular}} & \multirow{2}{*}{$\begin{array}{c}a \mathrm{H} \\
\text { in } \mathrm{H} 2 \mathrm{O}\end{array}$} & \multirow{2}{*}{$\begin{array}{c}\text { Stack } \\
\text { Temp. F }\end{array}$} & \multicolumn{2}{|c|}{ Dry gas meter temp. } & \multirow{2}{*}{$\begin{array}{l}\text { Hot box } \\
\text { Temp. }\end{array}$} & \multirow{2}{*}{$\begin{array}{l}\text { Probe } \\
\text { Temp }\end{array}$} & \multirow{2}{*}{\begin{tabular}{|c|} 
Last \\
Impinger
\end{tabular}} & \multirow{2}{*}{$\begin{array}{l}\text { Vacuum } \\
\text { in. } \mathrm{Hg}\end{array}$} & \\
\hline & & & & & & Inlet & Outlet & & & & & \\
\hline & $0.655: 30$ & 572.6 & 0.89 & 0.8 & 269 & 79 & 72 & 263 & 255 & 62 & 3,0 & \\
\hline & 0703 & 576.79 & 0.87 & 0.81 & 269 & 84 & 74 & 256 & 260 & 62 & 3.5 & \\
\hline & 0711 & 580.78 & 0.89 & 0.81 & 269 & 88 & 77 & 259 & 261 & 60 & $3-5$ & \\
\hline & $0720: 30$ & 585.76 & 0.21 & 0.80 & 269 & 92 & 80 & 260 & 256 & 61 & 3.75 & \\
\hline & $032: 45$ & 591.60 & 0.90 & 0.80 & 269 & 95 & 83 & 258 & 261 & 60 & 3.25 & \\
\hline & 0746 & 598.22 & 0.90 & 0.80 & 269 & 97 & 87 & 257 & 260 & 63 & 3.75 & \\
\hline & $304: 45$ & 607.23 & 0.92 & 0.81 & 271 & 97 & 89 & 257 & 259 & 65 & 3.75 & \\
\hline & 821 & 655.80 & 0,90 & 0.80 & $2 \pi$ & 96 & 89 & 253 & 254 & 56 & 375 & \\
\hline & $-32: 30$ & 621.60 & 0.90 & 0.80 & 27 & 95 & 89 & 258 & $2 \sqrt{3}$ & 53 & 3.25 & \\
\hline & $841: 30$ & 626.16 & 0.90 & 0.80 & 272 & 96 & 89 & 258 & 256 & 53 & 3,75 & \\
\hline & $859: 75$ & $635-33$ & 0.92 & $0-81$ & 272 & 96 & 69 & 256 & 258 & 53 & 3.75 & \\
\hline & $908: 45$ & 639.85 & & & & & & & & & & \\
\hline & & & & & & & & & & & & \\
\hline & & & & & & & & & & & & \\
\hline & & & & & & & & & & & & \\
\hline & & & & & & & & & & & & \\
\hline & & & & & & & & & & & & \\
\hline & & & & & & & & & & & & \\
\hline & & & & & & & & & & & & \\
\hline & & & & & & & & & & & & \\
\hline & & & & & & & & & & & & \\
\hline & & & & & & & & & & & & \\
\hline & & & $\dot{\theta}$ & & & & & & & & & \\
\hline & & & & & & & & & & & & \\
\hline & & & & & & & & & & & & \\
\hline & & & & & & & & & & & & \\
\hline & & & & & & 1 & 1 & & & & & \\
\hline & & & WRA & & & & $V$ & & & & & \\
\hline Avg. & - & $66 \%$ & 2. & 18.205 & $64 \%$ & 889 & 98. & $1 \% \%$ & $8 \%$ & 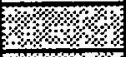 & \%. & $1 \%$ \\
\hline Check'd & & 130108 & $6 / 464$ & $1 \%$ & $8 / 38$ & $1.8 \%$ & $18 \%$ & $\% \%$ & $18 \%$ & $1.1 \%$ & \% & 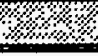 \\
\hline
\end{tabular}

CONSOLE

FILTER \#

AMBIENT TEMP. $\quad 69$

PROBE LENGTH 12

LINER MATERIAL CLLSS

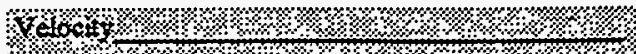

$\% 60$ onstist

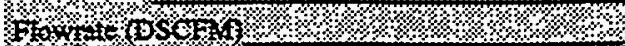

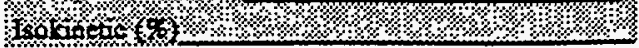

REMARKS

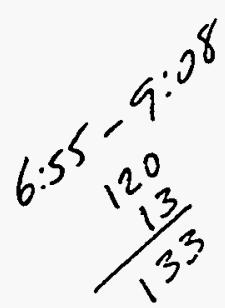

C-52 
SOLRCE SAIIPLING FIELD DATA SHEEI

Page $\perp$ of 1

Plant Name Plant Yates Station Boiler No. 1

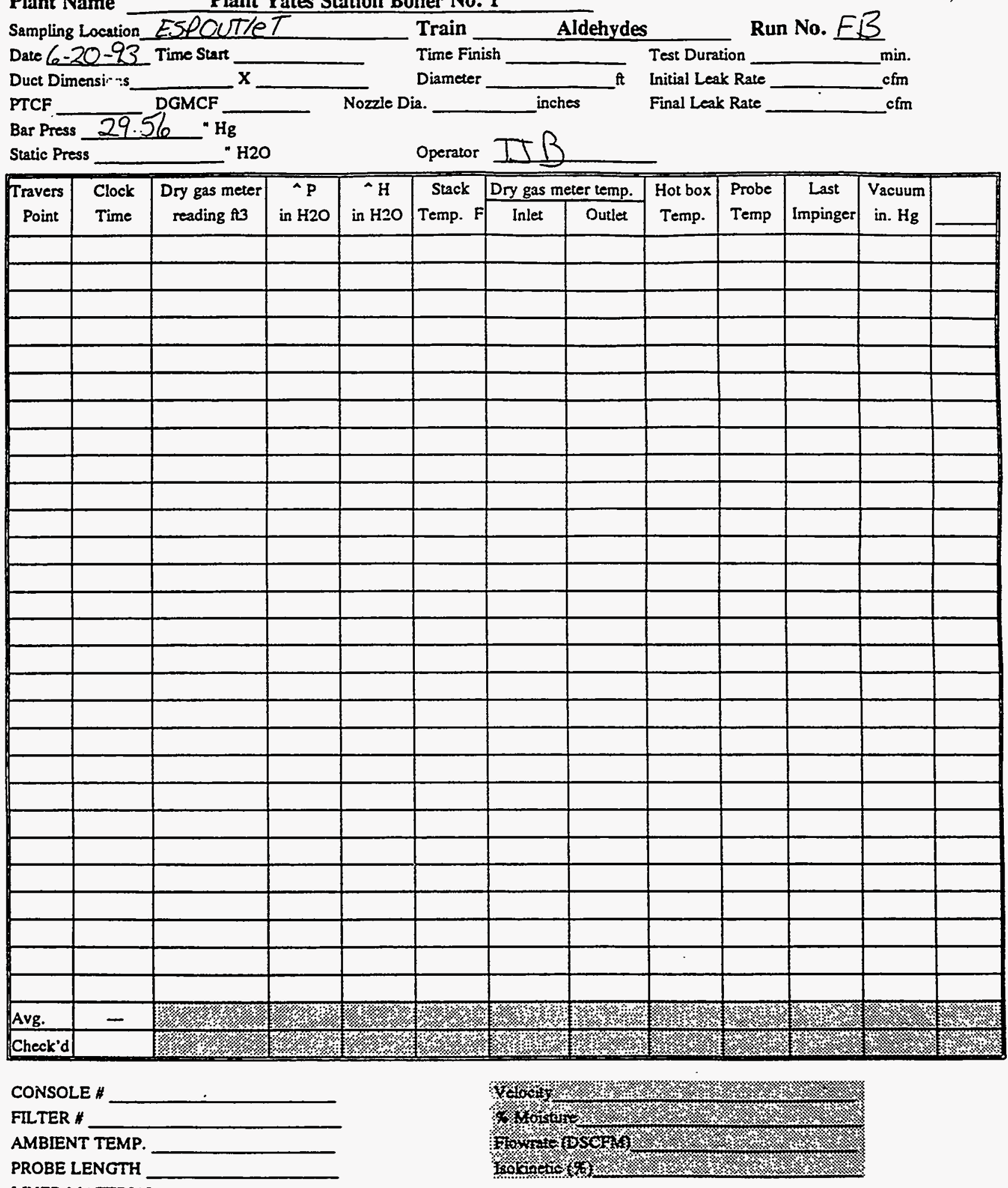

LINER MATERIAL 
Plant Name Plant Yates Station Boiler No. 1

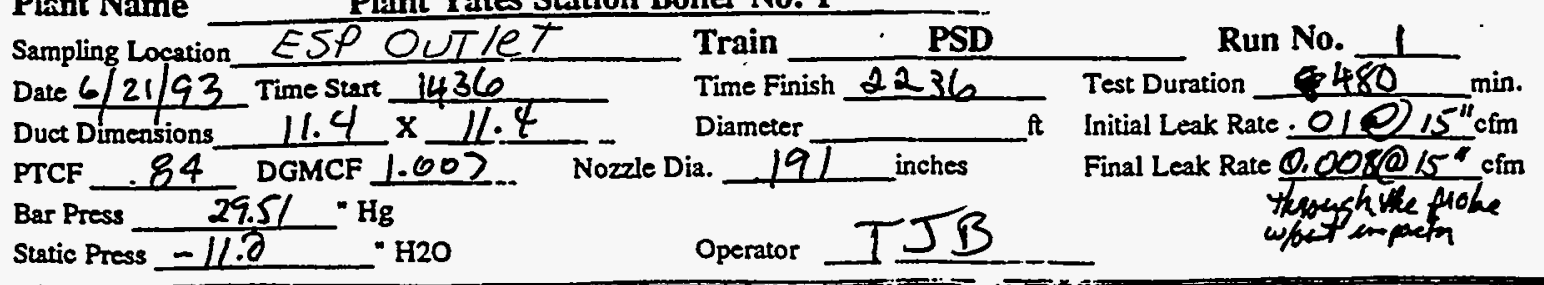

\begin{tabular}{|c|c|c|c|c|c|c|c|c|c|c|c|c|}
\hline Travers & Clock & Dry gas meter & $P$ & ${ }^{\wedge} \mathrm{H}$ & Stack & Dry gas $\mathrm{m}$ & ter temp. & riot box & Probe & Last & Vacuum & \\
\hline Point & Time & reading ft 3 & in $\mathrm{H} 2 \mathrm{O}$ & in $\mathrm{H} 2 \mathrm{O}$ & Temp. F & Inlet & Outlet & Temp. & Temp & Impinger & in. $\mathbf{H g}$ & \\
\hline $0^{\prime \prime}$ & 1436 & 62.67 & 95 & .98 & & & & & & & & \\
\hline $35^{\prime \prime}$ & & 82.85 & 98 & 95 & 278 & 85 & 78 & & & & & \\
\hline $115 "$ & & 88.12 & 38 & .95 & 278 & 84 & 78 & & & $\sqrt{2}$ & 29 & 680 \\
\hline $60^{1}$ & & 96.01 & 99 & 95 & 271 & 87 & 80 & & & & & \\
\hline $80^{\circ}$ & & 106.42 & Q7 & SS & 278 & 85 & 80 & & & & & \\
\hline $120^{\circ}$ & & 127.32 & .97 & .95 & 216 & 85 & 81 & & & & & \\
\hline $140^{4}$ & & 138.0 & 97 & 9 & 281 & 85 & 90 & & & & 9 & \\
\hline $180^{4}$ & & 158.87 & 99 & .92 & 281 & 88 & 86 & & & & 9 & \\
\hline $210^{\circ}$ & & 174.70 & .98 & .91 & 282 & 88 & 84 & & & & $\frac{6}{7}$ & \\
\hline 2404 & & 190.38 & 98 & 91 & 282 & 89 & 85 & & & & $g$ & \\
\hline $249^{\prime \prime}$ & & 195.10 & .98 & .91 & 282 & 88 & 83 & & & & 9 & \\
\hline 270 & & 206.08 & .98 & 91 & 282 & 87 & 83 & & & & $\Omega$ & \\
\hline 310 & 1946 & 225.73 & 0.98 & 0.93 & 283 & 86 & 81 & & & & 9 & \\
\hline 351 & 2027 & 247.52 & 1.00 & 0,97 & 292 & 85 & 81 & & & & 9 & \\
\hline 388 & 2104 & 267.27 & 1.00 & 0.97 & 282 & 86 & 81 & & & & 9.5 & \\
\hline 419 & 2135 & 283.52 & $1,0)$ & 0.97 & 2.83 & 87 & 81 & & & & 10 & \\
\hline 453 & 2209 & 302.04 & 1.00 & 098 & 283 & 88 & 82 & & & & 10 & \\
\hline 480 & 2236 & 316.850 & 1.00 & 0.98 & 278 & So & 83 & & & $i$ & 10 & \\
\hline & & & & & & & & & & &. & \\
\hline & & & & & & & & & $\therefore$ & & & \\
\hline & & & & & & & & & $\Sigma^{*}$ & & & \\
\hline & & & & & & & & & & & & \\
\hline & & & & & & & & & & & $\dot{-}$ & \\
\hline & & & & & & & & & & & & \\
\hline & & & & & & & & & & & & \\
\hline & & & & & & & & & & & & \\
\hline & & & & & & & & & & & & \\
\hline & & & & & & & & & & & & \\
\hline Avg. & $=$ & 28480 & 992 & 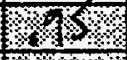 & 2860 & $8 \%$ & $\$$ & & $1 \%$ & 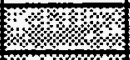 & 8 & \\
\hline Check'd & & $16 \%$ & $4 \%$ & $18 \%$ & $18 \%$ & 4. & 18 & $148 \%$ & $\%$ & (4) & (1). & \\
\hline
\end{tabular}

CONSOLE * $\frac{161396}{\text { FLTER * SeT } y}$
AMBIENT TEMP. $\frac{71}{7^{\prime}}$
PROBE LENGTH $\frac{5.5 .}{\text { LINER MATERIAL } 5.5}$

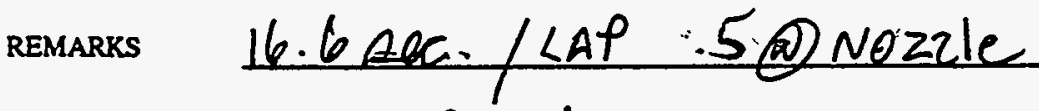

C-54.5acfm@imeter 
RADPIAN

FIELD DATA

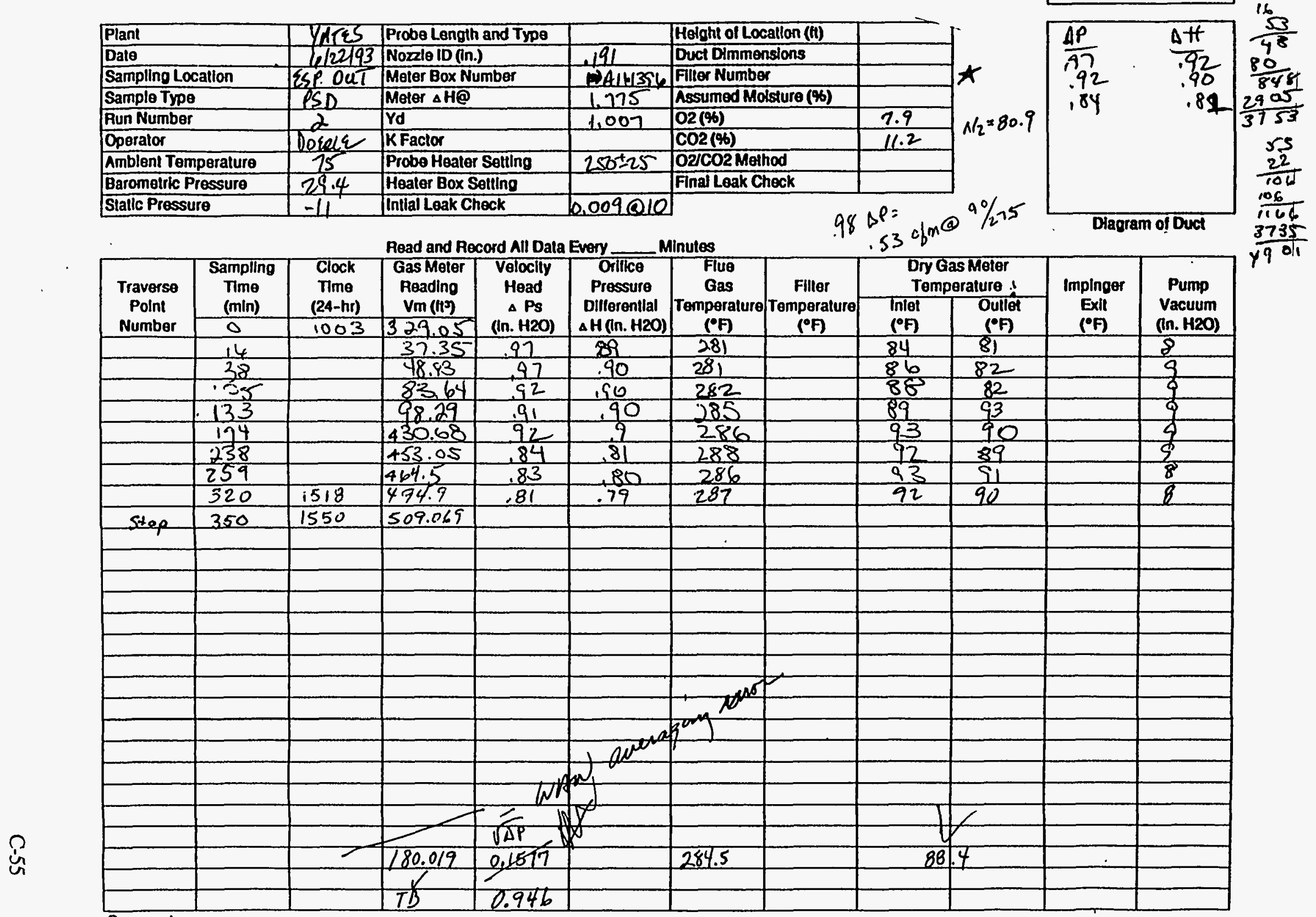

\begin{tabular}{ll|} 
Run & 2 \\
\hline
\end{tabular} 
SOURCE SAMFING FIELD DATA SHEET

Page _ of _

Plant Name

Plant Yates Station Boiler No. 1

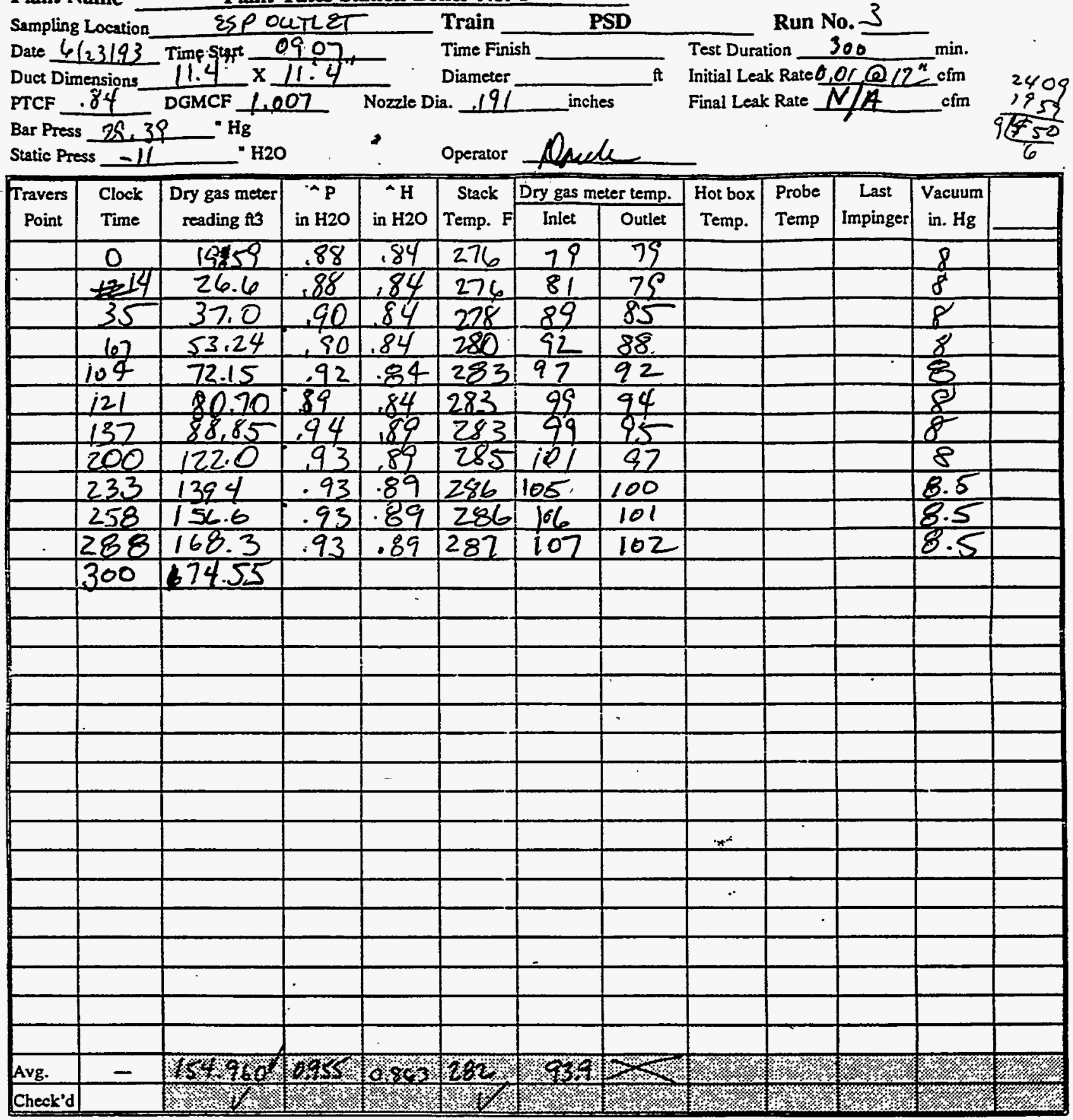

CONSOLE \# A16.1396

FILTER " set 5

AMBIENT TEMP.

PROBE LENGTH 6

LINER MATERIAL S.5Te+1

REMARKS

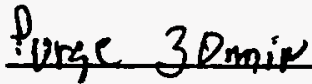

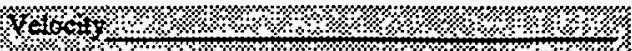

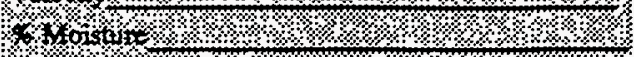

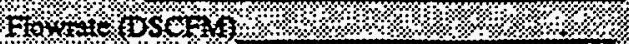

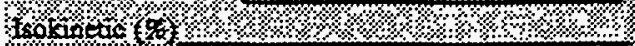

\section{C-56}


Plant Name oIV Plant Yates Station Boiler No. 1

Sampling Location ESP Outlet

Date (ef246-25 Time Start 0758

Duct Dumensions $11.4^{\prime \prime} \times 1 / 4^{\prime \prime}$

Diameter PTCF .84 DGMCF . .997 Bar Press $29.55 . \mathrm{Hg}$ Static Press $-11 . \mathrm{O} " \mathrm{H} 2 \mathrm{O}$

Train Particulate / Metals Time Finish $13 / 6$

\section{DATA SHEET}

\begin{tabular}{|c|c|c|c|c|c|c|c|c|c|c|c|c|}
\hline \multirow{2}{*}{$\begin{array}{c}\text { Travers } \\
\text { Point }\end{array}$} & \multirow{2}{*}{$\begin{array}{l}\text { Clock } \\
\text { Time }\end{array}$} & \multirow{2}{*}{$\begin{array}{c}\text { Dry gas meter } \\
\text { reading ft3 }\end{array}$} & \multirow{2}{*}{$\begin{array}{c}\text { P } \\
\text { in } \mathrm{H} 2 \mathrm{O}\end{array}$} & \multirow{2}{*}{$\begin{array}{c}\wedge \mathrm{H} \\
\text { in } \mathrm{H} 2 \mathrm{O}\end{array}$} & \multirow{2}{*}{$\begin{array}{c}\text { Stack } \\
\text { Temp. F }\end{array}$} & \multicolumn{2}{|c|}{ Dry gas meter temp. } & \multirow{2}{*}{$\begin{array}{l}\text { Hot box } \\
\text { Temp. }\end{array}$} & \multirow{2}{*}{$\begin{array}{l}\text { Probe } \\
\text { Temp }\end{array}$} & \multirow{2}{*}{$\begin{array}{c}\text { Last } \\
\text { Impinger }\end{array}$} & \multirow{2}{*}{$\begin{array}{l}\text { Vacuum } \\
\text { in. } \mathrm{Hg}_{\mathrm{g}}\end{array}$} & \\
\hline & & & & & & Inlet & Outlet & & & & & \\
\hline $1-1$ & 0758 & 827.24 & 83 & .8 & 274 & 72 & 71 & 246 & 244 & 66 & 5.5 & \\
\hline 2 & 0863 & 830.3 & .70 & .78 & 278 & 72 & 21 & 248 & 254 & 62 & 4.0 & \\
\hline 3 & 0808 & 832.12 & 40 & .38 & 278 & 25 & 72 & $2+9$ & 242 & 61 & 3.0 & \\
\hline 4 & 0813 & 833.9 & 26 & 25 & 277 & 27 & 73 & 253 & 261 & 62 & 3.0 & \\
\hline 5 & 0818 & 835.35 & 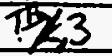 & 20.38 & 278 & 77 & 73 & 266 & 255 & 63 & 3.0 & \\
\hline 6 & $0 8 \longdiv { 2 3 }$ & 836.35 & 50 & .48 & 278 & 77 & 73 & 244 & 258 & 63 & 4.0 & \\
\hline 7 & 0828 & 838.7 & .62 & .60 & 278 & 78 & 74 & 254 & $26-6$ & 62 & 4.0 & \\
\hline 8 & 10833 & 841.0 & 68 & .66 & 276 & 79 & 75 & 244 & 264 & 60 & 4.0 & \\
\hline sed & 0838 & 843.02 & & Legk & $\checkmark$ & .010 & $10^{\prime \prime}$ & & & & & \\
\hline-1 & 0843 & 843.675 & .89 & .87 & 282 & 8 & 26 & 256 & 266 & 59 & 5,0 & \\
\hline 2 & 6848 & 846.14 & .68 & .67 & 282 & 82 & 76 & 256 & 259 & 59 & 5.0 & \\
\hline 3 & 0853 & 443.8 & 68 & .67 & 282 & 83 & 77 & 245 & 247 & 58 & 4.0 & \\
\hline 4 & 0858 & 850.61 & 92 & .92 & 281 & 84 & 78 & 255 & 260 & 59 & 5.0 & \\
\hline 5 & 0408 & 853.8 & .62 & .66 & 28 & 85 & 78 & 246 & $2<0$ & 60 & 5.0 & \\
\hline$C$ & 0908 & 855.53 & 60 & .60 & 280 & 86 & 78 & 253 & 267 & 60 & 5.01 & \\
\hline 7 & 0913 & 857.73 & .76 & .76 & 278 & 86 & 79 & 249 & 247 & 61 & 5.0 & \\
\hline 8 & 0918 & 85707 & .62 & .62 & 277 & 86 & 80 & 250 & 246 & 60 & 5.0 & \\
\hline STOP & 0923 & 862.38 & & centel & .007 & 010 & & & & & & \\
\hline 2.8 & 0943 & 862.99 & 48 & .48 & 225 & 85 & 83 & 244 & 247 & 65 & 4.0 & \\
\hline 2 & 0948 & 865.5 & 67 & .67 & 278 & 86 & 82 & 246 & 257 & 61 & 3.5 & \\
\hline$c$ & 0954 & 867.65 & .93 & .93 & 280 & 86 & 82 & 254 & 264 & 56 & 5.0 & \\
\hline 5 & 6959 & 870.90 & $i .0$ & 1.0 & 280 & 87 & 83 & 250 & 245 & 56 & 5.0 & \\
\hline 4 & 991004 & 873.1 & 1.3 & 1.3 & 282 & 89 & 84 & 254 & 265 & 57 & 5.0 & \\
\hline 3 & 1009 & 875.7 & 1.2 & $1 \cdot 2$ & 243 & 90 & 84 & $26 c$ & 246 & 55 & 5.0 & \\
\hline 2 & 1014 & 879.0 & .92 & .92 & 283 & 92 & 86 & 246 & 244 & 54 & 5.0 & \\
\hline 1 & 1019 & 881.53 & $1 \cdot 0$ & 1.0 & 283 & 93 & 87 & 257 & 243 & 53 & 5.5 & \\
\hline SToP & 1024 & 484.372 & & & & & & & & & & \\
\hline & & & & & & & & & & & & \\
\hline Avg. & - & $\{x<x=1$ & \%: & $8 \%$ & & $1 \%$ & & ४४ & 1 & $18 \%$ & & \\
\hline Check'd & & 1843 & 2 & 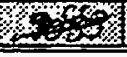 & 9259 & & 89 & $\times$ & (\%) & $1 \%$ & $18 \times$ & \\
\hline
\end{tabular}

CONSOLE " 161364

FILTER \#

AMBIENT TEMP.

PROBE LENGTH

LINER MATERIAL

REMARKS .197 NoZ2le No22IeID $11 \quad K=.973$

it $*$ Sampted PT6 $@$ Smin. $1.0^{*}$ Started Sampleins ax point 8
6. 4.6ostrute

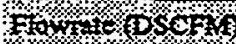

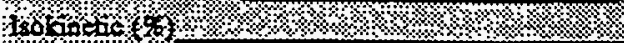

Yeloci:
j年NRRIC RINSE CHaht w/Aceston RINSE (F. 1/2). Secoño Rinse PERFORMED. 
Plant Name Plant Yates Station Boiler No. i

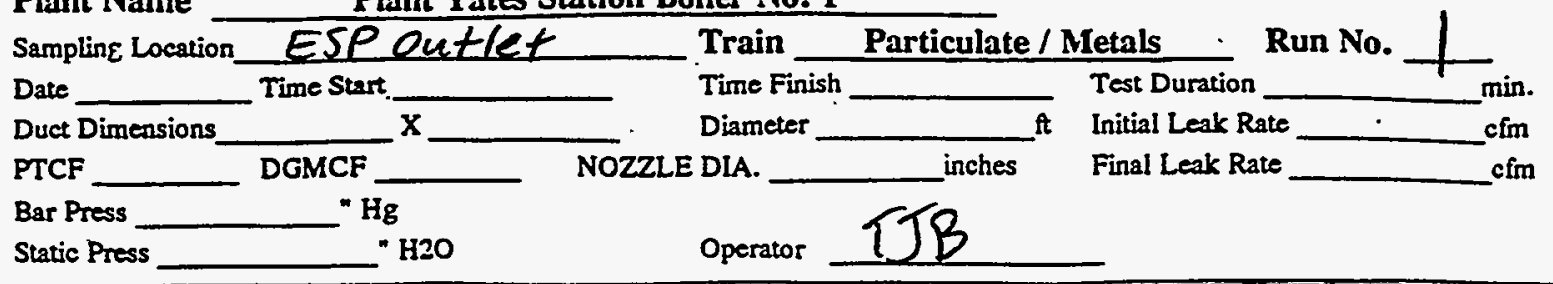

\begin{tabular}{|c|c|c|c|c|c|c|c|c|c|c|c|c|}
\hline Travers & Clock & Dry gas meter & & $\widehat{A H}$ & Stack & Dry gas n & ter temp. & Hot box & Probe & Last & Vacuum & \\
\hline Point & Time & $\mathrm{ng} \mathrm{ft}$ & in $\mathrm{H} 2 \mathrm{O}$ & in $\mathrm{H} 2 \mathrm{O}$ & Temp. F & Inlet & Outlet & Temp. & emp & ger & & \\
\hline $4-8$ & 1028 & 884.641 & .60 & 60 & 276 & 90 & 87 & 248 & 247 & 59 & 4.0 & \\
\hline & 1033 & $\$ 87.00$ & .82 & .82 & 278 & 92 & 88 & 253 & 261 & 56 & 5.0 & \\
\hline 4 & 1038 & 862.3 & 1.10 & 1,10 & 279 & 93 & 89 & 249 & 246 & 52 & 5.0 & \\
\hline 5 & 1043 & 892.07 & 1.3 & 1.3 & 280 & 93 & 89 & 253 & 267 & 52 & 5.5 & \\
\hline 8 & 1048 & 895.14 & 1.4 & 1.4 & 280 & 95 & 90 & 250 & 250 & 52 & 6.0 & \\
\hline 3 & 1053 & 89827 & 1.3 & 1.3 & 282 & 96 & 90 & 252 & 256 & 52 & 6.0 & \\
\hline 2 & 1058 & 901.8 & 1.1 & 1.1 & 283 & 96 & 91 & 248 & 265 & 52 & 5.5 & \\
\hline 1 & 1103 & 904.3 & .81 & 81 & 283 & 96 & 91 & 256 & 241 & 53 & 5.0 & \\
\hline STop & 1108 & 907.000 & & & $c+a k$ & $\sqrt{ }$ & 10 & $15^{11}$ & & & & \\
\hline $5 \cdot 8$ & 1151 & 907.516 & .71 & .7 .1 & 275 & 92 & .90 & 244 & 246 & 65 & 4.5 & \\
\hline 7 & 1156 & 910.0 & .82 & 82 & 278 & 93 & 90 & 253 & 249 & 54 & 5.0 & \\
\hline 6 & 1201 & $912-6$ & .68 & .68 & 279 & 94 & 90 & 214 & 251 & 55 & 5.0 & \\
\hline 5 & 1206 & 214.75 & .90 & 90 & 280 & 94 & .90 & 253 & 266 & $5 \cdot 3$ & 5.0 & \\
\hline 4 & 1211 & 918.0 & 1.3 & 1.3 & 282 & 94 & .90 & 250 & 253 & 49 & 5.0 & \\
\hline 3 & 1216 & 720.32 & $i-1$ & 1.1 & 283 & 95 & 90 & 256 & 257 & 49 & 5.0 & \\
\hline 2 & 1221 & 92325 & .68 & 68 & 283 & 96 & .90 & 251 & 263 & 50 & 55 & \\
\hline$l$ & 1226 & 925.62 & .69 & .69 & 283 & 96 & 91 & 248 & 246 & 52 & & \\
\hline STOP & 1231 & 928.021 & & Leak & $\checkmark$ & .067 & $015^{\prime \prime}$ & & & & & \\
\hline $6-8$ & 1235 & 928.27 & .80 & .80 & 279 & 96 & 92 & 250 & 255 & 52 & 5.0 & \\
\hline 7 & 1241 & 931.64 & .85 & .85 & 279 & 96 & 92 & 251 & 244 & 48 & 5.0 & \\
\hline 6 & 1246 & 934.22 & .75 & .75 & 280 & 98 & 92 & 247 & 245 & 48 & 5.0 & \\
\hline 5 & 1251 & 936.7 & .64 & 64 & 281 & 98 & 92 & 254 & 246 & 49 & 4.0 & \\
\hline 7 & 1256 & 938.95 & 65 & 65 & 282 & 98 & 93 & 249 & 267 & 49 & $4: 0$ & \\
\hline 3 & 1301 & 841.19 & .57 & .57 & 282 & 98 & 93 & 257 & 264 & 49 & 4.0 & \\
\hline 2 & 1306 & 943.32 & .89 & .89 & 283 & 97 & 94 & 249 & 252 & 49 & 5.0 & \\
\hline 1 & 1311 & 945.8 & .96 & .96 & 284 & 98 & 94 & 265 & 249 & 48 & 5 & \\
\hline SToP & $13 i 6$ & 948.490 & & & & & & & & & & \\
\hline & & & & & & & & & & & & \\
\hline Avg. & $=$ & $1,1848 \%$ & (४\%, & $8.8 \%$ & $\$ \%$ & $\%$ & 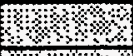 & 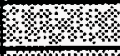 & \% & & & \\
\hline Check'd & & $1 / 4 / \%$ S & 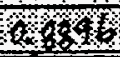 & 27 & & 18 & & & & & \% & \\
\hline
\end{tabular}

CONSOLE \#

FLTER \#

AMBIENT TEMP.

PROBE LENGTH

LINER MATERIAL

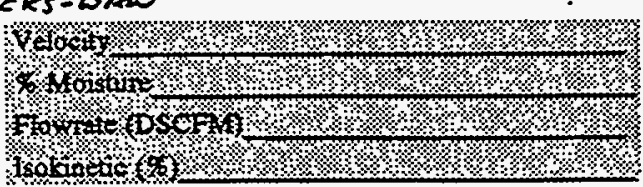

\section{REMARKS}


SOLRCE SAMPLING FIELD DATA S:IEET

$$
\text { Page }\{\text { of } 2
$$

Plant Name

Plant Yates Station Boiler No. 1

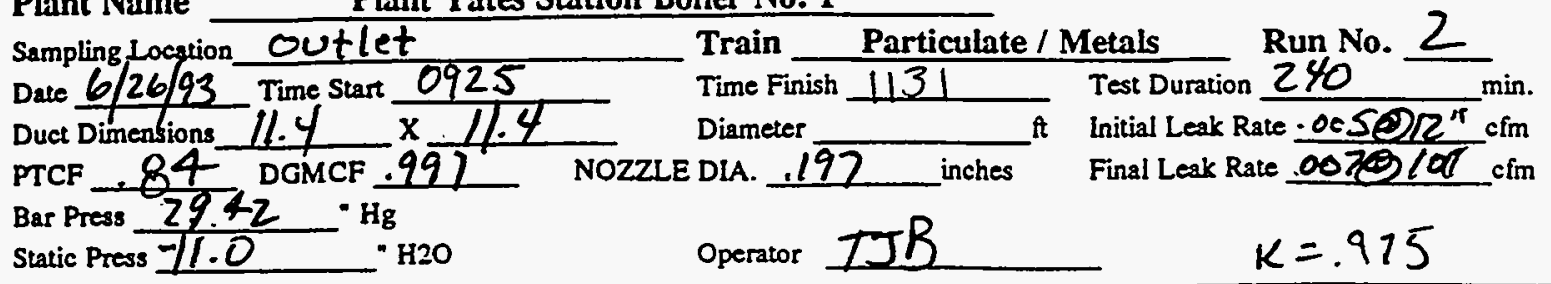

\begin{tabular}{|c|c|c|c|c|c|c|c|c|c|c|c|c|}
\hline \multirow{2}{*}{$\begin{array}{c}\text { Travers } \\
\text { Point }\end{array}$} & \multirow{2}{*}{$\begin{array}{l}\text { Clock } \\
\text { Time }\end{array}$} & \multirow{2}{*}{$\begin{array}{c}\text { Dry gas meter } \\
\text { reading ft }\end{array}$} & \multirow{2}{*}{$\begin{array}{c}A P \\
\text { in } \mathrm{H} 2 \mathrm{O}\end{array}$} & \multirow{2}{*}{$\begin{array}{c}\wedge \mathrm{H} \\
\text { in } \mathrm{H} 2 \mathrm{O}\end{array}$} & \multirow{2}{*}{$\begin{array}{c}\text { Stack } \\
\text { Temp. F }\end{array}$} & \multicolumn{2}{|c|}{ Dry gas meter temp. } & \multirow{2}{*}{$\begin{array}{c}\text { Hot box } \\
\text { Temp. }\end{array}$} & \multirow{2}{*}{$\begin{array}{l}\text { Probe } \\
\text { Temp }\end{array}$} & \multirow{2}{*}{$\begin{array}{c}\text { Last } \\
\text { Impinger }\end{array}$} & \multirow{2}{*}{$\begin{array}{l}\text { Vacuum } \\
\text { in. } \mathrm{Hg}\end{array}$} & \\
\hline & & & & & & Inlet & Outlet & & & & & \\
\hline-8 & 092.5 & 959.3 & .65 & .65 & 270 & 25 & 75 & 254 & 262 & 58 & 4.0 & \\
\hline 7 & 0930 & 961.4 & .81 & .81 & 277 & 75 & 75 & 255 & 268 & 49 & 4.0 & \\
\hline 6 & 0935 & 963.85 & .60 & .58 & 278 & 75 & 75 & 249 & 266 & 47 & 4.0 & \\
\hline 5 & 0940 & 965.87 & .35 & .34 & 219 & 78 & 76 & 251 & 259 & 51 & 4.0 & \\
\hline 4 & 0445 & 967.48 & .34 & .33 & 276 & 79 & 76 & 249 & 261 & 51 & 3.6 & \\
\hline & 0950 & 969.1 & .60 & .58 & 280 & 80 & 77 & 252 & 266 & 53 & 4.0 & \\
\hline 2 & 0955 & 971.0 & .82 & .81 & 281 & 80 & 77 & 247 & 247 & 52 & 4.0 & \\
\hline & 1000 & 473.8 & .86 & .84 & 280 & 81 & 78 & 245 & 258 & 51 & 5.0 & \\
\hline $5 \overline{S T P}$ & 1005 & 976.065 & & LeAK & 1 & .007 & $\infty 12^{\prime \prime}$ & & & & & \\
\hline $2-8$ & 1008 & 976.5 & .53 & .52 & 274 & 84 & 80 & 253 & 252 & 58 & 4.0 & \\
\hline & 1013 & 978.53 & .80 & .79 & 228 & 86 & 81 & 256 & 255 & 57 & 4.0 & \\
\hline 6 & 1018 & 980.91 & .62 & .62 & 279 & 86 & 81 & 249 & 248 & 53 & 9.0 & \\
\hline 5 & 1023 & 983.01 & .73 & .73 & 281 & 86 & 81 & 254 & 264 & 55 & 4.0 & \\
\hline 4 & 1028 & 985.5 & .99 & .99 & 282 & 86 & 82 & 249 & 245 & 53 & 5.0 & \\
\hline 3 & 1033 & 988.2 &., 78 & .78 & 283 & 89 & 83 & $26 \alpha$ & 253 & 52 & 4.0 & \\
\hline 2 & 1038 & 990.36 & .70 & .70 & 283 & 90 & 84 & 250 & 254 & 53 & 4.0 & \\
\hline$T$ & 1043 & 992.70 & .98 & 98 & 284 & 91 & 84 & 249 & 249 & 54 & 4.0 & \\
\hline STOP & 1048 & 995.32 & & LeAK & $d$ & .010 & $15^{11}$ & & & & & \\
\hline $3-8$ & 105 & 996.0 & .63 & .63 & 278 & 92 & 86 & 254 & 259 & 57 & 4.0 & \\
\hline 7 & 1056 & 998.3 & 1.0 & 1.0 & 279 & 93 & 87 & 253 & 247 & 55 & 5.0 & \\
\hline 6 & 1101 & 1001.02 & 1.2 & 1.2 & 281 & 93 & 87 & 247 & 251 & 54 & 5.0 & \\
\hline 5 & 1106 & $i 1003.15$ & 1.3 & 1.3 & 282 & 95 & 88 & 246 & 248 & 56 & 5.0 & \\
\hline 4 & 1111 & 1606.75 & 1.3 & 1.3 & 283 & 95 & 87 & 248 & 246 & 54 & 5.5 & \\
\hline 3 & 1116 & 1009.7 & 1.1 & 1.1 & 283 & 95 & 88 & 256 & $2<3$ & 56 & 6.0 & \\
\hline 2 & 112 & 1012.7 & .72 & .72 & 283 & 95 & 88 & 252 & 255 & 57 & 5.0 & \\
\hline 1 & 1126 & 1015.05 & .70 & .70 & 284 & 94 & 88 & 253 & 260 & 59 & 5.0 & \\
\hline STOP & $113 \mid$ & 1017.40 & & & & & & & & & & \\
\hline & & & & & & & & & & & & \\
\hline Avg. & $=$ & $101<0 \%$ & (6) & 18600 & $202 \times 1$ & \%\%, & 8,85 & 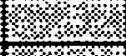 & $8 \%$ & 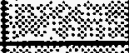 & ४ & 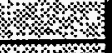 \\
\hline Check'd & & $1 \%$ & $21 \%$ & $1 \%$ & 1.1 .2 & 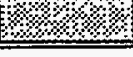 & 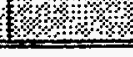 & & 89 & 8 & 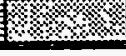 & \\
\hline CONSO & LE \# & & & & & yeros & 1). & 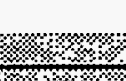 & $\%$ & 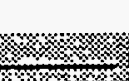 & & \\
\hline FILTER & & & & & & $4 \%$ & 3 & 8 & 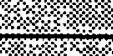 & צ. & & \\
\hline AMBIE & NT T & & & & & 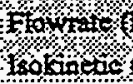 & (Osc) & 4 & ४ & 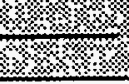 & & \\
\hline
\end{tabular}

REMARKS 


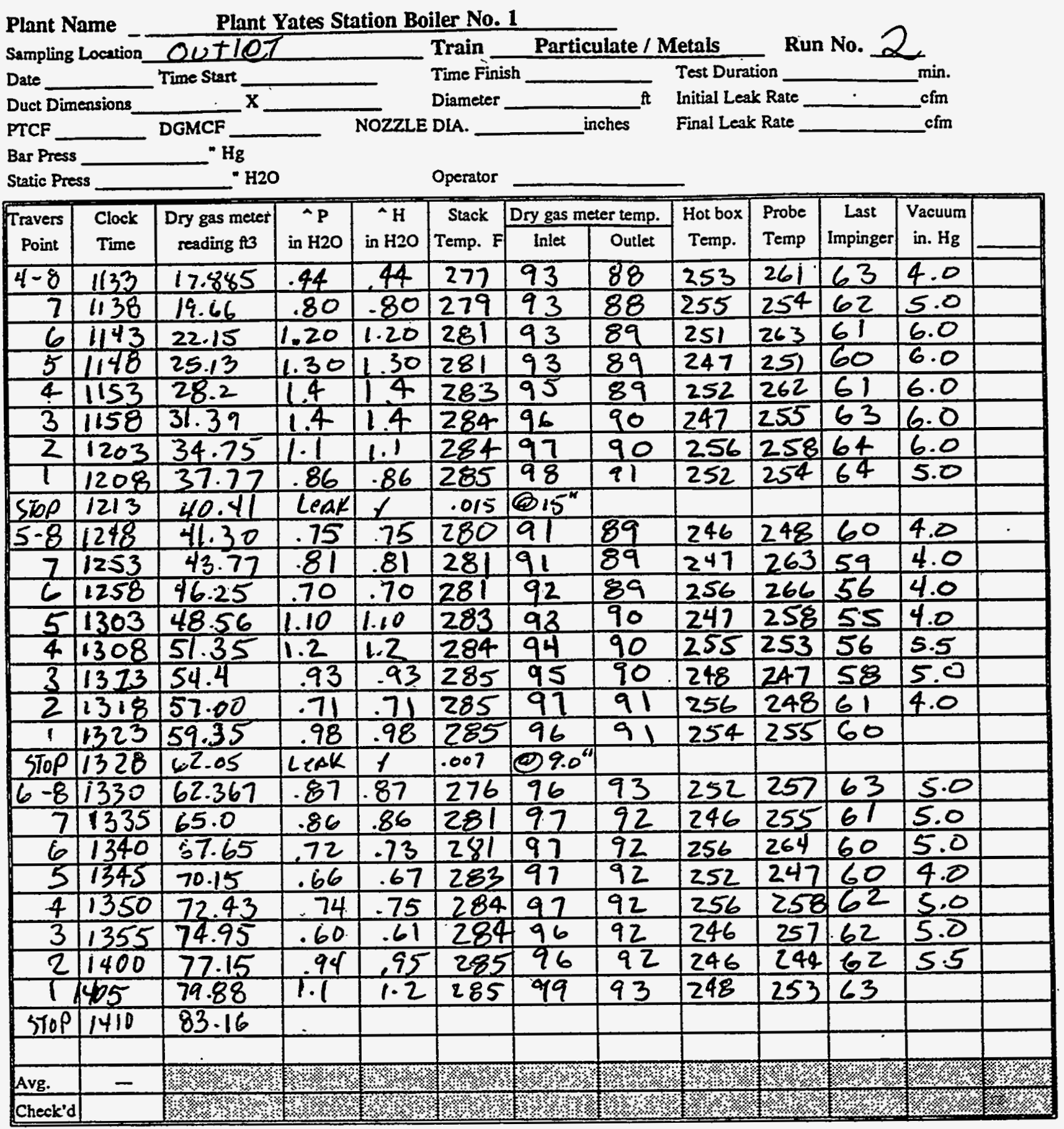

CONSOLE \#

FILTER \#

AMBIENT TEMP.

PROBE LENGTH

LINER MATERIAL
Y Yelocty $\%$ ২

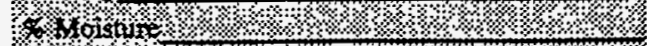

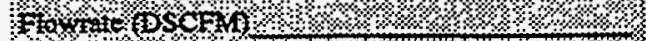

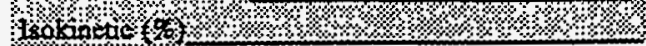

REMARKS 
Plant Name

Plant Yates Station Boiler No. 1

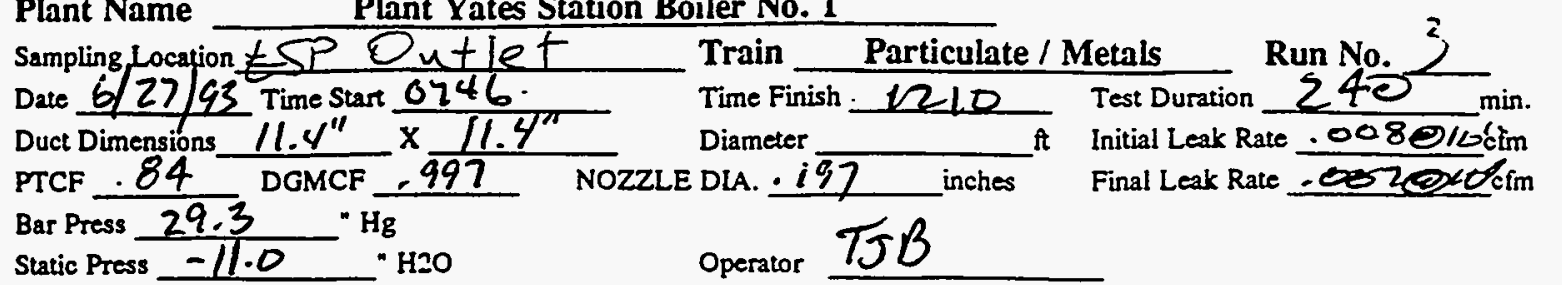

\begin{tabular}{|c|c|c|c|c|c|c|c|c|c|c|c|c|}
\hline \multirow{2}{*}{$\begin{array}{c}\text { Travers } \\
\text { Point }\end{array}$} & \multirow{2}{*}{$\begin{array}{l}\text { Clock } \\
\text { Time }\end{array}$} & \multirow{2}{*}{$\begin{array}{l}\text { Dry gas meter } \\
\text { reading ft3 }\end{array}$} & \multirow{2}{*}{$\begin{array}{c}\text { A } \mathrm{P} \\
\text { in } \mathrm{H} 2 \mathrm{O}\end{array}$} & \multirow{2}{*}{$\begin{array}{c}{ }^{4} \mathrm{H} \\
\text { in } \mathrm{H} 2 \mathrm{O}\end{array}$} & \multirow{2}{*}{$\begin{array}{l}\text { Stack } \\
\text { Temp. F }\end{array}$} & \multicolumn{2}{|c|}{ Dry gas meter temp. } & \multirow{2}{*}{$\begin{array}{l}\text { Hot box } \\
\text { Temp. }\end{array}$} & \multirow{2}{*}{$\begin{array}{l}\text { Probe } \\
\text { Temp }\end{array}$} & \multirow{2}{*}{$\begin{array}{c}\text { Last } \\
\text { Impinger }\end{array}$} & \multirow{2}{*}{$\begin{array}{l}\text { Vacuum } \\
\text { in. } \mathrm{Hg}\end{array}$} & \\
\hline & & & & & & Inlet & Outlet & & & & & \\
\hline $1-8$ & 0746 & 96.6 & 82 & .82 & 280 & 76 & 74 & 244 & 263 & 68 & 5.0 & \\
\hline & 0751 & 99.11 & .74 & .74 & 277 & $7 i$ & 74 & 247 & 264 & 62 & 4.0 & \\
\hline$c$ & 0756 & 101.41 & .56 & .55 & 278 & 79 & 25 & 252 & 255 & 56 & 4.0 & \\
\hline 5 & 0801 & 10347 & .34 & .33 & 278 & 80 & 75 & 246 & 251 & 57 & 30 & \\
\hline 4 & 0806 & 105,5 & .33 & .33 & 275 & 86 & 75 & 247 & 266 & 57 & 3.0 & \\
\hline 3 & 0811 & 106.64 & 65 & .65 & 280 & 81 & 76 & 250 & 246 & 52 & 3.0 & \\
\hline 2 & 0816 & 104.76 & .81 & .81 & 281 & 83 & 78 & 250 & $26 !$ & 53 & 4.0 & \\
\hline$T$ & 0821 & 111.18 & 1.1 & 1.1 & 282 & 84 & 78 & 249 & 261 & 52 & 5.0 & \\
\hline STOP & 0826 & 114.04 & & leAK & $v$ & .007 & & & & & & \\
\hline $2-8$ & 0829 & 114.535 & 55 & .55 & 274 & 85 & 80 & 246 & 249 & 57 & 4.0 & \\
\hline & 0834 & 116.64 & .87 & .86 & 278 & .89 & 81 & 254 & 267 & 55 & 4.0 & \\
\hline 6 & 0839 & 119.15 & 68 & .68 & 279 & 90 & 83 & 252 & 262 & 55 & 5.0 & \\
\hline 5 & 0844 & 121.53 & .67 & .67 & 280 & 90 & 83 & 247 & 265 & 55 & 4.5 & \\
\hline 4 & 0849 & 173.88 & 1.1 & 1.1 & 281 & 91 & 84 & 251 & 255 & 55 & 4.5 & \\
\hline 3 & 0854 & 126.88 & .76 & .76 & 282 & 92 & 85 & 244 & 261 & 56 & 5.5 & \\
\hline 2 & 0859 & 129.50 & .73 & .73 & 283 & 93 & 87 & 245 & 253 & 58 & 5.0 & \\
\hline & 0904 & 131.64 & .99 & .99 & 283 & 92 & 87 & 244 & 254 & 59 & 5.0 & \\
\hline STOP & 0909 & 134.355 & lPA & $K V$ & .010 & $15^{10}$ & & & & & & \\
\hline 3.8 & 0922 & 135.65 & .46 & .46 & 274 & 81 & 88 & 249 & 254 & 64 & 4.0 & \\
\hline 7 & 0927 & 137.60 & .75 & .75 & 280 & 90 & 88 & 245 & 254 & 60 & 4.0 & \\
\hline 6 & 0932 & 140.02 & .98 & .98 & 280 & 91 & 88 & 256 & 253 & 59 & 5.0 & \\
\hline 5 & 0937 & 142.77 & 99 & 1.0 & 282 & 91 & 87 & 244 & 247 & 57 & 5.5 & \\
\hline 4 & 0982 & 145.68 & 1.3 & 1.4 & 284 & 92 & 88 & 255 & 254 & 59 & 6.0 & \\
\hline 3 & 0947 & 149.08 & 1.2 & 1.3 & 284 & 93 & 88 & 246 & 246 & 61 & 6.0 & \\
\hline 2 & 0952 & 152.4 & 1.0 & 1.1 & 285 & 94 & 89 & 255 & 252 & 62 & 5.5 & \\
\hline 1 & 0957 & 155.27 & .75 & .76 & 285 & 95 & 89 & 247 & 255 & 65 & 6.0 & \\
\hline SIOP & 1062 & 157.746 & & & & & & & & & & \\
\hline & & & & & & & & & & & & \\
\hline Avg. & - & 125,536 & 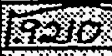 & 9,03 & 28249 & $=1$ & 1808 & 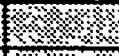 & $8 \%$ & & $3 \times$ & \&.\% \\
\hline ecek'd & & $1 \%$ & 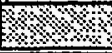 & & & & & & & $\rightarrow+$ & 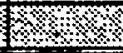 & \\
\hline
\end{tabular}

CONSOLE H 161364

FLTER " 927

AMBIENT TEMP.

PROBE LENGTH

LINER MATERIAL

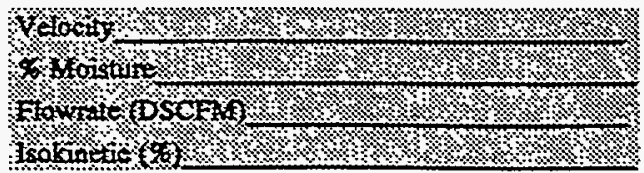

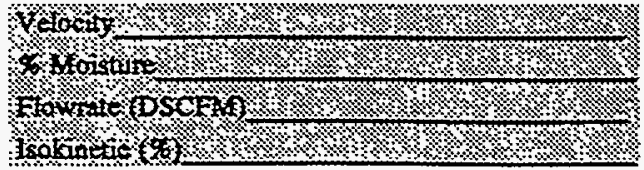

REMARKS 
Plant Name $\quad$ Plant Yates Station Boiler No. 1

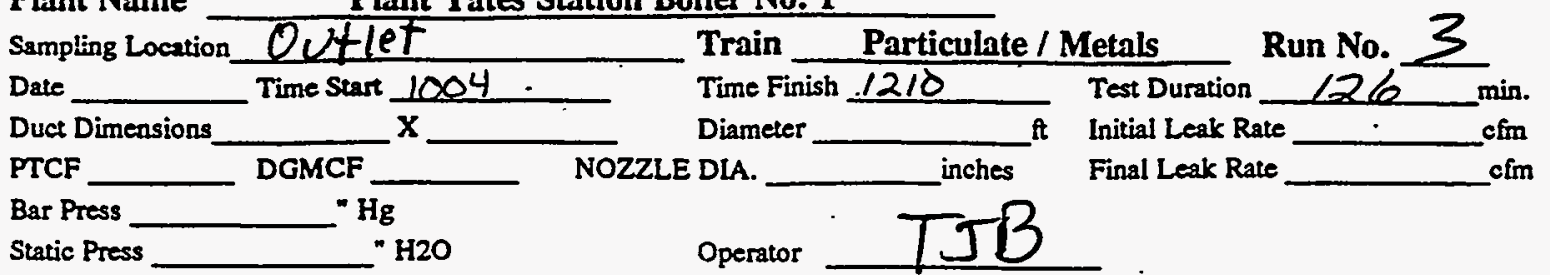

\begin{tabular}{|c|c|c|c|c|c|c|c|c|c|c|c|c|}
\hline \multirow{2}{*}{$\begin{array}{c}\text { Travers } \\
\text { Point }\end{array}$} & \multirow{2}{*}{$\begin{array}{l}\text { Clock } \\
\text { Time }\end{array}$} & \multirow{2}{*}{$\begin{array}{c}\text { Dry gas. meter } \\
\text { reading ft3 }\end{array}$} & \multirow{2}{*}{$\begin{array}{c}\wedge P \\
\text { in } \mathrm{H} 2 \mathrm{O}\end{array}$} & \multirow{2}{*}{$\begin{array}{c}\stackrel{4}{H} \\
\text { in } \mathrm{H} 2 \mathrm{O}\end{array}$} & \multirow{2}{*}{$\begin{array}{c}\text { Stack } \\
\text { Temp. F }\end{array}$} & \multicolumn{2}{|c|}{ Dry gas meter temp. } & \multirow{2}{*}{$\begin{array}{l}\text { Hot box } \\
\text { Temp. }\end{array}$} & \multirow{2}{*}{$\begin{array}{l}\text { Probe } \\
\text { Temp }\end{array}$} & \multirow{2}{*}{\begin{tabular}{|c|} 
Last \\
Impinger
\end{tabular}} & \multirow{2}{*}{$\begin{array}{l}\text { Vacuum } \\
\text { in. } \mathrm{Hg}\end{array}$} & \\
\hline & & & & & & Iniet & Outlet & & & & & \\
\hline $5-8$ & 1004 & 158.0 & .56 & .57 & 274 & 93 & 90 & 248 & 248 & 57 & 4.0 & \\
\hline 7 & 1009 & 160.14 & .88 & .89 & 280 & 94 & 90 & 245 & 257 & 54 & 5.0 & \\
\hline 6 & 1014 & 162.76 & 1.10 & 1.2 & 280 & 95 & $9 i$ & 256 & 250 & 50 & 6.0 & \\
\hline 5 & 1019 & 165.8 & 1.4 & 1.5 & 282 & 96 & 91 & 252 & 263 & 50 & 6.0 & \\
\hline 4 & 1024 & 169.0 & 1.4 & 1.5 & 284 & 96 & 91 & 254 & 259 & 51 & 7.0 & \\
\hline 3 & 1029 & 172.37 & 1.3 & 1.4 & 285 & 98 & 92 & 247 & 251 & 52 & 7.0 & \\
\hline 2 & 1034 & 175.78 & 1.2 & 1.3 & 285 & .99 & 92 & 247 & 245 & 53 & 7.0 & \\
\hline 1 & 1039 & 179.2 & .82 & .83 & 285 & 99 & 93 & 253 & 251 & 55 & 6.0 & \\
\hline STOP & 1044 & 182.03 & & & & & & & & & & \\
\hline 5.8 & 1047 & 182.655 & .65 & .66 & 278 & 96 & 93 & 257 & 245 & 59 & 5.0 & \\
\hline & 1052 & 184.98 & .87 & .88 & 280 & 97 & 93 & 249 & 260 & 58 & 5.0 & \\
\hline 6 & 1057 & 187.7 & .78 & .79 & 281 & 97 & 93 & 250 & 248 & 56 & 5.0 & \\
\hline 5 & 1102 & 190.2 & 1.1 & 1.2 & 282 & 98 & 93 & 254 & 252 & $5 \cdot 7$ & 6.0 & \\
\hline 4 & 1107 & $193: 0$ & 1.3 & 1.4 & 283 & 98 & 93 & 251 & 263 & 56 & 6.0 & \\
\hline 3 & 1112 & 196.4 & 1.3 & 1.4 & 284 & 99 & 94 & 253 & 244 & 55 & 6.0 & \\
\hline 2 & 1117 & 199.37 & .74 & .75 & 285 & 99 & 94 & 246 & 249 & 57 & 6.0 & \\
\hline 1 & 1122 & 202.01 & .86 & .87 & 285 & 99 & 94 & 255 & 247 & 59 & 5.0 & \\
\hline $35 p$ & 1127 & 204.638 & & & & & & & & & & \\
\hline $6-8$ & 1130 & 265.135 & 95 & .96 & 279 & 95 & 94 & 258 & 250 & 65 & 6.0 & \\
\hline 7 & 1135 & 208.04 & .89 & .90 & 282 & 97 & 94 & 254 & 251 & 62 & 6.0 & \\
\hline 6 & 1140 & 210.72 & .75 & .76 & 284 & 98 & 94 & $25 c$ & 254 & 62 & 5.0 & \\
\hline 5 & 1145 & 213.33 & 69 & .70 & 284 & 98 & 94 & 249 & 262 & 62 & 5.0 & \\
\hline 4 & 1150 & 215.6 & .59 & -60 & 284 & 98 & 94 & 244 & 260 & 63 & 5.0 & \\
\hline 3 & 1155 & 2177 & .56 & .59 & 286 & 97 & 93 & 244 & 259 & 65 & 5.0 & \\
\hline 2 & 1200 & 219.9 & .88 & .89 & 286 & 97 & 93 & 253 & 258 & 65 & 525 & \\
\hline 1 & 1205 & 222.5 & 1.0 & 1.1 & $2 x$ & 97 & 93 & 248 & 238 & 65 & 5.5 & \\
\hline SibP & 1210 & 225.3 & & & & & & & & & & \\
\hline vg. & - & 605334 & $98 \% 10$ & 9833 & 2878 & & 80.6 & 198 & $\$$ & & & \\
\hline Check'd & & $17 \% 8 \%$ & $13 \%$ & $6 \% .4$ & $6 \%$ & $18 \% 8$ & $1 \%$ & $18 \%$ (1) & $14 \%$ & & 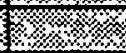 & \\
\hline
\end{tabular}

CONSOLE \#

FILTER \#

AMBIENT TEMP.

PROBE LENGTH

LINER MATERIAL
Wooct 1 \%

6 Oorstr

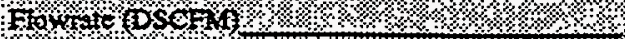

Isokineted

REMARKS 
$\wedge$

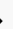

Plant Name $\quad$ Plant Yates Station Boiler No. 1
ESP OUTLET

Page __ of

Sampling Location ES OWT Train Bulk Particulate-Radionuclides Run No. 3

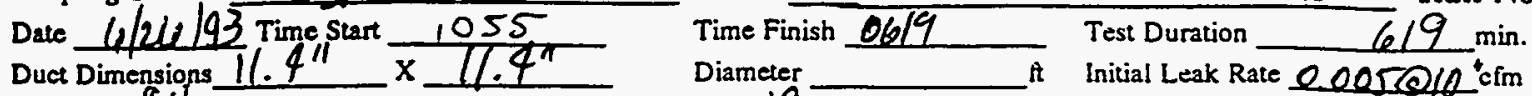

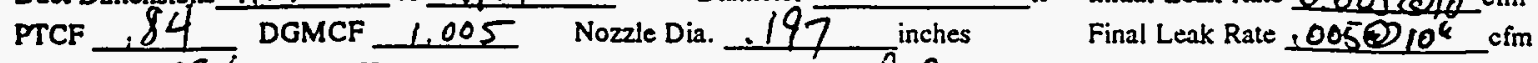
Bar Press $\frac{2942}{-11.0}={ }^{\mathrm{Hg}}=\quad \mathrm{K} 2 \mathrm{~K}=1.09$

\begin{tabular}{|c|c|c|c|c|c|c|c|c|c|c|c|c|}
\hline \multirow{2}{*}{$\begin{array}{c}\text { Travers } \\
\text { Point }\end{array}$} & \multirow{2}{*}{$\begin{array}{l}\text { Clock } \\
\text { Time }\end{array}$} & \multirow{2}{*}{$\begin{array}{c}\text { Dry gas meter } \\
\text { reading } f \mathrm{t} 3\end{array}$} & \multirow{2}{*}{$\begin{array}{c}A P \\
\text { in } \mathrm{H} 2 \mathrm{O}\end{array}$} & \multirow{2}{*}{$\begin{array}{c}{ }^{A} \\
\text { in } \mathrm{H} 2 \mathrm{O}\end{array}$} & \multirow{2}{*}{\begin{tabular}{|c|} 
Stack \\
Temp. F
\end{tabular}} & \multicolumn{2}{|c|}{ Dry gas meter temp. } & \multirow{2}{*}{$\begin{array}{c}\text { Hot box } \\
\text { Temp. }\end{array}$} & \multirow{2}{*}{$\begin{array}{l}\text { Probe } \\
\text { Temp }\end{array}$} & \multirow{2}{*}{$\begin{array}{c}\text { Last } \\
\text { Impinger }\end{array}$} & \multirow{2}{*}{$\begin{array}{l}\text { Vacuum } \\
\text { in. } \mathrm{Hg}\end{array}$} & \\
\hline & & & & & & Inlet & Outlet & & & & & \\
\hline & 0 & 913.21 & 105 & 1.2 & 278 & 87 & 85 & 260 & 149 & 65 & 1 & \\
\hline & 24 & 927.0 & 1.05 & 1.2 & 280 & 94 & 89 & 249 & 255 & 64 & 1 & \\
\hline & 47 & 939.92 & 1.05 & 1.2 & 282 & Q9 & 92 & 250 & 262 & 68 & 1 & \\
\hline & 62 & 948.42 & 1.05 & 1.2 & 284 & 102 & 95 & 254 & 248 & 57 & 1 & \\
\hline & 107 & 974.16 & 1.05 & 1.2 & 284 & 105 & 101 & 254 & 255 & 63 & 1 & \\
\hline & 146 & $996 \cdot 6$ & 1.05 & 1.2 & 282 & 109 & 105 & 255 & 249 & 59 & 1 & \\
\hline & 189 & 100.1 .45 & 1.05 & 1.2 & 286 & 104 & 103 & 252 & 246 & 59 & 1 & \\
\hline & 245 & 1054.43 & 1.05 & 1,2 & 286 & 104 & 101 & 252 & 251 & 63 & 1 & \\
\hline 367 & 262 & $109 / 2$ & 1.05 & 1.2 & 286 & 104 & 101 & 252 & 252 & 62 & 1 & \\
\hline & 432 & 164.5 & 1.05 & 1.2 & 286 & 06 & 102 & 352 & 252 & 58 & 1 & \\
\hline $\operatorname{Im} 9$ & 479.9 & 191.89 & 1.05 & 1.2 & 284 & 104 & 99 & 253 & 257 & 60 & 1 & \\
\hline & 543.3 & $228 \cdot 75$ & 105 & 1.2 & 254 & $0_{7}^{1} 98$ & 94 & 256 & 257 & 56 & 1 & \\
\hline & 624.5 & 275.50 & 1.05 & 1.2 & 281 & 98 & 93 & 253 & 261 & 58 & 1 & \\
\hline & $665 \cdot 7$ & 249.15 & 1.05 & 1.2 & 283 & 97 & 12 & 253 & 256 & 57 & 1 & \\
\hline & 720.5 & 330.40 & 6.05 & 1,2 & 281 & 94 & 50 & 253 & 262 & 53 & 1 & \\
\hline & 775.8 & 361.70 & 1.05 & 1.2 & 283 & 34 & 55 & 25 & 262 & 54 & 6 & \\
\hline & $S 37,2$ & 396.50 & 1.05 & 1.2 & 280 & Si & 87 & 250 & 262 & 54 & 1 & \\
\hline & 8915 & 427.20 & 1.05 & 1.2 & 280 & 52 & 87 & 252 & 253 & 53 & 1 & \\
\hline & 962.1 & 466.97 & 1.05 & 1.2 & 280 & 93 & 87 & 251 & 249 & 55 & 1 & \\
\hline & 10262 & 503.00 & 1.05 & 1.2 & 278 & 54 & 88 & 253 & $2 \sqrt{8}$ & 55 & 1 & \\
\hline & 1081.4 & 533.52 & 1.05 & 1.2 & 279 & 91 & 86 & 252 & 255 & 51 & 1 & \\
\hline & 11327 & 565.77 & 1.05 & 1.2 & 278 & 85 & 84 & 252 & $250^{\circ}$ & 51 & 1 & \\
\hline 927 & 0619 & 580.3 & & & & & & & & & & \\
\hline & & & & & & & & & & & & \\
\hline & & & & & & & & & & & & \\
\hline & & & & & & & & & & & & \\
\hline & & & & & & & & & & & & \\
\hline & & & & & & & & & & & & \\
\hline Avg. & - & 660,090 & 16028 & 18200 & 2620 & $\% \%$ & 969 & 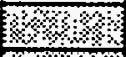 & $\%$ & 1.8 & 8 & \\
\hline Check'd & & \% & 8 & 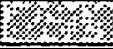 & 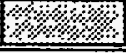 & 28 & $1 \%$ & $\mathrm{~s} / \% / \%$ & 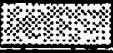 & , & & \\
\hline
\end{tabular}

CONSOLE * $A / 6 / 400$

FILTER "

AMBIENT TEMP. $\quad 80$

PROBE LENGTH $10^{\prime}$

LINER MATERIAL GLASS

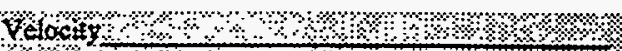

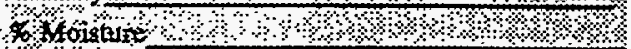

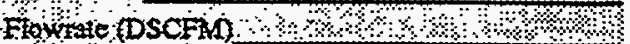

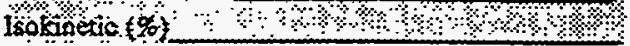

REMARKS 
SOURCE SAMPLING FIELD DATA SHEET

$$
\text { Page I of }
$$

Plant Name

Plant Yates Station Boiler No. 1

Sampling Location Outtlet.

Date $6 \sqrt{24 / 93}$ Time Start $/ 1 \% 3$

Duct Dimertsions

PTCF

Bar Press

Static Press

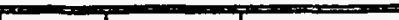

Travers Clock

Point $\mathrm{x}$. DGMCF " $\mathrm{Hg}$

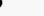

Train

Time Finish 12:00

Diameter

E DLA.

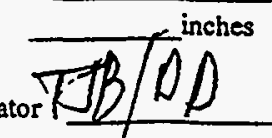

Particulate / Metals

Test Duration 30

Initial Leak Rate, $0 / \Theta 10^{\prime \prime}$

Final Leak Rate - $O\left(O O^{7}\right.$

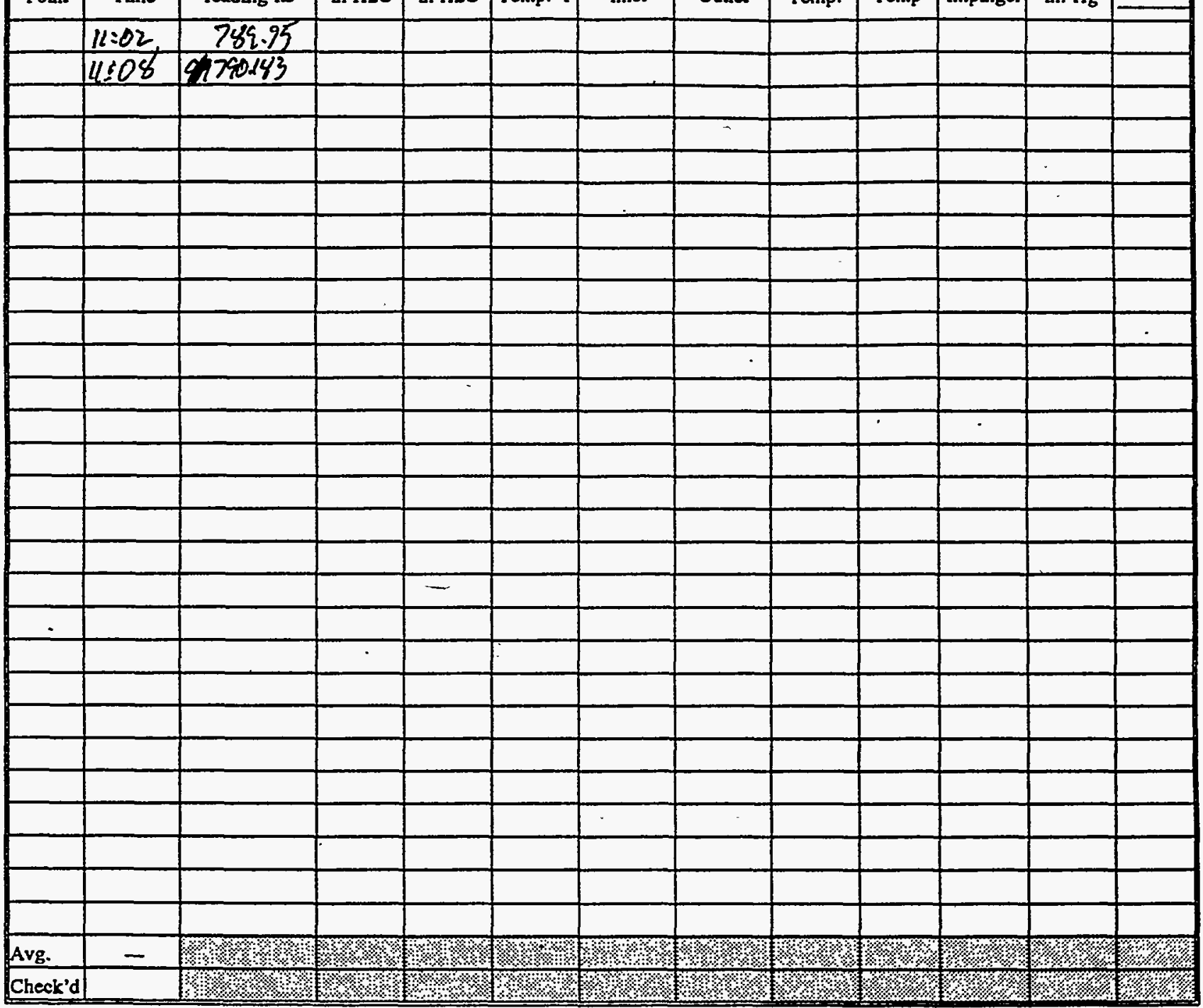

CONSOLE $16[364$

FILTER \# 907

AMBIENT TEMP.

PROBE LENGTH

LINER MATERIAL

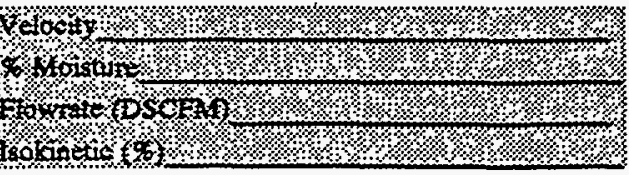

REMARKS 


\section{Flue-Gas Sampling Log}

\begin{tabular}{|c|c|}
\hline Sponsat: & 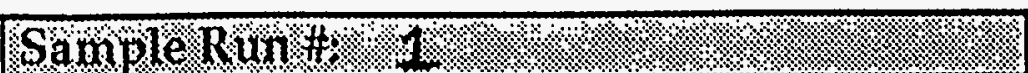 \\
\hline PSant Bocation: $1 \%$ & 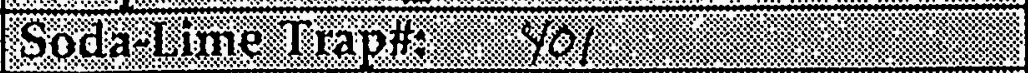 \\
\hline Dater & Todated -anbon \% \\
\hline Fuel Typer 2 (con & 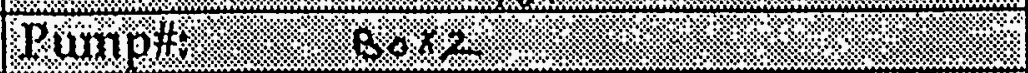 \\
\hline 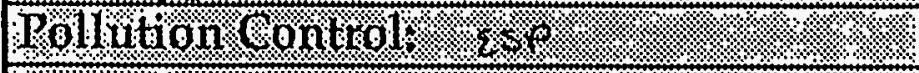 & Pgobet: \\
\hline Sampling roint & $\mathrm{TD}$ \\
\hline
\end{tabular}

\begin{tabular}{|c|c|c|c|c|c|c|c|c|}
\hline \multicolumn{3}{|c|}{ start } & \multicolumn{3}{|c|}{ stop } & \multirow{2}{*}{$\begin{array}{c}\text { elapsed } \\
\text { time } \\
\text { (min) } \\
\end{array}$} & \multirow{2}{*}{$\begin{array}{c}\text { mean } \\
\text { zero } \\
(1 / \text { min }) \\
\end{array}$} & \multirow{2}{*}{$\begin{array}{c}\text { mean } \\
\text { flow } \\
(1 / \mathrm{min})\end{array}$} \\
\hline $\begin{array}{c}\text { time } \\
(\mathrm{hh}: \mathrm{mm})\end{array}$ & $\begin{array}{c}\text { zero } \\
(1 / \mathrm{min})\end{array}$ & $\begin{array}{c}\text { flow } \\
(1 / \mathrm{min})\end{array}$ & $\begin{array}{c}\text { time } \\
(\mathrm{hh}: \mathrm{mm})\end{array}$ & $\begin{array}{c}\text { zero } \\
(1 / \mathrm{min})\end{array}$ & $\begin{array}{c}\text { flow } \\
(1 / \mathrm{min})\end{array}$ & & & \\
\hline 08,0 & $0.00 / 5^{\prime \prime}$ & .283 & 1323 & $0.00 / 1^{\prime \prime}$ & 243 & 313 & 0 & .26 \\
\hline & & & & & & & & \\
\hline & & & & & & & & \\
\hline & & & & & & & & \\
\hline & & & & & & & & \\
\hline & & & & & & & & \\
\hline & & & & & & & & \\
\hline
\end{tabular}

Integrator Volume (1):

Offset Correction (1):

Total Integrator Volume:

$\mathrm{CO}_{2}$ Mass Flow Correction:

Actual (dry STP) volume (1):

$\% \mathrm{O}_{2}: 78$

$\% \mathrm{CO}_{2}: \quad 11.2$

\% $\mathrm{H}_{2} \mathrm{O}: 10 \%$
COMMENTS:

Inital $L_{\text {gale }} R_{A T S}=0.00 \mathrm{e} / \mathrm{s}^{\prime} Q$ Probe $=0.00 \quad B \times$

Suitert $V_{M}=189$

Fonal vol $=118.9$

find onfset = - .05ka poobe 


\section{Flue-Gas Sampling Log}

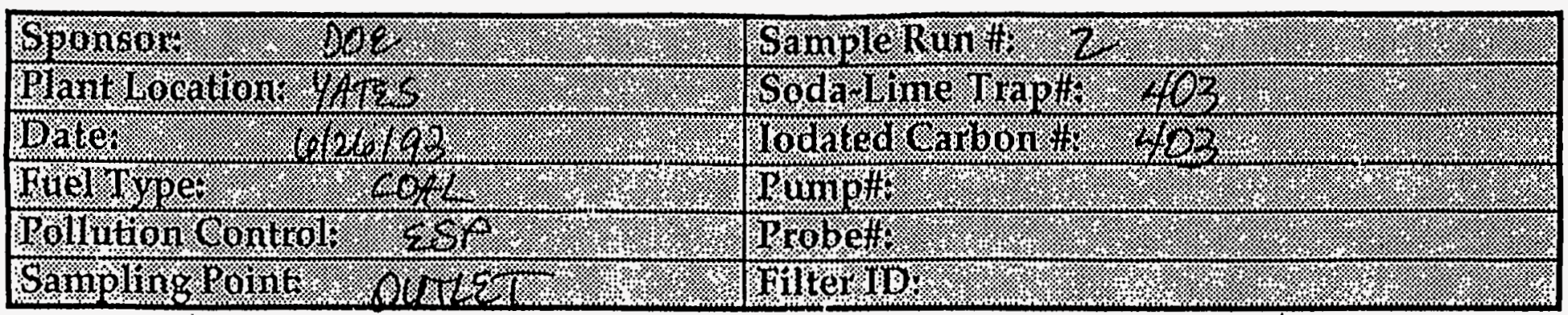

\begin{tabular}{|c|c|c|c|c|c|c|c|c|}
\hline \multicolumn{3}{|c|}{ start } & \multicolumn{3}{|c|}{ stop } & \multirow{2}{*}{$\begin{array}{c}\text { elapsed } \\
\text { time } \\
\text { (min) }\end{array}$} & \multirow{2}{*}{$\begin{array}{c}\text { mean } \\
\text { zero } \\
(1 / \mathrm{min}) \\
\end{array}$} & \multirow{2}{*}{$\begin{array}{c}\text { mean } \\
\text { flow } \\
(1 / \mathrm{min})\end{array}$} \\
\hline $\begin{array}{c}\text { time } \\
(\mathrm{hh}: \mathrm{mm})\end{array}$ & $\begin{array}{c}\text { zero } \\
(1 / \mathrm{min})\end{array}$ & $\begin{array}{c}\text { flow } \\
(1 / \mathrm{min})\end{array}$ & $\begin{array}{c}\text { time } \\
\text { (hh:mm) }\end{array}$ & $\begin{array}{c}\text { zero } \\
(\mathrm{I} / \mathrm{min})\end{array}$ & $\begin{array}{c}\text { flow } \\
(1 / \mathrm{min})\end{array}$ & & & \\
\hline 0925 & $1 B D-.48$ & 136809 & 1434 & -.54 & 326 & 309 & & \\
\hline 1434 & & .352 & & & & & & \\
\hline & & & & & & & & \\
\hline & & . & & & & & & \\
\hline & & & & & & & & \\
\hline & & & & & & & & \\
\hline & & & & & OTALS: & & & \\
\hline
\end{tabular}

Integrator Volume (1): 100.1

Offset Correction (1): $\quad-.048$

Total Integrator Volume:

$\mathrm{CO}_{2}$ Mass Flow Correction:

Actual (dry STP) volume (1):

$\% \mathrm{O}_{2}: \quad 8$

$\% \mathrm{CO}_{2}: 12$

$\% \mathrm{H}_{2} \mathrm{O}: 10$

ppm $\mathrm{SO}_{2}$ :

\begin{tabular}{|l|}
\hline COMMENTS: \\
\hline Theitual Volume $=0.0$ \\
\hline \\
\hline \\
\hline \\
\hline \\
\hline
\end{tabular}




\section{Flue-Gas Sampling Log}

\begin{tabular}{|c|c|}
\hline 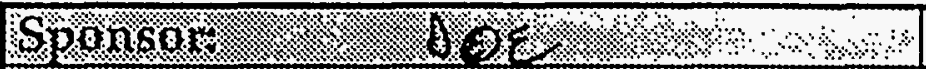 & Sample Run \#: $>>$ \\
\hline 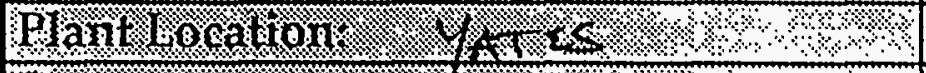 & Sodalime Trapt: 4 \\
\hline 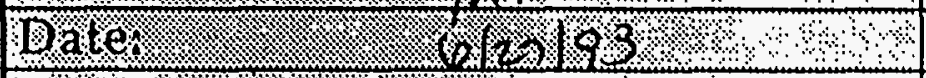 & lodated Carbon th 8,098 \\
\hline 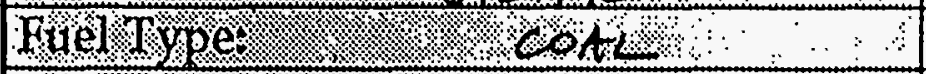 & Pumpitts \\
\hline Pollution - andorl. & Probett? \\
\hline 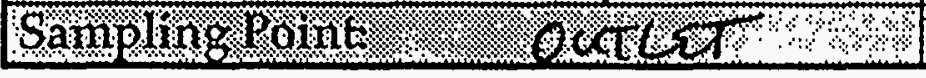 & \\
\hline
\end{tabular}

\begin{tabular}{|c|c|c|c|c|c|c|c|c|}
\hline \multicolumn{3}{|c|}{ start } & \multicolumn{3}{|c|}{ stop } & \multirow{2}{*}{$\begin{array}{c}\text { elapsed } \\
\text { time } \\
\text { (min) }\end{array}$} & \multirow{2}{*}{$\begin{array}{c}\text { mean } \\
\text { zero } \\
(1 / \mathrm{min}) \\
\end{array}$} & \multirow{2}{*}{$\begin{array}{c}\text { mean } \\
\text { flow } \\
(1 / \mathrm{min}) \\
\end{array}$} \\
\hline $\begin{array}{c}\text { time } \\
\text { (hh:mm) }\end{array}$ & $\begin{array}{c}\text { zero } \\
(1 / \mathrm{min})\end{array}$ & $\begin{array}{c}\text { flow } \\
(1 / \mathrm{min})\end{array}$ & $\begin{array}{c}\text { time } \\
\text { (hh:mm) }\end{array}$ & $\begin{array}{c}\text { zero } \\
(1 / \mathrm{min})\end{array}$ & $\begin{array}{c}\text { flow } \\
(1 / \mathrm{min})\end{array}$ & & & \\
\hline 0706 & $0 / 10^{\prime \prime}$ & .402 & 1126 & 0 & 386 & $245 \sigma^{\prime \prime}$ & 0 & .394 \\
\hline & & & & & & $260^{\prime \prime}$ & & \\
\hline & & & & & & & & \\
\hline & & & & & & & & \\
\hline & & & & & & & & \\
\hline & & & & & & & & \\
\hline & & & & & ГOTALS: & & & \\
\hline
\end{tabular}

Integrator Volume (1):

Offset Correction (I): $\quad 0.0$

Ofset Correction (1): - 1948

Total Integrator Volume: 100

$\mathrm{CO}_{2}$ Mass Flow Correction:

Actual (dry STP) volume (1): *

$\% \mathrm{O}_{2}$ :

$\% \mathrm{CO}_{2}$ :

g̊

$\% \mathrm{H}_{2} \mathrm{O} !$

$\mathrm{ppm} \mathrm{SO}_{2}$ :

\begin{tabular}{l}
\hline COMMENTS: \\
fintigl vol $=0.00$ \\
\hline funl unl $=100.0$ \\
\hline foul offot $=-.050$ \\
\hline \\
\hline
\end{tabular}




\section{Flue-Gas Sampling Log}

\begin{tabular}{|c|c|}
\hline 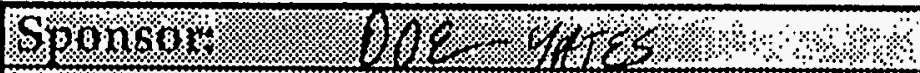 & 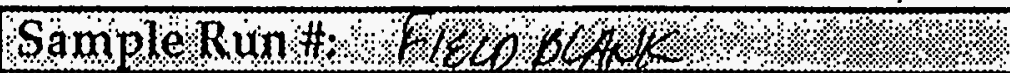 \\
\hline 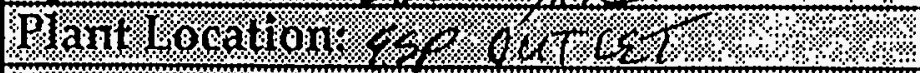 & Sodal Yine TrapH. $4 \mathrm{e}$ \\
\hline 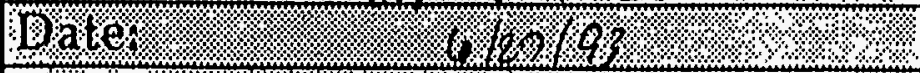 & lodated Qaibon H) $(4 / 9)$ \\
\hline $4.2 .2 .12 \%$ & Pumpt \\
\hline 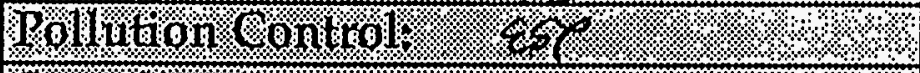 & Probet! \\
\hline 1., & Fiter IDY \\
\hline
\end{tabular}

\begin{tabular}{|c|c|c|c|c|c|c|c|c|}
\hline \multicolumn{3}{|c|}{ start } & \multicolumn{3}{|c|}{ stop } & \multirow{2}{*}{$\begin{array}{c}\text { elapsed } \\
\text { time } \\
\text { (min) } \\
\end{array}$} & \multirow{2}{*}{$\begin{array}{c}\text { mean } \\
\text { zero } \\
(1 / \mathrm{min}) \\
\end{array}$} & \multirow{2}{*}{$\begin{array}{c}\text { mean } \\
\text { flow } \\
(1 / \mathrm{min})\end{array}$} \\
\hline $\begin{array}{c}\text { time } \\
\text { (hh:mm) }\end{array}$ & $\begin{array}{c}\text { zero } \\
(1 / \mathrm{min})\end{array}$ & $\begin{array}{c}\text { flow } \\
(1 / \mathrm{min})\end{array}$ & $\begin{array}{c}\text { time } \\
\text { (hh:mm) }\end{array}$ & $\begin{array}{c}\text { zero } \\
(1 / \mathrm{min})\end{array}$ & $\begin{array}{c}\text { flow } \\
(1 / \mathrm{min})\end{array}$ & & & \\
\hline 1300 & 0 & 0 & & & & & & \\
\hline & & & & & & & & \\
\hline & & & & & & & & \\
\hline & & & & & & & & \\
\hline & & & & & & & & \\
\hline & & & & & & & & \\
\hline & & & & & OTALS: & & & \\
\hline
\end{tabular}

\begin{tabular}{|l|}
\hline Integrator Volume (1): \\
\hline Offset Correction (1): \\
\hline Total Integrator Volume: \\
\hline CO $\mathrm{O}_{2}$ Mass Flow Correction: \\
\hline Actual (dry STP) volume (1): \\
\hline$\% \mathrm{O}_{2}:$ \\
\hline$\% \mathrm{CO}_{2}:$ \\
\hline$\% \mathrm{H}_{2} \mathrm{O}:$ \\
\hline ppm $\mathrm{SO}_{2}:$ \\
\hline
\end{tabular}

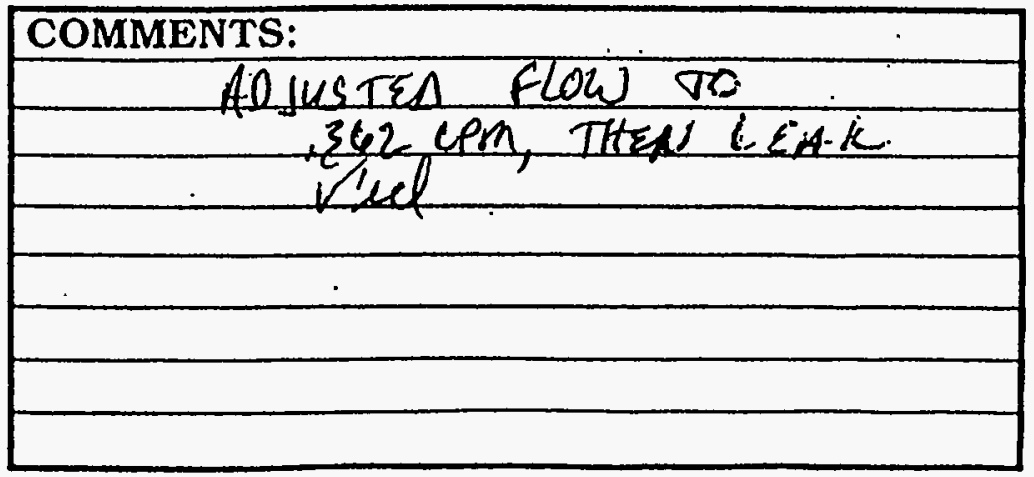



Plant Yates Station Boiler No. 1

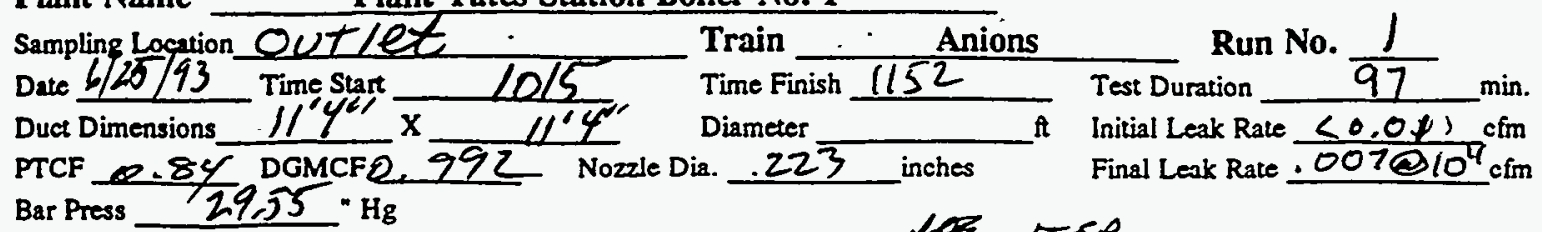

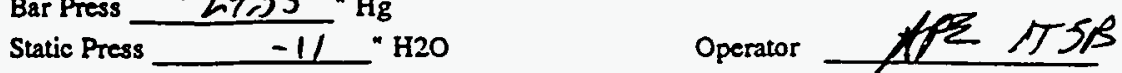

\begin{tabular}{|c|c|c|c|c|c|c|c|c|c|c|c|c|}
\hline \multirow{2}{*}{$\begin{array}{c}\text { Travers } \\
\text { Point }\end{array}$} & \multirow{2}{*}{$\begin{array}{l}\text { Clock } \\
\text { Time }\end{array}$} & \multirow{2}{*}{$\begin{array}{l}\text { Dry gas meter } \\
\text { reading ft3 }\end{array}$} & \multirow{2}{*}{$\begin{array}{c}\text { A P } \\
\text { in } \mathrm{H} 2 \mathrm{O}\end{array}$} & \multirow{2}{*}{$\begin{array}{c}\text { H } \\
\text { in } \mathrm{H} 2 \mathrm{O}\end{array}$} & \multirow{2}{*}{\begin{tabular}{|c|} 
Stack \\
Temp. F
\end{tabular}} & \multicolumn{2}{|c|}{ Dry gas meter temp. } & \multirow{2}{*}{$\begin{array}{c}\text { Hot box } \\
\text { Temp. }\end{array}$} & \multirow{2}{*}{$\begin{array}{l}\text { Probe } \\
\text { Temp }\end{array}$} & \multirow{2}{*}{\begin{tabular}{c|} 
Last \\
Impinger
\end{tabular}} & \multirow{2}{*}{$\begin{array}{c}\text { acuum } \\
\text { in. } \mathrm{Hg}\end{array}$} & \\
\hline & & & & & & Inlet & Outlet & & & & & \\
\hline & 1015 & 250.37 & 0.91 & 1.50 & 283 & 93 & 89 & $x^{\prime \prime}$ & 24 & 56 & $5 \pi$ & \\
\hline & $\begin{array}{ll}15 & 1\end{array}$ & & $T$ & & & & & & & & & \\
\hline & 1041 & 767,51 & 91 & 1.5 & 278 & 101 & 91 & 274 & 262 & 56 & $5^{\pi}$ & \\
\hline & 1052 & 774,74 & 0.93 & 1,5 & 280 & 102 & 92 & 255 & 253 & 56 & 5 & \\
\hline & 1110 & 786.22 & 0.91 & 145 & 283 & 102 & 93 & 256 & 248 & 39 & 5 & \\
\hline & 112 & 794,31 & 0.92 & 9.50 & 273 & 103 & 93 & 257 & 200 & 38 & 5 & \\
\hline & 439 & 806.74 & 0,92 & 1.55 & 2849 & 104 & 03 & 258 & 252 & 60 & 5 & \\
\hline & 1152 & 815.57 & & & & & & & & & & \\
\hline & & & & & & & & & & & & \\
\hline & & & & & & & & & & & & \\
\hline & & & & & & & & & & & & \\
\hline & & & & & & & & & & & & \\
\hline & & & & & & & & & & & & \\
\hline & & & & & & & & & & & & \\
\hline & & & & & & & & & & & & \\
\hline & & & & & & & & & & & & \\
\hline & & & & & & & & & & & & \\
\hline & & & & & & & & & & & & \\
\hline & & & & & & & & & & & & \\
\hline & & & & & & & & & & & & \\
\hline & & & & & & & & & & & & \\
\hline & & & & & & & & & & & & \\
\hline & & & & & 8 & & & & & & & \\
\hline & & & & & & & & & & & & \\
\hline & & & & & & & & & & & & \\
\hline & & & & & & & & & & & & \\
\hline & & & & & & & & & & & & \\
\hline & & & & & & & & & & & & \\
\hline Avg. & $=$ & 663260 & 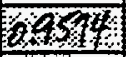 & $18 \%$ & $248 \%$ & $8 \% 6$ & ४४४४ & $3 \%$ & $8 \%$ & 8 & 1 & $8 \%$ \\
\hline Check'd & & 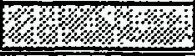 & $1 \%$ & $8 \% \%$ & $1 \% \%$ & $1 \% \%$ & $1 \% 1 \%$ & $18 \%$ & (t) & $\%$ & 8 & 8 \\
\hline
\end{tabular}

CONSOLE \#

FILTER " 722

AMBIENT TEMP.

PROBE LENGTH

LINER MATERIAL

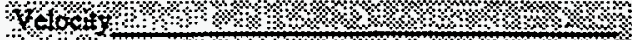
४. 0 oistrv:

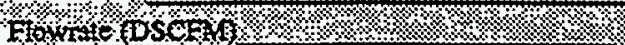

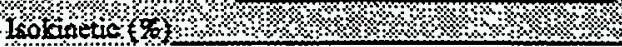

REMARKS

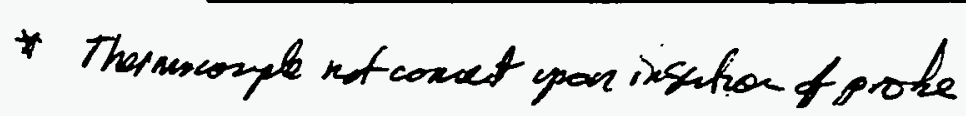



Plant Yates Station Boiler No. 1

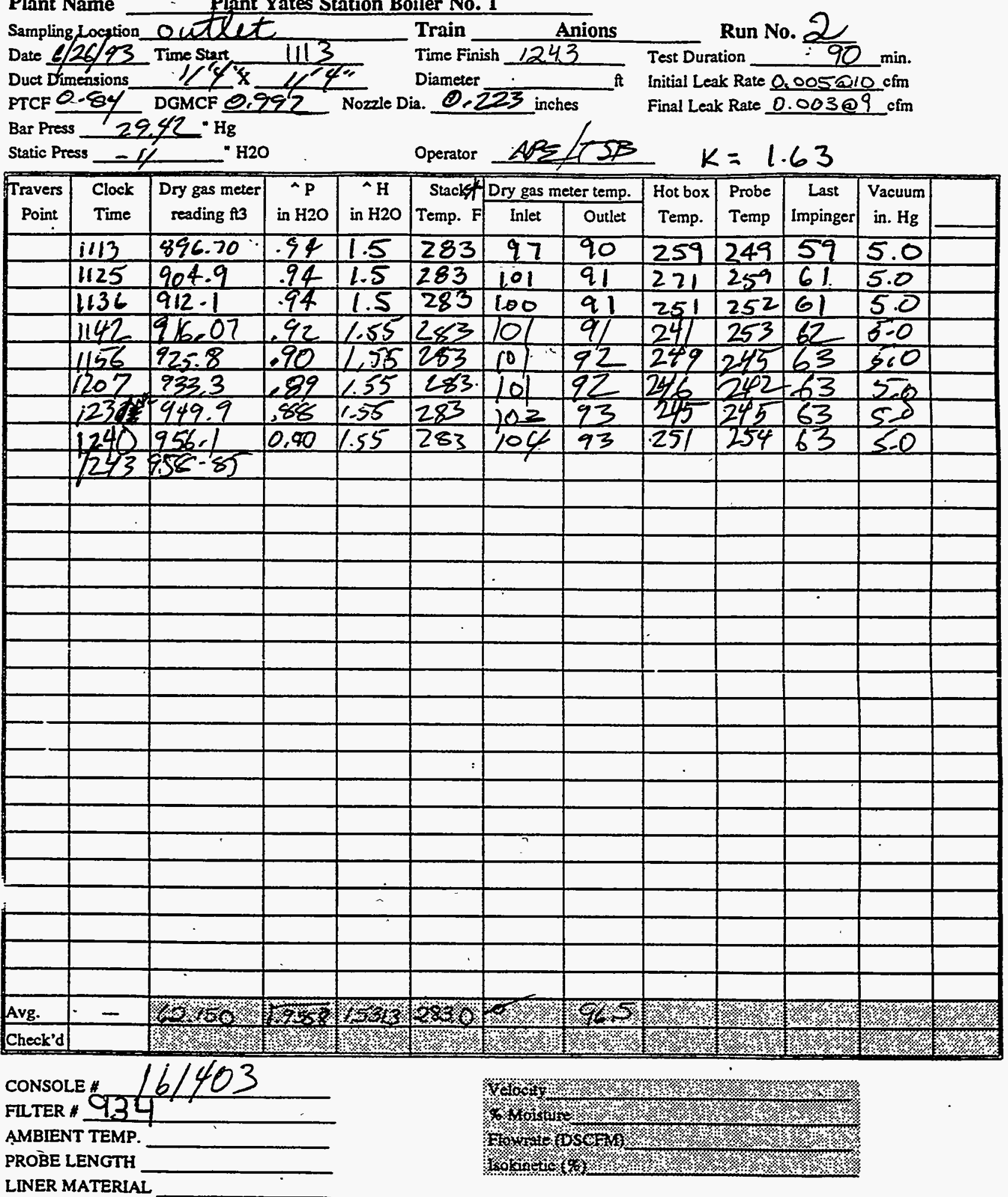

REMARKS

c-70 * tidet nossemed constart at oingle point 
SOLRCE SALPLING FIELD DATA SHEET

$$
\text { Page } 1 \text { of } 1
$$

Plant Name

Plant Yates Station Boiler No. 1

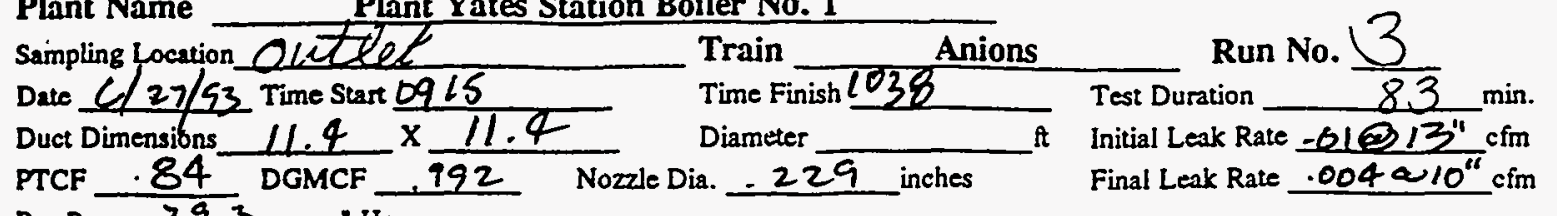

Bar Press $29.3 \cdot \mathrm{Hg}$

Static Press -11.0 Operator TJB

\begin{tabular}{|c|c|c|c|c|c|c|c|c|c|c|c|c|}
\hline \multirow{2}{*}{$\begin{array}{c}\text { Travers } \\
\text { Point }\end{array}$} & \multirow{2}{*}{$\begin{array}{l}\text { Clock } \\
\text { Time }\end{array}$} & \multirow{2}{*}{$\begin{array}{c}\text { Dry gas meter } \\
\text { reading } \mathrm{A} 3\end{array}$} & \multirow{2}{*}{$\begin{array}{c}A P \\
\text { in } \mathrm{H} 2 \mathrm{O}\end{array}$} & \multirow{2}{*}{$\begin{array}{c}\text { H } \\
\text { in } \mathrm{H} 2 \mathrm{O}\end{array}$} & \multirow{2}{*}{$\begin{array}{c}\text { Stack } \\
\text { Temp. F }\end{array}$} & \multicolumn{2}{|c|}{ Dry gas meter temp. } & \multirow{2}{*}{$\begin{array}{l}\text { Hot box } \\
\text { Temp. }\end{array}$} & \multirow{2}{*}{$\begin{array}{l}\text { Probe } \\
\text { Temp }\end{array}$} & \multirow{2}{*}{$\begin{array}{c}\text { Last } \\
\text { Impinger }\end{array}$} & \multirow{2}{*}{$\begin{array}{l}\text { Vacuum } \\
\text { in. } \mathrm{Hg}\end{array}$} & \\
\hline & & & & & & Inlet & Outlet & & & & & \\
\hline & 0915 & 47.70 & 87 & 1.6 & 280 & 10 & 94 & 247 & 250 & 65 & 5.0 & \\
\hline & 0920 & 51.28 & .87 & $1-6$ & 280 & 103 & 94 & 247 & 256 & 59 & 50 & \\
\hline & 10930 & 58.38 & .87 & 1.6 & 280 & 106 & 95 & 258 & 252 & 59 & 5.0 & \\
\hline & $\log 4.5$ & 69.04 & .87 & 1.6 & 280 & 106 & 95 & 253 & 260 & 58 & 5.0 & \\
\hline & 1015 & 91.28 & .87 & 1.6 & 2. & 108 & 97 & 253 & 246 & 59 & 50 & \\
\hline$T B$ & 1020 & & & & & 98 & 982 & 251 & 252 & $5 t$ & $\sqrt{3}$ & $i$ \\
\hline & 1027 & 100.1 & .87 & 1.6 & 280 & 108 & 97 & 255 & 251 & 65 & 5.0 & \\
\hline & 1038 & 108.364 & & & & & & & & & & \\
\hline & & & & & & & & & & & & \\
\hline & & & & & & & & & & & & \\
\hline & & & & & & & & & & & & \\
\hline & & & & & & & & & & & & \\
\hline & & & & & & & & & & & & \\
\hline & & & & & & & & & & & & \\
\hline & & & & & & & & & & & & \\
\hline & & & & & 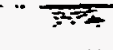 & & & & & & & \\
\hline & & & & & & & & & & & & \\
\hline & & & & & & & & & & & & \\
\hline & & & & & & & & & & & & \\
\hline & & & & & & & & & & & & \\
\hline & & & & & & & & & & & & \\
\hline & & & & & & & & & & & & \\
\hline & & & & & & & & & & & & \\
\hline & & & & & & & & & & & & \\
\hline & & & & & & & & & & & & \\
\hline & & & & & & & & & & & & \\
\hline & & & & & & & & & & & & . \\
\hline & & & & & & & & & & & & \\
\hline Avg. & - & 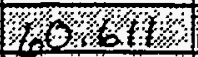 & 9322 & 6600 & 280.00 & $\%$ & $98 \%$ & $8 \%$ & 48 & 8.8 & 8 & 8 \\
\hline Check'd & & $10.8 \%$ & $1 \%$ & $1 \% 4$ & $1 \%$ & $8 \%$ & $\%$ & 2648 & ४े & 8 & ڤ & \\
\hline
\end{tabular}

CONSOLE \# 161403

FILTER " 901

AMBIENT TEMP.

PROBE LENGTH

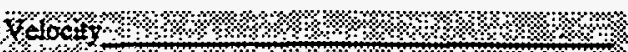

601 oistiviv $1.8 \%$ \%

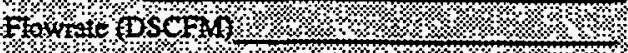

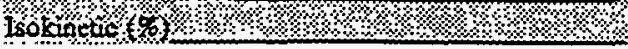

LINER MATERIAL 
SOLRCE SALPLING FIELD DATA SHEET

$$
\text { Page } 1 \text { of } 1
$$

Plant Name

Plant Yates Station Boiler No. 1

\begin{tabular}{|c|c|c|c|c|c|c|c|c|c|c|c|c|}
\hline \multirow{2}{*}{\multicolumn{2}{|c|}{ Plant Name - - }} & & & nions & & \multirow{2}{*}{\multicolumn{2}{|c|}{ Run No. $E_{s} B_{r}$}} & & \\
\hline & & \multicolumn{3}{|c|}{ ESP DLT } & Train - & & & \multirow{4}{*}{\multicolumn{4}{|c|}{$\begin{array}{l}\text { Test Duration } \\
\text { lnitial Leak Rate } \\
\text { Final Leak Rate } \\
\mathrm{cfm}\end{array}$}} & \\
\hline \multicolumn{2}{|c|}{$\begin{array}{l}\text { Sampling Location } \\
\text { Date } 6 / 2 / 1 / 93\end{array}$} & \multirow{2}{*}{\multicolumn{2}{|c|}{ Time Start $x$}} & & Time Finish & & & & & & & \\
\hline \multirow{2}{*}{\multicolumn{2}{|c|}{$\begin{array}{l}\text { Duct Dimensions } \\
\text { PTCF }\end{array}$}} & & & & & 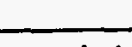 & \multirow[t]{2}{*}{ - $^{\mathfrak{t}}$} & & & & & \\
\hline & & \multirow{2}{*}{$\begin{array}{c}\text { DGMCF } \\
=\mathrm{Hg}\end{array}$} & & \multirow[t]{2}{*}{ Nozzle $D$} & ia. & inch & & & & & & \\
\hline \multicolumn{6}{|c|}{ Bar Press __ } & & & & & & & \\
\hline \multirow{6}{*}{$\begin{array}{c}\text { Travers } \\
\text { Point }\end{array}$} & \multirow{2}{*}{$\begin{array}{l}\text { Clock } \\
\text { Time }\end{array}$} & \multirow{2}{*}{$\begin{array}{c}\text { Dry gas meter } \\
\text { reading fl3 }\end{array}$} & \multirow{2}{*}{$\begin{array}{l}\wedge \mathrm{P} \\
\text { in } \mathrm{H} 2 \mathrm{O}\end{array}$} & \multirow{2}{*}{$\begin{array}{c}{ }^{\circ} \mathrm{H} \\
\text { in } \mathrm{H} 2 \mathrm{O}\end{array}$} & \multirow{2}{*}{$\begin{array}{c}\text { Stack } \\
\text { Temp. F }\end{array}$} & \multicolumn{2}{|c|}{ Dry gas meter temp. } & Hot box & Probe & Last & Vacuum & \\
\hline & & & & & & Inlet & Outlet & Temp. & Temp & Impinger & in. $\mathrm{Hg}$ & \\
\hline & & 34.100 & & & & & & & & & & \\
\hline & & 94,26 & & & & & & & & & & \\
\hline & & & & & & & & & & . & & \\
\hline & & & & & & & & - & & & & \\
\hline & & & & & & & & & & & & \\
\hline & & & & & & $\cdot$ & & & & & & \\
\hline & & & & & & & & & & & & \\
\hline & & & & & & & & & & & & \\
\hline & & & & & & & & & & & & \\
\hline & & & & & & & & & & & & \\
\hline & 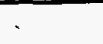 & & & & & & & & & & & \\
\hline & & & & & & & & & & & & \\
\hline & & & & & & & & & & & & \\
\hline & & & & & & & & & & & & \\
\hline & & & & & & & & & & & & \\
\hline & & & & & & & & & & & & \\
\hline & & & & $\ldots$ & & & & & & & & \\
\hline & & - & & & & & & & & & & \\
\hline & & & & & & & & & & & & \\
\hline & & & & & & & & & & & & \\
\hline & & & & & & & & - & 5 & & & \\
\hline & & & & & & v & & & & & & \\
\hline & & & & & & & & & & & & \\
\hline & & - & & & & & & & & & & \\
\hline & & & & & & & & & & & & \\
\hline & & & & & & & & & . & & & \\
\hline & & & & & & & & & & & & \\
\hline & & & & & - & & & & & & & \\
\hline Avg. & - & ४४४. & $8 \times .8$ & $8 \%$ & ४४४ & ४ং४ & $1 \%$ & 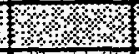 & \%॰. & 2 & 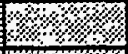 & 4 \\
\hline Check'd & & 180.8 & $5 \times$ & 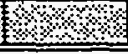 & 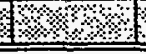 & $8 \%$ & २६ & 8 & $1 \%$ & 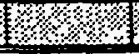 & $\% 1 \%$ & \% \\
\hline
\end{tabular}

CONSOLE \# A $61-364$

FILTER \#

AMBIENT TEMP.

PROBE LENGTH

LINER MATERIAL
Wlocity

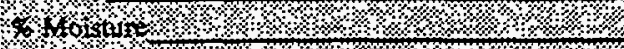

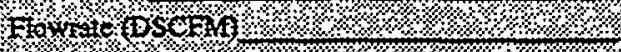

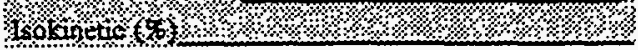

REMARKS

C-72 
Plant Name $s$ s $\quad$ Plant Yates Station Boiler No. 1

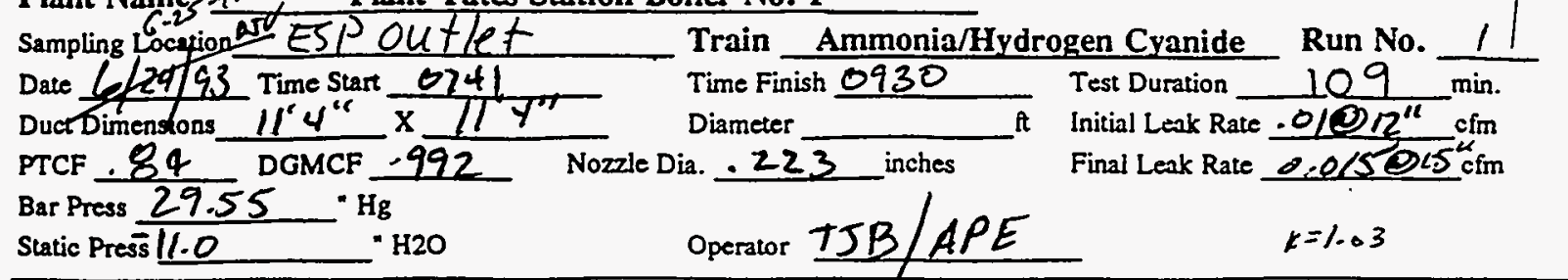

\begin{tabular}{|c|c|c|c|c|c|c|c|c|c|c|c|c|}
\hline \multirow{2}{*}{$\begin{array}{c}\text { Travers } \\
\text { Point }\end{array}$} & \multirow{2}{*}{$\begin{array}{l}\text { Clock } \\
\text { Time }\end{array}$} & \multirow{2}{*}{$\begin{array}{c}\text { Dry gas meter } \\
\text { reading } \mathrm{t} 33\end{array}$} & \multirow{2}{*}{$\begin{array}{c}\text { A } \\
\text { in } \mathrm{H} 2 \mathrm{O}\end{array}$} & \multirow{2}{*}{$\begin{array}{c}\wedge \mathrm{H} \\
\text { in } \mathrm{H} 2 \mathrm{O}\end{array}$} & \multirow{2}{*}{$\begin{array}{c}\text { Stack } \\
\text { Temp. F }\end{array}$} & \multicolumn{2}{|c|}{ Dry gas meter temp. } & \multirow{2}{*}{$\begin{array}{c}\text { Hot box } \\
\text { Temp. }\end{array}$} & \multirow{2}{*}{$\begin{array}{l}\text { Probe } \\
\text { Temp }\end{array}$} & \multirow{2}{*}{\begin{tabular}{|c|} 
Last \\
Impinger
\end{tabular}} & \multirow{2}{*}{$\begin{array}{l}\text { Vacuum } \\
\text { in. } \mathrm{Hg}\end{array}$} & \\
\hline & & & & & & Inlist & Outlet & & & & & \\
\hline & 874 & 674.000 & .95 & 1.55 & 278 & 75 & 74 & 267 & 271 & 63 & 8.0 & \\
\hline & 0810 & 623.5 & .95 & 1.55 & 280 & 24 & 80 & 258 & 265 & 60 & 8.0 & \\
\hline & 0816 & 697.43 & .95 & 1.50 & 280 & 95 & 81 & 254 & 262 & 58 & 80 & \\
\hline & 8825 & 703.5 & $889^{\circ}$ & 5,50 & 280 & 95 & 83 & 266 & 249 & 56 & 8.0 & \\
\hline & 0836 & 710.7 & .95 & 1.58 & 280 & 95 & 83 & 265 & 254 & 56 & 8.0 & \\
\hline & 0855 & 723.34 & 0.91 & 1.55 & 287 & $\frac{1}{26}$ & 85 & 257 & 246 & 56 & 80 & \\
\hline & 0914 & 73640 & 0.40 & 160 & 278 & 99 & 87 & 257 & 242 & -59 & 820 & \\
\hline & $0 x<d 3$ & 2747.525 & & & & & & & & & & \\
\hline & & & & & & & & & & & & \\
\hline & & & & & & & & & & & & \\
\hline & & & & & & & & & & & & \\
\hline & & & & & & & & & & & & \\
\hline & & & & & & & & & & & & \\
\hline & & & & & & & & & & & & \\
\hline & & & & & & & & & & & & \\
\hline & & & & & & & & & & & & \\
\hline & & & & & & & & & & & & \\
\hline & & & & & & & & & & & & \\
\hline & & & & & & & & & & & & \\
\hline & & & & & & & & & & & & \\
\hline & & & & & & & & & & & & \\
\hline & & & & & & & & & & & & \\
\hline & & & & & & & & & & & & \\
\hline & & & & & & & & & & & & \\
\hline & & & & & & & & & & & & \\
\hline & & & & & & & & & & & & \\
\hline & & & & & & & & & & & & \\
\hline & & & $\sqrt{A P}$ & & & & & & & & & \\
\hline Avg. & $=$ & $1 / 7,8 \mathrm{i} 5$ & 0960 & $16 \times 4$ & $1280 \%$ & 889 & ২৮২\% & & ২ংঃ৪ & $\%$ & 14\%8. & 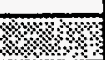 \\
\hline Check'd & 20 & $173,3,2,3$ & 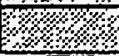 & $1 \%$ & $1 \% 8 \%$ & \% & $18 \% 8 \%$ & $1.4 \%$ & 18.2. & 18.8 & & 18 \\
\hline
\end{tabular}

CONSOLE " $16 / 403$

FILTER \#

AMBIENT TEMP.

PROBE LENGTH

LINER MATERIAL

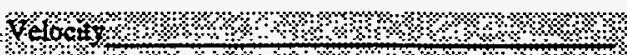

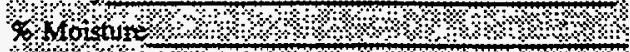

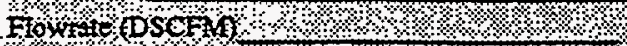
Joskntict 
Plant Name $a_{0} a^{3}$ Plant Yates Station Boiler No. 1

Sampling location Ois,iet

Date 20 Time Start

Duot Dimensibns !! : $\times 1 ! .7<$ Diameter —

PTCF -S4 DGMCF / F59 Nozzle Dia. 223 inches

Bar Press 29.82" $0.992 .0 \mathrm{JV}$

Static Press $-1 /$ "H2O DJ

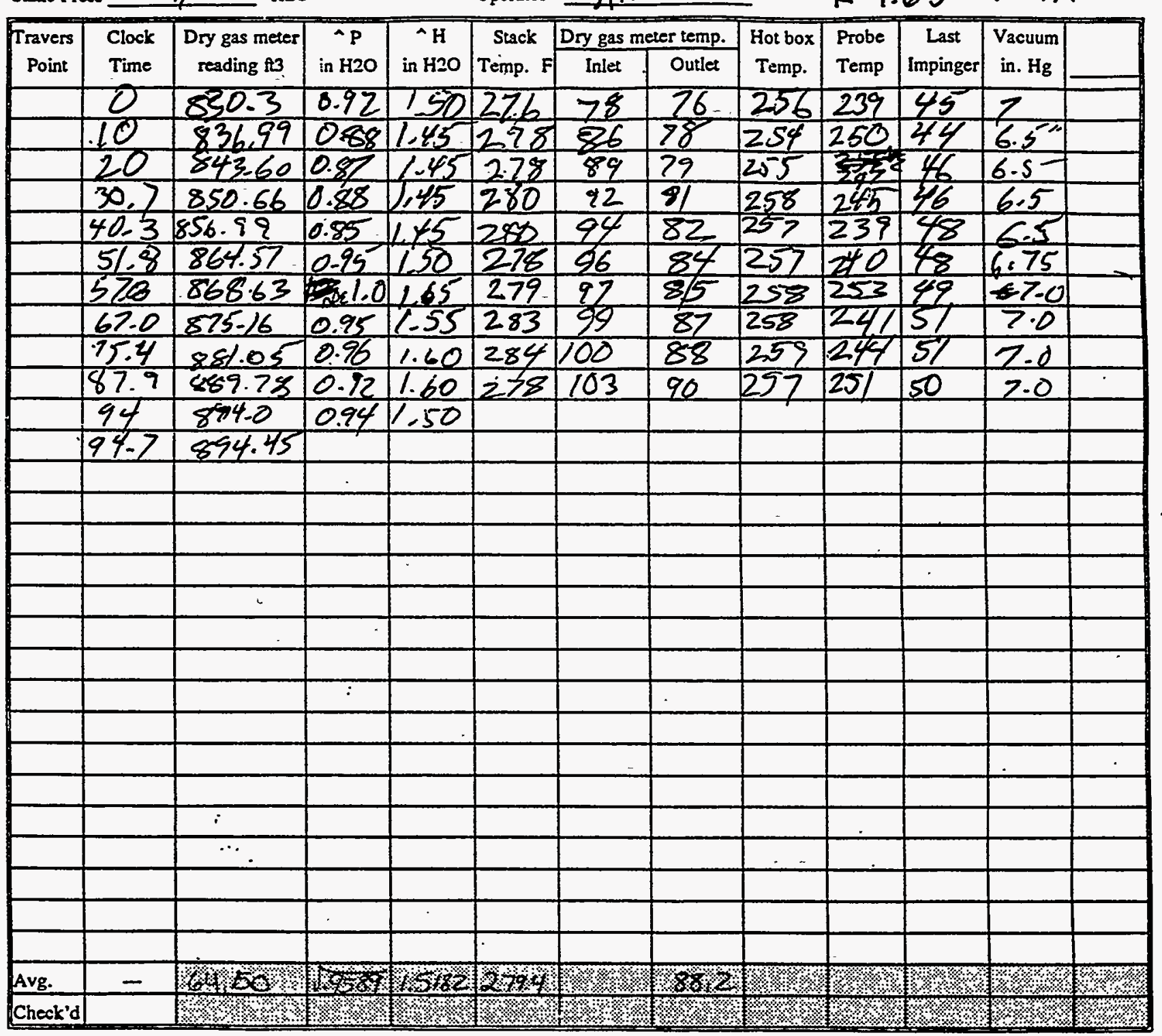

Train Ammonia/Hydrogen Cyanide Run No. Z

Time Finish $110^{4}$ Test Duration $95 \mathrm{~min}$ Initial Leak Rate .0070 Final Leak Rate $0.006 @ 2^{7} \mathrm{~cm}$ operator Ale $\quad K=1.63075^{\circ} \mathrm{Tm}=1.69 \mathrm{es}$
CONSOLE " 161403

FLLTER \#
AMBIENT TEMP.
PROBE LENGTH
LINER MATERIAL 
Plant Name

Plant Yates Station Boiler No. 1

Sampling Location ESP Outlet

Date $6 1 2 7 \longdiv { 9 3 }$ Time Start 72725

Train Ammonia/Hydrogen Cyanide Run No. 3

Duct Dimensions $11.4^{\prime \prime} \times 11.7^{\prime \prime}$

Time Finish 0856 Test Duration $\mathrm{Q} 1$

min.

PTCF .84 DGMCF $\$ 92$ Nozzle Dia?.22 3.224 inches

it Initial Leak Rate $\frac{01010^{11}}{\mathrm{cfm}}$

Static Press -11.0 Operator TJB $"$ H2O

\begin{tabular}{|c|c|c|c|c|c|c|c|c|c|c|c|c|}
\hline Travers & Clock & Dry gas meter & $A$ & ${ }^{\wedge} \mathrm{H}$ & Stack & Dry gas & ter temp. & Hot box & Probe & Last & Vacuum & \\
\hline Point & Time & reading ft3 & in $\mathrm{H} 2 \mathrm{O}$ & in $\mathrm{H} 2 \mathrm{O}$ & Temp. F & Inlet & Outlet & Temp. & Temp & Impinger & in. $\mathrm{Hg}$ & \\
\hline & 0725 & 983.0 & .89 & 1.6 & 280 & 81 & 77 & 254 & 263 & 68 & 6.0 & \\
\hline & 0733 & 988.45 & .89 & 1.6 & 280 & 90 & 79 & 253 & 260 & 59 & 6.0 & \\
\hline & 0741 & 993.96 & .89 & 1.6 & 280 & 96 & 81 & 262 & 258 & 54 & 6.0 & \\
\hline & 0753 & 1002.28 & .89 & 1.6 & 277 & 99 & 84 & 253 & 255 & 53 & 6.0 & \\
\hline & 0863 & 10002.26 & .85 & 1.6 & 278 & 101 & 87 & 254 & 258 & 53 & 6.0 & \\
\hline & 0818 & 10.9 .65 & .89 & 1.6 & 279 & 162 & 89 & 255 & 249 & 54 & 6.5 & \\
\hline & 0830 & 1028.04 & .89 & 1.6 & 280 & 106 & 92 & 256 & 257 & 52 & 65 & \\
\hline & 0845 & 1034.58 & -89 & 1.6 & 280 & 107 & 93 & 255 & 253 & 57 & & \\
\hline & 0856 & 1046.443 & & & & & & & & & & \\
\hline & & & & & & & & & & & & \\
\hline & & & & & & & & & & & & \\
\hline & & & & & & & & & & & & \\
\hline & & & & & & & & & & & & \\
\hline & & & & & & & & & & & & \\
\hline & & & & & & & & & & & & \\
\hline & & & & & & & & & & & & \\
\hline & & & & & & & & & & & & \\
\hline & & & & & & & & & & & & \\
\hline & & & & & & & & & & & & \\
\hline & & & & & & & & & & & & \\
\hline & & & & & & & & & & & & \\
\hline & & & & & & & & & & & & \\
\hline & & & & & & & & & & & & \\
\hline & & & & & & & & & & & & \\
\hline & & & & & & & & & & & & \\
\hline & & & & & & & & & & & & \\
\hline & & & & & & & & & & & & \\
\hline & & & & & & & & & & & & \\
\hline Avg. & - & $66 \% 463$ & kys & $1 \% 0 \%$ & 124 & $\%$ & 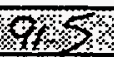 & 96 & 18 & $1 \%$ & $\because$ & . \\
\hline Check'd & & $18 \% 1 \%$ & $\%$ & $18 \%$ & $18 \%$ & $1 \% 1 \%$ & $18 \%$ & $4 \%$ & $1 \% \%$ & $1 \%$ & 1\%. & \\
\hline
\end{tabular}

CONSOLE 161403

FLLTER "

AMBIENT TEMP.

PROBE LENGTH

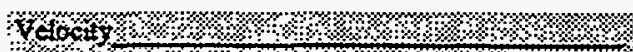

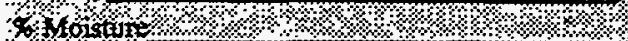

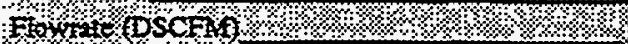

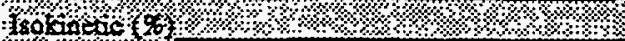

LINER MATERIAL

Remarks Broke Nozzk before run switehto 9.229 
Plant Name .

Sampling Location

Plant Yatés Station Boiler No. 1

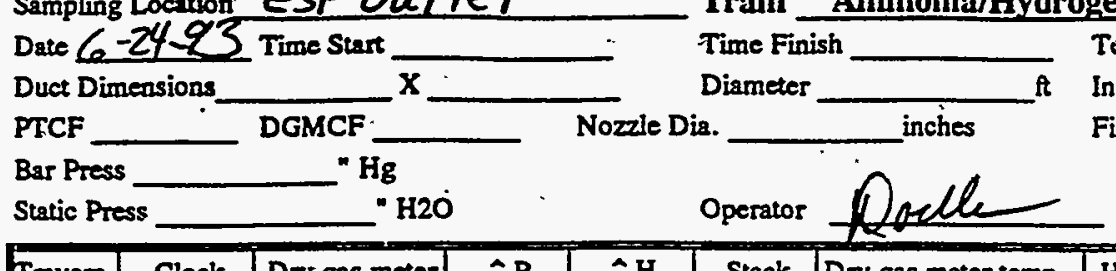

\begin{tabular}{|c|c|c|c|c|c|c|c|c|c|c|c|c|}
\hline \multirow{2}{*}{$\begin{array}{l}\text { Travers } \\
\text { Point }\end{array}$} & \multirow{2}{*}{$\begin{array}{l}\text { Clock } \\
\text { Time }\end{array}$} & \multirow{2}{*}{$\begin{array}{c}\text { Dry gas meter } \\
\text { reading ft } 3\end{array}$} & \multirow{2}{*}{$\begin{array}{c}\wedge \\
\text { in } \mathrm{H} 2 \mathrm{O}\end{array}$} & \multirow{2}{*}{$\begin{array}{c}\wedge \mathrm{H} \\
\text { in } \mathrm{H} 2 \mathrm{O}\end{array}$} & \multirow{2}{*}{$\begin{array}{c}\text { Stack } \\
\text { Temp. F }\end{array}$} & \multicolumn{2}{|c|}{ Dry gas meter temp. } & \multirow{2}{*}{$\begin{array}{c}\text { Hot box } \\
\text { Temp. }\end{array}$} & \multirow{2}{*}{$\begin{array}{l}\text { Probe } \\
\text { Temp }\end{array}$} & \multirow{2}{*}{$\begin{array}{c}\text { Last } \\
\text { Impinger }\end{array}$} & \multirow{2}{*}{$\begin{array}{l}\text { Vacuum } \\
\text { in. } \mathrm{Hg}\end{array}$} & \multirow{2}{*}{ 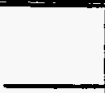 } \\
\hline & & & & & & Inlet & Outlet & & & & & \\
\hline & 1325 & 90183 & & & & & & & & & & \\
\hline & & 90.350 & & & & & & & & & & \\
\hline & & & & & & & & & & & & $\cdot$ \\
\hline & & & & & & & & & & & & \\
\hline & & & & & & & & & & & & \\
\hline & & & & & & & & & & & & \\
\hline & & & & & & & & & & & & \\
\hline & & & & & & & & & & & & \\
\hline & & & & & & & & & & & & \\
\hline & & & & & & & & & & & & \\
\hline & & & & & - & & & & & & & \\
\hline & & & & & & & & & & & & \\
\hline & & & & & & & & & & & - & \\
\hline & & & & & & & & & & & & \\
\hline & & & & & & & & & & & & \\
\hline & & & & & & & & & & & & \\
\hline & & & & & & & & & & - & & \\
\hline & & & & & & & & & & & & \\
\hline & & & & & & & & & & & & \\
\hline & & & & - & & & & & & & & \\
\hline & & & & & & & & & & & & \\
\hline & & & & & & & & & & & & \\
\hline & & & & & & & & & & & & \\
\hline & & & & & & & & & & & & \\
\hline & & & & & & & & & & & & \\
\hline & & & & . & & & & & & & & \\
\hline & & & & & & & & & & & & \\
\hline & - & te & & & & & & & & & & \\
\hline Avg. & $=$ & $\% \%, \%$ & \% $\$ \%$ & \%\%/ & 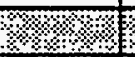 & $8 \%$ & $\% \%$ & \%ै/\% & \%\%\% & $\%$ & 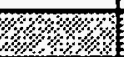 & \\
\hline Check'd & & $\%$ & 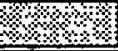 & ঔ \% & $8 \%$ \% & $1 \%$ & $\%$ & $\%$ & & & & \\
\hline
\end{tabular}

CONSOLE \# $\frac{A 161364}{654}$

AMBIENT TEMP.

PROBE LENGTH

LINER MATERIAL
Train Ammonia/fydrogen Cyanide Run No. $B_{\text {. }}$

Test Duration

Initial Leak Rate

Final Leak Rate min.

cfm

cfm 
Plant Name Plant Yates Station Boiler No. 1 Page 1 of 2

Sampling Location QUTLET

Date $6 / 24 / 93$ Time Start 1040

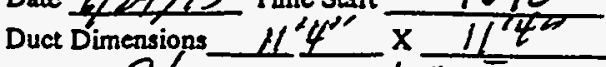

Run No. $i$

PTCF , 8 DGMCF $1 . \overline{005}$ Time Finish noteo Bar Press 29, 5 ? $\mathrm{Hg}$

Static Press $-1 / \quad$ H2O

Diameter

Nozzle Dia. $.19 \overline{7}$

97
Run No. Test Duration $1198 *$ min. At Initial Leak Rate $\angle .00$ cfm Final Leak Rate $0.00 \mathcal{T}^{\mathrm{cfm}}$

\begin{tabular}{|c|c|c|c|c|c|c|c|c|c|c|c|c|}
\hline \multirow{2}{*}{$\begin{array}{c}\text { Travers } \\
\text { Point }\end{array}$} & \multirow{2}{*}{$\begin{array}{l}\text { Clock } \\
\text { Timg } \\
\text { (inf }\end{array}$} & \multirow{2}{*}{$\begin{array}{l}\text { Dry gas meter } \\
\text { reading ft } 3\end{array}$} & \multirow{2}{*}{$\begin{array}{c}\wedge \\
\text { in } \mathrm{P} \\
\text { in }\end{array}$} & \multirow{2}{*}{$\begin{array}{c}-\mathrm{H} \\
\text { in } \mathrm{H} 2 \mathrm{O}\end{array}$} & \multirow{2}{*}{\begin{tabular}{c|} 
Stack \\
Temp. F
\end{tabular}} & \multicolumn{2}{|c|}{ Dry gas meter temp. } & \multirow{2}{*}{$\begin{array}{c}\text { Hot box } \\
\text { Temp. }\end{array}$} & \multirow{2}{*}{$\begin{array}{l}\text { Probe } \\
\text { Temp }\end{array}$} & \multirow{2}{*}{\begin{tabular}{|c|} 
Last \\
Impinger
\end{tabular}} & \multirow{2}{*}{\begin{tabular}{|l|} 
Vacuum \\
in. $\mathrm{Hg}$
\end{tabular}} & \\
\hline & & & & & & Inlet & Outlet & & & & & \\
\hline & 72 & 504.48 & 1.20 & $1-26$ & 283 & 92 & 89 & 257 & 277 & 9 & 5.75 & \\
\hline & 22.6 & 517.92 & 2.20 & $\angle 20$ & 284 & bz & 78 & 259 & 275 & 82 & 5.5 & \\
\hline & 46.8 & 532.23 & 110 & 1.15 & 286 & 107 & 99 & 255 & 281 & 72 & $5-25$ & \\
\hline & 53.0 & 541.725 & 7.20 & 1.25 & 285 & 108 & 101 & 256 & 278 & & 5.25 & \\
\hline & 88.9 & $557 \cdot 19$ & 725 & 1.30 & 288 & 113 & 106 & 258 & 277 & & $5-5$ & \\
\hline & 48.5 & 575.03 & .20 & 1.32 & 284 & 106 & 102 & 27 & $2 \widehat{33}$ & 70 & 5.5 & \\
\hline & 202 & 625.40 & 1.2 & 1.3 & 287 & 112 & 104 & 252 & 260 & 62 & 6 & \\
\hline & 264 & 662.61 & 1.2 & 1.3 & 288 & 115 & 109 & 253 & 281 & 67 & 6 & \\
\hline & 306.4 & 688.225 & 1.20 & $\angle 23$ & 289 & 108 & 03 & 253 & 266 & 63 & 5.5 & \\
\hline * & 329.0 & 702.5 & & & & & & & & & & \\
\hline$*$ & 329.0 & 702.5 & 1.2 & 1.23 & & & & & & & & \\
\hline sho & $40 \% .0$ & & & & & & & & & & & \\
\hline stert & 409.3 & 45 & 1.2 & $7-2$ & 282 & .88 & 80 & 257 & 254 & get & 2.5 & \\
\hline & 40.4 & & & & & & & & & & & \\
\hline & +12.4 & 765.80 & 25 & 1.35 & 223 & 90 & 82 & 255 & $27 \%$ & 69 & & \\
\hline 7 & $46 / 10$ & 795.07 & 1.25 & 1.35 & 277 & 91 & 86 & 25 & 271 & 64 & 125 & \\
\hline & 522.0 & 831.80 & 125 & 635 & $2 \times 4$ & 85 & 83 & 23 & 266 & 62 & 2,5 & \\
\hline & 592,4 & 873.94 & 1,25 & 1,35 & 283 & 52 & 85 & 253 & 270 & 66 & 2.5 & \\
\hline & $604 \mathrm{ce}$ & $906 \times 46$ & 1.25 & 4.35 & 283 & 93 & 86 & 252 & 271 & 68 & $2 \cdot 5$ & \\
\hline & 729.5 & 955.17 & 1.25 & 4.35 & 282 & 91 & 84 & 254 & 272 & 66 & 2,5 & \\
\hline & $78 x, 3$ & 917.07 & 1,25 & 435 & 279 & 94 & 87 & 251 & 282 & 66 & 2.5 & \\
\hline & 814214 & $1024 \cdot 10$ & 1125 & 63 & 279 & $\{3$ & 86 & 251 & 272 & 58 & 2.5 & \\
\hline & 913.5 & $67 \cdot 13$ & 1.25 & 1.35 & 280 & 94 & 56 & 252 & 272 & 58 & 2,5 & \\
\hline & 9719 & 103,91 & 1,25 & \&35 & 279 & 94 & 87 & 252 & 271 & 5 & 2.5 & \\
\hline & 1027.9 & 138.97 & 1.25 & $1: 35$ & 281 & 56 & 58 & 253 & 271 & 62 & $2 \cdot 5$ & \\
\hline & 1077.2 & 169.17 & 1.25 & $1: 35$ & 279 & $\$ 4$ & 87 & 252 & 274 & 58 & 2.5 & \\
\hline $19.4 \mathrm{hr}$ & 1137.1 & 206.40 & 1.20 & 1.25 & 279 & 93 & 86 & 252 & 276 & 45 & 2.5 & \\
\hline & 4667 & 22354 & & & & & & & & & & \\
\hline Avg. & 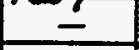 & $\%$ & $1 \%$ & (1) & $\% \%$ & ০॥। & 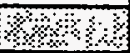 & (6×\%: & $4 \% \%$ & ২:\% ২ & (1) & \\
\hline Check'd & & 70 & $18 \%$ & 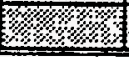 & $\% 8 \%$ & $00 \%$ & $4 \%$ & $2 \%$ & $18 \%$ & 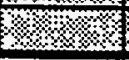 & 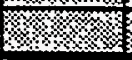 & 1 \\
\hline
\end{tabular}

CONSOLE " A/6/400

FILTER " 909

AMBIENT TEMP. $\frac{\text { SO }}{8}$

LINER MATERIAL

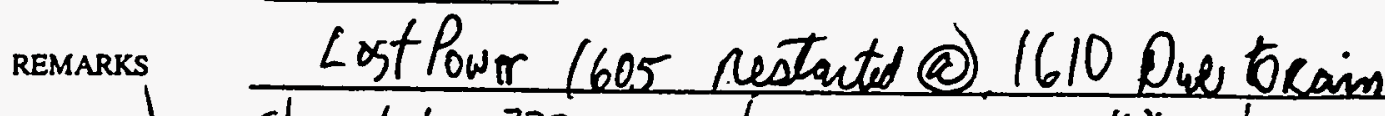
stop-strppelat 1730 trechaze impingers * timer wa 21 ...in ...LY. Tf...en.
Helocify 2 -

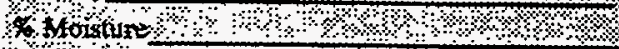

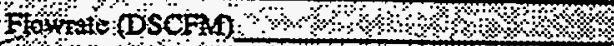
Iokinetio (\%) 
Plant Name

Plant Yates Station Boiler No. 1

Sampling Location ESP OUETCET

Date 6 lak 193 Time Start 1050

Duct Dimensions $\|^{\prime} y^{\prime \prime} \times \frac{1 \|^{\prime} y^{a}}{x}$

Train Bulk Particulate-Radionuclides

Run No. 2

Diameter PTCF 84 DGMCF 1005 Nozzle Dia. 197 inches

Bar Press 25.55 .

Static Press -11 - $\mathrm{H} 2 \mathrm{O}$

Operator AsDeTED MISF/TS

Initial Leak Rate 0.005 TII $^{\prime \prime}$

Final Leak Rate 0.00305 cfm

\begin{tabular}{|c|c|c|c|c|c|c|c|c|c|c|c|c|}
\hline \multicolumn{5}{|c|}{ Static Press -1$)$} & \multicolumn{4}{|c|}{ Operator LEDRTED MISFTS } & \multicolumn{3}{|c|}{$K=1.06$} & \\
\hline \multirow{2}{*}{$\begin{array}{c}\text { Travers } \\
\text { Point }\end{array}$} & \multirow{2}{*}{$\begin{array}{l}\text { Clock } \\
\text { Time }\end{array}$} & \multirow{2}{*}{$\begin{array}{c}\text { Dry gas meter } \\
\text { resding ft3 }\end{array}$} & \multirow{2}{*}{$\begin{array}{c}\mathrm{P} \\
\text { in } \mathrm{H} 2 \mathrm{O}\end{array}$} & \multirow{2}{*}{$\begin{array}{c}\mathrm{H} \\
\text { in } \mathrm{H} ? \mathrm{O}\end{array}$} & \multirow{2}{*}{$\begin{array}{c}\text { Stack } \\
\text { Temp. F }\end{array}$} & \multicolumn{2}{|c|}{ Dry gas meter temp. } & \multirow{2}{*}{$\begin{array}{l}\text { Hot box } \\
\text { Temp. }\end{array}$} & \multirow{2}{*}{$\begin{array}{l}\text { Probe } \\
\text { Temp }\end{array}$} & \multirow{2}{*}{\begin{tabular}{c|} 
Last \\
Impinger
\end{tabular}} & \multirow{2}{*}{$\begin{array}{l}\text { Vacuum } \\
\text { in. } \mathrm{Hg}\end{array}$} & \\
\hline & & & & & & Inlet & Outlet & & & & & \\
\hline 1050 & 10,50 & 243.171 & 1.0 & 1.1 & 283 & 83 & 84 & 258 & 280 & 70 & 5 & \\
\hline- & $15^{\prime \prime}$ & 252.04 & 1.0 & 1,1 & 283 & 87 & $P 4$ & 245 & 270 & 72 & 5 & \\
\hline & $5 q^{\prime \prime}$ & 225,96 & 1.0 & 1.1 & 284 & 96 & 89 & 254 & 282 & 70 & 5 & \\
\hline & 104 & 300.44 & 1.er & 1.2 & 284 & 97 & 92 & 254 & 275 & 68 & 5 & \\
\hline & 124,4 & 312.23 & 1,1 & 8.35 & 285 & 100 & .74 & 254 & 284 & $\mathbb{Z}$ & 41 & \\
\hline 1 & 150 & 322.64 & 1.0 & 1.1 & 285 & 102 & 96 & 251 & 270 & 25 & 5 & \\
\hline$=$ & 211 & 362.32 & 1.0 & 1,1 & 786 & 102 & 98 & 252 & 276 & 69 & 4 & \\
\hline & 265.1 & 392.19 & 1.05 & 1,1 & 286 & 105 & 100 & 253 & 253 & $\frac{w 1}{71}$ & $\frac{1}{4}$ & \\
\hline 4 & 312 & 417.51 & & & & & & & & & & \\
\hline 7 & 3120 & 40.6 & 1.0 & 1.1 & 287 & 103 & 100 & 253 & 261 & 68 & 2.0 & \\
\hline 1720 & 390. & 458.20 & 1.0 & 1.1 & 288 & 112 & 105 & 252 & 249 & 69 & 4.0 & \\
\hline 7 & 474,5 & $508: 98$ & 1.0 & L.1 & 284 & 107 & 101 & 253 & 255 & 68 & 4,0 & \\
\hline & 536.5 & 544.95 & 10 & I.1 & 285 & 101 & 96 & 253 & 260 & 65 & 4.0 & \\
\hline & 6066,0 & 584.01 & 1,0 & 1,1 & 280 & 99 & 93 & 252 & 253 & 61 & 4.0 & \\
\hline & 6515 & 60560 & 10 & 1.1 & 280 & $S 9$ & 93 & 253 & 25 & 63 & 4.0 & \\
\hline & $6\{3,6$ & 632,72 & 10 & 1.4 & 284 & 47 & 92 & 252 & 260 & 58 & 4.0 & \\
\hline & 7452 & 661.67 & 1,0 & 1.1 & 282 & 43 & SE & $3 \sqrt{2}$ & 255 & $\sqrt{5}$ & 4,0 & \\
\hline & 739.0 & 691.64 & 1.0 & 1.1 & 282 & 9 & 86 & 252 & 258 & 57 & 4.0 & \\
\hline & 8873 & 759.44 & 1,0 & LI & 280 & 94 & 88 & 253 & 264 & 61 & 4.0 & \\
\hline & 940.50 & 768.28 & 1.0 & Ler & 279 & 92 & 87 & 252 & 259 & 55 & 4.0 & \\
\hline & 1051.9 & 813.06 & 100 & 101 & 279 & 89 & 84 & 253 & 250 & 63 & 4.0 & \\
\hline & 1074,2 & 841.93 & Lia & 1.1 & 279 & 88 & 83 & 253 & 259 & 56 & 4.5 & \\
\hline & $1121 \cdot 3$ & 866.48 & 10 & L.t & 279 & 91 & 85 & 253 & 252 & 55 & 4.5 & \\
\hline & 1170 & 894.38 & .1 .0 & 1.1 & 280 & 90 & 85 & 252 & 261 & 55 & 5 & \\
\hline & 1182.4 & $90 / .34$ & & & & & & & & & & \\
\hline & & & & & & & & & & & & \\
\hline & & & & & & & & & & & & \\
\hline & & & & & & & & & & & & \\
\hline Avg. & - & 158,019 & $80 \%$ & $9.6 / \%$ & $28 \times 3$ & & 93.9 & & $8 \%$ & ४\% \% & 898 & 21 \\
\hline Check'd & & $18 \%$ & \% & $14 \%$ & $1 \%$ & \% & 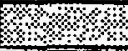 & $6 \%$ & $\%$ & 8 & $18 \%$ & \\
\hline
\end{tabular}

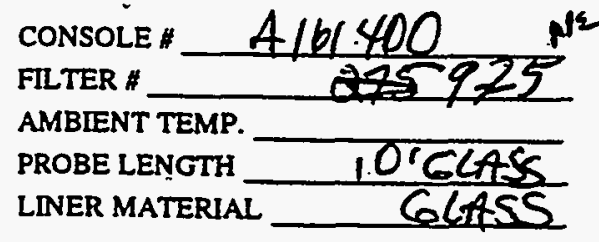

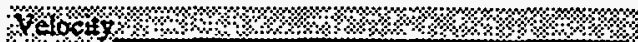

STEMARKS to Enpty water. From Imp si gell oK

C-78 Nole: soue ash seen downstrean of filter in hotbor / First halp of test 1050 to 1726 
$\wedge$

Plant Name Plant Yates Station Boiler No. 1
ESP OUTLET

Page _ of

Sampling Location ESP QUT Train Bulk Particulate-Radionuclides Run No. 3 Date Lefele $193 \overline{\text { Time Start } 1055}$ Time Finish 06/9 Test Duration 1019 min. Dict Dimensions $11.4^{\prime \prime} \times 11.4^{\prime \prime}$ Diameter PTCF, 84 DGMCF L 1.005 Nozzle Dia. .197 inches Final Leak Rate $0052010^{6} \mathrm{cfm}$

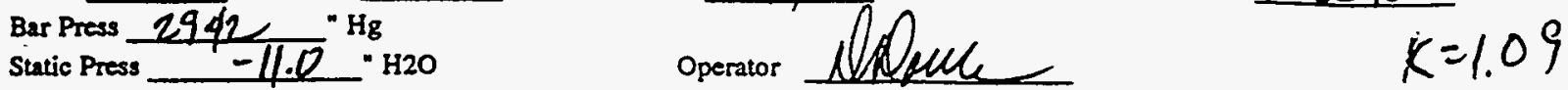

\begin{tabular}{|c|c|c|c|c|c|c|c|c|c|c|c|c|}
\hline \multirow{2}{*}{$\begin{array}{c}\text { Travers } \\
\text { Point }\end{array}$} & \multirow{2}{*}{$\begin{array}{l}\text { Clock } \\
\text { Time }\end{array}$} & \multirow{2}{*}{$\begin{array}{l}\text { Dry gas meter } \\
\text { reading ft3 }\end{array}$} & \multirow{2}{*}{$\begin{array}{c}A P \\
\text { in } \mathrm{H} 2 \mathrm{O}\end{array}$} & \multirow{2}{*}{$\begin{array}{c}\stackrel{A}{H} \\
\text { in } \mathrm{H} 2 \mathrm{O}\end{array}$} & \multirow{2}{*}{$\begin{array}{l}\text { Stack } \\
\text { Temp. F }\end{array}$} & \multicolumn{2}{|c|}{ Dry gas meter temp. } & \multirow{2}{*}{$\begin{array}{c}\text { Hot box } \\
\text { Temp. }\end{array}$} & \multirow{2}{*}{$\begin{array}{l}\text { Probe } \\
\text { Temp }\end{array}$} & \multirow{2}{*}{$\begin{array}{c}\text { Last } \\
\text { Impinger }\end{array}$} & \multirow{2}{*}{$\begin{array}{l}\text { Vacuum } \\
\text { in. Hg }\end{array}$} & \\
\hline & & & & & & Inlet & Outlet & & & & & \\
\hline & 0 & 913.21 & 1.05 & 1.2 & $278^{\circ}$ & 87 & 85 & 260 & 140 & 65 & 1 & \\
\hline & 24 & 927.0 & 1.05 & 1.2 & 280 & 94 & 89 & 249 & 255 & 64 & 1 & \\
\hline & 47 & 939.92 & 1.05 & 1.2 & 282 & 99 & 92 & 250 & 262 & 68 & 1 & \\
\hline & 62 & 948,42 & 1.05 & 1.2 & 284 & 102 & 95 & 254 & 248 & 57 & 1 & \\
\hline & 107 & 974.16 & 1.05 & 1.2 & 284 & 105 & 101 & 254 & 255 & 63 & 1 & \\
\hline & 196 & 996.6 & 1.05 & 1.2 & 282 & 109 & 105 & 255 & 249 & 59 & $T$ & \\
\hline & 189 & 1001.45 & 1.05 & 12 & 286 & 104 & 103 & $2 \sqrt{2}$ & 246 & 53 & 1 & \\
\hline & 245 & 1054.43 & 1.05 & 1,2 & 286 & 104 & 101 & 252 & 251 & 63 & f & \\
\hline 367 & 262 & $10 \% 2$ & 1.05 & 1.2 & 286 & 104 & 101 & 252 & 252 & 62 & 1 & \\
\hline & 432 & 164.5 & 1.05 & 1.2 & 286 & 106 & 102 & 352 & 252 & 58 & 1 & \\
\hline $\operatorname{Ims}$ & 479.9 & 191.89 & 1.05 & 1.2 & 284 & 104 & 99 & 253 & 257 & 60 & 1 & \\
\hline & 543.3 & $225 \cdot 75$ & 105 & 1.2 & 254 & 998 & 94 & 256 & $25 z$ & 56 & 1 & \\
\hline & 624.5 & 275.50 & 1.05 & 1.2 & 241 & S8 & 93 & 253 & 261 & 58 & 1 & \\
\hline & $6665 \cdot 7$ & 299.15 & 1.05 & 1.2 & 283 & 97 & 12 & 253 & 256 & 57 & $L$ & \\
\hline & 720.5 & 330.40 & 605 & 12 & 281 & 94 & 50 & 253 & 262 & 53 & 1 & \\
\hline & 775.8 & $36 / .70$ & 605 & 1.2 & 283 & 34 & ES & 25 & 262 & 54 & $t$ & \\
\hline & 837.2 & $396 \cdot 50$ & 1.05 & 1.2 & 280 & Si & 87 & 25 & 262 & 54 & 1 & \\
\hline & 89115 & $4+7.20$ & 1.05 & 1.2 & 280 & 52 & 87 & 252 & 253 & 53 & $L$ & \\
\hline & 9621 & 466.97 & 1.05 & 1.2 & 280 & 33 & 87 & 251 & 249 & 55 & $\perp$ & \\
\hline & 102602 & 503.00 & 1.05 & 1.2 & 278 & 54 & 88 & 253 & $25 x$ & 55 & $\angle$ & \\
\hline & 1081.4 & 533.52 & 1.05 & 1.2 & 279 & 91 & 86 & 252 & 255 & 51 & 1 & \\
\hline & 1133,7 & 565.77 & L.05 & 1.2 & 278 & 89 & 84 & 252 & 250 & 51 & 1 & \\
\hline C.21 & 0619 & 580.3 & & & & & & & & & & \\
\hline & & & & & & & & & & & & \\
\hline & & & & & & & & & & & & \\
\hline & & & & & & & & & & & & \\
\hline & & & & & & & & & & & & \\
\hline & & & & & & & & & & & & \\
\hline Avg. & - & 667098 & 6064 & 106 & 2620 & $0 \%$ & 669 & $8 \%$ & 88.8 & 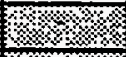 & & \\
\hline Check'd & & \% & 1.8 & 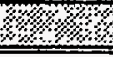 & 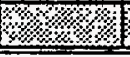 & 28 & 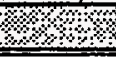 & $18 \times$ & 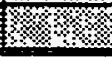 & $\ldots$ & 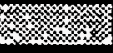 & \\
\hline
\end{tabular}

CONSOLE " $\$ 16 / 400$

FLTER \# 928

AMBIENT TEMP. 80

PROBE LENGTH $10^{\prime}$

LINER MATERIAL GLASS

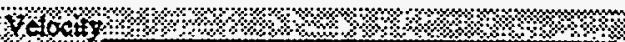
\% Thowate foschn

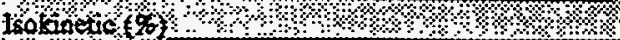

REMARKS 
Plart Name Plant Yates Station Boiler No. 1

Sampling Iozation

Date $6 / 24 / 93$ Time Star

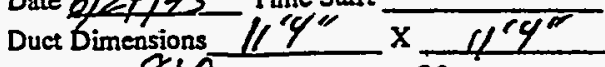
PTCF, $8 y$ DGMCF .998 Nozzle Dia Bar Press 29,53 " $\mathrm{Hg}$ Static Press $-/ /$ H2O

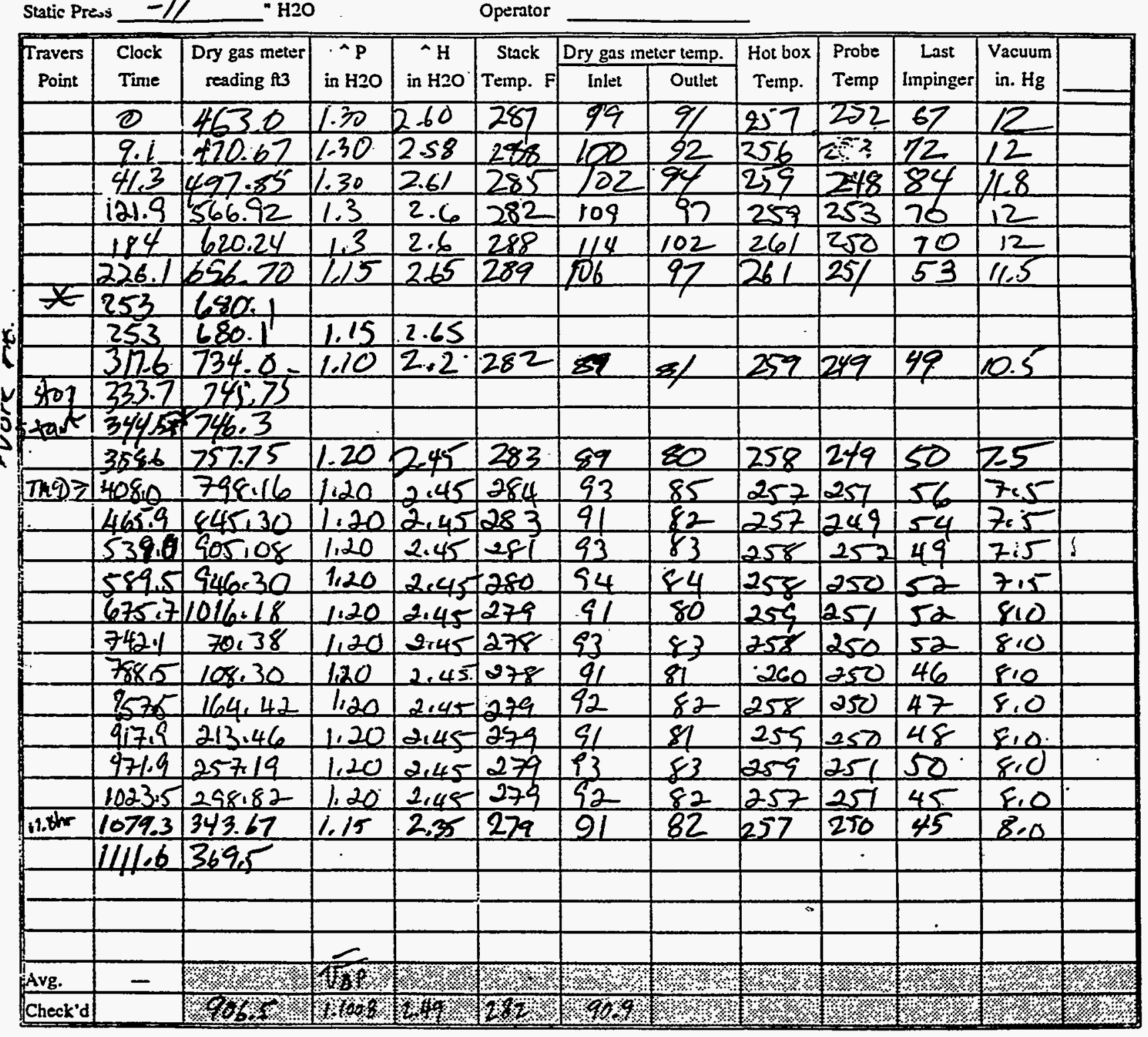

Train Bulk Particulate-Ex. Metals Run No. L

Time Finish COZOO \&625 Test Duration $110 /$ \& min. Diameter Initial Leak Rate $\frac{0.0 / 5}{0.014}$ Final Leak Rate $0-0 / 4$ cim $2 \longdiv { 2 3 }$ inches .230
CONSOLE \# A/61395

FILTER \# 9X5 929

AMBIENT TEMP. 90

PROBE LENGTH $10^{\prime}$

LINER MATERIAL

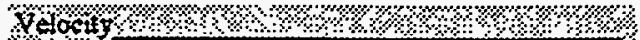

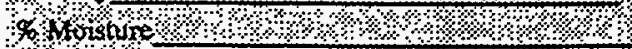

Howne (DSOFN) ২

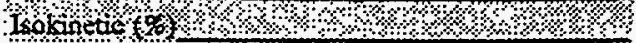

REMAPKS NOZ2LIETO09 $\quad 230 \quad .230 \quad .230$

C-80 Lost Pevev@1610 Duetonam restant es 1620

stop pillector treen to ctureimpriens * subtract 10-8min as flingros was 
Plant Name

Plant Yates Station Boiler No. 1

Sampling Location Ssp QUA

Date 6 2 6 6 33 Time Start 1040

Duct Dimensions $11.4 \times \frac{11.4}{4}$

PTCF 84 DGMCF 0.958 Nozzle Dia. 229 inches

Bar Press $\$ .555^{\circ} \mathrm{Hg}$

Static Press

" 120

Train Bulk Particulate-Ex. Metals

Time Finish 0636 6/27 Test Duration

Run No. 2

Initial Leak Rote $0.0090^{\mathrm{min}}$

Final Leak Rate $0.00697 \mathrm{cfm}$

operator Assonted Mestits

$K=1.9$

\begin{tabular}{|c|c|c|c|c|c|c|c|c|c|c|c|c|}
\hline \multirow{2}{*}{$\begin{array}{c}\text { Travers } \\
\text { Point }\end{array}$} & \multirow{2}{*}{$\begin{array}{l}\text { Clock } \\
\text { Time }\end{array}$} & \multirow{2}{*}{$\begin{array}{c}\text { Dry gas meter } \\
\text { reading fl }\end{array}$} & \multirow{2}{*}{$\begin{array}{c}\wedge \mathrm{P} \\
\text { in } \mathrm{H} 2 \mathrm{O}\end{array}$} & \multirow{2}{*}{$\begin{array}{c}-\mathrm{H} \\
\text { in } \mathrm{H} 2 \mathrm{O}\end{array}$} & \multirow{2}{*}{\begin{tabular}{c|} 
Stack \\
Temp. F
\end{tabular}} & \multicolumn{2}{|c|}{ Dry gas melur temp. } & \multirow{2}{*}{$\begin{array}{l}\text { Hot box } \\
\text { Temp. }\end{array}$} & \multirow{2}{*}{$\begin{array}{l}\text { Probe } \\
\text { Temp }\end{array}$} & \multirow{2}{*}{\begin{tabular}{c|} 
Last \\
Impinger
\end{tabular}} & \multirow{2}{*}{$\begin{array}{l}\text { Vacuum } \\
\text { in. } \mathrm{Hg}\end{array}$} & \\
\hline & & & & & & Inlet & Outlet & & & & & \\
\hline & 1040 & 390.40 & 1.2 & 2.3 & 282 & 79 & 77 & 278 & 254 & 63 & 8 & \\
\hline & $22^{4}$ & 50791 & 1.2 & 2.3 & 283 & 92 & 81 & 268 & 253 & 62 & 8 & \\
\hline & $70^{\prime \prime}$ & 446.06 & 1.2 & 2.3 & 284 & 100 & 88 & 257 & 254 & 64 & 8 & \\
\hline & $116^{2}$ & 483.1 & 1.2 & 2.3 & 284 & 101 & 9 & 260 & 252 & 53 & 8 & \\
\hline & 132,5 & 496,2 & 2 & $2-3$ & 285 & 183 & 92 & 259 & 250 & 34 & 8 & \\
\hline & 162 & 520.08 & 1.2 & 23 & 286 & 104 & 94 & 262 & 253 & 56 & 8 & \\
\hline & 222 & 569.59 & 1.2 & 2.3 & 286 & 105 & 95 & 259 & 253 & 50 & 8 & \\
\hline & 276.6 & 612.07 & 1.25 & 2,35 & 286 & 108 & 97 & 259 & 250 & 53 & 8 & \\
\hline STOP & 3160 & 644.78 & & & & & & & & & & \\
\hline stant & 00.00 & 644.92 & 1.2 & 2.3 & 286 & 104 & 97 & 261 & 253 & 54 & 5 & \\
\hline 1725 & 00.00 & 116.50 & & & & & & & & & & \\
\hline & .82 .9 & 783.04 & 1.2 & 2,3 & 286 & 106 & 47 & 261 & $2 \Omega$ & 57 & 5 & \\
\hline & 143.0 & 530.90 & 112 & 2,3 & 284 & 101 & $\$ 4$ & 255 & $2 \sqrt{2}$ & 52 & 5 & \\
\hline & 212,5 & 585,76 & 1,2 & 2.3 & 281 & 99 & 51 & 260 & 250 & 49 & 5 & \\
\hline & 258.0 & 921.91 & 1,2 & 2.3 & 281 & 98 & So & 260 & 251 & 5 & 5 & \\
\hline & 300.0 & 355.15 & 1.2 & 2.3 & 284 & 98 & 85 & 0 & 245 & 47 & 5 & \\
\hline & 357.8 & 996.15 & 1.2 & 2.3 & 281 & 95 & 86 & 259 & 251 & 48 & 5 & \\
\hline & 40515 & 1038,30 & 1,2 & 2.3 & 280 & 52 & 83 & 259 & 250 & 48 & 6 & \\
\hline & 493.7 & $1108 \cdot 51$ & 1.2 & 2,3 & 279 & 55 & 85 & 258 & 257 & 50 & 6 & \\
\hline & 546,9 & 1150,79 & 1,2 & 2.3 & 278 & 93 & 84 & 257 & 250 & 47 & 6 & \\
\hline & 628,5 & 1214.88 & 1.2 & $2 \cdot 3$ & 279 & 50 & 82 & 257 & 250 & 50 & 6 & \\
\hline & 680.4 & 1255,44 & 1.2 & 2.3 & 279 & 89 & 80 & $25 z$ & 250 & 50 & 6 & \\
\hline & 727.6 & 1291.96 & 1.2 & 23 & 280 & 92 & 82 & 259 & 289 & 44 & 6 & \\
\hline & 778 & 1232.13 & 1.2 & 23 & 280 & 32 & 83 & 258 & 255 & 40 & & \\
\hline & 787.1 & 1339.29 & & & & & & & & & & \\
\hline & & & & & & & & & & & & \\
\hline & & & & & & & & & & & & \\
\hline & & & & & & & & & & & & \\
\hline Avg. & - & $94 \times 180$ & $40: 35$ & 2,300 & 2825 & 92.6 & ॥ & $\%$ & $4 \%$ & $1 \%$ & «. & \\
\hline Check'd & & $18 \%$ & 48 & $4 \%$ & $1 \%$ & 18 & ॥४ & $4 \%$ & & $1 \times$ & 18 & \\
\hline
\end{tabular}

CONSOLE "- $\frac{A 16 / 335}{904}$

AMBIENT TEMP.

PROBE LENGTH

LINER MATERIAL

REMARKs Stopped 1600 removed spent Si.Gell

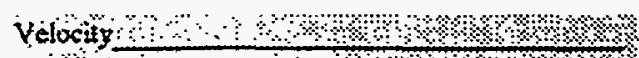

Fo Misture

Fowite DSCFAS

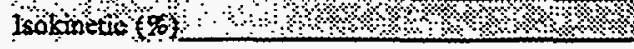


Plant Name

Sampling Location Esp Outlef

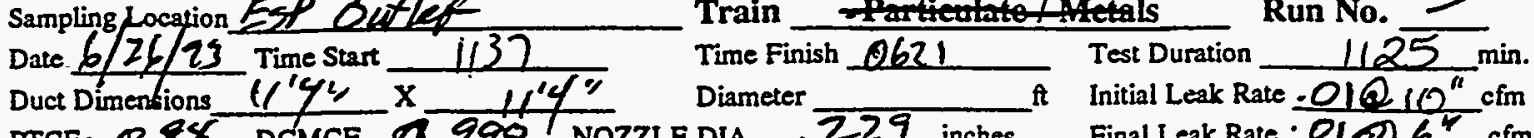

Run No. 3

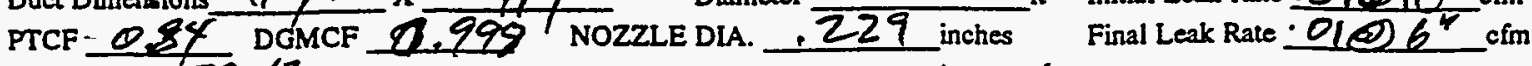

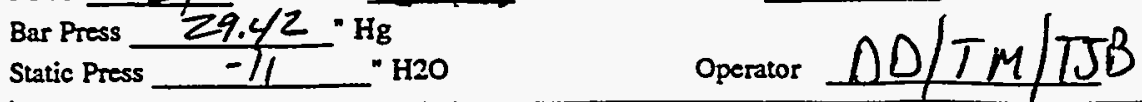

\begin{tabular}{|c|c|c|c|c|c|c|c|c|c|c|c|c|}
\hline \multirow{2}{*}{$\begin{array}{c}\text { Travers } \\
\text { Point }\end{array}$} & \multirow{2}{*}{$\begin{array}{l}\text { Clock } \\
\text { Time }\end{array}$} & \multirow{2}{*}{$\begin{array}{c}\text { Dry gas meter } \\
\text { reading ft3 }\end{array}$} & \multirow{2}{*}{$\begin{array}{c}\text { A } \\
\text { in } \mathrm{H} 2 \mathrm{O}\end{array}$} & \multirow{2}{*}{$\begin{array}{c}{ }^{\wedge} \mathrm{H} \\
\text { in } \mathrm{H} 2 \mathrm{O}\end{array}$} & \multirow{2}{*}{\begin{tabular}{|c|} 
Stack \\
Temp. F
\end{tabular}} & \multicolumn{2}{|c|}{ Dry gas meter temp. } & \multirow{2}{*}{$\begin{array}{l}\text { Hot box } \\
\text { Temp. }\end{array}$} & \multirow{2}{*}{$\begin{array}{l}\text { Probe } \\
\text { Temp }\end{array}$} & \multirow{2}{*}{$\begin{array}{c}\text { Last } \\
\text { Impinger }\end{array}$} & \multirow{2}{*}{$\begin{array}{l}\text { Vacuum } \\
\text { in. } \mathrm{Hg}\end{array}$} & \\
\hline & & & & & & Inlet & Outlet & & & & & \\
\hline & 0 & 342.80 & 97 & 19 & 282 & 87 & 82 & 224 & 253 & 62 & 4 & \\
\hline & 20 & 361.15 & 97 & 1.9 & 283 & 94 & 85 & 265 & 253 & 47 & 4 & \\
\hline & 66 & 394.7 & 97 & 1.9 & 286 & 104 & 96 & 250 & $2 \Omega$ & $\sqrt{3}$ & 4 & \\
\hline & 106 & 424.01 & .97 & 1.9 & 286 & 109 & 102 & 255 & 253 & 49 & 4 & \\
\hline & 107 & 454,32 & 97 & 19 & 286 & 106 & 101 & 259 & 249 & 54 & 4 & \\
\hline & 203 & 495.51 & 95 & 19 & 288 & 106 & 99 & 259 & 249 & $\sqrt{3}$ & 5 & \\
\hline & 268 & 543.4 & .97 & 1.9 & 290 & 103 & 96 & 254 & 254 & 48 & 5 & \\
\hline & 394 & 635.3 & 97 & 1.9 & 292 & 164 & 98 & 259 & 250 & 50 & 5 & \\
\hline $\operatorname{Tin} 9$ & 1441.7 & 66988 & 097 & 19 & 189 & 102 & 95 & 260 & 249 & 50 & 5 & \\
\hline & 502.6 & 713.70 & 0.97 & $1-9$ & 285 & 56 & 89 & 255 & 249 & 57 & 5 & \\
\hline & 583.2 & 772.25 & 0.97 & 1.9 & 284 & 97 & Fs & 257 & 249 & 45 & 5 & \\
\hline & 624.6 & 801.86 & 8.97 & 1.5 & 284 & 67 & 89 & 255 & 250 & 47 & 5 & \\
\hline & 6.796 & 840290 & 0.67 & 19 & 984 & 94 & 87 & 258 & 249 & 44 & 5 & \\
\hline & 735.0 & 880.77 & 0.97 & 1.9 & 284 & 94 & 87 & 255 & 249 & 44 & 5 & \\
\hline & 7564 & 924.70 & 0.97 & 1.9 & 282 & 92 & 85 & 254 & 249 & 46 & 5 & \\
\hline & 850.4 & 963.90 & 0.97 & 1.9 & 280 & 92 & 84 & 259 & 249 & 45 & 5 & \\
\hline & $\{21.4$ & $1014<22$ & 0.97 & $1-9$ & 250 & 92 & 85 & 260 & 249 & 46 & 5 & \\
\hline & 985.5 & 59.70 & 0.97 & 1.9 & 278 & 52 & 85 & 257 & 250 & 45 & 5 & \\
\hline & 1046.7 & 94.50 & 047 & 1.9 & 278 & $\xi$ & 84 & 257 & 249 & 42 & 5 & \\
\hline & 1097.0 & 135.63 & 0.57 & 1.9 & 278 & 54 & 82 & 258 & 247 & 42 & 5 & \\
\hline 2621 & 1125 & 159.605 & & & & & & & & & & \\
\hline & & & & & & & & & & & . & \\
\hline & & & & & & & & & & & & \\
\hline & & & & & & & & & & & & \\
\hline & & & & & & & & & & & & \\
\hline & & & & & & & & & & & & \\
\hline & & & & & & & & & & & & \\
\hline & & & & & 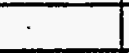 & & & & & & & \\
\hline Avg. & $=$ & $8 / 2,0, \delta$ & 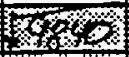 & 9800 & 385 & ४४४ & 9645 & $18 \%$ & & 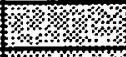 & $8 \% \%$ & \\
\hline Check'd & & -1 & 7.1 & & $1 \% \%$ & $1 \%$ & $\%$ & $8 \%$ & 6 & 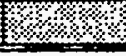 & $\infty$ & \\
\hline
\end{tabular}

CONSOLE \#-A161395

FILTER \# 925 QLARAZ

AMBIENT TEMP.

PROBE LENGTH

LINER MATERIAL

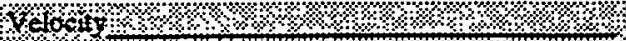

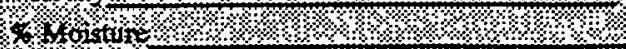

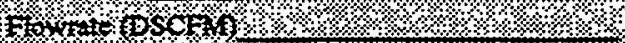

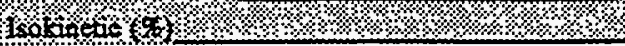

REMARKS 
ESP OUTLET

Page $\mathcal{L}$ of

Plant Name

Plant Yates Station Boiler No. 1

Sampling Location ESP OeaLEd Train Size Fract. Particulate Run No. 82

Date 2126193 Time Start 1130 Time Finish 06362/27 Test Duration 1109 min.

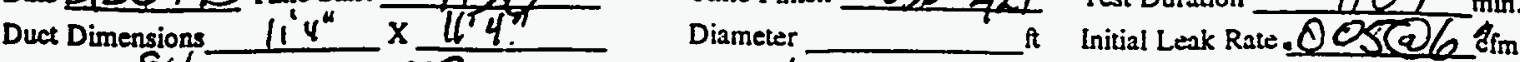

PTCF . .84 DGMCF 1.007 Nozzle Dia. .2/l_ inches Final Leak Rate cim

Bar Press $29.55^{\circ} \mathrm{Hg}$

Static Press $-11 \quad$ "H2O

operator 16 recle

TB

\begin{tabular}{|c|c|c|c|c|c|c|c|c|c|c|c|c|}
\hline \multirow{2}{*}{$\begin{array}{c}\text { Travers } \\
\text { Point }\end{array}$} & \multirow{2}{*}{$\begin{array}{l}\text { Clock } \\
\text { Time }\end{array}$} & \multirow{2}{*}{$\begin{array}{c}\text { Dry gas meter } \\
\text { reading ft3 }\end{array}$} & \multirow{2}{*}{$\begin{array}{c}\text { A } \\
\text { in } \mathrm{H} 2 \mathrm{O}\end{array}$} & \multirow{2}{*}{$\begin{array}{c}{ }^{-H} \\
\text { in } \mathrm{H} 2 \mathrm{O}\end{array}$} & \multirow{2}{*}{$\begin{array}{c}\text { Stack } \\
\text { Temp. F }\end{array}$} & \multicolumn{2}{|c|}{ Dry gas meter temp. } & \multirow{2}{*}{$\begin{array}{c}\text { Hot box } \\
\text { Temp. }\end{array}$} & \multirow{2}{*}{$\begin{array}{l}\text { Probe } \\
\text { Temp }\end{array}$} & \multirow{2}{*}{\begin{tabular}{c|} 
Last \\
Impinger
\end{tabular}} & \multirow{2}{*}{$\begin{array}{l}\text { Vacuum } \\
\text { in. } \mathrm{H}_{\mathrm{g}}\end{array}$} & \multirow{2}{*}{ 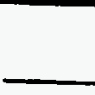 } \\
\hline & & & & & & Inlet & Outlet & & & & & \\
\hline & 0 & 5708.850 & 1.1 & 1.7 & 27 & 80 & 20 & & & 78 & 2 & \\
\hline & 26 & 586.28 & 14 & 17 & 229 & 92 & 81 & & & 10 & 2 & \\
\hline & & & $i, 0$ & 1.6 & 279 & 94 & 84 & & & 68 & 2 & \\
\hline & 64.6 & $6 / 3.32$ & 1.1 & 1.6 & 279 & 97 & 89 & & & 72 & 2 & 7 \\
\hline & 97 & 635.29 & +0 & 1.6 & 280 & 100 & 93 & & & 75 & 2 & \\
\hline 152 & Ltas & 676.05 & 1.0 & 1.6 & 287 & fol & 85 & & & 67 & 2 & \\
\hline & 2105 & 712.9 .5 & 2.96 & 1.6 & 286 & 604 & 97 & & & 10 & 2 & \\
\hline & 235.0 & 729.7 & 1.0 & 1.3 & 280 & 124 & 97 & & & 69 & 2 & \\
\hline & 268 & 749.2 & .98 & 1.3 & 281 & 104 & 99 & & & 20 & 2 & \\
\hline 1715 & 338 & 790.25 & .96 & 1.3 & 285 & 104 & 99 & & & 66 & 2 & \\
\hline$>$ & 426.5 & 839.85 & 0.96 & 1.3 & 258 & 100 & 95 & & & 65 & 2 & \\
\hline & i 88.4 & 878.60 & 0.96 & 1.3 & 281 & 58 & $\$ 3$ & & & 58 & 2 & \\
\hline & 5578 & 921.86 & 0,96 & 1.3 & 276 & $9 z$ & 92 & & & $\sqrt{8}$ & 3 & \\
\hline & 603.4 & 950,60 & 0,96 & 1.3 & 280 & 35 & 90 & & & 5.5 & 2 & \\
\hline & 6455 & 976.35 & 0,96 & 113 & 278 & 95 & 90 & & & 55 & 2 & \\
\hline & 6.97 .3 & 1007.95 & 0.96 & 13 & 275 & 92 & 87 & & & 54 & 2 & \\
\hline & 7514 & 1041.10 & 0.96 & 1.3 & 274 & 89 & 85 & & & 53 & 2 & \\
\hline & 838,7 & 1094.14 & 0.56 & 1.3 & 278 & 91 & 56 & & & 37 & 2 & \\
\hline simplstet & 692,5 & 11260172 & 0.96 & 1.3 & 272 & 91 & 85 & & & $\sqrt{3}$ & 2 & \\
\hline & 951.2 & 1161.42 & 0,96 & 113 & 274 & 86 & 80 & & & 48 & 2 & \\
\hline & 1003.7 & 1193.35 & 0.96 & 1.3 & 273 & 86 & 81 & & & 49 & 2 & \\
\hline & 1050.4 & 1221.52 & 0.96 & 1.3 & 274 & 88 & 82 & & & 45 & 2 & \\
\hline & $10 \% 20$ & 242.55 & 0,94 & 1.3 & 274 & 89 & 84 & & & 49 & 2 & \\
\hline & 1103 & 1253.08 & .94 & 1,3 & 278 & 88 & 83 & & & 46 & 2 & \\
\hline & 1108.7 & 1256.47 & & & & & & & & & & \\
\hline & & & & & & & & & & & & \\
\hline & & & & & & & & & & & & \\
\hline & & & & & & & & & & & & \\
\hline Avg. & - & 687.620 & 534 & 14180 & 287 & & 963 & $4 \quad \therefore$ & 18: & ४४। & \% & 3, \\
\hline Check'd & & $\% \%$ & 3953 & $4 \%$ & $10 \%$ & 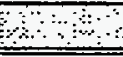 & $8 \mathrm{a}$ & $\%$ & $8 \%$ & 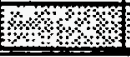 & $8 \%$ & 18 \\
\hline
\end{tabular}

CONSOLE "

FLTER \# 1258 (Th, Mble)

AMBIENT TEMP.

PROBE LENGTH

LINER MATERIAL

REMARKS

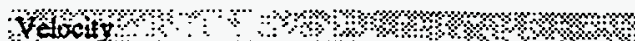

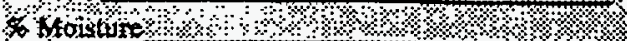

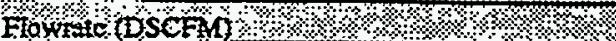

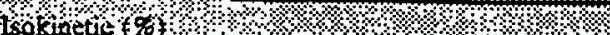


Plant Name Plant Yates Station Boiler No. 1

Sampling Location OLT $T E T$

Date 6 /24193 Time Start 0740

Duet Dimensions $1^{\prime} \psi^{*} \times \frac{11^{\prime} \psi^{\prime \prime}}{\mathrm{x}}$ Diameter PTCF .84 DGMCF 1.007 Nozzle Dia. .211 Bar Press 29,53 Static Press - -11 " H2O Operator Mrale, itial.
Train Size Fract. Particulate Run No. 4

Time Finish 000 \&/25 Test Dưration 1375.8 min.

it Initial Leak Rate $0.012012 \mathrm{~cm}$

Final Leak Rate cim $h \sim 1.30 \frac{95}{275}$

\begin{tabular}{|c|c|c|c|c|c|c|c|c|c|c|c|c|}
\hline \multirow{2}{*}{$\begin{array}{c}\text { Travers } \\
\text { Point }\end{array}$} & \multirow{2}{*}{$\begin{array}{l}\text { Clock } \\
\text { Time }\end{array}$} & \multirow{2}{*}{$\begin{array}{c}\text { Dry gas meter } \\
\text { reading ft3 }\end{array}$} & \multirow{2}{*}{ in $\mathrm{H}$. } & \multirow{2}{*}{$\begin{array}{c}{ }^{\wedge} \mathrm{H} \\
\text { in } \mathrm{H} 2 \mathrm{O}\end{array}$} & \multirow{2}{*}{$\begin{array}{c}\text { Stack } \\
\text { Temp. F }\end{array}$} & \multicolumn{2}{|c|}{ Dry gas meter temp. } & \multirow{2}{*}{$\begin{array}{l}\text { Hot box } \\
\text { Temp. }\end{array}$} & \multirow{2}{*}{$\begin{array}{l}\text { Probe } \\
\text { Temp. }\end{array}$} & \multirow{2}{*}{\begin{tabular}{|c|} 
Last \\
Impinger
\end{tabular}} & \multirow{2}{*}{$\begin{array}{l}\text { Vacuum } \\
\text { in. } \mathrm{Hg}\end{array}$} & \\
\hline & & & & & & Inlet & Outlet & & & & & \\
\hline & 0 & $7,5,378$ & .78 & 1.388 & 278 & 81 & 78 & & & 70 & 2 & \\
\hline & 9 & 720.37 & .95 & 1.463 & 278 & 83 & 78 & & & 66 & 2 & \\
\hline & 10 & 739.96 & 1.0 & 1.84 & 279 & 94 & 85 & & & 68 & 2 & \\
\hline & 6.4 & 754.17 & 1.0 & 1.4 & 281 & 55 & 88 & & & 69 & 2 & \\
\hline & 90 & 770.55 & 1.0 & 13 & 282 & 100 & 92 & & & 65 & 2 & \\
\hline & $13 i$ & 795.60 & 1.0 & 1.3 & 283 & 101 & 35 & & & 64 & 2 & \\
\hline & 163 & 815.04 & 1.0 & 1.3 & 284 & 104 & 97 & & & 67 & 2 & \\
\hline & 188 & 831.18 & 10 & 1.3 & 284 & 102 & 96 & & & 59 & 2 & \\
\hline & 211 & 846.38 & .95 & i. 3 & 285 & 104 & 96 & & & 61 & 2 & \\
\hline & 254 & 872.89 & 94 & 1.2 & 286 & 102 & 96 & & & 62 & 2 & \\
\hline & 290 & 894.6 & 1.0 & 1.4 & 283 & 92 & 93 & & & 57 & 2.0 & \\
\hline & 372 & 948,25 & 1.0 & 1,4 & 287 & 100 & 93 & & & 62 & 2 & \\
\hline & 439 & 989.68 & 1.0 & 1.4 & 290 & 105 & 99 & & & 45 & 2 & \\
\hline Q & 5 & Ste 800 & & & & & & & & & & \\
\hline & 624.8 & 1107.82 & .93 & 1.4 & 28 & 87 & 80 & & & 55 & 2 & \\
\hline & 6740 & 1138.68 & 0,93 & 4.4 & 282 & 89 & 83 & & & 55 & 2 & \\
\hline & 729,4 & 173,00 & 0,93 & 1,4 & 282 & 89 & 82 & & & $\sqrt{6}$ & 2 & \\
\hline & 801.6 & 217.31 & 0.93 & pi4 & 282 & 50 & $8\}$ & & & $5 z$ & 2.5 & \\
\hline & 857.1 & 251.94 & 0.93 & 1.4 & 279 & 89 & 83 & & & 62 & 2,5 & \\
\hline $23: 32$ & 941.6 & 304,910 & & & & & & & & & & \\
\hline $23 ! 26$ & $94 / 16$ & 3054125 & 0.93 & 1.4 & 279 & 84 & 79 & & & 61 & 2.5 & \\
\hline & 1003,0 & 344.17 & 0.93 & 2,4 & 277 & 90 & 82 & & & 64 & 2.5 & \\
\hline & 1049.0 & 372,53 & 0,86 & 1.3 & 279 & 88 & 81 & & & 54 & 2.5 & \\
\hline & III 18.2 & 416,54 & 0.86 & 1.3 & 178 & 89 & 82 & & & 52 & $2 \cdot 5$ & \\
\hline & 1177,5 & 451,70 & 0.86 & 1.3 & 278 & 88 & 81 & & & 51 & 2.5 & \\
\hline & 12326 & 1884110 & 0.86 & 1.3 & 278 & 90 & 83 & & & 57 & 2.5 & \\
\hline & 1283.0 & 513.84 & 0.86 & 1.3 & 278 & 89 & 83 & & & 50 & $2: 5$ & \\
\hline 22.542 & 1353.3 & 554.81 & 0.84 & 1.2 & 278 & 88 & 82 & & & 51 & 2.5 & \\
\hline Avg. & 1373.8 & $15 \% 7 \%$ & $1 \% \%$ & $1 \%$ & $\%$ & $13 \times$ & ४० & 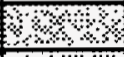 & $1 \%$ & \%०\% & 1\%\%? & $\%$ \\
\hline Check'd & & $83<3,2$ & 1958 & $1+3455$ & $128 \times$ & 18 & 808 & 10 & $\$$ & $1 \% 4$ & 1 & 28 \\
\hline
\end{tabular}

CONSOLE A

FILTER \# i25I (Th, imble)

AMBIENT TEMP.

PROBE LENGTH

LINER MATERIAL

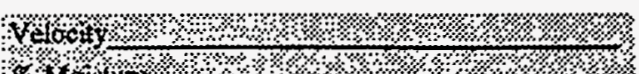

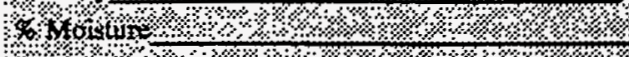

Howate (DSCDN)

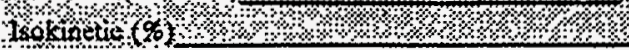

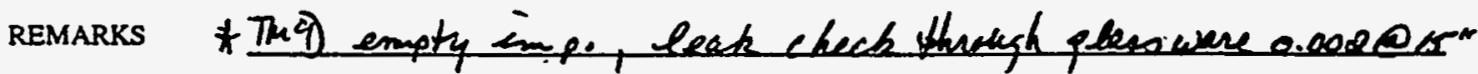


ESP OUTLET

Page 1 of 1

Plant Name

Plant Yates Station Boiler No. 1

Sampling Location ESP Out $\angle E$ Train Size Fract. Particulate Run No. 3

Date $6 / 26 / 13$ Time Start 1218 Time Finish $0627 \quad$ Test Duration $\frac{1090}{109}$ min

Duct Dimensions $1 l^{\prime} y^{x-11^{-9}}$ Dianneter

PTCF .84 DGMCF $\perp 607$ Nozzle Dia. 21 inches

Bar Press $29,42 . \mathrm{Hg}$

Static Press $-11.0 \quad-\mathrm{H} 2 \mathrm{O}$

Operator Xenen

Final Leak Rate cfm

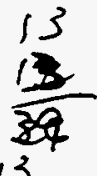

\begin{tabular}{|c|c|c|c|c|c|c|c|c|c|c|c|c|}
\hline \multirow{2}{*}{$\begin{array}{c}\text { Travers } \\
\text { Point }\end{array}$} & \multirow{2}{*}{$\begin{array}{l}\text { Clock } \\
\text { Time }\end{array}$} & \multirow{2}{*}{$\begin{array}{c}\text { Dry gas meter } \\
\text { reading ft3 }\end{array}$} & \multirow{2}{*}{$\begin{array}{l}\text { A } \mathrm{P} \\
\text { in } \mathrm{H} 2 \mathrm{O}\end{array}$} & \multirow{2}{*}{$\begin{array}{c}A \mathrm{H} \\
\text { in } \mathrm{H} 2 \mathrm{O}\end{array}$} & \multirow{2}{*}{$\begin{array}{c}\text { Stack } \\
\text { Temp. F }\end{array}$} & \multicolumn{2}{|c|}{ Dry gas meter temp. } & \multirow{2}{*}{$\begin{array}{c}\text { Hot box } \\
\text { Temp. }\end{array}$} & \multirow{2}{*}{$\begin{array}{l}\text { Probe } \\
\text { Temp }\end{array}$} & \multirow{2}{*}{\begin{tabular}{|c|} 
Last \\
Iinpinger
\end{tabular}} & \multirow{2}{*}{$\begin{array}{l}\text { Vacuum } \\
\text { in. } \mathrm{Hg}\end{array}$} & \\
\hline & & & & & & In!et & Outlet & & & & & \\
\hline & 0 & 258.76 & $1 \cdot 2$ & $1-6$ & 284 & 85 & 82 & - & 96 & & 3 & \\
\hline & 26 & 274.7 & 1.2 & 1.6 & 282 & 92 & 85 & & & & 3 & \\
\hline & 63 & 300.7 & 1.2 & 1.6 & 282 & 100 & 92 & & 128 & 48 & 3 & \\
\hline & 105 & 330.67 & 1.2 & 16 & 286 & 101 & 95 & & & 59 & 3 & \\
\hline & 161 & 320.1 & 1.3 & 1.7 & 283 & 104 & 99 & & & $5 \sqrt{5}$ & 3 & \\
\hline & 225 & 415.7 & 1,3 & 1.7 & 286 & 103 & 79 & & 124 & 55 & 3 & \\
\hline & 350 & 503.1 & 12 & 1.6 & 288 & 102 & 97 & & 127 & 51 & 2 & \\
\hline $\operatorname{Tin} x$ & 397.7 & 534.78 & 1.2 & 1.6 & 286 & 100 & 94 & & 127 & 56 & 2 & \\
\hline & 466.0 & 578112 & 1.2 & 1.6 & 287 & 94 & 89 & & 125 & 52 & 2 & \\
\hline & 5420 & 632.52 & $1 \cdot 2$ & 1.6 & 28 & 86 & 90 & & 129 & 50 & 2 & \\
\hline & 583.4 & 660.33 & 1.2 & 166 & 280 & 67 & 41 & & 129 & 49 & 2 & \\
\hline & 637,7 & 6965 & 1.1 & 1.5 & 281 & 96 & 90 & & 127 & 47 & 2 & \\
\hline & 693,5 & 732.30 & 1.1 & 1.5 & 281 & 56 & 90 & & 126 & 49 & 2 & \\
\hline & 754.5 & 771.07 & 1.0 & 1.4 & 278 & $\{3$ & 88 & & 125 & 49 & 2 & \\
\hline & 809.1 & 803.88 & 1.0 & 1.4 & 272 & 93 & 88 & & 121 & 49 & 2 & \\
\hline & 8728 & $846 \cdot 50$ & 1.0 & 1,4 & 276 & $\$ 2$ & 87 & & 130 & 49 & 2 & \\
\hline & 9439 & 884.54 & 1.0 & 1.4 & 274 & 63 & 87 & & 122 & 48 & 2 & \\
\hline & 999.1 & 917.17 & 100 & 1.4 & 274 & 91 & 86 & & 122 & 45 & 2 & \\
\hline & $1055 \%$ & 950.42 & 1.0 & 1.4 & 274 & 89 & 84 & & 125 & 47 & 2 & \\
\hline 0627 & 1090 & 970.557 & & & & & & & & & & \\
\hline & & & & & & & & & & & & \\
\hline & & & & & & & & & & & & \\
\hline & & & & & & & & & & & & \\
\hline & & & & & & & & & & & & \\
\hline & & & & & & & & & & & & \\
\hline & & & & & & & & & & & & \\
\hline & & & & & & & & & & & & \\
\hline & & & & & & & & & & & & \\
\hline Avg. & - & ৪\% ৪ / \% & $8 \%$ & 3 & ॥ & बि & 48 & 8 & ঋ४४ & $\$ \%$ & প\%? & . \\
\hline Check'd & & $1 \% 2$ & $\$ \%$ & $1 \%$ & $18 \%$ & $1 \%$ & 38 & 201 & $8 \%$ & 3 & 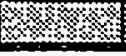 & \\
\hline
\end{tabular}

CONSOLE \#-ALC1394

FILTER \# 1255 (Th.mble)

AMBIENT TEMP.

PROBE LENGTH

LINER MATERIAL
Vewory

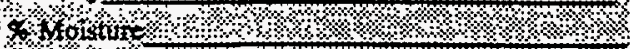

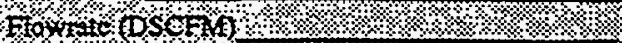

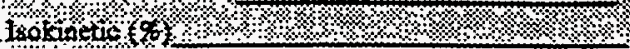

REMARKS 


\section{ORSAT DATA SHEET}

Plant Plant Yates Station Boiler No. 1

Location OUTLET

Run No.

Date $6 / 21 / 53$

Sorbing Reagents:

\section{Comments}

Operator TJP

\begin{tabular}{|c|c|c|c|c|c|c|c|}
\hline $\begin{array}{l}\text { Replicate } \\
\text { Number }\end{array}$ & $\begin{array}{l}\text { Original } \\
\text { Volume } \\
\text { Reading }\end{array}$ & $\begin{array}{c}(\mathrm{CO} 2) \\
\text { Reading } 2 \\
(\mathrm{ml})\end{array}$ & $\begin{array}{c}(\mathrm{CO} 2) \\
\text { Volume } \\
(2-1) \\
(\mathrm{ml}) \\
\end{array}$ & $\begin{array}{c}(\mathrm{O} 2) \\
\text { Reading } 3 \\
(\mathrm{ml})\end{array}$ & $\begin{array}{c}(\mathrm{O} 2) \\
\text { Volume } \\
(3-2) \\
(\mathrm{ml})\end{array}$ & $\begin{array}{c}\text { (CO) } \\
\text { Reading } 4 \\
(\mathrm{ml})\end{array}$ & $\begin{array}{c}(\mathrm{CO}) \\
\text { Volume } \\
(4-3) \\
(\mathrm{ml}) \\
\end{array}$ \\
\hline 1 & 0 & 6.0 & 6.0 & 19,4 & 13.4 & & \\
\hline 2 & e & 6.2 & 6.2 & 19.0 & 12.8 & & \\
\hline 3 & 0 & 6.6 & 6.6 & 19.6 & 13,0 & & \\
\hline & & & & & & & \\
\hline & & & & & & & \\
\hline & & & & & & & \\
\hline & & & & & & & \\
\hline
\end{tabular}

Averaged Results: $\quad \% \mathrm{CO}^{2} \quad 6.3^{*} \% 02 \frac{13.1^{*}}{\% \mathrm{CO}} \%-253$

Dry Molecular Weight, MW (dry) =

Run \#I Train orsat

ESP Inlet (CO)

(O2) 


\section{ORSAT DATA SHEET}

Plant Plant Yates Station Boiler No. 1

Comments

Location ESP Putlet

Run No. 2

Date

$6 / 22 / 93$

Sorbing Reagents: (CO2) (O2)

\begin{tabular}{|c|c|c|c|c|c|c|c|}
\hline $\begin{array}{l}\text { Replicate } \\
\text { Number }\end{array}$ & $\begin{array}{l}\text { Original } \\
\text { Volume } \\
\text { Reading }\end{array}$ & $\begin{array}{c}(\mathrm{CO} 2) \\
\text { Reading } 2 \\
(\mathrm{ml})\end{array}$ & $\begin{array}{c}(\mathrm{CO} 2) \\
\text { Volume } \\
(2-1) \\
(\mathrm{ml}) \\
\end{array}$ & $\begin{array}{c}\text { (O2) } \\
\text { Reading } 3 \\
(\mathrm{ml})\end{array}$ & $\begin{array}{c}(\mathrm{O} 2) \\
\text { Volume } \\
(3-2) \\
(\mathrm{ml}) \\
\end{array}$ & $\begin{array}{c}(\mathrm{CO}) \\
\text { Reading } 4 \\
(\mathrm{ml})\end{array}$ & $\begin{array}{c}(\mathrm{CO}) \\
\text { Volume } \\
(4-3) \\
(\mathrm{ml}) \\
\end{array}$ \\
\hline 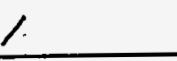 & 0,0 & 11,2 & 11,2 & $\angle 90$ & 78 & & \\
\hline 2 & 0.0 & $11 \cdot 1$ & 111 & 19.0 & 79 & & \\
\hline & & & & & & & \\
\hline & & & & & & & \\
\hline & & & & & & & \\
\hline & & & & & & & \\
\hline & & & & & & & \\
\hline$\cdot$ & & & & & & & \\
\hline
\end{tabular}

Averaged Results:

$\% \mathrm{CO} 2 \quad 1 / .2$

$\% \mathrm{CO}$ operator T73/tMP (CO) 


\section{ORSAT DATA SHEET}

Plant_Plant Yates Station Boiler No. 1

Comments

Location ESP catlet

Run No. 3

Date $6 / 23 / 93$

Operator TMP

Sorbing Reagents:

$(\mathrm{CO} 2)$

(O2) (CO).

\begin{tabular}{|c|c|c|c|c|c|c|c|}
\hline $\begin{array}{l}\text { Replicate } \\
\text { Number }\end{array}$ & $\begin{array}{l}\text { Original } \\
\text { Volume } \\
\text { Reading }\end{array}$ & $\begin{array}{l}(\mathrm{CO} 2) \\
\text { Reading } 2 \\
(\mathrm{ml})\end{array}$ & $\begin{array}{c}(\mathrm{CO} 2) \\
\text { Volume } \\
(2-1) \\
(\mathrm{ml})\end{array}$ & $\begin{array}{c}(\mathrm{O} 2) \\
\text { Reading } 3 \\
(\mathrm{ml})\end{array}$ & $\begin{array}{c}(\mathrm{O} 2) \\
\text { Volume } \\
(3-2) \\
(\mathrm{ml})\end{array}$ & $\begin{array}{c}\text { (CO) } \\
\text { Reading } 4 \\
(\mathrm{ml})\end{array}$ & $\begin{array}{c}(\mathrm{CO}) \\
\text { Volume } \\
(4-3) \\
(\mathrm{ml}) \\
\end{array}$ \\
\hline 1 & 0.0 & 10.6 & 10.6 & 19.0 & 8.4 & & \\
\hline 2 & 0.0 & 10.6 & 10.6 & 19.1 & 8.5 & & \\
\hline & & & & & & & \\
\hline & & & & & & & \\
\hline & & & & & & & \\
\hline & & & & & & & \\
\hline & & & & & & & \\
\hline
\end{tabular}

Averaged Results:
$\% \operatorname{co} 2-10.6$
$\% 028.5$
$\% \mathrm{CO}$
$\% \quad \mathrm{~N} 280.9$

Dry Molecular Weight, MW (dry) =

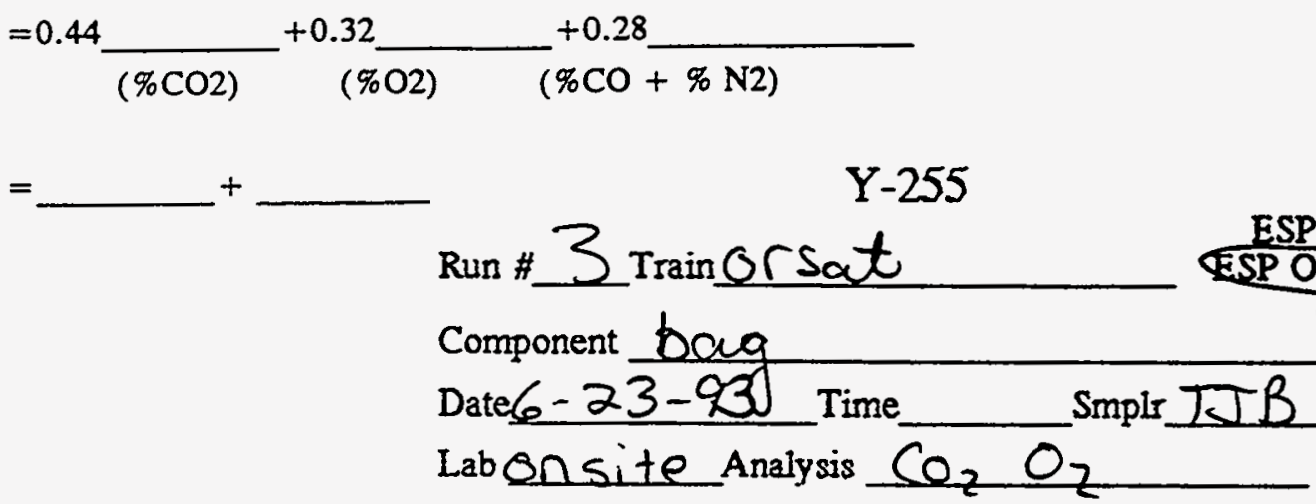

Tare Wt.

Final Wt. 


\section{ORSAT DATA SHEET}

Plant___ Plant Yates Station Boiler No. 1

Location EsP outlet

Date

$06 \cdot 25-93$

Comments

Sorbing Reagents:

$(\mathrm{CO} 2)$

(O2)

(CO)

\begin{tabular}{|c|c|c|c|c|c|c|c|}
\hline $\begin{array}{l}\text { Replicate } \\
\text { Number }\end{array}$ & $\begin{array}{l}\text { Original } \\
\text { Volume } \\
\text { Reading }\end{array}$ & $\begin{array}{c}\text { (CO2) } \\
\text { Reading } 2 \\
(\mathrm{ml})\end{array}$ & $\begin{array}{c}(\mathrm{CO} 2) \\
\text { Volume } \\
(2-1) \\
(\mathrm{ml}) \\
\end{array}$ & $\begin{array}{c}\text { (O2) } \\
\text { Reading } 3 \\
\text { (mi) }\end{array}$ & $\begin{array}{c}(\mathrm{O} 2) \\
\text { Volume } \\
(3-2) \\
(\mathrm{ml}) \\
\end{array}$ & $\begin{array}{c}\text { (CO) } \\
\text { Reading } 4 \\
(\mathrm{ml})\end{array}$ & $\begin{array}{c}(\mathrm{CO}) \\
\text { Volume } \\
(4-3) \\
(\mathrm{ml}) \\
\end{array}$ \\
\hline 1 & 0.0 & 11.2 & 11.2 & 18.8 & 7.6 & & \\
\hline 2 & 0.0 & 11.2 & 11.2 & 18.8 & 7.6 & & \\
\hline -. & & & & & & & \\
\hline & & & & . & & & \\
\hline & & & & & & & \\
\hline & & & & & & & \\
\hline & & & & & & & \\
\hline
\end{tabular}

Averaged Results:

$\%$ CO2_ $11,2 \quad \% 02 \quad 7,6$

Dry Molecular Weight, MW (dry) =

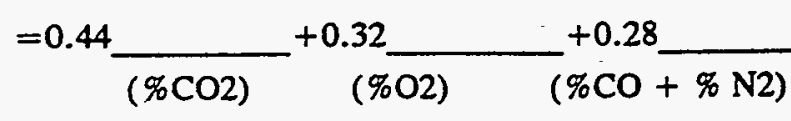

$=L^{+}+{ }_{\text {Run \# I Irain Orsat }}^{Y-329} \underbrace{\text { ESP Inlet }}_{\text {Stack }}$

Component baq

Date 6-25-93 Time 1540 smplr T JB

Lab on Site.

Analysis $\mathrm{CO}_{2} \mathrm{O}_{2}$

Tare WT(g)

Final $\mathrm{Wt}(\mathrm{g})$ 


\section{ORSAT DATA SHEET}

Plant__Plant Yates Station Boiler No. 1

Location ESP Ciktlet

Run No. phase 2 run 2

Date $6 / 26 / 93$

Sorbing Reagents:
Comments

Operator TMMP (CO)

\begin{tabular}{|c|c|c|c|c|c|c|c|}
\hline $\begin{array}{l}\text { Replicate } \\
\text { Number }\end{array}$ & $\begin{array}{l}\text { Original } \\
\text { Volume } \\
\text { Reading }\end{array}$ & $\begin{array}{c}(\mathrm{CO} 2) \\
\text { Reading } 2 \\
(\mathrm{ml})\end{array}$ & $\begin{array}{c}(\mathrm{CO} 2) \\
\text { Volume } \\
(2-1) \\
(\mathrm{ml}) \\
\end{array}$ & $\begin{array}{c}\text { (O2) } \\
\text { Reading } 3 \\
\text { (ml) }\end{array}$ & $\begin{array}{c}\text { (O2) } \\
\text { Volume } \\
(3-2) \\
(\mathrm{ml})\end{array}$ & $\begin{array}{c}\text { (CO) } \\
\text { Reading } 4 \\
(\mathrm{ml})\end{array}$ & $\begin{array}{c}(\mathrm{CO}) \\
\text { Volume } \\
(4-3) \\
(\mathrm{ml}) \\
\end{array}$ \\
\hline 1 & 0.0 & 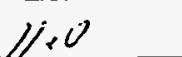 & 11.0. & 18,6 & 7.6 & & \\
\hline 2 & 0,0 & 11.2 & 11.2 & 18,6 & 7.4 & & \\
\hline & & & & & & & \\
\hline & & & & & & & \\
\hline & & & & & & & \\
\hline & & & & & & & \\
\hline & & & & & & & \\
\hline & & & & & & & \\
\hline
\end{tabular}

Averaged Results:

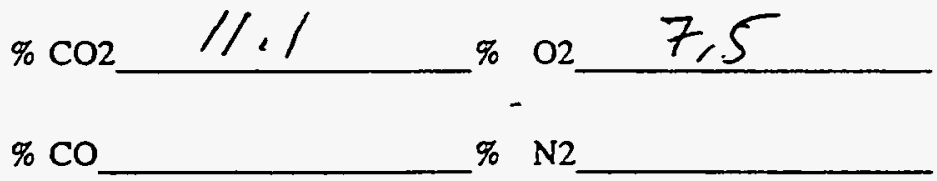

Dry Molecular Weight, MW (dry) =

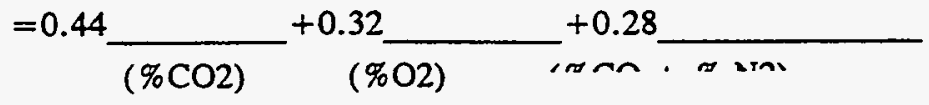

$$
\begin{aligned}
& Y-406 \\
& =L^{+}+^{+}{ }_{\text {Run }} 2_{\text {Train ONat }} \\
& \text { Component Phase 2 - Bag } \\
& \text { Date } 6-26-23 \text { Time } 1445 \text { Smpir ToB } \\
& \text { Lab onsite } \\
& \text { Tare WT }(\mathrm{g}) N_{\mathrm{C}} \\
& \text { Analysis } \mathrm{CO}_{2} \mathrm{O}_{2} \\
& \text { Final } \mathrm{Wt}(\mathrm{g}) \mathrm{Na}
\end{aligned}
$$




\section{ORSAT DATA SHEET}

Plant__Plant Yates Station Boiler No. 1

Location ESP Outkt

Run No. $2-3$

Date $\quad 4 / 27 / 53$

Sorbing Reagents:

$(\mathrm{CO} 2)$
Comments

Operator TMP

\begin{tabular}{|c|c|c|c|c|c|c|c|}
\hline $\begin{array}{l}\text { Replicate } \\
\text { Number }\end{array}$ & $\begin{array}{l}\text { Original } \\
\text { Volume } \\
\text { Reading }\end{array}$ & $\begin{array}{c}(\mathrm{CO} 2) \\
\text { Reading } 2 \\
(\mathrm{ml})\end{array}$ & $\begin{array}{c}(\mathrm{CO} 2) \\
\text { Volume } \\
(2-1) \\
(\mathrm{ml}) \\
\end{array}$ & $\begin{array}{c}(\mathrm{O} 2) \\
\text { Reading } 3 \\
(\mathrm{ml})\end{array}$ & $\begin{array}{c}(\mathrm{O} 2) \\
\text { Volume } \\
(3-2) \\
(\mathrm{ml}) \\
\end{array}$ & $\begin{array}{c}(\mathrm{CO}) \\
\text { Reading } 4 \\
(\mathrm{ml})\end{array}$ & $\begin{array}{c}(\mathrm{CO}) \\
\text { Volume } \\
(4-3) \\
(\mathrm{ml}) \\
\end{array}$ \\
\hline 1 & 10.0 & 11,4 & 11.4 & 19,0 & 7.6 & & \\
\hline 2 & bio & 11,4 & $1<.4$ & 190 & 7.6 & & \\
\hline & & & & & & & \\
\hline & & & & & & & \\
\hline & & & & & & & \\
\hline & & & & & & & \\
\hline & & & & & & & \\
\hline
\end{tabular}

Averaged Results:

$\% \mathrm{CO} 2 \quad 11.4 \% 02+7.6$

Dry Molecular; Weight, MW (dry) =

$$
=0.44 \underbrace{+0.32}_{(\% \mathrm{CO} 2)}+0.28
$$

$=+\ldots+\frac{\text { Run } \# 2-3 \text { Train oesAT }}{\text { Component ORSAT }}+\frac{Y 52}{\text { ESP Inlet }}$ 


\section{TRAVERSE FIELD DATA SHEET}

Plant Name Plant Yates Station Boiler Nol Sampling Location_ ESP OUTLET

Date $06-19-93$

Operator RvwiTwm
Stack Diameter $11^{\prime} 4$ " $\times 11$ '4"

Sample Port Diameter _ 4 "

Sample Porr Depth __ 18 '"

Distance Upstream

Distance downstream

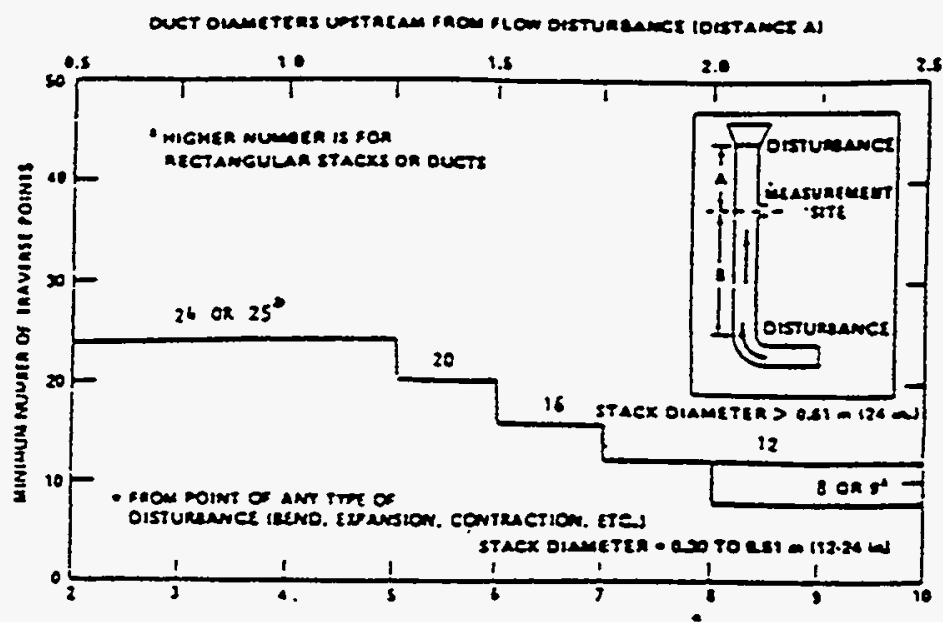

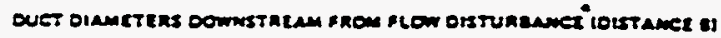

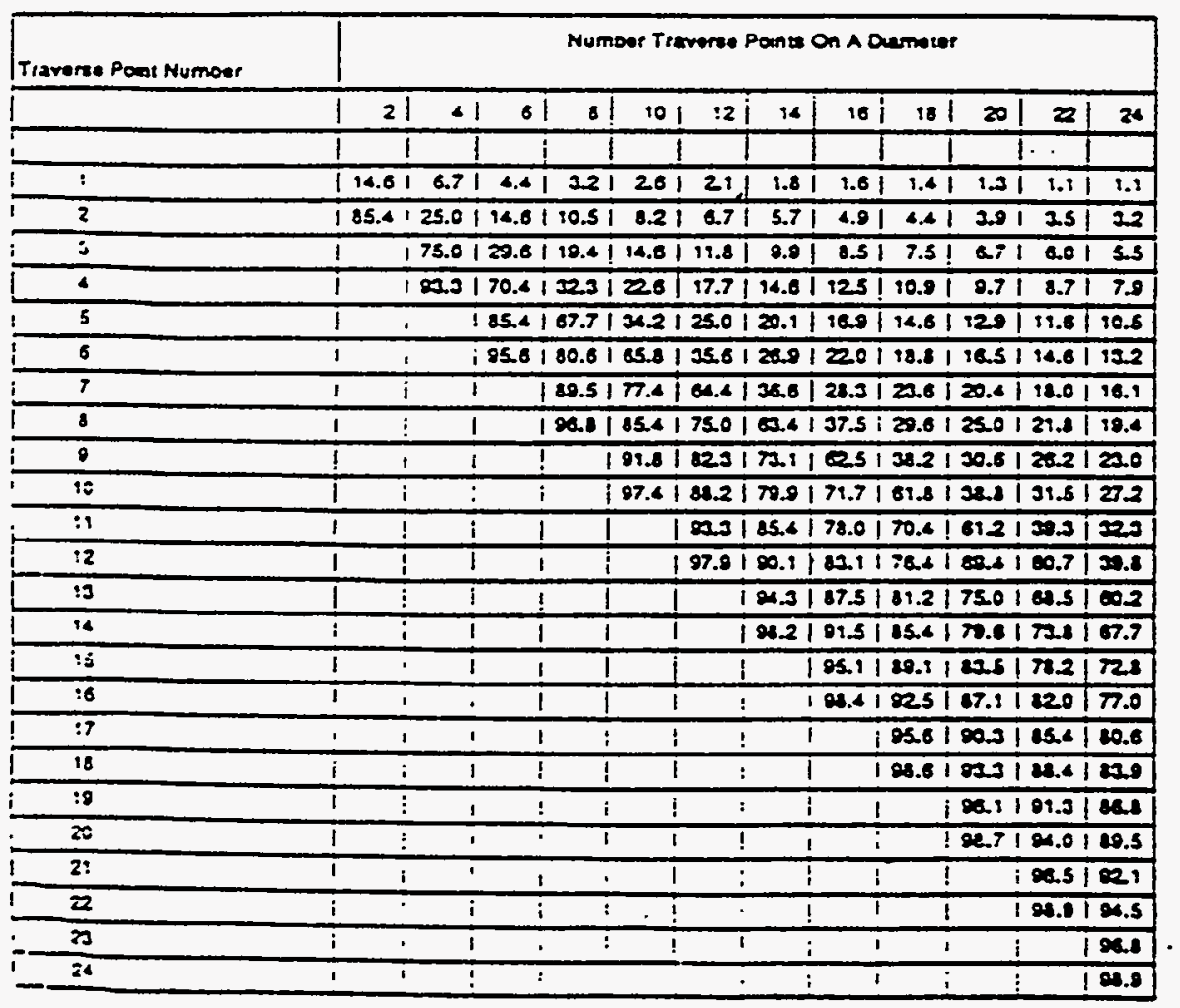

\begin{tabular}{|c|c|}
\hline & Traverse Points \\
\hline No. & Distance From Wall \\
\hline & PeeTofert \\
\hline 1 & 126.5 \\
\hline 2 & 143.5 \\
\hline 3 & 160.5 \\
\hline 4 & 177.5 \\
\hline 5 & 194.5 \\
\hline 5 & 1111.5 \\
\hline 7 & 11285 \\
\hline 8 & 1145.5 \\
\hline 9 & $T$ \\
\hline 70 & $T$ \\
\hline 17 & \\
\hline 72 & \\
\hline$\sqrt{3}$ & \\
\hline 14 & I \\
\hline 75 & $\mathrm{~T}$ \\
\hline 15 & \\
\hline 17 & \\
\hline 18 & \\
\hline 19 & \\
\hline 20 & \\
\hline 21 & 1 \\
\hline 22 & 1 \\
\hline 23 & \\
\hline 24 & iآ \\
\hline
\end{tabular}




\section{VELOCITY PROFILE FIELD DATA}

Plant Name Yates - Prelivancury

Sampling Location Inlef to Scrubber Sample ident. EsP Outlet

Date $6 / 14 / 93$ (MMDOry Time Star 1600 (HHMM) Time Finish 1630 (HHMM) Duct Dimensions $11^{\prime} 4^{\prime \prime}$ $x$ $114^{\prime \prime}$

ft. or Diameter

PTCF 0.84

Bar Press.

Static Press.

29.18

Operator Initials

$-11$

$\% \mathrm{H}_{2} \mathrm{O} \approx 7.0$

" Hg \% CO T

$" \mathrm{H}_{2} \mathrm{O} \% \mathrm{CO}_{2} \approx 9.0$ $\mathrm{OO}_{2}$

7.4

$\% \mathrm{~N}_{2}$

$\% \mathrm{H}_{2}$

$\% \mathrm{CH}_{4}$

foint 1 is all the way, in

\begin{tabular}{|c|c|c|c|c|c|c|c|c|c|}
\hline \multirow[b]{2}{*}{ Pt. } & \multicolumn{3}{|c|}{ Slack Tomp. of } & \multicolumn{3}{|c|}{ Velocity Prossure $\cdot \mathrm{H}_{2} \mathrm{O}$} & \multicolumn{2}{|c|}{ Other 1} & 1 \\
\hline & 11 & $* 2$ & Ave. & $m$ & 12 & Ave. & $m$ & 12 & Ave. \\
\hline$\omega 1-L^{2}$ & 207 & & & 0.88 & & & & & \\
\hline 2 & 205 & & & 0.25 & 0.90 & & & & \\
\hline 3 & 207 & & & $\theta=8$ & 0.66 & & & & \\
\hline 4 & $20 ?$ & & & 0.36 & & & & & \\
\hline 5 & $206^{\prime}$ & & & 0,35 & & & & & \\
\hline 6 & 200 & & & 0,52 & & & & & \\
\hline 2 & 192 & & & 20.65 & & & & & \\
\hline 8 & 192 & & & 0.68 & & & & & \\
\hline (1) $z-1$ & 200 & & & 0.85 & & & & & \\
\hline 2 & 205 & & & 0.46 & & & & & \\
\hline 3 & 209 & & & 0.24 & & & & & \\
\hline 4 & 209 & & & 0.92 & & & & & \\
\hline 5 & 205 & & & 0.62 & & & & & \\
\hline 6 & 203 & & & 0,56 & & & & & \\
\hline 7 & 154 & & & 0.7 & & & & & \\
\hline 8 & 194 & & & 0.47 & & & & & \\
\hline & & & & & & & & & \\
\hline & & & & & & & & & \\
\hline
\end{tabular}

Weather

Remarks

$12 \% \mathrm{CO}_{2}+7.4 \mathrm{O}_{2}+80.6 \omega_{2}=30.23$

$57.11 \mathrm{ft} / \mathrm{s}$

29.36 wet

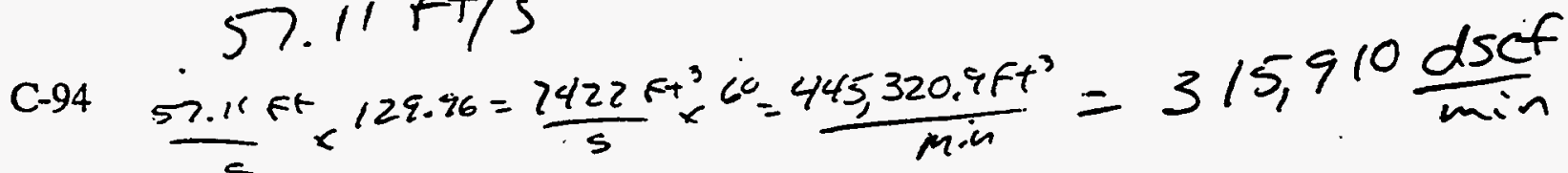




\section{VELOCITY PROFILE FIELD DATA}

Plant Name

Sampling Location Sample Ident.

Date (MMDDYY) Time Start (HHMM) Time Finish

Duct Dimensions ft.

PTCF

Bar Press.

Static Press.

Operator Intials H. or Diameter

$x$

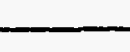

\begin{tabular}{|c|c|c|c|c|c|c|c|c|c|}
\hline \multirow[b]{2}{*}{ P. } & \multicolumn{3}{|c|}{ Stack Tomp. of } & \multicolumn{3}{|c|}{ Velocity Pressure ${ }^{\circ} \mathrm{H}_{2} \mathrm{O}$} & \multicolumn{2}{|c|}{ Otren I } & \\
\hline & $" 1$ & 12 & Ave. & $m$ & 12 & Ave. & $m$ & 12 & Ave. \\
\hline$\omega 3-1$ & 201 & & & 0.85 & & & & & \\
\hline 2 & 210 & 2क्र & & 0,94 & & & & & \\
\hline 7 & $2+8 ?$ & therements & k & 1.1 & & & & & \\
\hline 4 & 202 & & & 1.15 & & & & & \\
\hline 5 & 189 & & & 1.1 & & & & & \\
\hline 6 & 181 & & & 0,93 & & & & & \\
\hline 1 & 180 & & & 0.73 & & & & & \\
\hline 8 & 180 & & & 0,43 & & & & & \\
\hline$\omega_{4}-1$ & 203 & & & 0.88 & & & & & \\
\hline 2 & 152 & & & 0.99 & & & & & \\
\hline 3 & 191 & & & $+0 x^{6}=$ & & & & & \\
\hline 7 & 215 & & & 1.25 & & & & & \\
\hline 5 & 211 & & & 1.3 & & & & & \\
\hline 6 & 159 & & & 1.1 & & & & & \\
\hline 7 & 191 & & & 0.80 & & & & & \\
\hline 8 & 191 & & & 0.47 & & & & & \\
\hline & & & & & & & & & \\
\hline & & & & & & & & & \\
\hline
\end{tabular}

Weather

Remarks 


\section{VELOCITY PROFILE FIELD DATA}

Plant Name

Sampling Location

Date (MMDDYY) Time Start

Duct Dimensions

PTCF

Bar Press.

Static Press.

Operator Initials
Sample Ident.

(HHMM) Time Finish

A. or Diameter

(HHMM)

ft.
$\% \mathrm{H}_{2} \mathrm{O}$

" $\mathrm{Hg} \% \mathrm{CO}$

" $\mathrm{H}_{2} \mathrm{O} \% \mathrm{CO}_{2}$

$\% \mathrm{O}_{2}$
$\% \mathrm{~N}_{2}$

$\% \mathrm{H}_{2}$

$\% \mathrm{CH}_{4}$

\begin{tabular}{|c|c|c|c|c|c|c|c|c|c|}
\hline \multirow[b]{2}{*}{ P. } & \multicolumn{3}{|c|}{ Stack Tomp. of } & \multicolumn{3}{|c|}{ Volocity Prossure " $\mathrm{H}_{2} \mathrm{O}$} & \multicolumn{2}{|c|}{ Other I } & \multirow{2}{*}{ Avo. } \\
\hline & $" 1$ & $* 2$ & Ave. & $m$ & 12 & Avo. & $m$ & 12 & \\
\hline W5-1 & 215 & & & 0.99 & & & & & \\
\hline 2 & 221 & & & 0.97 & & & & & \\
\hline 3 & 2021 & & & 1.2 & & & & & \\
\hline 4 & 221 & & & 1.25 & & & & & \\
\hline 5 & 216 & & & 1.10 & & & & & \\
\hline 6. & 207 & & & 0.7 & & & & & \\
\hline$?$ & 191 & & & 0.8 & & & & & \\
\hline 8 & 81 & & & 0.58 & & & & & \\
\hline $136-1$ & 216 & & & 0.53 & & & & & \\
\hline$z$ & 225 & & & 0.85 & & & & & \\
\hline 3 & 227 & & & 0,66 & & & & & \\
\hline 4 & 226 & & & 0.71 & & & & & \\
\hline 5 & 215 & & & 0.59 & & & & & \\
\hline 6 & 204 & & & 0.69 & & & & & \\
\hline 7 & 154 & & & 0.81 & & & & & \\
\hline 8 & 191 & & & 0.22 & & & & & \\
\hline & $=$ & & & $\sqrt{\sqrt{4 e}}$ & & & & & \\
\hline & 203.7 & & & 0196 & & & & & \\
\hline
\end{tabular}

Remarks 
VOST FIELD DATA SHEET

PLANT Plant Yates Station Boiler No. 1 DATE $6,-21-83$

SAMPLING LOCATION STACK RUN NO.

OPERATOR

AMBIENT TEMPERATURE

$77^{\circ} \mathrm{F}$

BAROMETRIC PRESSURE $22.355^{\circ} \mathrm{H}$

BLANK TUBE NUMBERS T: $44 A$ TIC: $24 B$
ASSUMED MOISTURE \%

METER BOX NO.

METER FACTOR

PROBE HEATER SETTING

COMMENTS RA LA

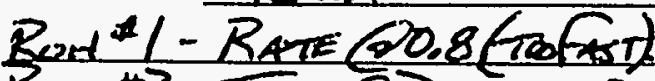

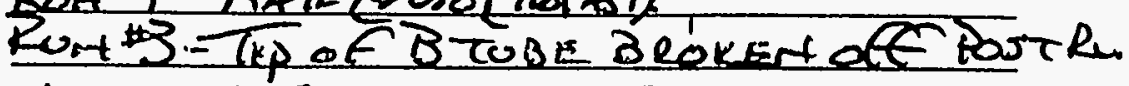

ALITuES CENTPAL TTUE

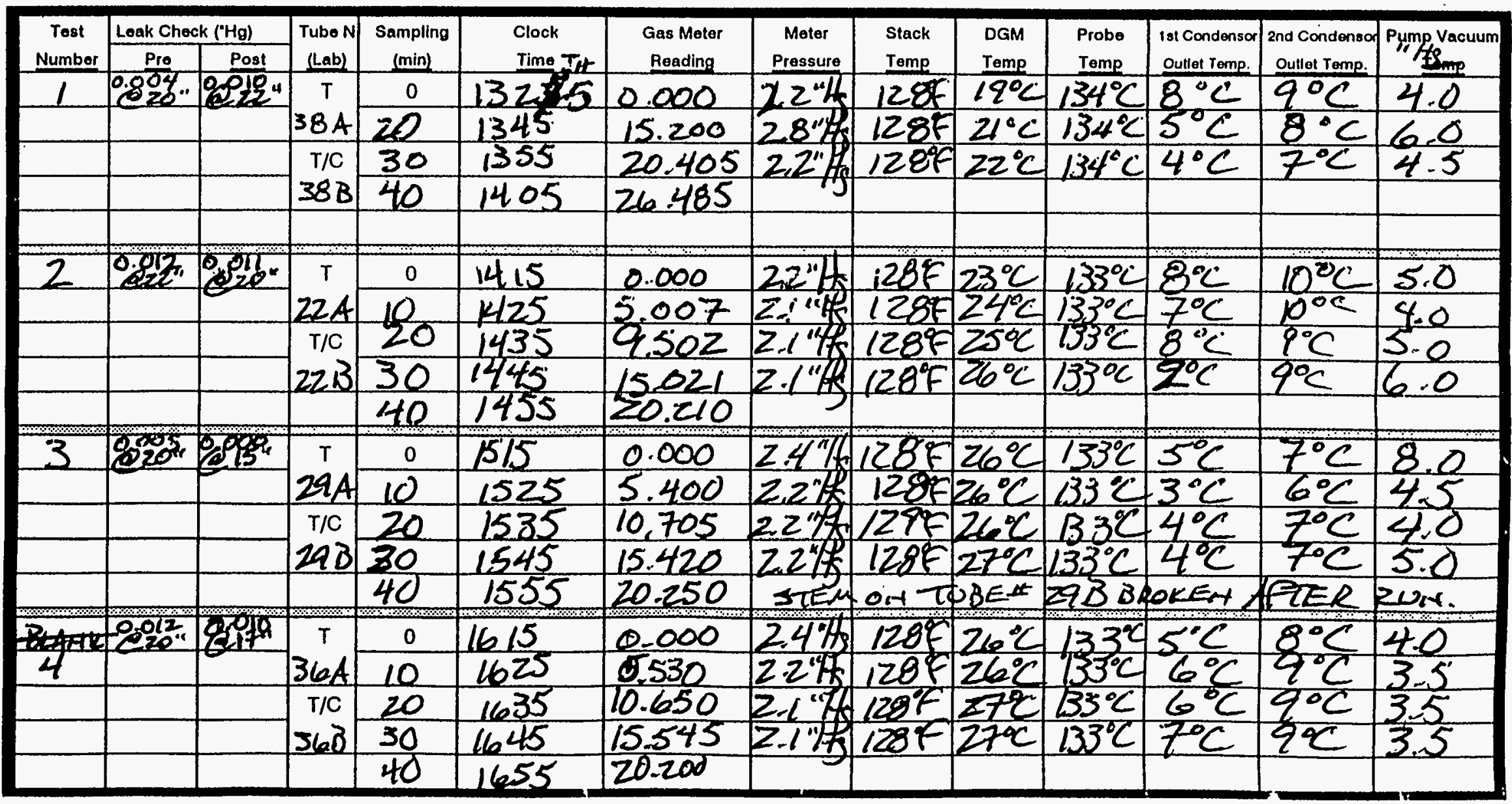


VOST FIELD DATA SHEET

\&

PLANT Plant Yates Station Boiler No. 1 DATE $19-2 Z-23$

SAMPLING LOCATION STARK

RUN NO._Z $Z$ TEST NO. Z Z

OPERATOR

AMBIENT TEMPERATURE $70^{\circ} \mathrm{F}$

BAROMETRIC PRESSURE $\quad 22,34$

BLANK TUBE NUMBERS T: $24 A^{T / C}, 24 B$
ASSUMED MOISTURE \% $\quad 12.0 \%$

METER BOX NO. $\sqrt{-l l}$ (PPR)

METER FACTOR 1.0113

PROBE HEATER SETTING $130^{\circ} \mathrm{C}$

COMMENTS_RACE/ALU10

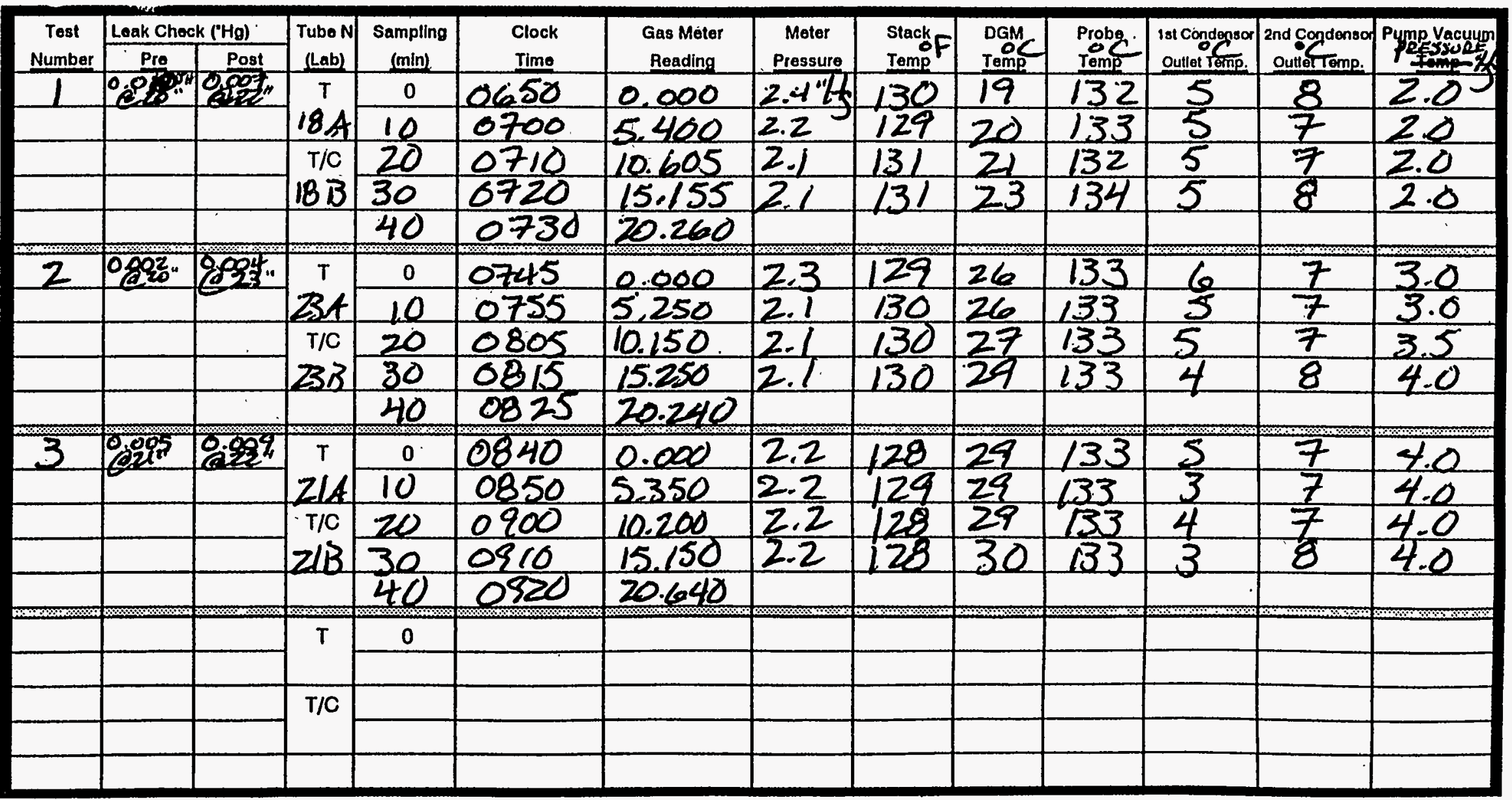




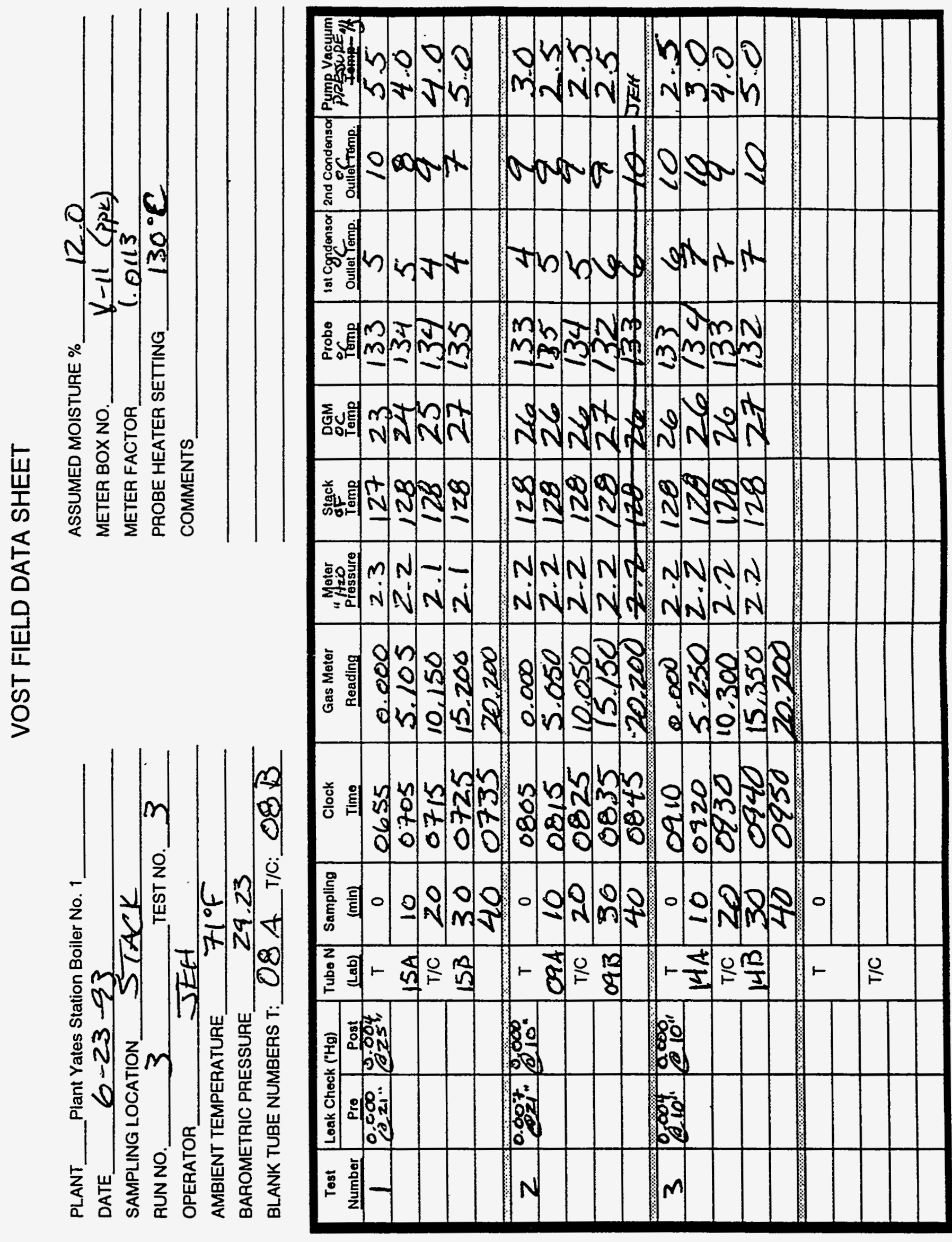


号

\section{VOST FIELD DATA SHEET}

PLANT__ Plant Yates Station Boiler No. 1

DATE $6-23-83$

SAMPLING LOCATION

SAACK

RUNN No. A $2 D, T$ TESTNO.

OPERATOR

TEH

AMBIENT TEMPERATURE

$87^{\circ} \mathrm{F}$

BAROMETRIC PAESSURE

$29-26$

BLANK TUBE NUMBEAS $T: 08 A$ T/C: $08 B$

ASSUMED MOISTURE \%

METER BOXNO

METER FACTOA

$\overline{\gamma-11}$

PROBE HEATER SETTING

1.0113

COMMENTS ANOSIT

CAL DATE 2/8/a3 FoC $\mu_{\text {ETEL BOX }}$

sample $y-194$ \& $y-195$

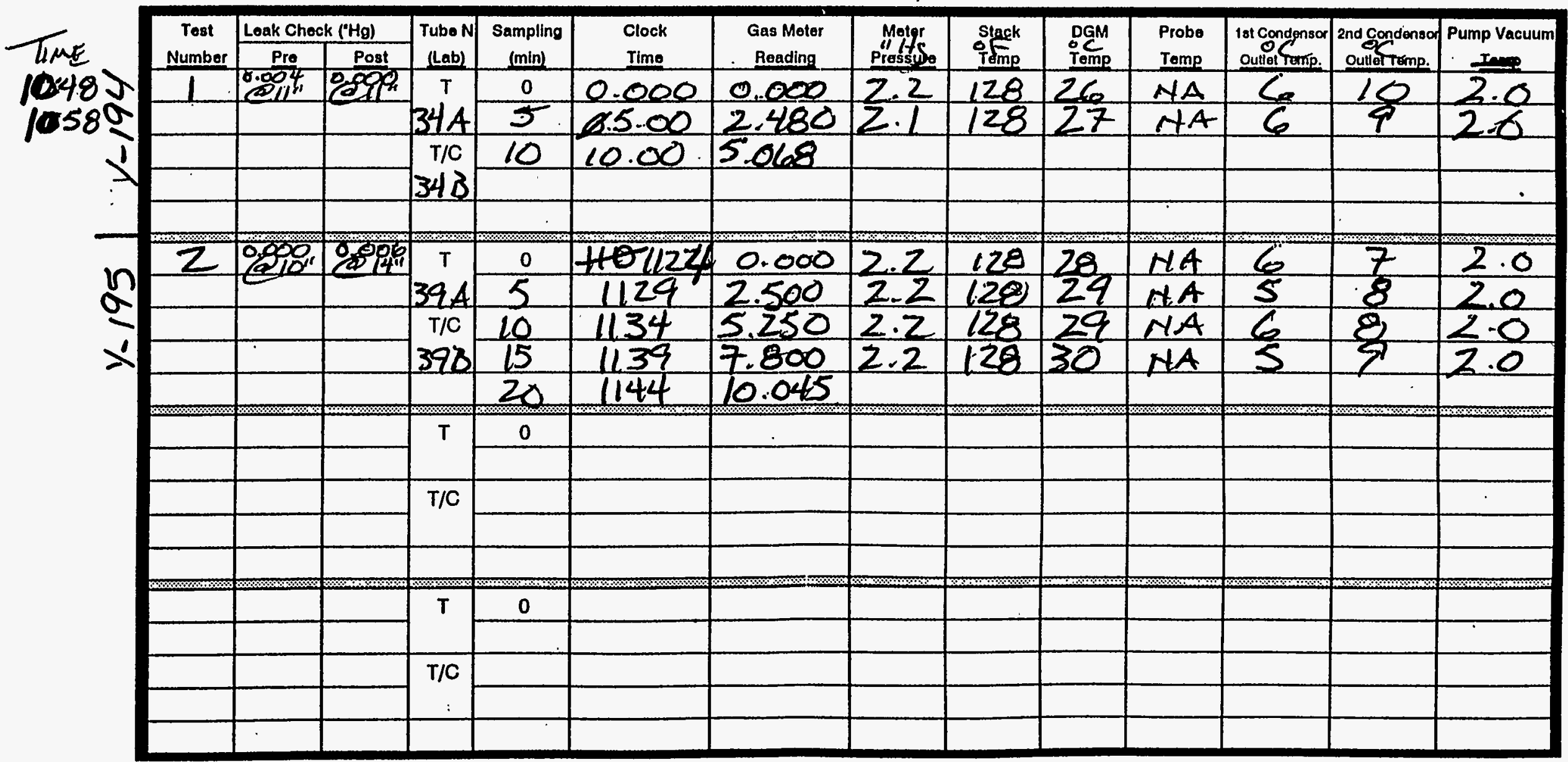


PLANT NAME Plant Yates Station Boiler No. 1

$62 /$ Ee Page 1 of 1

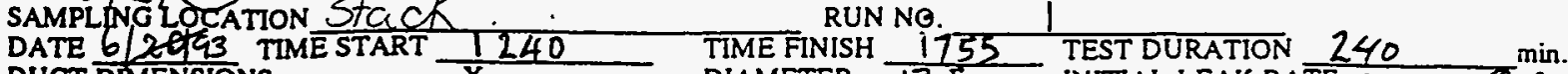

DUCT DIMENSIONS DIAMETER T3 13 INTIAL LEAK RATE 0.000 C $\mathrm{cfm} / 5 " 16$

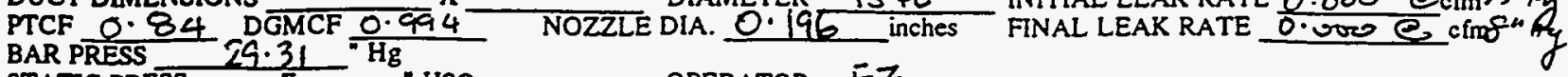

STATIC PRESS $-\frac{19.31}{0.5}$ "H2O OPERATOR EZ

W $15=1.245$

\begin{tabular}{|c|c|c|c|c|c|c|c|c|c|c|c|c|}
\hline \multirow{2}{*}{$\begin{array}{c}\text { Traverse } \\
\text { Point }\end{array}$} & \multirow{2}{*}{$\begin{array}{l}\text { Clock } \\
\text { Time }\end{array}$} & \multirow{2}{*}{$\begin{array}{l}\text { Dry gas meter } \\
\text { reading ft } 3\end{array}$} & \multirow{2}{*}{ in $\mathrm{H} 2 \mathrm{O}$} & \multirow{2}{*}{ in $\mathrm{H} 2 \mathrm{O}$} & \multirow{2}{*}{$\begin{array}{c}\text { Stack } \\
\text { Temp. } F\end{array}$} & \multicolumn{2}{|c|}{ Dry gas meter ternp. } & \multirow{2}{*}{$\begin{array}{l}\text { Hol box } \\
\text { Temp. }\end{array}$} & \multirow{2}{*}{$\begin{array}{l}\text { Probe } \\
\text { Temp }\end{array}$} & \multirow{2}{*}{$\begin{array}{c}\text { Last } \\
\text { Impinger }\end{array}$} & \multirow{2}{*}{$\begin{array}{l}\text { Vacuum } \\
\text { in. } \mathrm{Hg}_{\mathrm{g}}\end{array}$} & \multirow{2}{*}{$\begin{array}{c}\text { Cond. } \\
\text { Exit } \\
\text { Temp. F }\end{array}$} \\
\hline & & & & & & Inlet & Outlet & & & & & \\
\hline \multirow[t]{2}{*}{$E-1$} & 1240 & 756.882 & 0.75 & 0.934 & 126 & 73 & 72 & $25 i$ & 249 & 59 & 4.0 & 38 \\
\hline & 1250 & $762 \cdot 280$ & 0.74 & 0.92 & 127 & 75 & 72 & 251 & 256 & 55 & 4.0 & 38 \\
\hline \multirow[t]{2}{*}{$E-2$} & 1300 & 761.400 & 0.76 & 0.95 & 128 & 79 & 74 & 253 & 257 & 50 & 4,0 & 39 \\
\hline & 1310 & $712 \cdot 465$ & $10 \cdot 76$ & 0.95 & 128 & 83 & 75 & 255 & 251 & 47 & $\Delta \cdot 0$ & 41 \\
\hline \multirow[t]{2}{*}{$E-3$} & 1320 & 771.701 & 0.60 & 0.75 & 128 & 88 & 78 & 252 & 250 & 42 & 4.0 & 39 \\
\hline & 1330 & $782 \cdot 425$ & 0.62 & 0.77 & 128 & 90 & 80 & 253 & 264 & 45 & 4.0 & 39 \\
\hline \multirow{3}{*}{$\frac{5 T O P}{\sqrt{-1}}$} & $13<0$ & 187.198 & & PORT & chttent & $E$ & Konk & cucer & ore & e & 4ts & \\
\hline & 1345 & 787.270 & 0.75 & 0.934 & 127 & 89 & 82 & 251 & 252 & 52 & 4.0 & 38 \\
\hline & 1355 & 792.550 & 0.74 & 6.92 & 128 & 91 & 84 & 253 & 238 & 46 & 4.0 & 40 \\
\hline \multirow[t]{2}{*}{$N-2$} & 1405 & $797 \cdot 795$ & 0.75 & 0.934 & 129 & 95 & 85 & 254 & 256 & 49 & 4.5 & 39 \\
\hline & 1415 & $803 \cdot 140$ & $6 \cdot 75$ & 0.934 & 129 & 97 & 87 & 253 & 263 & 50 & 4.5 & 39 \\
\hline \multirow[t]{2}{*}{$N-3$} & 1425 & $808 \cdot 475$ & 0.60 & 0.75 & 129 & 99 & 89 & 255 & 247 & 50 & $4 \cdot 0$ & 41 \\
\hline & 1435 & 813.200 & 0.66 & 0.75 & 129 & 100 & 41 & 254 & 241 & 51 & 4.0 & 41 \\
\hline STOP & 1445 & 818.148 & & PORT & estrov & EE & LFar & GHECA & 04 & & $\mathrm{~kg}$ & \\
\hline \multirow[t]{2}{*}{$w-1$} & 1450 & 1818.201 & 0.68 & 0.85 & 115 & 98 & 92 & 255 & 242 & 56 & 4.0 & 40 \\
\hline & 1500 & 823.330 & 0.68 & 0.85 & 124 & 100 & 93 & 254 & 1240 & 53 & 4,0 & 43 \\
\hline \multirow[t]{2}{*}{$w-2$} & 1510 & 828.470 & 0.67 & 0.83 & 128 & 100 & 93 & 253 & 248 & 50 & 4.0 & 41 \\
\hline & 1520 & 833.575 & 0.67 & 0.83 & 128 & 101 & 94 & 254 & 245 & 49 & 4.0 & 40 \\
\hline \multirow[t]{2}{*}{$w-3$} & 1530 & 838.675 & 0.56 & 0.69 & 129 & 103 & 95 & 255 & 264 & 49 & 4.0 & 41 \\
\hline & 1540 & 843.775 & 10.56 & & 128 & 102 & 96 & 1254 & 240 & 51 & 4.0 & 41 \\
\hline STOP & 1550 & 848.095 & & Pont & CHAt & VGE & & & & he & flth & \\
\hline \multirow[t]{2}{*}{$s-1$} & 1655 & $848 \cdot 225$ & 0.68 & 0.85 & 124 & 88 & 88 & 251 & 254 & 55 & 46.3 & 36 \\
\hline & 1705 & 853.420 & 0.68 & 0.85 & 128 & 90 & 88 & 254 & 242 & 45 & 4,0 & 38 \\
\hline \multirow[t]{2}{*}{$s-2$} & 1715 & 858.480 & 0.74 & 0.92 & 122 & 94 & 89 & 251 & 240 & 50 & 4.0 & 39 \\
\hline & 1725 & 863.842 & 0.74 & 0.92 & 128 & 97 & 90 & 253 & 240 & 48 & $4 \cdot 0$ & 39 \\
\hline \multirow[t]{2}{*}{$5-3$} & 1735 & 869.155 & $|6-6|$ & 0.76 & 128 & 100 & 91 & 254 & 250 & 46 & 4.0 & 39 \\
\hline & 1445 & 874.035 & 0.62 & 0.77 & 128 & 101 & 92 & 255 & 256 & 47 & 4,0 & 39 \\
\hline END. & 1755 & 878.925 & & & & & & & & & & \\
\hline Avg. & - & $x$ & 0823 & 10030 & 42 & 102 & $\cos 2$ & \% & & + & \% & 1 \\
\hline eck'd & - & & & & & $\% \$$ & & & & & & \\
\hline
\end{tabular}

CONSOLE \# $A 161361$

FILTER \#

AMBIENT TEMP. 75

PROBE LENGTH $\frac{1}{6}$

LINER MATERIAL GLASS LINED

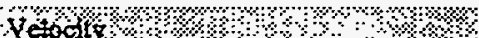

\% Howstus

Howrate tosean

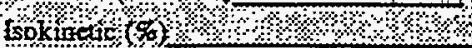

REMARKS

PITOR THBELEATL CHECK OR. 


\section{¿OODIFIED METHOD 5 FIELD DATA SHEET}

PLANT NAME Plant Yates Station Boiler No. 1

SAMPLIYG LOCATION STAEK.

RUN NO. 2

Page 1 of 1

DATE $6 / 22 / 93$ TIMESTART $\frac{2555}{\mathrm{x}}$ TIME FINISH $\frac{1115}{13}$ TEST DURATION $240^{\circ} \mathrm{min}$
DUCT DIMENSIONS

PTCF 0.84 DGMCF 0.994 NOZZLE DIA. 0.196 inches FINAL LEAK RATE 0.000 C $\mathrm{cm} 91.97 \mathrm{~g}$

BAR PRESS 29.34
STATIC PRESS -0.50

$K=1.245$

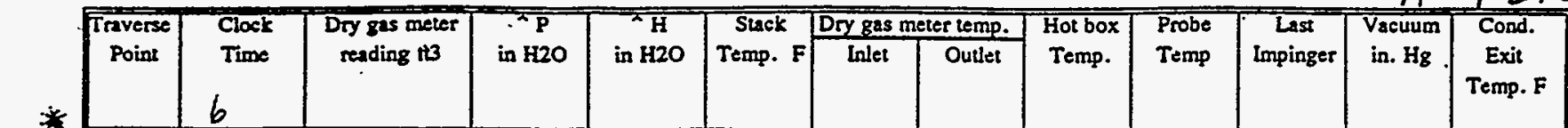

\begin{tabular}{|l|l|l|l|l|l|l|l|l|l|}
\hline$E-110755$ & 888.530 & 0.74 & 0.92 & 127 & 75 & 70 & 253 & 264 & 51 \\
\hline 0.8705 & 894.425 & 0.73 & 0.91 & 128 & 80 & 7.3 & 254 & 743 & 60 \\
\hline
\end{tabular}

\begin{tabular}{l|l|l|l|l|l|l|l|l}
$E-208715$ & 899.275 & 0.74 & 0.92 & 128 & 86 & 76 & 254 & 26 \\
\hline
\end{tabular}

\begin{tabular}{l|l|l|l|l|l|l|}
08525 & 964.330 & 0.74 & 0.92 & 129 & 89 \\
\hline
\end{tabular}

\begin{tabular}{llll|l|l|l|l|l|l|l|l|l|l}
$E-3$ & 68735 & 909.060 & 0.64 & 0.79 & 128 & 95 & 83 & 255 & 254 & 45 & 5.0 & 48
\end{tabular}

\begin{tabular}{ll|l|l|l|l|l|l|l|l|l|l|l|l|l}
0.845 & 914.450 & 0.64 & 0.79 & 128 & 96 & 85 & 255 & 265 & 42 & 5.0 & 43
\end{tabular}

STOP 08755919.437 PORT CHAMGE $\quad$ LEAK EHECK. OS Q \$"HG

\begin{tabular}{|l|l|l|l|l|l|l|l|l|l|l|l|l|l|}
\hline$N-1$ & 0800 & 919.592 & 0.73 & 0.91 & 127 & 94 & 86 & 2.51 & 248 & 47 & 60 & 41
\end{tabular} \begin{tabular}{ll|l|l|l|l|l|l|l|l|l|l|l|l}
0810 & 924.565 & 0.73 & 0.91 & 128 & 96 & 88 & 256 & 255 & 42 & 6.0 & 42
\end{tabular}

\begin{tabular}{l|l|l|l|l|l|l|l|l|l|l|l|l|l|l|}
\hline$N-2$ & 0820 & $930-160$ & 0.74 & 0.92 & 128 & 99 & 89 & 254 & 265 & 44 & $6: 0$ & 43 \\
\hline
\end{tabular}

\begin{tabular}{|l|l|l|l|l|l|l|l|l|l|l|l|l|}
\hline & 0830 & 935.485 & 0.74 & 0.92 & 128 & 101 & 91 & 255 & 260 & 47 & 6.0 & 44 \\
\hline$N-3$ & 0840 & 940.840 & 0.64 & 0.79 & 129 & 102 & 23 & 254 & 264 & 46 & 5.5 & 44 \\
\hline
\end{tabular}

\begin{tabular}{ll|l|l|l|l|l|l|l|l|l|l|l|}
0850 & 945.899 & 0.64 & 0.79 & 128 & 102 & 93 & 254 & 258 & 47 & 5.5 & 44 \\
\hline
\end{tabular}

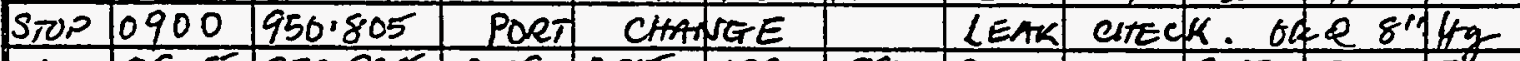

\begin{tabular}{lll|l|l|l|l|l|l|l|l|l|l}
\hline$\omega-1$ & 0905 & 950.895 & 0.68 & 0.85 & 128 & 98 & 93 & 254 & 245 & 53 & 5.5 & 42 \\
\hline
\end{tabular}

\begin{tabular}{ll|l|l|l|l|l|l|l|l|l|l|l|}
0910 & 956.145 & 0.68 & 0.85 & 128 & 100 & 94 & 255 & 261 & 48 & 5.5 & 43
\end{tabular}

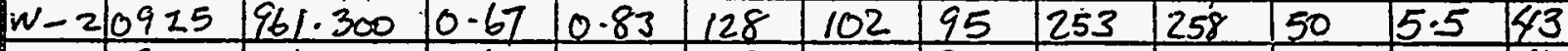

$\begin{array}{lllllllllllllll}0935 & 966.170 & 0.67 & 0.83 & 128 & 104 & 95 & 254 & 256 & 49 & 5.5 & 43\end{array}$

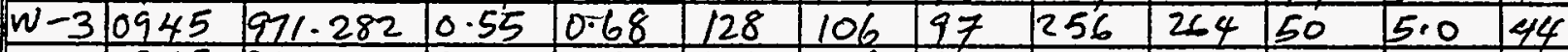

\begin{tabular}{ll|l|l|l|l|l|l|l|l|l|l|l}
0955 & 976.000 & 0.55 & 0.68 & 129 & 106 & 98 & 255 & 257 & 51 & 50 & 45
\end{tabular}

STOP 10059980.819 PORT CHANEE L0.001 LEAK CIFECK. 97

\begin{tabular}{ll|l|l|l|l|l|l|l|l|l|}
\hline$S-11015$ & 980.893 & 0.67 & 0.83 & 128 & 102 & 98 & 254 & 260 & 46
\end{tabular}

\begin{tabular}{l|l|l|l|l|l|l|l|l|l|l|}
1025 & 987.534 & 0.67 & 0.83 & 128 & 103 & 98 & 255 & 253 & 43 \\
\hline
\end{tabular}

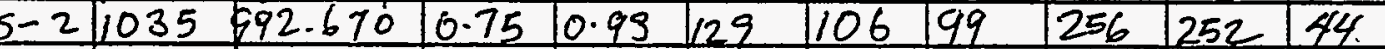

\begin{tabular}{|l|l|l|l|l|l|l|l|l|l|l|l|l|l}
$5-3$ & 1055 & 005.682 & 0.64 & 0.79 & 129 & 111 & 100 & 254 & 251 & 46 & 5.6 & 45
\end{tabular}

tet

END

\begin{tabular}{l|l|l|l|l|l|l|l|l|l|l|l|l|l|}
\hline EN & 110.5 & 010.763 & 0.64 & 0.79 & 129 & 110 & 101 & 253 & 256 & 47. & 5.0 & 45
\end{tabular}
sat 11115

thog Error-WW

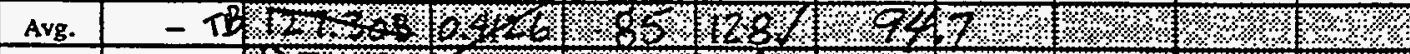

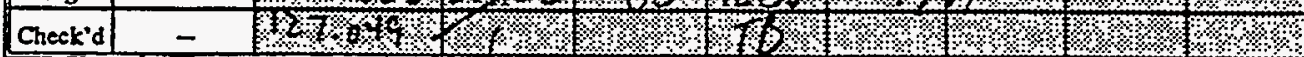

CONSOLE $A 16 \mid 361-0.82^{51}$

FILTER \#

AMBIENT TEMP. $75^{\circ} \mathrm{F}$

PROBE LENGTH $\frac{16^{\prime}}{6^{\prime}}$

LINER MATERIAL GLASS

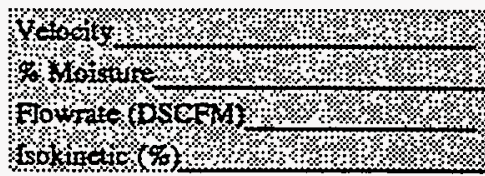

REMARKS

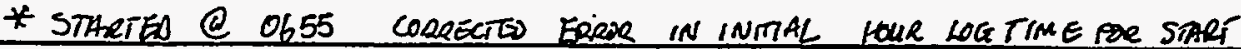

C-102 
MODIFIED iVIETHOD 5 FIELD DATA SHEET

PLANT NAME Plant Yates Station Boiler No. 1

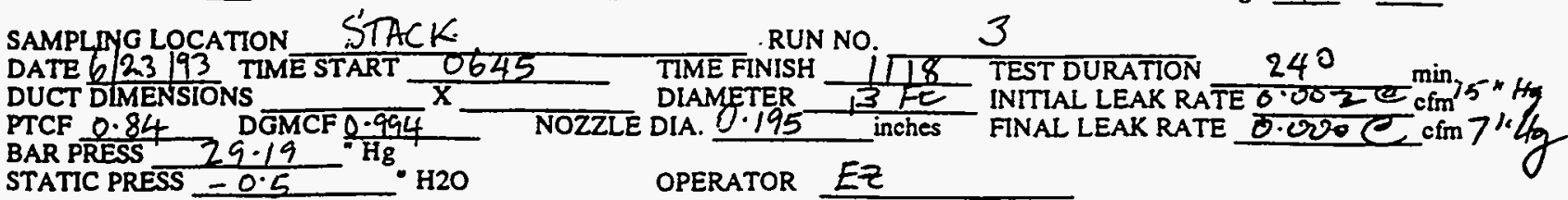

CONSOLE " A16/361

FLTER \#

AMBIENT TEMP. $\frac{77^{\circ} \mathrm{F}}{6^{7}}$

LINER MATERIAL GLASS 1etocits

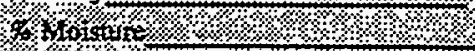

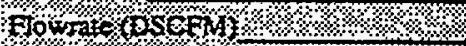

troxintete (6)

REMARKS

N135LE $\#$ 3C $0.195^{*} \cdot \phi^{\circ}$ 


\section{:HCEIFIEI :IETHCD 5 FIELD DATA SHEET}

PLANT NAME Plant Yates Station Boiler No. 1

$$
\text { Page } 1 \text { of } 1
$$

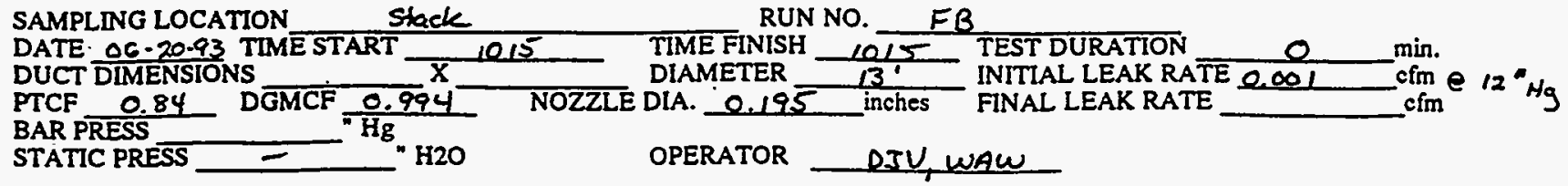

\begin{tabular}{|c|c|c|c|c|c|c|c|c|c|c|c|c|}
\hline \multirow{2}{*}{$\begin{array}{c}\text { Traverse } \\
\text { Point }\end{array}$} & \multirow{2}{*}{$\begin{array}{l}\text { Clock } \\
\text { Time }\end{array}$} & \multirow{2}{*}{$\begin{array}{l}\text { Dry gas meter } \\
\text { resding it } 3\end{array}$} & \multirow{2}{*}{$\begin{array}{l}P \\
\text { in } \mathrm{H} 2 \mathrm{O}\end{array}$} & \multirow{2}{*}{ in $\mathrm{H} 2 \mathrm{O}$} & \multirow{2}{*}{\begin{tabular}{c|} 
Stack \\
Temp. F
\end{tabular}} & \multicolumn{2}{|c|}{ Dry gas meter temp. } & \multirow{2}{*}{$\begin{array}{l}\text { Hot box } \\
\text { Temp. }\end{array}$} & \multirow{2}{*}{$\begin{array}{l}\text { Probe } \\
\text { Temp }\end{array}$} & \multirow{2}{*}{$\begin{array}{c}\text { Last } \\
\text { Impinger }\end{array}$} & \multirow{2}{*}{$\begin{array}{l}\text { Vaculm } \\
\text { in. } \mathrm{Hg}\end{array}$} & \multirow{2}{*}{$\begin{array}{l}\text { Cond. } \\
\text { Exit } \\
\text { Temp. F }\end{array}$} \\
\hline & & & & & & Inlet & Outlet & & & & & \\
\hline - & 1015 & 741.332 & - & - & $=$ & 81 & 80. & 250 & 268 & 25 & - & \\
\hline & & & & & & & & & & & & \\
\hline & & & & & & & & & & & & \\
\hline & & & & & & & & & & & & \\
\hline & & & & & & & & & & & & \\
\hline & & & & & & & & & & & & \\
\hline & & & & & & & & & & & & \\
\hline & & & & & & & & & & & & \\
\hline & & & & & & & & & & & & \\
\hline & & & & & & & & & & & & \\
\hline & & & & & & & & & & & & \\
\hline & & & & & & & & & & & & \\
\hline & . & & & & & & & $=$ & & & & \\
\hline & & & & & & & & & & & & \\
\hline & & & & & & & & & & & & \\
\hline & & & & & & & & & & & & \\
\hline & & & & & & . & & & & & & \\
\hline & & & & & & & & & & & & \\
\hline & & & & & & & & & & & & \\
\hline & & & & & & & & & & & & \\
\hline & & & & & & & & & & & & \\
\hline & & & & & & & & & & & & \\
\hline & & & & & & & & & & & & \\
\hline & & & & & & . & & & & & & \\
\hline & & & & & & & & & & & & \\
\hline & & & & & & & & & & & & \\
\hline & & & & & & & & & & & & \\
\hline & $\cdot$ & & & & & & & & & & & \\
\hline & & & & & & & & & & & & \\
\hline Avg. & - & 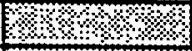 & $6 \times$ & ২४ & $\$ \%$ & ९.\%॰ & \%॰ & $\%$ & \%४\% & $\%$ & ఋ/\% & \%\%! \\
\hline Check'd & - & $1 \%, \quad 1 \% \%$ & 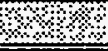 & $3 \% 8 \%$ & \$४४\% & $\$ 1 \%$ & $18 \%$ & 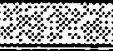 & $1 \%$ & $8 \%$ & \% & \\
\hline
\end{tabular}

CONSOLE \# AIGLISEI

FILTER \# _ -

AMBIENT TEMP. $80+$

PROBE LENGTH $6^{\prime}$

LINER MATERIAL Glass

REMARKS

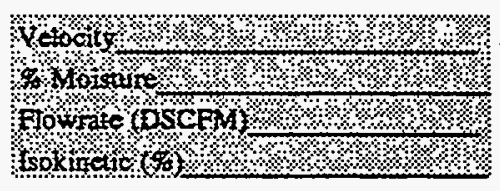


Plant Name

Sampling Locatio

Date .66 .21 .93

Duct Dimensions

PTCF 0.84 DGMCF

Static Press $-0.5 \quad H 2 O$

Plant Yates Station Boiler No. 1

STACK Train

Time Finish

Diameter $\mathrm{X}$ 1340 X
Aldehydes

1408 $13^{\prime}$

inches

ort Test Duration $28 \mathrm{~min}$. Initial Leak Rate 0.001 12 " cfm Final Leak Rate $40.00 i e e^{\prime \prime} \mathrm{cfm}$

\begin{tabular}{|c|c|c|c|c|c|c|c|c|c|c|c|c|}
\hline Travers & Clock & Dry gas meter & $-P$ & ${ }^{*} \mathrm{H}$ & Stack & Dry gas m & ter temp. & Hot box & Probe & Last & Vacuum & \\
\hline Point & Time & reading $\mathrm{ft} 3$ & in $\mathrm{H} 2 \mathrm{O}$ & in $\mathrm{H} 2 \mathrm{O}$ & Temp. F & Inlet & Outlet & Temp. & Temp & Impinger & in. $\mathrm{Hg}$ & \\
\hline$N-1$ & 1346 & 571.567 & 0.59 & 0.46 & 128 & 79 & 78 & 257 & 265 & 74 & 2.0 & \\
\hline$N-1$ & 1356 & 577,286 & 0.59 & 0.46 & 128 & 83 & 80 & 256 & 261 & 59 & 2.0 & \\
\hline$N-1$ & 1404 & 580.260 & 0.59 & 0.46 & 126 & 85 & 81 & 361 & 265 & 57 & 3.6 & \\
\hline Step & 1408 & 582.274 & & & & & & & & & & \\
\hline & & & & & & & & & & & & \\
\hline & & & & & & & & & & & & \\
\hline & & & & & & & & & & & & \\
\hline & & & & & & & & & & & & \\
\hline & & & & & & & & & & & & \\
\hline & & & & & & & & & & & & \\
\hline & & & & & & & & & & & & \\
\hline & & & & & & & & & & & & \\
\hline & & & & & & & & & & & & \\
\hline & & & & & & & & & & & & \\
\hline & & & & & & & & & & & & \\
\hline & & & & & & & & & & & & \\
\hline & & & & & & & & & & & & \\
\hline & & & & & & & & & & & & \\
\hline & & & & & & & & & & & & \\
\hline & & & & & & & & & & & & \\
\hline & & & & & & & & & & & & \\
\hline & & & & & & & & & & & & \\
\hline & & & & & & & & & & & & \\
\hline & & & & & & & & & & & & \\
\hline & & & & & & & & & & & & \\
\hline & & & & & & & & & & & & \\
\hline & & & & & & & & & & & & \\
\hline & & & $\overline{\pi P}$ & & & & & & & & & \\
\hline Avg. & - & 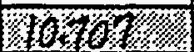 & Oathy & \%) & 31 & 1058 & $80 \%$ & X/\% & 91 & & পে & $8 \times$ \\
\hline Check'd & $1 /$ & $10470 \%$ & $\%$ & 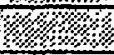 & & 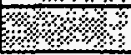 & औ/ $/ 4$ & $\% \%$ & & & 18 & $\%$ \\
\hline
\end{tabular}

CONSOLE \#_A161362

FILTER \# NA

AMBIENT TEMP. 구가

PROBE LENGTH $6 c^{\prime}$

LINER MATERIAL GlasS

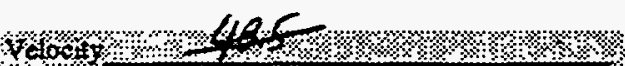

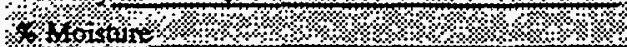

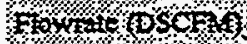

130knosoto 
Plant Name

Sampling Location STAEK

Date $06-22-93$ Time Start

Duct Dimensions

PTCF 0.84 DGMCF L.006 Nozzle Dia. 0.1747 inches

Bar Press 29.34" $\mathrm{Hg}$

Static Press -0.5 " H2O

Clock

Trave:

Point Time

Poir

lant Yates Station Boiler No. 1
Train

Time Finis

Diameter

Operator

D.TV

Aldehydes

Run No. 2

Final Leak Rates 0.00107 "cfm

13 it Initial Leak Rate 0.000 cfm $017^{\circ}$

$\mu=0.7753$

\begin{tabular}{|c|c|c|c|c|c|c|c|c|c|c|c|}
\hline Trave: & Clock & Dry gas meter & $\wedge \mathrm{P}$ & $\sim \mathrm{H}$ & Stack & Dry gas & er temp. & Hot box & Probe & Last & Vacuum \\
\hline Point & Time & reading ft3 & in $\mathrm{H} 2 \mathrm{O}$ & in $\mathrm{H} 2 \mathrm{O}$ & Temp. F & Inlet & Outlet & Temp. & Temp & Impinger & in. $\mathrm{Hg}$ \\
\hline$w-1$ & 0715 & 591.804 & 0.59 & 0.45 & 131 & 78 & 77 & 251 & 263 & 75 & 2.0 \\
\hline & Ler2x & 595,160 & 0.59 & 0.45 & 133 & 83 & 79 & 287 & 363 & 56 & 2.0 \\
\hline & Heszal & 597,715 & 0.59 & 0.45 & 133 & 85 & 80 & 257 & 26,5 & 56 & 3.6 \\
\hline & 0739 & 600.660 & $0.5 q$ & 0.45 & 133 & 88 & 82 & 264 & 259 & 58 & 2.0 \\
\hline & 0745 & 602.890 & & & & & & & & & \\
\hline & & & & & & & & & & & \\
\hline
\end{tabular}

\begin{tabular}{|l|l|l|l|l|l|l|l|l|}
\hline & & & & & & & & \\
\hline & & & & & & & & \\
\hline & & & & & & & &
\end{tabular}

\begin{tabular}{|l|l|l|l|l|l|l|l|l|l|l|l|}
\hline & & & & & & & & & & & \\
\hline & & & & & & & & & & & \\
\hline
\end{tabular}

\section{CONSOLE \# A16/362}

FLLTER * NA

AMBIENT TEMP. 70+

PROBE LENGTH $c^{\prime}$

LINER MATERIAL GlaSS

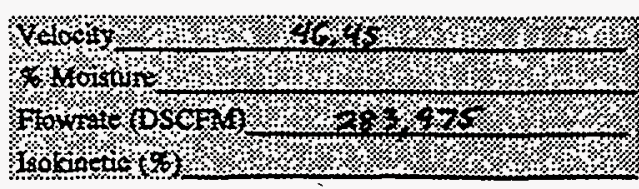
Stroisturi

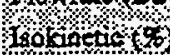

REMARKS

Single Pt.

All Times coT

C-106 
Plant Name Plant Yates Station Boiler No. 1

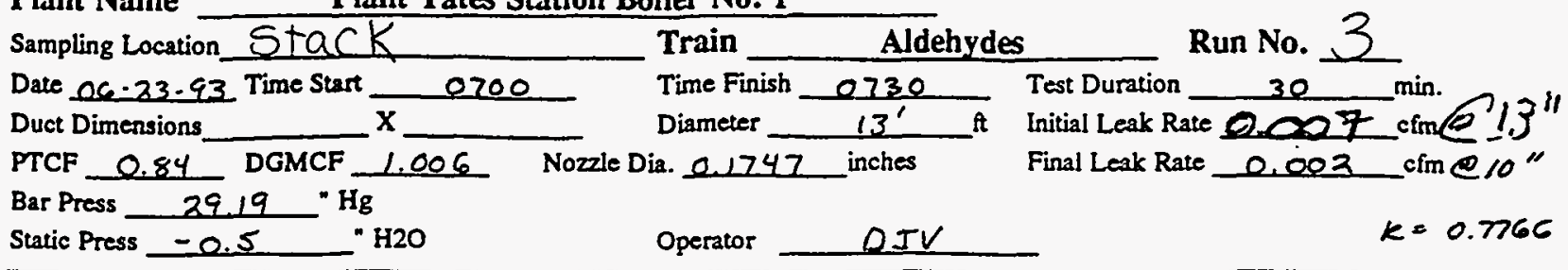

\begin{tabular}{|c|c|c|c|c|c|c|c|c|c|c|c|c|}
\hline Travers & Clock & Dry gas meter & $\wedge \mathbf{P}$ & ${ }^{\wedge} \mathrm{H}$ & $\begin{array}{l}\text { Stack } \\
\end{array}$ & Dry gas m & ter temp. & Hot box & Probe & Last & Vacuum & \\
\hline Point & Time & reading t 3 & in $\mathrm{H} 2 \mathrm{O}$ & in $\mathrm{H} 2 \mathrm{O}$ & Temp. F & Inlet & Outlet & Temp. & Temp & Impinger & in. $\mathrm{Hg}$ & \\
\hline$w-1$ & 0700 & 616.602 & 0.56 & 0.43 & 130 & 29 & 36 & 262 & 258 & 6.5 & 2.0 & \\
\hline & 0205 & 618.425 & 0.56 & 0.43 & 130 & 79 & 76 & 261 & 255 & 55 & 2.0 & \\
\hline & 0710 & 620.255 & 0.56 & 0.43 & 131 & 80 & 77 & 259 & 258 & 56 & 2.0 & \\
\hline & 0715 & 622.020 & 0.56 & 0.43 & 130 & 83 & 78 & 259 & 260 & 57 & 2.0 & \\
\hline & 0730 & 6.23 .895 & 0.55 & 0.43 & 131 & 83 & 28 & 260 & 257 & 57 & 2.0 & \\
\hline & 0725 & 625710 & 0.55 & 0.43 & 131 & 86 & 80 & 262 & 2.58 & 57 & 2.0 & \\
\hline Stop & 0230 & 627.531 & & & & & & & & & & \\
\hline & & & & & & & & & & & & \\
\hline & & & & & & & & & & & & \\
\hline & & & & & & & & & & & & \\
\hline & & & & & & & & & & & & \\
\hline & & & & & & & & & & & & \\
\hline & & & & & & & & & & & & \\
\hline & & & & & & & & & & & & \\
\hline & & & & & & & & & & & & \\
\hline & & & & & & & & & & & & \\
\hline & & & & & & & & & & & & \\
\hline & & & & & & & & & & & & \\
\hline & & & & & & & & & & & & \\
\hline & & & & & & & & & & & & \\
\hline & & & & & & & & & & & & \\
\hline & & & & & & & & & & & & \\
\hline & & & & & & & & & & & & \\
\hline & & & & & & & & & & & & \\
\hline & & & & & & & & & & & & \\
\hline & & & & & & & & & & & & \\
\hline & & & & & & & & & & & & \\
\hline & & & & & & & & & & & & \\
\hline Avg. & - & 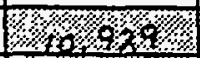 & O.3. & $\%$ & $4 \times 0,8$ & $\% \% / 2$ & $6 \% \%$ & $8 \%$ & ४४, & 8 & & \\
\hline Check'd & & $3 \% 1 / 248$ & $\% \% / \%$ & \% & $\% 1 \%$ & $1 \% \%$ & $1 \% \%$ & $1 \%$ & 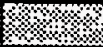 & 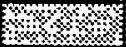 & & \& \\
\hline
\end{tabular}

CONSOLE H A161362

FILTER $\#$ AMBIENT TEMP. $\frac{70+}{6}$
PROBE LENGTH $\frac{6}{2}$
LINER MATERIAL

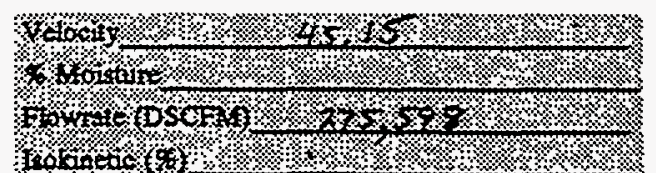

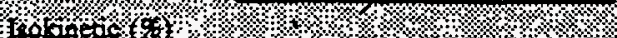


Plant Name

Plant Yates Station Boiler No. 1

\begin{tabular}{|c|c|c|c|c|c|c|c|c|c|c|c|c|}
\hline \multicolumn{5}{|c|}{$\begin{array}{l}\text { Plant Name } \\
\text { Sampling Location Stack }\end{array}$} & \multirow{5}{*}{\multicolumn{3}{|c|}{$\begin{array}{l}\text { Train } \\
\text { Time Finish } \frac{132159}{130} \\
\text { Diameter } \frac{\text { Aldehydes }}{\text { inches }} \\
\text { Operator JEAt }\end{array}$}} & & & & \\
\hline \multicolumn{5}{|c|}{ 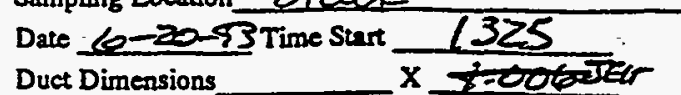 } & & & & \multirow{3}{*}{\multicolumn{5}{|c|}{ 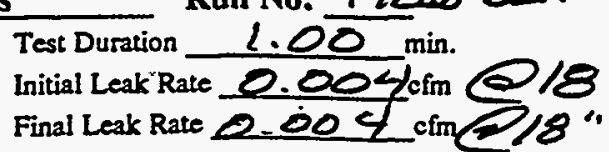 }} \\
\hline \multirow{2}{*}{\multicolumn{2}{|c|}{$\begin{array}{l}\text { PTCF }=.84 \\
\text { Bar Press 2S. }\end{array}$}} & \multirow{2}{*}{\multicolumn{2}{|c|}{ DGMCF 1.006}} & \multirow[t]{2}{*}{ Nozzie Dia. _ } & & & & & & & & \\
\hline & & & & & & & & & & & & \\
\hline \multicolumn{5}{|c|}{ Static Press $=0.51$} & & & & & & & & \\
\hline \multirow{2}{*}{$\begin{array}{c}\text { Travers } \\
\text { Point }\end{array}$} & \multirow{2}{*}{$\begin{array}{l}\text { Clock } \\
\text { Time }\end{array}$} & \multirow{2}{*}{\begin{tabular}{|c|} 
Dry gas meter \\
reading ft?
\end{tabular}} & \multirow{2}{*}{ in $\mathrm{H} 2 \mathrm{O}$} & \multirow{2}{*}{ in $\mathrm{H} 2 \mathrm{O}$} & \multicolumn{3}{|c|}{ Stack Dry gas meter temp. } & \multirow{2}{*}{$\begin{array}{c}\text { Hot box } \\
\text { Temp. }\end{array}$} & \multirow{2}{*}{$\begin{array}{l}\text { Probe } \\
\text { Temp }\end{array}$} & \multirow{2}{*}{\begin{tabular}{|c|} 
Last \\
Impinger
\end{tabular}} & Vacuum & \\
\hline & & & & & Temp. F & Inlet & Outles & & & & in. $\mathrm{Hg}$ & \\
\hline state & 1326 & 563.880 & & & & & & & & & 18 & \\
\hline Stop & $B 29$ & 564.932 & & & & & & & & & & \\
\hline & & & & & & & & & & & & \\
\hline & & & & - & & & & & & & & \\
\hline & & & & & & & & & & & & \\
\hline & & & & & & & & & & & & \\
\hline & & & & & & & & & & & & \\
\hline & & & & & & & & & & & & \\
\hline & & & & & & & & & & & & \\
\hline & & & & & & & & & & & & \\
\hline & & & & & & & & & & & & \\
\hline & & & & & & & & & & & & \\
\hline & & & & & & & & & & & & \\
\hline & & & & & & & & & & & & \\
\hline & & & & & & & & & & & & \\
\hline & & & & & & & & & & & & \\
\hline & & & & & & & & & & & & \\
\hline & & & & & & & & & & & & \\
\hline & & & & & & & & & & & & \\
\hline & & & & & & & & & & & & \\
\hline & & & & & & & & & & & & \\
\hline & & & & & & & & & & & & \\
\hline & & & & & & & & & & & & \\
\hline & & & & & & & & & & & & \\
\hline & & & & & & & & & & & & \\
\hline & & & & & & & & & & & & \\
\hline & & & & & & & & & & & & \\
\hline & & & & & . & & & & & & & \\
\hline Avg. & - & \%.\%०४ & $18 \%$ & 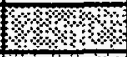 & $8 \% \%$ & $1 \% \%$ & 6.8 & $8 \%$ & ४४. & $5 \%$ & 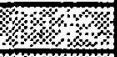 & $\$$ \\
\hline Check'd d & & $14.4 .8 \%$ & 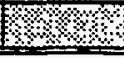 & $1.4 \%$ & $\$$ & 80. & 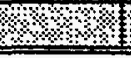 & $4 \times 18$. & 14.8 & 48 & ४ৃ\%: & (1) \\
\hline CONSOL & $E \#$ & $416136=$ & & & & 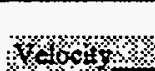 & 3. & $\%$ & \% & 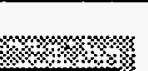 & & \\
\hline FILTER & 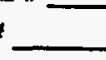 & $\longrightarrow$ & & & & 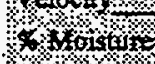 & ४४४४ & 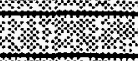 & 4 & ४. & & \\
\hline AMBIEN & T TEMP. & - & & & & $170,7=140$ & 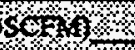 & \% \% & 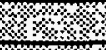 & \%० \% & & \\
\hline PROBE L & ENGTH & $88^{\circ} \mathrm{F}$ & & & & $180+0404$ & (6) & 2 & $\%$ & $4 \%$ & & \\
\hline LINER $\mathrm{M}$ & ATERIA & & & & & & & & & & & \\
\hline REMAR: & & $0<42-1$ & $1 k-$ & & & & & & & & & \\
\hline
\end{tabular}


WUEK $\delta / 221$ SOLRCE SAMPLING FIELD DATA SHEE:

$$
\text { Page } L_{\text {of }} L_{2}
$$

Plant Name

Plant Yates Station Boiler No. 1

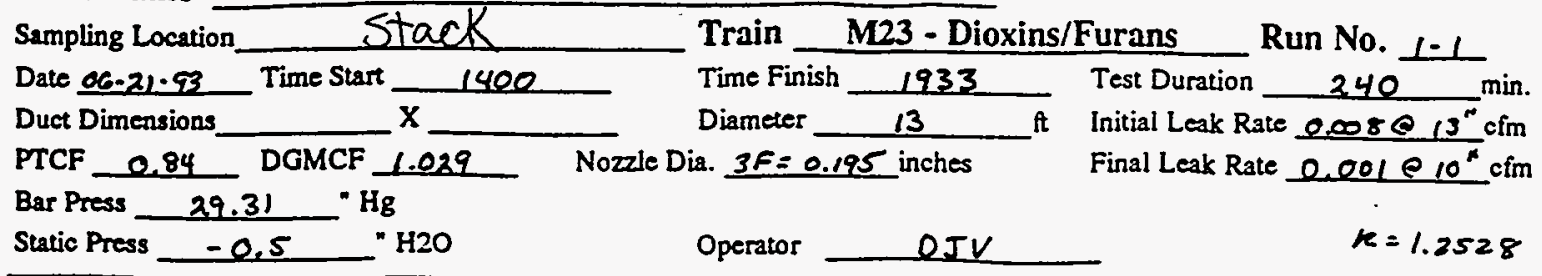

\begin{tabular}{|c|c|c|c|c|c|c|c|c|c|c|c|c|}
\hline \multirow{2}{*}{$\begin{array}{c}\text { Travers } \\
\text { Point }\end{array}$} & \multirow{2}{*}{$\begin{array}{l}\text { Clock } \\
\text { Time }\end{array}$} & \multirow{2}{*}{$\begin{array}{l}\text { Dry gas meter } \\
\text { reading ft3 }\end{array}$} & \multirow{2}{*}{$\begin{array}{c}\text { A P } \\
\text { in } \mathrm{H} 2 \mathrm{O}\end{array}$} & \multirow{2}{*}{$\begin{array}{c}\wedge \mathrm{H} \\
\text { in } \mathrm{H} 2 \mathrm{O}\end{array}$} & \multirow{2}{*}{$\begin{array}{c}\text { Stack } \\
\text { Temp. F }\end{array}$} & \multicolumn{2}{|c|}{ Dry gas meter temp. } & \multirow{2}{*}{$\begin{array}{l}\text { Hot box } \\
\text { Temp. }\end{array}$} & \multirow{2}{*}{$\begin{array}{l}\text { Probe } \\
\text { Temp }\end{array}$} & \multirow{2}{*}{\begin{tabular}{|c|} 
Last \\
Impinger
\end{tabular}} & \multirow{2}{*}{$\begin{array}{c}\text { Vacuum } \\
\text { in. } \mathrm{Hg}\end{array}$} & \multirow{2}{*}{$\begin{array}{l}\text { cond } \\
\text { out }\end{array}$} \\
\hline & & & & & & Inlet & Outlet & & & & & \\
\hline \multirow[t]{2}{*}{$E-1$} & 1400 & 678.367 & 0.67 & 0.84 & 122 & 68 & 67 & 254 & 243 & 56 & 5.0 & 58 \\
\hline & 1410 & 683.005 & 0.67 & 0.84 & 122 & 21 & 68 & 257 & 347 & 42 & 5.0 & 53 \\
\hline \multirow[t]{2}{*}{$\varepsilon \cdot 2$} & 1420 & 687.810 & 0.68 & 0.85 & 122 & 73 & 69 & 256 & 245 & 43 & 5.0 & 48 \\
\hline & 1430 & 692.705 & 0.67 & 0.84 & 123 & 27 & 72 & 357 & 256 & 42 & 50 & 5 \\
\hline \multirow[t]{2}{*}{$E \cdot 3$} & 1440 & 697.585 & 0.56 & 0.70 & 123 & 79 & 74 & 257 & $25 C$ & 45 & 4.5 & 61 \\
\hline & 1450 & 702.055 & 0.56 & 0.70 & ay & 84 & 28 & 259 & 243 & 48 & 4.5 & 52 \\
\hline \multirow{3}{*}{$\begin{array}{l}\text { Stop } \\
\mathrm{N}-1\end{array}$} & 1500 & 706.556 & & Leak ek & 0.001 & e $10^{\prime \prime}$ & & & & & & \\
\hline & 1505 & 200.678 & 0.70 & 0.88 & 123 & 80 & 28 & 256 & 241 & 58 & 5.0 & 55 \\
\hline & 1515 & 211.665 & 0.67 & 0.84 & 122 & 83 & 78 & 253 & 241 & 45 & 5.0 & 21 \\
\hline \multirow[t]{2}{*}{$N \cdot 2$} & 1525 & 716.625 & 0,70 & 0.88 & 122 & 84 & 79 & 259 & 242 & 44 & 5.0 & 48 \\
\hline & 1535 & 721.685 & 0.70 & 0.88 & 123 & 86 & 81 & 262 & 244 & 46 & 5.0 & 49 \\
\hline \multirow[t]{2}{*}{$N-3$} & 1545 & 726.650 & 0.59 & 0.74 & 124 & 90 & 83 & 260 & 247 & 47 & 4,5 & 50 \\
\hline & 1555 & 231,290 & 0.59 & 0.74 & 123 & 89 & 83 & 258 & 248 & 46 & 4.5 & 50 \\
\hline \multirow{3}{*}{$\begin{array}{l}\text { Stop } \\
\omega-1\end{array}$} & 1605 & 735,924 & & logk & $e t$ & 0 & 20 & 51 & & & & \\
\hline & 1720 & 736.028 & 0.62 & 0.78 & 127 & 80 & 79 & 250 & 245 & 60 & 5.0 & 57 \\
\hline & 1730 & 741.950 & 0.62 & 0.28 & 126 & 80 & 78 & 255 & 250 & 40 & 5.0 & 50 \\
\hline \multirow[t]{2}{*}{$w-2$} & 1740 & 745.415 & 0.62 & 0.78 & 124 & 83 & 80 & X57 & 247 & 42 & 5.0 & 52 \\
\hline & 1752 & 751.100 & 0.62 & 0.78 & 134 & 86 & 82 & 257 & 248 & 40 & 5.0 & 49 \\
\hline \multirow[t]{2}{*}{$w-3$} & 1800 & 254,870 & 0.50 & 0.62 & 124 & 86 & 82 & 261 & 256 & 42 & 4.5 & 50 \\
\hline & 1810 & 759145 & 0.51 & 0.63 & 124 & 86 & 81 & 245 & 252 & 43 & $4: 5$ & 50 \\
\hline \multirow{3}{*}{$\begin{array}{l}s \text { spp } \\
s-1\end{array}$} & 1820 & 763,481 & & leak & Le e & 0.0 & e, & 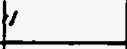 & & & & \\
\hline & $\lcm{1833}$ & 763.538 & 0.68 & 0.85 & 122 & 81 & 80 & 251 & 248 & 58 & 5.0 & 57 \\
\hline & 1843 & 268.505 & 0.70 & 0.88 & 122 & 83 & 80 & 250 & 257 & 42 & 5.5 & 50 \\
\hline \multirow[t]{2}{*}{$s-2$} & 1853 & 773.555 & 0.71 & 0.88 & 123 & 87 & 82 & 254 & $2 \neq 6$ & 47 & 5.5 & 52 \\
\hline & 1903 & 278.630 & 0.71 & 0.88 & 123 & 89 & 83 & 254 & 261 & 47 & 5.5 & 52 \\
\hline \multirow[t]{3}{*}{$5-3$} & 19,13 & 783.720 & 0.59 & 0.74 & 124 & 90 & 84 & 254 & 264 & 47 & 5.5 & 51 \\
\hline & 1923 & 788:405 & 0.59 & 0.74 & 124 & 90 & 84 & 343 & 251 & 48 & 5.5 & 52 \\
\hline & 1933 & 793.092 & & & & & & & & & & \\
\hline Avg. & 二 & 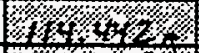 & 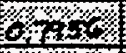 & 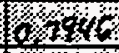 & $1,33,3$. & $18 \% 80$ & 83 & $\%$ & $8 \%$ & 188 & $18 \%$ & 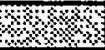 \\
\hline Check'd & & 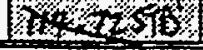 & (6) & & 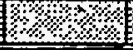 & $18 \%$ & 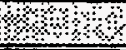 & $1 \% \%$ & 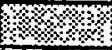 & $4 \%$ & \% ४ & 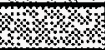 \\
\hline CONSOL & LE $\#$ & $161394^{C}$ & & & & Xes & 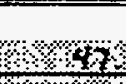 & 10 & 4 & 4 & & \\
\hline FILTER & & NA & & & & 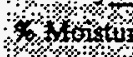 & $80 \%$ & $\%$ & $8 \%$ & 88 & & \\
\hline AMBIEN & $\begin{array}{l}\text { VT TEMP. } \\
\text { LENGTH }\end{array}$ & $\frac{70^{\prime}}{5^{\prime}}$ & & & & Howrate & $(\mathrm{Craf})$ & 2,3 & $3 x_{2}$ & 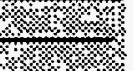 & & \\
\hline NER & MATER & r & & & & & & & & & & \\
\hline
\end{tabular}

REMARKS

All Times, CDT 
Plant Name

Plant Yates Station Boiler No. 1

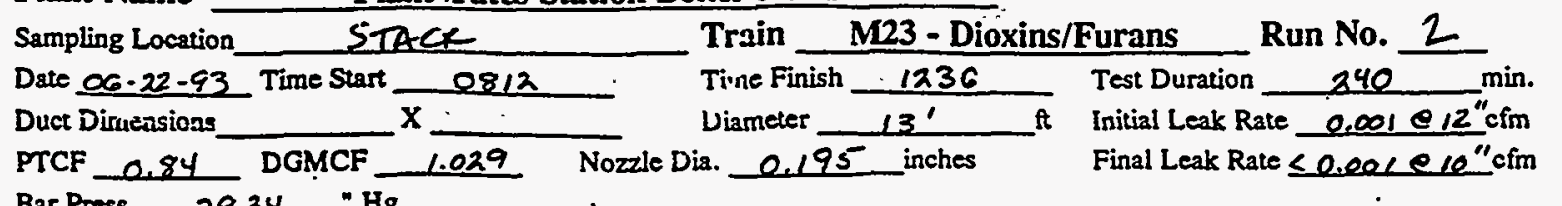
Bar Press 29.34 $\mathrm{Hg}$

Static Press $-0.5 \quad$. H2O

Operator

OJV

1.2352

\begin{tabular}{|c|c|c|c|c|c|c|c|c|c|c|c|c|}
\hline \multirow{2}{*}{$\begin{array}{c}\text { Travers } \\
\text { Point }\end{array}$} & \multirow{2}{*}{$\begin{array}{l}\text { Clock } \\
\text { Time }\end{array}$} & \multirow{2}{*}{$\begin{array}{c}\text { Dry gas meter } \\
\text { reading t3 } 3\end{array}$} & \multirow{2}{*}{$\begin{array}{c}\text { A } \\
\text { in } \mathrm{H} 2 \mathrm{O}\end{array}$} & \multirow{2}{*}{$\begin{array}{c}\mathrm{H} \\
\text { in } \mathrm{H} 2 \mathrm{O}\end{array}$} & \multirow{2}{*}{$\begin{array}{c}\text { Stack } \\
\text { Temp. } F\end{array}$} & \multicolumn{2}{|c|}{ Dry gas, meter temp. } & \multirow{2}{*}{$\begin{array}{l}\text { Hot box } \\
\text { Temp. }\end{array}$} & \multirow{2}{*}{$\begin{array}{l}\text { Probe } \\
\text { Temp }\end{array}$} & \multirow{2}{*}{$\begin{array}{c}\text { Last } \\
\text { Impinger }\end{array}$} & \multirow{2}{*}{$\begin{array}{l}\text { Vacuum } \\
\text { in. } \mathrm{Hg}\end{array}$} & \multirow{2}{*}{$\begin{array}{l}\text { cond } \\
\text { out }\end{array}$} \\
\hline & & & & & & Inlet. & Outlet & & & & & \\
\hline F.1 & 0812 & 809.159 & 0.73 & 0.90 & 127 & 72 & 71 & 248 & 253 & 65 & 5.0 & 61 \\
\hline & 0822 & 814.180 & 0.73 & 0.90 & 128 & 76 & 72 & 251 & 245 & 43 & 5.0 & 49 \\
\hline$E-2$ & 0832 & 819185 & 072 & 0.89 & 129 & 80 & 74 & 250 & 256 & 45 & 5.0 & 48 \\
\hline & 0842 & 824.240 & 0.72 & 0.89 & 129 & 82 & 76 & 252 & 249 & 41 & 5.0 & 49 \\
\hline$E-3$ & 0852 & 829255 & 0.64 & 0.79 & 129 & 84 & 78 & 251 & 253 & 44 & 5.0 & 51 \\
\hline & 0902 & 834.030 & 0.64 & 0.79 & 130 & 87 & 81 & 253 & 294 & 46 & 5.0 & 51 \\
\hline stop & 0912 & 838.804 & & & leok & et $=$ & $<0.001$ & e 10 & $H_{3}$ & & & \\
\hline$N-1$ & 0917 & 838.817 & 0.75 & 0.93 & 128 & 83 & 81 & 254 & 252 & 55 & 5,5 & 59 \\
\hline & 0927 & 844.050 & 0.35 & 0.93 & 129 & 82 & 82 & 252 & 242 & 43 & 5.5 & 52 \\
\hline$n-2$ & 0932 & 849.240 & 0.73 & 0.90 & 129 & 88 & 82 & 252 & 248 & 45 & 5.5 & 51 \\
\hline & 0947 & 854.465 & 0.73 & 0.90 & 128 & 90 & 84 & 253 & 251 & 46 & 5.5 & 51 \\
\hline$N-3$ & 0957 & 859.590 & 0.57 & 0.70 & 130 & 93 & 87 & $2 \sqrt{3}$ & 243 & 48 & 5,0 & 50 \\
\hline & 1007 & 864.165 & 0.57 & 0.70 & 130 & 94 & 88 & 355 & 243 & 46 & 5.0 & 49 \\
\hline stop & 1017 & 868.758 & & & look & ek: & 60.001 & e 10 & " $\mathrm{Hg}$ & & & \\
\hline$w-1$ & 1026 & 868.812 & 0.68 & 0.84 & 130 & 89 & 87 & 255 & 242 & $5 \dot{5}$ & 5.5 & $5 \%$ \\
\hline & 1037 & $874 \quad 365$ & 0.68 & 0.84 & 128 & 90 & 87 & 252 & 251 & 42 & 5.5 & 52 \\
\hline$w-2$ & 1047 & 879.200 & 0.64 & 0.79 & 129 & 92 & 88 & 254 & 250 & 44 & 5.0 & 50 \\
\hline & 1057 & 884.185 & 0.64 & 0.79 & 128 & 92 & 88 & 252 & 248 & 45 & 5.0 & 49 \\
\hline$\omega-3$ & 1107 & 888.940 & 0.54 & 0.67 & 128 & 93 & 89 & 252 & 2433 & 47 & 50 & 49 \\
\hline & 1117 & 893.445 & 0.54 & 0.67 & 129 & 94 & 90 & 254 & 265 & 47 & 5.0 & 50 \\
\hline Stap & 1127 & 897948 & & & leak & $c k=$ & $\leq 0.001$ & 0,12 & " $\mathrm{Atg}$ & & & \\
\hline$s-1$ & 1136 & 898.035 & 0.70 & 0.86 & 127 & 93 & 90 & 252 & 255 & 50 & 5.5 & 51 \\
\hline & 1146 & 903,140 & 0.30 & 0.86 & 128 & 94 & 90 & 252 & 248 & 46 & 5.5 & 49 \\
\hline$s-2$ & 1156 & 908,165 & 0.70 & 2.86 & 122 & 95 & 91 & 257 & 242 & 46 & 5.5 & 49 \\
\hline & 1206 & 913.280 & 0.71 & 0.88 & 126 & 95. & $q 1$ & $25^{2}$ & 266 & 43 & 5.5 & 48 \\
\hline $5-3$ & 1216 & 918,405 & 0.57 & 0.70 & $127^{\circ}$ & 98 & 93 & 355 & 257 & 45 & 5.0 & 48 \\
\hline & 1226 & 923.040 & 0.57 & $0>0$ & 127 & 97 & 93 & 253 & 263 & 48 & 6.0 & 60 \\
\hline Ead & 1236 & 927. & & & & & & & & & & \\
\hline Avg. & $=$ & $1,1 \%$ & $3,3,340$ & 080,800 & $1,6,3$ & $2 \%, \%$ & $\% \%$ & $8 \%$ & & $1 \% \%$ & 28. & $\%$ \\
\hline Check'd & & $6 \times 8,14$ & 18 & $19 \times 3$ & 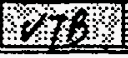 & $8 \%$ & $18 \%$ & 18 & $1 \%$ & $18 \%$ & ষষষ & $6 \%$ \\
\hline
\end{tabular}

CONSOLE " A $\quad$ A 161394

FLTER *

AMBIENT TEMP.

PROBE LENGTH

LINER MATERIAL

$70+$

$5^{1}$

Glass

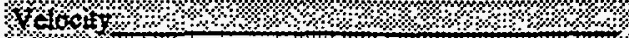

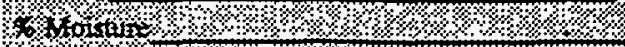

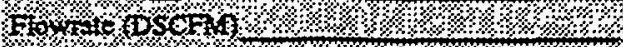

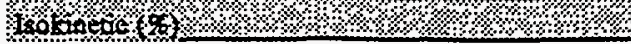

REMARKS

All Trover CDT 
Plant Name Plant Yates Station Boiler No. 1

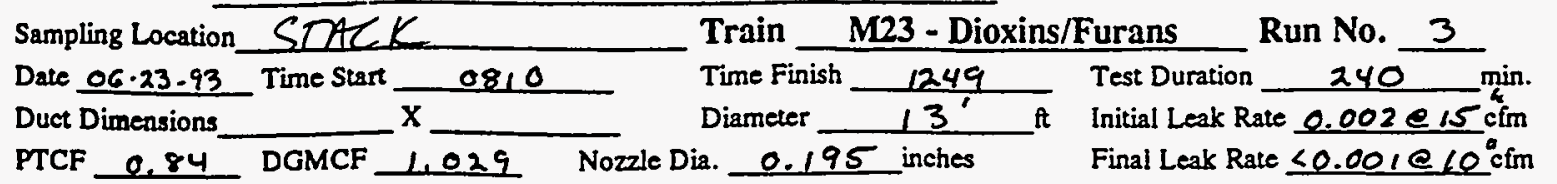
Bar Press $29.19 \cdot \mathrm{Hg}$ Static Press $-0.5=\mathrm{H} 2 \mathrm{O}$ Operator DJV 1,2420

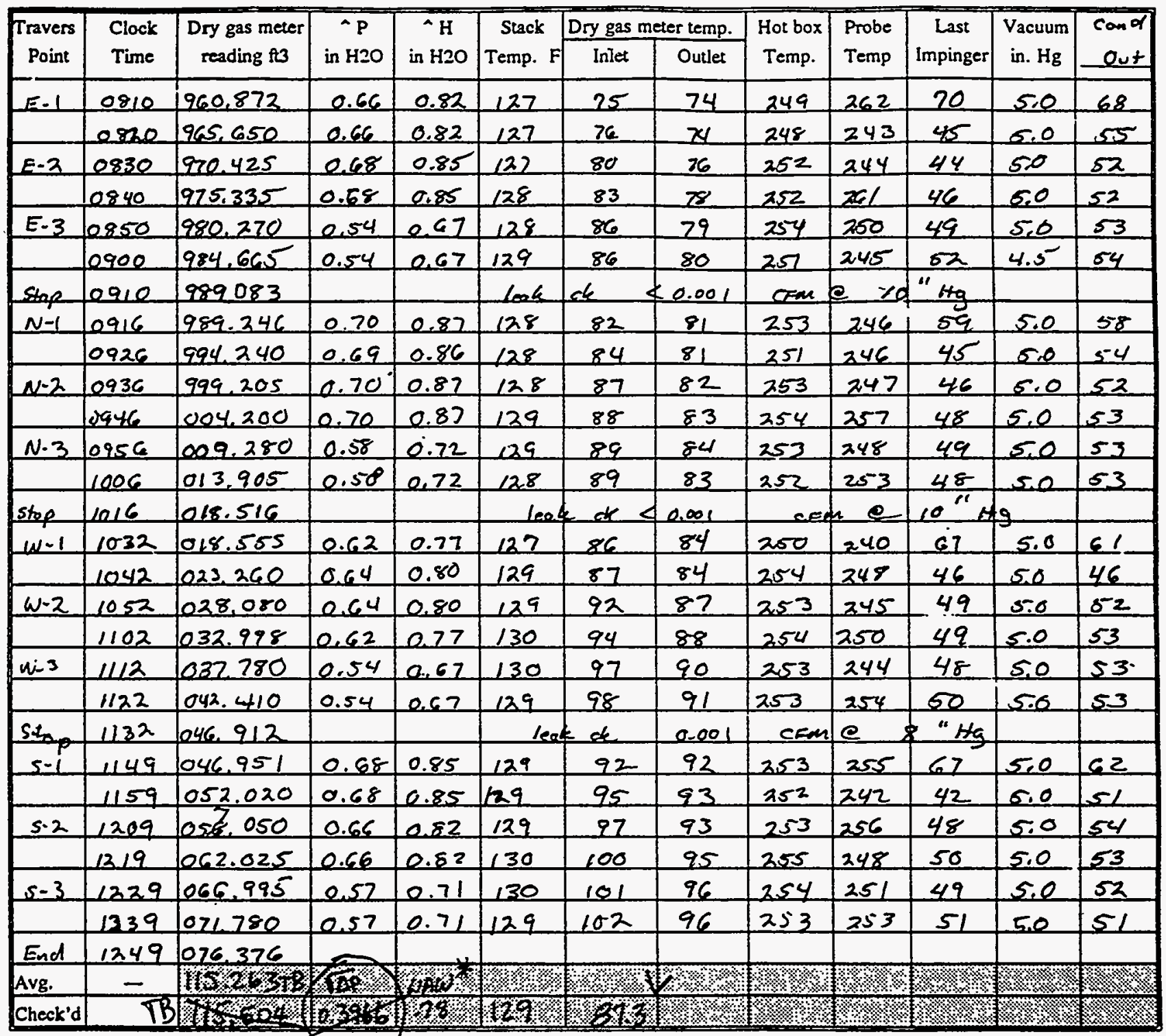

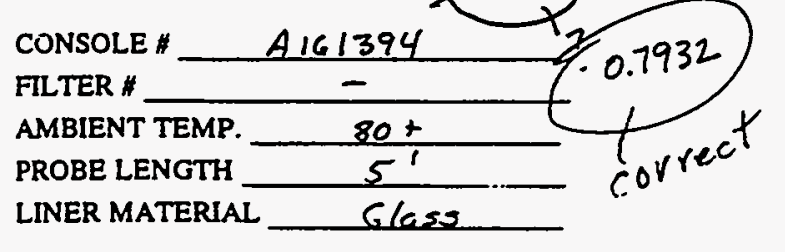


SOLRCE SAIIPLIYG FIELD DATA SHEET

Page ___ of ___

Plant Name

Plant Yates Station Boiler No. 1

Sampling Location stack

Train M23-Dioxins/Furans Run No. FB

Date or:20-93 Time Start

Time Finish 1037

Diameter $13^{\prime}$ f

Duct Dimensions 1032

PTCF 0.84 DGMCF 1.029 Nozzle Dia. 0.195 inches

Test Duration

min.

Bar Press _.29,36 $\mathrm{Hg}$

Static Press _ _ H2O Operator DTV,WAW

\begin{tabular}{|c|c|c|c|c|c|c|c|c|c|c|c|c|}
\hline \multirow{2}{*}{$\begin{array}{c}\text { Travers } \\
\text { Point }\end{array}$} & \multirow{2}{*}{$\begin{array}{l}\text { Clock } \\
\text { Time }\end{array}$} & \multirow{2}{*}{$\begin{array}{c}\text { Dry gas meter } \\
\text { reading } \mathrm{ft} 3\end{array}$} & \multirow{2}{*}{$\begin{array}{l}\text { P } \\
\text { in } H 20\end{array}$} & \multirow{2}{*}{$\begin{array}{c}{ }^{\wedge} \mathrm{H} \\
\text { in } \mathrm{H} 2 \mathrm{O}\end{array}$} & \multirow{2}{*}{\begin{tabular}{|c|} 
Stack \\
Temp. F
\end{tabular}} & \multicolumn{2}{|c|}{ Dry gas meter temp. } & \multirow{2}{*}{$\begin{array}{l}\text { Hot box } \\
\text { Temp. }\end{array}$} & \multirow{2}{*}{$\begin{array}{l}\text { Probe } \\
\text { Temp }\end{array}$} & \multirow{2}{*}{$\begin{array}{c}\text { Last } \\
\text { Impinger }\end{array}$} & \multirow{2}{*}{$\begin{array}{l}\text { Vacuum } \\
\text { in. } \mathrm{Hg}\end{array}$} & \multirow{2}{*}{ 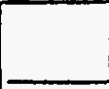 } \\
\hline & & & & & & Inlet & Outlet & & & & & \\
\hline - & 1037 & 661.294 & $=$ & - & - & 80 & 79 & 254 & 251 & 84 & - & - \\
\hline & & & & & & & & & & & & \\
\hline & & & & & & & & & & & & \\
\hline & & & & & & & & & & & & \\
\hline & & & & & & & & & & & & \\
\hline & & & & & & & & & & & & \\
\hline & & & & & & & & & & & & \\
\hline & & & & & & & & & & & & \\
\hline & & & & & & & & & & & & \\
\hline & & & & & & & & & & & & \\
\hline & & & & . & & & & & & & & \\
\hline & & & & & & & & & & & & \\
\hline & & & & & & & & & & & & \\
\hline & & & & & & & & & & & & \\
\hline & & & & & . & & & & & & & \\
\hline & & & & & & & & & & & & \\
\hline & & & & & & & & & & & & \\
\hline & & & & & & & & & & & & \\
\hline & & & & & & & & & & & & \\
\hline & & & & & & & & & & & & \\
\hline & & $\overline{-}$ & & & & & & & & & & . \\
\hline & & & & & & & & & & & & \\
\hline & 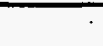 & & & & & & & & & & & \\
\hline & & 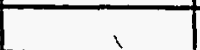 & & & & & & & & & & \\
\hline & & & & & & & & & & & & \\
\hline & & & & & & & & & & & & \\
\hline & & & & & & & & & & & & \\
\hline & & & & & & & & & & & & \\
\hline Avg. & - & \% ४४४\% & \%४। & $\% \%$ & \$४॰ & $\% \%$ & $\% \%$ & ২\% & প & \% & \%४ & m \\
\hline Check'd & & $\%$ & ४ै\%४ & \%ै\%४४ & $1 \%$ & ४\$\$ & $\% \%$ & $\% \%$ & \%1\% & $\%$ & \%\% & 奖 \\
\hline
\end{tabular}

CONSOLE \#-A161394

FILTER \# AMBIENT TEMP.

PROBE LENGTH

LINER MATERIAL $80 T$ $5^{\prime}$ Gkass afme 123 cim

Final Leak Rate 
بlant Name Plant Yates Station Boiler No. 1

Sampling Location Stack Train PSD

Run No.

Date $0,21-93$ Time Start Time Finish $0945(06-20-33)$ test Duration $987 \mathrm{~min}$ Duct Dimensions $x$ Diameter $\frac{13^{\prime}}{t}$ PTCF 0.84 DGMCF 0.994 Nozzle Dia. 0.196 inches Bar Press $29.31 " \mathrm{Hg}$ Static Press $-0.5 \quad \mathrm{H} 2 \mathrm{O}$ Operi'or DIV Final Leak Rate 0.00 Re $15^{\prime \prime} \mathrm{cfm}$

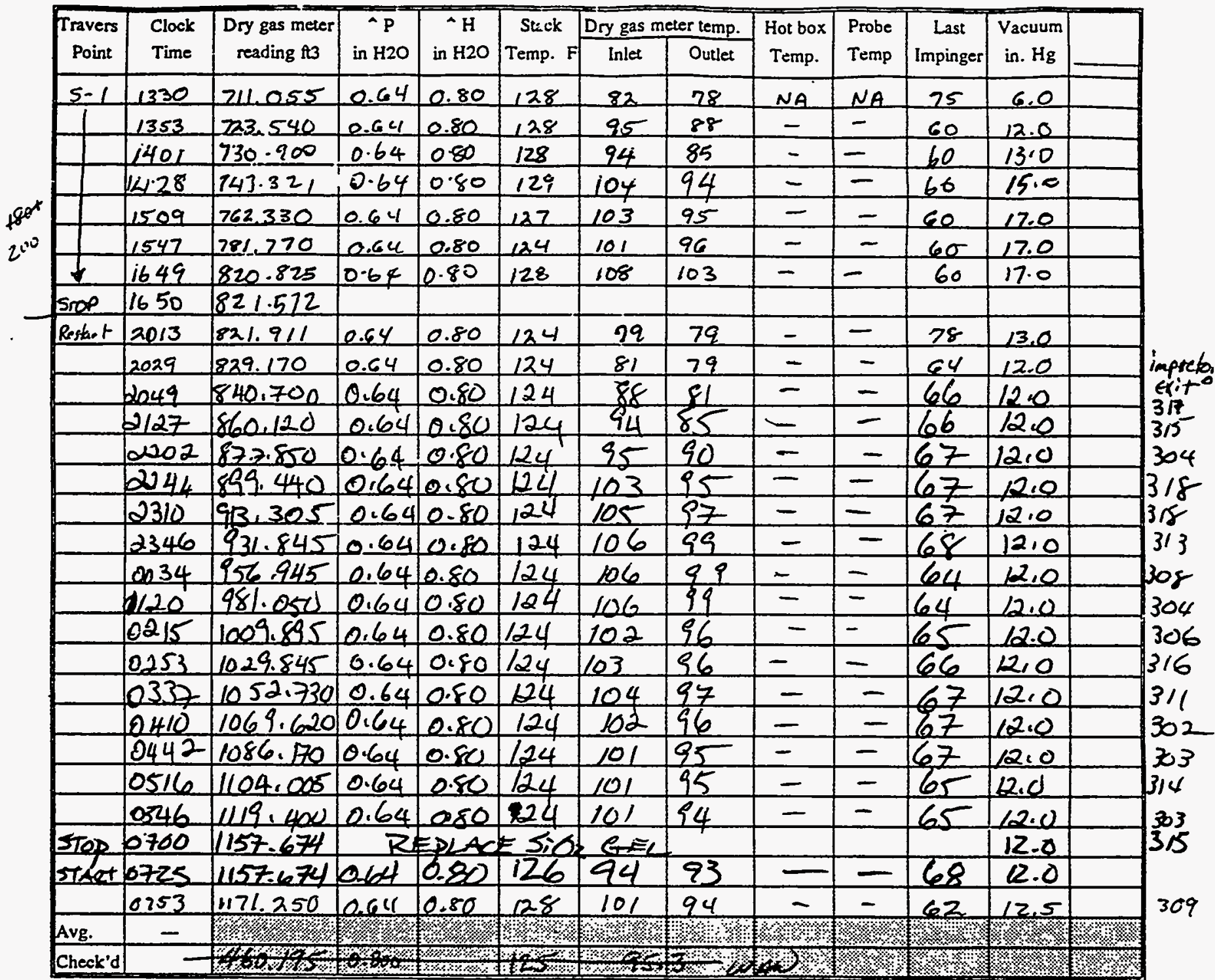

CONSOLE \# A 161365 FILTER * SET AA AMBIENT TEMP. PROBE LENGTH LINER MATERIAL
SEENEXT page for

W

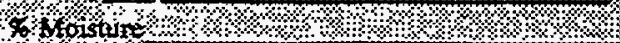

How rate (DS r n $\% \% \%$

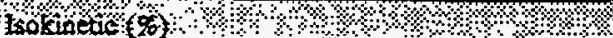


Slant Name

Sampling Location

Date $\propto \alpha-22-93$

Duct Dimensions

PTCF 0.84 DGMCF

Bar Press $29.34=\mathrm{Hg}$

Static Press $-0.5 \quad " \mathrm{H} 2 \mathrm{O}$

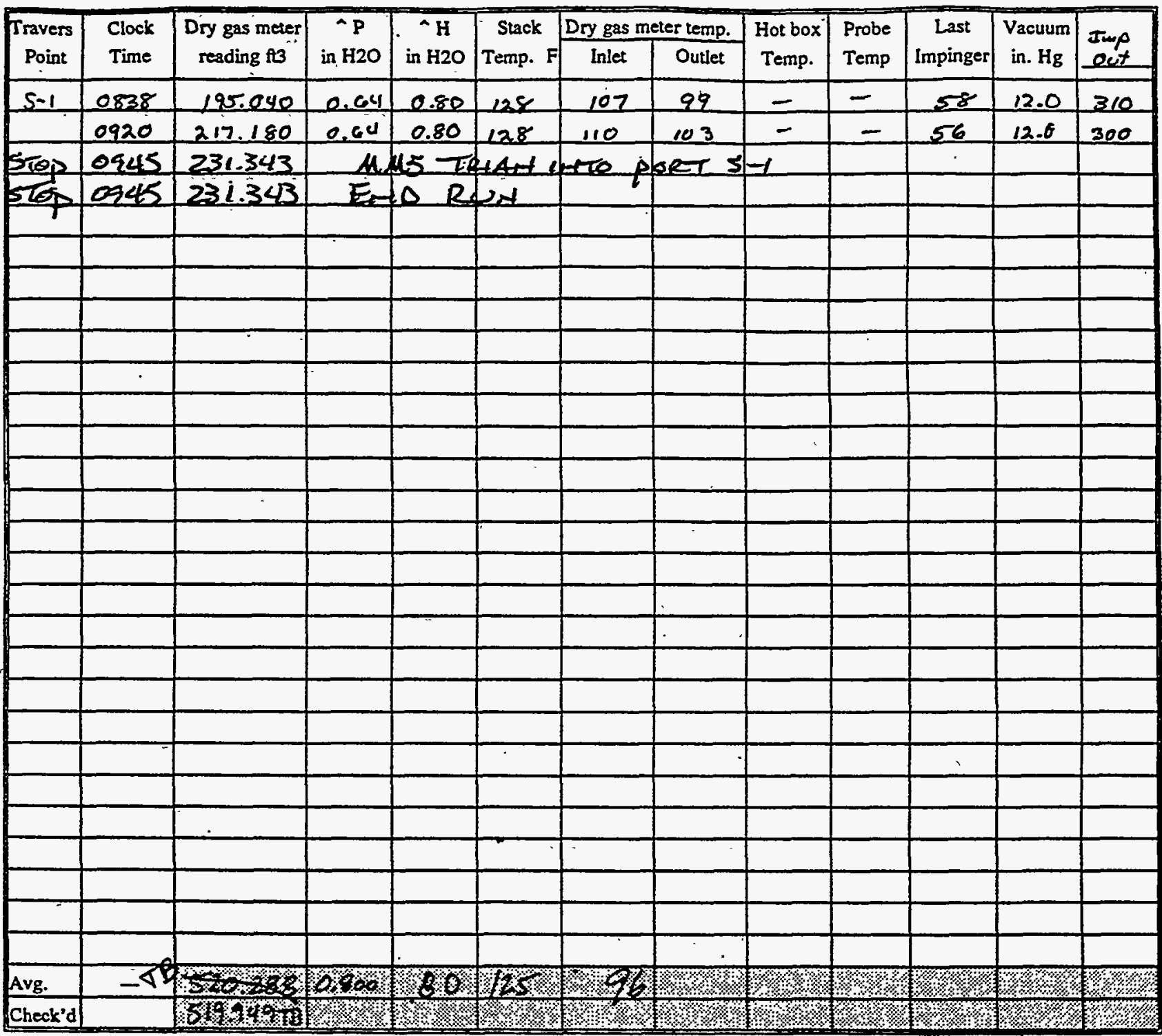

CONSOLE \# - A161365

FILTER * SET AA

AMBIENT TEMP. TOT

PROBE LENGTH

LINER MATERIAL

stael
PSD

$13^{\prime}$ th

Diameter

inches

Operator

Initial Leak Rate 0.00 cfm

Final Leak Rate $\mathrm{cfm}$
Test Duration $\mathrm{min}$

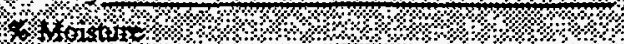

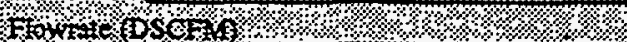
Isotinetio fot,

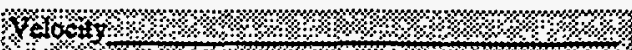

REMARKS

All Times CDT 
Plant Name

Plant Yates Station Boiler No. 1

Sampling Location StacK Train

Date eg-32.93 Time Start 1500

Duct Dimensions $x$
Time Finish $0953 \quad\left(\infty x^{-23-63}\right)$ Diameter $\mathrm{Hg}$ Bar Press 29.34 " $\mathrm{Hg}$ Static Press $=0.5 \quad$ H2O
Run No. 2 Test Duration $11 \overline{33}$ min. Initial Leak Rate $0.002020 \mathrm{c} \mathrm{cm}$ Final Leak Rate NA cim

\begin{tabular}{|c|c|c|c|c|c|c|c|c|c|c|c|c|}
\hline \multirow{2}{*}{$\begin{array}{c}\text { Travers } \\
\text { Point }\end{array}$} & \multirow{2}{*}{$\begin{array}{l}\text { Clock } \\
\text { Time }\end{array}$} & \multirow{2}{*}{$\begin{array}{c}\text { Dry gas meter } \\
\text { reading ft3 }\end{array}$} & \multirow{2}{*}{$\begin{array}{c}{ }^{\circ} \mathrm{P} \\
\text { in } \mathrm{H} 2 \mathrm{O}\end{array}$} & \multirow{2}{*}{$\begin{array}{c}A \mathrm{H} \\
\text { in } \mathrm{H} 2 \mathrm{O}\end{array}$} & \multirow{2}{*}{\begin{tabular}{|c|} 
Stack \\
Temp. F
\end{tabular}} & \multicolumn{2}{|c|}{ Dry gas meter temp. } & \multirow{2}{*}{$\begin{array}{c}\text { Hot box } \\
\text { Temp. }\end{array}$} & \multirow{2}{*}{$\begin{array}{l}\text { Probe } \\
\text { Temp }\end{array}$} & \multirow{2}{*}{\begin{tabular}{|c|} 
Last \\
Impinger
\end{tabular}} & \multirow{2}{*}{$\begin{array}{l}\text { Vacuum } \\
\text { in. } H_{g}\end{array}$} & \multirow{2}{*}{$\begin{array}{l}\operatorname{Imp} p \\
\text { Fimp }\end{array}$} \\
\hline & & & & & & Inlet & Outlet & & & & & \\
\hline $5-1$ & 1500 & 235.805 & 0.70 & 0.87 & 128 & 87 & 88 & $=$ & 二 & 78 & If & 300 \\
\hline & 1513 & 242.330 & 0,70 & 0.87 & 128 & 92 & 89 & - & - & 56 & 12 & 300 \\
\hline & 1524 & 248.240 & 0.70 & 0.87 & 128 & 97 & 90 & $=$ & - & 57 & 12 & 303 \\
\hline & 1558 & 262710 & 0.20 & 0.87 & 128 & 106 & 97 & - & - & 56 & 12 & 30.3 \\
\hline & $k, 26$ & $348 \cdot 840$ & 0,70 & 0.87 & 128 & 111 & 105 & - & - & 67 & 12 & 310 \\
\hline & 1855 & 364.285 & 0.70 & 0,87 & 128 & 108 & 102 & $=$ & - & 68 & 12 & 306 \\
\hline & 1932 & 384.435 & 0.70 & 0.87 & 128 & 107 & 101 & - & - & 67 & 12 & 309 \\
\hline & $\$ 031$ & 416.525 & 0.70 & 0.87 & 128 & 104 & 98 & - & - & 68 & 12 & 305 \\
\hline & 2058 & 431.145 & 0.70 & 087 & 208 & 104 & 97 & - & - & 67 & 12 & 311 \\
\hline & 2113 & 439.015 & 0.70 & 0.87 & 128 & 102 & 96 & - & $=$ & 66 & 12 & 311 \\
\hline & $22 / 0$ & 470.025 & 0.70 & 0.87 & 128 & 105 & 97 & $=$ & $=$ & 65 & 12 & 303 \\
\hline & 2236 & 483.630 & 0.70 & 0.87 & 128 & 106 & 98 & E & - & 64 & 12 & 304 \\
\hline & $23 / 3$ & 583.675 & 0.70 & 0.87 & 128 & 108 & 100 & $=$ & $=$ & 64 & 12 & $3 / 2$ \\
\hline & 2343 & 519,795 & 0.70 & 0.87 & 128 & 103 & 99 & $=$ & - & 65 & 12 & 302 \\
\hline & 0016 & $53<210$ & 0.70 & 0.87 & 128 & 100 & 96 & - & $=$ & 64 & 12 & 300 \\
\hline & 2047 & $5 \sqrt{2}-895$ & 0.70 & 0.87 & 128 & 97 & 93 & $=$ & $=$ & 63 & 12.5 & 304 \\
\hline & 10119 & 570.070 & 0.70 & 0.87 & 128 & 96 & 92 & $=$ & - & 624 & 12.5 & 310 \\
\hline & 0151 & 587,700 & 0.70 & 0.87 & 128 & 96 & 91 & - & - & 63 & 12.5 & 303 \\
\hline & 2226 & $606 \cdot 365$ & 0,70 & 0.87 & 128 & 95 & 90 & - & $=$ & 60 & 1215 & 30 \\
\hline & 0254 & 623.82 & 2.70 & 0.87 & 128 & 95 & 90 & - & $=$ & 59 & 12.5 & 295 \\
\hline & 0329 & 640.08 & 0.70 & 0.87 & 128 & 93 & 89 & - & $=$ & 60 & 12.5 & 308 \\
\hline & 0359 & 6.55 .94 & 0.70 & 0.87 & 128 & 95 & 89 & - & $=$ & 60 & 12.5 & 300 \\
\hline & 0424 & 669.56 & 0.70 & 0.87 & 128 & 92 & 88 & - & - & 61 & 12,5 & 302 \\
\hline & 0502 & 689.67 & 0.70 & 0.87 & 128 & 89 & 84 & - & - & 61 & 22,5 & 299 \\
\hline & 0533 & $706 \cdot 135$ & 0,70 & 0.87 & 128 & 87 & 82 & $=$ & - & 61 & 12,5 & 302 \\
\hline & 0558 & 79.375 & 0.70 & 0,87 & 128 & 88 & 82 & - & - & 61 & $12 \cdot 5$ & 307 \\
\hline & 6612 & 726.880 & 2.70 & 0887 & 128 & ? & $84 i$ & - & - & 61 & 125 & 288 \\
\hline & gans & 749.905 & 0.70 & 0.87 & 128 & 95 & 88 & - & - & 59 & 13.0 & 303 \\
\hline Avg. & - & $1 \%$ & 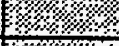 & U: & (5) & $18.1 \%$ & 1. & 4. & 9.8 & 18. & 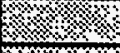 & 18.8 \\
\hline Check'd & & $\$ \%$ & 19 & $f \times$ & $1 \%$ & $18 \%$ & 4.8 & 3 & 8 & & (1) & 18 \\
\hline
\end{tabular}

CONSOLE \#

FILTER " SPT T

AMBIENT TEMP.

PROBE LENGTH

LINER MATERIAL
A.61305

D. $70-80 x$

81

Stee 1

Hoos 3.1010 on

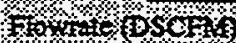

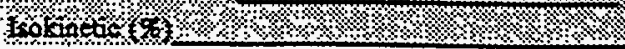


Plant Name

Plant Yates Station Boiler No. 1

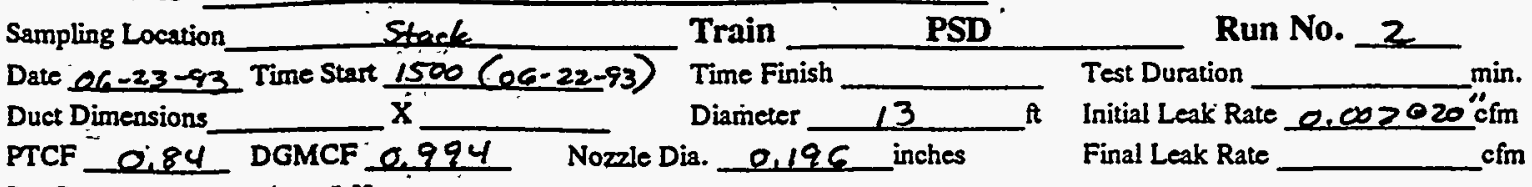

Bar Press $29.34 " \mathrm{Hg}$

Static Press $-0,5$ Operator $-\mathrm{H} 2 \mathrm{O}$ OJV.

1.2485

\begin{tabular}{|c|c|c|c|c|c|c|c|c|c|c|c|c|}
\hline \multirow{2}{*}{$\begin{array}{c}\text { Travers } \\
\text { Point }\end{array}$} & \multirow{2}{*}{$\begin{array}{l}\text { Clock } \\
\text { Time }\end{array}$} & \multirow{2}{*}{$\begin{array}{c}\text { Dry gas meter } \\
\text { reading ft } 3\end{array}$} & \multirow{2}{*}{ in $\mathrm{H} 2 \mathrm{O}$} & \multirow{2}{*}{$\begin{array}{c}{ }^{A} \mathrm{H} \\
\text { in } \mathrm{H} 2 \mathrm{O}\end{array}$} & \multirow{2}{*}{$\begin{array}{c}\text { Stack } \\
\text { Temp. F }\end{array}$} & \multicolumn{2}{|c|}{ Dry gas meter temp. } & \multirow{2}{*}{$\begin{array}{l}\text { Hot box } \\
\text { Temp. }\end{array}$} & \multirow{2}{*}{$\begin{array}{l}\text { Probe } \\
\text { Temp }\end{array}$} & \multirow{2}{*}{\begin{tabular}{c|} 
Last \\
Impinger
\end{tabular}} & \multirow{2}{*}{\begin{tabular}{|c|} 
acuum \\
in. $\mathrm{Hg}$
\end{tabular}} & \multirow{2}{*}{ Imp } \\
\hline & & & & & & Inlet & Outlet & & & & & \\
\hline \multirow[t]{2}{*}{$s-1$} & 0719 & 764.235 & 0.70 & 0.87 & 128 & 100 & 93 & - & $=$ & 60 & 13.0 & 305 \\
\hline & 0321 & 828.900 & 0.70 & 087 & 128 & 164 & 100 & - & $=$ & 65 & 13.0 & 300 \\
\hline \multirow[t]{2}{*}{ Ead } & 0753 & $845^{\circ}, 75$ & & & & & & & & & & \\
\hline & & . & & & & & & & & & & \\
\hline & & & & & & & & & & & & \\
\hline & & & & & & & & & & & & \\
\hline & & & $\therefore$ & & & & & & & & & \\
\hline & & & & & & & & & & & & \\
\hline & & & & & & & & & & & & \\
\hline & & & & & & & & & & & & \\
\hline & & & & & & & & & & & & \\
\hline & & & & & & & & & & & & \\
\hline & & & & & & & & & & & & \\
\hline & & & & & & & & & & & & \\
\hline & & & & & & & 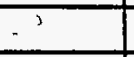 & & & & & \\
\hline & & & & & & & & & & & & \\
\hline & & & & & & & & & & & & \\
\hline & & & & & & & & & 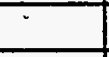 & & & \\
\hline & & & & & & & & & & & & \\
\hline & & & & & & & & & & & & \\
\hline & & & & & & & & . & & & & \\
\hline & & & & & & & & & & & & \\
\hline & & & & & & & & & & & & \\
\hline & & & & 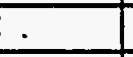 & & & & & & & & \\
\hline & & & & & & & & & & & & \\
\hline & & & . & & & & & & & & & \\
\hline & & & & & & & & & & & & \\
\hline & & & & & & & & & & & & \\
\hline Avg. & - & 18. & প४ং & \% & 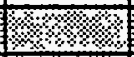 & ২॰ ४ & 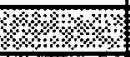 & \% & $8 \% \%$ & $8 \%$ & $\%$ & K\% \\
\hline Check'd & & $1600 \times 3$ & 0,36 & 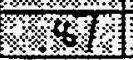 & 1328 & \% & 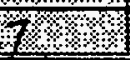 & $1 \%$ & $3 \%$ & $\sqrt{28.2}$ & 1848 & $18 \%$ \\
\hline
\end{tabular}

CONSOLE * AlG1365
FILTER * TEt T
AMBIENT TEMP. $\frac{20-80}{8^{\prime}}$
PROBE LENGTH $\frac{8^{\prime}}{\text { STEel }}$

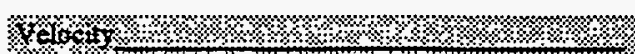

REMARKS 
LEב

SOURCE SAMPLINIG FIELD DATA SHEET

$$
\text { Page } 1 \text { of } 1
$$

Plant Name

Plant Yates Station Boiler No. 1

Sampling Location stack Train PSD

Run No. 3

Date es $-23-93$ Time Start

$\frac{1553}{x}$

Time Finish

-2=

Duct Dimensions

Diameter 13

PTCF 0.84 DGMCF 0.994 Nozzle Dia. 0.196 inches

Bar Press $39.19 \% \mathrm{Hg}$

Static Press $-0.5=\mathrm{H} 2 \mathrm{O}$

Operator

$0 \pi$

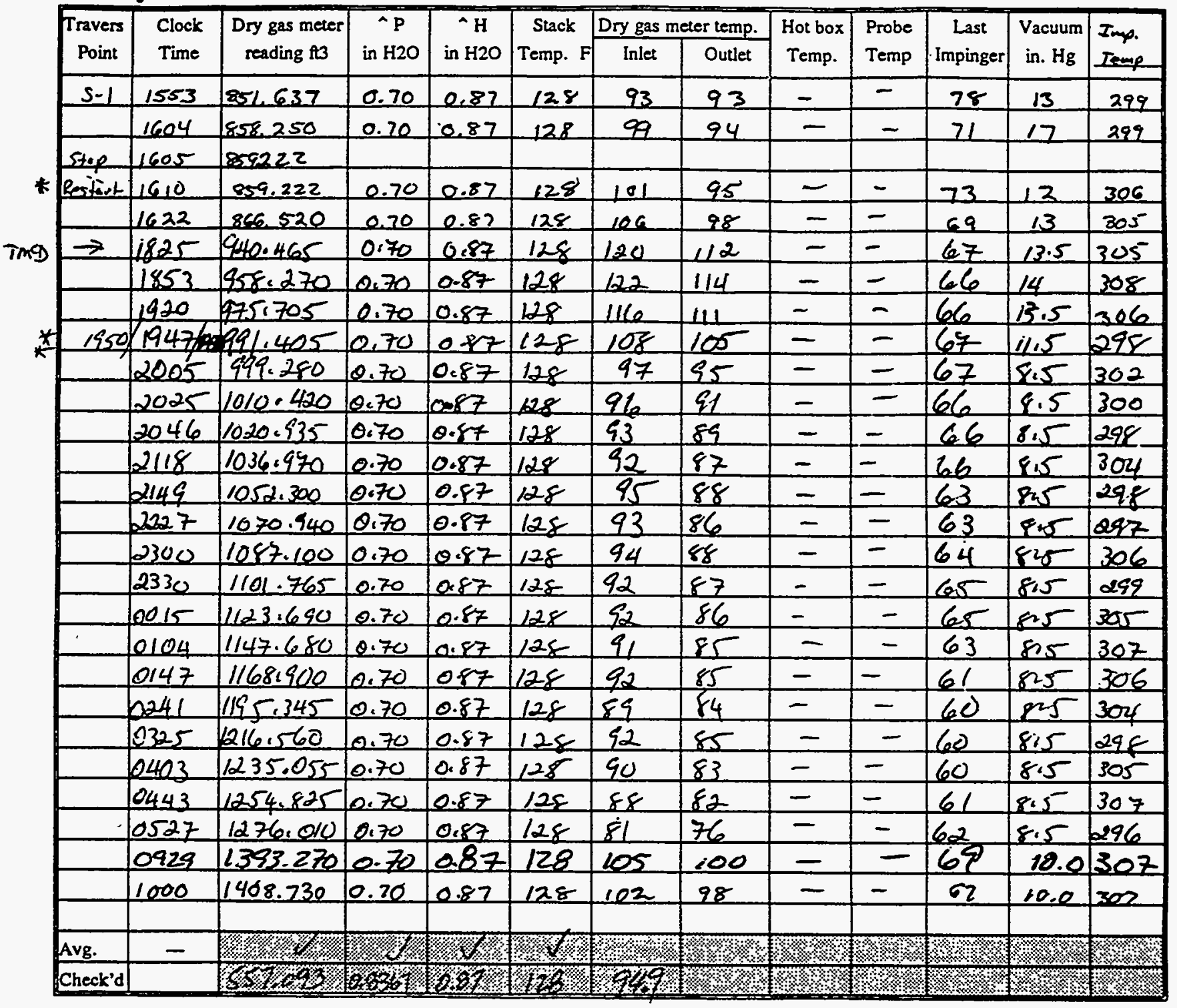

CONSOLE \#

FILTER " $-\square=$

AMBIENT TEMP.

PROBE LENGTH

LINER MATERIAL

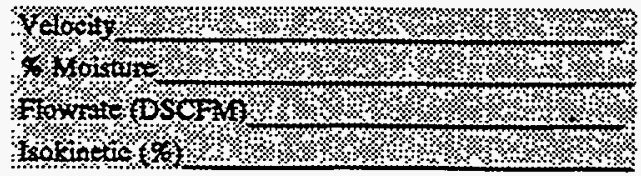

REMARKS - Romered plug in Silice Cel

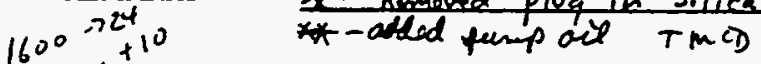


Plant Name Plant Yates Station Boiler No. 1

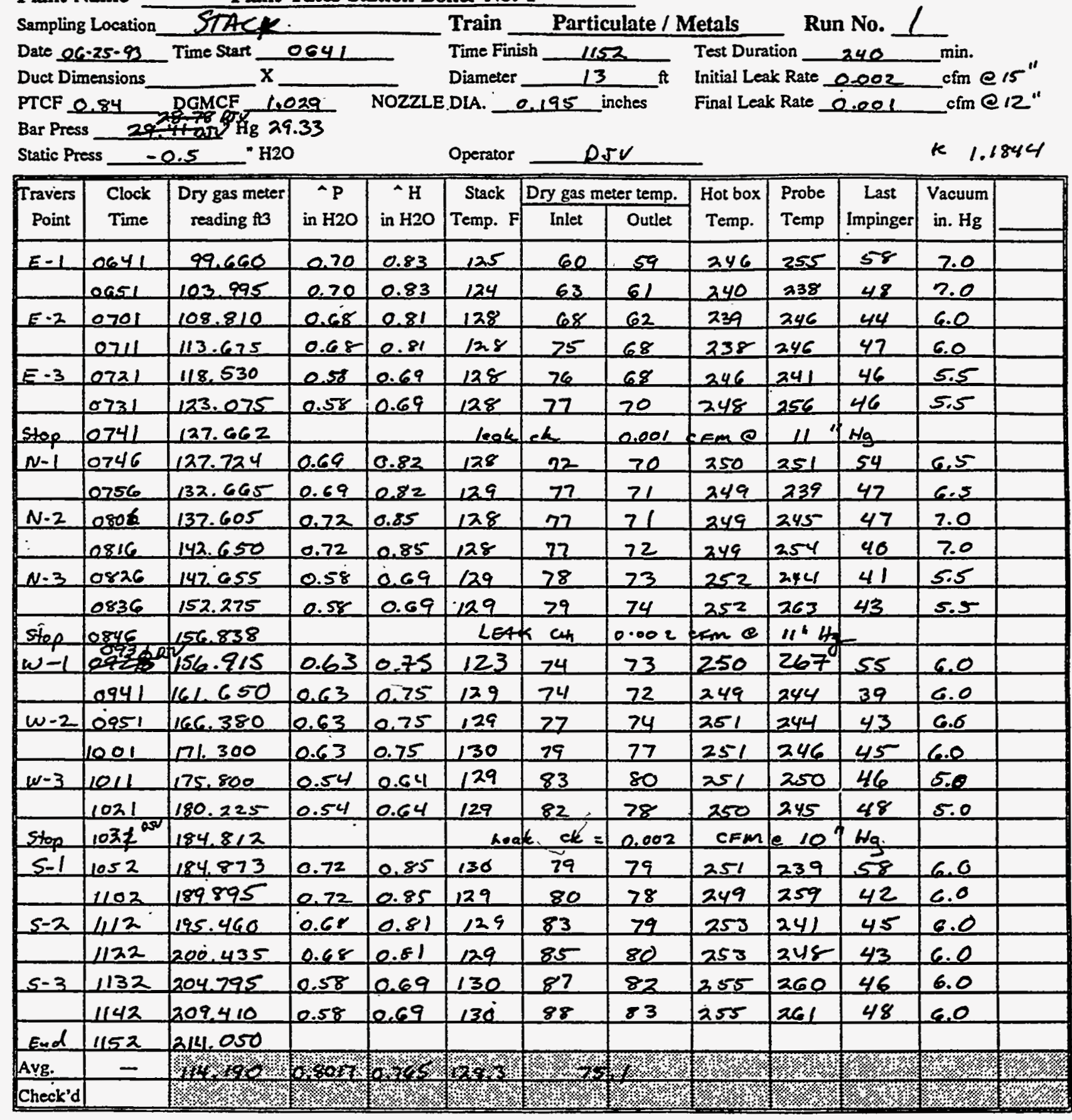

$$
\text { Page } L \text { of } \frac{\mathscr{Z}}{l_{\text {ON }}}
$$

CONSOLE \# A161394

FILTER \# $9 \overline{22}$

AMBIENT TEMP.

PROBE LENGTH

LINER MATERIAL

$5^{\prime}$

Glass

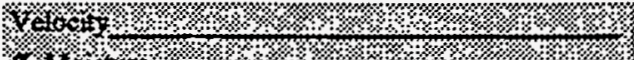

6 utisorits

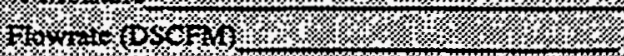

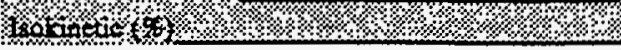

REMARKS All Time cet 
Plant Name

Plant Yates Station Boiler No. 1

Sampling Location StacK

Date $\frac{66-26.93}{}$ Time Start $\frac{0921}{-}$ Time Fimish $\frac{1356}{13^{\prime} \text { fi }}$

Train Particulate / Metals

Run No. 2

PTCF 0.84 DGMCF 1.029 NOZZLE DIA. 0.195 inches Test Duration $240 \mathrm{~min}$. Bar Press 39.36 " $\mathrm{Hg}$

Static Press -0.5 H2O

Operator

DJV

11891

\begin{tabular}{|c|c|c|c|c|c|c|c|c|c|c|c|c|}
\hline \multirow{2}{*}{$\begin{array}{c}\text { Travers } \\
\text { Point }\end{array}$} & \multirow{2}{*}{$\begin{array}{l}\text { Clock } \\
\text { Time }\end{array}$} & \multirow{2}{*}{$\begin{array}{c}\text { Dry gas meter } \\
\text { reading } \mathrm{tt} 3\end{array}$} & \multirow{2}{*}{$\begin{array}{c}\text { P } \\
\text { in } \mathrm{H} 2 \mathrm{O}\end{array}$} & \multirow{2}{*}{$\begin{array}{c}{ }^{*} \mathrm{H} \\
\text { in } \mathrm{H} 2 \mathrm{O}\end{array}$} & \multirow{2}{*}{$\begin{array}{c}\text { Stack } \\
\text { Temp. F }\end{array}$} & \multicolumn{2}{|c|}{ Dry gas meter temp. } & \multirow{2}{*}{$\begin{array}{l}\text { Hot box } \\
\text { Temp. }\end{array}$} & \multirow{2}{*}{$\begin{array}{l}\text { Probe } \\
\text { Temp }\end{array}$} & \multirow{2}{*}{$\begin{array}{c}\text { Last } \\
\text { Impinger }\end{array}$} & \multirow{2}{*}{$\begin{array}{l}\text { Vacuum } \\
\text { in. } \mathrm{Hg}\end{array}$} & \\
\hline & & & & & & Inlet & Outlet & & & & & \\
\hline \multirow[t]{2}{*}{$E-1$} & 0921 & 828.684 & 0.68 & 0.81 & 128 & 73 & 71 & 250 & 236 & 68 & 7,0 & \\
\hline & 0931 & 833.645 & 0.68 & 0.81 & 131 & 74 & 72 & 251 & 254 & 47 & 7.0 & \\
\hline \multirow[t]{2}{*}{$E-2$} & 0941 & 838.030 & 0.70 & 0.83 & 130 & 78 & 73 & 252 & 244 & 47 & 2.0 & \\
\hline & 0251 & 842.830 & 0.70 & 0.83 & 131 & 79 & 74 & 255 & 245 & 47 & 7.0 & \\
\hline \multirow[t]{2}{*}{$E-3$} & 1001 & 847,680 & 0.56 & 0.67 & 131 & 81 & 75 & 254 & 250 & 48 & 7.0 & \\
\hline & sech & 852.325 & 0.56 & 0.07 & $B 1$ & 81 & 75 & 253 & 261 & $5 /$ & to. & \\
\hline step & 1021 & 856.742 & & heat. & check & e.02 & $e \mu^{\prime \prime}$ & & & & & \\
\hline \multirow{2}{*}{ N-1 } & 1029 & 852432 & 0.64 & 0,76 & 130 & 79 & 76 & 262 & 254 & 58 & 6,0 & \\
\hline & 1039 & 862,260 & 0.64 & 0.76 & 131 & 85 & 79 & 255 & 237 & 47 & 6.0 & \\
\hline \multirow[t]{2}{*}{$N-2$} & 1049 & 966.925 & 0.64 & 0.76 & 125 & 88 & 81 & 252 & 246 & 48 & 6.0 & \\
\hline & 1059 & 871.700 & 0.65 & 0.77 & 130 & 85 & 80 & 257 & $25^{4}$ & 48 & Ge & \\
\hline \multirow[t]{2}{*}{$N-3$} & 1109 & 876.530 & 0.56 & 0.67 & 130 & 86 & 82 & 257 & 259 & 49 & 5.0 & \\
\hline & 1119 & 881.040 & 0.56 & 0.67 & 129 & 86 & 82 & $25 \pi$ & 250 & 51 & 5.0 & \\
\hline Stop & $\mu 2.9$ & 885.525 & & 4 & anc Che & $\underline{t e}$ & $.00 \mathrm{CF}$ & $\ln 0$ & $10^{\prime \prime} A$ & & & \\
\hline \multirow[t]{2}{*}{$m-1$} & 1136 & 885.585 & 0.64 & 0.76 & 129 & 84 & 83 & 252 & 241 & 62 & 5.5 & \\
\hline & $11 \times 6$ & 889.095 & 0.64 & 0.76 & 130 & 87 & 83 & 254 & 258 & 44 & 5.5 & \\
\hline \multirow[t]{2}{*}{$w-2$} & 1150 & 896.125 & 0.65 & 0.77 & 130 & 87 & 84 & 250 & 253 & 42 & 5.5 & \\
\hline & 1206 & 899.905 & 0.65 & 0.77 & 131 & 91 & 25 & 256 & 244 & 43 & 5.5 & \\
\hline \multirow[t]{2}{*}{ w. 3} & 1216 & 904,700 & 052 & 0.62 & 130 & 91 & $8 c$ & 254 & 255 & 43 & 5.0 & \\
\hline & 1226 & 909.030 & 0,52 & 0.62 & 130 & 91 & 86 & 254 & 241 & 48 & 5.0 & \\
\hline \multirow{3}{*}{$\frac{S \text { stop }}{s-1}$} & 1236 & 913.378 & & ie & $4 k$ & IfECK & 0.001 & $\operatorname{cin} d$ & $10^{4}$ & ff & & \\
\hline & $\begin{array}{r}1256 \\
+255 \\
\end{array}$ & 93.433 & 0.72 & 0.86 & 129 & 85 & 84 & 254 & 254 & 74 & 7.0 & \\
\hline & 1306 & 918.495 & 0.72 & 0.86 & 130 & 87 & 85 & 252 & 242 & 48 & 2.0 & \\
\hline \multirow[t]{2}{*}{$5 \cdot 2$} & 1316 & 923.675 & 0.66 & 0.78 & 130 & 89 & 86 & 257 & 244 & 50 & 6.0 & \\
\hline & 1326 & 928.435 & 0.66 & 0.78 & 130 & 90 & 87 & 254 & 256 & 51 & 6.0 & \\
\hline \multirow[t]{3}{*}{$s-3$} & 1336 & 933,300 & 0.64 & 0.76 & 131 & 91 & 87 & 247 & 255 & $\sqrt{3}$ & 6.0 & \\
\hline & 1346 & 938.160 & 0.64 & 0.76 & 130 & al & 87 & 254 & 254 & 53 & 6.0 & \\
\hline & 1356 & 942.895 & & & & & & & & & & \\
\hline Avg. & $=$ & 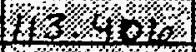 & 4,3 & orass & 30,0 & $1 \% \times 68$ & $60 \%$ & $6 \%$ & $\% \times$ & $\infty$ & 4 & \\
\hline Check'd & & $1 \%, 1 \% 2$ & & $18 \% 4 \%$ & $1 \%$ & $\% \%$ & & 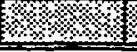 & & & & \\
\hline
\end{tabular}

CONSOLE \#

FILTER

AMBIENT TEMP.

PROBE LENGTH

LINER MATERIAL

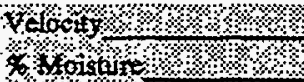

(1)

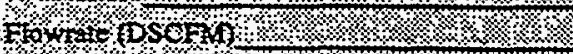

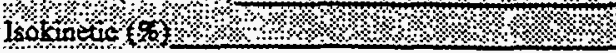

REMARKS 
Plant Name Plant Yates Station Boiler No. 1

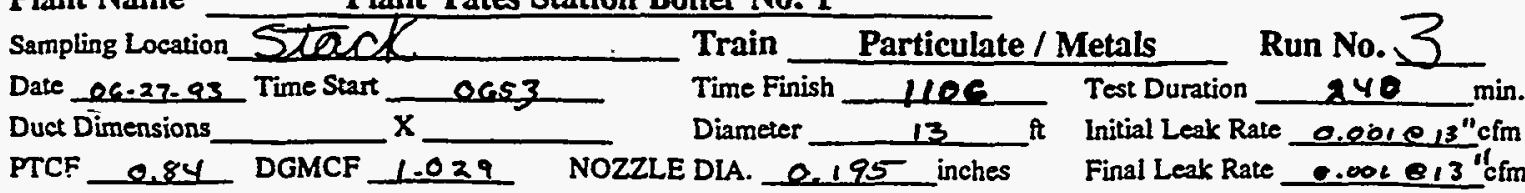
Bar Press 29.21 " Hg Static Press $-0.5-\mathrm{H} 2 \mathrm{O}$ Operator

\begin{tabular}{|c|c|c|c|c|c|c|c|c|c|c|c|c|}
\hline \multirow{2}{*}{$\begin{array}{c}\text { Travers } \\
\text { Point }\end{array}$} & \multirow{2}{*}{$\begin{array}{l}\text { Clock } \\
\text { Time }\end{array}$} & \multirow{2}{*}{$\begin{array}{l}\text { Dry gas meter } \\
\text { reading fi3 }\end{array}$} & \multirow{2}{*}{$\begin{array}{c}{ }^{A P} \\
\text { in } \mathrm{H} 2 \mathrm{O}\end{array}$} & \multirow{2}{*}{$\begin{array}{c}A \mathrm{H} \\
\text { in } \mathrm{H} 2 \mathrm{O}\end{array}$} & \multirow{2}{*}{\begin{tabular}{c|} 
Stack \\
Temp. F
\end{tabular}} & \multicolumn{2}{|c|}{ Dry gas meter temp. } & \multirow{2}{*}{$\begin{array}{l}\text { Hot box } \\
\text { Temp. }\end{array}$} & \multirow{2}{*}{$\begin{array}{l}\text { Probe } \\
\text { Temp }\end{array}$} & \multirow{2}{*}{$\begin{array}{c}\text { Last } \\
\text { Impinger }\end{array}$} & \multirow{2}{*}{$\begin{array}{l}\text { Vacuum } \\
\text { in. } \mathrm{Hg}\end{array}$} & \\
\hline & & & & & & Inlet & Outlet & & & & & \\
\hline$E-1$ & 0065 & 570.275 & 0.65 & 0.78 & 129 & 76 & 78 & 252 & 245 & 56 & 60 & \\
\hline & Lo703 & 575,480 & 0.66 & 0.78 & 129 & 78 & 76 & 249 & 241 & 48 & 5.5 & \\
\hline$E-2$ & 0713 & 580.150 & 0.69 & 0.82 & 130 & $80^{\circ}$ & 72 & 251 & 253 & 49 & 6.0 & \\
\hline & 0723 & 585.000 & 0.69 & 0.82 & 130 & 82 & 78 & 253 & 244 & 47 & 6.0 & \\
\hline$E-3$ & 0233 & 589.850 & 0,56 & 0.67 & $129^{\circ}$ & 86 & 82 & 255 & 359 & 51 & 5.0 & \\
\hline & 0743 & 594.305 & 0.56 & 0.67 & 130 & 87 & 82 & 355 & 257 & 45 & 5.0 & \\
\hline stop & 0253 & 598.773 & & & e & & $01 C E$ & & $e, 12$ & "Atg & & \\
\hline$N-1$ & 0258 & 598.888 & 0.68 & 0.81 & 130 & 86 & 84 & 257 & 264 & 57 & 6.0 & \\
\hline & 0808 & 603.800 & 0.68 & 0.81 & 130 & 87 & 83 & 251 & 250 & 45 & 6.0 & \\
\hline$N \cdot 2$ & 0818 & 608.210 & 0.70 & 0.83 & 131 & 89 & 86 & 252 & 260 & 48 & 6.0 & \\
\hline & 0828 & 6.13 .690 & 0.70 & 0.83 & 130 & 90 & 86 & 252 & 244 & 46 & 6.0 & \\
\hline$N-3$ & 0838 & 618.695 & 0.58 & 0.69 & 130 & 93 & 88 & 251. & 240. & 43 & 5.0 & \\
\hline & 0848 & 623.350 & 0.58 & 0.69 & 130 & 94 & 90 & 252 & $\pi 49$ & 44 & 5.0 & \\
\hline stop & 0858 & 627952 & - an & $0_{0=02}^{0,0}$ & 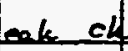 & & CEn & 11 & $\mathrm{Ha}$ & & & \\
\hline$w-1$ & 0902 & 628.026 & 0.64 & 0.76 & 130 & 95 & 92 & 256 & 259 & 51 & 5.5 & \\
\hline & 0912 & 632.295 & 0.64 & 0.76 & 130 & 95 & 92 & 253 & 242 & sil & 5.5 & \\
\hline$w-2$ & 0923 & 637.590 & 0.64 & 0.76 & 130 & 96 & 93 & 352 & 266 & 42 & 5.5 & \\
\hline & 0932 & 642.430 & 0.64 & 0.76 & 130 & 98 & 94 & 253 & 251 & 43 & 575 & \\
\hline$w-3$ & 0942 & 647.360 & 0.52 & 0,52 & 131 & 98 & 95 & 253 & 263 & 45 & 5.5 & \\
\hline & 0952 & 651.755 & 0.52 & 0.62 & 131 & 99 & 26 & 254 & 255 & 47 & 5.5 & \\
\hline Step & 1002 & 656.167 & & & Lenk Ck & 0.001 & ceme & $12 " \mathrm{He}$ & & & & \\
\hline $5-1$ & 1006 & 656.227 & 0.70 & 0.83 & 131 & $q 7$ & 96 & 243 & 258 & 57 & 6.0 & \\
\hline & 1016 & 661.315 & 0.70 & 0.83 & 131 & 99 & 96 & 253 & 254 & 44 & 6,0 & \\
\hline $5 \cdot 2$ & 1026 & 606,405 & 0.72 & 0.86 & 131 & 101 & 96 & 352 & 250 & 46 & 6.0 & \\
\hline & 1036 & 671.555 & 0.72 & 0.86 & 132 & 101 & 96 & 251 & 243 & 47 & 6.0 & \\
\hline$s-3$ & 1046 & 676.730 & 0.56 & 0.67 & 131 & 102 & 97 & 253 & 264 & 47 & 5.0 & \\
\hline & 1056 & 681.320 & 0.56 & 0.67 & 130 & 100 & 96 & 250 & 247 & 47 & 50 & \\
\hline End & 110. & $686.026^{2}$ & & & & & & & & & & \\
\hline Avg. & - & $815,6 \times$ & $2 \times 474$ & 6,3503 & 130,2 & 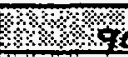 & 10.8 & 0. & 4.4 & $8 \%$ & $8 \%$ & \%. \\
\hline Check'd & & $18 \% 4$ & $\%$ & $86 \%$ & 18 & 8. & $1 \% \%$ & 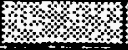 & భ & $4 \%$ & $484 \%$ & 18 \\
\hline
\end{tabular}

CONSOLE \# $A 161394$ FLTER \#-1055 AMBIENT TEMP. PROBE LENGTH $70-80$ LINER MATERIAL GLCSS

REMARKS

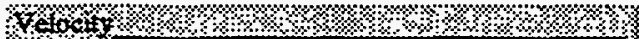

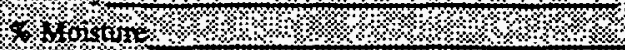

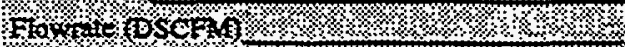

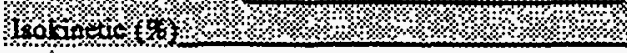


SOLRCE SAIIPLING FIELD DATA SHEET

$$
\text { Page } 1 \text { of }
$$

Plant Name

Plant Yates Station Boiler No. 1

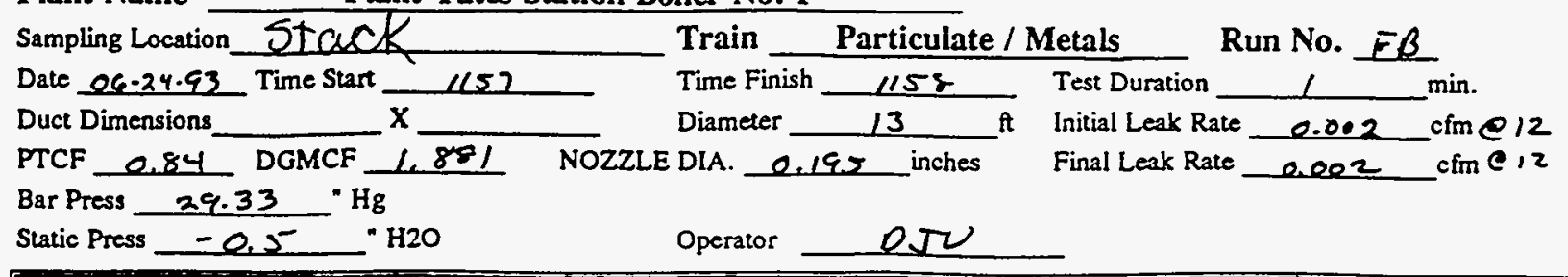

\begin{tabular}{|c|c|c|c|c|c|c|c|c|c|c|c|c|}
\hline Travers & Clock & Dry gas meter & $\wedge$ & ${ }^{\wedge} \mathrm{H}$ & Stack & Dry gas t & ter temp. & Hot box & \begin{tabular}{|l|} 
Probe \\
\end{tabular} & Last & Vacuum & \\
\hline Point & Time & reading ft3 & in $\mathrm{H} 2 \mathrm{O}$ & in $\mathrm{H} 2 \mathrm{O}$ & Temp. F & Inlet & Outlet & Temp. & Temp & Impinger & in. $\mathrm{Hg}$ & \\
\hline - & 1158 & 1076.633 & - & - & - & 81 & 81 & 250 & 253 & - & - & - \\
\hline & & & & & & & & & & & & \\
\hline & & & & & & & & & & & & \\
\hline & & & & & & & & & & & & \\
\hline & & & & & & & & & & & & \\
\hline & & & & & & & & & & & & \\
\hline & & & & & & & & & & & & \\
\hline & & & & & & & & & & & & \\
\hline & & & & & & & & & & & & \\
\hline & & & & & & & & & & & & \\
\hline & & & & & & & & & & & & \\
\hline & & & & & & & & & & & & \\
\hline & & & & & & & & & & & & \\
\hline & & & & & & & & & & & & \\
\hline & & & & & & & & & & & & \\
\hline & & & & & & & & & & & & \\
\hline & & & & & & & & & & & & \\
\hline & & & & & & & & & & & & \\
\hline & & & & & & & & & & & & \\
\hline & & & & & & & & & & & & \\
\hline & & & & & & & & & & & & \\
\hline & & & & & & & & & & & & \\
\hline & & & & & & & & & & & & \\
\hline & & & & & & & & & & & & \\
\hline & & & & & & & & & & & & \\
\hline & & & & & & & & & & & & \\
\hline & & & & & & & & & & & & \\
\hline & & & & & & & & & & & & \\
\hline Avg. & - & ४ & $18 \%$ & $6 / \%$ & \%४ & \% & $\%$ & ऐ॥ & ৫॥ & 4 & . & 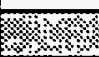 \\
\hline Check'd & & \%४ & $1 \% \%$ & $14 \%$ & $\%$ & 13 & $8 \% 3$ & $1 \%$ & $\% ?$ & 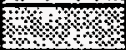 & $1 \%$ & 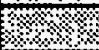 \\
\hline
\end{tabular}

\begin{tabular}{|c|c|}
\hline \multirow{2}{*}{ FILTER $\# \frac{96}{26(6 / 394}$} & Welocity \\
\hline & 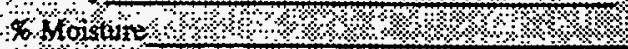 \\
\hline AMEIENT TEMP. & 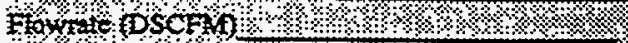 \\
\hline PROBE LENGTH & 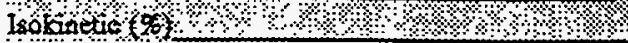 \\
\hline
\end{tabular}

LINER MATERIAL Glass 



\section{Flue-Gas Sampling Log}

\begin{tabular}{|c|c|}
\hline Sporion: $/ 2 \cos =3$ & Samplenunt, $\% /$ \\
\hline Plant loration & Soda Lime TrapHs 5 \% \\
\hline 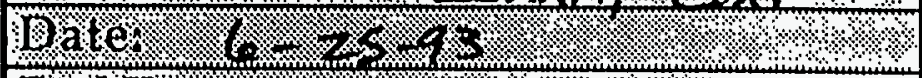 & Iodated Sorbon t) \& \\
\hline Fuel Tyee & Pump\#? 3 , \\
\hline 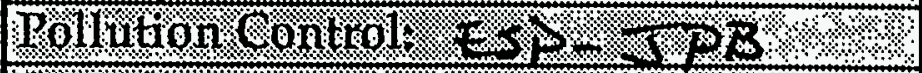 & Probet? 11 ? ? ? ? \\
\hline 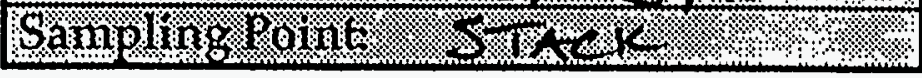 & TTM $/ 20$ \\
\hline
\end{tabular}

\begin{tabular}{|c|c|c|c|c|c|c|c|c|}
\hline \multicolumn{3}{|c|}{ start } & \multicolumn{3}{|c|}{ stop } & \multirow{2}{*}{$\begin{array}{c}\text { elapsed } \\
\text { time } \\
\text { (min) } \\
\end{array}$} & \multirow{2}{*}{$\begin{array}{c}\text { mean } \\
\text { zero } \\
(1 / \mathrm{min}) \\
\end{array}$} & \multirow{2}{*}{$\begin{array}{c}\text { mean } \\
\text { flow } \\
(1 / \mathrm{min})\end{array}$} \\
\hline $\begin{array}{c}\text { time } \\
(\mathrm{hh}: \mathrm{mm})\end{array}$ & $\begin{array}{c}\text { zero } \\
(1 / \mathrm{min})\end{array}$ & $\begin{array}{c}\text { flow } \\
(1 / \mathrm{min})\end{array}$ & $\begin{array}{c}\text { time } \\
\text { (hh:mm) }\end{array}$ & $\begin{array}{c}\text { zero } \\
(1 / \mathrm{min})\end{array}$ & $\begin{array}{c}\text { flow } \\
\text { (1/min) }\end{array}$ & & & \\
\hline 0705 & -0.026 & 0.500 & 1025 & -0.024 & 0.489 & 200.0 & -0.025 & 0.495 \\
\hline \multicolumn{9}{|c|}{. } \\
\hline & & & & & & & & \\
\hline & & & & & & & & \\
\hline & & & & & & & & \\
\hline & & & & & & & & \\
\hline & & & & & TOTALS: & & & \\
\hline
\end{tabular}

Integrator Volume (1): 0.0 Offset Correction (1): 0.10 Total Integrator Volume: 100.0 $\mathrm{CO}_{2}$ Mass Flow Correction: Actual (dry STP) volume (1): $\% 0_{2}: \quad 8.0$ $\% \mathrm{CO}_{2}: 10.0$ $\% \mathrm{H}_{2} \mathrm{O}: \quad 14 . \mathrm{O}$ ppm $\mathrm{SO}_{2}: \quad 200.0$
COMMENTS:

LEAK CNEEK $M E T E R=-0.026$ " " PROAE $=-0.025$

PRORE TEMP $=100^{\circ} \mathrm{C} \angle T<120^{\circ} \mathrm{K}$ 


\section{Flue-Gas Sampling Log}

\begin{tabular}{|c|c|}
\hline 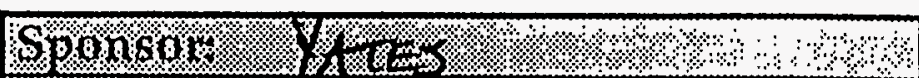 & Samplerint \\
\hline 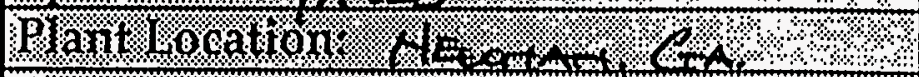 & 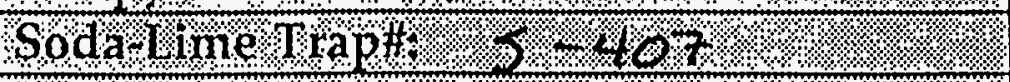 \\
\hline Dater $1,-2, \%$ & Lodated Sarbon $\%$ ? $<$ - \\
\hline Fuel T Ype- & PumpH $\%$ ? \\
\hline 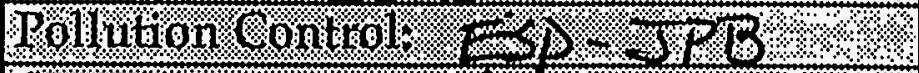 & Probett 120 \\
\hline 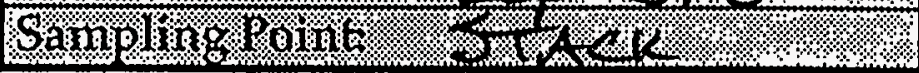 & Gi: \\
\hline
\end{tabular}

\begin{tabular}{|c|c|c|c|c|c|c|c|c|}
\hline \multicolumn{3}{|c|}{ start } & \multicolumn{3}{|c|}{ stop } & \multirow{2}{*}{$\begin{array}{c}\text { elapsed } \\
\text { time } \\
\text { (min) }\end{array}$} & \multirow{2}{*}{$\begin{array}{c}\text { mean } \\
\text { zero } \\
(1 / \mathrm{min})\end{array}$} & \multirow{2}{*}{$\begin{array}{c}\text { mean } \\
\text { flow } \\
(1 / \mathrm{min})\end{array}$} \\
\hline $\begin{array}{c}\text { time } \\
\text { (hh:mm) }\end{array}$ & $\begin{array}{c}\text { zero } \\
(1 / \mathrm{min})\end{array}$ & $\begin{array}{c}\text { flow } \\
(1 / \mathrm{min})\end{array}$ & $\begin{array}{c}\text { time } \\
\text { (hh:mm) }\end{array}$ & $\begin{array}{c}\text { zero } \\
(1 / \mathrm{min})\end{array}$ & $\begin{array}{c}\text { flow } \\
(1 / \mathrm{min})\end{array}$ & & & \\
\hline 9225 & -0.0212 & 0.500 & 1245 & aros 4 & 0,500 & 720 & $-0,0,5$ & $0.5 \cdot 2$ \\
\hline & & & & & & & & \\
\hline & & & & & & & & \\
\hline & & & & & & & & \\
\hline & & & & & & & & \\
\hline & & & & & TOTALS: & 200 & -0.025 & 0500 \\
\hline
\end{tabular}

Integrator Volume (1): 0.002 Offset Correction (1): jut 020 Total Integrator Volume: 100.00 $\mathrm{CO}_{2}$ Mass Flow Correction:

Actual (dry STP) volume (1):

$\% 0_{2}: 8.0$

$\% \mathrm{CO}_{2}: 10.0$

$\% \mathrm{H}_{2} \mathrm{O}:$

ppm $\mathrm{SO}_{2}$ :
COMMENTS:

LEAK CHECK THROX METER $=-0.026$ beth afteck TARow pled $=-0.026$ $100^{\circ} \mathrm{C} \angle T<120^{\circ} \mathrm{C}$ 

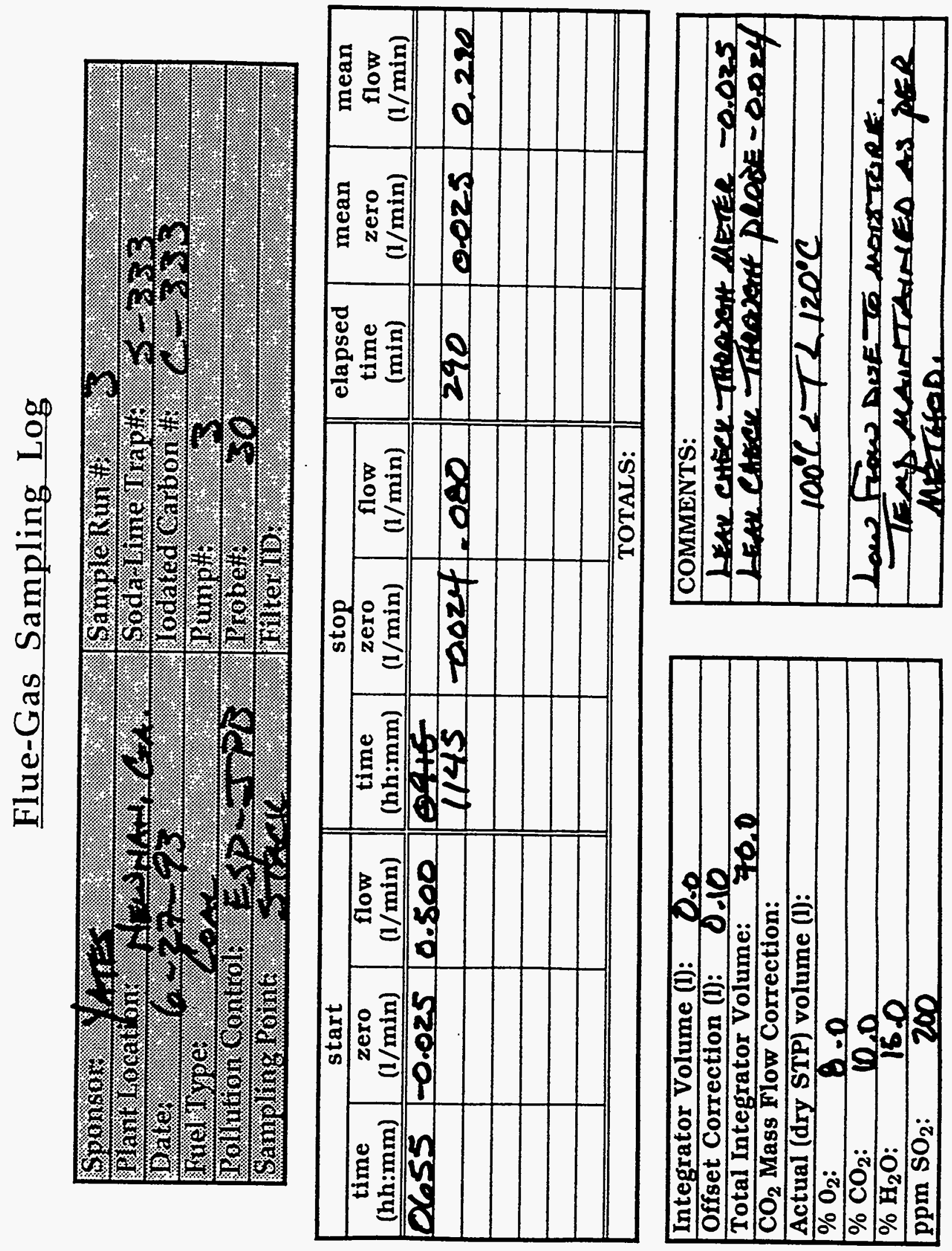


\section{Flue-Gas Sampling Log}

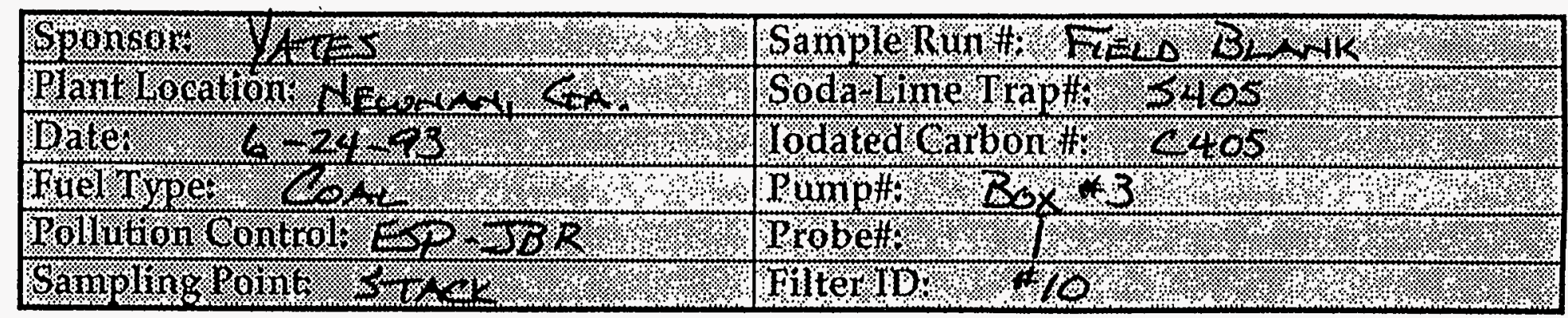

\begin{tabular}{|c|c|c|c|c|c|c|c|c|}
\hline \multicolumn{3}{|c|}{ start } & \multicolumn{3}{|c|}{ stop } & \multirow{2}{*}{$\begin{array}{c}\text { elapsed } \\
\text { time } \\
\text { (min) } \\
\end{array}$} & \multirow{2}{*}{$\begin{array}{c}\text { mean } \\
\text { zero } \\
(1 / \text { min }) \\
\end{array}$} & \multirow{2}{*}{$\begin{array}{c}\text { mean } \\
\text { flow } \\
(1 / \mathrm{min})\end{array}$} \\
\hline $\begin{array}{c}\text { time } \\
\text { (hh:mm) }\end{array}$ & $\begin{array}{c}\text { zero } \\
(1 / \mathrm{min})\end{array}$ & $\begin{array}{c}\text { flow } \\
(1 / \mathrm{min})\end{array}$ & $\begin{array}{c}\text { time } \\
(\mathrm{hh}: \mathrm{mm})\end{array}$ & $\begin{array}{c}\text { zero } \\
\text { (1/min) }\end{array}$ & $\begin{array}{c}\text { flow } \\
(1 / \mathrm{min})\end{array}$ & & & \\
\hline 1115 & -0.027 & 0.500 & 1120 & -0.026 & 0.500 & & & \\
\hline & & & & & & & & \\
\hline & . & & & & & & & \\
\hline & & & & & & & & \\
\hline & & & & & & & & \\
\hline & & & & & & & & \\
\hline & & & & & & & & \\
\hline & & & & & OTALS: & & & \\
\hline
\end{tabular}

Integrator Volume (1):

Offset Correction (1):

Total Integrator Volume:

$\mathrm{CO}_{2}$ Mass Flow Correction:

Actual (dry STP) volume (1):

$\% \mathrm{O}_{2}$ :

$\% \mathrm{CO}_{2}$ :

$\% \mathrm{H}_{2} \mathrm{O}$ :

ppm $\mathrm{SO}_{2}$ :
COMMENTS:

LEAK CHzK Iteox METEl $=-0.027$ 
SOLRCE SAMPLING FIELD DATA SHEET

Page 1 of 1

Plant Name $\quad$ Plant Yates Station Boiler No. 1

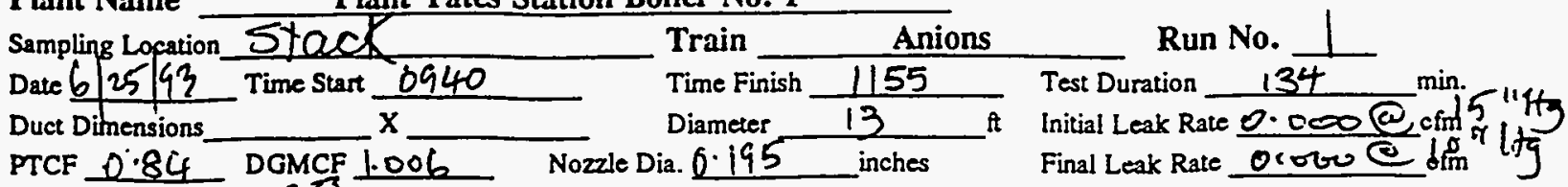

Bar Press $29+412933 \mathrm{Hg}$

Static Press -0.5 Operator EF K $K=1.1606$

\begin{tabular}{|c|c|c|c|c|c|c|c|c|c|c|c|c|}
\hline \multirow{2}{*}{$\begin{array}{c}\text { Travers } \\
\text { Point }\end{array}$} & \multirow{2}{*}{$\begin{array}{l}\text { Clock } \\
\text { Time }\end{array}$} & \multirow{2}{*}{$\begin{array}{c}\text { Dry gas meter } \\
\text { reading ft3 }\end{array}$} & \multirow{2}{*}{$\begin{array}{c}\text { P } \\
\text { in } \mathrm{H} 2 \mathrm{O}\end{array}$} & \multirow{2}{*}{$\begin{array}{c}{ }^{\wedge} \mathrm{H} \\
\text { in } \mathrm{H} 2 \mathrm{O}\end{array}$} & \multirow{2}{*}{\begin{tabular}{|c|} 
Stack \\
Temp. F
\end{tabular}} & \multicolumn{2}{|c|}{ Dry gas meter temp. } & \multirow{2}{*}{$\begin{array}{c}\text { Hot box } \\
\text { Temp. }\end{array}$} & \multirow{2}{*}{$\begin{array}{l}\text { Probe } \\
\text { Temp }\end{array}$} & \multirow{2}{*}{\begin{tabular}{|c|} 
Last \\
Impinger
\end{tabular}} & \multirow{2}{*}{\begin{tabular}{|c|} 
Vacuum \\
in. $\mathrm{Hg}$
\end{tabular}} & \\
\hline & & & & & & Inlet & Outlet & & & & & \\
\hline$N-3$ & 0940 & 739.155 & 0.62 & 0.719 & 131 & 85 & 85 & 254 & 253 & 61 & 1.0 & \\
\hline & 0950 & 743.920 & 0.62 & 0.72 & 132 & 58 & 85 & 255 & 260 & 53 & 1.0 & \\
\hline & 1000 & 748.655 & 0.62 & 0.72 & 133 & 91 & 86 & 254 & 264 & 54 & 1.0 & \\
\hline & 1018 & 756.778 & 0.62 & 0.72 & 133 & 95 & 88 & 251 & 256 & 56 & 1.0 & \\
\hline & 1041 & 167.445 & 0.62 & 0.72 & 133 & 97 & 90 & 252 & 260 & 57 & 1.0 & \\
\hline & 1055 & 174.002 & 0.62 & 0.72 & 132 & 97 & 9) & 253 & 258 & 58 & 1.0 & \\
\hline & i1 10 & 780.832 & $0.6^{2}$ & 0.72 & 132 & 97 & 91 & 253 & 255 & 53 & 1.0 & \\
\hline & 1141 & $795 \cdot 376$ & 0.62 & 0.72 & 132 & 98 & 92 & 251 & 258 & 53 & 1.0 & \\
\hline Nos & 1155 & 801.650 & & & & & & & & & & \\
\hline & & & & & & & & & & & & \\
\hline & & & & & & & & & & & & \\
\hline & & & & & & & & & & & & \\
\hline & & & & & & & & & & & & \\
\hline & & & & & & & & & & & & \\
\hline & & & & & & & & & & & & \\
\hline & & & & & & & & & & & & \\
\hline & & & & & & & & & & & & \\
\hline & & & & & & & & & & & & \\
\hline & & & & & & & & & & & & \\
\hline & & & & & & & & & & & & \\
\hline & & & & & & & & & & & & \\
\hline & & & & & & & & & & & & \\
\hline & & & & & & & & & & & & \\
\hline & & & & & & & & & & & & \\
\hline & & & & & & & & & & & & \\
\hline & & & & & & & & & & & & \\
\hline & & & & & & & & & & & & \\
\hline & & & & & & & & & & & & \\
\hline Avg. & - & 62446 & $\sqrt{35740}$ & \% & 632.2 & $1 \% \%$ & 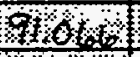 & $18 \%$ & 8.8 & 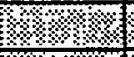 & $\$$ & 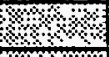 \\
\hline Check'd & & 11818.18 & $1 \% \%$ & $\% \%$ & $18 \%$ & $1 \%$ 4\% & \%०. & 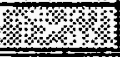 & $1 \%$ & ২. & ২ং & 83 \\
\hline
\end{tabular}

CONSOLE \# A161362

FILTER * 9O0

AMBIENT TEMP. $86^{\circ} T$

PROBE LENGTH $6^{\prime}$

LINER MATERIAL GLLSS

Yolocty $3 \%$ \%

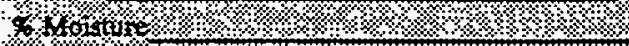

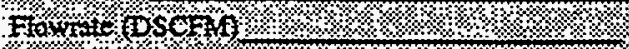

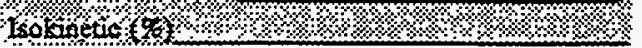

REMARKS 


$$
\text { Page } f_{\text {of } 1}
$$

Plant Name

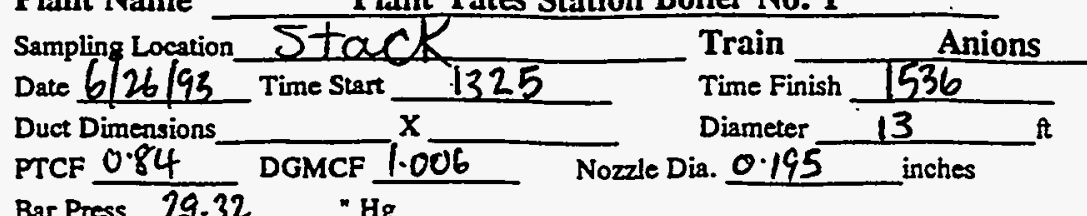
Plant Yates Station Boiler No. 1

Static Press $=0.5 \quad$ Operator Ez $\quad K 20 \quad K=1.1586$

\begin{tabular}{|c|c|c|c|c|c|c|c|c|c|c|c|c|}
\hline \multirow{2}{*}{$\begin{array}{l}\text { Travers } \\
\text { Point }\end{array}$} & \multirow{2}{*}{$\begin{array}{l}\text { Clock } \\
\text { Time }\end{array}$} & \multirow{2}{*}{$\begin{array}{c}\text { Dry gas meter } \\
\text { reading } \mathrm{ft} 3\end{array}$} & \multirow{2}{*}{$\begin{array}{c}-P \\
\text { in } \mathrm{H} 2 \mathrm{O}\end{array}$} & \multirow{2}{*}{$\begin{array}{c}-\mathrm{H} \\
\text { in } \mathrm{H} 2 \mathrm{O}\end{array}$} & \multirow{2}{*}{$\begin{array}{c}\text { Stack } \\
\text { Temp. F }\end{array}$} & \multicolumn{2}{|c|}{ Dry gas meter temp. } & \multirow{2}{*}{$\begin{array}{l}\text { Hot box } \\
\text { Temp. }\end{array}$} & \multirow{2}{*}{$\begin{array}{l}\text { Probe } \\
\text { Temp }\end{array}$} & \multirow{2}{*}{\begin{tabular}{c|} 
Last \\
Impinger
\end{tabular}} & \multirow{2}{*}{$\begin{array}{l}\text { Vacuum } \\
\text { in. Hg }\end{array}$} & \multirow{2}{*}{ 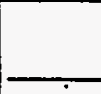 } \\
\hline & & & & & & Inlet & Outlet & & & & & \\
\hline$E-3$ & 1325 & 881.665 & $6 \cdot 60$ & 0.695 & 133 & 105 & 102 & 262 & 257 & 69 & 1.5 & \\
\hline & 1330 & 884.320 & 0.58 & 0.672 & 133 & 106 & 102 & 260 & 256 & 61 & 1.5 & \\
\hline & 1340 & $888 \cdot 460$ & 0.58 & 6.672 & 133 & 107 & 103 & 260 & 256 & 59 & 1.5 & \\
\hline & 1350 & 893.515 & 0.58 & 0.672 & 133 & 106 & 102 & 258 & 252 & 56 & 1.5 & \\
\hline & 1409 & $902 \cdot 185$ & 0.58 & 0.672 & 134 & 106 & 101 & 258 & 255 & 59 & 1.5 & \\
\hline & 1434 & 93.476 & 6.58 & 0.672 & 133 & 108 & 102 & 258 & 256 & 57 & 1.5 & \\
\hline & 1445 & 918.660 & 0.58 & 0.672 & 133 & 108 & 102 & 257 & 253 & 60 & 1.5 & \\
\hline & 1504 & 927.420 & 0.58 & 0.672 & 133 & 107 & 102 & 257 & 253 & 60 & 1.5 & \\
\hline & 1521 & 934.998 & 0.58 & 0.672 & 134 & 108 & 102 & 236 & 254 & 63 & 1.5 & \\
\hline & 1531 & $940 \cdot 110$ & 0.58 & 0.672 & 134 & 108 & 102 & 256 & 1255 & 60 & 1.5 & \\
\hline & 1536 & 942.028 & & & & & & & & & & \\
\hline & & & & & & & & & & & & \\
\hline & & & & & & & & & & & & \\
\hline & & & & & & & & & & & & \\
\hline & & & & & & & & & & & & \\
\hline & & & & & & & & & & & & \\
\hline & & & & $=$ & & & & & & & & \\
\hline & & & & & & & & & & & & \\
\hline & & & & & & & & & & & & \\
\hline & & & & & & & & & & & & \\
\hline & & & & & & & & & & & & \\
\hline & & & & & & & & & & & & \\
\hline & & & & & & & & & & & & \\
\hline & & & & & & & & & & & & \\
\hline & & & & & & & & & & & & \\
\hline & & & & & & & & & & & & $T$ \\
\hline & & & & & & & & & & & & \\
\hline & & & & & & & & & & & & \\
\hline Avg. & $\overline{-}$ & 060363 & 658 & G6) & 138 & \%४४\% & $10.4 \% 5$ & 4 & $\%$ & & ४ & \%४। \\
\hline Check'd & & $197 \%, 1$. & Wros & 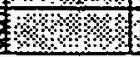 & ४४\% & \$४४४ & 10 & $\%$ & $\%$ & $\%$ & & $\%$ \\
\hline
\end{tabular}

CONSOLE \#RLEA A 61362

FILTER " 65 T 936

AMBIENT TEMP. $85^{\circ} \mathrm{F}$

PROBE LENGTH $6^{t}$

LINER MATERIAL GLASS
Run No. 2 Test Duration $\frac{2}{131}$ min. Initial Leak Rat6 $Q .00 i Q 15$ "cing Final Leak Rate $20.001 Q^{10}$ cinty 
Plant Name sampling Locution Stas C Date $62_{21}{ }_{93}$ Time Start 0845 Duct Dimensions PTCF 0.84 Bar Press 29.2 " $\mathrm{Hg}$

\begin{tabular}{|c|c|c|c|c|c|c|c|c|c|c|c|c|}
\hline Travers & Clock & Dry gas meter & $a p$ & $H$ & Stack & Dry gas & ter temp. & Hot box & Probe & Last & Vacuum & \\
\hline Point & Time & reading ft3 & in $\mathrm{H} 2 \mathrm{O}$ & in $\mathrm{H} 2 \mathrm{O}$ & Temp. F & Inlet & Outlet & Temp. & Temp & Impinger & in. $\mathrm{Hg}$ & \\
\hline-3 & 0845 & 995.520 & 0.640 & 0.74 & 132 & 93 & 91 & 264 & 260 & 69 & 1.0 & \\
\hline & 0850 & 997.990 & 0.640 & 0.74 & 132 & 94 & 9 & 259 & 258 & 55 & 1.0 & \\
\hline & 6900 & 003.000 & 0.640 & 0.74 & 132 & 98 & 92 & 259 & 257 & 54 & 1.0 & \\
\hline & 0910 & $007 \cdot 555$ & 0.640 & 0.74 & 133 & 101 & 94 & 259 & 260 & 56 & 1.0 & \\
\hline & 0930 & $6 / 6.980$ & $0.6 \mathrm{fo}$ & 0.74 & 133 & 104 & 97 & 260 & 260 & 56 & 1.3 & \\
\hline & 1002 & $032 \cdot 286$ & 0.640 & 0.74 & 133 & 107 & 100 & 260 & 261 & 61 & 1.0 & \\
\hline & 1010 & 035.830 & $0-645$ & 0.75 & 133 & 107 & 101 & 260 & 261 & 60 & 1.0 & \\
\hline & 1025 & 043.040 & 10.645 & 0.75 & 133 & 109 & 102 & 260 & 262 & 60 & 1.0 & \\
\hline & 1035 & 047.856 & 8.645 & 0.75 & 133 & 109 & 103 & 260 & 262 & 60 & 1.0 & \\
\hline & 1045 & 052.756 & 0.640 & 0.74 & 133 & 110 & 103 & 260 & 263 & 59 & 1.0 & \\
\hline & 1055 & 1057.495 & & & & & & & & & & \\
\hline & & & & & & & & & & & & \\
\hline & & & & & & & & & & & & \\
\hline & & & & & & & & & & & & \\
\hline & & & & & & & & & & & & \\
\hline & & & & & & & & & & & & \\
\hline & & & & & & & & & & & & \\
\hline & & & & & & & & & & & & \\
\hline & & & & & & & & & & & & \\
\hline & & & & & & & & & & & & \\
\hline & & & & & & & & & & & & \\
\hline & & & & & & & & & & & & \\
\hline & & & & & & & & & & & & \\
\hline & & & & & & & & & & & & \\
\hline & & & & & & & & & & & & \\
\hline & & & & & & & & & & & & \\
\hline & & & & & & & & & & & & \\
\hline & & & & & & & & & & & & \\
\hline g. & - & 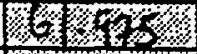 & 6 6 & $6 \sqrt[3]{34}$ & $133 \%$ & 1630 & 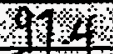 & 40 & 16 & 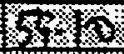 & $1 \%$ & \\
\hline heck'd & & $1 \%$ & 3618 & 7 & 88 & $1 \%$ & 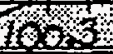 & 18 & 18 & 2 & 8 & \\
\hline
\end{tabular}
Train

Time Finish 1055 Diameter DGMCF Nozate
D.igs inches

Operat EZ
Run No. 3

Test Duration 130 min. Initial Leak Rate $\leq 0.00 i e$ ctm Firal Leak Rate $<0.001 e_{\text {crito }}$ "itg
CONSOLE A A16/362

FILTER * GUS

AMBIENT TEMP.

PROBE LENGTH

LINER MATERIAL $80^{\circ} \mathrm{F}$

GLASS

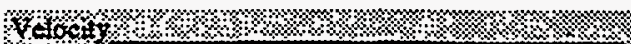
\%. 6 otstint

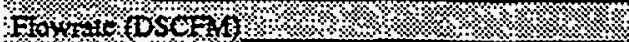

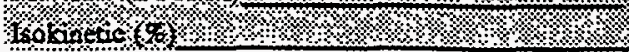

REMARKS 
Plant Name Plant Yates Station Boiler No. 1

\begin{tabular}{|c|c|c|c|c|c|c|c|c|c|c|c|c|}
\hline Sampling & Focytion. & STHek & & & Train & & ions & & Run No & 0. $E B$ & & \\
\hline Date 6 & 24193 & Time Start I & 126 & & Time Fini & sh 14 & 2 & $\overline{\text { Test Dura }}$ & tion & & & \\
\hline Duet Din & lensions & & & & Diameter & 13 & & Initial Lea & - & & & \\
\hline PTCF $C$ & $5 \cdot 84$ & DGMCF $1.00 \mathrm{C}$ & & Nozzle $\mathrm{Di}$ & 0.19 & 2 inct & & Final Leal & & & & \\
\hline Bar Press & 29.3 & $3 \quad \mathrm{Hg}$ & & & & & & & & & & \\
\hline Sta:ic Pre & -0 & 5 & & & Operator & Ez & & & & & & \\
\hline Travers & Clock & Dry gas meter & $A P$ & ${ }^{A} \mathrm{H}$ & Stack & Dry gas m & er temp. & Hot box & Probe & Last & Vacuum & \\
\hline Point & Time & reading t 3 & in $\mathrm{H} 2 \mathrm{O}$ & in $\mathrm{H} 2 \mathrm{O}$ & Temp. F & Inlet & Outlet & Temp. & Temp & | Impinger & in. $\mathrm{Hg}$ & \\
\hline & 1420 & $626-0.22$ & & & & & & & & & & \\
\hline & 1422 & 676.395 & & & & & & & & & & \\
\hline & & & & & & & & & & & & \\
\hline & & & & & & & & & & & & \\
\hline & & & & & & & & & & & & \\
\hline & & & & & & & & & & & & \\
\hline & & & & & & & & & & & & \\
\hline & & & & & & & & & & & & \\
\hline & & & & & & & & & & & & \\
\hline & & & & & & & & & & & & \\
\hline & & & & & & & & & & & & \\
\hline & & & & & & & & & & & & \\
\hline & & & & & & & & & & & & \\
\hline & & & & & & & & & & & & \\
\hline & & & & & & & & & & & & \\
\hline & & & & & & & & & & & & \\
\hline & & & & & & & & & & & & \\
\hline & & & & & & & & & & & & \\
\hline & & & . & & & & & & & & & \\
\hline & & & & & & & & & & & & \\
\hline & & & & & & & & & & & & \\
\hline & & & & & & & & & & & & \\
\hline & & & & & & & & & & & & \\
\hline & & & & & & & & & & & & \\
\hline & & & & & & & & & & & & \\
\hline & & & & & & & & & & & & \\
\hline & & & & & & & & & & & & \\
\hline & & & & & & & & & & & & \\
\hline Avg. & $=$ & \%. & $8 \%$ & 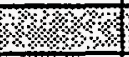 & $1 \%$ & $\% 8 \%$ & পি & S\%४ & ষ४ং & \$४४ & $\%$ & 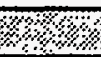 \\
\hline Check'd & & $1 \%$ & 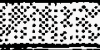 & $\%$ & $1 \% \vee \%$ & & $8 \% 8$ & $1 \% \%$ & ४ & 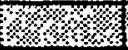 & 8 & \\
\hline
\end{tabular}

CONSOLE A16/362

FILTER *

AMBIENT TEMP. $88 \%$

PROBE LENGTH 67

LINER MATERIAL GILSS
X

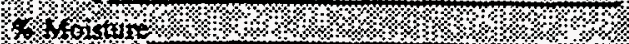

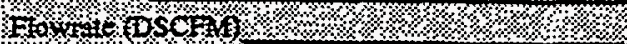

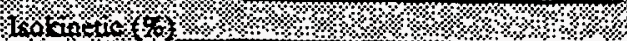

REMARKS

C-130 


$$
\text { Page } 1 \text { or } 1
$$

Plant Name $\quad$ Plant Yates Station Boiler No. 1

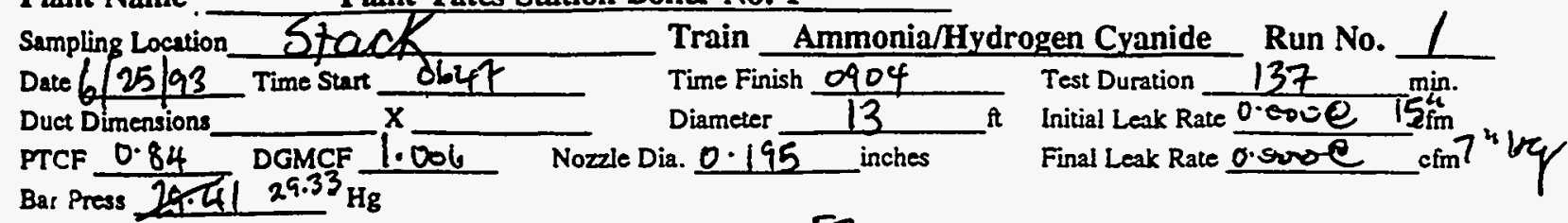
Sutic Press -0.5

\begin{tabular}{|c|c|c|c|c|c|c|c|c|c|c|c|c|}
\hline $\begin{array}{c}\text { Travers } \\
\text { Point }\end{array}$ & $\begin{array}{l}\text { Clock } \\
\text { Time }\end{array}$ & $\begin{array}{c}\text { Dry gas metcr } \\
\text { reading te3 }\end{array}$ & $\begin{array}{c}A P \\
\text { in } \mathrm{H} 2 \mathrm{O}\end{array}$ & $\begin{array}{c}-\mathrm{H} \\
\text { in } \mathrm{H} 2 \mathrm{O}\end{array}$ & \begin{tabular}{|c|} 
Stack \\
Temp. F
\end{tabular} & $\frac{\text { Dry gas }}{\text { Inlet }}$ & $\begin{array}{l}\text { eter temp. } \\
\text { Outlet }\end{array}$ & $\begin{array}{l}\text { Hot box } \\
\text { Temp. }\end{array}$ & $\begin{array}{l}\text { Probe } \\
\text { Temp }\end{array}$ & \begin{tabular}{|c|} 
Last \\
Impinger
\end{tabular} & \begin{tabular}{|l|} 
Vacuum \\
in. $\mathrm{Hg}$
\end{tabular} & 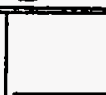 \\
\hline \multirow[t]{11}{*}{$w-3$} & 0647 & 677.224 & 0.57 & 0.69 & 130 & 78 & 74 & 256 & 254 & 60 & $2 \cdot 0$ & \\
\hline & 0700 & 683.225 & 0.57 & 0.69 & 130 & 82 & 76 & 254 & 251 & 59 & 2.0 & \\
\hline & 0713 & 689.235 & 0.57 & 0.69 & 131 & 85 & 78 & 254 & 261 & 58 & $2 \cdot 0$ & \\
\hline & 0733 & 1698.255 & 0.57 & $0-69$ & 132 & 90 & 82 & 254 & 260 & 56 & 20 & \\
\hline & 10747 & 1704.442 & 0.57 & 0.69 & 132 & 91 & 83 & 255 & 260 & 56 & $2 \cdot 0$ & \\
\hline & 0800 & 710.004 & 0.57 & 0.65 & 132 & 92 & 85 & 257 & 260 & 56 & 2.0 & \\
\hline & $\cos 13$ & 716.160 & 0.57 & 0.69 & 133 & 93 & 86 & 236 & 254 & 56 & 2.0 & \\
\hline & 0825 & 721.599 & 6.57 & 0.69 & 132 & 93 & 87 & 254 & 258 & 55 & 200 & \\
\hline & 0834 & 766.220 & 0.57 & 0.66 & 132 & 93 & 87 & 254 & 259 & 54 & 2.0 & \\
\hline & 0846 & $731 \cdot+50$ & 0.57 & 0.66 & 133 & 94 & 88 & 257 & 260 & 51 & 2,0 & \\
\hline & 0902 & $738 \cdot 225$ & 0.57 & 0.66 & 133 & 94 & 88 & 236 & 261 & 50 & 2.0 & \\
\hline \multicolumn{13}{|c|}{ Eas. 69047739005} \\
\hline & & & & & & & & & & & & \\
\hline & & & & & & & & & & & & \\
\hline & & & & & & & & & & & & \\
\hline & & & & & & & & & & & & \\
\hline & & & & & & & & & & & & \\
\hline & & & & & & & & & & & & \\
\hline & & & & & & & & & & & & \\
\hline & & & & & & & & & & & & \\
\hline & & & & & & & & & & & & \\
\hline & & & & & & & & & & & & \\
\hline & & & & & & & & & & & & \\
\hline & & & & & & & & & & & & \\
\hline & & & & & & & & & & & & \\
\hline & & & & & & & & & & & & \\
\hline & & & & & & & & & & & & \\
\hline & & & & & & & & & & & & \\
\hline Avg. & - & 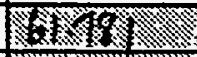 & 6.5 & 0.82 & (3) & $8 \mathrm{~s}$ & $8 \times$ & & 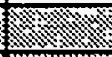 & 8. & 8 & \\
\hline Check'd & $\mathrm{RCC}$ & 10 & Sf & 1 & & $\ldots$ & 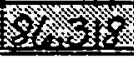 & 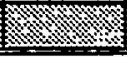 & 2 & 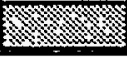 & 2 & $\$$ \\
\hline
\end{tabular}

CONSOLE $\quad A 161362^{\sqrt{.754983}}$

FILTER :

AMBIENT TEMP. $70^{\circ} \%$

PROBE LENGTH $b^{\top}$

LINER MATERIAL GLSS

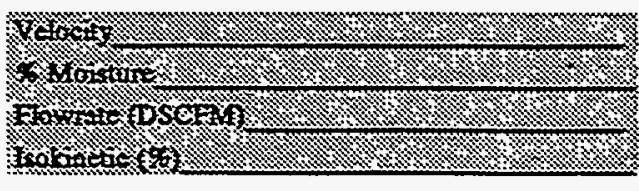

ŔEMARKS

* Chareo $K=1.1606$ 345ED on 142 moisruece 
SOLRCE SAMPLING FIELD DATA SHEET

$$
\text { Page } \operatorname{tof} 1
$$

Plant Name

Plant Yates Station Boiler No. 1

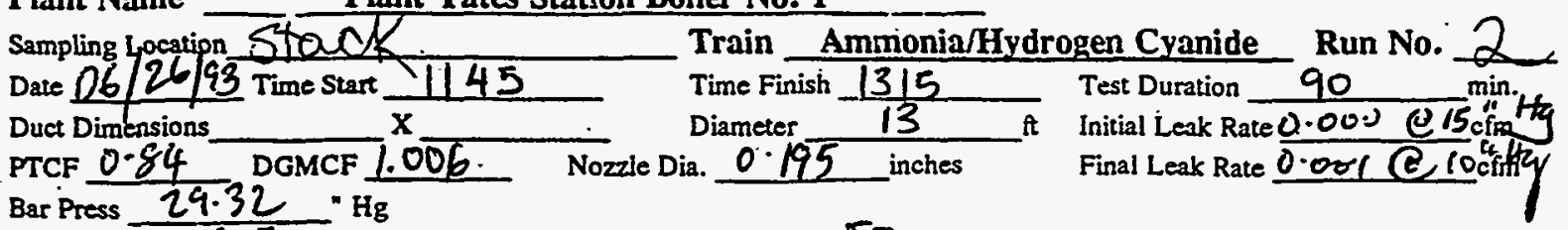

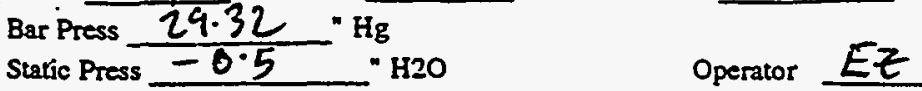

$K=1.1586$

\begin{tabular}{|c|c|c|c|c|c|c|c|c|c|c|c|c|}
\hline \multirow{2}{*}{$\begin{array}{c}\text { Truvers } \\
\text { Point }\end{array}$} & \multirow{2}{*}{$\begin{array}{l}\text { Clock } \\
\text { Time }\end{array}$} & \multirow{2}{*}{$\begin{array}{c}\text { Dry gas meter } \\
\text { reading ft3 }\end{array}$} & \multirow{2}{*}{$\begin{array}{c}-\mathrm{P} \\
\text { in } \mathrm{H} 2 \mathrm{O}\end{array}$} & \multirow{2}{*}{$\begin{array}{c}-\mathrm{H} \\
\text { in } \mathrm{H} 2 \mathrm{O}\end{array}$} & \multirow{2}{*}{$\begin{array}{l}\text { Stack } \\
\text { Temp. F }\end{array}$} & \multicolumn{2}{|c|}{ Dry gas meter temp. } & \multirow{2}{*}{$\begin{array}{c}\text { Hot box } \\
\text { Temp. }\end{array}$} & \multirow{2}{*}{$\begin{array}{l}\text { Probe } \\
\text { Temp }\end{array}$} & \multirow{2}{*}{$\begin{array}{c}\text { Last } \\
\text { Impinger }\end{array}$} & \multirow{2}{*}{$\begin{array}{l}\text { Vacuum } \\
\text { in. } \mathrm{Hg}\end{array}$} & \\
\hline & & & & & & Inlet & Outlet & & & & & \\
\hline$E-3$ & 1145 & 840.130 & $0.60^{\circ}$ & 0.695 & 134 & 91 & 90 & 239 & 252 & 70 & $4 \cdot 0$ & \\
\hline & 1150 & 842.895 & 0.60 & 0.695 & 133 & 91 & 90 & 249 & 252 & 58 & 40 & \\
\hline & 1155 & 844.820 & 0.60 & 0.695 & 133 & 94 & 91 & 260 & 256 & 56 & 4.0 & \\
\hline & 1200 & 847.075 & 0.60 & $0-695$ & 133 & 96 & 91 & 256 & 254 & 51 & 4.0 & \\
\hline & 1205 & 849.420 & 0.60 & 0.695 & 133 & 99 & 93 & 257 & 256 & 58 & 4.0 & \\
\hline & 1215 & 854.290 & 0.60 & 6695 & 133 & 101 & 95 & 258 & 253 & 57 & 4.0 & \\
\hline & 1230 & 860.910 & 0.58 & 0.672 & 134 & 104 & 97 & 264 & 258 & 54 & 4.0 & \\
\hline & 1243 & 866.811 & 0.58 & 0.672 & 133 & 107 & 99 & 263 & 261 & 54 & 4.0 & \\
\hline & 1255 & 872.695 & 6.58 & 0.672 & 134 & 107 & 101 & 262 & 257 & 55 & 410 & \\
\hline & 1309 & 878.699 & 0.58 & 0.672 & 134 & 109 & 102 & 263 & 256 & 54 & 4.0 & \\
\hline END & 1315 & 881.442 & & & & & & & & & & \\
\hline & & & & & & & & & & & & \\
\hline & & & & & & & & & & & & \\
\hline & & & & & & & & & & & & \\
\hline & & & & & & & & & & & & \\
\hline & & & & & & & & & & & & \\
\hline & & & & & & & & & & & & \\
\hline & & & & & & & & & & & & \\
\hline & & & & & & & & & & & & \\
\hline & & & & & & & & & & & & \\
\hline & & & & & & & & & & & & \\
\hline & & & & & & & & & & & & \\
\hline & & & & & & & & & & & & \\
\hline & & & & & & & & & & & & \\
\hline & & & . & & & & & & & & & \\
\hline & & & & & & & & & & & & \\
\hline & & & & & & & & & & & & \\
\hline & & & & & & & & & & & & \\
\hline Avg. & $=$ & 4 W & 155120 & 368 & 1329 & $\%$ & 9 & \%: & $4 \%$ & $2 \%$ & ४⿻ & צ' \\
\hline Check'd d & & $34 \%$ & 176808 & & & 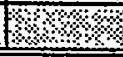 & 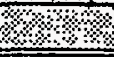 & 12 & 1 & 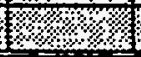 & 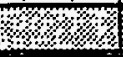 & \\
\hline
\end{tabular}

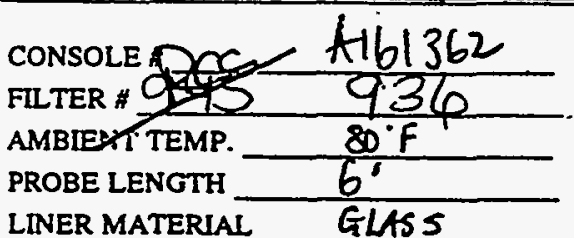

Yylocos

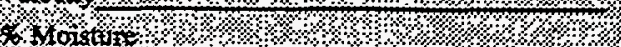

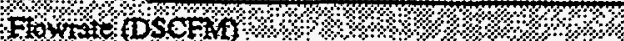

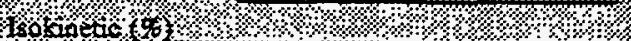

REMARKS

C-132 


$$
\text { page } 1 \text { of } 1
$$

Plant Name

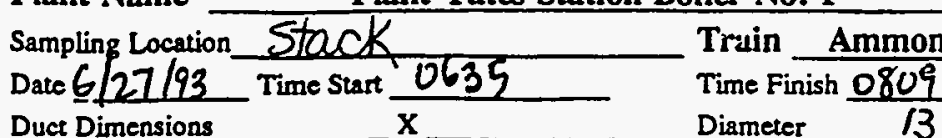

Duct Dimensions

PTCF 0.84 DGMCF 1.006 Nozzle Dia. 0.195 inches

Bar Press 29.21

Static Press - -0.5

Plant Yates Station Boiler No. 1

\begin{tabular}{|c|c|c|c|c|c|c|c|c|c|c|c|c|}
\hline Travers & Clock & Dry gas meter & ${ }^{\wedge} P$ & $\mathrm{H}$ & Stack & Dry gas r & eter temp. & Hot box & Erobe & Last & Vacuum & \\
\hline Point & Time & reading ft 3 & in $\mathrm{H} 2 \mathrm{O}$ & in $\mathrm{H} 2 \mathrm{O}$ & Temp. F & Inlet & Outlet & Temp. & Temp & Impinger & in. $\mathrm{Hg}$ & \\
\hline$\sqrt{-3}$ & 0635 & $451 \cdot 795$ & 0.62 & 0.12 & 133 & 78 & 75 & 265 & 257 & 62 & 4.5 & \\
\hline & 0640 & 954,000 & 0.62 & 0.72 & 133 & 80 & 76 & 263 & 256 & 59 & 4.5 & \\
\hline & 0649 & 1958.140 & $0-62$ & 0.72 & 133 & 84 & 78 & 264 & 1258 & 58 & 4.5 & \\
\hline & 0700 & 963.185 & 0.62 & 0.72 & 133 & 88 & 80 & 264 & 258 & 60 & $4 \cdot 5$ & \\
\hline & 0712 & 968.736 & 0.62 & 0.72 & 133 & 90 & 82 & 259 & 255 & 59 & $4 \cdot 5$ & \\
\hline & 0721 & 1973.022 & $0 b^{2}$ & 0.72 & 133 & 92 & 84 & 257 & 254 & 57 & 4.5 & \\
\hline & 0738 & $980 \cdot 840$ & $0-62$ & $0-72$ & 133 & 94 & 86 & 257 & 252 & 52 & 4.5 & \\
\hline & 10748 & 985.520 & 0.62 & 0.72 & 133 & 95 & 88 & 260 & 259 & 53 & 4.5 & \\
\hline & 6801 & $992-000$ & 0.62 & 0.72 & 133 & 97 & 90 & 260 & 258 & 54 & 4.5 & \\
\hline & 0809 & 995.300 & & & & & & & & & & \\
\hline & & & & & & & & & & & & \\
\hline & & & & & & & & & & & & \\
\hline & & & & & & & & & & & & \\
\hline & & & & & & & & & & & & \\
\hline & & & & & & & & & & & & \\
\hline & & & & & & & & & & & & \\
\hline & & & & & & & & & & & & \\
\hline & & & & & & & & & & & & \\
\hline & & & & & & & & & & & & \\
\hline & & & & & & & & & & & & \\
\hline & & & & & & & & & & & & \\
\hline & & & & & & & & & & & & \\
\hline & & & & & & & & & & & & \\
\hline & & & & & & & & & & & & \\
\hline & & & & & & & & & & & & \\
\hline & & & & & & & & & & & & \\
\hline & & & & & & & & & & & & \\
\hline & & & & & & & & & & & & \\
\hline Avg. & - & 63x & 6.6\% & 0.26 & $6 \%$ & $8 \%$ & SQ⿻ & 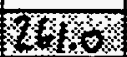 & 639 & S & $y$ & \\
\hline Check'd & & $1 \% 1 \%$ & $\sqrt{327600}$ & $1 \%$ & $18 \%$ & $16 \%$ & 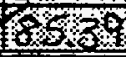 & 18 & 8.4 & & (ে) & \\
\hline
\end{tabular}

CONSOLE $A 161362$

FLLTER * 945

AMBIENT TEMP. $75^{\circ} \mathrm{F}$

PROBE LENGTH $6^{\prime}$

LINER MATERIAL GLAOSS

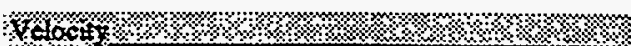

\% 10 of

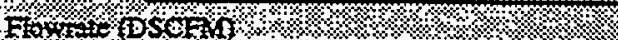

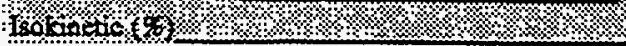

REMARKS 
Plant Name

Plant Yates Station Boiler No. 1

\begin{tabular}{|c|c|c|c|c|c|c|c|c|c|c|c|c|}
\hline \multicolumn{5}{|c|}{ Sampling Location STACK } & \multirow{2}{*}{\multicolumn{3}{|c|}{$\begin{array}{l}\text { Train } \frac{\text { Ammonia/Hydro }}{\text { Time Finish } 1415}\end{array}$}} & \multicolumn{2}{|c|}{ Tyanido } & \multicolumn{2}{|c|}{ Run No. FB } & \\
\hline \multirow{3}{*}{\multicolumn{2}{|c|}{$\begin{array}{l}\text { Date ob } 24 / 93 \\
\text { Duct Dintensions } \\
\text { PTCF } 0.84\end{array}$}} & \multirow{2}{*}{ Time Start } & \multirow[t]{2}{*}{1412} & & & & & \multirow{3}{*}{\multicolumn{2}{|c|}{$\begin{array}{l}\text { Test Duration } \\
\text { Initial Leak Rate } \\
\text { Final Leak Rate }\end{array}$}} & & & \\
\hline & & & & & \multirow{2}{*}{\multicolumn{3}{|c|}{ Diameter $\frac{13}{13 \text { inches }}$}} & & & \multirow{2}{*}{\multicolumn{2}{|c|}{ 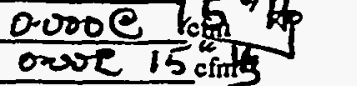 }} & \\
\hline & & DGMCF 1.00 & & Nozzle D & & & & & & & & \\
\hline \multirow{2}{*}{\multicolumn{5}{|c|}{$\begin{array}{l}\text { Bar Press } \frac{29.33}{-0.5} \\
\text { Static Press }-0.5 \mathrm{H}\end{array}$}} & \multirow[b]{2}{*}{ Operator } & \multirow[b]{2}{*}{ EZ } & \multirow[b]{2}{*}{ If } & \multirow{4}{*}{ Hot box } & \multirow{4}{*}{$\begin{array}{l}\text { Probe } \\
\text { Temp }\end{array}$} & \multirow{4}{*}{\begin{tabular}{|c|} 
Last \\
Impinger
\end{tabular}} & \multirow{4}{*}{\begin{tabular}{|c|} 
Vacuum \\
in. $\mathrm{Hg}$
\end{tabular}} & \\
\hline & & & & & & & & & & & & \\
\hline \multirow{2}{*}{$\begin{array}{c}\text { Travers } \\
\text { Point }\end{array}$} & \multirow{2}{*}{$\begin{array}{l}\text { Clock } \\
\text { Time }\end{array}$} & \multirow{2}{*}{$\begin{array}{c}\text { Dry gas meter } \\
\text { reading } \mathrm{ft} 3\end{array}$} & $A P$ & $\triangle \mathrm{H}$ & Stack & Dry gas m & eter temp. & & & & & \\
\hline & & & in $\mathrm{H} 2 \mathrm{O}$ & in $\mathrm{H} 2 \mathrm{O}$ & Temp. $\mathrm{F}$ & Inlet & Outlet & & & & & \\
\hline & 1412 & 675.990 & & & & & & & & & & \\
\hline & 14415 & 676.000 & & & & & & & & & & \\
\hline & & & & & - & & & & & & & \\
\hline & & & & & & & & & & & & \\
\hline & & & & & & & & & & & & \\
\hline & & & & & & & & & & & & \\
\hline & & & & & & & & & & & & \\
\hline & & & & & & & & & & & & \\
\hline & & & & & & & & & & & & \\
\hline & & & & & & & & & & & & \\
\hline & & & & & & & & & & & & \\
\hline & & & & & & & & & & & & \\
\hline & & & & & & & & & & & & \\
\hline & & & & & & & & & & & & \\
\hline & & & & & & & & & & & & \\
\hline & & & & & & & & & & & & \\
\hline & & & & & & & & & & & & \\
\hline & & & & & & & & & & & & \\
\hline & & & & & & & & & & & & \\
\hline & & & & & & & & & & & & \\
\hline & & & & & & ? & & & & & & \\
\hline & & & & & & & & & & & & \\
\hline & & & & & & & & & & & & \\
\hline & & & & & & & & & & & & \\
\hline & & & & & & & & & & & & \\
\hline & & & & & & & & & & & & \\
\hline & & & & & & & & . & & & & \\
\hline & & & & & & & & & & & & \\
\hline Avg. & - & ২ে\% \% & अ४\%? & $1 \% \%$ & ঙিং & $\% 4$ & ৬২ & ४ং & $\% \%$ & \%৫ & $\% \%$ & $18 \%$ \\
\hline Cheok'd & & 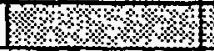 & 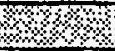 & +४ & 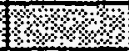 & $18 \%$ & 1\%? & 12 & 24.6 & 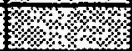 & $2 \%$ & \\
\hline
\end{tabular}

CONSOLE " Afbl 362

FILTER * 940

AMBIENT TEMP. 88

PROBE LENGTH ${ }^{\prime}$

LINER MATERIAL GLSSS

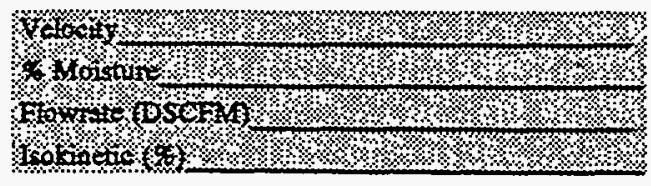

REMARKS

C-134 
Plant Name Plant Yates Station Boiler No. 1

Run No. 1 Sampling Location STACK Train Bulk Particulate-Radionuclides Date $10-24$-93 Time Start 1223 Time Finish 0153 Test Duration 816 min.

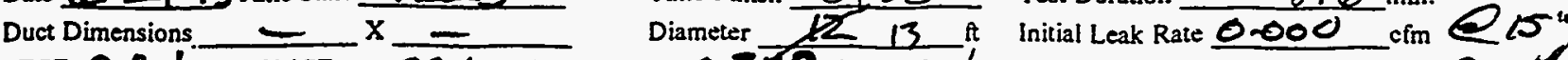
PTCF 0.84 DGMCF 0.994 Nozzle Dia. o 250 inches of $\mathrm{J}$ Final Leak Rate 0.000 cfm $C$ if Bar Press 2233 " $\mathrm{Hg}$ Static Press - $-0.5 \mathrm{Si}$ " $\mathrm{H2O}$ Operator JEH

\begin{tabular}{|c|c|c|c|c|c|c|c|c|c|c|c|c|}
\hline \multirow{2}{*}{$\begin{array}{c}\text { Travers } \\
\text { Point }\end{array}$} & \multirow{2}{*}{$\begin{array}{l}\text { Clock } \\
\text { Time }\end{array}$} & \multirow{2}{*}{$\begin{array}{l}\text { Dry gas meter } \\
\text { reading ft3 }\end{array}$} & \multirow{2}{*}{$\begin{array}{c}{ }^{4} \mathrm{P} \\
\text { in } \mathrm{H} 2 \mathrm{O}\end{array}$} & \multirow{2}{*}{$\begin{array}{l}{ }^{\circ} \mathrm{H} \\
\text { in } \mathrm{H} 2 \mathrm{O}\end{array}$} & \multirow{2}{*}{\begin{tabular}{c|} 
Stack \\
Temp. F
\end{tabular}} & \multicolumn{2}{|c|}{ Dry gas meler temp. } & \multirow{2}{*}{$\begin{array}{c}\text { Hot box } \\
\text { Temp. }\end{array}$} & \multirow{2}{*}{$\begin{array}{l}\text { Probe } \\
\text { Temp }\end{array}$} & \multirow{2}{*}{$\begin{array}{c}\text { Last } \\
\text { Impinger }\end{array}$} & \multirow{2}{*}{$\begin{array}{l}\text { Vacuum } \\
\text { in. } \mathrm{Hg}\end{array}$} & \multirow{2}{*}{ 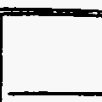 } \\
\hline & & & & & & Iniet & Outlet & & & & & \\
\hline $5-2$ & 1223 & 469.418 & 0.7 & $1-98$ & 128 & 94 & $\sum 4$ & 251 & 251 & 60 & 7.0 & \\
\hline & 1253 & 443,740 & 0.71 & 1.99 & 128 & 102 & 84 & 250 & 250 & 61 & 6.0 & \\
\hline & 1318 & 512.945 & 0,7 & 1.99 & 128 & 105 & 94 & 252 & 250 & 6.5 & $6-0$ & \\
\hline & 131. & 528.562 & 0.71 & 1.91 & 128 & 108 & $s 7$ & 250 & 251 & 55 & 6.0 & \\
\hline & 142 & 562.000 & 0.71 & 1.92 & 128 & 113 & 102 & 252 & 253 & 60 & $6-0$ & \\
\hline & 19.8 & 579.165 & 0.71 & 1.92 & 132 & 114 & 103 & 253 & 254 & 60 & 6.0 & \\
\hline & PIS & $610 \cdot 889$ & 0.71 & 1.92 & 131 & 114 & 104 & 254 & 253 & 63 & 6.0 & \\
\hline & & 612.880 & $E$ & Tf & & & & $=25$. & & & & \\
\hline & $\frac{152}{1552}$ & 612985 & 0.71 & 1.92 & 13.1 & 104 & 101 & 252 & 250 & 67 & 5.0 & \\
\hline & 1553 & 632.050 & 0.7 & 1.92 & 130 & 106 & 88 & 254 & 252 & 57 & 5.0 & \\
\hline$\Rightarrow$ & 1627 & 658.250 & 0.71 & 1.92 & 129 & 100 & 94 & 250 & 251 & 57 & 5.0 & \\
\hline 9 & 1904 & 776.56 & $0 \div 71$ & 1.92 & 130 & 93 & 85 & 253 & 243 & 68 & 5.0 & \\
\hline & 1934 & 799.40 & 0.71 & 1.92 & $|3|$ & 94 & 85 & 252 & 250 & 57 & 5.0 & \\
\hline & $20 * 6$ & 838.85 & 0.71 & 1,92 & 132 & S5 & 85 & 252 & 257 & 55 & 5,5 & \\
\hline & $2 / 26$ & 883.70 & 0,73 & 1.97 & 130 & 98 & 88 & 253 & 262 & 58 & 6.5 & \\
\hline stop & 2019 & 925,610 & & & & & & & & & & \\
\hline Stent & 2226 & 925,740 & 0.73 & 1.97 & 130 & 90 & 86 & 252 & 253 & 60 & 6.5 & \\
\hline & 2313 & 963.90 & 0,73 & 1.97 & 130 & 98 & 87 & 254 & 257 & 47 & 605 & \\
\hline & 0005 & 100559 & 0,73 & 1.97 & 130 & 59 & 88 & $2 \sqrt{2}$ & 254 & 51 & 6.5 & \\
\hline & 0101 & 50.41 & 0.73 & 1.97 & $1 / 30$ & 96 & 87 & 253 & 246 & 57 & 6.5 & \\
\hline stop & 0153 & 1069.204 & & & & & & & & & & \\
\hline & & & & & & & & & & & & \\
\hline & & & & & & & & & & & & \\
\hline & & & & & & & & & & & & \\
\hline & & & & & & & & & & & & \\
\hline & & & & & & & & & & & & \\
\hline & & & & & & & & & & & & \\
\hline & & & & & & & & & & & & \\
\hline Avg. & - & $45,4 s 50$ & 8458 & $4,4 \%$ & $2 / 2 \% 8$ & ल४ & 973 & $8 \%$ & $\%$ & \%ष्: & 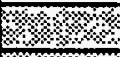 & 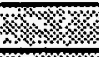 \\
\hline Check'd & & $18 \% \%$ & $1 \%$ & $\% \%$ & \%० & \%४४ & $8 \%$ & $18 \%$ & 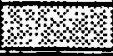 & & & \\
\hline
\end{tabular}

CONSOLE " A161365

FLTER \#

AMBIENT TEMP. $82^{\circ} \mathrm{C}$

PROBE LENGTH G'

LINER MATERIAL RYREX

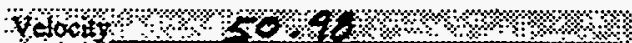

W Moustru

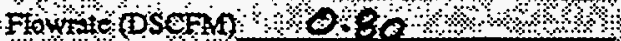

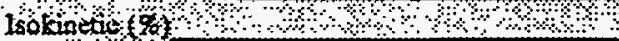

REMARKS Tili * otopped to empty impo, leak check thougl getersurere $0.001015^{\prime \prime}$

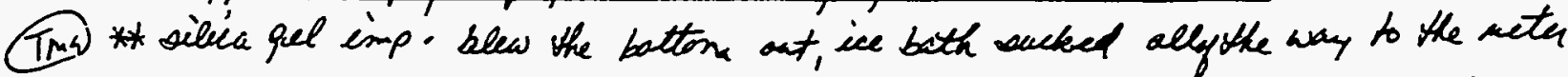


STACK

$$
\text { Page } 1 \text { of } 2
$$

Plant Name Plant Yates Station Boiler No. 1

Sampling Location_STACK Train Bulk Particulate-Radionuclides Run No. 2

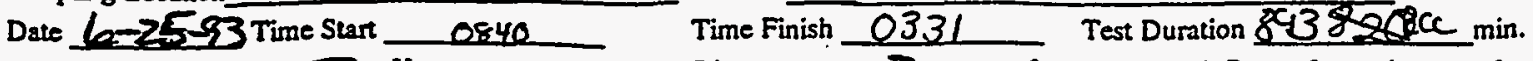

Duct Dimensions _ D Dimeler $\frac{13}{13}$ Initial Leak Rate 8 -ele cfm $20^{\prime \prime}$ PTCF_84 DGMCF_98B. Nozzle Dia. 0.240 inches Final Leak Rate 0.009 cfr@o/4" Bar Press 29.41. $" \mathrm{Hg}$

Static Press -0.51 Operator JEOt

\begin{tabular}{|c|c|c|c|c|c|c|c|c|c|c|c|c|}
\hline \multirow{2}{*}{$\begin{array}{c}\text { Travers } \\
\text { Point }\end{array}$} & \multirow{2}{*}{$\begin{array}{l}\text { Clock } \\
\text { Time }\end{array}$} & \multirow{2}{*}{$\begin{array}{c}\text { Dry gas meter } \\
\text { reading fl3 }\end{array}$} & \multirow{2}{*}{$\begin{array}{c}A P \\
\text { in } \mathrm{H} 2 \mathrm{O}\end{array}$} & \multirow{2}{*}{$\begin{array}{c}{ }^{\circ} \mathrm{H} \\
\text { in } \mathrm{H} 2 \mathrm{O}\end{array}$} & \multirow{2}{*}{$\begin{array}{c}\text { Stack } \\
\text { Temp. F }\end{array}$} & \multicolumn{2}{|c|}{ Dry gas meter temp. } & \multirow{2}{*}{$\begin{array}{l}\text { Hot box } \\
\text { Temp. }\end{array}$} & \multirow{2}{*}{$\begin{array}{l}\text { Probe } \\
\text { Temp }\end{array}$} & \multirow{2}{*}{$\begin{array}{c}\text { Last } \\
\text { Impinger }\end{array}$} & \multirow{2}{*}{$\begin{array}{l}\text { Vacuum } \\
\text { in. } \mathrm{Hg}\end{array}$} & \\
\hline & & & & & & Inlet & Outlet & & & & & \\
\hline $5-i$ & 0840 & 771.158 & .72 & 1.91 & IE-9 & & & 260 & 251 & & & \\
\hline stop & $\frac{0841}{t 03>0}$ & & & -93 & $\frac{\pi \beta}{120}$ & $1<$ & & & $=50$ & $5>$ & & \\
\hline & 0340 & $785: 200$ & -72 & 1.92 & 128 & 84 & 76 & 252 & 25 & 46 & 3.0 & $=$ \\
\hline & 0255 & 797.580 & -73 & & 129 & 21 & 80 & 252 & 250 & 47 & 30 & - \\
\hline Stap & 1042 & 831.423 & 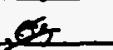 & & & & & & & & & \\
\hline Stant & 1324 & 831,423 & e. 58 & 1.53 & 127 & 83 & 83 & 255 & 347 & 81 & 3.0 & \\
\hline & 1333 & 837465 & 0.58 & 1,53 & 127 & 86 & 83 & 252 & 243 & 47 & 3.0 & \\
\hline & 1405 & 857.925 & $0 \cdot 76$ & 2.006 & 128 & 96 & 87 & 254 & 255 & 52 & 3.0 & \\
\hline & 1435 & 880.820 & 0.67 & 1.77 & 128 & 101 & 90 & 257 & 241 & 54 & 3.0 & \\
\hline$S \pi P$ & 1520 & 913.418 & Dor & hoved & mors & 1 & $m \sqrt{12}$ & $\tan$. & & & & \\
\hline STent & 1525 & 913.488 & 0.67 & 1.77 & 128 & 100 & 89 & 253 & 248 & 53 & $3 \cdot 0$ & \\
\hline & 1605 & 943.225 & 0.67 & 1.77 & 129 & 106 & 96 & 254 & 250 & 52 & 3.0 & \\
\hline- & 16.59 & 983.300 & 0.69 & 1.82 & 129 & 107 & 98 & 257 & 255 & 52 & 3.0 & \\
\hline STop & 1226 & 002.885 & Re & foved & Moisto & & & & & & & \\
\hline Start & 1749 & 002.855 & 0.69 & 1.82 & 130 & 96 & $\dot{q 4}$ & 254 & 246 & 81 & 3.0 & \\
\hline$\Rightarrow$ & 1855 & 59.65 & 0,72 & 1.93 & 130 & 106 & 96 & 254 & 261 & 53 & 3,0 & \\
\hline & 1935 & 86,21 & 0,72 & 1.93 & 130 & 107 & $G 7$ & 257 & 245 & 46 & 3,0 & \\
\hline & $20 / 4$ & 115.40 & 0.72 & 1.93 & 1629 & 108 & SE & 257 & 251 & 48 & 3.5 & \\
\hline step & 2107 & 154.179 & Ren & ared a & veature & les & check & 0.001 & $0,4^{k}$ & these & 4 alias & E \\
\hline $\operatorname{sent}$ & 2112 & 154.300 & 0,72 & 1.93 & 128 & 100 & Gs & 253 & 240 & 52 & $3 \cdot 5$ & \\
\hline & 2211 & 199.26 & 0.72 & 1.93 & 130 & 104 & 95 & 255 & 246 & 57 & 3.5 & \\
\hline & 2304 & 237.04 & 0.72 & 1.93 & 1.30 & 102 & 55 & 256 & 243 & 50 & 3,5 & \\
\hline & $\alpha_{35} 9$ & 276.93 & 0.72 & 1.93 & $\%$ B & 97 & 90 & $2 \sqrt{2}$ & 262 & $\Omega$ & 3.5 & \\
\hline 20 & $60 / 8$ & 269.746 & pen & ae & in. & & & & & & & \\
\hline skit & 0022 & 289.746 & 0.72 & 1.93 & 129 & 22 & 86 & 253 & 240 & 48 & 3,5 & \\
\hline & 0123 & 333.11 & 0.72 & 1.93 & 1029 & 95 & 87 & 254 & 245 & 55 & $3 \cdot 5$ & \\
\hline & 0218 & 373,51 & 0,72 & 193 & 128 & 96 & 88 & 255 & 264 & 50 & 3.5 & \\
\hline Avg. & 二 & $1 \% \% \%$ & $1 \%$ & $18 \%$ & $16 \%$ & \%॰ & $48 \%$ & $8.8 \%$ & $1 \%$ & K & 8. & \%: \\
\hline Check'd & & $14 \% 8 \%$ & $\$ \%$ & $18 \%$ & $18 \%$ & 1804 & $4 \times 4$ & (1) & S/2: & S: & (4) & 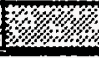 \\
\hline
\end{tabular}

CONSOLE " AL61397

FILTER * \#988

AMBIENT TEMP. $755^{\circ} \mathrm{F}$

PROBE LENGTH $C^{\prime}$

LINER MATERIAL PYEX

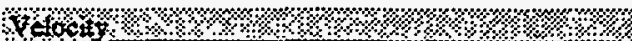

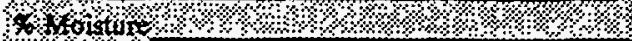

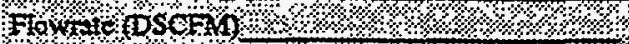

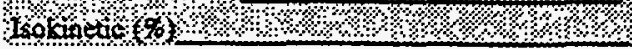

REMARKS 
MODIFIED METHOD 5 FIELD DATA SIRET

PLANT NAME Plant Yates Station Boiler No. 1

SAMPLING LOCATION SteCK

DATE 6-26-Y3 TIME START

DUCT DIMENSIONS DGMCF 0.485

BAR PRESS $29.41 \% \mathrm{Hg}$
STATIC PRESS -0.51

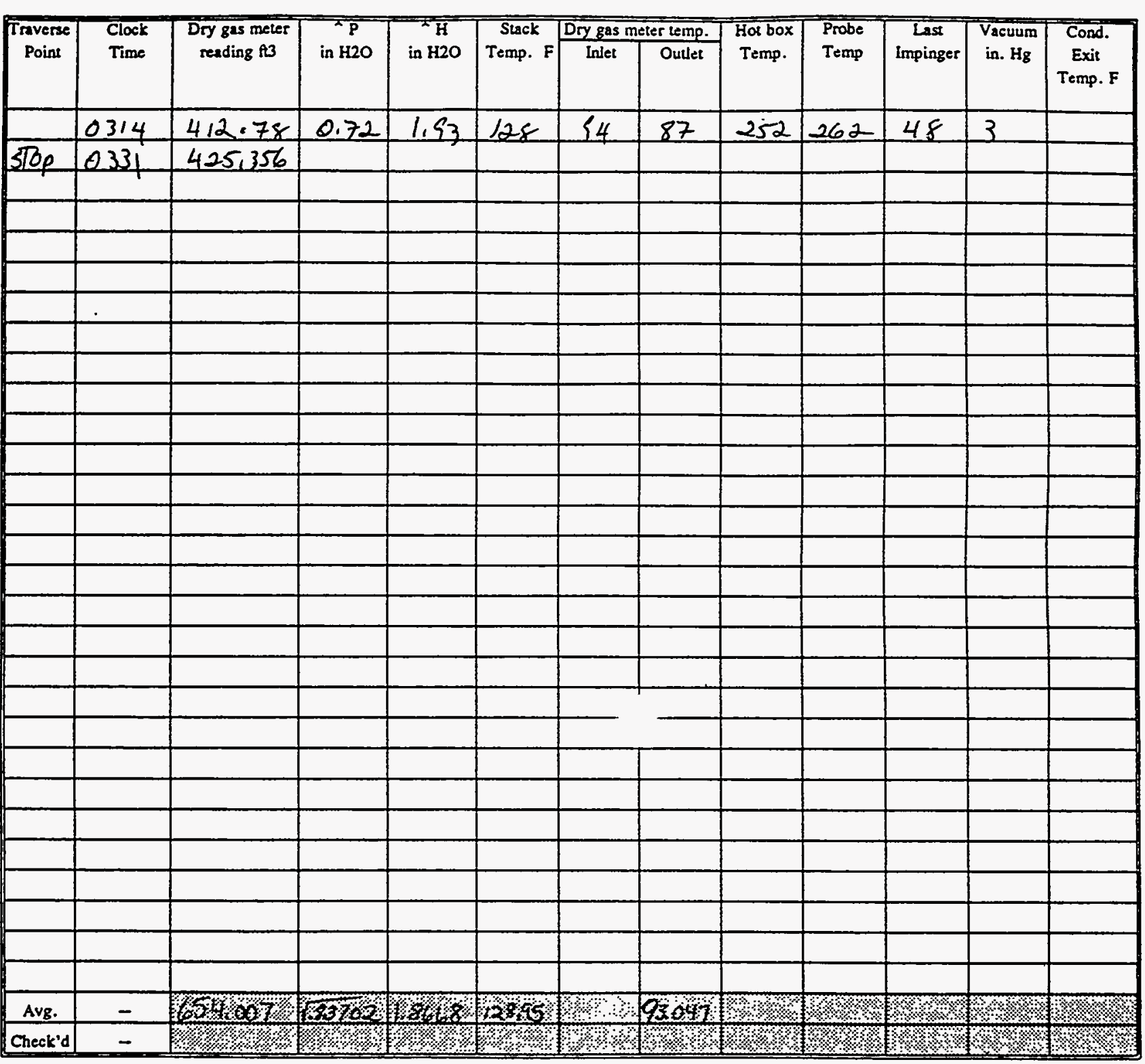

CONSOLE \#

FILTER *

AMBIENT TEMP.

PROBE LENGTH

LINER MATERIAL
RUN NO. 2

TIME FINISH TEST DURATION INITIAL LEAK RATE $\longrightarrow \mathrm{cfm}$ FINAL LEAK RATE — OPERATOR JEH/TMCD

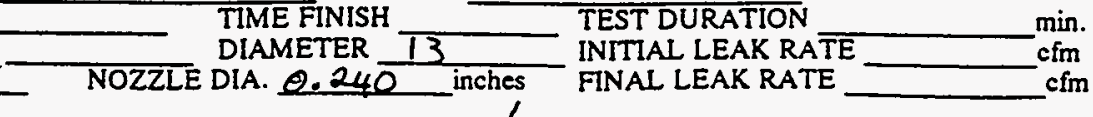

Page 2 of 2

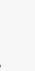


Plant Name Plant Yates Station Boiler No. 1

Sampling Location STCK

Date $2 .-25-33$ Time Start $1743 \times 3 / 357$

Duet Dimensions

PTCF $x$

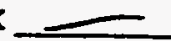

Bar Press $28-J 3 \quad H g$

Static Press Diameter Train

Time Finish

$\frac{0614}{3}$ $\frac{13}{16}$

0.240 inches

Operator $\rho J V / E B Z / J E H /$

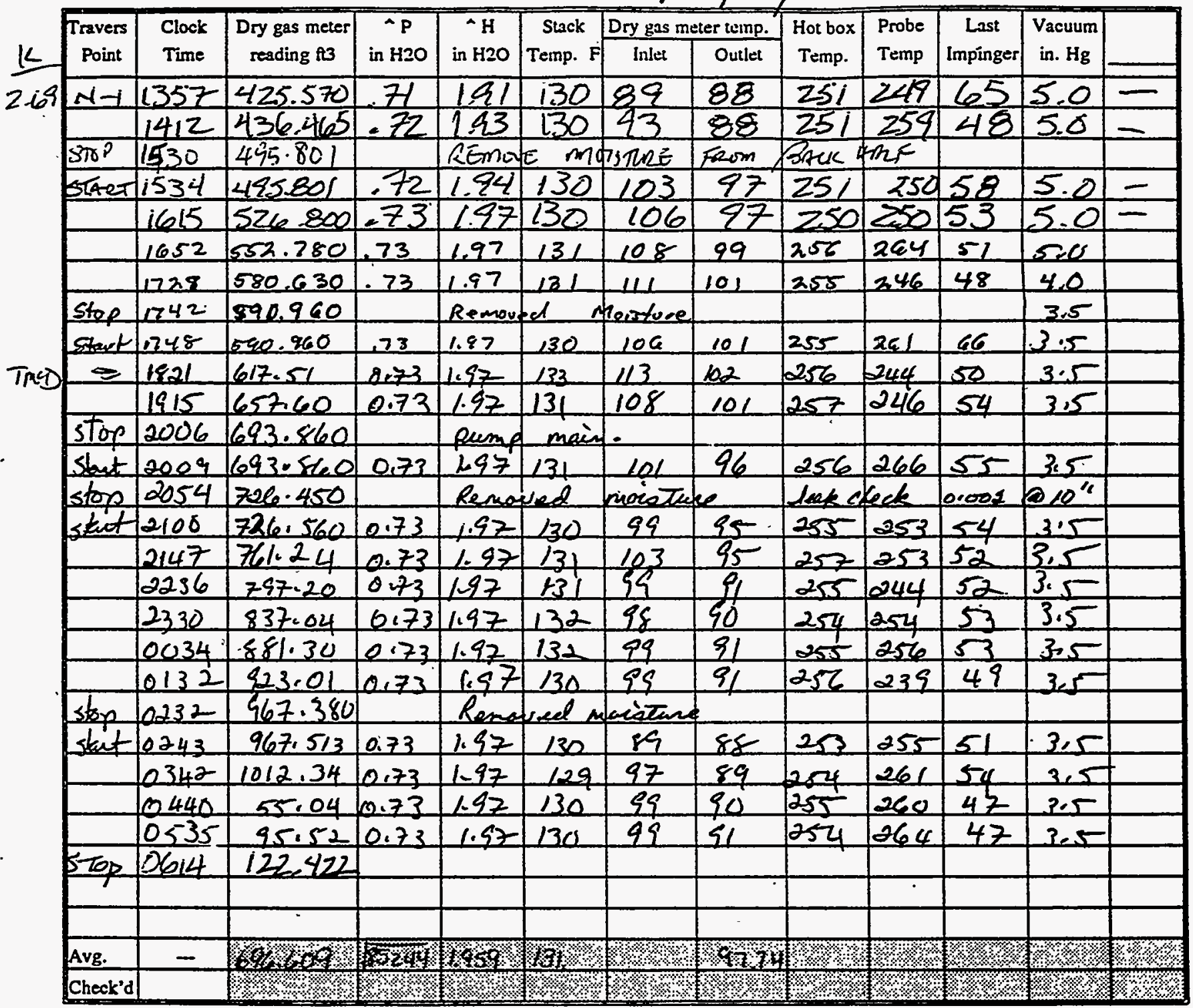

Page 1 of 1

RADIONOCLEIDES

ATE-E $=$ TS SEY RUN No. 3

Test Duration _ $908 \mathrm{~min}$.

Initial Leak Rate 0.000 cim $\sigma 20 "$

Final Leak Rate $\leq l .001$ cim $e$ 
STACK

Plant Name Plant Yates Station Boiler No. 1

Page 1 of 1

Date $6 / 24 / 93$ Time Star 1150

Duct Dimensions

Train Bulk Particulate-Ex. Metals

Run No. 1

PTCF .84 DGMCF 0.994 Nozzle Dia. 0.24 inches $x$

Time Finish $0725^{\prime}(0,25 / k 3)$ est Duration

1112 min.

it Initial Leak Rate 0.0000 df ${ }^{4}$ " $4 \mathrm{~g}$

Bar Press $29.33 \quad \mathrm{Hg}$

Static Press -0.5 Operator $E Z$

Final Leak Rate 0.000 e cim foffy

$k=2 \cdot 864$

\begin{tabular}{|c|c|c|c|c|c|c|c|c|c|c|c|c|}
\hline \multirow{2}{*}{$\begin{array}{c}\text { Travers } \\
\text { Point }\end{array}$} & \multirow{2}{*}{$\begin{array}{l}\text { Clock } \\
\text { Time }\end{array}$} & \multirow{2}{*}{$\begin{array}{c}\text { Dry gas meter } \\
\text { reading ft3 }\end{array}$} & \multirow{2}{*}{$\begin{array}{c}\text { A } \mathrm{P} \\
\text { in } \mathrm{H} 2 \mathrm{O}\end{array}$} & \multirow{2}{*}{ in $\mathrm{H}$. } & \multirow{2}{*}{$\begin{array}{c}\text { Stack } \\
\text { Temp. F }\end{array}$} & \multicolumn{2}{|c|}{ Dry gas meter teinp. } & \multirow{2}{*}{$\begin{array}{l}\text { Hot box } \\
\text { Teinp. }\end{array}$} & \multirow{2}{*}{$\begin{array}{l}\text { Probe } \\
\text { Temp }\end{array}$} & \multirow{2}{*}{$\begin{array}{c}\text { Last } \\
\text { Impinger }\end{array}$} & \multirow{2}{*}{$\begin{array}{l}\text { Vacuum } \\
\text { in. } \mathrm{Hg}\end{array}$} & \\
\hline & & & & & & Inlet & Outlet & & & & & \\
\hline$N-2$ & $11: 50$ & 151.048 & 0.62 & 1.176 & 128 & 89 & 88 & 254 & 259 & 60 & $6 \cdot 0$ & \\
\hline & $12 \cdot 08$ & 171.030 & 0.62 & 1.776 & 129 & 100 & 90 & 254 & 260 & 57 & 6.0 & \\
\hline & 1247 & 200.722 & 0.62 & 1.78 & 129 & 106 & 96 & 254 & 260 & 52 & 6.0 & \\
\hline & 1310 & 218.635 & 0.62 & 1.78 & 130 & 110 & 96 & 256 & 260 & 56 & 16.0 & \\
\hline & 1351 & 249.835 & 0.62 & 1.78 & i31 & 121 & 108 & 257 & 255 & 59 & 6.0 & \\
\hline & 1436 & 283.944 & 0.62 & 1.78 & 129 & 16 & 116 & 256 & 248 & 63 & $6 \cdot 0$ & \\
\hline & 1515 & 313.926 & 0.62 & 1.78 & 136 & 123 & 117 & 253 & 245 & 61 & 6.0 & \\
\hline STOP & 1525 & 321.817 & & & & & & & & & & \\
\hline STARE & 1532 & 321.820 & 062 & $1-78$ & 130 & 111 & 112 & 254 & 246 & 59 & 6.0 & \\
\hline & 1625 & 362.285 & 0.62 & 1.78 & 127 & 100 & 95 & 256 & 250 & 56 & 6.0 & \\
\hline$\rightarrow$ & 1908 & 480,62 & 0.62 & 1,78 & 129 & 94 & 86 & 254 & 239 & 62 & 6.0 & \\
\hline & 1836 & 501,92 & 0.62 & 1,78 & 130 & 96 & 85 & 253 & 253 & 49 & 6.0 & \\
\hline & 2029 & 537.65 & 0.62 & 1.78 & 130 & 96 & 85 & 255 & 253 & 53 & 5.5 & \\
\hline & 2128 & 580.24 & 0.62 & 1.78 & 129 & 105 & 93 & 256 & 242 & 57 & $5 \cdot 5$ & \\
\hline Stop & 2216 & 610.853 & & & & & & & & & & \\
\hline staut & 2307 & 610950 & 0.62 & 1,78 & 127 & 83 & 84 & 251 & 239 & 56 & 7.5 & \\
\hline & 0007 & 658.05 & 0,62 & 1.78 & 128 & 98 & 83 & 256 & 241 & 55 & 7.0 & \\
\hline & 0102 & 697.92 & 0.62 & 1.78 & 128 & 94 & 84 & 254 & 249 & $5 \sqrt{2}$ & 7.5 & \\
\hline & $0 / 55$ & 736.76 & 0.62 & 1.78 & 129 & 90 & 86 & $2 \sqrt{6}$ & 235 & 56 & $7 \sqrt{2}$ & \\
\hline & 0312 & 783.53 & 0.62 & $1.7 E$ & 129 & 96 & 85 & 255 & 247 & 50 & 7.5 & \\
\hline & oxer & 830.01 & 0,62 & 678 & 129 & 96 & 85 & 256 & 248 & 54 & 7.5 & \\
\hline & 0453 & 868,46 & 0.62 & 1.78 & 130 & 101 & 89 & $2 \sqrt{6}$ & 239 & 57 & 7.5 & \\
\hline skpp & 0524 & $891 \cdot 485$ & & & & & & & & & & \\
\hline \multirow[t]{4}{*}{$x *$} & 0,29 & $891 \cdot 598$ & 0,62 & 1.78 & 129 & 97 & 91 & 252 & 260 & 56 & $7 \cdot 5$ & \\
\hline & 0629 & 933.854 & 0.62 & 1.78 & 129 & 103 & 92 & 256 & 250 & 489 & 8.0 & \\
\hline & 0717 & 969.526 & 0.02 & 1.28 & 128 & $i 04$ & 94 & $25 b$ & 251 & 48 & 8.0 & \\
\hline & 0725 & $\pi 6.252$ & & & & & & & & & & \\
\hline & & & & & & & & & & & & \\
\hline Avg. & $=$ & $8 / 6.9 \%$ & $\sqrt{98940}$ & 1026 & 120.00 & $98 \%$ & 92,545 & $9 \%$ & $8 \%$ & (2. & & \\
\hline Check'd & & $18 \%$ & $18.8 \%$ & $\%$ & $1 \% \%$ & 13 & 9 & $1 \%$ & 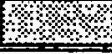 & & 18 & \\
\hline
\end{tabular}

CONSOLE \# A|b|36|

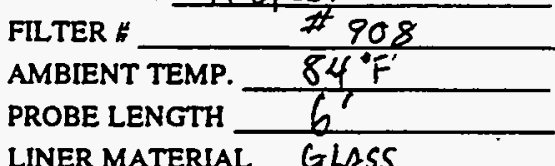

Velocity \$o Moistur Fawnete fSCFAM lokintie for
*** aenrued isp. ceted leak ches through flesswa $0.000 @ 14 "$

REMARKs * Rómore mosizues feom impantries 
STACK

Page 1 of 1

Plant Name Plant Yates Station Boiler No. 1

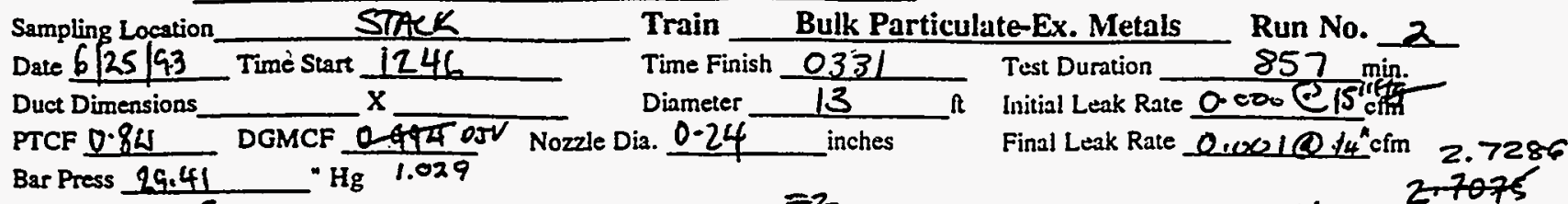

Bar Press 29.41 Operator EZ

\begin{tabular}{|c|c|c|c|c|c|c|c|c|c|c|c|c|}
\hline \multirow{2}{*}{$\begin{array}{c}\text { Travers } \\
\text { Point }\end{array}$} & \multirow{2}{*}{$\begin{array}{l}\text { Clock } \\
\text { Time }\end{array}$} & \multirow{2}{*}{$\begin{array}{c}\text { Dry gas meter } \\
\text { reading } \mathrm{A} 3\end{array}$} & \multirow{2}{*}{ in $\mathrm{H} 2 \mathrm{O}$} & \multirow{2}{*}{$\begin{array}{c}\wedge \mathrm{H} \\
\text { in } \mathrm{H} 2 \mathrm{O}\end{array}$} & \multirow{2}{*}{$\begin{array}{c}\text { Stack } \\
\text { Temp. F }\end{array}$} & \multicolumn{2}{|c|}{ Dry gas meter temp. } & \multirow{2}{*}{$\begin{array}{l}\text { Hot box } \\
\text { Temp. }\end{array}$} & \multirow{2}{*}{$\begin{array}{l}\text { Probe } \\
\text { Temp }\end{array}$} & \multirow{2}{*}{\begin{tabular}{|c|} 
Last \\
Impinger
\end{tabular}} & \multirow{2}{*}{$\begin{array}{l}\text { Vacuum } \\
\text { in. } \mathrm{Hg}\end{array}$} & \multirow[b]{2}{*}{-} \\
\hline & & & & & & Inlet & Outlet & & & & & \\
\hline$=-1$ & 1246 & 214.097 & 0.64 & 1.75 & 12.4 & 81 & 81 & $225^{\circ}$ & 2.59 & 74 & 3.0 & \\
\hline & .365 & $225 \cdot 225$ & 0.64 & 1.75 & 124 & 89 & 82 & 252 & 248 & 50 & $3 \cdot c$ & \\
\hline & 1322 & 237.899 & 0.64 & 1.75 & 124 & 94 & 85 & 254 & 250 & 52 & $3 \cdot 0$ & \\
\hline & 1400 & 264,902 & 6.64 & 1.75 & 124 & 99 & 89 & 254 & 250 & 53 & 3.0 & \\
\hline & 1430 & 255.726 & 0.64 & 1.75 & 124 & 101 & 92 & 250 & 262 & 52 & $3 \cdot 0$ & \\
\hline $\sin$ & 1528 & 326.305 & & \multicolumn{4}{|c|}{ econont morsinise From } & Rntin & & & & \\
\hline \multirow[t]{3}{*}{ STAR } & i531 & $32 C .890$ & 0.64 & 1.75 & 124 & 100 & $g_{1}$ & 251 & 260 & 53 & 3.0 & \\
\hline & 1612 & 355.845 & 0.64 & 1.75 & 129 & 101 & 92 & 254 & 250 & 53 & $3 \cdot 0$ & \\
\hline & 1658 & 389.995 & 0.64 & 1.75 & 124 & 101 & 92 & 253 & $2+4$ & 49 & 3.0 & \\
\hline stop & 1729 & 411.792 & & stope & 2 to & Rew & & +0 & & & & \\
\hline \multirow{4}{*}{ Shat } & 1750 & 411.792 & 264 & 4.75 & 126 & 87 & 88 & 348 & 252 & 73 & 2.0 & \\
\hline & 1902 & 464.37 & 264 & 1.75 & 226 & 96 & 87 & 254 & 253 & 46 & 2.0 & \\
\hline & 1936 & 488135 & 0.64 & 1,75 & 127 & 95 & 87 & 253 & 242 & 42 & 20 & \\
\hline & 2016 & $516 \cdot 39$ & 0.64 & 1.75 & 1627 & 96 & 87 & 253 & 248 & 4. & 2.0 & \\
\hline stop & 2114 & 556.829 & nemod & ad md & stues & lea & 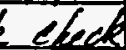 & $x / 8$ & $513^{\prime \prime}$ & exherensh & iflease & ere \\
\hline \multirow[t]{3}{*}{ stant } & 2118 & 556.935 & 0.64 & 1.75 & 125 & 86 & 83 & 252 & 253 & $\sqrt{3}$ & 2.0 & \\
\hline & 2212 & 555,23 & 0.64 & 1.75 & 126 & 91 & 82 & 253 & 259 & 47 & 2,1 & \\
\hline & 2305 & 632,71 & 0.64 & 1.75 & 127 & 52 & 84 & 253 & $2 \sqrt{5}$ & 46 & 2.0 & \\
\hline \multirow[t]{6}{*}{ Thes } & $1000+$ & $7 \cos 9 \theta$ & & & & & & & & & & \\
\hline & 0001 & 670.90 & 0.64 & 1.75 & 127 & 92 & 84 & 257 & 252 & 48 & 2.0 & \\
\hline & 0030 & 69125 & 064 & 1.75 & 177 & 85 & 88 & $2 \sqrt{2}$ & 25 & 47 & 2.0 & \\
\hline & 0125 & 729.41 & 0.64 & 1.75 & 126 & 86 & 79 & 253 & $2 \sqrt{6}$ & 8 & 2.0 & \\
\hline & 0219 & 767.02 & 0624 & 1.75 & 126 & 88 & 79 & 253 & 256 & 47 & 2.0 & \\
\hline & 6312 & 503.00 & 0.64 & 1.7 & 124 & 87 & 79 & 253 & 244 & 45 & 2.0 & \\
\hline \multirow[t]{3}{*}{ step } & 0331 & 815.698 & & & & & & & & & & \\
\hline & & & & & & & & & & & & \\
\hline & & & & & & & & & & & & \\
\hline & & & & & & & & & & & & \\
\hline$\frac{\text { Avg. }}{\text { Check'd }}$ & $=$ & $6,20,9$ & 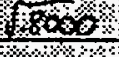 & 1.9.9. & $20 \%$ & $2 \%$ & 8205 & $8 \%$ & \% \% & $8 \%$ & $4 \%$ & $1 \% \%$ \\
\hline heck'd & & $3 \% 4.8 \%$ & $4 \%$ & \% & 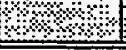 & 12.4 & & $18 \%$ & $1 \%$ & 8 & $6 / 4 \%$ & $18 \%$ \\
\hline
\end{tabular}

CONSOLE\# A|fH36- AIGlaqU

FILTER \#

AMBIENT TEMP. $78^{\circ} \mathrm{F}$

PROBE LENGTH $6 ?$

LINER MATERIAL GLES
Wênolty $1 \%$ \%

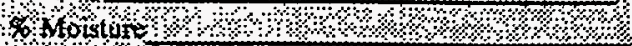

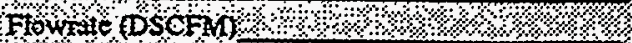

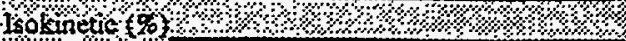

\section{REMARKS}




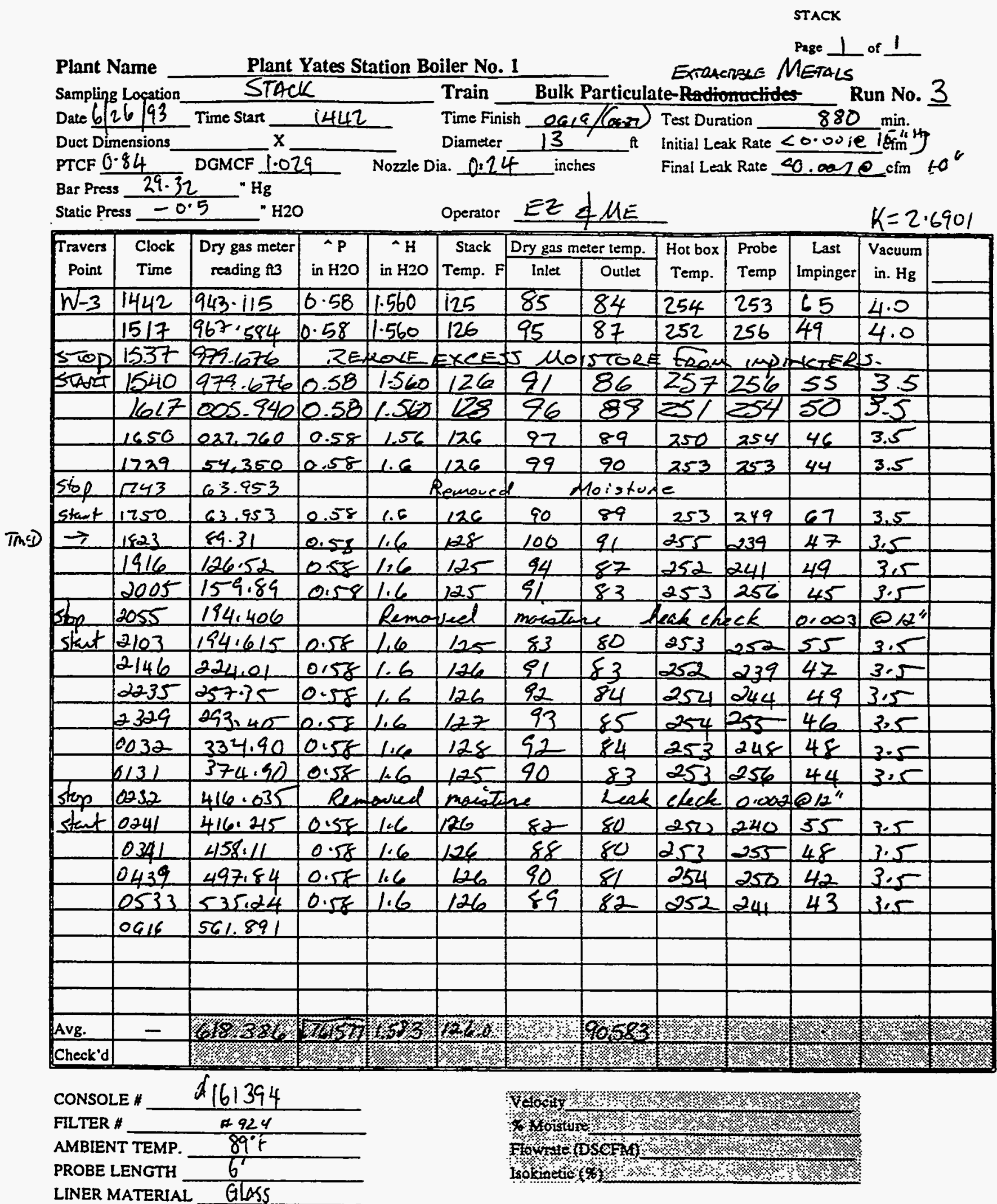

REMARKS 


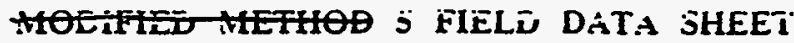

PLANT NAME Plant Yates Station Boiler No. 1

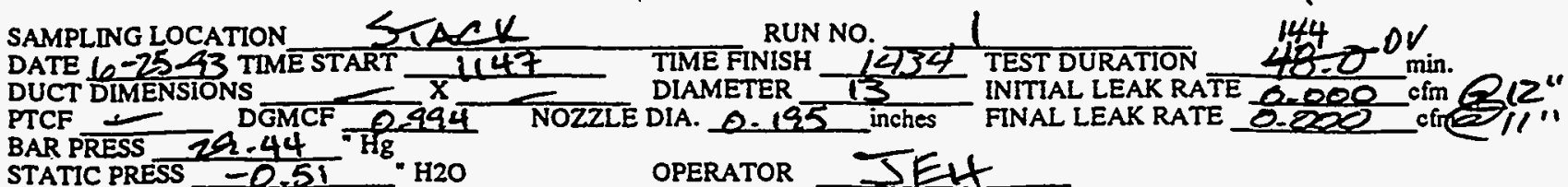

\begin{tabular}{|c|c|c|c|c|c|c|c|c|c|c|c|c|}
\hline \multirow{2}{*}{$\begin{array}{c}\text { Traverse } \\
\text { Point }\end{array}$} & \multirow{2}{*}{$\begin{array}{l}\text { Clock } \\
\text { Time }\end{array}$} & \multirow{2}{*}{$\begin{array}{c}\text { Dry ges meter } \\
\text { reading ft3 }\end{array}$} & \multirow{2}{*}{$\begin{array}{l}\mathrm{P} \\
\text { in } \mathrm{H} 2 \mathrm{O}\end{array}$} & \multirow{2}{*}{ in $\mathrm{H} 2 \mathrm{O}$} & \multirow{2}{*}{$\begin{array}{c}\text { Stuck } \\
\text { Temp. } F\end{array}$} & \multicolumn{2}{|c|}{ Dry gas meter lemp. } & \multirow{2}{*}{$\begin{array}{l}\text { Hot box } \\
\text { Temp. }\end{array}$} & \multirow{2}{*}{$\begin{array}{l}\text { Probe } \\
\text { Temp }\end{array}$} & \multirow{2}{*}{$\begin{array}{c}\text { Lust } \\
\text { Impinger }\end{array}$} & \multirow{2}{*}{\begin{tabular}{l|} 
Vacuum \\
in. $\mathrm{Hg}$
\end{tabular}} & \multirow{2}{*}{$\begin{array}{c}\text { Cond. } \\
\text { Exit } \\
\text { Temp. F }\end{array}$} \\
\hline & & & & & & Inlet & Outlet & & & & & \\
\hline$E-1$ & 1147 & 981.420 & .60 & 70 & 128 & 80 & 79 & 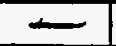 & $=$ & 68 & 1.0 & $=$ \\
\hline-2 & 1159 & 987.420 & -61 & 72 & 128 & 84 & 80 & $=$ & - & 52 & 1.5 & $=$ \\
\hline-3 & 1211 & 993.200 & .55 & .64 & 128 & 89 & 83 & - & - & 55 & 1.5 & $=$ \\
\hline Top & 1223 & 998.725 & & & & 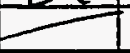 & & & & & & \\
\hline$s-1$ & $i 235$ & 998.725 & -60 & 30 & 128 & 86 & 84 & - & - & 67 & 1.0 & $=$ \\
\hline-2 & 1247 & 1004.380 & .61 & -72 & 128 & 43 & 87 & $\sim$ & $=$ & 54 & 1.5 & - \\
\hline-3 & 1259 & 1010.125 & $=58$ & .68 & 128 & $\frac{1}{27}$ & 90 & - & $=$ & 54 & $1-0$ & $=$ \\
\hline siop & 1311 & $10 i 5.654$ & $L$ & $x 4$ & OK & & & & & & & \\
\hline$\alpha-1$ & 1318 & 1015710 & -60 & -71 & 126 & 92 & 90 & $=$ & $=$ & 62 & 1.0 & - \\
\hline-21 & 1330 & 1021.400 & .61 & .72 & 125 & ये & 92 & $=$ & $=$ & 56 & 15 & $=$ \\
\hline-3 & 1342 & $102 z-265$ & 55 & .66 & 126 & 28 & 92 & - & $=$ & 59 & 1.0 & - \\
\hline $10 p$ & 1354 & 1032.900 & $\angle E$ & $4 k$ C & HECY & $0 k$ & & & & & & \\
\hline \multirow{4}{*}{$\frac{1}{-2}$} & 1358 & 1032.920 & -56 & .67 & 126 & 46 & 83 & - & - & 61 & 1.0 & - \\
\hline & 1410 & 1038510 & .58 & -76 & 125 & 100 & 24 & $=$ & $=$ & 56 & 1.0 & $=$ \\
\hline & 1422 & $1044-300$ & -59 & -71 & 126 & 102 & 85 & $=$ & $=$ & 58 & 1.0 & $=$ \\
\hline & 1434 & 1050,179 & & & & & & & & & & \\
\hline & & & & & & & & & & & & \\
\hline & & & & & & & & & & & & \\
\hline & & & & & & & & & & & & \\
\hline & & & & & & & & & & & & \\
\hline & & & & & & & & & & & & \\
\hline & & & & & & & & & & & & \\
\hline & & & & & & & & & & & & \\
\hline & & & & & & & & & & & & \\
\hline & & & & & & & & & & & & \\
\hline & & & & & & & & & & & & \\
\hline & & & & & & & & & & & & \\
\hline & & & & & & & & & & & & \\
\hline & & & & & & & & & & & & \\
\hline Avg. & $=$ & $x_{x}-x, 1$ & $96 \% 8$ & $9<4$ & $4 \times<.6$ & $18 \% 8$ & 54 & $18 \%$ & 8. & $8 \%$ & $8 \%$ & $1 \%$ \\
\hline Check'd & - & 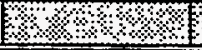 & $\%$ & $8 \% \div 8:$ & $10 \%$ & $18 \times 1$ & 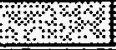 & \$4: & 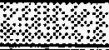 & 48 & 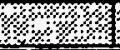 & $8 \%$ \\
\hline
\end{tabular}

CONSOLE $A 16.1361$

FILTER \#

AMBIENT TEMP. $81^{\circ} \mathrm{F}$

PROBE LENGTH $\frac{6}{6}$

LINER MATERIAL P

REMARKS

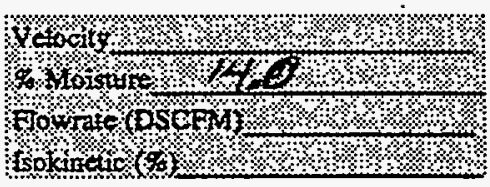

Page 1 of 1

144

8.0 min. DIA. 0.195 inches FINAL LEAK RATE 0.200 cfre OPERATOR TEH 
PLANT NAME Plant Yates Station Boiler No. 1

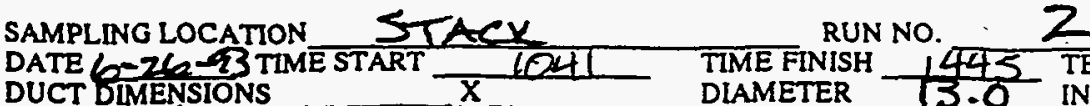

PTCF 84. DGMCF .944 $X$

BAR PRESS $72-32$ " $\mathrm{Hg}$

STATIC PRESS $=0.51$ H2O

OPERATOR JEH

Page 1 of 1

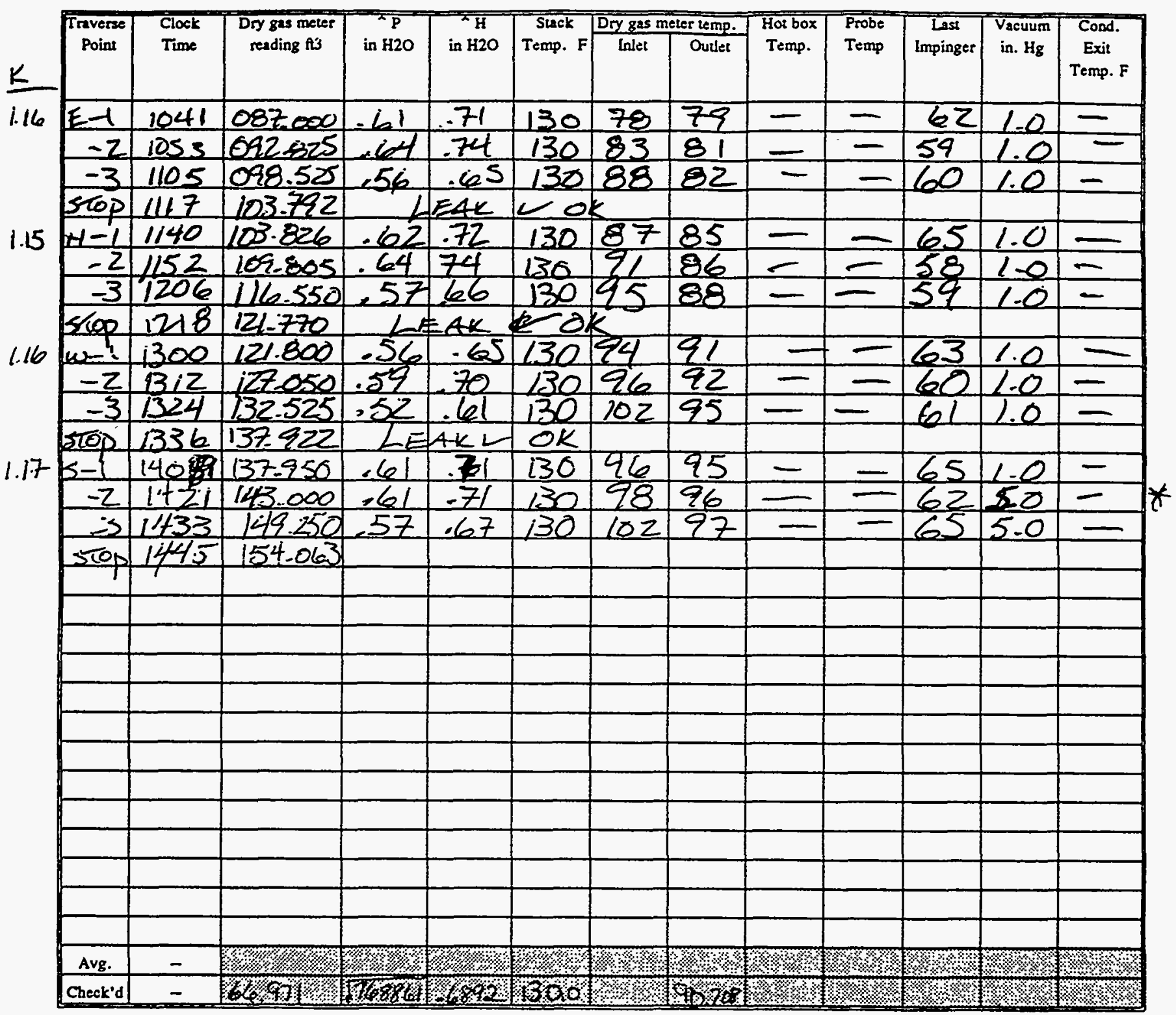

CONSOLE \# ALELBGL

FILTER \#- -

AMBIENT TEMP. $78 \%$

PROBE LENGTH 61

LINER MATERIAL PpREX

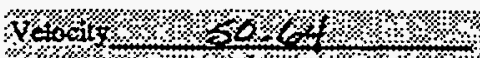

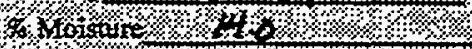

10073 (3SOFM

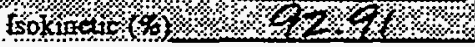

REMARKS

ALL TIMES COT * KOH CRYSTALEICT IH PROBE- 
NiED Fol S FIELD DATA SHEET

CHROME VI

PLANT NAME Plant Yates Station Boiler No. 1

$$
\text { Page } \perp \text { of }
$$

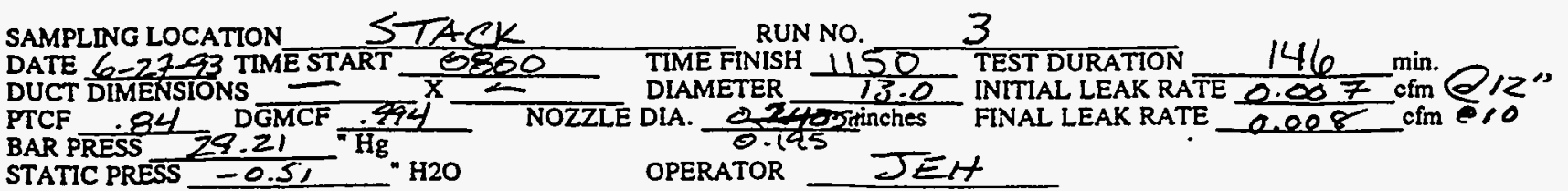

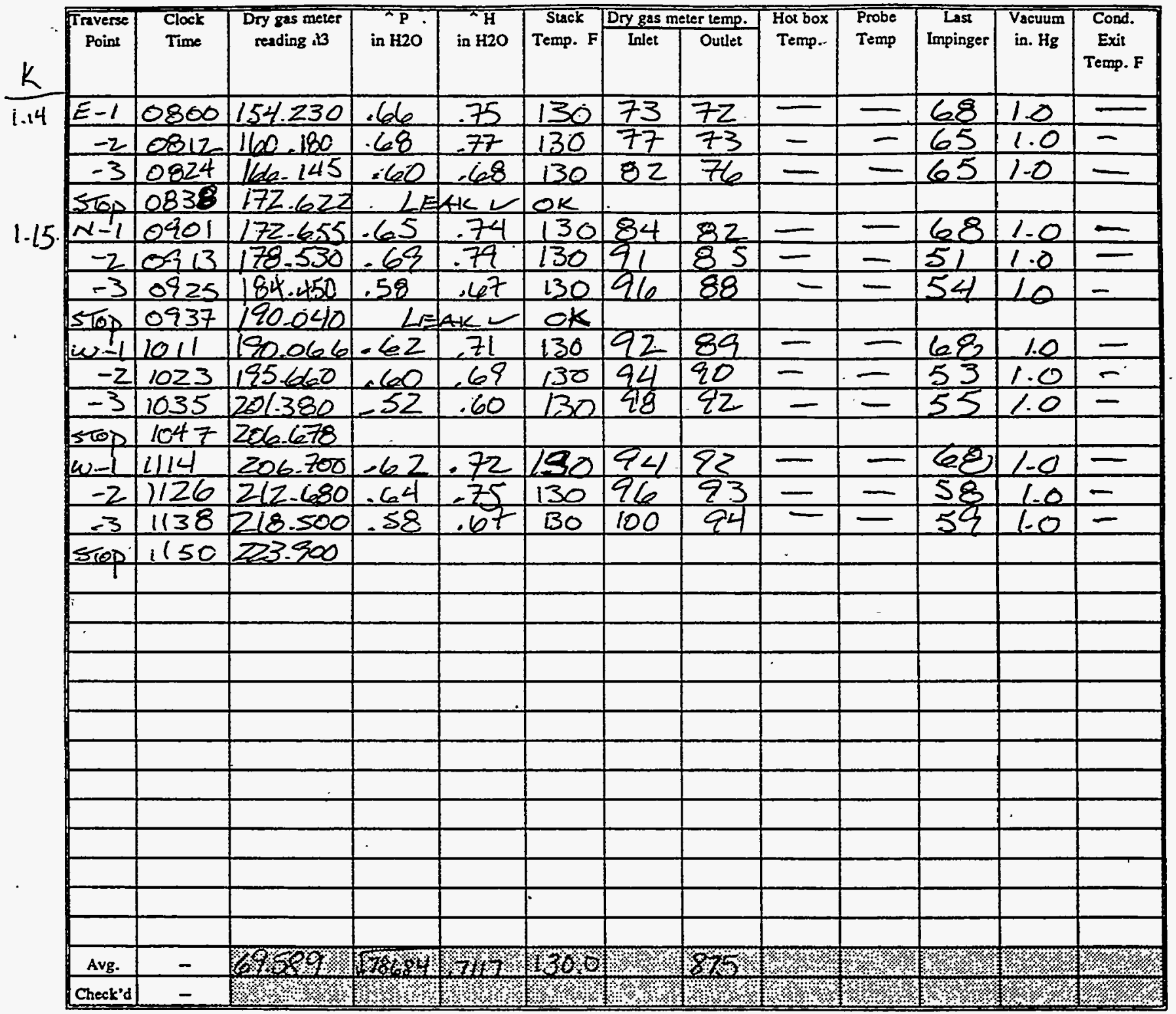

CONSOLE \# A161361.

FILTER \#

AMBIENT TEMP. $78^{\circ} \mathrm{F}$

PROBE LENGTH $6^{\prime}$

LINER MATERIAL PYREK

REMARKS ves al 3 -

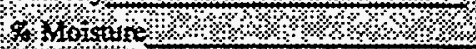

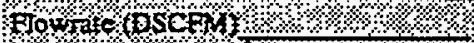

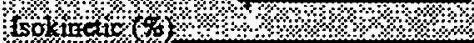




\section{ORSAT DATA SHEET}

Plant Plant Yates Station Boiler No. 1

\section{Location}

Run No.

Date $\frac{1}{6 / 21 / 93}$ Imp

Sorbing Reagents:

(CÓ2) (O2) Comments

Operator Itoñ DUV

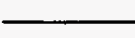

\begin{tabular}{|c|c|c|c|c|c|c|c|}
\hline $\begin{array}{l}\text { Replicate } \\
\text { Number }\end{array}$ & $\begin{array}{l}\text { Original } \\
\text { Volume } \\
\text { Reading }\end{array}$ & $\begin{array}{c}\text { (CO2) } \\
\text { Reading } 2 \\
(\mathrm{ml})\end{array}$ & $\begin{array}{c}(\mathrm{CO} 2)- \\
\text { Volume } \\
(2-1) \\
(\mathrm{ml})\end{array}$ & $\begin{array}{c}(\mathrm{O} 2) \\
\text { Reading } 3 \\
(\mathrm{ml})\end{array}$ & $\begin{array}{c}(\mathrm{O} 2) \\
\text { Volume } \\
(3-2) \\
(\mathrm{ml})\end{array}$ & $\begin{array}{c}(\mathrm{CO}) \\
\text { Reading } 4 \\
(\mathrm{ml})\end{array}$ & $\begin{array}{c}(\mathrm{CO}) \\
\text { Volume } \\
(4-3) \\
(\mathrm{ml})\end{array}$ \\
\hline 1 & 0.0 & 10.1 & 18.8 & 8.7 & & & \\
\hline 2 & 0.0 & 10.2 & 19,0 & 8.8 & & & \\
\hline & & & & & & & \\
\hline & & & & & & & \\
\hline & & & & & & & \\
\hline & & & & & & & \\
\hline & & & & & & & \\
\hline & & & & & & & \\
\hline
\end{tabular}

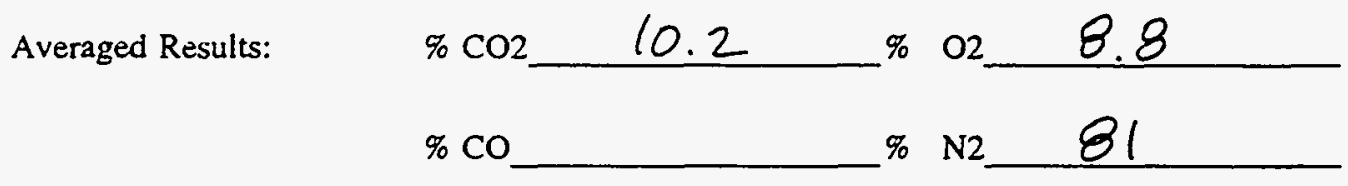

Dry Molecular Weight, MW (dry) =

$$
\begin{array}{ll}
\left.=0.44]_{(\% \mathrm{CO} 2)}^{+0.32}+\frac{0.28}{(\% \mathrm{O} 2)}+0 . \mathrm{CO}+\% \mathrm{~N} 2\right) & \\
= & \mathrm{Y}-096
\end{array}
$$

Run \# I Train orsat

Tare Wt. $\mathrm{Na}_{a}$ Final Wt. 


\section{ORSAT DATA SHEET}

$\begin{aligned} & \text { Plant__Plant Yates Station Boiler No: } 1 \\ & \text { Location_ STAK }\end{aligned}$
Run No. $\frac{2}{6-22-93}$
Date

Comments

Sorbing Reagents:__

\begin{tabular}{|c|c|c|c|c|c|c|c|}
\hline $\begin{array}{l}\text { Replicate } \\
\text { Number }\end{array}$ & $\begin{array}{l}\text { Original } \\
\text { Volume } \\
\text { Reading }\end{array}$ & $\begin{array}{c}(\mathrm{CO} 2) \\
\text { Reading } 2 \\
(\mathrm{ml})\end{array}$ & $\begin{array}{c}(\mathrm{CO} 2) \\
\text { Volume } \\
(2-1) \\
(\mathrm{ml}) \\
\end{array}$ & $\begin{array}{c}(\mathrm{O} 2) \\
\text { Reading } 3 \\
(\mathrm{ml})\end{array}$ & $\begin{array}{c}(\mathrm{O} 2) \\
\text { Volume } \\
(3-2) \\
(\mathrm{ml}) \\
\end{array}$ & $\begin{array}{c}(\mathrm{CO}) \\
\text { Reading } 4 \\
(\mathrm{ml})\end{array}$ & $\begin{array}{c}(\mathrm{CO}) \\
\text { Volume } \\
(4-3) \\
(\mathrm{ml}) \\
\end{array}$ \\
\hline 1 & 0.0 & 10.8 & 10.8 & 19.4 & 8.6 & & \\
\hline$z$ & 0.0 & 10.7 & 10.7 & 19.3 & 8.6 & & \\
\hline & & & & & & & \\
\hline & & & & & & & \\
\hline & & & & & & & \\
\hline & & & & & & & \\
\hline & & & & & & & \\
\hline
\end{tabular}

Averaged Results: $\begin{aligned} \% \mathrm{CO} 2 \mathrm{i0.8} & \% 02 \frac{8.6}{\% \mathrm{~N} 2.80 .6}\end{aligned}$

Dry Molecular Weight, MW (dry) =

$$
=0.44 \underbrace{}_{(\% \mathrm{CO} 2)}+0.32 \overbrace{(\% \mathrm{O} 2)}+0.28
$$$$
=
$$

Run 7 ESP Inlet

Run \# Train or Sat par

Date $6.22-93$ Time Smpir DJV

Lab on Site Analysis $\mathrm{CO}_{2} \mathrm{O}_{2}$

Tare Wt.

Final Wt. 


\section{ORSAT DATA SHEET}

Plant___Plant Yates Station Boiler No. 1

Location StaCK

Run No. 3

Date $6 / 22 / 93$

Sorbing Reagents:

$(\mathrm{CO} 2)$
Comments

Operator TMP

\begin{tabular}{|c|c|c|c|c|c|c|c|}
\hline $\begin{array}{l}\text { Replicate } \\
\text { Number }\end{array}$ & $\begin{array}{l}\text { Original } \\
\text { Volume } \\
\text { Reading }\end{array}$ & $\begin{array}{c}(\mathrm{CO} 2) \\
\text { Reading } 2 \\
(\mathrm{ml})\end{array}$ & $\begin{array}{c}(\mathrm{CO} 2) \\
\text { Volume } \\
(2-1) \\
(\mathrm{ml}) \\
\end{array}$ & $\begin{array}{c}(\mathrm{O} 2) \\
\text { Reading } 3 \\
(\mathrm{ml})\end{array}$ & $\begin{array}{c}(\mathrm{O} 2) \\
\text { Volume } \\
(3-2) \\
(\mathrm{ml})\end{array}$ & $\begin{array}{c}(\mathrm{CO}) \\
\text { Reading } 4 \\
(\mathrm{ml})\end{array}$ & $\begin{array}{c}(\mathrm{CO}) \\
\text { Volume } \\
(4-3) \\
(\mathrm{ml}) \\
\end{array}$ \\
\hline 1 & 0.0 & 10.2 & 10.2 & 18.6 & 8.4 & & \\
\hline 2 & 0.0 & 10.2 & 10.2 & 18.7 & 8.5 & & \\
\hline & & & & & & & \\
\hline & & & & & & & \\
\hline & & & & & & & \\
\hline & & & & & & & \\
\hline & & & & & & & \\
\hline & & & & & & & \\
\hline
\end{tabular}

Averaged Results:

$\% \operatorname{co} 2 \frac{10.2}{\% \mathrm{co}} \% \mathrm{O}^{2} \frac{8.5}{81.3}$

Dry Molecular Weight, MW (dry) =

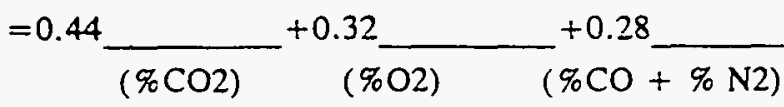

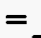
$+$

Run \#3 Train orset

Component bag

Date $6.23-23$ Time

Lab on site Analysis $\mathrm{CO}_{2} \mathrm{O}$

Tare Wt.

Final Wt.
ESP Inlet ESP Outlet

Stack Smplr DTV 


\section{ORSAT DATA SHEET}

Plant Plant Yates Station Boiler No. 1

Location

Run No.

Date $6 / 23 / 93$ $\angle A B$ - AUDIT SAMPLE

Sorbing Reagents:

$(\mathrm{CO} 2)$
Comments

Operator $T M P$

\begin{tabular}{|c|c|c|c|c|c|c|c|}
\hline $\begin{array}{l}\text { Replicate } \\
\text { Number }\end{array}$ & $\begin{array}{l}\text { Original } \\
\text { Volume } \\
\text { Reading }\end{array}$ & $\begin{array}{c}(\mathrm{CO} 2) \\
\text { Reading } 2 \\
(\mathrm{ml})\end{array}$ & $\begin{array}{c}(\mathrm{CO} 2) \\
\text { Volume } \\
(2-1) \\
(\mathrm{ml})\end{array}$ & $\begin{array}{c}(\mathrm{O} 2) \\
\text { Reading } 3 \\
(\mathrm{ml})\end{array}$ & $\begin{array}{c}(\mathrm{O} 2) \\
\text { Volume } \\
(3-2) \\
(\mathrm{ml})\end{array}$ & $\begin{array}{c}(\mathrm{CO}) \\
\text { Reading } 4 \\
(\mathrm{ml})\end{array}$ & $\begin{array}{c}(\mathrm{CO}) \\
\text { Volume } \\
(4-3) \\
(\mathrm{ml}) \\
\end{array}$ \\
\hline 1 & 0.0 & 0.0 & 0,0 & 9.0 & 9.0 & & \\
\hline$z$ & 0.0 & 0,0 & 0.0 & 9.0 & 9.0 & & \\
\hline & & & & & & & \\
\hline & & & & & & & \\
\hline & & & & & & & \\
\hline & & & & & & & \\
\hline & & & & & & & \\
\hline & & & & & & & \\
\hline
\end{tabular}

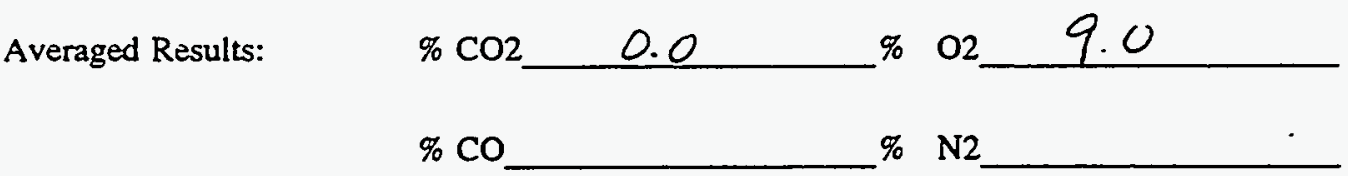

Dry Molecular Weight, MW (dry) =

$$
\begin{aligned}
& =0.44]_{(\% \mathrm{CO} 2)}^{+0.32}+\frac{0.28}{(\% \mathrm{O} 2)}(\% \mathrm{CO}+\% \mathrm{~N} 2) \\
& =
\end{aligned}
$$




\section{ORSAT DATA SHEET}

Plant Plant Yates Station Boiler No. 1

Comments

Location STACK

Run No. 2-1

Date

$06-25-93$

Operator TMP

Sorbing Reagents: $(\mathrm{CO} 2)$

(O2) (CO)

\begin{tabular}{|c|c|c|c|c|c|c|c|}
\hline $\begin{array}{l}\text { Replicate } \\
\text { Number }\end{array}$ & $\begin{array}{c}\text { Original } \\
\text { Volume } \\
\text { Reading }\end{array}$ & $\begin{array}{c}(\mathrm{CO} 2) \\
\text { Reading } 2 \\
(\mathrm{ml})\end{array}$ & $\begin{array}{c}(\mathrm{CO} 2) \\
\text { Volume } \\
(2-1) \\
(\mathrm{ml}) \\
\end{array}$ & $\begin{array}{c}(\mathrm{O} 2) \\
\text { Reading } 3 \\
(\mathrm{ml})\end{array}$ & $\begin{array}{c}(\mathrm{O} 2) \\
\text { Volume } \\
(3-2) \\
(\mathrm{ml})\end{array}$ & $\begin{array}{c}(\mathrm{CO}) \\
\text { Reading } 4 \\
(\mathrm{ml})\end{array}$ & $\begin{array}{c}(\mathrm{CO}) \\
\text { Volume } \\
(4-3) \\
(\mathrm{ml}) \\
\end{array}$ \\
\hline 1 & 0.0 & 11.0 & 11.0 & 18.8 & 7,8 & & \\
\hline 2 & 0.0 & 10.8 & 10.8 & 18.6 & 7.8 & & \\
\hline & & & & & & & \\
\hline & & & & & & & \\
\hline & & & & & & & \\
\hline & & & & & & & \\
\hline & & & & & & & \\
\hline
\end{tabular}

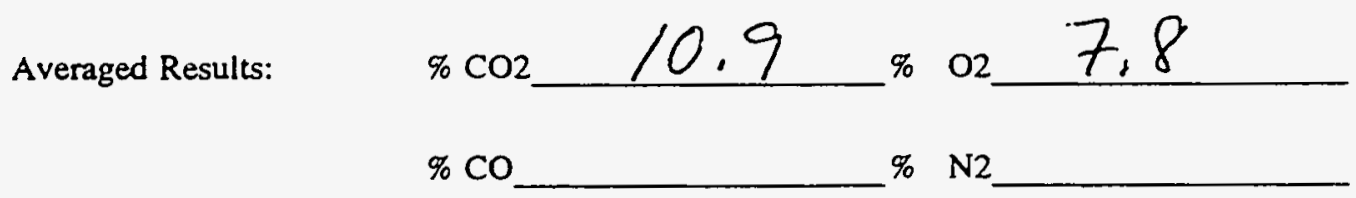

Dry Molecular Weight, MW (dry) =

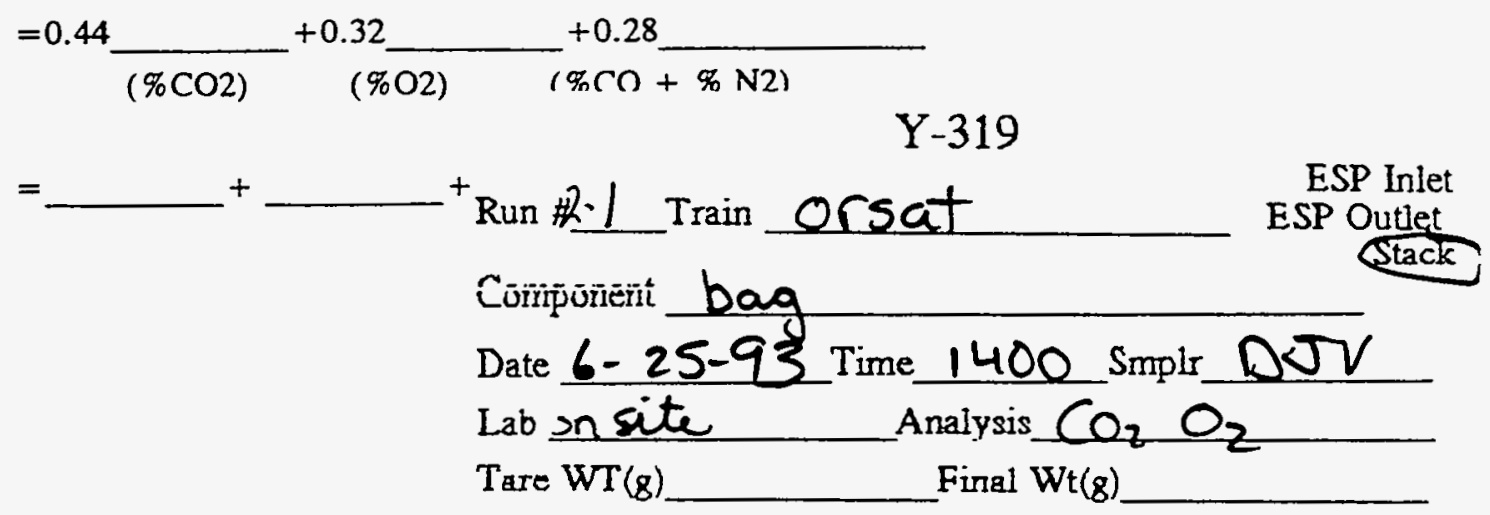




\section{ORSAT DATA SHEET}

Plant____Plant Yates.Station Boiler No. 1

Location STACK

Run No. phase 2 run 2

Date $6 / 26 / 93$

Sorbing Reagents:

$(\mathrm{CO} 2)$
Comments

operator TMP

(O2) (CO)

\begin{tabular}{|c|c|c|c|c|c|c|c|}
\hline $\begin{array}{l}\text { Replicate } \\
\text { Number }\end{array}$ & $\begin{array}{l}\text { Original } \\
\text { Volume } \\
\text { Reading }\end{array}$ & $\begin{array}{c}(\mathrm{CO} 2) \\
\text { Reading } 2 \\
(\mathrm{ml})\end{array}$ & $\begin{array}{c}\text { (CO2) } \\
\text { Volume } \\
(2-1) \\
(\mathrm{ml})\end{array}$ & $\begin{array}{c}(\mathrm{O} 2) \\
\text { Reading } 3 \\
(\mathrm{ml})\end{array}$ & $\begin{array}{c}\mathrm{O} 2) \\
\text { Volume } \\
(3-2) \\
(\mathrm{ml}) \\
\end{array}$ & $\begin{array}{c}\text { (CO) } \\
\text { Reading } 4 \\
(\mathrm{ml})\end{array}$ & $\begin{array}{c}(\mathrm{CO}) \\
\text { Volume } \\
(4-3) \\
(\mathrm{ml}) \\
\end{array}$ \\
\hline 1 & 0,0 & 11,4 & 11.4 & 18.8 & 7.4 & & \\
\hline 2 & 6.0 & i1. 4 & $11 \cdot 4$ & $\angle 8.8$ & 7.4 & & \\
\hline & & & & & & & \\
\hline & & & & & & & \\
\hline & & & & & & & \\
\hline & & & & & & & \\
\hline & & & & & & & \\
\hline & & & & & & & \\
\hline
\end{tabular}

Averaged Results:

$\% \operatorname{co} 2 \quad 11.4$

$\% \quad 02 \quad 7.4$

$\% \mathrm{CO}$ $\%$ N2

Dry Molecular Weight, MW (dry) =

$=0.44 \underbrace{}_{(\% \mathrm{CO} 2)}+0.32 \quad+0.28$

$=$ $+$

Run $\# 2-2$ Train ORSAT

ESP Inlet Component CRSAT

Date $6 / 26 / 93$ Time 1400 smpir DIV Lab Mobile Latio Analysis ORSAT

Tare WT(g) Final $W t(g)$ 


\section{ORSAT DATA SHEET}

Plant___ Plant Yates Station Boiler No. 1

Location STACK

Run No. $2-3$

Date $6 / 27 / 93$
Comments

Operator TMP

Sorbing Reagents:

$(\mathrm{CO} 2)$

$(\mathrm{O} 2)$

(CO)

\begin{tabular}{|c|c|c|c|c|c|c|c|}
\hline $\begin{array}{l}\text { Replicate } \\
\text { Number }\end{array}$ & $\begin{array}{l}\text { Original } \\
\text { Volume } \\
\text { Reading }\end{array}$ & $\begin{array}{c}(\mathrm{CO} 2) \\
\text { Reading } 2 \\
(\mathrm{ml})\end{array}$ & $\begin{array}{c}(\mathrm{CO} 2) \\
\text { Volume } \\
(2-1) \\
(\mathrm{ml}) \\
\end{array}$ & $\begin{array}{c}(\mathrm{O} 2) \\
\text { Reading } 3 \\
(\mathrm{ml})\end{array}$ & $\begin{array}{c}(\mathrm{O} 2) \\
\text { Volume } \\
(3-2) \\
(\mathrm{ml}) \\
\end{array}$ & $\begin{array}{c}\text { (CO) } \\
\text { Reading } 4 \\
\quad(\mathrm{ml})\end{array}$ & $\begin{array}{c}(\mathrm{CO}) \\
\text { Volume } \\
(4-3) \\
(\mathrm{ml}) \\
\end{array}$ \\
\hline 1 & 0.0 & 16.6 & 11.6 & 19,0 & 74 & & \\
\hline 2 & 2.0 & 1106 & $11+6$ & 19.0 & 7.4 & & \\
\hline & & & & & & & \\
\hline & & & & & & & \\
\hline & & & & & & & \\
\hline & & & & & & & \\
\hline & & & & & & & \\
\hline
\end{tabular}

Averaged Results:

$$
\begin{aligned}
& \% \mathrm{CO} 2 \\
& \% \mathrm{CO}
\end{aligned}
$$

11.6 $\%$

$02 \quad 7.4$ $\% \quad \mathrm{~N} 2$

Dry Molecular Weight, MW (dry) =

$$
\begin{aligned}
& =0.44 \underbrace{}_{(\% \mathrm{CO} 2)}+\frac{0.32}{(\% \mathrm{OO} 2)}(\% \mathrm{CO}+\% \mathrm{~N} 2) \\
& = \\
&
\end{aligned}
$$

Run $\# 2-3$ Train ORSAT

ESP Inlet ESP Outlet

Sta

Component orestr Date $6 / 27 / 93$ Time 1300 Smplr DTV Lab on site Tare WT(g) Analysis Final $\mathrm{Wt}(\mathrm{g})$ 


\section{TRAVERSE FIELD DATA SHEET}

\begin{tabular}{|c|c|c|}
\hline Plant Name & Plant Yates Station Boiler Nol & Stack Diameter $13^{\prime}$ \\
\hline Sampling Lo & Stack & Sample Port Diameter \\
\hline Date & $06 \cdot 18 \cdot 93$ & Sample Port Depth ___ G \\
\hline Operator & JEH & Distance Upstream_ \\
\hline
\end{tabular}

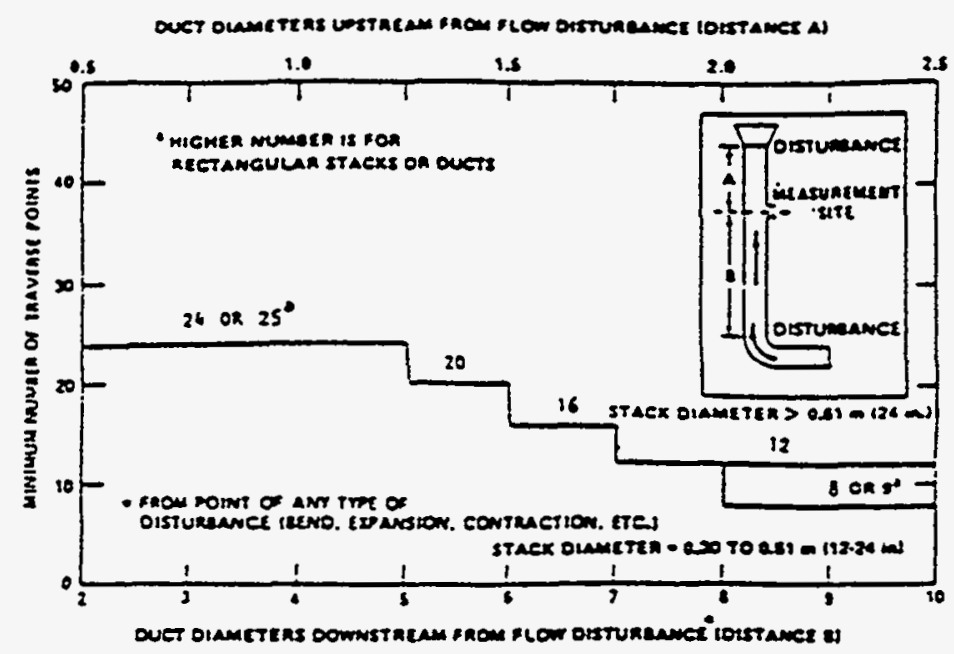

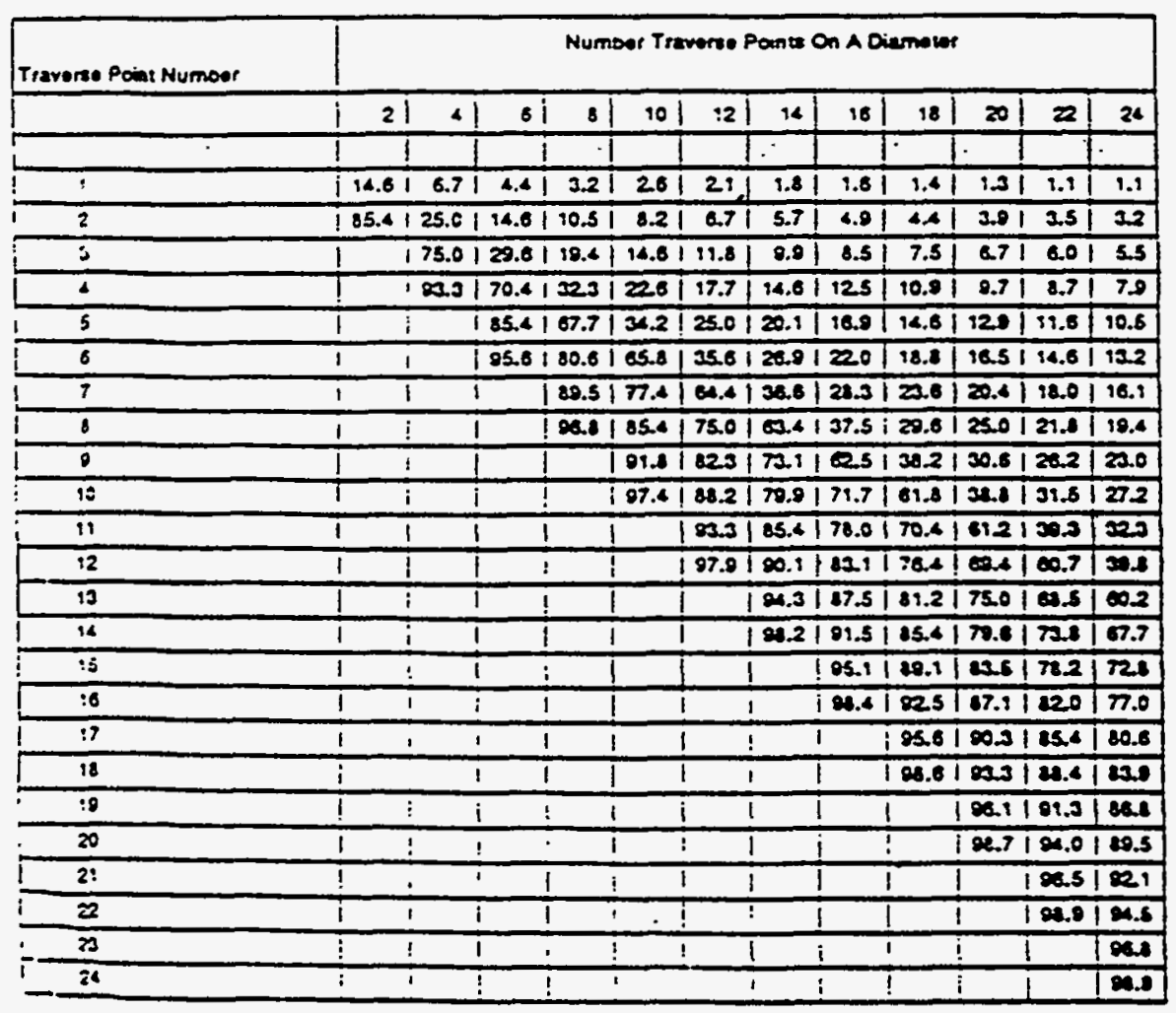

\begin{tabular}{|c|c|}
\hline \multicolumn{2}{|r|}{ Traverse Points } \\
\hline No. & Distance From Wall \\
\hline 7 & $1686-6 \pi$ \\
\hline 2 & $1228+6 \pi$ \\
\hline 3 & $46.2+6^{11}$ \\
\hline 4 & \\
\hline 5 & \\
\hline 6 & \\
\hline 7 & \\
\hline 8 & \\
\hline 9 & 1 \\
\hline 70 & 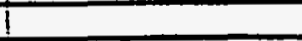 \\
\hline I1 & $T$ \\
\hline$\sqrt{2}$ & \\
\hline 33 & \\
\hline 14 & 1 \\
\hline 15 & 1 \\
\hline 16 & 1 \\
\hline 77 & \\
\hline 78 & \\
\hline 19 & \\
\hline 20 & \\
\hline 21 & 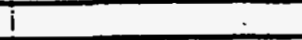 \\
\hline 22 & $T$ \\
\hline 23 & 1 \\
\hline 24 & \\
\hline
\end{tabular}




\section{VELOCITY PROFILE FIELD OATA}

Plant Name _ _ Yates

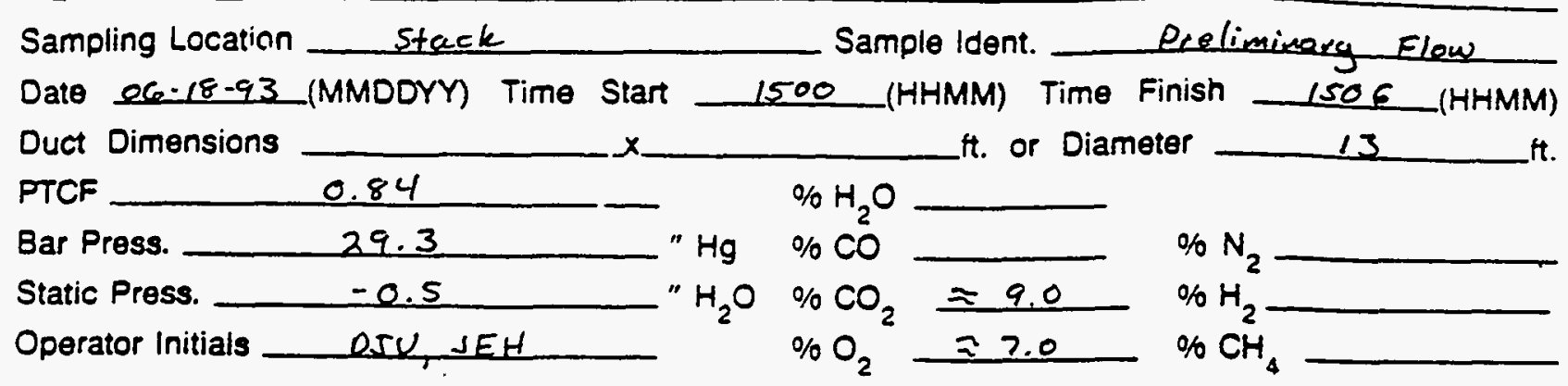

\begin{tabular}{|c|c|c|c|c|c|c|c|c|c|}
\hline \multirow[b]{2}{*}{ P. } & \multicolumn{3}{|c|}{ Stack Tomp. ${ }^{\circ} \mathrm{F}$} & \multicolumn{3}{|c|}{ Velociry Prossure " $\mathrm{H}_{2} \mathrm{O}$} & \multicolumn{2}{|c|}{ Other ( } & \\
\hline & 11 & $* 2$ & Ave. & $m$ & 12 & Avo. & 11 & 12 & Ave. \\
\hline$E \cdot 1$ & 122 & & & 0.70 & & & & & \\
\hline$E-2$ & 122 & & & 069 & & & & & \\
\hline$E-3$ & 121 & & & 0.61 & & & & & \\
\hline$N-1$ & 121 & & & 0.66 & & & & & \\
\hline$N-2$ & 122 & & & 0.71 & & & & & \\
\hline$N-3$ & 121 & & & 0.59 & & & & & \\
\hline$w-1$ & 122 & & & 0,68 & & & & & \\
\hline$w-2$ & 122 & & & 0.64 & & & & & \\
\hline$w-3$ & 122 & & & 0.49 & & & & & \\
\hline $5-1$ & 121 & & & 0.64 & & & & & \\
\hline$s-2$ & 122 & & & 0.67 & & & & & \\
\hline$s-3$ & 121 & & & 0.58 & & & & & \\
\hline & & & & & & & & & \\
\hline & & & & & & & & & \\
\hline & & & & & & & & & \\
\hline & & & & & & & & & \\
\hline & & & & & & & & & \\
\hline & & & & & & & & & \\
\hline
\end{tabular}

Weather

Remarks Plint 1 all the way in 


\section{VOST FIELD DATA SHEET}

PLANT__ Plant Yates Station Boiler No. 1

DATE $06-21-93$

SAMPLING LOCATION

ESP LNLET

RUN NO. TESTNO

OPERATOR RJW

AMBIENT TEMPERATURE

$80^{\circ} \mathrm{F}$

BAROMETAIC PRESSURE 29.51

BLANK TUBE NUMBERS T: $14528 \mathrm{~A} T / \mathrm{C}: 14528 \mathrm{~B}$
ASSUMED MOISTURE \% METER BOX NO

METER FACTOR

PROBE HEATER SETTING

167043 SAMpled $0.5 \mathrm{~L}$ PER Mint ZOL SAmples

\begin{tabular}{|c|c|c|c|c|c|c|c|c|c|c|c|c|c|}
\hline \multirow{2}{*}{$\begin{array}{c}\text { Test } \\
\text { Number }\end{array}$} & \multicolumn{2}{|c|}{ Loak Chock ("Hg) } & \multirow{2}{*}{$\begin{array}{l}\text { Tubo N } \\
\text { (Lab) }\end{array}$} & \multirow{2}{*}{$\begin{array}{c}\text { Sampling } \\
\text { (min) }\end{array}$} & \multirow{2}{*}{$\begin{array}{l}\text { Clock } \\
\text { Time }\end{array}$} & \multirow{2}{*}{$\begin{array}{l}\text { Gas Meter } \\
\text { Reading }\end{array}$} & \multirow{2}{*}{$\begin{array}{c}\text { Meter } \\
\text { Pressure } \\
\end{array}$} & \multirow{2}{*}{$\begin{array}{l}\text { Stack } \\
\text { Temp }\end{array}$} & \multirow{2}{*}{$\begin{array}{l}\text { DGM } \\
\text { Temp }\end{array}$} & \multirow{2}{*}{$\begin{array}{l}\text { Probs } \\
\text { Tomp }\end{array}$} & \multirow{2}{*}{$\begin{array}{l}\text { Ist Condensor } \\
\text { Oullat Temp. }\end{array}$} & \multirow{2}{*}{$\begin{array}{l}\text { 2nd Condenso } \\
\text { Oullet Temp. }\end{array}$} & \multirow{2}{*}{$\begin{array}{l}\text { Pump Vacuum } \\
\text { PQESTYRE }\end{array}$} \\
\hline & Pro & Post & & & & & & & & & & & \\
\hline \multirow{4}{*}{$1^{S T} P A, R$} & $0 @ 17^{\prime \prime}$ & & \multirow{2}{*}{$\begin{array}{c}T \\
14540 \mathrm{O}\end{array}$} & 0 & 1400 & 07.0002 & 1.4 & 306 & 76 & 250 & 55 & 59 & 50 \\
\hline & & & & 10 & 1410 & 11.85 & 1.5 & 309 & 78 & 242 & 53 & 59 & 50 \\
\hline & & & \multirow{2}{*}{$\begin{array}{c}T / C \\
14540 B\end{array}$} & 20 & 1420 & 16.90 & 1.4 & 307 & 81 & 256 & 53 & 58 & 5.0 \\
\hline & & & & 30 & 1430 & 22.17 & 1.4 & 310 & 82 & 256 & 53 & 58 & 5.0 \\
\hline$\psi$ & & $0=16^{11}$ & & STop & 1440 & 27.235 & & & & & & & \\
\hline \multirow{5}{*}{ ZNPPAR } & $0 \infty 15$ & & \multirow{2}{*}{$\begin{array}{c}T \\
14543 \mathrm{n}\end{array}$} & 0 & 1455 & 28.000 & 1.4 & 310 & 82 & 259 & 55 & 59 & 3.0 \\
\hline & & & & 10 & 1505 & 33,12 & 1.4 & 318 & 85 & 261 & 54 & 58 & 3.0 \\
\hline & & & \multirow{2}{*}{\begin{tabular}{|c|}
$T / C$ \\
$14543 B$ \\
\end{tabular}} & 20 & 1515 & 37.89 & 1.4 & 320 & 83 & 264 & 55 & 59 & 3.0 \\
\hline & & & & 30 & 1525 & 43.14 & 1.4 & 319 & 85 & 265 & 56 & 59 & 3.0 \\
\hline & & $0.917^{\prime \prime}$ & Hentu & STop & 1535 & 48.150 & & & & & & & \\
\hline \multirow[t]{4}{*}{$3^{20} P_{P A R}$} & $0,018^{\prime \prime}$ & & \multirow{2}{*}{$\begin{array}{c}T \\
45418\end{array}$} & 0 & 1550 & 50.000 & 1.5 & 300 & 85 & 265 & 55 & 52 & 4.0 \\
\hline & & & & 10 & 1600 & 54.84 & 1.5 & 301 & 85 & 266 & SS & 51 & 4.0 \\
\hline & & & \multirow{2}{*}{$\begin{array}{c}T / C \\
145410\end{array}$} & 20 & 1610 & 59.92 & 1.4 & 305 & 85 & $26 \mid$ & 55 & $\$ 2$. & 4.0 \\
\hline & & & & 30 & 1620 & 65.21 & 1.4 & 308 & 87 & 257 & 56 & 53 & 4.0 \\
\hline \multirow[t]{5}{*}{$\downarrow$} & & $0015^{\prime \prime}$ & & stpe & 1630 & 70.115 & & & & & & & \\
\hline & & & \multirow{2}{*}{$T$} & 0 & & & & & & & & & \\
\hline & & & & & & & & & & & & & \\
\hline & & & \multirow{2}{*}{$T / C$} & & & & & & & & & & \\
\hline & & & & & & & & & & & & & \\
\hline
\end{tabular}




\section{VOST FIELD DATA SHEET}

PLANT Plant Yates Station Boiler No. 1

DATE

$0 b-22-93$

SAMPLING LOCATION
RUN NO. ESP

ASSUMED MOISTURE \% METER BOX NO. METER FACTOR PAOBE HEATEA SETTING 0.9910 COMMENTS SAmplen a OSL Per min ZDL SAmples

\begin{tabular}{|c|c|c|c|c|c|c|c|c|c|c|c|c|c|}
\hline \multirow{2}{*}{$\begin{array}{c}\text { Test } \\
\text { Number } \\
\end{array}$} & \multicolumn{2}{|c|}{ Leak Chock $(\mathrm{Hg})$} & \multirow{2}{*}{\begin{tabular}{|l} 
Tubo N \\
(Lab)
\end{tabular}} & \multirow{2}{*}{$\begin{array}{l}\text { Sampling } \\
\text { _(min) }\end{array}$} & \multirow{2}{*}{$\begin{array}{l}\text { Clock } \\
\text { Time }\end{array}$} & \multirow{2}{*}{$\begin{array}{c}\text { Gas Meter } \\
\text { Reading }\end{array}$} & \multirow{2}{*}{$\begin{array}{c}\text { Moter } \\
\text { Pressure } \\
\end{array}$} & \multirow{2}{*}{$\begin{array}{l}\text { Stack } \\
\text { Temp }\end{array}$} & \multirow{2}{*}{$\begin{array}{l}\text { DGM } \\
\text { Temp }\end{array}$} & \multirow{2}{*}{$\begin{array}{l}\text { Probo } \\
\text { Temp }\end{array}$} & \multirow{2}{*}{$\begin{array}{l}\text { Ist Condonsor } \\
\text { Qullat Tomp. }\end{array}$} & \multirow{2}{*}{$\begin{array}{l}\text { 2nid Condenso } \\
\text { Outlet Tomp. }\end{array}$} & \multirow{2}{*}{$\begin{array}{l}\text { Pump Vacuum } \\
\text { PE SsSuRC } \\
\text { Stme }\end{array}$} \\
\hline & Pro & Post & & & & & & & & & & & \\
\hline \multirow{4}{*}{$1^{5 T}$ PAIR } & $0 @ 17^{\prime \prime}$ & & \multirow{2}{*}{$\begin{array}{c}T \\
145100\end{array}$} & 0 & 0742 & 71.000 & 1.4 & 274 & 73 & 257 & bl & 59 & 4.0 \\
\hline & & & & 10 & 0752 & 75.93 & 1.4 & 269 & 74 & 258 & 60 & 60 & 4.0 \\
\hline & & & \multirow{2}{*}{$\begin{array}{c}T / C \\
14510 B\end{array}$} & 20 & 0802 & 80.87 & 1.4 & 270 & 76 & 259 & 60 & 57 & 4.0 \\
\hline & & & & 30 & 0812 & 86.07 & 1.4 & 272 & 78 & 2.58 & 60 & 56 & 4.0 \\
\hline$\downarrow$ & & 02 is" & & Nop & 0822 & 91.045 & & & & & & & \\
\hline \multirow{4}{*}{$Z_{N O P} P_{A 1}$} & $0 @ 16^{\prime \prime}$ & & \multirow{2}{*}{$\begin{array}{c}T \\
145,3 A\end{array}$} & 0 & 0910 & 92.000 & 1.4 & 275 & 78 & 2101 & 63 & 58 & 5.0 \\
\hline & & & & 10 & 0920 & 96.94 & 1.4 & 280 & 79 & 260 & deo & 56 & 5.0 \\
\hline & & & \multirow{2}{*}{$\begin{array}{c}T / C \\
14513 \theta\end{array}$} & 20 & 0930 & 100.80 & 1.4 & 276 & 80 & 260 & 45 & 58 & 5,0 \\
\hline & & & & 30 & 0940 & 106.89 & 1.4 & 293 & 83 & 263 & 57 & 61 & 5.0 \\
\hline$\psi$ & & $6 Q 16^{\prime \prime}$ & & STop & .0950 & 112.030 & & & & & & & \\
\hline \multirow[t]{4}{*}{$3^{00}$ pair } & $0015^{\prime \prime}$ & & \multirow{2}{*}{$\begin{array}{c}T \\
14512 A\end{array}$} & 0 & 1001 & 113.000 & 1.4 & 295 & 84 & 262 & 58 & 63 & 4.0 \\
\hline & & & & 10 & 1011 & 118.16 & 1.4 & 302 & 84 & 262 & 57 & 61 & 5.0 \\
\hline & & & \multirow{2}{*}{$\begin{array}{c}T / C \\
145,12 B\end{array} \mid$} & 20 & 1021 & 123.14 & 1.4 & 300 & 85 & 264 & 57 & 62 & 5.0 \\
\hline & & & & 30 & 1031 & 128.21 & 1.4 & 301 & 86 & 263 & 57 & $E l$ & 5.0 \\
\hline \multirow[t]{6}{*}{$V$} & & $0016^{11}$ & 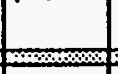 & STp & 1041 & 133.050 & & & & & & & \\
\hline & & & \multirow[t]{2}{*}{$T$} & 0 & & & & & & & & & \\
\hline & & & & & & & & & & . & & & \\
\hline & & & \multirow[t]{2}{*}{$T / C$} & & & & & & & & & & \\
\hline & & & & & & & & & & & & & \\
\hline & & & & & & & & & & & & & \\
\hline
\end{tabular}




\section{VOST FIELD DATA SHEET}

PLANT Plant Yates Station Boiler No. 1

DATE 06-23-92

SAMPLING LOCATION
RUN NO. ESP

ASSUMED MOISTURE \% METER BOXNO METER FACTOR PROBE HEATER SETTING COMMENTS SampleD Q O.S L POR mid Zol samples

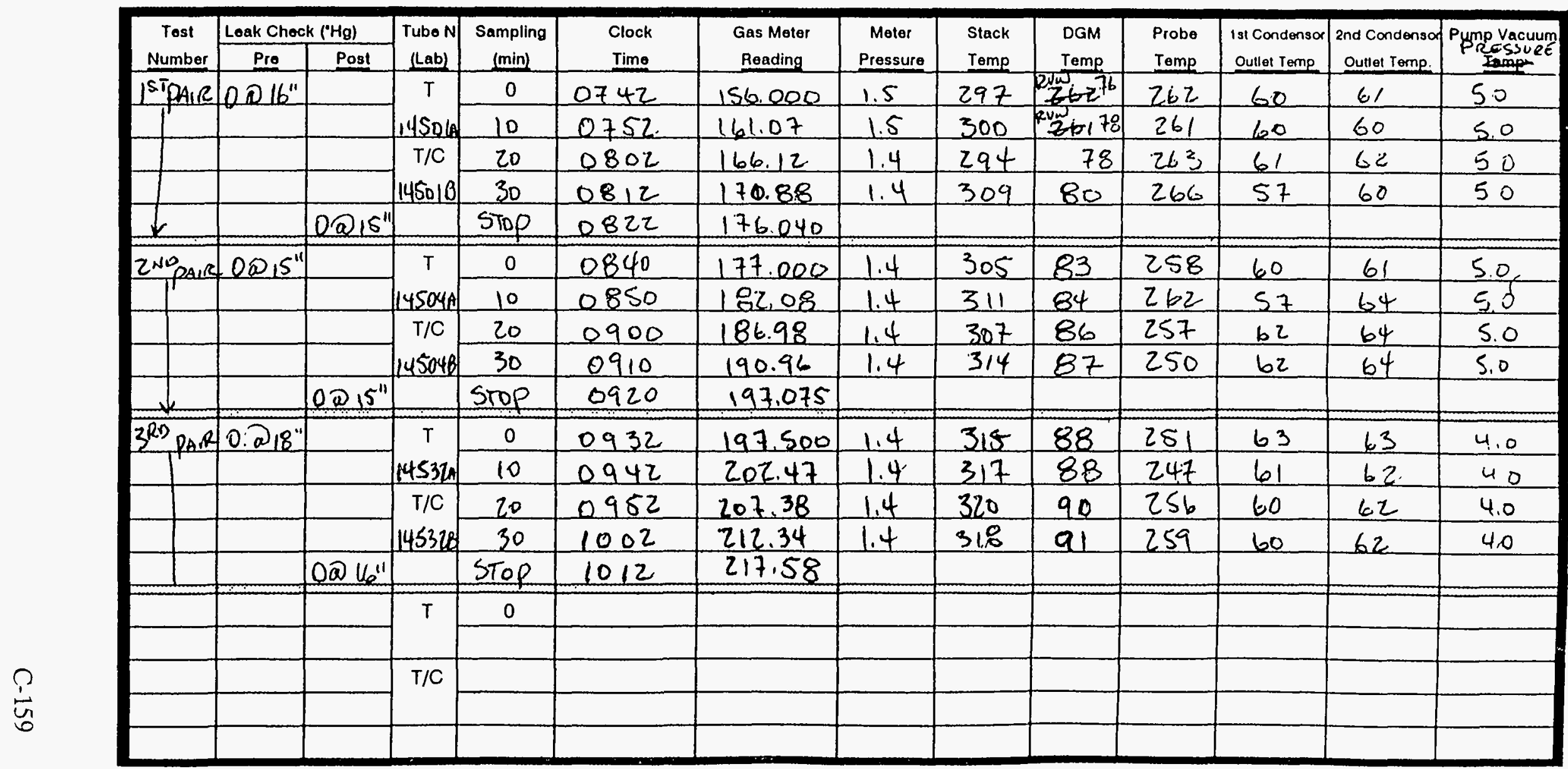


(ENireci)

MODIFIED MEZHCD 5 FIELD DATA SHEET

$\operatorname{cof} \bar{\jmath}$

PLANT NAME Plant Yates Station Boiler No. 1

SAMPLINGLOCATION ESP inlet

DATE 621993 TIMESTART $\frac{1155}{15}$

DUCT DTENSIONS $85 \quad \mathrm{X} / 57$ TIME FINISH

PTCF 0.84 DGMCF 0.999 NOZZLE DIAMETER

BAR PRESS $29.5171^{\circ \mathrm{Hg}}$

DIA. 0.358 inches

Page 1 of

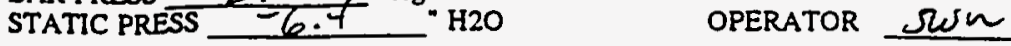

0401.822

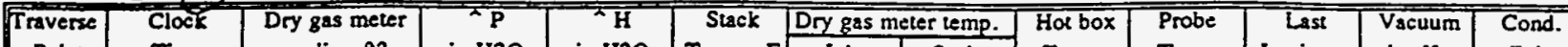

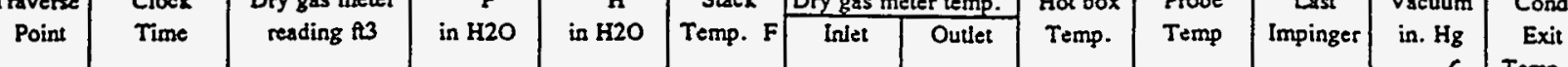

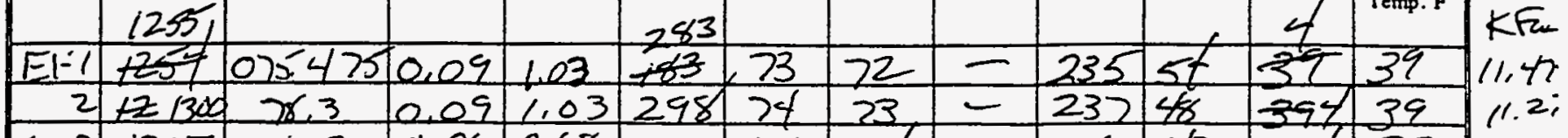

\begin{tabular}{ll|l|l|l|}
1305 & 80.9 \\
\hline
\end{tabular}

\begin{tabular}{lll|l|l|l}
0.06 & 0.68 & 297 & 76 & 24 & -
\end{tabular}

\begin{tabular}{lllll|l|l|l|l|l|l|l|}
41310 & 83.1 & 0.03 & 0.24 & 254 & 79 & 76 & -
\end{tabular}

\begin{tabular}{l|l|l|l|l|l}
5 & 1315 & 84.6 & 0.05 & 0.56 &
\end{tabular}

\begin{tabular}{l|l|l|l|l|l|l|l|l|l|}
1320 & 86,2 & 0.00 & 0.34 & 299 & 80 & 77 & -
\end{tabular}

TEST DURATION 240 K $\mathrm{K}$ 徒.

INITIAL LEAK RATE Q.012Q15' $\mathrm{cfm}$

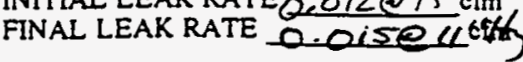

Stop $1325^{\circ}$ 88,020 God lealkrhed Eal $6^{\prime \prime} / \mathrm{t}$

\begin{tabular}{|l|l|l|l|l|l|l|l|l}
\hline$E 3-1$ & 1336 & $\times 88.065$ & 0.02 & 0.22 & 295 & 80 & 78 & -
\end{tabular}

\begin{tabular}{l|l|l|l|l|l|l|l|l}
2 & 1341 & 557 & 0.02 & 0.22 & 308 & 80 & 78 & -
\end{tabular}

2.

$1 6 \longdiv { 1 }$

$31346 \quad 91.0$

51356

92,8

0.04

0,45

307

80078 -

308 8

$8179-$

$0.10 / .15$

30783

80

$=$

Stop 1406 101:046 Good leak check a 6 "'th

\begin{tabular}{|c|c|c|c|c|c|c|c|c|}
\hline$E 4-1$ & 1415 & 101.119 & 0.02 & 0.23 & 290 & 85 & 82 & -
\end{tabular}

\begin{tabular}{l|l|l|l}
2 & 1420 & 102.7 & 0.04
\end{tabular}

\begin{tabular}{l|l|l|l|l|l}
3 & $1 / 25$ & 104.3 & 0.06 & 0.68 &
\end{tabular}

\begin{tabular}{l|l|l|}
-1 & 1430 & 106.3 \\
\hline 5 & $14(35$ & 109.4 \\
\hline
\end{tabular}

\begin{tabular}{l|l|l|l|l|l}
5 & 1435 & 109.4 & 0.18 & 2.0
\end{tabular}

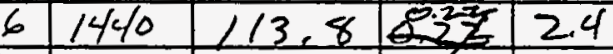

308

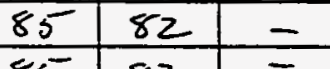

24560

\begin{tabular}{|l|l|}
\hline 2 & 42 \\
\hline 2 & $4 / 3$ \\
\hline
\end{tabular}

\begin{tabular}{|l|l|l|l|}
243 & 57 & 2 & 43 \\
257 & 55 & 2 & 43 \\
\hline
\end{tabular}

\begin{tabular}{l|l|l|l}
310 & 85 & 82 & -
\end{tabular}

250

\begin{tabular}{l|l|l}
308 & 88 & 83 \\
\hline
\end{tabular}

$83:-$

$24 \sqrt{3}$

52

\begin{tabular}{|l|l|}
5 & 42 \\
\hline 7 & 43 \\
\hline 8 & 44 \\
\hline
\end{tabular}

stop 1445 i12,043 Goed lonk kheck of $10^{\prime 14}$

El:

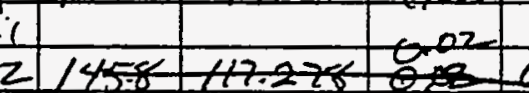

$3 / y_{2} 3 / 18,8$

\begin{tabular}{l|l|l|l|l|l|}
4 & 1450.4 & 120.4 & 0.06 & 0.65 \\
5 & 1573 &
\end{tabular}

61518

Nhext Dafa sheet

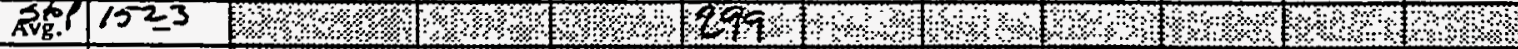

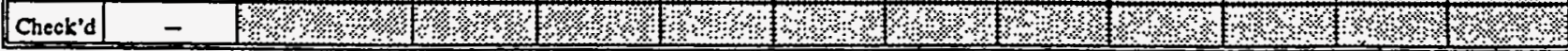

CONSOLE H

FILTER \# Erstack

AMBIENT TEMP. $90^{\circ} \mathrm{F}$

PROBE LENGTH $8 \mathrm{ft}$

LINER MATERIAL guarte glass

REMARKS
Vetocity $\%$ \% $\%$ ४ अ

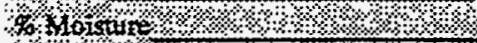

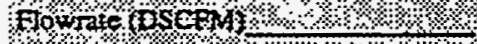

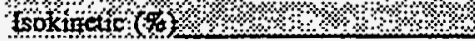


PLANT NAME Plant Yates Station Boiler No. 1

SAMPLING ZOCATION tnlet

DATE 6/24GTIMSTART

DUCT DIMENSIONS

PTCF DGMCF $\begin{array}{ll}\mathrm{X} & \text { TIME FINISH } \\ \text { DIAMETER }\end{array}$

Page __ of

BAR PRESS

STATIC PRESS NOZZLE DIA.

OPERATOR

\begin{tabular}{|c|c|c|c|c|c|c|c|c|c|c|c|c|}
\hline \multirow{2}{*}{$\begin{array}{c}\text { Traverse } \\
\text { Point }\end{array}$} & \multirow{2}{*}{$\begin{array}{l}\text { Clock } \\
\text { Time }\end{array}$} & \multirow{2}{*}{$\begin{array}{l}\text { Dry gas meter } \\
\text { reading } \mathrm{ft} 3\end{array}$} & \multirow{2}{*}{ in $\mathrm{H} 2 \mathrm{O}$} & \multirow{2}{*}{$\begin{array}{l}{ }^{2} \mathrm{H} \\
\text { in } \mathrm{H} 2 \mathrm{O}\end{array}$} & \multirow{2}{*}{$\begin{array}{c}\text { Stack } \\
\text { Temp. F }\end{array}$} & \multicolumn{2}{|c|}{ Dry gas meter lemp. } & \multirow{2}{*}{$\begin{array}{l}\text { Hot box } \\
\text { Temp. }\end{array}$} & \multirow{2}{*}{$\begin{array}{l}\text { Probe } \\
\text { Temp }\end{array}$} & \multirow{2}{*}{$\begin{array}{c}\text { Last } \\
\text { Impinger }\end{array}$} & \multirow{2}{*}{$\begin{array}{l}\text { Vacuum } \\
\text { in. } \mathrm{Hg}\end{array}$} & \multirow{2}{*}{$\begin{array}{c}\text { Cond. } \\
\text { Exit } \\
\text { Temp. F }\end{array}$} \\
\hline & & & & & & Inlet & Outlet & & & & & \\
\hline$E_{6-1}$ & 1458 & 117278 & 0.02 & 0.23 & $3 / 8$ & 85 & 84 & - & 230 & 62 & 3 & \\
\hline 2 & 1503 & 118,8 & 0.03 & 0.33 & 323 & 86 & 84 & - & 235 & 60 & 4 & \\
\hline 3 & 1508 & 120.4 & 0.06 & 0.65 & 320 & 85 & 84 & - & 241 & 58 & 5 & 45 \\
\hline 4 & 15,3 & & 0.1 & 1.1 & 320 & 82 & 84 & - & 258 & 56 & 6 & 42 \\
\hline 5 & 1598 & 125,4 & 0.16 & 1.7 & 2321 & 88 & 84 & - & 244 & 57 & 7 & 48 \\
\hline 6 & 1523 & 129,5 & 0.2 & 2.2 & 330 & 90 & 86 & - & 240 & 55 & 2 & 50 \\
\hline stop & 1528 & $\angle 32.626$ & & & & $\mathrm{CO}_{4}$ & & & & & & \\
\hline & & & & & & & & & & & & \\
\hline$\omega 2-1$ & $15^{-47}$ & 13253 & 0.02 & 0,2 & 278 & 87 & 86 & - & 230 & -59 & 3 & \\
\hline 2 & 1546 & 134.1 & 0.04 & 0.44 & 300 & 82 & 85 & - & $253^{-}$ & SR. & 4 & 4 \\
\hline 3 & 1551 & 135.6 & 0.05 & 0.56 & 243 & 87 & 85 & - & 240 & 53 & $C$ & 49 \\
\hline 4 & 1556 & 132.7 & 0,03 & 0.33 & 302 & 88 & 86 & - & 245 & 54 & 4 & 42 \\
\hline 5 & 1601 & 129,5 & 0.06 & 6.67 & 300 & 87 & 86 & - & 247 & 54 & 5 & 42 \\
\hline 6 & 1606 & $14 \sqrt{2}, 0$ & 0.17 & 1,5 & 305 & 51 & 87 & - & 246 & 57 & 8 & $4 d$ \\
\hline Step & $16 / 1$ & 145.331 & & & & $\bar{x}=87$ & & & & & & \\
\hline & & & & & & & & & & & & \\
\hline wey-1 & $16 / 8$ & 145,552 & 0.02 & 0,2 & 298 & 90 & 87 & - & 230 & 55 & 3 & 44 \\
\hline 2 & 1623 & tates & 2,04 & 0,54 & 295 & 90 & 88 & - & 254 & 57 & 5 & \\
\hline 3 & 1628 & 148.5 & 0.07 & 0.78 & 291 & 90 & 88 & - & 253 & 54 & 5 & $4 \sqrt{3}$ \\
\hline 4 & 1633 & 150.5 & 0,12 & 1,3 & 298 & 51 & 88 & - & 255 & 52 & 7 & 43 \\
\hline 5 & 1638 & 154,2 & 0,15 & 1.7 & 286 & 53 & 89 & - & 254 & 52 & 5 & $5 / 5$ \\
\hline 6 & 1643 & 157,7 & 0.16 & 1.8 & 282 & 95 & 50 & $=$ & 252 & 52 & 5 & $9 / 6$ \\
\hline sto & 1658 & 160,865 & & & & & & & & & & \\
\hline & & & & & & $x=90$ & & & & & & \\
\hline & & & & & & & & & & & & \\
\hline & & & & & & & & & & & & \\
\hline & & & & & & & & & & & & \\
\hline & & & & & & & & & & & & \\
\hline & & & & & & & & & & & & \\
\hline Avg. & - & $4 \% \%$ & $\% \%$, & \%०\% & 86, & $38 \%$ & $31 \%$ & \%४४ & $18 \%$ & $18 \%$ & $\%$ & $\%$ \\
\hline Check'd & - & $10 \%$ & $1 \%$ \% & $1 \%$ \% & 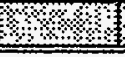 & 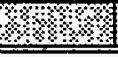 & $\$ 3$, & 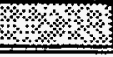 & 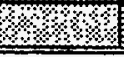 & & & \\
\hline
\end{tabular}

CONSOLE \#

FILTER \#

AMBIENT TEMP.

PROBE LENGTH

LINER MATERIAL

REMARKS

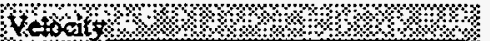

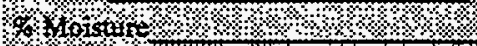

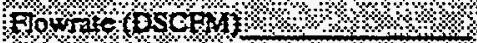

sokntolst TEST DURAPTON INITIAL LEAK RATE FINAL LEAK RATE $\min$. $\longrightarrow \mathrm{cfm}$ Phare ( Runl 
FiANT NAME Plant Yates Station Boiler No. 1

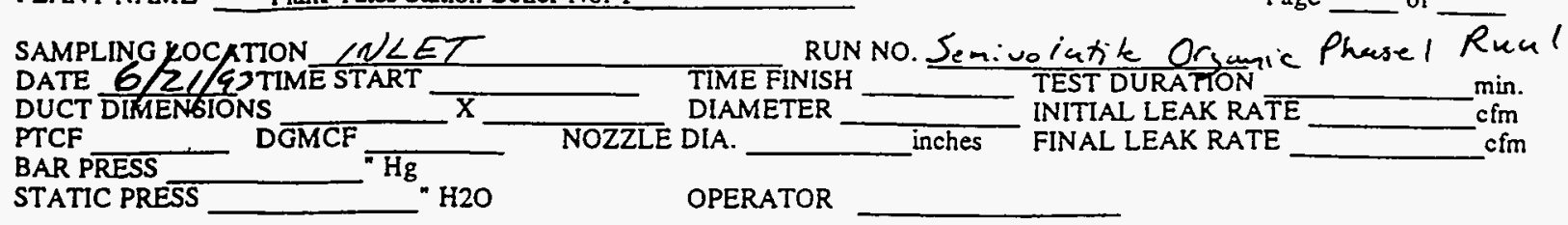

\begin{tabular}{|c|c|c|c|c|c|c|c|c|c|c|c|c|}
\hline \multirow{2}{*}{$\begin{array}{c}\text { Traverse } \\
\text { Point }\end{array}$} & \multirow{2}{*}{$\begin{array}{l}\text { Clock } \\
\text { Time }\end{array}$} & \multirow{2}{*}{$\begin{array}{c}\text { Dry gas meter } \\
\text { reading } \mathrm{A} 3\end{array}$} & \multirow{2}{*}{$\begin{array}{l}\mathrm{P} \\
\text { in } \mathrm{H} 2 \mathrm{O}\end{array}$} & \multirow{2}{*}{$\begin{array}{l}{ }^{2} \mathrm{H} \\
\text { in } \mathrm{H} 2 \mathrm{O}\end{array}$} & \multirow{2}{*}{$\begin{array}{c}\text { Stack } \\
\text { Temp. F }\end{array}$} & \multicolumn{2}{|c|}{ Dry gas meler lemp. } & \multirow{2}{*}{$\begin{array}{l}\text { Hot box } \\
\text { Temp. }\end{array}$} & \multirow{2}{*}{$\begin{array}{l}\text { Probe } \\
\text { Temp }\end{array}$} & \multirow{2}{*}{\begin{tabular}{c|} 
Last \\
Impinger
\end{tabular}} & \multirow{2}{*}{$\begin{array}{l}\text { Vacuum } \\
\text { in. } \mathrm{Hg}\end{array}$} & \multirow{2}{*}{$\begin{array}{c}\text { Cond. } \\
\text { Exit } \\
\text { Temp. F }\end{array}$} \\
\hline & & & & & & Inlet & Outlet & & & & & \\
\hline W6 1 & 1658 & 161,014 & 0.01 & 0,11 & 265 & 90 & 89 & $=$ & 225 & 61 & 2 & 46 \\
\hline 2 & 1703 & 162.0 & 0.02 & 0.22 & 281 & 90 & 90 & 二 & 253 & 61 & 4 & 47 \\
\hline 3 & 1708 & $=$ & 0.02 & 0,22 & 280 & 90 & 89 & $=$ & 242 & 60 & 4 & 48 \\
\hline 4 & 1713 & $165 \times 0$ & 0.03 & 0.35 & 241 & 90 & 89 & - & 225 & 60 & 4 & 57 \\
\hline 5 & 1718 & $\sim$ & 0.05 & 0.57 & 271 & 51 & 85 & - & 238 & 60 & 5 & 51 \\
\hline$c$ & 1723 & 168.3 & 0.05 & 0.57 & 273 & 91 & 90 & -1 & 249 & $\cos$ & 5 & 52 \\
\hline stop & 1228 & 170.421 & & & & & & & & & & \\
\hline & & & & & & & & & & & & \\
\hline w\& & 1245 & 171.000 & 0.06 & 0.69 & 273 & 89 & 89 & - & 227 & 64 & 5 & 56 \\
\hline 2 & 1750 & 123,0 & 0.03 & 0.34 & 22274 & 89 & $\frac{89}{89}$ & - & 232 & 60 & 4 & 52 \\
\hline 3 & 1725 & i) 417 & 0.02 & 0.23 & 279 & 90 & $\frac{89}{89}$ & - & $x 19$ & 58 & 4 & 47 \\
\hline 4 & 1800 & 176,1 & 0.02 & 0,23 & 229 & 90 & 89 & - & 253 & 58 & 4 & 46 \\
\hline 5 & 1805 & 1224 & 0.02 & 0,23 & 273 & 90 & 89 & - & 244 & 59 & 4 & 45 \\
\hline$\frac{6}{\sin \theta}$ & $\frac{1810}{1815}$ & 150683 & c. .04 & 0,46 & 282 & 91 & 90 & - & $2 \mathrm{~s} / 1$ & 56 & 5 & 45 \\
\hline & & & & & & & & & & & & \\
\hline & & & & & & & & & & & & \\
\hline & & & & & & & & & & & & \\
\hline & & & & & & & & & & & & \\
\hline & & & & & & & & & & & & \\
\hline & & & & & & & & & & & & \\
\hline & & & & & & & & & & & & \\
\hline & & & & & & & & & & & & \\
\hline & & & & & & & & & & & & \\
\hline & & & & & & & & & & & & \\
\hline & & & & & & & & & & & & \\
\hline & & & & & & & & & & & & \\
\hline & & & & & & & & & & & & \\
\hline & & & & & & & & & & & & \\
\hline Avg. & - & 103219 & $3 p d=$ & 02 & 2424 & $88^{\circ}$ & 354 & \%) & $\because \because$ & 31 & \%ल & 36 \\
\hline Check'd & - & 1) & \% & $\%$ & 16 & $\because$ & 15 & खि & : & 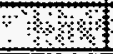 & 8 & \% \\
\hline
\end{tabular}

CONSOLE \#

FILTER \#

AMBIENT TEMP.

PROBE LENGTH

LINER MATERIAL

REMARKS
Yetocily : \%

W:MAthe Aownte (psech, $\mathrm{H}$ tsokiretis to
U1 - vost collectia E8-Aldehyde eolled E7 - PSO collectia

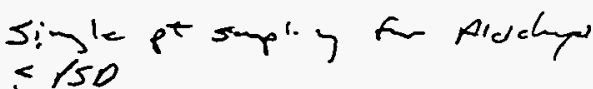




\section{MUDIFIEL IIETHOD 5 FIELD DATA SHEE $i$}

PLANT NAME Plant Yates Station Boiler No. 1

SAMPLING LGCATTON ESPINLET

DATE 62243 TIMESTART 0729

DUCT DIMENSIONS 8 ' $6^{\prime \prime} \frac{0}{\mathrm{x}} 1 \mathrm{~S}^{\prime} \cdot 7^{\prime}$ ' DIAMETER

PTCF 0.84 DGMCF 0.999 NOZZLE DIA. 0.358 inches

STATIC PRESS -6.2 "H2O OPERATOR SWM
Page 1 of 3

2 Senidotatic fhasel Run 2 TEST DURATION 740 min. INITIAL LEAK RATE $0.0106 \mathrm{cfm} / 5 \%$ FINAL LEAK RATE $0,018 \mathrm{efm}_{12} \% \mathrm{f}$

\begin{tabular}{|c|c|c|c|c|c|c|c|c|c|c|c|c|}
\hline \multirow{2}{*}{$\begin{array}{c}\text { Traverse } \\
\text { Point }\end{array}$} & \multirow{2}{*}{$\begin{array}{l}\text { Clock } \\
\text { Time }\end{array}$} & \multirow{2}{*}{$\begin{array}{l}\text { Dry gas meter } \\
\text { reading f3 }\end{array}$} & \multirow{2}{*}{ in $\mathrm{H} 2 \mathrm{O}$} & \multirow{2}{*}{ in $\mathrm{H} 2 \mathrm{O}$} & \multirow{2}{*}{$\begin{array}{c}\text { Stack } \\
\text { Temp. F }\end{array}$} & \multicolumn{2}{|c|}{ Dry gas meler lemp. } & \multirow{2}{*}{$\begin{array}{l}\text { Hot box } \\
\text { Temp. }\end{array}$} & \multirow{2}{*}{$\begin{array}{l}\text { Probe } \\
\text { Temp }\end{array}$} & \multirow{2}{*}{$\begin{array}{c}\text { Last } \\
\text { limpinger }\end{array}$} & \multirow{2}{*}{ 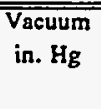 } & \multirow{2}{*}{$\begin{array}{l}\text { Cond. } \\
\text { Exit } \\
\text { Temp. F }\end{array}$} \\
\hline & & & & & & \begin{tabular}{|l|} 
Inlet \\
\end{tabular} & Outlet & & & & & \\
\hline $68-1$ & 729 & 187,155 & 0.07 & 0.77 & $27^{\circ}$ & 72 & 71 & - & 233 & 56 & 3 & 56 \\
\hline 2 & 234 & 182.3 & 0.06 & 0.66 & 22 & 23 & 72 & - & 253 & 54 & 6 & 53 \\
\hline 3 & 739 & 141,3 & 0.03 & 0.33 & 274 & 75 & 72 & $=$ & 251 & 52 & 4 & 56 \\
\hline 4 & $24 f$ & 153,0 & 0.02 & 0.22 & 271 & 75 & 73 & $=$ & 247 & 56 & 3 & 53 \\
\hline 5 & 249 & 194,30 & 0.03 & 0.33 & 269 & 26 & 73 & - & 250 & 58 & 5 & 56 \\
\hline 6 & 254 & 195.9 & 0,04 & 0.44 & 269 & 77 & 24 & - & 250 & 57 & 6 & 54 \\
\hline Stop & 754 & 197.450 & Gox & Final & teakd & theck & & & & & & \\
\hline & & & & & & fum & & & 224 & & & \\
\hline $6 k-1$ & 825 & 198.107 & 0,03 & 0,34 & $2=4$ & 27 & 75 & - & 272 & 58. & 2 & 18 \\
\hline 2 & 830 & 1499 & 0,01 & 0,45 & $\frac{21}{2}$ & 77 & 75 & - & 254 & 53 & 3 & 16 \\
\hline 3 & 835 & 201.6 & 0.06 & 0.68 & 279 & 28 & 76 & $=$ & 248 & 51 & 4 & 40 \\
\hline 4 & 840 & 203.8 & 0.07 & 0.79 & 280 & 81 & 27 & - & 243 & 49 & 4 & 46 \\
\hline 5 & 845 & 206,3 & O.te & 0.68 & 279 & 82 & 78 & - & 243 & 45 & 4 & 47 \\
\hline 6 & 850 & 208.6 & 0.10 & 1.1 & & 85 & 80 & & & 49 & 5 & 47 \\
\hline$s+$ & 855 & 211.382 & Gool & Finald & kak de & WK & & & & & & \\
\hline & & & So00 & Luig & $E x$ (a) & ecols & $k$ & & & & & \\
\hline wi4-i & 930 & 211,568 & 0.03 & 0.34 & 276 & 80 & 80 & - & 222 & 58 & 3 & 46 \\
\hline 2. & 935 & $2 B .3$ & 0.05 & 0.55 & $23^{-0}$ & 81 & 80 & - & 252 & 55 & 3 & 47 \\
\hline 3 & $940^{\circ}$ & 215,3 & 0.07 & 0,77 & 294 & 82 & 80 & - & 245 & 53 & 5 & 45 \\
\hline$\exists$ & 945 & 212.7 & $0, \Omega$ & 1,3 & 251 & 83 & 80 & - & 250 & 54 & 5 & 48 \\
\hline 5 & $\$ 50$ & 220,7 & 0.15 & 1.7 & 293 & 85 & 81 & - & 244 & 51 & 6 & 18 \\
\hline 6 & GS5 & 224,3 & 0.17 & 1,9 & 293 & 88 & 82 & $=$ & 258 & 53 & 7 & 50 \\
\hline Steg & 1000 & 227,878 & Exosd & Teak & breck & & & & & & & \\
\hline & & & & & & & & & & & & \\
\hline & & & & & & & & & & & & \\
\hline & & & & & & & & & & & & \\
\hline & & & & & & & & & & & & \\
\hline & & & & & & & & & & & & \\
\hline & & & & & & & & & & & & \\
\hline Avg. & - & $1+\bullet$ & ?ै, & ?. & एా+ & मै। & $\$$ & $\$$ & $8 \%$ & 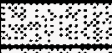 & $\$ 4$ & 80 \\
\hline Check'd & - & O००० & 81 & $\%$ & ४०० & 13 & 180 & 0 & 13 & 80 & $\$$ & , \\
\hline
\end{tabular}

CONSOLE \# A161363

FILTER \#

AMBIENT TEMP. SOe start

PROBE LENGTH geft

LINER MATERIAL quart2

REMARKS
Velocily

Q

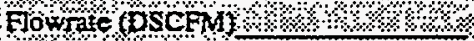

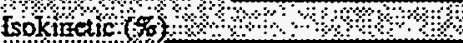




\section{MODIFIED .METHOD 3 FIELD DATA SHEET}

I'LANT NAME Plant Yates Station Boiler No. 1

SAMPLING LOCATION Inlet DATE DUCT DIMENSIONS PTCF TIME START

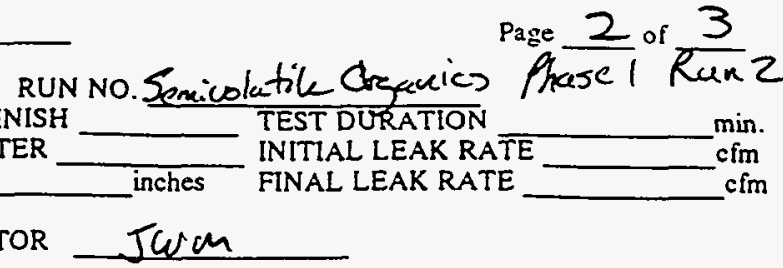

\begin{tabular}{|c|c|c|c|c|c|c|c|c|c|c|c|c|}
\hline \multirow{2}{*}{$\begin{array}{c}\text { Traverse } \\
\text { Point }\end{array}$} & \multirow{2}{*}{$\begin{array}{l}\overline{\text { Ciock }} \\
\text { Time }\end{array}$} & \multirow{2}{*}{$\begin{array}{l}\text { Dry gas meter } \\
\text { reading fi } 3\end{array}$} & \multirow{2}{*}{ in $\mathrm{H} 2 \mathrm{O}$} & \multirow{2}{*}{ in $\mathrm{H} 2 \mathrm{O}$} & \multirow{2}{*}{$\begin{array}{c}\text { Stack } \\
\text { Temp. F }\end{array}$} & \multicolumn{2}{|c|}{ Dry gas meter temp. } & \multirow{2}{*}{$\begin{array}{l}\text { Hor box } \\
\text { Temp. }\end{array}$} & \multirow{2}{*}{$\begin{array}{l}\text { Probe } \\
\text { Temp }\end{array}$} & \multirow{2}{*}{$\begin{array}{c}\text { Last } \\
\text { Impinger }\end{array}$} & \multirow{2}{*}{$\begin{array}{l}\text { Vacuum } \\
\text { in. } \mathrm{Hg}_{\mathrm{g}}\end{array}$} & \multirow{2}{*}{$\begin{array}{c}\text { Cond. } \\
\text { Exit } \\
\text { Temp. F }\end{array}$} \\
\hline & & & & & & Inlet & Outlet & & & & & \\
\hline$k 2-1$ & 1003 & 222,968 & 0.03 & 0.33 & 292 & 82 & 84 & - & 242 & 60 & 3 & 50 \\
\hline 2 & 1008 & 225.7 & 0.04 & 0,44 & 298 & 88 & 84 & - & 247 & co & 3 & 57 \\
\hline 3 & 1013 & 231.6 & 0.05 & 0.55 & 302 & 87 & 84 & $=$ & 250 & 54 & 4 & 4 \\
\hline 4 & 1018 & 233.6 & 0.09 & 0.99 & 303 & 88 & 84 & - & 252 & 52 & 5 & 47 \\
\hline 5 & 1023 & 236.4 & 0.12 & 1,3 & 319 & 50 & 85 & - & 253 & 50 & 6 & 46 \\
\hline 6 & 1028 & 239.6 & 0.16 & 1.8 & 319 & 91 & 86 & $=$ & 245 & 50 & 2 & 76 \\
\hline Stap & 1033 & 243.148 & $G_{\infty}$ & $-1 r_{n}$ & led & icch & eck & & & & & \\
\hline & & & $\xi_{\infty}$ & d In & tial 1 & eate & eeck & & & & & \\
\hline$E 7$ & $-5 w^{x}$ & & & & & & & & & & & \\
\hline$E-1 z$ & 1049 & 243.311 & 0.04 & $0.4 a$ & 325 & 87 & 86 & - & 229 & 58 & 4 & $1 / 5$ \\
\hline 27 & 1054 & 245,6 & 0.05 & 0.55 & 328 & 8 & 86 & $=$ & 249 & 58 & 5 & 44 \\
\hline 34 & 1059 & 247.5 & 0,08 & 0,87 & 330 & 87 & 86 & - & 248 & 5 & 5 & 45 \\
\hline 45 & 1104 & 250.2 & 0.12 & 1,3 & 337 & 89 & 86 & - & 254 & 52 & 7 & ctc \\
\hline 56 & $110 \%$ & 253,2 & 0,18 & 20 & $3 / 1$ & 91 & 87 & - & 251 & 52 & 8 & $4 \sqrt{3}$ \\
\hline 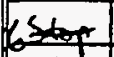 & 1114 & 257.3 & 0.21 & 2.2 & 336 & 93 & 88 & - & & 53 & 10 & 45 \\
\hline stap & 1119 & 261.159 & Gow & Ofine & leat & chet & & & & & & \\
\hline$E 5-1$ & 1126 & $26 / .347$ & 0.02 & 0.21 & 313 & 91 & 85 & - & 228 & 61 & 3 & 53 \\
\hline 2 & $\angle 136$ & 262,8 & 0.03 & 0.32 & 324 & 91 & 89 & - & 256 & 60 & 4 & sद \\
\hline 3 & 1136 & 264,3 & 0.07 & 0.75 & 323 & 92 & 85 & $=$ & 250 & 58 & 5 & 49 \\
\hline 4 & $114 \mid$ & 266.7 & 0,13 & 1.4 & 327 & 93 & 90 & $=$ & 250 & 53 & 8 & 45 \\
\hline 57 & 1146 & 265.8 & 0.19 & 2.0 & 330 & 91 & 90 & - & 250 & 55 & 10 & 49 \\
\hline 6 & 1651 & 273,8 & 0,20 & 2,1 & 324 & 96 & 91 & - & 242 & 38 & 11 & 50 \\
\hline STOR & 1156 & 277.405 & & & & & & & & & & \\
\hline & & & & & & & & & & & & \\
\hline & & & & & & & & & & & & \\
\hline & & & & & & & & & & & & \\
\hline & & & & & & & & & & & & \\
\hline & & & & & & & & & & & & \\
\hline Avg. & - & $\% \propto$ & 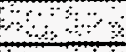 & + & $\therefore:$ & $\therefore \therefore<\cdots$ & $\because \therefore$ & $\because \quad \because$ & $\because \quad: \div$ & 8 & 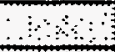 & (1:: \\
\hline Check'd & - & at, & 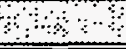 & $\because \%$ & $\cdots+n^{2}$ & $\because:$ ? & $\because$ & $\because:$ & & 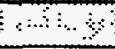 & $6 \%$ & en: \\
\hline
\end{tabular}

CONSOLE \#

FILTER \#

AMBIENT TEMP.

PROBE LENGTH

LINER MATERIAL

REMARKS
Vetocity

\&iloistur

Flowrate tDSCEM

tsokintole (\%) 


\section{MÓdIFIED METHOD:5 FIELD DítA SHEET}

ILANT NAME Plant Yates Station Boiler No. 1_Page 3 of 3

sampling location Inlet run no. Semicutatice Phase $\left(R_{\text {ren }} z\right.$

DATE TIMESTART

DUCT DIMENSIONS

PTCF

BAR PRESS
STATIC PRESS

NS

DGMCF

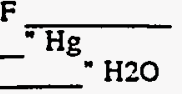
- DIAMETER

NOZZLE DIA. TIME FINISH

OPERATOR JWM TEST DURATION INITIAL LEAK RATE $\min$. FINAL LEAK RATE — $\mathrm{cfm}$

\begin{tabular}{|c|c|c|c|c|c|c|c|c|c|c|c|c|}
\hline $\mid$ Traverse & clock & Dry gas meter & $\bar{P}$ & $\overline{\mathrm{H}}$ & $\overline{\overline{\text { Stack }}}$ & Dry gas m & ler temp. & Hot box & Probe & List & \begin{tabular}{|l|} 
Vacuum \\
\end{tabular} & $\begin{array}{l}\text { Cond. } \\
\end{array}$ \\
\hline Point & Time & reading f 3 & in $\mathrm{H} 2 \mathrm{O}$ & in $\mathrm{k} 2 \mathrm{O}$ & Temp. $F$ & \begin{tabular}{|l|} 
Inlet \\
\end{tabular} & Outlet & Temp. & Temp & Impinget & in. $\mathrm{Hg}_{\mathrm{g}}$ & $\begin{array}{c}\text { Exit } \\
\text { Temp. F }\end{array}$ \\
\hline$\omega_{3}-1$ & 1227 & 278.979 & 0.03 & 0.32 & 306 & 88 & 88 & 323 & 223 & 64 & 3 & 33 \\
\hline 2 & 1232 & 280.4 & 0.02 & 0.21 & 313 & 87 & 87 & $=$ & 235 & 64 & 2 & 56 \\
\hline 3 & 1237 & 281,7 & 0.65 & 0.51 & 344 & 87 & 82 & $=$ & 250 & 60 & 5 & 53 \\
\hline 4 & 1242 & 283,8 & 0.07 & 0.75 & 316 & 90 & 88 & $=$ & 250 & 58 & 6 & 49 \\
\hline 5 & 1242 & 286.3 & 0.10 & 1.1 & 316 & 91 & 88 & $=$ & 235 & 56 & 2 & 46 \\
\hline 6 & 1252 & 289.0 & 0.14 & 1,5 & 315 & 93 & 89 & $=$ & 243 & 56 & 9 & 47 \\
\hline stop & 1257 & 292.345 & Sis & fing & 1/cal & ches & \& & 3000 & $i_{n}<\bar{f}$ & 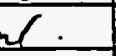 & & \\
\hline$\omega t-1$ & 1316 & 292.700 & ong & 0.96 & 311 & 91 & 84 & - & 225 & 57 & 7 & 49 \\
\hline 2 & 1316 & - & 008 & 0.86 & 312 & 91 & 89 & $=$ & 242 & 52 & 7 & ds \\
\hline 3 & 1321 & 298.0 & 0.04 & 0.43 & 311 & 91 & 89 & - & 248 & 59 & 5 & 50 \\
\hline 4 & 1326 & 299,8 & 0.04 & 0.43 & 305 & 91 & 89 & $=$ & $2 \sqrt{9}$ & 61 & 5 & 57 \\
\hline 5 & 1331 & 301.7 & 0.04 & 0.43 & 305 & 51 & 89 & $=$ & 252 & 62 & 5 & 49 \\
\hline 6 & 1336 & 303,5 & 0.04 & 0.43 & 305 & S1 & 59 & $=$ & $2+3$ & 64 & $s^{-}$ & 52 \\
\hline Stop & 1341 & 305,4111 & & & & Lk & .01 & 2 & "16 & & & \\
\hline & & & & & & & & & 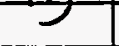 & & & \\
\hline & & - zero & e.tat & leak & chec & $k-4$ & in & & & & & \\
\hline & & & & & & & & & & & & \\
\hline & & & & & & & & & & & & \\
\hline & & & & & & & & & & & & \\
\hline & & & & & & & & & & & & \\
\hline & & & & & & & & & & & & \\
\hline & & & & & & & & & & & & \\
\hline & & & & & & & & & & & & \\
\hline & & & & & & & & & & & & \\
\hline & & & & & & & & & & & & \\
\hline & & & & & & & & & & & & \\
\hline & & & & & & & & & & & & \\
\hline & & & & & & & & & & & & \\
\hline & & & $\sqrt{D P}$ & & & & - & & & & & \\
\hline Avg. & $=$ & 105045 & $0<2<5$ & $0.85 \% 25$ & 30352 & 18.8 & 74 & २० & ४०० & ४४ & পিষ & $\%$ \\
\hline Check'd & - & 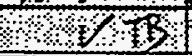 & ४०। & WUan & $2 \%$ & 13 & ४४ & $\$ 8 \%$ & \%४० & 10 & $4 \%$ & 10 \\
\hline
\end{tabular}

CONSOLE \#

FILTER \#

AMBIENT TEMP.

PROBE LENGTH

LINER MATERIAL

REMARKS

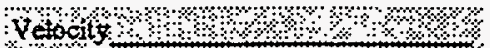

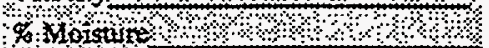

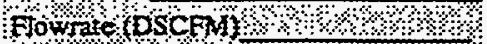

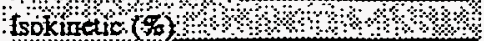


PLANT NAME Plant Yates Station Boiler No. 1

SAMPLINGLOQATION $1 \mathrm{~N}(e T / 2$ TIME FINISH NO 1230

DUCT DIMENSIONS

PTCF 0.84 DGMCF 0.999 NOZZLE DIA. 0.35 inches

BAR PRESS 29.39 " $\mathrm{Hg}$

OPERATOR 358 rwm

Page 1 of 3

STATIC PRESS -60 OPERATOR H2O JWm

\begin{tabular}{|c|c|c|c|c|c|c|c|c|c|c|c|c|}
\hline \multirow{2}{*}{$\begin{array}{c}\text { Traverse } \\
\text { Point }\end{array}$} & \multirow{2}{*}{$\begin{array}{l}\text { Clock } \\
\text { Time }\end{array}$} & \multirow{2}{*}{$\begin{array}{l}\text { Dry gas meter } \\
\text { reading } \mathrm{A} 3\end{array}$} & \multirow{2}{*}{ in $\mathrm{H} 2 \mathrm{O}$} & \multirow{2}{*}{ in $\mathrm{H} 2 \mathrm{O}$} & \multirow{2}{*}{$\begin{array}{c}\text { Stsck } \\
\text { Temp. F }\end{array}$} & \multicolumn{2}{|c|}{ Dry gas meter temp. } & \multirow{2}{*}{$\begin{array}{l}\text { Hot box } \\
\text { Temp. }\end{array}$} & \multirow{2}{*}{$\begin{array}{l}\text { Probe } \\
\text { Temp }\end{array}$} & \multirow{2}{*}{$\begin{array}{c}\text { Last } \\
\text { Impinger }\end{array}$} & \multirow{2}{*}{$\begin{array}{l}\text { Vacuum } \\
\text { in. } \mathrm{Hg}\end{array}$} & \multirow{2}{*}{$\begin{array}{c}\text { Cond. } \\
\text { Exit } \\
\text { Temp. F }\end{array}$} \\
\hline & & & & & & Inlet & Outlet & & & & & \\
\hline$E \mid-1$ & 0707 & 34121 & 0.1 & 1.1 & 290 & 69 & 68 & - & 230 & 51 & 3,5 & 40 \\
\hline 2 & 0212 & 317,0 & 0.08 & 0.87 & 290 & 21 & 69 & - & 256 & 51 & 4 & 42 \\
\hline 3 & 0217 & 319.5 & 0.07 & 0.76 & 293 & 74 & 20 & - & 250 & 52 & 4 & 43 \\
\hline 4 & 0722 & 321.8 & 0.05 & 0.54 & 293 & 75 & 21 & - & 250 & 53 & 3 & $5 / 4$ \\
\hline 5 & 0227 & 323.8 & 0.06 & 0.65 & 292 & 26 & 72 & - & 242 & 453 & & 4 \\
\hline 6 & 0732 & 326.0 & $0 . \infty$ & 0.65 & 287 & 78 & 73 & $=$ & 244 & 52 & 4.0 & 42 \\
\hline 5700 & 0737 & 328.105 & Geod & keak & heck & & & & & & & \\
\hline E $3-1$ & 0740 & 328.32 & 0,2 & 0.22 & 293 & 78 & 74 & - & 240 & 62 & 2,0 & 56 \\
\hline-2 & 0745 & 329.9 & 0.03 & 0,33 & 298 & 79 & 75 & - & 241 & 65 & 3,0 & 58 \\
\hline-3 & 0750 & 331.4 & 6,05 & 0.55 & 297 & 80 & 76 & - & 247 & 70 & 40 & 55 \\
\hline-4 & 0755 & 333.4 & 0.08 & 0.87 & 297 & 52 & 77 & - & 252 & 68 & 4.5 & 51 \\
\hline 5 & 0800 & 336.0 & 0.11 & 1.2 & 296 & 83 & 20 & - & 255 & 68 & 5 & 49 \\
\hline 6 & 0405 & 339.2 & 0.16 & 1.75 & 292 & 86 & 25 & - & 254 & 69 & 2 & 50 \\
\hline stop & 0810 & 342.495 & & & & & & & & & & \\
\hline & & & & & & & & & & & & \\
\hline ES-1 & 817 & 342.765 & 0.03 & 0.33 & 300 & 84 & 80 & - & 226 & 69 & 3 & 58 \\
\hline 2 & 822 & 44,3 & 0.05 & 0.55 & 309 & 84 & 80 & - & 258 & 69 & 3.5 & 54 \\
\hline 3 & 827 & 346.1 & 0.06 & 0.66 & 309 & 85 & 81 & - & 245 & 69 & 4 & 50 \\
\hline 4 & 832 & 348,5 & 0.12 & 1.32 & 313 & 88 & 83 & - & 248 & 20 & 6 & 50 \\
\hline 5 & 837 & 357.7 & 0.17 & 1,9 & 311 & 89 & 84 & - & 250 & 71 & 7 & 49 \\
\hline 6 & $8 / 2$ & 355,4 & 0,22 & 2.4 & 311 & 93 & 86 & - & 246 & 72 & ร & 57 \\
\hline Stor & 847 & 360,062 & & & & & & & & & & \\
\hline & & & & & & & & & & & & \\
\hline & & & & & & & & & & & & \\
\hline & & & & & & & & & & & & \\
\hline & & & & & & & & & & & & \\
\hline & & & & & & & & & & & & \\
\hline & & & & & & & & & & & & \\
\hline & & & & & & & & & & & & \\
\hline Avg. & - & 45,667 & 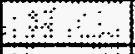 & 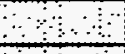 & $\because \quad \therefore$ & $\infty$ & $\therefore \because \because$ & $\therefore$ & $\because \cdots$ & $\therefore$ & \% & 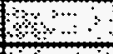 \\
\hline Check'd & - & 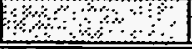 & & & $\therefore \because \because$ & 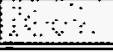 & & 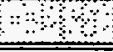 & 3 & & & 18 \\
\hline
\end{tabular}

CONSOLE \#

FILTER \#

AMBIENT TEMP.

PROBE LENGTH

LINER MATERIAL
Vetocity

qo Monsture

Wow ate (DScRM)

tsokinetic $(\%):$ का

REMARKS 


\section{MODIFIED METHOẼ 5 FIELD DAZA SHEET}

PLANT NAME Plant Yates Statis, $\Omega$ Boiler No. 1

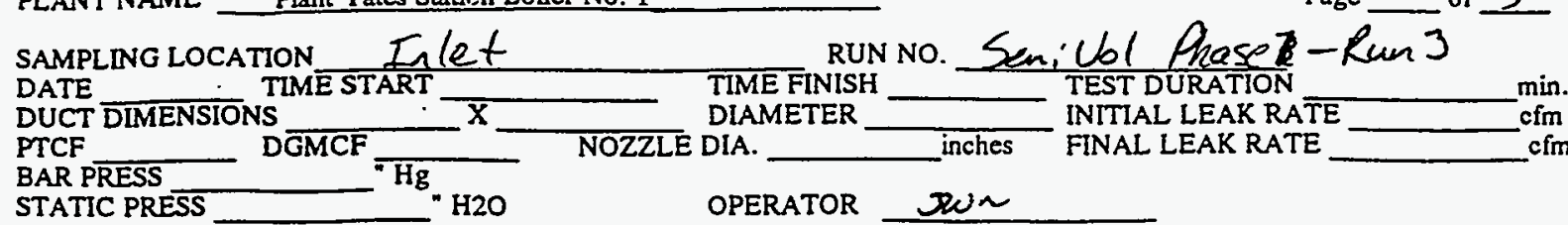

\begin{tabular}{|c|c|c|c|c|c|c|c|c|c|c|c|c|}
\hline Traverse & Clock & Dry gas meter & $\bar{P}$ & $2 \mathrm{H}$ & Stack & Dry gas m & ter temp. & Hot box & Probe & Last & Vacuum & \\
\hline Point & Time & reading f 3 & in $\mathrm{H} 2 \mathrm{O}$ & in $\mathrm{H} 20$ & Temp. F & Inlet & Outlet & Temp. & Temp & Impinger & & $\begin{array}{c}\text { Exit } \\
\text { Temp. F }\end{array}$ \\
\hline EII & 851 & $360.172-1$ & 0.03 & 0.33 & 316 & 9 & 87 & $=$ & 227 & 658 & 53 & 5 \\
\hline$z$ & 856 & 361,8 & 0.03 & 0.33 & 320 & 92 & 88 & - & 257 & 57 & 3 & 57 \\
\hline 3 & 4 and & 363.2 & 0.05 & 0.53 & 326 & 92 & 88 & - & 243 & $S B$ & 4 & 53 \\
\hline 4 & 906 & 365.8 & 009 & 1.0 & 327 & 52 & 59 & - & 252 & 53 & 5 & 57 \\
\hline 5 & 911 & 368.5 & $0.15^{-}$ & 1.7 & 332 & 94 & 89 & - & $24 / 253$ & 52 & 2 & 48 \\
\hline 6 & qiie & 372.1 & 0.2 & 2.3 & 330 & 76 & 91 & - & 246 & 52 & 9.5 & 50 \\
\hline top & 921 & 376.091 & $\Leftrightarrow$ & ilect & 60 & $z_{0}$ & $\mathrm{ul}^{\prime}$ & & & . & & \\
\hline & & & ser & Lees & - ches & $2 E$ & पैंa & & & & & \\
\hline$\omega=2-1$ & Sisth & $3 \times 0.420$ & 0.03 & 0.33 & 278 & 90 & 89 & - & 219 & 65 & 3 & 5 \\
\hline & $95 \%$ & 378.2 & 0.03 & 0.32 & 300 & 51 & 85 & - & 258 & 60 & 3.5 & 52 \\
\hline 3 & Gjह & 379.5 & 0.06 & 0.44 & 304 & 51 & 89 & - & 250 & $3 \overline{3}$ & & \\
\hline 4 & 1001 & 381.8 & 0.07 & 0.78 & 307 & 51 & 89 & - & 248 & 58 & 5 & \\
\hline 5 & 1006 & 384.2 & 0,12 & 1.3 & 297 & 93 & 90 & - & 248 & 52 & 7 & \\
\hline 6 & 1011 & 387.4 & 0.15 & 127 & 307 & 56 & 91 & - & 250 & 57 & 8 & \\
\hline $5+2 p$ & 1016 & 340.767 & & $\ell$ Fn & & & $c k$ & & & & & \\
\hline $1,1<-1$ & 1029 & 390.980 & 0,02 & 0.22 & 790 & 7 & 32 & - & 216 & $\infty 7$ & 3 & 9 \\
\hline 2 & 1027 & 392.5 & 0.02 & 0.22 & 298 & 95 & 93 & $\div$ & 242 & 64 & 3 & 53 \\
\hline 3 & 1032 & 373.8 & 0.05 & 0.25 & 257 & 5,5 & 93 & - & 245 & 58 & $5^{-}$ & 53 \\
\hline 4 & 6037 & 396.0 & 2.1 & $\mathrm{ke} 1$ & 307 & 26 & 93 & - & 242 & 52 & 2 & 45 \\
\hline$\pi$ & 1042 & $39 x=8$ & 0,13 & 1.45 & רפ3 & 92 & 93 & - & 244 & 52 & 8 & 59 \\
\hline 6 & 1047 & 402.0 & 0.14 & 1.6 & 299 & Sq & 94 & $=$ & 245 & 52 & 8.5 & $\overline{7}$ \\
\hline $58 p$ & 1052 & 405.540 & 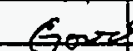 & $\sigma^{\prime}$ & 1 iea & $k c h$ & $c k$ & & & & & \\
\hline & & & & & & & & & & & & \\
\hline & & & & & & & & & & & & \\
\hline & & & & & & & & & & & & \\
\hline & & & & & & & & & & & & \\
\hline & & & & & & & & & & & & \\
\hline & & & & & & & & & & & & \\
\hline Avg. & - & 46820 & 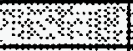 & \%०, & +1 & 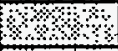 & ४४ & $14 \%$ & $\%$ & ४४3 & $\%$ & \\
\hline Check'd & - & 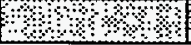 & 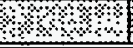 & & $\$ 2 \%$ & & & $1 \%$ & & & & \\
\hline
\end{tabular}

CONSOLE \#

FILTER \#

AMBIENT TEMP.

PROBE LENGTH

LINER MATERIAL

REMARKS
Vetocil 1 \$४४४४४४४

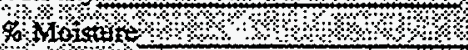

Blow rate toSCEM)

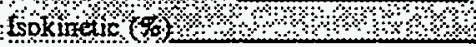




\section{MON:FIED METHOD 5 FIELD DAT:C SHIEET}

PLANT NAME Plant Yates Station Boiler No. 1

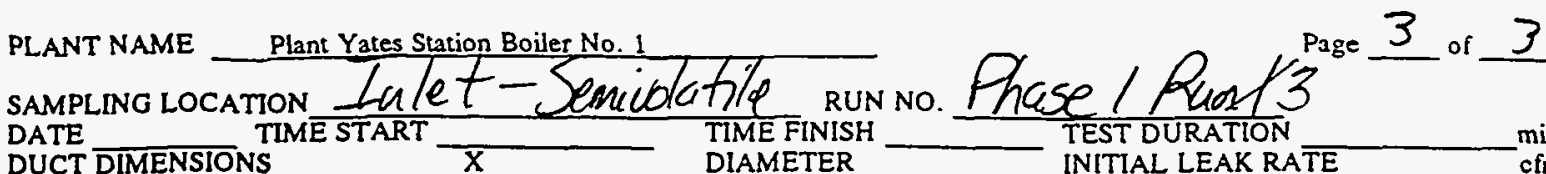

DUCT DIMENSIONS

PTCF

STATIC PRESS DGMCF " $\mathrm{H}$
DIAMETER

DIA.

OPERATOR JU/M " $\mathrm{H} 2 \mathrm{O}$ INITIAL LEAK RATE FINAL LEAK RATE

\section{E} mir. $\mathrm{cfn}_{i}$

\begin{tabular}{|c|c|c|c|c|c|c|c|c|c|c|c|c|}
\hline \multirow{2}{*}{$\begin{array}{c}\text { Traverse } \\
\text { Point }\end{array}$} & \multirow{2}{*}{$\begin{array}{l}\text { Clock } \\
\text { Time }\end{array}$} & \multirow{2}{*}{ 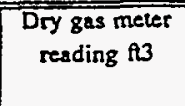 } & \multirow{2}{*}{ in $\mathrm{H} 2 \mathrm{P}$} & \multirow{2}{*}{ in $\mathrm{H} 2 \mathrm{O}$} & \multirow{2}{*}{$\begin{array}{c}\text { Stsck } \\
\text { Temp. F }\end{array}$} & \multicolumn{2}{|c|}{ Dry gas meter lemp. } & \multirow{2}{*}{$\begin{array}{l}\text { Hol box } \\
\text { Temp. }\end{array}$} & \multirow{2}{*}{$\begin{array}{l}\text { Probe } \\
\text { Temp }\end{array}$} & \multirow{2}{*}{$\begin{array}{c}\text { Last } \\
\text { Impinger }\end{array}$} & \multirow{2}{*}{$\begin{array}{l}\text { Vacuum } \\
\text { in. } \mathrm{Hg}\end{array}$} & \multirow{2}{*}{$\begin{array}{c}\text { Cond. } \\
\text { Exit } \\
\text { Temp. F }\end{array}$} \\
\hline & & & & & & Inlet & Outet & & & & & \\
\hline 161 & 1111 & 405.659 & 0.01 & 0.11 & 299 & Ges & 93 & - & 215 & 69 & 3 & 56 \\
\hline 2 & 1116 & $406 . \gamma$ & 0,02 & 0.22 & 302 & 93 & 93 & - & 234 & 65 & 3 & 55 \\
\hline 3 & 1121 & 408.2 & 0.03 & 0.34 & 299 & 54 & 93 & - & 247 & 62 & 4 & 53 \\
\hline 4 & 1126 & 4094 & 003 & 0.301 & 289 & 54 & 93 & $\sim$ & 248 & 60 & 4 & 53 \\
\hline 51 & 1131 & 411.6 & 0.04 & 0.45 & 291 & 95 & 94 & - & 248 & 60 & & 52 \\
\hline 6 & 1136 & $=$ & 0.07 & 0.78 & 281 & 52 & 95 & - & $x / 8$ & 60 & 6 & 53 \\
\hline stop & 1141 & 416,100 & Sen & $\angle$ Fina & & & & & & & & \\
\hline $6 \sqrt{6} 11$ & 1220 & 416.178 & 0.04 & 0.45 & 289 & 91 & 90 & - & 226 & 63 & 4 & 53 \\
\hline 2 & 1225 & $4 \sqrt{18}, 7$ & 0.03 & 0.34 & 250 & E & 51 & - & 249 & 51 & & 53 \\
\hline 3 & 1230 & 420.4 & 0.02 & 0.23 & 281 & $\sqrt{2}$ & 91 & $=$ & 25 & 62 & & 527 \\
\hline 4 & 1235 & 421.8 & 0.01 & 0,11 & 294 & 93 & 91 & - & $2+5$ & $60^{-}$ & 3.5 & 57 \\
\hline 5 & 1240 & 423.0 & $0 d t$ & 0.44 & 293 & 94 & $\varepsilon 1$ & - & 24 & 65 & & 52 \\
\hline 6 & 1245 & 424.7 & 0.03 & 0.33 & 291 & 55 & 93 & - & 245 & 62 & & 54 \\
\hline Stop & 1250 & 596,397 & & & & & & & & & & \\
\hline & & Final & eats & heck & 0,0 & 140 & & & & & & \\
\hline & & & & & & & & & & & & \\
\hline & & & & & & & & & & & & \\
\hline & & & & & & & & & & & & \\
\hline & & & & & & & & & & & & \\
\hline & & & & & & & & & & & & \\
\hline & & & & & & & & & & & & \\
\hline & & & & & & & & & & & & \\
\hline & & & & & & & & & & & & \\
\hline & & & & & & & & & & & & \\
\hline & & & & & & & & & & & & \\
\hline & & & & & & & & & & & & \\
\hline & & & & & & & 6 & & & & & \\
\hline & & $T B$ & $\sqrt{\Delta P}$ & & $B$ & & & & & & & \\
\hline Avg. & - & 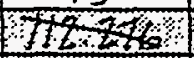 & 0,240 & 2135 & 305 & $\therefore 8$ & 8 & $\therefore \therefore$ & & ॥? & 2 & \\
\hline Check'd & $=$ & $1 u_{3}+53$ & TBSI & $4 \%$ & 30025 & $\therefore$ & 28 & $\therefore$ & 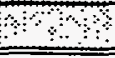 & & 6 & $1 \%$ \\
\hline CONSOL & LE\# & & & & Vefocity & 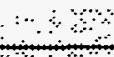 & $\because: \because$ & $\because=\ddot{3}$ & & & & \\
\hline FILTER & & & & & \% Noistal & $\$$ & $\because$ & ख़ & & & & \\
\hline AMBIEN & VT TEMP. & & & & Alowrate & (DSCEM) & 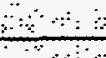 & 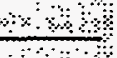 & & & & \\
\hline PROBE I & LENGTH & & & & Isokinetic & $(\pi)$ & & 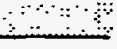 & & & & \\
\hline
\end{tabular}




\section{MODIFIED METHOD 3 FIZLD DATA SHEET}

PLANT NAME Plant Yates Station Boiler No. 1

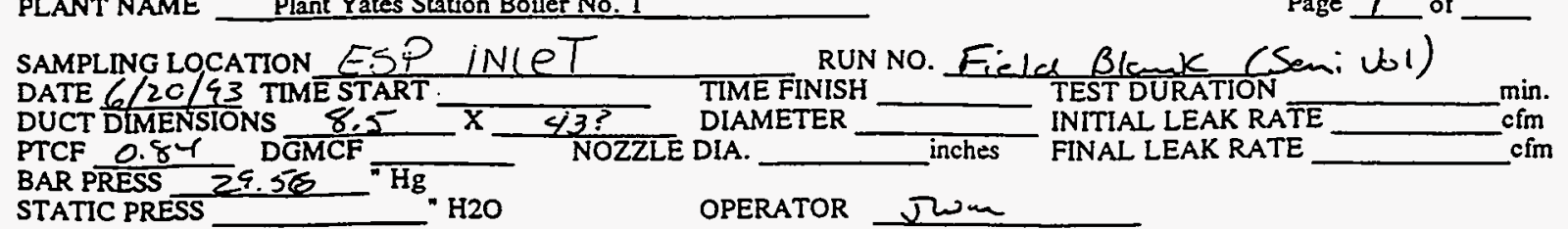

\begin{tabular}{|c|c|c|c|c|c|c|c|c|c|c|c|c|}
\hline \multirow{2}{*}{$\begin{array}{c}\text { Traverse } \\
\text { Point }\end{array}$} & \multirow{2}{*}{$\begin{array}{l}\text { Clock } \\
\text { Time }\end{array}$} & \multirow{2}{*}{$\begin{array}{c}\text { Dry gas meter } \\
\text { reading } t 33\end{array}$} & \multirow{2}{*}{ in $\mathrm{H} 2 \mathrm{O}$} & \multirow{2}{*}{$\begin{array}{l}\mathrm{H} \\
\text { in } \mathrm{H} 2 \mathrm{O}\end{array}$} & \multirow{2}{*}{$\begin{array}{c}\text { Stack } \\
\text { Temp. } F\end{array}$} & \multicolumn{2}{|c|}{ Dry gas meter lemp. } & \multirow{2}{*}{$\begin{array}{l}\text { Hot box } \\
\text { Temp. }\end{array}$} & \multirow{2}{*}{$\begin{array}{l}\text { Probe } \\
\text { Temp }\end{array}$} & \multirow{2}{*}{$\begin{array}{c}\text { Last } \\
\text { Impinger }\end{array}$} & \multirow{2}{*}{$\begin{array}{l}\text { Vacuum } \\
\text { in. } \mathrm{Hg}\end{array}$} & \multirow{2}{*}{$\begin{array}{l}\text { Cond. } \\
\text { Exit } \\
\text { Temp. F }\end{array}$} \\
\hline & & & & & & Inlet & Outlet & & & & & \\
\hline & & $x 61.325$ & & & & & & & & & & \\
\hline & & 064.965 & & & & & & & & & & \\
\hline & & & & & & & & & & & & \\
\hline & & & & & . & & & & & & & \\
\hline & & & & & & & & & & & & \\
\hline & & & & & & & & & & & & \\
\hline & & & & & & & & & & & & \\
\hline & & & & & & & & & & & & \\
\hline & & & & & & & & & & & & \\
\hline & & & & & & & & & & & & \\
\hline & & & & & & & & & & & & \\
\hline & & & & & & & & & & & & \\
\hline & & & & & & & & & & & & \\
\hline & & & & & & & & & & & & \\
\hline & & & & & & & & & & & & \\
\hline & & & & & & & & & & & & \\
\hline & & & & & & & & & & & & \\
\hline & & & & & & & & & & & & \\
\hline & & & & & & & & & & & & \\
\hline & & & & & & & & & & & & \\
\hline & & & & & & & & & & & & \\
\hline & & & & & & & & & & & & \\
\hline & & & & & & & & & & & & \\
\hline & & & & & & & & & & & & \\
\hline & & & & & & & & & & & & \\
\hline & & & & & & & & & & & & \\
\hline & & & & & & & & & & & & \\
\hline & & & & & & & & & & & & \\
\hline & & & & & & & & & & & & \\
\hline Avg. & - & ४४४४४ & ४९। & ڤ४ & अ४ & $\$$ & अस & ४४/ & n) & \%म & ४॥ & $2 \% \%$ \\
\hline Check'd & - & ४४ ४। & ४\$। & 31 & ४४ & ४म & 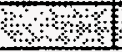 & २०ै & $\$ \%$ & म॥ & ॥ & ॥ \\
\hline $\begin{array}{l}\text { CONSOI } \\
\text { FILTER } \\
\text { AMBIEK } \\
\text { PROBE }\end{array}$ & $\begin{array}{l}E \# \text { A } \\
\text { [ TEMP. } \\
\text { ENGTH }\end{array}$ & 90 & & & 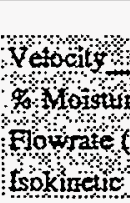 & $\begin{array}{l}\text { (qsepM } \\
\text { (\%) }\end{array}$ & 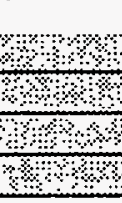 & की & & & & \\
\hline
\end{tabular}

REMARKS 


$$
\text { Page } 1 \text { of } 1
$$

Plant Name

Plant Yates Station Boiler No. 1

Sampling Location INLET

Dato $6-2-9 ;$ Time Start $\frac{13 / 6}{\mathrm{~S} / 5}$ Time Finish $\angle 345$

PTCF . 84 DGMCF 1.009 Nozzle Dia. .275 inches

Bar Press $29,51 . \mathrm{Hg}$

Static Press $-6.4=\mathrm{H} 2 \mathrm{O}$

Operator MEO

Run No. 1 .

\begin{tabular}{|c|c|c|c|c|c|c|c|c|c|c|c|c|}
\hline Travers & Clock & Dry gas meter & ${ }^{4 P}$ & ${ }^{\wedge} \mathrm{H}$ & Stack & Dry gas & eter temp. & Hot box & Probe & Last & Vacuum & \\
\hline Point & Time & reading ft 3 & in $\mathrm{H} 2 \mathrm{O}$ & in $\mathrm{H} 2 \mathrm{O}$ & Temp. F & Inlet & Outlet & Temp. & Temp & Impinger & in. $\mathrm{Hg}$ & 3.86 \\
\hline NA & $\angle 310^{2}$ & $582>3 x$ & 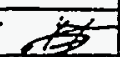 & 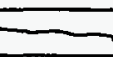 & & & & & & & & \\
\hline & $13 / 5$ & 584.03 & 11 & 42 & 314 & 77 & 77 & $11 / 2$ & 257 & 63 & 4.0 & 5.8 \\
\hline & 1320 & 595,94 & 11 & 47 & 313 & 28 & 77 & & 245 & 63 & 40 & 3,8 \\
\hline & 1325 & 587.60 & 110 & 38 & $3 / 5$ & 79 & 70 & & 258 & 64 & Po & 3.7 \\
\hline & 1336 & $589.5 \%$ & .16 & 38 & 310 & 8,1 & 79 & & 751 & 63 & 4,0 & 3.20 \\
\hline & 4335 & 591.04 & $e / 0$ & 38 & $3<4$ & 82 & 80 & & 250 & 63 & 3.5 & 3.76 \\
\hline & 1340 & 592.81 & 10 & $3 Q$ & 314 & 84 & 1 & & 251 & 61 & $4, \infty$ & 3.16 \\
\hline & 2345 & 594515 & 10 & 38 & 314 & 85 & 21 & & 25 & 61 & $(4.0)$ & 3.16 \\
\hline & & & & & & & & & & & & \\
\hline & & & & & & & & & & & & \\
\hline & & 12.281 & & & & & & & & & & \\
\hline & & & & & & & & & & & & \\
\hline & & & & & & & & & & & & \\
\hline & & & & & & & & & & & & \\
\hline & & & & & & & & & & & & \\
\hline & & & & & & & & & & & & \\
\hline & & & & & & & & & & & & \\
\hline & & & & & & & & & & & & \\
\hline & & & & & & & & & & & & \\
\hline & & & & & & & & & & & & \\
\hline & & & & & & & & & & & & \\
\hline & & & & & & & & & & & & \\
\hline & & & & & & & & & & & & \\
\hline & & & & & & & & & & & & \\
\hline & & & & & & & & & & & & \\
\hline & & & & & & & & & & & & \\
\hline & & & & & & & & & & & & \\
\hline & & & $\sqrt{\Delta P}$ & & & & & & & & & \\
\hline Avg. & - & \%:ZZZ & 0332 & 10.39 & 315 & 81 & 79 & $8:$ & 852 & १४ & अ० & 1:: \\
\hline Check'd & & $1 \times 1 \%$ & 6 & 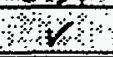 & $\therefore$ & $\therefore \quad \ldots$ & 17 & 113 & 3 & ४९४ & $1 \%$ & 2 \\
\hline
\end{tabular}

CONSOLE " Al6/402

FILTER \# $\mathrm{Na}$

AMBIENT TEMP. $80^{\circ} \mathrm{F}$

PROBE LENGTH

LINER MATERIAL glass velocity

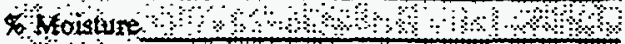

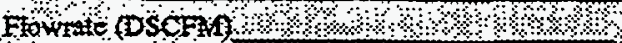

Isoknetic $(5)$ oै

REMARKS

Single port collection from Port E-8 


$$
\text { Page } 1 \text { of } 1
$$

Plant Name

Plant Yates Station Boiler No. 1

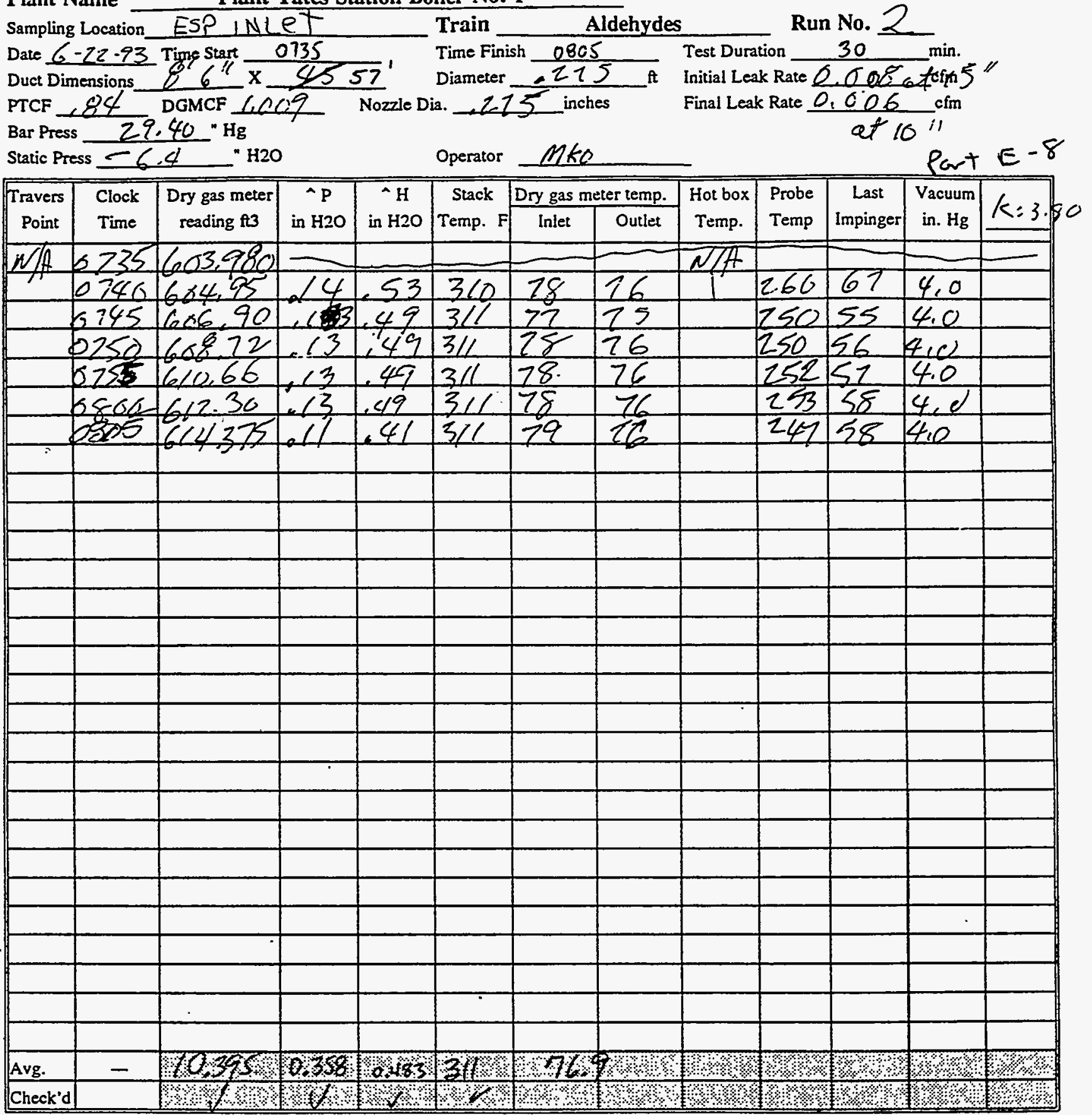

CONSOLE $A / 6 / 40 Z$

FILTER \#

AMBIENT TEMP.

PROBE LENGTH $\angle 0^{\prime}$

LINER MATERIAL Slass vefoowy $\mathrm{H}$

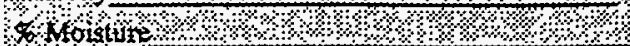
Howrate DSCGM $1 \% \%$ \%

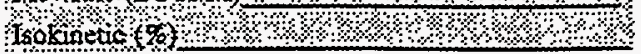

REMARKS

C-172 single point sample collection from port E-8 
Plant Name

Plant Yates Station Boiler No. 1

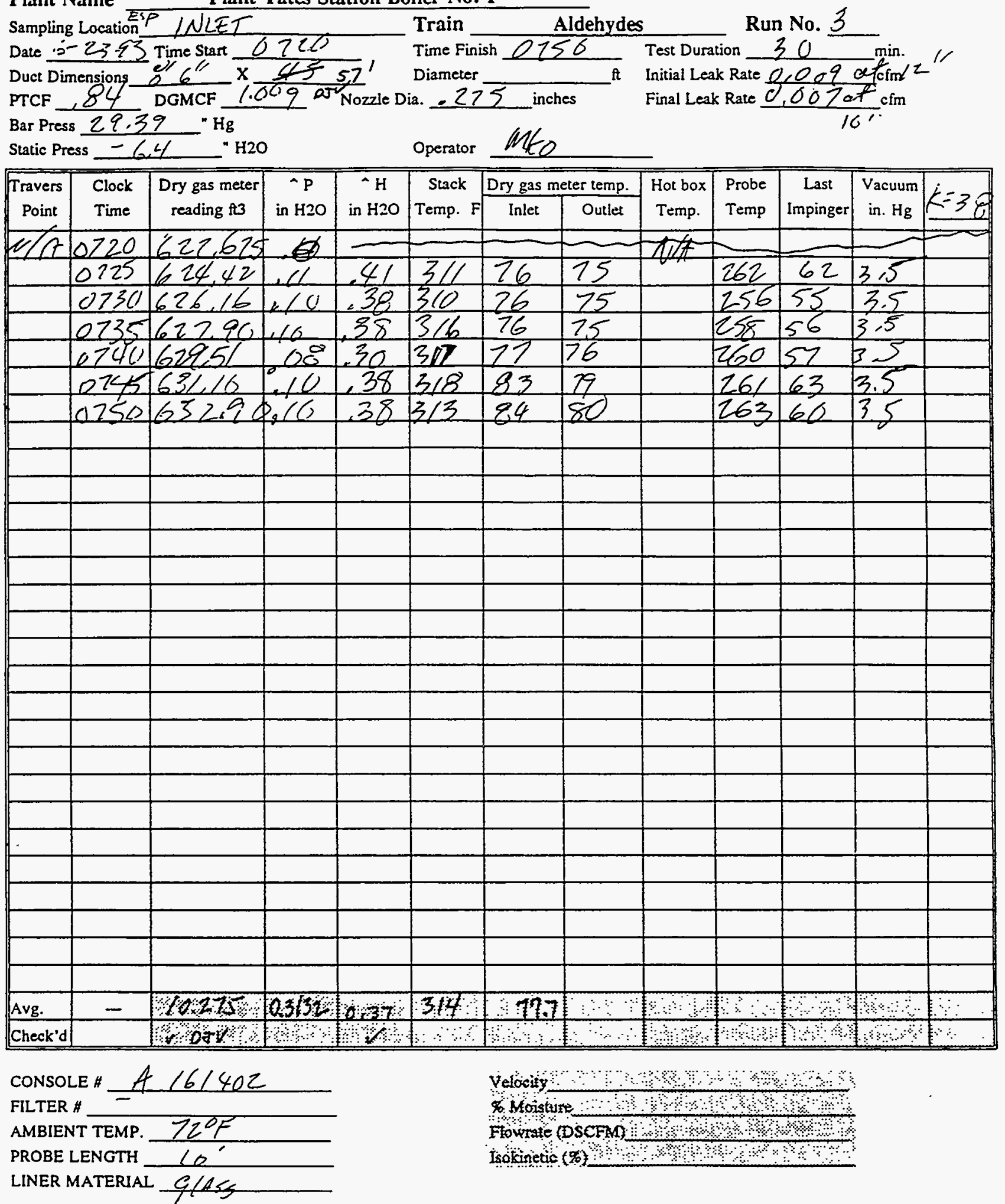


Plant Name

Plant Yates Station Boiler No. 1
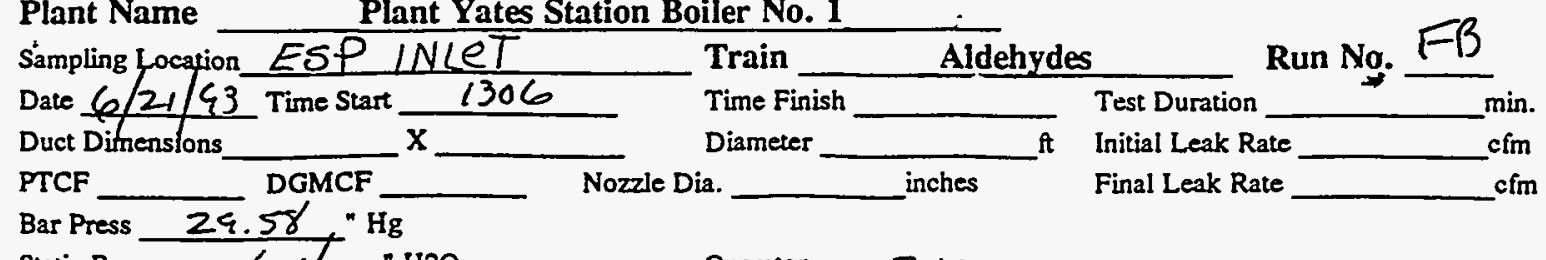
Entered

SOLRCE SAMPLING FIELD DATA SHEET

Page ___ of ___

Plant Name

Sampling Location in $/ x$ Train

Plant Yates Station Boiler No. 1

Date 6-I/ Time Start is55,

Train $\quad$ PSD

Time Finish 1740

Duct Dimensions \& $8^{\prime} 6$ 15150 Diameter

PTCF .84 DGMCF 9880 Nozzle Dia.

Static Press -64.420

operator $M k O$

Run No.

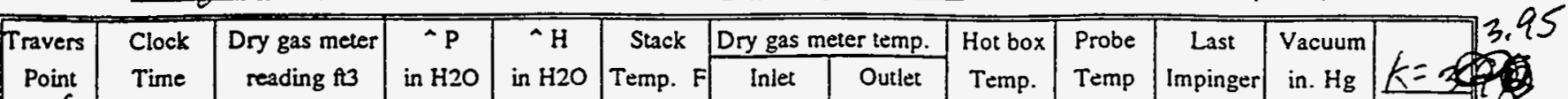

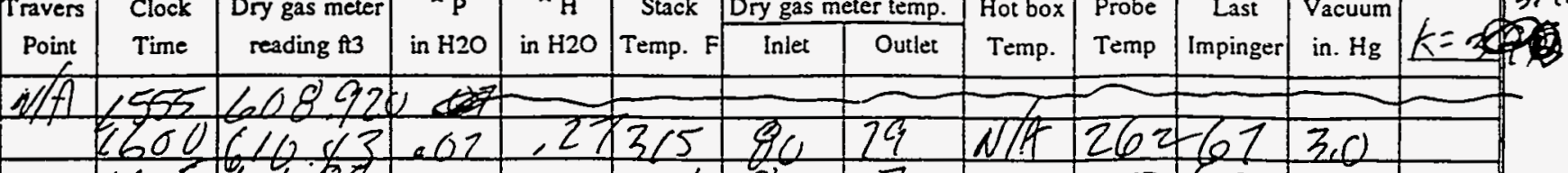

$1605 \% 11.84 .07,2734$

$1610,613,29$

$16(5) 614,12.017 .27$

1620616,161007

6625627.57 .67

$163069 \times 4$

16351620.62

i640 6218

1645623,33

$650624,13.0$

165 626.25.07.27

$.200627 .75,01$

1205629

\begin{tabular}{l|l}
1706 & 630,57
\end{tabular}

17563204

27

$2 \pi$

3,5

(2)

77

253.66 B.

1720633,15

$.07 \times 27$

$3 / 9$

79

$2 5 \longdiv { 5 7 }$

3,0

12603493.0127

$634.231 .07 \cdot 27$

$1730 \quad 63637.0727$

1735638.00 .01

0740639650202.27

$3 / 7$ 8

80

247583.0

27316

318

2

80

25758

2दि 60

2,5

82 हु

2451573.0

318 8 80

255573.0

\begin{tabular}{ll|l}
320 & 07 & 83
\end{tabular}

$2^{2} 751$

3.0

$322-88$ 84

25558

उस क्ष

$\frac{84}{85}$

32089

186

235

3.0

24859

3.0

\begin{tabular}{l|l|l}
319 & 89 & 86 \\
31890 & 86
\end{tabular}

15 59

310

31990

31790

क्ण

31990

26

318

91

86

86

उa 9 का

3201187

87

\begin{tabular}{ll|l|l|l|l|l|}
\hline & & & & & \\
\hline
\end{tabular}

\begin{tabular}{|l|l|l|l|l|l|}
\hline & & & & & \\
\hline
\end{tabular}

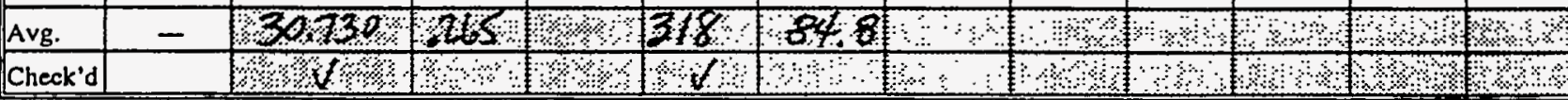

CONSOLE A Al6/397

FILTER \# Thioble \#1314

AMBIENT TEMP.

PROBE LENGTH $<0$

LINER MATERIAL S/AS5
Velootity : $\cdots+\cdots+\cdots$

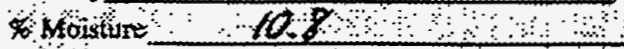

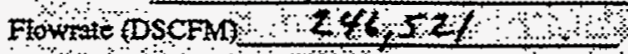

1sokinetie of 104

Single point sample collection from port $I \& E 7$ Jwm 
Plant Name Plant Yates Station Boiler No. 1

Sampling Location NN1et Train

Date $6-22-93$ Time Start 0925

Duct Dirgegsions $8.6^{\prime \prime} \times \frac{57^{\prime}}{}$

PTe Nozzle D

Bar Press 29.40 ${ }^{\circ} \mathrm{Hg}$

Static Press -6.4 "H2O

PSD

Time Finish $1 / \angle E S$

Diameter

$-$

inches

Operator MLo

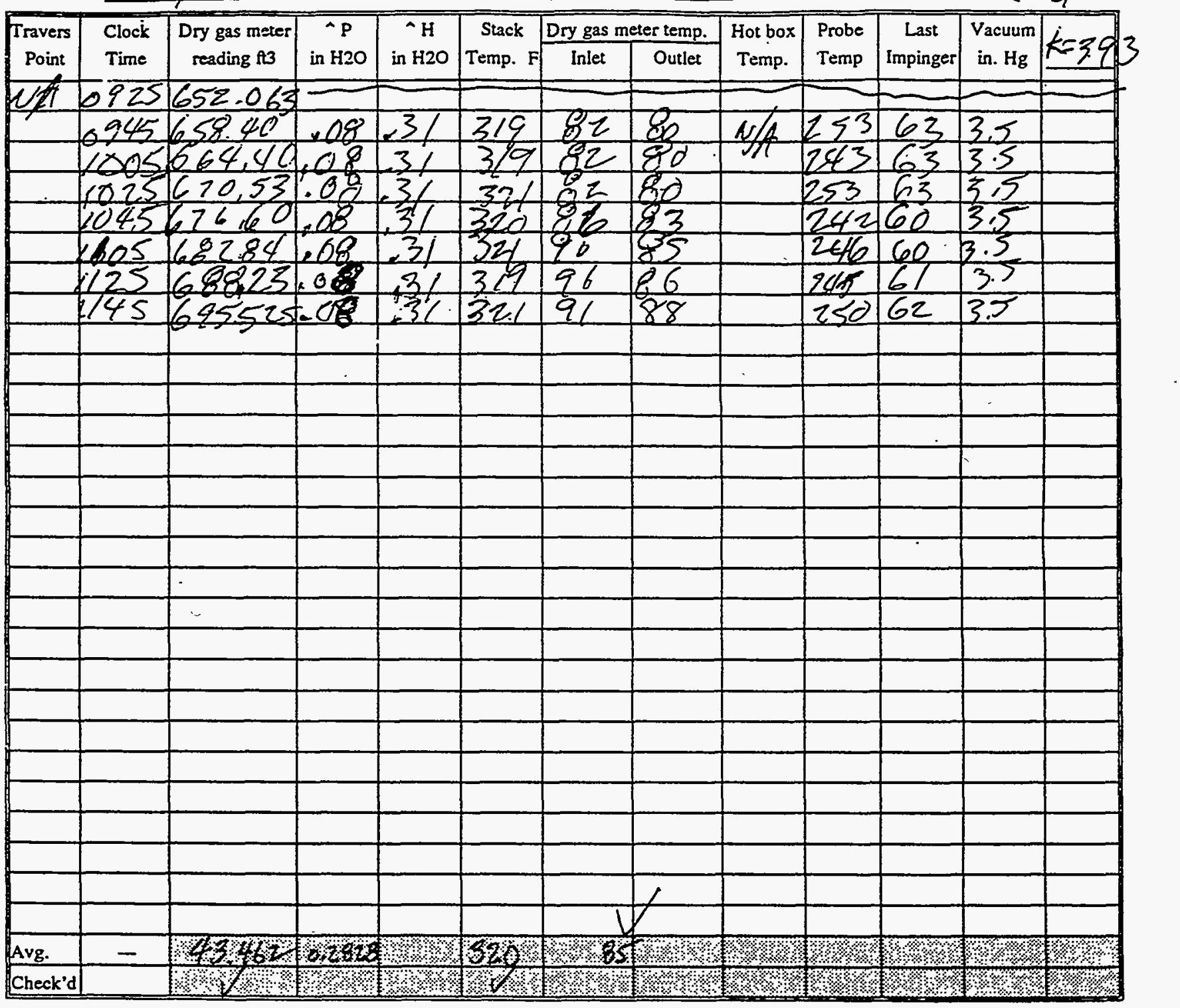

Run No. 2 Test Duration $140 \overline{0} \mathrm{~min}$.

Final Leak Rate NA cim
Initial Leak Rate 0.048 of cind $8{ }^{\prime \prime}$ 
SOLRCE SAMPLING FIELD DATA SHEET

$$
\text { Page } 1 \text { of }
$$

Plant Name

Piant Yates Station Boiler No. 1

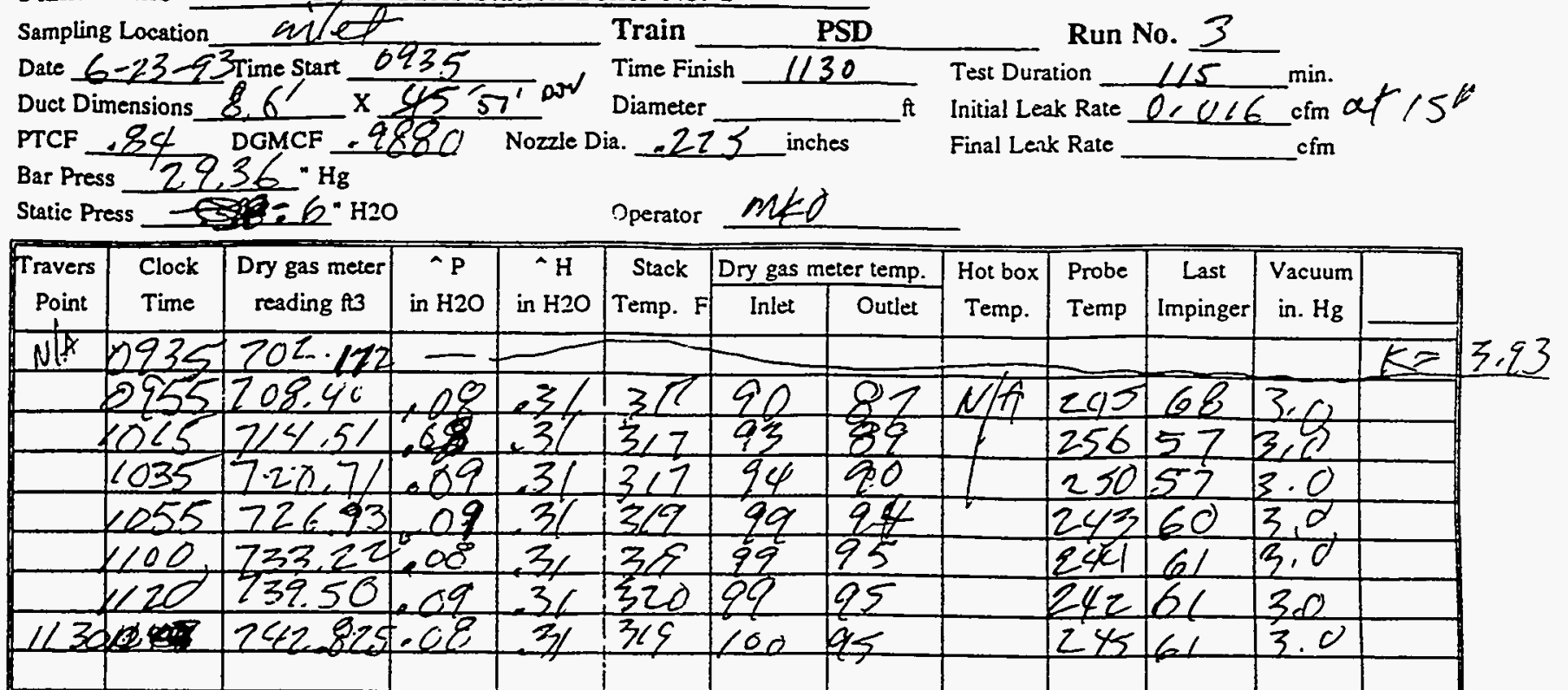

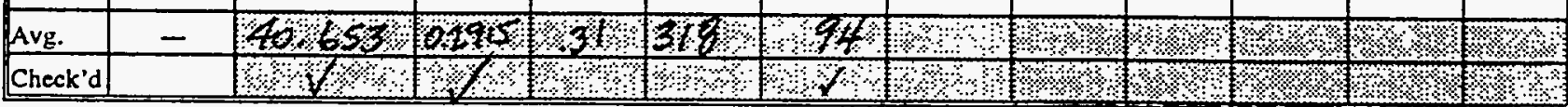

CONSOLE \# A/6/397

FILTER \#

AMBIENT TEMP.

PROBE LENGTH

78

LINER MATERIAL 55

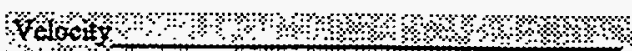

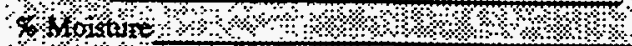

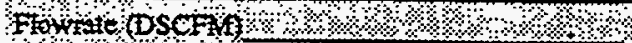

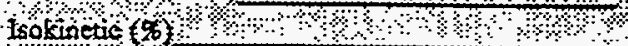

REMARKS 
Plant Name

Plant Yates Station Boiler No. 1

Date 6/25/93 Time Start 0800 Time Finish 1405 Test Duration $240 \%$ min.

Duct Dimensions $8.6 " \mathrm{x} 455 \mathrm{~J}$ J Diameter

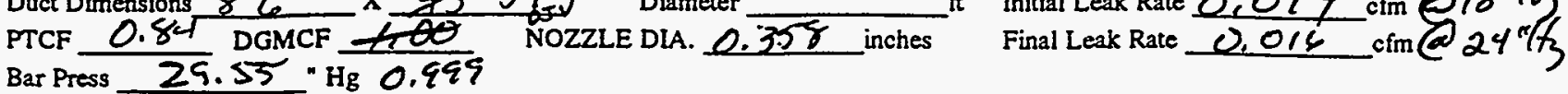

Static Press -5.8 Operator J20 m

\begin{tabular}{|c|c|c|c|c|c|c|c|c|c|c|c|c|}
\hline \multirow{2}{*}{\begin{tabular}{|c|} 
Travers \\
Point
\end{tabular}} & \multirow{2}{*}{$\begin{array}{l}\text { Clock } \\
\text { Time }\end{array}$} & \multirow{2}{*}{$\begin{array}{c}\text { Dry gas meter } \\
\text { reading ft } 3\end{array}$} & \multirow{2}{*}{$\begin{array}{c}\text { A } \\
\text { in } \mathrm{H} 2 \mathrm{O}\end{array}$} & \multirow{2}{*}{$\begin{array}{c}{ }^{\wedge} \mathrm{H} \\
\text { in } \mathrm{H} 2 \mathrm{O}\end{array}$} & \multirow{2}{*}{$\begin{array}{l}\text { Stack } \\
\text { Temp. F }\end{array}$} & \multicolumn{2}{|c|}{ Dry gas meter temp. } & \multirow{2}{*}{$\begin{array}{l}\text { Hot box } \\
\text { Temp. }\end{array}$} & \multirow{2}{*}{$\begin{array}{l}\text { Probe } \\
\text { Temp }\end{array}$} & \multirow{2}{*}{$\begin{array}{c}\text { Last } \\
\text { Impinger }\end{array}$} & \multirow{2}{*}{$\begin{array}{c}\text { Vacuum } \\
\text { in. } \mathrm{Hg}\end{array}$} & \\
\hline & & & & & & Inlet & Outlet & & & & & \\
\hline $6 x^{6}-1$ & 0800 & 446,205 & $0 . \alpha_{i}$ & 0.66 & 277 & 74 & 73 & $2=\frac{3 z^{24}}{2}$ & 226 & & 7 & \\
\hline 2 & 805 & $4486^{\circ}$ & 0.04 & 0.44 & 283 & 72 & 72 & - & 248 & & 5 & \\
\hline 3 & 810 & 450,2 & 0.07 & 0.33 & 284 & 24 & 73 & $=$ & 247 & & 4.5 & \\
\hline 4 & 815 & $\{\$ 2.0$ & 0.02 & 0.22 & 276 & 24 & 73 & - & 246 & 45 & 3 & \\
\hline 5 & 820 & 453.0 & 0.02 & 0.22 & 289 & 25 & 73 & $=$ & 227 & 48 & 3 & \\
\hline 6 & 825 & 454,6 & 0.06 & 0.66 & 275 & 26 & 73 & $=$ & 252 & 46 & 2 & \\
\hline Stop & 830 & 1.56 .576 & Goot & $d / \infty k$ & Cheek & & & & & & & \\
\hline wer & 836 & 456677 & 0.03 & 0.33 & 286 & $7)$ & 75 & $=$ & 225 & 45 & 4 & \\
\hline 2 & 841 & $4 / 58.6$ & 0.03 & 0.33 & 258 & 25 & 26 & - & 253 & 50 & 4 & \\
\hline 3 & 846 & 468.2 & 0.04 & 0.44 & 288 & 72 & 77 & $=$ & 246 & 57 & 5 & \\
\hline 4 & s. & 462,1 & 0.07 & 0.77 & 284 & 82 & 79 & تد. & 232 & 45 & 7.5 & \\
\hline 5 & 856 & 464,5 & 0.06 & 0.66 & 286 & 84 & 79 & $=$ & 254 & 9 & 7 & \\
\hline 6 & 201 & 4666 & 0,09 & 0.58 & 293 & 86 & 81 & $=$ & 249 & & 9 & \\
\hline Stop & 906 & 469.185 & Gosd & leals & chec & $\varepsilon$ & & & & & & \\
\hline 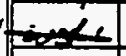 & 922 & 469.800 & 0.03 & 0.33 & 250 & 83 & 82 & - & 221 & $5 \%$ & 5 & \\
\hline 2 & 927 & 471.6 & 0.04 & 0.54 & 289 & 83 & 81 & - & 255 & 53 & 5 & \\
\hline 3 & 932 & 423.4 & 0.07 & 0.77 & 306 & 83 & 82 & $=$ & 244 & 49 & 7.5 & \\
\hline 4 & 937 & $4 \times 6.0$ & 0.01 & 1.1 & 292 & 85 & 82 & - & 248 & & el & \\
\hline 5 & 842 & 478.7 & 0,15 & 6 & 292 & 88 & 83 & - & $24 / 3$ & & 18 & \\
\hline 6 & 942 & 482.2 & 0.15 & 127 & 285 & So & 84 & $\sim$ & 242 & 83 & 19 & \\
\hline stiop & 952 & 485.872 & & & & & & & & & & \\
\hline$\omega_{2}-1$ & 1020 & 486.100 & 0.03 & 0,33 & 251 & 83 & 82 & - & 232 & 54 & 5 & \\
\hline 2 & 1025 & $4 \sqrt{88} 3$ & 0.04 & 0.44 & 250 & 83 & 82 & $=$ & 256 & 52 & 5 & \\
\hline 3 & 1030 & 485.8 & 0.05 & 0.53 & 293 & 84 & 83 & $=$ & $2+3$ & 50 & 6 & \\
\hline 4 & 1035 & 492.0 & 0,08 & 0.88 & 296 & 86 & 84 & $=$ & 247 & 49 & $\Sigma$ & \\
\hline 5 & $\cos 0$ & 494.2 & 0,14 & 1.55 & 299 & 88 & 84 & $=$ & $24 / 6$ & 48 & 12 & \\
\hline 6 & 1045 & 497.6 & $\partial . k$ & 1.53 & 300 & 90 & $85^{-}$ & - & $2 / 3$ & 51 & $n$ & \\
\hline Stop & $1050^{\circ}$ & 501.030 & & & & & & & & & & \\
\hline Avg. & -84 & 4.213 & 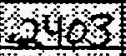 & Flo & $301 \%$ & ৪॰४ & $8 \%$ & 3818 & 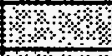 & 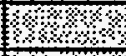 & $\%$ & \\
\hline Check'd & & $\%$ & $18 \%$ & $18 \%$ & $\$ \%$ & $1 \%$ & 2 & $1 \%$ & & & 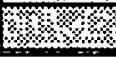 & \\
\hline
\end{tabular}

CONSOLE\# 161363

FILTER \# 1252

AMBIENT TEMP.

PROBE LENGTH

LINER MATERIAL

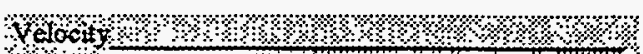

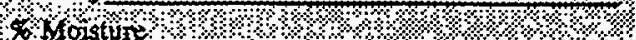

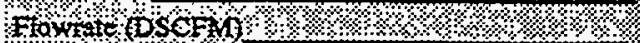

Isoknotstot

remarks Good pitut leek cleck 


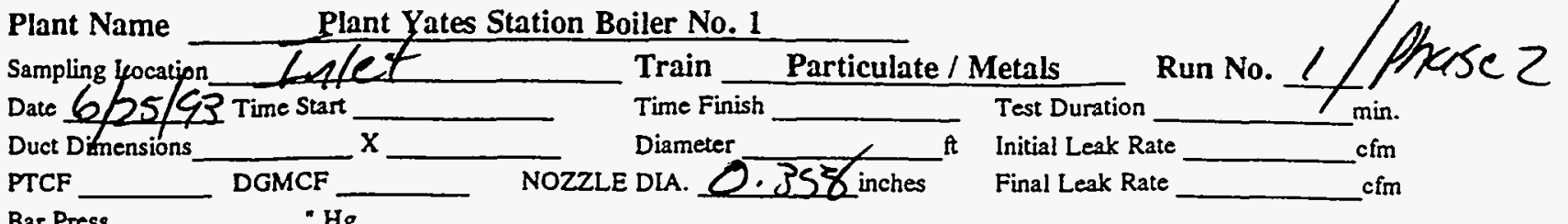
Bar Press " $\mathrm{H} 2 \mathrm{O}$ Operator JuW

Static Press

\begin{tabular}{|l|l|l|l|l|l|l|l|l|l|l|l|l|l|}
\hline Travers & Clock & Dry gas meter & $\wedge \mathrm{P}$ & $\wedge \mathrm{H}$ & Stack & Dry gas meter temp. & Hot box & Probe & Last & Vacuum \\
\cline { 2 - 5 }
\end{tabular}

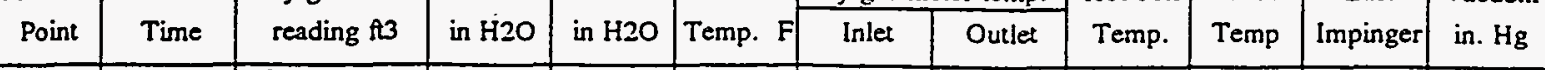

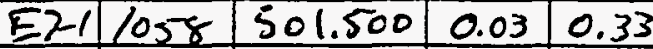
$2 / 103.503 .2$ \begin{tabular}{l|l|l|l|l|l}
3 & 1108 & 505.0 & 0.06 & 0.66 \\
\hline
\end{tabular}

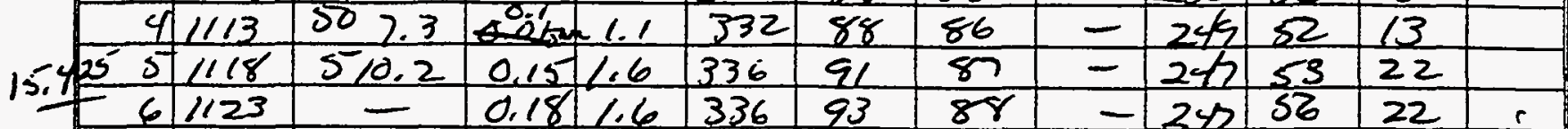
$316,88-86-223$ 5 515 \begin{tabular}{|c|c|c|c|}
324 & 87 & 86 & -1
\end{tabular} $-125$ \begin{tabular}{l|l|l}
253 & 53 & 6
\end{tabular} stap 1128 516.925 Leakclest $0.011023^{\prime \prime \prime l}$ - Changed Silia Gelimpinger

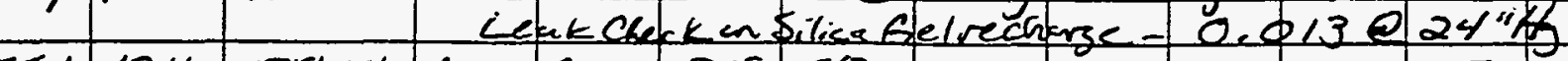
\begin{tabular}{|c|c|c|c|c|c|c|c|c|c|c|c|}
\hline$E 5-1$ & 1211 & 518.040 & 0.02 & 0.22 & 309 & 82 & 82 & - & 233 & 65 & 5 \\
\hline 2 & 1216 & - & 0.04 & 0.44 & 313 & 82 & 82 & - & 249 & 54 & 6.5 \\
\hline 3 & 1221 & 521.6 & 0.07 & 0.72 & 315 & 83 & 82 & - & 244 & 52 & 9.0 \\
\hline 4
\end{tabular}

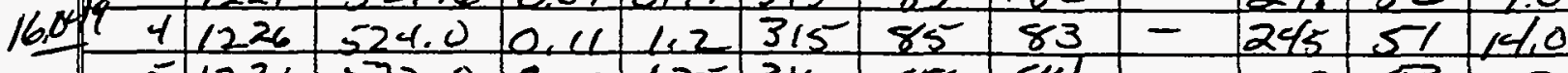
\begin{tabular}{l|l|l|l|l|l|l|l|l|l|l|l|l|}
5 & 1231 & 527.0 & 0.16 & 1.75 & 316 & 88 & 84 & - & 253 & 53 & 22
\end{tabular} \begin{tabular}{l|l|l|l|l|l|l|l|l|l|l|l|}
6 & 1236 & 530.4 & 0.22 & 1.25 & 315 & 90 & 85 & -216 & 62 & 22
\end{tabular} stop 1241534,084 Good ceak checred $23 \% \mathrm{ft}$ \begin{tabular}{l|l|l|l|l|l|l|}
\hline E3-1 & 2.53 & 534.268 & 0.02 & 0.22 & 298 \\
\hline
\end{tabular}

\begin{tabular}{|c|c|c|c|c|c|c|c|c|c|c|c|c|}
\hline E3-1 & $253^{-}$ & 534,268 & 0.02 & 0.22 & 298 & $8 n$ & 85 & - & 236 & 62 & 5 & \\
\hline 2 & $1 x^{2} / 300$ & & 0.02 & 0.22 & 305 & 86 & 85 & - & 224 & 58 & 5 & \\
\hline 3 & 1305 & 5323 & 0.04 & 0.44 & 311 & 86 & 85 & - & 241 & 54 & 7 & \\
\hline 4 & 1310 & 5.572 & 0.07 & 0,77 & $3 / 2$ & 87 & 85 & - & 253 & 4 & 10 & \\
\hline 5 & 1315 & 541.6 & 0,1 & 21 & 316 & 89 & 86 & $=$ & $24 \sqrt{3}$ & $5 / 8$ & 15 & \\
\hline 6 & 1320 & 544.4 & 8 & $t, 7^{1,5}$ & 308 & 92 & 83 & - & 249 & 5 & 22 & \\
\hline Ston & 1325 & 547.772 & Seltere & Janem & & & & & & & & \\
\hline El-r & 1335 & 548.300 & 0,09 & 1.0 & 308 & 50 & 87 & $=$ & 209 & 49 & 17 & \\
\hline 2 & 1310 & - & 0.07 & 0.76 & 307 & 90 & 87 & - & $24 / 3$ & $4 / 9$ & 12 & \\
\hline 3 & 1345 & 553.2 & 0.05 & 0.54 & 307 & 90 & 87 & - & 142 & 52 & 9 & \\
\hline 4 & 1350 & 535,3 & 0,03 & 0.33 & 305 & 90 & 88 & - & 252 & 33 & 7 & \\
\hline 5 & 1355 & 557.0 & 0.03 & 0.33 & 304 & S1 & 88 & $=$ & 253 & 54 & 2 & \\
\hline 6 & $3+34+\infty$ & 558.7 & 0.04 & 0.44 & 284 & 51 & 88 & $=$ & $25 / 6$ & 53 & 9 & \\
\hline A & $7205^{-1}$ & 560,86 & $\%$ & $4 \% \%$ & \%४\% & ४ै० & $\%$ & $8 \%$ & $\$$ & 4 & 81 & पष: \\
\hline Check'd & & Bt: $2 \times$ & \%० & & \% & $8 \% 8$ & $1 \% 92$ & 98 & $8 \%$ & & 80 & क: \\
\hline
\end{tabular}

CONSOLE \#

FILTER \#

AMBIENT TEMP.

PROBE LENGTH

LINER MATERIAL
Velocify

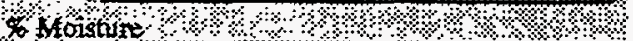

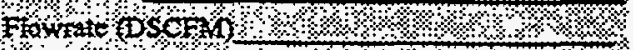
lsobinetie to $8 \%$ औ

REMARKS Could not pull the proper rate through the silicagel impinger. The impinger mass determined, and then the silica gel 
Plant Name Plant Yates Station Boiler No. 1

Sampling Location Inlet Date G/26/93 Time Start 0935 Train Particulate / Metals Run No. $2 /$ Prase 2 DUCF Dúmensions 0.84 DGMCF 0.999 NOZZLE DIA. 0.358 inches Time Finish $16 / 1$ Test Duration $240 \%$ min. Bar Press $29.56 ; \mathrm{Hg}$

Static Press -0.58 H2O Operator Twn Initial Leak Rate $0.0206 \mathrm{~cm} @ 23^{\prime \prime / / 5}$ Final Leak Rate $0.012 \mathrm{cim} 24 \mathrm{\prime \prime}$ $\triangle H E=1.822$

\begin{tabular}{|c|c|c|c|c|c|c|c|c|c|c|c|c|}
\hline \multirow{2}{*}{$\begin{array}{l}\text { Travers } \\
\text { Point }\end{array}$} & \multirow{2}{*}{$\begin{array}{l}\text { Clock } \\
\text { Time }\end{array}$} & \multirow{2}{*}{$\begin{array}{l}\text { Dry gas meter } \\
\text { reading ft3 }\end{array}$} & \multirow{2}{*}{$\begin{array}{c}-P \\
\text { in } \mathrm{H} 2 \mathrm{O}\end{array}$} & \multirow{2}{*}{$\begin{array}{c}-\mathrm{H} \\
\text { in } \mathrm{H} 2 \mathrm{O}\end{array}$} & \multirow{2}{*}{$\begin{array}{c}\text { Stack } \\
\text { Temp. F }\end{array}$} & \multicolumn{2}{|c|}{ Dry gas meter temp. } & \multirow{2}{*}{$\begin{array}{l}\text { Hot box } \\
\text { Temp. }\end{array}$} & \multirow{2}{*}{$\begin{array}{l}\text { Probe } \\
\text { Temp }\end{array}$} & \multirow{2}{*}{$\begin{array}{c}\text { Last } \\
\text { Impinger }\end{array}$} & \multirow{2}{*}{$\begin{array}{l}\text { Vacuum } \\
\text { in. } \mathrm{Hg}\end{array}$} & \multirow{2}{*}{ Kactor } \\
\hline & & & & & & Inlet & Outlet & & & & & \\
\hline$E /-1$ & 935 & 579944 & 0.1 & 1.1 & 289 & 72 & 72 & - & 222 & 52 & 10 & 10.8 \\
\hline 2 & 940 & 582.9 & 0.08 & 087 & 294 & 23 & 72 & - & 262 & 45 & 8 & \\
\hline 3 & 945 & 585.5 & 0.05 & 0.55 & 253 & 25 & 72 & - & 254 & 49 & 6 & \\
\hline 4 & 950 & 587.5 & 0.03 & 0.33 & 295 & 76 & 23 & - & $2 \sqrt{6}$ & $\sqrt{3}$ & 5 & \\
\hline 5 & 953 & 587.2 & 0.03 & 0.33 & 296 & 27 & 74 & $=$ & 257 & 54 & 5 & 105 \\
\hline 6 & 1000 & 550.9 & 0.03 & 0.33 & 287 & 28 & 75 & - & 244 & 53 & 5 & \\
\hline Stop & 1005 & $5 \overline{5}, 536$ & $\theta 00$ & 1 leak & cheek & E2: & 5 & & & & & \\
\hline & & & & & & & & & & & & \\
\hline$E 3-1$ & 10,1 & 572.298 & 0,03 & 0.39 & 290 & 78 & 26 & - & $2 / 9$ & 54 & 5 & \\
\hline 2 & $10 / 6$ & 554.7 & 0.02 & 0.22 & 305 & 25 & 76 & - & $2 \times 4$ & 52 & 4 & \\
\hline 3 & 1021 & 546.0 & 0.05 & $0.33^{-}$ & 306 & 80 & 7) & - & 251 & 48 & 6 & \\
\hline 4 & 1026 & 3981 & 0.08 & 0.88 & 304 & 82 & 78 & $=$ & 249 & 46 & 9 & \\
\hline 5 & 1031 & 600.4 & 0.11 & 1.2 & 302 & $8 \%$ & 79 & - & 257 & 47 & 125 & \\
\hline 6 & 1036 & 603.9 & 0,15 & 1.6 & 300 & 87 & 80 & - & $24 / 3$ & 47 & 18 & \\
\hline Stop & 1041 & 502.235 & Gee & Cleak & clecek & $224 \%$ & & & & & & \\
\hline & & & & & & & & & & & & \\
\hline$E 51$ & 1113 & 602.821 & 0.03 & 0.33 & 298 & 82 & 80 & - & 212 & 32 & 5 & \\
\hline & 1118 & 609.6 & 0.02 & 0.22 & 309 & 82 & 81 & $=$ & 227 & 54 & $y$ & \\
\hline 31 & 1123 & 611.0 & 0.07 & 0,27 & $3 / 2$ & 83 & 81 & - & 25 & 52 & 8 & \\
\hline 4 & $j 128$ & 613.57 & 0,14 & 1.5 & $3 / 3$ & 87 & 83 & $=$ & 245 & 59 & 18 & \\
\hline 5 & 1133 & $6 / 6,7$ & 0.14 & 1.6 & $3 / 3$ & 85 & 83 & $=$ & 247 & 53 & 19 & \\
\hline 6 & $\angle 438$ & 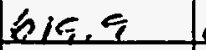 & 0.19 & 1.2 & 310 & 90 & 83 & - & $24 / 3$ & 55 & 22 & \\
\hline stap & $11<\sqrt{3}$ & 623.582 & & 600 & LEAK & 19 & $\mathrm{Ha}$ & & & & & \\
\hline & & & & & & & & & & & & \\
\hline & & & & & & & & & & & & \\
\hline & & & & & & & & & & & & \\
\hline & & & & & & & & & & & & \\
\hline & & & & & & & & & & & & \\
\hline Avg. & $-2 a$ & $140,00 \% 8 \%$ & 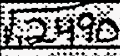 & 7392 & 899 & $\$$ & 87 & $8 \%$ & S. & $8 \%$ & & 0 \\
\hline Check'd & & $1 \% 4 \%$ & 88 & 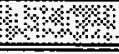 & 184 & $5 \%$ & ४ & $8 \%$ & +8 & & 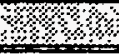 & \\
\hline
\end{tabular}

CONSOLE \# $16 / 363$

FILTER \# 250

AMBIENT TEMP.

PROBE LENGTH

LINER MATERIAL

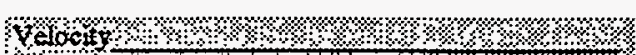

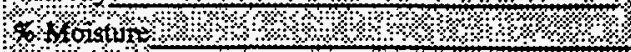

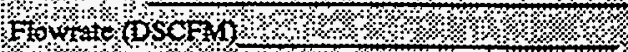

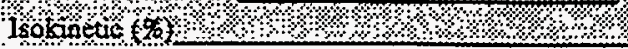

REMARKS 
Plant Name

Plant Yates Station Boiler No. 1

Sampling Location In In Let

Date 6 26/9? Time Start

Duct Dimensions

PTCF

Bar Press

Static Press
Train

Time Finish

$\mathrm{X}$ NOZZLE DIA. $\cdot \mathrm{Hg}$

" $\mathrm{H} 2 \mathrm{O}$

Particulate / Metals Run No.

Test Duration _

Initial Leak Rate _____ c c cm Final Leak Rate _ _ c cfm

\begin{tabular}{|c|c|c|c|c|c|c|c|c|c|c|c|c|}
\hline \multirow{2}{*}{\begin{tabular}{|c|} 
Travers \\
Point
\end{tabular}} & \multirow{2}{*}{$\begin{array}{l}\text { Clock } \\
\text { Time }\end{array}$} & \multirow{2}{*}{$\begin{array}{c}\text { Dry gas meter } \\
\text { reading ft3 }\end{array}$} & \multirow{2}{*}{$\begin{array}{c}\text { A } \\
\text { in } \mathrm{H} 2 \mathrm{O}\end{array}$} & \multirow{2}{*}{$\begin{array}{c}4 \mathrm{H} \\
\text { in } \mathrm{H} 2 \mathrm{O}\end{array}$} & \multirow{2}{*}{\begin{tabular}{|c|} 
Stack \\
Temp. F
\end{tabular}} & \multicolumn{2}{|c|}{ Dry gas meter temp. } & \multirow{2}{*}{$\begin{array}{c}\text { Hot box } \\
\text { Temp. }\end{array}$} & \multirow{2}{*}{\begin{tabular}{|l|} 
Probe \\
Temp
\end{tabular}} & \multirow{2}{*}{\begin{tabular}{|c|} 
Last \\
Impinger
\end{tabular}} & \multirow{2}{*}{$\begin{array}{l}\text { Vacuum } \\
\text { in. } \mathrm{Hg}\end{array}$} & \multirow[b]{2}{*}{ 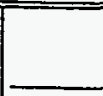 } \\
\hline & & & & & & Inlet & Outlet & & & & & \\
\hline$E \geq-1$ & Eq 1148 & 623.800 & 0.03 & 0.33 & 322 & 86 & 84 & - & 248 & 55 & 6.0 & \\
\hline 2 & 1153 & 1025.9 & 0.04 & 0.44 & 321 & 88 & 85 & - & 250 & 56 & 6.0 & \\
\hline 3 & 1158 & 67.6 & 0.07 & 0,77 & 323 & 90 & 86 & - & 251 & 55 & 9.0 & \\
\hline 4 & 1203 & 329.9 & 0.1 & 1.1 & 328 & 91 & 86 & $=$ & 249 & 54 & 12.0 & \\
\hline \multirow{2}{*}{$\begin{array}{l}5 \\
6 \\
\end{array}$} & 1208 & 632.6 & 0.14 & 81.5 & 332 & 93 & 87 & - & 247 & 53 & 20.0 & \\
\hline & 1213 & 635.9 & 0.18 & 84,5 & 335 & 94 & 87 & - & 245 & 53 & 220 & \\
\hline \multirow{2}{*}{ step } & 1218 & 639.164 & & ad lea & ared & $k e$ & "rM & & & & & \\
\hline & & & & & & & & & & & & \\
\hline \multirow{2}{*}{$\frac{(k b)-1}{2}$} & 1336 & 639.840 & 0.03 & 0.33 & 274 & 84 & 83 & - & 232 & 60 & 6 & \\
\hline & 134 & - & 0.04 & 0.44 & 299 & 84 & 83 & - & 246 & 49 & 7 & \\
\hline 3 & $134 / 6$ & $64 \sqrt{3} .3$ & 0.04 & octel & 293 & 85 & 84 & - & 241 & क) & 7 & \\
\hline \multirow{3}{*}{4} & 1357 & - & 0.08 & 0.88 & 255 & 87 & 89 & - & 253 & 47 & 12 & \\
\hline & 1352 & 647.7 & 0.12 & 1.3 & 256 & 88 & 84 & - & 249 & 47 & 18 & \\
\hline & 1401 & $65 \%$ & 0.15 & 1.5 & 295 & 91 & 85 & - & 244 & 57 & 22 & \\
\hline \multirow{2}{*}{ Stp } & 1406 & 654.580 & & & & 22 & Hs & & & & & \\
\hline & & & & & & & & & & & & \\
\hline$n<41$ & $1 / 22$ & 654,791 & 0.03 & 0.33 & 288 & 8 & 85 & $=$ & 217 & 63 & 6 & \\
\hline \multirow{2}{*}{2} & $1 / 27$ & 633.6 & 0.05 & 005 & 298 & 87 & 85 & $=$ & 253 & 5 & 8 & \\
\hline & $14 / 32$ & 638.6 & 0.06 & 0.66 & 296 & 88 & 85 & - & 244 & 45 & 10 & \\
\hline \multirow{3}{*}{$\begin{array}{l}4 \\
5 \\
6\end{array}$} & 1437 & 661.0 & 0.11 & 1,2 & 300 & \& & 86 & - & 245 & 48 & 18 & \\
\hline & 1442 & 6641 & 0.15 & 1.65 & 293 & 93 & 87 & - & $25 k 1$ & 51 & 22 & \\
\hline & 1447 & 667.3 & 0.11 & 1.2 & 280 & 95 & 91 & - & 243 & 52 & 18 & \\
\hline \multirow[t]{2}{*}{ sop } & 1452 & 670.100 & & & & $B$ & & & & & & \\
\hline & & & & & & & & & & & & \\
\hline \multirow{2}{*}{ 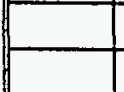 } & & & & & & & & 2 & & & & \\
\hline & & & & & & & & & & & & \\
\hline \multirow{2}{*}{+} & & & & & & & & & & & & \\
\hline & & & & & & & & & & & & \\
\hline Avg. & - & $\$$ & \%४\% & $\%$ & क\%: & $\$ 2$ & 83 & ? & ४० & $6 \%$ & 18 & 4,1 \\
\hline Check'd & & Hै। & \%? & 081 & ४४ & $4 \%$ & आ! & $1 \% 8$ & $8 \bullet$ & $16 \%$ & ४ & 101 \\
\hline
\end{tabular}

CONSOLE \#

FILTER \#

AMBIENT TEMP.

PROBE LENGTH

LINER MATERIAL
Velocty

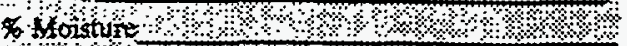

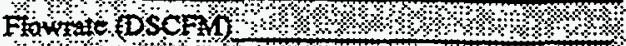
1 solontic $(\%)$.

REMARKS 


$$
\text { Page } 3 \text { of } 3
$$

Plant Name

Plant Yates Station Boiler No. 1

Sampling focation Intet

Date $62_{6}$ G Time Start

Duct Dintensions

PTCF DGMCF $\mathrm{X} \quad$ Time Finish

NOZZLE DIA. " $\mathrm{Hg}$

Bar Press

Static Press " $\mathrm{H2O}$
Particulate / Metals

Test Duration Initial Leak Rate Final Leak Rate inches

Operator Ju

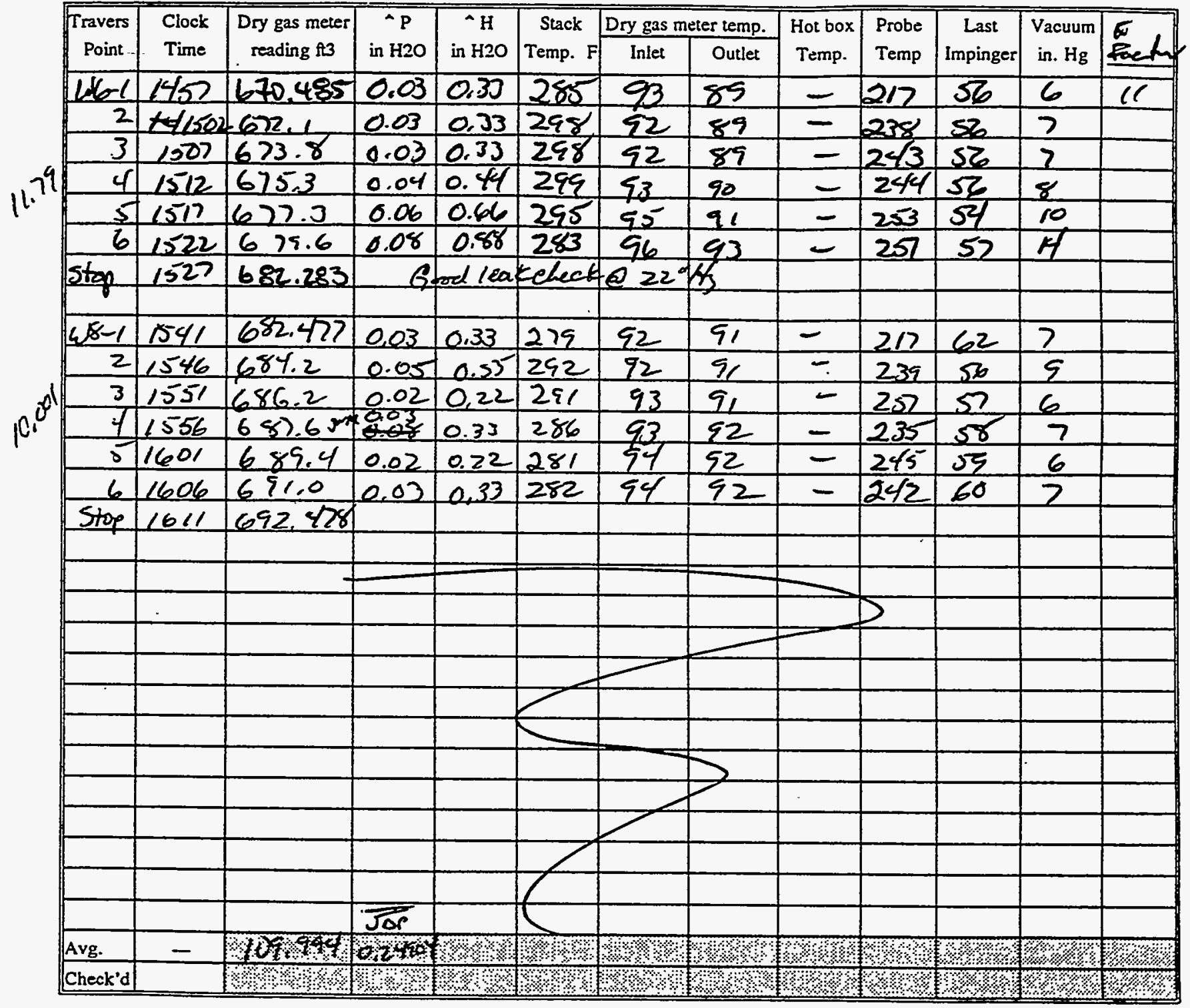

CONSOLE \#

FILTER \#

AMBIENT TEMP.

PROBE LENGTH

LINER MATERIAL

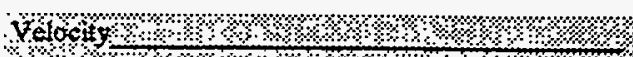

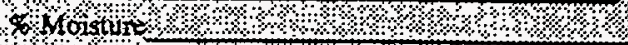

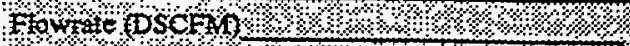

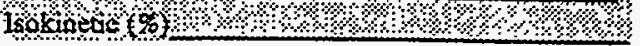

REMARKS 


$$
\text { Page } 1 \text { of } 3
$$

Plant Name

Plant Yates Station Boiler No. 1

Sampling focation INLeT

Date $6 / 27 / 93$ Time Start

Duct Dimensions $86^{\prime \prime} \times \frac{45}{49}$ Diameter Bar Press 2द. 4 " $\mathrm{Hg}$

Static Press $\frac{24,5}{2,5}$ H2O

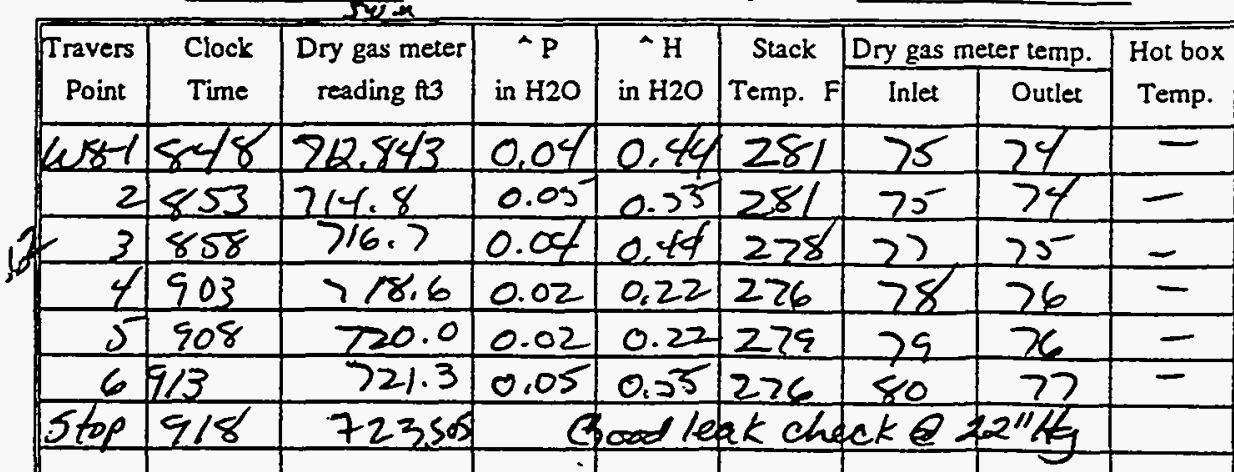

Operator SWm Train $\frac{\text { Particulate / Metals }}{1405}$ Run No.3/Phase 2 Initial Leak Rate $0.017 \mathrm{cfm} 024 \%$ Final Leak Rate 0.010 cim $23^{1}$ if

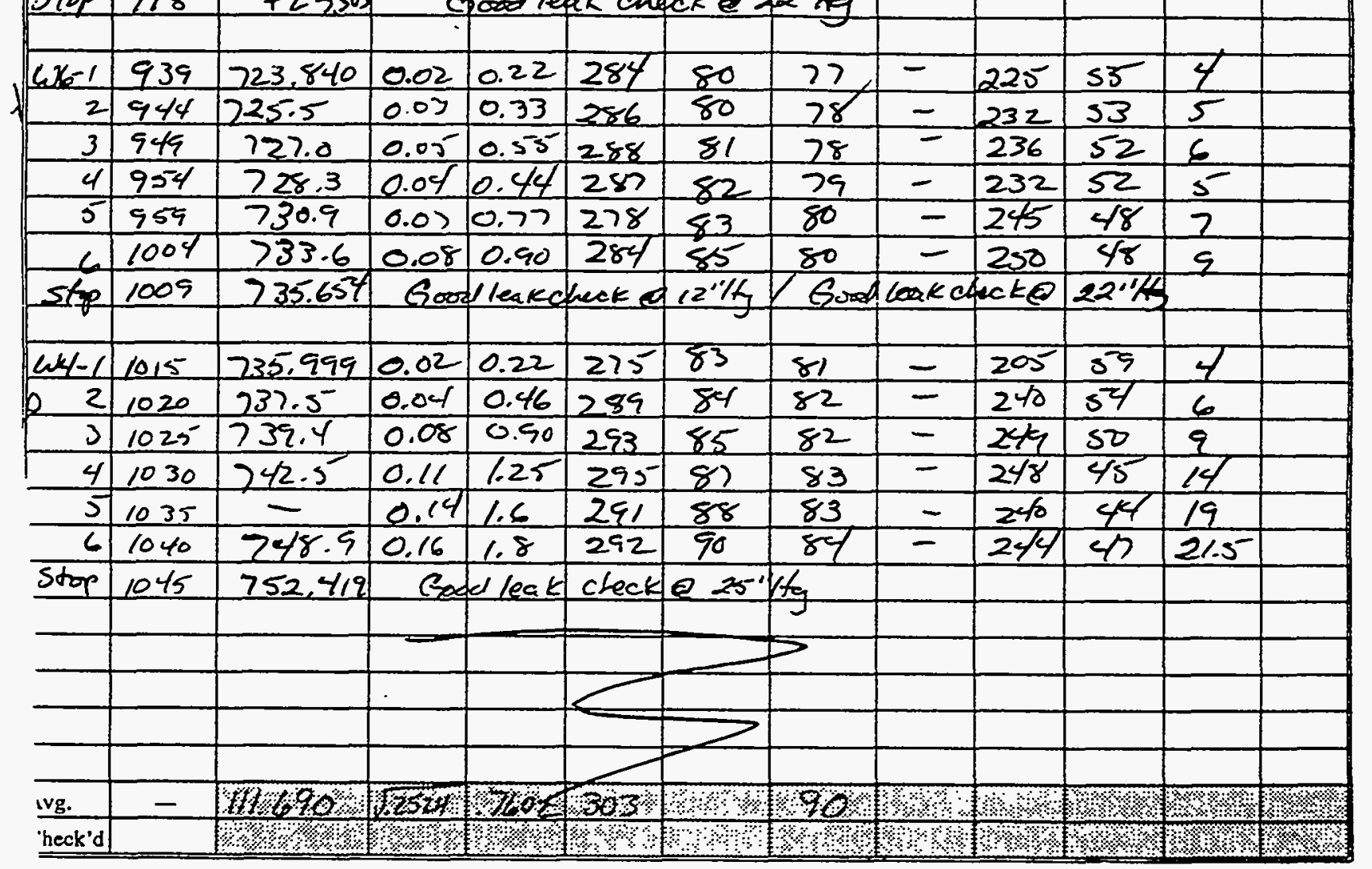

ONSOLE "A161363

ILTER \# 916 thimble

MBIENT TEMP. 80

ZOBE LENGTH 8 FF

NER MATERIAL_glass
Velocot

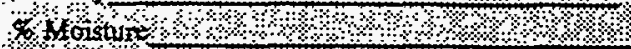

Ftowite D DCFW,

1robonede $6 \%$ \% $\$$

imarks Good Leak check of pitot tube thine (all Phase 2 pitots slines were, leak cheaked wherc applicable.)

AT END of RUN-Thimble becance dislodaed from l. alds. 


$$
\text { Page } 2 \text { of } 3
$$

Plant Name Plant Yates Station Boiler No. 1

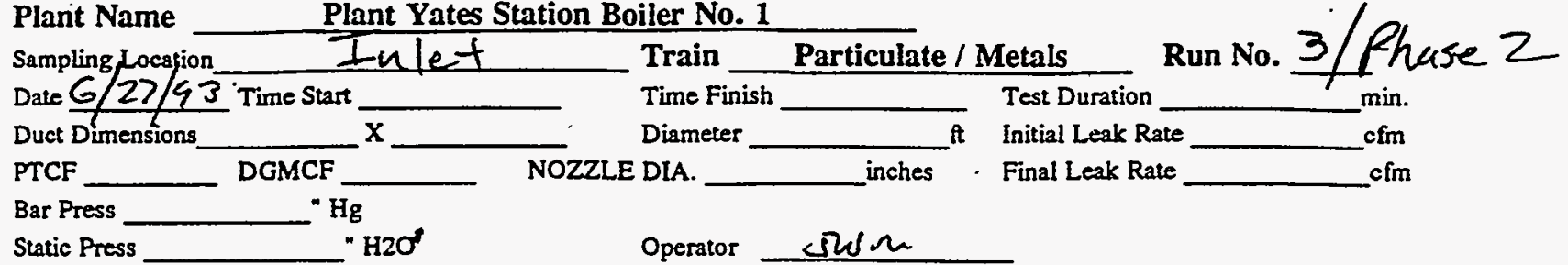

\begin{tabular}{|c|c|c|c|c|c|c|c|c|c|c|c|c|}
\hline \multirow{2}{*}{$\begin{array}{c}\text { Travers } \\
\text { Point }\end{array}$} & \multirow{2}{*}{$\begin{array}{l}\text { Clock } \\
\text { Time }\end{array}$} & \multirow{2}{*}{$\begin{array}{c}\text { Dry gas meter } \\
\text { reading ft } 3\end{array}$} & \multirow{2}{*}{$\begin{array}{c}{ }^{\wedge} \mathrm{P} \\
\text { in } \mathrm{H} 2 \mathrm{O}\end{array}$} & \multirow{2}{*}{$\begin{array}{c}{ }^{4} \mathrm{H} \\
\text { in } \mathrm{H} 2 \mathrm{O}\end{array}$} & \multirow{2}{*}{\begin{tabular}{|c|} 
Stack \\
Temp. F
\end{tabular}} & \multicolumn{2}{|c|}{ Dry gas meter temp. } & \multirow{2}{*}{$\begin{array}{c}\text { Hot box } \\
\text { Temp. }\end{array}$} & \multirow{2}{*}{$\begin{array}{l}\text { Probe } \\
\text { Temp }\end{array}$} & \multirow{2}{*}{\begin{tabular}{|c|} 
Last \\
Impinger
\end{tabular}} & \multirow{2}{*}{$\begin{array}{l}\text { Vacuum } \\
\text { in. } \mathrm{Hg}\end{array}$} & \multirow{2}{*}{ Ketert } \\
\hline & & & & & & Inlet & Outlet & & & & & \\
\hline$w^{2}-1$ & 1049 & 732.642 & 0.02 & 0.22 & 285 & 87 & 84 & $=$ & 204 & 60 & 4 & \\
\hline 2 & 1054 & $75 \% 1$ & 0.03 & 0.33 & 298 & 87 & 84 & - & 221 & 53 & 5 & \\
\hline 3 & 1055 & 753,7 & 0.04 & 0.44 & 307 & 88 & 85 & - & 243 & 53 & 6 & \\
\hline 4 & 1104 & 757.7 & 0.09 & 0.99 & 299 & 85 & 86 & - & 257 & 49 & 11 & 11,06 \\
\hline 5 & 1109 & $760-2$ & 0.14 & 2.53 & 302 & 91 & 87 & $=$ & 241 & 47 & 19 & \\
\hline 6 & $+2+1114$ & 763.9 & 0.15 & 1.7 & 301 & 44 & 88 & - & & 50 & 22 & \\
\hline stop & 1119 & 767.291 & Gd & ped at & $22 \%$ & Lea & shak & & \multicolumn{3}{|c|}{ linitial leakcheck } & \\
\hline$E \geq-1$ & 1148 & 768450 & 0.03 & 0.33 & 317 & 85 & 87 & - & 216 & 65 & 6 & $4,+2$ \\
\hline 2 & 1153 & 770.2 & 0.04 & 0,44 & 322 & 89 & 87 & $\dot{-}$ & 240 & 55 & 7 & \\
\hline 3 & 1158 & 272.0 & 0.06 & 0.66 & 328 & 90 & 87 & - & 242 & 52 & 8 & \\
\hline 4 & 1203 & 234.3 & 0.09 & 1.0 & 330 & 51 & 88 & $=$ & 244 & 57 & 12 & \\
\hline 5 & 1208 & 727.0 & 0,28 & 1.6 & 333 & 93 & 89 & $=$ & $24 / 2$ & 54 & 22 & \\
\hline 6 & 1213 & 780.6 & 0.19 & 1.6 & 336 & 95 & 50 & - & & 57 & 22 & \\
\hline Stop & 1218 & 783,812 & & \multicolumn{2}{|c|}{ Food leakched } & & 16 & 0.01 & \multicolumn{2}{|c|}{$(A 3 / \mathrm{ain})$} & & \\
\hline $3-1$ & 1225 & 784.027 & 0.02 & 0.22 & 316 & 92 & 50 & - & 222 & 67 & 5 & \\
\hline 2 & 1230 & 785.6 & 0.04 & 0,45 & 322 & 92 & 89 & $=$ & 247 & 60 & 7 & \\
\hline 3 & 1235 & 787.4 & 0.07 & 0.77 & 321 & 52 & 50 & - & 248 & 57 & 11 & \\
\hline 4) & $12 \% 0$ & 790.0 & 0.11 & 1.25 & 321 & 92 & 91 & - & 250 & 58 & 18 & \\
\hline 37 & $124 / 5$ & 792.5 & 0.14 & 1.55 & 322 & 96 & 92 & - & 251 & 59 & 21 & \\
\hline 6 & 1250 & 796,6 & 0.16 & 1.4 & 322 & 97 & 92 & $=$ & 245 & 63 & 22 & \\
\hline top & 1255 & 799.342 & & & & & & & & & & \\
\hline & & & 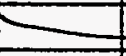 & & & & & & & & & \\
\hline & & & & & & & & & & $S$ & & \\
\hline & & & & & & & & & & & & \\
\hline & & & & 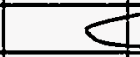 & & & & & & & & \\
\hline & & & 500 & & & & 3 & & & & & \\
\hline . & - & 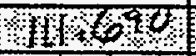 & 0.25 & $3 \% \%$ & ४ং & Æै। & \%४ & 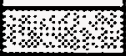 & $\% \%$ & 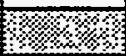 & 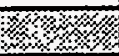 & t) \\
\hline k'd & & ४०० & ४९७ & 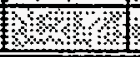 & $1 \% 8 \%$ & 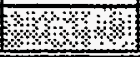 & ४४\% & $1 \% 1 \%$ & \% & 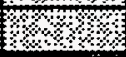 & $128 \%$ & \%ะ/ \\
\hline
\end{tabular}

SOLE \#

ER \#

IENT TEMP.

3E LENGTH

R MATERIAL

IRKS
Yeloch $1 \% \% \%, \%$ \%

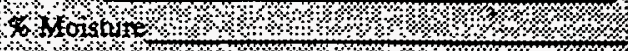

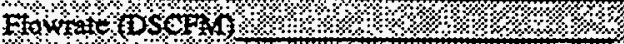

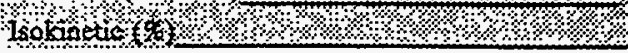


SOLRCE SAHPLING FIELD DATA SHEET

Page 3 of 3

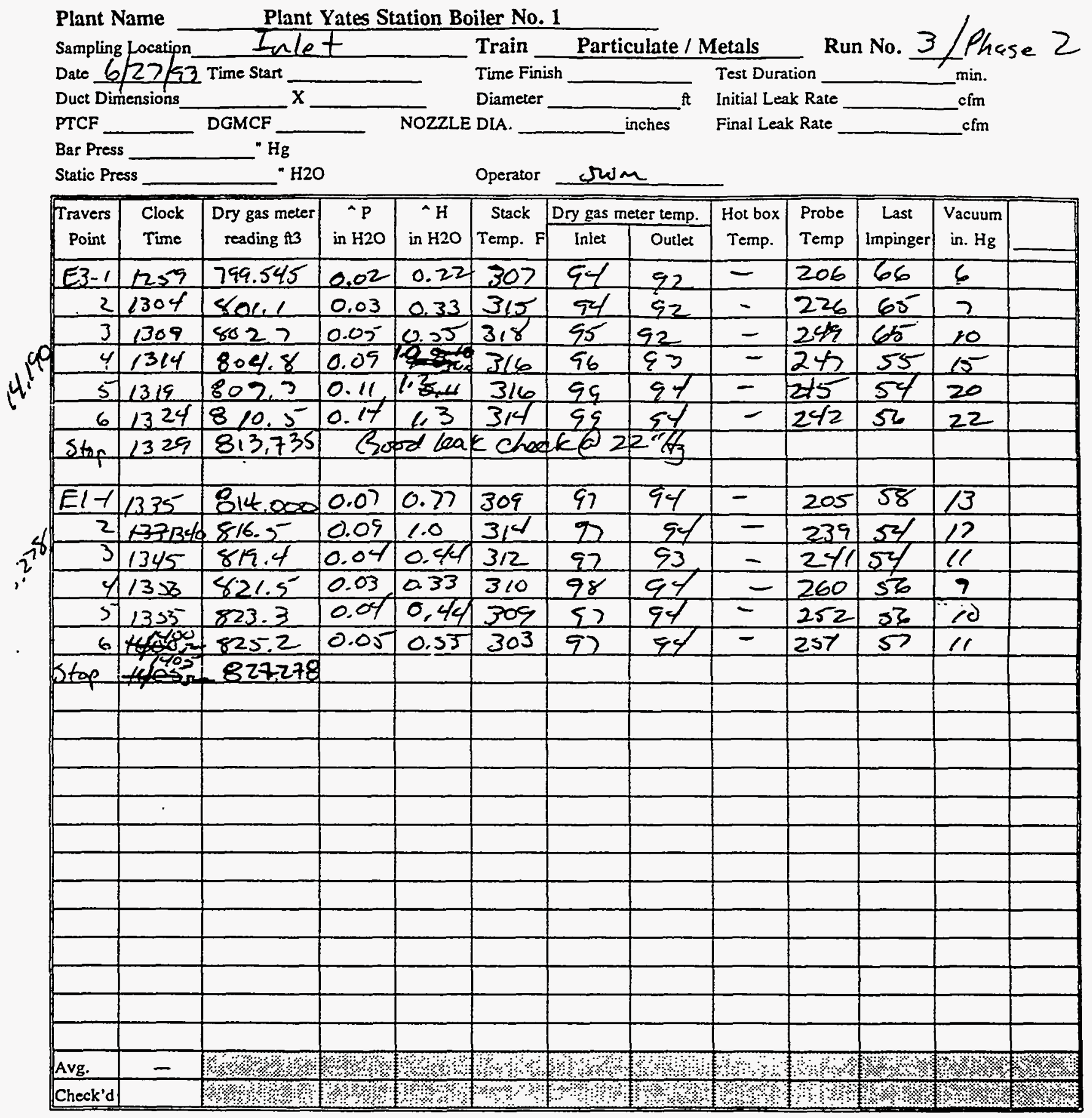

CONSOLE \#

FILTER \#

AMBIENT TEMP.

PROBE LENGTH

LINER MATERIAL
Velocif

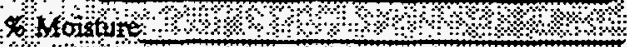

Ftawate (DSCFN) $\mathrm{OH} / \%$

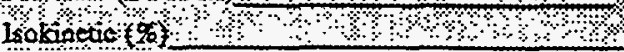


SOLRCE SAMPEING FIELD DATA SHEET

Page $\perp_{\text {of }}$

Plant Name $\quad$ Plant Yates Station Boiler No. 1

Sampling Location Inlet

Date $24 \mathrm{Jun} 93$ Time Start _L206 Time Finish

Duct Dimensions

PTCF

Bar Press

Static Press _ $\mathrm{H2O}$
Train Particulate / Metals

Time Finish NOZZLE DIA. $0, \overline{358}$ inches DGMCF

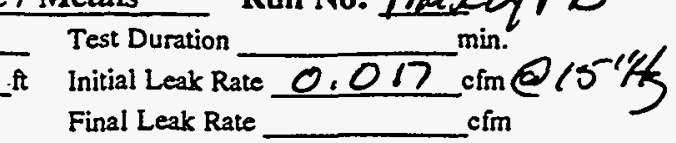

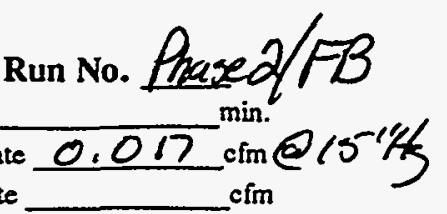

\begin{tabular}{|c|c|c|c|c|c|c|c|c|c|c|c|c|}
\hline Travers & Clock & Dry gas meter & ${ }^{\wedge} P$ & ${ }^{\wedge} \mathrm{H}$ & Stack D & Dry gas me & ter temp. & Hot box & Poobe & Last & Vacuum & \\
\hline Point & Time & reading $\mathrm{f} 3$ & in $\mathrm{H} 2 \mathrm{O}$ & in $\mathrm{H} 2 \mathrm{O}$ & Temp. F & Inlet & Outlet & Temp. & Temp & Impinger & in. $\mathrm{Hg}$ & \\
\hline & 1206 & 426,55 & & & & & & & & & & \\
\hline & 1211 & $4 / 26.845$ & & & & & & & & & & \\
\hline & & & & & & & & & & & & \\
\hline & & & & & & & & & & & & \\
\hline & & & & & & & & & & & & \\
\hline & & & & & & & & & & & & \\
\hline & & & & & & & & & & & & \\
\hline & & & & & & & & & & & & \\
\hline & & & & & & & & & & & & \\
\hline & & & & & & & & & & & & \\
\hline & & & & & & & & & & & & \\
\hline & & & & & & & & & & & & \\
\hline & & & & & & & & & & & & \\
\hline & & & & & & & & & & & & \\
\hline & & & & & & & & & & & & \\
\hline & & & & & & & & & & & & \\
\hline & & & & & & & & & & & & \\
\hline & & & & & & & & & & & & \\
\hline & & & & & & & & & & & & \\
\hline & & & & & & & & & & & & \\
\hline & & & & & & & & & & & & \\
\hline & & & & & & & & & & & & \\
\hline & & & & & & & & & & & & \\
\hline & & & & & & & & & & & & \\
\hline & & & & & & & & & & & & \\
\hline & & & & & & & & & & & & \\
\hline & & & & & & & & & & & & \\
\hline & & & & & & & & & & & & \\
\hline Avg. & $=$ & $18 \%$ & $8 \% \%$ & $8 \%$ & $\%$ & $8 \times$ & $8 \% 8 \%$ & 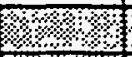 & $3 \%$ & $8 \%$ & 88 & $8 \%$ \\
\hline Check'd & & $10 \%$ & $6 \%$ & 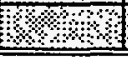 & 8 & 830 & 184 & $1 \% 8 \%$ & $\$$ & $2 x$ & & (s) \\
\hline
\end{tabular}

operator Jum

console H Quotz A161863

FILTER \# 1254

AMBIENT TEMP. 85

PROBE LENGTH 8

LINER MATERIAL Quartz

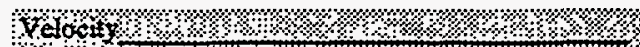

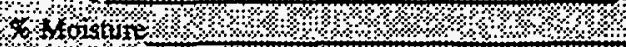

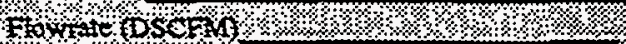

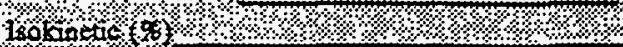

REMARKS

C-186 


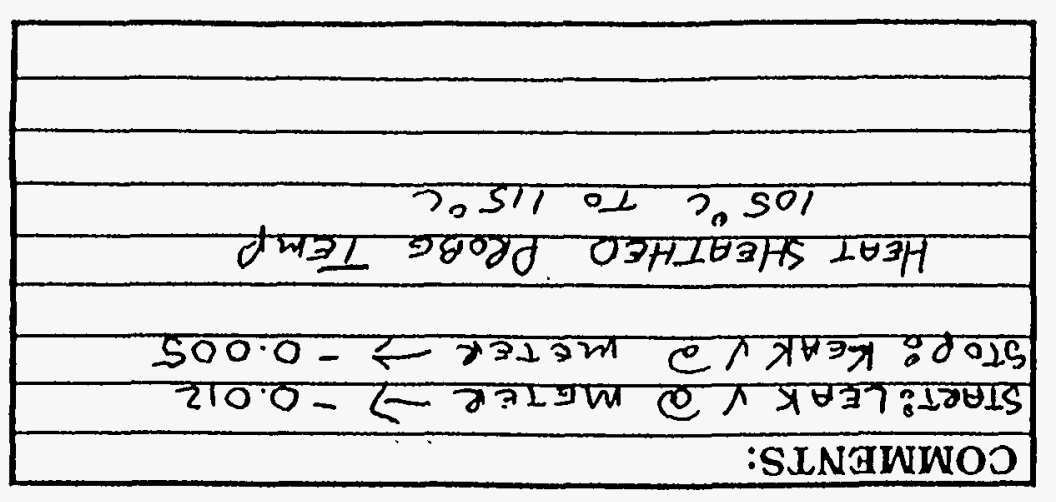

\begin{tabular}{|c|c|c|}
\hline & णवन वा ण्डा & $\overline{z^{2} \text { OS udd }}$ \\
\hline & $a^{\prime} t$ & $: \mathrm{O}_{\mathrm{H}}^{\tau_{\mathrm{H}}}$ \\
\hline & 001 & $:{ }^{2} 00 \%$ \\
\hline & वप्र & $::_{0}^{2} \%$ \\
\hline \multicolumn{3}{|c|}{ 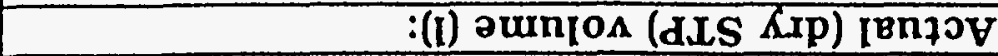 } \\
\hline \multicolumn{3}{|c|}{ :UOI702.IOD MOLH SSEW ${ }^{2}$ OD } \\
\hline \multicolumn{3}{|c|}{ 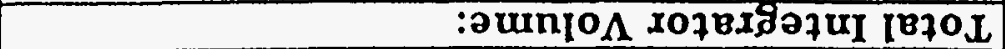 } \\
\hline \multicolumn{3}{|c|}{$:(\mathrm{l})$ uoj702x100 725110 } \\
\hline 0.001 & :(I) aumno & 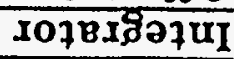 \\
\hline
\end{tabular}

\begin{tabular}{|c|c|c|c|c|c|c|c|c|}
\hline उवपह व & $5800.0-$ & $5 \varepsilon 2$ & \multicolumn{6}{|c|}{ :STVIOL } \\
\hline & & & & & & & & \\
\hline & & & & & & & & \\
\hline & & & & & & & & \\
\hline & & & & & & & & \\
\hline & & & & & & & & \\
\hline & & & & & & & & \\
\hline sqव्ठ० 0 & $58000-$ & डर2 क्र & $\varepsilon t 20$ & $5000-$ & 0011 & 0050 & $210 \%$ & SबसO \\
\hline $\begin{array}{c}\text { (ụ̂u/l) } \\
\text { suolf }\end{array}$ & $\begin{array}{c}\text { (u!̣u/l) } \\
\text { oIวz }\end{array}$ & $\begin{array}{l}\text { (utur) } \\
\text { วưry }\end{array}$ & 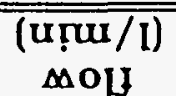 & $\begin{array}{c}(\mathrm{u} ! u \mathrm{u} / \mathrm{I}) \\
01 \partial z\end{array}$ & $\begin{array}{c}\text { (ưur:yч) } \\
\text { วux!7 }\end{array}$ & $\begin{array}{c}\text { (uruur / I) } \\
\text { suolf }\end{array}$ & $\begin{array}{c}\text { (u!u } / \text { I) } \\
0.1 \partial z\end{array}$ & $\begin{array}{c}\text { (ưu: } \\
\text { วư) }\end{array}$ \\
\hline urвวน & uвว & pasdera & & do7s & & & $7 \times 875$ & \\
\hline
\end{tabular}

\begin{tabular}{|c|c|}
\hline 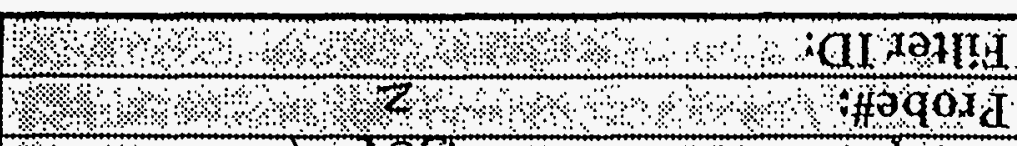 & 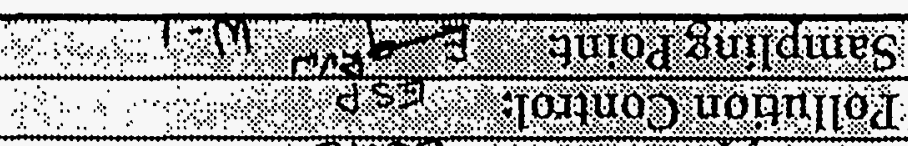 \\
\hline 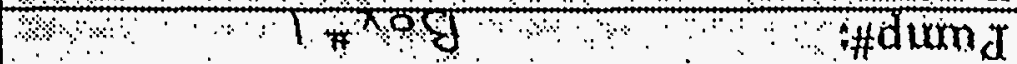 & 7160? \\
\hline 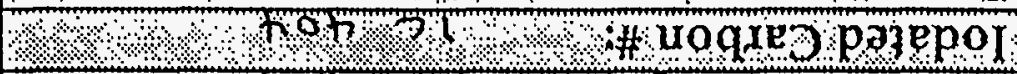 & $4: 1485+32=9 \%$ \\
\hline ४ ४४ & 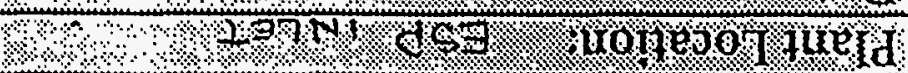 \\
\hline ॠ & 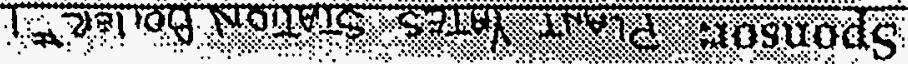 \\
\hline
\end{tabular}

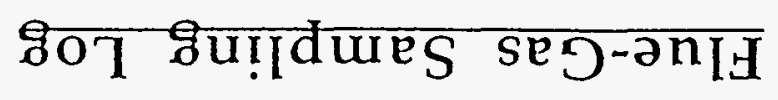




\begin{tabular}{|c|c|}
\hline Sponoriv: & 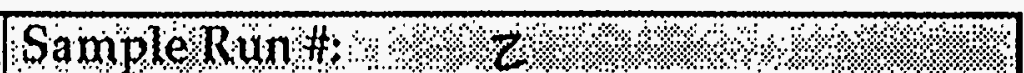 \\
\hline Prant Lacalon & 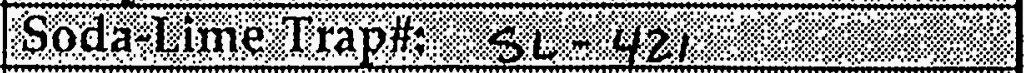 \\
\hline 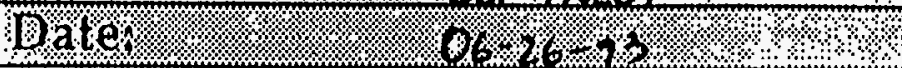 & lodared Carbon tt: $T 20$. \\
\hline 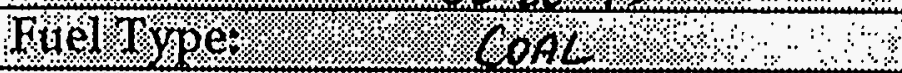 & PuiripH \\
\hline 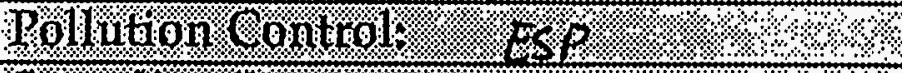 & 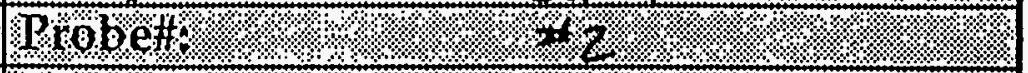 \\
\hline 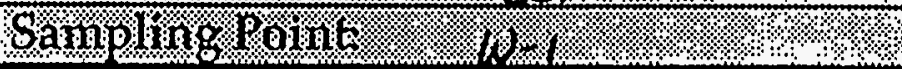 & Fiter IO \\
\hline
\end{tabular}

\begin{tabular}{|c|c|c|c|c|c|c|c|c|}
\hline \multicolumn{3}{|c|}{ start } & \multicolumn{3}{|c|}{ stop } & \multirow{2}{*}{$\begin{array}{c}\text { elapsed } \\
\text { time } \\
\text { (min) } \\
\end{array}$} & \multirow{2}{*}{$\begin{array}{c}\text { mean } \\
\text { zero } \\
(1 / \text { min }) \\
\end{array}$} & \multirow{2}{*}{$\begin{array}{c}\text { mean } \\
\text { flow } \\
(1 / \mathrm{min})\end{array}$} \\
\hline $\begin{array}{c}\text { time } \\
\text { (hh:mm) }\end{array}$ & $\begin{array}{c}\text { zero } \\
(1 / \mathrm{min}) \\
\end{array}$ & $\begin{array}{c}\text { flow } \\
(1 / \mathrm{min}) \\
\end{array}$ & $\begin{array}{c}\text { time } \\
(\mathrm{hh}: \mathrm{mm})\end{array}$ & $\begin{array}{c}\text { zero } \\
(1 / \mathrm{min}) \\
\end{array}$ & $\begin{array}{c}\text { flow } \\
(1 / \mathrm{min})\end{array}$ & & & \\
\hline 1045 & -0.003 & 0.500 & 3121512 & -0.006 & 0.242 & 267 & & \\
\hline & & & & & & & & \\
\hline & & & & & & & & \\
\hline & & & & & & & & \\
\hline & & & & & & & & \\
\hline & & & & & & & & \\
\hline & & & & & & & & \\
\hline & & & & & OTALS: & & & \\
\hline
\end{tabular}

Integrator Volume (1): Offset Correction (1):

Total Integrator Volume:

$\mathrm{CO}_{2}$ Mass Flow Correction:

Actual (dry STP) volume (1):

$\% \mathrm{O}_{2}$ :

$\% \mathrm{CO}_{2}$ :

$\% \mathrm{H}_{2} \mathrm{O}$ :

ppm $\mathrm{SO}_{2}$ :
100.0

B.O

10.0

7.0

$1500 T_{0} z 000$

\begin{tabular}{|c|}
\hline COMMENTS: \\
\hline START:LEAKV@ METER - 0.006 \\
\hline STOP:LEAKV@ METER-0.008 \\
\hline HEAT SHEATHED PROBE TEMP \\
\hline $105^{\circ} \mathrm{C}$ To $115^{\circ} \mathrm{C}$ \\
\hline \\
\hline \\
\hline \\
\hline
\end{tabular}




\section{Flue-Gas Sampling Log}

\begin{tabular}{|c|c|}
\hline Soonson: & 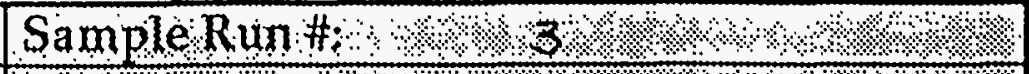 \\
\hline 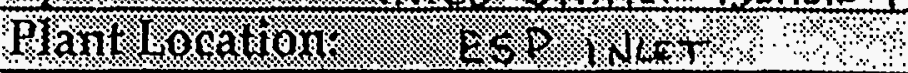 & Soda-Line Trapts 8.64 \\
\hline Oater & 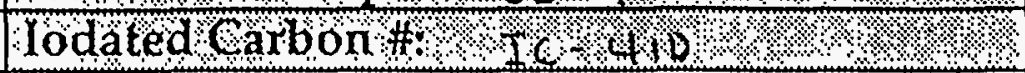 \\
\hline $1.200 \%$ & $\mathrm{Pu}$ \\
\hline 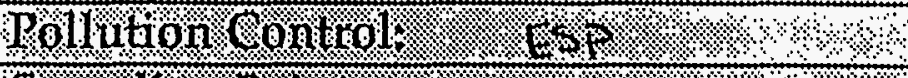 & 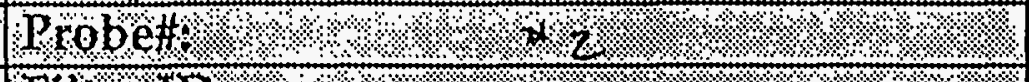 \\
\hline$t_{*}$ & \\
\hline
\end{tabular}

\begin{tabular}{|c|c|c|c|c|c|c|c|c|}
\hline \multicolumn{3}{|c|}{ start } & \multicolumn{3}{|c|}{ stop } & \multirow{2}{*}{$\begin{array}{c}\text { elapsed } \\
\text { time } \\
\text { (min) } \\
\end{array}$} & \multirow{2}{*}{$\begin{array}{c}\text { mean } \\
\text { zero } \\
(1 / \mathrm{min}) \\
\end{array}$} & \multirow{2}{*}{$\begin{array}{c}\text { mean } \\
\text { flow } \\
(1 / \mathrm{min})\end{array}$} \\
\hline $\begin{array}{c}\text { time } \\
\text { (hh:mm) }\end{array}$ & $\begin{array}{c}\text { zero } \\
(1 / \mathrm{min})\end{array}$ & $\begin{array}{c}\text { flow } \\
(1 / \mathrm{min})\end{array}$ & $\begin{array}{c}\text { time } \\
(\mathrm{hh}: \mathrm{mm})\end{array}$ & $\begin{array}{c}\text { zero } \\
(1 / \mathrm{min})\end{array}$ & $\begin{array}{c}\text { flow } \\
(1 / \min )\end{array}$ & & & \\
\hline 0715 & -0.006 & 0.500 & 1145 & 0.265 & 0.265 & 270 & 0.3 .8 .000 & 0.3825 \\
\hline & & & & $R V W$ & & & Ruin & \\
\hline & & & & & & & & \\
\hline & & & & & & & & \\
\hline & & & & & & & & \\
\hline & & & & & & & & \\
\hline & & & & & & & & \\
\hline & & & & & OTALS: & & & \\
\hline
\end{tabular}

\begin{tabular}{|c|}
\hline Integrator Volume (1): \\
\hline Offset Correction (1): \\
\hline Total Integrator Volume: \\
\hline $\mathrm{CO}_{2}$ Mass Flow Correction: \\
\hline Actual (dry STP) volume (1): \\
\hline$\% \mathrm{O}_{2}:$ \\
\hline$\% \mathrm{CO}_{2}$ \\
\hline$\% \mathrm{H}_{2} \mathrm{O}:$ \\
\hline 1500702000 \\
\hline
\end{tabular}

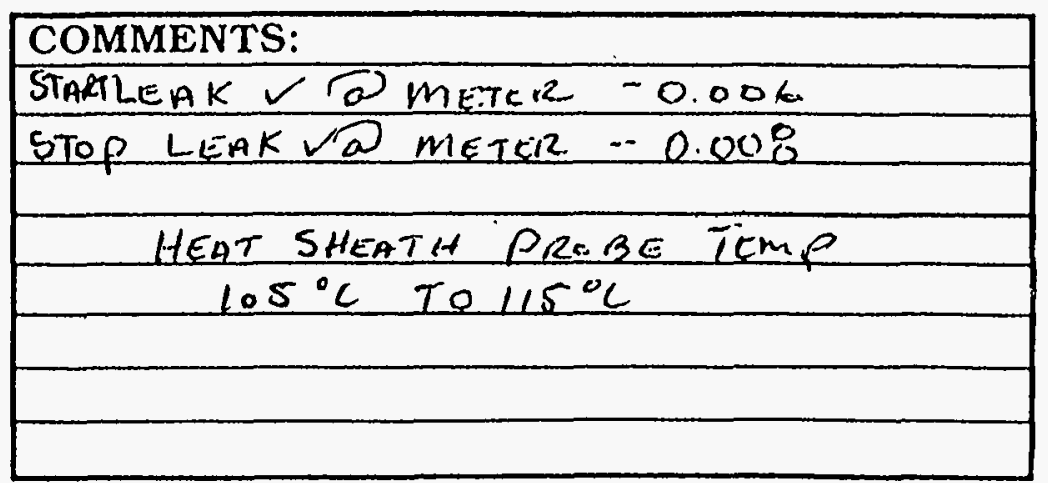




\section{Flue-Gas Sampling Log}

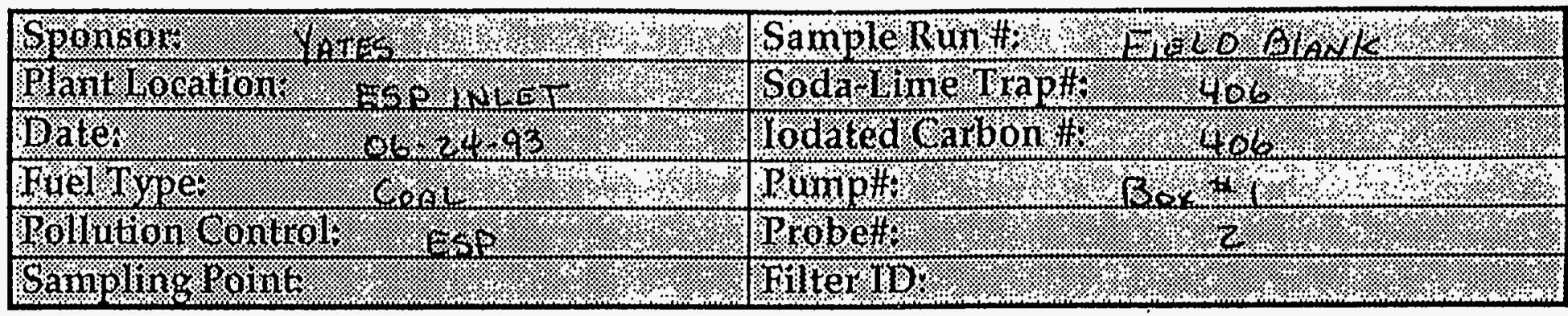

\begin{tabular}{|c|c|c|c|c|c|c|c|c|}
\hline \multicolumn{3}{|c|}{ start } & \multicolumn{3}{|c|}{ stop } & \multirow{2}{*}{$\begin{array}{c}\text { elapsed } \\
\text { time } \\
\text { (min) }\end{array}$} & \multirow{2}{*}{$\begin{array}{c}\text { mean } \\
\text { zero } \\
(1 / \mathrm{min})\end{array}$} & \multirow{2}{*}{$\begin{array}{c}\text { mean } \\
\text { flow } \\
(1 / \text { min) }\end{array}$} \\
\hline $\begin{array}{c}\text { time } \\
\text { (hh:mm) }\end{array}$ & $\begin{array}{c}\text { zero } \\
(1 / \mathrm{min})\end{array}$ & $\begin{array}{c}\text { flow } \\
(1 / \mathrm{min})\end{array}$ & $\begin{array}{c}\text { time } \\
\text { (hh:mm) }\end{array}$ & $\begin{array}{c}\text { zero } \\
(1 / \mathrm{min})\end{array}$ & $\begin{array}{c}\text { flow } \\
(1 / \mathrm{min})\end{array}$ & & & \\
\hline 1200 & -0.011 & 0.50 & 1210 & -0.011 & 0.500 & & & \\
\hline & & & & & & & & \\
\hline & & & & & & & & \\
\hline & & & & & & & & \\
\hline & & & & & & & & \\
\hline & & & & & & & & \\
\hline & & & & & & & & \\
\hline & & & & & TOTALS: & & & \\
\hline
\end{tabular}

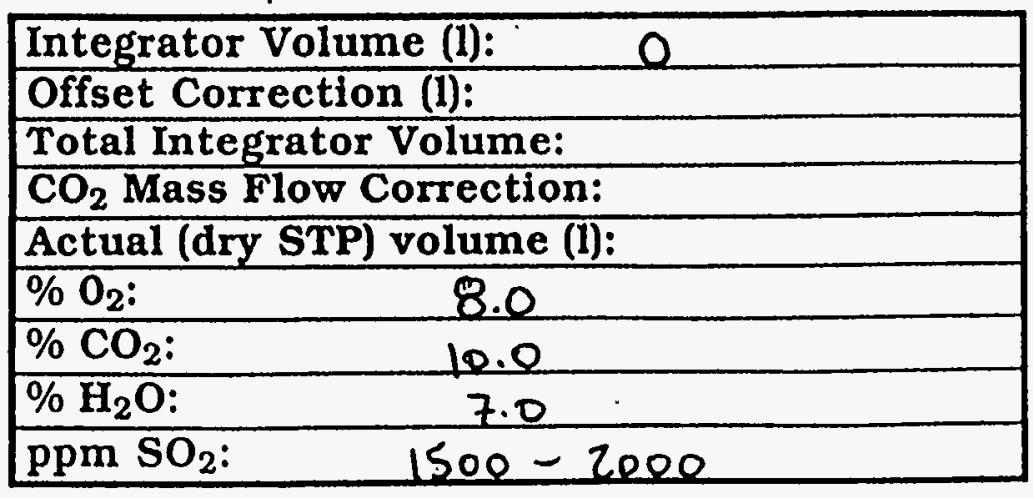

\begin{tabular}{|c|}
\hline COMMENTS: \\
\hline LEAK $\vee Q$ METER $\rightarrow-0.011$ \\
\hline HEAT SHEATHER PROBE TEMP \\
\hline COS ${ }^{\circ} \mathrm{C}$ \\
\hline \\
\hline \\
\hline
\end{tabular}




$$
\text { Page } f \text { of } 1
$$

Plant Name

Plant Yates Station Boiler No. 1

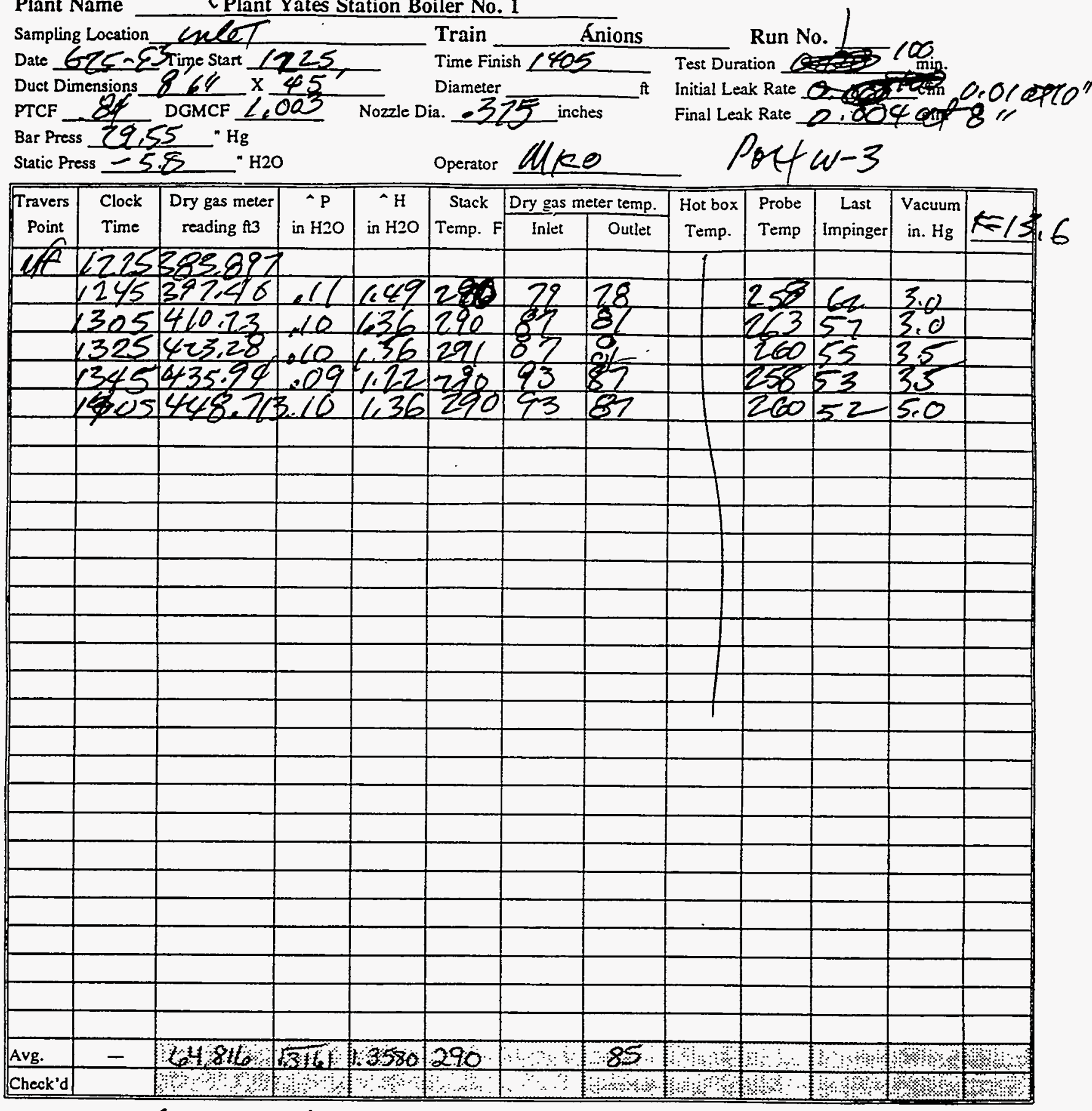

CONSOLE" A 664404

FILTER \# 1229

AMBIENT TEMP. 98

PROBE LENGTH CO

LINER MATERIAL ST
Veloct

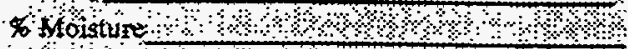

Faviate (DSCFin

lokintio fot :

REMARKS 

Plant Yates Station Boiler No. 1

ANisns

Train Run No.

Sampling Location lecte

Date 6-26943Time Star 1108

Duct Dimensions \&!6 $\times 457$

Duct Dimensions 86 Diameter

PTCF $\_84$ DGMCF $\angle \overline{003}$ Nozzle Dia. 1375 inches

Bar Press $2 \varepsilon: 50$ " $\mathrm{Hg}$

Static Press $58^{\circ} " \mathrm{H} 2 \mathrm{O}$

Operator

Hit
Test Duration ___ $65 \mathrm{Smin}$.

it Initial Leak Rate $0.00 \%$ cice $/ 0 \%$

Final Leak Rate 0 eco $\mathrm{cfm}$

at 84

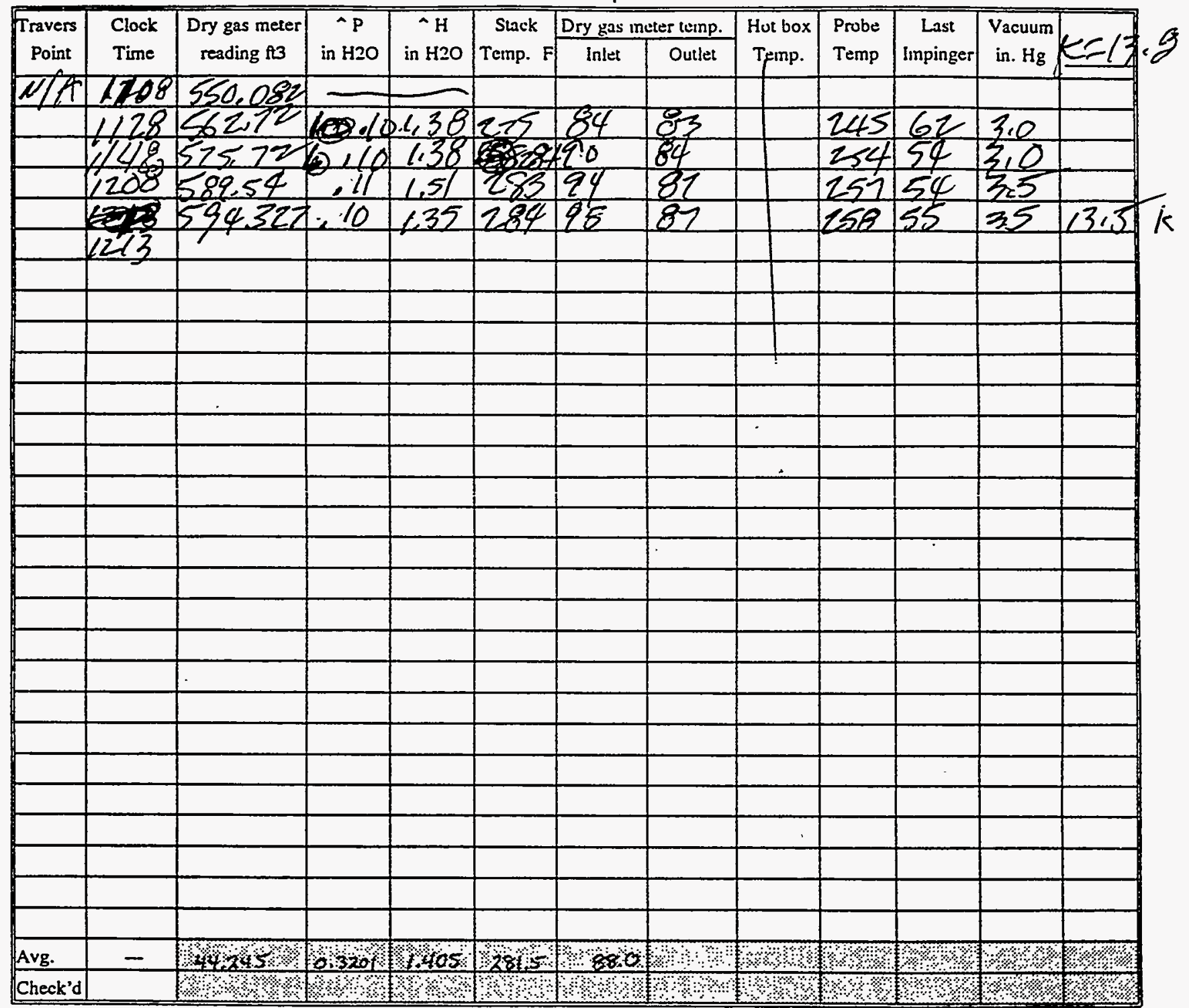

CONSOLE \# A $/ 6 \% 401$

THIMBLE \# $\# 1232$

AMBIENT TEMP. \C

PROBE LENGTH

LINER MATERIAL SltSS

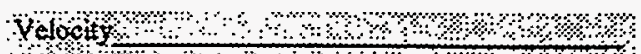

\% Moistur

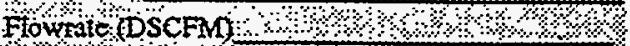

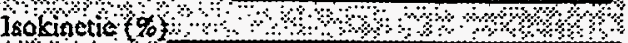

REMARKS

C-192 


$$
\text { Page _ of _ }
$$

Plant Name

Plant Yates Station Boiler No. 1

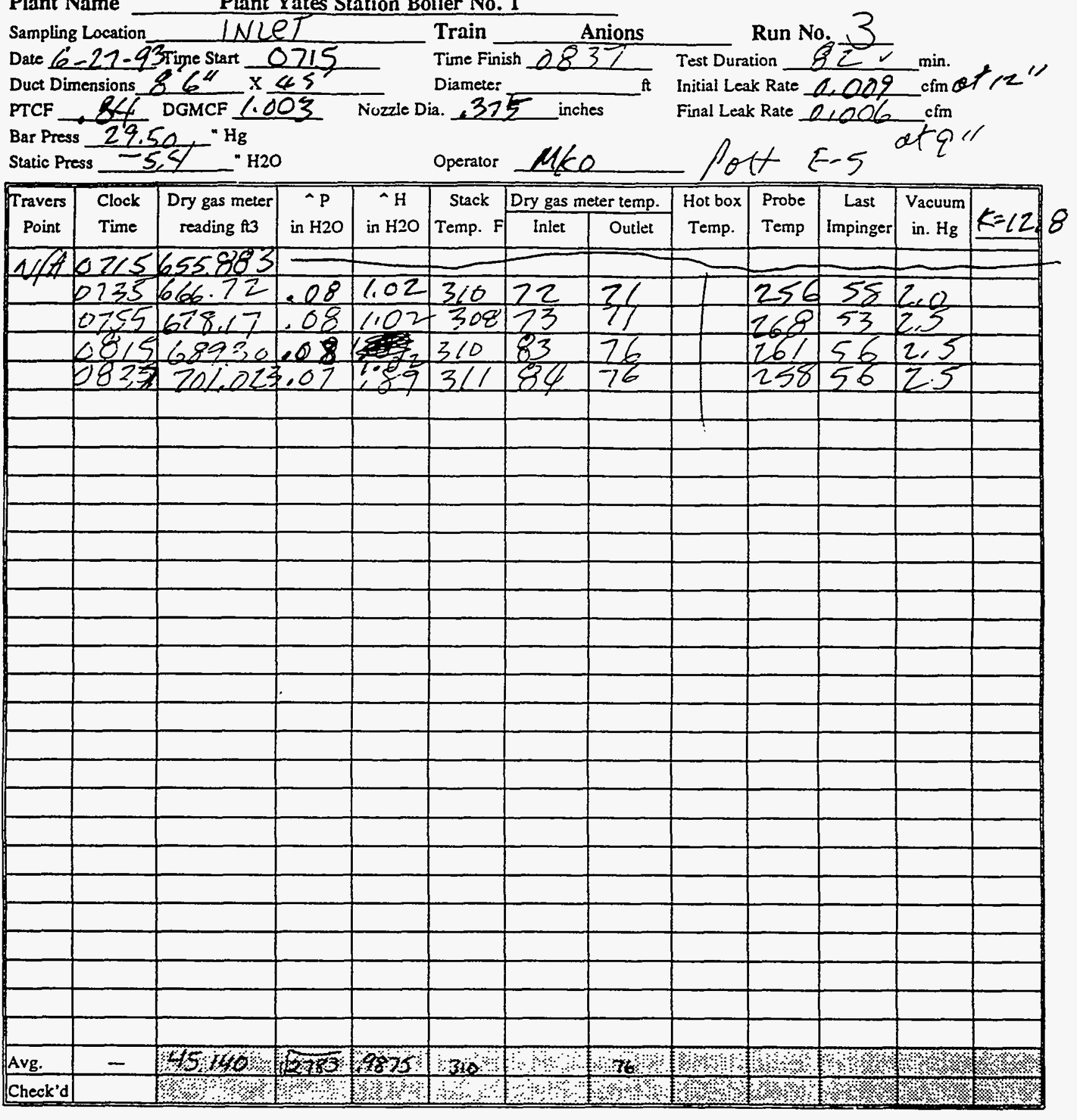

CONSOLE \#_A $A 61401$

FILTER \# -

AMBIENT TEMP.

PROBE LENGTH 107

LINER MATERIAL $\frac{5 / 455}{5 / 4}$
Fof

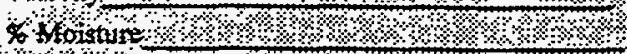

Fow

Isokstetofto 
SOLRCE SAMPLISG FIELD DATA SHEET

$$
\text { Page } 1 \text { of }
$$

Plant Name Plant Yates Station Boiler No. 1

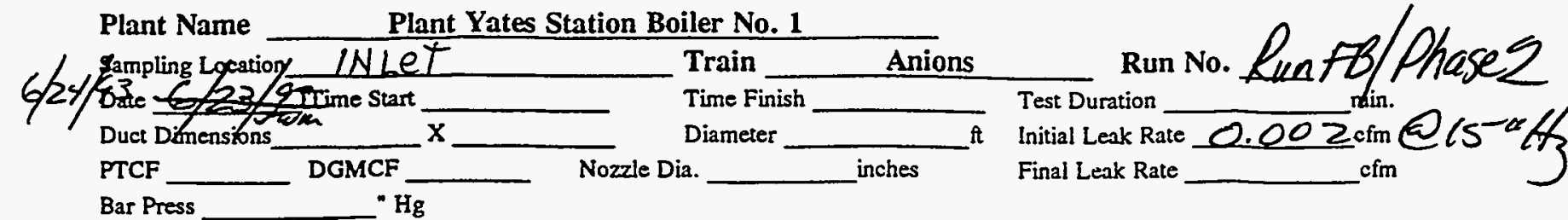

Bar Press
Static Press

\begin{tabular}{|c|c|c|c|c|c|c|c|c|c|c|c|c|}
\hline \multirow{2}{*}{$\begin{array}{l}\text { Travers } \\
\text { Point }\end{array}$} & \multirow{2}{*}{$\begin{array}{l}\text { Clock } \\
\text { Time }\end{array}$} & \multirow{2}{*}{$\begin{array}{c}\text { Dry gas meter } \\
\text { reading ft3 }\end{array}$} & \multirow{2}{*}{$\begin{array}{c}-P \\
\text { in } \mathrm{H} 2 \mathrm{O}\end{array}$} & \multirow{2}{*}{$\begin{array}{c}-\mathrm{H} \\
\text { in } \mathrm{H} 2 \mathrm{O}\end{array}$} & \multirow{2}{*}{$\begin{array}{c}\text { Stack } \\
\text { Temp. F }\end{array}$} & \multicolumn{2}{|c|}{ Dry gas meter temp. } & \multirow{2}{*}{$\begin{array}{l}\text { Hot box } \\
\text { Temp. }\end{array}$} & \multirow{2}{*}{$\begin{array}{l}\text { Probe } \\
\text { Temp }\end{array}$} & \multirow{2}{*}{$\begin{array}{c}\text { Last } \\
\text { Impinger }\end{array}$} & \multirow{2}{*}{$\begin{array}{l}\text { Vacuum } \\
\text { in. } \mathrm{Hg}\end{array}$} & \multirow[t]{2}{*}{. } \\
\hline & & & & & & Inlet & Outlet & & & & & \\
\hline & 1410 & 63664 & & & & & & & & & & \\
\hline & 14 & 637163 & & & & & & & & & & \\
\hline & & & & & & & & & & & & \\
\hline & & & & & & & & & & & & \\
\hline & & & & & & & & & & & & \\
\hline & & & & & & & & & & & & \\
\hline & & & & & & & & & & & & \\
\hline & & & & & & & & & & & & \\
\hline & & & & & & & & & & & & \\
\hline & & & & & & & & & & & & \\
\hline & & & & & & & & & & & & \\
\hline & & & & & & & & & & & & \\
\hline & & & & & & & & & & & & \\
\hline & & & & & & & & & & & & \\
\hline & & & & & & & & & & & & \\
\hline & & & & & & & & & & & & \\
\hline & & & & & & & & & & & & \\
\hline & & & & & & & & & & & & \\
\hline & & & & & & & & & & & & \\
\hline & & & & & & & & & & & & \\
\hline & & & & & & & & & & & & \\
\hline & & & & & & & & & & & & \\
\hline & & & i & & & & & & & & & \\
\hline & & & & & & & & & & & & \\
\hline & & & & & & & & & & & & \\
\hline & & & & & & & & & & & & \\
\hline & & & & & & & & & & & & \\
\hline & & & & & & & & & & & & \\
\hline Avg. & - & ৪४\%/\% & ॠ\% & $\% \%$ & ॥ै। & ২০! & ڤ। & ২ি। & $\$$ & $1 \%$ & ४४ & $\%$ \\
\hline Check'd & & ४४४ & ४४ & 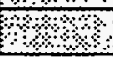 & ß३: & ४०० & ڤ & Sै। & ४४ & ४४४ও & 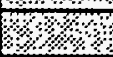 & \\
\hline
\end{tabular}

CONSOLE \#

FILTER \#

AMBIENT TEMP.

PROBE LENGTH

LINER MATERIAL

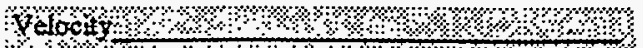

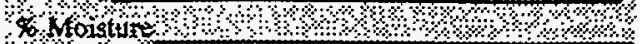

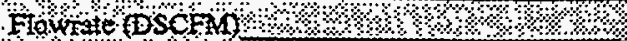

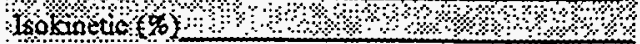

REMARKS 
Plant Name Plant Yates Station Boiler No. 1

Sampling Location SF ESP IN Nlet Train Ammonia/Hydrogen Cyanide Run No. 1

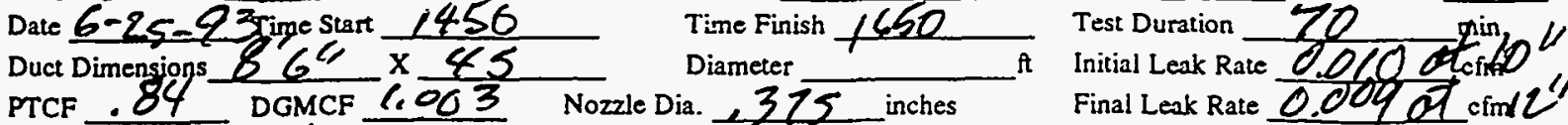
PTCF . . 24 DGMCF 1.003 Nozzle Dia. 375 inches Final Leak Rate 0.009 of cim/"

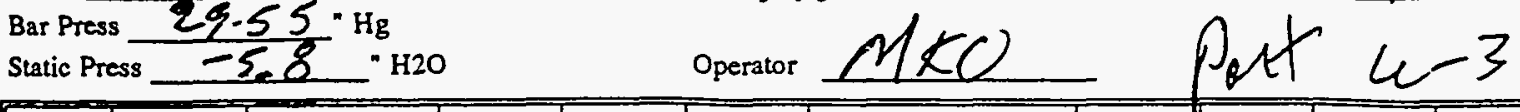

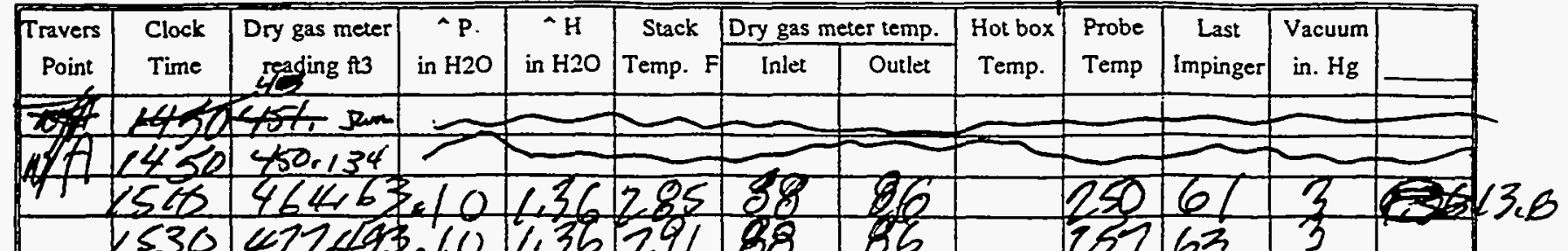

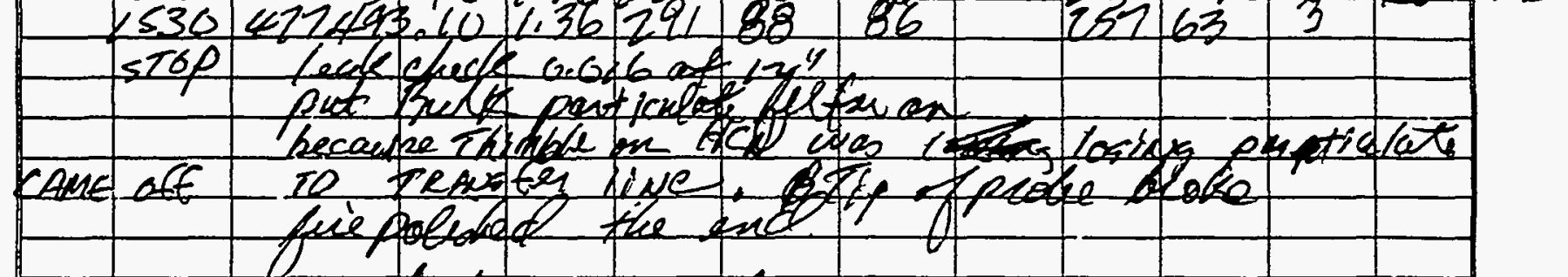

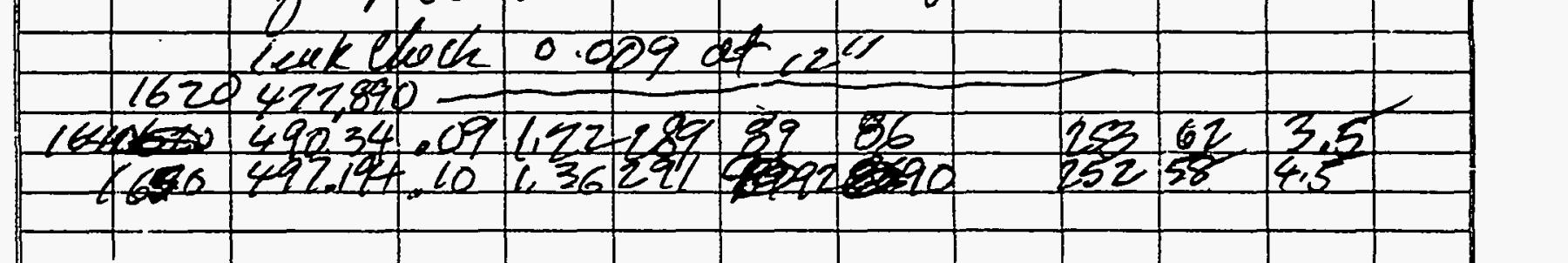
\begin{tabular}{|l|l|l|l|l|l|l|l|l|l|l|l|}
\hline \\
\hline
\end{tabular}

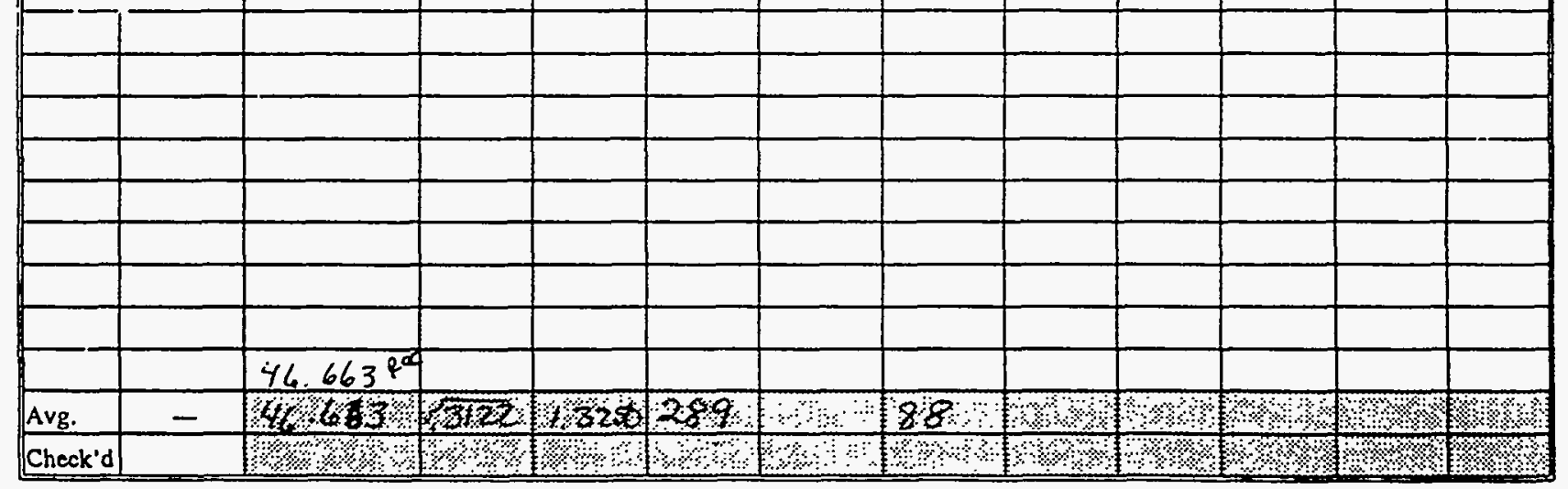

CONSOLE

AMBIENT TEMP.

PROBE LENGTH ZO'Slass

LINER MATERIAL STIS

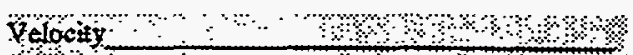

* Noisture $\quad: \quad \square$

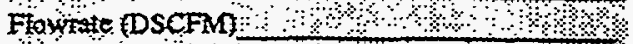
1ookinetic $\{\%$ \&

REMARKS 


$$
\text { Page } 1 \text { of } 1
$$

Plant Name Plant Yates Station Boiler No. 1

Sampling Location IN/LeT

Date 6-26-93 Time Start 6930

Duct Dimensions $86 \times 45$

PTCF $=84$ DGMCF $/ 200^{3}$

Bar Press $29.510 . \mathrm{Hg}$

Static Press -5.8 - H2O

\begin{tabular}{|c|c|c|c|c|}
\hline $\begin{array}{c}\text { Travers } \\
\text { Point }\end{array}$ & $\begin{array}{c}\text { Clock } \\
\text { Time }\end{array}$ & $\begin{array}{c}\text { Dry gas meter } \\
\text { reading ft3 }\end{array}$ & $\begin{array}{c}\wedge \\
\text { in } \mathrm{H} 2 \mathrm{O}\end{array}$ & $\begin{array}{c}\wedge \\
\text { in } \mathrm{H} \\
\mathrm{H} 2 \mathrm{O}\end{array}$ \\
\hline
\end{tabular}
Train Ammonia/Hydrogen Cyanide Run No. 2

Time Finish 1035 Test Duration \& $65 \mathrm{~min}$.

Nozzie Dia. $3 7 \longdiv { 5 }$ inches

Operator $M K O$ ft

Final Leak Rate 0.006 cim $f 811$

Paf $\omega-4$

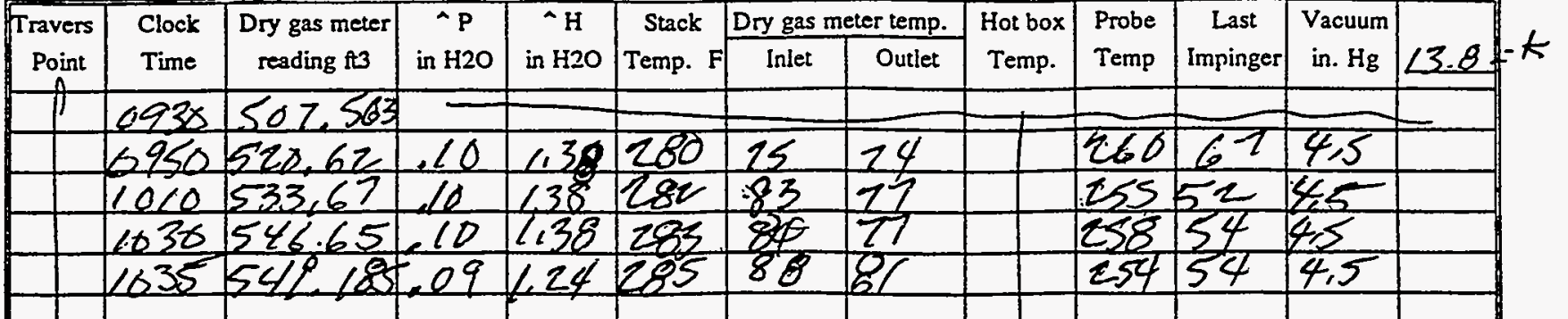

\begin{tabular}{|l|l|l|l|l|l|l|}
\hline 1 & & & & & & \\
\hline & & & & & & \\
\hline & & & & & & \\
\hline & & & & & & \\
\hline & & & & & & \\
\hline
\end{tabular}

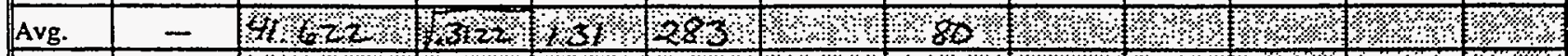

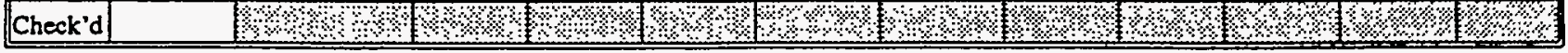

CONSOLE "Al6/40/

FILTER \# -

AMBIENT TEMP.

PROBE LENGTH

LINER MATERIAL GlAE2
Yerooty

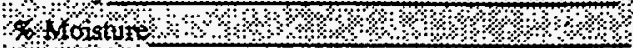

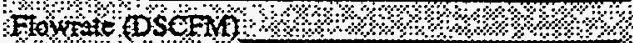

13okinsolof

REMARKS 


\section{SOLRCE SAHPLING FIELD DATA SHEET}

Plant Name

Plant Yates Station Boiler No. 1

$$
\begin{aligned}
& \text { Sone as KunZum } \\
& \text { Train Ammonia/Hydrogen Cyanide }
\end{aligned}
$$

Sampling Location IN LET

$$
\begin{aligned}
& \text { Date } 6-26-9 \text { Time Stan } 1420 \\
& \text { Duct Dimensions o } 66^{\prime \prime} \times \leqslant 5 \\
& \text { PTCF }+84 \text { DGMCF } 1003 \text { Nozzle Dia. } 1375 \text { inches }
\end{aligned}
$$$$
\text { Bar Press } 29 \% 5 \text {. } \mathrm{Hg}
$$

\begin{tabular}{|c|c|c|c|c|c|c|c|c|c|c|c|c|}
\hline Travers & Clock & Dry gas meter & $A p$ & ${ }^{\wedge} \mathrm{H}$ & Stack & Dry gas $m$ & ter temp. & Hot box & Probe & Last & Vacuum & \\
\hline Point & Time & reading ft 3 & in $\mathrm{H} 2 \mathrm{O}$ & in $\mathrm{H} 2 \mathrm{O}$ & Temp. F & Inlet & Outlet & Temp. & Temp & Impinger & in. $\mathrm{Hg}$ & $1,3,5$ \\
\hline WAt & 1420 & 595320 & & & & & & & & & + & \\
\hline & 1440 & 61013 & .11 & 148 & $2 B 1$ & 96 & 9,3 & & 260 & 668 & 5,0 & \\
\hline & 1500 & 622.85 & 29 & 124 & 25 & .95 & 92 & & $76 t$ & 103 & 5.5 & \\
\hline & 520 & 636474 & .20 & $4 \xi \xi$ & 186 & 95 & 32 & & 169 & 62 & 5.5 & \\
\hline & & & & & & & & & & & & \\
\hline & & & & & & & & & & & & \\
\hline & & & & & & & & & & & & \\
\hline & & & & & & & & & & & & \\
\hline & & & & & & & & & & & & \\
\hline & & & & & & & & & & & & \\
\hline & & & & & & & & & & & & \\
\hline & & & & & & & & & & & & \\
\hline & & & & & & & & & & & & \\
\hline & & & & & & & & & & & & \\
\hline & & & & & & & & & & & & \\
\hline & & & & & & & & & & & & \\
\hline & & & & & & & & & & & & \\
\hline & & & & & & & & & & & & \\
\hline & & & & & & & & & & & & \\
\hline & & & & & & & & & & & & \\
\hline & & & & & & & & & & & & \\
\hline & & & & & & & & & & & & \\
\hline & & & & & & & & & & & & \\
\hline & & & & & & & & & & & & \\
\hline & & & & & & & & & & & & \\
\hline & & & & & & & & & & & & \\
\hline & & & & & & & & & & & & \\
\hline & & & & & & & & & & & & \\
\hline Avg. & $=$ & $61265 \%$ & 367 & $1634 \%$ & 2884 & $\% 3$ & 948 & $1 \% \%$ & 81 & $8 \%$ & 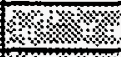 & $=8 \%$ \\
\hline Check'd & & $\$ 4 \%$ & 010 & $8 \%$ & 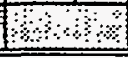 & $\$$ & 180 & 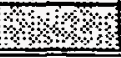 & 8 & $8 \%$ & 18.4 & ( \\
\hline
\end{tabular}$$
\text { Static Press }-5 \& \cdot \mathrm{H} 2 \mathrm{O}
$$$$
\text { Operator } M /<0
$$

Run No. 3

Time Finish 1520 Test Duration 60

CONSOLE \#

FILTER * =

AMBIENT TEMP. 72

PROBE LENGTH

REMARKS
Velocit

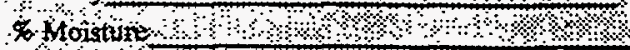

Fayme (DSSHA

isokinetio w का 
Plant Name

Sampling Location INLET

Date $6-2793$ Time Start 0920

Duct Dimensigns \& $6 "$ " 45

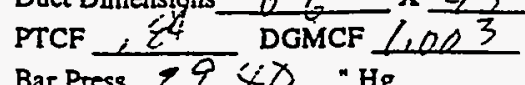

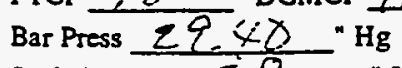

Static Press $-5 \frac{O}{2} "$ H2O

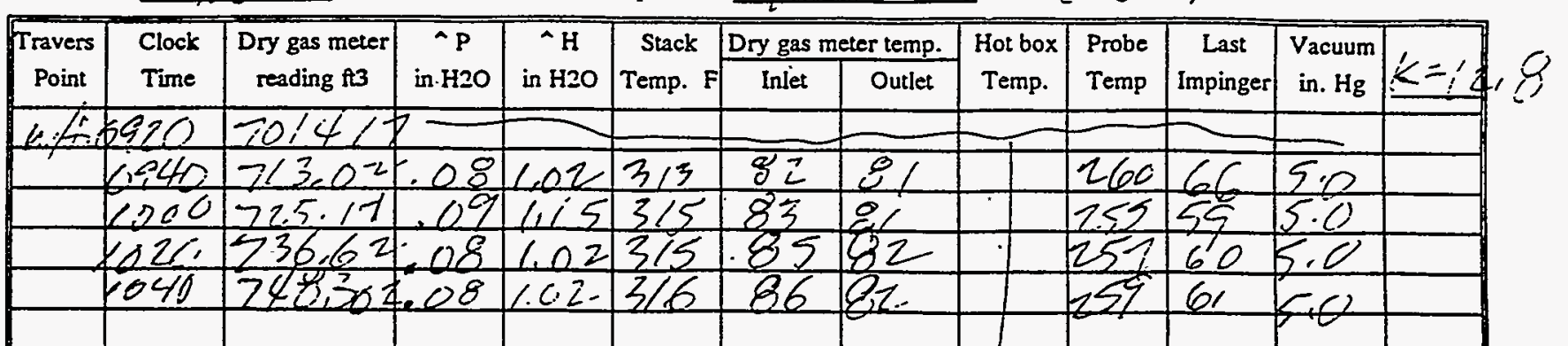

Train Ammonia/Hydrogen Cyanide Run No. 4

Time Finish 1040 Test Duration \& 80

Diameter

th

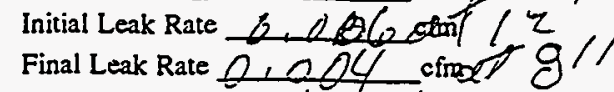

E.5 poit

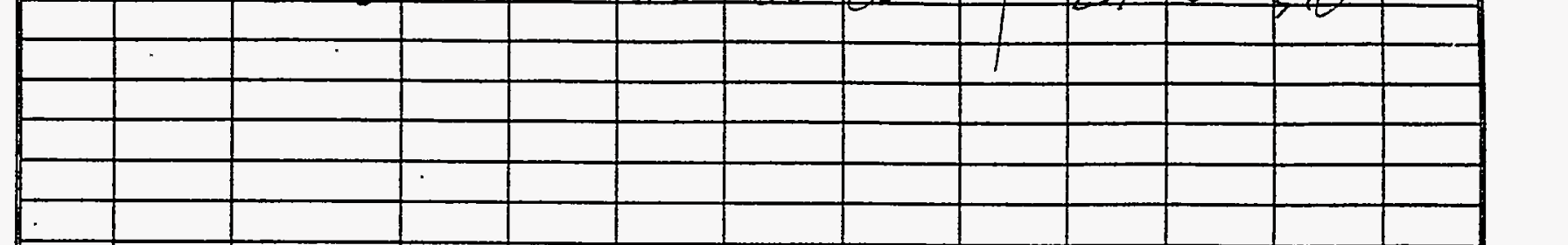

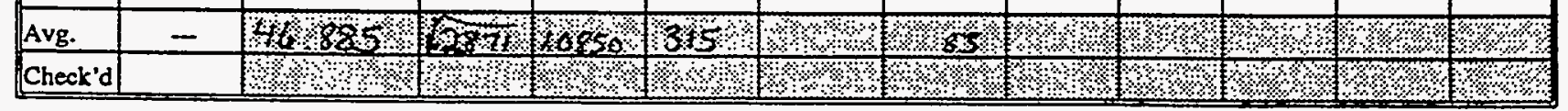

CONSOLE\# flGiliol

AMBIENT TEMP.

PROBE LENGTH

LINER MATERLAL Y1ASS
Yelocits/

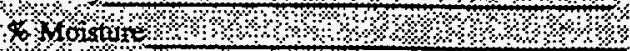

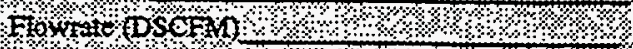

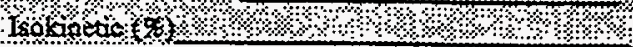

REMARKS 


$$
\text { Page } 1 \text { of } 1
$$

Plant Name Sampling rocation Inte 1 Date $6 / 24 / 5$ PTCF Bar Press Static Press

\begin{tabular}{|c|c|c|c|c|}
\hline $\begin{array}{c}\text { Travers } \\
\text { Point }\end{array}$ & $\begin{array}{l}\text { Clock } \\
\text { Time }\end{array}$ & $\begin{array}{c}\text { Dry gas meter } \\
\text { reading ft3 }\end{array}$ & in $\mathrm{H} 2 \mathrm{O}$ & $\begin{array}{c}\text { H } \\
\text { in } \mathrm{H} 2 \mathrm{O}\end{array}$ \\
\hline & 352 & 633.0537 & & \\
\hline & $\angle 103$ & 636.689 & & \\
\hline
\end{tabular}
DGMCF N Nozzle Dia.
Train Ammonia/Hydrogen Cyanide

Time Finish $\mathrm{AOS}$

Diameter $\mathrm{Hg}$ $\mathrm{H} 2 \mathrm{O}$ perator JWh

Final Leak Rate
Run No. Run blfkase 2 min. cfm cfm Stack Dry gas meter temp.

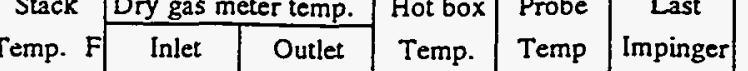

\begin{tabular}{l|l|l|l|l|l|l} 
& & & & & & \\
\end{tabular}

\begin{tabular}{|c|c|c|c|c|c|c|c|c|c|c|c|c|}
\hline & & & & & & & & & & & & \\
\hline & - & (2) & & & & & & & & 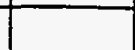 & [ & 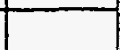 \\
\hline & & & & & & & & & & & & \\
\hline & & & & & & & & & & & & \\
\hline & & & & & & & & & & & & \\
\hline & & & & & & & & & & & & \\
\hline & & & & & & & & & & & 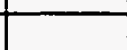 & \\
\hline & & & & & & & & & & & & \\
\hline & & & & & & & & & & & & \\
\hline & & & & & & & & & & & & \\
\hline & & & & & & & & & & & & \\
\hline & & & & & & & & & & & & \\
\hline & & & & & & & & & & & & \\
\hline & & & & & & & & & 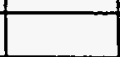 & & & \\
\hline & & & & & & & & & & 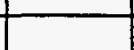 & 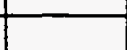 & \\
\hline & & & & & & & & & & & & \\
\hline & & & & & & & & & & & & \\
\hline & & & & & & & & & & & & \\
\hline & & & & & & & & & & & & \\
\hline & & & & & & & & & & & & \\
\hline & & & & & & & & & & & & \\
\hline & & & & & & & & & & & & \\
\hline & & & & & & & & & & & & \\
\hline & & & & & & & & & 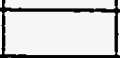 & 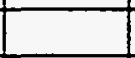 & & \\
\hline & & & & & & & & & & & & \\
\hline & & & & & & & & & & & & \\
\hline & & & & & & & & & & 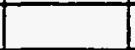 & & $\mathrm{L}$ \\
\hline Avg. & - & ४४००८\% & ए। & अ & $\because 3$ & $8 \div$ & $8 \%$ & 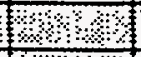 & Q & 13\% & ! & 80 \\
\hline Check'd & & \% \% & 31 & $3 \%$ & 3 & $9 \mathrm{~m}$ & \%? & $1 \%$ & ॥ & $18 \%$ & 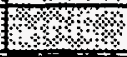 & $16 \%$ \\
\hline
\end{tabular}

CONSOLE \#

FILTER \#

AMBIENT TEMP.

PROBE LENGTH

LINER MATERIAL
Woromy

L Moustir

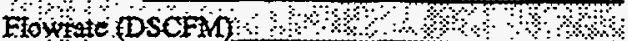

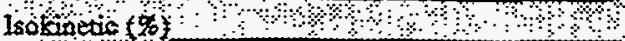


SOLRCE SAMPLING FIELD DATA SHEET

ESP INLET

Plant Name Plant Yates Station Boiler No. 1

Run No. $L$

Sampling Location iselot

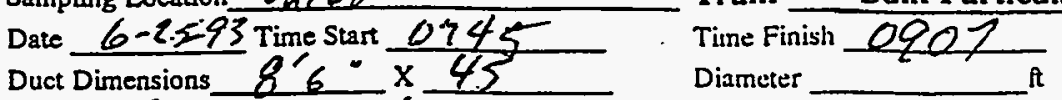

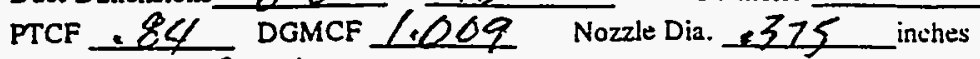

Bar Press $29,55 . \mathrm{Hg}$

Static Press - -6.4 " H2O

operator MKC

Final Leak Rate 0,0206 cim $1 /$

\begin{tabular}{|c|c|c|c|c|c|c|c|c|c|c|c|c|}
\hline Travers & Clock & Dry gas meter & $\wedge p$ & $-\mathrm{H}$ & Stack & Dry gas in & ter teinp. & Hot box & Probe & Last & Vacuum & 6 \\
\hline Point & Time & reading f 3 & in $\mathrm{H} 2 \mathrm{O}$ & in $\mathrm{H} 2 \mathrm{O}$ & Tenp. F & Inlet & Outlet & Temp. & Temp & Iinpinger & in. $\mathrm{Hg}$ & -134 \\
\hline AfA & 6745 & 656 & 5048 & 768 & & & & utf & & & & \\
\hline & 0.805 & 661.72 & 18 & 648 & 300 & 18 & 77 & & 250 & 61 & 3.0 & \\
\hline & 0825 & 679.80 & +6 & $1,3,5$ & 302 & 84 & 74 & & 247 & 54 & 310 & \\
\hline & 2945 & 694 & 3 & 175 & 300 & 85 & 80 & & 243 & 56 & $(1,2$ & \\
\hline & 6907 & 208.84 & $\angle 3$ & 1.75 & 301 & 220 & 83 & & 244 & 69 & 4,0 & \\
\hline & & & & & & & & & & & & \\
\hline & & & & & & & & & & & & \\
\hline & & & & & & $=$ & & & & & & \\
\hline & & & - & & aed & & & & & & & \\
\hline & & & & & & 6 & & & & & & \\
\hline & & & & & D. & & $A$ & & & & & \\
\hline & & & & & & $a^{n}$ & & $E_{0}$ & 5 & & & \\
\hline & & & & & & $\frac{1}{15}$ & $21, V$ & 6 & & & & \\
\hline & & & & & $E x^{f}$ & $r a+5$ & & & & & & \\
\hline & & & & & & & & & & & & \\
\hline & & inl & & & 142 & & & & & & & \\
\hline & & & & $\pi \omega^{\circ}$ & $7 t^{2}$ & & & & & & & \\
\hline & & & & & & & & & & & & \\
\hline & & & & & & & & & & & & \\
\hline & & & & & & & & & & & & \\
\hline & & & & & & & & & & & & \\
\hline & & & & & & & & & & & & \\
\hline & & & & & & & & & & & & \\
\hline & & & & & & & & & & & & \\
\hline & & & & & & & & & & & & \\
\hline & & & & & & & & & & & & \\
\hline & & & & & & & & & & & & \\
\hline & & & & & & & & & & & & \\
\hline Avg. & -24 & 53605 & $\sqrt{3380}$ & 19825 & 301 & ॥० & $82 \%$ & $\%$ & 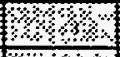 & $\$$ & 1\% & \\
\hline Check'd & 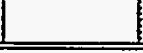 & 13 & $\$$ & ॥े & 10 & $\because \%$ & $1 \%$ & $\$ 1 \%$ & 10 & & 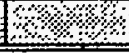 & \\
\hline
\end{tabular}

CONSOLE\#

THIMBLE \# -

AMBIENT TEMP. 14

PROBE LENGTH $10^{\prime}$

LINER MATERIAL S Stass

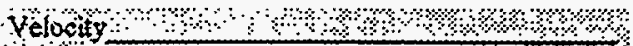

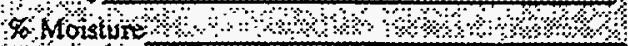
Fowrat (DSCEM) isokineto $6 \%$ औ

REMARKS 
SOLRCE SA.MPLIYG FIELD DATA SHEET

ESP INLET
Page $f$ of 1

Plant Name

Plant Yates Station Boiler No. 1

Sampling Location icy êt

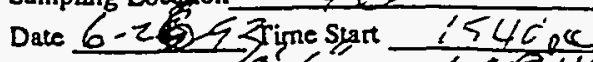

Duct Dimensions 860

Train Bulk Particulate-Radionuclides

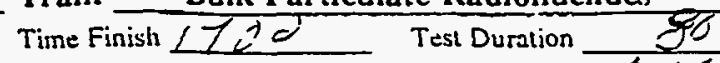

Run No. 2

PTCF \& \&4 DGMCF 1.009 Nozzle Dia. -375 inches

it

Bar Press $29.56 \quad \mathrm{Hg}$

Static Press =

Operator $M / E C$

Final Leak Rate 0.00? cfm

\begin{tabular}{|c|c|c|c|c|c|c|c|c|c|c|c|c|}
\hline \multirow{2}{*}{$\begin{array}{c}\text { Travers } \\
\text { Point }\end{array}$} & \multirow{2}{*}{$\begin{array}{l}\text { Clock } \\
\text { Time }\end{array}$} & \multirow{2}{*}{$\begin{array}{c}\text { Dry gas meter } \\
\text { reading ft3 }\end{array}$} & \multirow{2}{*}{$\begin{array}{c}\text { P } \\
\text { in } \mathrm{H}_{2} \mathrm{O}\end{array}$} & \multirow{2}{*}{$\begin{array}{c}A \mathrm{H} \\
\text { in } \mathrm{H} 2 \mathrm{O}\end{array}$} & \multirow{2}{*}{\begin{tabular}{|c|} 
Stack \\
Temp. F
\end{tabular}} & \multicolumn{2}{|c|}{ Dry gas incter temp. } & \multirow{2}{*}{$\begin{array}{l}\text { Hot box } \\
\text { Temp. }\end{array}$} & \multirow{2}{*}{$\begin{array}{l}\text { Probe } \\
\text { Temp }\end{array}$} & \multirow{2}{*}{\begin{tabular}{|c|} 
Last \\
limpinger
\end{tabular}} & \multirow{2}{*}{$\begin{array}{c}\text { Vacuum } \\
\text { in. } \mathrm{Hg}\end{array}$} & \\
\hline & & & & & & Inlet & Outlet & & & & & \\
\hline$\alpha / A$ & 1540 & 0,66050 & & & & & & & & & & \\
\hline & 6600 & $870<6$ & .11 & $7,4.5$ & 285 & 100 & 97 & & 24 & 57 & 43 & $k=$ \\
\hline & $16-20$ & 930,4 & 14 & 105 & 3.6 & 100 & 94 & & 231 & 67 & 4.5 & $k=13$ \\
\hline & $11,1 / 4$ & 900.74 & .07 & 89 & 215 & .20 & 94 & & $65^{\prime}$ & $6 \%$ & 45 & $k=(2$ \\
\hline & $\angle 20<1$ & 31200 & 828 & est & 326 & $\angle 420$ & 95 & & 249 & 62 & 4.5 & $k^{\prime}=12$ \\
\hline & & & & & & & & & & & & \\
\hline & & & & & & & & & & & & \\
\hline
\end{tabular}

Avg.

-11 $6 4 9 5 0 \% \longdiv { 2 9 0 5 }$

1 1. $3 \ldots 7$

Check'd

$\%$

CONSOLE\# A/6/4OZ

THIMBLE \#-

AMBIENT TEMP. 28

PROBE LENGTH $\angle O$

LINER MATERIAL $\triangle S$

Pof E-7 E-7Pot?

Velointy

go itoisture.

Flowrate (DSCFM)

lsokinetic $(\%)$

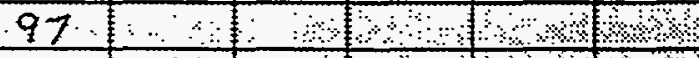
(1) 1 ग) 


\section{SOURCE SAMPLING FIELD DATA SHEET}

ESP INLET

Page ___ of

Plant Yates Station Boiler No. 1

Sampling Location $1-1$ \&

Train Bulk Particulate-Radionuclides

Run No 3

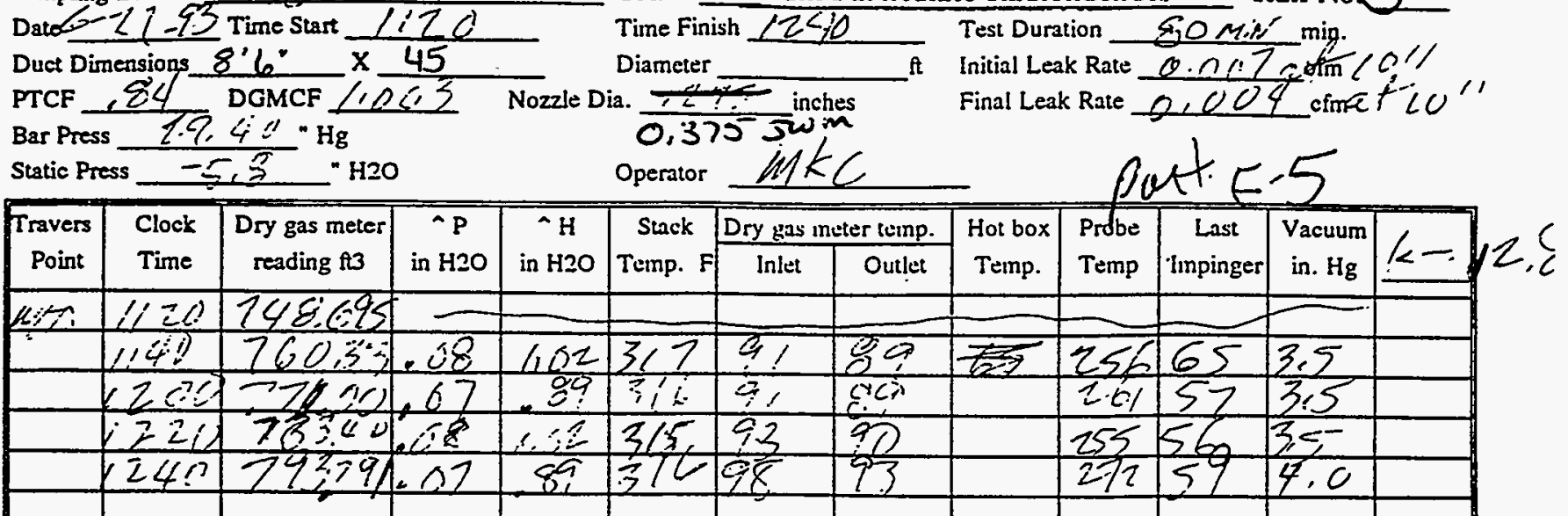

\begin{tabular}{|c|c|c|c|c|c|c|c|c|c|c|c|c|}
\hline & & & & & & & & & & & & \\
\hline & & & & & & & & & & 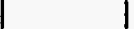 & & \\
\hline & & & & & & & & & & & & \\
\hline & & & & & & & & & & & & \\
\hline & & & & & & & & & & & & \\
\hline & & & & & & & & & & & & \\
\hline & & & & & & & & & & & & \\
\hline & & & & & & & & & & & & \\
\hline & & & & & & & & & & & & \\
\hline & & & & & & & & & & & & \\
\hline & & & & & & & & & & & & \\
\hline & & & & & & & & & & & & \\
\hline & & & & & & & & & & & & \\
\hline & & & & & & & & & & & & \\
\hline & & & & & & & & & & & & \\
\hline & & & & & & & & & & & & \\
\hline & & & & & & & & & & & & \\
\hline & & & & & & & & & & & & \\
\hline & & & & & & & & & & & & \\
\hline & & & & & & & & & & & & \\
\hline & & & & & & & & & & & & \\
\hline & & & & & & & & & & & & \\
\hline & & & & & & & & & & & & \\
\hline & & & & & & & & & & & & \\
\hline Avg. & - & $55004 \%$ & $\sqrt{2737}$ & 9955 & 316 & । & 1233 & ४४\% & $8 \%$ & 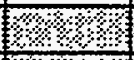 & $18 \%$ & $\%$ \\
\hline Check'd & & 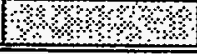 & $12 \%$ & 10\% & 8 & $101 \%$ & 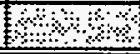 & $18 \%$ & $18 \%$ & S? & $1 \% 1$ & 18 \\
\hline
\end{tabular}

CONSOLE \#

THIMBLE \#

AMBIENT TEMP.

PROBE LENGTH

LINER MATERIAL $5 / 45 \%$

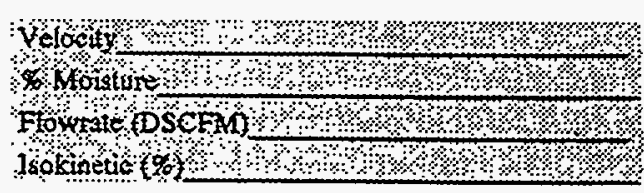

REMARKS 
SOLRCE SAMPLI:NG FIELD DATA SHEET

ESP INLET

Page 1 of 1

Plant Name Plant Yates Station Boiler No. 1

Sampling Location Train

Bulk Particulate-Ex. Metals

Run No.

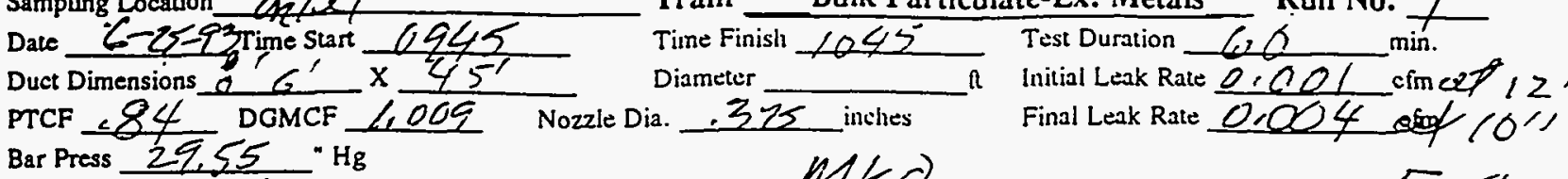

Static Press -5.8 "H2O

operator M/KC)

E-S

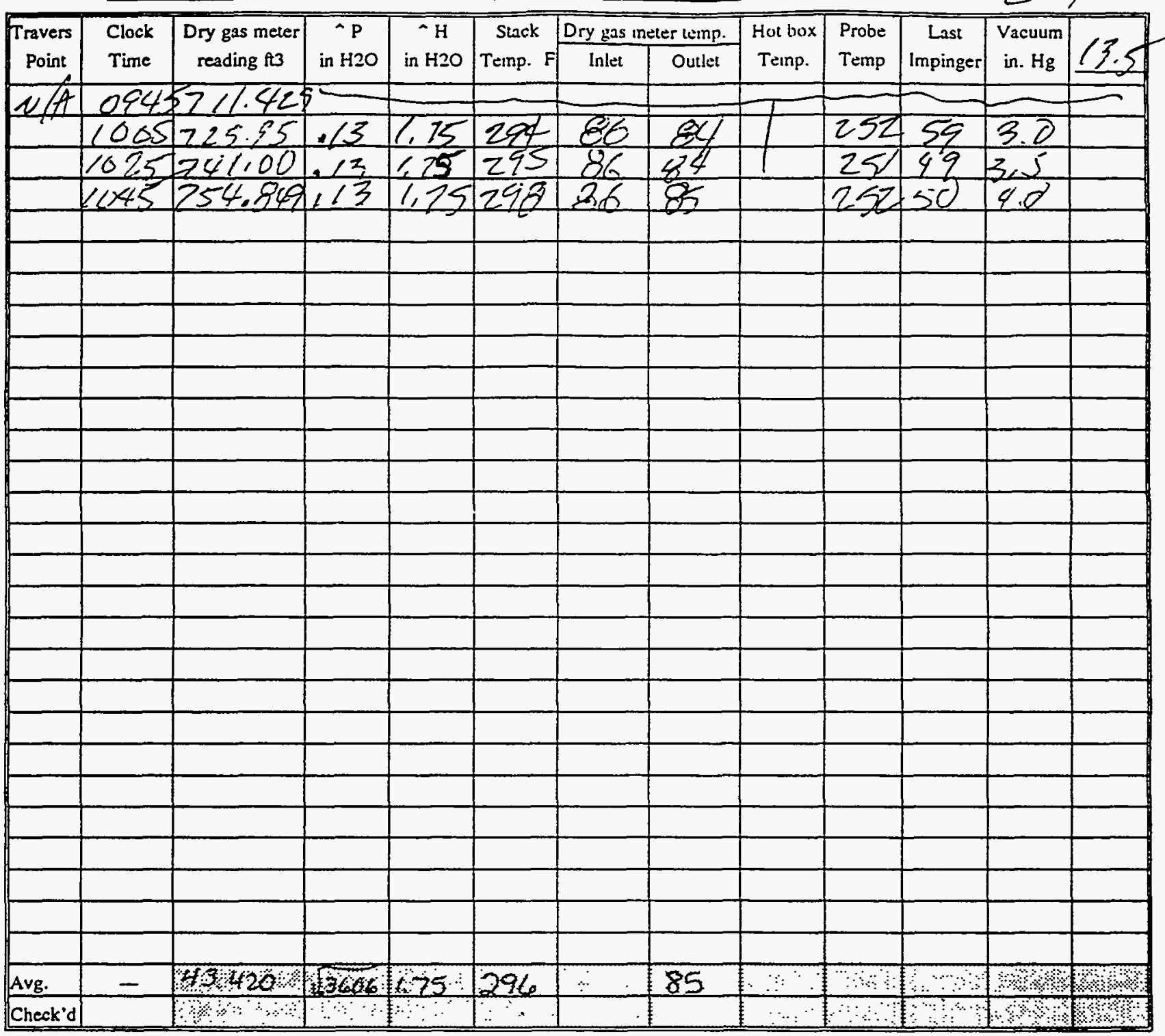

CONSOLE "AL6/402

FLLTER \# (Th.nble)

AMBIENT TEMP. 78

PROBE LENGTH $10 / 2 / 455$

LINER MATERIAL $\mathrm{S} / \mathrm{A} S$
Velocity

\%o Muisture

Flowrate (DSCFM)

lsokintic (\%)

REMARKS 
Location

Date Ce- 26 \&3ime Start

PTCF $\leqslant 84$ DGMCF $\times 40$

Bar Press Z7,56" $\mathrm{Hg}$

Static Press -528 "H2O

Train

Bulk Particulate-Ex. Metals

Tine Finisl 1505

Diameter Ne it

Test Duration.

Initial Leak Rate 0.01

$\min$.

Final Leak Rate $0.007 \mathrm{cfm}$
Operator $(\bar{j})$

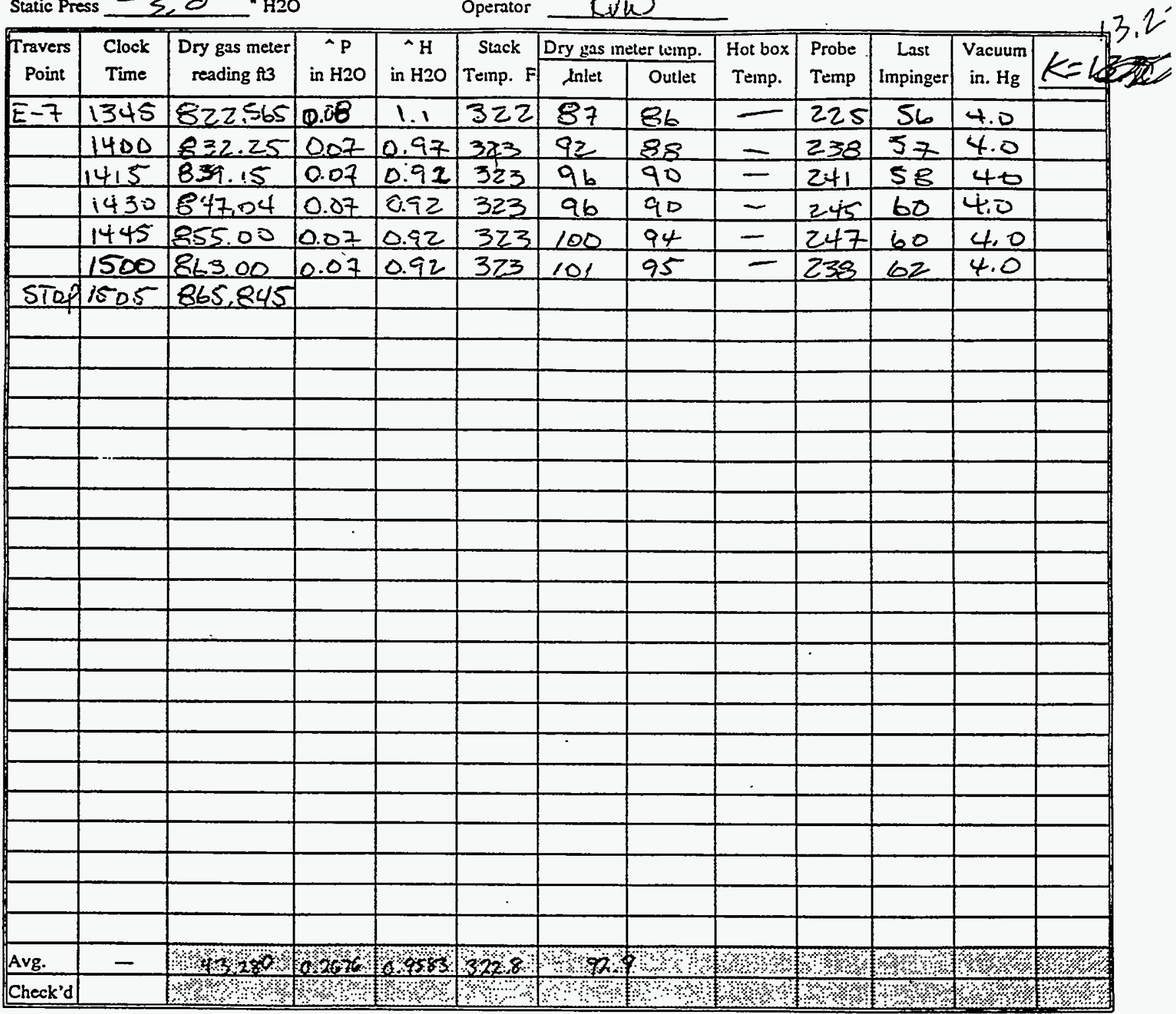

CONSOLE \#

A $16 / 401$

FILTER " 1065 (Th.mble) AMBIENT TEMP. PROBE LENGTH LINER MATERIAL 78 $2.0^{\prime}$ 55 
SOL'RCE SAMPLING FIELD DATA SHEET

ESP INLET

Plant Name

Plant Yates Station Boiler No. 1

Page $L$ of $L$

Sampling Location un $\mathrm{Ce}$

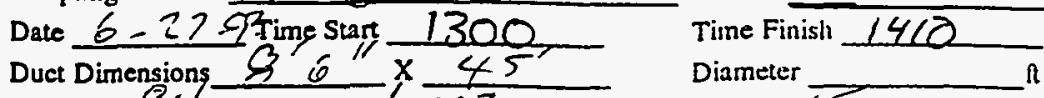

BTCF 14 DGMCF 1

Static Press $-5,8=$ H2O

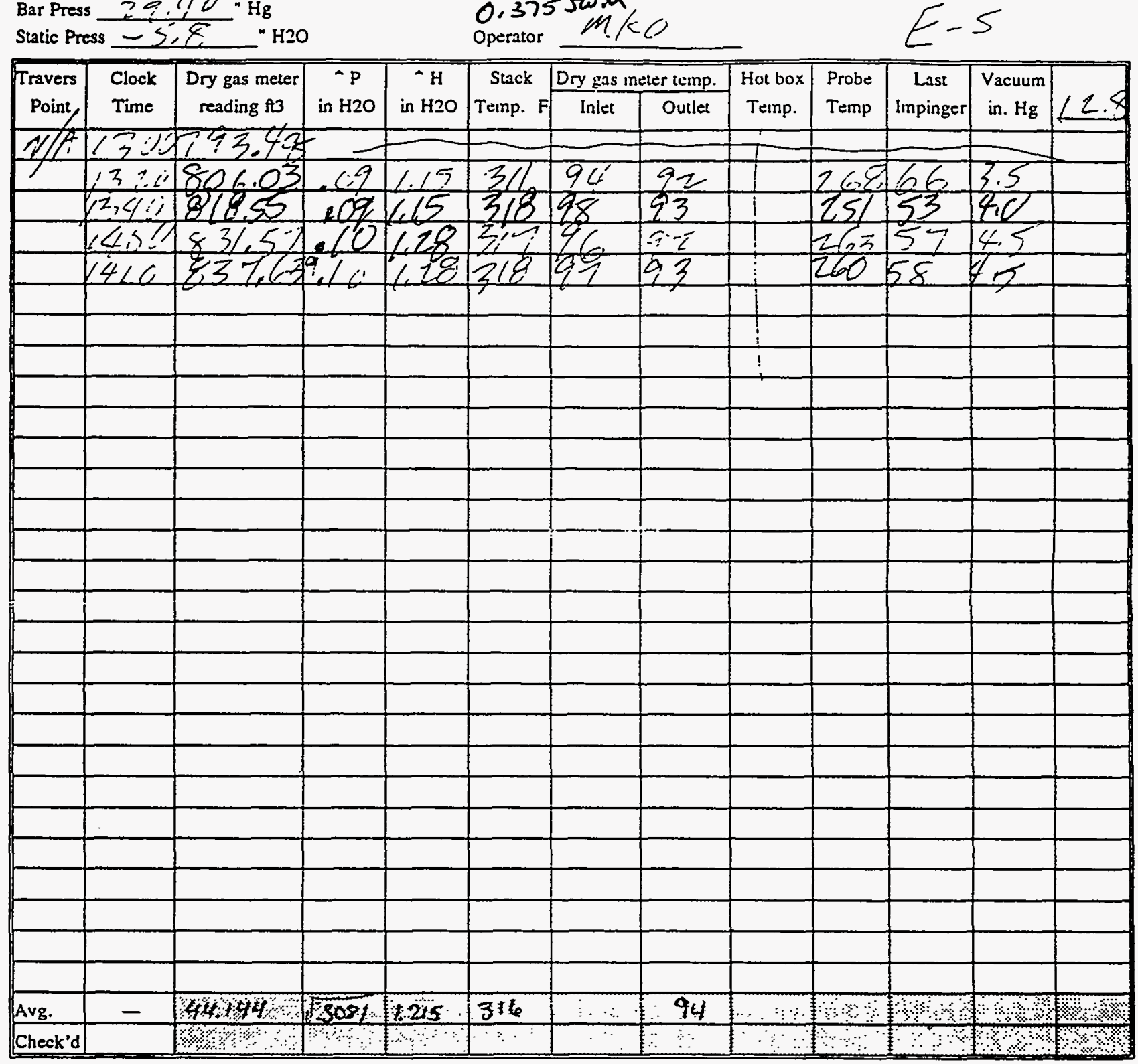

CONSOLE \# $A(6 / 4 \mathrm{C})$

FILTER \# $10 \mathrm{OO}$ (Thimble)

AMBIENT TEMP. 76

PROBE LENGTH 10

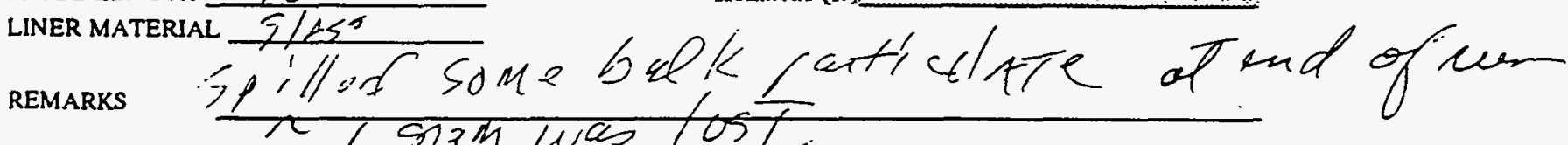

C-205
Velocity.

* Mưisturte

Flowage (DSCFA)

Isokinetic f os:
Test Duration 70 min.

Initial Leak Rate 6.029 cm a 10

Final Leak Rate 0.006 $\mathrm{cm}$ है। $10^{\prime \prime}$ 
Plant Name

Plant Yates Station Boiler No. 1

Train Size Fract. Particulate Run No.

Sampling Location winle

Date $6-25-93$ Time Start 0600

Duct Dimensigns $866^{\circ} \times 45$

PTCF .08 DGMCF .9880

Diameter

Bar Press $29.55^{\circ} \mathrm{Hg}$

Static Press -6.4 "H2O

Nozzle Dia. .375 inches

Test Duration $\angle \ll d$ min.

Initial Leak Rate $\operatorname{lros} 9{ }_{\mathrm{cm}}^{\mathrm{min}} \alpha \mathrm{ff}_{\mathrm{s}} \mathrm{ft}$

Final Leak Rate cfm

\begin{tabular}{|c|c|c|c|c|c|c|c|c|c|c|c|c|}
\hline \multirow{2}{*}{\begin{tabular}{|c|} 
Travers \\
Point
\end{tabular}} & \multirow{2}{*}{$\begin{array}{l}\text { Clock } \\
\text { Time }\end{array}$} & \multirow{2}{*}{$\begin{array}{c}\text { Dry gas meter } \\
\text { reading tt3 }\end{array}$} & \multirow{2}{*}{$\begin{array}{c}\text { A } P \\
\text { in } \mathrm{H} 2 \mathrm{O}\end{array}$} & \multirow{2}{*}{$\begin{array}{c}{ }^{4} \\
\text { in } \mathrm{H} 2 \mathrm{O}\end{array}$} & \multirow{2}{*}{$\begin{array}{c}\text { Stack } \\
\text { Temp. } F\end{array}$} & \multicolumn{2}{|c|}{ Dry gas meter temp. } & \multirow{2}{*}{$\begin{array}{l}\text { Hot box } \\
\text { Temp. }\end{array}$} & \multirow{2}{*}{$\begin{array}{l}\text { Probe } \\
\text { Temp }\end{array}$} & \multirow{2}{*}{\begin{tabular}{|c|} 
Last \\
Impinger
\end{tabular}} & \multirow{2}{*}{$\begin{array}{l}\text { Vacuum } \\
\text { in. Hg }\end{array}$} & \multirow{2}{*}{$k=3.0$} \\
\hline & & & & & & Inlet & Outlet & & & & & \\
\hline N/A & 2800 & 341.86 & & & & & & whth & & & & \\
\hline & 0820 & 348.23 & 208 & .31 & 290 & 76 & 25 & & 248 & 61 & 2.0 & \\
\hline & 10840 & 354,58 & 008 & 31 & 2.86 & ह1 & 17 & & 245 & 61 & 200 & \\
\hline & 5900 & 360.87 & $=61$ & 31 & 288 & 838 & 78 & & 120 & 62 & 2.0 & \\
\hline & 2920 & 367.68 & .08 & .37 & 280 & 822 & 78 & & 261 & 66 & 2.0 & \\
\hline & 6940 & $77 \frac{1}{3} 42$ & ece & $3 /$ & 289 & 83 & $7 \theta$ & & 262 & 64 & 28 & \\
\hline & $\$ 1020$ & 379.80 & -09 & 31 & 796 & 86 & 8 & & 251 & $\ln 5$ & 3,0 & \\
\hline & $\cot 6$ & 38362 & .08 & 31 & 258 & 81 & 81 & & 154 & 64 & 3.5 & \\
\hline & & & & & & & & & & & & \\
\hline & & & & & & & & & & & & \\
\hline & & & & . & & & & & & & & \\
\hline & & & & & & & & & & & & \\
\hline & & & & & & & & & & & & \\
\hline & & & & & & & & & & & & \\
\hline & & & & & & & & & & & & \\
\hline & & & & & & & & & & & & \\
\hline & & & & & & & & & & & & \\
\hline & & & & & & & & & & & & \\
\hline & & & & & & & & & & & & \\
\hline & & & & & & & & & & & & \\
\hline & & & & & & & & & & & & \\
\hline & & & & & & & & & & & & \\
\hline & & & & & & & & & & & & \\
\hline & & & & & & & & & & & & \\
\hline & & & & & & & & & & & & \\
\hline & & & & & & & & & & & & \\
\hline & & & & & & & & & & & & \\
\hline & & & & & & & & & & & & \\
\hline Avg. & - & 410608 & 8826 & $37 \%$ & 288 & 6 & 810 & 3 & ओ० & \%। & $1 \%$ & $\% 8 \%$ \\
\hline Check'd & & $10 \%$ & $\$ 1$ & +3: & +1 & ? & $8 \%$ & $\$$ & $\$ 3$ & $\%$ & $18 \%$ & $1 \%$ \\
\hline
\end{tabular}

CONSOLE H Al6/40/.

FILTER \# F1308 (47mim) Thimble AMBIENT TEMP.

PROBE LENǴTH

PROBE LENGTH MATERI S

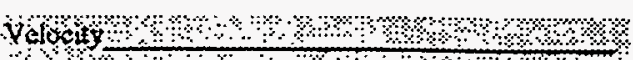

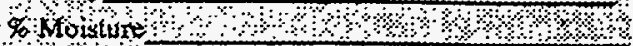

Fow War (DSCFin)

Isolinetio $(6)$ ॥ ।

REMARKS 
Plant Name Plant Yates Station Boiler No. 1

Run No. 2

Sampling Location inete

Date $6-26-43$ Time Start 647

Duct Dimensions $g^{\prime} \mathrm{CH}^{\prime} \times 45^{\prime}$ Bar Press $32.5 \mathrm{C}$ " $\mathrm{Hg}$

Static Press - 5- "H2O Train Size Fract. Particulate
Time Finish 125

Nozzle Dia. .275 inches

Nozzle Dia. .275 inches

operator MKo

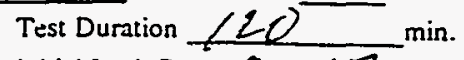

it Initial Leak Rate 0,017 cimat $10^{\prime \prime}$

Final Leak Rate NA cim

\begin{tabular}{|c|c|c|c|c|c|c|c|c|c|c|c|c|}
\hline \multirow{2}{*}{$\begin{array}{r}\text { Travers } \\
\text { Point }\end{array}$} & \multirow{2}{*}{$\begin{array}{l}\text { Clock } \\
\text { Time }\end{array}$} & \multirow{2}{*}{$\begin{array}{r}\text { Dry gas meter } \\
\text { reading } \beta^{2} Z\end{array}$} & \multirow{2}{*}{ - $\begin{array}{c}-\mathrm{P} \\
\text { in } \mathrm{H} 2 \mathrm{O}\end{array}$} & \multirow{2}{*}{$\begin{array}{c}\text { H } \\
\text { in } \mathrm{H} 2 \mathrm{O}\end{array}$} & \multirow{2}{*}{\begin{tabular}{|l|} 
Stack \\
Tenp. $F$
\end{tabular}} & \multicolumn{2}{|c|}{ Dry gas meter temp. } & \multirow{2}{*}{$\begin{array}{c}\text { Hot box } \\
\text { Temp. }\end{array}$} & \multirow{2}{*}{\begin{tabular}{|l|} 
Probe \\
Temp
\end{tabular}} & \multirow{2}{*}{$\begin{array}{c}\text { Last } \\
\text { Impinger }\end{array}$} & \multirow{2}{*}{$\begin{array}{l}\text { Vacuum } \\
\text { in. } \mathrm{Hg}\end{array}$} & \multirow[b]{2}{*}{$k=3$} \\
\hline & & & & & & Inlet & Outlet & & & & & \\
\hline & 1915 & $7696=$ & & & & & & $A / h$ & & & & \\
\hline & 0935 & 717.03 & 16 & 42 & 311 & 81 & 29 & & 245 & 62 & 3,0 & \\
\hline & 6955 & 70387 & 0 & .38 & 2,1 & है2 & 80 & & 246 & 161 & 3.0 & \\
\hline & 615 & 790,78 & .10 & 38 & 311 & 86 & 84 & & 244 & 60 & 3,0 & \\
\hline & 1045 & 79824 & 612 & 46 & 310 & 85 & 82 & & 242 & 61 & 30 & \\
\hline & 105 & 005.16 & $0 / 2$ & $4 c$ & 311 & 88 & 84 & & 101 & 600 & 3.0 & \\
\hline & 145 & $8,13.7 .8$ & .10 & 38 & 311 & 89 & 86 & & 252 & 59 & 3.5 & \\
\hline & & & & & & & & & & & & \\
\hline & - & & & & & 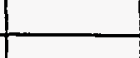 & & & & - & & \\
\hline & & & & & & & & & & & & \\
\hline & & & & & & & & & & & & \\
\hline & & & & & & & & & & & & \\
\hline & & & & & & & & & & & & \\
\hline & & & & & & & & $=$ & & & & \\
\hline & & & & & & & & & & & & \\
\hline & & & & & & & & & & & & \\
\hline & & & & & & & & & & & & \\
\hline & & & & & & & & & & & & \\
\hline & & & & & & & & & & & & \\
\hline & & & & & & & & & & & & \\
\hline & & & & & & & & & & & & \\
\hline & & & & & & & & & & & & \\
\hline & & & & & & & & & & & & \\
\hline & & & & & & & & & & & & \\
\hline & & & & & & & & & & & & \\
\hline & & & & & & & & & & & & \\
\hline Avg. & - & $63, \pi 350$ & 8.3289 & 0.943 & 310.2 & 83 & 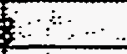 & & 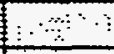 & म० & (4) & $1 \%$ \\
\hline Check'd & & $10 \% 7 \%$ & !! & 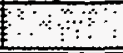 & ब & $10 \quad$ & \%. & $1 \%$ & 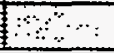 & ४ & $1 \%$ & $1 \%$ \\
\hline
\end{tabular}

CONSOLE " $\mathrm{A} / 6 / 402$

FILTER \# 311 (7) AMBIENT TEMP.

PROBE LENGTH

LINER MATERIAL 76 10

(A5S

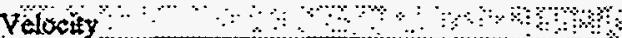

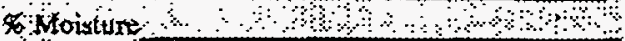

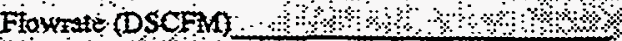
Isokinetic $€$ \%

REMARKS 
Plant Name Plant Yates Station Boiler No. 1

Sampling Location enCt

Date $6-27-2 \overline{3}$ Time Start 0740

Duet Dimensions $g^{\prime} 6 " 1 \times 45$

PTCF 0.84 DGMCF 1.009 Nozzle Dia.

Bar Press 2, 50 " $\mathrm{Hg}$

Static Press $-5.8=\mathrm{H} 2 \mathrm{O}$

\begin{tabular}{|c|c|c|c|c|c|c|c|c|c|c|c|c|}
\hline \multirow{2}{*}{$\begin{array}{c}\text { Travers } \\
\text { Point }\end{array}$} & \multirow{2}{*}{$\begin{array}{l}\text { Clock } \\
\text { Time }\end{array}$} & \multirow{2}{*}{$\begin{array}{c}\text { Dry gas meter } \\
\text { reading ft } 3\end{array}$} & \multirow{2}{*}{$\begin{array}{c}\wedge \mathrm{P} \\
\text { in } \mathrm{H} 2 \mathrm{O}\end{array}$} & \multirow{2}{*}{$\begin{array}{c}\mathrm{H} \\
\text { in } \mathrm{H} 2 \mathrm{O}\end{array}$} & \multirow{2}{*}{$\begin{array}{c}\text { Stack } \\
\text { Temp. } F\end{array}$} & \multicolumn{2}{|c|}{ Dry gas meter teinp. } & \multirow{2}{*}{$\begin{array}{l}\text { Hot box } \\
\text { Temp. }\end{array}$} & \multirow{2}{*}{$\begin{array}{l}\text { Probe } \\
\text { Temp }\end{array}$} & \multirow{2}{*}{\begin{tabular}{|c|} 
Last \\
Impinger
\end{tabular}} & \multirow{2}{*}{$\begin{array}{l}\text { Vacuum } \\
\text { in. } \mathrm{Hg}\end{array}$} & \multirow{2}{*}{$k=3$} \\
\hline & & & & & & Inlet & Outlet & & & & & \\
\hline$E-8$ & 0740 & 938.170 & 0.08 & $0.3 i$ & 310 & 74 & 73 & 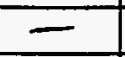 & 240 & 63 & 2.2 & \\
\hline & 0755 & 942.70 & 0.09 & 0.34 & 312 & 78 & 75 & - & 235 & $6 z$ & 20 & \\
\hline & 0810 & 948.27 & 0.08 & 0.31 & 3,4 & 81 & 78 & $=$ & 237 & 60 & 20 & \\
\hline & 0825 & 952.28 & 209 & 0.34 & 314 & 82 & 79 & - & 238 & 61 & 2.0 & \\
\hline & 0840 & 958.47 & 0.08 & 0.31 & 314 & 84 & 80 & - & 247 & 62 & 2.0 & \\
\hline & 0855 & 962.12 & 0.08 & 0.31 & 314 & 86 & 82 & - & 249 & 63 & 2.0 & \\
\hline & 0910 & 966.85 & 0.08 & 0.31 & 314 & 87 & $\$ 4$ & - & 246 & 64 & 20 & \\
\hline & 0925 & 971.45 & 0.08 & 0.31 & 315 & 87 & 84 & - & 241 & 65 & 2.0 & \\
\hline & 0940 & 975.93 & 0.08 & 0.31 & 314 & 89 & 87 & - & 243 & 65 & 2,0 & \\
\hline STOp & 0955 & 980.847 & & & & & & & & & & \\
\hline & & & & & & & & & & & & \\
\hline & & & & & & & & & & & & \\
\hline & & & & & & & & & & & & \\
\hline & & & & & & & & & & & & \\
\hline & & & & & & & & & & & & \\
\hline & & & & & & & & & & & & \\
\hline & & & & & & & & & & & & \\
\hline & & & & & & & & & & & & \\
\hline & & & & & & & & & & & & \\
\hline & & & & & & & & & & & & \\
\hline & & & & & & & & & & & & \\
\hline & & & & & & & & & & & & \\
\hline & & & & & & & & & & & & \\
\hline & & & & & & & & & & & & \\
\hline & & & & & & & & & & & & \\
\hline & & & & & & & & & & & & \\
\hline & & & & & & & & & & & & \\
\hline & & & $\sqrt{28 \%}$ & & & & & & & & & \\
\hline Avg. & - & $48,6,27$ & 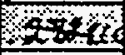 & 3200 & 313 & +1 & 682 & $\$ \$$ & सx & $\%$ & \%४\$ & \\
\hline Check'd & & $4 \%$ & $\% \%$ & $\$ 3$ & खि & खी। & ०ै। & $1 \%$ & & & & \\
\hline
\end{tabular}

Train Size Fract. Particulate Run No.

Time Finish 0955

Diameter

Test Duration $135=$ min.

Initial Leak Rate $0,0 / 4 \mathrm{~cm}$ at $/ 0^{\circ}$

Final Leak Rate $\mathrm{Ma} \mathrm{cfm}$

e 275 inches
Operator Rus 


\section{ORSAT DATA SHEET}

Plant Plant Yates Station Boiler No. 1

Location ESP IN

Run No.

Date

Sorbing Reagents:

$(\mathrm{CO} 2)$

(O2)
Comments

Operator JwM

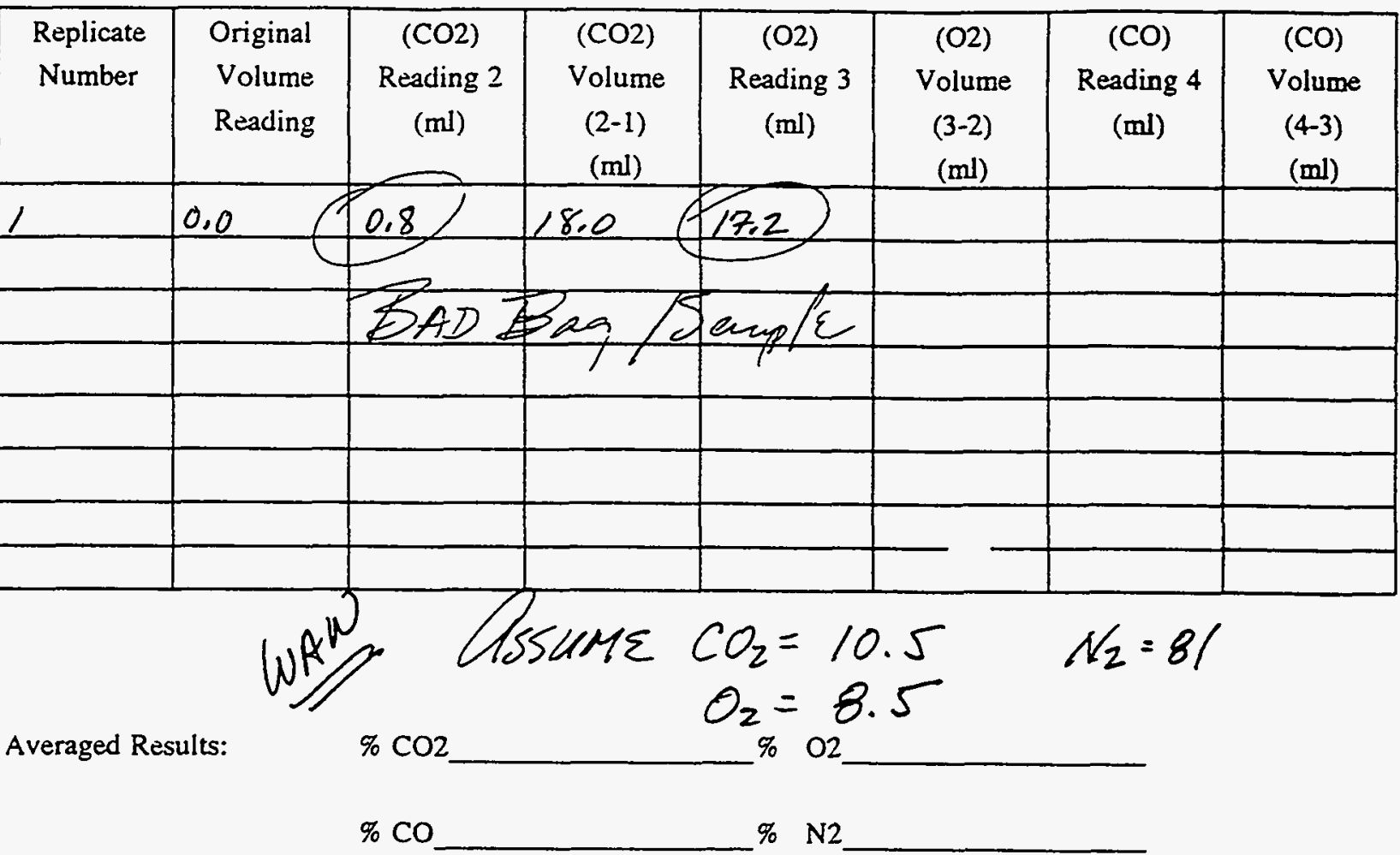

Dry Molecular Weight, MW (dry) =

$$
\begin{aligned}
& =0.44 \underset{(\% \mathrm{CO} 2)}{+0.32}+\frac{0.28}{(\% \mathrm{O} 2)}+(\% \mathrm{CO}+\% \mathrm{~N} 2) \\
& =+\ldots+\ldots \\
& \text { Run \# Train orsat }
\end{aligned}
$$

Component baa

Date $6-21-93$ Time 1930 smplrJWM

Labon site Analysis $\mathrm{CO}_{2} \mathrm{O}_{2}$

Tare Wt.

Final Wt. 


\section{ORSAT DATA SHEET}

Plant Plant Yates Station Boiler No. 1

Location

Run No.

Date Esp Inlet

Sorbing Reagents:

$(\mathrm{CO} 2)$
Comments

Operator Thm / Thp

(O2) (CO)

\begin{tabular}{|c|c|c|c|c|c|c|c|}
\hline $\begin{array}{l}\text { Replicate } \\
\text { Number }\end{array}$ & $\begin{array}{l}\text { Original } \\
\text { Volume } \\
\text { Reading }\end{array}$ & $\begin{array}{l}(\mathrm{CO} 2) \\
\text { Reading } 2 \\
(\mathrm{ml})\end{array}$ & $\begin{array}{c}(\mathrm{CO} 2) \\
\text { Volume } \\
(2-1) \\
(\mathrm{ml})\end{array}$ & $\begin{array}{c}(\mathrm{O} 2) \\
\text { Reading } 3 \\
(\mathrm{ml})\end{array}$ & $\begin{array}{c}(\mathrm{O} 2) \\
\text { Volume } \\
(3-2) \\
(\mathrm{mi})\end{array}$ & $\begin{array}{c}\text { (CO) } \\
\text { Reading } 4 \\
(\mathrm{ml})\end{array}$ & $\begin{array}{c}(\mathrm{CO}) \\
\text { Volume } \\
(4-3) \\
(\mathrm{ml}) \\
\end{array}$ \\
\hline 1 & 0.0 & 10.2 & 10,2 & $\angle 8,0$ & 78 & & \\
\hline 2 & 0.0 & 10,0 & 10,0 & 18.6 & Sile & & \\
\hline 3 & 0,0 & 10.0 & 10,0 & 18.6 & 816 & & \\
\hline & & & & & & & \\
\hline & & & & & & & \\
\hline & & & & & & & \\
\hline & & & & & & & \\
\hline
\end{tabular}

Averaged Results:

$\% \operatorname{co} 2-10.2$

$\% \quad 02 \quad 8.6$

$\% \mathrm{CO}$

* N2 81.2

Dry Molecular Weight, MW (dry) =

$=0.44 \frac{(\% \mathrm{CO} 2)}{(\% \mathrm{O} 2)}+0.32 \quad(\% \mathrm{CO}+\% \mathrm{~N} 2)^{+0.28}$

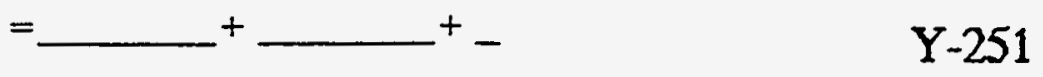

Run 2 Train orsat,

Date $6-22-935$ Time SmpirJwM

Lab en site Analysis $\mathrm{CO}_{2} \mathrm{O}_{2}$

Tare Wt.

Final Wt. 


\section{ORSAT DATA SHEET}

Plant Plant Yates Station Boiler No. 1

Comments

Location ESP inlet

Run No. 3

Date $6 \longdiv { 2 3 / 9 3 }$

Operator TMP

Sorbing Reagents:

$(\mathrm{CO} 2)$

(O2) (CO)

\begin{tabular}{|c|c|c|c|c|c|c|c|}
\hline $\begin{array}{l}\text { Replicate } \\
\text { Number }\end{array}$ & $\begin{array}{l}\text { Original } \\
\text { Volume } \\
\text { Reading }\end{array}$ & $\begin{array}{c}(\mathrm{CO} 2) \\
\text { Reading } 2 \\
(\mathrm{ml})\end{array}$ & $\begin{array}{c}(\mathrm{CO} 2) . \\
\text { Volume } \\
(2-1) \\
(\mathrm{ml}) \\
\end{array}$ & $\begin{array}{c}(\mathrm{O} 2) \\
\text { Reading } 3 \\
(\mathrm{ml})\end{array}$ & $\begin{array}{c}(\mathrm{O} 2) \\
\text { Volume } \\
(3-2) \\
(\mathrm{ml}) \\
\end{array}$ & $\begin{array}{c}\text { (CO) } \\
\text { Reading } 4 \\
(\mathrm{ml})\end{array}$ & $\begin{array}{c}(\mathrm{CO}) \\
\text { Volume } \\
(4-3) \\
(\mathrm{ml}) \\
\end{array}$ \\
\hline 1 & 0.0 & 10.8 & 10.8 & 19.0 & 8.2 & & \\
\hline 2 & 0.0 & 10.9 & 10,9 & 19.4 & 8.5 & & \\
\hline 3 & 0.0 & 10.8 & 10.8 & 19.0 & 8.2 & & \\
\hline & & & & & & & \\
\hline & & & & & & & \\
\hline & & & & & & & \\
\hline & & & & & & & \\
\hline & & & & & & & \\
\hline
\end{tabular}

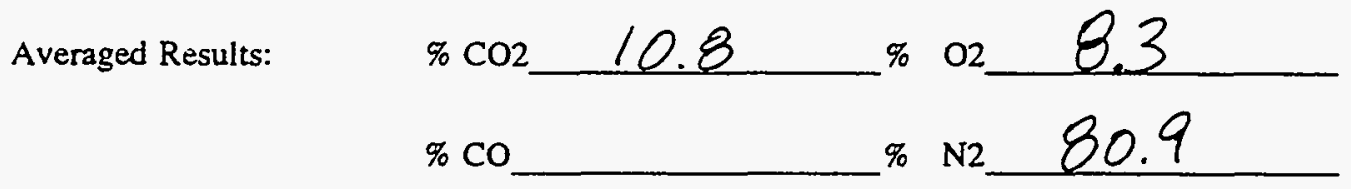

Dry Molecular Weight, MW (dry) =

$$
=0.44 \underbrace{}_{(\% \mathrm{CO} 2)}+0.32 \quad+0.28
$$

$={ }^{+}{ }^{+}+\quad \mathrm{Y}-256$

Run \#3 Train orsat

ESP Inlet ESP Outlet

Stack

Component baca

Date $6-23-93$ Time Smplr IWM

Lab on Site Analysis $\mathrm{CO}_{2} \mathrm{O}_{2}$

Tare Wt.

Final Wt. 


\section{ORSAT DATA SHEET}

Plant____Plant Yates Station Boiler No. 1

Comments

Location ESP Inlet

Run No. Metals Ruy $2-1$

Date $6 / 25 / 93$

Sorbing Reagents:

$(\mathrm{CO} 2)$

(O2)

Operator TMP (CO)

\begin{tabular}{|c|c|c|c|c|c|c|c|}
\hline $\begin{array}{l}\text { Replicate } \\
\text { Number }\end{array}$ & $\begin{array}{l}\text { Original } \\
\text { Volume } \\
\text { Reading }\end{array}$ & $\begin{array}{c}(\mathrm{CO} 2) \\
\text { Reading } 2 \\
(\mathrm{ml})\end{array}$ & $\begin{array}{l}\mathrm{CO} 2) \\
\text { Volume } \\
(2-1) \\
(\mathrm{ml}) \\
\end{array}$ & $\begin{array}{c}(\mathrm{O} 2) \\
\text { Reading } 3 \\
(\mathrm{ml})\end{array}$ & $\begin{array}{c}(\mathrm{O} 2) \\
\text { Volume } \\
(3-2) \\
(\mathrm{ml})\end{array}$ & $\begin{array}{c}\text { (CO) } \\
\text { Reading } 4 \\
(\mathrm{ml})\end{array}$ & $\begin{array}{c}(\mathrm{CO}) \\
\text { Volume } \\
(4-3) \\
(\mathrm{ml}) \\
\end{array}$ \\
\hline i & 0.0 & 10,2 & 10.2 & 19.0 & 8.8 & & \\
\hline 2 & 0.0 & 0.0 & 10,0 & 19.0 & 9.0 & & \\
\hline & & & & & & & \\
\hline & & & & & & & \\
\hline & & & & & & & \\
\hline & & & & & & & \\
\hline & & & & & & & \\
\hline & & & & & & & \\
\hline
\end{tabular}

Averaged Results:

$$
\begin{aligned}
& \% \mathrm{CO} 2 \\
& \% \mathrm{CO}
\end{aligned}
$$

$\% 02 \quad 9.9$

$\% \mathrm{~N} 2$

Dry Molecular Weight, MW (dry) =

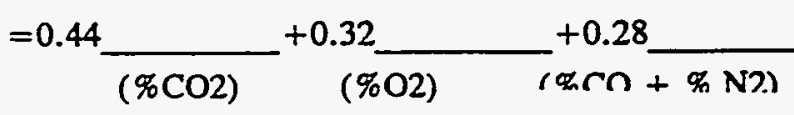

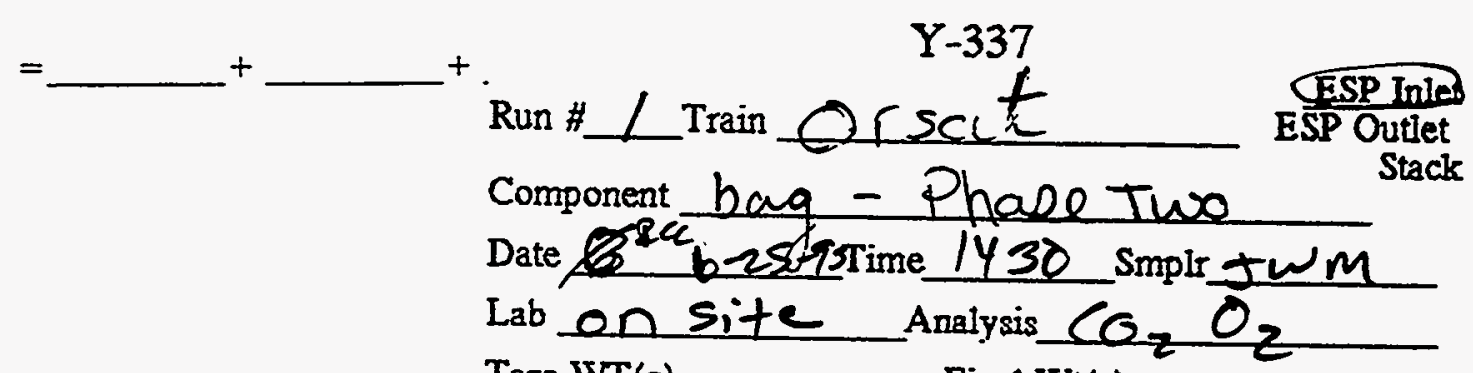




\section{ORSAT DATA SHEET}

Plant Plant Yates Station Boiler No. 1 Location ESP Inlet

Run No.

Date $2-3$ $6 / 27 / 93$
Comments

Operator

TMP

Sorbing Reagents:

$(\mathrm{c} / 2)$

$(\mathrm{O} 2)$ (CO)

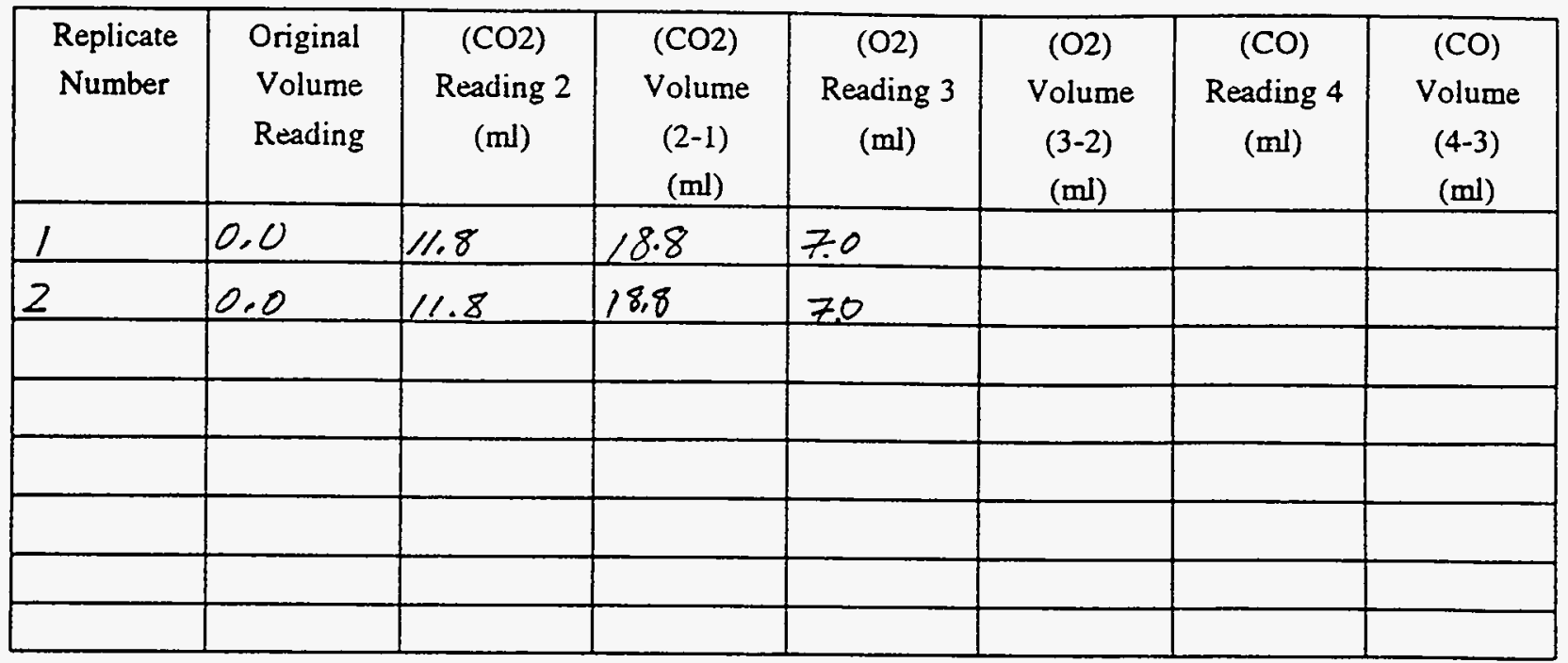

Averaged Results:

$\% \mathrm{CO} 2$

$9 \quad 02 \quad 7.0$

$\% \mathrm{CO}$ $\%$ N2

Dry Molecular Weight, MW (dry) =

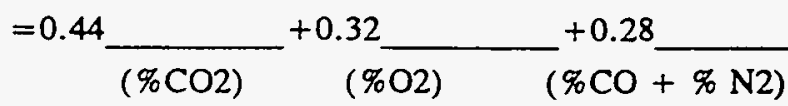

$=$ $+$ $+$

Run \#2-3Train ORSAT

ESP Inld ESP Outlet Stack

Component ORSAT

Date $6 / 27 / 93$ Time 1400 Smplr JWM

Lab on Site Analysis $\mathrm{O}_{2} / \mathrm{CO}_{4}$

Tare WT(g)

Final $W t(g)$ C-213 



\section{TRAVERSE FIELD DATA SHEET}

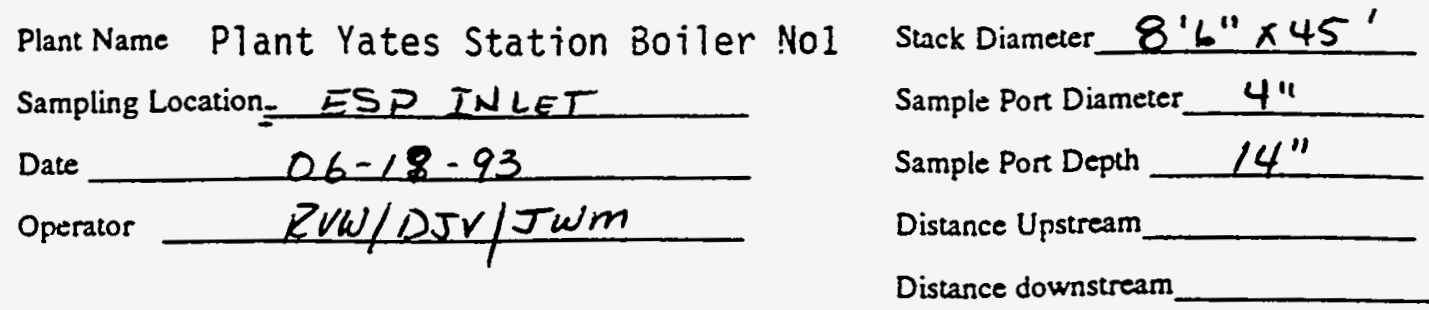

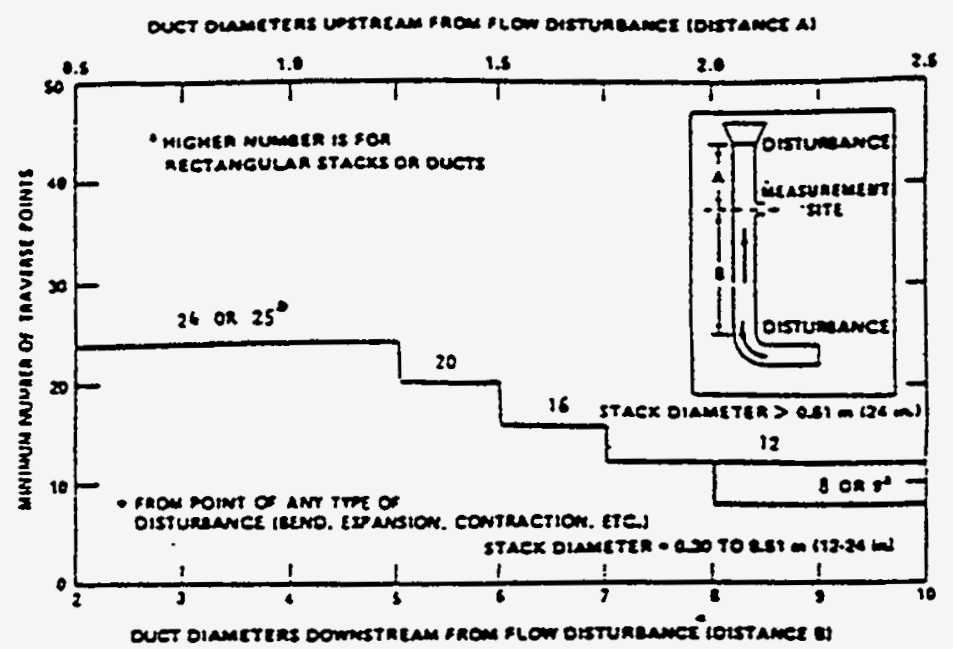

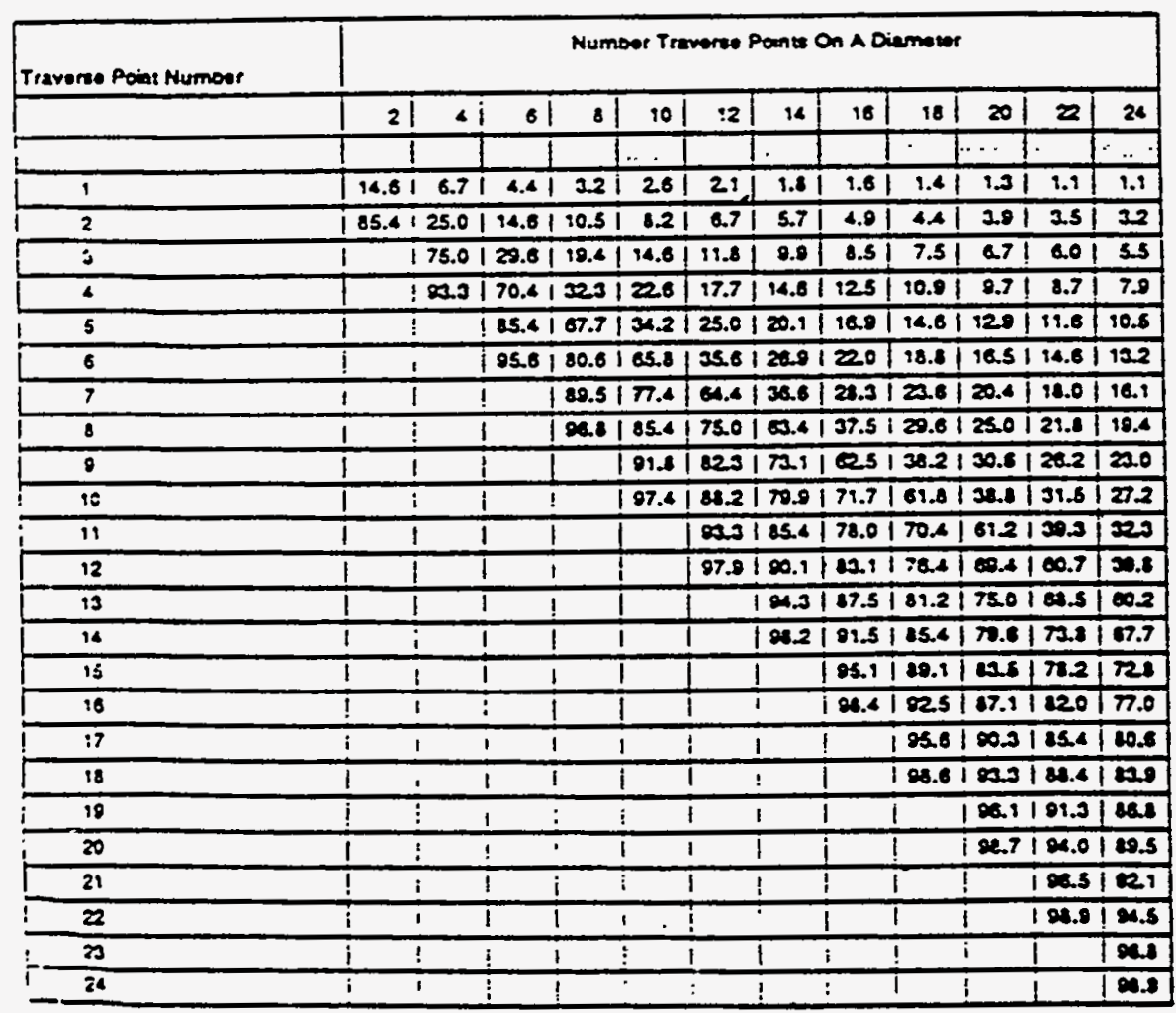

\begin{tabular}{|c|c|}
\hline \multicolumn{2}{|c|}{ Traverse Points } \\
\hline No. & Distance From Wall \\
\hline & 25eT4 loteluase \\
\hline 7 & ــ \\
\hline & 39.5 \\
\hline 3 & 56.5 \\
\hline 4 & 73.5 \\
\hline 5 & 90.5 \\
\hline 6 & 107.5 \\
\hline 7 & \\
\hline 8 & \\
\hline 9 & \\
\hline 70 & \\
\hline 17 & \\
\hline$\sqrt{2}$ & \\
\hline 13 & \\
\hline 74 & \\
\hline 75 & \\
\hline 76 & \\
\hline 77 & \\
\hline 78 & \\
\hline 19 & \\
\hline 20 & \\
\hline 27 & \\
\hline 22 & \\
\hline 23 & \\
\hline 24 & \\
\hline
\end{tabular}





\section{VELOCITY PROFILE FIELD DATA}

Piant Name Inlet Preliminary velaity traverse 75 mw Production Sampling Location Inlet Sample Ident.

Date 6/19/43 (MMDDYY) Time Start 1100 (HHMM) Time Finish 1230 (HHMM) Duct Dimensions $8.5^{\prime}$ $45^{\prime}$ ft. or Diameter H. PTCF 0.84

Bar Press. 29.58

Static Press. $-6.5$

Operator Initials
\& DJV, JWM

$$
\% \mathrm{H}_{2} \mathrm{O} z 7.0
$$

$\% \mathrm{CO}$ $\mathrm{H}_{2} \mathrm{O}$
9.0 7.4
$\% \mathrm{~N}_{2}$

$\% \mathrm{H}_{2}$ $\% \mathrm{CH}_{4}$

1 all the way in

\begin{tabular}{|c|c|c|c|c|c|c|c|c|c|}
\hline \multirow[b]{2}{*}{ PI. } & \multicolumn{3}{|c|}{ Stack Tomp. of } & \multicolumn{3}{|c|}{ Velocity Pressure $" \mathrm{H}_{2} \mathrm{O}$} & \multicolumn{2}{|c|}{ Other I } & \\
\hline & $\# 1$ & 12 & Ave. & $n$ & 12 & Ave. & $n$ & 12 & Ave. \\
\hline$E 1-1$ & 283 & 284 & & $0.055^{\circ}$ & 0.06 & & & & \\
\hline 2 & 285 & 285 & & 0,06 & 206 & & & & \\
\hline 3 & 285 & 287 & & 0,0 & 0035 & & & & \\
\hline 4 & 284 & 285 & & 0.025 & 0.02 & & & & \\
\hline 5 & 283 & 283 & & 0025 & 003 & & & & \\
\hline$C_{2}$ & 269 & 265 & & 0.02 & 0.03 & & & & \\
\hline$E_{2}-1$ & 281 & 282 & & 0.02 & 0.02 & & & & \\
\hline 2 & 282 & 283 & & 0,02 & $0.015^{-}$ & & & & \\
\hline 3 & 254 & 284 & & 0,01 & 0,02 & & & & \\
\hline 4 & 282 & 282 & & 0.03 & 0,02 & & & & \\
\hline & 274 & 275 & & 0.04 & 0.03 & & & & \\
\hline & 261 & 263 & & 0,0 & 0.05 & & & & \\
\hline$F 3-1$ & 294 & & & 0.02 & & & & & \\
\hline 2 & 295 & & & 0.02 & & & & & \\
\hline 3 & 255 & & & 0.04 & & & & & \\
\hline 4 & 256 & & & 0.08 & & & & & \\
\hline 5 & & & & 0.09 & & & & & \\
\hline & 20 & & & 0.13 & & & & & \\
\hline
\end{tabular}

Weather Ave $\sqrt{d p}=0.2537$ Stack Tamp: $283^{\circ} \mathrm{F}$

Piemarks Vel $=17.12$ fos ACFM $=393,904$ DSCFM 


\section{VELOCITY PROFILE FIELD DATA}

Plant Name

Sampling Location

Date (MMDDYY) Time Start

Duct Dimensions __ $x$

PTCF

Bar Press.

Static Press.

Operator Initials

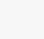

Sample Ident.

(HHMM) Time Finish

(HHMM)

ft. or Diameter

ft.

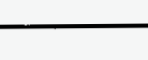




\section{VELOCITY PROFILE FIELD DATA}

Plant Name

Sampling Location

Date (MMDOYY) Time Start

Duct Dimensions

PTCF

Bar Press.

Static Press. $\frac{0.6-6.4}{} \mathrm{H}_{2} \mathrm{O}$

Operator Initials

$x$
Sample Ident.

(HHMM) Time Finish

ft. or Diameter

(HHMM)

$\% \mathrm{H}_{2} \mathrm{O}$

$\%$ CO

$\% \mathrm{CO}_{2}$ $\% \mathrm{O}_{2}$
$\% \mathrm{~N}_{2}$

$\% \mathrm{H}_{2}$

$\% \mathrm{CH}_{4}$

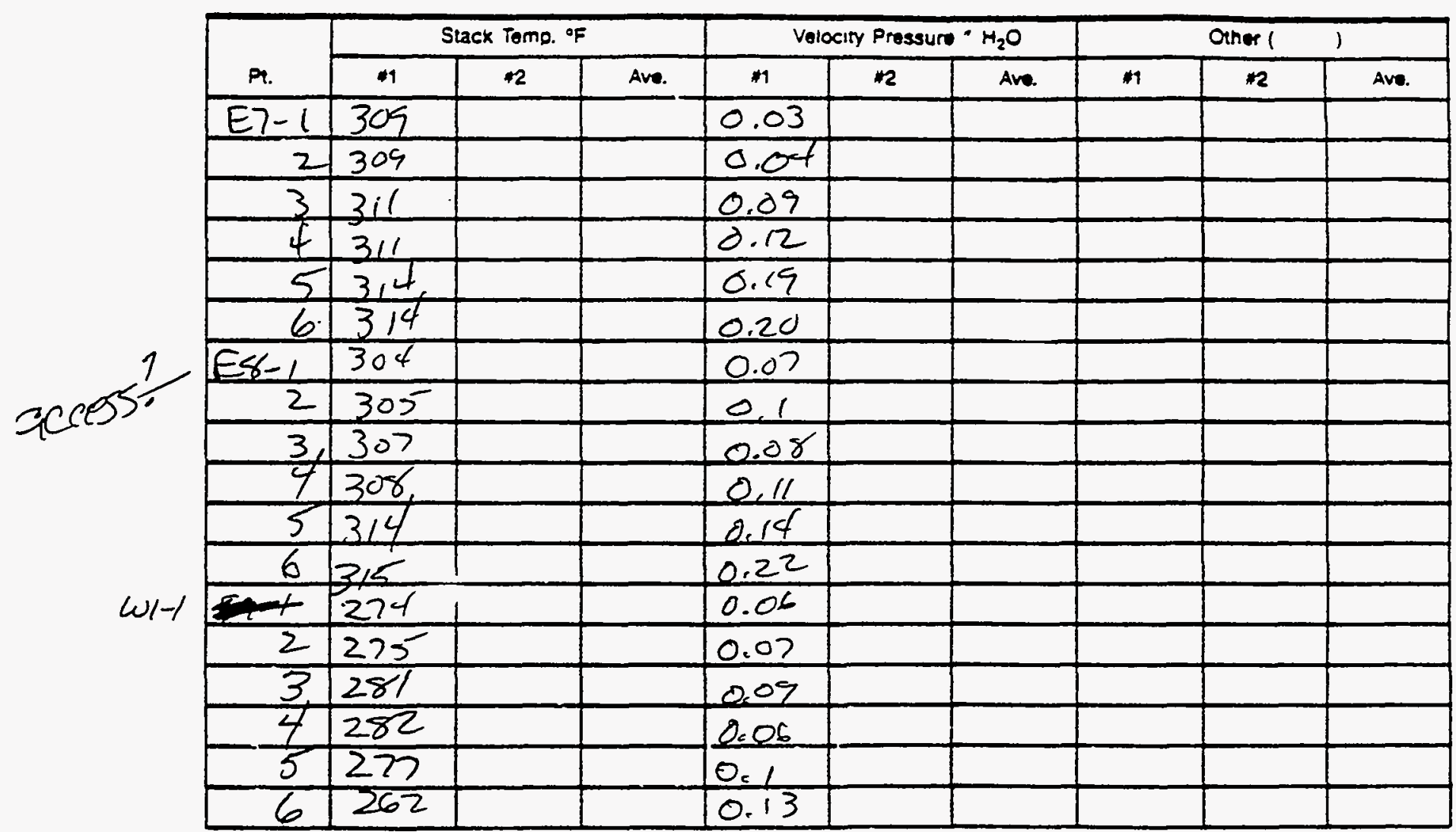

Weather

Remarks 


\section{VELOCITY PROFILE FIELD DATA}

Plant Name

Sampling Location

Date

Duct Dimensions PTCF

Bar Press.

Static Press.

Operator Initials
Sample Ident.

(HHMM) Time Finish

ft. or Diameter (HHMM) (MMDOYY) Time Start $x$
$\% \mathrm{H}_{2} \mathrm{O}$

$\% \mathrm{CO}$

$\% \mathrm{CO}_{2}$ $\% \mathrm{O}_{2}$
$\% \mathrm{~N}_{2}$

$\% \mathrm{H}_{2}$

$\% \mathrm{CH}_{4}$

\begin{tabular}{|c|c|c|c|c|c|c|c|c|c|}
\hline \multirow[b]{2}{*}{ P. } & \multicolumn{3}{|c|}{ Stack Tomb. of } & \multicolumn{3}{|c|}{ Velocty Pressure - $\mathrm{H}_{2} \mathrm{O}$} & \multicolumn{2}{|c|}{ Other I } & 1 \\
\hline & 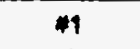 & *2 & Ave. & $n$ & $* 2$ & Ave. & $m$ & 12 & Ave. \\
\hline$w_{2}-1$ & 273 & & & 0.04 & & & & & \\
\hline 2 & 277 & & & 0.03 & & & & & \\
\hline 3 & 277 & & & 10.05 & & & & & \\
\hline 4 & 279 & & & 0,07 & & & & & \\
\hline 5 & 286 & & & 0.16 & & & & & \\
\hline 6 & 226 & & & 0.15 & & & & & \\
\hline$w 3-1$ & 278 & & & 0,02 & & & & & \\
\hline 2 & 202 & & & 0.04 & & & & & \\
\hline 3 & 284 & & & 0,06 & & & & & \\
\hline 4 & 283 & & & 0.13 & & & & & \\
\hline 5 & 281 & & & 0,17 & & & & & \\
\hline 6 & 279 & & & 0,15 & & & & & \\
\hline$i v 3 t-1$ & 284 & & & 0.03 & & & & & \\
\hline 2 & $2 \gamma 0$ & & & 0.05 & & & & & \\
\hline 3 & 282 & & & 0.08 & & & & & \\
\hline 7 & 289 & & & 0.13 & & & & & \\
\hline$\frac{1}{5}$ & 280 & & & 0,67 & & & & & \\
\hline 6 & 272 & & & 0.13 & & & & & \\
\hline
\end{tabular}

Weather

Remarks 


\section{VELOCITY PROFILE FIELD DATA}

Plant Name

Sampling Location

Sample Ident.

Date (MMDOYY) Time Star (HHMM) Time Finish

Duct Dimensions

ft. or Diameter (HHMM) PTCF $x$

Bar Press.

Static Press.

Operator Initials

$\% \mathrm{H}_{2} \mathrm{O}$
$" \mathrm{Hg} \% \mathrm{CO}$
$" \mathrm{H}_{2} \mathrm{O} \% \mathrm{CO}_{2}$

$\% \mathrm{~N}_{2}$

$\% \mathrm{H}_{2}$

$\% \mathrm{CH}_{4}$

\begin{tabular}{|c|c|c|c|c|c|c|c|c|c|}
\hline \multirow[b]{2}{*}{ P. } & \multicolumn{3}{|c|}{ Stack Tomp. ${ }^{\circ} \mathrm{F}$} & \multicolumn{3}{|c|}{ Velocity Prossure $-\mathrm{H}_{2} \mathrm{O}$} & \multicolumn{2}{|c|}{ Other 1} & \\
\hline & $m$ & +2 & Ave. & $" 1$ & 22 & Ave. & $m$ & 12 & Ave. \\
\hline $655-1$ & 275 & & & 0.04 & & & & & \\
\hline 2 & 275 & & & 0.06 & & & & & \\
\hline 3 & $2+4$ & & & 0.10 & & & & & \\
\hline 4 & 277 & & & 0.11 & & & & & \\
\hline 5 & 273 & & & 0.13 & & & & & \\
\hline 6 & 262 & & & 0.15 & & & & & \\
\hline$\omega 6-1$ & 266 & & & $0.0^{3}$ & & & & & \\
\hline 2 & 266 & & & 0,03 & & & & & \\
\hline 3 & 272 & & & 0.05 & & & & & \\
\hline 4 & 271 & & & 0.06 & & & & & \\
\hline 5 & 265 & & & 0.0 & & & & & \\
\hline 6 & 261 & & & 0,16 & & & & & \\
\hline$\omega 7-1$ & 260 & & & 0.02 & & & & & \\
\hline 2 & 263 & & & 0.02 & & & & & \\
\hline 3 & 263 & & & 0.02 & & & & & \\
\hline 4 & 258 & & & 0.02 & & & & & \\
\hline 5 & 260 & & & 0.04 & & & & & \\
\hline 6 & 243 & & & 0.04 & & & & & \\
\hline
\end{tabular}

Weather

Remarks 


\section{VELOCITY PROFILE FIELD DATA}

Plant Name

Sampling Location

Date (MMDOYY) Time Start

Duet Dimensions

PTCF 0.84

Bar Press.

Static Press.

Operator Initials
29.58

$-6.4$

Jwk
Sample Ident.

(HHMM) Time Finish

(HHMM)

ft. or Diameter

ft.

$\% \mathrm{H}_{2} \mathrm{O} \approx 7.0$

$" \mathrm{Hg} \% \mathrm{CO}=\% \mathrm{~N}_{2}$

$" \mathrm{H}_{2} \mathrm{O} \% \mathrm{CO}_{2} \longrightarrow \% \mathrm{H}_{2}$

$\% \mathrm{O}_{2}-7.4 \quad \% \mathrm{CH}_{4}$

\begin{tabular}{|c|c|c|c|c|c|c|c|c|c|}
\hline \multirow[b]{2}{*}{ q. } & \multicolumn{3}{|c|}{ Stack Tomp. of } & \multicolumn{3}{|c|}{ Veiccity Prossure " $\mathrm{H}_{2} \mathrm{O}$} & \multicolumn{2}{|c|}{ Other ( } & \\
\hline & 41 & 42 & Ave. & $n 1$ & $\# 2$ & Ave. & $n$ & 12 & Ave. \\
\hline $6 \sqrt{8}-1$ & 254 & & & 0.04 & & & & & \\
\hline 2 & 262 & & & 0.09 & & & & & \\
\hline 3 & 267 & & & 0.02 & & & & & \\
\hline 7 & 264 & & & 0.01 & & & & & \\
\hline 5 & 250 & & & 0.02 & & & & & \\
\hline 6 & 253 & & & 0.08 & & & & & \\
\hline & & & & & & & & & \\
\hline & & & & & & & & & \\
\hline & & & & & & & & & \\
\hline & & & & & & & & & \\
\hline & & & & & & & & & \\
\hline & & & & & & & & & \\
\hline & & & & & & & & & \\
\hline & & & & & & & & & \\
\hline & & & & & & & & & \\
\hline & & & & & & & & & \\
\hline & & & & 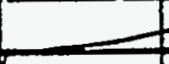 & & & & & \\
\hline & 282.9 & & & 0.2556 & & & & & \\
\hline
\end{tabular}

Weather

$V e l=17.113$

ACEM $=191,966$

Remarks

DSCEN $=123,417$

Facing parts

C- 222

(East) El

$\leqslant 8$

$w-1$

Wr cwest 


\section{APPENDIX D: QUALITY ASSURANCE/QUALITY CONTROL}

Appendix D presents a summary of analytical results for QC samples, estimates of measurement precision and accuracy based on analysis of QC samples, and potential limitations in the use of the data.

Overall, QA/QC data associated with this program indicate that measurement data are acceptable and defensible. The $\mathrm{QA} / \mathrm{QC}$ data indicate that the quality control mechanisms were effective in ensuring measurement data reliability within the expected limits of sampling and analytical error.

Quality control data provide information for identifying and defining qualitative limitations associated with measurement data. The following key types of $\mathrm{QC}$ procedures provide the primary basis for quantitatively evaluating data quality:

- Field and laboratory blank samples;

- Duplicate field samples;

- Matrix and surrogate spiked samples;

- Laboratory control samples; and

- Performance evaluation (audit) samples.

Additional details of the project QA/QC program are documented in the DOE Quality Assurance Project Plan.

\section{Sample Collection}

Several factors are evaluated to determine acceptable sample collection. Key components of the sampling equipment including the Pitot tubes, thermocouples, orifice meters, dry gas meters, and sampling nozzles were calibrated in the Radian Source Sampling Laboratory before use in the field. These calibrations were also checked after the equipment was returned to the laboratory after the field activities. The presampling calibrations were reviewed by the Radian QA Coordinator as part of the on-site Technical Systems audit. 
Appendix D: Quality Assurance/Quality Control

These calibrations as well as the post sampling calibrations are on file at Radian Corporation. Standard EPA methods or other acceptable sampling methods were used to collect the organic, metal, and anion samples. The sampling runs were well documented, and all gas samples were collected at rates of between 90 and $110 \%$ of the isokinetic rates. Sufficient data were collected to ensure acceptable data completeness and comparability of the measurements.

Gas samples were collected from the ESP inlet, ESP outlet, and stack as integrated samples for most analyses over a specified time period. Solid samples of coal, limestone, bottom ash, ESP fly ash, and FGD slurry were collected at hourly intervals over each of the test runs. These individual grabs were combined to provide a single composite sample of each stream for each of the three test runs. Liquid streams were also collected as hourly grabs which were combined to provide a single composite for analysis for each test run. Liquid streams include the ash pond, gypsum recycle water, ash sluice filtrates, FGD slurry filtrate, limestone slurry filtrate, and the inlet and outlet to the condenser. All sampling was conducted while the plant was operating at 85 to $100 \%$ of full load and should be representative of typical operation for Plant Yates.

\section{Analytical Quality Control Results}

Generally, the type of quality control information obtained pertains to measurement precision, accuracy (which includes precision and bias), and blank effects that are determined using various types of replicate, spiked and blank samples. The specific characteristics evaluated depend on the type of quality control checks performed. For example, blanks may be prepared at different stages in the sampling and analysis process to isolate the source of the blank effect. Similarly, replicate samples may be generated at different stages to isolate and measure sources of variability. The QA/QC measures used as part of this program data evaluation protocol and the characteristic information obtained are summarized in Table D-1. The absence of any of these types of quality control checks from the data for a particular analytical technique does not necessarily reflect poorly on the quality of the data but does limit the ability to estimate the magnitude of the measurement error and hence, prevents placing an estimate of confidence in the results.

As shown in Table D-1, different QC checks provide different types of information, particularly pertaining to the sources of inaccuracy, imprecision, and blank effects. As part of this program, measurement precision and accuracy are typically being estimated from QC indicators that cover as much of the total sampling and analytical process as feasible. Precision and accuracy measurements are based primarily on the actual sample matrix. The precision and accuracy estimates obtained experimentally during the test program are compared to the data quality objectives (DQOs) established for the program as listed in the project QAPP.

These DQOs were not intended to be used as validation criteria but as empirical estimates of the precision and accuracy that would be expected from existing. reference measurement methods and that would be considered acceptable. The precision and accuracy objectives are not necessarily derived from analyses of the same types of samples being investigated. 
Table D-1

Types of Quality Control Samples

QC Activity

Characteristic Measured

\section{Precision}

Replicate samples collected over time under the same conditions

Duplicate field samples collected simultaneously

Duplicate Analyses of a Single Sample

Matrix- or Media-Spiked Duplicates

Laboratory Control Sample Duplicates

Surrogate-Spiked Sample Sets

Accuracy (Including Bias and Precision)

Matrix-Spiked Samples

Media-Spiked Samples

Surrogate-Spiked Samples

Laboratory Control Samples (LCS)
Total variability, including process or temporal, sampling, and analytical, but not bias.

Sampling plus analytical variability at the actual sample concentrations.

Analytical variability at the actual sample concentrations.

Sampling plus analytical variability at an established concentration.

Analytical variability in the absence of sample matrix effects.

Analytical variability in the sample matrix but at an established concentration.

Analyte recovery in the sample matrix, indicating possible matrix interferences and other effects. In a single sample indicates both random error (imprecision) and systematic error (bias).

Same as matrix-spiked samples. Used where a matrix-spiked sample is not feasible, such as the stack sampling methods.

Analyte recovery in the sample matrix, to the extent that the surrogate compounds are chemically similar to the compounds of interest. Primarily used as indicator of analytical efficacy.

Analyte recovery in the absence of actual sample matrix effects. Used as an indicator of analytical control. 
Appendix D: Quality Assurance/Quality Control

Table D-1 (Continued)

QC Activity

Standard Reference Material

\section{Blank Effects}

Field Blank

Trip Blank

Method Blank

Reagent Blank

\section{Characteristic Measured}

Analyte recovery in a matrix similar to the actual samples.

Total sampling plus analytical blank effect, including sampling equipment and reagents, sample transport and storage, and analytical reagents and equipment.

Blank effects arising from sample transport and storage. Typically only used for volatile organic compound analyses.

Blank effects inherent in analytical method, including reagents and equipment.

Blank effects from reagents used. 
Although analytical precision and accuracy are relatively easy to quantify and control, sampling precision and accuracy are unique to each sample matrix. Data that do not meet these objectives are not necessarily unacceptable. Rather, the intent is to document the precision and accuracy obtained, and the objectives serve as benchmarks for comparison. The effects of not meeting the objectives should be considered in light of the intended use of the data.

Table D-2 presents the types of quality control data reported for the program and a summary of precision and accuracy estimates. Almost all of the quality control results met the project objectives.

The following potential problems were identified by the quality control data.

- Chloromethane, methylene chloride, and tetrachloroethene were found in one or more of the field blanks analyzed for VOST. In many cases, the same concentrations were also found in the field samples.

- A standard limestone sample (NIST 1C) was submitted blind as a performance audit sample. Aluminum, silicon, and sodium recoveries in this sample were below $50 \%$, and the recovery of potassium was greater than 200 percent. This may indicate a similar low bias for these elements in the limestone process streams.

- Selenium showed no spike recovery in the impinger solutions analyzed by GFAAS. However, selenium recoveries in the audit samples submitted by RTI showed recoveries of 104 and 113 percent.

A discussion of the overall measurement precision, accuracy and blank effects is presented below for each measurement type.

Precision is a measure of the reproducibility of measurements under a given set of conditions. It is expressed in terms of the distribution, or scatter, of the data, calculated as the standard deviation or coefficient of variation ( $\mathrm{CV}$, standard deviation divided by the mean). For duplicates, precision is expressed as the relative percent difference (RPD).

Accuracy is a measure of the degree of conformity of a value generated by a specific procedure to be assumed or accepted true value, and includes both precision and bias. Bias is the persistent positive or negative deviation of the method average value from the assumed or accepted true value.

The efficiency of the analytical procedure for a given sample matrix is quantified by the analysis of spiked samples containing target or indicator analytes or other quality assurance measures, as necessary. However, all spikes, unless made to the flowing stream ahead of the sampling, produce only estimates of the recovery of the analyte through all of the measurement steps occurring after the addition of the spike. A good spike recovery tells little about the true value of the sample before spiking. 
Table D-2

Summary of Precision and Accuracy Estimates

\begin{tabular}{|c|c|c|c|c|c|}
\hline \multirow[b]{2}{*}{ Measurement Parameter } & \multirow[b]{2}{*}{ How Measured } & \multicolumn{2}{|c|}{ Objectives } & \multicolumn{2}{|c|}{ Measured } \\
\hline & & $\begin{array}{l}\text { Precision } \\
\text { (\% RPD) }\end{array}$ & $\begin{array}{c}\text { Accuracy } \\
\text { (\% Recovery) }\end{array}$ & $\begin{array}{l}\text { Precision } \\
\text { (\% RPD) }\end{array}$ & $\begin{array}{c}\text { Accuracy } \\
\text { (\% Recovery) }\end{array}$ \\
\hline $\begin{array}{l}\text { Semivolatile Organics in Gas Solid Phase - } \\
\text { sw8270 }\end{array}$ & $\begin{array}{l}\text { Precision- Matrix-Spiked Duplicates } \\
\text { Accuracy - Matrix Spikes }\end{array}$ & & & & \\
\hline Acenaphthene & & 54 & $47-145$ & 4.1 & 86 \\
\hline 4-Chloro-3-methylphenol & & 69 & $22-147$ & 5.0 & 84 \\
\hline 2-Chlorophenol & & 62 & $23-134$ & 3.0 & 82 \\
\hline 1,4-Dichlorobenzene & & 58 & $20-124$ & 3.2 & 80 \\
\hline 2,4-Dinitrotoluene & & 55 & $39-139$ & 3.2 & 78 \\
\hline n-Nitrosodipropylamine & & 130 & $0.1-230$ & 6.3 & 60 \\
\hline 4-Nitrophenol & & 78 & $0.1-132$ & 7.0 & 89 \\
\hline Pentachlorophenol & & 84 & $14-176$ & 9.0 & 45 \\
\hline Phenol & & 43 & $5-112$ & 3.4 & 58 \\
\hline Pyrede & & 36 & $52-115$ & 4.1 & 86 \\
\hline 1,2,4-Trichlorobemzene & & 55 & $44-142$ & 4.0 & 90 \\
\hline $\begin{array}{l}\text { Semivolatile Organics in Fly Ash - } \\
\text { Sw8270 }\end{array}$ & $\begin{array}{l}\text { Precision- Matrix-Spiked Duplicates } \\
\text { Accuracy - Matrix Spikes }\end{array}$ & & & & \\
\hline Acenaphthene & & 54 & $47-145$ & 1.3 & 82 \\
\hline 4-Chloro-3-methylphenol & & 69 & $22-147$ & 5.6 & 84 \\
\hline 2-Chlorophenol & & 62 & $23-134$ & 1.8 & 84 \\
\hline 1,4-Dichlorobenzene & & 58 & $20-124$ & 2.5 & 81 \\
\hline 2,4-Dinitrotoluene & & 55 & $39-139$ & 2.7 & 76 \\
\hline n-Nitrosodipropylamine & & 130 & $0.1-230$ & 7.8 & 60 \\
\hline 4-Nitrophenol & & 78 & $0.1-132$ & 37 & 49 \\
\hline Pentachlorophenol & & 84 & $14-176$ & 5.3 & 64 \\
\hline Phenol & & 43 & $5-112$ & 2.7 & 76 \\
\hline Pyrene & & 36 & $52-115$ & 17.7 & $48 Q$ \\
\hline 1,2,4-Trichlorobenzene & & 55 & $44-142$ & 1.2 & 89 \\
\hline $\begin{array}{l}\text { Semivolatile Organics in FGD Solids - } \\
\text { sw8270 }\end{array}$ & $\begin{array}{l}\text { Precision- Matrix-Spiked Duplicates } \\
\text { Accuracy - Matrix Spikes }\end{array}$ & & & & \\
\hline Acensphthene & & 54 & $47-145$ & 7.3 & 82 \\
\hline 4-Chloro-3-methylphenol & & 69 & $22-147$ & 9.3 & 76 \\
\hline 2-Chlorophenol & & 62 & $23-134$ & 7.1 & 84 \\
\hline 1,4-Dichlorobenzene & & 58 & $20-124$ & 8.7 & 80 \\
\hline 2,4-Dinitrotoluene & & 55 & $39-139$ & 4.0 & 74 \\
\hline n-Nitrosodipropylamine & & 130 & $0.1-230$ & 14 & 52 \\
\hline 4Nitrophenol & & 78 & $0.1-132$ & 14 & 92 \\
\hline Pentachlorophenol & & 84 & $14-176$ & 4.1 & 74 \\
\hline Phenol & & 43 & $5-112$ & 5.5 & 73 \\
\hline Pyrene & & 36 & $52-115$ & 4.4 & 90 \\
\hline 1,2,4-Trichlorobenzene & & 55 & $44-142$ & 9.8 & 92 \\
\hline $\begin{array}{l}\text { Semivolatile Organics in Aqueous Streams } \\
\text { - SW8270 }\end{array}$ & $\begin{array}{l}\text { Precision- Matrix-Spiked Duplicates } \\
\text { Accuracy - Matrix Spikes }\end{array}$ & & & & \\
\hline Acenaphthene & & 54 & $47-145$ & 11 & 79 \\
\hline 4-Chloro-3-methylphenol & & 69 & $22-147$ & 10 & 83 \\
\hline 2-Chlorophenol & & 62 & 23-134 & 10 & 80 \\
\hline 1,4-Dichlorobenzene & & 58 & $20-124$ & 6.8 & 72 \\
\hline 2,4-Dinitrotoluene & & 55 & $39-139$ & 7.4 & 82 \\
\hline n-Nitrosodipropylamine & & 130 & $0.1-230$ & 12 & 75 \\
\hline 4-Nitrophenol & & 78 & $0.1-132$ & 8.6 & 47 \\
\hline Pentachlorophenol & & 84 & $14-176$ & 11 & 72 \\
\hline Phenol & & 43 & $5-112$ & 12 & 40 \\
\hline Pyrene & & 36 & $52-115$ & 7.6 & 78 \\
\hline 1,2,4-Trichlorobenzene & & 55 & $44-142$ & 9.7 & . 82 \\
\hline
\end{tabular}


Table D-2 (Continued)

\begin{tabular}{|c|c|c|c|c|c|}
\hline \multirow[b]{2}{*}{ Measurement Parameter } & \multirow[b]{2}{*}{ How Measured } & \multicolumn{2}{|c|}{ Objectives } & \multicolumn{2}{|c|}{ Messured } \\
\hline & & $\begin{array}{l}\text { Precision } \\
\text { (\% RPD) }\end{array}$ & $\begin{array}{c}\text { Accuracy } \\
\text { (\% Recovery) }\end{array}$ & $\begin{array}{l}\text { Precision } \\
\text { (\% RPD) }\end{array}$ & $\begin{array}{c}\text { Accuracy } \\
\text { (\% Recovery) }\end{array}$ \\
\hline $\begin{array}{l}\text { Dioxins and Furans in Stack Gas Solid } \\
\text { Phase }\end{array}$ & $\begin{array}{l}\text { Precision: NA } \\
\text { Accuracy: Internal Standard Recovery }\end{array}$ & & & & \\
\hline${ }^{19} \mathrm{C}_{\mathrm{tz}}-2,3,7,8-\mathrm{TCDF}$ & & 50 & $40-120$ & & 60 \\
\hline${ }^{19} \mathrm{C}_{12}-2,3,7,8-\mathrm{TCDD}$ & & 50 & $40-120$ & & 61 \\
\hline${ }^{13} \mathrm{C}_{12}-1,2,3,7,8-\mathrm{PeCDF}$ & & 50 & $40-120$ & & 56 \\
\hline${ }^{13} \mathrm{C}_{12}-1,2,3,7,8-\mathrm{PeCDD}$ & & 50 & $40-120$ & & 63 \\
\hline${ }^{19} \mathrm{C}_{12}-1,2,3,6,7,8-\mathrm{Hx} C D F$ & & 50 & $40-120$ & & 69 \\
\hline${ }^{19} \mathrm{C}_{12-}-1,2,3,6,7,8-\mathrm{HxCDD}$ & & 50 & $40-120$ & & 69 \\
\hline${ }^{19} \mathrm{C}_{12}-1,2,3,4,6,7,8-\mathrm{HpCDF}$ & & 50 & $40-120$ & & 57 \\
\hline${ }^{19} \mathrm{C}_{12}-1,2,3,4,6,7,8-\mathrm{HpCDD}$ & & 50 & $40-120$ & & 64 \\
\hline${ }^{19} \mathrm{C}_{12}-1,2,3,4,6,7,8,9-\mathrm{OCDD}$ & & 50 & $40-120$ & & 50 \\
\hline \multirow[t]{2}{*}{ PCDD/PCDF } & Precision - NA & & & & \\
\hline & $\begin{array}{l}\text { Accuracy - Internal Standard Recovery, } \\
\text { average for all samples analyzed. }\end{array}$ & & & & \\
\hline${ }^{19} \mathrm{C}_{12} 2,3,7,8-\mathrm{TCDF}$ & & & $40-120$ & & 57.2 \\
\hline${ }^{13} \mathrm{C}_{12}-2,3,7,8-\mathrm{TCDD}$ & & & $40-120$ & & 54.7 \\
\hline${ }^{19} \mathrm{C}_{12}-1,2,3,7,8-\mathrm{PeCDF}$ & & & $40-120$ & & 55.7 \\
\hline${ }^{19} \mathrm{C}_{12}-1,2,3,7,8-\mathrm{PeCDD}$ & & & $40-120$ & & 63.3 \\
\hline${ }^{13} \mathrm{C}_{12}-1,2,3,6,7,8-\mathrm{HxCDF}$ & & & $40-120$ & & 69.2 \\
\hline${ }^{13} \mathrm{C}_{12}-1,2,3,6,7,8-\mathrm{HxCDD}$ & & & $40-120$ & & 69.0 \\
\hline${ }^{19} \mathrm{C}_{12}-1,2,3,4,6,7,8-\mathrm{HpCDF}$ & & & $40-120$ & & 57.1 \\
\hline${ }^{13} \mathrm{C}_{12}-1,2,3,4,6,7,8-\mathrm{HpCDD}$ & & & $40-120$ & & 63.6 \\
\hline${ }^{13} \mathrm{C}_{12}-1,2,3,4,6,7,8,9-\mathrm{OCDD}$ & & & $40-120$ & & 50.0 \\
\hline \multirow[t]{2}{*}{ PCDD/PCDF in Stack Gas } & Precision - NA & & & & \\
\hline & $\begin{array}{l}\text { Accuracy - Surrogate Spike Recovery, } \\
\text { average for all samples analyzed. }\end{array}$ & & & & \\
\hline${ }^{5} \mathrm{Cl}_{4}-2,3,7,8-\mathrm{TCDD}$ & & & $70-130$ & & 118.4 \\
\hline${ }^{13} \mathrm{C}_{12}-2,3,4,7,8-\mathrm{PeCDF}$ & & & $70-130$ & & 113.2 \\
\hline${ }^{31} \mathrm{C}_{12}-1,2,3,4,7,8-\mathrm{HxCDF}$ & & & $70-130$ & & 120.8 \\
\hline${ }^{13} \mathrm{C}_{12}-1,2,3,4,7,8-\mathrm{HxCDD}$ & & & $70-130$ & & 141.6 \\
\hline${ }^{13} \mathrm{C}_{12}-1,2,3,4,7,8,9-\mathrm{HpCDF}$ & & & $70-130$ & & 104.7 \\
\hline${ }^{19} \mathrm{C}_{12}-1,2,3,7,8,9-\mathrm{H} \times \mathrm{CDF}$ & & & $70-130$ & & 75.4 \\
\hline${ }^{13} \mathrm{C}_{12}-2,3,4,6,7,8-\mathrm{HxCDF}$ & & & $70-130$ & & 84.3 \\
\hline Volatile Organics in Vapor Phase - & Precision - NA & & & & \\
\hline SW8240 & Accuracy - Surrogate Spike Recovery & & & & \\
\hline 1,2-Dichloroethane-d4 & & 50 & $70-130$ & & 114 \\
\hline Toluene-d8 & & 50 & $70-130$ & & 101 \\
\hline 4-Bromofluorobenzene & & 50 & $70-130$ & & 108 \\
\hline Aldehydes in Vapor Phase & $\begin{array}{l}\text { Precision - Duplicate Analyses } \\
\text { Accuracy - Matrix Spiked Samples }\end{array}$ & & & & \\
\hline Acetaldehyde & & 50 & $50-150$ & 10 & 94 \\
\hline Formaldehyde & & 50 & $50-150$ & 36 & 90 \\
\hline Aldehydes in Aqueous Streams & $\begin{array}{l}\text { Precision - Duplicate Analyses } \\
\text { Accuracy - Matrix Spiked Samples }\end{array}$ & & & & \\
\hline Acetaldehyde & & 50 & $50-150$ & 14 & 101 \\
\hline Formaldehyde & & 50 & $50-150$ & 18 & 94 \\
\hline
\end{tabular}


Appendix D: Quality Assurance/Quality Control

Table D-2 (Continued)

\begin{tabular}{|c|c|c|c|c|c|}
\hline \multirow[b]{2}{*}{ Measurement Parameter } & \multirow[b]{2}{*}{ How Measured } & \multicolumn{2}{|c|}{ Objectives } & \multicolumn{2}{|c|}{ Messured } \\
\hline & & $\begin{array}{l}\text { Precision } \\
\text { (\% RPD) }\end{array}$ & $\begin{array}{c}\text { Accuracy } \\
\text { (\% Recovery) }\end{array}$ & $\begin{array}{l}\text { Precision } \\
\text { (\% RPD) }\end{array}$ & $\begin{array}{c}\text { Accuracy } \\
\text { (\% Recovery) }\end{array}$ \\
\hline Metals in Gas Solid Phase - ICP-AES & $\begin{array}{l}\text { Precision - Matrix-spiked pairs } \\
\text { Accuracy - Matrix-spiked Sample }\end{array}$ & & & & \\
\hline Aluminum & & 20 & $75-125$ & $62 Q$ & $62 Q$ \\
\hline Antimony & & 20 & $75-125$ & 20 & 84 \\
\hline Barium & & 20 & $75-125$ & $30 Q$ & 75 \\
\hline Beryllium & & 20 & $75-125$ & $<1$ & 89 \\
\hline Chromium & & 20 & $75-125$ & 2.9 & 88 \\
\hline Cobalt & & 20 & $75-125$ & 1 & 91 \\
\hline Copper & & 20 & $75-125$ & $<1$ & 93 \\
\hline Manganese & & 20 & $75-125$ & 2.2 & 91 \\
\hline Molybdenum & . & 20 & $75-125$ & 3.7 & 94 \\
\hline Nickel & & 20 & $75-125$ & 5 & 89 \\
\hline Vanadium & & 20 & $75-125$ & 2.2 & 94 \\
\hline Metals in Gas Solid Phase - ICP-AES & $\begin{array}{l}\text { Precision - NA } \\
\text { Accuracy - Standard reference material } \\
\text { (NIST 1633a Fly Ash) }\end{array}$ & & & & \\
\hline Aluminum & & 20 & $75-125$ & & 94 \\
\hline Antimony & & 20 & $75-125$ & & NC \\
\hline Barium & & 20 & $75-125$ & & 82 \\
\hline Beryllium & & 20 & $75-125$ & & $147 Q$ \\
\hline Calcium & & 20 & $75-125$ & & 99 \\
\hline Chromium & & 20 & $75-125$ & & 96 \\
\hline Cobalt & & 20 & $75-125$ & & 88 \\
\hline Copper & & 20 & $75-125$ & & 95 \\
\hline Iron & & 20 & $75-125$ & & 93 \\
\hline Magnesium & & 20 & $75-125$ & & 95 \\
\hline Manganese & & 20 & $75-125$ & & 94 \\
\hline Potassium & & 20 & $75-125$ & & 109 \\
\hline Nickel & $\cdot$ & 20 & $75-125$ & & 94 \\
\hline Silicon & & 20 & $75-125$ & & 98 \\
\hline Sodium & & 20 & $75-125$ & & 96 \\
\hline Strontium & & 20 & $75-125$ & & 92 \\
\hline Titanium & & 20 & $75-125$ & & 97 \\
\hline Vanadium & & 20 & $75-125$ & & 95 \\
\hline Zine & & 20 & $75-125$ & & 97 \\
\hline Metals in Gas Vapor Phase - ICP-AES & $\begin{array}{l}\text { Precision - Matrix-spiked Duplicates } \\
\text { Accuracy - Matrix-spiked Sample }\end{array}$ & & & & \\
\hline Aluminum & & 20 & $75-125$ & $<1$ & 104 \\
\hline Antimony & & 20 & $75-125$ & 4 & 101 \\
\hline Barium & & 20 & $75-125$ & 0 & 106 \\
\hline Beryllium & & 20 & $75-125$ & 0 & 108 \\
\hline Boron & & 20 & $75-125$ & 2.9 & 104 \\
\hline Chromium & & 20 & $75-125$ & 0 & 105 \\
\hline Cobalt & & 20 & $75-125$ & 0 & 102 \\
\hline Copper & & 20 & $75-125$ & 0 & 105 \\
\hline Manganese & & 20 & $75-125$ & $<1$ & 104 \\
\hline Molybdenum & & 20 & $75-125$ & 2.0 & 100 \\
\hline Nickel & & 20 & $75-125$ & 0 & 102 \\
\hline Vanadium & & 20 & $75-125$. & 0 & 107 \\
\hline
\end{tabular}


Table D-2 (Continued)

\begin{tabular}{|c|c|c|c|c|c|}
\hline \multirow[b]{2}{*}{ Measurement Parameter } & \multirow[b]{2}{*}{ How Measured } & \multicolumn{2}{|c|}{ Objectives } & \multicolumn{2}{|c|}{ Measured } \\
\hline & & $\begin{array}{l}\text { Precision } \\
\text { (\% RPD) }\end{array}$ & $\begin{array}{c}\text { Accuracy } \\
\text { (\% Recovery) }\end{array}$ & $\begin{array}{l}\text { Precision } \\
\text { (\% RPD) }\end{array}$ & $\begin{array}{l}\text { Accuracy } \\
\text { (\% Recovery) }\end{array}$ \\
\hline $\begin{array}{l}\text { Metals in Gas Vapor Phase - ICP-AES } \\
\text { (HNO } / \mathrm{H}_{2} \mathrm{O}_{2} \text { Impinger Solution) }\end{array}$ & $\begin{array}{l}\text { Precision - NA } \\
\text { Accuracy - Standard reference material } \\
\text { (EPA ICP-19) }\end{array}$ & & & & \\
\hline Antimony & & 20 & $75-125$ & & 93 \\
\hline Beryllium & & 20 & $75-125$ & & 101 \\
\hline Calcium & & 20 & $75-125$ & & 109 \\
\hline Chromium & & 20 & $75-125$ & & 99 \\
\hline Cobalt & & 20 & $75-125$ & & 100 \\
\hline Copper & & 20 & $75-125$ & & 119 \\
\hline Iron & & 20 & $75-125$ & & 93 \\
\hline Manganese & & 20 & $75-125$ & & 97 \\
\hline Molybdenum & & 20 & $75-125$ & & 108 \\
\hline Nickel & & 20 & $75-125$ & & 102 \\
\hline Vanadium & & 20 & $75-125$ & & 103 \\
\hline Metals in Coal - INAAS & $\begin{array}{l}\text { Precision - NA } \\
\text { Accuracy - Standard Reference Material } \\
\text { (NIST } 1632 \mathrm{~b} \text { coal) }\end{array}$ & & & & \\
\hline Antimony & & 20 & $80-120$ & & 94 \\
\hline Barium & & 20 & $80-120$ & & 99 \\
\hline Beryllium & & 20 & $80-120$ & & 109 \\
\hline Boron & & 20 & $80-120$ & & 99 \\
\hline Chromium & & 20 & $80-120$ & & 99 \\
\hline Cobalt & & 20 & $80-120$ & . & NC \\
\hline Copper & & 20 & $80-120$ & & 99 \\
\hline Manganese & & 20 & $80-120$ & & 103 \\
\hline Molybdenum & & 20 & $80-120$ & & 102 \\
\hline Nickel & & 20 & $80-120$ & & 99 \\
\hline Vanadium & & 20 & $80-120$ & & 97 \\
\hline Metals in Limestone - ICP-AES & $\begin{array}{l}\text { Precision - NA } \\
\text { Accuracy- Standard reference material } \\
\text { (NIST Limestone lc) }\end{array}$ & & & & \\
\hline Aluminum & & 20 & $75-125$ & & $14 Q$ \\
\hline Calcium & & 20 & $75-125$ & & 101 \\
\hline Iron & & 20 & $75-125$ & & $70 Q$ \\
\hline Magnesium & & 20 & $75-125$ & & $69 Q$ \\
\hline Manganese & & 20 & $75-125$ & & $74 Q$ \\
\hline Potassium & & 20 & $75-125$ & & $224 Q$ \\
\hline Silicon & & 20 & $75-125$ & & $1.5 \mathrm{Q}$ \\
\hline Sodium & & 20 & $75-125$ & & $47 Q$ \\
\hline Strontium & & 20 & $75-125$ & & 97 \\
\hline Metals in FGD Solids - ICP-AES & $\begin{array}{l}\text { Precision - Matrix-spiked Duplicates } \\
\text { Accuracy - Matrix-spiked Samples }\end{array}$ & & & & \\
\hline Aluminum & & 20 & $75-125$ & 8.7 & 94 \\
\hline Antimony & & 20 & $75-125$ & 4.7 & 83 \\
\hline Barium & & 20 & $75-125$ & 6.0 & 84 \\
\hline Beryllium & & 20 & $75-125$ & 4.6 & 81 \\
\hline Boron & & 20 & $75-125$ & $28 Q$ & 91 \\
\hline Chromium & & 20 & $75-125$ & 5.7 & 82 \\
\hline Cobalt & & 20 & $75-125$ & 5.6 & 78 \\
\hline Copper & & 20 & $75-125$ & 5.1 & 87 \\
\hline Manganese & & 20 & $75-125$ & 15 & 79 \\
\hline Molybdenum & & 20 & $75-125$ & 5.1 & 79 \\
\hline Nickel & & 20 & $75-125$ & 5.0 & 79 \\
\hline Vanadium & & 20 & $75-125$ & 5.6 & 84 \\
\hline
\end{tabular}


Table D-2 (Continued)

\begin{tabular}{|c|c|c|c|c|c|}
\hline \multirow[b]{2}{*}{ Measurement Parameter } & \multirow[b]{2}{*}{ How Measured } & \multicolumn{2}{|c|}{ Objectives } & \multicolumn{2}{|c|}{ Measured } \\
\hline & & $\begin{array}{l}\text { Precision } \\
\text { (\% RPD) }\end{array}$ & $\begin{array}{c}\text { Accuracy } \\
(\% \text { Recovery) }\end{array}$ & $\begin{array}{l}\text { Precision } \\
\text { (\% RPD) }\end{array}$ & $\begin{array}{c}\text { Accuracy } \\
\text { (\% Recovery) }\end{array}$ \\
\hline Metals in ESP Fly Ash - ICP-AES & $\begin{array}{l}\text { Precision - Matrix-spiked Duplicates } \\
\text { Accuracy - Matrix-spiked Samples }\end{array}$ & & & & \\
\hline Aluminum & & 20 & $75-125$ & 16 & 78 \\
\hline Antimony & & 20 & $75-125$ & 8.4 & 91 \\
\hline Barium & & 20 & $75-125$ & 10.2 & 85 \\
\hline Beryllium & & 20 & $75-125$ & 1.8 & 92 \\
\hline Chromium & & 20 & $75-125$ & 1.7 & 94 \\
\hline Cobalt & & 20 & $75-125$ & 1.8 & 93 \\
\hline Copper & & 20 & $75-125$ & 2.4 & 95 \\
\hline Manganese & & 20 & $75-125$ & 2.5 & 92 \\
\hline Molybdenum & & 20 & $75-125$ & 4.5 & 84 \\
\hline Nickel & & 20 & $75-125$ & 5.2 & 96 \\
\hline Vanadium & & 20 & $75-125$ & 2.8 & 94 \\
\hline $\begin{array}{l}\text { Metals in Aqueous Process Streams - } \\
\text { ICP-AES }\end{array}$ & $\begin{array}{l}\text { Precision - Matrix-spiked Duplicates } \\
\text { Accuracy - Matrix-spiked Samples }\end{array}$ & & & & \\
\hline Aluminum & t & 20 & $75-125$ & 4.4 & 96 \\
\hline Antimony & & 20 & $75-125$ & 16 & 87 \\
\hline Barium & & 20 & $75-125$ & 7.6 & $: 99$ \\
\hline Beryllium & & 20 & $75-125$ & 4.4 & 92 \\
\hline Boron & & 20 & $75-125$ & 1.0 & 96 \\
\hline Chromium & & 20 & $75-125$ & 4.9 & 92 \\
\hline Cobalt & & 20 & $75-125$ & 4.6 & 89 \\
\hline Copper & & 20 & $75-125$ & 4.0 & 96 \\
\hline Manganese & & 20 & $75-125$ & 4.5 & 92 \\
\hline Molybdenum & & 20 & $75-125$ & 4.8 & 89 \\
\hline Nickel & & 20 & $75-125$ & 7.3 & 90 \\
\hline Vanadium & & 20 & $75-125$ & 3.6 & 95 \\
\hline $\begin{array}{l}\text { Metals in Aqueous Process Streams - } \\
\text { ICP-AES }\end{array}$ & $\begin{array}{l}\text { Precision - NA } \\
\text { Accuracy - Performance Audit Samples } \\
\text { (2 concentrations) }\end{array}$ & & & & \\
\hline Antimony & & 20 & $75-125$ & & $127 Q / 82$ \\
\hline Beryllium & & 20 & $75-125$ & & $99 / 93$ \\
\hline Calcium & & 20 & $75-125$ & & $169 Q$ \\
\hline Chromium & & 20 & $75-125$ & & $94 / 97$ \\
\hline Cobalt & & 20 & $75-125$ & & $100 / 87$ \\
\hline Copper & & 20 & $75-125$ & & $96 / 110$ \\
\hline Iron & & 20 & $75-125$ & & $103 / 139 Q$ \\
\hline Magnesium & & 20 & $75-125$ & & $131 Q$ \\
\hline Manganese & & 20 & $75-125$ & & $96 / 95$ \\
\hline Molybdenum & & 20 & $75-125$ & & $98 / 114$ \\
\hline Nickel & & 20 & $75-125$ & & $104 / 111$ \\
\hline Titanium & & 20 & $75-125$ & & 98 \\
\hline Vansdium & & 20 & $75-125$ & & $96 / 104$ \\
\hline Zinc & & 20 & $75-125$ & & 99 \\
\hline $\begin{array}{l}\text { Metals in Gas Vapor Phase - GFAAS and } \\
\text { CVAAS }\end{array}$ & $\begin{array}{l}\text { Precision - Matrix spiked Duplicates } \\
\text { Accuracy - Matrix Spiked Samples }\end{array}$ & & & & \\
\hline Arsenic & & 20 & $75-125$ & 4.0 & 100 \\
\hline Cadmium & & 20 & $75-125$ & $<1$ & 114 \\
\hline Lead & & 20 & $75-125$ & $45 Q$ & 84 \\
\hline Mercury & & 20 & $75-125$ & 1.3 & 98 \\
\hline Selenium & & 20 & $75-125$ & $94 Q$ & 0 \\
\hline Metals in Gas Solid Phase - CVAAS & $\begin{array}{l}\text { Precision - Matrix spiked Duplicates } \\
\text { Accuracy - Matrix Spiked Samples }\end{array}$ & & & & \\
\hline Mercury & & 20 & $75-125$ & 1.0 & $128 \mathrm{Q}$ \\
\hline Metals in Gas Vapor Phase - CVAAS & $\begin{array}{l}\text { Precision - NA } \\
\text { Accuracy - Performance Audit Samples }\end{array}$ & & & & \\
\hline Mercury (KMnO Impinger Solution) & & 20 & $75-125$ & & $33 Q$ \\
\hline
\end{tabular}

D-10 
Table D-2 (Continued)

\begin{tabular}{|c|c|c|c|c|c|}
\hline \multirow[b]{2}{*}{ Measurement Parameter } & \multirow[b]{2}{*}{ How Measured } & \multicolumn{2}{|c|}{ Objectives } & \multicolumn{2}{|c|}{ Measured } \\
\hline & & $\begin{array}{l}\text { Precision } \\
\text { (\% RPD) }\end{array}$ & $\begin{array}{c}\text { Accuracy } \\
\text { (\% Recovery) }\end{array}$ & $\begin{array}{l}\text { Precision } \\
\text { (\% RPD) }\end{array}$ & $\begin{array}{c}\text { Accuracy } \\
\text { (\% Recovery) }\end{array}$ \\
\hline $\begin{array}{l}\text { Metals in Process Solid Streams - GFAAS } \\
\text { and CVAAS }\end{array}$ & $\begin{array}{l}\text { Precision - Matrix spiked Duplicates } \\
\text { Accuracy - Matrix Spiked Samples }\end{array}$ & & & & \\
\hline Arsenic & & 20 & $75-125$ & $<1$ & 104 \\
\hline Cadmium & & 20 & $75-125$ & 8.8 & 110 \\
\hline Lead & & 20 & $75-125$ & 1.2 & 86 \\
\hline Mercury & & 20 & $75-125$ & 2.6 & 107 \\
\hline Selenium & & 20 & $75-125$ & $25.3 \mathrm{Q}$ & 103 \\
\hline $\begin{array}{l}\text { Metals in Solid Phase - GFAAS and } \\
\text { CVAAS }\end{array}$ & $\begin{array}{l}\text { Precision - NA } \\
\text { Accuracy - Standard reference material } \\
\text { (NIST 1633a Fly Ash) }\end{array}$ & & & & \\
\hline Arsenic & & 20 & $75-125$ & & NA \\
\hline Cadmium & & 20 & $75-125$ & & NA \\
\hline Lead & & 20 & $75-125$ & & NA \\
\hline Mercury & & 20 & $75-125$ & & 119 \\
\hline Selenium & & 20 & $75-125$ & & NA \\
\hline $\begin{array}{l}\text { Metals in Aqueous Process Streams - } \\
\text { GFAAS and CVAAS }\end{array}$ & $\begin{array}{l}\text { Precision - Matrix Spiked Duplicates } \\
\text { Accuracy - Matrix Spiked Samples }\end{array}$ & & & & \\
\hline Arsenic & & 20 & $75-125$ & 4.2 & 99 \\
\hline Cadmium & & 20 & $75-125$ & 2.2 & 108 \\
\hline Lead & & 20 & $75-125$ & 12 & 76 \\
\hline Mercury & & 20 & $75-125$ & $24.6 \mathrm{Q}$ & $35 Q$ \\
\hline Selenium & & 20 & $75-125$ & $41.2 \mathrm{Q}$ & 76.4 \\
\hline $\begin{array}{l}\text { Metals in Aqueous Process Streams - } \\
\text { GFAAS and CVAAS }\end{array}$ & $\begin{array}{l}\text { Precision - NA } \\
\text { Accuracy - Performance Audit Samples } \\
\text { (2 concentrations) }\end{array}$ & & & & \\
\hline Arsenic & & 20 & $75-125$ & & $94 / 100$ \\
\hline Cadmium & & 20 & $75-125$ & & $93 / 100$ \\
\hline Lead & & 20 & $75-125$ & & $99 / 96$ \\
\hline Selenium & & 20 & $75-125$ & & $96 / 50$ \\
\hline Metals in Gas Vapor - ICP/MS & Precision - NA & & & & \\
\hline (HNO $/ \mathrm{H}_{2} \mathrm{O}_{2}$ Impinger Solution) & Accuracy - Performance Audit Samples & & & & \\
\hline Antimony & & NA & NA & & 89 \\
\hline Arsenic & & NA & NA & & 109 \\
\hline Beryllium & & NA & $\mathrm{NA}$ & & 98 \\
\hline Cadmium & & NA & NA & & 97 \\
\hline Chromium & & NA & NA & & 97 \\
\hline Cobalt & & NA & NA & & 88 \\
\hline Copper & & NA & NA & & 83 \\
\hline Lead & & NA & NA & & 87 \\
\hline Manganese & & NA & NA & & 97 \\
\hline Molybdenum & & NA & NA & & 94 \\
\hline Nickel & & $\mathrm{NA}$ & $\mathrm{NA}$ & & 90 \\
\hline Selenium & & NA & NA & & 106 \\
\hline Vanadium & & NA & $\mathrm{NA}$ & & 93 \\
\hline
\end{tabular}


Table D-2 (Continued)

\begin{tabular}{|c|c|c|c|c|c|}
\hline \multirow[b]{2}{*}{ Measurement Parameter } & \multirow[b]{2}{*}{ How Measured } & \multicolumn{2}{|c|}{ Objectives } & \multicolumn{2}{|c|}{ Measured } \\
\hline & & $\begin{array}{l}\text { Precision } \\
\text { (\% RPD) }\end{array}$ & $\begin{array}{c}\text { Accuracy } \\
\text { (\% Recovery) }\end{array}$ & $\begin{array}{l}\text { Precision } \\
\text { (\% RPD) }\end{array}$ & $\begin{array}{c}\text { Accuracy } \\
\text { (\% Recovery) }\end{array}$ \\
\hline Extractable Metals - ICP/MS & Precision - Duplicate Analysis & & & & \\
\hline Nitric acid digestate) & Accuracy - Matrix-Spiked Samples & & & & \\
\hline Antimony & & 20 & NA & $40 Q$ & NA \\
\hline Arsenic & & 20 & $75-125$ & $434 Q$ & 118 \\
\hline Barium & & 20 & $75-125$ & 5.8 & 94 \\
\hline Beryllium & & 20 & $75-125$ & 11 & 108 \\
\hline Cadmium & & 20 & $75-125$ & 0 & 94 \\
\hline Chromium & & 20 & $75-125$ & 9.4 & 98 \\
\hline Cobalt & & 20 & $75-125$ & 7.7 & 100 \\
\hline Copper & & 20 & $75-125$ & 19 & 100 \\
\hline Lead & & 20 & $75-125$ & 1.6 & 83 \\
\hline Manganese & & 20 & $75-125$ & 9.6 & 108 \\
\hline Mercury & & 20 & $75-125$ & NC & $852 Q$ \\
\hline Molybdenum & & 20 & NA & 12 & $\mathrm{NA}$ \\
\hline Nickel & & 20 & $75-125$ & 13 & 103 \\
\hline Selenium & & 20 & $75-125$ & $43 Q$ & $138 \mathrm{Q}$ \\
\hline Vanadium & & 20 & $75-125$ & 3.6 & 109 \\
\hline $\begin{array}{l}\text { Extractable Metals - ICP/MS } \\
\text { (Gastric fluid leachate) }\end{array}$ & $\begin{array}{l}\text { Precision - Duplicate analysis } \\
\text { Accuracy - Matrix-spiked samples }\end{array}$ & & & & \\
\hline Antimony & & 20 & NA & 6.5 & NA \\
\hline Arsenic & & 20 & $75-125$ & NC & OQ \\
\hline Barium & & 20 & $75-125$ & 1.5 & 85 \\
\hline Beryllium & & 20 & $75-125$ & 12 & 79 \\
\hline Cadmium & & 20 & $75-125$ & $27 Q$ & 107 \\
\hline Chromium & & 20 & $75-125$ & 4.2 & 88 \\
\hline Cobalt & & 20 & $75-125$ & 3.4 & 92 \\
\hline Copper & & 20 & $75-125$ & 14 & 92 \\
\hline Lead & & 20 & $75-125$ & 3.2 & 97 \\
\hline Manganese & & 20 & $75-125$ & 3.2 & 710 \\
\hline Mercury & & 20 & $75-125$ & $61 Q$ & 124 \\
\hline Molybdenum & & 20 & NA & 10 & NA \\
\hline Nickel & & 20 & $75-125$ & 3.7 & 81 \\
\hline Selenium & & 20 & $75-125$ & NC & 84 \\
\hline Vanadium & & 20 & $75-125$ & NC & OQ \\
\hline Metals in Gas Solid Phase - GDMS & $\begin{array}{l}\text { Precision - NA } \\
\text { Accuracy - Standard Reference Material }\end{array}$ & & & & \\
\hline Aluminum & (NIST 1633a Fly Ash) & & & & \\
\hline Antimony & & NA & NA & & $180 Q$ \\
\hline Barium & & NA & NA & & NC \\
\hline Beryllium & & NA & NA & & $357 Q$ \\
\hline Calcium & & NA & NA & & NC \\
\hline Chromium & & NA & NA & & $70 Q$ \\
\hline Cobalt & & NA & NA & & $140 Q$ \\
\hline Copper & & NA & NA & & $\mathrm{NC}$ \\
\hline Iron & & NA & NA & & $203 Q$ \\
\hline Magnesium & & NA & NA & & 79 \\
\hline Manganese & & NA & NA & & 120 \\
\hline Potassium & & NA & NA & & $58 Q$ \\
\hline Nickel & & NA & NA & & 119 \\
\hline Silicon & & NA & NA & & 315 \\
\hline Sodium & . & NA & NA & & 111 \\
\hline Strontium & & NA & NA & - & $39 Q$ \\
\hline Titanium & & NA & NA & & $320 Q$ \\
\hline Vanadium & & NA & NA & & 1310 \\
\hline Zine & & NA & NA & & $141 Q$ \\
\hline & & NA & NA & & $129 Q$ \\
\hline
\end{tabular}


Appendix D: Quality Assurance/Quality Control

\section{Table D-2 (Continued)}

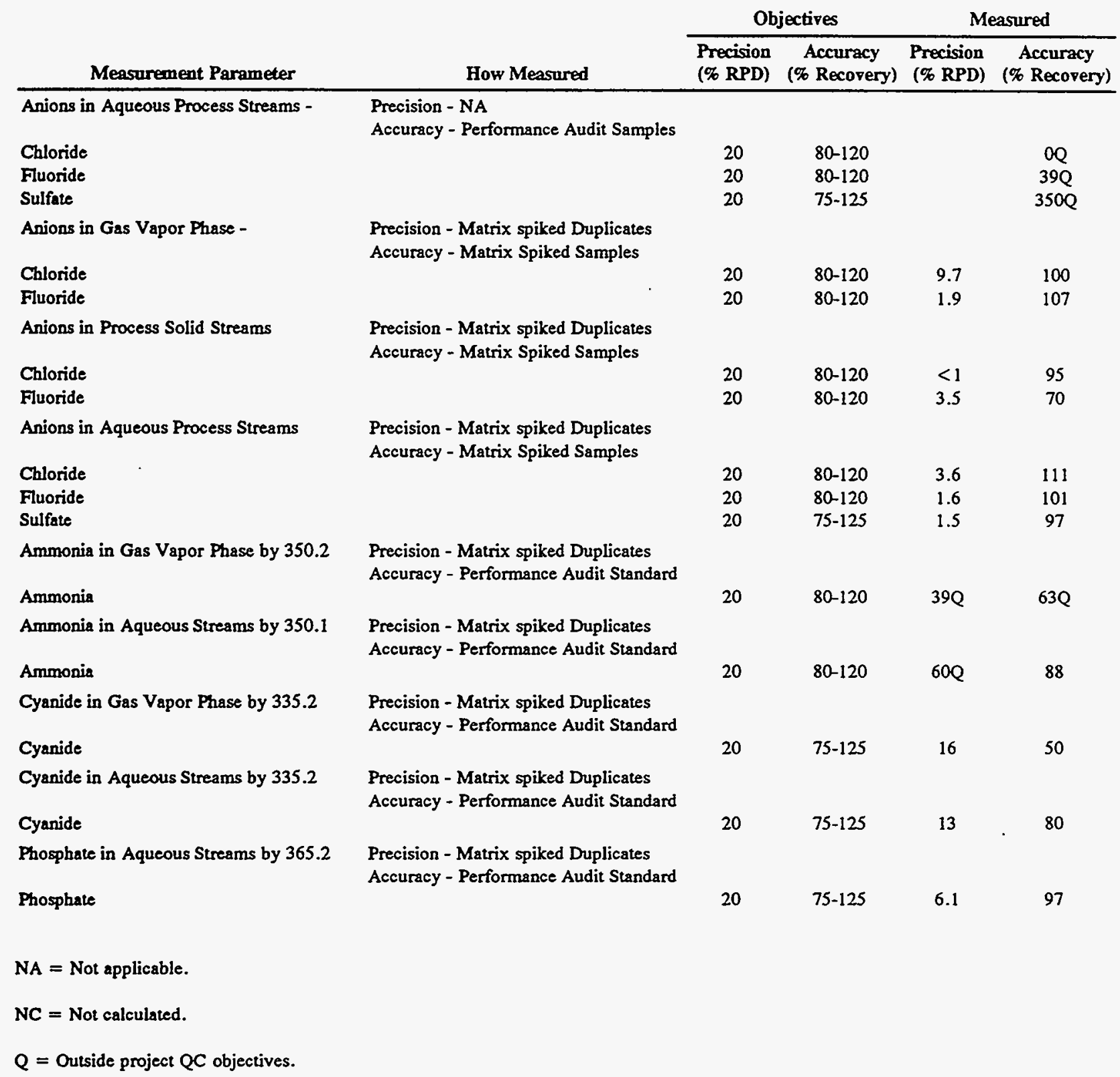


Representativeness expresses the degree to which sample data accurately and precisely represent a characteristic of a population, parameter variations at a sampling point, or an environmental condition. The representativeness criterion is based on making certain that the sampling locations are properly selected and that a sufficient number of samples are collected.

Comparability is a qualitative parameter expressing the confidence with which one data set can be compared to another. Sampling data should be comparable with other measurement data for similar samples under similar conditions. This goal is achieved using standard techniques to collect and analyze representative samples and by reporting results in appropriate units. Data sets can be compared with confidence when the precision and accuracy is known.

Completeness is an expression of the number of valid measurements obtained compared with the number planned for a given study. The goal is to generate a sufficient amount of valid data.

\section{Semivolatile Organics}

Precision. The precision of the semivolatile organic analyses was estimated using matrix spiked duplicate pairs. The precision was met for all of the gas-phase solid samples, the gas vapor-phase samples, the solid stream samples, and aqueous-phase sample streams. The precision estimates are summarized for each stream in Table D-2.

Accuracy. The accuracy of the semivolatile analyses was estimated using matrix spiked duplicate samples. All of the spiked compounds analyzed in the gas solid-phase samples and the aqueous process streams were within the accuracy objectives. Matrix spikes into the solid process streams were all within the recovery objects for all analytes in the FGD solid stream and all the except pyrene in the ESP ash solids. Recovery for pyrene was $51 \%$ and $56 \%$ (project objective--52-115\%) for the ESP ash sample and 48\% and 37\% for the ESP ash field duplicate.

Blank Effects. Acetophenone and benzoic acid were found in one or more of the field blanks associated with the gas-phase solids analyses. The concentrations of these compounds in the blanks, however, were not significant in comparison to the concentrations found in the samples. Several phthalates were also found in the field blanks. The concentrations found in the samples were about the same level as found in the blanks and are therefore considered an artifact of the sampling and handling process.

\section{Volatile Organics}

Precision. Precision for volatile organic analysis of the aqueous process streams was estimated using matrix spiked duplicate samples. The $50 \%$ precision objectives were met for each of the volatile analytes used for the matrix spikes. 
Accuracy. Accuracy for the volatile organic analyses in the aqueous process streams was estimated using matrix spiked samples and accuracy for the gas vapor-phase streams was estimated using surrogates spiked into each sample prior to analysis. The accuracy objectives for recoveries ranging from $0.1 \%$ to $234 \%$ were met for all analytes of interest (actual recoveries ranged from $70-136 \%$ ) for the aqueous streams. Accuracy objectives for surrogate recoveries of 70 to $130 \%$ for the gas-phase streams were met for all samples except for toluene-d8 in one stack sample. Accuracy based on the analysis of two laboratory method spikes met the recovery objectives for all analytes of interest except for one acetone, chloromethane, chloroethane, and methylene chloride spike.

Blank Effects. Chloromethane, methylene chloride, and tetrachloroethene were found in one or more of the field gas vapor-phase blank samples. In most cases these compounds were found in the investigative field samples at about the same level as in the field blank or at lower concentrations. The sampling, handling, and transport from the field may have contributed this observed contamination. Chloromethane and methylene chloride were also found in one laboratory blank.

\section{Aldehydes}

Precision. Precision for the aldehyde analyses was estimated using duplicate sample analyses. The precision objectives of $50 \%$ were met for both formaldehyde and acetaldehyde in the gas vapor-phase samples and the aqueous process stream sample analyses.

Accuracy. Accuracy for the aldehydes was estimated using matrix spiked samples. The project accuracy objectives of recoveries of $50-150 \%$ were met for the gas vapor-phase and aqueous stream sample spikes for both formaldehyde and acetaldehyde.

Blank Effects. Formaldehyde and acetaldehyde were found in concentrations (3.8-8.2 $\mu \mathrm{g}$, formaldehyde; 2.7-8.6 $\mu \mathrm{g}$, acetaldehyde) above the reporting limits in the field blanks to the gas vapor-phase sampling train. Low levels (within 3 times the detection limit) of these analytes were also found in two of the four laboratory (method) blanks but were not found in the trip blanks.

\section{Metals}

Precision. The precision of metals analyses by ICP-AES, GFAAS, and CVAAS was estimated for samples using matrix-spiked duplicate samples. The precision objectives (RPD $<20 \%$ ) were met for all target analytes analyzed by ICP-AES except aluminum and barium in the gas solid-phase spiked samples and boron in the process solid-spiked samples. The precision objectives for the GFAAS analyses were met except for lead in the gas vapor-phase matrix-spiked samples, selenium in the process solid matrix-spiked samples, and mercury and selenium in the aqueous process stream matrix spikes. In most of these cases, the concentrations of the analytes of interest were within 10 times the detection limit where the precision would not be expected as good or the spiked amount was low ( $<4$ times) the amount found in the original sample. 
Appendix D: Quality Assurance/Quality Control

Accuracy. The accuracy of metals analyses was estimated for the gas solid-phase samples using standard reference material (NIST 1633a fly ash) submitted blind to the laboratory as a performance audit sample. All of the metals analyzed by ICP-AES were within the 75-125\% accuracy objectives except for beryllium (147\%) which was recovered above the objectives. The fly ash (NIST 1633a) reference standard was also submitted for GDMS analysis. The results for this analysis are shown in Table D-2. Accuracy objectives were not assigned to the GDMS analyses since this technique has not been validated or widely used for these types of samples at the present time. However, the recoveries have been compared to the accuracy objectives for ICP-AES and flagged with a $Q$ when outside the QC objectives.

The accuracy of the metals analyses was estimated for coal samples using a standard reference coal sample (NIST 1632b) submitted blind to the laboratory. All of the metals analyzed by INAA in the reference sample were within the $75-125 \%$ accuracy objective.

The accuracy of the metals analyses was estimated for the limestone samples using a standard reference limestone (NIST Limestone $1 \mathrm{C}$ ) submitted blind to the laboratory. The results show that the recoveries for most of the metals were outside the 75-125\% accuracy objectives. Aluminum, silicon, and sodium recoveries were $50 \%$, and the recovery for potassium was greater than 200 percent. The recoveries of these analytes may show a similar bias in the limestone process streams.

The accuracy of the metals analyses for the gas vapor-phase samples and the aqueous process streams were estimated using performance audit samples prepared from EPA reference standards. The gas-phase audit sample was prepared in the solutions used for the impingers (multi-metals train) and the two aqueous-phase samples were prepared in HPLC grade water. The results show that the recoveries of all the metals analyzed by ICP-AES and GFAAS were within the $75-125 \%$ accuracy objectives except Sb (127\%), Ca (169\%), Fe (139\%), and $\mathrm{Mg}(131 \%)$ by ICP-AES and Se (50\%) and Hg (33\%) by GFAAS. The concentrations of these elements in the samples were at or near the detection limit and are not expected to be as accurate as concentrations at higher levels (at least 10 times the detection limit). The gasphase audit sample prepared in the $\mathrm{HNO}_{3} / \mathrm{H}_{2} \mathrm{O}_{2}$ impinger solution was also analyzed by ICP/MS. The results for this analysis showed recoveries ranging from 83 to $109 \%$, all within the accuracy objectives for ICP-AES (accuracy objectives were not assigned for ICP/MS).

Matrix-spiked samples were also used to determine the accuracy of the metals analyses in the gas, process solids, and aqueous process matrices. Recoveries for the target analytes were within the $75-125 \%$ accuracy objectives except for selenium (0\% recovery) in the gas vaporphase matrix mercury (35\% recovery) in the aqueous process stream matrix.

Blank Effects. Aluminum, iron, manganese, and nickel were found at concentrations above the reporting limits in the field blanks to the gas vapor-phase sampling train. These elements were also found to a lesser extent in the impinger reagent blank solutions. Field blank filters combined with probe/nozzle rinses were also analyzed to determine the contribution of the filter media to the gas solid-phase components. Background or blank correction was 
performed for the gas-phase samples using the results of the analysis of the impinger reagent blanks and the blank filter media.

\section{Anions}

Precision. Precision for the anions analyses was estimated for the gas vapor-phase samples, process solid streams, and aqueous process streams by the analysis of matrix spiked samples. The precision objectives of $20 \%$ were met for chloride, fluoride, and sulfate except for chloride and sulfate in one matrix spike pair from the stack with RPDs of $22 \%$ and $24 \%$, respectively.

Accuracy. Accuracy for the anions analyses was estimated using matrix spiked duplicate samples. The accuracy objectives of $80-120 \%$ recovery were met for all analytes and all sample matrices except for the fluoride spikes into the ESP ash solid samples with recoveries of $56 \%$ and 60 percent. A performance audit sample was submitted for analysis of the target anions in an aqueous matrix. The recoveries for this sample were outside the accuracy objectives for all three analytes. This sample was prepared with each analyte concentration at the MDL; therefore, no corrective action was initiated.

\section{Cyanide, Ammonia, and Phosphate}

Precision. Precision for the cyanide, ammonia, and phosphate analyses was estimated using matrix spiked duplicate sample analyses. The precision objectives of $20 \%$ were met for each of the analytes for both the gas vapor-phase and aqueous process streams except for ammonia spikes into the JBR process liquids. The spike concentration was too low in comparison to the level found in the native process sample.

Accuracy. Accuracy for ammonia, cyanide and phosphate was estimated using both matrix spiked duplicate samples and "double blind" performance audit samples. The accuracy objectives (cyanide, 75-125\%; ammonia, 80-120\%; phosphate, 75-125\%) were met for all matrix spiked samples except for the ammonia spikes into the JBR process liquids with recoveries at 60 and 273 percent. Recoveries for the performance audit samples met the accuracy objectives for all analytes with recoveries of $88 \%$ for ammonia, $80 \%$ for cyanide, and $97 \%$ for phosphate. Recoveries for performance audit samples spiked into the gas vapor-phase impinger solutions were not as good as the aqueous spiked audit samples. The recovery for ammonia in the impinger solutions was $63 \%$ and the recovery for cyanide was 50 percent. The aqueous spikes and impinger spikes were performed using the same spiking solutions and were spiked at the same concentration levels. 


\section{Performance Evaluation Audit Samples}

Performance audit samples are samples of known composition which provide a point-in-time assessment of analytical performance. Audit samples were prepared for this study by spiking known concentrations of target analytes from EPA Quality Control Check material, vendorcertified standard material, or standards obtained from NIST (formerly NBS). Audit samples are similar to QCCS except that they are submitted "double blind" to the analytical laboratory. That is, the laboratory does not know the identity or composition of the audit samples.

Audit samples were prepared at concentration levels simulating the expected range of the analytes in the field samples when possible. Organic audit samples were not prepared because the laboratories performing organic analyses have consistently shown acceptable performance on surrogate recoveries and internal quality control samples. Results for these samples are shown in Table D-2.

\section{Quality Assurance Audits}

The purpose of a quality assurance audit is to provide an objective, independent assessment of a sampling or measurement effort. It ensures that the sampling procedures, data generating, data gathering, and measurement activities produce reliable and useful results. Sometimes inadequacies are identified in the sampling/measurement system and/or the quality control program. In such cases, audits provide the mechanism for implementing corrective action.

A technical systems audit (TSA) is an on-site, qualitative review of the various aspects of a total sampling and/or analytical system. It is an assessment of overall effectiveness and represents a subjective evaluation of a set of interactive systems with respect to strengths, deficiencies, and potential areas of concern. The audit consists of observations and documentation of all aspects of the measurement effort. Checklists that delineate the critical aspects of each methodology are used by the Radian auditor during the audit to document all observations. In addition to evaluating sampling and analytical procedures and techniques, the systems audit emphasizes review of all recordkeeping and data handling systems including:

- Calibration documentation for analytical instrumentation and sampling apparatus;

- Documentation of quality control data (control charts, etc.);

- Completeness of data forms and notebooks;

- Data review and validation procedures;

- Sample logging procedures;

- Chain-of-custody procedures; 
- Documentation of maintenance; and

- Review of malfunction reporting procedures.

A technical systems audit of the Radian sampling and on-site analytical efforts was conducted on June $23-25,1993$ at Plant Yates by Barbara Hayes, a member of Radian's Quality Assurance Section. No critical or major concerns were observed during the audit; therefore, no Recommendations for Corrective Action (RCAs) were made. The sampling team was led by Dave Virbick and the analytical team was led by David Maxwell. The sampling team appeared well versed in the sampling methodology and requirements of the program. The equipment and instrumentation were generally in good working condition. All sampling and measurement procedures conformed to those described in the site Management Plan. Sampling information and any problems encountered were recorded onto preformatted data sheets or into bound laboratory notebooks. Duplicate samples were collected for the solid and aqueous streams at a rate of ten percent or one duplicate set per sample type (bottom ash, fly ash, etc.).

Sample collection procedures used by the sampling team followed those outlined in the site test plan. A detailed sampling schedule was used by the team to guide the collection of the samples for each analytical species at each sampling point.

No problems were identified with the sample custody procedures or documentation. A detailed master logbook was prepared prior to the field effort for all samples to be collected during each sampling period. This log was updated as the various samples were collected with the actual dates and times of sample collection. Samples were labelled with preformatted sample labels and stored at ambient temperature or cooled as required by the analytical species. Chain-of-custody forms were filled out and the samples were prepared for shipment to the laboratories for analysis.

Calibration of all on-site equipment was checked and found to be up-to-date. The analytical balance and top loading balance in the on-site laboratory trailer had been calibrated and certified within the past year. In addition, certified weights were available for daily balance checkout. All dry gas meters, consoles, Pitot tubes, and nozzles had been calibrated in the Radian Source Sampling Laboratory prior to being transported to the field location. Documentation for each of the observed instruments and equipment in use could be found in the records maintained by the sampling crew chief in the on-site laboratory. Sufficient replacement units were on hand to allow for breakage or equipment malfunction.

Recordkeeping practices by the project team were observed to be sound. Entries were made onto preformatted data sheets in ink, without erasures, signed and the time noted as each sample was collected.

\section{Coal Round Robin}

An interlaboratory study consisting of a coal round robin analysis was conducted by CONSOL, Inc. The objective of this round robin study was to estimate the analytical 
variability one can expect on trace element analyses when comparing results from the same laboratory or results from two or more laboratories. The results of CONSOL's study is contained in the document entitled "Interlaboratory Variability and Accuracy of Coal Analyses in the U.S. Department of Energy Utility Air Toxics Assessment Program," which follows this section. The results from Radian's laboratory are designated as "Lab III" in the above referenced document. Radian's objectives in assessing this data are (1) to compare Radian's round robin results with the overall results of the study, and (2) based on this assessment, determine if a change in any of the analytical methods for Phase $I$ should be made.

The analytical accuracy for each laboratory involved in the round robin study was measured by a comparative analysis of a standard reference material (SRM) coal sample (NIST 1632b). Each laboratory's analytical results for the standard reference material were compared to the certified or informational (non-certified) values. The round robin criteria for accurate results was $90-110 \%$ recovery of the SRM's certified value. (This is more stringent than the 80-. $120 \%$ recovery objective established for the program at Plant Yates). The following discussion addresses the performance of Radian's subcontracted coal laboratories with respect to the accuracy and precision assessments conducted by CONSOL on the NIST SRM.

\section{Discussion of Results}

The results of Radian's analysis of the SRM and the SRM-certified values are shown in Table D-3. Accuracy and precision objectives for the SRM coal in the round robin study were met by Radian for all ultimate and proximate parameters (\% ash, C, H, N, S, and HHV) with the exception of one sulfur analysis which was reported outside the objective range for accuracy and precision. The methods used for ultimate, proximate, and HHV analyses are current ASTM protocols and are consistent with the methods used by most of the other laboratories. No change in the analytical approach for Phase II of this project is warranted.

Major ash minerals were primarily determined by instrumental neutron activation analysis (INAA). Silicon dioxide $\left(\mathrm{SiO}_{2}\right)$ and sulfur trioxide $\left(\mathrm{SO}_{3}\right)$ were not reported for the Plant Yates or the round robin study. The accuracy and precision objectives were met for all major ash minerals reported except calcium, magnesium and potassium. For future work, other ASTM methods (ASTM D-4326 or alternate) should be used to improve analytical bias and precision for these elements. This is especially important where these major elements are considered key factors in assessing mass flow rates in material balance closures.

Radian analyzed most of the trace elements in coal by INAA. Other methods of analysis using different preparation techniques were performed for $\mathrm{As}, \mathrm{B}, \mathrm{Be}, \mathrm{Cd}, \mathrm{F}, \mathrm{Hg}, \mathrm{Pb}$, and Se. Of the target trace elements, $82 \%$ were detected. Cadmium, copper, and nickel were not detected. The results for copper and nickel are surprising, since this same SRM (1632b) was used as an internal audit sample during the Plant Yates study, and recovery by the same method (INAA) was $99 \%$ for both elements. Cadmium was determined by ICP-AES and this technique does not have the sensitivity to detect cadmium at the levels present in the SRM. Analysis of cadmium by graphite furnace-AA will be specified in Phase II of this project. 
The accuracy objectives of the round robin study were met for $50 \%$ of the detected trace elements. Elements meeting accuracy objectives were barium, chromium, cobalt, and vanadium. Certified values for boron, beryllium, fluorine, and mercury are not available for this SRM, so no accuracy measurements were performed for these elements in the round robin report. However, the results for these noncertified elements appear consistent with those from the other laboratories. Elements that did not meet the $90-110 \%$ recovery range were arsenic, cobalt (1 result), manganese, molybdenum, lead, antimony, and selenium. (Antimony, manganese and molybdenum SRM recovery values obtained during the Plant Yates study were well within the $90-110 \%$ objective of the round robin study. See Table D-2.)

One of the requirements of the round robin study was to report analytical results for the target analytes that were determined by the same methods used to report plant coal sample results. For the Yates project (and the coal round robin study), Radian performed multiple techniques for some elements (i.e., INAA vs. GFAA or ICP-AES) to provide comparative results, especially where questionable results by any one technique had been previously encountered. Performance evaluation (PE) audit samples (SRMs) were submitted for analysis by each method and the accuracy and precision were assessed before selecting the best qualified data for reporting and for use in material balance calculations.

\section{Comments}

One of the conclusions evident from the round robin study is that there is a high degree of variability and repeatability between methods, laboratories, and duplicate results for trace elements. Evidence of the variability in trace element analyses can be shown, for example, with neutron activation analysis where unacceptable results were reported for the analysis of the NIST SRM in the round robin study, but the same technique produced $90-110 \%$ recovery for the same elements in the NIST $1632 \mathrm{~b}$ standard reference coal submitted as an audit sample during this project. This suggests that the performance of some techniques, like INAA, may vary substantially between repeated analysis and analytical batches. Neutron activation appears to be a cost effective analytical technique; however, as with all analytical techniques, the results must be evaluated on a case-by-case basis.

Although the round robin analysis is useful for indicating problematic methods and poor quality control, the project-specific quality control activities should be used for assessing the accuracy and precision of the coal analyses performed at each site. 
Appendix D: Quality Assuraince/Quality Control

Table D-3

Radian Lab analysis of Standard Reference Coal, 1632b

\begin{tabular}{|c|c|c|c|c|c|}
\hline Parameter & Certified Value & $\begin{array}{l}\text { Analytical } \\
\text { Method }\end{array}$ & $\begin{array}{c}\text { Average \% } \\
\text { Recovery }\end{array}$ & Run 1 & Run 2 \\
\hline \multicolumn{6}{|c|}{ Ulitmate/Proximate (\% Dry Basis) } \\
\hline Ash & 6.80 & D 3174 & 99.6 & 6.78 & 6.77 \\
\hline Carbon & 78.11 & D 5373 & 99.4 & 77.74 & 77.52 \\
\hline Hydrogen & 5.07 & D 5373 & 101.2 & 5.14 & 5.12 \\
\hline Nitrogen & 1.56 & D 5373 & 97.1 & 1.54 & 1.49 \\
\hline Sulfur & 1.89 & D 4239 & 140.7 & 1.93 & $3.39^{2}$ \\
\hline Chlorine & 0.126 & D 4208 & 84.5 & 0.107 & 0.106 \\
\hline BTU/lb & 13,890 & D 2015 & 99.2 & 13,767 & 13,797 \\
\hline \multicolumn{6}{|c|}{ Major Ash Minerals } \\
\hline $\mathrm{SiO}_{2}$ & 44.03 & - & & - & - \\
\hline $\mathrm{Al}_{2} \mathrm{O}_{3}$ & 23.75 & INAA & 98.5 & 24.37 & 22.43 \\
\hline $\mathrm{TiO}_{2}$ & 1.11 & INÁA & 92.8 & 0.97 & 1.09 \\
\hline $\mathrm{Fe}_{2} \mathrm{O}_{3}$ & 15.96 & INAA & 91.7 & 14.24 & 15.04 \\
\hline $\mathrm{CaO}$. & 4.2 & INAA & 53.5 & $2.3^{2}$ & $2.19^{2}$ \\
\hline $\mathrm{MgO}$ & 0.93 & INAA & 80.1 & $0.77^{\circ}$ & $0.72^{2}$ \\
\hline $\mathrm{Na}_{2} \mathrm{O}$ & 1.02 & INAA & 85.3 & 0.87 & 0.87 \\
\hline $\mathrm{K}_{2} \mathrm{O}$ & 1.33 & INAA & 74.1 & $1.07^{2}$ & $0.9^{2}$ \\
\hline $\mathrm{P}_{2} \mathrm{O}_{5}$ & - & ICP-AES & - & 0.36 & 0.39 \\
\hline $\mathrm{SO}_{3}$ & - & - & - & - & - \\
\hline
\end{tabular}


Table D-3 (Continued)

\begin{tabular}{lccccc}
\multicolumn{1}{c}{ Parameter } & Certified Value & $\begin{array}{c}\text { Analytical } \\
\text { Method }\end{array}$ & $\begin{array}{c}\text { Average } \% \\
\text { Recovery }\end{array}$ & Run 1 & Run 2 \\
\hline Trace Elements & & & & & \\
$\mathrm{As}$ & 3.72 & GF/AA & 53.8 & $2^{\mathrm{b}}$ & $2^{\mathrm{b}}$ \\
$\mathrm{B}$ & - & ICP-AES & - & 61 & 60 \\
$\mathrm{Ba}$ & 67.5 & INAA & 106.6 & 71.2 & 72.7 \\
$\mathrm{Be}$ & - & ICP-AES & - & 0.6 & 0.6 \\
$\mathrm{Cd}$ & 0.0573 & ICP-AES & - & $<0.2$ & $<0.2$ \\
$\mathrm{Cr}$ & $11^{\mathrm{d}}$ & INAA & 96.4 & 11 & 10.2 \\
$\mathrm{Co}$ & 2.29 & INAA & 89.5 & 2.09 & $2.01^{\mathrm{c}}$ \\
$\mathrm{Cu}$ & 6.28 & INAA & -- & $<35.3$ & $<35.7$ \\
$\mathrm{~F}$ & - & D 3761 & - & 40 & 40 \\
$\mathrm{Hg}$ & - & DGA/CVAA & - & 0.05 & 0.05 \\
$\mathrm{Mn}$ & 12.4 & INAA & 86.3 & $10.8^{\mathrm{c}}$ & $10.6^{\mathrm{c}}$ \\
$\mathrm{Mo}$ & $0.9^{\mathrm{d}}$ & INAA & 191.7 & $1.55^{\mathrm{b}}$ & $1.9^{\mathrm{b}}$ \\
$\mathrm{Ni}$ & 6.1 & INAA & 145.1 & $<8.8$ & $<8.9^{\mathrm{b}}$ \\
$\mathrm{Pb}$ & 3.67 & ICP-AES & 81.7 & $3^{\mathrm{c}}$ & $3^{\mathrm{c}}$ \\
$\mathrm{Sb}$ & $0.24^{\mathrm{d}}$ & INAA & 81.3 & $0.196^{\mathrm{c}}$ & $0.194^{\mathrm{c}}$ \\
$\mathrm{Se}$ & 1.29 & GF/AA & 77.5 & $1^{\mathrm{c}}$ & $1^{\mathrm{c}}$ \\
$\mathrm{V}$ & $14^{\mathrm{d}}$ & INAA & 101.1 & 14.2 & 14.1
\end{tabular}

- Results exceed ASTM reproducibility limits.

${ }^{b}$ Results exceed certified values by more than 25 percent.

' Results exceed certified values by more than 10 percent.

d Informational value (not certified). 
Interlaboratory Variability and Accuracy of Coal Analyses in the U.S. Department of Energy Utility Air Toxics Assessment Program

\author{
Lawrence W. Rosendale \\ Matthew S. DeVito \\ CONSOL Inc. \\ Research and Development \\ 4000 Brownsville Road \\ Library, PA 15129
}




\section{INTRODUCTION}

The 1990 Clean Air Act Amendments (CAAA) empower the Environmental Protection Agency to set emission standards for a variety of potentially hazardous air pollutants from combustion sources. In order to define emissions from coal combustion sources, the U.S. Department of Energy (DOE) is coordinating an air toxics assessment program to characterize stack emissions from coal-fired utility boilers of volatile and semi-volatile organics, metals and anions specified in Title III of the Clean Air Act Amendments of 1990. The information from the DOE study will enable the Environmental Protection Agency to properly classify coal-fired utility boilers with regard to the CAAA and evaluate the potential risk to human health posed by these types of emission sources.

The first phase of DOE study consisted of sampling eight power plants. These plants represented a diverse range of boiler configurations, emission controis, and coal feeds. Part of the sampling protocol at each of the sites was to collect representative samples of the feed coal to the boiler. By analyzing the feed coal as well as all gas, solid, and water effluent streams, a material balance around each site could be established. A material balance closure near $100 \%$ would indicate that sampling and analyses of all streams was handled properly, and reliable emission estimates could be calculated.

Five laboratories participated in analyzing samples that were collected at the eight test sites. As part of the DOE program, CONSOL R\&D conducted a coal analysis round robin among these laboratories. The primary purpose of this study was to estimate the analytical variability one can expect on trace element analyses when comparing results from the same laboratory or results from two or more laboratories.

Trace elements in coal generally are defined as those elements that occur at concentrations of 100 parts per million (ppm) or less. Seventeen trace elements were included in this study. Thirteen of these elements are listed in the 1990 CAAA as hazardous air pollutants. Earlier studies ${ }^{1}$ have shown the interlaboratory variability of trace element analyses can be quite large. This analytical variability should be considered when determining the potential emissions from coal combustion sources.

The variability of other commonly measured coal quality parameters also was evaluated.

\section{COAL SAMPLES}

The coal samples used in the round robin study were supplied to CONSOL R\&D by the prime contractor at each of the eight test sites. These were the same coals that were being fed to the boilers during the testing period at each site. The coals were geologically diverse and ranged from lignite to bituminous in rank. Once received, all sample reduction and preparation was according to ASTM D 2013 "Standard Method of Preparing Coal Samples for Analyses". ${ }^{2}$ A spinning riffle was used to divide the gross sample prepared from each coal into homogenous splits. This is the preferred method in the coal industry to divide a sample of coal into several samples having the same composition and is widely used in commercially sponsored coal analyses round robin programs. 
Each participating laboratory was provided duplicate samples of each of the eight coals, along with a sample of a National Institute for Standard and Technology (NIST) certified reference coal. The samples were randomized and were identified only by code letters. Each laboratory was requested to analyze the samples in duplicate using the same procedures used to analyze the samples from the DOE Air Toxics Assessment programs. By using this round robin design, intralaboratory repeatability and interlaboratory reproducibility, as well as individual laboratory precision, could be established. The suite of analyses included in this study is shown below:

\begin{tabular}{lllll}
\multicolumn{1}{c}{ Proximate-Ultimate } & \multicolumn{2}{c}{ Major Ash Elements } & & \multicolumn{2}{c}{ Trace Elements } \\
\cline { 5 - 6 } \cline { 5 - 6 } \cline { 5 - 6 } Moisture & $\mathrm{SiO}_{2}$ & & $\mathrm{As}$ & $\mathrm{Hg}$ \\
Ash & $\mathrm{Al}_{2} \mathrm{O}_{3}$ & & $\mathrm{~B}$ & $\mathrm{Mn}$ \\
Carbon & $\mathrm{TiO}_{2}$ & & $\mathrm{Ba}$ & $\mathrm{Mo}$ \\
Hydrogen & $\mathrm{Fe}_{2} \mathrm{O}_{3}$ & & $\mathrm{Be}$ & $\mathrm{Ni}$ \\
Nitrogen & $\mathrm{CaO}$ & & $\mathrm{Cd}$ & $\mathrm{Pb}$ \\
Sulfur & $\mathrm{MgO}$ & & $\mathrm{Cr}$ & $\mathrm{Sb}$ \\
Chlorine & $\mathrm{Na}_{2} \mathrm{O}$ & & $\mathrm{Co}$ & $\mathrm{Se}$ \\
Heating Value (Btu/lb) & $\mathrm{K}_{2} \mathrm{O}$ & & $\mathrm{Cu}$ & $\mathrm{V}$ \\
& $\mathrm{P}_{2} \mathrm{O}_{5}$ & & $\mathrm{~F}$ & \\
& $\mathrm{SO}_{3}$ & & &
\end{tabular}

The average interlaboratory results for this suite of analyses for all eight samples are shown in Table 1. Individual laboratory results for all samples are presented in Appendix A. Samples identified as A\&J and B\&K are Illinois basin bituminous coals. Samples C\&L, F\&O, and H\&Q are mid-sulfur bituminous coals. Sample D\&M is a subbituminous coal from the Powder River basin. Sample G\&P is also a subbituminous coal. Sample E\&N is ranked as a lignite.

\section{ANALYTICAL TECHNIQUES}

The analytical techniques used by the participating laboratories to complete the suite of analysis in this study are shown in Table 2. No one parameter was measured by all laboratories by the same analytical technique. All of the labs used ASTM standard methods for the Proximate and Ultimate analyses. However, numerous techniques were used for the major ash and trace element analyses. The techniques included graphite furnace atomic absorption (GF/AA), inductively coupled plasma emission spectroscopy (ICP/ES), inductively coupled plasma mass spectroscopy (ICP/MS), instrumental neutron activation analyses (INAA), ion chromatography (IC), cold vapor atomic fluorescence (CV/AF), and X-ray fluorescence (XRF). Mercury was measured by gold amalgam cold vapor atomic absorption (GAVCVAA), double gold amalgam cold vapor atomic absorption (DGA VCVAA), and cold vapor atomic fluorescence (CV/AF). The techniques of $A A$, GF/AA, ICP/ES, ICP/MS, IC, and CVAA require that the analysis sample first be put into solution before being introduced into the instrument. INAA, XRF, GA/CVAA, and DGAVCVAA analyses can be performed on the whole coal or an ash sample of the coal. 


\section{ACCURACY}

The accuracy of analyses performed by each laboratory was evaluated using the NIST Standard Reference Coal $1632 \mathrm{~b}$. This Pittsburgh seam coal is the most characterized standard reference material available from NIST. Certified or informational values are listed for all of the parameters included in this study except for boron, barium, fluorine, phosphorus, and mercury. For trace elements, all definitive results (" $<$ " values ignored) that fell within $10 \%$ of the certified or informational value arbitrarily were considered accurate values. Values outside this range were considered to be inaccurate. ASTM interlaboratory reproducibility limits were the criteria for accuracy on all other analyses. Table 3 shows the results reported by the each laboratory for NIST SRM 1632b. Using the previously described criteria for accuracy, the percentage of accurate results (accurate results/total definitive results) was calculated. Parameters without a certified or informational value were not included.

The table below shows the percentage of accurate results reported by each lab for the suite of trace elements, the percentage of accurate results for all analyses, and the percentage of trace element results that were reported as definitive. Although lab IV showed the highest percentage of accurate results (75\%), that figure is based on only the $80 \%$ of definitive results reported by that laboratory.

As shown in the table below, the percentage of accurate trace element analyses ranged from $38 \%$ to $75 \%$. Non-definitive results reported for antimony, cadmium, copper, fluorine, molybdenum, nickel, and selenium. Only one laboratory reported definitive results for the entire suite of trace elements. The most troublesome elements, with respect to accuracy, were arsenic, cadmium, molybdenum, antimony, and selenium. Only one lab reported accurate results for cadmium, molybdenum or antimony.

The Proximate and Ultimate analyses reported by labs II, III, IV, and V were all within ASTM reproducibility limits except for a single sulfur analysis. Lab I reported results that exceeded ASTM reproducibility limits for hydrogen, nitrogen, sulfur chlorine and heating value. Two labs reported all major ash elements within ASTM limits. Lab I exceeded limits for silicon, iron, calcium, magnesium, and potassium. Lab III exceeded limits for calcium, magnesium, and potassium. Lab $\mathrm{IV}$ performed only a limited number of major ash element analyses, but reported results for aluminum and potassium that were outside established ASTM reproducibility limits.

$\%$ ACCURATE RESULTS ON NIST 1632b

\begin{tabular}{|c|c|c|c|}
\hline Lab & $\begin{array}{c}\text { Definitive } \\
\text { Trace Element Results }\end{array}$ & $\begin{array}{c}\text { Trace } \\
\text { Elements }\end{array}$ & All Analyses \\
\hline I & 88 & 38 & 43 \\
\hline II & 100 & 73 & 88 \\
\hline III & 82 & 50 & 63 \\
\hline IV & 80 & 75 & 80 \\
\hline V & 100 & 48 & 78 \\
\hline
\end{tabular}




\section{REPRODUCIBILTY}

The percent relative standard deviation (PRSD) of the analytical results was chosen to represent interlaboratory reproducibility in this study. Table 4 shows the average PRSD for all labs, on all samples, for the entire suite of analyses. Reproducibility for trace elements ranged from 11.0 PRSD for vanadium to 60.7 PRSD for molybdenum. The average PRSD for all of the trace elements (all coals, all labs) was $27.9 \%$. In most cases the PRSDs for cadmium, copper and antimony are based on results from only three laboratories. These elements were either below detection limits at laboratories II and III or were not determined.

Excluding Lab I's results, Proximate and Ultimate analyses were generally within ASTM limits. Aside from the determination of percent ash this particular laboratory reported only a single sulfur analyses on the standard reference material that was within established ASTM limits. Chlorine, although not generally considered a trace element in coal, is listed in the 1990 CAAA as a hazardous air pollutant. It showed an average PRSD for all labs of $37.2 \%$. Three of the coals sampled in the study are ranked subbituminous or lignites. Chlorine on these samples (D\&M, $E \& N, G \& P)$ was reported as below detection limits $(0.01$ and $0.02 \%)$ by two laboratories and not determined by another laboratory. Therefore, the PRSD for these three samples was calculated with data from only two labs. The reproducibility estimates for chlorine may have been larger if more labs had reported data.

Major ash elements were determined with an average PRSD of $21.7 \%$. This is only slightly better than the average PRSD of $27.9 \%$ for trace elements. Phosphorous, calcium, and magnesium had PRSDs greater than 35\%. Including only labs II and V, the overall average PRSD for the major ash elements drops to $7 \%$. These were the only labs that did not exceed ASTM limits on the certified reference material. Labs I and III showed a consistent low bias for calcium and magnesium on most samples as well as on the certified reference material. Lab I showed poor intralaboratory repeatability for most major ash elements.

Figure 1 shows the interlaboratory reproducibility as PRSD for the suite of trace elements on all samples. The overall average PRSDs for $\mathrm{V}, \mathrm{F}, \mathrm{Be}, \mathrm{Mn}, \mathrm{B}, \mathrm{Hg}, \mathrm{Cu}, \mathrm{Sb}$, and $\mathrm{Cr}$, and $\mathrm{Ba}$ are between 9.6 and $22.9 \%$. PRSDs for $\mathrm{Ba}, \mathrm{Co}, \mathrm{Ni}$, and Se were somewhat poorer, averaging nearly $30 \%$. $\mathrm{Ni}$, As, $\mathrm{Cd}, \mathrm{Pb}$ and Mo showed the most variability with PRSDs from 36.2 to $60.7 \%$.

Figure 2 shows the average interlaboratory reproducibility for the suite of trace elements, as well as the range of PRSDs, for each element on each sample. Although the average PRSD for many elements is reasonably good $(-20 \%)$, on any given sample the range of reported values can be quite large. The average minimum PRSD for interlaboratory trace element analyses was $13.6 \%$. The average maximum was $48.1 \%$. $\mathrm{Ba}, \mathrm{Cd}, \mathrm{Cu}, \mathrm{Hg}, \mathrm{Mo}, \mathrm{Ni}, \mathrm{Pb}$ and $\mathrm{Sb}$ all had a $\mathrm{PRSD}$ range over $30 \%$. The range of reported values for $\mathrm{Mo}, \mathrm{Ni}$, and $\mathrm{Cd}$ on some samples was $52 \%, 76 \%$, and $110 \%$ respectively. This shows that outliers are to be expected when comparing trace element analyses between laboratories.

\section{REPEATABILITY}

Figure 3 shows the average intralaboratory repeatability for each trace element for ail coals. Intralaboratory repeatability was calculated as the average percent difference in a given 
laboratory's results on the eight paired samples. The data show that the overall laboratory repeatability on trace elements ranged from a low of $7.8 \%$ for chromium to a high of $32.5 \%$ for cadmium. The average repeatability for all trace elements was $14.6 \%$. Overall intralaboratory repeatability for all elements by all labs was less than $10 \%$ on half of the analyses, less than $20 \%$ on $68 \%$, and less than $30 \%$ on $75 \%$ of all trace element results. In general, elements with lower between-lab reproducibility also had lower same-lab repeatability. Similarly, elements like cadmium, that showed reproducibilities with a high PRSD, had higher average repeatabilities, with the exception of molybdenum. This element had a relatively low repeatability (16.8\%), but showed the highest reproducibility $(60.7 \%)$. This may suggest bias in the various methods used for its determination. Data showing the complete list of individual laboratory repeatability for all samples is presented in Appendix B.

\section{VARIABILITY vS COAL RANK}

Figure 4 shows the variability in interlaboratory trace element analyses as PRSD plotted as a function of the as-determined heating value for the eight coals. The as-determined heating value of a coal is one way to roughly establish coal rank. The data clearly show that trace element analytical variability is a function of coal rank, increasing as the coal rank decreases. This is not unusual; many ASTM coal standards have precision statements that are rank-dependant. In the case of the eight coals studied here, as the heating value of the coal (Btu/lb) decreases, the analytical variability of trace elements increases. Sample pairs A\&J, C\&L, H\&Q, F\&O, and B\&K are bituminous coals. Samples G\&P and D\&M are subbituminous and samples E\&N are classified as lignites. A regression analyses of the data is shown in Figure 5 and has an $r^{2}$ value of 0.95 . Average trace element intralaboratory repeatability showed a similar trend. The overall trace element repeatability for the bituminous coals was slightly better $(14.8 \%)$ than that for the subbituminous and lignite samples (20.2\%).

\section{MERCURY}

Of the potential hazardous air pollutants mentioned in the CAAA, mercury is receiving the most attention regarding possible emissions from coal combustion sources. As mentioned earlier, four of the five laboratories in this study used some form of gold amalgamation followed by cold vapor atomic absorption for mercury analyses, the other used cold vapor atomic fluorescence. The table below summarizes intralaboratory repeatability and interlaboratory reproducibility for mercury analyses. Repeatability is shown as the percent difference in a laboratory's results on the eight paired samples, and reproducibility is shown as PRSDs.

\section{REPEATABILITY AND REPRODUCIBILITY OF MERCURY RESULTS}

\begin{tabular}{|c|c|c|c|c|c|c|c|c|c|}
\hline & A\&J & B\&K & C\&L & D\&M & E\&N & F\&O & G\&P & $\mathrm{H} \& \mathrm{Q}$ & Avg. \\
\hline $\begin{array}{l}\text { Repeatability, } \\
\text { as } \% \text { difference }\end{array}$ & 11.3 & 46.3 & 19.1 & 19.1 & 25.8 & 11.7 & 8.6 & 21.2 & 17.6 \\
\hline $\begin{array}{l}\text { Reproducibility, } \\
\text { as PRSD }\end{array}$ & 10.4 & 40.6 & 24.8 & 16.7 & 16.9 & 20.4 & 9.1 & 26.1 & 20.6 \\
\hline
\end{tabular}

A recent, more extensive round robin on mercury analyses ${ }^{3}$ estimated inrerlaboratory reproducibility and intralaboratory repeatability at 25 and $50 \%$, respectively. That particular round robin 
involved three coal samples and 12 laboratories. Although the majority of laboratories in that study also used cold vapor atomic absorption for mercury analyses, some data were provided by labs using neutron activation and cold vapor atomic fluorescence.

\section{SUMMARY AND CONCLUSIONS}

Based on the analyses of the certified reference coal, even the best laboratory in this study reported trace element levels to within $10 \%$ of their certified value only about $80 \%$ of the time. On average, only $57 \%$ of the reported data from all labs met this $10 \%$ level of accuracy.

The techniques used in many laboratories for trace element analyses produced a significant number of non-definitive $("<")$ results. If certain detection limits are required, analytical techniques must be specified.

Although the overall interlaboratory trace element reproducibility is $28 \%$, it may be very poor, approaching $60 \%$ for some elements.

Interlaboratory reproducibility for trace element analyses is dependent on coal rank. As coal rank decreases, analytical variability increases.

The variability of coal trace element analyses makes accurate estimates of emissions from combustion sources difficult, especially if the estimates are based solely on feed coal analyses.

\section{RECOMMENDATIONS FOR CONDUCIING FUTURE COAL ANALYSES ROUND ROBIN PROGRAM}

1. Follow ASTM standard method E 691. This standard lists specific guidelines for conducting an interlaboratory coal analysis round robin program. The standard also specifies software for the statistical interpretation of results. Both the method and the software are available from ASTM for a nominal fee. One of the guidelines violated in this round robin was the number of participating laboratories. E 691 states that a minimum of six laboratories is necessary to generate ASTM precision statements. For that reason we were unable to use the software from this standard that would have generated ASTM limits for repeatability and reproducibility.

2. Laboratories that are candidates for the round robin should be evaluated. Based on the data reported on the standard reference coal in this study, it is obvious that Lab I was not proficient with coal analyses. Laboratories that are candidates for round robins should be audited by someone familiar with the guidelines set forth in ASTM D 4182, "Evaluation of Laboratories Using ASTM Procedures in the Sampling and Analysis of Coal and Coke". These labs also should be able to demonstrate their ability to conform with ASTM D 4621, "Accountability and Quality Control in the Coal Analysis Laboratory". A lab not in compliance with either of the standards should not be included in the study. As a minimum, candidate labs should be able to demonstrate proficiency by analyzing a certified reference material within specified precision limits prior to conducting the actual round robin.

3. Specify the minimum detection limits that are required for each element. Based on the large number of non-definitive results reported for several of the trace elements it is apparent that 
most laboratories are not using techniques that can accurately assess the levels of some of the trace elements found in coal. Using half the detection limit, which is the common practice for treating this type of result, would lead to a considerable overestimation of some trace element levels. Examples of this overestimation based on half the detection limit are found in Table 3. For instance, Lab III reported an average detection limit for $\mathrm{Cu}$ as $35.5 \mathrm{ppm}$. Using one half of this value, or $17.8 \mathrm{ppm}$, would overstate the certified value for $\mathrm{Cu}$ on this sample by nearly three fold.

\section{REFERENCES}

1. Lengyel, John Jr. and Obermiller, Edward L. "Interlaboratory Variability and Accuracy in Trace Element Analyses of Coal". Proceedings, Fourth Annual Pittsburgh Coal Conference, Pittsburgh, PA, 1987, pp. 148-159.

2. "ASTM Volume 05.05 Gaseous Fuels; Coal and Coke", American Society for Testing and Materials, Philadelphia, PA, 1993.

3. Lengyel, John Jr., Devito, M. S., and Bilonick, R. A. "Interlaboratory and Intralaboratory Variability in The Analyses of Mercury in Coal". Paper to be presented at the Air Waste Management Association Annual Meeting, Cincinnati, $\mathrm{OH}, 6 / 19-24 / 94$. 
Table 1. Average of Interlaboratory Results for All Samples.

$\begin{array}{cccccccc}\text { A\&J } & \text { B\&K } & \text { C\&L } & \text { D\&M } & \text { E\&N } & \text { F\&O } & \text { G\&P } & H \& O \\ \text { ILBASIN } & \text { ILBASIN } & \underline{B I T} . & \text { PRB } & \text { NDLIG. } & \underline{B I T} . & \underline{\text { SUB.BIT. }} & \underline{B I T} .\end{array}$

Trace Elements

$\mathrm{As}$
$\mathrm{S}$
$\mathrm{Ba}$
$\mathrm{Be}$
$\mathrm{Cd}$
$\mathrm{Cr}$
$\mathrm{Co}$
$\mathrm{Cu}$
$\mathrm{F}$
$\mathrm{Hg}$
$\mathrm{Mn}$
$\mathrm{Mo}$
$\mathrm{Ni}$
$\mathrm{Pb}$
$\mathrm{Sb}$
$\mathrm{Se}$
$\mathrm{V}$

Proximate \& Ultimate

Ash

Carbon

Hydrogen

Nitogen

Sulfur

Chlorine

Heating Valt

Maior Ash Elements

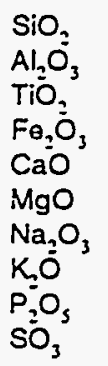

ppm Dry Coal

$\begin{array}{rrrrrrrr}2.39 & 2.74 & 9.43 & 1.24 & 7.64 & 26.0 & 1.70 & 3.45 \\ 227 & 212 & 72.3 & 83.4 & 126 & 70.7 & 76.5 & 169 \\ 47.3 & 48.9 & 31.1 & 370 & 568 & 76.1 & 312 & 48.6 \\ 1.33 & 1.61 & 1.33 & 0.42 & 0.72 & 2.37 & 1.29 & 1.41 \\ 0.580 & 1.013 & 0.112 & 0.058 & 0.079 & 0.085 & 0.560 & 0.508 \\ 28.3 & 34.7 & 16.3 & 4.40 & 8.05 & 20.0 & 9.61 & 21.4 \\ 3.87 & 3.57 & 5.50 & 0.86 & 2.10 & 6.95 & 4.14 & 4.42 \\ 10.7 & 11.3 & 8.47 & 9.52 & 9.28 & 21.2 & 14.5 & 13.1 \\ 97.1 & 112 & 58.0 & 44.3 & 56.9 & 81.3 & 80.3 & 79.5 \\ 0.101 & 0.109 & 0.126 & 0.084 & 0.145 & 0.260 & 0.080 & 0.085 \\ 41.3 & 34.3 & 18.4 & 145 & 123 & 26.5 & 76.6 & 29.0 \\ 8.34 & 7.91 & 1.87 & 7.93 & 3.98 & 4.54 & 2.11 & 5.80 \\ 17.6 & 18.5 & 14.1 & 5.09 & 7.26 & 28.2 & 6.84 & 18.3 \\ 9.12 & 13.1 & 5.00 & 5.22 & 3.31 & 13.6 & 8.86 & 8.47 \\ 0.49 & 0.79 & 0.64 & 0.47 & 0.75 & 2.10 & 1.74 & 0.62 \\ 2.94 & 3.16 & 1.92 & 0.84 & 0.80 & 2.56 & 1.18 & 2.21 \\ 36.6 & 46.3 & 31.0 & 9.36 & 16.8 & 34.0 & 26.1 & 38.5\end{array}$

\section{$\%$ Dry Basis}

$\begin{array}{rrrrrrrr}11.99 & 12.54 & 11.56 & 11.7 & 16.71 & 13.35 & 20.57 & 10.59 \\ 69.58 & 69.80 & 72.08 & 67.6 & 58.80 & 70.26 & 61.27 & 71.03 \\ 4.87 & 4.78 & 4.96 & 4.80 & 4.53 & 4.86 & 4.78 & 5.14 \\ 1.33 & 1.33 & 1.39 & 1.01 & 0.89 & 1.37 & 1.05 & 1.42 \\ 3.42 & 3.53 & 3.26 & 1.15 & 1.12 & 3.01 & 0.65 & 2.89 \\ 0.064 & 0.074 & 0.085 & 0.03 & 0.040 & 0.140 & 0.039 & 0.115 \\ 12214 & 12189 & 12888 & 11350 & 9601 & 12452 & 10636 & 12587\end{array}$

$\%$ Dry Ash

$\begin{array}{rrrrrrrr}44.58 & 49.7 & 44.98 & 42.12 & 39.48 & 45.67 & 59.26 & \mathbf{5 1 . 5 5} \\ 16.78 & 18.6 & 21.41 & 16.48 & 10.58 & 22.54 & 20.62 & 21.74 \\ 0.89 & 0.99 & 0.99 & 0.88 & 0.47 & 1.22 & 1.00 & 1.03 \\ 15.95 & 15.1 & 24.75 & 6.07 & 6.14 & 21.33 & 4.45 & 16.39 \\ 4.11 & 2.69 & 1.04 & 7.79 & 10.54 & 1.50 & 3.29 & 2.46 \\ 0.77 & 0.82 & 0.60 & 2.55 & 2.97 & 0.73 & 0.93 & 0.79 \\ 0.91 & 0.75 & 0.43 & 0.29 & 0.84 & 0.30 & 0.23 & 0.84 \\ 1.95 & 2.20 & 1.84 & 0.51 & 1.35 & 2.17 & 1.26 & 2.50 \\ 0.29 & 0.36 & 0.16 & 0.37 & 0.17 & 0.58 & 0.04 & 0.26 \\ 4.57 & 2.61 & 1.39 & 11.41 & 15.08 & 1.71 & 3.68 & 2.56\end{array}$


Table 2. Analytical Methods Used on DOE Air Toxics Assessment Coal Samples.

\begin{tabular}{l} 
Parameter \\
\hline Moisture \\
Ash \\
Carbon \\
Hydrogen \\
Nitrogen \\
Sulfur \\
Chlorine \\
Btu/lb \\
Major Ash Elements \\
\hline $\mathrm{SiO}_{2}$ \\
$\mathrm{Al}_{2} \mathrm{O}_{3}$ \\
$\mathrm{TiO}_{2}$ \\
$\mathrm{Fe}_{2} \mathrm{O}_{3}$ \\
$\mathrm{CaO}$ \\
$\mathrm{MgO}$ \\
$\mathrm{NaO}^{\mathrm{O} O}$ \\
$\mathrm{~K}_{2} \mathrm{O}_{3}$ \\
$\mathrm{P}_{2} \mathrm{O}_{5}$ \\
$\mathrm{SO}_{3}$
\end{tabular}

\begin{tabular}{c} 
Lab I \\
\hline D3173 \\
D3174 \\
D3178 \\
$D 3178$ \\
$D 3179$ \\
$D 3177$ \\
$D 4208$ \\
.$D 2015$
\end{tabular}

\begin{tabular}{l} 
Lab II \\
\hline D 5142 \\
D 5142 \\
D 5373 \\
D 5373 \\
D 5373 \\
D 4239 \\
LECO \\
D 1989
\end{tabular}

\begin{tabular}{l} 
Lab III \\
\hline D 3173 \\
D 3174 \\
D 5373 \\
D 5373 \\
D 5373 \\
D 4239 \\
D 4208 \\
D 2015
\end{tabular}

\begin{tabular}{ccc} 
Lab IV & Lab V \\
\cline { 1 - 1 }$D 3173$ & & $D 3173$ \\
$D 3174$ & & $D 3174$ \\
$D 3178$ & & $D 5373$ \\
$D 3178$ & & $D 5373$ \\
$D 3179$ & & $D 5373$ \\
$D 4239$ & & $D 4239$ \\
$\star \star \star I C$ & & $D 4208$ \\
$D 2015$ & & $D 2015$
\end{tabular}

Trace Elements
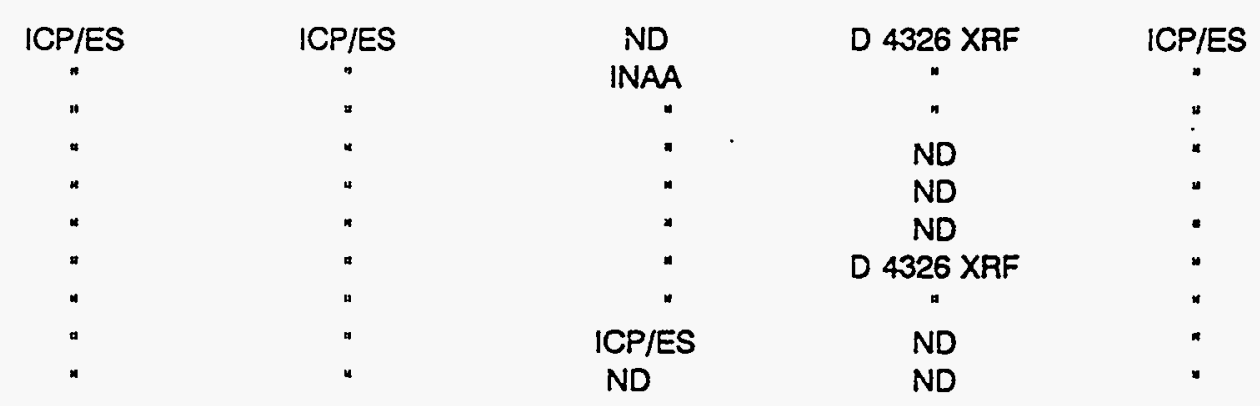

\begin{tabular}{l}
\hline $\mathrm{As}$ \\
$\mathrm{B}$ \\
$\mathrm{Ba}$ \\
$\mathrm{Be}$ \\
$\mathrm{Cd}$ \\
$\mathrm{Cr}$ \\
$\mathrm{Co}$ \\
$\mathrm{Cu}$ \\
$\mathrm{Cu}$ \\
$\mathrm{F}$ \\
$\mathrm{Hg}$ \\
$\mathrm{Mn}$ \\
$\mathrm{Mo}$ \\
$\mathrm{Ni}$ \\
$\mathrm{Pb}$ \\
$\mathrm{Sb}$ \\
$\mathrm{Se}$ \\
$\mathrm{V}$
\end{tabular}
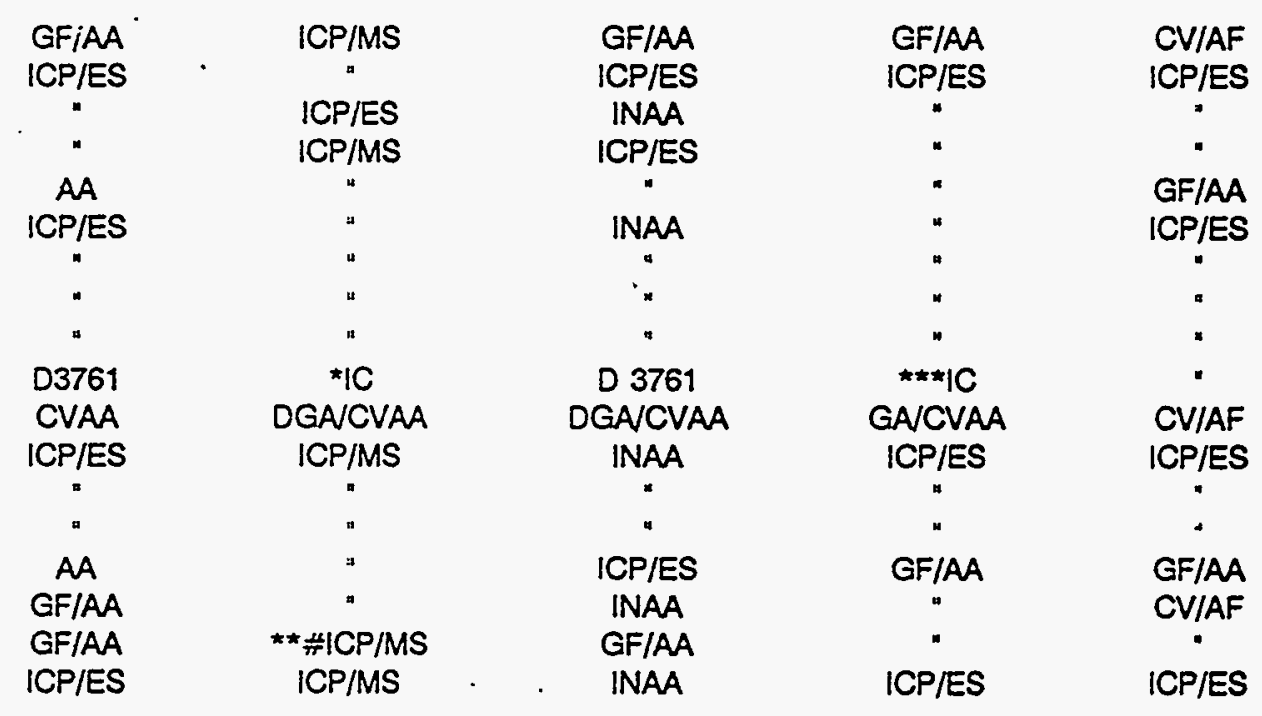

*IC Hydropyrolysis with IC Finish

*\#ICP!MS Hydropyrolysis with ICP/MS Finish

$\approx$ "IC-Soluble Species Only

$\begin{array}{ll}\text { AA } & \text { Atomic Absorption } \\ \text { CVAA } & \text { Cold Vapor Atomic Absorption } \\ \text { CV/AF } & \text { Cold Vapor Atomic Fluorescence } \\ \text { DGAVVAA } & \text { Double Gold Amalgam Cold Vapor Atomic Absorption } \\ \text { GFIAA } & \text { Graphite Furnace Atomic Absorption } \\ \text { IC } & \text { lon Chromatography }\end{array}$

ICP/ES Inductively Coupled Plasma Emission Spectroscopy inductively Coupled Plasme Mass Spectroscopy INAA instrumental Neutron Activation Analyses

ND Not Determined

XRF X-ray Fluorescence 
Table 3. Individual Laboralory Analyses of National Institute of Standard and Technology, Standard Reference Coal 1632b.

\begin{tabular}{|c|c|c|c|c|c|c|}
\hline PARAMEIER & $\begin{array}{l}\text { CERTIFUED } \\
\text { VALUEE }\end{array}$ & Run? ${ }^{L A B I}$ Run? & 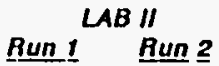 & Run 1 $1_{\text {Bun 2 }}^{\text {LAB III }}$ & $\stackrel{\text { LAB } 1 \mathrm{~N}}{\text { Run } ?}$ & $\begin{array}{l}\angle A B V \\
\text { Bun } 1\end{array}$ \\
\hline
\end{tabular}

\begin{tabular}{|c|c|c|c|c|c|c|c|c|c|c|c|}
\hline $\begin{array}{l}\text { As } \\
\text { B }\end{array}$ & 3.72 & $\frac{3.04}{87.1}$ & $\begin{array}{l}3.54 \\
81.0\end{array}$ & $\begin{array}{l}3.71 \\
52.0\end{array}$ & $\begin{array}{l}3.87 \\
51.0\end{array}$ & $\underset{61}{2}$ & $\frac{2}{60}$ & $\underset{60}{2}$ & $\begin{array}{l}\text { ND } \\
55\end{array}$ & $\begin{array}{r}4.1 \\
31.1\end{array}$ & $\begin{array}{r}3.1 \\
18.6\end{array}$ \\
\hline $\mathrm{Ba}$ & 67.5 & 50.6 & 48.5 & 80.0 & 66.4 & 71.2 & 72.7 & 63 & 70 & 67.2 & 67.6 \\
\hline $8 \theta$ & & $\overline{0.93}$ & $\overline{0.8 \overline{2}}$ & 0.58 & 0.59 & 0.6 & 0.6 & 0.5 & 0.6 & 0.693 & 0.668 \\
\hline $\mathrm{Cd}$ & 0.0573 & 0.27 & 0.41 & 0,040 & 0.080 & $<0.2$ & $<0.2$ & $<0.2$ & $<0.2$ & 0.028 & ND \\
\hline $\mathrm{Cr}$ & $\$ 11$ & 12.2 & 11.1 & 8.7 & 0.64 & 11 & 10.2 & $\underline{\mathbf{g}}$ & 11 & 7,6 & 8,1 \\
\hline Co & 2.29 & 4.15 & 2.83 & 1.88 & $\overline{2.08}$ & 2.08 & 2.01 & $\underline{\underline{2}}$ & 2 & 2.18 & 1.42 \\
\hline $\mathrm{Cu}$ & 6.28 & 6.07 & $\overline{5.87}$ & 5.4 & 5.86 & $<35.3$ & $<35.7$ & 6 & $\bar{B}$ & 8.4 & 8.8 \\
\hline$F$ & & $<100$ & $<100$ & 43.0 & 35.9 & 40 & 40 & ND & NO & 41 & 41 \\
\hline $\mathrm{Hg}$ & & 0.17 & 0.15 & 0.090 & 0.005 & 0.05 & 0.05 & 005 & 007 & 0057 & 0062 \\
\hline$M n$ & 12.4 & 11:1 & $11: 1$ & 11.5 & 12 & 108 & 10.6 & 12 & 13 & 10.9 & 11.1 \\
\hline Mo & 0.8 & 6.38 & 2.63 & 0.85 & 0.8 & $15 \overline{5}$ & 1.9 & $<3$ & $<3$ & ND & ND \\
\hline $\mathrm{Ni}$ & 61 & 8 & 7.39 & 5.65 & 8.23 & $<8.8$ & $<8.0$ & 6 & 7 & 5.2 & 6 \\
\hline $\mathrm{Pb}$ & 3.67 & 3.44 & 3.44 & 3.81 & 4.03 & $\underline{\mathbf{3}}$ & $\underline{\mathbf{3}}$ & 4 & $\overline{4}$ & $\underline{3.2}$ & 18 \\
\hline Sb & ${ }^{*} 0.24$ & $<0.8$ & $<0.8$ & 0.22 & 0.23 & 0.196 & 0.184 & $<1$ & $<1$ & ND & ND \\
\hline Se & 1.29 & 1.42 & 0.75 & 1.48 & 1.52 & -1 & 1 & 1 & NO & 1.23 & 0.751 \\
\hline v & *14 & 10.2 & 182 & 11.0 & 12.7 & $14 \overline{2}$ & 14.1 & 14 & 15 & 15.3 & 14.8 \\
\hline
\end{tabular}

Single-underlined results oxceod certified values by more than $10 \%$ Double-underlined results oxceed certifiod values by more than $25 \%$ - Informational Value

w. Dry Coal

$\begin{array}{lr}\text { Ash } & 6.80 \\ \text { Carbon } & 78.11 \\ \text { Hydrogen } & 5.07 \\ \text { Nitrogen } & 1.58 \\ \text { Sulfur } & 1.89 \\ \text { Chlorine } & 0.126 \\ \text { Btu/lb } & 13890\end{array}$

\begin{tabular}{|c|c|c|c|}
\hline 6.92 & 8.91 & 8.01 & 6.01 \\
\hline 76.4 & 76.97 & 77.03 & 78.30 \\
\hline 6.7 & 6,1 & 5.03 & 4.99 \\
\hline$\pi$ & 0.48 & 1.54 & 1.0 \\
\hline 2,27 & 9 & 1.80 & 1.82 \\
\hline 0.030 & 0,09 & 0.112 & 0.108 \\
\hline 170 & 130 & 13809 & 13800 \\
\hline
\end{tabular}

6.78
77.74
5.14
1.54
1.93
0.107
13767

$\begin{array}{rrrrr}6.77 & 6.78 & 6.79 & 6.78 & 6.83 \\ 77.52 & 76.89 & 76.72 & 77.62 & 77.2 \\ 5.12 & 4.94 & 4.94 & 5.06 & 5.01 \\ 1.49 & 1.5 & 1.58 & 1.46 & 1.41 \\ 3.39 & 1.06 & 1.95 & 1.02 & 1.01 \\ 3.106 & \text { ND } & \text { ND } & 0.12 & 012 \\ 0.106 & 13760 & 13763 & 13774 & 13778\end{array}$

Underlined results exceod AST $M$ reproducibility limits

$\begin{array}{lr}\mathrm{SiO}_{2} & 44.03 \\ \mathrm{Al}_{2} \mathrm{O}_{1} & 23.75 \\ \mathrm{TiO}_{2} & 1.11 \\ \mathrm{Fo}_{2} \mathrm{O}_{3} & 15.08 \\ \mathrm{CaO} & 4.2 \\ \mathrm{MgO} & 0.93 \\ \mathrm{NaO} & 1.02 \\ \mathrm{~K} \mathrm{O}_{2} & 1.33 \\ \mathrm{P}_{2} \mathrm{O}_{3} & \\ \text { SO, } & \end{array}$

$\begin{array}{rr}50,15 & 47 \\ 25.7 & 23 \\ 1.37 & 1 \\ 17.99 & 10.75 \\ 1.72 & 1 \\ 2.24 & 0.23 \\ 1.12 & 1 \\ 1.2 & 1 \\ 0.20 & 0 \\ \text { ND } & \end{array}$

$\begin{array}{rrr}47.08 & 45.27 & 45.41 \\ 23.70 & 24.00 & 25.00 \\ 1.25 & 1.1 & 1.11 \\ 10.75 & 16.80 & 17.03 \\ 1.72 & 4.64 & 4.63 \\ 0.23 & 1.03 & 1.02 \\ 1.05 & 1.04 & 1.05 \\ 1.24 & 1.39 & 1.37 \\ 0.24 & 0.17 & 0.18 \\ \text { ND } & 4.14 & 4.15\end{array}$

$w \%$, Dry Ash

Undorlinod rosults oxcood ASTM reproducibility limits

\begin{tabular}{|c|c|c|c|c|c|}
\hline ND & ND & 4462 & ND & 44.4 & 438 \\
\hline 24.37 & 22.43 & 18.57 & ND & 24.3 & 242 \\
\hline 0.97 & 1.00 & 0.04 & ND & 1 & 0.8 \\
\hline 14.24 & 15.04 & ND & ND & 16.4 & 10 \\
\hline 2,3 & 2.19 & ND & ND & 4.2 & 4.2 \\
\hline 0.77 & $2.2 \overline{2}$ & ND & ND & 0.05 & 0.97 \\
\hline 0.87 & 0.07 & 1.01 & ND & 1 & 1 \\
\hline 1.07 & 2.9 & 2.05 & ND & 1.3 & 1.3 \\
\hline 0.30 & 0.30 & ND & ND & 0.23 & 023 \\
\hline ND & ND & ND & ND & 4.08 & 4.54 \\
\hline
\end{tabular}


Table 4. Percent Relative Standard Deviation for All Samples.

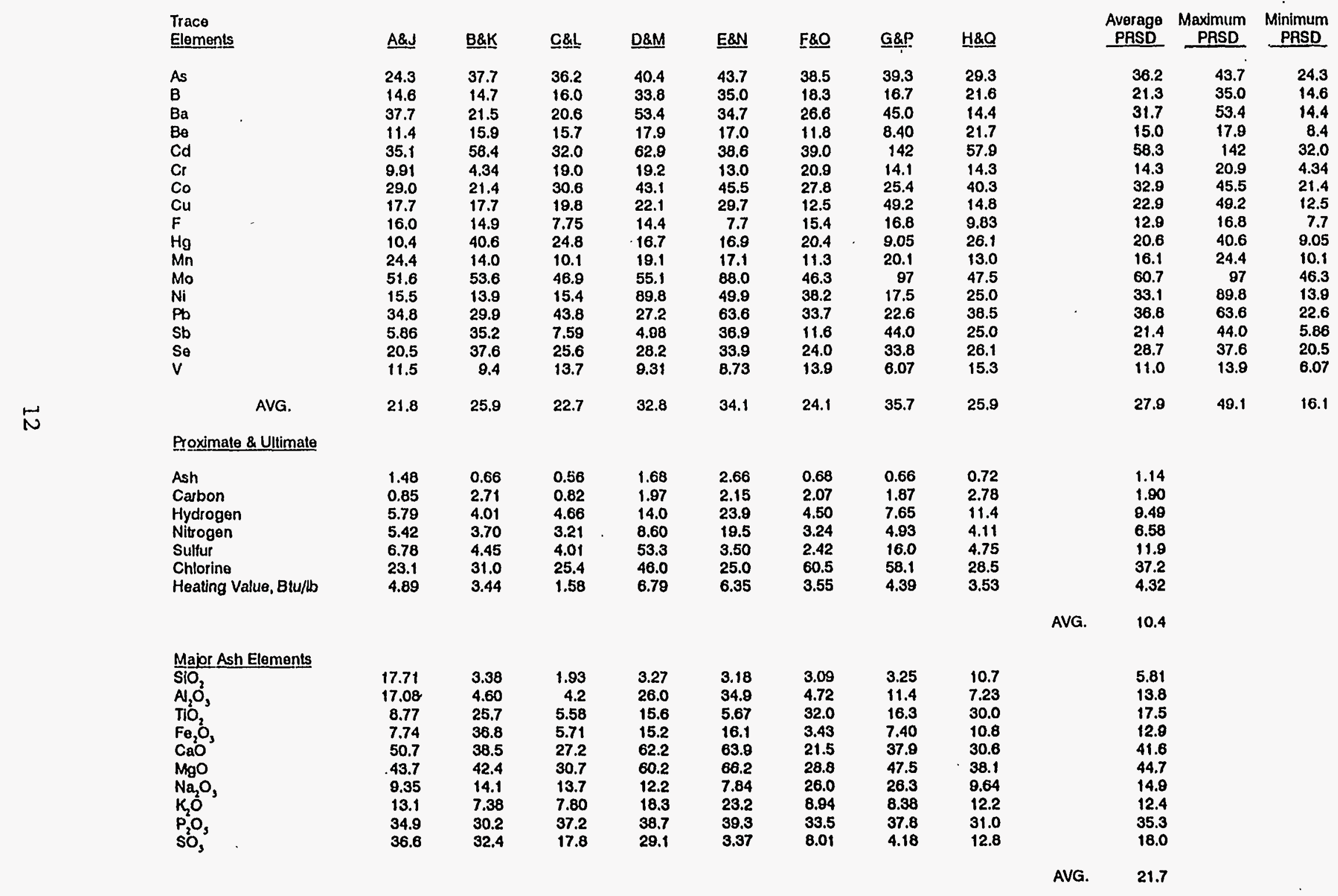




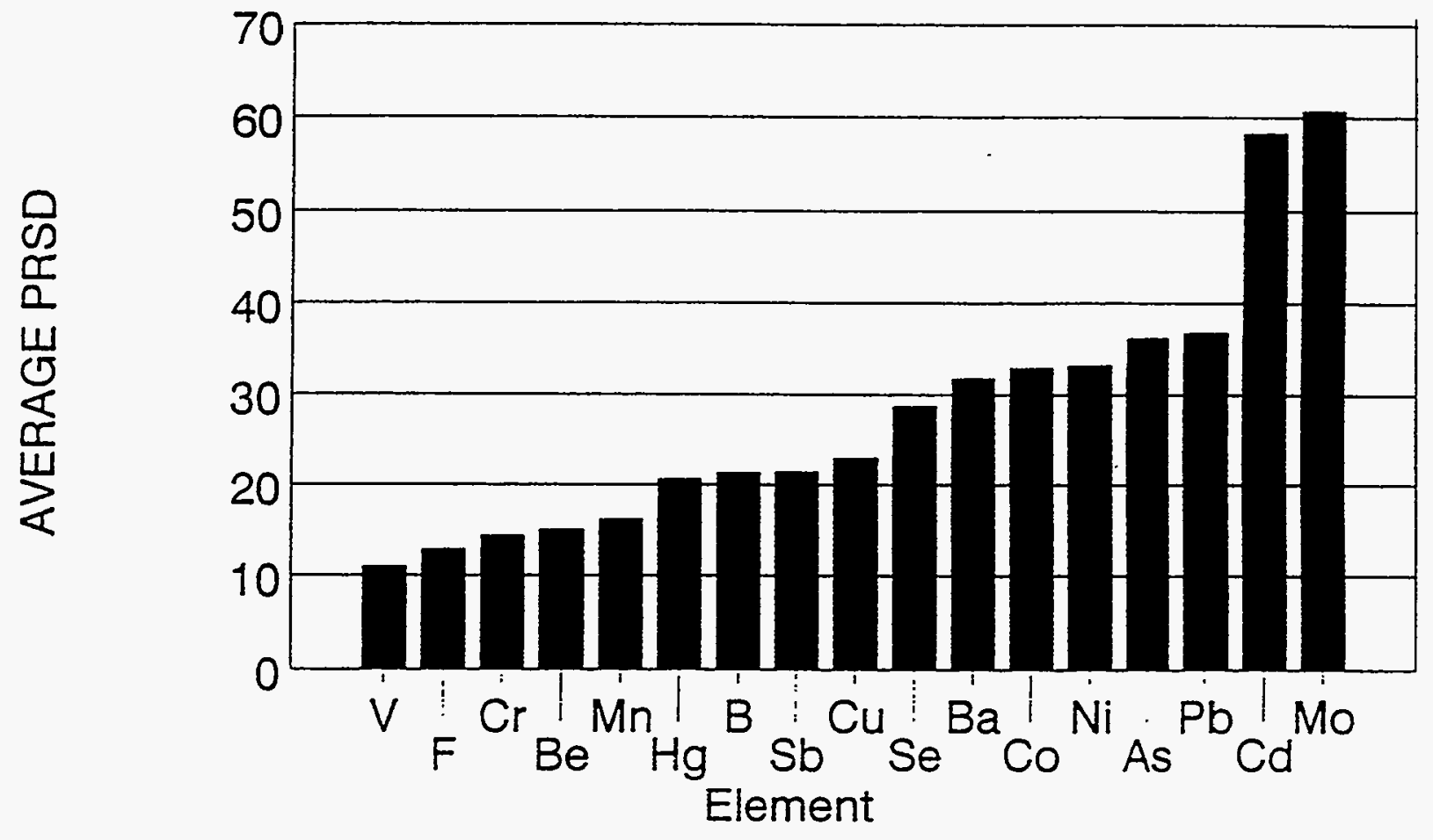

Figure 1. Average Variability for All Coals. 


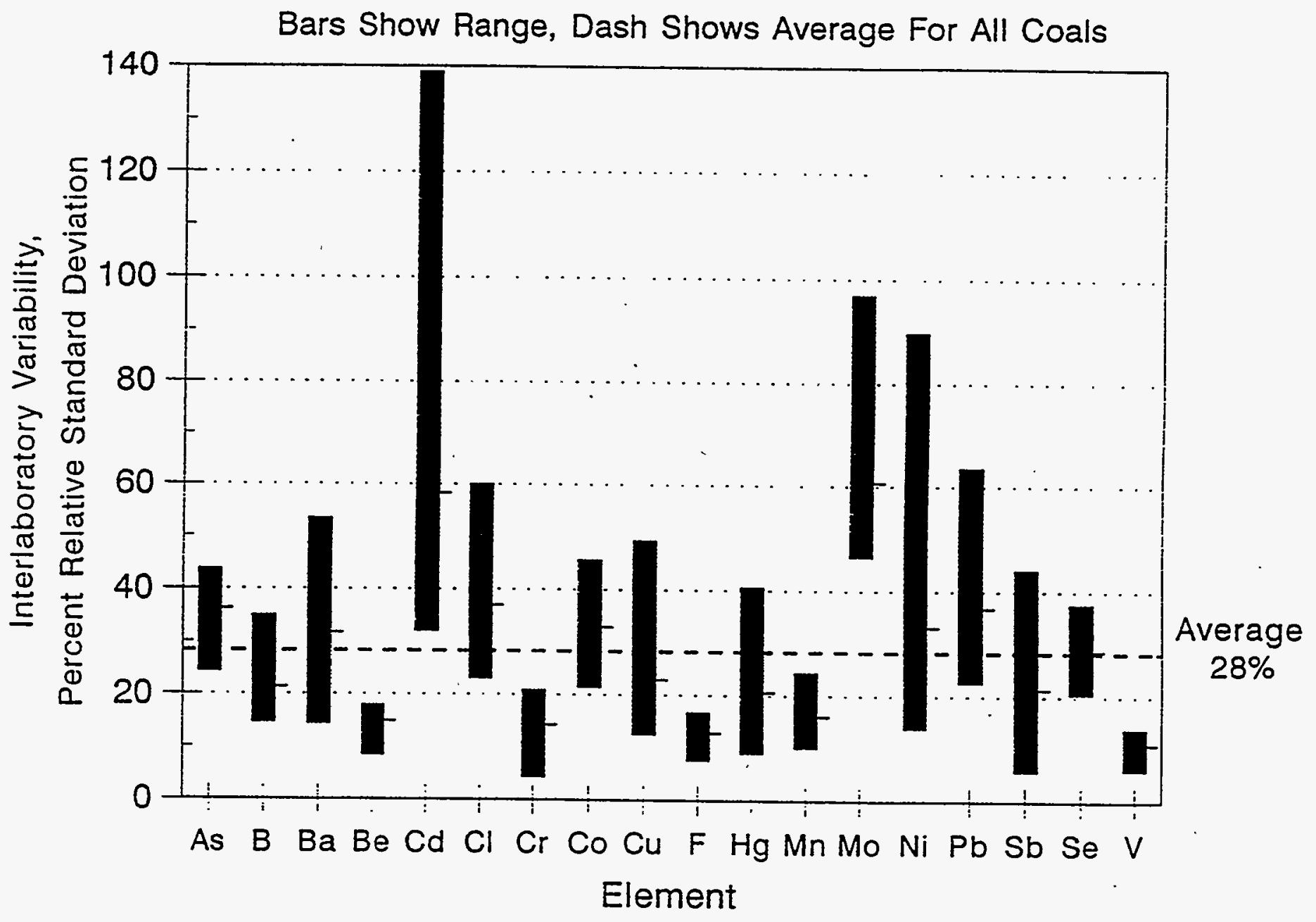

Figure 2. Interlaboratory Variability by Element 


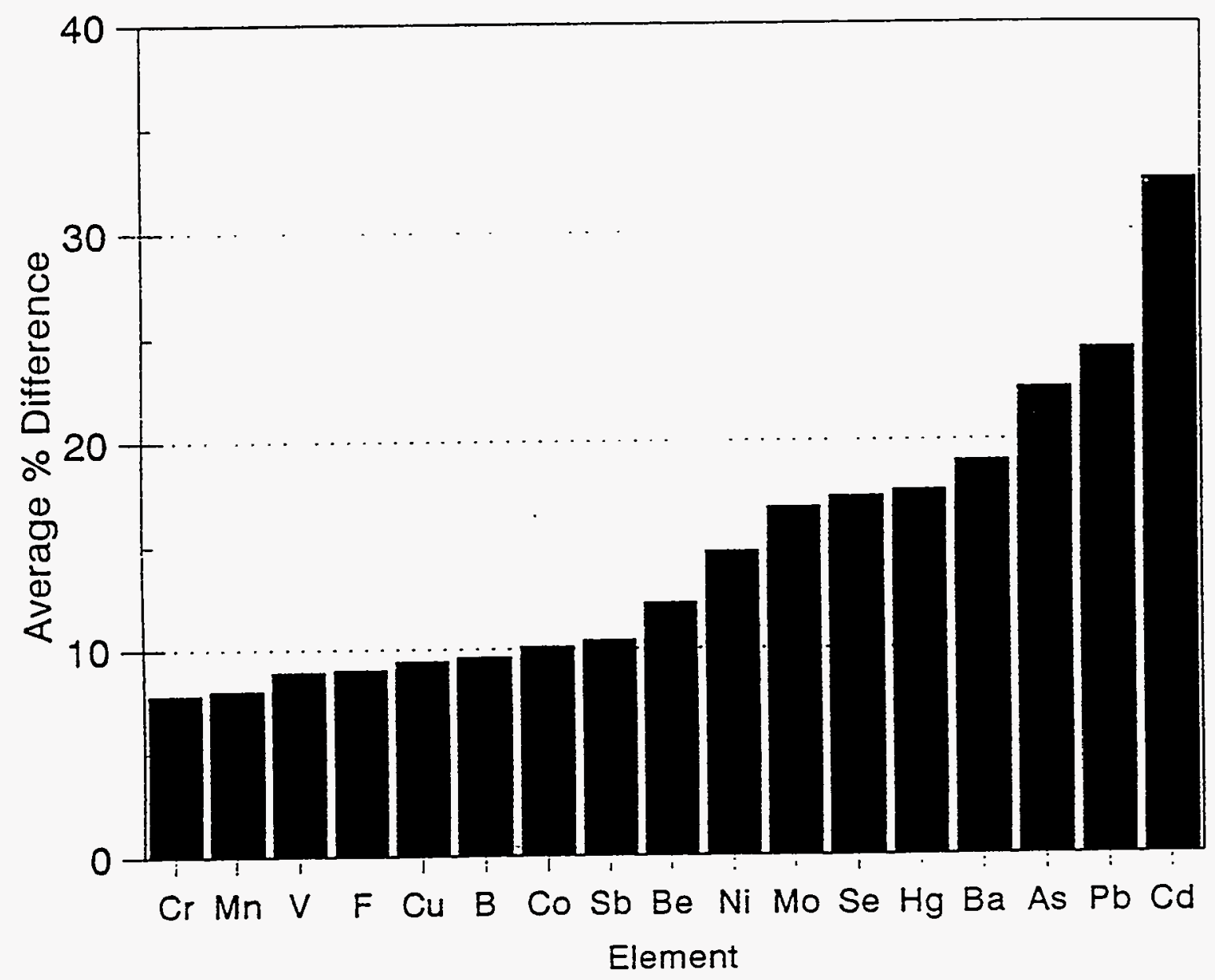

Figure 3. Average Interlaboratory Repeatability. 


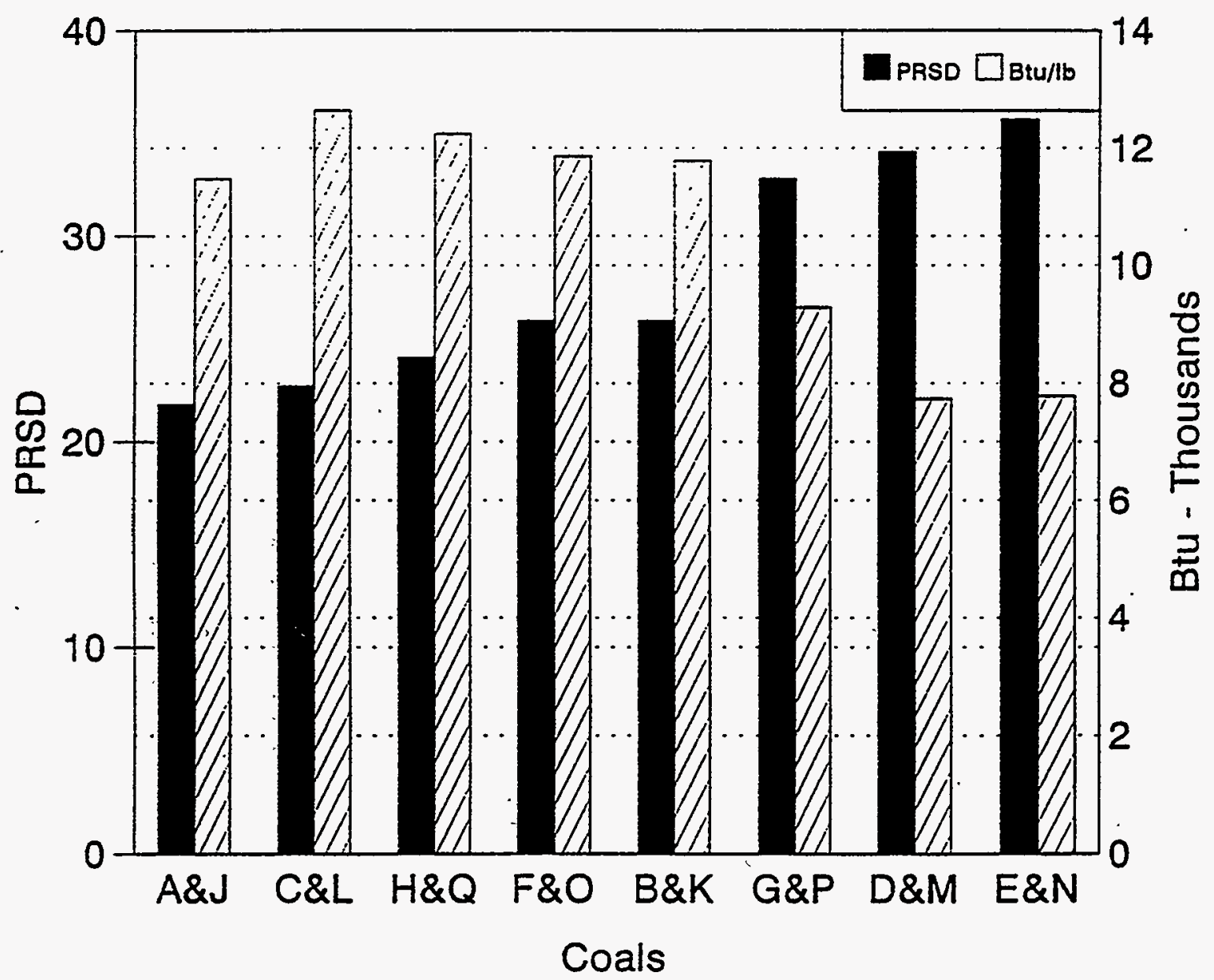

Figure 4. Comparison of Interlaboratory Variability vs. Heating Value. 


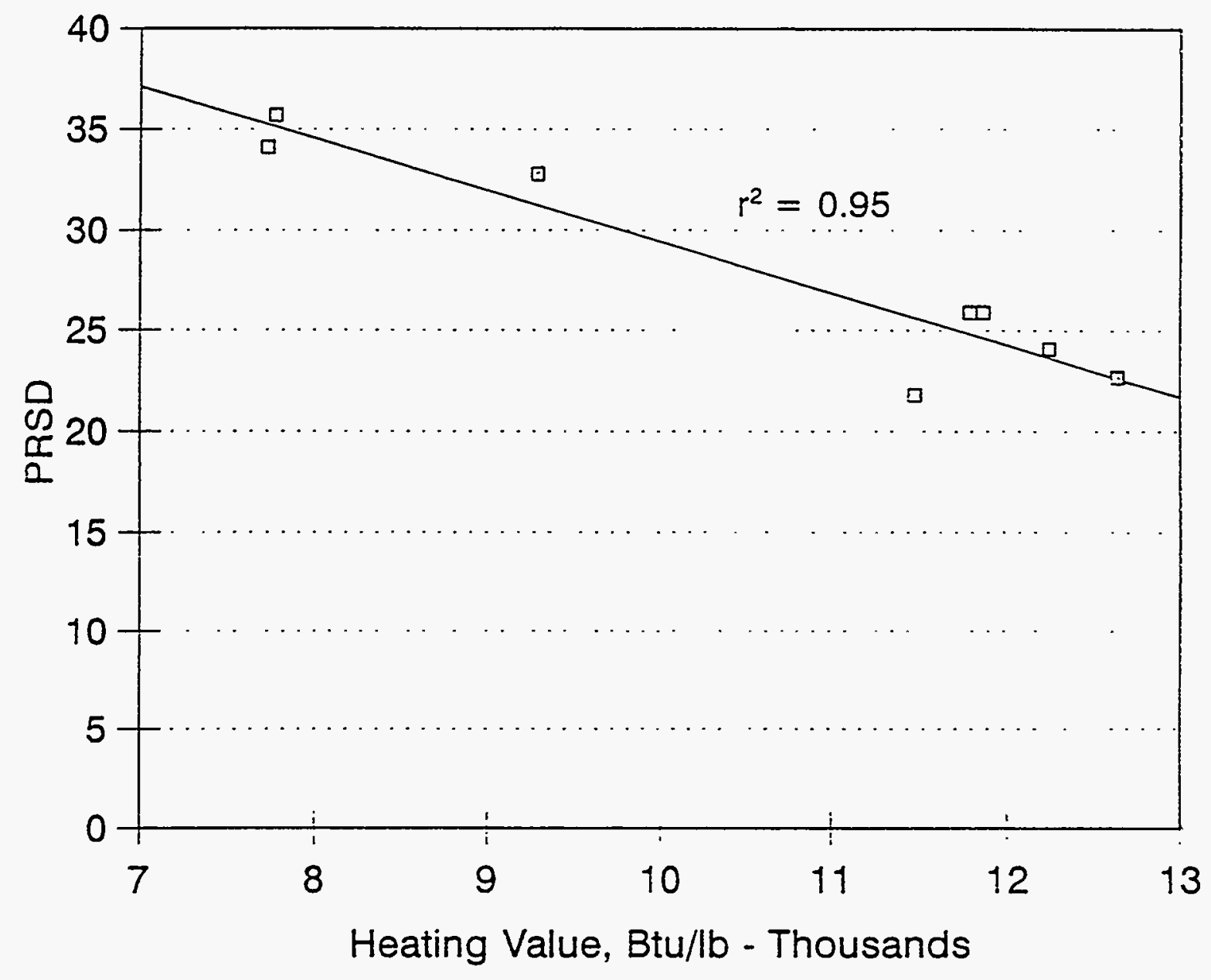

Figure 5. Correlation of Variability vs. Heating Value. 
APPENDIX A

\section{INDIVIDUAL LABORATORY ANALYSIS OF ROUND ROBIN SAMPLES}


INDIVIDUAL LABORATOAY ANALYSES OF ROUND ROBIN SAMPLE A

PPM DAY WHOIE COAL BASIS

TRACE

ELEMENTS

As

$\mathrm{B}$
$\mathrm{Ba}$

Be

$\mathrm{Be}$

Cr

$\mathrm{Cu}$

$\mathrm{F}$

$\mathrm{Hg}$

Mo

Ni

$\mathrm{Pb}$

So

$\overrightarrow{0}$

LAB I RUN 1 RUN 2 RUN 1 RUN2 RUN 1 RUN 2 RUN 1 RUN 2 LAB III

LAB IV

LAB $V$

$\begin{array}{rrrrrr}2.36 & 3.01 & 3.43 & 3.46 & 2 & \\ 236.33 & 290.64 & 179.81 & 182.77 & 250 & 230 \\ 29 & 32.29 & 55.8 & 63.3 & 76.7 & 7 \\ 1.29 & 1.61 & 1.1 & 1.09 & 1.3 & 1.3 \\ 0.5 & 0.55 & 0.57 & 0.59 & <0.3 & <0.3 \\ 25.78 & 30.14 & 26.56 & 24.44 & 25.2 & 28 \\ 4.73 & 5.81 & 3.41 & 3.35 & 3.28 & 3.44 \\ 8.7 & 10.76 & 8.76 & 8.54 & <37.3 & <38.3 \\ <100 & <100 & 108.92 & 107.67 & 100 & 100 \\ <0.1 & <0.1 & 0.094 & 0.095 & 0.09 & 0.09 \\ 36.52 & 39.83 & 51.8 & 51.8 & 29.3 & 31.2 \\ 11.82 & 8.61 & 7.01 & 6.78 & 15.1 & 14.6 \\ 17.19 & 19.38 & 16.32 & 15.28 & 12.8 & 14 \\ 4.08 & 6.89 & 10.89 & 10.71 & 8 & \\ <0.8 & <0.8 & 0.52 & 0.53 & 0.466 & 0.51 \\ 3.01 & 3.55 & 3.58 & 3.61 & 3 & \\ 35.45 & 40.9 & 29.03 & 28.9 & 34.3 & 35.8\end{array}$

\% DRY BASIS

PROXIMATE \& ULTIMATE

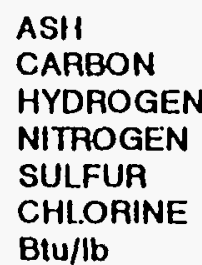

$12.16 \quad 12.18$

68.39

68.88

4.97

1.25

3.44

12460

5.88
1.26
3.6
0.05

0.05
11297

12.08
70.09
4.83
1.37
3.44
0.077
12478

12.13
70.22
4.79
1.41
3.48
0.064
12462

12.18
70.32
4.89
1.48
3.46
0.075
12425

12.26
70.15
4.92
1.4
3.42
0.072
12477

11.83
69.2
4.67
1.35
3.41
ND
12453

11.75
69.25
4.6
1.31
3.4
ND
12455

11.86

69.2

4.76

1.25

3.43

0.1

12427

11.95

69.14

4.71

1.28

0.09

12402

\section{\% DRY ASH}

MANOR ASH ELEMENTS

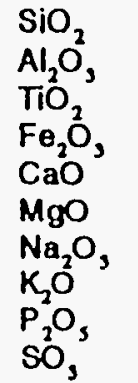

$\begin{array}{rr}39.75 & 49.24 \\ 13.18 & 15.36 \\ 0.8 & 0.97 \\ 13.89 & 16.43 \\ 2.47 & 2.23 \\ 0.4 & 0.35 \\ 0.77 & 0.96 \\ 1.92 & 2.24 \\ 0.26 & 0.3 \\ \text { ND } & \text { ND }\end{array}$

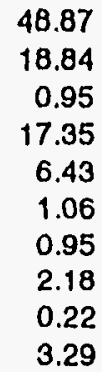

$\begin{array}{rrr}\text { ND } & \text { ND } & 47.03 \\ 16.37 & 17.74 & 18.21 \\ 0.72 & 0.7 & 0.89 \\ 15.21 & 15.17 & \text { ND } \\ 2.36 & 2.21 & \text { ND } \\ 0.59 & 0.72 & \text { ND } \\ 0.78 & 0.78 & 0.97 \\ 1.68 & 1.85 & 2.01 \\ 0.2 & 0.24 & \text { ND } \\ \text { ND } & \text { ND } & \text { ND }\end{array}$


PPM DRY WHOLE COAL BASIS

TRACE LAB I LAB II

ELEMENTS

\section{RUN 1 RUN 2}

$\mathrm{As}$
$\mathrm{B}$
$\mathrm{Ba}$
$\mathrm{Be}$
$\mathrm{Cd}$
$\mathrm{Cr}$
$\mathrm{Co}$
$\mathrm{Cu}$
$\mathrm{F}$
$\mathrm{Hg}$
$\mathrm{Mn}$
$\mathrm{Mo}$
$\mathrm{Ni}$
$\mathrm{Pb}$
$\mathrm{Sb}$
$\mathrm{Se}$
$\mathrm{V}$

กั

$\begin{array}{rr}2.7 & 2.79 \\ 260.01 & 258.48 \\ 37.44 & 34.12 \\ 1.87 & 1.86 \\ 0.92 & 0.77 \\ 36.4 & 35.15 \\ 5.62 & 4.55 \\ 11.44 & 11.37 \\ <100 & <100 \\ <0.1 & <0.1 \\ 32.24 & 31.02 \\ 7.28 & 7.03 \\ 19.76 & 18.61 \\ 7.49 & 2.38 \\ <0.8 & <0.8 \\ 3.33 & 1.45 \\ 49.92 & 50.66\end{array}$

PROXIMATE \& ULTIMATE

ASH

CARBON

HYDROGEN

NITROGEN

SULFUR

CHLORINE

Btu/lb

1.2 .68
68.33
5.1
1.26
3.63
0.05
11900

MANOR ASH ELEMENTS

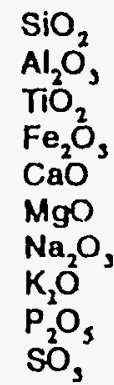

$\mathrm{SO}_{2}$
12.54
67.79

67.79

5.29

3.63

0.05

11480

\section{RUN 1}

$\begin{array}{rr}3.26 & 3.18 \\ 193.41 & 189.71 \\ 47.8 & 49.3 \\ 1.37 & 1.44 \\ 0.97 & 1 \\ 32.57 & 35.14 \\ 3.43 & 3.58 \\ 9.61 & 9.79 \\ 124.37 & 125.42 \\ 0.131 & 0.115 \\ 40.6 & 39.9 \\ 7.2 & 7.36 \\ 16.94 & 17.49 \\ 14.95 & 14.77 \\ 0.69 & 0.69 \\ 4.71 & 4.78 \\ 38.79 & 39.29\end{array}$

12.69
70.23

70.23

4.82
1.33

3.43

0.084

12398 .

$$
\begin{array}{r}
12.72 \\
70.07 \\
4.84 \\
1.44 \\
3.49 \\
0.077 \\
12402
\end{array}
$$

$$
49.47
$$$$
18.69
$$

51.04

19.41

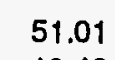

19.46

0.99

17.83
3.85

3.85

3.94

1.09

0.79

. 2.39

0.26
IAB III BUN 1 BUN 2

$\begin{array}{rr}1 & 2 \\ 260 & 270 \\ 64.3 & 73.7 \\ 1.5 & 1.5 \\ <0.3 & <0.3 \\ 35.2 & 34.5 \\ 3.57 & 3.53 \\ <41.8 & <42.4 \\ 110 & 120 \\ 0.11 & 0.11 \\ 29.9 & 28.1 \\ <13.6 & <13.8 \\ 22.9 & 21.8 \\ 15 & 16 \\ 0.707 & 0.566 \\ 3 & 4 \\ 44.7 & 49.1\end{array}$

\% DRY BASIS$$
12.56
$$$$
70.12
$$$$
4.83
$$$$
1.42
$$$$
\begin{array}{r}
3.46 \\
0.079
\end{array}
$$$$
0.079
$$

12376

$$
\begin{array}{r}
12.53 \\
69.95 \\
4.81 \\
1.4 \\
3.47 \\
0.078
\end{array}
$$$$
\{2367
$$

\%.DRY ASH

$\begin{array}{rrr}\text { ND } & \text { ND } & 50.45 \\ 18.28 & 19.4 & 19.05 \\ 0.86 & 0.78 & 0.96 \\ 16.7 & 16.42 & \text { ND } \\ 1.84 & 1.97 & \text { ND } \\ 0.77 & 0.77 & \text { ND } \\ 0.78 & 0.7 & 0.73 \\ 2.25 & 2.22 & 2.26 \\ 0.51 & 0.51 & \text { ND } \\ \text { ND } & \text { ND } & \text { ND }\end{array}$

LAB IV 1 RUN_2 RUN1 BUN2?

5
190
47
1.4
$<0.4$
38
3
10
$N D$
0.12
38
5
21
15
$<1$
1
47

ND
200
46
1.3
$<0.4$
37
3
10
$N D$
0.11
37
3
21
15
$<1$
$N D$
47

5.3
227
46.5
1.8
0.573
31.1
2.77
13.2
88
0.105
35
4.9
17.3
10.2
2.56
3.2
49.5

1.2
192
46.5
1.89
0.941
32.8
3.07
13.8
95
0.106
34.8
6.6
19.4
9.1
$N D$
2.5
49.8

\subsection{5}

68.86

4.51

1.35

3.48

12390

12.55

68.82

4.56

1.3
3.47

ND

12378

12.43

68.84

4.68

1.33

3.51

0.1

12350

12.48

68.78

4.68

1.27

3.48

0.12

12321 
INDIVIDUAL LABORATORY ANALYSES OF ROUND ROBIN SAMPI.E C

PPM DAY WHOLE COAL BASIS

TRACE

ELEMENTS

As
$\mathrm{B}$
$\mathrm{Ba}$
$\mathrm{Be}$
$\mathrm{Cd}$
$\mathrm{Cr}$
$\mathrm{Co}$
$\mathrm{Cu}$
$\mathrm{F}$
$\mathrm{Hg}$
$\mathrm{Mn}$
$\mathrm{Mo}$
$\mathrm{Ni}$
$\mathrm{Pb}$
$\mathrm{Sb}$
$\mathrm{Se}$
$\mathrm{V}$
LAB I RUN 1 RUN

3.06

91.69

28.52
1.63

0.08

21.39
9.37

9.88

$<100$

$<0.1$
18.34

3.77
16.3

3.77

$<0.8$

1.94
37.69

$N$

$\begin{array}{rrr}5.82 & 13.61 & 13.04 \\ 86.72 & 66.46 & 63.46 \\ 27.55 & 32.2 & 34.9 \\ 1.63 & 1.13 & 1.17 \\ 0.08 & 0.1 & 0.11 \\ 20.4 & 16.77 & 15.9 \\ 8.67 & 4.51 & 4.46 \\ 8.06 & 6.98 & 6.95 \\ <100 & 63.96 & 63.22 \\ 0.16 & 0.147 & 0.143 \\ 18.36 & 15.7 & 16.4 \\ 3.06 & 1.62 & 1.65 \\ 16.32 & 12.44 & 12.06 \\ 0.65 & 6.44 & 6.52 \\ <0.8 & 0.66 & 0.7 \\ 1.53 & 2.47 & 2.57 \\ 37.75 & 24.63 & 25.27\end{array}$

PROXIMATE \& ULTIMATE

ASH

Btu/lb
CARBON
HYDROGEN

NITROGEN

SULFUR

CHLORINE

11.52
72.79
4.85
1.44
3.15
0.092
12957

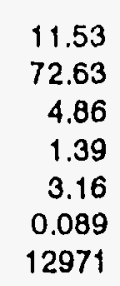

MANOH ASH ELEMENTS

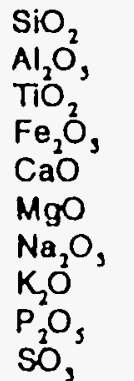

$\begin{array}{rr}47 & 09 \\ 23 & 24 \\ 1 & 08 \\ 25 & 13 \\ 0 & 64 \\ 0 & 35 \\ 0 & 54 \\ 2 & 12 \\ 0 & 13 \\ N D\end{array}$

4515
21.56
104
25.11
0.64
0.33
037
201
0.12
ND

IAB IV PUN 2

$\begin{array}{rr}5 & 7 \\ 80 & 80 \\ 34.6 & 45.2 \\ 1.3 & 1.2 \\ <0.3 & <0.3 \\ 17.2 & 18.2 \\ 4.92 & 5.13 \\ <38 & <39.3 \\ 60 & 60 \\ 0.1 & 0.11 \\ 19 & 18.5 \\ 1.71 & 2.87 \\ 10.4 & 10.7 \\ 5 & 7 \\ 0.603 & 0.654 \\ 1 & 2 \\ 30.6 & 29.9\end{array}$

6
73
35
1.2
$<0.4$
19
5
8
$N D$
0.14
22
$<6$
15
7
$<1$
2
33

$N D$
76
35
1.2
$<0.4$
20
7
8
$N D$
0.14
23
$<6$
15
8
-1
1
33

\% DAY BASIS

$\begin{array}{rrrrrr}11.64 & 11.6 & 11.57 & 11.51 & 11.61 & 11.59 \\ 72.98 & 72.72 & 71.64 & 71.72 & 71.99 & 71.86 \\ 4.99 & 4.98 & 46 & 4.6 & 4.85 & 4.86 \\ 1.42 & 1.42 & 1.45 & 1.45 & 1.43 & 1.36 \\ 3.28 & 3.27 & 3.13 & 3.18 & 3.37 & 3.16 \\ 0.098 & 0.104 & \text { ND } & \text { ND } & 0.11 & 0.11 \\ 12972 & 12932 & 12989 & 12953 & 12906 & 12906\end{array}$

* DAY Aśl

$\begin{array}{rr}45.02 & 45.57 \\ 21.31 & 21.63 \\ 0.96 & 0.98 \\ 25.63 & 26.06 \\ 1.22 & 1.29 \\ 0.71 & 0.69 \\ 0.4 & 0.42 \\ 1.93 & 1.89 \\ 0.07 & 0.08 \\ 1.44 & 1.51\end{array}$

$\begin{array}{rrr}\text { ND } & \text { ND } & 44.73 \\ 19.36 & 18.78 & 21.74 \\ 1.1 & 1.09 & 0.99 \\ 23.41 & 24.61 & \text { ND } \\ 1.17 & 1.04 & \text { ND } \\ 0.72 & 0.63 & \text { ND } \\ 0.38 & 0.41 & 0.42 \\ 1.77 & 1.9 & 1.85 \\ 0.21 & 0.23 & \text { ND } \\ \text { ND } & \text { ND } & \text { ND }\end{array}$

$\begin{array}{rr}12.1 & 13.4 \\ 79.1 & 54 \\ 35.2 & 34.3 \\ 1.53 & 1.51 \\ 0.079 & 0.237 \\ 9.9 & 12.4 \\ 4.03 & 4.6 \\ 10.9 & 11.2 \\ 58 & 53 \\ 0.135 & 0.145 \\ 19 & 19.6 \\ \text { ND } & 0.977 \\ 14.2 & 13.8 \\ 4.5 & 5.7 \\ \text { ND } & N D \\ 0.837 & 1.1 \\ 33 & 33.2\end{array}$

33.2

$\begin{array}{lrr}\text { ND } & 44.5 & 44.3 \\ \text { ND } & 21.4 & 21.5 \\ \text { ND } & 0.9 & 0.9 \\ \text { ND } & 25.2 & 25.4 \\ \text { ND } & 1.1 & 1.1 \\ \text { ND } & 0.73 & 0.71 \\ \text { ND } & 0.44 & 0.46 \\ \text { ND } & 1.7 & 1.8 \\ \text { ND } & 0.15 & 0.23 \\ \text { ND } & 1.04 & 1.05\end{array}$


PPM DRY WHOLE COAL BASIS

TAACE ELEMENTS

N

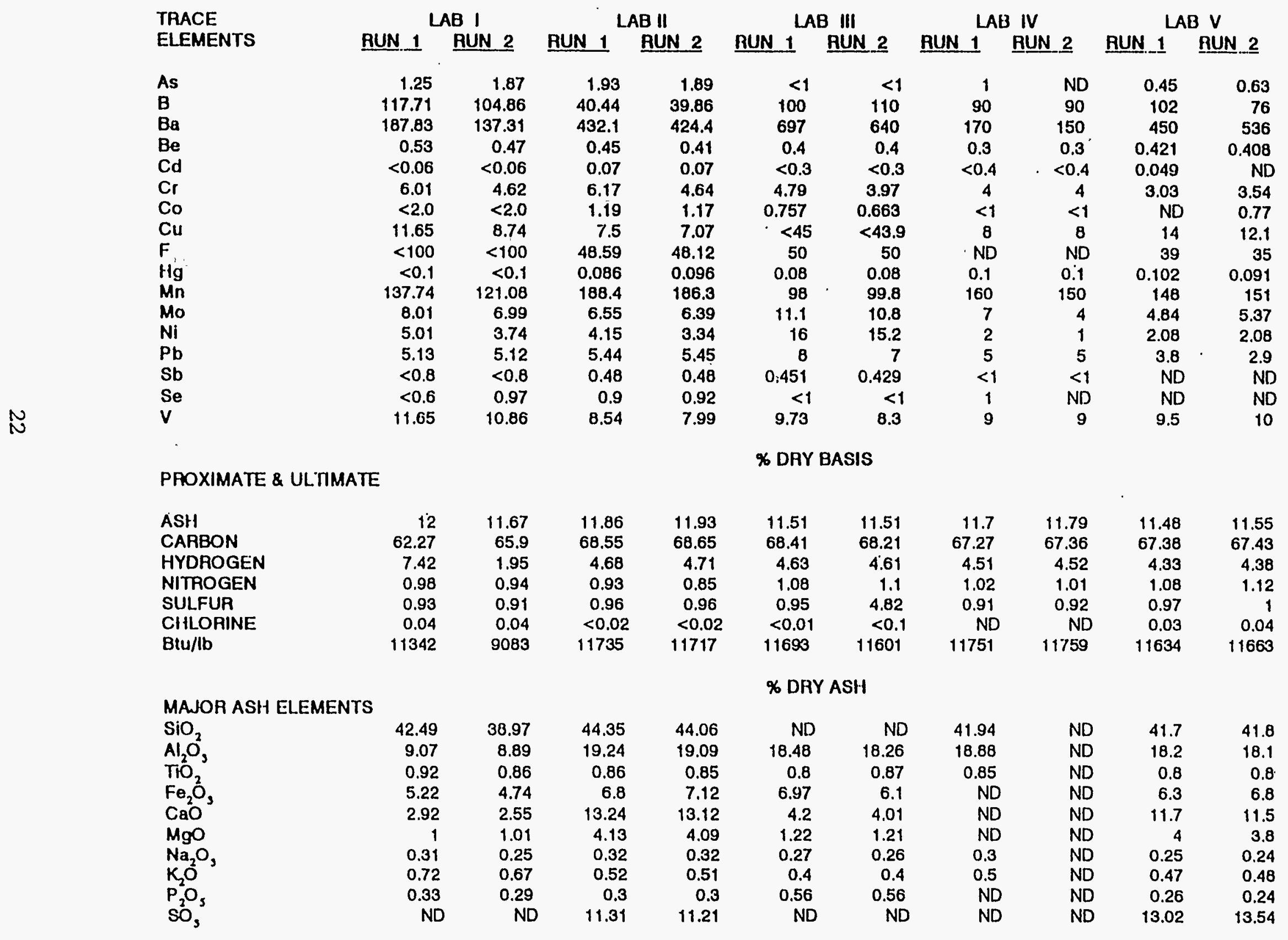


INDIVIDUAL LABORATORY ANALYSES OF ROUND ROBIN SAMPLE E

PPM DAY WHOLE COAL BASIS

TRACE

ELEMENTS

As
B
$\mathrm{Ba}$
$\mathrm{Be}$
$\mathrm{Cd}$
$\mathrm{Cr}$
$\mathrm{Co}$
$\mathrm{Cu}$
$\mathrm{F}$
$\mathrm{Hg}$
$\mathrm{Mn}$
$\mathrm{Mo}$
$\mathrm{Ni}$
$\mathrm{Pb}$
$\mathrm{Sb}$
$\mathrm{Se}$
$\mathrm{V}$
LAB I RUN 1 RUN_2 RUN 1

$<0.6$
153.79
192.23

192.23

0.82
0.12

8.59$$
\begin{array}{r}
3.33 \\
9.36
\end{array}
$$

$<100$

$<0.1$

108.93

3.59

8.07

1.92

$<0.8$

$<0.6$

17.94

8.63
139.65

266.6

0.71

$<0.06$

7.87
2.79

8.89

$<100$

$<0.1$

3.3

5.71
$<0.6$

$<0.8$

$<0.6$
16.5
PROXIMATE \& ULTIMATE

ASH

CARBON

HYDROGEN

NITROGEN

SULFUR

CHLOAINE

Btu/lb

17.69
55.85
7.41
0.09
1.15
0.03
9252

16.32
54.93
7.38
0.88
1.09
0.03
8208

16.15

59.58

4.21

0.99

1.13

$<0.02$

9842

MANOR ASH ELEMENTS

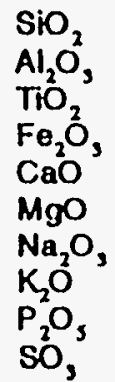

37.26
3.01
0.45
4.35
2.23
0.94
0.67
1.4
0.13
ND

$\begin{array}{rr}36.67 & 39.92 \\ 3.53 & 12.68 \\ 0.44 & 0.45 \\ 4.67 & 6.93 \\ 3.16 & 17.34 \\ 1.15 & 4.96 \\ 0.72 & 0.89 \\ 0.12 & 1.39 \\ 0.13 & 0.13 \\ N D & 14.99\end{array}$

LAB III RUN 1 LAB \|

11.53

45.15

658.9

0.72

7.88

2.66

6.97

55.8

0.159

149.2

2.77

6.97

3.04

0.77

0.88
14.34

RUN 2

11.69
45.15
669.8
0.73
0.1
9.85
2.54
7.1
60.87
0.144
151.2
2.75
7.62
2.63
0.72
0.98
14.32

RUN 1 BUN 2

LAB IV

$\begin{array}{rrr}4 & 5 & 7 \\ 150 & 150 & 130 \\ 795 & 687 & 400 \\ 0.7 & 0.7 & 0.6 \\ <0.3 & <0.3 & <0.4 \\ 9.8 & 8.14 & 8 \\ 1.91 & 1.91 & 1 \\ <48.2 & <46.3 & 7 \\ 60 & 60 & N D \\ 0.17 & 0.17 & 0.18 \\ 93.9 & 88.8 & 140 \\ 7.51 & 7.13 & <6 \\ 18.1 & <17.4 & 6 \\ 4 & 4 & 4 \\ 0.679 & 0.073 & <1 \\ <1 & <1 & 1 \\ 16.4 & 15.5 & 17\end{array}$

\% DRY BASIS

16.19
59.55
4.15
0.91
1.13
$<0.02$
9841

16.23
59.05
4.24
1.02
1.15
$<0.01$
9920

16.29
59.17
4.31
1.02
1.14
$<0.01$
9914

17.45
58.91
3.92
0.79
1.13
$N D$
9777


39.61
12.38
0.49
$N D$
$N D$
$N D$
0.87
1.25
$N D$
$N D$

17.5
58.61
3.9
0.82
1.12
ND
9823


ND
ND
ND
ND
ND
ND
ND
ND
ND
ND

\section{* DAY ASII}

40.18
12.69
0.46
7
17.53
4.97
0.89
1.39
0.14
15.21

LAB V

RUN 1 RUN 2

$\begin{array}{rrr}8 & 8.4 & 9.2 \\ 140 & 151 & 138\end{array}$

$\begin{array}{lll}380 & 714 & 701\end{array}$

$\begin{array}{ccc}0.7 & 0.639 & 0.732 \\ <0.4 & 0.052 & 0.092\end{array}$

$<0.4 \quad 0.052$

$\begin{array}{rrr}8 & 6.4 & 6 \\ 2 & 2.02 & N D\end{array}$

$\begin{array}{lll}7 & 11.9 & 11\end{array}$

$\begin{array}{rrr}\text { ND } & 54 & 57 \\ 0.18 & 0.113 & 0.136\end{array}$

$\begin{array}{lll}140 & 124 & 122\end{array}$

$\begin{array}{lll}<6 & \text { ND } & 0.977\end{array}$

$\begin{array}{lll}3 & 3.7 & 4.92\end{array}$

$4 \quad 4 \quad 1.8$

ND $\quad 0.746$

$16.2 \quad 16.2$

$\begin{array}{lrr}\text { ND } & 38.5 & 38.7 \\ \text { ND } & 11.6 & 11.7 \\ \text { ND } & 0.5 & 0.4 \\ \text { ND } & 6.7 & 6.6 \\ \text { ND } & 16.2 & 16.3 \\ \text { ND } & 4.8 & 4.8 \\ \text { ND } & 0.84 & 0.84 \\ \text { ND } & 1.3 & 1.3 \\ \text { ND } & 0.13 & 0.11 \\ \text { ND } & 15.42 & 16.02\end{array}$




\section{PPM DRY WHOLE COAL BASIS}

TRACE

ELEMENTS

As
B
$\mathrm{Ba}$
$\mathrm{Be}$
$\mathrm{Cd}$
$\mathrm{Cr}$
$\mathrm{Co}$
$\mathrm{Cu}$
$\mathrm{F}$
$\mathrm{Hg}$
$\mathrm{Mn}$
$\mathrm{Mo}$
$\mathrm{Ni}$
$\mathrm{Pb}$
$\mathrm{Sb}$
$\mathrm{Se}$
$\mathrm{V}$
LAB I RUN 1 BUN

$\begin{array}{rr}4.82 & 50.43 \\ 89.23 & 96.74 \\ 55.38 & 53.51 \\ 2.67 & 2.78 \\ 0.07 & 0.09 \\ 22.56 & 22.64 \\ 9.74 & 11.32 \\ 21.54 & 21.61 \\ <100 & <100 \\ 0.21 & 0.27 \\ 25.64 & 15.73 \\ 7.38 & 6.48 \\ 26.67 & 29.84 \\ 7.28 & <0.6 \\ 1.95 & 2.88 \\ 1.13 & 2.26 \\ 40 & 42.19\end{array}$

PROXIMATE \& ULTIMATE

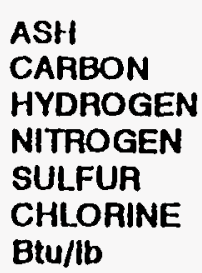

13.42
66.75
5.3
1.39
3.1
0.6
12207

$\begin{array}{rr}13.42 & 13.45 \\ 71.23 & 71.11 \\ 4.76 & 4.77 \\ 1.43 & 1.43 \\ 2.9 & 2.95 \\ 0.155 & 0.14 \\ 12674 & 12648\end{array}$

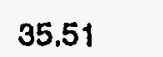

35.51

86.4

2.14

0.1

25.35

5.9
17.35

90.46

0.238

26.6

4.25

21.98

15.67

2.2

3.27

28.06

\section{MAJOR ASH ELEMENTS}

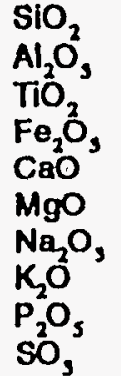

$\begin{array}{rrr}45.86 & 49.3 & 47.18 \\ 23.1 & 24.62 & 23.19 \\ 1.12 & 1.23 & 1.06 \\ 20.76 & 23.02 & 21.68 \\ 1.18 & 1.07 & 1.85 \\ 0.43 & 0.33 & 0.87 \\ 0.22 & 0.21 & 0.3 \\ 2.39 & 2.22 & 2.3 \\ 0.47 & 0.53 & 0.48 \\ \text { ND } & \text { ND } & 1.78\end{array}$

RUN 2 RUN III

35.07
63.46
98.1
2.18
0.12
28.97
5.88
17.07
92.55
0.251
26.6
4.46
22.39
15.66
2.25
3.29
27.98

27.98

$\begin{array}{rr}17 & 17 \\ 73 & 76 \\ 93 & 85.6 \\ 1.9 & 2 \\ <0.3 & <0.3 \\ 19.7 & 21.7 \\ 6.23 & 6 \\ <37.8 & <37.4 \\ 90 & 100 \\ 0.24 & 0.26 \\ 27 & 23.2 \\ 3.65 & 3.8 \\ 26.8 & 28.2 \\ \cdot 15 & 15 \\ 1.97 & 2.1 \\ 2 & 2 \\ 33.6 & 36.3\end{array}$

\% DRY BASIS

13.4
71.38
4.88
1.39
3
0.122
12609

LAB IV AUN 1 RUN 2

24
68
83
2.3
$<0.4$
20
8
20
ND
0.25
30
$<6$
25
16
2
3
35

LAB V

RUN 1 RUN.2

$\begin{array}{crr}\text { ND } & 28.7 & 28.1 \\ 65 & 64.9 & 53.4 \\ 83 & 59 & 67.3 \\ 2.4 & 2.75 & 2.41 \\ <0.4 & 0.093 & N D \\ 21 & 11 & 14.4 \\ 7 & 4.56 & 3.59 \\ 21 & 22.2 & 29 \\ \text { ND } & 63 & 65 \\ 0.25 & 0.338 & 0.323 \\ 31 & 25.5 & 26.6 \\ <6 & 1.92 & 1.51 \\ 28 & 23.5 & 23.8 \\ 17 & 12.3 & 11.5 \\ 2 & N D & N D \\ \text { ND } & 1.5 & 2.2 \\ 36 & 35.5 & 38.2\end{array}$

\section{\% DRY ASH}

$\begin{array}{rrrrlrr}46.04 & \text { ND } & \text { ND } & 44.91 & \text { ND } & 46.1 & 45.3 \\ 23.37 & 22.98 & 23.97 & 22.55 & \text { ND } & 22.1 & 22.2 \\ 1.07 & 1.3 & 1.12 & 1.12 & \text { ND } & 1 & 1 \\ 22.01 & 20.9 & 19.67 & \text { ND } & \text { ND } & 21.4 & 21 \\ 1.91 & 1.44 & 1.36 & \text { ND } & \text { ND } & 1.7 & 1.8 \\ 0.87 & 0.73 & 0.86 & \text { ND } & \text { ND } & 0.86 & 0.86 \\ 0.3 & 0.25 & 0.25 & 0.38 & \text { ND } & 0.24 & 0.26 \\ 2.32 & 1.92 & 2.11 & 2.05 & \text { ND } & 2.2 & 2.2 \\ 0.46 & 0.89 & 0.89 & \text { ND } & \text { ND } & 0.45 & 0.46 \\ 1.83 & \text { ND } & \text { ND } & \text { ND } & \text { ND } & 1.53 & 1.49\end{array}$


INDIVIDUJAL. LABORATORY ANALYSES OF ROUND ROBIN SAMPLE G

PPM DRY WHOLE COAL BASIS

TRACE

ELEMENTS

$$
\begin{aligned}
& \mathrm{As} \\
& \mathrm{B} \\
& \mathrm{Ba} \\
& \mathrm{Be} \\
& \mathrm{Cd} \\
& \mathrm{Cr} \\
& \mathrm{Co} \\
& \mathrm{Cu} \\
& \mathrm{F} \\
& \mathrm{Hg} \\
& \mathrm{Mn} \\
& \mathrm{Mo} \\
& \mathrm{Ni} \\
& \mathrm{Pb} \\
& \mathrm{Sb}
\end{aligned}
$$

Mo

N
LAB I RUN 2

\subsection{3}

95.36

95.36

1.53

$<0.06$

10.96
5.59

5.59
52.61

$<100$

$<0.1$

54.81

2.52
7.45

6.25

1.97

$<0.6$

29.6

$\begin{array}{rr}1.65 & 2.53 \\ 74.61 & 87.94 \\ 88.87 & 404.6 \\ 1.21 & 1.33 \\ <0.06 & .0 .01 \\ 8.56 & 12.89 \\ 4.83 & 3.96 \\ 10.53 & 10.44 \\ <100 & 92.65 \\ <0.1 & 0.097 \\ 50.47 & 99.5 \\ <2 & 1.75 \\ 6.69 & 8.4 \\ 5.05 & 10.02 \\ 0.99 & 1.72 \\ <0.6 & 1.62 \\ 24.14 & 24.82\end{array}$

PAOXIMATE \& ULTIMATE

ASH

CARBON

NITROGEN

SULFUR

CHLORINE

Btu/lb

MANOR ASH ELEMENTS

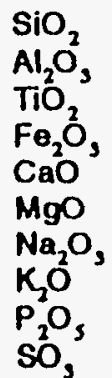

20.52

58.09

5.82

1.01
0.6

0.6
0.08

9769

\subsection{6}

18.16

0.98
4.35

2.24

0.23

0.12
1.16

1.16

0.04
ND$$
9471
$$$$
10855
$$

$\begin{array}{rr}50.22 & 61.22 \\ 16.1 & 22.76 \\ 0.81 & 0.96 \\ 3.5 & 4.63 \\ 2.01 & 4.68 \\ 0.33 & 1.33 \\ 0.11 & 0.25 \\ 1.09 & 1.4 \\ 0.03 & 0.03 \\ \text { ND } & 3.53\end{array}$

\% DRY BASIS

20.66
62.02
4.62
1.03
0.73
$<0.02$
10858

$$
\begin{array}{r}
20.6 \\
61.81 \\
4.71 \\
1.1 \\
0.71
\end{array}
$$$$
20.63
$$$$
61.95
$$$$
4.76
$$$$
\begin{array}{r}
0.71 \\
<0.01
\end{array}
$$$$
10848
$$$$
\begin{aligned}
& 1.06 \\
& 0.69
\end{aligned}
$$$$
0.69
$$$$
10048
$$

\section{\% DAY ASH}

LAB III

1 RUN 2

2
82
250

250
1

$<0.6$

$<0.6$

$<0.01$

10.44

4.07
10.47

10.47

91.53

0.093
100.7

1.73

7.74
10.06

10.06

1.72

1.84
25.52

$\begin{array}{cc}1 & 1 \\ 86 & 84 \\ 402 & 461 \\ 1.2 & 1.2 \\ <0.4 & <0.4 \\ 10.2 & 10 \\ 4.24 & 4.38 \\ <40.5 & <42.9 \\ 90 & 90 \\ 0.08 & 0.08 \\ 73.9 & 82.7 \\ 6.65 & 5.92 \\ <15.2 & <16.1 \\ 12 & 12 \\ 1.38 & 1.63 \\ 1 & 1 \\ 25 & 26.8\end{array}$$$
\begin{array}{r}
9 \\
4 \\
10
\end{array}
$$$$
\begin{array}{r}
\text { ND } \\
0.07
\end{array}
$$$$
\begin{array}{r}
0.07 \\
77
\end{array}
$$$$
\begin{gathered}
<6 \\
6
\end{gathered}
$$$$
\begin{array}{r}
6 \\
10
\end{array}
$$$$
\begin{aligned}
& 1 \\
& 2
\end{aligned}
$$

$N D$
65
250
1.3
$<0.6$
10
4
10
$N D$
0.07
82
$<6$
4
11
1
ND
29

$\begin{array}{rrrrrrr}61.62 & \text { ND } & \text { ND } & 59.37 & 60.34 & 59.8 & 59.6 \\ 22.61 & 20.51 & 22.92 & 21.59 & 21.81 & 21.1 & 20.7 \\ 0.93 & 1.35 & 1.48 & 1.19 & 0.94 & 0.8 & 0.8 \\ 4.68 & 4.48 & 4.87 & \text { ND } & \text { ND } & 4.6 & 4.6 \\ 4.68 & 1.52 & 2.13 & \text { ND } & \text { ND } & 4.2 & 4.2 \\ 1.32 & 0.73 & 0.84 & \text { ND } & \text { ND } & 1.3 & 1.3 \\ 0.27 & 0.2 & 0.23 & 0.31 & 0.19 & 0.25 & 0.29 \\ 1.39 & 1.15 & 1.27 & 1.23 & 1.28 & 1.3 & 1.3 \\ 0.03 & 0.05 & 0.03 & \text { ND } & \text { ND } & 0.05 & 0.1 \\ 3.54 & \text { ND } & \text { ND } & \text { ND } & \text { ND } & 3.79 & 3.7\end{array}$

$\begin{array}{rr}0.75 & 1.21 \\ 60.7 & 47.4 \\ 365 & 389 \\ 1.47 & 1.39 \\ 0.036 & 0.34 \\ 7 & 7.5 \\ 2.34 & 2.38 \\ 14.1 & 14.7 \\ 73 & 78 \\ 0.078 & 0.071 \\ 76.3 & 75.5 \\ 0.429 & 0.795 \\ 6.4 & 6.4 \\ 6.1 & 7.5 \\ 4.43 & 3.22 \\ 1.07 & 1.77 \\ 27 & 27.9\end{array}$

$\begin{array}{rrrr}20.64 & 20.61 & 20.71 & 20.86 \\ 61.25 & 61.29 & 61.35 & 61.13 \\ 4.51 & 4.5 & 4.35 & 4.56 \\ 1.04 & 1.04 & 1.09 & 1.09 \\ 0.69 & 0.67 & 0.72 & 0.69 \\ \text { ND } & \text { nd } & 0.04 & 0.04 \\ 10848 & 10857 & 10804 & 10797\end{array}$


PPM DAY WHOLE COAL BASIS

TRACE ELEMENTS

As
$B$
$\mathrm{Ba}$
$\mathrm{Be}$
$\mathrm{Cd}$
$\mathrm{Cr}$
$\mathrm{Co}$
$\mathrm{Cu}$
$\mathrm{F}$
$\mathrm{Hg}$
$\mathrm{Mn}$
$\mathrm{Mo}$
$\mathrm{Ni}$
$\mathrm{Pb}$
$\mathrm{Sb}$
$\mathrm{Se}$
$\mathrm{V}$

LAB I

$$
<0.6
$$

$\begin{array}{rr}<0.6 & 3.63 \\ 203.01 & 181.49 \\ 37.4 & 33.09 \\ 1.71 & 1.49\end{array}$

$\begin{array}{rr}1.71 & 1.49 \\ 0.46 & 0.4 \\ 22.44 & 21.35 \\ 6.41 & 7.79\end{array}$

$\begin{array}{rr}6.41 & 7.79 \\ 13.89 & 11.74\end{array}$

$<100$

$<0.1$

26.71
5.98

20.3

5.45

$<0.8$

1.39

40.6

$$
<100
$$

0.15

23.49

6.73

18.15

$<0.6$

$<0.8$

1.71
37.37

LAB II

LAB III

LAB IV

LAB V

RUN 1 BUN 2

$\begin{array}{rr}4.63 & 4.51 \\ 142.76 & 134.99 \\ 51.1 & 50\end{array}$

142.76
51.1

1.23

0.56
19.58

3.59 .

10.99

92.92

0.098

31.7
5.05

15.19

10.6
0.62

3.09
31.43

50
1.26

1.26
0.63
19.89

19.89

3.62

11.19
93.09

0.098

RUN 1 RUN 2

BUN 1 RUN 2

RUN 1 RUN 2

$\begin{array}{rr}3 & 3 \\ 160 & 170 \\ 54.5 & 49.9 \\ 1.1 & 1.1 \\ <0.2 & <0.2 \\ 23.1 & 20.1 \\ 4.08 & 3.71 \\ <34.0 & <32.2 \\ 80 & 80 \\ 0.05 & 0.05 \\ 21.2 & 22.3 \\ 11.5 & 11.4 \\ 13.6 & 13.4 \\ 9 & 9 \\ 0.585 & 0.417 \\ 2 & 2 \\ 36.1 & 36.5\end{array}$

3
160
50
1.3
$<0.4$
22
5
12
2.84
0.05
31
4
18
11
$<1$
2
39

ND
150
48
12

3.14 .3

$\begin{array}{rr}167 & 142 \\ 48.8 & 46\end{array}$

$\begin{array}{lll}1.2 & 1.5 & 1.46\end{array}$

$\begin{array}{lll}<0.4 & 0.332 & 0.107\end{array}$

$22 \quad 18.2 \quad 17.8$

$2.48 \quad 2.47$

$\begin{array}{rr}15.1 & 14.8 \\ 71 & 71\end{array}$

$0.118 \quad 0.098$

$27.3 \quad 26.7$

$3.4 \quad 3.54$

$16.2 \quad 16.3$

$15: 32$

10.73

0.61

31.58

\% DAY BASIS

\section{PROXIMATE \& ULTIMATE}

ASH
CARBON
HYDROGEN
NITROGEN
SULFUR
CHLORINE
BtU/lb

10.47
67.37
6
1.29
3.08
0.06
11827

$\begin{array}{rr}10.68 & 10.67 \\ 67.64 & 72.52 \\ 6.63 & 4.91 \\ 1.43 & 1.4 \\ 2.87 & 2.8 \\ 0.06 & 0.122\end{array}$

10.71

$$
72.14
$$

72.14
4.8

1.54

2.84

0.124

12828

10.57
72.59
5.1
1.46
2.87
0.135
12815

10.5
72.71
5.01
1.5
2.86
0.148
12809

10.51

10.51

71.27

10.48

71.23

10.59

71.23

4.81
1.43

2.86

$2.86 \quad-1.43$

ND

2.86
0.14

12734

6.8

ND

1.9

39.6

\% DRY ASH

MANOR ASH ELEMENTS

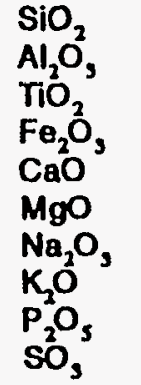

50.3
23.13
1.16
16.05
1.71
0.39
0.85
2.83
0.21
ND

$\begin{array}{rr}44.98 & 50.71 \\ 18.88 & 22.1 \\ 0.98 & 1.09 \\ 14.01 & 16.52 \\ 1.54 & 3.3 \\ 0.38 & 1.06 \\ 0.69 & 0.91 \\ 2.41 & 2.6 \\ 0.18 & 0.18 \\ \text { ND } & 2.24\end{array}$

50.64
22.14
1.09
16.59
3.39
1.07
0.93
2.61
0.2
2.3

ND
21.61
1.1
15.37
1.89
0.85
0.79
2.78
0.35
ND

ND
20.21
1.02
13.41
1.68
0.85
0.72
2.29
0.34
ND

48.97
21.32
1.08
ND
ND
ND
0.76
2.28
ND
ND

$\begin{array}{lrr}\text { ND } & 49.7 & 49.6 \\ \text { ND } & 21.4 & 21 \\ \text { ND } & 0.9 & 0.9 \\ \text { ND } & 16.1 & 16.1 \\ \text { ND } & 2.9 & 2.9 \\ \text { ND } & 1 & 1 \\ \text { ND } & 0.96 & 0.88 \\ \text { ND } & 2.4 & 2.4 \\ \text { ND } & 0.27 & 0.22 \\ \text { ND } & 2.93 & 2.7\end{array}$


INDIVIDUAL LABORATORY ANALYSES OF ROUND ROBIN SAMPLE J

PPM DRY WHOLE COAL BASIS

TRACE

ELEMENTS

RUN 1 LAB I RUN 2 RUN LAB II

LAB III

LAB IV

$\mathrm{As}$
$\mathrm{B}$
$\mathrm{Ba}$
$\mathrm{Be}$
$\mathrm{Cd}$
$\mathrm{Cr}$
$\mathrm{Co}$
$\mathrm{Cu}$
$\mathrm{F}$
$\mathrm{Hg}$
$\mathrm{Mn}$
$\mathrm{Mo}$
$\mathrm{Ni}$
$\mathrm{Pb}$
$\mathrm{Sb}$
$\mathrm{Se}$
$\mathrm{V}$

1.03
311.53

$\begin{array}{rr}2.9 & 3.42 \\ 257.9 & 186.96\end{array}$

3.22

1.61

0.88

34.38
6.45

6.45

0.01

0.01
0.18

17.19

10.74
21.48

21.48

$<0.6$

$<0.8$

1.93

27.94

1.5

1.01

26.86

5.48

10.75

0.01

$<0.1$

35.46

7.52
19.34

8.81

$<0.8$

2.79

3.34

3.34
179.35

179.35
57.7

1.15

0.6

26.3

3.65

9.35

111.15
0.117

0.117

53.4

7.07
16.12

16.12

11.16

0.51
4.16

4.16

1.19

0.65

26.97

3.59

9.18

110.27

0.111

51.8

7.04
16.55

16.55

10.85

0.49

PAOXIMATE \& ULTIMATE

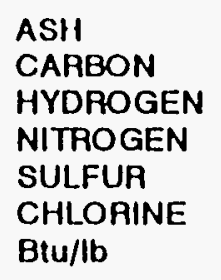

12.2
69.43
4.78
1.29
3.52
0.04
10161

$\begin{array}{rr}12.17 & 12.13 \\ 69.07 & 70.45 \\ 5.7 & 4.86 \\ 1.3 & 1.26 \\ 4.05 & 3.46 \\ 0.04 & 0.08 \\ 11035 & 12502\end{array}$

3.99
33.8

2
230
54.7
1.4
$<0.3$

UN 2

N 1 RUN 2 RUN 1 RUN 2

28.6
3.49

2
220
55.6
1.4
$<0.3$

2
200

nd
210

$\begin{array}{rr}2.1 & 2.2 \\ 222 & 205 \\ \text { ND } & 51.6 \\ 1.47 & 1.43 \\ 0.417 & 0.276\end{array}$

26.5

26.5
3.13

$<39.2$
100

$<35.2$

0.1

110
0.1

30.6

16.7

15.3

28.2
15.6

15.6
13.2

16
0.49

3

12
0.421

0.421
3

33.5

32.1

51
1.1
$<0.4$

49
1.2

1.2

0.417

0.276

30
3
10

28
3

26
2.52

33.3
2.63

4.35

0.09

13.

13.9

ND

0.113

87

45
5

45
5

42.6
5.2

0.107

$18.3 \quad 21.5$

7.6

ND

7

11
$<1$
3

36

\% DAY BASIS

$38.5 \quad 38.6$

MANOR ASH ELEMENTS

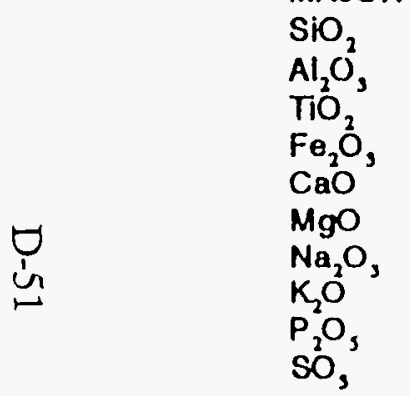

$\begin{array}{rrr}7.17 & 43.52 & 48.35 \\ 5.65 & 13.51 & 18.95 \\ 1.09 & 0.9 & 0.94 \\ 15.11 & 13.89 & 17.2 \\ 1.85 & 1.98 & 6.55 \\ 0.15 & 0.28 & 1.06 \\ 0.69 & 0.9 & 0.93 \\ 1.7 & 2.02 & 2.17 \\ 0.28 & 0.24 & 0.27 \\ \text { ND } & \text { ND } & 2.98\end{array}$

12.16
70.4
4.84
1.26
3.42
0.075
12493

11.75
70.01
4.88
1.37
3.53
0.079
12493

11.77
69.92
4.95
1.42
2.15
0.076
12515

11.89

11.87

11.84

$68.98 \quad 69.34$

$\begin{array}{rrrr}69.56 & 69.4 & 68.98 & 69.34 \\ 4.43 & 4.47 & 4.77 & 4.73\end{array}$

$\begin{array}{llll}4.43 & 4.47 & 4.77 & 4.73 \\ 1.27 & 1.31 & 1.32 & 1.25\end{array}$

$\begin{array}{llll}3.42 & 3.44 & 3.44 & 3.39\end{array}$

$\begin{array}{rrrr}\text { ND } & \text { ND } & 0.11 & 0.01 \\ 12446 & 12451 & 12410 & 12422\end{array}$

\% DAY ASH

46.95
18.67
0.93
17.23
6.45
1.04
0.91
2.15
0.29
2.88

$\begin{array}{rrr}\text { ND } & \text { ND } & 48.17 \\ 18.56 & 17.23 & 18.57 \\ 0.9 & 0.74 & 0.94 \\ 14.94 & 14.01 & \text { ND } \\ 2.21 & 2.1 & \text { ND } \\ 0.92 & 0.74 & \text { ND } \\ 0.85 & 0.82 & 1.01 \\ 1.47 & 1.25 & 2.05 \\ 0.51 & 0.55 & \text { ND } \\ \text { ND } & \text { ND } & \text { ND }\end{array}$

$\begin{array}{lrr}\text { ND } & 47.5 & 48.2 \\ \text { ND } & 17.6 & 17.8 \\ \text { ND } & 0.9 & 0.9 \\ \text { ND } & 16.4 & 16.8 \\ \text { ND } & 5.3 & 5.5 \\ \text { ND } & 1 & 1 \\ \text { ND } & 0.99 & 1 \\ \text { ND } & 2.1 & 2.1 \\ \text { ND } & 0.24 & 0.28 \\ \text { ND } & 5.86 & 6.05\end{array}$


PPM DAY WHOLE COAL BASIS

TRACE

ELEMENTS

\section{As}

Ba

$\mathrm{Ba}$

Cd

Cr

Cu

$\mathrm{F}$

$M n$

Mo

Ni

$\mathrm{Sb}$

$\stackrel{N}{\infty}$
LAB I

2.49
228.69
32.22
1.66
2.18
33.26
4.57
11.43
0.01
0.18
28.07
7.07
17.67
9.77
$<0.8$
2.81
46.78

2.8
238.84
32.19
1.77
2.08
33.23
4.88
11.42
0.01
0.19
28.04
7.58
17.65
14.54
$<0.8$
3.53
45.69

BUN 1

3.18
173

$\begin{array}{rr}3.18 & 3.22 \\ 173 & 167.02\end{array}$

48.5

1.34

1.01

35.54

3.44

9.61

128.14

0.107

39.9

7.39
17.46

17.46
.15 .25

0.68
5.56

38.76

PROXIMATE \& ULTIMATE

ASH

CARBON

HYDROGEN

NITHOGEN

SULFUR

CHLORINE

Btu/lb

12.59
68.06
4.98
1.33
4
0.04
11326

12.38
81.55
4.6
1.35
3.88
0.03
11013

12.63
70.23
4.82
1.34
3.4
0.073
12359

MANOR ASH ELEMENTS

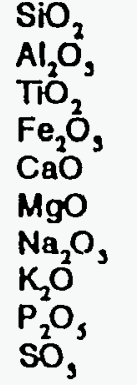

$\begin{array}{rrr}46.73 & 51.78 & 51.75 \\ 17.43 & 19.36 & 19.39 \\ 0.98 & 0.99 & 0.98 \\ 15.59 & 19.07 & 18.9 \\ 1.41 & 3.81 & 3.68 \\ 0.26 & 1.09 & 1.09 \\ 0.27 & 0.77 & 0.76 \\ 2.32 & 2.36 & 2.35 \\ 0.27 & 0.31 & 0.28 \\ \text { ND } & 1.87 & 1.82\end{array}$

LAB III

RUN 1 RUN 2 RUN LAB IV

$\begin{array}{rr}1 & 2 \\ 200 & 180 \\ 61.1 & 57.4 \\ 1.7 & 1.7 \\ <0.3 & <0.3 \\ 36.9 & 34.2 \\ 3.67 & 3.42 \\ <35.4 & <33.9 \\ 110 & 120 \\ 0.011 & 0.011 \\ 27.3 & 28.5 \\ 17.6 & 18.4 \\ 13.5 & 12.2 \\ 18 & 18 \\ 0.657 & 0.597 \\ 3 & 3 \\ 44.8 & 46.8\end{array}$

2
200
52
1.2
$<0.4$
32
3
9
ND
0.012
34
$<0$
18
15
$<$
3
42

\% DAY basis

12.6
70.02
4.87
1.32
3.43
0.09
12363

12.44
69.61
4.91
1.41
3.51
0.086
12391

12.49
69.21
4.9
1.36
3.54
0.088
12411

12.47
68.99
4.55
1.29
3.48
ND
12392
12.46 68.92
4.53
1.35
3.45
ND

12389

\section{\% DAY ASH}

$\begin{array}{rrr}\text { ND } & \text { ND } & 48.95 \\ 18.74 & 17 & 18.5 \\ 0.85 & 0.71 & 1.66 \\ 1.74 & 1.59 & \text { ND } \\ 1.92 & 1.81 & \text { ND } \\ 0.74 & 0.81 & \text { ND } \\ 0.8 & 0.7 & 0.77 \\ 1.71 & 2.05 & 1.95 \\ 0.59 & 0.51 & \text { ND } \\ \text { ND } & \text { ND } & \text { ND }\end{array}$

$\begin{array}{lrr}\text { ND } & 50.6 & 51 \\ \text { ND } & 18.6 & 18.4 \\ \text { ND } & 0.9 & 1 \\ \text { ND } & 17.5 & 17.4 \\ \text { ND } & 3.5 & 3.5 \\ \text { ND } & 1.1 & 1.1 \\ \text { ND } & 0.92 & 0.82 \\ \text { ND } & 2.2 & 2.2 \\ \text { ND } & 0.39 & 0.32 \\ \text { ND } & 3.56 & 3.54\end{array}$

RUN 1 RUN_2

$\begin{array}{rr}12.44 & 12.62 \\ 68.7 & 68.93 \\ 4.69 & 4.7 \\ 1.33 & 1.26 \\ 3.44 & 3.39 \\ 0.07 & 0.07 \\ 12384 & 12388\end{array}$

$$
\begin{array}{r}
2.8 \\
205 \\
56.5 \\
2.37 \\
0.184 \\
38.1 \\
3.84 \\
15.9 \\
88 \\
0.095 \\
40.8 \\
6.9 \\
23 \\
9.5 \\
\text { ND } \\
2.2 \\
57.9
\end{array}
$$


INDIVIDUAL LABORATORY ANALYSES OF ROUND ROBIN SAMPLE L

PPM DAY WHOLE COAL. BASIS

TRACE

ELEMENTS

As
$\mathrm{B}$
$\mathrm{Ba}$
$\mathrm{Be}$
$\mathrm{Cd}$
$\mathrm{Cr}$
$\mathrm{Co}$
$\mathrm{Cu}$
$\mathrm{F}$
$\mathrm{Hg}$
$\mathrm{Mn}$
$\mathrm{Mo}$
$\mathrm{Ni}$
$\mathrm{Pb}$
$\mathrm{Sb}$
$\mathrm{Se}$
$\mathrm{V}$
LAB I RUN 1

14.26

81.46

25.46

1.32

0.09

16.29

6.11

7.33

$<100$

$<0.1$
15.27

$<2$

13.24

3.46

$<0.8$

1.93

30.55
RUN

10.18

PROXIMATE \& ULTIMATE

ASH

CARBON

HYDROGEN

NITHOGEN

SULFUR

CHLORINE

Btu/lb

11.58
71.12

71.12
5.17

1.36

3.41

0.05

12539

MANOR ASH ELEMENTS

$\mathrm{SiO}_{2}$
$\mathrm{Al}_{2} \mathrm{O}$,
$\mathrm{TiO}_{2}$
$\mathrm{Fe}_{2} \mathrm{O}$,
$\mathrm{CaO}$
$\mathrm{MgO}$
$\mathrm{Na}_{2} \mathrm{O}$,
$\mathrm{KO}_{2} \mathrm{O}$
$\mathrm{P}_{2} \mathrm{O}_{5}$
$\mathrm{SO}_{3}$

39.57
19.93
0.94
22.63
0.5
0.26
0.37
1.7
0.11
ND

98.77

27.49

1.63

0.12

20.36

9.67
8.96

8.96

0.19
18.33

3.56

16.29

3.67

$<0.8$

2.14

37.67

LAB II

RUN 1

13.18

62.87

32.7

0.99

0.15

15.08

4.54

6.91

61.87

0.155

16.3
1.58

12.39

6.67

0.67

2.65

24.64

11.56

71.51

5.41

1.37

3.52

0.06

13308

11.45

72.74

4.9

1.39

3.12

0.091

13004

$$
\begin{array}{r}
11.53 \\
72.82 \\
4.88 \\
1.42 \\
3.17 \\
0.078 \\
13009
\end{array}
$$

\subsection{9}

23.29

1.07
26.45

26.45

0.6

0.28

0.38

2.02

0.13

13.29
64.7
32.9
1.05
0.15
14.92
4.43
6.76
61.71
0.154
16.3
1.54
12.18
6.55
0.66
2.74
24.07

45.60

45.66

21.77
0.97

26.21

1.28

0.7

0.41

1.9

0.1
1.64

45.89
21.86
0.98
26.12
1.29
0.71
0.41
1.92
0.1
1.62

LAB III

LAB IV

\begin{abstract}
RUN 1 RUN
\end{abstract}

$\begin{array}{rr}7 & 8 \\ 79 & 72\end{array}$

$34.4 \quad 34.1$

$\begin{array}{rr}34.4 & 34.1 \\ 1.5 & 1.5\end{array}$

$<0.3 \quad<0.3$

$\begin{array}{rr}17 & 16.5 \\ 5.18 & 5.56\end{array}$

$<34.9<32.6$

$60 \quad 50$

0.12

19.3

1.87

19.3

15
0.546

32.7

0.12
17.5

2.02

16.7

0.597

32.5

\% DRY ASH

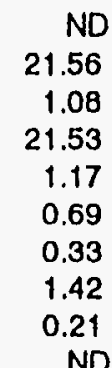

8
59
30
1.1
$<0.2$
15
4
7
$N D$
0.1
18
$<3$
14
6
$<1$
2
28

\section{\% DRY BASIS}

$\begin{array}{rrrrrr}11.61 & 11.61 & 11.45 & 11.38 & 11.49 & 11.67 \\ 72.69 & 72.38 & 71.92 & 71.97 & 71.59 & 71.67 \\ 5.03 & 5.05 & 4.88 & 4.87 & 4.82 & 4.81 \\ 1.43 & 1.42 & 1.41 & 1.38 & 1.34 & 1.23 \\ 3.26 & 3.29 & 3.08 & 3.15 & 3.29 & 3.25 \\ 0.099 & 0.096 & \text { ND } & \text { ND } & 0.1 & 0.09 \\ 12925 & 12950 & 12977 & 12973 & 12925 & 12936\end{array}$

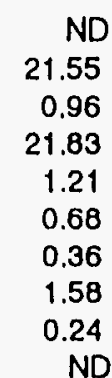

ND
63

30

1.1
$<0.2$

$<0.2$
16

16

7
ND

0.1
18

18
$<3$

12
6

$<$

$<1$
ND
27

NN 1 RUN 2

$\begin{array}{rr}10.9 & 10.7 \\ 63.9 & 50.1 \\ N D & 33 \\ 1.43 & 1.44 \\ 0.088 & 0.054 \\ 11.7 & 11.9 \\ 4.49 & 4.33 \\ 11 & 10.6 \\ 52 & 52 \\ 0.185 & 0.176 \\ 18.9 & 19.2 \\ \text { ND } & N D \\ 14.3 & 14.7 \\ 4.7 & 4.3 \\ \text { ND } & N D \\ 1.1 & 2.3 \\ 32.8 & 32.3\end{array}$


INDIVIDUAL LABORATORY ANALYSES OF ROUND ROBIN SAMPLE M

PPM DAY WHOLE COAL BASIS

TRACE

ELEMENTS

$\omega$
LAB I

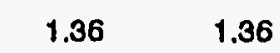

1.36
101.72

161.27

0.52

$<0.06$

5.21
$<2.0$

$<2.0$
10.42

$<100$

$<0.1$
119.09

119.09
7.57

7.57
4.09

4.09

$<0.8$

$<0.6$

9.68

$$
\begin{array}{r}
1.36 \\
105.45 \\
173.68 \\
0.5 \\
<0.06 \\
5.09 \\
2.73 \\
10.3 \\
<100 \\
<0.1 \\
119.09 \\
7.2 \\
4.47 \\
4.84 \\
<0.8 \\
<0.6 \\
10.67
\end{array}
$$

LAB III

1 RUN

LAB V

UN 1 RUN 2

PROXIMATE \& ULTIMATE

ASH

CARBON

HYDROGEN

NITROGEN

SULFUR

CHLORINE

Btu/lb

11.94
67.62
7.29
0.98
0.89
0.01
10898

MAJOR ASH ELEMENTS

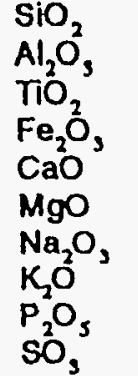

$\begin{array}{rr}1.7 .4 & 1.75 \\ 26.13 & 31.55 \\ 438.5 & 451.3 \\ 0.52 & 0.53 \\ 0.1 & 0.11 \\ 4.8 & 4.76 \\ 1.19 & 1.16 \\ 8,21 & 8.21 \\ 50.01 & 53.25 \\ 0.082 & 0.08 \\ 184.4 & 186.5 \\ 6.93 & 7.33 \\ 3.6 & 3.56 \\ 5.49 & 5.44 \\ 0.49 & 0.5 \\ 0.98 & 0.95 \\ 9.3 & 9.35\end{array}$

12.07
67.2
6.03
1
0.83
0.01
8333

11.74
68.81
4.72
0.84
0.98
$<0.02$
11747

11.88
68.56
4.75
0.97
0.99
$<0.02$
11743

$\begin{array}{rr}2 & 1 \\ 99 & 100 \\ 559 & 589 \\ 0.4 & 0.4 \\ <0.3 & <0.3 \\ 4.94 & 5.01 \\ 0.619 & 0.641 \\ <36.7 & <41.6 \\ 40 & 40 \\ 0.07 & 0.07 \\ 126.3 & 132.7 \\ 18.7 & 19.8 \\ 7.91 & 10.4 \\ 7 & 8 \\ 0.479 & 0.481 \\ 1 & 1 \\ 8.68 & 9.07\end{array}$

1
97
120
0.3
$<0.4$
3
1
7
$N D$
0.06
140
5
1
5
$<1$
1
8

* DRY BASIS

11.54
68.36
4.72
1.15
1.05
$<0.1$
11738
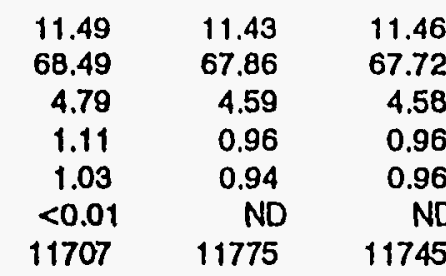

11.53

67.51

4.38
1.11

0.98

0.04

11670

11.62
67.67

4.33

1.1

0.98

0.04

11662

\section{* DRY ASH}

$\begin{array}{rr}41.85 & 43.44 \\ 7.77 & 18.96 \\ 0.86 & 0.81 \\ 4.85 & 7.05 \\ 2.16 & 12.82 \\ 1.11 & 4.04 \\ 0.24 & 0.29 \\ 0.46 & 0.5 \\ 0.31 & 0.29 \\ \text { ND } & 1.77\end{array}$

43.5

18.97

0.81

7.64

12.83

4.02

0.32

0.51

0.29

0.29
11.84

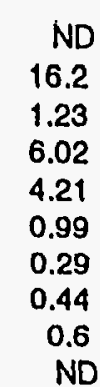

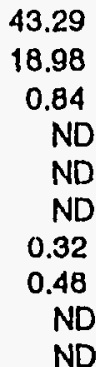

$\begin{array}{lrr}\text { ND } & 40.3 & 40.9 \\ \text { ND } & 19.5 & 19.1 \\ \text { ND } & 0.8 & 0.8 \\ \text { ND } & 5.9 & 5.6 \\ \text { ND } & 11.4 & 11.4 \\ \text { ND } & 3.9 & 3.9 \\ \text { ND } & 0.32 & 0.38 \\ \text { ND } & 0.49 & 0.51 \\ \text { ND } & 0.29 & 0.27 \\ \text { ND } & 14.48 & 14.08\end{array}$
11.43
67.86
4.59
0.96
0.94
ND
11775


INDIVIDUAL LABORATORY ANALYSES OF ROUND ROBIN SAMPLE N

PPM DRY WHOLE COAL BASIS

TAACE

LAB 1

LAB II

LAB III

LAB IV

LAB V

ELEMENTS

RUN 1 RUN

UN 2

As
B
Ba
$\mathrm{Be}$
$\mathrm{Cd}$
$\mathrm{Cr}$
$\mathrm{Co}$
$\mathrm{Cu}$
$\mathrm{F}$
$\mathrm{Hg}$
$\mathrm{Mn}$
$\mathrm{Mo}$
$\mathrm{Ni}$
$\mathrm{Pb}$
$\mathrm{Sb}$
$\mathrm{Se}$
$\mathrm{V}$

11.83
199.3

361.24

0.97

0.11
10.09

10.09
4.73

4.73

11.58

$<100$

$<0.1$

137.02

3.99

3.61

$<0.8$

0.95

10.07
149.18

335.65

0.77

$<0.06$
7.71

3.11

8.95

$<100$

$<0.1$

105.67

3.85
5.59

2.98

$<0.8$

$<0.6$

16.16

11.69
41.06

41.06
695.5

0.51

0.13

8.01

2.78

7.72

62.27

0.129

150.8

2.82

7.3

2.6
0.77

1.03

15.72

11.71
49.2

49.2
655

0.51

0.13

8.45

2.67

7.57

62.91

0.167

147.9

2.88

7.49

2.5
0.79

1.03

15.78

\section{PROXIMATE \& ULTIMATE}

ASH
CARBON
HYDROGEN
NITROGEN
SULFUR
CHLORINE
BTU/lb

16.73

58.35

16.96

58.36

4.36
0.82

1.02

1.02

ND
9107

7314

16.11
59.77
4.23
0.91
1.15
$<0.02$
9887

16.15

59.64

4.25
0.91

1.13

$<0.02$

9881

MANOR ASH ELEMENTS

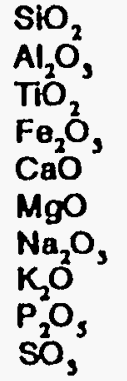

46.27
4.36
0.57
5.22
4.9
1.23
0.94
1.79
0.19
ND

$\begin{array}{rrr}34.56 & 41.36 & 40.88 \\ 3.6 & 12.34 & 12.09 \\ 0.44 & 0.43 & 0.42 \\ 4.19 & 7.09 & 7.06 \\ 3.9 & 17.58 & 17.35 \\ 1.34 & 4.8 & 4.73 \\ 0.82 & 0.87 & 0.84 \\ 1.24 & 1.37 & 1.33 \\ 0.14 & 0.13 & 0.12 \\ \text { ND } & 14.56 & 14.4\end{array}$

4
145
73
0.8
$<0.4$
9.06
1.85

$<39.7$

50
0.11

93.1

10.5

15.5

0.672

$<1$

19.4

5
5
145
77.9
0.8
$<0.4$
8.67
1.95
$<40.7$
50
0.1
96.5
11
16.4
8
0.704
$<1$
19.2

\% DAY BASIS

$\begin{array}{rrrrrr}16.64 & 16.46 & 16.74 & 16.69 & 17.06 & 17.32 \\ 59.26 & 59.22 & 58.96 & 59.22 & 59.26 & 59.64 \\ 4.28 & 4.31 & 4.06 & 4.02 & 3.8 & 3.87 \\ 1.06 & 1.05 & 0.81 & 0.77 & 1.02 & 0.99 \\ 1.18 & 1.16 & 1.13 & 1.14 & 1.13 & 1.12 \\ <0.01 & <0.01 & \text { ND } & \text { ND } & 0.04 & 0.04 \\ 9924 & 9906 & 9906 & 9894 & 9892 & 9885\end{array}$

\% DAY ASH

$\begin{array}{rrr}\text { ND } & \text { ND } & 39.59 \\ 12.98 & 13.13 & 12.28 \\ 0.44 & 0.53 & 0.48 \\ 6.25 & 6.38 & \text { ND } \\ 4.77 & 5.06 & \text { ND } \\ 1.11 & 1.05 & \text { ND } \\ 0.8 & 0.81 & 0.85 \\ 1.19 & 1.36 & 1.26 \\ 0.33 & 0.31 & \text { ND } \\ \text { ND } & \text { ND } & \text { ND }\end{array}$

$\begin{array}{lrr}\text { ND } & 39.6 & 39.4 \\ \text { ND } & 12.1 & 12.2 \\ \text { ND } & 0.5 & 0.5 \\ \text { ND } & 6.6 & 6.6 \\ \text { ND } & 15.9 & 16 \\ \text { ND } & 4.7 & 4.7 \\ \text { ND } & 0.95 & 0.92 \\ \text { ND } & 1.4 & 1.4 \\ \text { ND } & 0.18 & 0.15 \\ \text { ND } & 15.11 & 14.94\end{array}$

10.1
124
729
1.13
$N D$
6
1.51
13.2
56
0.155
124
0.44
11.8
0.05
ND
ND
16.2

7.32

3.87

1.12

0.04
9885 
PPM DRY WHOLE COAL BASIS

TRACE

ELEMENTS

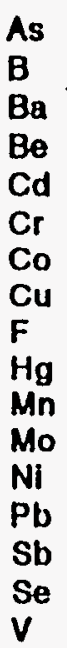

LAB RUN 1 RUN 2

$\begin{array}{rr}46.12 & 35.85 \\ 99.41 & 74.78 \\ 53.29 & 48.15 \\ 2.97 & 2.25 \\ 0.11 & 0.06 \\ 22.55 & 18.44 \\ 9.74 & 9.12 \\ 23.57 & 18.44 \\ 0.01 & 0.1 \\ 0.14 & 0.3 \\ 26.64 & 21.51 \\ 10.25 & 5.33 \\ 27.67 & 21.51 \\ 9.94 & 11.27 \\ 2.15 & 1.43 \\ 2.05 & 2.15 \\ 44.07 & 33.8\end{array}$

PROXIMATE \& ULTIMATE

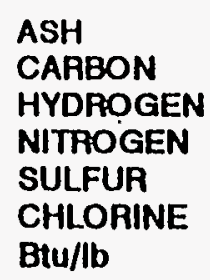

13.29
69.61
5.06
1.3
3.08
0.02
11774

\subsection{6} 69.56
5.24 5.24 1.31 3.1 0.02 11530

MANOR ASH ELEMENTS

$\mathrm{SiO}_{2}$

$\mathrm{Fe}_{2} \mathrm{O}$

$\mathrm{Fe}_{2} \mathrm{O}_{3}$

$\mathrm{MgO}$

$\mathrm{Na}_{2} \mathrm{O}$,

$\mathrm{K}_{2} \mathrm{O}$

$\mathrm{P}_{2} \mathrm{O}_{5}$
LAB II

RUN 2 RUN III

RUN 1 LAB IV

LAB V

\section{$34.96 \quad 36.04$}

$58.5 \quad 62.38$

84.8

1.9

0.14

20.68

5.9

17.81

80.03

0.248

27.2
4.05

4.05

21.12

15.29

2.09

3.39

28.47

\section{1}

73
107

2.7

2.7
$<0.3$

$<0.3$

21
6.67

6.67
$<31$

90

0.23

27.4

5.09

54.5

22.1

15.14

2.17

3.37

30.13

$\begin{array}{rc}18 & 27 \\ 77 & 72 \\ 100 & 85 \\ 2.4 & 2.1 \\ <0.3 & <0.4 \\ 22.6 & 20 \\ 7.72 & 8 \\ <32.6 & 22 \\ 90 & N D \\ 0.23 & 0.2 \\ 30.4 & 30 \\ 5.68 & <6 \\ 61.9 & 26 \\ 20 & 19 \\ 1.78 & 2 \\ 3 & 3 \\ 32.1 & 28\end{array}$

ND $\quad 29.4 \quad 31$

$\begin{array}{lrr}80 & 54.5 & 47.8 \\ 89 & \text { ND } & 85\end{array}$

$\begin{array}{lll}2.4 & 2.58 & 2.61\end{array}$

$<0.4 \quad 0.11 \quad$ ND

$20 \quad 13.3 \quad 13.9$

$\begin{array}{rrr}7 & 4.6 & 5.8 \\ 22 & 22.7 & 23.5\end{array}$

$\begin{array}{lrr}22 & 22.7 & 23.5 \\ \text { ND } & 73 & 73\end{array}$

$\begin{array}{lll}0.2 & 0.399 & 0.353\end{array}$

$31 \quad 26 \quad 26.4$

$<6 \quad 1.85 \quad 2.79$

$25 \quad 23.7 \quad 24.1$

$\begin{array}{rrr}18 & 10.5 & 9.7 \\ 2 & 2.6 & 2.4\end{array}$

$\begin{array}{lll}\text { ND } & 3.3 & 2.2\end{array}$

$\begin{array}{llllll}32.3 & 32.1 & 28 & 26 & 35.6 & 36.6\end{array}$

\% DAY BASIS

$\begin{array}{rr}13.32 & 13.3 \\ 71.35 & 71.16 \\ 4.82 & 4.78 \\ 1.34 & 1.47 \\ 2.92 & 2.97 \\ 0.13 & 0.13 \\ 12737 & 12720\end{array}$

$\begin{array}{rrrrrr}13.28 & 13.4 & 13.12 & 13.18 & 13.31 & 13.46 \\ 71.19 & 71.46 & 70.38 & 70.79 & 70.5 & 70.66 \\ 4.91 & 5 & 4.6 & 4.65 & 4.76 & 4.79 \\ 1.41 & 1.37 & 1.36 & 1.38 & 1.33 & 1.35 \\ 3.02 & 2.99 & 3.01 & 3.04 & 2.93 & 2.91 \\ 0.127 & 0.13 & N D & N D & 0.12 & 0.12 \\ 12654 & 12655 & 12690 & 12708 & 12644 & 12637\end{array}$

\% DAY ASH

$\begin{array}{rrrrrrr}52.88 & 39.14 & 46.16 & 46.9 & \text { ND } & \text { ND } & 42.89 \\ 24.76 & 20.13 & 23.46 & 23.32 & 20.52 & 20.27 & 21.3 \\ 1.29 & 0.96 & 1.09 & 1.08 & 1.03 & 1.02 & 2.32 \\ 23.15 & 17.41 & 22.28 & 22.17 & 20.6 & 22.79 & \text { ND } \\ 1.19 & 0.97 & 1.84 & 1.8 & 1.31 & 1.22 & \text { ND } \\ 0.37 & 0.44 & 0.88 & 0.87 & 0.83 & 0.77 & \text { ND } \\ 0.24 & 0.21 & 0.31 & 0.29 & 0.25 & 0.25 & 0.36 \\ 2.51 & 2.11 & 2.32 & 2.32 & 2.27 & 2.33 & 1.72 \\ 0.53 & 0.4 & 0.48 & 0.47 & 0.97 & 0.85 & \text { ND } \\ \text { ND } & \text { ND } & 1.83 & 1.75 & \text { ND } & \text { ND } & \text { ND }\end{array}$

$\begin{array}{lrr}\text { ND } & 45.3 & 45 \\ \text { ND } & 22.5 & 22.6 \\ \text { ND } & 1.1 & 1.1 \\ \text { ND } & 21 & 21.4 \\ \text { ND } & 1.7 & 1.7 \\ \text { ND } & 0.85 & 0.85 \\ \text { ND } & 0.47 & 0.44 \\ \text { ND } & 2.2 & 2.2 \\ \text { ND } & 0.49 & 0.53 \\ \text { ND } & 1.74 & 1.74\end{array}$


INDIVIDUAL LABORATORY ANALYSES OF ROUND ROBIN SAMPLE P

PPM DAY WHOLE COAL BASIS

TRACE

RUN 1 LAB I'

LAB II

LAB III

LAB IV

LAB V

ELEMENTS

As
$B$
$B a$
$B o$
$C d$
$\mathrm{Cr}$
$\mathrm{Co}$
$\mathrm{Cu}$
$\mathrm{F}$
$\mathrm{Hg}$
$\mathrm{Mn}$
$\mathrm{Mo}$
$\mathrm{Ni}$
$\mathrm{Pb}$
$\mathrm{Sb}$
$\mathrm{Se}$
$\mathrm{V}$

$\begin{array}{rr}1.75 & 2.19 \\ 89.74 & 90.81 \\ 82.08 & 79.87 \\ 1.42 & 1.42 \\ <0.06 & 2.95 \\ 10.84 & 10.72 \\ 6.24 & 6.24 \\ 13.13 & 14.22 \\ 0.01 & <100 \\ <0.1 & 0.16 \\ 51.44 & 47.05 \\ 2.96 & 2.85 \\ 8.54 & 8.1 \\ 7.33 & 8.1 \\ 1.42 & 1.97 \\ 1.2 & 1.03 \\ 26.27 & 27.35\end{array}$$$
2.48
$$

2.48
75.17

PFOXIMATE \& ULTIMATE

\section{ASH}

CARBON

HYDPOGEN

NITROGEN

SULFUR

CHLOAINE

Btu/lb

20.56
60.52
5.12
1.02
0.61
0.01
10329

MANOR ASH ELEMENTS

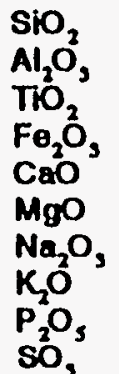

57.03
16.09
0.98
4.11
2.31
0.32
0.13
1.09
0.03
ND

397.2

1.14

1.14
$<.01$

9.42

4.15

11.56

87.98

0.082

90.6

1.68

7.28

9.45

1.7

1.59
22.37

22.37

20.54
61.06
5.39
1.02
0.64
0.01
9469

20.58
62.04
4.65
0.98
0.7
$<0.02$
10913

2.6
75.9
377.8
1.16
$<0.1$
9.9

9.9

11.49

88.66

0.089

90.6

1.66

8.23
9.63

9.63

1.73

1.72
23.81

$\begin{array}{rr}1 & 1 \\ 80 & 77 \\ 495 & 462 \\ 1.2 & 1.4 \\ <0.4 & <0.4 \\ 10.8 & 9.9 \\ 4.34 & 3.79 \\ <39.2 & <35.7 \\ 80 & 80 \\ 0.07 & 0.08 \\ 82.5 & 79.1 \\ <19.6 & <17.8 \\ <14.7 & <13.4 \\ 11 & 9 \\ 1.77 & 1.55 \\ 1 & 1 \\ 26.1 & 21.6\end{array}$

1
82
230
1.3

1.3
$<0.6$

10

5
11
10

ND

0.08
87

$<8$

5
10

10
2

$<1$
28

× DAY BASIS

20.6
62.16
4.66
1
0.072
$<0.02$
10898

20.44
62.33
4.8
1.11
0.71
$<0.01$
10872

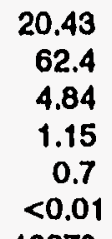

20.24

61.56

4.61

1.08

0.69

10852

10870

\section{\% DRY ASH}

$\begin{array}{rrr}55.93 & 61.79 & 61.01 \\ 15.09 & 22.5 & 22.16 \\ 0.98 & 0.95 & 0.93 \\ 3.88 & 4.84 & 4.86 \\ 2.01 & 4.57 & 4.51 \\ 0.28 & 1.34 & 1.31 \\ 0.11 & 0.27 & 0.26 \\ 1.03 & 1.39 & 1.39 \\ 0.04 & 0.04 & 0.04 \\ \text { ND } & 3.61 & 3.52\end{array}$

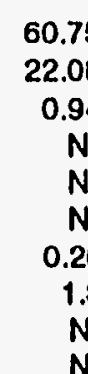

$N D$
74
240
1.1
$<0.6$
9
3
10
$N D$
0.08
79
$<8$
6
9
1
$N D$
26

2.3
45.2
385
1.32
0.018
7.6
2.74
13.7
56
0.078
77.1
0.488
5.9
6.72
2.6
0.79
27

2.4

65.9

374

1.35

ND

7.4

3.41

13.4

0.077

75.4

ND

7.3
7

ND

0.26

26.1

$\begin{array}{rc}\text { ND } & \text { ND } \\ 22.53 & 19.93 \\ 1 & 1.04 \\ 4.5 & 4.35 \\ 2.38 & 2.52 \\ 0.93 & 0.91 \\ 0.26 & 0.24 \\ 1.32 & 1.28 \\ 0.02 & 0.03 \\ \text { ND } & \text { ND }\end{array}$

60.75
22.08
0.94
ND
ND
ND
0.26
1.3
ND
ND

$\begin{array}{rrr}20.29 & 20.51 & 20.75 \\ 61.24 & 61.09 & 61.27 \\ 4.65 & 4.51 & 4.58 \\ 1 & 1.09 & 1.08 \\ 0.7 & 0.7 & 0.71 \\ \text { ND } & 0.04 & 0.04 \\ 10865 & 10857 & 10830\end{array}$

$\begin{array}{lll}59.54 & 58.2 & 58.8\end{array}$

$\begin{array}{lll}21.79 & 21.1 & 20.9\end{array}$

$\begin{array}{rrr}0.93 & 1 & 1 \\ \text { ND } & 4.4 & 4.5\end{array}$

ND $\quad 4.3 \quad 4.3$

ND $\quad 1.2 \quad 1.2$

$\begin{array}{lll}0.22 & 0.27 & 0.27\end{array}$

$\begin{array}{lll}1.27 & 1.3 & 1.3\end{array}$

$\begin{array}{lll}\text { ND } & 0.04 & 0.04\end{array}$ 
TAACE ELEMENTS

As
B
Ba
Bo
$\mathrm{Cd}$
$\mathrm{Cr}$
$\mathrm{Co}$
$\mathrm{Cu}$
$\mathrm{F}$
$\mathrm{Hg}$
$\mathrm{Mn}$
$\mathrm{Mo}$
$\mathrm{Ni}$
$\mathrm{Pb}$
$\mathrm{Sb}$
$\mathrm{Se}$
$\mathrm{V}$

LAB I RUN 1 RUN 2

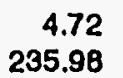

235.98

39.69

1.93

0.55
25.74

7.08

12.87

$<100$

$<0.1$

33.25

6.54
21.45

6.22

$<0.8$

1.39

48.27

PPM DAY WHOLE COAL BASIS

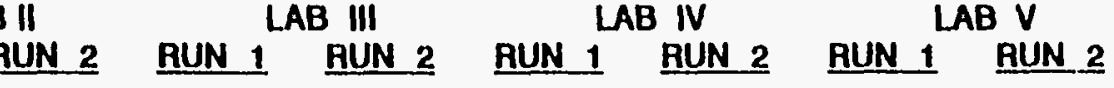

AUN 2 RUN 1 RUN 2 RUN 1 RUN 2 RUN 1 RUN 2

AUN 2 RUN 1 RAB III 2 LAB IV 2 RUN 1 RUN 2 RUN 1 RUN 2

PROXIMATE \& ULTIMATE

ASH
CARBON
HYDROGEN
NITROGEN
SULFUR
CHLORINE
BLU/Ib

MANOR ASH ELEMENTS
SiO,
Al,
$T_{2} O_{2}$
$\mathrm{Fe}_{2} \mathrm{O}_{3}$
$\mathrm{CaO}^{\prime}$
$\mathrm{MgO}$
$\mathrm{Na}_{2} \mathrm{O}_{3}$
$\mathrm{KO}_{3}$
$\mathrm{P}_{2} \mathrm{O}_{5}$
$\mathrm{SO}_{3}$

$\begin{array}{rrr}5.67 & 4.39 & 4.43 \\ 288.74 & 138.35 & 135.55 \\ 41.71 & 50.9 & 50.8 \\ 2.35 & 1.11 & 1.18 \\ 1.39 & 0.66 & 0.63 \\ 32.08 & 19.39 & 20.28 \\ 8.77 & 3.61 & 3.59 \\ 18.18 & 10.72 & 10.79 \\ <100 & 80.61 & 80.89 \\ 0.18 & 0.098 & 0.109 \\ 34.22 & 32.4 & 33.2 \\ 9.09 & 5.06 & 5.1 \\ 24.6 & 15.19 & 15.24 \\ 1.39 & 10.87 & 10.68 \\ <0.8 & 0.61 & 0.58 \\ 2.03 & 3.04 & 2.91 \\ 57.75 & 31.51 & 32.81\end{array}$

$\begin{array}{rr}10.61 & 10.58 \\ 66.15 & 68.69 \\ 6.38 & 5.87 \\ 1.41 & 1.42 \\ 3.25 & 3.25 \\ 0.07 & 0.08 \\ 12206 & 11290\end{array}$

10.65
72.54
4.89
1.48
2.77
0.139
12901

\section{160}

$160 \quad 180$

56.8

$<0.2$

21.9

3.88

$<34.3$

$<34.3$
0.07

0.07

29.7

$<8.6$
28.4

28.4

0.445

3
36.6

3
180
67.1

$$
1.5
$$

$$
<0.2
$$$$
21.5
$$$$
4.23
$$$$
<34.8
$$$$
\begin{array}{r}
80 \\
0.07
\end{array}
$$$$
0.07
$$$$
29.3
$$$$
29.7
$$$$
12
$$$$
\begin{array}{r}
12 \\
0.596
\end{array}
$$$$
\begin{array}{r}
3 \\
35.7
\end{array}
$$

35.7

* DRY Basis

10.76
72.7
4.89
1.48
2.76
0.137
12875

10.56
72.68
5.11
1.52
2.78
0.148
12785

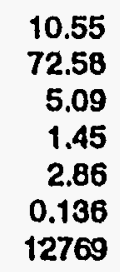

10.46

71.32

4.71

4.71
1.37

2.9

ND

12815

3
160
50
1.2

170

170
47
1.2

$<0.3$

$<2$
5

5

12
ND

0.08

30

$<6$

16

$<1$

NID

$2.3 \quad 3.3$

$140 \quad 160$

$48.6 \quad 50.2$

$1.44 \quad 1.48$

$0.286 \quad 0.089$

$\begin{array}{rr}0.28 & 17.4\end{array}$

$2.79 \quad 2.29$

$15.3 \quad 15.3$

$\begin{array}{rr}70 & 75 \\ 0.117 & 0.113\end{array}$

$26.6 \quad 0.113$

4.34

$17.3 \quad 16.5$

$6.8 \quad 6.2$

2.4
40

ND
1.87

39.4

\section{\% DRY ASH}

$\begin{array}{rrr}60.66 & 69.31 & 50.76 \\ 24.82 & 26.73 & 22.2 \\ 1.37 & 1.64 & 1.11 \\ 18.79 & 21.68 & 16.92 \\ 1.7 & 1.56 & 3.31 \\ 0.34 & 0.28 & 1.03 \\ 0.91 & 1.01 & 0.87 \\ 2.92 & 3.41 & 2.58 \\ 0.22 & 0.3 & 0.2\end{array}$

50.64
22.07
1.01
16.92
3.4
1.04
0.89
2.56
0.21
2.32

$\begin{array}{rrr}\text { ND } & \text { ND } & 49.64 \\ 19.79 & 19.71 & 21.62 \\ 0.27 & 0.27 & 1.07 \\ 16.53 & 16.39 & \text { ND } \\ 2.22 & 2.01 & \text { ND } \\ 0.69 & 0.66 & \text { ND } \\ 0.7 & 0.81 & 0.81 \\ 1.9 & 2.04 & 2.38 \\ 0.39 & 0.43 & \text { ND } \\ \text { ND } & \text { ND } & \text { ND }\end{array}$

$\begin{array}{rrr}10.51 & 10.62 & 10.64 \\ 71.6 & 71.25 & 71.23 \\ 4.73 & 4.77 & 4.79 \\ 1.36 & 1.34 & 1.31 \\ 2.92 & 2.87 & 2.78 \\ \text { ND } & 0.1 & 0.1 \\ 12809 & 12768 & 12733\end{array}$

$\begin{array}{lrr}\text { ND } & 50.1 & 50.2 \\ \text { ND } & 21.7 & 21.5 \\ \text { ND } & 1.2 & 1.2 \\ \text { ND } & 15.4 & 15.5 \\ \text { ND } & 2.9 & 3 \\ \text { ND } & 1 & 1 \\ \text { ND } & 0.9 & 0.91 \\ \text { ND } & 2.5 & 2.4 \\ \text { ND } & 0.21 & 0.21 \\ \text { ND } & 2.82 & 2.9\end{array}$


APPENDIX B

INTRALABORATORY TRACE ELEMENT REPEATABחITY AS PERCENT DIFFERENCE 
Laboratory Repeatability

Samples A \& J

\begin{tabular}{|c|c|c|c|c|c|c|c|c|}
\hline $\begin{array}{l}\text { TAACE } \\
\text { ELEMENTS }\end{array}$ & $\overline{L A B}$ & LAB II & LAB III & LAB IV & LAB V & MEAN & SDEV & $\overline{\text { PRSD }}$ \\
\hline As & $31.0 \%$ & $1.9 \%$ & $0.0 \%$ & $0.0 \%$ & $6.7 \%$ & $7.9 \%$ & $13.2 \%$ & $166.3 \%$ \\
\hline$B$ & $7.7 \%$ & $1.0 \%$ & $6.5 \%$ & $11.5 \%$ & $14.3 \%$ & $8.2 \%$ & $5.1 \%$ & $62.0 \%$ \\
\hline $\mathrm{Ba}$ & $65.2 \%$ & $6.3 \%$ & $29.7 \%$ & $12.2 \%$ & $63.1 \%$ & $35.3 \%$ & $27.7 \%$ & $78.5 \%$ \\
\hline $\mathrm{Be}$ & $57.1 \%$ & $6.6 \%$ & $7.4 \%$ & $16.0 \%$ & $2.1 \%$ & $17.8 \%$ & $22.5 \%$ & $126.2 \%$ \\
\hline $\mathrm{Cd}$ & $9.1 \%$ & $7.5 \%$ & & & $27.9 \%$ & $14.8 \%$ & $11.4 \%$ & $76.7 \%$ \\
\hline $\mathrm{Cr}$ & $12.4 \%$ & $4.4 \%$ & $3.5 \%$ & $17.3 \%$ & $16.8 \%$ & $10.9 \%$ & $6.6 \%$ & $61.0 \%$ \\
\hline Co & $0.5 \%$ & $6.9 \%$ & $1.5 \%$ & $50.0 \%$ & $23.2 \%$ & $16.4 \%$ & $20.9 \%$ & $127.2 \%$ \\
\hline $\mathrm{Cu}$ & & $6.9 \%$ & & $23.3 \%$ & $2.6 \%$ & $10.9 \%$ & $10.9 \%$ & $99.8 \%$ \\
\hline$F$ & & $2.2 \%$ & $4.9 \%$ & & $24.6 \%$ & $10.6 \%$ & $12.2 \%$ & $115.8 \%$ \\
\hline $\mathrm{Hg}$ & & $18.7 \%$ & $10.5 \%$ & $10.5 \%$ & $5.3 \%$ & $11.3 \%$ & $5.5 \%$ & $49.1 \%$ \\
\hline Mn & $36.7 \%$ & $1.5 \%$ & $2.8 \%$ & $18.2 \%$ & $2.2 \%$ & $12.3 \%$ & $15.3 \%$ & $124.4 \%$ \\
\hline Mo & $11.2 \%$ & $2.3 \%$ & $8.4 \%$ & $50.0 \%$ & $9.0 \%$ & $16.2 \%$ & $19.2 \%$ & $118.6 \%$ \\
\hline $\mathrm{Ni}$ & $11.0 \%$ & $3.3 \%$ & $6.1 \%$ & $20.0 \%$ & $11.1 \%$ & $10.3 \%$ & $6.3 \%$ & $61.5 \%$ \\
\hline $\mathrm{Pb}$ & $21.8 \%$ & $1.9 \%$ & $54.5 \%$ & $12.8 \%$ & $7.8 \%$ & $19.8 \%$ & $20.8 \%$ & $105.1 \%$ \\
\hline Sb & & $4.9 \%$ & $7.1 \%$ & & & $6.0 \%$ & $1.6 \%$ & $26.2 \%$ \\
\hline $\mathrm{Se}$ & $32.6 \%$ & $12.5 \%$ & $18.2 \%$ & $0.0 \%$ & $17.4 \%$ & $16.1 \%$ & $11.7 \%$ & $72.7 \%$ \\
\hline v & $6.7 \%$ & $13.2 \%$ & $6.6 \%$ & $17.7 \%$ & $1.4 \%$ & $9.1 \%$ & $6.4 \%$ & $69.7 \%$ \\
\hline Average & $23.3 \%$ & $6.0 \%$ & $11.2 \%$ & $18.5 \%$ & $14.7 \%$ & $13.8 \%$ & $7.9 \%$ & $57.8 \%$ \\
\hline
\end{tabular}

Laboratory Repeatability

Samples B \& K

\begin{tabular}{|l|r|r|r|r|r|r|r|r|}
\hline \hline TRACE & LAB I & LAB II & LAB III & LAB IV & LAB V & MEAN & SDEV & PRSD \\
\hline ELEENTS & & & & & & \\
\hline As & $3.7 \%$ & $0.6 \%$ & $0.0 \%$ & $85.7 \%$ & $32.1 \%$ & $24.4 \%$ & $36.8 \%$ & $150.5 \%$ \\
Ba & $10.3 \%$ & $11.8 \%$ & $33.0 \%$ & $2.5 \%$ & $3.2 \%$ & $12.2 \%$ & $12.4 \%$ & $101.6 \%$ \\
$\mathrm{Be}$ & $10.5 \%$ & $2.0 \%$ & $15.2 \%$ & $8.2 \%$ & $13.6 \%$ & $9.9 \%$ & $5.2 \%$ & $52.4 \%$ \\
$\mathrm{Cd}$ & $8.4 \%$ & $1.8 \%$ & $12.5 \%$ & $3.8 \%$ & $9.5 \%$ & $7.2 \%$ & $4.4 \%$ & $60.5 \%$ \\
$\mathrm{Cr}$ & $86.4 \%$ & $0.0 \%$ & & & $67.7 \%$ & $51.4 \%$ & $45.5 \%$ & $88.5 \%$ \\
$\mathrm{Co}$ & $7.3 \%$ & $1.9 \%$ & $2.0 \%$ & $6.9 \%$ & $7.1 \%$ & $5.0 \%$ & $2.8 \%$ & $55.9 \%$ \\
$\mathrm{Cu}$ & $7.3 \%$ & $1.6 \%$ & $0.1 \%$ & $0.0 \%$ & $3.1 \%$ & $2.4 \%$ & $3.0 \%$ & $123.9 \%$ \\
$\mathrm{~F}$ & $0.2 \%$ & $0.5 \%$ & & $5.1 \%$ & $9.5 \%$ & $3.8 \%$ & $4.4 \%$ & $115.4 \%$ \\
$\mathrm{Hg}$ & & $5.2 \%$ & $0.0 \%$ & & $0.5 \%$ & $1.9 \%$ & $2.8 \%$ & $149.1 \%$ \\
$\mathrm{Mn}$ & & $14.8 \%$ & $163.6 \%$ & $4.3 \%$ & $2.3 \%$ & $46.3 \%$ & $78.4 \%$ & $169.5 \%$ \\
$\mathrm{Mo}$ & $12.0 \%$ & $0.9 \%$ & $3.9 \%$ & $2.7 \%$ & $6.8 \%$ & $5.2 \%$ & $4.3 \%$ & $82.8 \%$ \\
$\mathrm{Ni}$ & $2.3 \%$ & $1.4 \%$ & & & $9.9 \%$ & $4.5 \%$ & $4.7 \%$ & $102.6 \%$ \\
$\mathrm{~Pb}$ & $8.3 \%$ & $1.6 \%$ & $54.0 \%$ & $12.7 \%$ & $9.6 \%$ & $17.2 \%$ & $20.9 \%$ & $121.6 \%$ \\
$\mathrm{Sb}$ & $84.5 \%$ & $3.8 \%$ & $14.9 \%$ & $3.3 \%$ & $2.1 \%$ & $21.7 \%$ & $35.5 \%$ & $163.5 \%$ \\
$\mathrm{Se}$ & & $2.2 \%$ & $1.5 \%$ & & & $1.8 \%$ & $0.5 \%$ & $25.0 \%$ \\
$\mathrm{~V}$ & $28.1 \%$ & $10.1 \%$ & $15.4 \%$ & $100.0 \%$ & $7.3 \%$ & $32.2 \%$ & $38.7 \%$ & $120.4 \%$ \\
\hline Average & $2.7 \%$ & $2.4 \%$ & $4.3 \%$ & $7.0 \%$ & $4.0 \%$ & $2.3 \%$ & $56.9 \%$ \\
\hline
\end{tabular}




\section{Laboratory Repeatability \\ Samples C \& L}

\begin{tabular}{|l|r|r|r|r|r|r|r|r|}
\hline TRACE & LAB I & LAB II & LAB III & LAB IV & LAB V & MEAN & SDEV & PRSD \\
\hline ELEMENTS & & & & & & \\
\hline As & $93.4 \%$ & $0.7 \%$ & $22.2 \%$ & $28.6 \%$ & $16.6 \%$ & $32.3 \%$ & $35.7 \%$ & $110.6 \%$ \\
$\mathrm{Ba}$ & $1.0 \%$ & $1.8 \%$ & $5.8 \%$ & $19.9 \%$ & $15.5 \%$ & $8.8 \%$ & $8.5 \%$ & $96.2 \%$ \\
$\mathrm{Be}$ & $5.7 \%$ & $2.3 \%$ & $15.2 \%$ & $15.4 \%$ & $71.2 \%$ & $22.0 \%$ & $28.1 \%$ & $128.1 \%$ \\
$\mathrm{Cd}$ & $10.0 \%$ & $12.0 \%$ & $18.2 \%$ & $8.7 \%$ & $5.8 \%$ & $10.9 \%$ & $4.6 \%$ & $42.5 \%$ \\
$\mathrm{Cr}$ & $27.0 \%$ & $35.3 \%$ & & & $76.0 \%$ & $46.1 \%$ & $26.2 \%$ & $56.9 \%$ \\
$\mathrm{Co}$ & $13.1 \%$ & $8.5 \%$ & $5.5 \%$ & $22.9 \%$ & $5.7 \%$ & $11.1 \%$ & $7.2 \%$ & $65.0 \%$ \\
$\mathrm{Cu}$ & $13.4 \%$ & $0.0 \%$ & $6.6 \%$ & $40.0 \%$ & $2.2 \%$ & $12.4 \%$ & $16.2 \%$ & $130.5 \%$ \\
$\mathrm{~F}$ & $9.6 \%$ & $1.9 \%$ & & $13.3 \%$ & $2.3 \%$ & $6.8 \%$ & $5.6 \%$ & $83.1 \%$ \\
$\mathrm{Hg}$ & & $2.9 \%$ & $8.7 \%$ & & $6.5 \%$ & $6.0 \%$ & $2.9 \%$ & $48.8 \%$ \\
$\mathrm{Mn}$ & $17.1 \%$ & $6.3 \%$ & $13.3 \%$ & $33.3 \%$ & $25.3 \%$ & $19.1 \%$ & $10.5 \%$ & $55.0 \%$ \\
$\mathrm{Mo}$ & $8.8 \%$ & $1.5 \%$ & $1.9 \%$ & $22.2 \%$ & $1.3 \%$ & $7.2 \%$ & $9.0 \%$ & $125.7 \%$ \\
$\mathrm{Ni}$ & $62.9 \%$ & $4.7 \%$ & $16.3 \%$ & & & $28.0 \%$ & $30.8 \%$ & $110.2 \%$ \\
$\mathrm{~Pb}$ & $9.9 \%$ & $0.3 \%$ & $52.2 \%$ & $14.3 \%$ & $3.5 \%$ & $16.0 \%$ & $20.9 \%$ & $130.6 \%$ \\
$\mathrm{Sb}$ & $46.9 \%$ & $2.0 \%$ & $66.7 \%$ & $22.2 \%$ & $12.5 \%$ & $30.1 \%$ & $26.4 \%$ & $87.7 \%$ \\
$\mathrm{Se}$ & & $2.2 \%$ & $9.5 \%$ & & & $5.9 \%$ & $5.1 \%$ & $87.6 \%$ \\
$\mathrm{~V}$ & $15.9 \%$ & $6.7 \%$ & $28.6 \%$ & $0.0 \%$ & $54.8 \%$ & $21.2 \%$ & $21.6 \%$ & $102.0 \%$ \\
\hline Average & $10.1 \%$ & $2.4 \%$ & $7.5 \%$ & $18.2 \%$ & $1.7 \%$ & $8.0 \%$ & $6.7 \%$ & $84.1 \%$ \\
\hline
\end{tabular}

\section{Laboratory Repeatability}

Samples D \& M

\begin{tabular}{|l|r|r|r|r|r|r|r|r||}
\hline TRACE & LAB I & LAB II & LAB III & LAB IV & LAB V & MEAN & SDEV & PRSD \\
\hline ELEMENTS & & & & & & \\
$\mathrm{BS}$ & $13.7 \%$ & $9.0 \%$ & & $0.0 \%$ & $1.9 \%$ & $6.1 \%$ & $6.4 \%$ & $103.5 \%$ \\
$\mathrm{Ba}$ & $7.2 \%$ & $32.8 \%$ & $5.4 \%$ & $7.0 \%$ & $23.3 \%$ & $15.1 \%$ & $12.3 \%$ & $81.2 \%$ \\
$\mathrm{Be}$ & $0.3 \%$ & $3.8 \%$ & $15.2 \%$ & $20.7 \%$ & $3.9 \%$ & $8.8 \%$ & $8.7 \%$ & $99.1 \%$ \\
$\mathrm{Cd}$ & $0.2 \%$ & $19.9 \%$ & $0.0 \%$ & $15.4 \%$ & $16.6 \%$ & $10.4 \%$ & $9.6 \%$ & $91.8 \%$ \\
$\mathrm{Cr}$ & & $40.0 \%$ & & & $32.5 \%$ & $36.2 \%$ & $5.3 \%$ & $14.7 \%$ \\
$\mathrm{Co}$ & $3.2 \%$ & $12.3 \%$ & $12.7 \%$ & $13.3 \%$ & $1.1 \%$ & $8.5 \%$ & $5.9 \%$ & $69.1 \%$ \\
$\mathrm{Cu}$ & & $0.4 \%$ & $11.9 \%$ & & $11.0 \%$ & $7.8 \%$ & $6.4 \%$ & $82.1 \%$ \\
$\mathrm{~F}$ & $1.6 \%$ & $11.9 \%$ & & $6.5 \%$ & $12.2 \%$ & $8.0 \%$ & $5.0 \%$ & $62.7 \%$ \\
$\mathrm{Hg}$ & & $6.6 \%$ & $22.2 \%$ & & $5.3 \%$ & $11.3 \%$ & $9.4 \%$ & $83.2 \%$ \\
$\mathrm{Mn}$ & & $11.6 \%$ & $13.3 \%$ & $50.0 \%$ & $1.6 \%$ & $19.1 \%$ & $21.2 \%$ & $110.9 \%$ \\
$\mathrm{Mo}$ & $8.3 \%$ & $1.0 \%$ & $26.8 \%$ & $3.3 \%$ & $5.9 \%$ & $9.0 \%$ & $10.3 \%$ & $113.7 \%$ \\
$\mathrm{Ni}$ & $1.5 \%$ & $9.7 \%$ & $55.0 \%$ & $20.0 \%$ & $7.4 \%$ & $18.7 \%$ & $21.3 \%$ & $113.9 \%$ \\
$\mathrm{~Pb}$ & $2.2 \%$ & $4.5 \%$ & $52.1 \%$ & $0.0 \%$ & & $14.7 \%$ & $25.0 \%$ & $170.0 \%$ \\
$\mathrm{Sb}$ & $13.8 \%$ & $0.4 \%$ & $0.0 \%$ & $0.0 \%$ & $0.0 \%$ & $2.8 \%$ & $6.1 \%$ & $216.4 \%$ \\
$\mathrm{Se}$ & & $3.1 \%$ & $8.7 \%$ & & & $5.9 \%$ & $4.0 \%$ & $67.5 \%$ \\
$\mathrm{~V}$ & & $5.9 \%$ & & $0.0 \%$ & & $2.9 \%$ & $4.1 \%$ & $141.4 \%$ \\
\hline & $10.1 \%$ & $12.1 \%$ & $1.6 \%$ & $5.7 \%$ & $3.1 \%$ & $6.5 \%$ & $4.5 \%$ & $68.7 \%$ \\
\hline \hline
\end{tabular}


Laboratory Repeatability

Samples E \& N

\begin{tabular}{|l|r|r|r|r|r|r|r|r|}
\hline TRACE & LAB I & LAB II & LAB III & LAB IV & LAB V & MEAN & SDEV & PRSD \\
\hline As & & & & & & \\
$\mathrm{B}$ & $86.9 \%$ & $0.8 \%$ & $0.0 \%$ & $85.7 \%$ & $7.7 \%$ & $36.2 \%$ & $45.8 \%$ & $126.6 \%$ \\
$\mathrm{Ba}$ & $17.1 \%$ & $0.0 \%$ & $3.4 \%$ & $7.1 \%$ & $10.6 \%$ & $7.6 \%$ & $6.6 \%$ & $86.2 \%$ \\
$\mathrm{Be}$ & $41.2 \%$ & $1.6 \%$ & $163.0 \%$ & $8.6 \%$ & $4.7 \%$ & $43.8 \%$ & $68.5 \%$ & $156.3 \%$ \\
$\mathrm{Cd}$ & $12.8 \%$ & $34.8 \%$ & $13.3 \%$ & $8.0 \%$ & $29.3 \%$ & $19.6 \%$ & $11.7 \%$ & $59.4 \%$ \\
$\mathrm{Cr}$ & $8.7 \%$ & $26.1 \%$ & & & $26.8 \%$ & $20.5 \%$ & $10.2 \%$ & $49.9 \%$ \\
$\mathrm{Co}$ & $7.8 \%$ & $7.4 \%$ & $1.2 \%$ & $0.0 \%$ & $0.0 \%$ & $3.3 \%$ & $4.0 \%$ & $121.5 \%$ \\
$\mathrm{Cu}$ & $24.6 \%$ & $4.7 \%$ & $0.5 \%$ & $40.0 \%$ & $31.7 \%$ & $20.3 \%$ & $17.1 \%$ & $84.3 \%$ \\
$\mathrm{~F}$ & $11.8 \%$ & $8.3 \%$ & & $0.0 \%$ & $24.9 \%$ & $11.2 \%$ & $10.3 \%$ & $92.0 \%$ \\
$\mathrm{Hg}$ & & $7.0 \%$ & $18.2 \%$ & & $0.9 \%$ & $8.7 \%$ & $8.8 \%$ & $100.6 \%$ \\
$\mathrm{Mn}$ & & $2.3 \%$ & $47.3 \%$ & $32.3 \%$ & $21.2 \%$ & $25.8 \%$ & $18.9 \%$ & $73.5 \%$ \\
$\mathrm{Mo}$ & $15.4 \%$ & $0.6 \%$ & $3.7 \%$ & $7.4 \%$ & $0.8 \%$ & $5.6 \%$ & $6.1 \%$ & $110.2 \%$ \\
$\mathrm{Ni}$ & $12.9 \%$ & $3.2 \%$ & $38.0 \%$ & & $50.7 \%$ & $26.2 \%$ & $21.9 \%$ & $83.7 \%$ \\
$\mathrm{~Pb}$ & $7.3 \%$ & $1.4 \%$ & & $11.8 \%$ & $66.0 \%$ & $21.6 \%$ & $29.9 \%$ & $138.4 \%$ \\
$\mathrm{Sb}$ & $109.8 \%$ & $10.6 \%$ & $72.0 \%$ & $28.6 \%$ & $96.7 \%$ & $63.5 \%$ & $42.8 \%$ & $67.4 \%$ \\
$\mathrm{Se}$ & & $4.6 \%$ & $58.6 \%$ & & & $31.6 \%$ & $38.2 \%$ & $120.9 \%$ \\
$\mathrm{~V}$ & & $10.2 \%$ & & $0.0 \%$ & $70.6 \%$ & $26.9 \%$ & $38.2 \%$ & $141.7 \%$ \\
\hline Average & $33.6 \%$ & $7.8 \%$ & $33.7 \%$ & $18.1 \%$ & $27.7 \%$ & $23.3 \%$ & $19.5 \%$ & $83.9 \%$ \\
\hline
\end{tabular}

Laboratory Repeatability

Samples F \& 0

\begin{tabular}{|l|r|r|r|r|r|r|r|r||}
\hline TRACE & LAB I & LAB II & LAB III & LAB IV & LAB V & MEAN & SDEV & PRSD \\
\hline Es & & & & & & \\
$\mathrm{B}$ & $38.9 \%$ & $0.6 \%$ & $13.7 \%$ & $11.8 \%$ & $6.1 \%$ & $14.2 \%$ & $14.7 \%$ & $103.5 \%$ \\
$\mathrm{Ba}$ & $6.5 \%$ & $5.8 \%$ & $0.7 \%$ & $13.3 \%$ & $14.5 \%$ & $8.2 \%$ & $5.7 \%$ & $70.1 \%$ \\
$\mathrm{Be}$ & $7.1 \%$ & $7.6 \%$ & $14.7 \%$ & $4.7 \%$ & $53.0 \%$ & $17.4 \%$ & $20.2 \%$ & $116.1 \%$ \\
$\mathrm{Cd}$ & $4.3 \%$ & $9.5 \%$ & $26.7 \%$ & $4.3 \%$ & $0.6 \%$ & $9.1 \%$ & $10.3 \%$ & $113.9 \%$ \\
$\mathrm{Cr}$ & $6.1 \%$ & $20.4 \%$ & & & $16.7 \%$ & $14.4 \%$ & $7.4 \%$ & $51.6 \%$ \\
$\mathrm{Co}$ & $9.8 \%$ & $30.2 \%$ & $5.2 \%$ & $2.5 \%$ & $6.8 \%$ & $10.9 \%$ & $11.1 \%$ & $102.0 \%$ \\
$\mathrm{Cu}$ & $11.0 \%$ & $2.3 \%$ & $16.2 \%$ & $0.0 \%$ & $24.3 \%$ & $10.8 \%$ & $10.0 \%$ & $92.7 \%$ \\
$\mathrm{~F}$ & $2.7 \%$ & $5.7 \%$ & & $7.1 \%$ & $10.3 \%$ & $6.4 \%$ & $3.1 \%$ & $48.9 \%$ \\
$\mathrm{Hg}$ & & $21.1 \%$ & $5.4 \%$ & & $13.1 \%$ & $13.2 \%$ & $7.8 \%$ & $59.3 \%$ \\
$\mathrm{Mn}$ & $8.7 \%$ & $6.3 \%$ & $8.3 \%$ & $22.2 \%$ & $12.9 \%$ & $11.7 \%$ & $6.3 \%$ & $54.3 \%$ \\
$\mathrm{Mo}$ & $15.1 \%$ & $2.3 \%$ & $14.1 \%$ & $0.0 \%$ & $0.6 \%$ & $6.4 \% !$ & $7.5 \%$ & $117.5 \%$ \\
$\mathrm{Ni}$ & $11.7 \%$ & $6.8 \%$ & $36.4 \%$ & & $30.0 \%$ & $21.2 \%$ & $14.2 \%$ & $67.1 \%$ \\
$\mathrm{~Pb}$ & $13.9 \%$ & $2.6 \%$ & $71.6 \%$ & $3.8 \%$ & $1.1 \%$ & $18.6 \%$ & $30.1 \%$ & $161.5 \%$ \\
$\mathrm{Sb}$ & $97.8 \%$ & $2.9 \%$ & $20.9 \%$ & $11.4 \%$ & $16.4 \%$ & $29.9 \%$ & $38.5 \%$ & $129.0 \%$ \\
$\mathrm{Se}$ & $29.7 \%$ & $4.4 \%$ & $11.4 \%$ & $0.0 \%$ & & $11.4 \%$ & $13.1 \%$ & $115.1 \%$ \\
$\mathrm{~V}$ & $21.3 \%$ & $3.0 \%$ & $22.2 \%$ & $0.0 \%$ & $39.1 \%$ & $17.1 \%$ & $16.0 \%$ & $93.2 \%$ \\
\hline Average & $5.4 \%$ & $4.5 \%$ & $8.2 \%$ & $27.2 \%$ & $2.1 \%$ & $9.5 \%$ & $10.2 \%$ & $107.3 \%$ \\
\hline
\end{tabular}




\section{Laboratory Repeatability}

Samples G \& P

\begin{tabular}{|l|r|r|r|r|r|r|r|r||}
\hline \hline TRACE & LAB I & LAB II & LAB II & LAB IV & LAB V & MEAN & SDEV & PRSD \\
\hline El & & & & & \\
As & $21.3 \%$ & $0.4 \%$ & $0.0 \%$ & $66.7 \%$ & $82.3 \%$ & $34.1 \%$ & $38.2 \%$ & $112.0 \%$ \\
$\mathrm{Ba}$ & $6.0 \%$ & $16.8 \%$ & $8.0 \%$ & $5.9 \%$ & $2.7 \%$ & $7.9 \%$ & $5.3 \%$ & $67.6 \%$ \\
$\mathrm{Be}$ & $12.9 \%$ & $5.9 \%$ & $10.3 \%$ & $6.2 \%$ & $0.7 \%$ & $7.2 \%$ & $4.7 \%$ & $65.1 \%$ \\
$\mathrm{Cd}$ & $3.6 \%$ & $17.1 \%$ & $8.0 \%$ & $4.3 \%$ & $6.9 \%$ & $8.0 \%$ & $5.4 \%$ & $68.0 \%$ \\
$\mathrm{Cr}$ & & & & & $165.0 \%$ & $165.0 \%$ & & \\
$\mathrm{Co}$ & $9.9 \%$ & $18.8 \%$ & $2.4 \%$ & $0.0 \%$ & $3.4 \%$ & $6.9 \%$ & $7.6 \%$ & $109.9 \%$ \\
$\mathrm{Cu}$ & $18.0 \%$ & $1.5 \%$ & $5.9 \%$ & $0.0 \%$ & $26.3 \%$ & $10.3 \%$ & $11.4 \%$ & $110.3 \%$ \\
$\mathrm{~F}$ & $79.1 \%$ & $9.7 \%$ & & $4.9 \%$ & $6.1 \%$ & $24.9 \%$ & $36.2 \%$ & $144.9 \%$ \\
$\mathrm{Hg}$ & & $4.2 \%$ & $11.8 \%$ & & $29.7 \%$ & $15.2 \%$ & $13.1 \%$ & $86.1 \%$ \\
$\mathrm{Mn}$ & & $10.5 \%$ & $6.5 \%$ & $13.3 \%$ & $3.9 \%$ & $8.6 \%$ & $4.2 \%$ & $48.8 \%$ \\
$\mathrm{Mo}$ & $6.7 \%$ & $10.0 \%$ & $3.1 \%$ & $4.3 \%$ & $0.5 \%$ & $4.9 \%$ & $3.6 \%$ & $73.4 \%$ \\
$\mathrm{Ni}$ & $80.4 \%$ & $4.1 \%$ & & & $86.0 \%$ & $56.8 \%$ & $45.7 \%$ & $80.5 \%$ \\
$\mathrm{~Pb}$ & $16.2 \%$ & $4.0 \%$ & & $9.5 \%$ & $3.1 \%$ & $8.2 \%$ & $6.0 \%$ & $73.8 \%$ \\
$\mathrm{Sb}$ & $30.9 \%$ & $5.1 \%$ & $18.2 \%$ & $10.0 \%$ & $0.9 \%$ & $13.0 \%$ & $11.9 \%$ & $91.4 \%$ \\
$\mathrm{Se}$ & $13.5 \%$ & $0.3 \%$ & $9.8 \%$ & $40.0 \%$ & $98.5 \%$ & $32.4 \%$ & $39.8 \%$ & $122.7 \%$ \\
$\mathrm{~V}$ & & $4.4 \%$ & $0.0 \%$ & & $92.0 \%$ & $32.2 \%$ & $51.9 \%$ & $161.4 \%$ \\
\hline Average & $23.0 \%$ & $7.6 \%$ & $7.1 \%$ & $13.0 \%$ & $36.0 \%$ & $25.9 \%$ & $18.9 \%$ & $73.1 \%$ \\
\hline \hline
\end{tabular}

Laboratory Repeatability

Samples H \& Q

\begin{tabular}{|l|r|r|r|r|r|r|r|r|}
\hline \hline TRACE & LAB I & LAB II & LAB III & LAB IV & LAB V & MEAN & SDEV & PRSD \\
\hline ELEMENTS & & & & & & \\
\hline As & $96.4 \%$ & $3.6 \%$ & $0.0 \%$ & $0.0 \%$ & $27.7 \%$ & $25.5 \%$ & $41.3 \%$ & $161.7 \%$ \\
$\mathrm{~B}$ & $30.8 \%$ & $1.4 \%$ & $3.0 \%$ & $6.3 \%$ & $3.0 \%$ & $8.9 \%$ & $12.4 \%$ & $139.5 \%$ \\
$\mathrm{Ba}$ & $14.4 \%$ & $0.6 \%$ & $17.1 \%$ & $1.0 \%$ & $4.1 \%$ & $7.4 \%$ & $7.8 \%$ & $104.1 \%$ \\
$\mathrm{Be}$ & $28.9 \%$ & $8.4 \%$ & $30.8 \%$ & $4.1 \%$ & $1.4 \%$ & $14.7 \%$ & $14.1 \%$ & $95.7 \%$ \\
$\mathrm{Cd}$ & $77.1 \%$ & $8.1 \%$ & & & $15.7 \%$ & $33.6 \%$ & $37.8 \%$ & $112.5 \%$ \\
$\mathrm{Cr}$ & $27.6 \%$ & $0.5 \%$ & $0.5 \%$ & $0.0 \%$ & $1.7 \%$ & $6.0 \%$ & $12.1 \%$ & $199.6 \%$ \\
$\mathrm{Co}$ & $11.0 \%$ & $0.1 \%$ & $4.0 \%$ & $0.0 \%$ & $2.6 \%$ & $3.6 \%$ & $4.5 \%$ & $126.6 \%$ \\
$\mathrm{Cu}$ & $19.1 \%$ & $3.1 \%$ & & $0.0 \%$ & $2.3 \%$ & $6.1 \%$ & $8.8 \%$ & $143.0 \%$ \\
$\mathrm{~F}$ & & $14.1 \%$ & $0.0 \%$ & & $2.1 \%$ & $5.4 \%$ & $7.6 \%$ & $141.0 \%$ \\
$\mathrm{Hg}$ & $18.2 \%$ & $5.5 \%$ & $33.3 \%$ & $42.9 \%$ & $6.3 \%$ & $21.2 \%$ & $16.6 \%$ & $78.0 \%$ \\
$\mathrm{Mn}$ & $29.4 \%$ & $3.4 \%$ & $30.2 \%$ & $1.6 \%$ & $0.9 \%$ & $13.1 \%$ & $15.3 \%$ & $116.4 \%$ \\
$\mathrm{Mo}$ & $20.6 \%$ & $0.1 \%$ & & & $18.3 \%$ & $13.0 \%$ & $11.2 \%$ & $86.4 \%$ \\
$\mathrm{Ni}$ & $18.0 \%$ & $0.3 \%$ & $73.1 \%$ & $5.7 \%$ & $3.9 \%$ & $20.2 \%$ & $30.3 \%$ & $150.1 \%$ \\
$\mathrm{~Pb}$ & $33.1 \%$ & $1.0 \%$ & $24.4 \%$ & $4.4 \%$ & $10.2 \%$ & $14.6 \%$ & $13.6 \%$ & $93.2 \%$ \\
$\mathrm{Sb}$ & & $3.3 \%$ & $3.8 \%$ & & $100.0 \%$ & $35.7 \%$ & $55.7 \%$ & $155.9 \%$ \\
$\mathrm{Se}$ & $9.8 \%$ & $2.5 \%$ & $40.0 \%$ & $0.0 \%$ & $22.7 \%$ & $15.0 \%$ & $16.5 \%$ & $110.2 \%$ \\
$\mathrm{~V}$ & $30.5 \%$ & $2.1 \%$ & $0.4 \%$ & $1.3 \%$ & $0.8 \%$ & $7.0 \%$ & $13.1 \%$ & $187.8 \%$ \\
\hline Average & $31.0 \%$ & $3.4 \%$ & $18.6 \%$ & $5.2 \%$ & $13.2 \%$ & $14.8 \%$ & $15.2 \%$ & $103.2 \%$ \\
\hline
\end{tabular}


Laboratory Repeatability All Coals

\begin{tabular}{|l|r|r|r|r|r|r|r|r|}
\hline TRACE & LAB I & LAB II & LAB III & LAB IV & LAB V & MEAN & SDEV & PRSD \\
\hline ELEMENTS & & & & & & & \\
\hline $\mathrm{BS}$ & $48.2 \%$ & $2.2 \%$ & $4.5 \%$ & $34.8 \%$ & $22.6 \%$ & $22.5 \%$ & $19.7 \%$ & $87.6 \%$ \\
$\mathrm{Ba}$ & $10.8 \%$ & $8.9 \%$ & $8.2 \%$ & $9.2 \%$ & $10.9 \%$ & $9.6 \%$ & $1.2 \%$ & $12.4 \%$ \\
$\mathrm{Be}$ & $19.7 \%$ & $3.8 \%$ & $35.1 \%$ & $9.6 \%$ & $26.8 \%$ & $19.0 \%$ & $12.6 \%$ & $66.6 \%$ \\
$\mathrm{Cd}$ & $15.7 \%$ & $13.8 \%$ & $14.6 \%$ & $8.1 \%$ & $9.0 \%$ & $12.2 \%$ & $3.4 \%$ & $28.2 \%$ \\
$\mathrm{Cr}$ & $26.8 \%$ & $17.2 \%$ & & & $53.6 \%$ & $32.5 \%$ & $18.9 \%$ & $58.0 \%$ \\
$\mathrm{Co}$ & $11.4 \%$ & $10.5 \%$ & $4.1 \%$ & $7.9 \%$ & $5.3 \%$ & $7.8 \%$ & $3.2 \%$ & $40.3 \%$ \\
$\mathrm{Cu}$ & $10.7 \%$ & $2.2 \%$ & $5.9 \%$ & $16.3 \%$ & $15.5 \%$ & $10.1 \%$ & $6.1 \%$ & $60.2 \%$ \\
$\mathrm{~F}$ & $15.5 \%$ & $6.0 \%$ & & $7.5 \%$ & $8.8 \%$ & $9.4 \%$ & $4.2 \%$ & $44.5 \%$ \\
$\mathrm{Hg}$ & & $7.9 \%$ & $8.9 \%$ & & $10.3 \%$ & $9.0 \%$ & $1.2 \%$ & $13.6 \%$ \\
$\mathrm{Mn}$ & $5.5 \%$ & $9.5 \%$ & $37.0 \%$ & $26.1 \%$ & $9.8 \%$ & $17.6 \%$ & $13.4 \%$ & $76.3 \%$ \\
$\mathrm{Mo}$ & $16.6 \%$ & $2.6 \%$ & $10.8 \%$ & $7.5 \%$ & $2.4 \%$ & $8.0 \%$ & $6.0 \%$ & $74.7 \%$ \\
$\mathrm{Ni}$ & $25.4 \%$ & $4.0 \%$ & $19.3 \%$ & $8.8 \%$ & $26.4 \%$ & $16.8 \%$ & $10.0 \%$ & $59.7 \%$ \\
$\mathrm{~Pb}$ & $10.9 \%$ & $2.2 \%$ & $38.6 \%$ & $9.7 \%$ & $12.3 \%$ & $14.7 \%$ & $13.9 \%$ & $94.3 \%$ \\
$\mathrm{Sb}$ & $54.8 \%$ & $3.5 \%$ & $34.0 \%$ & $11.6 \%$ & $18.3 \%$ & $24.4 \%$ & $20.4 \%$ & $83.3 \%$ \\
$\mathrm{Se}$ & $5.4 \%$ & $3.1 \%$ & $13.8 \%$ & $5.0 \%$ & $24.8 \%$ & $10.4 \%$ & $9.0 \%$ & $86.7 \%$ \\
$\mathrm{~V}$ & $13.5 \%$ & $6.9 \%$ & $15.5 \%$ & $12.5 \%$ & $38.0 \%$ & $17.3 \%$ & $12.0 \%$ & $69.5 \%$ \\
\hline Average & $18.0 \%$ & $6.8 \%$ & $6.7 \%$ & $10.5 \%$ & $2.5 \%$ & $8.9 \%$ & $5.8 \%$ & $65.3 \%$ \\
\hline
\end{tabular}

\begin{tabular}{|cc|}
\hline \multicolumn{2}{|c|}{ Average Repeatability by Coals } \\
Coal & Avg \\
& \\
A \& J & $13.8 \%$ \\
B \& K & $14.8 \%$ \\
C \& L & $17.2 \%$ \\
D \& M & $11.3 \%$ \\
E \& N & $23.3 \%$ \\
F \& O & $13.6 \%$ \\
G \& P & $25.9 \%$ \\
H \& Q & $14.7 \%$ \\
\hline
\end{tabular}


DOE COAL ROUND ROBIN TRACE ELEMENT REPEATABIITY RESULTS

$\%$ of Individual Lab Analysis Within Repeatability Ranges

\begin{tabular}{||l|r|r|r|r|r|r||}
\hline Repeatability Range & Lab I & Lab II & Lab III & Lab IV & Lab V & All Labs \\
\hline Less than 10\% & 31.0 & 79.0 & 42.0 & 46.0 & 52.0 & 50.0 \\
10 to $20 \%$ & 24.0 & 14.0 & 19.0 & 17.0 & 15.0 & 18.0 \\
20 to $30 \%$ & 8.0 & 2.0 & 7.0 & 7.0 & 11.0 & 7.0 \\
30 to 50\% & 7.0 & 4.0 & 6.0 & 6.0 & 3.0 & 5.0 \\
Greater than 50\% & 10.0 & 0.0 & 9.0 & 4.0 & 12.0 & 7.0 \\
Non Determined & 20.0 & 1.0 & 18.0 & 21.0 & 7.0 & 13.0 \\
\hline
\end{tabular}




\section{APPENDIX E: ANALYTICAL PROTOCOL}

\section{Introduction}

This appendix contains brief descriptions of the analytical methods used. The analogous water, solid, and gas methods are described together.

Methods used for sample analysis are presented in Table E-1. Most of the laboratory methods identified in this document were published by the United States Environmental Protection Agency in "Test Methods for Evaluating Solid Waste, Physical/Chemical Methods, SW-846," Third Edition, or "Methods for Chemical Analysis of Water and Wastes." Additional methods identified were published in "Criteria for Identification of Hazardous and Extremely Hazardous Wastes," "Guidelines Establishing Test Procedures for the Analysis of Pollutants Under the Clean Water Act," 40 CFR 136, 49 FR 209 (26 October 1984), Annual Book of ASTM Standards, Volume 4.08, and "Standard Methods for the Examination of Water and Wastewater."

\section{Extraction Methods}

Extraction/digestion methods for liquid and solid matrices are briefly described in this section.

\section{Method SW3005}

\section{Acid Digestion of Aqueous Samples for Analyses by ICP}

This method is an acid digestion procedure used to prepare water samples for metals analysis. The digested samples can be analyzed for total recoverable and dissolved metals determination by either flame (FLAA) or inductively coupled plasma atomic emission spectroscopy (ICP-AES). Samples may be analyzed for the following metals:

$\begin{array}{lllll}\text { Aluminum } & \text { Cadmium } & \text { Iron } & \text { Nickel } & \text { Thallium } \\ \text { Antimony } & \text { Calcium } & \text { Lead } & \text { Potassium } & \text { Vanadium } \\ \text { Arsenic } & \text { Chromium } & \text { Magnesium } & \text { Selenium } & \text { Zinc } \\ \text { Barium } & \text { Cobalt } & \text { Manganese } & \text { Silver } & \\ \text { Beryllium } & \text { Copper } & \text { Molybdenum } & \text { Sodium } & \end{array}$


Appendix E: Analytical Protocol

Table E-1

Analytical Methods Used During Sampling Activities at Plant Yates

\begin{tabular}{|c|c|c|c|}
\hline \multirow[b]{2}{*}{ Parameter } & \multicolumn{3}{|c|}{ Analytical Method } \\
\hline & Water & Gas & Solids \\
\hline Moisture Content & NA & NA & A-D3173 2 \\
\hline Particulate Loading & NA & EPA M5/M17 & NA \\
\hline Particle Size Distribution & NA & EPA & \\
\hline Ultimate & NA & NA & ASTM D-3176 3 \\
\hline Proximate & $\mathrm{NA}$ & NA & ASTM D-3172 \\
\hline Carbon & NA & NA & ASTM D-5373 \\
\hline Sulfur & NA & NA & ASTM D-4239 \\
\hline Heating Value & $N A^{3}$ & NA & ASTM D-2015 \\
\hline Chloride & E300.0 & E300.0 & SM4500-Cl-D ${ }^{8}$ \\
\hline Fluoride & E340.2 & E340.2 & E340.29 \\
\hline Phosphate & E365.2 & E365.2 & NA \\
\hline Sulfate & E300.0 & $\mathrm{E} 300.0$ & $\mathrm{E} 300.0^{10}$ \\
\hline Sulfite & E377.1 & NA & E377.1" \\
\hline Ammonia & E350.1 & E350.2 & NA \\
\hline Cyanide, Total & SW9012 & SW9012 & NA \\
\hline ICP-AES Metals & SW6010 & SW6010 & SW6010 12 \\
\hline ICP-MS Metals & sW6020 & SW6020 & sw6020 $0^{13}$ \\
\hline Metals & NA & NA & INAA \\
\hline Metals & NA & NA & GDMS \\
\hline Arsenic & sW7060 & SW7060 & sW7060 14 \\
\hline Cadmium & sw7131 & SW7131 & $S W 7131^{15}$ \\
\hline Lead & SW7421 & SW7421 & sW7421 $1^{16}$ \\
\hline Mercury & SW7470 & SW7471 & SW7471 ${ }^{17}$ \\
\hline Selenium & SW7740 & SW7740 & SW7740 18 \\
\hline Aldehydes & SW8315 & E0011a & NA \\
\hline Volatile Organic Compounds & SW8240 & SW8240 & NA \\
\hline Semivolatile Organic Compounds & SW8270 & SW8270 & SW8270 19 \\
\hline Polychlorinated Dioxins and Furans & NA & Method 23 & Method $23^{20}$ \\
\hline Radionuclides & NA & NA & E901.1/900.0 $0^{21}$ \\
\hline
\end{tabular}


For analysis of total recoverable metals, the entire sample is acidified at collection time with nitric $\left(\mathrm{HNO}_{3}\right)$ acid to a $\mathrm{pH}<2$. At the time of analysis, a $50-\mathrm{mL}$ aliquot of the sample is heated with $1 \mathrm{~mL}$ of $1: 1$ nitric acid and $5 \mathrm{~mL}$ of hydrochloric acid and reduced to a specific volume. The sample must not be boiled because antimony is volatile and easily lost. The digestate is then adjusted to a final volume of $50 \mathrm{~mL}$ with reagent water.

For analysis of dissolved metals, the samples are filtered through a $0.45 \mu \mathrm{m}$ filter immediately upon collection in the field, and acidified with nitric $\left(\mathrm{HNO}_{3}\right)$ acid to a $\mathrm{pH}<2$. For analysis, the sample is digested as described above.

\section{Modified Method SW302022}

Acid Digestion of Aqueous Samples for Analyses by Graphite Furnace Atomic Absorption Spectroscopy

Water samples are digested according to a modification of method SW3020. In Method SW3020, the sample is treated in a manner similar to that described in Method SW3005 except that $1 \mathrm{~mL}$ of $1: 1 \mathrm{HNO}_{3}$ and $5 \mathrm{~mL}$ of $\mathrm{H}_{2} \mathrm{O}_{2}$ are used.

\section{Microwave Assisted Acid Digestion of Solids}

Microwave assisted digestion is applicable to the preparation of solid samples and water samples containing solids for metals analysis by FLAA or GFAA or ICP. A representative sample of up to $0.5 \mathrm{~g}$ (wet weight) is digested with concentrated nitric acid for 60 minutes using microwave heating in a suitable laboratory microwave unit. The sample is placed in a Teflon PFA vessel with $10 \mathrm{~mL}$ of concentrated acid. The vessel is capped and heated in the microwave unit for three 20-minute intervals with 5-minute cooling period between each heating period. After the samples are cooled and vented, $5 \mathrm{~mL}$ of hydrofluoric acid and 1 $\mathrm{mL}$ of hydrochloric acid are added and the sample is digested for 15 minutes. After cooling, the vessel contents are diluted to volume and analyzed by the appropriate SW-846 method. A separate sample is dried for a total solids and/or percent moisture determination.

Some samples can contain diverse matrix types, which may present specific analytical problems. Spiked samples and any relevant standard reference material are processed to aid in determining whether the method is applicable to a given matrix.

\section{SW3500 Series Methods Organic Extraction and Sample Preparation}

The SW3500 series methods are used to quantitatively extract nonvolatile and semivolatile organic compounds from various sample matrices. Prior to analysis, a sample of a known volume or weight is solvent extracted, then dried and concentrated in a Kuderna-Danish apparatus. 
Appendix E: Analytical Protocol

\section{Method SW3510 23 \\ Separatory Extraction}

Method SW3510 is designed to quantitatively extract nonvolatile and semivolatile organic compounds from liquid samples using standard separatory funnel techniques. The sample and extracting solvent must be immiscible in order to yield recovery of target compounds. Subsequent cleanup and detection methods are described in the organic analytical method that will be used to analyze the extract.

Samples are adjusted to a specified extraction $\mathrm{pH}$ and extracted with the appropriate solvent for the analytical method. Methylene chloride should be employed when a solvent is not specified.

\section{Method SW352024 \\ Liquid-Liquid Extraction}

Method SW3520 is designed to quantitatively extract nonvolatile and semivolatile organic compounds from liquid samples using standard liquid/liquid techniques. The sample and extracting solvent must be immiscible in order to yield recovery of target compounds. Subsequent cleanup and detection methods are described in the organic analytical method that will be used to analyze the extract.

Samples are adjusted to a specified extraction $\mathrm{pH}$ and extracted with the appropriate solvent for the analytical method. Methylene chloride should be employed when a solvent is not specified.

\section{Method SW354025 Soxhlet Extraction}

Method SW3540 is a procedure for extracting nonvolatile and semivolatile organic compounds from solids such as soils and sludges. The Soxhlet extraction process ensures intimate contact of the sample matrix with the extraction solvent. Extraction is accomplished by mixing the solid sample with anhydrous sodium sulfate, placing it in an extraction thimble or between two plugs of glass wool, and extracting it with an appropriate solvent in the Soxhlet extractor. Methylene chloride should be employed when a solvent is not specified. The extract is dried and concentrated, and then treated using a clean-up method, or analyzed directly by the appropriate measurement technique.

\section{Method SW355026 Sonication Extraction}

Method SW3550 is a procedure for extracting nonvolatile and semivolatile organic compounds from solids such as soils and sludges. The sonication process ensures intimate contact of the sample matrix with the extraction solvent. Extraction is accomplished by mixing the solid sample with anhydrous sodium sulfate, mixing with the extraction medium, and dispersing into the solvent by sonication. The extract is dried and then concentrated. 
The resulting solution may then be cleaned up or analyzed directly using the appropriate technique.

\section{Method SW503027 \\ Purge-and-Trap Method}

Method SW5030 is used to determine the concentration of volatile organic compounds (VOCs) in a variety of liquid and solid matrices. It is based upon a purge-and-trap gas chromatographic procedure. The method is applicable to the types of samples collected for this project. The success of this method depends on the level of interferences in the sample; results may vary due to the large variability and complexity of some matrices.

A direct purge-and-trap can be performed for low-concentration samples. If higher concentrations are expected, a portion of the solid sample is dispersed in methanol to dissolve the volatile organic constituents. A portion of the methanol solution is combined with water in a purging chamber. An inert gas is then bubbled through the solution at ambient temperature to transfer the volatile components to the vapor phase. The vapor is swept through a sorbent column where the volatile components are trapped. After purging is completed, the sorbent column is heated and backflushed with inert gas to desorb the components onto a gas chromatographic column. The gas chromatographic column is heated to elute the components that are detected by the appropriate detector.

\section{Organic and Inorganic Analytical Methods for Water and Solid Samples}

\section{Method ASTM D-3173 Percent Moisture}

Percent moisture was determined for solid samples undergoing analysis for organic and inorganic analytes. The percent moisture must be known so that the analytical results can be reported on a dry weight basis (i.e., $\mu \mathrm{g} / \mathrm{kg}$ or $\mathrm{mg} / \mathrm{kg}$ ). The sample is weighed, dried, and then re-weighed. Percent moisture is calculated as:

$$
\frac{\text { Wet Weight - Dried Weight }}{\text { Wet Weight }} \times 100
$$

\section{Method E300.0 \\ Anions $\left(\mathrm{Cl}, \mathrm{F}\right.$ and $\mathrm{SO}_{4}$ by lon Chromatography}

Water samples were analyzed for fluoride, chloride, and sulfate anions by ion chromatography using U.S. EPA Method 300.0. Ion chromatography is a rapid method for separating and analyzing complex solutions of ionic species. The technique employs a carbonate/ bicarbonate eluent and ion exchange resins to separate individual ions, and a suppressor column to remove the eluent ions. The detection and quantitation of the anions is performed conductimetrically. 
Appendix E: Analytical Protocol

Method E350.1

Nitrogen, Ammonia

Ammonia nitrogen in water samples were measured by U.S. EPA Method 350.1. This method is an automated colorimetric procedure in which alkaline phenol and hypochlorite react with ammonia to form an indophenol blue complex that is proportional to the ammonia concentration. The blue color is intensified with sodium nitroprusside and is measured at $630-660 \mathrm{~nm}$.

\section{Method SW9012 28 \\ Cyanide, Total}

Water and impinger samples were analyzed for total cyanide using SW9012. Cyanide as hydrocyanic acid (HCN) is released from cyanide complexes by means of an reflux-distillation under highly acidic conditions. The released cyanide is absorbed into a scrubber containing sodium hydroxide solution. The cyanide ion in the absorbing solution is then determined using an automated UV colorimetry. The colorimetric procedure is sensitive to about $0.02 \mathrm{mg} / \mathrm{L}$.

\section{Method 365. $2^{29}$ \\ Total Phosphate}

Total phosphate was determined on acid-preserved water samples using EPA Method 365.2. Complexed phosphates are digested to the ortho-phosphate form by heating with sulfuric acid and potassium persulfate. The ortho-phosphate is reacted with ammonium molybdate and antimony potassium tartrate to form an antimony-phospho-molybdate complex which is reduced to an intensely blue-colored complex by ascorbic acid. The sample intensity is measured at 650 or $880 \mathrm{~nm}$ and compared with the intensity of a standard phosphate solution.

\section{Method SW6010 30}

ICP Metals

Samples are analyzed for trace elements or metals using SW6010. Analysis for most metals requires digestion of the sample with acid. This digestion is performed as SW846 Method 3005 for water or SW846 Method 3050 for solids. Following digestion, the trace elements are simultaneously or sequentially determined using ICP-AES.

\section{Methods}

SW7060 $31 / S W 7041^{32} / S W 7131^{33} / S W 7421^{34} / S W 7740^{35} / S W 7841^{36}$

Graphite Furnace Atomic Absorption Metals Analyses for Arsenic, Cadmium, Lead, and Selenium

Graphite furnace AA spectrometry was used to measure concentrations of arsenic (As), cadmium (Cd), lead (Pb), and selenium (Se) in the water and solid samples. The samples are extracted using SW3020 or SW3050 as appropriate. Discrete aliquots of sample extract are deposited in a graphite tube furnace in microliter amounts. The graphite tube is 
resistively heated by an electrical current. The sample solution is dried and charred to remove sample matrix components, and then atomized at temperatures sufficient to vaporize the element of interest. Matrix modification is used to eliminate interference effects, and may also enhance the vaporization efficiency and allow lower detection limits. This method usually has a linear analysis range at the ppb or sub-ppb level.

\section{Method SW747037/SW7471 38 Mercury - Manual Cold-Vapor Technique}

Liquid (water and impinger) and solid samples were analyzed for mercury using SW7470 and SW7471, respectively. This method is a cold-vapor flameless AA technique based on the absorption of radiation by mercury vapor. Mercury is reduced to the elemental state and aerated from solution in a closed system. The mercury vapor passes through a cell positioned in the light path of an AA spectrophotometer. Mercury concentration is measured as a function of absorbance.

\section{Instrumental Neutron Activation Analysis (INAA)}

Neutron activation is a non-destructive technique that measures the number and energy of gamma and X-rays emitted by the radioactive isotopes produced in the sample matrix by irradiation with thermal neutrons. The samples require no special preparation except for encapsulation in high purity polyethylene vials prior to irradiation. Both samples and standards of the elements of interest are irradiated in a nuclear reactor. Each sample is then counted on a gamma ray detector to produce its characteristic gamma ray spectrum. Quantitation of sample concentration is done by comparison with the energy spectra from those standards run simultaneously with the unknown samples.

This technique is applicable to determining bulk composition and is feasible for very small sample quantities. The method does not introduce any contaminating or interfering substances, and it provides a multi-element analysis. It is not applicable to those elements that have either extremely short half-lives, or those elements, such as lead, that do not produce radioactive isotopes.

\section{Glow Discharge Mass Spectrometry (GDMS)}

Glow discharge mass spectrometry was used as an alternative to INAA for determining the bulk composition of the size fractionated fly ash samples. In this technique, the sample is mixed with silver powder and is pressed into the shape of a pin to serve as a conducting electrode in a low-pressure argon plasma ionization chamber. Sample atoms are sputtered into the plasma and then ionized. The plasma is a constant matrix in which the ionization efficiencies of the elements also remain constant. The ionization efficiencies expressed as relative sensitivity factors (RSFs) are used to convert ion intensities to elemental concentrations. The application of this technique to fly ash particles has been demonstrated successfully, and it can provide a complete analysis on the target list, including fluorine, beryllium, and lead, that cannot be determined by INAA. 
Appendix E: Analytical Protocol

\section{EPA Method 0011 A $^{39}$ \\ Aldehydes}

Aldehydes in the gas, liquid, and solid samples were determined using EPA Method 0011A. Samples collected in dinitrophenylhydrazine (DNPH) are extracted with methylene chloride and then solvent exchanged to acetonitrile. The acetonitrile is concentrated and analyzed by high performance liquid chromatography as the DNPH adduct.

\section{Method SW824040 \\ Volatile Organic Compounds}

Volatile, or purgeable, organics in water and by VOST in the gas streams were analyzed using Method SW8240. This method uses a purge-and-trap GC/MS technique. An inert gas is bubbled through the water samples to transfer the purgeable organic compounds from the liquid to vapor phase. The vapor is then swept through a sorbent trap where the purgeable organics are trapped. The trap is backflushed and heated to desorb the purgeable organics onto a gas chromatographic column where they are separated and then detected with a mass spectrometer. VOST samples are thermally desorbed from the resin/charcoal traps and analyzed directly.

\section{Method SW827041 \\ Semivolatile Organic Compounds}

Semivolatile organics, also known as base/neutral and acid extractables (BNA), were analyzed using Method SW8270. These techniques quantitatively determine the concentration of a number of semivolatile organic compounds. Organic compounds are extracted from the sample with methylene chloride at a $\mathrm{pH}$ greater than 12 to obtain base/neutral extractables. Acid extractable compounds are obtained from the sample by extraction with methylene chloride at a pH of 2 or less. Both base/neutral and acid extracts are then concentrated by removal of the methylene chloride through evaporation. Compounds of interest are separated and quantified using a GC/MS.

\section{Method $23^{42}$ \\ Chlorinated Dioxins and Furans}

Flue gas and gas particulate samples were analyzed for chlorinated dioxins and furans using Method 23. The dioxins and furans are extracted from the samples with toluene using the soxhlet extraction described in Method 23. The extracts are cleaned by passing the solvent through alumina, silica gel, and carbon columns. The cleaned extracts are concentrated and injected onto the a fused silica capillary column of a gas chromatograph/mass spectrometer. 


\section{References}

1. U.S. Environmental Protection Agency. Office of Solid Waste. "Method 3005: Acid Digestion of Waters for Total Recoverable or Dissolved Metals for Analysis by Flame Atomic Absorption Spectroscopy or Inductively Coupled Plasma Spectroscopy," Test Methods for Evaluating Solid Waste. SW-846, 3rd ed. Washington, D.C. (November 1986).

2. American Society for Testing and Materials. "Test Method for Moisture in the Analysis Sample of Coal and Coke," 1991 Annual Book of ASTM Standards. Section 5, Vol. 5.05, Method D-3173. Philadelphia, PA (1991).

3. American Society for Testing and Materials. "Standard Practice of Ultimate Analysis of coal and Coke," 1991 Annual Book of ASTM Standards. Section 5, Vol. 5.05, Method D-3176-89. Philadelphia, PA (1991).

4. American Society for Testing and Materials. "Standard Practice of Proximate Analysis of Coal and Coke," 1991 Annual Book of ASTM Standards. Section 5, Vol. 5.05, Method D-3172-89. Philadelphia, PA (1991).

5. American Society for Testing and Materials. "Test Methods for Instrumental Determination of Carbon, Hydrogen, and Nitrogen in Laboratory Samples of Coal and Coke," 1991 Annual Book of ASTM Standards. Section 5, Vol. 5.05, Method D-5373. Philadelphia, PA (1991).

6. American Society for Testing and Materials. "Test Method for Sulfur in the Analysis Sample of Coal and Coke Using High Temperature Tube Furnace Combustion Methods," 1991 Annual Book of ASTM Standards. Section 5, Vol. 5.05, Method D-4239. Philadelphia, PA (1991).

7. American Society for Testing and Materials. "Standard Test Method for Gross Calorific Value of Coal and Coke by the Adiabatic Bomb Calorimeter," 1991 Annual Book of ASTM Standards. Section 5, vol. 5.05, Method D-2015-85. Philadelphia, PA (1991).

8. American Public Health Association, et al. "4500-Cl-D. Potentiometric Method," Standard Methods for the Examination of Water and Wastewater. 17th ed. Washington, D.C. (1989).

9. U.S. Environmental protection Agency. Environmental Monitoring and Support Laboratory. "Fluoride, Method 340.2 (Potentiometric, Ion Selective Electrode)," Methods for Chemical Analysis of Water and Wastes. EPA-600/4-79-020. Cincinnati, OH (March 1983). 
Appendix E: Analytical Protocol

10. J.W. O'Dell, J.D. Pfaff, M.E. Gales, and G.D. McKee. U.S. Environmental Protection Agency. Environmental Monitoring and Support Laboratory. "Test Method: The Determination of Inorganic Anions in Water by Ion Chromatography--Method 300.0." EPA-600/4-84-017. Cincinnati, OH (March 1984).

11. U.S. Environmental Protection Agency. Environmental Monitoring and Support Laboratory. "Sulfite, Method 377.1 (Titrimetric)," Methods for Chemical Analysis of Water and Wastes. EPA-600/4-79-020. Cincinnati, OH (March 1983).

12. U.S. Environmental Protection Agency. Office of Solid Waste. "Method 6010: Inductively Coupled Plasma Atomic Emission Spectroscopy," Test Methods for Evaluating Solid Waste. SW-846, 3rd ed. Washington, D.C. (November 1986).

13. U.S. Environmental Protection Agency. Office of Solid Waste. "Method 6020: Inductively Coupled Plasma - Mass Spectrometry," Test Methods for Evaluating Solid Waste. SW-846, 3rd ed. Washington, D.C. (November 1986).

14. U.S. Environmental Protection Agency. Office of Solid Waste. "Method 7060: Arsenic (AA, Furnace Technique)," Test Methods for Evaluating Solid Waste. SW846, 3rd ed. Washington, D.C. (November 1986).

15. U.S. Environmental Protection Agency. Office of Solid Waste. "Method 7131: Cadmium (AA, Furnace Technique)," Test Methods for Evaluating Solid Waste. SW846, 3rd ed. Washington, D.C. (November 1986).

16. U.S. Environmental Protection Agency. Office of Solid Waste. "Method 7421: Lead (AA, Furnace Technique)," Test Methods for Evaluating Solid Waste. SW-846, 3rd ed. Washington, D.C. (November 1986).

17. U.S. Environmental Protection Agency. Office of Solid Waste. "Method 7471: Mercury in Solid or Semisolid Waste (Manual Cold-Vapor Technique," Test Methods for Evaluating Solid Waste. SW-846, 3rd ed. Washington, D.C. (November 1986).

18. U.S. Environmental Protection Agency. Office of Solid Waste. "Method 7740: Selenium (AA, Fumace Technique)," Test Methods for Evaluating Solid Waste. SW846, 3rd ed. Washington, D.C. (November 1986).

19. U.S. Environmental Protection Agency. Office of Solid Waste. "Method 8270: Gas Chromatography/Mass Spectrometry for Semivolatile Organics: Capillary Column Technique," Test Methods for Evaluating Solid Waste. SW-846, 3rd ed. Washington, D.C. (November 1986).

20. 40 CFR 266, Appendix IX: Methods Manual for Compliance with the BIF Regulations. "Determination of Polychlorinated Dibenzo-p-Dioxins (PCDDs) and Polychlorinated Dibenzofurans (PCDFs) from Stationary Sources (Method 23)." 
21. U.S. Environmental Protection Agency. Methods 901.1 and 900.0. Prescribed Procedures for the Measurement of Radioactivity in Drinking Water. EPA-600/4/80032 (1980).

22. U.S. Environmental Protection Agency. Office of Solid Waste. "Method 3020: Acid Digestion of Aqueous Samples and Extracts for Total Metals for Analysis by GFAA Spectroscopy," Test Methods for Evaluating Solid Waste. SW-846, 3rd ed. Washington, D.C. (November 1986).

23. U.S. Environmental Protection Agency. Office of Solid Waste. "Method 3510: Separatory Funnel Liquid-Liquid Extraction," Test Methods for Evaluating Solid Waste. SW-846, 3rd ed. Washington, D.C. (November 1986).

24. U.S. Environmental Protection Agency. Office of Solid Waste. "Method 3520: . Continuous Liquid-Liquid Extraction," Test Methods for Evaluating Solid Waste. SW484, 3rd ed. Washington, D.C. (November 1986).

25. U.S. Environmental Protection Agency. Office of Solid Waste. "Method 3540: Soxhlet Extraction," Test Methods for Evaluating Solid Waste. SW-484, 3rd ed. Washington, D.C. (November 1986).

26. U.S. Environmental Protection Agency. Office of Solid Waste. "Method 3550: Sonication Extraction," Test Methods for Evaluating Solid Waste. SW-484, 3rd ed. Washington, D.C. (November 1986).

27. U.S. Environmental Protection Agency. Office of Solid Waste. "Method 5030: Purge-and-Trap," Test Methods for Evaluating Solid Waste. SW-484, 3rd ed. Washington, D.C. (November 1986).

28. U.S. Environmental Protection Agency. Office of Solid Waste. "Method 9012: Total and Amenable Cyanide (Colorimetric, Automated UV)," Test Methods for Evaluating Solid Waste. SW-484, 3rd ed. Washington, D.C. (November 1986).

29. U.S. Environmental Protection Agency. Environmental Monitoring and Support Laboratory. "Phosphorus, All Forms, Method 365.2 (Colorimetric, Ascorbic Acid, Single Reagent)," Methods for Chemical Analysis of Water and Wastes. EPA-600/4-79020. Cincinnati, OH (March 1983).

30. U.S. Environmental Protection Agency. Office of Solid Waste. "Method 6010: Inductively Coupled Plasma Atomic Emission Spectroscopy," Test Methods for Evaluating Solid Waste. SW-846, 3rd ed. Washington, D.C. (November 1986).

31. U.S. Environmental Protection Agency. Office of Solid Waste. "Method 7060: Arsenic (AA, Furnace Technique)," Test Methods for Evaluating Solid Waste. SW846, 3rd ed. Washington, D.C. (November 1986). 
Appendix E: Analytical Protocol

32. U.S. Environmental Protection Agency. Office of Solid Waste. "Method 7041: Antimony (Atomic Absorption, Furnace Technique)," Test Methods for Evaluating Solid Waste. SW-846, 3rd ed. Washington, D.C. (November 1986).

33. U.S. Environmental Protection Agency. Office of Solid Waste. "Method 7131: Cadmium (AA, Furnace Technique)," Test Methods for Evaluating Solid Waste. SW846 , 3rd ed. Washington, D.C. (November 1986).

34. U.S. Environmental Protection Agency. Office of Solid Waste. "Method 7421: Lead (AA, Furnace Technique)," Test Methods for Evaluating Solid Waste. SW-846, 3rd ed. Washington, D.C. (November 1986).

35. U.S. Environmental Protection Agency. Office of Solid Waste. "Method 7740: Selenium (AA, Furnace Technique)," Test Methods for Evaluating Solid Waste. SW846 , 3rd ed. Washington, D.C. (November 1986).

36. U.S. Environmental Protection Agency, Office of Solid Waste. "Method 7841: Thallium (AA, Furnace Technique)." Test Methods for Evaluating Solid Waste. SW846, 3rd ed. Washington, D.C. November 1986.

37. U.S. Environmental Protection Agency. Office of Solid Waste. "Method 7470: Mercury in Liquid Waste (Manual Cold-Vapor Technique)," Test Methods for Evaluating Solid Waste. SW-846, 3rd ed. Washington, D.C. (November 1986).

38. U.S. Environmental Protection Agency. Office of Solid Waste. "Method 7471: Mercury in Solid or Semisolid Waste Manual Cold-Vapor Technique," Test Methods for Evaluating Solid Waste. SW-846, 3rd ed. Washington, D.C. (November 1986).

39. 40 CFR 266, Appendix IX: Methods Manual for Compliance with the BIF Regulations. "Analysis for Aldehydes and Ketones by High Performance Liquid Chromatography (HPLC) (Method 0011A)."

40. U.S. Environmental Protection Agency. Office of Solid Waste. "Method 8240: Gas Chromatography/Mass Spectrometry for Volatile Organics," Test Methods for Evaluating Solid Waste. SW-846, 3rd ed. Washington, D.C. (November 1986).

41. U.S. Environmental Protection Agency. Office of Solid Waste. "Method 8270: Gas Chromatography/Mass Spectrometry for Semivolatile Organics: Capillary Column Technique," Test Methods for Evaluating Solid Waste. SW-846, 3rd ed. Washington, D.C. (November 1986).

42. 40 CFR 266, Appendix IX: Methods Manual for Compliance with the BIF Regulations. "Determination of Polychlorinated Dibenzo-p-Dioxins (PCDDs) and Polychlorinated Dibenzofurans (PCDFs) from Stationary Sources (Method 23)." 


\section{APPENDIX F: ERROR PROPAGATION AND UNCERTAINTY CALCULATIONS}

An error propagation analysis was performed on calculated results to determine the contribution of process, sampling, and analytical variability and measurement bias to the overall uncertainty in the result. This uncertainty was determined by propagating the bias and precision error of individual parameters through the calculation of the results. This uncertainty does not represent the total uncertainty in the result since some important bias errors are unknown and have been assigned a value of zero for this analysis. Also, the uncertainties calculated apply only over the period of time during which the measurements were made.

The procedure described below is based on ANSI/ASME PTC 19.1-1985, "Measurement Uncertainty."

\section{Nomenclature}

$r=$ Calculated result, a function of several parameters;

$S_{p i}=$ Sample standard deviation of parameter $i$

$\theta_{\mathrm{i}}=$ Sensitivity of the result to parameter $\mathrm{i}$;

$\beta_{\mathrm{pi}}=$ Bias error estimate for parameter $\mathrm{i}$;

$v_{i}=$ Degrees of freedom in parameter $i$;

$v_{\mathrm{r}}=$ Degrees of freedom in result;

$S_{r}=$ Precision component of result uncertainty;

$b_{r}=$ Bias component of result uncertainty;

$\mathrm{t}=$ Student " $\mathrm{t}$ " factor (two-tailed distribution at 95\%);

$\mathrm{U}_{\mathrm{r}}=$ Uncertainty in $\mathrm{r}$; and

$\mathrm{N}_{\mathrm{i}}=$ Number of measurements of parameter $\mathrm{i}$. 
For a result, $r$, the uncertainty in $r$ is calculated as:

$$
U_{r}=\sqrt{\beta_{r}^{2}+\left(S_{r} * t\right)^{2}}
$$

The components are calculated by combining the errors in the parameters used in the result calculation.

$$
\begin{aligned}
& \beta_{r}=\sqrt{\sum_{i=1}^{j}\left(\theta_{i} * \beta_{\overline{p i}}\right)^{2}} \\
& S_{r}=\sqrt{\sum_{i=1}^{j}\left(\theta_{i} * S_{\overline{p i}}\right)^{2}}
\end{aligned}
$$

The sensitivity of the result to each parameter is found from a Taylor series estimation method:

$$
\theta_{i}=\frac{\partial r}{\partial p_{i}}
$$

Or using a perturbation method (useful in computer applications):

$$
\theta_{i}=\frac{\mathbf{r}_{P_{i}}+\Delta P_{i}-r_{P_{i}}}{\Delta P_{i}}
$$

The standard deviation of the average for each parameter is calculated as:

$$
S_{\overline{p i}}=\frac{S_{p i}}{\sqrt{N}}
$$


The degrees of freedom for each parameter is found from

$$
\mathrm{v}_{\mathbf{i}}=\mathrm{N}_{\mathbf{i}}-1
$$

and the degrees of freedom for the result if found by weighing the sensitivity and precision error in each parameter.

$$
v_{t}=\frac{S_{t}^{4}}{\sum_{i=1}^{j}\left[\frac{\left(S_{\overline{p i}} \times \theta_{i}\right)^{4}}{v_{i}}\right]}
$$

The student " $t$ " in Equation 1 is associated with the degrees of freedom in the result.

The precision error terms are easily generated using collected data. The bias error terms are more difficult to quantify. The percentage bias assumed in certain flow rates is based on how accurately particular flows were felt to be measured. For example, the coal flow rate was measured by counting (nominally) $500 \mathrm{lb}$ buckets. While this method has good precision, there is likely to be a bias. A $5 \%$ bias is therefore assumed for the coal flow rate to account for the uncertainty. Similarly, measurements of slurry flow rates in FGD systems are quite precise, but are frequently biased. For this reason a $20 \%$ bias was assumed for limestone and JBR blowdown slurry flow rates. The following conventions were used for this report:

- $5 \%$ bias in coal flow rates.

- $20 \%$ bias in limestone slurry and JBR blowdown slurry flow rates.

- No bias in gas flow rates.

- No bias in analytical results unless the result is less than detection limit. Then one-half the detection limit is used for both the parameter value and its bias in calculations.

In addition to the assumptions about bias errors referred to above, the calculations also assume that the population distribution of each measurement is normally distributed and that the samples collected reflect the true population.

Also, the uncertainty calculated is only for the average value over the sampling period. The uncertainty does not represent long-term process variations. In other words, the calculated uncertainty does not include a bias term to reflect the fact that the sampled system was probably not operating (and emitting) at conditions equivalent to the average conditions for 
that system over a longer period (in other words, autocorrelation may be important). $\Lambda_{n}$ example of the confidence interval calculation is provided below.

\section{Confidence Interval Calculations}

The following example shows an example calculation for the $95 \%$ confidence interval for emission factor. This procedure utilizes the same method outlined earlier in this appendix. The example uses concentration data for mercury in the stack gas.

$$
\mathrm{E}=\frac{\left(\mathrm{Q}_{\mathrm{gas}} * \mathrm{C}_{\mathrm{i}, \mathrm{s}}\right)+\left(\mathrm{Q}_{\mathrm{gas}} * \mathrm{C}_{\mathrm{i}, \mathrm{v}}\right)}{\mathrm{H}_{\text {coas }} * \mathrm{~F}_{\text {coal }} *\left(1-\mathrm{C}_{\mathrm{w}, \mathrm{coal}}\right)} * 2204.6
$$

where:

$$
\begin{aligned}
\mathrm{E} & =\text { Emission factor in } \mathrm{lb} / 10^{12} \mathrm{Btu} ; \\
\mathrm{Q}_{\text {stackgas }} & =\text { Gas flow rate, } \mathrm{Nm}^{3} / \mathrm{hr} ; \\
\mathrm{C}_{\mathrm{i}, \mathrm{s}} & =\text { Solid-phase conc., } \mu \mathrm{g} / \mathrm{Nm}^{3} ; \\
\mathrm{C}_{\mathrm{i}, \mathrm{v}} & =\text { Vapor-phase conc., } \mu \mathrm{g} / \mathrm{Nm}^{3} ; \\
\mathrm{H}_{\text {coal }} & =\text { Coal higher heating value, Btu/lb on a dry basis; } \\
\mathrm{F}_{\text {coal }} & =\text { Coal feed rate, } \mathrm{lb} / \mathrm{hr} ; \\
\mathrm{C}_{\mathrm{w}, \text { coal }} & =\text { Coal water content, weight fraction; and } \\
2204.6 & =\text { Conversion from } \mu \mathrm{g} / \mathrm{Btu} \text { to } \mathrm{lb} / 10^{12} \mathrm{Btu} .
\end{aligned}
$$

The values used to calculate the emission factor and the confidence interval are as follows: 


\begin{tabular}{|c|c|c|c|c|c|c|}
\hline & & & Par & leter & & \\
\hline & $\begin{array}{c}Q_{\text {trackgas }} \\
\mathrm{Nm}^{3} / \mathrm{hr}\end{array}$ & $\begin{array}{c}\mathrm{C}_{\mathrm{i}, \mathrm{s}} \\
\mu \mathrm{g} / \mathrm{Nm}^{3}\end{array}$ & $\begin{array}{c}\mathrm{C}_{\mathrm{i}, \mathrm{v}} \\
\mu \mathrm{g} / \mathrm{Nm}^{3}\end{array}$ & $\begin{array}{c}\mathbf{H}_{\text {ooal }} \\
\text { Btu/lb }\end{array}$ & $\begin{array}{c}\mathrm{C}_{\mathrm{w}, \text { cosl }} \\
\mathrm{g} / \mathrm{g}\end{array}$ & $\begin{array}{c}F_{\text {cosl }} \\
\mathrm{lb} / \mathrm{hr}\end{array}$ \\
\hline Mean & 456,000 & 0.00707 & 3.04 & 12,700 & 0.117 & 91,000 \\
\hline$S_{p}$ & 3,990 & 0.00638 & 0.11 & 260 & 0.0087 & 3,200 \\
\hline$S_{\bar{p}}$ & 2,310 & 0.00451 & 0.064 & 150 & 0.0050 & 380 \\
\hline $\mathrm{N}$ & 3 & 2 & 3 & 3 & 3 & 71 \\
\hline$\beta_{p}$ & 0 & 0 & 0 & 0 & 0 & 4,540 \\
\hline$\theta$ & $6.6 \times 10^{6}$ & 0.99 & 0.99 & $-2.3 \times 10^{4}$ & 2.73 & $-3.2 \times 10^{5}$ \\
\hline$v_{p}$ & 2 & 1 & 2 & 2 & 2 & 70 \\
\hline
\end{tabular}

The calculation of the sensitivity, $\theta$, for the vapor-phase concentration is shown below:

Vapor-phase analytical: $2.92 \mu \mathrm{g} / \mathrm{Nm}^{3}$

\section{$3.13 \mu \mathrm{g} / \mathrm{Nm}^{3}$ \\ $3.07 \mu \mathrm{g} / \mathrm{Nm}^{3}$}

$$
\begin{aligned}
\mathrm{N} & =3 \\
\text { Mean } & =\Sigma \mathrm{C}_{\mathrm{i}, \mathrm{v}} / \mathrm{N}=3.04 \\
\mathrm{~S}_{\mathrm{p}} & =\sqrt{ }\left[\Sigma\left(\mathrm{C}_{\mathrm{i}, \mathrm{v}}-\text { Mean }\right)^{2} /(\mathrm{N}-1)\right]=0.11 \\
\mathrm{~S}_{\overline{\mathrm{p}}} & =\frac{0.11}{\sqrt{3}}=0.064
\end{aligned}
$$

As explained above, the $\beta$ for analytical results is set equal to zero.

$$
\beta_{\mathrm{p}}=0
$$

Next, calculate the sensitivity using perturbation method. The perturbation is equal to the standard deviation:

$$
\begin{aligned}
\theta & =\left[\mathrm{r}_{\mathrm{Ci}, \mathrm{v}}=3.15-\mathrm{r}_{\mathrm{Ci}, \mathrm{v}=3.04}\right] / 0.11=[3.109-3.00] / 0.11 \\
& =0.99
\end{aligned}
$$

Similar calculations are performed for each parameter. 
The precision component is then found by root-sum-squaring the product of the normalized standard deviations and their respective sensitivities.

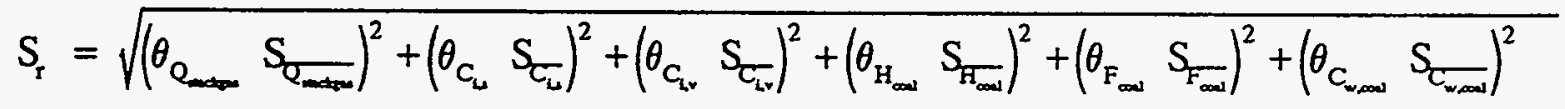

$$
\begin{aligned}
& S_{r}=0.066
\end{aligned}
$$

The bias component is found using the same equation substituting $\beta p$ for the $S p$ term.

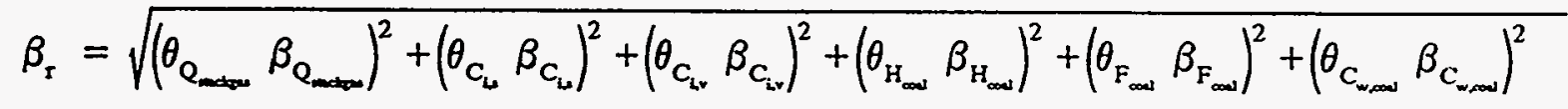

$$
\begin{aligned}
& \beta_{\mathrm{r}}=0.14
\end{aligned}
$$

The uncertainty in the result is then

$$
U_{r}=\sqrt{\beta_{r}^{2}+\left(t \times S_{r}\right)^{2}}
$$

To calculate the Student $t$ factor, the degrees of freedom must be calculated using the following equation:

$$
\begin{aligned}
v_{r} & =\frac{S_{r}^{4}}{\sum_{i=1}^{j} \frac{\left(S_{p i} \theta_{i}\right)^{4}}{v_{p i}}} \\
& =2.7
\end{aligned}
$$

The Student $\mathrm{t}$ factor for a two-tailed $95 \%$ confidence interval with 2.7 degrees of freedom is 3.2. The uncertainty in the emission factor can now be calculated. 


$$
\begin{aligned}
U_{r} & =\sqrt{(0.14)^{2}+(3.2 \times .066)^{2}} \\
& =0.25
\end{aligned}
$$

The emission rate is calculated as $3.0 \mathrm{lb} / 10^{12} \mathrm{Btu}$.

The value is reported as $3.0 \pm 0.3 \mathrm{lb} / 10^{12} \mathrm{Btu}$. 


\section{APPENDIX G: TREATMENT OF NONDETECTS, VALUES OUTSIDE OF THE CALIBRATION RANGE, AND BLANKS}

Treatment of nondetects (analytical results for which the concentration of the species of interest is below the detection limit of the method) and blank values is of critical importance in this program because detection levels and blank concentrations are often on the same order of magnitude as sample values. When the results are then used for risk assessments or policy decisions, treatment of the data becomes important. This discussion describes how blank and nondetect values are to be treated in presenting/developing reported results.

\section{Nondetects}

The discussion presented below explains how averages, sums, and reported emission values are to be calculated for all species given various combinations of detected and nondetected values.

All values detected. The arithmetic average or sum is taken, as appropriate. No special techniques required.

All values below the detection limit. For individual test runs or species, the data are to be reported as "ND < (detection limit)." For cases where all three runs are below the detection limit, the average is reported as nondetected less than the average detection limit of the three runs.

Some values are detected and some are nondetects. As an approximation, half of the detection limit for nondetect values and the actual value for detects will be used to determine reported values. As an example of averaging, an average for three test runs with results of 10,8 , and ND $<6$ would be 7 . As an example for summing (such as for mercury fractions), individual species values of $50, \mathrm{ND}<1$, and $\mathrm{ND}<2$ would be summed to provide a value of $50+0.5+1$, or 51.5 . In reporting these types of sums or average no " $<$ " sign is used. The only exception to this rule occurs when the average is less than the highest detection limit of the nondetected values. In this case, the average is reported as "ND < (the highest detection limit)." For example, 5, ND $<4$, and ND $<3$ would be reported as "ND <4." 
This approach is also used to obtain test train totals which required analyses of separate fractions for each individual run. Specifically, the volatile, metals, and anion test train totals for each run are obtained by addition of test train fractions which were analyzed separately.

Fractions from the volatile test train included separate analyses of the tenax and tenax/charcoal tubes for each sample period. Separate analyses were conducted on the filterable and gaseous test train components for both the metals and anion test trains.

Detection limit ratio. These methods of treating the data may result in some loss of information in going from raw data to final values. Specifically, what is often lost is the amount of a final emission value that is attributable to detection limits and the amount that is attributable to measured values. In order to quantify and present this information, all results in this report are presented along with the "Detection Limit Component Ratio," which is calculated as the ratio of the contribution of detection limit values to a final emission result.

For example, a set of three values of $16, \mathrm{ND}<6$, and $\mathrm{ND}<5$ should be reported as 7 , with a detection limit ratio of $26 \%[(3+2.5) /(16+3+2.5)]$, while a set of values of $12, \mathrm{ND}<6$, and 9 should be reported as 8 , with a detection limit ratio of 13 percent. The different ratios provide insight as to the extent something is "really there" and, it is hoped, can help provide better information to those making decisions on risk and policy issues.

\section{Values Outside the Calibration Range}

It is possible that the reported lab data will be outside the calibration range of the instrument. Data reported below the lower detection limit will be flagged with a qualifier (e.g., "J"). Data with the "J" flag will have been tentatively identified and tentatively quantified. Data reported above the upper detection limit will be flagged with a qualifier (e.g., "E"). Data with the " $E$ " flag will have been positively identified and tentatively quantified. Data with both qualifiers will be estimates. Consider $\mathrm{J}$ and $\mathrm{E}$ values to be quantitatively representative when calculating averages. Neither flag should cause a value to be weighted more or less important. The J and E data qualifiers should appear in the respective laboratory analytical report. The data qualifiers need not appear on the calculated data summaries.

\section{Blank Values}

The level and treatment of blank values is important in interpreting data, since in some cases species are detected but not at levels significantly higher than blanks. In these cases, measured values may not represent emissions, but rather just limitations of the method. However, most of the test methods used in this program either do not allow subtraction of blanks or are silent on how to treat blank values.

When a method does not specify how the sample will be blank-corrected, the appropriate blank train values should be subtracted. Laboratory and site/reagent blanks will be analyzed and the results evaluated for identification of contamination. If a sample compound is blankcorrected, the data will be flagged by a "B." If the value is blank-corrected below the detection limit, it should be reported as "ND < (detection limit) BC." A "C" flag indicates 
that the blank value was greater than the sampled value. In no case should the blankcorrected values be reported below the method detection limit. 
APPENDIX H: DETAILED ANALYTICAL RESULTS 
Appendix H: Detailed Analytical Results

\section{TABLE OF CONTENTS}

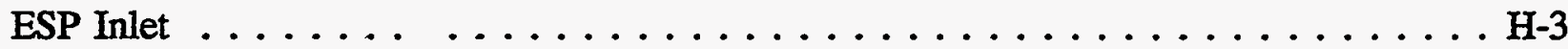

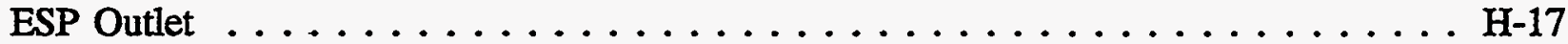

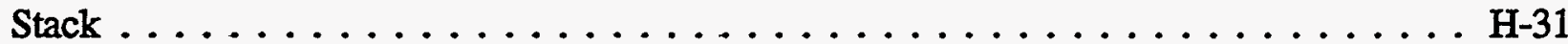

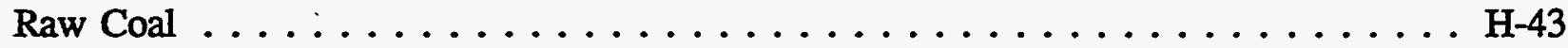

Feed Coal . . . . . . . . . . . . . . . . . . . . . H-45

Pulverizer Rejects . . . . . . . . . . . . . . . . . . . . . H-49

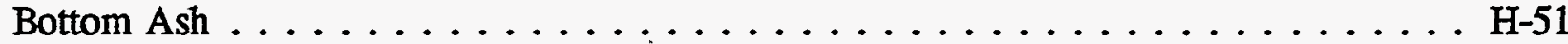

Sluiced Fly Ash $\ldots \ldots \ldots \ldots \ldots \ldots \ldots \ldots \ldots \ldots \ldots \ldots \ldots \ldots$ H-57

ESP Hopper Ash (Field 1) . . . . . . . . . . . . . . . H-63

ESP Hopper Ash (Field 2) . . . . . . . . . . . . . . . . . . . . H-69

Raw Limestone $\ldots \ldots \ldots \ldots \ldots \ldots \ldots \ldots \ldots \ldots$. . . . . . . . . . . . . . . . . . . .

Limestone Slurry Solids $\ldots \ldots \ldots \ldots \ldots \ldots \ldots \ldots$. . . . . . . . . H-77

JBR Underflow Slurry Solids . . . . . . . . . . . . . . . . . . . . H-79

Ash Pond Water . . . . . . . . . . . . . . . . . . . . . . H-85

Bottom Ash Sluice Filtrate $\ldots \ldots \ldots \ldots \ldots \ldots \ldots \ldots \ldots$ H-91

ESP Fly Ash Sluice Filtrate $\ldots \ldots \ldots \ldots \ldots \ldots \ldots \ldots \ldots \ldots$ H-97

Gypsum Pond Water . . . . . . . . . . . . . . . . . . . . . . H-103

JBR Underflow Slurry Filtrate . . . . . . . . . . . . . . . . . . . H-109

Limestone Slurry Filtrate . . . . . . . . . . . . . . . . . . . . H-115

Cooling Water . . . . . . . . . . . . . . . . . . . . . . H-121

Coal Pile Run-Off . . . . . . . . . . . . . . . . . . . . . H-127 


\section{Gas Stream Data}

SAMPLE STREAM: ESP INLET

\begin{tabular}{|c|c|c|c|c|c|c|c|c|c|c|c|c|}
\hline $\begin{array}{c}\text { Analyte } \\
\text { Group }\end{array}$ & Specie & $\begin{array}{c}\text { Analytical } \\
\text { Method }\end{array}$ & Units & $\begin{array}{c}\text { Run } \\
1 \\
\end{array}$ & & $\begin{array}{c}\text { Run } \\
2 \\
\end{array}$ & & $\begin{array}{c}\text { Run } \\
3 \\
\end{array}$ & & Average & $\begin{array}{c}95 \% \\
\mathrm{Cl} \\
\end{array}$ & $\begin{array}{c}\text { DL } \\
\text { Ratio }\end{array}$ \\
\hline Partlculate Loading & & Grav & $\mathrm{g} / \mathrm{Nm} 3$ & 8.305 & & 9.017 & & 9.533 & & 8.952 & 1.53 & \\
\hline Reduced Species & Ammonia as $N$ & EPA 350.1 & ug/Nm3 & 27.98 & B & 32.33 & B & 26.65 & $B$ & 29 & 7.38 & \\
\hline Reduced Species & Hydrogen Cyanide & SW 9012 & ug/Nm3 & 0.043 & J & 0.221 & J & 0.199 & J & 0.154 & 0.24 & \\
\hline Anlons - Vapor Phase & Chloride & EPA 300.0 & ug/Nm3 & 127,702 & & 105,013 & & 102,681 & & 111,799 & 34,338 & \\
\hline Anions - Vapor Phase & Fluoride & EPA 340.2 & ug/Nm3 & 7,866 & & 8,946 & & 8,123 & & 8,311 & 1,401 & \\
\hline Anions - Vapor Phase & Sulfate & EPA 300.0 & ug/Nm3 & $7,339,547$ & & $7,389,801$ & & $7,662,782$ & & $7,464,043$ & 432,118 & \\
\hline Anions - Particulate & Chloride & EPA 300.0 & $\mathrm{ug} / \mathrm{Nm} 3$ & 3,703 & & 10,334 & & 4,333 & & 6,123 & 9,094 & \\
\hline Anions - Particulate & Fluoride & EPA 340.2 & $\mathrm{ug} / \mathrm{Nm} 3$ & 0.248 & B & 2.01 & B & 1.72 & B & 1.33 & 2.35 & \\
\hline Anions - Particulate & Sulfate & EPA 300.0 & $\mathrm{ug} / \mathrm{Nm} 3$ & 52,251 & & 124,668 & & 61,094 & & 79,338 & 98,145 & \\
\hline Anlons - Tolal & Chloride & EPA 300.0 & ug/Nm3 & 131,404 & & 115,347 & & 107,014 & & 117,922 & 30,799 & \\
\hline Anions - Total & Suifate & EPA 300.0 & $\mathrm{ug} / \mathrm{Nm} 3$ & $7,391,798$ & & $7,514,469$ & & $7,723,876$ & & $7,543,381$ & 417,161 & \\
\hline Radionuclides & Actinium-228@338 KeV & EPA 901.1 & $\mathrm{pCi} / \mathrm{g}$ & 16 & & 32 & & 34 & & 24.7 & 35.9 & $11 \%$ \\
\hline Radionuclides & Actinium-228@911 KeV & EPA 901.1 & $\mathrm{pCl} / \mathrm{g}$ & 16 & & 18 & & 27 & & 20.3 & 14.6 & \\
\hline Radionuclides & Actinium-228 $968 \mathrm{KeV}$ & EPA 901.1 & $\mathrm{pCl} / \mathrm{g}$ & 22 & & 34 & & 43 & & 29.3 & 41.0 & $13 \%$ \\
\hline Radionuclides & Bismuth-212@727 KeV & EPA 901.1 & $\mathrm{pCi} / \mathrm{g}$ & 37 & $<$ & 43 & $<$ & 38 & $<$ & 39.3 & - & $100 \%$ \\
\hline Radionuclides & Bismuth-214@1120.4 KeV & EPA 901.1 & $\mathrm{pCl} / \mathrm{g}$ & 25 & $<$ & 24 & $<$ & 24 & $<$ & 24.3 & -. & $100 \%$ \\
\hline Radlonuclides & Blsmuth-214@1764.7 KeV & EPA 901.1 & $\mathrm{pCl} / \mathrm{g}$ & 71 & $<$ & 34 & & 60 & & 49.3 & 70.9 & $11 \%$ \\
\hline Radionuclides & Bismuth-214@609.4 KeV & EPA 901.1 & $\mathrm{pCl} / \mathrm{g}$ & 21 & & 28 & & 35 & & 28.0 & 17.4 & \\
\hline Radionuclides & K-40@1460 KeV & EPA 901.1 & $\mathrm{pCl} / \mathrm{g}$ & 170 & & 150 & & 380 & & 233 & 317 & \\
\hline Radionuclides & Lead-210@ $96 \mathrm{KeV}$ & EPA 901.1 & $\mathrm{pCl} / \mathrm{g}$ & 73 & & 94 & & 70 & & 79.0 & 32.5 & \\
\hline Radionuclides & Lead-212@ $238 \mathrm{KeV}$ & EPA 901.1 & $\mathrm{pCl} / \mathrm{g}$ & 11 & & 20 & & 26 & & 19.0 & 18.8 & \\
\hline Radionuclides & Lead-214@295.2 KeV & EPA 901.1 & $\mathrm{pCl} / \mathrm{g}$ & 24 & & 16 & & 32 & & 24.0 & 19.9 & \\
\hline Radionuclides & Lead-214@352.0 KeV & EPA 901.1 & $\mathrm{pCl} / \mathrm{g}$ & 24 & & 23 & & 29 & & 25.3 & 7.99 & \\
\hline Radionuclides & Radium-226@186.0 KeV & EPA 901.1 & $\mathrm{pCi} / \mathrm{g}$ & 110 & & 130 & & 150 & & 130 & 50 & \\
\hline Radionuclides & Thallium-208@ $583 \mathrm{KeV}$ & EPA 901.1 & $\mathrm{pCi} / \mathrm{g}$ & 12 & & 19 & & 20 & & 17.0 & 10.8 & \\
\hline
\end{tabular}


Gas Stream Data

SAMPLE STREAM: ESP INLET

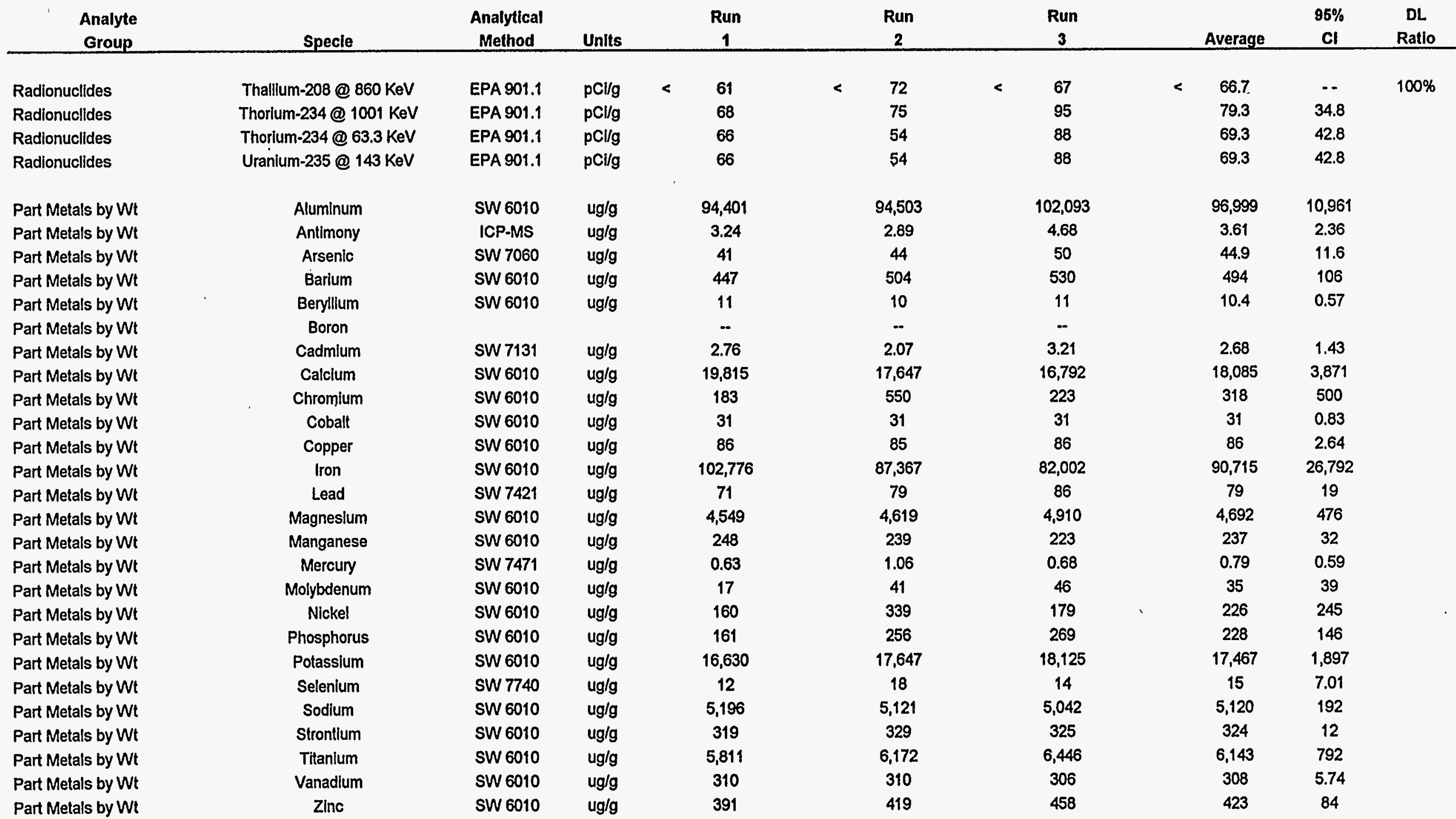

ESP Inlet - Page 2 


\section{Gas Stream Data}

SAMPLE STREAM: ESP INLET

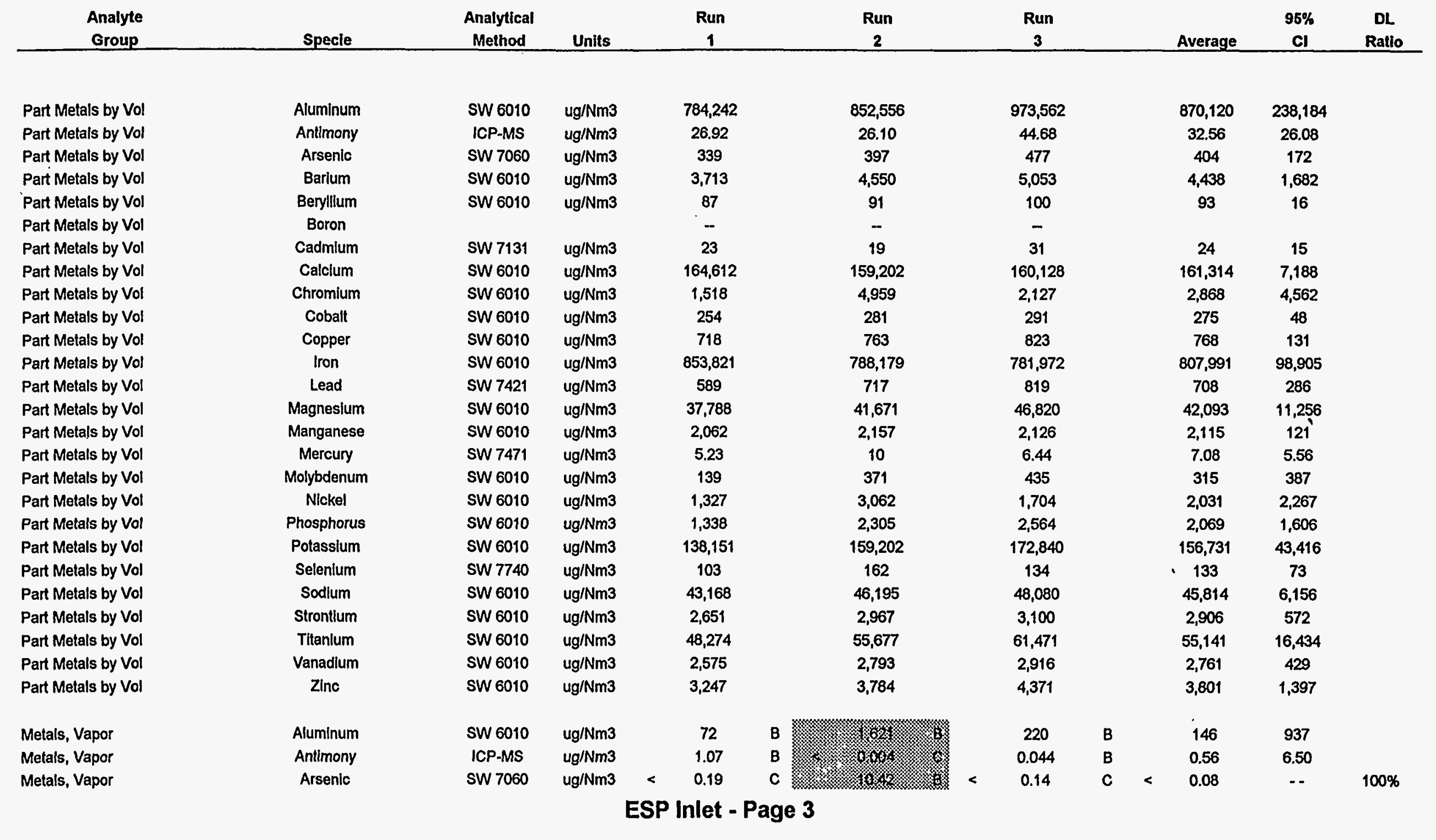




\section{Gas Stream Data}

SAMPLE STREAM: ESP INLET

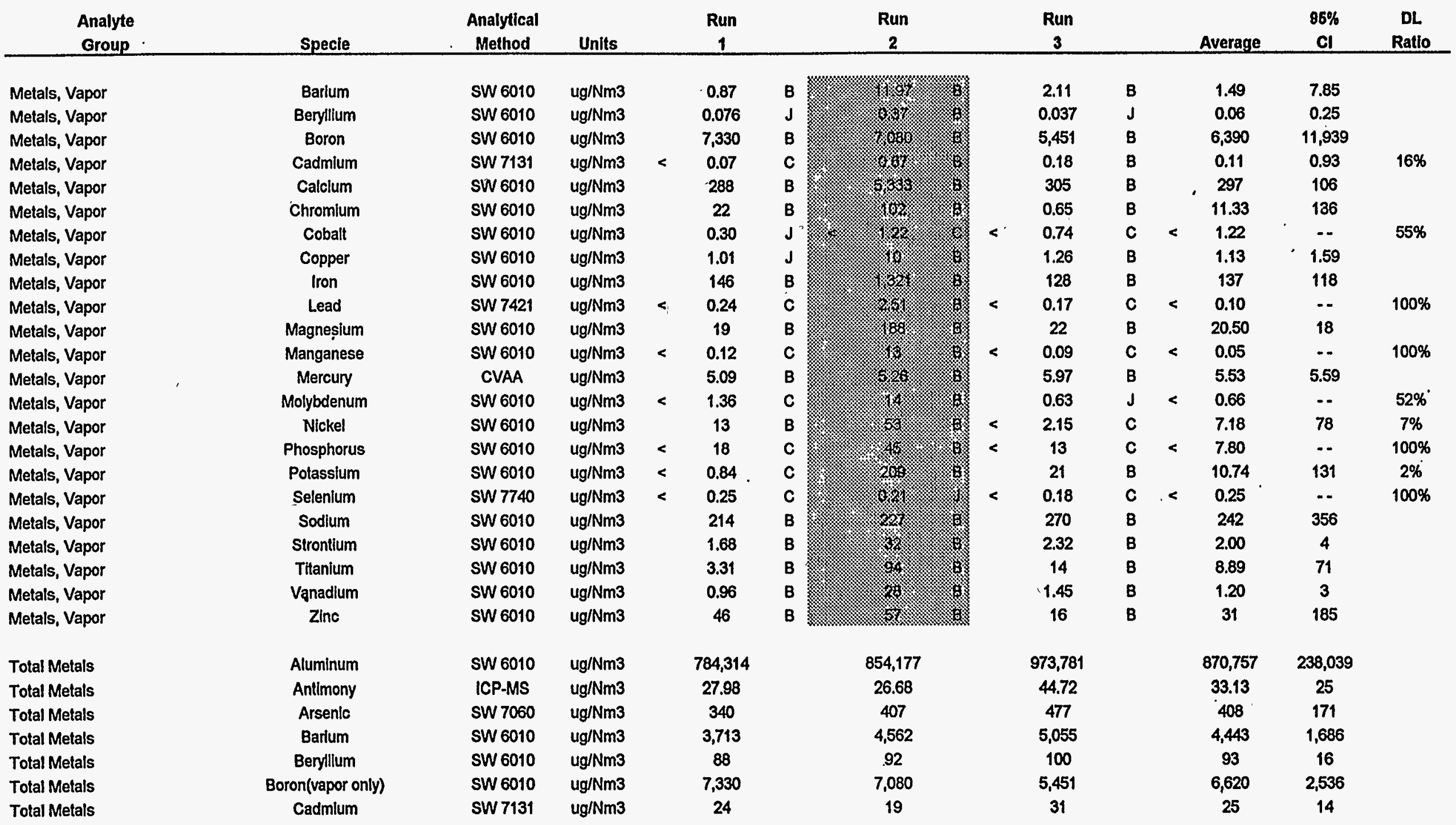




\section{Gas Stream Data}

SAMPLE STREAM: ESP INLET

\begin{tabular}{|c|c|c|c|c|c|c|c|c|c|}
\hline $\begin{array}{c}\text { Analyte } \\
\text { Group }\end{array}$ & Specie & $\begin{array}{c}\text { Analytical } \\
\text { Method }\end{array}$ & Units & $\begin{array}{c}\text { Run } \\
1 \\
\end{array}$ & $\begin{array}{c}\text { Run } \\
2 \\
\end{array}$ & $\begin{array}{c}\text { Run } \\
3 \\
\end{array}$ & Average & $\begin{array}{c}96 \% \\
\mathrm{Cl} \\
\end{array}$ & $\begin{array}{c}\text { DL } \\
\text { Ratio }\end{array}$ \\
\hline Total Metals & Calcium & SW 6010 & $\mathrm{ug} / \mathrm{Nm} 3$ & 164,900 & 164,535 & 160,433 & 163,289 & 6,162 & \\
\hline Total Metals & Chromium & SW 6010 & $\mathrm{ug} / \mathrm{Nm} 3$ & 1,540 & 5,061 & 2,127 & 2,909 & 4,686 & \\
\hline Total Metals & Cobalt & SW 6010 & ug/Nm3 & 254 & 283 & 293 & 277 & 49 & \\
\hline Total Metals & Copper & SW 6010 & $\mathrm{ug} / \mathrm{Nm} 3$ & 719 & 773 & 825 & 772 & 131 & \\
\hline Total Metals & Iron & SW 6010 & $\mathrm{ug} / \mathrm{Nm} 3$ & 853,967 & 789,500 & 782,099 & 808,522 & 98,206 & \\
\hline Total Metals & Lead & SW 7421 & $\mathrm{ug} / \mathrm{Nm} 3$ & 590 & 719 & 819 & 710 & 286 & \\
\hline Total Metals & Magneslum & SW 6010 & ug/Nm3 & 37,807 & 41,859 & 46,842 & 42,169 & 11,243 & \\
\hline Total Metals & Manganese & SW 6010 & $\mathrm{ug} / \mathrm{Nm} 3$ & 2,063 & 2,170 & 2,127 & 2,120 & 134 & \\
\hline Total Metals & Mercury & SW 7471 & $\mathrm{ug} / \mathrm{Nm} 3$ & 10 & 15 & 12 & 13 & 5.60 & \\
\hline Total Metals & Molybdenum & SW 6010 & $\mathrm{ug} / \mathrm{Nm} 3$ & 141 & 385 & 436 & 321 & 391 & \\
\hline Total Metals & Nickel & SW 6010 & $\mathrm{ug} / \mathrm{Nm} 3$ & 1,341 & 3,115 & 1,707 & 2,054 & 2,328 & \\
\hline Total Metals & Phosphorus & SW 6010 & $\mathrm{ug} / \mathrm{Nm} 3$ & 1,356 & 2,350 & 2,578 & 2,095 & 1,614 & \\
\hline Total Metals & Potassium & SW 6010 & $\mathrm{ug} / \mathrm{Nm} 3$ & 138,153 & 159,411 & 172,861 & 156,808 & 43,476 & \\
\hline Total Metals & Selenium & SW 7740 & $\mathrm{ug} / \mathrm{Nm} 3$ & 104 & 162 & 135 & 134 & 72 & \\
\hline Total Metals & Sodium & SW 6010 & $\mathrm{ug} / \mathrm{Nm} 3$ & 43,382 & 46,422 & 48,349 & 46,051 & 6,222 & \\
\hline Total Metals & Strontium & SW 6010 & $\mathrm{ug} / \mathrm{Nm} 3$ & 2,653 & 2,999 & 3,102 & 2,918 & 585 & \\
\hline Total Metals & Titanium & SW 6010 & $\mathrm{ug} / \mathrm{Nm} 3$ & 48,277 & 55,771 & 61,485 & 55,178 & 16,457 & \\
\hline Total Metals & Vanadium & SW 6010 & $\mathrm{ug} / \mathrm{Nm} 3$ & 2,576 & 2,820 & 2,917 & 2,771 & 437 & \\
\hline Total Metals & Zinc & SW 6010 & $\mathrm{ug} / \mathrm{Nm} 3$ & 3,293 & 3,842 & 4,388 & 3,841 & 1,360 & \\
\hline Hg Vapor, Bloom & Mercury, Elemental & CVAFS & $\mathrm{ug} / \mathrm{Nm} 3$ & 2.43 & 2.36 & 1.15 & 1.98 & 1.78 & \\
\hline Hg Vapor, Bloom & Mercury II & CVAFS & $\mathrm{ug} / \mathrm{Nm} 3$ & 4.38 & 3.46 & 4.45 & 4.10 & 1.37 & \\
\hline Hg Vapor, Bloom & Mercury, Methyl & CVAFS & $\mathrm{ug} / \mathrm{Nm} 3$ & 0.10 & 0.28 & 0.57 & 0.31 & 0.59 & \\
\hline Hg Vapor, Bloom & Mercury, Total & CVAFS & $\mathrm{ug} / \mathrm{Nm} 3$ & 6.91 & 6.09 & 6.17 & 6.39 & 1.12 & \\
\hline Extract Metals, Nitric & Antimony & ICP-MS & $u g / g$ & 2.37 & 3.04 & 2.62 & 2.68 & 0.85 & \\
\hline Extract Metals, Nitric & Arsenic & ICP-MS & $\mathrm{ug} / \mathrm{g}$ & 36.33 & 63.18 & 28.23 & 43 & 45 & \\
\hline Extract Metals, Nitric & Barium & ICP-MS & $u g / g$ & 181 & 287 & 192 & 220 & 145 & \\
\hline Extract Metals, Nitric & Beryllium & ICP-MS & $u g / g$ & 3.36 & 5.14 & 3.83 & 4.11 & 2.29 & \\
\hline Extract Metals, Nitric & Boron & ICP-MS & $u g / g$ & 1.495 & 1,871 & 1,181 & 1,516 & 857 & \\
\hline Extract Metals, Nitric & Cadmium & ICP-MS & $\mathrm{ug} / \mathrm{g}$ & 0.72 & 2.28 & 4.03 & 2.22 & 4.57 & $5 \%$ \\
\hline
\end{tabular}




\section{Gas Stream Data}

SAMPLE STREAM: ESP INLET

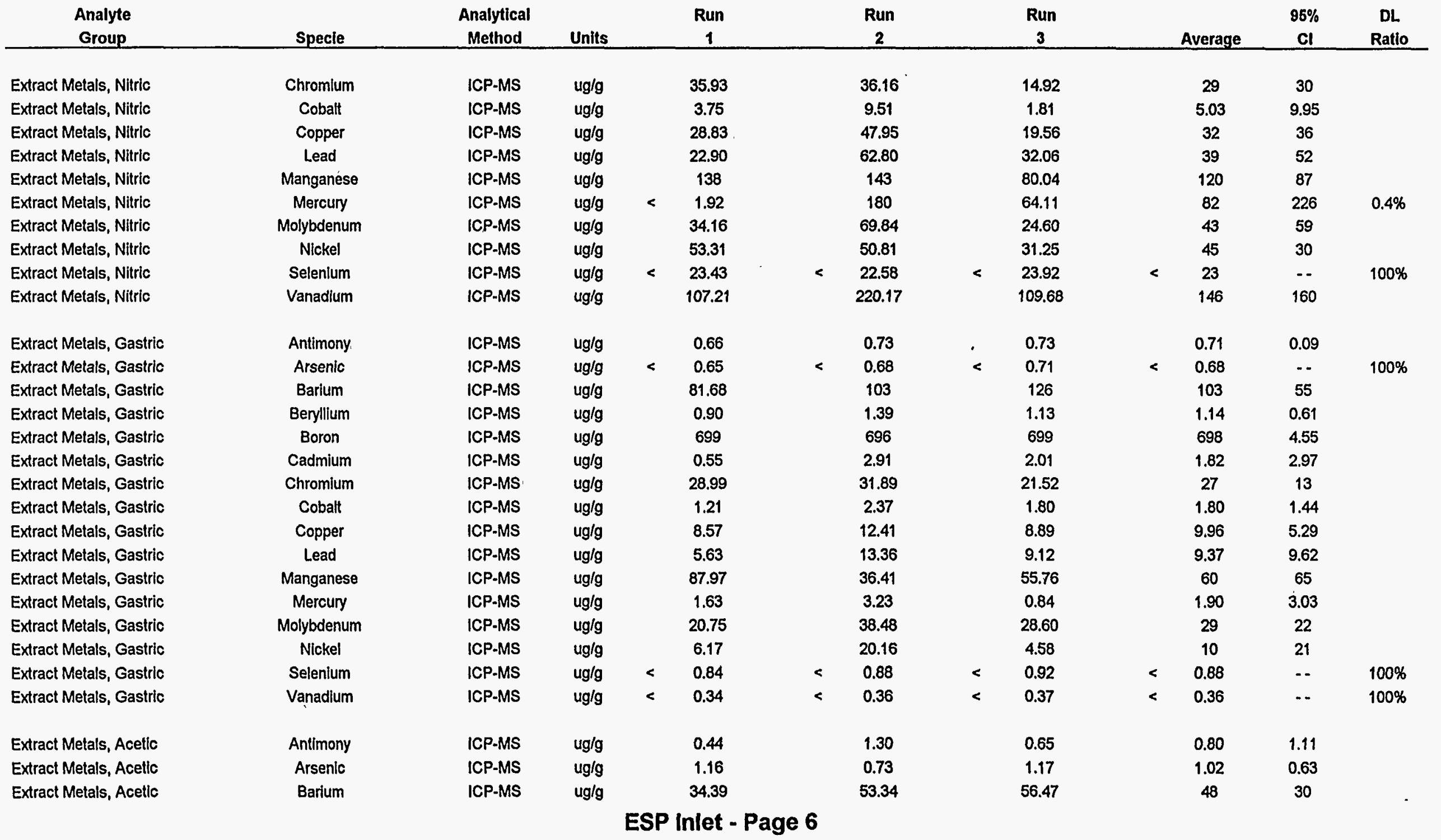




\section{Gas Stream Data}

SAMPLE STREAM: ESP INLET

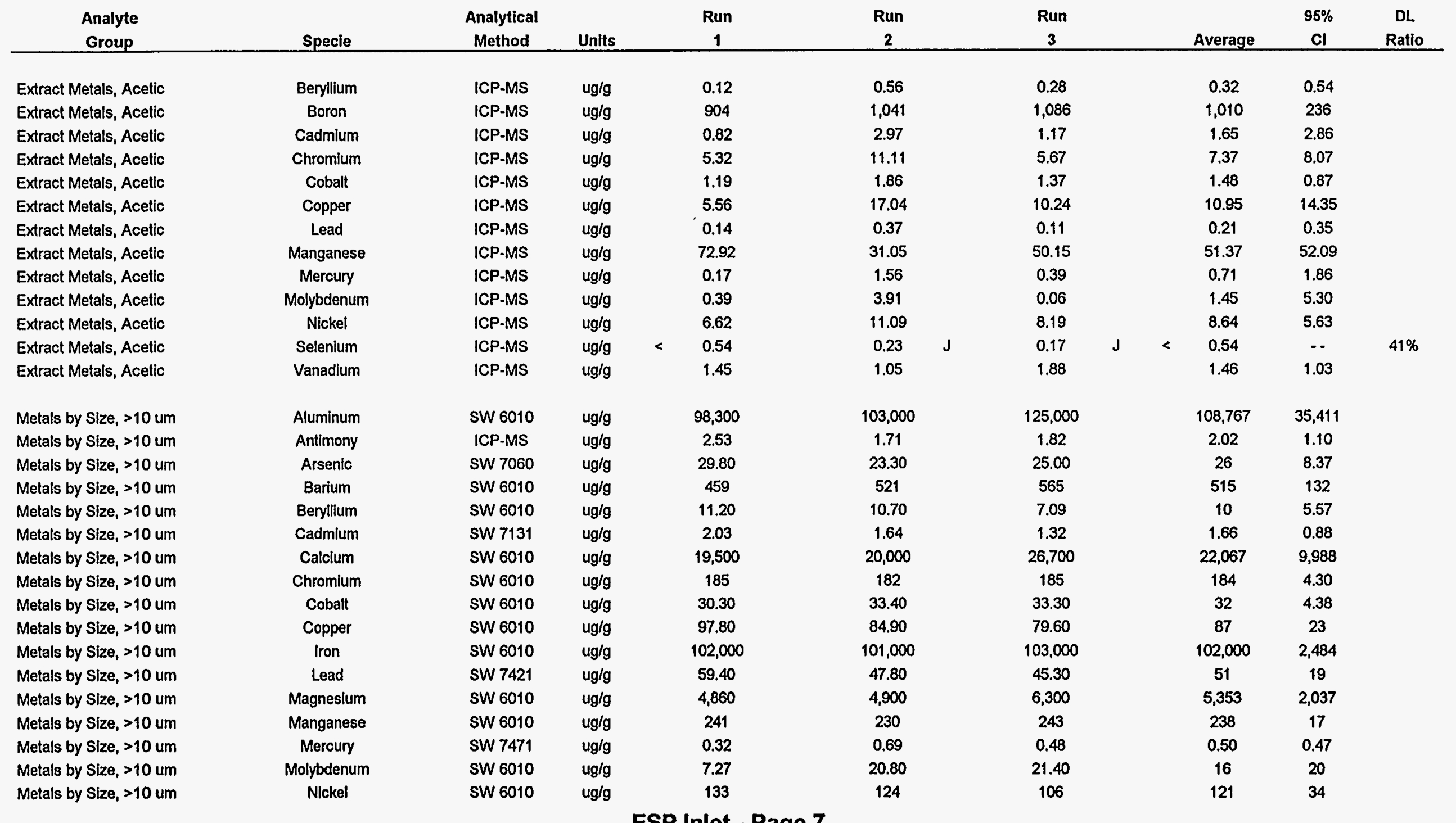


Gas Stream Data

SAMPLE STREAM: ESP INLET

\begin{tabular}{|c|c|c|c|c|c|c|c|c|c|c|c|c|c|}
\hline $\begin{array}{c}\text { Analyte } \\
\text { Group }\end{array}$ & Specie & $\begin{array}{l}\text { Analytical } \\
\text { Method }\end{array}$ & Unilts & & $\begin{array}{c}\text { Run } \\
1 \\
\end{array}$ & & $\begin{array}{c}\text { Run } \\
2 \\
\end{array}$ & & $\begin{array}{c}\text { Run } \\
3 \\
\end{array}$ & & Average & $\begin{array}{c}96 \% \\
\mathrm{Cl} \\
\end{array}$ & $\begin{array}{c}\text { DL } \\
\text { Ratio }\end{array}$ \\
\hline Metals by Size, $>10$ um & Phosphorus & sW 6010 & $u g / g$ & $<$ & 72.60 & $<$ & 72.20 & $<$ & 72.20 & $<$ & 72 & .- & $100 \%$ \\
\hline Metals by Size, $>10$ um & Potassium & SW 6010 & $u g / g$ & & 17,800 & & 17,900 & & 19,700 & & 18,467 & 2,656 & \\
\hline Metals by Size, >10 um & Selenium & SW 7740 & $u g / g$ & & 6.47 & & 10.70 & & 15.00 & & 11 & 11 & \\
\hline Metals by Size, $>10$ um & Sllicon & SW 6010 & ug/g & & 223,000 & & 223,000 & & 209,000 & & 218,333 & 20,081 & \\
\hline Metals by Size, $>10$ um & Sodium & SW 6010 & ug/g & & 5,470 & & 4,330 & & 4,060 & & 4,620 & 1,859 & \\
\hline Metals by Size, >10 um & Strontium & SW 6010 & ug/g & & 340 & & 330 & & 402 & & 357 & 97 & \\
\hline Metals by Size, $>10$ um & Titanium & SW 6010 & ug/g & & 6,340 & & 6,210 & & 5,900 & & 6,150 & 562 & \\
\hline Metals by Size, >10 um & Vanadium & SW 6010 & $u g / g$ & & 310 & & 296 & & 274 & & 293 & 45 & \\
\hline Metals by Size, $>10$ um & Zino & SW 6010 & $u g / g$ & & 346 & & 276 & & 243 & & 288 & 131 & \\
\hline Metals by Size, 10-3 um & Aluminum & SW 6010 & ug/g & & 123,000 & & 107,000 & & 123,000 & & 117,667 & 22,949 & \\
\hline Metals by Size, $10-3$ um & Antimony & ICP-MS & ug/g & & 6.04 & & 4.19 & & 4.19 & & 4.81 & 2.66 & \\
\hline Metals by Size, 10-3 um & Arsenic & sW 7060 & ug/g & & 82.90 & & 72.10 & & $\mathbf{5 7 . 9 0}$ & & 71 & 31 & \\
\hline Metals by Size, $10-3$ um & Barium & SW 6010 & ug/g & & 575.00 & & 572.00 & & 745.00 & & 631 & 246 & \\
\hline Metals by Size, 10-3 um & Beryllium & sW 6010 & ug/g & & 16.50 & & 11.30 & & 10.50 & & 13 & 8.09 & \\
\hline Metals by Size, $10-3$ um & Cadmlum & SW 7131 & $u g / g$ & & 7.30 & & 5.81 & & 4.40 & & 5.84 & 3.60 & \\
\hline Metals by Size, $10-3$ um & Calcium & SW 6010 & $u g / g$ & & 14,500 & & 15,000 & & 26,300 & & 18,600 & 16,578 & \\
\hline Metals by Size, $10-3$ um & Chromium & SW 6010 & ug/g & & 225 & & 215 & & 213 & & 218 & 16 & \\
\hline Metals by Size; $10-3 \mathrm{um}$ & Cobalt & SW 6010 & ug/g & & 45.70 & & 42.40 & & 41.40 & & 43 & 5.59 & \\
\hline Metals by Size, $10-3$ um & Copper & SW 6010 & ug/g & & 152 & & 140 & & 135 & & 142 & 22 & \\
\hline Metals by Size, $10-3 \mathrm{um}$ & Iron & SW 6010 & $u g / g$ & & 60,700 & & 59,300 & & 72,900 & & 64,300 & 18,584 & \\
\hline Metals by Size, $10-3$ um & Lead & SW 7421 & ug/g & & 157 & & 104 & & 97 & & 119 & 82 & \\
\hline Metals by Size, $10-3$ um & Magnesium & SW 6010 & ug/g & & 6,460 & & 6,480 & & 6,110 & & 6,350 & 517 & \\
\hline Metals by Size, $10-3$ um & Manganese & SW 6010 & $u g / g$ & & 228 & & 211 & & 238 & & 226 & 34 & \\
\hline Metals by Size, $10-3$ um & Mercury & sW.7471 & $u g / g$ & & 0.22 & & 0.60 & & 0.60 & & 0.47 & 0.54 & \\
\hline Metals by Size, 10-3 um & Molybdenum & SW 6010 & $u g / g$ & & 55.90 & & 51.90 & & 30.50 & & 46 & 34 & \\
\hline Metals by Size, 10-3 um & Nickel & SW 6010 & ug/g & & 182 & & 128 & & 145 & & 152 & 69 & \\
\hline Metals by Size, $10-3$ um & Phosphorus & SW 6010 & ug/g & $<$ & 72.80 & $<$ & 72.60 & $<$ & 72.50 & $<$ & 73 & $\cdots$ & $100 \%$ \\
\hline Metals by Size, $10-3$ um & Potassium & SW 6010 & $u g / g$ & & 23,300 & & 21,500 & & 20,700 & & 21,833 & 3,308 & \\
\hline Metals by Size, 10-3 um & Selenium & SW 7740 & $u g / g$ & & 6.29 & & 2.39 & $<$ & 1.15 & & 3.09 & 7.25 & $6 \%$ \\
\hline Metals by Size, $10-3$ um & Sillicon & SW 6010 & $u g / g$ & & 236,000 & & 231,000 & & 225,000 & & 230,667 & 13,683 & \\
\hline
\end{tabular}

ESP Inlet - Page 8 


\section{Gas Stream Data}

SAMPLE STREAM: ESP INLET

\begin{tabular}{|c|c|c|c|c|c|c|c|c|c|}
\hline $\begin{array}{c}\text { Analyte } \\
\text { Group }\end{array}$ & Specie & $\begin{array}{c}\text { Analytical } \\
\text { Method }\end{array}$ & Units & $\begin{array}{c}\text { Run } \\
1 \\
\end{array}$ & $\begin{array}{c}\text { Run } \\
2 \\
\end{array}$ & $\begin{array}{c}\text { Run } \\
3 \\
\end{array}$ & Average & $\begin{array}{c}95 \% \\
\mathrm{Cl} \\
\end{array}$ & $\begin{array}{c}\text { DL } \\
\text { Ratio }\end{array}$ \\
\hline Metals by Size, 10-3 um & Sodium & SW 6010 & ug/g & 7,780 & 6,780 & 5,660 & 6,740 & 2,635 & \\
\hline Metals by Size, 10-3 um & Strontium & SW 6010 & $u g / g$ & 389 & 381 & 382 & 384 & 11 & \\
\hline Metals by Size, $10-3$ um & Titanlum & SW 6010 & ug/g & 6,530 & 7,270 & 6,700 & 6,833 & 963 & \\
\hline Metals by Size, $10-3$ um & Vanadium & SW 6010 & $\mathrm{ug} / \mathrm{g}$ & 463 & 399 & 312 & 391 & 188 & \\
\hline Metals by Size, 10-3 um & Zinc & SW 6010 & $u g / g$ & 868 & 709 & 613 & 730 & 320 & \\
\hline Metals by Size, $<3$ um & Aluminum & SW 6010 & ug/g & 133,000 & 143,000 & 129,000 & 135,000 & 17,915 & \\
\hline Metals by Size, $<3$ um & Antimony & ICP-MS & $u g / g$ & 11.85 & 11.48 & 7.68 & 10 & 5.73 & \\
\hline Metals by Size, $<3$ um & Arsenic & SW 7060 & ug/g & 147.00 & 209.00 & 119.00 & 158 & 114 & \\
\hline Metals by Size, $<3$ um & Barlum & SW 6010 & ug/g & 716.00 & 965.00 & 664.00 & 782 & 400 & \\
\hline Metals by Size, $<3$ um & Beryllium & SW 6010 & $u g / g$ & 21.50 & 14.90 & 14.50 & 17 & 10 & \\
\hline Metals by Size, $<3$ um & Cadmium & SW 7131 & $u g / g$ & 16.70 & 18.90 & 9.66 & 15 & 12 & \\
\hline Metals by Size, <3 um & Calcium & SW 6010 & ug/g & 16,300 & 25,500 & 16,100 & 19,300 & 13,342 & \\
\hline Metals by Size, <3 um & Chromlum & SW 6010 & $u g / g$ & 262 & 260 & 216 & 246 & 65 & \\
\hline Melals by Size, $<3$ um & Cobalt & SW 6010 & ug/g & 75.70 & 59.20 & 54.30 & 63 & 28 & \\
\hline Metals by Size, $<3$ um & Copper & SW 6010 & $u g / g$ & 210 & 203 & 171 & 195 & 52 & \\
\hline Metals by Size, $<3$ um & Iron & SW 6010 & ug/g & 59,500 & 59,800 & 56,400 & 58,567 & 4,676 & \\
\hline Metals by Size, $<3$ um & Lead & SW 7421 & ug/g & 227 & 128 & 171 & 175 & 123 & \\
\hline Metals by Size, $<3$ um & Magnesium & SW 6010 & ug/g & 7,270 & 8,140 & 6,980 & 7,463 & 1,500 & \\
\hline Metals by Size, $<3$ um & Manganese & SW 6010 & ug/g & 282 & 289 & 231 & 267 & 79 & \\
\hline Metals by Size, $<3$ um & Mercury & SW 7471 & ug/g & 0.69 & 0.70 & 0.52 & 0.63 & 0.25 & \\
\hline Metals by Size, <3 um & Molybdenum & SW 6010 & ug/g & 134.00 & 100.00 & 76.30 & 103 & 72 & \\
\hline Metals by Size, <3 um & Nickel & SW 6010 & ug/g & 213.00 & 213.00 & 179.00 & 202 & 49 & \\
\hline Metals by Size, <3 um & Phosphorus & SW 6010 & ug/g & 499.00 & 443.00 & 25.10 & 499 & -- & $35 \%$ \\
\hline Metals by Size, $<3$ um & Potassium & SW 6010 & ug/g & 24,000 & 25,700 & 23,800 & 24,500 & 2,594 & \\
\hline Metals by Size, $<3$ um & Selenlum & SW 7740 & ug/g & 7.95 & 6.34 & 0.79 & 7.95 & -- & $36 \%$ \\
\hline Metals by Size, $<3$ um & Sillicon & SW 6010 & ug/g & 240,000 & 210,000 & 220,000 & 223,333 & 37,949 & \\
\hline Metals by Size, $<3$ um & Sodlum & SW 6010 & $u g / g$ & 8,900 & 7,890 & 7,080 & 7,957 & 2,265 & \\
\hline Metals by Size, $<3$ um & Strontium & SW 6010 & ug/g & 428 & 478 & 385 & 430 & 116 & \\
\hline Metals by Size, <3 um & Titanium & SW 6010 & ug/g & 7,040 & 6,750 & 7,120 & 6,970 & 484 & \\
\hline Metals by Size, $<3$ um & Vanadium & SW 6010 & ug/g & 688 & 580 & 6,980 & 2,749 & 9,103 & \\
\hline
\end{tabular}




\section{Gas Stream Data}

SAMPLE STREAM: ESP INLET

\begin{tabular}{|c|c|c|c|c|c|c|c|c|c|c|c|c|c|}
\hline $\begin{array}{l}\text { Analyte } \\
\text { Group } \\
\end{array}$ & Specie & $\begin{array}{c}\text { Analytical } \\
\text { Method }\end{array}$ & Units & & $\begin{array}{c}\text { Run } \\
1 \\
\end{array}$ & & $\begin{array}{c}\text { Run } \\
2 \\
\end{array}$ & & $\begin{array}{c}\text { Run } \\
3 \\
\end{array}$ & & Average & $\begin{array}{c}95 \% \\
\mathrm{Cl} \\
\end{array}$ & $\begin{array}{c}\text { DL } \\
\text { Ratio }\end{array}$ \\
\hline Metals by Size, $<3$ um & Zinc & SW 6010 & $u g / g$ & & 1,220 & & 1,210 & & 473 & & 968 & 1,064 & \\
\hline Organics, Aldehydes & Acetaldehyde & BIF-0011 & $\mathrm{ug} / \mathrm{Nm} 3$ & & 69.68 & & 123 & & 204 & & 132 & 169 & \\
\hline Organics, Aldehydes & Fomaldehyde & BIF-0011 & $\mathrm{ug} / \mathrm{Nm} 3$ & & 34.84 & & 70.95 & & 75.72 & & 61 & 56 & \\
\hline Organics, Semi-Volatile & 1,2,4,5-Tetrachlorobenzene & SW 8270 & $\mathrm{ng} / \mathrm{Nm} 3$ & $<$ & 221 & $<$ & 200 & $<$ & 140 & $<$ & 187 & -. & $100 \%$ \\
\hline Organics, Semi-Volatile & 1,2,4-Trichlorobenzene & SW 8270 & $\mathrm{ng} / \mathrm{Nm} 3$ & $<$ & 226 & $<$ & 204 & $<$ & 211 & $<$ & 214 & -- & $100 \%$ \\
\hline Organics, Semi-Volatile & 1,2-Dichlorobenzene & SW 8270 & $\mathrm{ng} / \mathrm{Nm} 3$ & $<$ & 298 & $<$ & 269 & $<$ & 228 & $<$ & 265 & - & $100 \%$ \\
\hline Organics, Seml-Volatile & 1,2-Diphenylhydrazine & SW 8270 & $\mathrm{ng} / \mathrm{Nm} 3$ & $<$ & 38,206 & $<$ & 34,545 & $<$ & 35,932 & $<$ & 36,227 & -- & $100 \%$ \\
\hline Organics, Semi-Volatile & 1,3-Dichlorobenzene & SW 8270 & $\mathrm{ng} / \mathrm{Nm} 3$ & $<$ & 151 & $<$ & 137 & $<$ & 258 & $<$ & 182 & .. & $100 \%$ \\
\hline Organics, Semi-Volatile & 1,4-Dichlorobenzene & SW 8270 & $\mathrm{ng} / \mathrm{Nm3}$ & $<$ & 309 & $<$ & 279 & $<$ & 211 & $<$ & 266 & $\ldots$ & $100 \%$ \\
\hline Organics, Semi-Volatile & 1-Chloronaphthalene & SW 8270 & $\mathrm{ng} / \mathrm{Nm} 3$ & $<$ & 246 & $<$ & 222 & $<$ & 193 & $<$ & 220 & -. & $100 \%$ \\
\hline Organics, Semi-Volatile & 1-Naphthylamine & SW 8270 & $\mathrm{ng} / \mathrm{Nm} 3$ & $<$ & 596 & $<$ & 539 & $<$ & 729 & $<$ & 621 & $\cdots$ & $100 \%$ \\
\hline Organics, Seml-Volatile & 2,3,4,6-Tetrachlorophenol & SW 8270 & $\mathrm{ng} / \mathrm{Nm} 3$ & $<$ & 192 & $<$ & 174 & $<$ & 167 & $<$ & 178 & $\cdots$ & $100 \%$ \\
\hline Organics, Semi-Volatile & 2,4,6-Trichlorophenol & SW 8270 & $n g / N m 3$ & $<$ & 133 & $<$ & 121 & $<$ & 182 & $<$ & 145 & $\cdots$ & $100 \%$ \\
\hline Organics, Semi-Volatile & 2,4-Dichlorophenol & SW 8270 & $\mathrm{ng} / \mathrm{Nm} 3$ & $<$ & 169 & $<$ & 153 & $<$ & 204 & $<$ & 176 & $\cdots$ & $100 \%$ \\
\hline Organics, Semi-Volatile & 2,4-Dimethylphenol & SW 8270 & $\mathrm{ng} / \mathrm{Nm} 3$ & $<$ & 420 & $<$ & 380 & $<$ & 467 & $<$ & 422 & $\ldots$ & $100 \%$ \\
\hline Organics, Semi-Volatile & 2,4-Dinitrophenol & SW 8270 & $\mathrm{ng} / \mathrm{Nm3}$ & $<$ & 2,674 & $<$ & 2,418 & $<$ & 1,502 & $<$ & 2,198 & $=$ & $100 \%$ \\
\hline Organics, Semi-Volatile & 2,4-Dinitrotoluene & SW 8270 & $\mathrm{ng} / \mathrm{Nm} 3$ & $<$ & 210 & $<$ & 190 & $<$ & 212 & $<$ & 204 & -- & $100 \%$ \\
\hline Organies, Semi-Volatile & 2,6-Dichlorophenol & SW 8270 & $n g / N m 3$ & $<$ & 276 & $<$ & 250 & $<$ & 184 & $<$ & 237 & - & $100 \%$ \\
\hline Organics, Semi-Volatile & 2,6-Dinitrotoluene & SW 8270 & $\mathrm{ng} / \mathrm{Nm} 3$ & $<$ & 132 & $<$ & 120 & $<$ & 309 & $<$ & 187 & -- & $100 \%$ \\
\hline Organics, Semi-Volatile & 2-Chloronaphthalene & SW 8270 & $\mathrm{ng} / \mathrm{Nm} 3$ & $<$ & 124 & $<$ & 112 & $<$ & 141 & $<$ & 126 & $\cdots$ & $100 \%$ \\
\hline Organics, Semi-Volatile & 2-Chlorophenol & SW 8270 & $\mathrm{ng} / \mathrm{Nm} 3$ & $<$ & 292 & $<$ & 264 & $<$ & 228 & $<$ & 261 & $-\cdot$ & $100 \%$ \\
\hline Organics, Semi-Volatile & 2-Methylnaphthalene & SW 8270 & $\mathrm{ng} / \mathrm{Nm} 3$ & $<$ & 252 & $<$ & 228 & $<$ & 131 & $<$ & 204 & -- & $100 \%$ \\
\hline Organics, Semi-Volatile & 2-Methylphenol(o-cresol) & SW 8270 & $\mathrm{ng} / \mathrm{Nm} 3$ & & 936 & & 3,524 & $<$ & 111 & & 1,505 & 4,478 & $1 \%$ \\
\hline Organics, Semi-Volatile & 2-Naphthylamine & SW 8270 & $\mathrm{ng} / \mathrm{Nm} 3$ & $<$ & 745 & $<$ & 674 & $<$ & 575 & $<$ & 665 & -- & $100 \%$ \\
\hline Organics, Semi-Volatile & 2-Nitroaniline & SW 8270 & $\mathrm{ng} / \mathrm{Nm} 3$ & $<$ & 154 & $<$ & 139 & $<$ & 238 & $<$ & 177 & -. & $100 \%$ \\
\hline Organics, Semi-Volatile & 2-Nitrophenol & SW 8270 & $\mathrm{ng} / \mathrm{Nm} 3$ & $<$ & 168 & $<$ & 152 & $<$ & 188 & $<$ & 169 & $\cdots$ & $100 \%$ \\
\hline Organics, Semi-Volatile & 2-Plcoline & SW 8270 & $\mathrm{ng} / \mathrm{Nm} 3$ & $<$ & 416 & $<$ & 377 & $<$ & 297 & $<$ & 363 & -- & $100 \%$ \\
\hline Organics, Seml-Volatile & 3,3'-Dlchlorobenzidine & SW 8270 & $\mathrm{ng} / \mathrm{Nm} 3$ & $<$ & 187 & $<$ & 169 & $<$ & 120 & $<$ & 159 & -- & $100 \%$ \\
\hline
\end{tabular}

ESP Inlet - Page 10 


\section{Gas Stream Data}

SAMPLE STREAM: ESP INLET

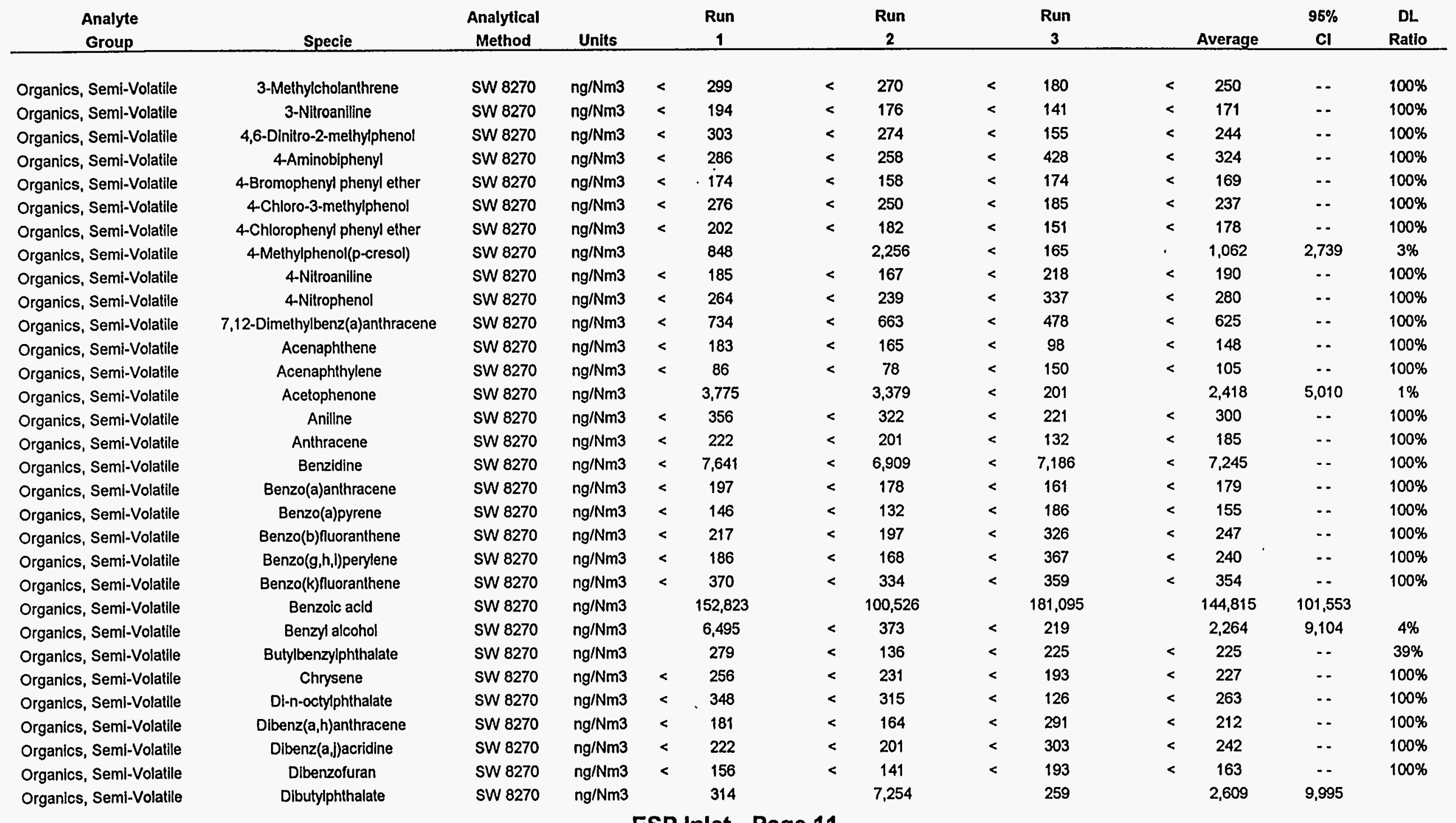


SAMPLE STREAM: ESP INLET

\begin{tabular}{|c|c|c|c|c|c|c|c|c|c|c|c|c|c|}
\hline $\begin{array}{l}\text { Analyte } \\
\text { Group }\end{array}$ & Specie & $\begin{array}{c}\text { Analytical } \\
\text { Method }\end{array}$ & Units & & $\begin{array}{c}\text { Run } \\
1 \\
\end{array}$ & & $\begin{array}{c}\text { Run } \\
2 \\
\end{array}$ & & $\begin{array}{c}\text { Run } \\
3 \\
\end{array}$ & & Average & $\begin{array}{c}95 \% \\
\mathrm{Cl} \\
\end{array}$ & $\begin{array}{c}\text { DL } \\
\text { Ratio }\end{array}$ \\
\hline Organics, Semi-Volatile & Dlethylphthalate & SW 8270 & $\mathrm{ng} / \mathrm{Nm} 3$ & & 353 & & 331 & $<$ & 185 & & 259 & 359 & $12 \%$ \\
\hline Organics, Semi-Volatile & Dimethylphthalate & SW 8270 & $\mathrm{ng} / \mathrm{Nm} 3$ & $<$ & 107 & $<$ & 97 & $<$ & 121 & $<$ & 108 & $\cdots$ & $100 \%$ \\
\hline Organics, Semi-Volatile & Diphenylamine & SW 8270 & $\mathrm{ng} / \mathrm{Nm} 3$ & $<$ & 202 & $<$ & 182 & $<$ & 100 & $<$ & 161 & $\cdots$ & $100 \%$ \\
\hline Organics, Semi-Volatile & Ethyl methanesulfonate & SW 8270 & $\mathrm{ng} / \mathrm{Nm} 3$ & $<$ & $\cdot 192$ & $<$ & 174 & $<$ & 244 & $<$ & 203 & $\cdots$ & $100 \%$ \\
\hline Organic's, Semi-Volatile & Fluoranthene & SW 8270 & ng/Nm3 & $<$ & 244 & $<$ & 220 & $<$ & 169 & $<$ & 211 & - & $100 \%$ \\
\hline Organics, Semi-Volalile & Fluorene & SW 8270 & $\mathrm{ng} / \mathrm{Nm} 3$ & $<$ & 128 & $<$ & 116 & $<$ & 137 & $<$ & 127 & $-\infty$ & $100 \%$ \\
\hline Organics, Semi-Volatile & Hexachlorobenzene & SW 8270 & $\mathrm{ng} / \mathrm{Nm} 3$ & $<$ & 89 & $<$ & 81 & $<$ & 113 & $<$ & 94 & $\cdots$ & $100 \%$ \\
\hline Organics, Semi-Volatile & Hexachlorobutadlene & SW 8270 & $\mathrm{ng} / \mathrm{Nm} 3$ & $<$ & 267 & $<$ & 241 & $<$ & 184 & $<$ & 231 & -- & $100 \%$ \\
\hline Organics, Semi-Volatile & Hexachlorocyclopentadiene & SW 8270 & $\mathrm{ng} / \mathrm{Nm} 3$ & $<$ & 3,408 & $<$ & 3,081 & $<$ & 2,116 & $<$ & $.2,869$ & -- & $100 \%$ \\
\hline Organics, Semi-Volatile & Hexachloroethane & SW 8270 & $\mathrm{ng} / \mathrm{Nm} 3$ & $<$ & 227 & $<$ & 205 & $<$ & 228 & $<$ & 220 & -- & $100 \%$ \\
\hline Organics, Semi-Volatile & Indeno(1,2,3-cd)pyrene & SW 8270 & $\mathrm{ng} / \mathrm{Nm} 3$ & $<$ & 201 & $<$ & 181 & $<$ & 478 & $<$ & 287 & -- & $100 \%$ \\
\hline Organics, Semi-Volatile & Isophorone & SW 8270 & $\mathrm{ng} / \mathrm{Nm} 3$ & $<$ & 110 & $<$ & 99 & $<$ & 221 & $<$ & 143 & $\cdots$ & $100 \%$ \\
\hline Organics, Semi-Volatile & Methyl methanesulfonate & SW 8270 & $\mathrm{ng} / \mathrm{Nm} 3$ & $<$ & 19,103 & $<$ & 17,273 & $<$ & 17,966 & $<$ & 18,114 & $\cdots$ & $100 \%$ \\
\hline Organics, Semi-Volatile & N-Nitrosodimethylamine & SW 8270 & $\mathrm{ng} / \mathrm{Nm} 3$ & $<$ & 508 & $<$ & 459 & $<$ & 282 & $<$ & 417 & $\cdots$ & $100 \%$ \\
\hline Organics, Semi-Volatile & N-Nitrosodiphenylamine & SW 8270 & $\mathrm{ng} / \mathrm{Nm} 3$ & $<$ & 216 & $<$ & 196 & $<$ & 97 & $<$ & 169 & $\cdots$ & $100 \%$ \\
\hline Organics, Semi-Volatile & N-Nitrosodipropylamine & SW 8270 & $\mathrm{ng} / \mathrm{Nm} 3$ & $<$ & 287 & $<$ & 259 & $<$ & 235 & $<$ & 260 & $\cdots$ & $100 \%$ \\
\hline Organics, Semi-Volatile & N-Nitrosopiperidine & SW 8270 & $\mathrm{ng} / \mathrm{Nm} 3$ & $<$ & 360 & $<$ & 326 & $<$ & 215 & $<$ & 300 & $\because$ & $100 \%$ \\
\hline Organics, Semi-Volatile & Naphthalene & SW 8270 & ng/Nm3 & & 894 & & 719 & & 1,085 & & 899 & 456 & \\
\hline Organics, Semi-Volatile & Nitrobenzene & SW 8270 & $\mathrm{ng} / \mathrm{Nm3}$ & $<$ & 202 & $<$ & 182 & $<$ & 303 & $<$ & 229 & $-\cdot$ & $100 \%$ \\
\hline Organics, Semi-Volatile & Pentachlorobenzene & SW 8270 & ng/Nm3 & $<$ & 169 & $<$ & 153 & $<$ & 134 & $<$ & 152 & $\cdots$ & $100.0 \%$ \\
\hline Organics, Semi-Volatile & Pentachloronitrobenzene & SW 8270 & $\mathrm{ng} / \mathrm{Nm} 3$ & $<$ & 791 & $<$ & 715 & $<$ & 496 & $<$ & 667 & $\cdots$ & $100 \%$ \\
\hline Organics, Semi-Volatile & Pentachlorophenol & SW 8270 & $n g / N m 3$ & $<$ & 330 & $<$ & 298 & $<$ & 319 & $<$ & 316 & $\cdots$ & $100 \%$ \\
\hline Organics, Semi-Volatile & Phenacetin & SW 8270 & $\mathrm{ng} / \mathrm{Nm} 3$ & $<$ & 206 & $<$ & 187 & $<$ & 139 & $<$ & 177 & -- & $100 \%$ \\
\hline Organics, Semi-Volatile & Phenanthrene & SW 8270 & $\mathrm{ng} / \mathrm{Nm} 3$ & $<$ & 238 & $<$ & 215 & $<$ & 168 & $<$ & 207 & $\cdots$ & $100 \%$ \\
\hline Organics, Seml-Volatile & Phenol & SW 8270 & $\mathrm{ng} / \mathrm{Nm} 3$ & & 3,236 & & 11,642 & & 10,169 & & 8,349 & 11,151 & \\
\hline Organics, Semi-Volatile & Pronamide & SW 8270 & $\mathrm{ng} / \mathrm{Nm} 3$ & $<$ & 282 & $<$ & 255 & $<$ & 87 & $<$ & 208 & $\cdots$ & $100 \%$ \\
\hline Organics, Semi-Volatile & Pyrene & SW 8270 & ng/Nm3 & $<$ & 179 & $<$ & 162 & $<$ & 147 & $<$ & 162 & $\cdots$ & $100 \%$ \\
\hline Organics, Semi-Volatile & Pyridine & SW 8270 & $\mathrm{ng} / \mathrm{Nm} 3$ & $<$ & 443 & $<$ & 401 & $<$ & 211 & $<$ & 352 & $\cdots$ & $100 \%$ \\
\hline Organics, Semi-Volatile & bis(2-Chloroethoxy)methane & SW 8270 & $\mathrm{ng} / \mathrm{Nm} 3$ & $<$ & 215 & $<$ & 194 & $<$ & 218 & $<$ & 209 & $\cdots$ & $100 \%$ \\
\hline
\end{tabular}

ESP Inlet - Page 12 


\section{Gas Stream Data}

SAMPLE STREAM: ESP INLET

\begin{tabular}{|c|c|c|c|c|c|c|c|c|c|c|c|c|c|}
\hline $\begin{array}{c}\text { Analyte } \\
\text { Group }\end{array}$ & Specie & $\begin{array}{c}\text { Analytical } \\
\text { Method }\end{array}$ & Units & & $\begin{array}{c}\text { Run } \\
1 \\
\end{array}$ & & $\begin{array}{c}\text { Run } \\
2 \\
\end{array}$ & & $\begin{array}{c}\text { Run } \\
3 \\
\end{array}$ & & Average & $\begin{array}{c}95 \% \\
\mathrm{Cl} \\
\end{array}$ & $\begin{array}{c}\text { DL } \\
\text { Ratio }\end{array}$ \\
\hline Organics, Semi-Volatile & bis(2-Chloroethyl)ether & SW 8270 & $\mathrm{ng} / \mathrm{Nm} 3$ & $<$ & 280 & $<$ & 253 & $<$ & 138 & $<$ & 223 & -. & $100 \%$ \\
\hline Organics, Semi-Volatile & bis(2-Chloroisopropyl)elher & SW 8270 & $\mathrm{ng} / \mathrm{Nm} 3$ & $<$ & 277 & $<$ & 251 & $<$ & 287 & $<$ & 272 & $\cdots$ & $100 \%$ \\
\hline Organics, Semi-Volatile & bis(2-Ethylhexyl)phthalate & SW 8270 & $\mathrm{ng} / \mathrm{Nm} 3$ & & 875 & & 1,199 & & 2,156 & & 1,410 & 1,655 & \\
\hline Organics, Semi-Volatile & p-Chloroaniline & SW 8270 & $\mathrm{ng} / \mathrm{Nm} 3$ & $<$ & 214 & $<$ & 193 & $<$ & 268 & $<$ & 225 & -. & $100 \%$ \\
\hline Organics, Semi-Volatile & p-Dimethylaminoazobenzene & SW 8270 & $\mathrm{ng} / \mathrm{Nm} 3$ & $<$ & 197 & $<$ & 178 & $<$ & 261 & $<$ & 212 & - & $100 \%$ \\
\hline Organics, Volatile & 1,1,1-Trichloroethane & SW 8240 & $\mathrm{ng} / \mathrm{Nm} 3$ & & 798 & & 589 & & 731 & & 706 & 265 & \\
\hline Organics, Volatile & 1,1,2,2-Tetrachloroethane & SW 8240 & $\mathrm{ng} / \mathrm{Nm} 3$ & $<$ & 532 & $<$ & 535 & $<$ & 535 & $<$ & 534 & - & $100 \%$ \\
\hline Organics, Volatile & 1,1,2-Trichloroethane & SW 8240 & $\mathrm{ng} / \mathrm{Nm} 3$ & $<$ & 532 & $<$ & 535 & $<$ & 535 & $<$ & 534 & $\cdots$ & $100 \%$ \\
\hline Organics, Volatile & 1,1-Dichloroethane & SW 8240 & $\mathrm{ng} / \mathrm{Nm} 3$ & $<$ & 532 & $<$ & 535 & $<$ & 535 & $<$ & 534 & -. & $100 \%$ \\
\hline Organics, Volatile & 1.1-Dichloroethene & SW 8240 & $\mathrm{ng} / \mathrm{Nm} 3$ & $<$ & 532 & $<$ & 535 & $<$ & 535 & $<$ & 534 & $\cdots$ & $100 \%$ \\
\hline Organics, Volatile & 1,2-Dichlorobenzene & SW 8240 & $\mathrm{ng} / \mathrm{Nm} 3$ & $<$ & 532 & $<$ & 535 & $<$ & 535 & $<$ & 534 & $\cdots$ & $100 \%$ \\
\hline Organics, Volatile & 1,2-Dichloroethane & SW 8240 & $\mathrm{ng} / \mathrm{Nm} 3$ & $<$ & 532 & $<$ & 535 & $<$ & 535 & $<$ & 534 & - & $100 \%$ \\
\hline Organics, Volatile & 1,2-Dichloropropane & SW 8240 & $\mathrm{ng} / \mathrm{Nm} 3$ & $<$ & 532 & $<$ & 535 & $<$ & 535 & $<$ & 534 & -. & $100 \%$ \\
\hline Organics, Volatile & 1,4-Dichlorobenzene & SW 8240 & $\mathrm{ng} / \mathrm{Nm} 3$ & $<$ & 532 & $<$ & 535 & $<$ & 535 & $<$ & 534 & $\cdots$ & $100 \%$ \\
\hline Organics, Volatile & 2-Butanone & SW 8240 & $\mathrm{ng} / \mathrm{Nm} 3$ & $<$ & 2,661 & $<$ & 2,677 & $<$ & 2,674 & $<$ & 2,671 & -. & $100 \%$ \\
\hline Organics, Volatile & 2-Hexanone & SW 8240 & $\mathrm{ng} / \mathrm{Nm} 3$ & $<$ & 2,661 & $<$ & 2,677 & $<$ & 2,674 & $<$ & 2,671 & $\cdots$ & $100 \%$ \\
\hline Organics, Volatile & 4-Methyl-2-Pentanone & SW 8240 & $\mathrm{ng} / \mathrm{Nm} 3$ & $<$ & 2,661 & $<$ & 2,677 & $<$ & 2,674 & $<$ & 2,671 & $\cdots$ & $100 \%$ \\
\hline Organics, Volatile & Acetone & SW 8240 & $\mathrm{ng} / \mathrm{Nm} 3$ & $<$ & 2,661 & & 45,690 & $<$ & 2,673 & & 16,119 & 63,622 & $6 \%$ \\
\hline Organics, Volatile & Benzene & SW 8240 & $\mathrm{ng} / \mathrm{Nm} 3$ & & 763 & & 1,125 & & 1,301 & & 1,063 & 682 & \\
\hline Organics, Volatile & Bromodichloromelhane & SW 8240 & $\mathrm{ng} / \mathrm{Nm} 3$ & $<$ & 532 & $<$ & 535 & $<$ & 535 & $<$ & 534 & -. & $100 \%$ \\
\hline Organics, Volatile & Bromoform & SW 8240 & $\mathrm{ng} / \mathrm{Nm} 3$ & $<$ & 532 & $<$ & 535 & $<$ & 535 & $<$ & 534 & -. & $100 \%$ \\
\hline Organics, Volatile & Bromomethane & SW 8240 & $\mathrm{ng} / \mathrm{Nm} 3$ & $<$ & 532 & $<$ & 535 & $<$ & 535 & $<$ & 534 & -. & $100 \%$ \\
\hline Organics, Volatile & Carbon Disulfide & SW 8240 & $\mathrm{ng} / \mathrm{Nm} 3$ & & 585 & & 18,917 & & 1,818 & & 7,107 & 25,456 & \\
\hline Organics, Volatile & Carbon Tetrachloride & SW 8240 & $\mathrm{ng} / \mathrm{Nm} 3$ & $<$ & 532 & $<$ & 535 & $<$ & 535 & $<$ & 534 & - & $100 \%$ \\
\hline Organics, Volatile & Chlorobenzene & SW 8240 & $\mathrm{ng} / \mathrm{Nm} 3$ & $<$ & 532 & $<$ & 535 & $<$ & 535 & $<$ & 534 & - & $100 \%$ \\
\hline Organics, Volatile & Chloroethane & SW 8240 & $n g / N m 3$ & $<$ & 532 & $<$ & 535 & $<$ & 535 & $<$ & 534 & $\cdots$ & $100 \%$ \\
\hline Organics, Volatile & Chloroform & SW 8240 & $\mathrm{ng} / \mathrm{Nm} 3$ & $<$ & 532 & $<$ & 535 & $<$ & 535 & $<$ & 534 & .. & $100 \%$ \\
\hline Organics, Volatile & Chloromethane & SW 8240 & $n g / N m 3$ & $<$ & 532 & $<$ & 535 & $<$ & 535 & $<$ & 534 & -. & $100 \%$ \\
\hline Organics, Volatile & Dibromochloromethane & SW 8240 & $n g / N m 3$ & $<$ & 532 & $<$ & 535 & $<$ & 535 & $<$ & 534 & $\cdots$ & $100 \%$ \\
\hline
\end{tabular}




\section{Gas Stream Data}

SAMPLE STREAM: ESP INLET

\begin{tabular}{|c|c|c|c|c|c|c|c|c|c|c|c|c|c|}
\hline $\begin{array}{c}\text { Analyte } \\
\text { Group }\end{array}$ & Specie & $\begin{array}{c}\text { Analytical } \\
\text { Method }\end{array}$ & Units & & $\begin{array}{c}\text { Run } \\
1\end{array}$ & & $\begin{array}{c}\text { Run } \\
2 \\
\end{array}$ & & $\begin{array}{c}\text { Run } \\
3 \\
\end{array}$ & & Average & $\begin{array}{c}96 \% \\
\mathrm{Cl} \\
\end{array}$ & $\begin{array}{c}\mathrm{DL} \\
\text { Ratio } \\
\end{array}$ \\
\hline Organics, Volatile & Ethyl Benzene & SW 8240 & $\mathrm{ng} / \mathrm{Nm} 3$ & $<$ & 532 & $<$ & 535 & $<$ & 535 & $<$ & 534 & .. & $100 \%$ \\
\hline Organics, Volatile & Methylene Chloride & SW 8240 & $\mathrm{ng} / \mathrm{Nm} 3$ & & 30,861 & & 67,992 & & 422,046 & & 173,633 & 536,447 & \\
\hline Organics, Volatile & Styrene & SW 8240 & $\mathrm{ng} / \mathrm{Nm} 3$ & $<$ & 532 & $<$ & 535 & $<$ & 535 & $<$ & 534 & .. & $100 \%$ \\
\hline Organics, Volatile & Tetrachloroethene & SW 8240 & $\mathrm{ng} / \mathrm{Nm3}$ & & 1,401 & & 857 & & 838 & & 1,032 & 795 & \\
\hline Organics, Volatile & Toluene & SW 8240 & $\mathrm{ng} / \mathrm{Nm} 3$ & & 585 & & 893 & & 2,139 & & 1,206 & 2,044 & \\
\hline Organics, Volatile & Trichloroethene & SW 8240 & $n g / N m 3$ & $<$ & 532 & $<$ & 535 & $<$ & 535 & $<$ & 534 & $\cdots$ & $100 \%$ \\
\hline Organics, Volatile & Trichlorofluoromethane & SW 8240 & $n g / N m 3$ & & 568 & & 5,746 & & 21,240 & & 9,185 & 26,724 & \\
\hline Organics, Volatile & Vinyl Acelate & SW 8240 & $\mathrm{ng} / \mathrm{Nm} 3$ & $<$ & 2,661 & $<$ & 2,677 & $<$ & 2,674 & $<$ & 2,671 & $\cdots$ & $100 \%$ \\
\hline Organics, Volatile & Vinyl Chloride & SW 8240 & $n g / N m 3$ & $<$ & 532 & $<$ & 535 & $<$ & 535 & $<$ & 534 & .. & $100 \%$ \\
\hline Organics, Volatile & cis-1,3-Dichloropropene & SW 8240 & $\mathrm{ng} / \mathrm{Nm} 3$ & $<$ & 532 & $<$ & 535 & $<$ & 535 & $<$ & 534 & $\cdots$ & $100 \%$ \\
\hline Organics, Volatile & m,p-Xylene & SW 8240 & $\mathrm{ng} / \mathrm{Nm} 3$ & $<$ & 532 & $<$ & 535 & $<$ & 535 & $<$ & 534 & $\cdots$ & $100 \%$ \\
\hline Organics, Volatile & O-Xylene & SW 8240 & $\mathrm{ng} / \mathrm{Nm} 3$ & $<$ & 532 & $<$ & 535 & $<$ & 535 & $<$ & 534 & $\cdots$ & $100 \%$ \\
\hline Organics, Volatile & trans-1,2-Dichloroethene & SW 8240 & $\mathrm{ng} / \mathrm{Nm} 3$ & $<$ & 532 & $<$ & 535 & $<$ & 535 & $<$ & 534 & $\cdots$ & $100 \%$ \\
\hline Organics, Volatile & trans-1,3-Dichloropropene & SW 8240 & $\mathrm{ng} / \mathrm{Nm} 3$ & $<$ & 532 & $<$ & 535 & $<$ & 535 & $<$ & 534 & $\cdots$ & $100 \%$ \\
\hline
\end{tabular}

Note: Shaded data has been invalidated due to particulate contamination of impinger solutions and was not used to calcualte average impinger concentrations. 


\section{Gas Stream Data}

SAMPLE STREAM: ESP OUTLET

\begin{tabular}{|c|c|c|c|c|c|c|c|c|c|c|c|c|}
\hline $\begin{array}{l}\text { Analyte } \\
\text { Group }\end{array}$ & Specie & $\begin{array}{c}\text { Analytical } \\
\text { Method }\end{array}$ & Units & $\begin{array}{c}\text { Run } \\
1 \\
\end{array}$ & & $\begin{array}{c}\text { Run } \\
2 \\
\end{array}$ & & $\begin{array}{c}\text { Run } \\
3 \\
\end{array}$ & & Average & $\begin{array}{c}85 \% \\
\mathrm{Cl} \\
\end{array}$ & $\begin{array}{c}\text { DL } \\
\text { Ratio }\end{array}$ \\
\hline Particulate Loading & & Grav & $\mathrm{g} / \mathrm{Nm3}$ & 0.1469 & & 0.1201 & & 0.1582 & & 0.1417 & 0.05 & \\
\hline Reducèd Species & Ammonla as $\mathrm{N}$ & EPA 350.1 & ug/Nm3 & 28.78 & & 31.84 & & 19.67 & & 27 & 16 & \\
\hline Reduced Specles & Hydrogen Cyanide & SW 9012 & $u g / N m 3$ & 0.17 & & 1.14 & & 1.47 & & 0.93 & 1.68 & \\
\hline Anions - Vapor Phase & Chloride & EPA 300.0 & ug/Nm3 & 148,560 & & 153,339 & & 104,650 & & 135,516 & 66,674 & \\
\hline Anions - Vapor Phase & Fluoride & EPA 340.2 & ug/Nm3 & 9,124 & & 7,899 & & 6,570 & & 7,865 & 3,174 & \\
\hline Anions - Vapor Phase & Sulfate & EPA 300.0 & ug/Nm3 & $7,279,750$ & & $7,109,346$ & & $6,176,702$ & & $6,855,266$ & $1,475,195$ & \\
\hline Anions - Particulate & Chlorlde & EPA 300.0 & $\mathrm{ug} / \mathrm{Nm} 3$ & 71.7 & & 61.7 & & 1.7 & & 45 & 94 & \\
\hline Anlons - Particulate & Fluoride & EPA 340.2 & ug/Nm3 & 0.22 & & 0.07 & & 0.06 & & 0.12 & 0.21 & \\
\hline Anions - Particulate & Sulfate & EPA 300.0 & ug/Nm3 & 3,875 & & 4,465 & & 4,304 & & 4,215 & 758 & \\
\hline Anions - Total & Chioride & EPA 300.0 & $u g / N m 3$ & 148,631 & & 153,400 & & 104,652 & & 135,561 & 66,765 & \\
\hline Anions - Total & Fluoride & EPA 340.2 & ug/Nm3 & 9,125 & & 7,899 & & 6,570 & & 7,865 & 3,174 & \\
\hline Anions - Total & Sulfate & EPA 300.0 & $u g / N m 3$ & $7,283,625$ & & $7,113,811$ & & $6,181,006$ & & $6,859,481$ & $1,474,900$ & \\
\hline Radionuclides & $\mathrm{K}-40 @ 1460 \mathrm{KeV}$ & EPA 901.1 & $\mathrm{pCl} / \mathrm{g}$ & 86 & & 61 & & 71 & & 73 & 31 & \\
\hline Part Metals by Wt & Aluminum & sW 6010 & $u g / g$ & 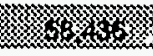 & 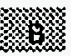 & 101,041 & B & 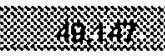 & 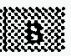 & 101,041 & -- & \\
\hline Part Metals by Wt & Antimony & ICP-MS & $\mathrm{ug} / \mathrm{g}$ & 2.474 & 0 & 2.992 & $\cdots$ & 2.770 & $* *$ & 2.745 & 0.65 & \\
\hline Part Metals by.Wt & Arsenic & SW 7060 & $\mathrm{ug} / \mathrm{g}$ & 95.69 & B & 134 & $\mathbf{B}$ & 122.22 & $B$ & 117 & 48 & \\
\hline Part Melals by Wt & Barlum & SW 6010 & $u g / g$ & so & 8 & 618 & B & 絁滋 & 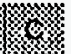 & 618 & -. & \\
\hline Part Metals by Wt & Beryllium & SW 6010 & ug/g & $x$ & 8 裙 & 14 & B & 信 & 䋞 & 14 & -- & \\
\hline Part Metals by Wt & Boron & SW 6010 & ug/g & - & & - & & - & & - & - & \\
\hline Part Melals by Wt & Cadmium & SW 7131 & $\mathrm{ug} / \mathrm{g}$ & \% & \% & 8.91 & B & 4 & \% & 8.91 & -- & \\
\hline Part Metals by Wt & Calclum & SW 6010 & ug/g & 桨40 & 8 & 14,791 & B & 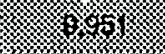 & K & 14,791 & - & \\
\hline Part Metals by Wt & Chromium & SW 6010 & ug/g & \% & 喽 & 192 & B & 䋇 & 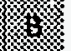 & 192 & $\cdots$ & \\
\hline Part Metals by Wt & Cobalt & SW 6010 & $\mathrm{ug} / \mathrm{g}$ & (7x) & 翟 & 37 & B & 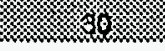 & 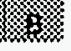 & 37 & -- & \\
\hline Part Metals by Wt & Copper & SW 6010 & $\mathrm{ug} / \mathrm{g}$ & 109 & B & 132 & B & 106 & B & 116 & 35 & \\
\hline Part Metals by Wt & Iron & SW 6010 & $\mathrm{ug} / \mathrm{g}$ & 59,773 & B & 66,900 & $B$ & 55,621 & B & 60,765 & 14,172 & \\
\hline \multicolumn{13}{|c|}{ ESP Outlet - Page 1} \\
\hline
\end{tabular}


SAMPLE STREAM: ESP OUTLET

\begin{tabular}{|c|c|c|c|c|c|c|c|c|c|c|c|c|}
\hline $\begin{array}{c}\text { Analyte } \\
\text { Group }\end{array}$ & Specie & $\begin{array}{c}\text { Analytical } \\
\text { Method }\end{array}$ & Units & $\begin{array}{c}\text { Run } \\
1 \\
\end{array}$ & & $\begin{array}{c}\text { Run } \\
2 \\
\end{array}$ & & $\begin{array}{c}\text { Run } \\
3 \\
\end{array}$ & & Average & $\begin{array}{r}95 \% \\
\mathrm{Cl} \\
\end{array}$ & $\begin{array}{c}\text { DL } \\
\text { Ratlo }\end{array}$ \\
\hline Part Metals by Wt & Lead & SW 7421 & ug/g' & (x) & 梦 & 153 & B & 姳 & 26 & 153 & - & \\
\hline Part Metals by Wt & Magneslum & SW 6010 & $u g / g$ & 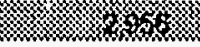 & 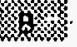 & 5,471 & $\mathbf{B}$ & 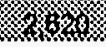 & 㱍 & 5,471 & - & \\
\hline Part Metals by Wt & Manganese & SW 6010 & $u g / g$ & 242 & B & 271 & B & 216 & 8 & 243 & 68 & \\
\hline Part Metals by Wt & Mercury & SW 7471 & ug/g & 0.77 & B & 1.01 & B & 0.90 & B & 0.90 & 0.30 & \\
\hline Part Metals by Wt & Molybdenum & SW 6010 & $u g / g$ & 53.71 & B & 72 & B & 48.78 & B & 58 & 31 & \\
\hline Part Metals by Wt & Nickel & SW 6010 & $u g / g$ & 147 & B & 167 & B & 155 & $B$ & 157 & 25 & \\
\hline Part Metals by Wt & Phosphorus & SW 6010 & $u g / g$ & 86 & 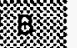 & 830 & B & 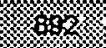 & kn & 830 & - & \\
\hline Part Metals by Wt & Potassium & SW 6010 & $u g / g$ & 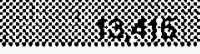 & 䋞 & 17,893 & B & 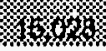 & 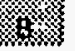 & 17,893 & - & \\
\hline Part Metals by Wt & Selenlum & SW 7740 & ug/g & 970.70 & B & 366 & B & 383.66 & B & 574 & 855 & \\
\hline Part Metals by Wt & Sodium & SW 6010 & ug/g & $4 x$ & 栘 & 6,683 & B & \% & x & 6,683 & - & \\
\hline Part Metals by Wt & Stronlium & SW 6010 & úg/g & 然泣. & \% & 361 & B & 1. & . & 361 & - & \\
\hline Part Metals by Wt & Titanium & SW 6010 & $u g / g$ & 4,710 & B & 5,983 & B & 5,446 & B & 5,380 & 1,587 & \\
\hline Part Metals by Wt & Vanadium & SW 6010 & ug/g & 349.83 & B & 422 & B & 369.32 & B & 381 & 93 & \\
\hline Part Metals by Wt & Zine & SW 6010 & ug/g & 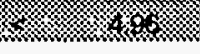 & 校 & 903 & B & . & (x) & 903 & - & \\
\hline Part Metals by Vol & Aluminum & SW 6010 & $u g / N m 3$ & 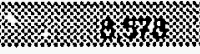 & 的 & 12,141 & B & 6 & 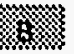 & 12,141 & - & \\
\hline Part Metals by Vol & Antimony & ICP-MS & ug/Nm3 & 0.363 & & 0.359 & & 0.438 & & 0.387 & 0.110 & \\
\hline Part Metals by Vol & Arsenic & SW 7060 & $\mathrm{ug} / \mathrm{Nm} 3$ & 14.05 & B & 16 & B & 19.33 & B & 16 & 6.63 & \\
\hline Part Metals by Vol & Barium & SW 6010 & ug/Nm3 & \% & 柆 & 74 & B & 6 & 的 & 74 & - & \\
\hline Part Metals by Vol & Beryllium & SW 6010 & $\mathrm{ug} / \mathrm{Nm} 3$ & 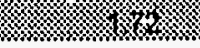 & 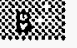 & 1.65 & B & 紋镂 & \% & 1.65 & -- & \\
\hline Part Metals by Vol & Boron & & & $-\infty$ & & - & & $-\infty$ & & - & - & \\
\hline Part Metals by Vol & Cadmium & SW 7131 & $u g / N m 3$ & . & 玟 & 1.07 & B & 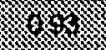 & 器 & 1.07 & - & \\
\hline Part Metals by Vol & Cạlclum & SW 6010 & $\mathrm{ug} / \mathrm{Nm} 3$ & Fing & 6 & 1,777 & B & 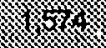 & 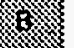 & 1,777 & - & \\
\hline Part Metals by Vol & Chromlum & SW 6010 & $\mathrm{ug} / \mathrm{Nm3}$ & 慈 & 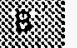 & 23 & B & x & 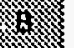 & 23 & - & \\
\hline Part Metals by Vol & Cobalt & SW 6010 & ug/Nm3 & in & 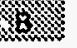 & 4.45 & B & . & $\ldots$ & 4.45 & - & \\
\hline Part Metals by Vol & Copper & SW 6010 & ug/Nm3 & 16 & B & 16 & B & 17 & B & 16 & 1.20 & \\
\hline Part Metals by Vol & Iron & SW 6010 & ug/Nm3 & 8,774 & B & 8,039 & B & 8,798 & $\mathbf{B}$ & 8,537 & 1,073 & \\
\hline Part Metals by Vol & Lead & SW 7421 & ug/Nm3 & \% & 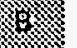 & 18 & B & \% & 1 & 18 & - & \\
\hline Part Metals by Vol & Magneslum & SW 6010 & $\mathrm{ug} / \mathrm{Nm} 3$ & (x) & s & 657 & B & 鷀 & $\ldots$ & 657 & - & \\
\hline Part Metals by Vol & Manganese & SW 6010 & ug/Nm3 & 35.55 & B & 33 & B & 34.21 & B & 34 & 3.74 & \\
\hline Part Metals by Vol & Mercury & SW 7471 & $\mathrm{ug} / \mathrm{Nm} 3$ & 0.11 & B & 0.12 & B & 0.14 & B & 0.13 & 0.04 & \\
\hline
\end{tabular}

\section{ESP Outlet - Page 2}




\section{Gas Stream Data}

SAMPLE STREAM: ESP OUTLET

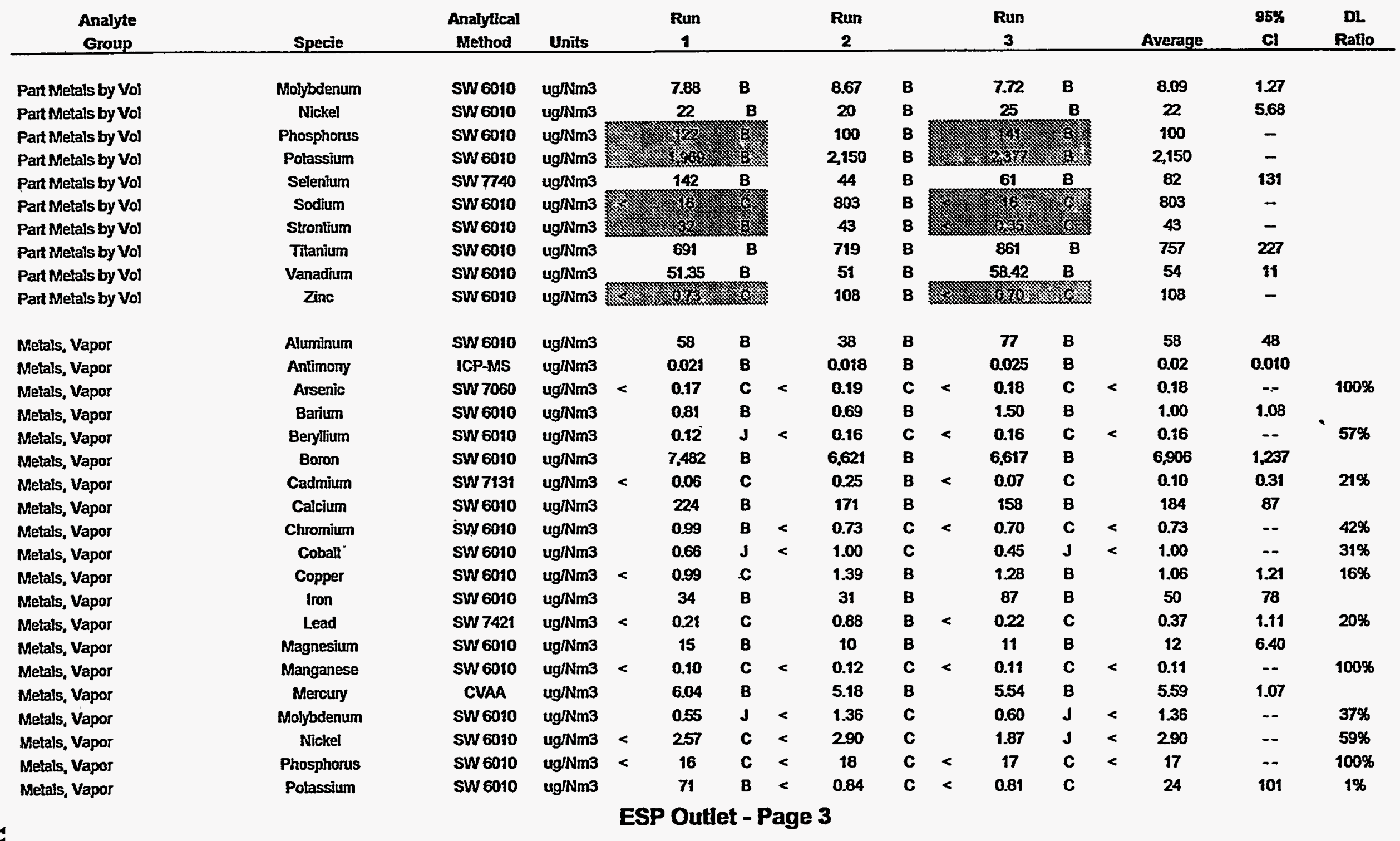




\section{Gas Stream Data}

SAMPLE STREAM: ESP OUTLET

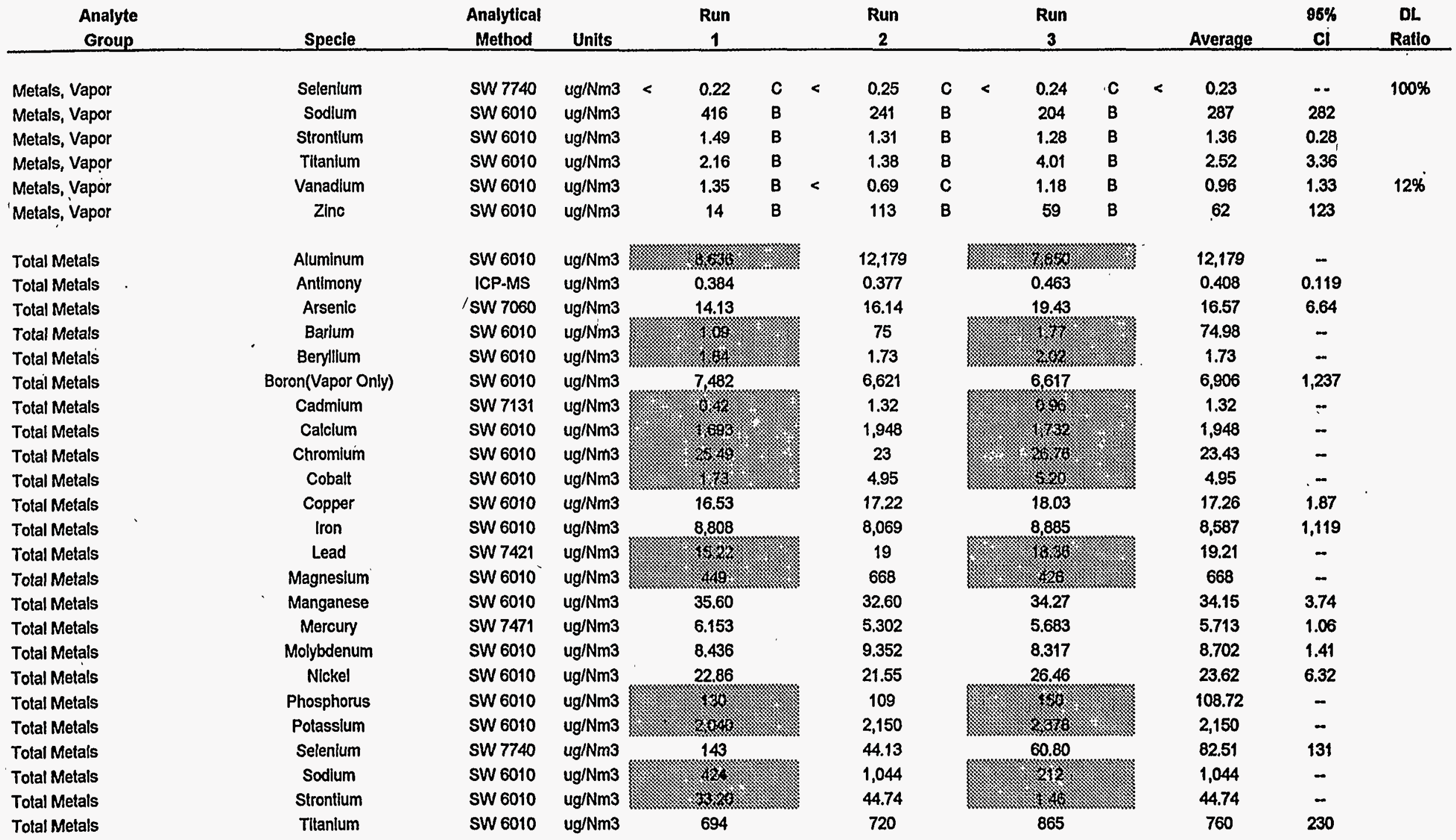

ESP Outlet - Page 4 


\section{Gas Stream Data}

SAMPLE STREAM: ESP OUTLET

\begin{tabular}{|c|c|c|c|c|c|c|c|c|c|c|c|c|}
\hline $\begin{array}{c}\text { Analyte } \\
\text { Group }\end{array}$ & Specle & $\begin{array}{c}\text { Analytical } \\
\text { Method }\end{array}$ & Units & & $\begin{array}{c}\text { Run } \\
1 \\
\end{array}$ & $\begin{array}{c}\text { Run } \\
2 \\
\end{array}$ & & $\begin{array}{c}\text { Run } \\
3 \\
\end{array}$ & & Average & $\begin{array}{c}96 \% \\
\mathrm{Cl} \\
\end{array}$ & $\begin{array}{c}\text { DL } \\
\text { Ratio }\end{array}$ \\
\hline Total Metals & Vanadium & SW 6010 & ug/Nm3 & & 52.70 & 51.11 & & 59.60 & & 54.47 & 11 & \\
\hline Total Metals & Zlnc & SW 6010 & ug/Nm3 & & ma & 221 & & 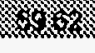 & & 221.22 & - & \\
\hline Hg Vapor, Bloom & Mercury, Elemental & CVAFS & ug/Nm3 & & 2.52 & 2.60 & & 2.38 & & 2.50 & 0.28 & \\
\hline Hg Vapor, Bloom & Mercury II & CVAFS & ug/Nm3 & & 5.07 & 3.78 & & 3.64 & & 4.16 & 1.96 & \\
\hline Hg Vapor, Bloom & Mercury, Methyt & CVAFS & ug $/ \mathrm{Nm} 3$ & & 0.72 & 0.75 & & 0.42 & & 0.63 & 0.45 & \\
\hline Hg Vapor, Bloom & Mercury, Total & CVAFS & $\mathrm{ug} / \mathrm{Nm} 3$ & & 8.32 & 7.14 & & 6.43 & & 7.30 & 2.36 & \\
\hline Extract Metals, Nitric & Antimony & ICP-MS & $u g / g$ & & 4.790 & 2.379 & & 2.471 & & 3.21 & 3.39 & \\
\hline Extract Metals, Niltric & Arsenic & ICP-MS & ug/g & & 94 & 116 & & 85 & & 98.39 & 39.98 & \\
\hline Extract Metals, Nitric & Barium & ICP.MS & ug/g & & 316 & 322 & & 315 & & 318 & 8.38 & \\
\hline Extract Metals, Nitric & Beryllium & ICP-MS & $\mathrm{ug} / \mathrm{g}$ & & 3.992 & 8.127 & & 4.183 & & 5.43 & 5.80 & \\
\hline Extract Metals, Nitric & Boron & ICP-MS & $\mathrm{ug} / \mathrm{g}$ & & 2413 & 1987 & & 1430 & & 1,943 & 1,225 & \\
\hline Extract Melals, Nitric & Cadmium & ICP-MS & $\mathrm{ug} / \mathrm{g}$ & & 14 & 13 & & 1.521 & & 9.79 & 17.83 & \\
\hline Extract Metals, Nitric & Chromium & ICP-MS & ug/g & & 92 & 54 & & 47 & & 64 & 61 & \\
\hline Extract Metals, Nitric & Cobalt & ICP-MS & ug/g & & 18 & 18 & & 15 & & 17 & 3.76 & \\
\hline Extract Metals, Nitric & Copper & ICP-MS & $\mathrm{ug} / \mathrm{g}$ & & 113 & 91 & & 91 & & 98 & 32 & \\
\hline Extract Metals, Nitric & Lead & ICP-MS & $\mathrm{ug} / \mathrm{g}$ & & 126 & 120 & & 102 & & 116 & 31 & \\
\hline Extract Metals, Nitric & Manganese & ICP-MS & $u g / g$ & & 2,584 & 197 & & 132 & & 971 & 3,471 & \\
\hline Extract Metals, Nitric & Mercury & ICP-MS & ug/g & & 8.782 & 1.784 & $<$ & 1.853 & & 3.83 & 10.71 & $8 \%$ \\
\hline Extract Metals, Nitric & Molybdenum & ICP.MS & ug/g & & 72 & 80 & & 64 & & 72 & 21 & \\
\hline Extract Metals, Nitric & Nickel & ICP-MS & $\mathrm{ug} / \mathrm{g}$ & & 95 & 93 & & 63 & & 84 & 46 & \\
\hline Extract Metals, Nitric & Selenium & ICP-MS & $u g / g$ & $<$ & 24 & 24 & $<$ & 23 & $<$ & 23.26 & -. & $100 \%$ \\
\hline Extract Metals, Nitric & Vanadlum & ICP-MS & ug/g & & 325 & 339 & & 152 & & 272 & 259 & \\
\hline Extract Metals, Gastric & Antimany & ICP-MS & $u g / g$ & & 1.024 & 0.769 & & 1.068 & & 0.95 & 0.40 & \\
\hline Extract Metals, Gastric & Arsenic & ICP-MS & $\mathrm{ug} / \mathrm{g}$ & $<$ & 0.668 & 0.629 & $<$ & 0.684 & $<$ & 0.66 & -- & $100 \%$ \\
\hline Extract Metals, Gastric & Barlum & ICP-MS & $\mathrm{ug} / \mathrm{g}$ & & 115 & 129 & & 132 & & 125 & 22 & \\
\hline Extract Metals, Gastric & Beryllium & ICP-MS & $\mathrm{ug} / \mathrm{g}$ & & 2.829 & 2.909 & & 2.416 & & 2.72 & 0.66 & \\
\hline Extract Metals, Gastric & Boron & ICP-MS & $u g / g$ & & 861 & 792 & & 814 & & 822 & 88 & \\
\hline Extract Metals, Gastric & Cadmium & ICP-MS & $u g / g$ & & 4.803 & 7.294 & & 5.486 & & 5.86 & 3.20 & \\
\hline
\end{tabular}




\section{Gas Stream Data}

SAMPLE STREAM: ESP OUTLET

\begin{tabular}{|c|c|c|c|c|c|c|c|c|c|c|}
\hline $\begin{array}{c}\text { Analyte } \\
\text { Group }\end{array}$ & Specie & $\begin{array}{c}\text { Analytical } \\
\text { Method }\end{array}$ & Units & $\begin{array}{c}\text { Run } \\
1 \\
\end{array}$ & $\begin{array}{c}\text { Run } \\
2 \\
\end{array}$ & $\begin{array}{c}\text { Run } \\
3 \\
\end{array}$ & & Average & $\begin{array}{c}96 \% \\
\text { CI } \\
\end{array}$ & $\begin{array}{c}\text { DL } \\
\text { Ratio }\end{array}$ \\
\hline Extract Metals, Gastric & Chromium & ICP-MS & ug/g & 52 & $6 \dot{3}$ & 49 & & 54 & 18 & \\
\hline Extract Metals, Gastric & Cobalt & ICP-MS & $u g / g$ & 5.432 & 6.286 & 4.678 & & 5.47 & 2.00 & \\
\hline Extract Metals, Gastric & Copper & ICP-MS & ug/g & 36 & 36 & 29 & & 33 & 9.29 & \\
\hline Extract Metals, Gastric & Lead & ICP-MS & ug/g & 34 & 35 & 30 & & 33 & 7.07 & \\
\hline Extract Metals, Gastric & Manganese & ICP-MS & $\mathrm{ug} / \mathrm{g}$ & 49 & 48 & 41 & & 46 & 10.69 & \\
\hline Extract Metals, Gastric & Mercury & ICP.MS & ug/g & 0.479 & 0.345 & 0.318 & & 0.38 & 0.22 & \\
\hline Extract Metals, Gastric & Molybdenum & ICP-MS & ug/g & 62 & 66 & 56 & & 61 & 11.70 & \\
\hline Extract Metals, Gastric & Nickel & ICP-MS & ug/g & 38 & 47 & 30 & & 38 & 22 & \\
\hline Extract Metals, Gastric & Selenium & ICP-MS & ug/g & 17 & 21 & 16 & & 18 & 6.83 & \\
\hline Extract Metals, Gastric & Vanadium & ICP-MS & $\mathrm{ug} / \mathrm{g}$ & 127 & 152 & 89 & & 122.27 & 78.53 & \\
\hline Extract Metals, Acetic & Antimony & ICP-MS & ug/g & 1.023 & 0.882 & 0.721 & & 0.88 & 0.38 & \\
\hline Extract Metals, Acetic & Arsenic & ICP-MS & ug/g & 5.183 & 2.711 & 2.250 & & 3.38 & 3.92 & \\
\hline Extract Metals, Acetic & Barium & ICP-MS & ug/g & 45 & 38 & 49 & & 44.11 & 13.44 & \\
\hline Extract Metals, Acetlc & Beryllium & ICP-MS & $u g / g$ & 1.197 & 0.976 & 0.769 & & 0.98 & 0.53 & \\
\hline Extract Metals, Acetic & Boron & ICP-MS & ug/g & 779 & 1000 & 942 & & 907 & 284 & \\
\hline Extract Metals, Acetic & Cadmium & ICP-MS & ug/g & 3.243 & 22 & 3.394 & & 9.57 & 26.91 & \\
\hline Extract Metals, Acellć & Chromium & ICP-MS & ug/g & 21 & . 21 & 16 & & 19.47 & 7.19 & \\
\hline Extract Metals, Acetlc & Cobalt & ICP.MS & ug/g & 4.566 & 9.437 & 4.058 & & 6.02 & 7.38 & \\
\hline Extract Metals, Acetlc & Copper & ICP-MS & ug/g & 19 & 19 & 16 & & 17.90 & 4.94 & \\
\hline Extract Metals, Acetlc & Lead & ICP-MS & $u g / g$ & 1.950 & 1.220 & 1.317 & & 1.50 & 0.98 & \\
\hline Extract Metals, Acetic & Manganese & ICP-MS & ug/g & 39 & 43 & 36 & & 39 & 8.45 & \\
\hline Extract Metals, Acetlc & Mercury & ICP-MS & ug/g & 0.309 & 0.019 & 0.077 & J & 0.13 & 0.38 & \\
\hline Extract Metals, Acetic & Molybdenum & ICP-MS & ug/g & 9.913 & 1.379 & 2.010 & & 4.43 & 11.81 & . \\
\hline Extract Metals, Acetic & Nickel & ICP-MS & ug/g & 22 & 23 & 23 & & 23 & 1.03 & \\
\hline Extract Metals, Acetic & Selenium & ICP-MS & ug/g & 3.938 & 2.786 & 5.471 & & 4.07 & 3.35 & \\
\hline Extract Metals, Acetic & Vanadium & ICP-MS & $u g / g$ & 9.440 & 2.758 & 1.856 & & 4.68 & 10.29 & \\
\hline Metals by Size, $>10$ um & Aluminum & SW 6010 & ug/g & 70,100 & 66,700 & 79,300 & & 72,033 & 16,195 & \\
\hline Metals by Stze, $>10$ um & Antimony & ICP-MS & $u g / g$ & 3.58 & 2.74 & 3.17 & & 3.17 & 1.04 & \\
\hline Metals by Size, $>10$ um & Arsenlc & SW 7060 & ug/g & 58 & 41 & 49 & & 49 & 21 & \\
\hline
\end{tabular}




\section{Gas Stream Data}

SAMPLE STREAM: ESP OUTLET

\begin{tabular}{|c|c|c|c|c|c|c|c|c|c|}
\hline $\begin{array}{c}\text { Analyte } \\
\text { Group }\end{array}$ & Specie & $\begin{array}{c}\text { Analytical } \\
\text { Method }\end{array}$ & Units & $\begin{array}{c}\text { Run } \\
1 \\
\end{array}$ & $\begin{array}{c}\text { Run } \\
2 \\
\end{array}$ & $\begin{array}{c}\text { Run } \\
3 \\
\end{array}$ & Average & $\begin{array}{c}96 \% \\
\mathrm{Cl} \\
\end{array}$ & $\begin{array}{c}\text { DL } \\
\text { Ratio } \\
\end{array}$ \\
\hline Metals by Size, > 10 um & Barium & SW 6010 & ug/g & 409 & 347 & 424 & 393 & 101 & \\
\hline Metals by Size, $>10$ um & Beryllium & SW 6010 & ug/g & 18 & 4.04 & 8.05 & 10 & 18 & \\
\hline Metals by Size, $>10$ um & Cadmium & SW 7131 & ug/g & 4.03 & 2.76 & 4.03 & 3.61 & 1.82 & \\
\hline Metals by Size, $>10$ um & Calclum & SW 6010 & $u g / g$ & 15,800 & 12,800 & 13,500 & 14,033 & 3,899 & \\
\hline Metals by Size, $>10$ um & Chromium & SW 6010 & $\mathbf{u g} / \mathrm{g}$ & 197 & 219 & 223 & 213 & 35 & \\
\hline Metals by Size $>10$ um & Cobalt & SW 6010 & ug/g & 40 & 26 & 30 & 32 & 18 & \\
\hline Metals by Size, $>10$ um & Copper & SW 6010 & $u g / g$ & 117 & 94 & 94 & 102 & 33 & \\
\hline Metals by Size, $>10$ um & Iron & SW 6010 & $\mathrm{ug} / \mathrm{g}$ & 95,000 & 203,000 & 169,000 & 155,667 & 137,187 & \\
\hline Metals by Size, $>10$ um & Lead & SW 7421 & $\mathrm{ug} / \mathrm{g}$ & 86 & 62 & 68 & 72 & 31 & \\
\hline Metals by Size,$>10$ um & Magnesium & SW 6010 & ug/g & 3,000 & 3,920 & 4,270 & 3,730 & 1,630 & \\
\hline Metals by Size, $>10$ um & Manganese & SW 6010 & ug/g & 299 & 1,160 & 723 & 727 & 1,070 & \\
\hline Metals by Size, $>10$ um & Mercury & SW 7471 & ug/g & 0.59 & 0.60 & 0.45 & 0.55 & 0.21 & \\
\hline Metals by Size $>10$ um & Molybdenum & SW 6010 & ug/g & 46 & 37 & 47 & 43 & 13 & \\
\hline Metals by Size $>10$ um & Nickel & SW 6010 & ug $/ g$ & 174 & 105 & 109 & 129 & 96 & \\
\hline Metals by Size,$>10$ um & Phosphorus & SW 6010 & ug/g & 71 & 71 & 71 & 71 & $\cdots$ & $100 \%$ \\
\hline Metals by Size, $>10 \mathrm{um}$ & Potassium & SW 6010 & ug/g & 15,500 & 13,300 & 15,000 & 14,600 & 2,865 & \\
\hline Metals by Size $>10 \mathrm{um}$ & Selenium & SW 7740 & ug/g & 76 & 245 & 153 & 158 & 210 & \\
\hline Metals by Size $>10$ um & Silicon & SW 6010 & ug/g & 207,000 & 145,000 & 174,000 & 175,333 & 77,068 & \\
\hline Metals by Size, $>10$ um & Sodlum & SW 6010 & ug/g & 7,310 & 4,640 & 4,450 & 5,467 & 3,973 & \\
\hline Metals by Size, $>10$ um & Strontium & SW 6010 & ug/g & 309 & 267 & 305 & 294 & 58 & \\
\hline Metals by Slze, > 10 um & Titanium & SW 6010 & ug/g & 6,170 & 4,640 & 4,940 & 5,250 & 2,014 & \\
\hline Metals by Size, $>10$ um & Vanadlum & SW 6010 & ug/g & 340 & 247 & 272 & 286 & 120 & \\
\hline Metals by Slze, $>10 \mathrm{um}$ & Zinc & SW 6010 & $u g / g$ & 517 & 346 & 378 & 414 & 226 & \\
\hline Metals by Size, 10 - 3 um & Aluminum & SW 6010 & $u g / g$ & 75,800 & 119,000 & 120,000 & 104,933 & 62,693 & \\
\hline Metals by Size, $10-3$ um & Antimony & ICP-MS & ug/g & 8.95 & 8.65 & 8.12 & 8.57 & 1.05 & \\
\hline Metals by Size, $10-3$ um & Arsenlc & SW 7060 & $\mathrm{ug} / \mathrm{g}$ & 132 & 124 & 125 & 127 & 11 & \\
\hline Metals by Size, $10-3$ um & Barium & SW 6010 & $u g / g$ & 603 & 668 & 616 & 629 & 85 & \\
\hline Metals by Size, $10-3$ um & Berylllum & SW 6010 & ug/g & 25 & 15 & 15 & 18 & 15 & \\
\hline Metals by Size, $10-3$ um & Cadmlum & SW 7131 & ug/g & 12 & 10 & 10 & 11 & 2.39 & \\
\hline Metals by Size, $10-3$ um & Calclum & SW 6010 & $u g / g$ & 13,500 & 14,700 & 13,700 & 13,967 & 1,597 & \\
\hline
\end{tabular}


SAMPLE STREAM: ESP OUTLET

\begin{tabular}{|c|c|c|c|c|c|c|c|c|c|}
\hline $\begin{array}{c}\text { Analyte } \\
\text { Group }\end{array}$ & Specie & $\begin{array}{c}\text { Analytical } \\
\text { Method }\end{array}$ & Units & $\begin{array}{c}\text { Run } \\
1 \\
\end{array}$ & $\begin{array}{c}\text { Run } \\
2 \\
\end{array}$ & $\begin{array}{c}\text { Run } \\
3 \\
\end{array}$ & Average & $\begin{array}{c}95 \% \\
\mathrm{Cl} \\
\end{array}$ & $\begin{array}{c}\text { DL } \\
\text { Ratio }\end{array}$ \\
\hline Metals by Size, 10 - 3 um & Chromlum & SW 6010 & $u g / g$ & 282 & 297 & 246 & 275 & 65 & \\
\hline Metals by Size, $10-3$ um & Cobalt & SW 6010 & ug/g & 50 & 55 & 48 & 51 & 10 & \\
\hline Metals by Size, $10-3$ um & Copper & SW 6010 & ug/g & 165 & 187 & 157 & 170 & 39 & \\
\hline Metals by Size, $10-3$ um & Iron & SW 6010 & $u g / g$ & 60,900 & 69,600 & 58,700 & 63,067 & 14,320 & \\
\hline Metals by Size, $10-3$ um & Lead & SW 7421 & ug/g & 193 & 190 & 189 & 191 & 5.17 & \\
\hline Metals by Size, $10-3$ um & Magnesium & SW 6010 & ug/g & 3,190 & 6,600 & 5,100 & 4,963 & 4,246 & \\
\hline Metals by Size, $10-3$ um & Manganese & SW 6010 & $u g / g$ & 253 & 334 & 255 & 281 & 115 & \\
\hline Metals by Size, $10-3$ um & Mercury & SW 7471 & ug/g & 0.76 & 0.48 & 0.36 & 0.48 & -- & $18 \%$ \\
\hline Metals by Slze, $10-3$ um & Molybdenum & SW 6010 & $u g / g$ & 90 & 80 & 70 & 80 & 25 & \\
\hline Metals by Size, $10-3$ um & Nickel & SW 6010 & ug/g & 245 & 192 & 197 & 211 & 73 & \\
\hline Metals by Size, $10-3$ um & Phosphorus & SW 6010 & $u g / g$ & 193 & 220 & 272 & 228 & 100 & \\
\hline Metals by Size, $10-3$ um & Polassium & SW 6010 & $u g / g$ & 18,500 & 24,300 & 21,100 & 21,300 & 7,217 & - \\
\hline Metals by Size, $10-3$ um & Selenium & SW 7740 & $\mathbf{u g} / \mathrm{g}$ & 58 & 46 & 31 & 45 & 33 & \\
\hline Metals by Size, $10-3$ um & Sillicon & SW 6010 & $u g / g$ & 211,000 & 227,000 & 216,000 & 218,000 & 20,335 & \\
\hline Melals by Size, $10-3$ um & Sodium & SW 6010 & $u g / g$ & 8,080 & 8,420 & 7,280 & 7,927 & 1,454 & \\
\hline Metals by Size, $10-3$ um & Strontium & SW 6010 & $u g / g$ & 319 & 413 & 363 & 365 & 117 & \\
\hline Metals by Size, $10-3$ um & Titanlum & SW 6010 & $u g / g$ & 6,540 & 7,220 & 6,810 & 6,857 & 851 & \\
\hline Metals by Size, $10-3$ um & Vanadlum & SW 6010 & ug/g & 505 & 548 & 475 & 509 & 91 & \\
\hline Metals by Size, $10-3$ um & Zinc & SW 6010 & ug/g & 1,090 & 1,120 & 1,030 & 1,080 & 114 & \\
\hline Metals by Size, < 3 um & Aluminum & SW 6010 & $\mathrm{ug} / \mathrm{g}$ & 123,000 & 125,000 & 117,000 & 121,667 & 10,343 & \\
\hline Metals by Size, $<3$ um & Antimony & ICP-MS & $u g / g$ & 13.10 & 13.78 & 13.17 & 13 & .0 .94 & \\
\hline Metals by Size, < 3 um & Arsenic & sW 7060 & $u g / g$ & 183 & 198 & 226 & 202 & 54 & \\
\hline Metals by Size, < 3 um & Barium & SW 6010 & $\mathrm{ug} / \mathrm{g}$ & 773 & 782 & 719 & 758 & 85 & \\
\hline Metals by Size, < 3 um & Beryllium & SW 6010 & $\mathrm{ug} / \mathrm{g}$ & 14 & 14 & 18 & 15 & 5.02 & \\
\hline Metals by Size, < 3 um & Cadmium & SW 7131 & $\mathrm{ug} / \mathrm{g}$ & 23 & 23 & 17 & 21 & 8.04 & \\
\hline Metals by Size, $<3$ um & Calcium & SW 6010 & $\mathrm{ug} / \mathrm{g}$ & 17,100 & 16,000 & 15,400 & 16,167 & 2,142 & \\
\hline Metals by Size, < 3 um & Chromium & SW 6010 & $\mathrm{ug} / \mathrm{g}$ & 326 & 284 & 259 & 290 & 84 & \\
\hline Metals by Size, < 3 um & Cobalt & SW 6010 & $\mathrm{ug} / \mathrm{g}$ & 69 & 65 & 57 & 64 & 15 & \\
\hline Metals by Size, < 3 um & Copper & SW 6010 & $u g / g$ & 332 & 222 & 195 & 250 & 180 & \\
\hline Metals by Size, $<3$ um & Iron & SW 6010 & ug/g & 70,300 & 67,000 & 66,500 & 67,933 & 5,130 & \\
\hline
\end{tabular}




\section{Gas Stream Data}

SAMPLE STREAM: ESP OUTLET

\begin{tabular}{|c|c|c|c|c|c|c|c|c|c|c|c|c|c|}
\hline $\begin{array}{c}\text { Analyte } \\
\text { Group }\end{array}$ & Specie & $\begin{array}{l}\text { Analytical } \\
\text { Method }\end{array}$ & Units & & $\begin{array}{c}\text { Run } \\
1 \\
\end{array}$ & & $\begin{array}{c}\text { Run } \\
2 \\
\end{array}$ & & $\begin{array}{c}\text { Run } \\
3 \\
\end{array}$ & & Average & $\begin{array}{c}96 \% \\
\mathrm{Cl} \\
\end{array}$ & $\begin{array}{c}\text { DL } \\
\text { Ratio }\end{array}$ \\
\hline Metals by Size, < 3 um & Lead & SW 7421 & ug/g & & 311 & & 236 & & 124 & & 224 & 234 & \\
\hline Metals by Size, < 3 um & Magnesium & SW 6010 & $u g / g$ & & 7,870 & & 7,080 & & 5,160 & & 6,703 & 3,462 & \\
\hline Metals by Size, < 3 um & Manganese & SW 6010 & ug/g & & 327 & & 325 & & 306 & & 319 & 29 & \\
\hline Metals by Size, < 3 um & Mercury & SW 7471 & $u g / g$ & & 0.44 & & 0.32 & & 0.40 & & 0.39 & 0.15 & \\
\hline Metals by Size, < 3 um & Molybdenum & SW 6010 & $u g / g$ & & 138 & & 117 & & 98 & & 118 & 49 & \\
\hline Metals by Size, $<3$ um & Nickel & SW 6010 & ug/g & & 259 & & 227 & & 220 & & 235 & 52 & \\
\hline Metals by Size, $<3$ um & Phosphorus & SW 6010 & ug/g & & 528 & & 773 & & 1,160 & & 820 & 792 & \\
\hline Metals by Size, < 3 um & Potasslum & SW 6010 & ug/g & & 25,100 & & 22,500 & & 20,500 & & 22,700 & 5,730 & \\
\hline Metals by Slze, $<3$ um & Selenium & SW 7740 & $u g / g$ & & 79 & & 55 & & 45 & & 60 & 43 & \\
\hline Metals by Size, $<3$ um & Silicon & SW 6010 & ug/g & & 213,000 & & 209,000 & & 199,000 & & 207,000 & 17,915 & \\
\hline Metals by Size, $<3$ um & Sodium & SW 6010 & $u g / g$ & & 9,490 & & 8,240 & & 7,210 & & 8,313 & 2,837 & \\
\hline Metals by Size, $<3$ um & Strontlum & SW 6010 & ug/g & & 460 & & 439 & & 389 & & 429 & 91 & \\
\hline Metals by Size, $<3$ um & Titanium & SW 6010 & ug/g & & 6,880 & & 6,820 & & 6,960 & & 6,887 & 174 & \\
\hline Metals by Size, $<3$ um & Vanadium & SW 6010 & ug/g & & 852 & & 781 & & 668 & & 767 & 231 & \\
\hline Metals by Size, $<3$ um & Zinc & SW 6010 & ug/g & & 1,790 & & 1,580 & & 1,570 & & 1,647 & 309 & \\
\hline Organics, Aldehydes & Acetaldehyde & BIF-0011 & $\mathrm{ug} / \mathrm{Nm} 3$ & & 2.38 & & 1.22 & & 0.14 & & 1.24 & 2.78 & \\
\hline Organics, Aldehydes & Fomaldehyde & BIF-0011 & $\mathrm{ug} / \mathrm{Nm} 3$ & & 1.01 & & 0.40 & & 0.11 & & 0.50 & 1.15 & \\
\hline Organics, Seml-Volatile & 1,2,4,5-Tetrachlorobenzene & sw 8270 & $\mathrm{ng} / \mathrm{Nm} 3$ & $<$ & 182 & $<$ & 180 & $<$ & 131 & $<$ & 164 & -- & $100 \%$ \\
\hline Organics, Semi-Volatlle & 1,2,4-Trichlorobenzene & SW 8270 & $\mathrm{ng} / \mathrm{Nm} 3$ & $<$ & 186 & $<$ & 184 & $<$ & 197 & $<$ & 189 & -. & $100 \%$ \\
\hline Organics, Seml-Volalle & 1,2-Dichlorobenzene & SW 8270 & $\mathrm{ng} / \mathrm{Nm} 3$ & $<$ & 245 & $<$ & 243 & $<$ & 213 & $<$ & 234 & -. & $100 \%$ \\
\hline Organics, Semi-Volatile & 1,2-Diphenylhydrazine & SW 8270 & $\mathrm{ng} / \mathrm{Nm} 3$ & $<$ & 31,477 & $<$ & 31,174 & $<$ & 33,586 & $<$ & 32,079 & .. & $100 \%$ \\
\hline Organics, Semi-Volatile & 1,3-Dichlorobenzene & SW 8270 & $\mathrm{ng} / \mathrm{Nm} 3$ & $<$ & 125 & $<$ & 123 & $<$ & 241 & $<$ & 163 & -. & $100 \%$ \\
\hline Organics, Semi-Volatile & 1,4-Dichlorobenzene & SW 8270 & $\mathrm{ng} / \mathrm{Nm} 3$ & $<$ & 254 & $<$ & 252 & $<$ & 197 & $<$ & 235 & -. & $100 \%$ \\
\hline Organics, Semi-Volatile & 1-Chloronaphthalene & SW 8270 & $\mathrm{ng} / \mathrm{Nm} 3$ & $<$ & 203 & $<$ & 201 & $<$ & 180 & $<$ & 195 & -- & $100 \%$ \\
\hline Organics, Semi-Volatile & 1-Naphthylamine & .SW 8270 & $\mathrm{ng} / \mathrm{Nm} 3$ & $<$ & 491 & $<$ & 486 & $<$ & 682 & $<$ & 553 & -. & $100 \%$ \\
\hline Organics, Semi-Volatile & $2,3,4,6$-Tetrachlorophenol & SW 8270 & $\mathrm{ng} / \mathrm{Nm} 3$ & $<$ & 158 & $<$ & 157 & $<$ & 156 & $<$ & 157 & -- & $100 \%$ \\
\hline Organics, Semi-Volatile & 2,4,5-Trichlorophenol & SW 8270 & $n g / N m 3$ & $<$ & 104 & $<$ & 103 & $<$ & 171 & $<$ & 126 & -- & $100 \%$ \\
\hline Organics, Semi-Volatile & 2,4,6-Trichlorophenol & SW 8270 & $\mathrm{ng} / \mathrm{Nm} 3$ & $<$ & 110 & $<$ & 109 & $<$ & 170 & $<$ & 130 & -- & $100 \%$ \\
\hline Organics, Semi-Volatlle & 2,4-Dlchlorophenol & SW 8270 & $\mathrm{ng} / \mathrm{Nm} 3$ & $<$ & 139 & $<$ & 138 & $<$ & 191 & $<$ & 156 & .. & $100 \%$ \\
\hline
\end{tabular}




\section{Gas Stream Data}

SAMPLE STREAM: ESP OUTLET

\begin{tabular}{|c|c|c|c|c|c|c|c|c|c|c|c|c|c|}
\hline $\begin{array}{c}\text { Analyte } \\
\text { Group }\end{array}$ & Specie & $\begin{array}{c}\text { Analytical } \\
\text { Method }\end{array}$ & Units & & $\begin{array}{c}\text { Run } \\
1 \\
\end{array}$ & & $\begin{array}{c}\text { Run } \\
2 \\
\end{array}$ & & $\begin{array}{c}\text { Run } \\
3 \\
\end{array}$ & & Average & $\begin{array}{c}96 \% \\
\mathbf{C l} \\
\end{array}$ & $\begin{array}{c}\text { DL } \\
\text { Ratio }\end{array}$ \\
\hline Organics, Semi-Volatile & 2,4-Dimethylpheno! & SW 8270 & $\mathrm{ng} / \mathrm{Nm} 3$ & $<$ & 346 & $<$ & 343 & $<$ & 437 & $<$ & 375 & -. & $100 \%$ \\
\hline Organics, Semi-Volatile & 2,4-Dinitrophenol & SW 8270 & $\mathrm{ng} / \mathrm{Nm} 3$ & $<$ & 2,203 & $<$ & 2,182 & $<$ & 1,404 & $<$ & 1,930 & -. & $100 \%$ \\
\hline Organics, Seml-Volatile & 2,4-Dinitrotoluene & SW 8270 & $\mathrm{ng} / \mathrm{Nm} 3$ & $<$ & 173 & $<$ & 171 & $<$ & 198 & $<$ & 181 & $-\cdot$ & $100 \%$ \\
\hline Organics, Semi-Volatile & 2,6-Dichlorophenol & SW 8270 & $\mathrm{ng} / \mathrm{Nm} 3$ & $<$ & 228 & $<$ & 225 & $<$ & 172 & $<$ & 208 & - & $100 \%$ \\
\hline Organics, Sem!-Volatile & 2,6-Dinitrotoluene & SW 8270 & $\mathrm{ng} / \mathrm{Nm} 3$ & $<$ & 109 & $<$ & 108 & $<$ & 289 & $<$ & 169 & -- & $100 \%$ \\
\hline Organics, Semi-Volatile & 2-Chloronaphthalene & SW 8270 & $\mathrm{ng} / \mathrm{Nm} 3$ & $<$ & 102 & $<$ & 101 & $<$ & 132 & $<$ & 112 & $\cdots$ & $100 \%$ \\
\hline Organics, Semi-Volatile & 2-Chlorophenol & SW 8270 & $\mathrm{ng} / \mathrm{Nm} 3$ & $<$ & 240 & $<$ & 238 & $<$ & 213 & $<$ & 231 & $\cdots$ & $100 \%$ \\
\hline Organics, Semi-Volatile & 2-Methylnaphthalene & SW 8270 & $\mathrm{ng} / \mathrm{Nm} 3$ & $<$ & 208 & $<$ & 206 & $<$ & 122 & $<$ & 179 & $\cdots$ & $100 \%$ \\
\hline Organics, Semi-Volatile & 2-Methylphenol(o-cresol) & SW 8270 & $\mathrm{ng} / \mathrm{Nm} 3$ & & 2,487 & & 2,837 & . & 10,378 & & 5,234 & 11,076 & \\
\hline Organics, Semi-Volatile & 2-Naphthylamine & SW 8270 & $\mathrm{ng} / \mathrm{Nm} 3$ & $<$ & 614 & $<$ & 608 & $<$ & 537 & $<$ & 586 & $\ldots$ & $100 \%$ \\
\hline Organics, Semi-Volatile & 2-Nitroaniline & SW 8270 & $\mathrm{ng} / \mathrm{Nm} 3$ & $<$ & 127 & $<$ & 125 & $<$ & 223 & $<$ & 158 & - & $100 \%$ \\
\hline Organics, Semi-Volatile & 2-Nitrophenol & SW 8270 & $\mathrm{ng} / \mathrm{Nm3}$ & $<$ & 138 & $<$ & 137 & $<$ & 175 & $<$ & 150 & $\cdots$ & $100 \%$ \\
\hline Organics, Semi-Volatile & 2-Plcoline & SW 8270 & $\mathrm{ng} / \mathrm{Nm3}$ & $<$ & 343 & $<$ & 340 & $<$ & 278 & $<$ & 320 & - & $100 \%$ \\
\hline Organics, Semi-Volatile & 3,3'-Dichlorobenzldine & SW 8270 & $\mathrm{ng} / \mathrm{Nm3}$ & $<$ & 154 & $<$ & 153 & $<$ & 112 & $<$ & 140 & $\cdots$ & $100 \%$ \\
\hline Organics, Semi-Volatile & 3-Methylcholanthrene & SW 8270 & $\mathrm{ng} / \mathrm{Nm} 3$ & $<$ & 246 & $<$ & 244 & $<$ & 168 & $<$ & 219 & -- & $100 \%$ \\
\hline Organics, Semi-Volatile & 3-Nitroaniline & SW 8270 & $\mathrm{ng} / \mathrm{Nm3}$ & $<$ & 160 & $<$ & 159 & $<$ & 132 & $<$ & 150 & -- & $100 \%$ \\
\hline Organics, Semi-Volatile & 4,6-Dinitro-2-methylphenol & SW 8270 & $\mathrm{ng} / \mathrm{Nm3}$ & $<$ & 249 & $<$ & 247 & $<$ & 144 & $<$ & 214 &.- & $100 \%$ \\
\hline Organics, Semi-Volatile & 4-Aminobiphenyl & SW 8270 & $\mathrm{ng} / \mathrm{Nm3}$ & $<$ & 235 & $<$ & 233 & $<$ & 400 & $<$ & 289 & $\cdots$ & $100 \%$ \\
\hline Organics, Semi-Volatile & 4Bromophenyl phenyl & SW 8270 & $\mathrm{ng} / \mathrm{Nm3}$ & $<$ & 144 & $<$ & 142 & $<$ & 163 & $<$ & 149 & $-\cdot$ & $100 \%$ \\
\hline Organics, Semi-Volatile & 4-Chloro-3-methylphenol & SW 8270 & $\mathrm{ng} / \mathrm{Nm3}$ & $<$ & 228 & $<$ & 225 & $<$ & 173 & $<$ & 209 & $\cdots$ & $100 \%$ \\
\hline Organics, Semi-Volatile & 4-Chlorophenyl phenyl ether & SW 8270 & $\mathrm{ng} / \mathrm{Nm} 3$ & $<$ & 166 & $<$ & 165 & $<$ & 141 & $<$ & 157 & -. & $100 \%$ \\
\hline Organics, Semi-Volatile & 4-Methylphenol(p-cresol) & SW 8270 & $\mathrm{ng} / \mathrm{Nm3}$ & & 2,068 & & 1,443 & & 1,679 & & 1,730 & 784 & \\
\hline Organics, Semi-Volatile & 4-Nitroaniline & SW 8270 & $\mathrm{ng} / \mathrm{Nm3}$ & $<$ & 152 & $<$ & 151 & $<$ & 204 & $<$ & 169 & -- & $100 \%$ \\
\hline Organics, Seml-Volatile & 4-Nitrophenol & SW 8270 & $\mathrm{ng} / \mathrm{Nm} 3$ & $<$ & 218 & $<$ & 215 & $<$ & 315 & $<$ & 249 & $\cdots$ & $100 \%$ \\
\hline Organics, Semi-Volatile & 7,12-Dimethylbenz(a)anthracene & SW 8270 & $\mathrm{ng} / \mathrm{Nm3}$ & $<$ & 604 & $<$ & 599 & $<$ & 447 & $<$ & 550 & -. & $100 \%$ \\
\hline Organics, Seml-Volatile & Acenaphthene & 'SW 8270 & $\mathrm{ng} / \mathrm{Nm3}$ & $<$ & 150 & $<$ & 149 & $<$ & 91 & $<$ & 130 & -. & $100 \%$ \\
\hline Organics, Semi-Volatile & Acenaphthylene & SW 8270 & $\mathrm{ng} / \mathrm{Nm} 3$ & $<$ & 71 & $<$ & 70 & $<$ & 140 & $<$ & 94 & -- & $100 \%$ \\
\hline Organics, Semi-Volatile & Acetophenone & SW 8270 & $\mathrm{ng} / \mathrm{Nm3}$ & & 3,525 & & 2,930 & & 3,322 & & 3,259 & 751 & \\
\hline Organics, Semi-Volatile & Anilline & SW 8270 & $\mathrm{ng} / \mathrm{Nm} 3$ & $<$ & 294 & $<$ & 291 & $<$ & 207 & $<$ & 264 & $\cdots$ & $100 \%$ \\
\hline Organics, Seml-Volatile & Anthracene & SW 8270 & $\mathrm{ng} / \mathrm{Nm3}$ & $<$ & 183 & $<$ & 181 & $<$ & 124 & $<$ & 163 & -. & $100 \%$ \\
\hline Organics, Semi-Volatile & Benzidine & SW 8270 & $\mathrm{ng} / \mathrm{Nm} 3$ & $<$ & 6,295 & $<$ & 6,235 & $<$ & 6,717 & $<$ & 6,416 & $\cdots$ & $100 \%$ \\
\hline
\end{tabular}

ESP Outlet - Page 10 


\section{Gas Stream Data}

SAMPLE STREAM: ESP OUTLET

\begin{tabular}{|c|c|c|c|c|c|c|c|c|c|c|c|c|c|}
\hline $\begin{array}{l}\text { Analyte } \\
\text { Group }\end{array}$ & Specie & $\begin{array}{c}\text { Analytical } \\
\text { Method }\end{array}$ & Units & & $\begin{array}{c}\text { Run } \\
1\end{array}$ & & $\begin{array}{c}\text { Run } \\
2 \\
\end{array}$ & & $\begin{array}{c}\text { Run } \\
3 \\
\end{array}$ & & Average & $\begin{array}{c}96 \% \\
\mathrm{Cl}\end{array}$ & $\begin{array}{c}\text { DL } \\
\text { Ratio }\end{array}$ \\
\hline Organics, Semi-Volatile & Benzo(a)anthracene & SW 8270 & $\mathrm{ng} / \mathrm{Nm} 3$ & $<$ & 162 & $<$ & 161 & $<$ & 151 & $<$ & 158 & $-\cdot$ & $100 \%$ \\
\hline Organics, Semi-Volatile & Benzo(a)pyrene & SW 8270 & $\mathrm{ng} / \mathrm{Nm} 3$ & $<$ & 121 & $<$ & 119 & $<$ & 174 & $<$ & 138 & $\cdots$ & $100 \%$ \\
\hline Organics, Semi-Volatlle & Benzo(b)fluoranthene & SW 8270 & $\mathrm{ng} / \mathrm{Nm} 3$ & $<$ & 179 & $<$ & 177 & $<$ & 305 & $<$ & 220 & $\cdots$ & $100 \%$ \\
\hline Organics, Semi-Volatile & Benzo $(g, h, i)$ perylene & SW 8270 & $\mathrm{ng} / \mathrm{Nm} 3$ & $<$ & 153 & $<$ & 152 & $<$ & 343 & $<$ & 216 & - . & $100 \%$ \\
\hline Organics, Semi-Volatile & Benzo(k)fluoranthene & SW 8270 & $\mathrm{ng} / \mathrm{Nm} 3$ & $<$ & 305 & $<$ & 302 & $<$ & 336 & $<$ & 314 & $\cdots$ & $100 \%$ \\
\hline Organics, Semi-Volatile & Benzolc acid & SW 8270 & ng/Nm3 & & 123,074 & & 105,679 & & 160,875 & & 129,876 & 70,107 & \\
\hline Organics, Semi-Volatile & Benzyl alcohol & SW 8270 & $\mathrm{ng} / \mathrm{Nm} 3$ & & 12,685 & $<$ & 337 & $<$ & 205 & & 4,319 & 18,001 & $2 \%$ \\
\hline Organics, Semi-Volatile & Butylbenzylphthalate & SW 8270 & $\mathrm{ng} / \mathrm{Nm} 3$ & & 409 & & 324 & & 274 & & 336 & 170 & \\
\hline Organics, Semi-Volatile & Chrysene & SW 8270 & $\mathrm{ng} / \mathrm{Nm} 3$ & $<$ & 211 & $<$ & 209 & $<$ & 180 & $<$ & 200 & $-\cdot$ & $100 \%$ \\
\hline Organics, Semi-Volatile & Di-n-octylphthalate & SW 8270 & $\mathrm{ng} / \mathrm{Nm} 3$ & $<$ & 287 & $<$ & 284 & $<$ & 118 & $<$ & 230 & $-\cdot$ & $100 \%$ \\
\hline Organics, Semi-Volatile & Dibenz(a,h)anthracene & SW 8270 & $\mathrm{ng} / \mathrm{Nm} 3$ & $<$ & 149 & $<$ & 148 & $<$ & 272 & $<$ & 190 & - & $100 \%$ \\
\hline Organics, Semi-Volatile & Dibenz $(a, j)$ acridine & SW 8270 & $\mathrm{ng} / \mathrm{Nm} 3$ & $<$ & 183 & $<$ & 181 & $<$ & 283 & $<$ & 216 & $\cdots$ & $100 \%$ \\
\hline Organics, Semi-Volatile & Dibenzofuran & SW 8270 & $\mathrm{ng} / \mathrm{Nm} 3$ & $<$ & 128 & $<$ & 127 & $<$ & 180 & $<$ & 145 & - & $100 \%$ \\
\hline Organics, Semi-Volatile & Dibutylphthalate & SW 8270 & $\mathrm{ng} / \mathrm{Nm} 3$ & $<$ & 155 & & 209 & $<$ & 109 & $<$ & 155 & $\cdots$ & $39 \%$ \\
\hline Organics, Semi-Volatile & Diethylphthalate & SW 8270 & $\mathrm{ng} / \mathrm{Nm} 3$ & & 434 & $<$ & 105 & $<$ & 173 & & 191 & 525 & $24 \%$ \\
\hline Organics, Semi-Volatile & Dimethylphenethylamine & SW 8270 & $\mathrm{ng} / \mathrm{Nm} 3$ & $<$ & 37,772 & $<$ & 37,409 & $<$ & 40,303 & $<$ & 38,494 & -. & $100 \%$ \\
\hline Organics, Semi-Volatile & Dimethylphthalate & SW 8270 & $\mathrm{ng} / \mathrm{Nm} 3$ & $<$ & 88 & $<$ & 87 & $<$ & 113 & $<$ & 96 & -- & $100 \%$ \\
\hline Organics, Semi-Volatile & Diphenylamine & SW 8270 & $\mathrm{ng} / \mathrm{Nm} 3$ & $<$ & 166 & $<$ & 165 & $<$ & 93 & $<$ & 141 & $\cdots$ & $100 \%$ \\
\hline Organics, Semi-Volatile & Ethyl methanesulfonate & SW 8270 & $\mathrm{ng} / \mathrm{Nm} 3$ & $<$ & 158 & $<$ & 157 & $<$ & 228 & $<$ & 181 & $-\cdot$ & $100 \%$ \\
\hline Organics, Semi-Volatile & Fluoranthene & SW 8270 & $\mathrm{ng} / \mathrm{Nm} 3$ & $<$ & 201 & $<$ & 199 & $<$ & 158 & $<$ & 186 & -- & $100 \%$ \\
\hline Organics, Semi-Volatile & Fluorene & SW 8270 & $\mathrm{ng} / \mathrm{Nm} 3$ & $<$ & 106 & $<$ & 105 & $<$ & 128 & $<$ & 113 & -. & $100 \%$ \\
\hline Organics, Semi-Volatile & Hexachlorobenzene & SW 8270 & $\mathrm{ng} / \mathrm{Nm3}$ & $<$ & 74 & $<$ & 73 & $<$ & 105 & $<$ & 84 & -. & $100 \%$ \\
\hline Organics, Seml-Volatile & Hexachlorobutadlene & SW 8270 & $\mathrm{ng} / \mathrm{Nm} 3$ & $<$ & 220 & $<$ & 218 & $<$ & 172 & $<$ & 203 & $\cdots$ & $100 \%$ \\
\hline Organics, Semi-Volatile & Hexachlorocyclopentadiene & SW 8270 & $\mathrm{ng} / \mathrm{Nm} 3$ & $<$ & 2,808 & $<$ & 2,781 & $<$ & 1,978 & $<$ & 2,522 & $-\cdot$ & $100 \%$ \\
\hline Organics, Semi-Volatile & Hexachloroethane & SW 8270 & $\mathrm{ng} / \mathrm{Nm} 3$ & $<$ & 187 & $<$ & 185 & $<$ & 213 & $<$ & 195 & - & $100 \%$ \\
\hline Organics, Semi-Volatile & Indeno(1,2,3-cd)pyrene & SW 8270 & $\mathrm{ng} / \mathrm{Nm} 3$ & $<$ & 165 & $<$ & 164 & $<$ & 447 & $<$ & 259 & $-\cdot$ & $100 \%$ \\
\hline Organics, Semi-Volatile & Isophorone & SW 8270 & $\mathrm{ng} / \mathrm{Nm3}$ & $<$ & 90 & $<$ & 89 & $<$ & 207 & $<$ & 129 & $-\cdot$ & $100 \%$ \\
\hline Organics, Semi-Volatile & Methyl methanesulfonate & SW 8270 & $\mathrm{ng} / \mathrm{Nm3}$ & $<$ & 15,738 & $<$ & 15,587 & $<$ & 16,793 & $<$ & 16,039 & $\cdots$ & $100 \%$ \\
\hline Organics, Semi-Volatile & N-Nitroso-di-n-butylamine & SW 8270 & $\mathrm{ng} / \mathrm{Nm} 3$ & $<$ & 412 & $<$ & 408 & $<$ & 211 & $<$ & 344 & - & $100 \%$ \\
\hline Organics, Seml-Volatile & N-Nitrosodimethylamine & SW 8270 & $\mathrm{ng} / \mathrm{Nm} 3$ & $<$ & 419 & $<$ & 415 & $<$ & 264 & $<$ & 366 & $-\cdot$ & $100 \%$ \\
\hline Organics, Semi-Volatile & N-Nitrosodiphenylamine & SW 8270 & $\mathrm{ng} / \mathrm{Nm} 3$ & $<$ & 178 & $<$ & 176 & $<$ & 90 & $<$ & 148 & -- & $100 \%$ \\
\hline
\end{tabular}

ESP Outlet - Page 11 
SAMPLE STREAM: ESP OUTLET

\begin{tabular}{|c|c|c|c|c|c|c|c|c|c|c|c|c|c|}
\hline $\begin{array}{c}\text { Analyte } \\
\text { Group }\end{array}$ & Specie & $\begin{array}{c}\text { Analytical } \\
\text { Method }\end{array}$ & Units & & $\begin{array}{c}\text { Run } \\
1 \\
\end{array}$ & & $\begin{array}{c}\text { Run } \\
2 \\
\end{array}$ & & $\begin{array}{c}\text { Run } \\
3 \\
\end{array}$ & & Average & $\begin{array}{c}96 \% \\
\mathrm{Cl} \\
\end{array}$ & $\begin{array}{r}\text { DL } \\
\text { Ratio } \\
\end{array}$ \\
\hline Organics, Semi-Volatile & N-Nitrosodipropylamine & SW 8270 & $\mathrm{ng} / \mathrm{Nm} 3$ & $<$ & 236 & $<$ & 234 & $<$ & 220 & $<$ & 230 & .. & $100 \%$ \\
\hline Organics, Semi-Volatile & N-Nitrosopiperidine & SW 8270 & $\mathrm{ng} / \mathrm{Nm} 3$ & $<$ & 297 & $<$ & 294 & $<$ & 201 & $<$ & 264 & $\cdots$ & $100 \%$ \\
\hline Organics, Semi-Volatile & Naphthalene & SW 8270 & $\mathrm{ng} / \mathrm{Nm} 3$ & & 957 & & 773 & & 1,562 & & 1,097 & 1,025 & \\
\hline Organics, Semi-Volatile & Nitrobenzene & SW 8270 & $\mathrm{ng} / \mathrm{Nm} 3$ & $<$ & 166 & $<$ & 165 & $<$ & 283 & $<$ & 205 & $\cdots$ & $100 \%$ \\
\hline Organics, Semi-Volatile & Pentachlorobenzene & SW 8270 & $\mathrm{ng} / \mathrm{Nm} 3$ & $<$ & 139 & $<$ & 138 & $<$ & 126 & $<$ & 134 & $\cdots$ & $100 \%$ \\
\hline Organics, Semi-Volatile & Pentachloronitrobenzene & SW 8270 & $\mathrm{ng} / \mathrm{Nm} 3$ & $<$ & 652 & $<$ & 645 & $<$ & 463 & $<$ & 587 & $\cdots$ & $100 \%$ \\
\hline Organics, Semi-Volatile & Pentachlorophenol & SW 8270 & $\mathrm{ng} / \mathrm{Nm} 3$ & $<$ & 272 & $<$ & 269 & $<$ & 299 & $<$ & 280 & $\cdots$ & $100 \%$ \\
\hline Organics, Semi-Volatile & Phenacetin & SW 8270 & $\mathrm{ng} / \mathrm{Nm} 3$ & $<$ & 170 & $<$ & 168 & $<$ & 130 & $<$ & 156 & $\cdots$ & $100 \%$ \\
\hline Organics, Semi-Volatile & Phenanthrene & SW 8270 & $\mathrm{ng} / \mathrm{Nm} 3$ & $<$ & 196 & $<$ & 194 & $<$ & 157 & $<$ & 182 & - & $100 \%$ \\
\hline Organics, Semi-Volatile & Phenol & SW 8270 & $\mathrm{ng} / \mathrm{Nm} 3$ & & 4,407 & & 5,767 & & 15,449 & & 8,541 & 14,959 & \\
\hline Organics, Semi-Volatile & Pronamide & SW 8270 & $\mathrm{ng} / \mathrm{Nm} 3$ & $<$ & 233 & $<$ & 230 & $<$ & 81 & $<$ & 181 & $\cdots$ & $100 \%$ \\
\hline Organics, Semi-Volatile & Pyrene & SW 8270 & $\mathrm{ng} / \mathrm{Nm} 3$ & $<$ & 147 & $<$ & 146 & $<$ & 137 & $<$ & 143 & - & $100 \%$ \\
\hline Organics, Semi-Volatile & Pyridine & SW 8270 & $\mathrm{ng} / \mathrm{Nm} 3$ & $<$ & 365 & $<$ & 362 & $<$ & 197 & $<$ & 308 & $\cdots$ & $100 \%$ \\
\hline Organics, Semi-Volatile & bis(2-Chloroethoxy)methane & SW 8270 & $\mathrm{ng} / \mathrm{Nm} 3$ & $<$ & 177 & $<$ & 175 & $<$ & 204 & $<$ & 185 & $\cdots$ & $100 \%$ \\
\hline Organics, Semi-Volatile & bis(2-Chloroethyl)ether & SW 8270 & $\mathrm{ng} / \mathrm{Nm} 3$ & $<$ & 230 & $<$ & 228 & $<$ & 129 & $<$ & 196 &.- & $100 \%$ \\
\hline Organics, Seml-Volatile & bis(2-Chloroisopropyl)ether & SW 8270 & $\mathrm{ng} / \mathrm{Nm} 3$ & $<$ & 229 & $<$ & 226 & $<$ & 268 & $<$ & 241 & -. & $100 \%$ \\
\hline Organics, Semi-Volatile & bis(2-Ethylhexyl)phthalate & SW 8270 & $\mathrm{ng} / \mathrm{Nm} 3$ & & 7,271 & & 3,367 & & 33,922 & & 14,853 & 41,311 & \\
\hline Organics, Semi-Volatile & p-Chloroaniline & SW 8270 & $\mathrm{ng} / \mathrm{Nm} 3$ & $<$ & 176 & $<$ & 174 & $<$ & 250 & $<$ & 200 & $\cdots$ & $100 \%$ \\
\hline Organics, Seml-Volatlle & p-Dimethylaminoazobenzene & SW 8270 & $\mathrm{ng} / \mathrm{Nm} 3$ & $<$ & 162 & $<$ & 161 & $<$ & 244 & $<$ & 189 & $\cdots$ & $100 \%$ \\
\hline Organics, Volatile & 1,1,1-Trichloroethane & SW 8240 & $\mathrm{ng} / \mathrm{Nm} 3$ & & 757 & & 697 & & 608 & & 687 & 186 & \\
\hline Organics, Volatile & 1,1,2,2-Tetrachloroethane & SW 8240 & $\mathrm{ng} / \mathrm{Nm3}$ & $<$ & 512 & $<$ & 536 & $<$ & 537 & $<$ & 528 &.- & $100 \%$ \\
\hline Organics, Volatile & 1,1,2-Trichloroethane & SW 8240 & ng/Nm3 & $<$ & 512 & $<$ & 536 & $<$ & 537 & $<$ & 528 & $\cdots$ & $100 \%$ \\
\hline Organics, Volatile & 1,1-Dichloroethane & SW 8240 & $\mathrm{ng} / \mathrm{Nm} 3$ & $<$ & 512 & $<$ & 536 & $<$ & 537 & $<$ & 528 & -- & $100 \%$ \\
\hline Organles, Volatile & 1,1-Dichloroethene & SW 8240 & $\mathrm{ng} / \mathrm{Nm3}$ & $<$ & 512 & $<$ & 536 & $<$ & 537 & $<$ & 528 & $\cdots$ & $100 \%$ \\
\hline Organics, Volatile & 1,2-Dichlorobenzene & SW 8240 & $\mathrm{ng} / \mathrm{Nm} 3$ & $<$ & 512 & $<$ & 536 & $<$ & 537 & $<$ & 528 & -- & $100 \%$ \\
\hline Organics, Volatile & 1,2-Dichloroethane & SW 8240 & ng/Nm3 & $<$ & 512 & $<$ & 536 & $<$ & 537 & $<$ & 528 & $\cdots$ & $100 \%$ \\
\hline Organics, Volatile & 1,2-Dichloropropane & SW 8240 & $\mathrm{ng} / \mathrm{Nm} 3$ & $<$ & 512 & $<$ & 536 & $<$ & 537 & $<$ & 528 & $\cdots$ & $100 \%$ \\
\hline Organics, Volatile & 1,3-Dichlorobenzene & SW 8240 & $\mathrm{ng} / \mathrm{Nm} 3$ & $<$ & 512 & $<$ & 536 & $<$ & 537 & $<$ & 528 & - & $100 \%$ \\
\hline Organics, Volatile & 1,4-Dichlorobenzene & SW 8240 & $\mathrm{ng} / \mathrm{Nm} 3$ & $<$ & 512 & $<$ & 536 & $<$ & 537 & $<$ & 528 & $\cdots$ & $100 \%$ \\
\hline Organics, Volatile & 2-Butanone & SW 8240 & $\mathrm{ng} / \mathrm{Nm3}$ & $<$ & 2,561 & $<$ & 2,681 & $<$ & 2,683 & $<$ & 2,642 & -- & $100 \%$ \\
\hline
\end{tabular}




\section{Gas Stream Data}

SAMPLE STREAM: ESP OUTLET

\begin{tabular}{|c|c|c|c|c|c|c|c|c|c|c|c|c|c|}
\hline $\begin{array}{l}\text { Analyte } \\
\text { Group }\end{array}$ & Specie & $\begin{array}{c}\text { Analytical } \\
\text { Method }\end{array}$ & Units & & $\begin{array}{c}\text { Run } \\
1 \\
\end{array}$ & & $\begin{array}{c}\text { Run } \\
2 \\
\end{array}$ & & $\begin{array}{c}\text { Run } \\
3 \\
\end{array}$ & & Average & $\begin{array}{c}85 \% \\
\mathrm{Cl} \\
\end{array}$ & $\begin{array}{c}\text { DL } \\
\text { Ratio }\end{array}$ \\
\hline Organics, Volatile & 2-Hexanone & SW 8240 & $n g / N m 3$ & $<$ & 2,561 & $<$ & 2,681 & $<$ & 2,683 & $<$ & 2,642 & $\cdots$ & $100 \%$ \\
\hline Organics, Volatile & 4-Methyl-2-Pentanone & SW 8240 & $\mathrm{ng} / \mathrm{Nm} 3$ & $<$ & 2,561 & $<$ & 2,681 & $<$ & 2,683 & $<$ & 2,642 & -- & $100 \%$ \\
\hline Organics, Volatile & Acetone & SW 8240 & $\mathrm{ng} / \mathrm{Nm} 3$ & $<$ & 2,561 & $<$ & 2,681 & $<$ & 2,683 & $<$ & 2,642 & -- & $100 \%$ \\
\hline Organics, Volatile & Benzene & SW 8240 & $\mathrm{ng} / \mathrm{Nm3}$ & & 1,366 & & 1,555 & & 1,502 & & 1,474 & 243 & \\
\hline Organics, Volatile & Bromodichloromethane & SW 8240 & $\mathrm{ng} / \mathrm{Nm} 3$ & $<$ & 512 & $<$ & 536 & $<$ & 537 & $<$ & 528 & -- & $100 \%$ \\
\hline Organics, Volatile & Bromoform & SW 8240 & $\mathrm{ng} / \mathrm{Nm} 3$ & $<$ & 512 & $<$ & 536 & $<$ & 537 & $<$ & 528 & $\cdots$ & $100 \%$ \\
\hline Organics, Volatile & Bromomethane & SW 8240 & $\mathrm{ng} / \mathrm{Nm} 3$ & $<$ & 654 & $<$ & 536 & $<$ & 537 & $<$ & 576 & -- & $100 \%$ \\
\hline Organics, Volatile & Carbon Dlsulfide & SW 8240 & $\mathrm{ng} / \mathrm{Nm} 3$ & & 2,356 & & 6,901 & & 948 & & 3,402 & 7,730 & \\
\hline Organics, Volatile & Carbon Tetrachloride & SW 8240 & $\mathrm{ng} / \mathrm{Nm} 3$ & $<$ & 512 & $<$ & 536 & $<$ & 537 & $<$ & 528 & - & $100 \%$ \\
\hline Organics, Volatile & Chlorobenzene & SW 8240 & $\mathrm{ng} / \mathrm{Nm} 3$ & $<$ & 512 & $<$ & 536 & $<$ & 537 & $<$ & 528 & -. & $100 \%$ \\
\hline Organics, Volatile & Chloroethane & SW 8240 & $\mathrm{ng} / \mathrm{Nm} 3$ & $<$ & 512 & $<$ & 536 & $<$ & 537 & $<$ & 528 & - & $100 \%$ \\
\hline Organics, Volatile & Chloroform & SW 8240 & $\mathrm{ng} / \mathrm{Nm} 3$ & $<$ & 512 & $<$ & 536 & $<$ & 537 & $<$ & 528 & $\cdots$ & $100 \%$ \\
\hline Organics, Volatile & Chloromethane & SW 8240 & $\mathrm{ng} / \mathrm{Nm3}$ & $<$ & 512 & $<$ & 536 & $<$ & 537 & $<$ & 528 & -- & $100 \%$ \\
\hline Organics, Volatile & Dibromochloromethane & SW 8240 & $\mathrm{ng} / \mathrm{Nm} 3$ & $<$ & 512 & $<$ & 536 & $<$ & 537 & $<$ & 528 & -- & $100 \%$ \\
\hline Organics, Volatile & Ethyl Benzene & SW 8240 & $\mathrm{ng} / \mathrm{Nm3}$ & $<$ & 512 & $<$ & 536 & $<$ & 537 & $<$ & 528 & $\cdots$ & $100 \%$ \\
\hline Organics, Volatile & Methylene Chloride & SW 8240 & $\mathrm{ng} / \mathrm{Nm} 3$ & & 18,300 & & 47,739 & & 31,659 & & 32,566 & 36,621 & \\
\hline Organics, Volatile & Styrene & SW 8240 & $\mathrm{ng} / \mathrm{Nm3}$ & $<$ & 512 & $<$ & 536 & $<$ & 537 & $<$ & 528 & - & $100 \%$ \\
\hline Organics, Volatile & Tetrachloroethene & SW 8240 & $\mathrm{ng} / \mathrm{Nm} 3$ & & 1,021 & & 786 & & 644 & & 817 & 473 & \\
\hline Organics, Volatile & Toluene & SW 8240 & $\mathrm{ng} / \mathrm{Nm} 3$ & & 688 & & 1,341 & & 1,502 & & 1,177 & 1,071 & \\
\hline Organics, Volatile & Trichloroethene & SW 8240 & $\mathrm{ng} / \mathrm{Nm} 3$ & $<$ & 512 & $<$ & 536 & $<$ & 537 & $<$ & 528 & $-\cdot$ & $100 \%$ \\
\hline Organics, Volatile & Trichlorofluoromethane & SW 8240 & $\mathrm{ng} / \mathrm{Nm} 3$ & $<$ & 512 & & 679 & $<$ & 537 & $<$ & 537 & - & $44 \%$ \\
\hline Organics, Volatile & Vinyl Acetate & SW 8240 & $\mathrm{ng} / \mathrm{Nm} 3$ & $<$ & 2,561 & $<$ & 2,681 & $<$ & 2,683 & $<$ & 2,642 & $\cdots$ & $100 \%$ \\
\hline Organics, Volatile & Vinyl Chloride & SW 8240 & $\mathrm{ng} / \mathrm{Nm3}$ & $<$ & 512 & $<$ & 536 & $<$ & 537 & $<$ & 528 & $-\cdot$ & $100 \%$ \\
\hline Organics, Volatile & cls-1,3-Dlchloropropene & SW 8240 & $\mathrm{ng} / \mathrm{Nm} 3$ & $<$ & 512 & $<$ & 536 & $<$ & 537 & $<$ & 528 & - & $100 \%$ \\
\hline Organics, Volatile & $m, p-X y l e n e$ & SW 8240 & $\mathrm{ng} / \mathrm{Nm} 3$ & & 789 & $<$ & 536 & $<$ & 537 & $<$ & 537 & -. & $40 \%$ \\
\hline Organics, Volatile & o-Xylene & SW 8240 & $\mathrm{ng} / \mathrm{Nm} 3$ & $<$ & 512 & $<$ & 536 & $<$ & 537 & $<$ & 528 & $\cdots$ & $100 \%$ \\
\hline Organics, Volatile & trans-1,2-Dichloroethene & SW 8240 & $\mathrm{ng} / \mathrm{Nm} 3$ & $<$ & 512 & $<$ & 536 & $<$ & 537 & $<$ & 528 & -- & $100 \%$ \\
\hline Organics, Volatile & Irans-1,3-Dlchloropropene & SW 8240 & $\mathrm{ng} / \mathrm{Nm} 3$ & $<$ & 512 & $<$ & 536 & $<$ & 537 & $<$ & 528 & - & $100 \%$ \\
\hline
\end{tabular}

Vote: Shaded data has been invalldated due to high background in filter substrate. Shaded data is not included in "average" data calculatlon.

\section{ESP Outlet - Page 13}




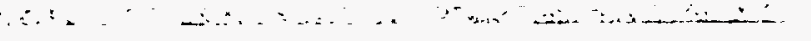




\section{Gas Stream Data}

\section{SAMPLE STREAM: STACK}

\begin{tabular}{|c|c|c|c|c|c|c|c|c|c|c|c|c|c|c|}
\hline $\begin{array}{c}\text { Analyte } \\
\text { Group }\end{array}$ & Specie & $\begin{array}{l}\text { Analytical } \\
\text { Method }\end{array}$ & Units & $\begin{array}{c}\text { Run } \\
1 \\
\end{array}$ & & $\begin{array}{c}\text { Run } \\
2 \\
\end{array}$ & & & $\begin{array}{c}\text { Run } \\
3 \\
\end{array}$ & & & Average & $\begin{array}{c}85 \% \\
\mathrm{Cl} \\
\end{array}$ & $\begin{array}{c}\text { DL } \\
\text { Ratio }\end{array}$ \\
\hline Particulate Loading & & Grav & $\mathrm{g} / \mathrm{Nm} 3$ & 0.0192 & & 0.0118 & & & 0.0125 & & & 0.0145 & 0.0101 & \\
\hline Reduced Specles & Ammonla as $\mathrm{N}$ & EPA 350.1 & ug/Nm3 & 18.72 & B & 5.91 & B & & 8.98 & B & & 11.20 & 16.62 & \\
\hline Reduced Species & Cyanide & SW 9012 & ug/Nm3 & 4.87 & & 8.55 & & & 71.99 & & & 28 & 93.74 & \\
\hline Anions - Vapor Phase & Chlorlde & EPA 300.0 & $\mathrm{ug} / \mathrm{Nm} 3$ & 294 & & 914 & & & 411 & & & 540 & 819 & \\
\hline Anions - Vapor Phase & Fluoride & EPA 340.2 & ug/Nm3 & 126 & & 96 & & & 150 & & & 124 & 66 & \\
\hline Anions - Vapor Phase & Sulfate & EPA 300.0 & $\mathrm{ug} / \mathrm{Nm3}$ & 754,933 & & 633,232 & & & 650,180 & & & 679,449 & 163,764 & \\
\hline Anlons - Partlculate & Chloride & EPA 300.0 & ug/Nm3 & 345.2 & & 203.6 & & & 93.4 & & & 214 & 314 & \\
\hline Antons - Particulate & Fluoride & EPA 340.2 & ug/Nm3 & 0.057 & & 0.063 & & & 0.032 & & & 0.051 & 0.041 & \\
\hline Anions - Particulate & Sulfate & EPA 300.0 & $u g / N m 3$ & 9,961 & B & 4,121 & B & & 3,633 & $B$ & & 5,905 & 8,748 & \\
\hline Anlons - Total & Chloride & EPA 300.0 & $\mathrm{ug} / \mathrm{Nm} 3$ & 640 & & 1,118 & & & 504 & & & 754 & 801 & \\
\hline Anlons - Total & Fluoride & EPA 340.2 & ug/Nm3 & 125.9 & & 96.5 & & & 149.8 & & & 124 & $6 ̨ 6$ & \\
\hline Anions - Total & Sulfate & EPA 300.0 & $\mathrm{ug} / \mathrm{Nm3}$ & 764,894 & & 637,353 & & & 653,814 & & & 685,353 & 172,349 & \\
\hline Radionuclides & $\mathrm{K}-40 @ 1460 \mathrm{KeV}$ & EPA 901.1 & $\mathrm{pCl} / \mathrm{g}$ & 56 & & 56 & & & 62 & & $<$ & 56 & - & $47 \%$ \\
\hline Part Metals by Wt & Aluminum & SW 6010 & $\mathbf{u g} / \mathrm{g}$ & 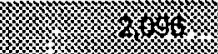 & 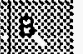 & 14,330 & B & & 13,177 & B & & 13,754 & 7,328 & \\
\hline Part Metals by Wt & Antimony & ICP-MS & $u g / g$ & 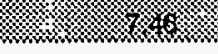 & (x) & 4.22 & B & & 3.33 & B & & 3.77 & 5.66 & \\
\hline Part Metals by Wt & Arsenic & SW 7060 & $u g / g$ & 66 & B & 87 & B & & 76 & B & & 81 & 71 & \\
\hline Part Metals by Wt & Barium & SW 6010 & ug/g & 器。 & 6 & 303 & B & & 126 & B & & 214 & 1,120 & \\
\hline Part Metals by Wt & Berylllum & SW 6010 & ug/g & 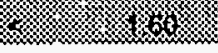 & 億 & 3.11 & B & & 2.77 & B & & 2.94 & 2.12 & \\
\hline Part Metals by Wt & Boron & SW 6010 & ug/g & -- & & -- & & & - & & & -- & - & \\
\hline Part Metals by Wt & Cadmium & SW 7131 & ug/g & 将器 & 9 & 35 & B & & 48 & B & & 41 & 79 & \\
\hline Part Metals by Wt & Calclum & SW 6010 & ug/g & \% & 6 & 16,154 & B & & 21,087 & B & & 18,621 & 31,343 & \\
\hline Part Metals by Wt & Chromium & SW 6010 & ug/g & 洏。 & \% & 93 & B & & 565 & B & & 329 & 2,995 & \\
\hline Part Metals by Wt & Cobalt & SW 6010 & ug/g & 4 & א. & 18 & $J$ & $<$ & 37 & C & $<$ & 37 & - & $52 \%$ \\
\hline Part Metals by Wt & Copper & SW 6010 & ug/g & r. & א్ & 60 & B & & 52 & B & & 56 & 49 & \\
\hline Part Metals by WI & Iron & SW 6010 & $u g / g$ & 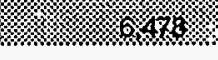 & 6k & 9,994 & 8 & & 13,386 & B & & 11,690 & 21,547 & \\
\hline
\end{tabular}




\section{Gas Stream Data}

SAMPLE STREAM: STACK

\begin{tabular}{|c|c|c|c|c|c|c|c|c|c|c|c|c|c|c|c|}
\hline $\begin{array}{c}\text { Analyte } \\
\text { Group }\end{array}$ & Specie & $\begin{array}{c}\text { Analytlcal } \\
\text { Method }\end{array}$ & Units & $\begin{array}{c}\text { Run } \\
1 \\
\end{array}$ & & & $\begin{array}{c}\text { Run } \\
2 \\
\end{array}$ & & & $\begin{array}{c}\text { Run } \\
3 \\
\end{array}$ & & & Average & $\begin{array}{c}96 \% \\
\mathrm{CI} \\
\end{array}$ & $\begin{array}{c}\text { DL } \\
\text { Ratlo }\end{array}$ \\
\hline Part Metals by Wt & Lead & SW 7421 & $u g / g$ & 4 & 格 & & 37 & $\mathbf{B}$ & & 34 & B & & 36 & 20 & \\
\hline Part Metals by Wt & Magnesium & SW 6010 & ug/g & 4 & $x$ & & 1,940 & B & & 3,627 & B & & 2,784 & 10,716 & \\
\hline Part Metals by Wt & Manganese & SW 6010 & $u g / g$ & 1 & 8 & & 285 & B & & 691 & B & & 488 & 2,579 & \\
\hline Part Metals by Wt & Mercury & SW 7471 & ug/g & \% & צ & & 0.972 & B & $<$ & 0.320 & c & & 0.57 & 5.16 & $\cdot 14 \%$ \\
\hline Part Metals by Wt & Molybdenum & SW 6010 & ug/g & $\%$ & 攻 & & 100 & B & & 100 & B & & 73 & 118 & \\
\hline Part Metals by Wt & Nickel & SW 6010 & ug/g & 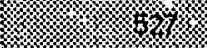 & 8 & & 382 & B & & 4,636 & B & $\cdot$ & 2,509 & 27,022 & \\
\hline Part Metals by Wt & Phosphorus & SW 6010 & ug/g & 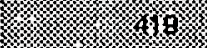 & 聯 & $<$ & 217 & C & $<$ & 162 & c & $<$ & 217 & -- & $100 \%$ \\
\hline Part Metals by Wt & Polassium & SW 6010 & ug/g & 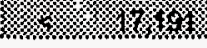 & 絸 & & 3,020 & $J$ & & 2,772 & $\mathbf{J}$ & & 2,896 & 1,576 & \\
\hline Part Metals by Wt & Selenlum & SW 7740 & ug/g & 3,331 & B & & 819 & B & & 979 & B & & 1,710 & 3,495 & \\
\hline Part Metals by Wt & Sodium & SW 6010 & ug/g & 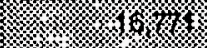 & $\%$ & & 4,046 & B & & 4,350 & B & & 4,198 & 1,932 & \\
\hline Part Metals by Wt & Strontlum & SW 6010 & ug/g & \% & 奴 & & 102 & B & & 111 & B & & 106 & 53 & \\
\hline Part.Metals by Wt & Titanium & SW 6010 & $u g / g$ & 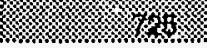 & x & & 1,044 & B & & 784 & B & & 914 & 1,656 & \\
\hline Part Metals by Wit & Vanadium & SW 6010 & $u g / g$ & 92.56 & $B$ & & 130 & B & & 114 & B & & 112 & 46 & \\
\hline Part Metals by Wt & Zinc & SW 6010 & $\mathrm{ug} / \mathrm{g}$ & 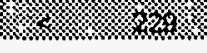 & 6 & & 650 & B & & 423 & B & & 536 & 1,446 & \\
\hline Part Metals by Vol & Aluminum & SW 6010 & $\mathrm{ug} / \mathrm{Nm} 3$ & 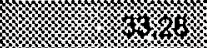 & 暗 & & 171 & B & & 211 & B & & 191 & 255 & \\
\hline Part Metals by Vol & Antimony & ICP.MS & ug/Nm3 & (6) & & & 0.050 & & & 0.053 & & & 0.052 & 0.019 & \\
\hline Part Metals by Vol & Arsenic & SW 7060 & ug/Nm3 & 1.053 & B & & 1.03 & B & & 1.21 & B & & 1.10 & 0.239 & \\
\hline Part Metals by Vol & Barium & SW 6010 & $u g / N m 3$ & 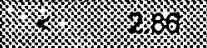 & 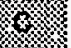 & & 3.61 & B & & 2.02 & B & & 2.814 & 10.081 & \\
\hline Part Metals by Vol & Beryllium & SW 6010 & $\mathrm{ug} / \mathrm{Nm} 3$ & 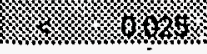 & 器 & & 0.037 & B & & 0.044 & B & & 0.041 & 0.047 & \\
\hline Part Metals by Vol & Boron & & & - & & & - & & & - & & & & & \\
\hline Part Metals by Vol & Cadmium & SW 7131 & $\mathrm{ug} / \mathrm{Nm} 3$ & 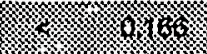 & 器 & & 0.419 & B & & 0.763 & B & & 0.591 & 2.18 & \\
\hline Part Metals by Vol & Calcium & SW 6010 & $u g / N m 3$ & 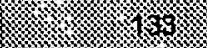 & 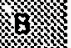 & & 193 & B & & 338 & B & & 265 & 921 & \\
\hline Part Metals by Vol & Chromium & SW 6010 & $\mathrm{ug} / \mathrm{Nm} 3$ & \% & 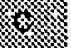 & & 1.11 & B & & 9.04 & B & & 5.07 & 50 & \\
\hline Part Metals by Vol & Cobalt & SW 6010 & $\mathrm{ug} / \mathrm{Nm} 3$ & \% & 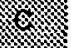 & & 0.21 & $\mathbf{J}$ & $<$ & 0.597 & C & $<$ & 0.597 & $\cdots$ & $59 \%$ \\
\hline Part Metals by Vol & Copper & SW 6010 & ug/Nm3 & s & . & & 0.711 & B & & 0.831 & B & & 0.771 & 0.759 & \\
\hline Part Metals by Vol & Iron & SW 6010 & $u g / N m 3$ & 18 & 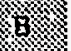 & & 119 & $\mathbf{B}$ & & 214 & B & & 167 & 604 & \\
\hline Part Metals by Vol & Lead & SW 7421 & $\mathrm{ug} / \mathrm{Nm} 3$ & $1 \%$ & y & & 0.445 & B & & 0.546 & B & & 0.495 & 0.642 & \\
\hline Part Metals by Vol & -Magneslum & SW 6010 & $\mathrm{ug} / \mathrm{Nm} 3$ & 3 & 6 & & 23.13 & $\mathbf{B}$ & & 58.05 & B & & 41 & 222 & \\
\hline Part Metals by Vol & Manganese & SW 6010 & ug/Nm3 & $8 \%$ & 19. & & 3.40 & B & & 11.06 & B & & 7.23 & 49 & \\
\hline Part Metals by Vol & Mercury & SW 7474 & ug/Nm3 & aisos & s. & & 0.0116 & B & $<$ & 0.0051 & C & & 0.0071 & 0.0573 & $18 \%$ \\
\hline
\end{tabular}

Stack - Page 2 


\section{Gas Stream Data}

SAMPLE STREAM: STACK

\begin{tabular}{|c|c|c|c|c|c|c|c|c|c|c|c|c|c|c|c|c|}
\hline $\begin{array}{c}\text { Analyte } \\
\text { Group }\end{array}$ & Specie & $\begin{array}{c}\text { Analytical } \\
\text { Method }\end{array}$ & Units & & $\begin{array}{c}\text { Run } \\
1 \\
\end{array}$ & & & $\begin{array}{c}\text { Run } \\
2 \\
\end{array}$ & & & $\begin{array}{c}\text { Run } \\
3 \\
\end{array}$ & & & Average & $\begin{array}{c}95 \% \\
\mathrm{Cl} \\
\end{array}$ & $\begin{array}{c}\text { DL } \\
\text { Ratto } \\
\end{array}$ \\
\hline Part Metals by Vol & Molybdenum & SW 6010 & ug/Nm3 & & 161 & e & & 1.19 & B & & 1.60 & B & & 1.40 & 2.64 & \\
\hline Part Metals by Vol & Nickel & SW 6010 & ug/Nm3 & & \% & fo & & 4.56 & B & & 74.20 & B & & 39.38 & 442 & \\
\hline Part Metals by Vol & Phosphorus & SW 6010 & ug/Nm3 & & \% & 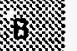 & $<$ & 2.59 & c & $<$ & 2.60 & $\mathrm{C}$ & $<$ & 2.59 & $\ldots$ & $100 \%$ \\
\hline Part Metals by Vol & Potassium & SW 6010 & ug/Nm3 & & 維 & 紑 & & 36.01 & J & & 44.37 & $J$ & & 40.19 & 53.13 & \\
\hline Part Metals by Vol & Selenium & sW 7740 & ug/Nm3 & & 52.88 & $\mathbf{B}$ & & 9.76 & B & & 15.68 & $\mathbf{B}$ & & 26.11 & 58.07 & \\
\hline Part Metals by Vol & Sodium & SW 6010 & $\mathrm{ug} / \mathrm{Nm} 3$ & & 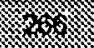 & 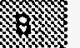 & & 48.23 & B & & 69.62 & $\mathbf{B}$ & & 58.93 & 136 & \\
\hline Part Metals by Vol & Strontium & SW 6010 & ug/Nm3 & & 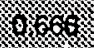 & 1 & & 1.22 & B & & 1.77 & $\mathbf{B}$ & & 1.49 & 3.51 & \\
\hline Part Metals by Vol & Titanium & sW 6010 & $u g / N m 3$ & & 㡭 & 歞 & & 12.45 & B & & 12.55 & B & & 12.50 & 0.59 & \\
\hline Part Metals by Vol & Vanadium & sW 6010 & ug/Nm3 & & 1.469 & B & & 1.55 & B & & 1.83 & B & & 1.61 & 0.468 & \\
\hline Part Metals by Vol & Zinc & SW 6010 & $\mathrm{ug} / \mathrm{Nm} 3$ & - & 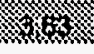 & ( & & 7.75 & B & & 6.76 & B & & 7.26 & 6.27 & \\
\hline Metals, Vapor & Aluminum & SW 6010 & ug/Nm3 & & 8.25 & B & $<$ & 8.70 & $\mathrm{c}$ & $<$ & 7.59 & C & $<$ & 8.70 & $\cdots$ & $50 \%$ \\
\hline Metals, Vapor & Antimony & ICP-MS & $\mathrm{ug} / \mathrm{Nm} 3$ & & 0.012 & B & & 0.012 & B & & 0.013 & B & & 0.012 & 0.0019 & \\
\hline Metals, Vapor & Arsenic & SW 7060 & ug/Nm3 & $<$ & 0.156 & c & $<$ & 0.201 & $c$ & $<$ & 0.176 & c & $<$ & 0.178 & 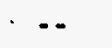 & $100 \%$ \\
\hline Metals, Vapor & Barium & SW 6010 & ug/Nm3 & $<$ & 0.126 & C & & 0.113 & $J$ & $<$ & 0.142 & C & $<$ & 0.142 & -. & $54 \%$ \\
\hline Metals, Vapor & Beryllium & SW 6010 & ug/Nm3 & $<$ & 0.131 & C & $<$ & 0.170 & C & & 0.032 & $\mathbf{J}$ & $<$ & 0.170 & -. & $82 \%$ \\
\hline Metals, Vapor & Boron & SW 6010 & $\mathrm{ug} / \mathrm{Nm} 3$ & & 468 & B & & 412 & B & & 440 & B & & 440 & 70 & \\
\hline Metals, Vapor & Cadmlum & SW 7131 & $\mathrm{ug} / \mathrm{Nm} 3$ & $<$ & 0.056 & c & $<$ & 0.073 & C & $<$ & 0.063 & c & $<$ & 0.064 & $\cdots$ & $100 \%$ \\
\hline Metals, Vapor & Calclum & SW 6010 & $\mathrm{ug} / \mathrm{Nm} 3$ & $<$ & 35.09 & $c$ & & 34.91 & $\mathbf{J}$ & $<$ & 39.57 & C & $<$ & 39.57 & -. & $52 \%$ \\
\hline Metals, Vapor & Chromium & SW 6010 & $\mathrm{ug} / \mathrm{Nm} 3$ & $<$ & 0.590 & c & $<$ & 0.763 & C & $<$ & 0.666 & C & $<$ & 0.673 & $\cdots$ & $100 \%$ \\
\hline Metals, Vapor & Cobalt & SW 6010 & $\mathrm{ug} / \mathrm{Nm} 3$ & & 0.218 & $\mathbf{J}$ & & 0.211 & $\mathbf{J}$ & & 0.751 & $J$ & & 0.394 & 0.770 & \\
\hline Metals, Vapor & Copper & SW 6010 & ug/Nm3 & & 2.32 & B & & 0.910 & $\mathbf{J}$ & $<$ & 1.02 & C & & 1.25 & 2.36 & $14 \%$ \\
\hline Metals, Vapor & Iron & SW 6010 & $\mathrm{ug} / \mathrm{Nm} 3$ & & 1.71 & B & $<$ & 1.83 & c & $<$ & 1.59 & C & $<$ & 1.83 & -. & $50 \%$ \\
\hline Metals, Vapor & Lead & SW 7421 & ug/Nm3 & $<$ & 0.190 & c & $<$ & 0.245 & $c$ & $<$ & 0.214 & C & $<$ & 0.216 & $\ldots$ & $100 \%$ \\
\hline Metals, Vapor & Magnesium & SW 6010 & $\mathrm{ug} / \mathrm{Nm} 3$ & & 5.55 & $B$ & $<$ & 6.98 & C & & 5.27 & $\mathbf{J}$ & $<$ & 6.98 & -. & $24 \%$ \\
\hline Metals, Vapor & Manganese & SW 6010 & ug/Nm3 & $<$ & 0.094 & c & $<$ & 0.121 & $c$ & $<$ & 0.106 & c & $<$ & 0.107 & -. & $100 \%$ \\
\hline Metals, Vapor & Mercury & CVAA & $\mathrm{ug} / \mathrm{Nm} 3$ & & 2.92 & B & & 3.13 & $B$ & & 3.07 & B & & 3.04 & 0.269 & \\
\hline Metals, Vapor & Molybdenum & SW 6010 & $\mathrm{ug} / \mathrm{Nm} 3$ & & 0.12 & $J$ & & 0.13 & $J$ & & 0.10 & J & & 0.116 & 0.048 & \\
\hline Metals, Vapor & Nickel & SW 6010 & $u g / N m 3$ & $<$ & 2.34 & c & & 2.88 & $J$ & $<$ & 2.64 & c & $<$ & 2.64 & $\cdots$ & $46 \%$ \\
\hline Metals, Vapor & Phosphorus & SW 6010 & $u g / N m 3$ & $<$ & 14.46 & $c$ & $<$ & 18.68 & $c$ & $<$ & 16.31 & $c$ & $<$ & 16.48 & -. & $100 \%$ \\
\hline Metals, Vapor & Potasslum & sW 6010 & ug/Nm3 & & 32.28 & B & $<$ & 0.88 & C & & 77.56 & B & & 36.76 & 96.28 & $0.4 \%$ \\
\hline
\end{tabular}




\section{Gas Stream Data}

SAMPLE STREAM: STACK

\begin{tabular}{|c|c|c|c|c|c|c|c|c|c|c|c|c|c|c|c|c|}
\hline $\begin{array}{c}\text { Analyte } \\
\text { Group }\end{array}$ & Specie & $\begin{array}{c}\text { Analytical } \\
\text { Method }\end{array}$ & Units & & $\begin{array}{c}\text { Run } \\
1 \\
\end{array}$ & & & $\begin{array}{c}\text { Run } \\
2 \\
\end{array}$ & & & $\begin{array}{c}\text { Run } \\
3 \\
\end{array}$ & & & Average & $\begin{array}{c}98 \% \\
\mathrm{Cl} \\
\end{array}$ & $\begin{array}{c}\text { DL } \\
\text { Ratlo }\end{array}$ \\
\hline Metals, Vapor & Selenium & SW 7740 & $\mathrm{ug} / \mathrm{Nm} 3$ & & 0.11 & $\mathbf{J}$ & & 0.84 & B & $\cdot$ & 1.40 & B & & 0.781 & 1.61 & \\
\hline Metals, Vapor & Sodlum & SW 6010 & ug/Nm3 & $<$ & 9.41 & C & $<$ & 12.16 & c & $<$ & 10.61 & C & $<$ & 10.73 & - & $100 \%$ \\
\hline Metals, Vapor & Strontlum & SW 6010 & $\mathrm{ug} / \mathrm{Nm} 3$ & $<$ & 0.04 & C & $<$ & 0.05 & C & $<$ & 0.04 & C & $<$ & 0.045 &.$- t$ & $100 \%$ \\
\hline Metals, Vapór & Titanium. & SW 6010 & ug/Nm3 & $<$ & 0.242 & $c$ & & 0.190 & $\mathbf{J}$ & $<$ & 0.273 & C & $<$ & 0.273 & - & $58 \%$ \\
\hline Metais, Vapor & Vanadium & SW 6010 & $\mathrm{ug} / \mathrm{Nm} 3$ & & 0.422 & $\mathbf{J}$ & & 0.420 & $\mathbf{J}$ & & 0.821 & B & & 0.554 & 0.574 & \\
\hline Metals, Vapor & Zinc & sw 6010 & $u g / N m 3$ & & 1.11 & B & & 373 & B & & 114 & B & & 163 & 474 & \\
\hline Total Metals & Aluminum & SW 6010 & ug/Nm3 & & 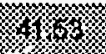 & & & 175 & & & 215 & & & 195 & 251 & \\
\hline Total Metals & Antimony & ICP-MS & ug/Nm3 & & max & & & 0.06 & & & 0.07 & & & 0.065 & 0.028 & \\
\hline Total Metals & Arsenic & SW 7060 & $\mathrm{ug} / \mathrm{Nm} 3$ & & 1.13 & & & 1.13 & & & 1.30 & & & 1.19 & 0.236 & \\
\hline Total Metals & - Barium ' & SW 6010 & ug/Nm3 & 榮 & w. & & & 3.72 & & & 2.09 & & & 2.906 & 10.351 & \\
\hline Total Metals & Beryllium & SW 6010 & ug/Nm3 & & 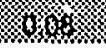 & & & 0.12 & & & 0.08 & & & 0.099 & 0.288 & \\
\hline Total Metals & Boron(vapor only) & SW 6010 & ug/Nm3 & & 468 & & & 412 & & & 440 & & & 440 & 70 & \\
\hline Total Metals & Cadmium & SW 7131 & $\mathrm{ug} / \mathrm{Nm} 3$ & & 的 & & & 0.46 & & & 0.79 & & & 0.625 & 2.152 & \\
\hline Total Melals' & Chromium & SW 6010 & $\mathrm{ug} / \mathrm{Nm}^{3}$ & 4 & 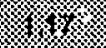 & & & 1.49 & & & 9.37 & & & 5.431 & 50.05 & \\
\hline Total Metals & Cobalt & SW 6010 & ug/Nm3 & & ঋ & & & 0.42 & & & 1.05 & & & 0.735 & 4.000 & \\
\hline Total Metals & Copper & SW 6010 & $\mathrm{ug} / \mathrm{Nm3}$ & & x & & & 1.62 & & & 1.34 & & & 1.480 & 1.784 & \\
\hline Total Metals & Iron & SW 6010 & ug/Nm3 & & 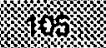 & & & 120 & & & 215 & & & 168 & 603 & \\
\hline Total Metals & Lead & SW 7421 & $\mathrm{ug} / \mathrm{Nm} 3$ & & 40 & & & 0.57 & & & 0.65 & & & 0.610 & 0.543 & \\
\hline Total Metals & Magneslum & SW 6010 & $\mathrm{ug} / \mathrm{Nm} 3$ & & 然維 & & & 26.62 & & & 63.32 & & & 44.97 & 233 & \\
\hline Total Metals & Manganese & SW 6010 & $u g / N m 3$ & & 新 & & & 3.46 & & & 11.11 & & & 7.284 & 48.623 & \\
\hline Total Metals & Mercury & SW 7471 & ug/Nm3 & & 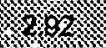 & & & 3.14 & & & 3.07 & & & 3.107 & 0.439 & \\
\hline Total Metals & Molybdenum & SW 6010 & $\mathrm{ug} / \mathrm{Nm3}$ & & $1 \%$ & & & 1.32 & & & 1.70 & & & 1.512 & 2.393 & \\
\hline Total Metals & Nickel & SW 6010 & ug/Nm3 & & . & & & 7.44 & & & 75.52 & & & 41.48 & 433 & \\
\hline Total Metals & Phosphorus & SW 6010 & $\mathrm{ug} / \mathrm{Nm3}$ & & 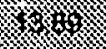 & & $<$ & 10.63 & & $<$ & 9.45 & & $<$ & 10.04 & -- & $100 \%$ \\
\hline Tolal Metals & Potasslum & SW 6010 & $\mathrm{ug} / \mathrm{Nm3}$ & & 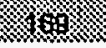 & & & 36.44 & & & 122 & & & 79.19 & 543 & \\
\hline Total Metals & Selenium & SW 7740 & ug/Nm3 & & 52.99 & & & 10.60 & & & $.17 .08^{\circ}$ & & & 27 & 57 & \\
\hline Total Metals & Sodium & SW 6010 & $\mathrm{ug} / \mathrm{Nm3}$ & & s & & & 54.31 & & & 74.93 & & & 64.62 & 131 & \\
\hline Total Metals & Strontlum & SW 6010 & ug/Nm3 & & m. & & & 1.24 & & & 1.79 & & & 1.517 & 3.486 & \\
\hline Total Metals & Titanium & SW 6010 & ug/Nm3 & & 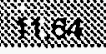 & & & 12.64 & & & 12.68 & & & 12.66 & 0.255 & \\
\hline
\end{tabular}

Stack - Page 4 


\section{Gas Stream Data}

SAMPLE STREAM: STACK

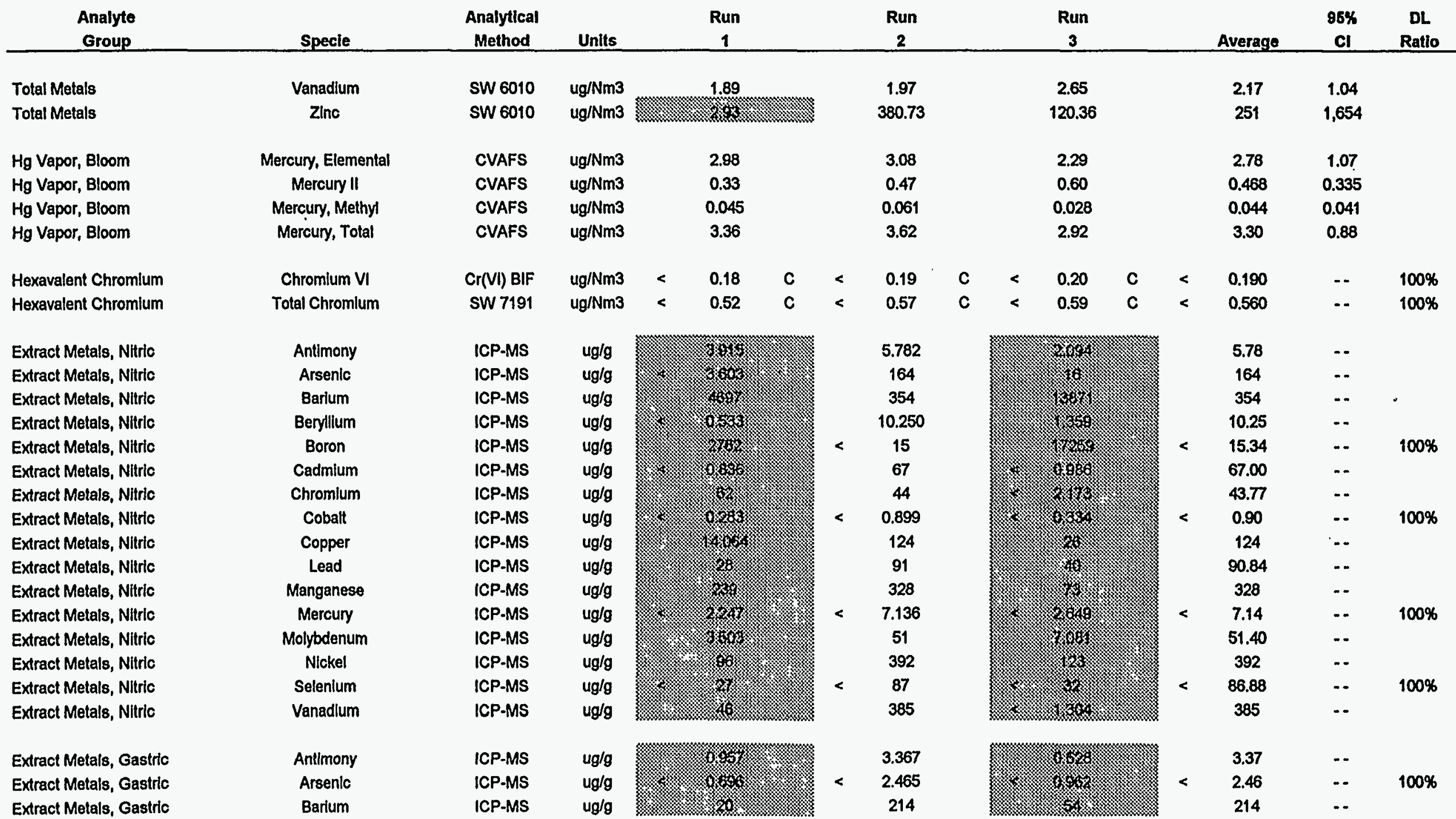




\section{Gas Stream Data}

SAMPLE STREAM: STACK

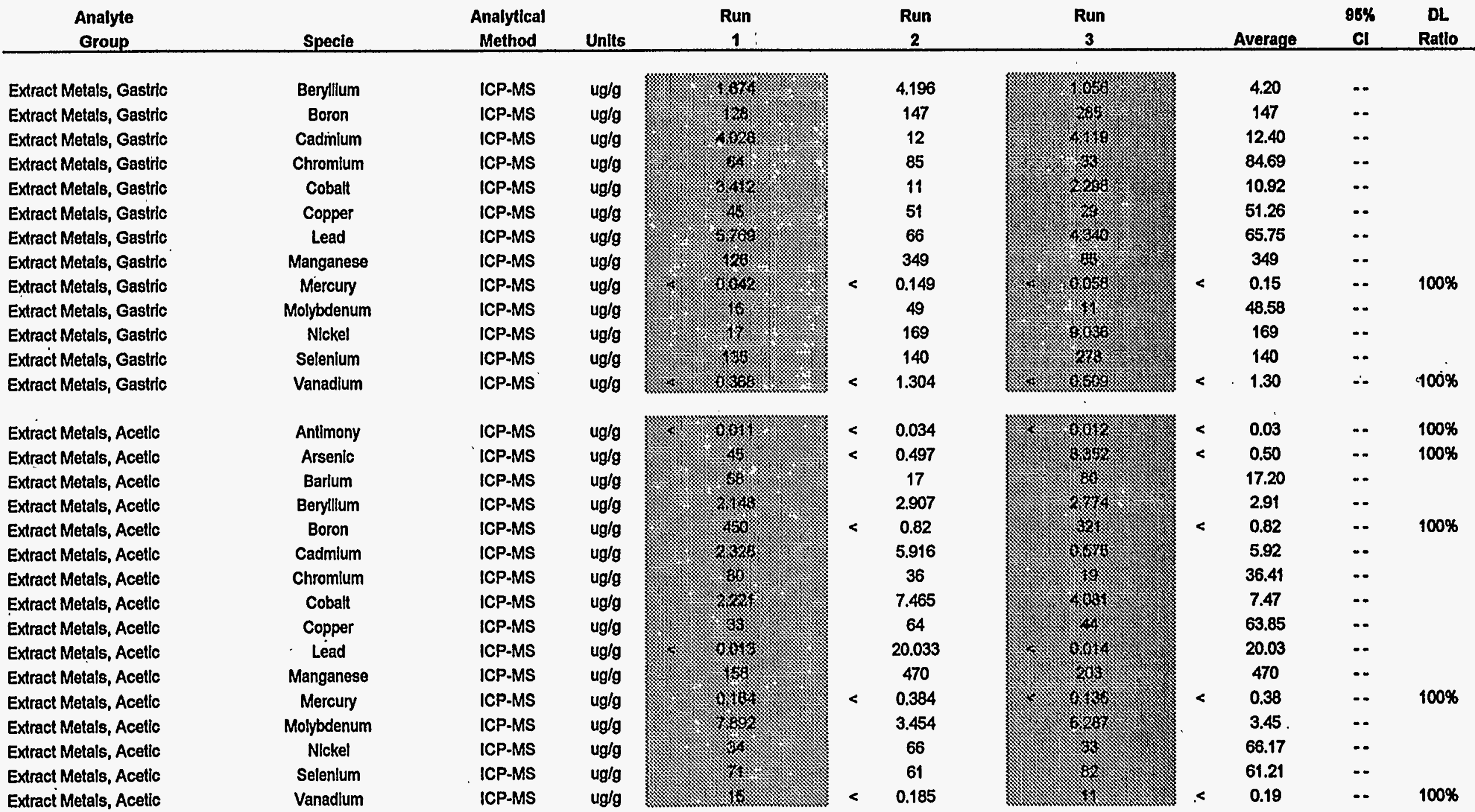

\section{Stack - Page 6}




\section{Gas Stream Data}

SAMPLE STREAM: STACK

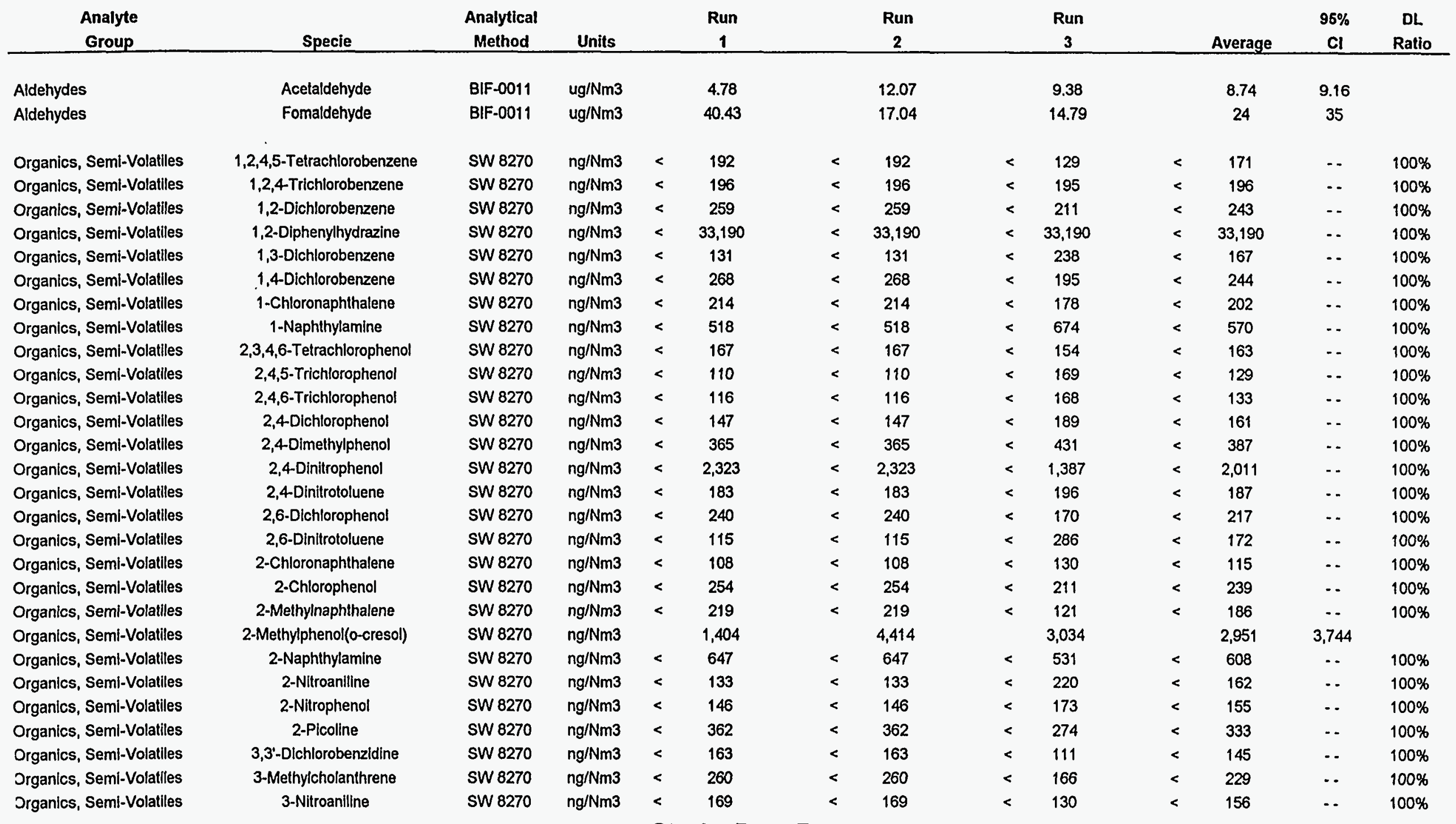




\section{Gas Stream Data}

SAMPLE STREAM: STACK

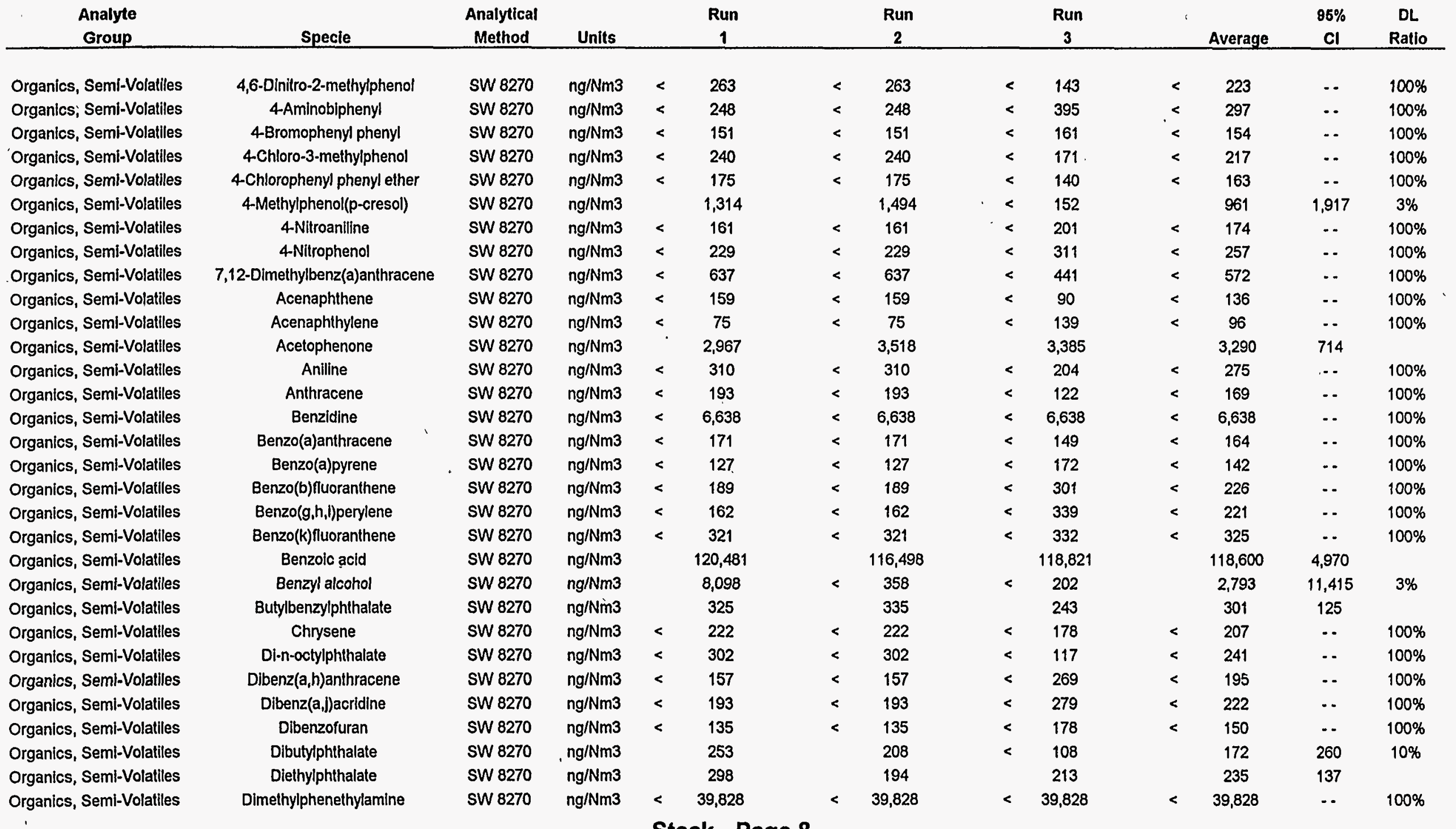

\section{Stack - Page 8}




\section{Gas Stream Data}

SAMPLE STREAM: STACK

\begin{tabular}{|c|c|c|c|c|c|c|c|c|c|c|c|c|c|}
\hline $\begin{array}{c}\text { Analyte } \\
\text { Group }\end{array}$ & Specie & $\begin{array}{c}\text { Analytical } \\
\text { Method }\end{array}$ & Units & & $\begin{array}{c}\text { Run } \\
1 \\
\end{array}$ & & $\begin{array}{c}\text { Run } \\
2 \\
\end{array}$ & & $\begin{array}{c}\text { Run } \\
3 \\
\end{array}$ & & Average & $\begin{array}{c}95 \% \\
\mathrm{Cl} \\
\end{array}$ & $\begin{array}{c}\mathrm{DL} \\
\text { Ratio }\end{array}$ \\
\hline Organics, Seml-Volatiles & Dimethylphthalate & SW 8270 & $\mathrm{ng} / \mathrm{Nm} 3$ & $<$ & 93 & $<$ & 93 & & 435 & & 176 & 557 & $18 \%$ \\
\hline Organics, Semi-Volatiles & Diphenylamine & SW 8270 & $\mathrm{ng} / \mathrm{Nm} 3$ & $<$ & 175 & $<$ & 175 & $<$ & 92 & $<$ & 147 & -. & $100 \%$ \\
\hline Organics, Semi-Volatiles & Ethyl methanesulfonate & SW 8270 & $\mathrm{ng} / \mathrm{Nm} 3$ & $<$ & 167 & $<$ & 167 & $<$ & 225 & $<$ & 186 & - & $100 \%$ \\
\hline Organics, Semi-Volatiles & Fluoranthene & SW 8270 & $\mathrm{ng} / \mathrm{Nm} 3$ & $<$ & 212 & $<$ & 212 & $<$ & 156 & $<$ & 193 & -- & $100 \%$ \\
\hline Organics, Semi-Volatiles & Fluorene & SW 8270 & $\mathrm{ng} / \mathrm{Nm} 3$ & $<$ & 112 & $<$ & 112 & $<$ & 126 & $<$ & 116 & $\cdots$ & $100 \%$ \\
\hline Organics, Semi-Volatlles & Hexachlorobenzene & SW 8270 & $\mathrm{ng} / \mathrm{Nm} 3$ & $<$ & 78 & $<$ & 78 & $<$ & 104 & $<$ & 87 & $\cdots$ & $100 \%$ \\
\hline Organics, Seml-Volatiles & Hexachlorobutadlene & SW 8270 & $\mathrm{ng} / \mathrm{Nm} 3$ & $<$ & 232 & $<$ & 232 & $<$ & 170 & $<$ & 211 & -- & $100 \%$ \\
\hline Organics, Semi-Volatiles & Hexachlorocyclopentadiene & SW 8270 & $\mathrm{ng} / \mathrm{Nm} 3$ & $<$ & 2,961 & $<$ & 2,961 & $<$ & 1,955 & $<$ & 2,625 & -- & $100 \%$ \\
\hline Organics, Seml-Volatiles & Hexachloroethane & SW 8270 & $\mathrm{ng} / \mathrm{Nm} 3$ & $<$ & 197 & $<$ & 197 & $<$ & 211 & $<$ & 202 & -. & $100 \%$ \\
\hline Organics, Semi-Volatiles & Indeno(1,2,3-cd)pyrene & SW 8270 & $\mathrm{ng} / \mathrm{Nm} 3$ & $<$ & 174 & $<$ & 174 & $<$ & 441 & $<$ & 263 & - & $100 \%$ \\
\hline Organics, Semi-Volatiles & Isophorone & SW 8270 & $\mathrm{ng} / \mathrm{Nm} 3$ & $<$ & 95 & $<$ & 95 & $<$ & 204 & $<$ & 132 & - & $100 \%$ \\
\hline Organics, Semi-Volatiles & Melhyl methanesulfonate & SW 8270 & $\mathrm{ng} / \mathrm{Nm} 3$ & $<$ & 16,595 & $<$ & 16,595 & $<$ & 16,595 & $<$ & 16,595 & -. & $100 \%$ \\
\hline Organics, Semi-Volatiles & N-Nitroso-di-n-butylamine & SW 8270 & $\mathrm{ng} / \mathrm{Nm} 3$ & $<$ & 435 & $<$ & 435 & $<$ & 209 & $<$ & 359 & -. & $100 \%$ \\
\hline Organics, Semi-Volatiles & N-Nitrosodimethylamine & SW 8270 & $\mathrm{ng} / \mathrm{Nm} 3$ & $<$ & 441 & $<$ & 441 & $<$ & 261 & $<$ & 381 & - & $100 \%$ \\
\hline Organics, Semi-Volatiles & N-Nitrosodipropylamine & SW 8270 & $\mathrm{ng} / \mathrm{Nm} 3$ & $<$ & 249 & $<$ & 249 & $<$ & 217 & $<$ & 239 & - - & $100 \%$ \\
\hline Organics, Seml-Volatiles & N-Nitrosopiperidine & SW 8270 & $\mathrm{ng} / \mathrm{Nm} 3$ & $<$ & 313 & $<$ & 313 & $<$ & 198 & $<$ & 275 & - & $100 \%$ \\
\hline Organics, Semi-Volatiles & Naphthalene & SW 8270 & $\mathrm{ng} / \mathrm{Nm} 3$ & & 1,955 & & 1,470 & & 1,175 & & 1,533 & 978 & \\
\hline Organics, Semi-Volatiles & Nitrobenzene & SW 8270 & $n g / N m 3$ & $<$ & 175 & $<$ & 175 & $<$ & 279 & $<$ & 210 & -. & $100 \%$ \\
\hline Organics, Semi-Volatiles & Pentachlorobenzene & sW 8270 & $\mathrm{ng} / \mathrm{Nm} 3$ & $<$ & 147 & $<$ & 147 & $<$ & 124 & $<$ & 139 & - & $100 \%$ \\
\hline Organics, Semi-Volatiles & Pentachloronitrobenzene & SW 8270 & $\mathrm{ng} / \mathrm{Nm} 3$ & $<$ & 687 & $<$ & 687 & $<$ & 458 & $<$ & 611 & -- & $100 \%$ \\
\hline Organics, Semi-Volatiles & Pentachlorophenol & SW 8270 & $\mathrm{ng} / \mathrm{Nm} 3$ & $<$ & 287 & $<$ & 287 & $<$ & 295 & $<$ & 290 & -- & $100 \%$ \\
\hline Organics, Seml-Volatiles & Phenacetin & SW 8270 & $\mathrm{ng} / \mathrm{Nm} 3$ & $<$ & 179 & $<$ & 179 & $<$ & 128 & $<$ & 162 & $\cdots$ & $100 \%$ \\
\hline Organics, Seml-Volatiles & Phenanthrene & SW 8270 & $\mathrm{ng} / \mathrm{Nm} 3$ & $<$ & 206 & $<$ & 206 & $<$ & 155 & $<$ & 189 & $\cdots$ & $100 \%$ \\
\hline Organics, Semi-Volatiles & Phenol & SW 8270 & $\mathrm{ng} / \mathrm{Nm} 3$ & & 5,277 & & 11,417 & & 11,285 & & 9,326 & 8,713 & \\
\hline Organics, Seml-Volatlles & Pronamlde & SW 8270 & $\mathrm{ng} / \mathrm{Nm} 3$ & $\dot{<}$ & 245 & $<$ & 245 & $<$ & 80 & $<$ & 190 & -. & $100 \%$ \\
\hline Organles, Semi-Volatiles & Pyrene & SW 8270 & $\mathrm{ng} / \mathrm{Nm} 3$ & $<$ & 155 & $<$ & 155 & $<$ & 135 & $<$ & 149 & - & $100 \%$ \\
\hline Organics, Semi-Volatiles & Pyridine & SW 8270 & $\mathrm{ng} / \mathrm{Nm} 3$ & $<$ & 385 & $<$ & 385 & $<$ & 195 & $<$ & 322 & -- & $100 \%$ \\
\hline Jrganics, Semi-Volatiles & bls(2-Chloroelhoxy)methane & SW 8270 & $\mathrm{ng} / \mathrm{Nm} 3$ & $<$ & 187 & $<$ & 187 & $<$ & 201 & $<$ & 191 & -- & $100 \%$ \\
\hline Jrganics, Seml-Volatlles & bis(2-Chloroethyl)ether & SW 8270 & $\mathrm{ng} / \mathrm{Nm} 3$ & $<$ & 243 & $<$ & 243 & $<$ & 127 & $<$ & 204 & -- & $100 \%$ \\
\hline Jrganics, Seml-Volatiles & bis(2-Chlorolsopropy) ether & SW 8270 & $\mathrm{ng} / \mathrm{Nm} 3$ & $<$ & 241 & $<$ & 241 & $<$ & 265 & $<$ & 249 & $\cdots$ & $100 \%$ \\
\hline
\end{tabular}




\section{Gas Stream Data}

SAMPLE STREAM: STACK

\begin{tabular}{|c|c|c|c|c|c|c|c|c|c|c|c|c|c|c|}
\hline $\begin{array}{c}\text { Analyte } \\
\text { Group }\end{array}$ & Specie & $\begin{array}{c}\text { Analytical } \\
\text { Method }\end{array}$ & Units & & $\begin{array}{c}\text { Run } \\
1 \\
\end{array}$ & & $\begin{array}{c}\text { Run } \\
2 \\
\end{array}$ & & $\begin{array}{c}\text { Run } \\
3 \\
\end{array}$ & & & Average & $\begin{array}{c}96 \% \\
\mathrm{Cl} \\
\end{array}$ & $\begin{array}{r}\text { DL } \\
\text { Ratio } \\
\end{array}$ \\
\hline Organics, Semi-Volatiles & bis(2-Ethylhexyl)phthalate & SW 8270 & $\mathrm{ng} / \mathrm{Nm} 3$ & & 2,005 & & 1,099 & & 1,019 & & & 1,374 & 1,360 & \\
\hline Organics, Semi-Volatiles & p-Chloroaniline & SW 8270 & $\mathrm{ng} / \mathrm{Nm} 3$ & $<$ & 186 & $<$ & 186 & $<$ & 247 & & $<$ & 206 & -- & $100 \%$ \\
\hline Organics, Semi-Volatiles & p-Dimethylaminoazobenzene & SW 8270 & $\mathrm{ng} / \mathrm{Nm} 3$ & $<$ & 171 & $<$ & 171 & $<$ & 241 & & $<$ & 194 & -- & $100 \%$ \\
\hline Organics, Volatile & 1,1,1-Trichloroethane & SW 8240 & $\mathrm{ng} / \mathrm{Nm} 3$ & & 881 & & 774 & $<$ & 545 & & & 643 & 807 & $14 \%$ \\
\hline Organics, Volatile & 1,1,2,2-Tetrachloroethane & SW 8240 & $\mathrm{ng} / \mathrm{Nm} 3$ & $<$ & 497 & $<$ & 538 & $<$ & 545 & & $<$ & 527 & .. & $100 \%$ \\
\hline Organics, Volatile & 1,1,2-Trichloroethane & SW 8240 & $\mathrm{ng} / \mathrm{Nm} 3$ & $<$ & 497 & $<$ & 538 & $<$ & 545 & & $<$ & 527 & $\cdots$ & $100 \%$ \\
\hline Organics, Volatile & 1,1-Dichloroethane & SW 8240 & $\mathrm{ng} / \mathrm{Nm} 3$ & $<$ & 497 & $<$ & 538 & $<$ & 545 & & $<$ & 527 & $\cdots$ & $100 \%$ \\
\hline Organics, Volatile & 1,1-Dlchloroethene & SW 8240 & $\mathrm{ng} / \mathrm{Nm3}$ & $<$ & 497 & $<$ & 538 & $<$ & 545 & & $<$ & 527 & - & $100 \%$ \\
\hline Organics, Volatile & 1,2-Dichlorobenzene & SW 8240 & $\mathrm{ng} / \mathrm{Nm} 3$ & $i<$ & 497 & $<$ & 538 & $<$ & 545 & & $<$ & 527 & $\cdots$ & $100 \%$ \\
\hline Organics, Volatile & 1,2-Dichloroethane & SW 8240 & $\mathrm{ng} / \mathrm{Nm} 3$ & $<$ & 497 & $<$ & 538 & $<$ & 545 & & $<$ & 527 & -. & $100 \%$ \\
\hline Organics, Volatile & 1,2-Dichloropropane & SW 8240 & $\mathrm{ng} / \mathrm{Nm} 3$ & $<$ & 497 & $<$ & 538 & $<$ & 545 & & $<$ & 527 & $\cdots$ & $100 \%$ \\
\hline Organics, Volatile & 1,3-Dichlorobenzene & SW 8240 & $\mathrm{ng} / \mathrm{Nm} 3$ & $<$ & 497 & $<$ & 538 & $<$ & 545 & & $<$ & 527 & $\cdots$ & $100 \%$ \\
\hline Organics, Volatile & 1,4-Dichlorobenzene & SW 8240 & $\mathrm{ng} / \mathrm{Nm} 3$ & $<$ & 497 & $<$ & 538 & $<$ & 545 & & $<$ & 527 & -- & $100 \%$ \\
\hline Organics, Volatile & 2-Butanone & SW 8240 & $\mathrm{ng} / \mathrm{Nm} 3$ & $<$ & 2,485 & $<$ & 2,690 & $<$ & 2,725 & & $<$ & 2,633 & -- & $100 \%$ \\
\hline Organics, Volatile & 2-Hexanone & SW 8240 & $\mathrm{ng} / \mathrm{Nm} 3$ & $<$ & 2,485 & $<$ & 2,690 & $<$ & 2,725 & & $<$ & 2,633 & -- & $100 \%$ \\
\hline Organics, Volatile & 4-Methyl-2-Pentanone & SW 8240 & $\mathrm{ng} / \mathrm{Nm} 3$ & $<$ & 2,485 & $<$ & 2,690 & $<$ & 2,725 & & $<$ & 2,633 & $\ldots$ & $100 \%$ \\
\hline Organics, Volatile & Acetone & SW 8240 & $\mathrm{ng} / \mathrm{Nm} 3$ & & 2,965 & $<$ & 2,690 & & 6,341 & & & 3,550 & 6,332 & $13 \%$ \\
\hline Organics, Volatile & Benzene & SW 8240 & $\mathrm{ng} / \mathrm{Nm} 3$ & & 1,153 & & 1,329 & & 1,435 & & & 1,306 & 355 & \\
\hline Organics, Volalile & Bromodichloromethane & SW 8240 & $\mathrm{ng} / \mathrm{Nm} 3$ & $<$ & 497 & $<$ & 538 & $<$ & 545 & & $<$ & 527 & $\cdots$ & $100 \%$ \\
\hline Organics, Volatile & Bromoform & SW 8240 & $\mathrm{ng} / \mathrm{Nm} 3$ & $<$ & 497 & $<$ & 538 & $<$ & 545 & & $<$ & 527 & $\cdots$ & $100 \%$ \\
\hline Organics, Volatile & Bromomethane & SW 8240 & $\mathrm{ng} / \mathrm{Nm} 3$ & $<$ & 497 & $<$ & 538 & $<$ & 545 & & $<$ & 527 & $\cdots$ & $100 \%$ \\
\hline Organics, Volatile & Carbon Disulfide & SW 8240 & $\mathrm{ng} / \mathrm{Nm} 3$ & & 1,978 & & 2,797 & & 1,998 & & & 2,258 & 1,160 & \\
\hline Organics, Volatile & Carbon Tetrachloride & SW 8240 & $\mathrm{ng} / \mathrm{Nm} 3$ & $<$ & 497 & $<$ & 538 & $<$ & 545 & & $<$ & 527 & -. & $100 \%$ \\
\hline Organies, Volatile & Chlorobenzene & SW 8240 & ng/Nm3 & $<$ & 497 & $<$ & 538 & $<$ & 545 & & $<$ & 527 & $\cdots$ & $100 \%$ \\
\hline Organics, Volatile & Chloroethane & SW 8240 & $n g / N m 3$ & $<$ & 497 & $<$ & 538 & $<$ & 545 & & $<$ & 527 & -- & $100 \%$ \\
\hline Organics, Volatile & Chloroform & SW 8240 & $n g / N m 3$ & $<$ & 497 & $<$ & 538 & $<$ & 545 & & $<$ & 527 & $\cdots$ & $100 \%$ \\
\hline Organics, Volatile & Chloromelhane & SW 8240 & $\mathrm{ng} / \mathrm{Nm} 3$ & & 7,880 & & 10,034 & $<$ & 545 & & & 6,062 & 12,741 & $1 \%$ \\
\hline Organics, Volatile & Dibromochloromethane & SW 8240 & $\mathrm{ng} / \mathrm{Nm} 3$ & $<$ & 497 & $<$ & 538 & $<$ & 545 & & $<$ & 527 & -- & $100 \%$ \\
\hline Organics, Volatile & Ethyl Benzene & SW 8240 & $\mathrm{ng} / \mathrm{Nm3}$ & $<$ & 497 & $<$ & 538 & $<$ & 545 & & $<$ & 527 & $\ldots$ & $100 \%$ \\
\hline Organics, Volatile & Methylene Chloride & SW 8240 & $\mathrm{ng} / \mathrm{Nm} 3$ & & 242,946 & & 110,653 & & 22,912 & & & 125,503 & 275,181 & \\
\hline
\end{tabular}

\section{Stack - Page 10}




\section{Gas Stream Data}

SAMPLE STREAM: STACK

\begin{tabular}{|c|c|c|c|c|c|c|c|c|c|c|c|c|c|c|c|}
\hline $\begin{array}{c}\text { Analyte } \\
\text { Group }\end{array}$ & Specie & $\begin{array}{c}\text { Analytical } \\
\text { Method }\end{array}$ & Units & & $\begin{array}{c}\text { Run } \\
1 \\
\end{array}$ & & & $\begin{array}{c}\text { Run } \\
2 \\
\end{array}$ & & $\begin{array}{c}\text { Run } \\
3 \\
\end{array}$ & & & Average & $\begin{array}{c}95 \% \\
\text { CI } \\
\end{array}$ & $\begin{array}{c}\text { DL } \\
\text { Ratio }\end{array}$ \\
\hline Organics, Volatile & Styrene & SW 8240 & $\mathrm{ng} / \mathrm{Nm} 3$ & $<$ & 544 & & $<$ & 538 & $<$ & 545 & & $<$ & 542 & -. & $100 \%$ \\
\hline Organics, Volatile & Toluene & SW 8240 & $\mathrm{ng} / \mathrm{Nm} 3$ & & 1,989 & & & 2,474 & & 1,670 & & & 2,044 & 1,006 & \\
\hline Organics, Volatlle & Trichloroethene & SW 8240 & $\mathrm{ng} / \mathrm{Nm} 3$ & $<$ & 497 & & $<$ & 538 & $<$ & 545 & & $<$ & 527 & -- & $100 \%$ \\
\hline Organics, Volatile & Trichlorofluoromethane & SW 8240 & $\mathrm{ng} / \mathrm{Nm} 3$ & & 741 & & & 1,919 & & 690 & & & 1,117 & 1,727 & \\
\hline Organics, Volatile & Vinyl Acetate & SW 8240 & ng/Nm3 & $<$ & 2,485 & & $<$ & 2,690 & $<$ & 2,725 & & $<$ & 2,633 & -. & $100 \%$ \\
\hline Organics, Volatile & Vinyl Chloride & SW 8240 & $\mathrm{ng} / \mathrm{Nm} 3$ & $<$ & 497 & & $<$ & 538 & $<$ & 545 & & $<$ & 527 & -. & $100 \%$ \\
\hline Organics, Volatile & cis-1,3-Dichloropropene & SW 8240 & $\mathrm{ng} / \mathrm{Nm3}$ & $<$ & 497 & & $<$ & 538 & $<$ & 545 & & $<$ & 527 & - & $100 \%$ \\
\hline Organies, Volatile & m,p-Xylene & SW 8240 & $\mathrm{ng} / \mathrm{Nm} 3$ & $<$ & 544 & & $<$ & 538 & $<$ & 545 & & $<$ & 542 & $\cdots$ & $100 \%$ \\
\hline Organics, Volatile & o-Xylene & SW 8240 & $\mathrm{ng} / \mathrm{Nm3}$ & $<$ & .497 & & $<$ & 538 & $<$ & 545 & & $<$ & 527 & $\cdots$ & $100 \%$ \\
\hline Organics, Volatile & trans-1,2-Dichloroethene & SW 8240 & $\mathrm{ng} / \mathrm{Nm3}$ & $<$ & 497 & & $<$ & 538 & $<$ & 545 & & $<$ & 527 & $\cdots$ & $100 \%$ \\
\hline Organics, Volatile & trans-1,3-Dichloropropene & SW 8240 & $\mathrm{ng} / \mathrm{Nm} 3$ & $<$ & 497 & & $<$ & 538 & $<$ & 545 & & $<$ & 527 & -. & $100 \%$ \\
\hline Dioxins/Furans & 1234678-HpCDD & HR-GCMS & $\mathrm{ng} / \mathrm{Nm} 3$ & $<$ & 0.0067 & & $<$ & 0.0656 & $<$ & 0.0068 & & $<$ & 0.0264 & - & $100 \%$ \\
\hline Dioxins/Furans & $123478-\mathrm{H} \times C D D$ & HR-GCMS & $\mathrm{ng} / \mathrm{Nm} 3$ & $<$ & 0.0067 & & $<$ & 0.0328 & $<$ & 0.0068 & & $<$ & 0.0154 & $-\cdot$ & $100 \%$ \\
\hline Dioxins/Furans & 123478-HxCDF & HR-GCMS & ng/Nm3 & & 0.0020 & & $<$ & 0.0164 & $<$ & 0.0034 & & $<$ & 0.0164 & -. & $83 \%$ \\
\hline Dloxins/Furans & 1234789-HpCDF & HR-GCMS & $\mathrm{ng} / \mathrm{Nm3}$ & $<$ & 0.0067 & & $<$ & 0.0328 & $<$ & 0.0068 & & $<$ & 0.0154 & -. & $100 \%$ \\
\hline Dioxins/Furans & 123678-HxCDD & HR-GCMS & $\mathrm{ng} / \mathrm{Nm} 3$ & $<$ & 0.0034 & & $<$ & 0.0230 & $<$ & 0.0034 & & $<$ & 0.0099 & - & $100 \%$ \\
\hline Dioxins/Furans & 123678-HxCDF & HR-GCMS & $\mathrm{ng} / \mathrm{Nm3}$ & $<$ & 0.0020 & & $<$ & 0.0131 & $<$ & 0.0024 & & $<$ & 0.0058 & .. & $100 \%$ \\
\hline Dloxins/Furans & 12378-PeCDD & HR-GCMS & $\mathrm{ng} / \mathrm{Nm3}$ & $<$ & 0.0020 & & $<$ & 0.0098 & $<$ & 0.0024 & & $<$ & 0.0047 & $\cdots$ & $100 \%$ \\
\hline Dloxins/Furans & 12378-PeCDF & HR-GCMS & $\mathrm{ng} / \mathrm{Nm} 3$ & $<$ & 0.0013 & & $<$ & 0.0066 & $<$ & 0.0017 & & $<$ & 0.0032 & - & $100 \%$ \\
\hline Dloxins/Furans & 123789-HxCDD & HR-GCMS & $\mathrm{ng} / \mathrm{Nm3}$ & $<$ & 0.0034 & & $<$ & 0.0295 & $<$ & 0.0034 & & $<$ & 0.0121 & -. & $100 \%$ \\
\hline Dioxins/Furans & 123789-HxCDF & HR-GCMS & $\mathrm{ng} / \mathrm{Nm3}$ & $<$ & 0.0034 & & $<$ & 0.0197 & $<$ & 0.0034 & & $<$ & 0.0088 & -- & $100 \%$ \\
\hline Dloxins/Furans & 234678-HXCDF & HR-GCMS & ng/Nm3 & & 0.0034 & & $<$ & 0.0164 & & 0.0030 & & $<$ & 0.0164 & -- & $56 \%$ \\
\hline Dloxins/Furans & 23478-PeCDF & HR-GCMS & $\mathrm{ng} / \mathrm{Nm3}$ & $<$ & 0.0013 & & $<$ & 0.0066 & $<$ & 0.0017 & & $<$ & 0.0032 & -- & $100 \%$ \\
\hline Dioxins/Furans & 2378-TCDD & HR-GCMS & $\mathrm{ng} / \mathrm{Nm} 3$ & $<$ & 0.0017 & & $<$ & 0.0066 & $<$ & 0.0017 & & $<$ & 0.0033 & - & $100 \%$ \\
\hline Dioxins/Furans & 2378-TCDF & HR-GCMS & $\mathrm{ng} / \mathrm{Nm} 3$ & & 0.0020 & $M$ & $<$ & 0.0033 & & 0.0017 & & $<$ & 0.0033 & -. & $31 \%$ \\
\hline Dioxins/Furans & OCDD & HR-GCMS & $\mathrm{ng} / \mathrm{Nm} 3$ & & 0.0168 & & $<$ & 0.1313 & $<$ & 0.0102 & & $<$ & 0.1313 & -. & $81 \%$ \\
\hline Dloxins/Furans & OCDF & HR-GCMS & $\mathrm{ng} / \mathrm{Nm3}$ & & 0.0168 & & $<$ & 0.1313 & & 0.0136 & $M$ & $<$ & 0.1313 & $\cdots$ & $68 \%$ \\
\hline Dloxins/Furans & Tolal HpCDD & HR-GCMS & $\mathrm{ng} / \mathrm{Nm} 3$ & $<$ & 0.0067 & & $<$ & 0.0656 & $<$ & 0.0068 & & $<$ & 0.0264 & $\cdots$ & $100 \%$ \\
\hline
\end{tabular}




\section{Gas Stream Data}

SAMPLE STREAM: STACK

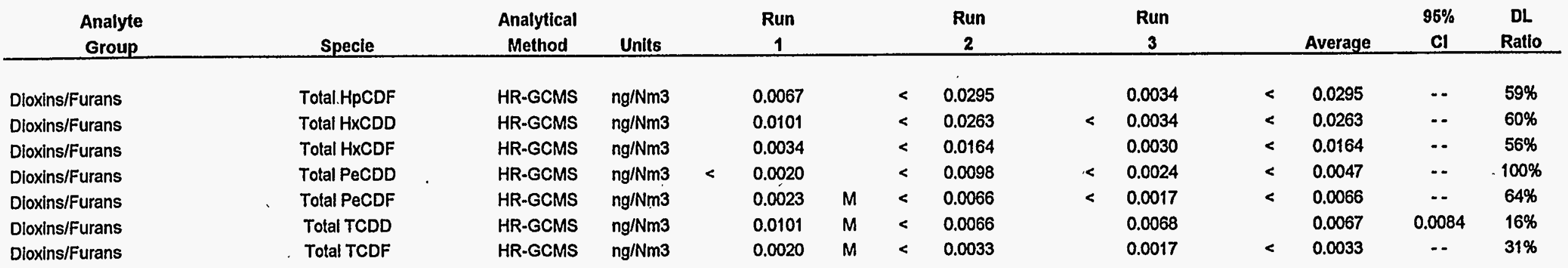

Note: Shaded data invalid due to high background in filter substrate. Shaded data not used in calculation of average.

$M=$ Maximum Estimated Concentration 


\section{Solid Stream Data}

Sample Stream: Raw Coal

\begin{tabular}{|c|c|c|c|c|c|c|c|c|c|c|}
\hline $\begin{array}{c}\text { Analyte } \\
\text { Group }\end{array}$ & Specie & Method & Units & $\begin{array}{c}\text { Run } \\
1 \\
\end{array}$ & $\begin{array}{c}\text { Run } \\
2 \\
\end{array}$ & $\begin{array}{r}\text { Run } \\
\mathbf{3 a} \\
\end{array}$ & $\begin{array}{r}\text { Run } \\
\mathbf{3 d} \\
\end{array}$ & Average & $\begin{array}{c}95 \% \\
\text { Cl }\end{array}$ & $\begin{array}{c}\text { DL } \\
\text { Ratio }\end{array}$ \\
\hline Anions & Chloride & D4208 & ug/g & 1250 & 1410 & 1390 & 1500 & 1,350 & 217 & \\
\hline Anions & Fluoride & D3761 & ug/g & 120 & 140 & 110 & 120 & 123 & 38 & \\
\hline Metals & Aluminum & INAA & ug/g & 12,847 & 15,153 & 14,863 & 13,776 & 14,287 & 3,121 & \\
\hline Metals & Antimony & INAA & ug/g & 0.77 & 0.56 & 0.52 & 0.49 & 0.62 & 0.33 & \\
\hline Metals & Arsenic & GFAA & ug/g & 3.00 & 3.00 & 3.00 & 3.00 & 3.00 & & \\
\hline Metals & Barium & INAA & ug/g & 120 & 108 & 106 & 110 & 112 & 19 & \\
\hline Motals & Beryllium & ICPES & ug/g & 1.20 & 1.10 & 1.10 & 1.10 & 1.13 & 0.14 & \\
\hline Metals & Boron & ICPES & ug/g & 110 & 120 & 100 & 100 & 110 & 25 & \\
\hline Motals & Bromine & INAA & ug/g & 7.16 & 7.89 & 7.20 & 6.89 & 7.42 & 1.02 & \\
\hline Metals & Cadmium & ICPES & ug/g & 0.700 & 0.200 & 0.700 & 0.200 & 0.533 & 0.717 & \\
\hline Metals & Calclum & INAA & ug/g & 2,793 & 3,611 & 2,624 & 2,677 & 3,010 & 1,311 & \\
\hline Metals & Cerium & INAA & ug/g & 15.18 & 16.56 & 16.60 & 15.81 & 16.11 & 2.01 & \\
\hline Metals & Cesium & INAA & ug/g & 1.10 & 1.21 & 1.20 & 1.15 & 1.17 & 0.16 & \\
\hline Metals & Chlorine & INAA & ug/g & 1,169 & 1,180 & 1,269 & 1,427 & 1,206 & 136 & \\
\hline Metals & Chromium & INAA & $u g / g$ & 25.66 & 25.92 & 25.67 & 23.57 & 25.75 & 0.37 & \\
\hline Metals & Cobalt & INAA & $u g / g$ & 3.99 & 4.12 & 4.13 & 3.80 & 4.08 & 0.19 & \\
\hline Metals & Copper & INAA & $u g / g$ & 23.58 & 63.57 & 38.73 & 38.93 & 41.96 & 50.15 & \\
\hline Metals & Europium & INAA & $u g / g$ & 0.300 & 0.294 & 0.305 & 0.306 & 0.299 & 0.014 & \\
\hline Metals & Hafnium & INAA & $\mathrm{ug} / \mathrm{g}$ & 0.667 & 0.652 & 0.696 & 0.728 & 0.672 & 0.056 & \\
\hline Metals & lodine & INAA & $u g / g$ & 2.09 & 1.99 & 1.94 & 1.05 & 2.09 & -. & $21 \%$ \\
\hline Motals & Iron & INAA & $\mathrm{ug} / \mathrm{g}$ & 12,989 & 13,405 & 12.074 & 11,827 & 12,823 & 1,691 & \\
\hline Metals & Lanthanum & INAA & ug/g & 6.53 & 7.37 & 6.39 & 6.41 & 6.76 & 1.31 & \\
\hline Metals & Lead & ICPES & $u g / g$ & 8.00 & 8.00 & 11.00 & 8.00 & 9.00 & 4.30 & \\
\hline Motals & Lutetium & INAA & $\mathrm{ug} / \mathrm{g}$ & 0.119 & 0.121 & 0.121 & 0.101 & 0.120 & 0.003 & \\
\hline Metals & Magnesium & INAA & $\mathrm{ug} / \mathrm{g}$ & 653 & 641 & 686 & 630 & 660 & 57.87 & \\
\hline Metals & Manganese & INAA & $\mathrm{ug} / \mathrm{g}$ & 22.05 & 24.41 & 26.78 & 24.63 & 24.41 & 5.88 & \\
\hline Motals & Mercury & DGACVAA & $u g / g$ & 0.040 & 0.040 & 0.050 & 0.040 & 0.043 & 0.014 & \\
\hline Metals & Molybdenum & INAA & $\mathrm{ug} / \mathrm{g}$ & 20.29 & 21.36 & 13.53 & 21.63 & 18.39 & 10.54 & \\
\hline Metals & Neodymium & INAA & $u g / g$ & 7.09 & 9.32 & 7.50 & 11.38 & 7.97 & 2.95 & \\
\hline Motals & Nickol & INAA & $u g / g$ & 39.21 & 46.03 & 34.57 & 25.89 & 39.94 & 14.32 & \\
\hline Vetals & Phosphorus & ICPES & $\mathrm{ug} / \mathrm{g}$ & 70 & 150 & 66 & 97 & 95 & 118 & \\
\hline netals & Potassium & INAA & ug/g & 2.940 & 2,182 & 4,034 & 3,125 & 3,052 & 2,313 & \\
\hline netals & Rubldium & INAA & ug/g & 19.71 & 22.53 & 20.40 & 19.57 & 20.88 & 3.66 & \\
\hline netals & Samarium & INAA & ug/g & 1.45 & 1.54 & 1.30 & 1.27 & 1.43 & 0.31 & \\
\hline
\end{tabular}

Raw Coal - Page 1 
Solid Stream Data

Sample Stream: Raw Coal

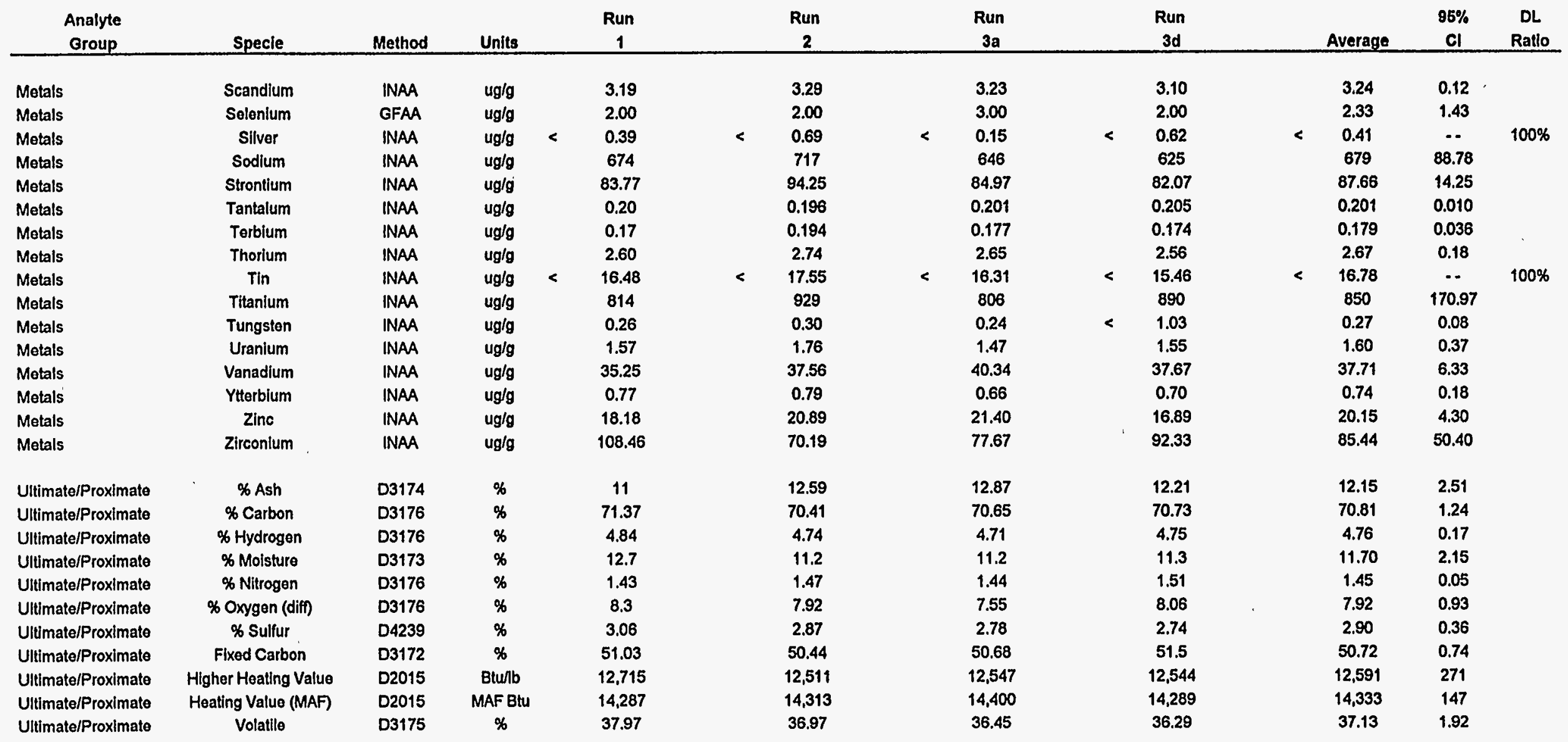

Raw Coal - Page 2 
Solid Stream Data

Sample Stream: Feed Coal

\begin{tabular}{|c|c|c|c|c|c|c|c|c|c|c|}
\hline $\begin{array}{c}\text { Analyte } \\
\text { Group }\end{array}$ & Specie & $\begin{array}{l}\text { Analytical } \\
\text { Method }\end{array}$ & Units & $\begin{array}{c}\text { Run } \\
1 \\
\end{array}$ & $\begin{array}{c}\text { Run } \\
2 \\
\end{array}$ & $\begin{array}{c}\text { Run } \\
3 \\
\end{array}$ & $\begin{array}{c}\text { Run } \\
3 d\end{array}$ & Average & $\begin{array}{c}95 \% \\
\mathrm{Cl} \\
\end{array}$ & $\begin{array}{c}\text { DL } \\
\text { Ratio }\end{array}$ \\
\hline $\begin{array}{l}\text { Anions } \\
\text { Anions }\end{array}$ & $\begin{array}{l}\text { Chloride } \\
\text { Fluoride }\end{array}$ & $\begin{array}{l}\text { D4208 } \\
\text { D3761 }\end{array}$ & $\begin{array}{l}u g / g \\
u g / g\end{array}$ & $\begin{array}{c}1,410 \\
100\end{array}$ & $\begin{array}{c}1,430 \\
100\end{array}$ & $\begin{array}{c}1,360 \\
100\end{array}$ & $\begin{array}{c}1,400 \\
110\end{array}$ & $\begin{array}{c}1,400 \\
100\end{array}$ & 90 & \\
\hline Metals & Aluminum & INAA & ug/g & 13,856 & 14,674 & 14,977 & 15,511 & 14,502 & 1,441 & \\
\hline Metals & Antimony & INAA & ug/g & 0.68 & 0.57 & 0.57 & 0.65 & 0.61 & 0.16 & \\
\hline Metals & Arsenic & GFAA & $\mathrm{ug} / \mathrm{g}$ & 2.00 & 3.00 & 2.00 & 3.00 & 2.33 & 1.43 & \\
\hline Metals & Barlum & INAA & ug/g & 66.1 & 70.3 & 103 & 89.1 & 79.9 & 50.7 & \\
\hline Metals & Beryllium & ICPES & ug/g & 1.10 & 1.10 & 1.10 & 1.20 & 1.10 & & \\
\hline Metals & Boron & ICPES & ug/g & 100 & 100 & 100 & 120 & 100 & & \\
\hline Metals & Bromine & INAA & ug/g & 7.25 & 7.67 & 7.38 & 8.24 & 7.44 & 0.53 & \\
\hline Metals & Cadmium & ICPES & ug/g & 0.30 & 0.30 & 0.30 & 0.40 & 0.30 & & \\
\hline Metals & Calcium & INAA & ug/g & 1,764 & 1,941 & 2,717 & 2,365 & 2,141 & 1,260 & \\
\hline Metals & Cerium & INAA & ug/g & 15.3 & 14.7 & 17.4 & 16.7 & 15.8 & 3.5 & \\
\hline Metals & Cesium & INAA & $\mathrm{ug} / \mathrm{g}$ & 1.16 & 1.04 & 1.31 & 1.13 & 1.17 & 0.34 & \\
\hline Metals & Chlorlne & INAA & $\mathrm{ug} / \mathrm{g}$ & 1,220 & 1,293 & 1,222 & 1,266 & 1,245 & 103 & \\
\hline Metals & Chromlum & INAA & $u g / g$ & 26.0 & 24.7 & 23.7 & 27.8 & 24.8 & 2.9 & \\
\hline Metals & Cobalt & INAA & ug $/ \mathrm{g}$ & 3.81 & 2.63 & 4.08 & 4.01 & 3.51 & 1.92 & \\
\hline Metals & Copper & INAA & ug/g & 59.5 & 9.83 & 39.0 & 23.0 & 36.1 & 62.1 & \\
\hline Metals & Europium & INAA & $\mathrm{ug} / \mathrm{g}$ & 0.32 & 0.27 & 0.32 & 0.29 & 0.30 & 0.08 & \\
\hline Metals & Hafnium & INAA & ug/g & 0.68 & 0.66 & 0.78 & 0.83 & 0.70 & 0.16 & \\
\hline Metals & lodine & INAA & $u g / g$ & 1.66 & 1.32 & 0.87 & 1.03 & 1.66 & .. & $27 \%$ \\
\hline Metals & Iron & INAA & ug/g & 11,814 & 10,938 & 11,390 & 11,939 & 11,381 & 1,089 & \\
\hline Metals & Lanthanum & INAA & ug/g & 6.76 & 7.02 & 7.15 & 7.44 & 6.98 & 0.49 & \\
\hline Metals & Lead & ICPES & $u g / g$ & 9.00 & 8.00 & 7.00 & 8.00 & 8.00 & 2.48 & \\
\hline Metals & Lutellum & INAA & $u g / g$ & 0.13 & 0.11 & 0.11 & 0.12 & 0.12 & 0.03 & \\
\hline Metals & Magnesium & INAA & ug/g & 586 & 489 & 626 & 705 & 567 & 175 & \\
\hline Metals & Manganese & INAA & $u g / g$ & 24.9 & 22.8 & 22.5 & 24.4 & 23.4 & 3.3 & \\
\hline Metals & Mercury & DGACVAA & $u g / g$ & 0.09 & 0.07 & 0.07 & 0.09 & 0.08 & 0.03 & \\
\hline Metals & Molybdenum & INAA & ug/g & 23.6 & 19.5 & 23.8 & 21.8 & 22.3 & 6.1 & \\
\hline Metals & Neodymium & INAA & ug/g & 8.55 & 8.70 & 6.17 & 8.11 & 7.81 & 3.53 & \\
\hline Metals & Nickel & INAA & ug/g & 29.9 & 32.7 & 27.5 & 46.4 & 30.0 & 6.39 & \\
\hline Metals & Phosphorus & ICPES & ug/g & 77.0 & 87.0 & 89.0 & 89.0 & 84.3 & 160 & \\
\hline Metals & Polassium & INAA & ug/g & 3,395 & 3,538 & 2,982 & 2,594 & 3,305 & 717 & \\
\hline Metals & Rubidium & INAA & $\mathrm{ug} / \mathrm{g}$ & 20.7 & 18.0 & 20.8 & 21.8 & 19.8 & 3.92 & \\
\hline Metals & Samarium & INAA & $u g / g$ & 1.45 & 1.37 & 1.37 & 1.53 & 1.40 & 012 & \\
\hline Metals & Scandium & INAA & ug/g & 3.14 & 3.03 & 3.36 & 3.35 & 3.18 & 0.42 & \\
\hline Metals & Selenium & GFAA & ug/g & 2.00 & 2.00 & 3.00 & 3.00 & 2.33 & 1.43 & \\
\hline
\end{tabular}


Solld Stream Data

Sample Stream: Feed Coal

\begin{tabular}{|c|c|c|c|c|c|c|c|c|c|c|c|}
\hline $\begin{array}{c}\text { Analyte } \\
\text { Group }\end{array}$ & Specie & $\begin{array}{c}\text { Analytical } \\
\text { Melhod }\end{array}$ & Units & $\begin{array}{c}\text { Run } \\
1 \\
\end{array}$ & $\begin{array}{c}\text { Run } \\
2 \\
\end{array}$ & $\begin{array}{c}\text { Run } \\
3 \\
\end{array}$ & $\begin{array}{c}\text { Run } \\
3 d\end{array}$ & & Average & $\begin{array}{c}95 \% \\
\mathrm{Cl} \\
\end{array}$ & $\begin{array}{c}\text { DL } \\
\text { Ratio }\end{array}$ \\
\hline Metals & Silver ${ }^{\prime-}$ & INAA & ug/g & 0.61 & 0.45 & 0.49 & 0.48 & $<$ & 0.52 & $\ldots$ & $100 \%$ \\
\hline Metals & Sodium & INAA & ug/g & 663 & 632 & 597 & 653 & & 631 & 82 & \\
\hline Metals & Strontium & INAA & $\mathrm{ug} / \mathrm{g}$ & 76.1 & 77.8 & 70.6 & 46.8 & & 74.9 & 9.3 & \\
\hline Metals & Tantalum & INAA & ug/g & 0.18 & 0.19 & 0.21 & 0.20 & & 0.19 & 0.04 & \\
\hline Mețals & Terblum & INAA & $\mathrm{ug} / \mathrm{g}$ & 0.18 & 0.16 & 0.19 & 0.18 & & 0.18 & 0.03 & \\
\hline Metals & Thorium & INAA & $\mathrm{ug} / \mathrm{g}$ & 2.57 & 2.42 & 2.80 & 2.77 & & 2.60 & 0.47 & \\
\hline Metals & Tin & INAA & $\mathrm{ug} / \mathrm{g}$ & 15.6 & 16.1 & 16.2 & 17.2 & $<$ & 15.9 & $\ldots$ & $100 \%$ \\
\hline Metals & Tilanium & INAA & $\mathrm{ug} / \mathrm{g}$ & 912 & 818 & 953 & 732 & & 894 & 172 & \\
\hline Metals & Tungsten & INAA & $\mathrm{ug} / \mathrm{g}$ & 0.44 & 0.20 & 1.08 & 0.29 & $<$ & 1.08 & .. & $46 \%$ \\
\hline Metals & Uranium & INAA & $\mathrm{ug} / \mathrm{g}$ & 2.03 & 1.69 & 1.56 & 2.04 & & 1.76 & 0.60 & \\
\hline Metals & Vanadium & INAA & . ug/g & 39.3 & 40.0 & 39.1 & 40.4 & & 39.4 & 1.2 & \\
\hline Metals & Ytterbium & INAA & $\mathrm{ug} / \mathrm{g}$ & 0.71 & 0.62 & 6,584 & 0.73 & & 2,195 & 9,442 & \\
\hline Metals & Zinc & INAA & ug/g & 18.1 & 38.0 & 19.0 & 37.9 & & 25.0 & 28 & \\
\hline Metals & Zirconium & INAA & ug/g & 61.8 & 147.6 & 77.3 & 111.6 & & 85.3 & 146 & $12 \%$ \\
\hline Ultimate/Proximate & $\%$ Ash & D3174 & $\%$ & 10.5 & 11.3 & 11.6 & 12.2 & & 11.1 & 1.4 & \\
\hline Uitimate/Proximate & \% Carbon & 03176 & $\%$ & 72.2 & 72.1 & 71.8 & 71.3 & & 72.0 & 0.5 & \\
\hline Ultimate/Proximate & \% Hydrogen & D3176 & $\%$ & 4.82 & 4.83 & 4.83 & 4.83 & & 4.83 & 0.01 & \\
\hline Ultimate/Proximate & $\%$ Nitrogen & D3176 & $\%$ & 1.55 & 1.55 & 1.45 & 1.49 & & 1.52 & 0.14 & \\
\hline Ultimate/Proximate & $\%$ Oxygen (diff) & D3176 & $\%$ & 8.03 & 7.61 & 7.59 & 7.52 & & 7.74 & 0.62 & \\
\hline Uitimate/Proximate & $\%$ Sulfur & 04239 & $\%$ & 2.87 & 2.65 & 2.69 & 2.66 & & 2.74 & 0.29 & \\
\hline Uitimate/Proximate & Fixed Carbon & D3172 & $\%$ & 51.4 & 49.7 & 51.4 & 50.8 & & 50.8 & 2.5 & \\
\hline Ultimate/Proximate & Higher Healing Value & D2015 & Btu/lb & 12,721 & 12,699 & 12,670 & 12,673 & & 12,697 & 64 & \\
\hline Ultimate/Proximate & Heating Value (MAF) & D2015 & MAF Btu & 14,217 & 14,314 & 14,339 & 14,436 & & 14,290 & 160 & \\
\hline Ultimate/Proximate & Volatile & D3175 & $\%$ & 38.1 & 36.0 & 36.9 & 37.0 & & 37.0 & 2.7 & \\
\hline Radionuclides & Aclinium-228@ @ 338 KeV & EPA901.1 & $\mathrm{pCl} / \mathrm{g}$ & 0.40 & 0.40 & 0.20 & 0.20 & & 0.33 & 0.29 & \\
\hline Radionuclides & Aclinium-228@911 KeV & EPA901.1 & $\mathrm{pCl} / \mathrm{g}$ & 0.30 & 0.30 & 0.40 & 0.30 & & 0.33 & 0.14 & \\
\hline Radionuclides & Actinium-228@ $968 \mathrm{KeV}$ & EPA901.1 & $\mathrm{pCl} / \mathrm{g}$ & ND & ND & 0.20 & ND & & 0.07 & 0.29 & \\
\hline Radionuclides & Blsmuth-212 @ $727 \mathrm{KeV}$ & EPA901.1 & $\mathrm{pCl} / \mathrm{g}$ & ND & ND & ND & ND & & ND & & \\
\hline Radionuclides & Blsmuth-214 @ $1120.4 \mathrm{KeV}$ & EPA901.1 & $\mathrm{pCl} / \mathrm{g}$ & 0.80 & 1.10 & 0.90 & 0.90 & & 0.93 & 0.38 & \\
\hline Radionuclides & Bismuth-214@1764.7 KeV & EPA901.1 & $\mathrm{pCl} / \mathrm{g}$ & ND & 0.30 & ND & 0.40 & & 0.10 & 0.43 & \\
\hline Radionuclides & Bismuth-214@609.4 KeV & EPA901.1 & $\mathrm{pCl} / \mathrm{g}$ & 0.70 & 0.60 & 0.70 & 0.60 & & 0.67 & 0.14 & \\
\hline Radionuclides & $\mathrm{K}-40 @ 1460 \mathrm{KeV}$ & EPA901.1 & $\mathrm{pCl} / \mathrm{g}$ & 1.20 & 2.90 & ND & 3.20 & & 1.37 & 3.62 & \\
\hline Radionuclides & Lead-210@46 KeV & EPA901.1 & $\mathrm{pCl} / \mathrm{g}$ & 1.20 & 1.00 & 1.70 & 1.00 & & 1.30 & 0.90 & \\
\hline Radionuclides & Lead-212 @ $238 \mathrm{KeV}$ & EPA901.1 & $\mathrm{pCl} / \mathrm{g}$ & 0.20 & 0.20 & 0.20 & 0.20 & & 0.20 & 0.00 & \\
\hline Radionuclides & Lead-214@295.2 KeV & EPA901.1 & $\mathrm{pCl} / \mathrm{g}$ & 0.70 & 0.60 & 0.60 & 0.40 & & 0.63 & 0.14 & \\
\hline Radionuclides & Lead-214@352.0 KeV & EPA901.1 & $\mathrm{pCl} / \mathrm{g}$ & 0.70 & 0.60 & 0.60 & 0.50 & & 0.63 & 0.14 & \\
\hline
\end{tabular}

\section{Feed Coal - Page 2}


Solid Stream Data

Sample Stream: Feed Coal

\begin{tabular}{|c|c|c|c|c|c|c|c|c|c|c|}
\hline $\begin{array}{c}\text { Analyte } \\
\text { Group }\end{array}$ & Specie & $\begin{array}{c}\text { Analytical } \\
\text { Method }\end{array}$ & Units & $\begin{array}{c}\text { Run } \\
1 \\
\end{array}$ & $\begin{array}{c}\text { Run } \\
2 \\
\end{array}$ & $\begin{array}{c}\text { Run } \\
3 \\
\end{array}$ & $\begin{array}{c}\text { Run } \\
3 d\end{array}$ & Average & $\begin{array}{c}95 \% \\
\mathrm{Cl} \\
\end{array}$ & $\begin{array}{c}D L \\
\text { Ratio }\end{array}$ \\
\hline Radionuclides & Radium-226@186.0 KeV & EPA901.1 & $\mathrm{pCl} / \mathrm{g}$ & 1.00 & 1.50 & 1.00 & 1.60 & 1.17 & 0.72 & \\
\hline Radionuclides & Thaillum-208 @ $583 \mathrm{KeV}$ & EPA901.1 & $\mathrm{pCi} / \mathrm{g}$ & 0.20 & 0.30 & 0.40 & 0.40 & 0.30 & 0.25 & \\
\hline Radionuclldes & Thallium-208 @ $860 \mathrm{KeV}$ & EPA901.1 & $\mathrm{pCl} / \mathrm{g}$ & ND & ND & ND & ND & ND & & \\
\hline Radionuclides & Thorium-234@ $63.3 \mathrm{KeV}$ & EPA901.1 & $\mathrm{pCl} / \mathrm{g}$ & 0.60 & 1.60 & 0.70 & 1.30 & 0.97 & 1.37 & \\
\hline Radionuclides & Thorlum-234@92.6 KeV & EPA901.1 & $\mathrm{pCl} / \mathrm{g}$ & 0.70 & 0.50 & 0.80 & 0.50 & 0.67 & 0.38 & \\
\hline Radionuclides & Uranium-235 @ $143 \mathrm{KeV}$ & EPA901.1 & $\mathrm{pCl} / \mathrm{g}$ & 0.20 & ND & ND & ND & 0.07 & 0.29 & \\
\hline
\end{tabular}

Feed Coal - Page 3 
Solid Stream Data

Sample Stream: Pulverizer Rejects

\begin{tabular}{|c|c|c|c|c|c|c|c|c|c|c|}
\hline $\begin{array}{c}\text { Analyte } \\
\text { Group }\end{array}$ & Specie & $\begin{array}{c}\text { Analytical } \\
\text { Method }\end{array}$ & Units & $\begin{array}{c}\text { Run } \\
1 \\
\end{array}$ & $\begin{array}{c}\text { Run } \\
2 \\
\end{array}$ & $\begin{array}{c}\text { Run } \\
3 \\
\end{array}$ & $\begin{array}{c}\text { Run } \\
\text { 3d }\end{array}$ & Average & $\begin{array}{c}95 \% \\
\mathrm{Cl} \\
\end{array}$ & $\begin{array}{c}\text { DL. } \\
\text { Ratio }\end{array}$ \\
\hline Anions & Chloride & D4208 & ug/g & 520 & 540 & 460 & 460 & 507 & 103 & \\
\hline Anlons & Fluoride & D3761 & $\mathrm{ug} / \mathrm{g}$ & 330 & 310 & 330 & 340 & 323 & 29 & \\
\hline Metals & Aluminum & INAA & $\mathrm{ug} / \mathrm{g}$ & 22,782 & 28,605 & 30,095 & 32,254 & 27,161 & 9,601 & \\
\hline Metals & Antimony & INAA & $\mathrm{ug} / \mathrm{g}$ & 1.03 & 1.35 & 1.34 & 1.14 & 1.24 & 0.45 & \\
\hline Metals & Arsenic & GFAA & ug/g & 32.0 & 67.0 & 42.0 & 40.0 & 47.0 & 44.8 & \\
\hline Metals & Barium & INAA & ug/g & 540 & 123 & 327 & 339 & 330 & 519 & \\
\hline Metals & Beryllium & ICPES & ug/g & 1.90 & 1.90 & 0.60 & 1.10 & 1.47 & 1.86 & \\
\hline Metals & Boron & ICPES & $\mathrm{ug} / \mathrm{g}$ & 100 & 170 & 75 & 73 & 115 & 122 & \\
\hline Metals & Bromine & INAA & ug/g & 4.85 & 4.42 & 3.65 & 4.98 & 4.31 & 1.51 & \\
\hline Metals & Cadmlum & ICPES & $\mathrm{ug} / \mathrm{g}$ & 1.00 & 7.80 & 3.40 & 1.80 & 4.07 & 8.57 & \\
\hline Metals & Calcium & INAA & $\mathrm{ug} / \mathrm{g}$ & 11,715 & 15,640 & 10,690 & 11,298 & 12,682 & 6,490 & \\
\hline Metals & Cerium & INAA & ug/g & 25.9 & 33.1 & 30.7 & 33.6 & 29.9 & 9.06 & \\
\hline Metals & Cesium & INAA & ug/g & 1.88 & 2.30 & 2.23 & 2.72 & 2.14 & 0.55 & \\
\hline Metals & Chlorine & INAA & $\mathrm{ug} / \mathrm{g}$ & 554 & 643 & 559 & 648 & 585 & 125 & \\
\hline Metals & Chromium & INAA & $\mathrm{ug} / \mathrm{g}$ & 58.0 & 64.2 & 69.5 & 76.1 & 63.9 & 14.3 & \\
\hline Metals & Cobalt & INAA & $\mathrm{ug} / \mathrm{g}$ & 7.41 & 8.02 & 7.87 & 8.38 & 7.77 & 0.80 & \\
\hline Metals & Copper & INAA & $\mathrm{ug} / \mathrm{g}$ & 81.5 & 94.2 & 59.0 & 56.1 & 68.4 & 85.2 & $14 \%$ \\
\hline Metals & Europlum & INAA & $\mathrm{ug} / \mathrm{g}$ & 0.59 & 0.65 & 0.67 & 0.67 & 0.64 & 0.11 & \\
\hline Metals & Hafnium & INAA & $\mathrm{ug} / \mathrm{g}$ & 2.30 & 1.82 & 2.34 & 2.47 & 2.15 & 0.73 & \\
\hline Metals & lodine & INAA & $u g / g$ & 1.44 & 1.92 & 2.65 & 2.63 & 2.00 & 1.52 & \\
\hline Metals & Iron & INAA & $\mathrm{ug} / \mathrm{g}$ & 133,094 & 126,965 & 119,458 & 112,069 & 126,506 & 16,967 & \\
\hline Metals & Lanthanum & INAA & $u g / g$ & 14.5 & 17.4 & 16.5 & 16.6 & 16.2 & 3.7 & \\
\hline Metals & Lead & ICPES & $\mathrm{ug} / \mathrm{g}$ & 41.0 & 48.0 & 23.0 & 33.0 & 37.3 & 32.0 & \\
\hline Metals & Lutetlum & INAA & $\mathrm{ug} / \mathrm{g}$ & 0.23 & 0.18 & 0.20 & 0.26 & 0.20 & 0.06 & \\
\hline Metals & Magnesium & INAA & ug/g & 1,226 & 1,467 & 1,420 & 1,696 & 1,371 & 318 & \\
\hline Metals & Manganese & INAA & $\mathrm{ug} / \mathrm{g}$ & 93.9 & 80.1 & 122 & 122 & 98.6 & 52.7 & \\
\hline Metals & Mercury & DGACVAA & $\mathrm{ug} / \mathrm{g}$ & 0.26 & 0.090 & 0.040 & 0.21 & 0.130 & 0.287 & \\
\hline Metals & Molybdenum & INAA & $\mathrm{ug} / \mathrm{g}$ & 18.36 & 17.3 & 4.07 & 4.17 & 13.2 & 19.8 & \\
\hline Metals & Neodymium & INAA & $\mathrm{ug} / \mathrm{g}$ & 19.56 & 20.6 & 16.3 & 30.3 & 18.8 & 5.6 & \\
\hline Metals & Nickel & INAA & $u g / g$ & 56 & 115 & 103 & 117 & 115 & $\ldots$ & $66 \%$ \\
\hline Metals & Phosphorus & ICPES & ug/g & 1,200 & 2,500 & 780 & 990 & 1,493 & 2,228 & \\
\hline Metals & Potassium & INAA & ug/g & 2,707 & 5,303 & 8.54 & 4,558 & 2,673 & 6,577 & \\
\hline Metals & Rubldlum & INAA & $u g / g$ & 41.0 & 36.4 & 36.3 & 40.9 & 37.9 & 6.6 & \\
\hline Metals & Samarlum & INAA & $u g / g$ & 2.18 & 2.50 & 2.54 & 2.67 & 2.41 & 0.49 & \\
\hline
\end{tabular}

Pulverizer Rejects - Page 1 
Solid Stream Data

Sample Stream: Pulverizer Rejects

\begin{tabular}{|c|c|c|c|c|c|c|c|c|c|c|c|}
\hline $\begin{array}{l}\text { Analyte } \\
\text { Group }\end{array}$ & Specie & $\begin{array}{c}\text { Analytical } \\
\text { Method }\end{array}$ & Units & $\begin{array}{c}\text { Run } \\
1\end{array}$ & $\begin{array}{c}\text { Run } \\
2 \\
\end{array}$ & $\begin{array}{c}\text { Run } \\
3 \\
\end{array}$ & $\begin{array}{c}\text { Run } \\
3 d \\
\end{array}$ & & Average & $\begin{array}{r}96 \% \\
\mathrm{Cl} \\
\end{array}$ & $\begin{array}{c}\text { DL } \\
\text { Ratio }\end{array}$ \\
\hline Metals & Scandlum & INAA & ug/g & 4.60 & 5.83 & 5.22 & 6.32 & & 5.22 & 1.53 & \\
\hline Metals & Selenium & GFAA & ug/g & 7.00 & 9.00 & 10.00 & 7.00 & & 8.67 & 3.79 & \\
\hline Metals & Silver & INAA & ug/g & 1.30 & 1.87 & 1.94 & 1.44 & $<$ & 1.94 & -- & $59 \%$ \\
\hline Metals & Sodium & INAA & ug/g & 1,169 & 998 & 1,160 & 1,162 & & 1,109 & 239 & \\
\hline Metals & Strontium & INAA & ug/g & 308 & 377 & 658 & 297 & & 448 & 461 & \\
\hline Metals & Tantalum & INAA & ug/g & 0.43 & 0.57 & 0.55 & 0.48 & & 0.52 & 0.18 & \\
\hline Metals & Terbium & INAA & ug/g & 0.32 & 0.29 & 0.35 & 0.40 & & 0.32 & 0.08 & \\
\hline Metals & Thorlum & INAA & ug/g & 3.79 & 4.41 & 4.22 & 5.43 & & 4.14 & 0.79 & \\
\hline Metals & $\operatorname{Tin}$ & INAA & ug/g & 31.9 & 30.7 & 29.5 & 28.0 & $<$ & 30.7 & -. & $49 \%$ \\
\hline Metals & Titanium & INAA & ug/g & 1,993 & 1,936 & 2,020 & 2,028 & & 1,983 & 106 & \\
\hline Metals & Tungsten & INAA & ug/g & 0.30 & 0.49 & 0.74 & 1.05 & $<$ & 0.74 & $\cdots$ & $32 \%$ \\
\hline Metals & Uranlum & INAA & $\mathrm{ug} / \mathrm{g}$ & 3.84 & 4.95 & 3.51 & 4.09 & & 4.10 & 1.87 & \\
\hline Metals & Vanadium & INAA & $\mathrm{ug} / \mathrm{g}$ & 61.5 & 56.0 & 61.8 & 66.2 & & 59.8 & 8.2 & \\
\hline Metals & Ytterblum & INAA & ug/g & 1.09 & 1.86 & 1.32 & 1.44 & & 1.42 & 0.99 & \\
\hline Metals & Zine & INAA & ug/g & 486 & 1,594 & 1,503 & 559 & & 1,194 & 1,528 & \\
\hline Metals & Zlrconlum & INAA & ug/g & 291 & 251 & 448 & 240 & & 330 & 259 & \\
\hline
\end{tabular}

Pulverizer Rejects - Page 2 


\section{Solid Stream Data}

Sample Stream: Bottom Ash

\begin{tabular}{|c|c|c|c|c|c|c|c|c|c|c|c|c|c|c|c|c|c|c|}
\hline $\begin{array}{l}\text { Analyte } \\
\text { Group }\end{array}$ & Specie & $\begin{array}{c}\text { Analytical } \\
\text { Method }\end{array}$ & Units & & $\begin{array}{c}\text { Run } \\
1\end{array}$ & & & $\begin{array}{c}\text { Run } \\
2\end{array}$ & & & $\begin{array}{c}\text { Run } \\
3 \\
\end{array}$ & & $\begin{array}{c}\text { Run } \\
3 d\end{array}$ & & & Average & $\begin{array}{c}95 \% \\
\mathrm{Cl} \\
\end{array}$ & $\begin{array}{c}\text { DL } \\
\text { Ratio }\end{array}$ \\
\hline Anions & Chioride & SM407C & ug/g & & 172 & & $<$ & 99.8 & & & 163 & $<$ & 99.8 & & & 128 & 169 & $13 \%$ \\
\hline Anions & Fluorido & EPA 340.2 & $u g / g$ & & 30.9 & & & 21.4 & & & 42.3 & & 16.7 & & & 31.5 & 26.0 & \\
\hline Motals & Aluminum & SW 6010 & ug/g & & 75,600 & & & 80,800 & & & 72,000 & & 70,200 & & & 76,133 & 10,991 & \\
\hline Metals & Antimony & ICP-MS & ug/g & & 1.21 & & & 1.15 & & & 1.05 & & 0.95 & & & 1.14 & 0.20 & \\
\hline Motals & Arsenic & SW 7060 & $\mathbf{u g} / \mathrm{g}$ & & 4.28 & & & 8.67 & & & 8.49 & & 4.92 & & & 7.15 & 6.17 & \\
\hline Metals & Barlum & SW 6010 & $u g / g$ & & 428 & & & 481 & & & 461 & & 460 & & & 457 & 66 & \\
\hline Motals & Beryllium & SW 6010 & ug/g & & 8.47 & & & 8.17 & & & 6.30 & & 6.51 & & & 7.65 & 2.92 & \\
\hline Metals & Boron & ICPES & ug/g & & 360 & & & 240 & & & 250 & & 240 & & & 283 & 165 & \\
\hline Motals & Cadmlum & SW 7131 & ug/g & & 0.29 & $J$ & & 0.18 & J & & 0.49 & & 0.29 & $J$ & & 0.32 & 0.39 & \\
\hline Metals & Calcium & SW 6010 & ug/g & & 21,800 & & & 19,900 & & & 19,100 & & 18,600 & & & 20,267 & 3,445 & \\
\hline Motals & Chromium & SW 6010 & ug/g & & 196 & & & 197 & & & 184 & & 182 & & & 192 & 18 & \\
\hline Motals & Cobalt & SW 6010 & $u g / g$ & & 33.1 & & & 32.1 & & & 29.7 & & 27.5 & & & 31.6 & 4.34 & \\
\hline Metals & Copper & SW 6010 & ug/g & & 84.0 & & & 76.9 & & & 69.6 & & 68.3 & & & 76.8 & 17.9 & \\
\hline Metals & Iron & SW 6010 & ug/g & & 144,000 & & & 127,000 & & & 120,000 & & 118,000 & & & 130,333 & 30,663 & \\
\hline Metals & Lead & SW 7421 & ug/g & & 20.2 & & & 21.2 & & & 18.2 & & 18.3 & & & 19.9 & 3.8 & \\
\hline Motals & Magneslum & SW 6010 & ug/g & & 3740 & & & 3850 & & & 3230 & & 3070 & & & 3,607 & 822 & \\
\hline Metals & Manganese & SW 6010 & ug/g & & 296 & & & 262 & & & 253 & & 240 & & & 270 & 56 & \\
\hline Metals & Mercury & SW 7471 & ug/g & & 0.0048 & $\mathbf{J}$ & $<$ & 0.0109 & & $<$ & 0.0114 & & 0.0048 & $J$ & $<$ & 0.0114 & .. & $70 \%$ \\
\hline Motals & Molybdenum & SW 6010 & ug/g & & 4.57 & & $<$ & 2.89 & & $<$ & 2.97 & & 4.52 & & $<$ & 2.97 & -. & $39 \%$ \\
\hline Metals & Nickel & SW 6010 & ug/g & & 138 & & & 130 & & & 126 & & 124 & & & 131 & 15 & \\
\hline Metals & Phosphorus & SW 6010 & ug/g & & 308 & & & 413 & & & 470 & & 420 & & & 396 & 207 & \\
\hline Motals & Potasslum & SW 6010 & ug/g & & 14.200 & & & 14,600 & & & 13,700 & & 13,200 & & & 14,167 & 1.120 & \\
\hline Metals & Solonlum & SW 7740 & ug/g & $<$ & 1.13 & & $<$ & 1.13 & & $<$ & 1.16 & $<$ & 1.14 & & $<$ & 1.14 & .. & $100 \%$ \\
\hline Metals & Silicon & SW 6010 & ug/g & & 213,000 & & & 209,000 & & & 218,000 & & 216,000 & & & 213,333 & 11,203 & \\
\hline Metals & Sodium & SW 6010 & ug/g & & 3,850 & & & 3,610 & & & 3,380 & & 3,300 & & & 3,613 & 584 & \\
\hline Metals & Strontium & SW 6010 & $u g / g$ & & 280 & & & 297 & & & 264 & & 260 & & & 280 & 41 & \\
\hline Motals & Titanium & SW 6010 & $u g / g$ & & 5,450 & & & 5,810 & & & 5,400 & & 5,430 & & & 5,553 & 556 & \\
\hline Metals & Vanadium & SW 6010 & ug/g & & 281 & & & 286 & & & 264 & & 260 & & & 277 & 29 & \\
\hline Metals & ZInc & SW 6010 & ug/g & & 216 & & & 229 & & & 194 & & 186 & & & 213 & 44 & \\
\hline Ultimate/Proximate & \% Carbon & D3176 & $\%$ & & 1.18 & & & 1.53 & & & 4.29 & & 3.46 & & & 2.33 & 4.23 & \\
\hline Uitimate/Proximato & \% Sulfur & D4239 & $\%$ & & 0.053 & & & 0.052 & & & 0.340 & & 0.133 & & & 0.148 & 0.412 & \\
\hline Radionuclides & Actinium-228@338 KoV & EPA 901.1 & $\mathrm{pcilg}$ & & 2.1 & & & 2.1 & & & 2.1 & & 2.2 & & & 2.1 & 0 & \\
\hline
\end{tabular}

Bottom Ash - Page 1 
Sample Stream: Bottom Ash

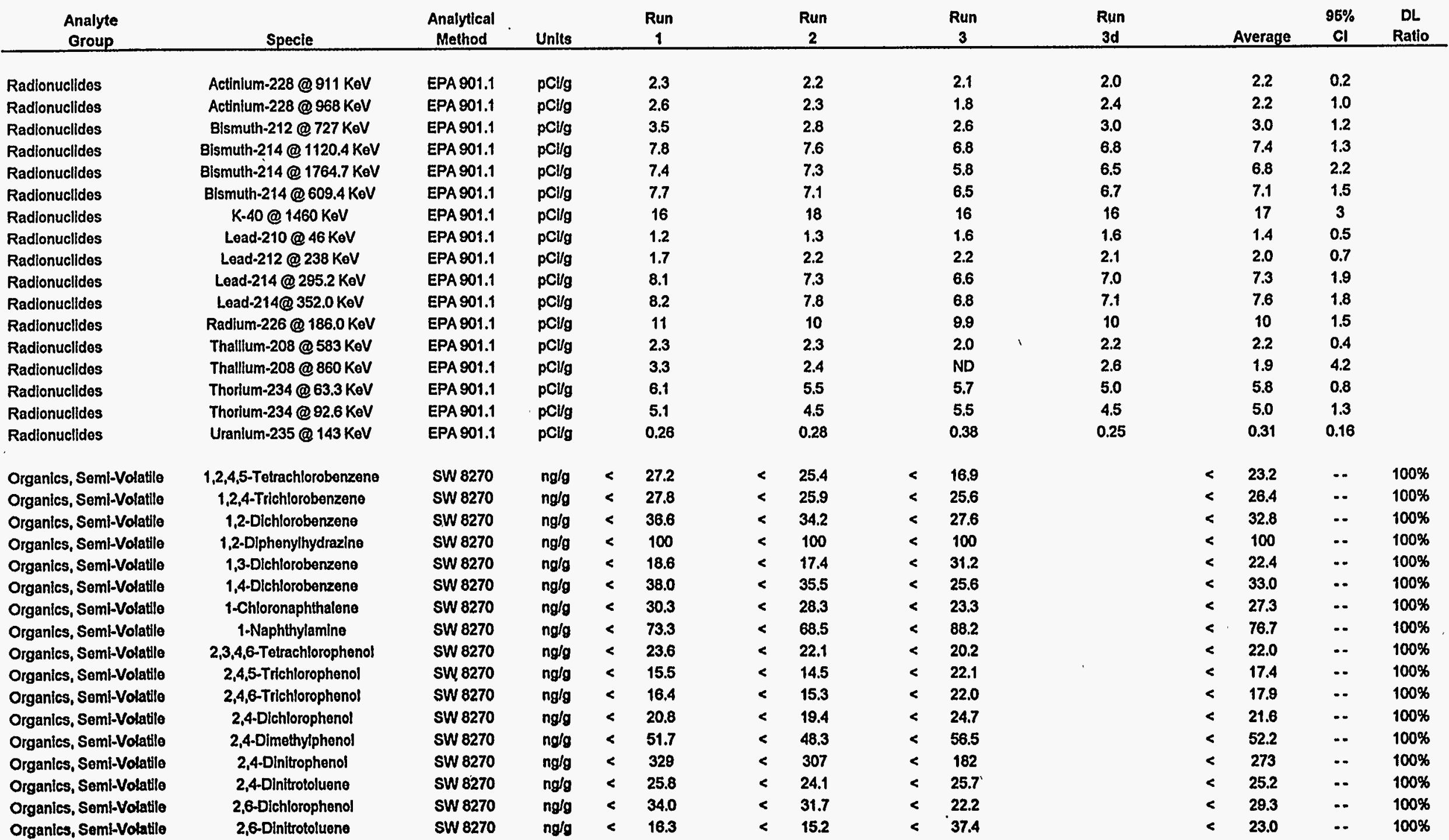

Bottom Ash - Page 2 


\section{Solid Stream Data}

Sample Stream: Bottom Ash

\begin{tabular}{|c|c|c|c|c|c|c|c|c|c|c|c|c|c|c|c|}
\hline $\begin{array}{l}\text { Analyte } \\
\text { Group }\end{array}$ & Specie & $\begin{array}{l}\text { Analytical } \\
\text { Method }\end{array}$ & Units & & $\begin{array}{c}\text { Run } \\
1\end{array}$ & & & $\begin{array}{c}\text { Run } \\
2 \\
\end{array}$ & & $\begin{array}{c}\text { Run } \\
3 \\
\end{array}$ & $\begin{array}{c}\text { Run } \\
3 d\end{array}$ & & Average & $\begin{array}{c}95 \% \\
\text { CI }\end{array}$ & $\begin{array}{c}\text { DL } \\
\text { Ratio }\end{array}$ \\
\hline Organics. Semi-Volatile & 2-Chloronaphthalene & SW 8270 & $\mathrm{ng} / \mathrm{g}$ & $<$ & 15.2 & & $<$ & 14.2 & $<$ & 17.0 & & $<$ & 15.5 & -. & $100 \%$ \\
\hline Organics, Semi-Volatile & 2-Chlorophenol & SW 8270 & $\mathrm{ng} / \mathrm{g}$ & $<$ & 35.9 & & $<$ & 33.5 & $<$ & 27.6 & & $<$ & 32.3 & -. & $100 \%$ \\
\hline Organics, Semi-Volatile & 2-Methylnaphthalene & SW 8270 & $\mathbf{n g} / \mathbf{g}$ & & 78.9 & & $<$ & 29.0 & $<$ & 15.8 & & & 33.8 & 97 & $22 \%$ \\
\hline Organics, Semi-Volatile & 2-Methylphenol(o-cresol) & SW 8270 & $\mathrm{ng} / \mathrm{g}$ & $<$ & 25.1 & & $<$ & 23.4 & $<$ & 13.5 & & $<$ & 20.7 & $\cdots$ & $100 \%$ \\
\hline Organics, Semi-Volatile & 2-Naphthylamine & SW 8270 & $\mathrm{ng} / \mathrm{g}$ & $<$ & 91.6 & & $<$ & 85.6 & $<$ & 69.5 & & $<$ & 82.2 & -. & $100 \%$ \\
\hline Organics, Semi-Volatile & 2-Nitroaniline & SW 8270 & $\mathrm{ng} / \mathrm{g}$. & $<$ & 18.9 & & $<$ & 17.6 & $<$ & 28.8 & & $<$ & 21.8 & -. & $100 \%$ \\
\hline Organics, Semi-Volatile & 2-Nitrophenol & SW 8270 & $\mathrm{ng} / \mathrm{g}$ & $<$ & 20.7 & & $<$ & 19.3 & $<$ & 22.7 & & $<$ & 20.9 & .. & $100 \%$ \\
\hline Organics, Semi-Volatile & 2-Picoline & SW 8270 & $\mathrm{ng} / \mathrm{g}$ & $<$ & 51.2 & & $<$ & 47.8 & $<$ & 35.9 & & $<$ & 45.0 & .. & $100 \%$ \\
\hline Organics, Semi-Volatile & 3,3'-Dichlorobenzidine & SW 8270 & $\mathrm{ng} / \mathrm{g}$ & $<$ & 23.0 & & $<$ & 21.5 & $<$ & 14.5 & & $<$ & 19.7 & $\cdots$ & $100 \%$ \\
\hline Organics, Semi-Volatile & 3-Methylcholanthrene & SW 8270 & $\mathrm{ng} / \mathrm{g}$ & $<$ & 36.8 & & $<$ & 34.4 & $<$ & 21.7 & & $<$ & 31.0 & -. & $100 \%$ \\
\hline Organics, Semi-Volatile & 3-Nitroaniline & SW 8270 & $\mathrm{ng} / \mathrm{g}$ & $<$ & 23.9 & & $<$ & 22.3 & $<$ & 17.1 & & $<$ & 21.1 & .. & $100 \%$ \\
\hline Organics, Semi-Volatile & 4,6-Dinitro-2-methyiphenol & SW 8270 & $\mathrm{ng} / \mathrm{g}$ & $<$ & 37.2 & & $<$ & 34.8 & $<$ & 18.7 & & $<$ & 30.2 & .. & $100 \%$ \\
\hline Organics, Semi-Volatile & 4-Aminobiphenyl & SW 8270 & $\mathrm{ng} / \mathrm{g}$ & $<$ & 35.1 & & $<$ & 32.8 & $<$ & 51.7 & & $<$ & 39.9 & -. & $100 \%$ \\
\hline Organics, Semi-Volatile & 4-Bromophenyl phenyl & SW 8270 & $n g / g$ & $<$ & 21.4 & & $<$ & 20.0 & $<$ & 21.0 & & $<$ & 20.8 & .. & $100 \%$ \\
\hline Organics, Semi-Volatile & 4-Chloro-3-methylphenol & SW 8270 & $\mathrm{ng} / \mathrm{g}$ & $<$ & 34.0 & & $<$ & 31.7 & $<$ & 22.4 & & $<$ & 29.4 & -. & $100 \%$ \\
\hline Organics, Semi-Volatile & 4-Chlorophenyl phenyl ether & SW 8270 & $\mathrm{ng} / \mathrm{g}$ & $<$ & 24.8 & & $<$ & 23.2 & $<$ & 18.3 & & $<$ & 22.1 & -. & $100 \%$ \\
\hline Organics, Semi-Volatile & 4-Nitroaniline & SW 8270 & $\mathrm{ng} / \mathrm{g}$ & $<$ & 22.7 & & $<$ & 21.2 & $<$ & 26.3 & & $<$ & 23.4 & -. & $100 \%$ \\
\hline Organics, Semi-Volatile & 4-Nitrophenol & SW 8270 & $\mathrm{ng} / \mathrm{g}$ & $<$ & 32.5 & & $<$ & 30.3 & $<$ & 40.7 & & $<$ & 34.5 & -. & $100 \%$ \\
\hline Organics, Semi-Volatile & 7,12-Dimethylbenz(a)anthracene & SW 8270 & $\mathrm{ng} / \mathrm{g}$ & $<$ & 90.2 & & $<$ & 84.3 & $<$ & 57.8 & & $<$ & 77.4 & -. & $100 \%$ \\
\hline Organics, Semi-Volatile & Acenaphthene & sW 8270 & $\mathrm{ng} / \mathrm{g}$ & $<$ & 22.5 & & $<$ & 21.0 & $<$ & 11.8 & & $<$ & 18.4 & -. & $100 \%$ \\
\hline Organics, Semi-Volatile & Acenaphthylene & SW 8270 & $\mathrm{ng} / \mathrm{g}$ & $<$ & 10.6 & & $<$ & 9.9 & $<$ & 18.2 & & $<$ & 12.9 & -. & $100 \%$ \\
\hline Organics, Semi-Volatile & Acetophenone & SW 8270 & $\mathrm{ng} / \mathrm{g}$ & $<$ & 21.6 & & $<$ & 20.1 & $<$ & 24.3 & & $<$ & 22.0 & $\cdots$ & $100 \%$ \\
\hline Organics, Semi-Volatile & Aniline & SW 8270 & $n g / g$ & $<$ & 43.8 & & $<$ & 40.9 & $<$ & 26.8 & & $<$ & 37.2 & .. & $100 \%$ \\
\hline Organics, Semi-Volatile & Anthracene & SW 8270 & $\mathrm{ng} / \mathrm{g}$ & & 14.6 & $\mathrm{~J}$ & $<$ & 25.5 & $<$ & 16.0 & & $<$ & 25.5 & -. & $59 \%$ \\
\hline Organics, Semi-Volatile & Benzldine & SW 8270 & $n g / g$ & $<$ & 20.0 & & $<$ & 20.0 & $<$ & 20.0 & & $<$ & 20.0 & .. & $100 \%$ \\
\hline Organics, Semi-Volatile & Benzo(a)anthracene & SW 8270 & $\mathrm{ng} / \mathrm{g}$ & & 21.0 & $\mathrm{~J}$ & $<$ & 22.6 & $<$ & 19.5 & & $<$ & 22.6 & -. & $50 \%$ \\
\hline Organics, Semi-Volatile & Benzo(a)pyrene & SW 8270 & $\mathrm{ng} / \mathrm{g}$ & $<$ & 18.0 & & $<$ & 16.8 & $<$ & 22.5 & & $<$ & 19.1 & -. & $100 \%$ \\
\hline Organics, Semi-Volatile & Benzo(b)fluoranthene & sw 8270 & $\mathrm{ng} / \mathrm{g}$ & & 24.2 & & $<$ & 25.0 & $<$ & 39.5 & & $<$ & 39.5 & -. & $57 \%$ \\
\hline Organics, Semi-Volatile & Benzo(g,h,i)perylene & SW 8270 & $\mathrm{ng} / \mathrm{g}$ & & 11.8 & $\mathrm{~J}$ & $<$ & 21.4 & $<$ & 44.3 & & $<$ & 44.3 & .. & $74 \%$ \\
\hline Organics, Semi-Volatile & Benzo(k)fluoranthene & SW 8270 & $\mathrm{ng} / \mathrm{g}$ & & 24.2 & & $<$ & 42.5 & $<$ & 43.4 & & $<$ & 43.4 & .. & $64 \%$ \\
\hline Organics, Semi-Volatile & Benzoic acid & SW 8270 & $\mathrm{ng} / \mathrm{g}$ & $<$ & 186 & & $<$ & 174 & $<$ & 1,680 & & $<$ & 680 & .. & $100 \%$ \\
\hline Organies, Semi-Volatilo & Benzyl alcohol & sW 8270 & $\mathrm{ng} / \mathrm{g}$ & $<$ & 50.7 & & $<$ & 47.4 & $<$ & 26.5 & & $<$ & 41.5 & -. & $100 \%$ \\
\hline Organics, Semi-Volatile & Butylbenzylphthalate & SW 8270 & $\mathrm{ng} / \mathrm{g}$ & $<$ & 18.5 & & $<$ & 17.2 & $<$ & 27.2 & & $<$ & 21.0 & -. & $100 \%$ \\
\hline Organics, Semi-Volatile & Chrysene & SW 8270 & $\mathrm{ng} / \mathrm{g}$ & & 12.0 & $J$ & $<$ & 29.4 & $<$ & 23.3 & & $<$ & 29.4 & .. & $69 \%$ \\
\hline
\end{tabular}

Bottom Ash - Page 3 
Sample Stream: Bottom Ash

\begin{tabular}{|c|c|c|c|c|c|c|c|c|c|c|c|c|c|c|c|}
\hline $\begin{array}{l}\text { Analyte } \\
\text { Group }\end{array}$ & Specie & $\begin{array}{c}\text { Analytical } \\
\text { Method }\end{array}$ & Units & & $\begin{array}{c}\text { Run } \\
1 \\
\end{array}$ & & & $\begin{array}{c}\text { Run } \\
2 \\
\end{array}$ & & $\begin{array}{c}\text { Run } \\
3 \\
\end{array}$ & $\begin{array}{c}\text { Run } \\
\mathbf{3 d}\end{array}$ & & Average & $\begin{array}{c}96 \% \\
\mathrm{Cl} \\
\end{array}$ & $\begin{array}{c}\text { DL } \\
\text { Ratio }\end{array}$ \\
\hline Organics, Semi-Volatile & Di-n-octylphthalato & SW 8270 & $\mathrm{ng} / \mathrm{g}$ & $<$ & 42.8 & & $<$ & 40.0 & $<$ & 15.3 & & $<$ & 32.7 & . & $100 \%$ \\
\hline Organics, Semi-Volatile & Dibenz $(a, h)$ anthracene & SW 8270 & $\mathrm{ng} / \mathrm{g}$ & $<$ & 22.3 & & 4 & 20.8 & $<$ & 35.2 & & $<$ & 26.1 & $\cdots$ & $100 \%$ \\
\hline Organics, Semi-Volatile & Dibonz(a,j)acridine & SW 8270 & $n g / g$ & $<$ & 27.3 & & $<$ & 25.5 & $<$ & 36.6 & & $<$ & 29.8 & -. & $100 \%$ \\
\hline Organics, Semi-Volatile & Dibenzofuran & SW 8270 & $\mathrm{ng} / \mathrm{g}$ & $<$ & 19.2 & & $<$ & 17.9 & $<$ & 23.3 & & $<$ & 20.1 & - & $100 \%$ \\
\hline Organics, Semi-Volatile & Dibutylphthalate & SW 8270 & $\mathrm{ng} / \mathrm{g}$ & $<$ & 23.2 & & $<$ & 21.6 & $<$ & 14.1 & & $<$ & 19.6 & - & $100 \%$ \\
\hline Organics, Semi-Volatile & Diethylphthalate & SW 8270 & $n g / g$ & $<$ & 15.8 & & $<$ & 14.7 & $<$ & 22.4 & & $<$ & 17.6 & - & $100 \%$ \\
\hline Organics, Semi-Volatile & Dimethyiphenethylamine ${ }^{\circ}$ & SW 8270 & $\mathrm{ng} / \mathrm{g}$ & $<$ & 120 & , & $<$ & 120 & $<$ & 120 & & $<$ & 120 & $\cdots$ & $100 \%$ \\
\hline Organics, Semi-Volatile & Dimethyiphthalate & SW 8270 & $\mathbf{n g} / \mathbf{g}$ & $<$ & 13.2 & & $<$ & 12.3 & $<$ & 14.6 & & $<$ & 13.4 & -. & $100 \%$ \\
\hline Organics, Semi-Volatile & Diphenylamino & SW 8270 & $\mathbf{n g} / \mathbf{g}$ & $<$ & 24.8 & & $<$ & 23.2 & $<$ & 12.0 & & $<$ & 20.0 & - & $100 \%$ \\
\hline Organics, Semi-Volatile & Ethyl methanesulfonate & SW 8270 & ng/g & $<$ & 23.6 & & $<$ & 22.1 & $<$ & 29.5 & & $<$ & 25.1 & -. & $100 \%$ \\
\hline Organics, Semi-Volatile & Fluoranthene & SW 8270 & $\mathbf{n g} / \mathbf{g}$ & $<$ & 30.0 & & $<$ & 28.0 & $<$ & 20.5 & & $<$ & 26.2 & - & $100 \%$ \\
\hline Organics, Semi-Volatile & Fluorene & SW 8270 & $\mathrm{ng} / \mathrm{g}$ & & 11.3 & $\mathbf{J}$ & $<$ & 14.7 & $<$ & 16.5 & & $<$ & 16.5 & .. & $58 \%$ \\
\hline Organics, Semi-Volatile & Hexachlorobenzene & SW 8270 & $\mathrm{ng} / \mathrm{g}$ & $<$ & 11.0 & & $<$, & 10.3 & $<$ & 13.6 & & $<$ & 11.6 & -. & $100 \%$ \\
\hline Organics, Semi-Volatile & Hexachlorobuladiene & SW 8270 & $n g / g$ & $<$ & 32.8 & & $<$ & 30.6 & $<$ & 22.2 & & $<$ & 28.5 & - & $100 \%$ \\
\hline Organics, Semi-Volatile & Hexachlorocyclopentadiene & SW 8270 & $\mathrm{ng} / \mathrm{g}$ & $<$ & 419 & & $<$, & 391 & $<$ & 256 & & $<$ & 355 & .- & $100 \%$ \\
\hline Organics, Semi-Volatilo & Hexachloroethane & SW 8270 & $\mathrm{ng} / \mathrm{g}$ & $<$ & 27.9 & & $<$ & 26.1 & $<$ & 27.6 & & $<$ & 27.2 & $\cdots$ & $100 \%$ \\
\hline Organics, Semi-Volatile & Indeno(1,2,3-cd)pyrene & SW 8270 & $\mathrm{ng} / \mathrm{g}$ & $<$ & 24.7 & & $<$ & 23.0 & $<$ & 57.8 & & $<$ & 35.2 & - & $100 \%$ \\
\hline Organics, Semi-Volatile & Isophorone & SW 8270 & $\mathrm{ng} / \mathrm{g}$ & $\xi_{u}$ & 13.5 & & $<$ & 12.6 & $<$ & 26.8 & & $<$ & 17.6 & -. & $100 \%$ \\
\hline Organics, Semi-Volatile & Methyl methanesulfonate & SW 8270 & $\mathrm{ng} / \mathrm{g}$ & $<$ & 50.0 & & $<$ & 50.0 & $<$ & 50.0 & & $<$ & 50.0 & .. & $100 \%$ \\
\hline Organics, Semi-Volatile & N-Nitroso-dl-n-butylamine & SW 8270 & $\mathrm{ng} / \mathrm{g}$ & $<$ & 61.6 & & $<$ & 57.5 & $<$ & 27.3 & & $<$ & 48.8 & - & $100 \%$ \\
\hline Organics, Semi-Volatile & N-Nitrosodimethylamine & SW 8270 & $\mathrm{ng} / \mathrm{g}$ & $<$ & 62.5 & & $<$ & 58.4 & $<$ & 34.2 & & $<$ & 51.7 & $\cdots$ & $100 \%$ \\
\hline Organics, Semi-Volatile & N-Nittrosodiphenylamine & SW 8270 & $\mathrm{ng} / \mathrm{g}$ & $<$ & 26.6 & & $<$ & 24.8 & $<$ & 11.7 & & $<$ & 21.0 & - & $100 \%$ \\
\hline Organics, Semi-Volatile & N-Nitrosodipropylamine & SW 8270 & $\mathrm{ng} / \mathrm{g}$ & $<$ & 35.3 & & $<$ & 33.0 & $<$ & 28.4 & & $<$ & 32.2 & $\cdots$ & $100 \%$ \\
\hline Organics, Semi-Volatile & N-Niltrosopiperidine & SW 8270 & $\mathrm{ng} / \mathrm{g}$ & $<$ & 44.3 & & $<$ & 41.4 & $<$ & 25.9 & & $<$ & 37.2 & $\cdots$ & $100 \%$ \\
\hline Organics, Semi-Volatile & Naphthalene & SW 8270 & $\mathrm{ng} / \mathrm{g}$ & & 52.2 & & $<$ & 32.0 & $<$ & 20.8 & & $<$ & 32.0 & - & $34 \%$ \\
\hline Organics, Semi-Volatile & Nitrobenzene & SW 8270 & $\mathrm{ng} / \mathrm{g}$ & $<$ & 24.8 & & $<$ & 23.2 & $<$ & 36.6 & & $<$ & 28.2 & -. & $100 \%$ \\
\hline Organics, Semi-Volatile & Pentachlorobenzene & SW 8270 & ng/g & $<$ & 20.8 & & $<$ & 19.4 & $<$ & 16.3 & & $<$ & 18.8 & $\cdots$ & $100 \%$ \\
\hline Organics, Seml-Volatile & Pentachloronitrobenzene & SW 8270 & $\mathrm{ng} / \mathrm{g}$ & $<$ & 97.3 & & $<$ & 90.8 & $<$ & 60.0 & & $<$ & 82.7 & $\cdots$ & $100 \%$ \\
\hline Organics, Semi-Volatile & Pentachlorophenol & SW 8270 & $\mathrm{ng} / \mathrm{g}$ & $<$ & 40.6 & & $<$ & 37.9 & $<$ & 38.6 & & $<$ & 39.0 & $\cdots$ & $100 \%$ \\
\hline Organics, Semi-Volatile & Phenacetin & SW 8270 & $\mathrm{ng} / \mathrm{g}$ & $<$ & 25.4 & & $<$ & 23.7 & $<$ & 16.8 & & $<$ & 22.0 & - & $100 \%$ \\
\hline Organics, Semi-Volatile & Phenanthrene & SW 8270 & $\mathrm{ng} / \mathrm{g}$ & & 31.1 & & $<$ & 27.3 & $<$ & 20.3 & & $<$ & 27.3 & .. & $43 \%$ \\
\hline Organics, Semi-Volatile & Phenol & SW 8270 & $\mathrm{ng} / \mathrm{g}$ & $<$ & 18.7 & & $<$ & 17.5 & $<$ & 38.4 & & $<$ & 24.9 & - & $100 \%$ \\
\hline Organics, Semi-Volatile & Pronamide & SW 8270 & $\mathrm{ng} / \mathrm{g}$ & $<$ & 34.7 & & $<$ & 32.4 & $<$ & 10.5 & & $<$ & 25.9 & - & $100 \%$ \\
\hline Organics, Semi-Volatile & Pyrene & SW 8270 & $\mathrm{ng} / \mathrm{g}$ & $<$ & 22.0 & & $<$ & 20.5 & $<$ & 17.7 & & $<$ & 20.1 & - & $100 \%$ \\
\hline Organics, Semi-Volatlle & Pyridine & SW 8270 & $\mathrm{ng} / \mathrm{g}$ & $<$ & 54.5 & & $<$ & 50.9 & $<$ & 25.6 & & $<$ & 43.7 & -. & $100 \%$ \\
\hline
\end{tabular}

Bottom Ash - Page 4 


\section{Solid Stream Data}

Sample Stream: Bottom Ash

\begin{tabular}{|c|c|c|c|c|c|c|c|c|c|c|c|c|}
\hline $\begin{array}{l}\text { Analyte } \\
\text { Group }\end{array}$ & Specie & $\begin{array}{c}\text { Analytical } \\
\text { Method }\end{array}$ & Units & & $\begin{array}{c}\text { Run } \\
1 \\
\end{array}$ & $\begin{array}{c}\text { Run } \\
2 \\
\end{array}$ & $\begin{array}{c}\text { Run } \\
3 \\
\end{array}$ & $\begin{array}{c}\text { Run } \\
\text { 3d }\end{array}$ & & Average & $\begin{array}{c}95 \% \\
\mathrm{Cl}\end{array}$ & $\begin{array}{c}\text { DL } \\
\text { Ratio }\end{array}$ \\
\hline Organics, Semi-Volatile & bis(2-Chloroethoxy)methane & SW 8270 & $\mathbf{n g} / \mathbf{g}$ & $<$ & 26.4 & 24.7 & 26.3 & & $<$ & 25.8 & $\cdots$ & $100 \%$ \\
\hline Organics, Semi-Volatile & bis(2-Chloroethyl)ether & SW 8270 & $\mathrm{ng} / \mathrm{g}$ & $<$ & 34.4 & 32.1 & 16.6 & & $<$ & 27.7 & -. & $100 \%$ \\
\hline Organics, Semi-Volatile & bls(2-Chloroisopropyl)ether & SW 8270 & $\mathrm{ng} / \mathrm{g}$ & $<$ & 34.1 & 31.9 & 34.7 & & $<$ & 33.6 & - & $100 \%$ \\
\hline Organics, Semi-Volatile & bis(2-Ethylhexyl)phthalate & SW 8270 & $\mathrm{ng} / \mathrm{g}$ & $<$ & 86.0 & 157.0 & 25.2 & & $<$ & 86.0 & . & $26 \%$ \\
\hline Organics, Semi-Volatile & p.Chloroanilline & SW 8270 & $\mathrm{ng} / \mathrm{g}$ & $<$ & 26.3 & 24.5 & 32.4 & & $<$ & 27.7 & . & $100 \%$ \\
\hline Organics, Semi-Volatile & p-Dimethylaminoazobenzene & SW 8270 & $n g / g$ & $<$ & 24.2 & 22.6 & 31.5 & & $<$ & 26.1 & .. & $100 \%$ \\
\hline
\end{tabular}




\section{Solid Stream Data}

Sample Stream: Sluiced Fly Ash

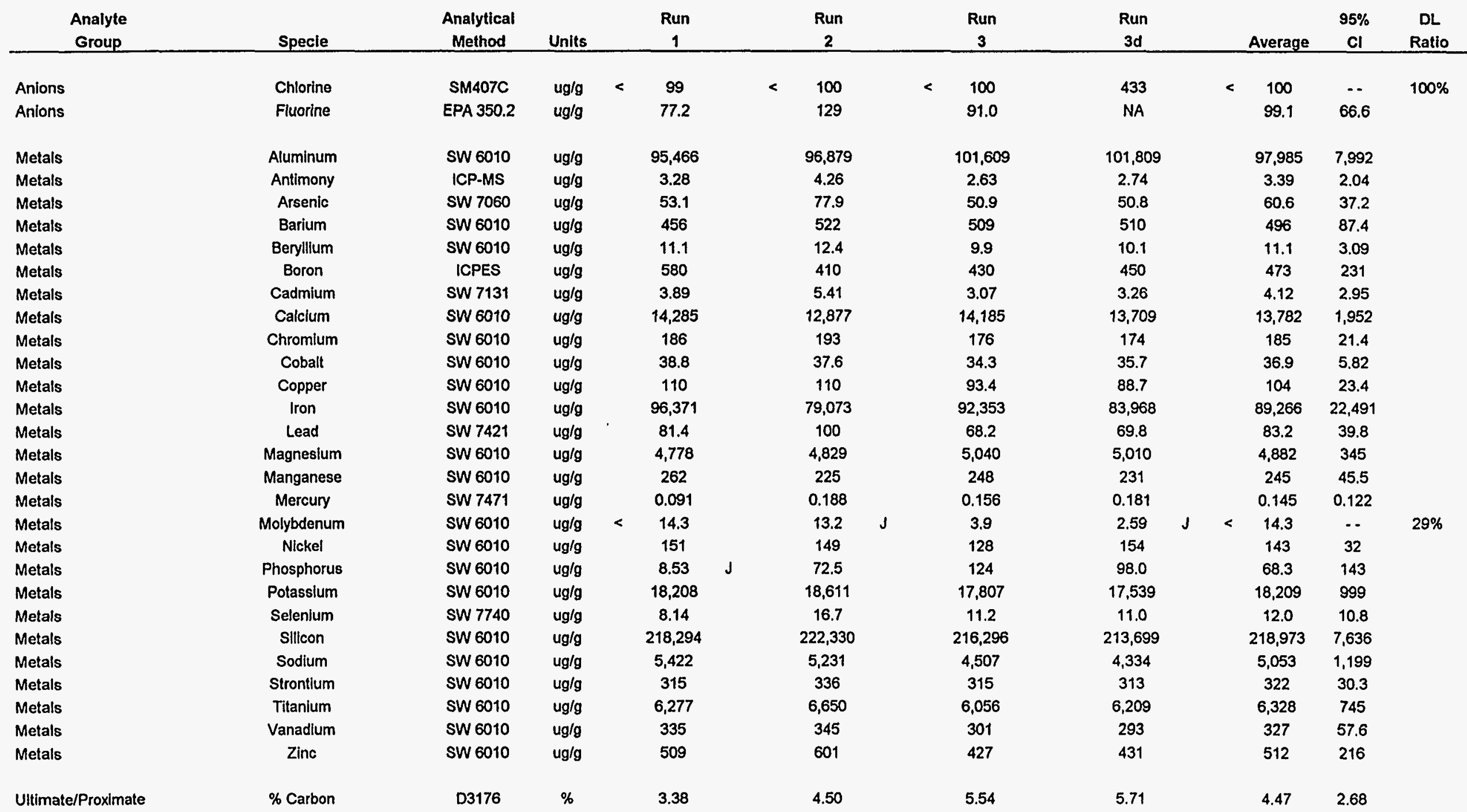

Sluiced Fly Ash - Page 1 


\section{Solld Stream Data}

Sample Stream: Sluiced Fly Ash

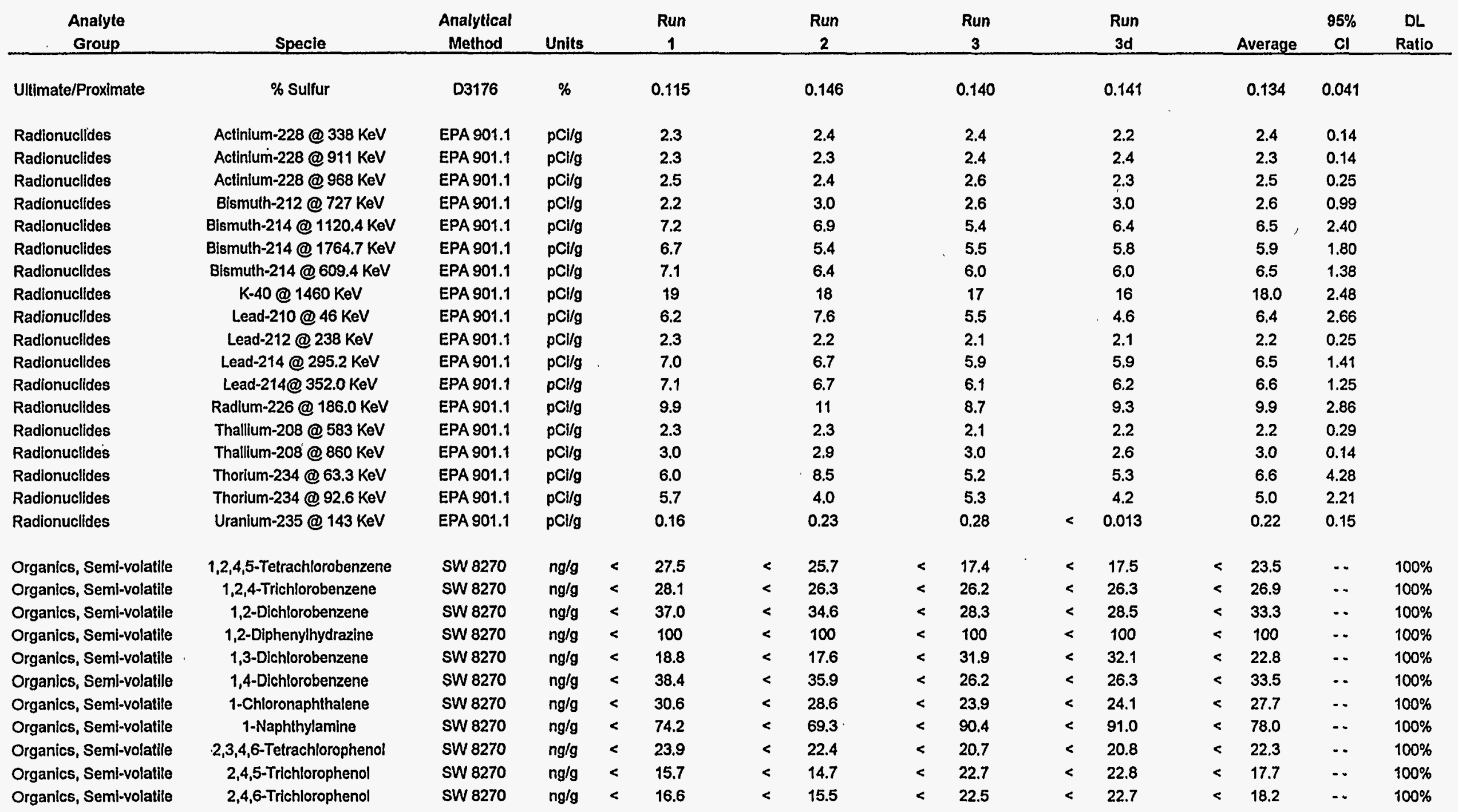

Sluiced Fly Ash - Page 2 


\section{Solid Stream Data}

Sample Stream: Sluiced Fly Ash

\begin{tabular}{|c|c|c|c|c|c|c|c|c|c|c|c|c|c|c|c|}
\hline $\begin{array}{c}\text { Analyte } \\
\text { Group }\end{array}$ & Specie & $\begin{array}{c}\text { Analytical } \\
\text { Method }\end{array}$ & Units & & $\begin{array}{c}\text { Run } \\
1 \\
\end{array}$ & & $\begin{array}{c}\text { Run } \\
2 \\
\end{array}$ & & $\begin{array}{c}\text { Run } \\
3 \\
\end{array}$ & & $\begin{array}{c}\text { Run } \\
3 d\end{array}$ & & Average & $\begin{array}{c}95 \% \\
\text { Cl } \\
\end{array}$ & $\begin{array}{c}\mathrm{DL} \\
\text { Ratio }\end{array}$ \\
\hline Organics, Semi-volatile & 2,4-Dichlorophenol & SW 8270 & $n g / g$ & $<$ & 21.1 & $<$ & 19.7 & $<$ & 25.3 & $<$ & 25.5 & $<$ & 22.0 & - & $100 \%$ \\
\hline Organics, Semi-volatile & 2,4-Dimethylphenol & SW 8270 & $\mathbf{n g} / \mathbf{g}$ & $<$ & 52.3 & $<$ & 48.9 & $<$ & 57.9 & $<$ & 58.2 & $<$ & 53.0 & $\ldots$ & $100 \%$ \\
\hline Organics, Semi-volatile & 2,4-Dinitrophenol & SW 8270 & $n g / g$ & $<$ & 333 & $<$ & 311 & $<$ & 186 & $<$ & 187 & $<$ & 277 & -- & $100 \%$ \\
\hline Organics, Semi-volatile & 2,4-Dinitrotoluene & SW 8270 & $\mathbf{n g} / \mathbf{g}$ & $<$ & 26.1 & $<$ & 24.4 & $<$ & 26.3 & $<$ & 26.5 & $<$ & 25.6 & $\cdots$ & $100 \%$ \\
\hline Organics, Semi-volatile & 2,6-Dlchlorophenol & SW 8270 & $\mathrm{ng} / \mathrm{g}$ & $<$ & 34.4 & $<$ & 32.1 & $<$ & 22.8 & $<$ & 22.9 & $<$ & 29.8 & - & $100 \%$ \\
\hline Organics, Semi-volatile & 2,6-Dinitrotoluene & SW 8270 & $\mathbf{n g} / \mathbf{g}$ & $<$ & 16.4 & $<$ & 15.4 & $<$ & 38.3 & $<$ & 38.6 & $<$ & 23.4 & -. & $100 \%$ \\
\hline Organics, Seml-volatile & 2-Chlorophenol & sW 8270 & $\mathrm{ng} / \mathrm{g}$ & $<$ & 36.3 & $<$ & 34.0 & $<$ & 28.3 & $<$ & 28.5 & $<$ & 32.9 & -. & $100 \%$ \\
\hline Organics, Semi-voiatile & 2-Methyinaphthalene & SW 8270 & $\mathbf{n g} / \mathbf{g}$ & $<$ & 31.4 & $<$ & 29.3 & $<$ & 16.2 & $<$ & 16.3 & $<$ & 25.6 & $\cdots$ & $100 \%$ \\
\hline Organics, Semi-volatile & 2-Methylphenol(o-cresol) & SW 8270 & $n g / g$ & $<$ & 25.4 & $<$ & 23.7 & $<$ & 13.8 & $<$ & 13.9 & $<$ & 21.0 & . & $100 \%$ \\
\hline Organics, Semi-volatile & 2-Naphthylamine & SW 8270 & $n g / g$ & $<$ & 92.7 & $<$ & 86.7 & $<$ & 71.2 & $<$ & 71.7 & $<$ & 83.5 & - & $100 \%$ \\
\hline Organics, Semi-volatile & 2-Nitroanilline & SW 8270 & $n g / g$ & $<$ & 19.1 & $<$ & 17.9 & $<$ & 29.5 & $<$ & 29.7 & $<$ & 22.2 & -. & $100 \%$ \\
\hline Organics, Semi-volatile & 2-Nitrophenol & SW 8270 & $\mathrm{ng} / \mathrm{g}$ & $<$ & 20.9 & $<$ & 19.6 & $<$ & 23.2 & $<$ & 23.4 & $<$ & 21.2 & $\ldots$ & $100 \%$ \\
\hline Organics, Semi-volatile & 2-Picoline & SW 8270 & $\mathrm{ng} / \mathrm{g}$ & $<$ & 51.8 & $<$ & 48.4 & $<$ & 36.8 & $<$ & 37.1 & $<$ & 45.7 & -- & $100 \%$ \\
\hline Organics, Semi-volatile & 3,3'-Dichlorobenzidine & SW 8270 & $\mathrm{ng} / \mathrm{g}$ & $<$ & 23.3 & $<$ & 21.8 & $<$ & 14.8 & $<$ & 14.9 & $<$ & 20.0 & -- & $100 \%$ \\
\hline Organics, Semi-volatile & 3-Nitroanillne & SW 8270 & $\mathrm{ng} / \mathrm{g}$ & $<$ & 24.2 & $<$ & 22.6 & $<$ & 17.5 & $<$ & 17.6 & $<$ & 21.4 & - - & $100 \%$ \\
\hline Organics, Semi-volatile & 4,6-Dinitro-2-methylphenol & sW 8270 & $n g / g$ & $<$ & 37.6 & $<$ & 35.2 & $<$ & 19.1 & $<$ & 19.3 & $<$ & 30.6 & - & $100 \%$ \\
\hline Organics, Semi-volatile & 4-Aminobiphenyl & SW 8270 & $\mathrm{ng} / \mathrm{g}$ & $<$ & 35.6 & $<$ & 33.2 & $<$ & 53.0 & $<$ & 53.3 & $<$ & 40.6 & - & $100 \%$ \\
\hline Organics, Semi-volatile & 4-Bromophenyl phenyl & SW 8270 & $n g / g$ & $<$ & 21.7 & $<$ & 20.3 & $<$ & 21.5 & $<$ & 21.7 & $<$ & 21.2 & - & $100 \%$ \\
\hline Organics, Semi-volatile & 4-Chloro-3-methylphenol & SW 8270 & $\mathrm{ng} / \mathrm{g}$ & $<$ & 34.4 & $<$ & 32.1 & $<$ & 22.9 & $<$ & 23.1 & $<$ & 29.8 & - & $100 \%$ \\
\hline Organics, Semi-volatlle & 4-Chlorophenyl phenyl ether & SW 8270 & $n g / g$ & $<$ & 25.1 & $<$ & 23.5 & $<$ & 18.7 & $<$ & 18.9 & $<$ & 22.4 & -- & $100 \%$ \\
\hline Organics, Semi-volatile & 4-Methylphenol(p-cresol) & SW 8270 & $\mathrm{ng} / \mathrm{g}$ & $<$ & 27.3 & $<$ & 25.6 & $<$ & 20.4 & $<$ & 20.6 & $<$ & 24.4 & -- & $100 \%$ \\
\hline Organics, Semi-volatile & 4-Nitroanilline & SW 8270 & $n g / g$ & $<$ & 23.0 & $<$ & 21.5 & $<$ & 27.0 & $<$ & 27.2 & $<$ & 23.8 & -. & $100 \%$ \\
\hline Organics, Seml-volatile & 4-Nitrophenol & SW 8270 & $\mathrm{ng} / \mathrm{g}$ & $<$ & 32.8 & $<$ & 30.7 & $<$ & 41.7 & $<$ & 42.0 & $<$ & 35.1 & -. & $100 \%$ \\
\hline Organics, Semi-volatile & 7,12-Dlmethylbenz(a)anthracene & SW 8270 & $\mathrm{ng} / \mathrm{g}$ & $<$ & 91.3 & $<$ & 85.3 & $<$ & 59.2 & $<$ & 59.6 & $<$ & 78.6 & - & $100 \%$ \\
\hline Organics, Semi-volatile & Acenaphthene & SW 8270 & $\mathrm{ng} / \mathrm{g}$ & $<$ & 22.7 & $<$ & 21.2 & $<$ & 12.1 & $<$ & 12.2 & $<$ & 18.7 & -- & $100 \%$ \\
\hline Organics, Semi-volatile & Acenaphthylene & SW 8270 & $\mathrm{ng} / \mathrm{g}$ & $<$ & 10.7 & $<$ & 10.0 & $<$ & 18.6 & $<$ & 18.7 & $<$ & 13.1 & -. & $100 \%$ \\
\hline Organics, Seml-volatile & Acetophenone & SW 8270 & $\mathbf{n g} / \mathbf{g}$ & $<$ & 21.8 & $<$ & 20.4 & $<$ & 24.9 & $<$ & 25.0 & $<$ & 22.4 & $\cdots$ & $100 \%$ \\
\hline Organics, Seml-volatile & Anilline & SW 8270 & $\mathbf{n g} / \mathbf{g}$ & $<$ & 44.4 & $<$ & 41.5 & $<$ & 27.4 & $<$ & 27.6 & $<$ & 37.8 & - & $100 \%$ \\
\hline Organics, Semi-volatlle & Anthracene & SW 8270 & $\mathbf{n g} / \mathbf{g}$ & $<$ & 27.6 & $<$ & 25.8 & $<$ & 16.4 & $<$ & 16.5 & $<$ & 23.3 & -- & $100 \%$ \\
\hline Organics, Semi-volatile & Benzidine & SW 8270 & $\mathrm{ng} / \mathrm{g}$ & $<$ & 20 & $<$ & 20 & $<$ & 20 & $<$ & 20 & $<$ & 20 & - & $100 \%$ \\
\hline
\end{tabular}




\section{Solid Stream Data}

Sample Stream: Sluiced Fly Ash

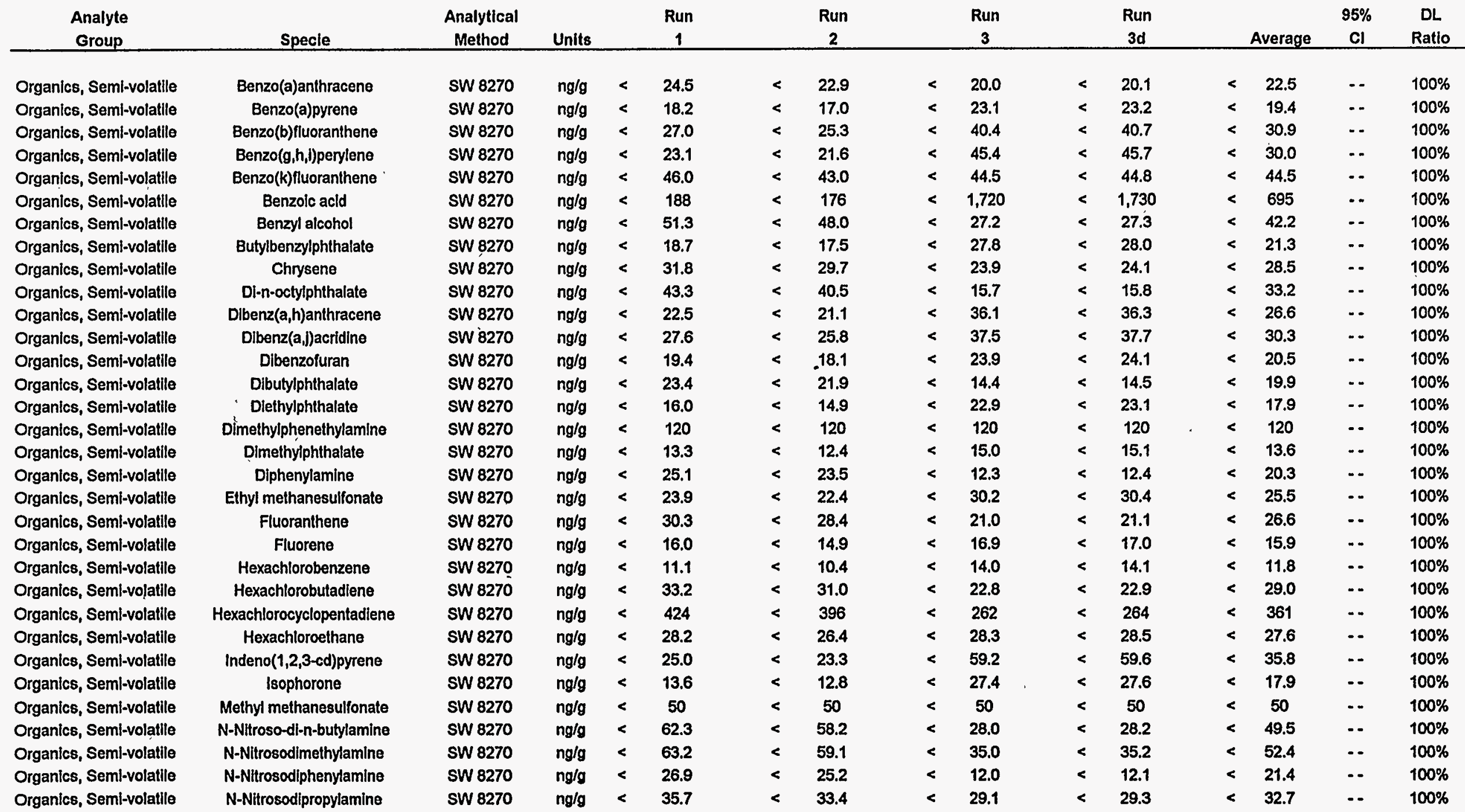

Sluiced Fly Ash - Page 4 


\section{Solid Stream Data}

Sample Stream: Sluiced Fly Ash

\begin{tabular}{|c|c|c|c|c|c|c|c|c|c|c|c|c|c|c|c|}
\hline $\begin{array}{c}\text { Analyte } \\
\text { Group }\end{array}$ & Specie & $\begin{array}{c}\text { Analytical } \\
\text { Method }\end{array}$ & Units & & $\begin{array}{c}\text { Run } \\
1 \\
\end{array}$ & & $\begin{array}{c}\text { Run } \\
2 \\
\end{array}$ & & $\begin{array}{c}\text { Run } \\
3 \\
\end{array}$ & & $\begin{array}{c}\text { Run } \\
3 d\end{array}$ & & Average & $\begin{array}{c}95 \% \\
\mathbf{C l} \\
\end{array}$ & $\begin{array}{c}\text { DL } \\
\text { Ratio }\end{array}$ \\
\hline Organics, Semi-volatile & N-Nitrosopiperidine & SW 8270 & $\mathrm{ng} / \mathrm{g}$ & $<$ & 44.8 & $<$ & 41.9 & $<$ & 26.6 & $<$ & 26.7 & $<$ & 37.8 & - & $100 \%$ \\
\hline Organics, Semi-volatile & Naphthalene & SW 8270 & $\mathrm{ng} / \mathrm{g}$ & $<$ & 34.7 & $<$ & 32.4 & $<$ & 21.3 & $<$ & 21.4 & $<$ & 29.5 & -. & $100 \%$ \\
\hline Organics, Semi-volatile & Nitrobenzene & SW 8270 & $\mathrm{ng} / \mathrm{g}$ & $<$ & 25.1 & $<$ & 23.5 & $<$ & 37.5 & $<$ & 37.7 & $<$ & 28.7 & -- & $100 \%$ \\
\hline Organics, Semi-volatile & Pentachlorobenzene & SW 8270 & $\mathrm{ng} / \mathrm{g}$ & $<$ & 21.1 & $<$ & 19.7 & $<$ & 16.6 & $<$ & 16.8 & $<$ & 19.1 & -. & $100 \%$ \\
\hline Organics, Semi-volatile & Pentachloronitrobenzene & SW 8270 & $\mathbf{n g} / \mathbf{g}$ & $<$ & 98.4 & $<$ & 92.0 & $<$ & 61.4 & $<$ & 61.8 & $<$ & 83.9 & - & $100 \%$ \\
\hline Organics, Semi-volatile & Pentachlorophenol & SW 8270 & $\mathrm{ng} / \mathrm{g}$ & $<$ & 41.1 & $<$ & 38.4 & $<$ & 39.6 & $<$ & 39.8 & $<$ & 39.7 & - . & $100 \%$ \\
\hline Organics, Semi-volatile & Phenanthrene & SW 8270 & $\mathrm{ng} / \mathrm{g}$ & $<$ & 29.6 & $<$ & 27.6 & $<$ & 20.8 & $<$ & 21.0 & $<$ & 26.0 & - - & $100 \%$ \\
\hline Organics, Semi-volatile & Phenol & SW 8270 & $\mathrm{ng} / \mathrm{g}$ & $<$ & 19.0 & $<$ & 17.7 & $<$ & 39.3 & $<$ & 39.6 & $<$ & 25.3 & -- & $100 \%$ \\
\hline Organics, Semi-volatile & Pronamide & SW 8270 & $n g / g$ & $<$ & 35.1 & $<$ & 32.8 & $<$ & 10.7 & $<$ & 10.8 & $<$ & 26.2 & - - & $100 \%$ \\
\hline Organics, Semi-volatile & Pyrene & SW 8270 & $\mathrm{ng} / \mathrm{g}$ & $<$ & 22.2 & $<$ & 20.8 & $<$ & 18.2 & $<$ & 18.3 & $<$ & 20.4 & - & $100 \%$ \\
\hline Organics, Semi-volatile & Pyridine & SW 8270 & $\mathrm{ng} / \mathrm{g}$ & $<$ & 55.1 & $<$ & 51.6 & $<$ & 26.2 & $<$ & 26.3 & $<$ & 44.3 & 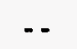 & $100 \%$ \\
\hline Organics, Semi-volatile & bis(2-Chloroethoxy)methane & SW 8270 & $\mathrm{ng} / \mathrm{g}$ & $<$ & 26.7 & $<$ & 25.0 & $<$ & 27.0 & $<$ & 27.2 & $<$ & 26.2 & - & $100 \%$ \\
\hline Organics, Semi-volatile & bis(2-Chloroethyl)ether & SW 8270 & $\mathrm{ng} / \mathrm{g}$ & $<$ & 34.8 & $<$ & 32.5 & $<$ & 17.0 & $<$ & 17.2 & $<$ & 28.1 & - & $100 \%$ \\
\hline Organics, Semi-volatile & bis(2-Chloroisopropyl)ether & SW 8270 & $\mathrm{ng} / \mathrm{g}$ & $<$ & 34.5 & $<$ & 32.3 & $<$ & 35.5 & $<$ & 35.8 & $<$ & 34.1 & $\cdots$ & $100 \%$ \\
\hline Organics, Semi-volatile & p-Chloroaniline & SW 8270 & $\mathrm{ng} / \mathrm{g}$ & $<$ & 26.6 & $<$ & 24.8 & $<$ & 33.2 & $<$ & 33.4 & $<$ & 28.2 & - & $100 \%$ \\
\hline Organics, Semi-volatile & p-Dimethylaminoazobenzene & SW 8270 & $\mathrm{ng} / \mathrm{g}$ & $<$ & 24.5 & $<$ & 22.9 & $<$ & 32.3 & $<$ & 32.5 & $<$ & 26.6 & $\cdots$ & $100 \%$ \\
\hline
\end{tabular}




\section{Solid Stream Data}

Sample Stream: ESP Hopper Ash-Field 1

\begin{tabular}{|c|c|c|c|c|c|c|c|c|c|c|}
\hline $\begin{array}{c}\text { Analyle } \\
\text { Group }\end{array}$ & Specie & $\begin{array}{c}\text { Analytical } \\
\text { Method }\end{array}$ & Units & $\begin{array}{c}\text { Run } \\
1 \\
\end{array}$ & $\begin{array}{c}\text { Run } \\
2 \\
\end{array}$ & $\begin{array}{c}\text { Run } \\
3 \\
\end{array}$ & $\begin{array}{c}\text { Run } \\
3 d\end{array}$ & Average & $\begin{array}{c}95 \% \\
\mathrm{Cl} \\
\end{array}$ & $\begin{array}{c}\text { DL } \\
\text { Ratio }\end{array}$ \\
\hline Anions & Chloride & SM407C & ug/g & 474 & 523 & 99.80 & 665 & 349 & 646 & $5 \%$ \\
\hline Anions & Fluoride & EPA 340.2 & ug/g & 70.8 & 87.7 & 110 & 111 & 89.5 & 49 & \\
\hline Metals & Aluminum & SW 6010 & $\mathbf{u g} / \mathbf{g}$ & 104,000 & 113,224 & 74,047 & 102,201 & 97,091 & 50,884 & \\
\hline Metals & Antimony & ICP-MS & $\mathbf{u g} / \mathbf{g}$ & 3.42 & 2.94 & 2.61 & 2.50 & 2.99 & 1.01 & \\
\hline Metals & Arsenic & SW 7060 & ug/g & 50.0 & 41.0 & 45.6 & 48.3 & 45.5 & 11.2 & \\
\hline Metals & Barium & SW 6010 & $\mathbf{u g} / \mathbf{g}$ & 461 & 564 & 456 & 505 & 494 & 152 & \\
\hline Metals & Beryllium & SW 6010 & ug/g & 10.8 & 12.2 & 9.60 & 15.9 & 10.9 & 3.26 & \\
\hline Metals & Cadmium & SW 7131 & ug/g & 3.59 & 3.06 & 3.14 & 3.29 & 3.26 & 0.72 & \\
\hline Metals & Calclum & SW 6010 & ug/g & 19,900 & 18,837 & 15,030 & 18,737 & 17,922 & 6,362 & \\
\hline Metals & Chromium & SW 6010 & $u g / g$ & 182 & 196 & 171 & 181 & 183 & 31.2 & \\
\hline Metals & Cobalt & SW 6010 & $u g / g$ & 33.8 & 35.8 & 32.5 & 33.9 & 34.0 & 4.13 & \\
\hline Metals & Copper & SW 6010 & $u g / g$ & 104.0 & 104.2 & 86.3 & 88.8 & 98.2 & 25.6 & \\
\hline Metals & Iron & SW 6010 & $\mathrm{ug} / \mathrm{g}$ & 97,800 & 88,275 & 84,268 & 88,975 & 90,114 & 17,269 & \\
\hline Metals & Lead & SW 7421 & $u g / g$ & 75.2 & 67.3 & 74.5 & 67.8 & 72.4 & 10.8 & \\
\hline Metals & Magnesium & SW 6010 & $u g / g$ & 5,400 & 5,010 & 3,337 & 5,080 & 4,582 & 2,723 & \\
\hline Metals & Manganese & SW 6010 & ug/g & 243 & 211 & 203 & 215 & 219 & 52.0 & \\
\hline Metals & Mercury & SW 7471 & $u g / g$ & 0.09 & 0.12 & 0.16 & 0.15 & 0.12 & 0.09 & \\
\hline Metals & Molybdenum & SW 6010 & ug/g & 25.3 & 32.8 & 17.6 & 22.8 & 25 & 18.8 & \\
\hline Metals & Nickel & SW 6010 & $u g / g$ & 140 & 118 & 124 & 124 & 127 & 27.9 & \\
\hline Metals & Phosphorus & SW 6010 & $u g / g$ & 104 & 71.7 & 150 & 69.7 & 96.7 & 143 & $12 \%$ \\
\hline Metals & Potasslum & SW 6010 & ug/g & 18,600 & 17,535 & 16,132 & 18,136 & 17,422 & 3,075 & \\
\hline Metals & Selentum & SW 7740 & ug/g & 8.60 & 7.88 & 11.4 & 10.4 & 9.30 & 4.66 & \\
\hline Metals & Sillicon & SW 6010 & ug/g & 217,000 & 238,472 & 212,423 & 200,395 & 222,632 & 34,552 & \\
\hline Metals & Sodium & SW 6010 & $u g / g$ & 5,630 & 5,361 & 4,679 & 4,870 & 5,223 & 1,217 & \\
\hline Metals & Strontium & SW 6010 & $u g / g$ & 330 & 368 & 272 & 325 & 323 & 120 & \\
\hline Metals & TItanlum & SW 6010 & $u g / g$ & 6,120 & 6,042 & 6,192 & 5,932 & 6,118 & 187 & \\
\hline Metals & Vanadium & SẂ 6010 & $\mathrm{ug} / \mathrm{g}$ & 322 & 302 & 293 & 298 & 305 & 37.4 & \\
\hline Melals & Zinc & SW 6010 & $u g / g$ & 472 & 406 & 422 & 394 & 433 & 85.8 & \\
\hline Radionuclides & Actlnium-228 @ $338 \mathrm{KeV}$ & EPA 901.1 & $\mathrm{pCi} / \mathrm{g}$ & 2.3 & 2.1 & 2.0 & 1.9 & 2.1 & 0.4 & \\
\hline Radionuclldes & Actinlum-228@ @ $911 \mathrm{KeV}$ & EPA 901.1 & $\mathrm{pCl} / \mathrm{g}$ & 2.3 & 2.0 & 2.0 & 2.3 & 2.1 & 0.4 & \\
\hline Radionuclides & Actinium-228 @ $968 \mathrm{KeV}$ & EPA 901.1 & pClg & 2.8 & 2.4 & 2.1 & 1.8 & 2.4 & 0.9 & \\
\hline
\end{tabular}


sample Stream: ESP Hopper Ash-Field 1

\begin{tabular}{|c|c|c|c|c|c|c|c|c|c|c|c|c|c|c|c|}
\hline $\begin{array}{c}\text { Analyte } \\
\text { Group }\end{array}$ & Specie & $\begin{array}{c}\text { Analytical } \\
\text { Method }\end{array}$ & Units & & $\begin{array}{c}\text { Run } \\
1\end{array}$ & & $\begin{array}{c}\text { Run } \\
2 \\
\end{array}$ & & $\begin{array}{c}\text { Run } \\
3 \\
\end{array}$ & & $\begin{array}{c}\text { Run } \\
\text { 3d }\end{array}$ & & Average & $\begin{array}{c}95 \% \\
\mathrm{Cl} \\
\end{array}$ & $\begin{array}{c}\text { DL } \\
\text { Ratio }\end{array}$ \\
\hline Radionuclides & Bismuth-212@727 KeV & EPA 901.1 & $\mathrm{pCl} / \mathrm{g}$ & & 3.4 & & 2.8 & & 2.1 & & 2.7 & & 2.8 & 1.6 & \\
\hline Radionuclides & Bismuth-214@1120.4 KeV & EPA 901.1 & $\mathrm{pCl} / \mathrm{g}$ & & 7.3 & & 5.8 & & 5.3 & & 5.5 & & 6.1 & 2.6 & \\
\hline Radionuclides & Bismuth-214@1764.7 KeV & EPA 901.1 & $\mathrm{pCl} / \mathrm{g}$ & & 6.9 & & 5.1 & & 5.6 & & 5.2 & & 5.9 & 2.3 & \\
\hline Radionuclides & Bismuth-214@609.4 KeV & EPA 901.1 & $\mathrm{pCl} / \mathrm{g}$ & & 7.2 & & 5.6 & & 5.9 & & 5.5 & & 6.2 & 2.1 & \\
\hline Radionuclides & $\mathrm{K}-40 @ 1460 \mathrm{KeV}$ & EPA 901.1 & $\mathrm{pCl} / \mathrm{g}$ & & 19 & & 16 & & 16 & & 19 & & 17 & 4.3 & \\
\hline Radionuclides & Lead-210@46 KeV & EPA 901.1 & $\mathrm{pCl} / \mathrm{g}$ & & 5.6 & & 5.1 & & 5.6 & & 3.7 & & 5.4 & 0.7 & \\
\hline Radionuclides & Lead-212@238 KeV & EPA 901.1 & $\mathrm{pCl} / \mathrm{g}$ & & 2.4 & & 1.8 & & 2.1 & & 2.0 & & 2.1 & 0.7 & \\
\hline Radionuclides & Lead-214@295.2 KeV & EPA 901.1 & $\mathrm{pCl} / \mathrm{g}$ & & 6.8 & & 5.7 & & 5.9 & & 5.8 & & 6.1 & 1.5 & \\
\hline Radionuclides & Lead-214@352.0 KeV & EPA 901.1 & $\mathrm{pCl} / \mathrm{g}$ & & 7.2 & & 5.6 & & 5.9 & & 6.0 & & 6.2 & 2.1 & \\
\hline Radionuclldes & Radium-226@186.0 KeV & EPA 901.1 & $\mathrm{pCl} / \mathrm{g}$ & & 10 & & 8.8 & & 8.3 & & 9.3 & & 9.0 & 2.2 & \\
\hline Radionuclides & Thallium-208@ $583 \mathrm{KeV}$ & EPA901.1 & $\mathrm{pCl} / \mathrm{g}$ & & 2.2 & & 2.0 & & 2.0 & & 2.1 & & 2.1 & 0.3 & \\
\hline Radionuclides & Thallium-208@ $860 \mathrm{KeV}$ & EPA 901.1 & $\mathrm{pCl} / \mathrm{g}$ & & 2.7 & & 2.3 & & 1.2 & & 2.7 & & 2.1 & 1.9 & \\
\hline Radionuclides & Thorium-234 @ $63.3 \mathrm{KeV}$ & EPA 901.1 & $\mathrm{pCl} / \mathrm{g}$ & & 6.3 & & 5.8 & & 4.6 & & 5.4 & & 5.6 & 2.2 & \\
\hline Radionuclides & Thorlum-234@92.6 KeV & EPA 901.1 & $\mathrm{pCl} / \mathrm{g}$ & & 4.6 & & 3.6 & & 4.8 & & 3.8 & & 4.3 & 1.6 & \\
\hline Radionuclides & Uranium-235 @ $143 \mathrm{KeV}$ & EPA 901.1 & $\mathrm{pCl} / \mathrm{g}$ & & 0.24 & & 0.3 & & 0.1 & & 0.3 & & 0.2 & 0.2 & \\
\hline Organics, Semi-volatile & 1,2,4,5-Tetrachlorobenzene & sw 8270 & $\mathrm{ng} / \mathrm{g}$ & $<$ & 19.2 & $<$ & 13.0 & $<$ & 12.9 & $<$ & 13.0 & $<$ & 15.0 & $\ldots$ & $100 \%$ \\
\hline Organics, Semi-volatlle & 1,2,4-Trichlorobenzene & sW 8270 & $n g / g$ & $<$ & 19.6 & $<$ & 19.6 & $<$ & 19.5 & $<$ & 19.6 & $<$ & 19.6 & $\ldots$ & $100 \%$ \\
\hline Organics, Semi-volatile & 1,2-Dichlorobenzene & SW 8270 & $\mathrm{ng} / \mathrm{g}$ & $<$ & 25.9 & $<$ & 21.2 & $<$ & 21.1 & $<$ & 21.2 & $<$ & 22.7 & -. & $100 \%$ \\
\hline Organics, Seml-volatile & 1,2-Diphenylhydrazine & SW 8270 & ng/g & $<$ & 100 & $<$ & 100 & $<$ & 100 & $<$ & 100 & $<$ & 100 & $\cdots$ & $100 \%$ \\
\hline Organics, Semi-volatlle & 1,3-Dichlorobenzene & SW 8270 & $\mathrm{ng} / \mathrm{g}$ & $<$ & 13.2 & $<$ & 23.9 & $<$ & 23.8 & $<$ & 23.9 & $<$ & 20.3 & -- & $100 \%$ \\
\hline Organics, Semi-volatile & 1,4-Dichlorobenzene & SW 8270 & $\mathbf{n g} / \mathbf{g}$ & $<$ & 26.8 & $<$ & 19.6 & $<$ & 19.5 & $<$ & 19.6 & $<$ & 22.0 & $\ldots$ & $100 \%$ \\
\hline Organics, Semi-volatile & 1-Chloronaphthalene & SW 8270 & $\mathrm{ng} / \mathrm{g}$ & $<$ & 21.4 & $<$ & 17.9 & $<$ & 17.8 & $<$ & 17.9 & $<$ & 19.0 & $\cdots$ & $100 \%$ \\
\hline Organics, Semi-volatlle & 1-Naphthylamine & SW 8270 & $\mathrm{ng} / \mathrm{g}$ & $<$ & 51.8 & $<$ & 67.7 & $<$ & 67.4 & $<$ & 67.7 & $<$ & 62.3 & -- & $100 \%$ \\
\hline Organics, Semi-volatile & 2,3,4,6-Tetrachlorophenol & SW 8270 & $\mathrm{ng} / \mathrm{g}$ & $<$ & 16.7 & $<$ & 15.5 & $<$ & 15.4 & $<$ & 15.5 & $<$ & 15.9 & $\cdots$ & $100 \%$ \\
\hline Organics, Semi-volatile & 2,4,5-Trichlorophenol & SW 8270 & $\mathrm{ng} / \mathrm{g}$ & $<$ & 11.0 & $<$ & 17.0 & $<$ & 16.9 & $<$ & 17.0 & $<$ & 15.0 & -- & $100 \%$ \\
\hline Organics, Semi-volatile & 2,4,6-Trichlorophenol & SW 8270 & ng/g & $<$ & 11.6 & $<$ & 16.9 & $<$ & 16.8 & $<$ & 16.9 & $<$ & 15.1 & $\cdots$ & $100 \%$ \\
\hline Organics, Semi-volatile & 2,4-Dichlorophenol & SW 8270 & $\mathrm{ng} / \mathrm{g}$ & $<$ & 14.7 & $<$ & 19.0 & $<$ & 18.9 & $<$ & 19.0 & $<$ & 17.5 & $\cdots$ & $100 \%$ \\
\hline Organics, Semi-volatile & 2,4-Dimethyiphenol & SW 8270 & $\mathrm{ng} / \mathrm{g}$ & $<$ & 36.5 & $<$ & 43.3 & $<$ & 43.1 & $<$ & 43.3 & $<$ & 41.0 & -. & $100 \%$ \\
\hline Organics, Semi-volatile & 2,4-Dinitrophenol & SW 8270 & $\mathrm{ng} / \mathrm{g}$ & $<$ & 233 & $<$ & 139 & $<$ & 139 & $<$ & 139 & $<$ & 170 & -. & $100 \%$ \\
\hline Organics, Semi-volatile & 2,4-Dinitrotoluene & SW 8270 & $\mathrm{ng} / \mathrm{g}$ & $<$ & 18.3 & $<$ & 19.7 & $<$ & 19.6 & $<$ & 19.7 & $<$ & 19.2 & $\cdots$ & $100 \%$ \\
\hline Organics, Seml-volatile & 2,6-Dichlorophenol & SW 8270 & $\mathrm{ng} / \mathrm{g}$ & $<$ & 24.0 & $<$ & 17.1 & $<$ & 17.0 & $<$ & 17.1 & $<$ & 19.4 & $\cdots$ & $100 \%$ \\
\hline Organics, semi-volatile & 2,6-Dinitrotoluene & SW 8270 & $\mathbf{n g} / \mathrm{g}$ & $<$ & 11.5 & $<$ & 28.7 & $<$ & 28.6 & $<$ & 28.7 & $<$ & 22.9 & -. & $100 \%$ \\
\hline
\end{tabular}




\section{Solid Stream Data}

Sample Stream: ESP Hopper Ash-Field 1

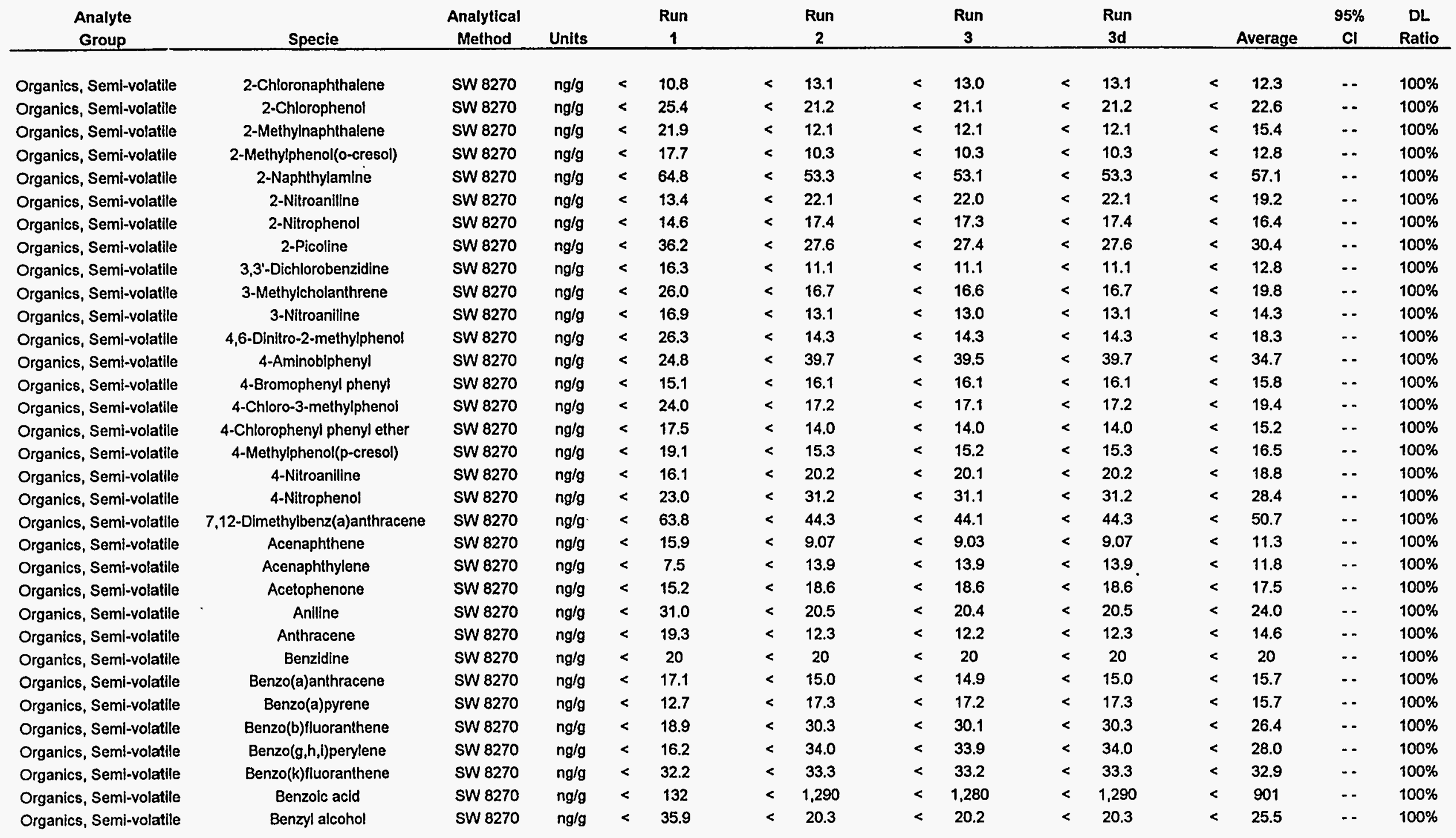

ESP Hopper Ash (Field 1) - Page 3 


\section{Solid Stream Data}

Sample Stream: ESP Hupper Ash-Field 1

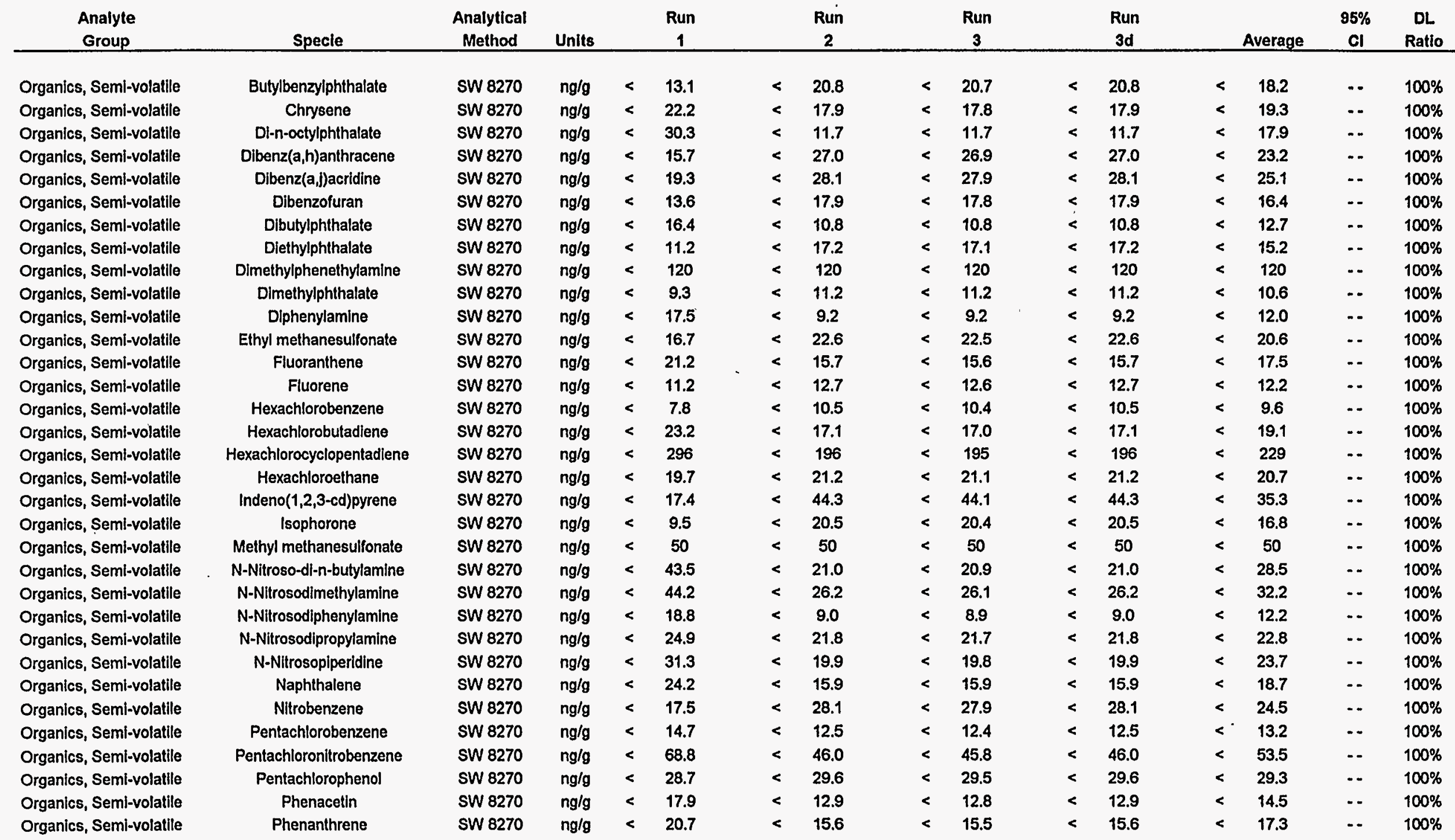

ESP Hopper Ash (Field 1) - Page 4 


\title{
Solid Stream Data
}

Sample Stream: ESP Hopper Ash-Field 1

\begin{tabular}{|c|c|c|c|c|c|c|c|c|c|c|c|c|c|c|c|}
\hline $\begin{array}{l}\text { Analyte } \\
\text { Group }\end{array}$ & Specie & $\begin{array}{c}\text { Analytical } \\
\text { Method }\end{array}$ & Units & & $\begin{array}{c}\text { Run } \\
1\end{array}$ & & $\begin{array}{c}\text { Run } \\
2 \\
\end{array}$ & & $\begin{array}{c}\text { Run } \\
3 \\
\end{array}$ & & $\begin{array}{c}\text { Run } \\
3 d\end{array}$ & & Average & $\begin{array}{c}95 \% \\
\mathrm{Cl} \\
\end{array}$ & $\begin{array}{c}\mathrm{DL} \\
\text { Ratio }\end{array}$ \\
\hline Organics, Semi-volatile & Phenol & SW 8270 & $\mathrm{ng} / \mathrm{g}$ & $<$ & 13.3 & $<$ & 29.4 & $<$ & 29.3 & $<$ & 29.4 & $<$ & 24.0 & - & $100 \%$ \\
\hline Organics, Semi-volatile & Pronamide & SW 8270 & $\mathrm{ng} / \mathrm{g}$ & $<$ & 24.6 & $<$ & 8.03 & $<$ & 8.00 & $<$ & 8.03 & $<$ & 13.5 & $\cdots$ & $100 \%$ \\
\hline Organics, Semi-volatlle & Pyrene & SW 8270 & $\mathrm{ng} / \mathrm{g}$ & $<$ & 15.5 & $<$ & 13.6 & $<$ & 13.5 & $<$ & 13.6 & $<$ & 14.2 & $-\cdot$ & $100 \%$ \\
\hline Organics, Semi-volatile & Pyridine & SW 8270 & $\mathrm{ng} / \mathrm{g}$ & $<$ & 38.5 & $<$ & 19.6 & $<$ & 19.5 & $<$ & 19.6 & $<$ & 25.9 & - & $100 \%$ \\
\hline Organics, Semi-volatile & bls(2-Chloroelhoxy)methane & SW 8270 & $\mathrm{ng} / \mathrm{g}$ & $<$ & 18.7 & $<$ & 20.2 & $<$ & 20.1 & $<$ & 20.2 & $<$ & 19.7 & $\cdots$ & $100 \%$ \\
\hline Organics, Seml-volatile & bis(2-Chloroelhyl)ether & SW 8270 & $\mathrm{ng} / \mathrm{g}$ & $<$ & 24.3 & $<$ & 12.8 & $<$ & 12.7 & $<$ & 12.8 & $<$ & 16.6 & $\cdots$ & $100 \%$ \\
\hline Organics, Semi-volatile & bis(2-Chloroisopropyl)ether & SW 8270 & $\mathrm{ng} / \mathrm{g}$ & $<$ & 24.1 & $<$ & 26.6 & $<$ & 26.5 & $<$ & 26.6 & $<$ & 25.7 & -- & $100 \%$ \\
\hline Organics, Semi-volattle & bis(2-Ethylhexyl)phthalate & SW 8270 & $\mathrm{ng} / \mathrm{g}$ & & 550 & $<$ & 19.4 & $<$ & 19.3 & $<$ & 19.4 & & 190 & 775 & $3 \%$ \\
\hline Organics, Semi-volatile & p-Chloroaniline & SW 8270 & $\mathrm{ng} / \mathrm{g}$ & $<$ & 18.6 & $<$ & 24.8 & $<$ & 24.7 & $<$ & 24.8 & $<$ & 22.7 & $\ldots$ & $100 \%$ \\
\hline Organics, Semi-volatile & p-Dimethylaminoazobenzene & SW 8270 & $\mathrm{ng} / \mathrm{g}$ & $<$ & 17.1 & $<$ & 24.2 & $<$ & 24.1 & $<$ & 24.2 & $<$ & 21.8 & - & $100 \%$ \\
\hline
\end{tabular}

\author{
ESP Hopper Ash (Field 1) - Page 5
}




\section{Solid Stream Data}

Sample Stream: ESP Hopper Ash-Field 2

\begin{tabular}{|c|c|c|c|c|c|c|c|c|c|c|c|c|}
\hline $\begin{array}{c}\text { Analyte } \\
\text { Group }\end{array}$ & Specie & $\begin{array}{c}\text { Analytical } \\
\text { Method }\end{array}$ & Units & $\begin{array}{c}\text { Run } \\
1 \\
\end{array}$ & & $\begin{array}{c}\text { Run } \\
2 \\
\end{array}$ & $\begin{array}{c}\text { Run } \\
3 \\
\end{array}$ & $\begin{array}{c}\text { Run } \\
3 d\end{array}$ & & Average & $\begin{array}{c}95 \% \\
\mathrm{Cl} \\
\end{array}$ & $\begin{array}{c}\text { DL } \\
\text { Ratio }\end{array}$ \\
\hline Anions & Chloride & SM407C & ug/g & 99.90 & $<$ & 99.70 & 99.80 & 99.80 & $<$ & 99.8 & .. & $100 \%$ \\
\hline Anions & Fluoride & EPA 340.2 & ug/g & 139,00 & & 152.00 & 83.40 & 45.40 & & 124.8 & 90.5 & \\
\hline Metals & Aluminum & SW 6010 & $u g / g$ & 83,768 & & 89,800 & 92,100 & 68,200 & & 88,556 & 10,691 & \\
\hline Metals & Antimony & ICP-MS & $u g / g$ & 4.83 & & 3.87 & 3.86 & 3.76 & & 4.19 & 1.38 & \\
\hline Metals & Arsenic & SW 7060 & $u g / g$ & 74.2 & & 67.4 & 74.2 & 61.1 & & 71.9 & 9.8 & \\
\hline Metals & Barium & SW 6010 & $u g / g$ & 449 & & 503 & 526 & 467 & & 493 & 98.3 & \\
\hline Metals & Beryllium & SW 6010 & ug/g & 18.7 & & 16.5 & 16.3 & 19.2 & & 17.2 & 3.36 & \\
\hline Metals & Cadmium & SW 7131 & $u g / g$ & 5.73 & & 5.20 & 5.33 & 5.03 & & 5.42 & 0.69 & \\
\hline Metals & Calclum & SW 6010 & ug/g & 15,230 & & 16,000 & 15,700 & 14,800 & & 15,643 & 964 & \\
\hline Metals & Chromium & SW 6010 & $u g / g$ & 194 & & 193 & 271 & 190 & & 219 & 111 & \\
\hline Metals & Cobalt & SW 6010 & ug/g & 41.3 & & 45.5 & 41.3 & 38.8 & & 42.7 & 6.04 & \\
\hline Metals & Copper & SW 6010 & $u g / g$ & 126 & & 109 & 218 & 107 & & 151 & 146 & \\
\hline Metals & Iron & SW 6010 & ug/g & 83,968 & & 78,500 & 77,600 & 74,600 & & 80,023 & 8,562 & \\
\hline Metals & Lead & SW 7421 & $u g / g$ & 103 & & 87.0 & 97.7 & 97.3 & & 96.0 & 20.5 & \\
\hline Metals & Magnesium & SW 6010 & $u g / g$ & 3,627 & & 4,170 & 4,420 & 2,620 & & 4,072 & 1,007 & \\
\hline Metals & Manganese & SW 6010 & $u g / g$ & 227 & & 212 & 209 & 206 & & 216 & 24.6 & \\
\hline Metals & Mercury & SW 7471 & ug/g & 0.096 & & 0.202 & 0.235 & 0.258 & & 0.178 & 0.181 & \\
\hline Metals & Molybdenum & SW 6010 & ug/g & 49.1 & & 35.5 & 61.4 & 38.1 & & 48.7 & 32.2 & \\
\hline Metals & Nickel & SW 6010 & $\mathrm{ug} / \mathrm{g}$ & 165 & & 166 & 144 & 154 & & 158 & 31.1 & \\
\hline Metals & Phosphorus & SW 6010 & ug/g & 72.9 & $<$ & 71.4 & 71.3 & 72.7 & $<$ & 71.9 & - & $100 \%$ \\
\hline Metals & Potassium & SW 6010 & ug/g & 17,936 & & 17,800 & 18,600 & 16,000 & & 18,112 & 1,064 & \\
\hline Metals & Selenium & SW 7740 & ug/g & 15.1 & & 17.3 & 17.5 & 16.2 & & 16.6 & 3.27 & \\
\hline Metals & Sillicon & SW 6010 & ug/g & 221,443 & & 215,000 & 209,000 & 218,000 & & 215,148 & 15,459 & \\
\hline Metals & Sodium & SW 6010 & ug/g & 6,603 & & 5,660 & 5,590 & 5,750 & & 5,951 & 1,406 & \\
\hline Metals & Strontium & SW 6010 & ug/g & 309 & & 333 & 340 & 300 & & 327 & 41 & \\
\hline Metals & Titanlum & SW 6010 & ug/g & 6,583 & & 6,410 & 6,360 & 6,650 & & 6,451 & 291 & \\
\hline Metals & Vanadium & SW 6010 & $u g / g$ & 382 & & 347 & 341 & 348 & & 357 & 55 & \\
\hline Metals & Zinc & SW 6010 & $u g / g$ & 653 & & 570 & 566 & 606 & & 596 & 122 & \\
\hline Radionuclides & Actinium-228@338 KeV & EPA 901.1 & $\mathrm{pCl} / \mathrm{g}$ & 2.3 & & 2.0 & 2.2 & 2.4 & & 2.2 & 0.4 & \\
\hline Radionuclides & Actinium-228 @ $911 \mathrm{KeV}$ & EPA 901.1 & $\mathrm{pCl} / \mathrm{g}$ & 2.4 & & 2.2 & 2.0 & 2.3 & & 2.2 & 0.5 & \\
\hline Padionuclides & Actinlum-228@968 KeV & EPA 901.1 & $\mathrm{pCl} / \mathrm{g}$ & 2.6 & & 2.6 & 2.7 & 2.7 & & 2.6 & 0.1 & \\
\hline
\end{tabular}




\section{Solid Stream Data}

Sample Stream: ESP Hopper Ash-Field 2

\begin{tabular}{|c|c|c|c|c|c|c|c|c|c|c|c|c|c|c|}
\hline $\begin{array}{c}\text { Analyte } \\
\text { Group }\end{array}$ & Specie & $\begin{array}{c}\text { Analytical } \\
\text { Method }\end{array}$ & Units & & $\begin{array}{c}\text { Run } \\
1 \\
\end{array}$ & & $\begin{array}{c}\text { Run } \\
2 \\
\end{array}$ & & $\begin{array}{c}\text { Run } \\
3 \\
\end{array}$ & $\begin{array}{c}\text { Run } \\
3 d\end{array}$ & & Average & $\begin{array}{c}95 \% \\
\mathbf{C l} \\
\end{array}$ & $\begin{array}{c}D L \\
\text { Ratio }\end{array}$ \\
\hline Radlonuclides & Bismuth-212@ $927 \mathrm{KeV}$ & EPA 901.1 & $\mathrm{pCl} / \mathrm{g}$ & & 3.4 & & 2.4 & & 2.7 & 2.7 & & 2.8 & 1.3 & \\
\hline Radionuclides & Bismuth-214@1120.4 KeV & EPA 901.1 & $\mathrm{pClig}$ & & 6.6 & & 6.2 & & 6.0 & 6.0 & & 6.3 & 0.8 & \\
\hline Radionuclides & Bismuth-214@1764.7 KeV & EPA 901.1 & pCilg & & 6.1 & & 5.6 & & 5.4 & 5.6 & & 5.7 & 0.9 & \\
\hline Radionuclides & Bismuth-214@609.4 KeV & EPA 901.1 & $\mathrm{pCi} / \mathrm{g}$ & & 6.9 & & 5.5 & & 5.7 & 6.2 & & 6.0 & 1.9 & \\
\hline Radionuclides & $\mathrm{K}-40 @ 1460 \mathrm{KeV}$ & EPA 901.1 & $\mathrm{pCl} / \mathrm{g}$ & & 18 & & 17 & & 17 & 19 & & 17 & 1.4 & \\
\hline Radionuclides & Lead-210@ $96 \mathrm{KeV}$ & EPA 901.1 & $\mathrm{pCl} / \mathrm{g}$ & & 7.8 & & 7.3 & & 8.4 & 7.6 & & 7.8 & 1.4 & \\
\hline Radionuclides & Lead-212@238 KoV & EPA 901.1 & $\mathrm{pCi} / \mathrm{g}$ & & 1.8 & & 1.6 & & 2.2 & 1.9 & & 1.9 & 0.8 & \\
\hline Radionuclides & Lead-214 @ 295.2 KeV & EPA 901.1 & $\mathrm{pCl} / \mathrm{g}$ & & 6.6 & & 5.8 & & 5.7 & 6.0 & & 6.0 & 1.2 & \\
\hline Radionuclides & Lead-214@352.0 KeV & EPA 901.1 & $\mathrm{pCl} / \mathrm{g}$ & & 6.6 & & 5.7 & & 6.0 & 6.4 & & 6.1 & 1.1 & \\
\hline Radionuclides & Radium-226 @ $186.0 \mathrm{KeV}$ & EPA 901.1 & $\mathrm{pCl} / \mathrm{g}$ & & 11 & & 9.2 & & 8.9 & 9.5 & & 9.7 & 2.8 & \\
\hline Radionuclides & Thallium-208@ @ $583 \mathrm{KeV}$ & EPA 901.1 & $\mathrm{pCl} / \mathrm{g}$ & & 2.3 & & 2.2 & & 2.0 & 2.2 & & 2.2 & 0.4 & \\
\hline Radionuclides & Thallium-208 @ $860 \mathrm{KeV}$ & EPA 901.1 & $\mathrm{pCl} / \mathrm{g}$ & & 3.6 & & ND & & 3.1 & 2.6 & & 2.2 & 4.8 & \\
\hline Radionuclides & Thorium-234@63.3 KeV & EPA 901.1 & $\mathrm{pCl} / \mathrm{g}$ & & 6.2 & & 5.1 & & 5.1 & 5.8 & & 5.5 & 1.6 & \\
\hline Radionuclides & Thorium-234@92.6 KeV & EPA 901.1 & $\mathrm{pCl} / \mathrm{g}$ & & 4.3 & & 4.6 & & 5.5 & 4.3 & & 4.8 & 1.6 & \\
\hline Radionuclides & Uranium-235@143 KeV & EPA 901.1 & $\mathrm{pCl} / \mathrm{g}$ & & 0.28 & & 0.3 & & 2.2 & 0.2 & & 0.9 & 2.8 & \\
\hline Organics, Semi-volatile & 1,2,4,5-Tetrachlorobenzene & SW 8270 & $n g / g$ & $<$ & 19.3 & $<$ & 13.0 & $<$ & 13.0 & . & $<$ & 15.1 & - & $100 \%$ \\
\hline Organics, Semi-volatlle & 1,2,4-Trichlorobenzene & SW 8270 & $\mathrm{ng} / \mathrm{g}$ & $<$ & 19.7 & $<$ & 19.6 & $<$ & 19.6 & & $<$ & 19.6 & $\therefore$ & $100 \%$ \\
\hline Organics, Semi-volatile & 1,2-Dichlorobenzene & SW 8270 & $n g / g$ & $<$ & 26.0 & $<$ & 21.1 & $<$ & 21.1 & & $<$ & 22.7 & - & $100 \%$ \\
\hline Organics, Semi-volattle & 1,2-Diphenylhydrazine & SW 8270 & $\mathrm{ng} / \mathrm{g}$ & $<$ & 100 & $<$ & 100 & $<$ & 100 & & $<$ & 100 & - - & $100 \%$ \\
\hline Organics, Semi-volatile & 1,3-Dlchlorobenzene & SW 8270 & $\mathbf{n g} / \mathrm{g}$ & $<$ & 13.2 & $<$ & 23.9 & $<$ & 23.9 & & $<$ & 20.3 & $\cdots$ & $100 \%$ \\
\hline Organics, Semi-volatile & 1,4-Dichlorobenzene & SW 8270 & $\mathbf{n g} / \mathbf{g}$. & $<$ & 27.0 & $<$ & 19.6 & $<$ & 19.6 & ' & $<$ & 22.1 & - & $100 \%$ \\
\hline Organics, Semi-volatile & 1-Chloronaphthalene & SW 8270 & $\mathrm{ng} / \mathrm{g}$ & $<$ & 21.5 & $<$ & 17.9 & $<$ & 17.9 & & $<$ & 19.1 & - & $100 \%$ \\
\hline Organics, Semi-volatile & 1-Naphthylamine & SW 8270 & $n g / g$ & $<$ & 52.1 & $<$ & 67.6 & $<$ & 67.6 & & $<$ & 62.4 & - & $100 \%$ \\
\hline Organics, Semi-volatlle & 2,3,4,6-Tetrachlorophenol & SW 8270 & $\mathrm{ng} / \mathrm{g}$ & $<$ & 16.8 & $<$ & 15.5 & $<$ & 15.5 & & $<$ & 15.9 & - & $100 \%$ \\
\hline Organics, Semi-volatile & 2,4,5-Trichlorophenol & SW 8270 & $\mathrm{ng} / \mathrm{g}$ & $<$ & 11.0 & $<$ & 16.9 & $<$ & 16.9 & & $<$ & 14.9 & $-\cdot$ & $100 \%$ \\
\hline Organics, Semi-volatile & 2,4,6-Trichlorophenol & SW 8270 & $\mathrm{ng} / \mathrm{g}$ & $<$ & 11.7 & $<$ & 16.8 & $<$ & 16.8 & & $<$ & 15.1 & -- & $100 \%$ \\
\hline Organics, Semi-volatile & 2,4-Dichlorophenol & sW 8270 & $\mathrm{ng} / \mathrm{g}$ & $<$ & 14.8 & $<$ & 18.9 & $<$ & 18.9 & & $<$ & 17.5 & $\cdots$ & $100 \%$ \\
\hline Organics, Semi-volatile & 2,4-Dimethylphenol & SW 8270 & $\mathrm{ng} / \mathrm{g}$ & $<$ & 36.7 & $<$ & 43.3 & $<$ & 43.3 & ' & $<$ & 41.1 & $\cdots$ & $100 \%$ \\
\hline Organics, Semi-volatile & 2,4-Dinitrophenol & SW 8270 & $\mathrm{ng} / \mathrm{g}$ & $<$ & 234 & $<$ & 139 & $<$ & 139 & & $<$ & 171 & - & $100 \%$ \\
\hline Organics, Semi-volatile & 2,4-Dinitrotoluene & SW 8270 & $\mathrm{ng} / \mathrm{g}$ & $<$ & 18.4 & $<$ & 19.7 & $<$ & 19.7 & & $<$ & 19.3 & $\cdots$ & $100 \%$ \\
\hline Organics, Semi-volatile & 2,6-Dichlorophenol & SW 8270 & $\mathrm{ng} / \mathrm{g}$ & $<$ & 24.1 & $<$ & 17.0 & $<$ & 17.0 & & $<$ & 19.4 & -. & $100 \%$ \\
\hline Organics, Seml-volatile & 2,6-Dinitrotoluene & SW 8270 & $\mathrm{ng} / \mathrm{g}$ & $<$ & 11.6 & $<$ & 28.7 & $<$ & 28.7 & & $<$ & 23.0 & . & $100 \%$ \\
\hline
\end{tabular}

ESP Hopper Ash (Field 2) - Page 2 
Solid Stream Data

Sample Stream: ESP Hopper Ash-Field 2

\begin{tabular}{|c|c|c|c|c|c|c|c|c|c|c|c|c|c|c|}
\hline $\begin{array}{c}\text { Analyte } \\
\text { Group }\end{array}$ & Specie & $\begin{array}{c}\text { Analytical } \\
\text { Method }\end{array}$ & Units & & $\begin{array}{c}\text { Run } \\
1 \\
\end{array}$ & & $\begin{array}{c}\text { Run } \\
2 \\
\end{array}$ & & $\begin{array}{c}\text { Run } \\
3 \\
\end{array}$ & $\begin{array}{c}\text { Run } \\
3 d\end{array}$ & & Average & $\begin{array}{c}95 \% \\
\mathrm{Cl} \\
\end{array}$ & $\begin{array}{c}\text { DL } \\
\text { Ratio }\end{array}$ \\
\hline Organics, Semi-volallie & 2-Chloronaphthalene & SW 8270 & $\mathrm{ng} / \mathrm{g}$ & $<$ & 10.8 & $<$ & 13.1 & $<$ & 13.1 & & $<$ & 12.3 & .. & $100 \%$ \\
\hline Organics, Semi-volatile & 2-Chlorophenol & SW 8270 & $\mathrm{ng} / \mathrm{g}$ & $<$ & 25.5 & $<$ & 21.1 & $<$ & 21.1 & & $<$ & 22.6 & - & $100 \%$ \\
\hline Organics, Semi-volatile & 2-Methylnaphthalene & SW 8270 & $\mathrm{ng} / \mathrm{g}$ & $<$ & 22.0 & $<$ & 12.1 & $<$ & 12.1 & & $<$ & 15.4 & -. & $100 \%$ \\
\hline Organics, Semi-volatile & 2-Methylphenol(o-cresol) & SW 8270 & $\mathrm{ng} / \mathrm{g}$ & $<$ & 17.8 & $<$ & 10.3 & $<$ & 10.3 & & $<$ & 12.8 & - & $100 \%$ \\
\hline Organics, Semi-volatile & 2-Naphthylamine & SW 8270 & $\mathrm{ng} / \mathrm{g}$ & $<$ & 65.1 & $<$ & 53.3 & $<$ & 53.3 & & $<$ & 57.2 & .. & $100 \%$ \\
\hline Organics, Semi-volatile & 2-Nitroanillne & SW 8270 & $\mathrm{ng} / \mathrm{g}$ & $<$ & 13.4 & $<$ & 22.1 & $<$ & 22.1 & & $<$ & 19.2 & - & $100 \%$ \\
\hline Organics, Semi-volatile & 2-Nitrophenol & SW 8270 & $\mathrm{ng} / \mathrm{g}$ & $<$ & 14.7 & $<$ & 17.4 & $<$ & 17.4 & & $<$ & 16.5 & $\cdots$ & $100 \%$ \\
\hline Organics, Seml-volatile & 2-Picoline & SW 8270 & $\mathrm{ng} / \mathrm{g}$ & $<$ & 36.4 & $<$ & 27.5 & $<$ & 27.5 & & $<$ & 30.5 & - & $100 \%$ \\
\hline Organics, Semi-volatile & 3,3'-Dlchlorobenzidine & SW 8270 & $n g / g$ & $<$ & 16.4 & $<$ & 11.1 & $<$ & 11.1 & & $<$ & 12.9 & $\cdots$ & $100 \%$ \\
\hline Organics, Semi-volatile & 3-Methylcholanthrene & SW 8270 & $\mathrm{ng} / \mathrm{g}$ & $<$ & 26.2 & $<$ & 16.6 & $<$ & 16.6 & & $<$ & 19.8 & -- & $100 \%$ \\
\hline Organics, Semi-volatile & 3-Nitroaniline & SW 8270 & $\mathrm{ng} / \mathrm{g}$ & $<$ & 17.0 & $<$ & 13.1 & $<$ & 13.1 & & $<$ & 14.4 & - & $100 \%$ \\
\hline Organics, Semi-volatile & 4,6-Dinitro-2-methylphenol & sw 8270 & $n g / g$ & $<$ & 26.5 & $<$ & 14.3 & $<$ & 14.3 & & $<$ & 18.4 & - & $100 \%$ \\
\hline Organics, Semi-volatile & 4-Aminobiphenyl & SW 8270 & $\mathrm{ng} / \mathrm{g}$ & $<$ & 25.0 & $<$ & 39.6 & $<$ & 39.6 & & $<$ & 34.7 & - & $100 \%$ \\
\hline Organics, Semi-volatile & 4-Bromophenyl phenyl & SW 8270 & $\mathrm{ng} / \mathrm{g}$ & $<$ & 15.2 & $<$ & 16.1 & $<$ & 16.1 & & $<$ & 15.8 & -. & $100 \%$ \\
\hline Organics, Seml-volatile & 4-Chloro-3-methylphenol & SW 8270 & $\mathrm{ng} / \mathrm{g}$ & $<$ & 24.1 & $<$ & 17.1 & $<$ & 17.1 & & $<$ & 19.4 & - - & $100 \%$ \\
\hline Organics, Seml-volatile & 4-Chlorophenyl phenyl ether & SW 8270 & $\mathrm{ng} / \mathrm{g}$ & $<$ & 17.6 & $<$ & 14.0 & $<$ & 14.0 & & $<$ & 15.2 & - & $100 \%$ \\
\hline Organics, Semi-volatile & 4-Methylphenol(p-cresol) & sw 8270 & $n g / g$ & $<$ & 19.2 & $<$ & 15.3 & $<$ & 15.3 & & $<$ & 16.6 & -. & $100 \%$ \\
\hline Organics, Semi-volatile & 4-Nitroaniline & SW 8270 & $\mathrm{ng} / \mathrm{g}$ & $<$ & 16.2 & $<$ & 20.2 & $<$ & 20.2 & & $<$ & 18.9 & - & $100 \%$ \\
\hline Organics, Semi-volatile & 4-Nitrophenol & SW 8270 & $\mathrm{ng} / \mathrm{g}$ & $<$ & 23.1 & $<$ & 31.2 & $<$ & 31.2 & & $<$ & 28.5 & -- & $100 \%$ \\
\hline Organics, Seml-volatlle & 7,12-Dimethylbenz(a)anthracene & SW 8270 & $\mathrm{ng} / \mathrm{g}$ & $<$ & 64.1 & $<$ & 44.3 & $<$ & 44.3 & & $<$ & 50.9 & - & $100 \%$ \\
\hline Organics, Semi-volatile & Acenaphthene & SW 8270 & $\mathrm{ng} / \mathrm{g}$ & $<$ & 16.0 & $<$ & 9.06 & $<$ & 9.06 & & $<$ & 11.4 &.- & $100 \%$ \\
\hline Organics, Seml-volatile & Acenaphthylene & SW 8270 & $\mathbf{n g} / \mathbf{g}$ & $<$ & 7.55 & $<$ & 13.9 & $<$ & 13.9 & & $<$ & 11.8 & .. & $100 \%$ \\
\hline Organics, Seml-volatile & Acetophenone & SW 8270 & $\mathrm{ng} / \mathrm{g}$ & $<$ & 15.3 & $<$ & 18.6 & $<$ & 18.6 & & $<$ & 17.5 & -- & $100 \%$ \\
\hline Organics, Semi-volatile & Anlline & SW 8270 & $\mathrm{ng} / \mathrm{g}$ & $<$ & 31.2 & $<$ & 20.5 & $<$ & 20.5 & & $<$ & 24.1 & .- & $100 \%$ \\
\hline Organics, Seml-volatile & Anthracene & SW 8270 & $n g / g$ & $<$ & 19.4 & $<$ & 12.3 & $<$ & 12.3 & & $<$ & 14.7 & -- & $100 \%$ \\
\hline Organics, Seml-volatile & Benzldine & SW 8270 & $n g / g$ & $<$ & 20.0 & $<$ & 20.0 & $<$ & 20.0 & & $<$ & 20.0 & -. & $100 \%$ \\
\hline Organics, Semi-volatile & Benzo(a)anthracene & SW 8270 & $\mathrm{ng} / \mathrm{g}$ & $<$ & 17.2 & $<$ & 15.0 & $<$ & 15.0 & & $<$ & 15.7 & -. & $100 \%$ \\
\hline Organics, Semi-volatlle & Benzo(a)pyrene & SW 8270 & $n g / g$ & $<$ & 12.8 & $<$ & 17.2 & $<$ & 17.2 & & $<$ & 15.7 & -. & $100 \%$ \\
\hline Organics, Semi-volatile & Benzo(b)fluoranthene & SW 8270 & $\mathrm{ng} / \mathrm{g}$ & $<$ & 19.0 & $<$ & 30.2 & $<$ & 30.2 & & $<$ & 26.5 & -. & $100 \%$ \\
\hline Organics, Seml-volatile & Benzo $(g, h, l)$ perylene & SW 8270 & $n g / g$ & $<$ & 16.3 & $<$ & 34.0 & $<$ & 34.0 & & $<$ & 28.1 & -. & $100 \%$ \\
\hline Organics, Semi-volatile & Benzo(k)fluoranthene & SW 8270 & $\mathrm{ng} / \mathrm{g}$ & $<$ & 32.3 & $<$ & 33.3 & $<$ & 33.3 & & $<$ & 33.0 & -. & $100 \%$ \\
\hline Organics, Semi-volatlle & Benzolc acld & SW 8270 & $n g / g$ & $<$ & 132 & $<$ & 1,290 & $<$ & 1,290 & & $<$ & 904 & - & $100 \%$ \\
\hline Organics, Seml-volatile & Benzyl alcohol & SW 8270 & $n g / g$ & $<$ & 36.1 & $<$ & 20.3 & $<$ & 20.3 & & $<$ & 25.6 & .. & $100 \%$ \\
\hline
\end{tabular}




\section{Solid Stream Data}

Sample Stream: ESP Hopper Ash-Field 2

\begin{tabular}{|c|c|c|c|c|c|c|c|c|c|c|c|c|c|c|}
\hline $\begin{array}{c}\text { Analyte } \\
\text { Group }\end{array}$ & Specie & $\begin{array}{c}\text { Analytical } \\
\text { Method }\end{array}$ & Units & & $\begin{array}{c}\text { Run } \\
1 \\
\end{array}$ & & $\begin{array}{c}\text { Run } \\
2 \\
\end{array}$ & & $\begin{array}{c}\text { Run } \\
3 \\
\end{array}$ & $\begin{array}{c}\text { Run } \\
3 d\end{array}$ & & Average & $\begin{array}{c}95 \% \\
\text { CI } \\
\end{array}$ & $\begin{array}{c}\text { DL } \\
\text { Ratio }\end{array}$ \\
\hline Organics, Semi-votatile & Butylbenzylphthalate & SW 8270 & $\mathrm{ng} / \mathrm{g}$ & $<$ & 13.1 & $<$ & 20.8 & $<$ & 20.8 & & $<$ & 18.2 & $\cdots$ & $100 \%$ \\
\hline Organics, Semi-votatile & Chrysene & SW 8270 & $n g / g$ & $<$ & 22.3 & $<$ & 17.9 & $<$ & 17.9 & & $<$ & 19.4 & $\cdots$ & $100 \%$ \\
\hline Organics, Semi-volatile & Dl-n-octylphthalate & SW 8270 & $\mathrm{ng} / \mathrm{g}$ & $<$ & 30.4 & $<$ & 11.7 & $<$, & 11.7 & & $<$ & 17.9 & $\cdots$ & $100 \%$ \\
\hline Organics, Semi-volatile & Dlbenz $(a, h)$ anthracene & SW 8270 & $\mathrm{ng} / \mathrm{g}$ & $<$ & 15.8 & $<$ & 27.0 & $<$ & 27.0 & & $<$ & 23.3 & $\cdots$ & $100 \%$ \\
\hline Organics, Semi-volatile & Dlbenz(a,j)acridine & SW 8270 & ng/g & $<$ & 19.4 & $<$ & 28.0 & $<$ & 28.0 & & $<$ & 25.1 & -- & $100 \%$ \\
\hline Organics, Semi-volatile & Dibenzofuran & SW 8270 & $\mathbf{n g} / \mathbf{g}$ & $<$ & 13.6 & $<$ & 17.9 & $<$ & 17.9 & & $<$ & 16.5 & $\cdots$ & $100 \%$ \\
\hline Organics, Semi-volatile & Dibutylphthalate & SW 8270 & $\mathbf{n g} / \mathbf{g}$ & $<$ & 16.5 & $<$ & 10.8 & $<$ & 10.8 & & $<$ & 12.7 & $\cdots$ & $100 \%$ \\
\hline Organics, Semi-volatile & Dlethylphthalate & SW 8270 & $n g / g$ & $<$ & 11.2 & $<$ & 17.1 & $<$ & 17.1 & & $<$ & 15.1 & $\cdots$ & $100 \%$ \\
\hline Organics, Semi-volatile & Dimethylphenethylamine & SW 8270 & $n g / g$ & $<$ & 120.0 & $<$ & 120.0 & $<$ & 120.0 & & $<$ & 120 & -- & $100 \%$ \\
\hline Organics, Semi-volatile & Dimethylphthalate & SW 8270 & $\mathrm{ng} / \mathrm{g}$ & $<$ & 9.4 & $<$ & 11.2 & $<$ & 11.2 & & $<$ & 10.6 & $\cdots$ & $100 \%$ \\
\hline Organics, Semi-volatile & Diphenylamine & SW 8270 & $\mathrm{ng} / \mathrm{g}$ & $<$ & 17.6 & $<$ & 9.22 & $<$ & 9.22 & & $<$ & 12.0 & $\cdots$ & $100 \%$ \\
\hline Organics, Semi-volatile & Ethyl methanesulfonate & SW 8270 & $\mathrm{ng} / \mathrm{g}$ & $<$ & 16.8 & $\leq$ & 22.6 & $<$ & 22.6 & & $<$ & 20.7 & $\cdots$ & $100 \%$ \\
\hline Organics, Semi-volatile & Fluoranthene & SW 8270 & $n g / g$ & $<$ & 21.3 & $<$ & 15.7 & $<$ & 15.7 & & $<$ & 17.6 & $\cdots$ & $100 \%$ \\
\hline Organics, Semi-volatile & Fluorene & SW 8270 & $\mathbf{n g} / \mathbf{g}$ & $<$ & 11.2 & $<$ & 12.7 & $<$ & 12.7 & & $<$ & 12.2 & $\cdots$ & $100 \%$ \\
\hline Organics, Semi-volatile & Hexachlorobenzene & SW 8270 & $\mathbf{n g} / \mathbf{g}$ & $<$ & 7.82 & $<$ & 10.5 & $<$ & 10.5 & & $<$ & 9.6 & -- & $100 \%$ \\
\hline Organics, Semi-volatile & Hexachlorobutadiene & SW 8270 & ng/g & $<$ & 23.3 & $<$ & 17.0 & $<$ & 17.0 & & $<$ & 19.1 & -- & $100 \%$ \\
\hline Organics, Seml-volatile & Hexachlorocyclopentadiene & SW 8270 & $\mathrm{ng} / \mathrm{g}$ & $<$ & 298 & $<$ & 196 & $<$ & 196 & & $<$ & 230 & -- & $100 \%$ \\
\hline Organics, Semi-volatile & Hexachloroethane & SW 8270 & ng/g & $<$ & 19.8 & $<$ & 21.1 & $<$ & 21.1 & & $<$ & 20.7 & - & $100 \%$ \\
\hline Organics, Semi-volatile & Indeno(1,2,3-cd)pyrene & SW 8270 & $\mathbf{n g} / \mathbf{g}$ & $<$ & 17.5 & $<$ & 44.3 & $<$ & 44.3 & & $<$ & 35.4 & $\cdots$ & $100 \%$ \\
\hline Organics, Semi-volatile & Isophorone & SW 8270 & $\mathrm{ng} / \mathrm{g}$ & $<$ & 9.58 & $<$ & 20.5 & $<$ & 20.5 & & $<$ & 16.9 & $\cdots$ & $100 \%$ \\
\hline Organics, Semi-volatile & Methyl methanesulfonate & SW 8270 & $\mathrm{ng} / \mathrm{g}$ & $<$ & 50.0 & $<$ & 50.0 & $<$ & 50.0 & & $<$ & 50.0 & $\cdots$ & $100 \%$ \\
\hline Organics, Semi-volatile & N-Nitroso-di-n-butylamine & SW 8270 & $\mathrm{ng} / \mathrm{g}$ & $<$ & 43.8 & $<$ & 20.9 & $<$ & 20.9 & & $<$ & 28.5 & $\cdots$ & $100 \%$ \\
\hline Organics, Semi-volatile & N-Nitrosodimethylamine & SW 8270 & $\mathrm{ng} / \mathrm{g}$ & $<$ & 44.4 & $<$ & 26.2 & $<$ & 26.2 & & $<$ & 32.3 & -- & $100 \%$ \\
\hline Organics, Semi-volatlle & N-Nitrosodiphenylamine & SW 8270 & $\mathrm{ng} / \mathrm{g}$ & $<$ & 18.9 & $<$ & 8.96 & $<$ & 8.96 & & $<$ & 12.3 & $\cdots$ & $100 \%$ \\
\hline Organics, Semi-volatile & N-Nitrosodipropylamine & SW 8270 & ng/g & $<$ & 25.1 & $<$ & 21.8 & $<$ & 21.8 & & $<$ & 22.9 & $\cdots$ & $100 \%$ \\
\hline Organics, Semi-volatile & N-Nitrosopiperidine & SW 8270 & $n g / g$ & $<$ & 31.5 & $<$ & 19.9 & $<$ & 19.9 & & $<$ & 23.8 & -- & $100 \%$ \\
\hline Organics, Semi-volatile & Naphthalene & SW 8270 & $\mathrm{ng} / \mathrm{g}$ & $<$ & 24.3 & $<$ & 15.9 & $<$ & 15.9 & & $<$ & 18.7 & $\cdots$ & $100 \%$ \\
\hline Organics, Semi-volattle & Nitrobenzene & SW 8270 & $\mathrm{ng} / \mathrm{g}$ & $<$ & 17.6 & $<$ & 28.0 & $<$ & 28.0 & & $<$ & 24.5 & $\therefore$ & $100 \%$ \\
\hline Organics, Semi-volattle & Pentachlorobenzene & SW 8270 & $\mathrm{ng} / \mathrm{g}$ & $<$ & 14.8 & $<$ & 12.5 & $<$ & 12.5 & & $<$ & 13.3 & $\cdots$ & $100 \%$ \\
\hline Organics, Semi-volatile & Pentachloronitrobenzene & SW 8270 & $\mathrm{ng} / \mathrm{g}$ & $<$ & 69.1 & $<$ & 46.0 & $<$ & 46.0 & & $<$ & 53.7 & $\cdots$ & $100 \%$ \\
\hline Organics, Semi-volátile & Pentachlorophenol & SW 8270 & $\mathrm{ng} / \mathrm{g}$ & $<$ & 28.9 & $<$ & 29.6 & $<$ & 29.6 & & $<$ & 29.4 & -- & $100 \%$ \\
\hline Organics, Semi-volatile & Phenacetin & SW 8270 & $\mathrm{ng} / \mathrm{g}$ & $<$ & 18.0 & $<$ & 12.9 & $<$ & 12.9 & & $<$ & 14.6 & $\cdots$ & $100 \%$ \\
\hline Organics, Semi-volatlle & Phenanthrene & SW 8270 & $n g / g$ & $<$ & 20.8 & $<$ & 15.6 & $<$ & 15.6 & & $<$ & 17.3 & -. & $100 \%$ \\
\hline
\end{tabular}

ESP Hopper Ash (Field 2) - Page 4 


\section{Solid Stream Data}

Sample Stream: ESP Hopper Ash-Field 2

\begin{tabular}{|c|c|c|c|c|c|c|c|c|c|c|c|c|c|c|}
\hline $\begin{array}{l}\text { Analyte } \\
\text { Group }\end{array}$ & Specie & $\begin{array}{l}\text { Analytical } \\
\text { Method }\end{array}$ & Units & & $\begin{array}{c}\text { Run } \\
1\end{array}$ & & $\begin{array}{c}\text { Run } \\
2\end{array}$ & & $\begin{array}{c}\text { Run } \\
3\end{array}$ & $\begin{array}{c}\text { Run } \\
\text { 3d }\end{array}$ & & Average & $\begin{array}{c}95 \% \\
\mathrm{Cl}\end{array}$ & $\begin{array}{c}\text { DL } \\
\text { Ratio }\end{array}$ \\
\hline Organics, Semi-volatile & Phenol & SW 8270 & $\mathrm{ng} / \mathrm{g}$ & $<$ & 13.3 & $<$ & 29.4 & $<$ & 29.4 & & $<$ & 24.0 & -- & $100 \%$ \\
\hline Organics, Semi-volatile & Pronamide & SW 8270 & $\mathrm{ng} / \mathrm{g}$ & $<$ & 24.7 & $<$ & 8.0 & $<$ & 8.0 & & $<$ & 13.6 & -- & $100 \%$ \\
\hline Organics, Semi-volatile & Pyrene & SW 8270 & $\mathrm{ng} / \mathrm{g}$ & $<$ & 15.6 & $<$ & 13.6 & $<$ & 13.6 & & $<$ & 14.3 & -- & $100 \%$ \\
\hline Organics, Semi-volatile & Pyridine & SW 8270 & $\mathrm{ng} / \mathrm{g}$ & $<$ & 38.7 & $<$ & 19.6 & $<$ & 19.6 & & $<$ & 26.0 & -. & $100 \%$ \\
\hline Organics, Semi-volatile & bis(2-Chloroethoxy)methane & SW 8270 & $\mathrm{ng} / \mathrm{g}$ & $<$ & 18.8 & $<$ & 20.2 & $<$ & 20.2 & & $<$ & 19.7 & - & $100 \%$ \\
\hline Organics, Semi-volatile & b/s(2-Chloroethy)ether & SW 8270 & $\mathrm{ng} / \mathrm{g}$ & $<$ & 24.4 & $<$ & 12.8 & $<$ & 12.8 & & $<$ & 16.7 & $\ldots$ & $100 \%$ \\
\hline Organics, Semi-volatile & bis(2-Chloroisopropyl)ether & SW 8270 & $\mathrm{ng} / \mathrm{g}$ & $<$ & 24.2 & $<$ & 26.6 & $<$ & 26.6 & & $<$ & 25.8 & - & $100 \%$ \\
\hline Organics, Semi-volatile & bis(2-Ethylhexyl)phthalate & sW 8270 & $\mathrm{ng} / \mathrm{g}$ & & 467 & & 120 & $<$ & 19.3 & & & 199 & 593 & $2 \%$ \\
\hline Organics, Semi-volatile & p-Chloroanillne & SW 8270 & $\mathrm{ng} / \mathrm{g}$ & $<$ & 18.7 & $<$ & 24.8 & $<$ & 24.8 & & $<$ & 22.8 & - & $100 \%$ \\
\hline Organics, Semi-volatile & p-Dlmethylaminoazobenzene & SW 8270 & $\mathrm{ng} / \mathrm{g}$ & $<$ & 17.2 & $<$ & 24.2 & $<$ & 24.2 & & $<$ & 21.9 & $\ldots$ & $100 \%$ \\
\hline
\end{tabular}




\section{Solid Stream Data}

Sample Stream: Raw Limestone

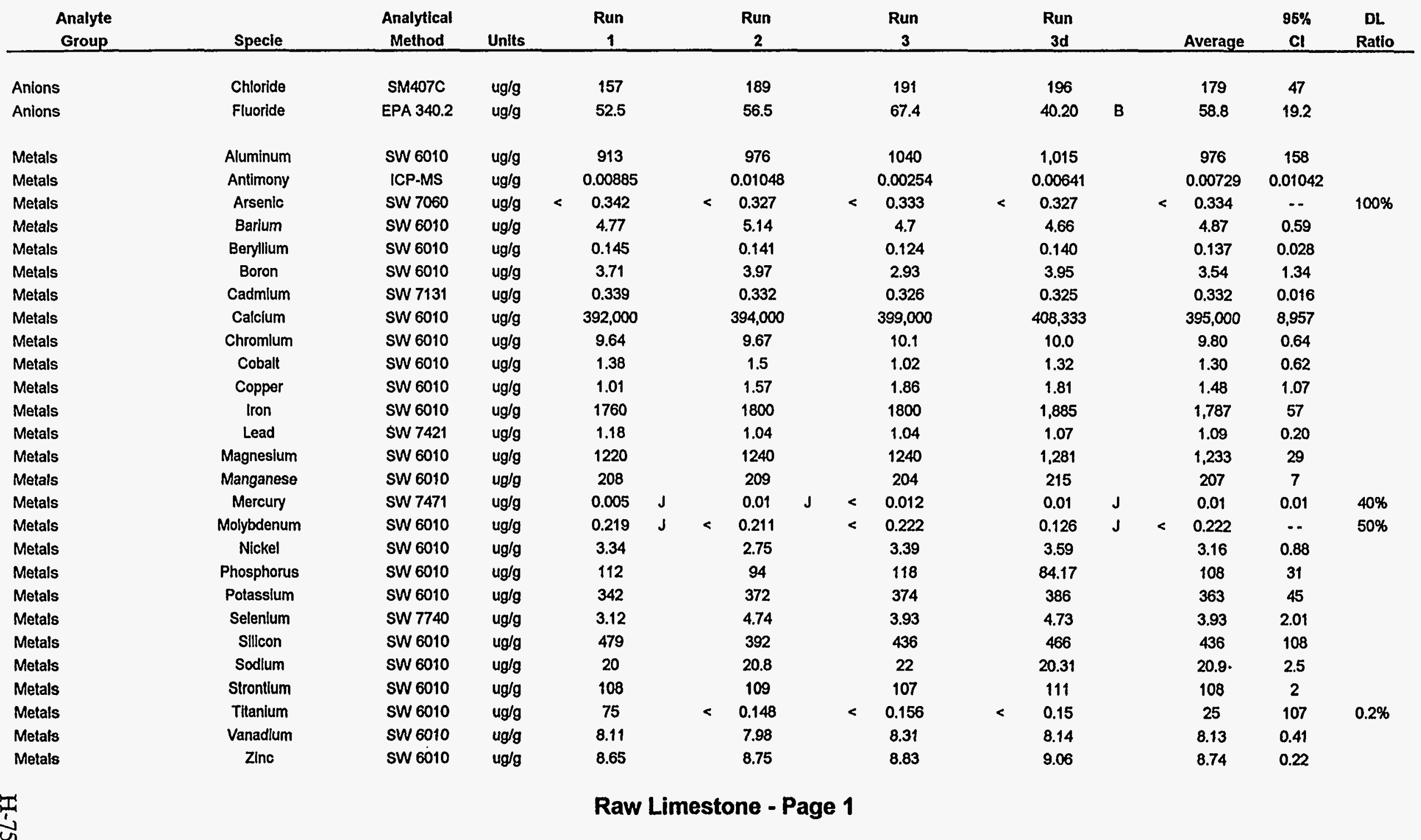




\section{Solid Stream Data}

Sample Stream: Raw Limestone

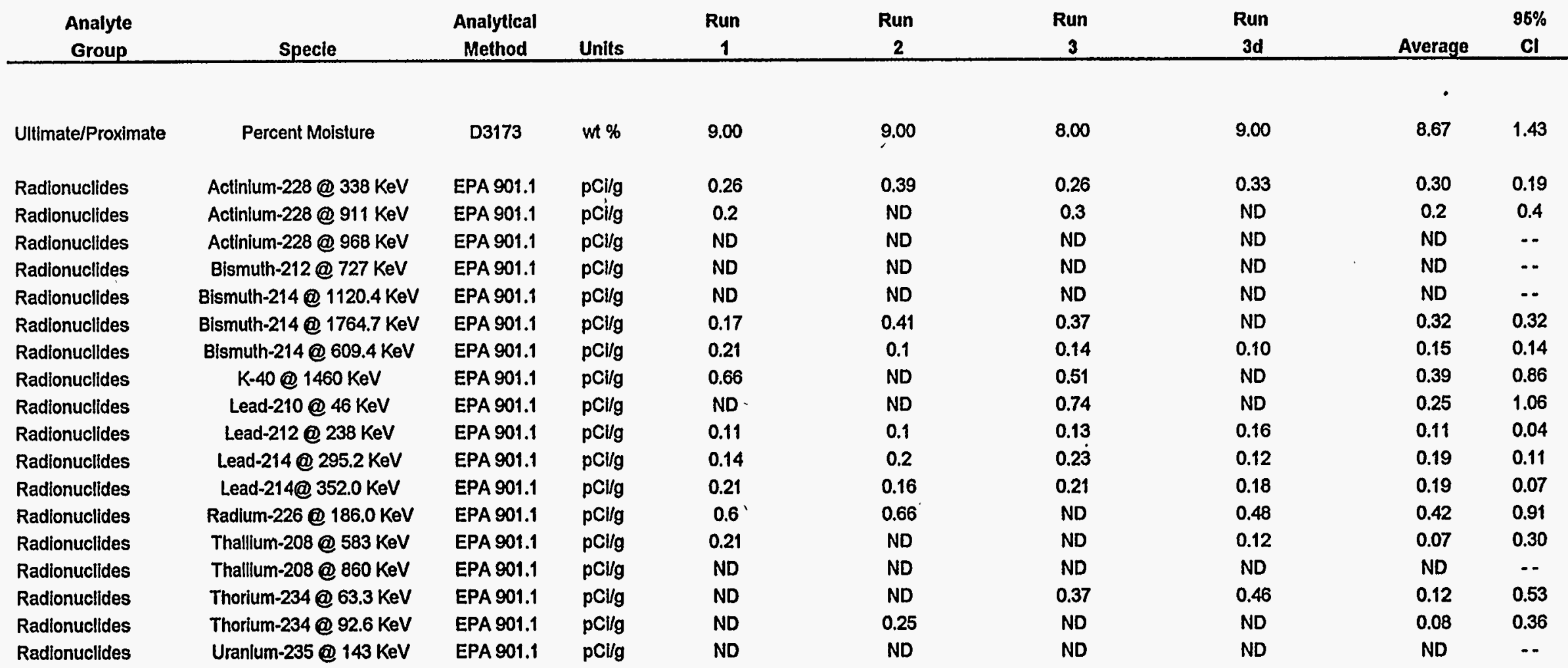

ND= Not Detected, (no detection limit specified)

Raw Limestone - Page 2 


\section{Solid Stream Data}

Sample Stream: Limestone Slurry Solids

\begin{tabular}{|c|c|c|c|c|c|c|c|c|c|c|c|c|c|c|c|c|c|}
\hline $\begin{array}{c}\text { Analyte } \\
\text { Group }\end{array}$ & Specie & $\begin{array}{c}\text { Analytical } \\
\text { Method }\end{array}$ & Units & & $\begin{array}{c}\text { Run } \\
1 \\
\end{array}$ & & & $\begin{array}{c}\text { Run } \\
2 \\
\end{array}$ & & $\begin{array}{c}\text { Run } \\
3 \\
\end{array}$ & & & $\begin{array}{c}\text { Run } \\
3 d\end{array}$ & & Average & $\begin{array}{c}95 \% \\
\mathrm{Cl} \\
\end{array}$ & $\begin{array}{c}\text { DL } \\
\text { Ratio }\end{array}$ \\
\hline Anions & Chloride & SM407C & ug/g & & 5,270 & & & 3,950 & & 2,950 & & & 5,590 & & 4,057 & 2891 & \\
\hline Anions & Fluoride & EPA 340.2 & $u g / g$ & & 99.50 & & & 64.10 & & 92.00 & & & 98.00 & & 85.20 & 46.34 & \\
\hline Metals & Aluminum & SW 6010 & $u g / g$ & & 814 & & & 609 & & 845 & & & 865 & & 756 & 318 & \\
\hline Metals & Antimony & SW 6010 & $u g / g$ & & 0.020 & & & 0.020 & & 0.018 & & & 0.014 & & 0.019 & 0.003 & \\
\hline Metals & Arsenic & SW 7060 & $u g / g$ & $<$ & 0.34 & & $<$ & 0.32 & $<$ & 0.34 & & $<$ & 0.36 & $<$ & 0.33 & - & $100 \%$ \\
\hline Metals & Barium & SW 6010 & ug/g & & 5.67 & & & 5.15 & & 5.33 & & & 5.22 & & 5.39 & 0.66 & \\
\hline Metals & Beryllium & SW 6010 & ug/g & & 0.15 & & & 0.13 & & 0.15 & & & 0.14 & & 0.14 & 0.02 & \\
\hline Metals & Boron & SW 6010 & $u g / g$ & & 241 & & & 194 & & 172 & & & 258 & & 202 & 88 & \\
\hline Metals & Cadmium & SW 7131 & $u g / g$ & & 0.61 & & & 0.59 & & 0.62 & & & 0.63 & & 0.61 & 0.04 & \\
\hline Metals & Calcium & SW 6010 & $u g / g$ & & 382,490 & & & 404,082 & & 390,244 & & & 377,174 & & 392,272 & 27,173 & \\
\hline Metals & Chromium & SW 6010 & $u g / g$ & & 13.39 & & & 12.45 & & 14.30 & & & 13.70 & & 13.38 & 2.30 & \\
\hline Metals & Cobalt & SW 6010 & ug/g & & 1.72 & & & 1.38 & & 1.35 & & & 1.52 & & 1.48 & 0.51 & \\
\hline Metals & Copper & SW 6010 & $u g / g$ & & 3.75 & & & 3.50 & & 3.88 & & & 3.62 & & 3.71 & 0.48 & \\
\hline Metals & Iron & SW 6010 & $u g / g$ & & 2,571 & & & 2,214 & & 2,738 & & & 2,620 & & 2,508 & 665 & \\
\hline Metals & Lead & SW 7421 & ug/g & & 0.96 & & & 0.94 & & 1.03 & & & 1.09 & & 0.98 & 0.11 & \\
\hline Metals & Magneslum & SW 6010 & $u g / g$ & & 1,456 & & & 1,306 & & 1,397 & & & 1,457 & & 1,386 & 187 & \\
\hline Metals & Manganese & SW 6010 & $u g / g$ & & 424 & & & 419 & & 445 & & & 417 & & 429 & 33 & \\
\hline Metals & Mercury & SW 7471 & ug/g & & 0.01 & $\mathbf{J}$ & $<$ & 0.01 & & 0.01 & J & & 0.01 & $<$ & 0.01 & $-\cdot$ & $29 \%$ \\
\hline Metals & Molybdenum & SW 6010 & ug/g & & 0.24 & & & 0.38 & & 0.06 & $J$ & $<$ & 0.22 & & 0.23 & 0.40 & \\
\hline Metals & Nickel & SW 6010 & ug/g & & 3.88 & & & 3.09 & & 5.12 & & & 3.63 & & 4.03 & 2.54 & \\
\hline Metals & Phosphorus & SW 6010 & $u g / g$ & & 106 & & & 110 & & 114 & & & 111 & & 110 & 10 & \\
\hline Metals & Potassium & SW 6010 & $\mathrm{ug} / \mathrm{g}$ & & 355 & & & 298 & & 360 & & & 350 & & 338 & 86 & \\
\hline Metals & Selenium & SW 7740 & $u g / g$ & & 8.11 & & & 7.46 & & 9.63 & & & 10.67 & & 8.40 & 2.77 & \\
\hline Metals & Silicon & SW 6010 & $\mathrm{ug} / \mathrm{g}$ & & 398 & & & 263 & & 435 & & & 491 & & 365 & 224 & \\
\hline Metals & Sodlum & SW 6010 & ug/g & & 62.37 & & & 55.20 & & 47.12 & & & 61.52 & & 54.90 & 18.95 & \\
\hline Metals & Strontium & SW 6010 & $u g / g$ & & 113 & & & 109 & & 113 & & & 110 & & 112 & 5.29 & \\
\hline Metals & Titanium & SW 6010 & $\mathrm{ug} / \mathrm{g}$ & $<$ & 0.17 & & $<$ & 0.16 & $<$ & 0.16 & & $<$ & 0.16 & $<$ & 0.16 & $-\cdot$ & $100 \%$ \\
\hline Metals & Vanadium & SW 6010 & ug/g & & 7.83 & & & 4.72 & & 7.63 & & & 7.65 & & 6.73 & 4.32 & \\
\hline Metals & Zinc & SW 6010 & $\mathrm{ug} / \mathrm{g}$ & & 10.04 & & & 8.82 & & 10.51 & & & 9.95 & & 9.79 & 2.17 & \\
\hline
\end{tabular}

Limestone Slurry Solids - Page 1 


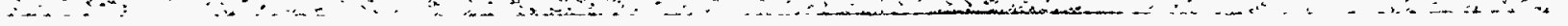




\section{Solid Stream Data}

Sample Stream: JBR Underflow Slurry Solids

\begin{tabular}{|c|c|c|c|c|c|c|c|c|c|c|c|c|}
\hline $\begin{array}{l}\text { Analyte } \\
\text { Group }\end{array}$ & Specie & $\begin{array}{c}\text { Analytical } \\
\text { Method }\end{array}$ & Units & & $\begin{array}{c}\text { Run } \\
1\end{array}$ & $\begin{array}{c}\text { Run } \\
2 \\
\end{array}$ & $\begin{array}{c}\text { Run } \\
3 \\
\end{array}$ & $\begin{array}{c}\text { Run } \\
3 d\end{array}$ & & Average & $\begin{array}{c}95 \% \\
\mathrm{Cl}\end{array}$ & $\begin{array}{c}\text { DL } \\
\text { Ratlo }\end{array}$ \\
\hline Anions & Chloride & SM407C & ug/g & & 9,310 & 9,470 & 9,870 & 9,840 & & 9,550 & 717 & \\
\hline Anions & Fluoride & EPA 340.2 & $u g / g$ & & 684 & 777 & 789 & 594 & & 750 & 143 & \\
\hline Anions & Sulfate & EPA 300.0 & ug/g & & 500,000 & 493,000 & 496,000 & 495,000 & & 496,333 & 8,725 & \\
\hline Anions & Sulfite & EPRI-FGD-M2 & $\mathrm{ug} / \mathrm{g}$ & $<$ & 240 & 240 & 240 & 240 & $<$ & 240 & $\cdots$ & $100 \%$ \\
\hline Metals & Aluminum & SW 6010 & $u g / g$ & & 1,031 & 1,184 & 1,081 & 1,064 & & 1,099 & 194 & \\
\hline Metals & Antimony & ICP-MS & $u g / g$ & & 0.067 & 0.086 & 0.066 & 0.073 & & 0.073 & 0.028 & \\
\hline Metals & Arsenic & SW 7060 & $u g / g$ & $<$ & 0.40 & 0.47 & 0.36 & 0.39 & $<$ & 0.41 & - & $100 \%$ \\
\hline Metals & Barium & SW 6010 & $\mathrm{ug} / \mathrm{g}$ & & 3.61 & 4.35 & 4.09 & 4.08 & & 4.02 & 0.94 & \\
\hline Metals & Beryllium & sW 6010 & $u g / g$ & & 0.10 & 0.16 & 0.13 & 0.19 & & 0.13 & 0.07 & \\
\hline Metals & Boron & SW 6010 & $u g / g$ & & 417 & 445 & 413 & 422 & & 425 & 43 & \\
\hline Metals & Cadmium & SW 7131 & $\mathrm{ug} / \mathrm{g}$ & & 0.26 & 0.24 & 0.24 & 0.23 & & 0.25 & 0.04 & \\
\hline Metals & Calcium & SW 6010 & $u g / g$ & & 260,714 & 256,627 & 248,786 & 231,317 & & 255,376 & 15,059 & \\
\hline Metals & Chromium & SW 6010 & $\mathrm{ug} / \mathrm{g}$ & & 10.39 & 12.41 & 11.10 & 11.07 & & 11.30 & 2.54 & \\
\hline Metals & Cobalt & SW 6010 & $u g / g$ & & 0.90 & 1.19 & 0.87 & 1.23 & & 0.99 & 0.43 & \\
\hline Metals & Copper & SW 6010 & $u g / g$ & & 2.48 & 3.10 & 2.61 & 2.70 & & 2.73 & 0.81 & \\
\hline Metals & Iron & SW 6010 & $u g / g$ & & 2,060 & 2,349 & 2,148 & 2,112 & & 2,186 & 369 & \\
\hline Metals & Lead & SW 7421 & $\mathrm{ug} / \mathrm{g}$ & & 0.86 & 0.91 & 0.75 & 0.87 & & 0.84 & 0.21 & \\
\hline Metals & Magnesium & SW 6010 & $\mathrm{ug} / \mathrm{g}$ & & 785 & 860 & 795 & 796 & & 813 & 102 & \\
\hline Metals & Manganese & SW 6010 & $u g / g$ & & 100 & 108 & 100 & 101 & & 103 & 11.08 & \\
\hline Metals & Mercury & SW 7471 & $\mathrm{ug} / \mathrm{g}$ & & 0.19 & 0.15 & 0.19 & 0.16 & & 0.18 & 0.06 & \\
\hline Metals & Molybdenum & SW 6010 & $u g / g$ & & 1.23 & 1.65 & 1.58 & 1.21 & & 1.48 & 0.56 & \\
\hline Metals & Nickel & SW 6010 & $u g / g$ & & 2.32 & 3.36 & 2.79 & 2.70 & & 2.82 & 1.29 & \\
\hline Metals & Phosphorus & SW 6010 & $u g / g$ & & 74.76 & 92.17 & 96.48 & 74.26 & & 87.80 & 28.57 & \\
\hline Metals & Potassium & SW 6010 & ug/g & & 238 & 370 & 312 & 319 & & 307 & 164 & \\
\hline Metals & Selenium & SW 7740 & ug/g & & 25.71 & 25.90 & 25.00 & 20.40 & & 25.54 & 1.18 & \\
\hline Metals & Sillcon & SW 6010 & $u g / g$ & & 469 & 458 & 414 & 447 & & 447 & 72.50 & \\
\hline Metals & Sodium & SW 6010 & $u g / g$ & & 82.62 & 87.71 & 82.04 & 89.21 & & 84.12 & 7.75 & \\
\hline Metals & Strontium & SW 6010 & $u g / g$ & & 73.21 & 76.99 & 71.12 & 72.60 & & 73.77 & 7.39 & \\
\hline Metals & Titanium & SW 6010 & ug/g & & 20.12 & 24.10 & 18.57 & 23.37 & & 20.93 & 7.08 & \\
\hline Metals & Vanadium & SW 6010 & $u g / g$ & & 9.01 & 10.73 & 9.82 & 8.90 & & 9.85 & 2.14 & \\
\hline Metals & Zinc & SW 6010 & $\mathrm{ug} / \mathrm{g}$ & & 7.86 & 8.90 & 8.33 & 9.99 & & 8.36 & 1.30 & \\
\hline
\end{tabular}




\section{Solid Stream Data}

Sample Stream: JBR Underflow Slurry Solids

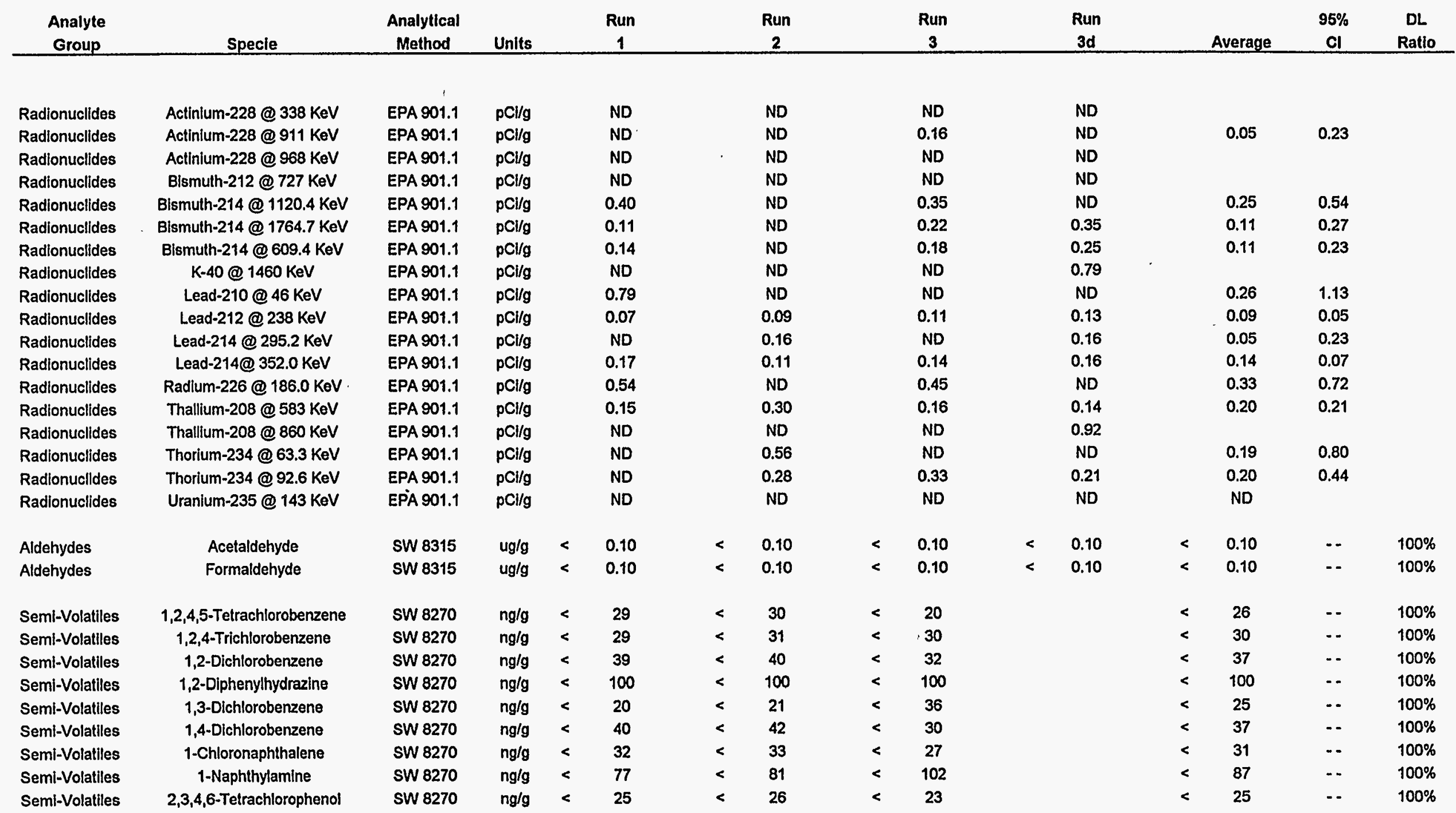

JBR Underflow Slurry Solids - Page 2 


\section{Solid Stream Data}

Sample Stream: JBR Underflow Slurry Solids

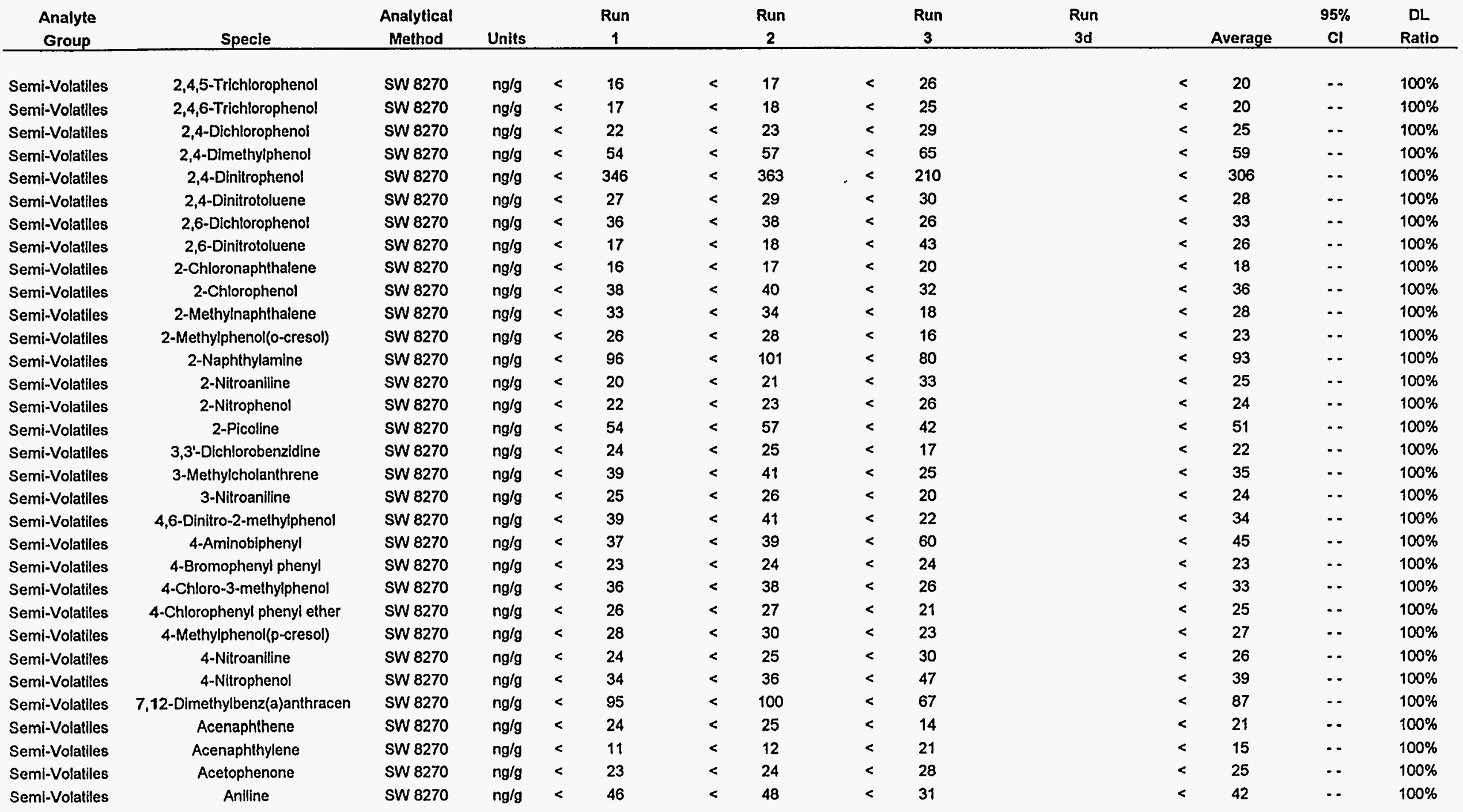


Sample Stream: JaR Underflow Slurry Solids

\begin{tabular}{|c|c|c|c|c|c|c|c|c|c|c|c|c|c|c|c|}
\hline $\begin{array}{c}\text { Analyte } \\
\text { Group }\end{array}$ & Specie & $\begin{array}{l}\text { Analytical } \\
\text { Method }\end{array}$ & Units & & $\begin{array}{c}\text { Run } \\
1 \\
\end{array}$ & & $\begin{array}{c}\text { Run } \\
2 \\
\end{array}$ & & & $\begin{array}{c}\text { Run } \\
3 \\
\end{array}$ & $\begin{array}{c}\text { Run } \\
3 d\end{array}$ & & Average & $\begin{array}{c}95 \% \\
\mathrm{Cl} \\
\end{array}$ & $\begin{array}{c}\text { DL. } \\
\text { Ratio }\end{array}$ \\
\hline Semi-Volatiles & Anthracene & SW 8270 & $\mathbf{n g} / \mathbf{g}$ & $<$ & 29 & $<$ & 30 & & $<$ & 19 & & $<$ & 26 & - & $100 \%$ \\
\hline Semi-Volatiles & Benzidine & SW 8270 & $n g / g$ & $<$ & 20 & $<$ & 20 & 1 & $<$ & 20 & & $<$ & 20 & $\cdots$ & $100 \%$ \\
\hline Semi-Volatiles & Benzo(a)anthracene & SW 8270 & $\mathrm{ng} / \mathrm{g}$ & $<$ & 26 & $<$ & 27 & & $<$ & 23 & & $<$ & 25 & $\cdots$ & $100 \%$ \\
\hline Semi-Volatiles & Benzo(a)pyrene & SW 8270 & $\mathrm{ng} / \mathrm{g}$ & $<$ & 19 & $<$ & 20 & & $<$ & 26 & & $<$ & 22 & $\cdots$ & $100 \%$ \\
\hline Semi-Volatiles & Benzo(b)fiuoranthene & SW 8270 & $\mathrm{ng} / \mathrm{g}$ & $<$ & 28 & $<$ & 30 & & $<$ & 46 & & $<$ & 34 & $\cdots$ & $100 \%$ \\
\hline Semi-Volatiles & Benzo $(g, h, l)$ perylene & SW 8270 & $\mathrm{ng} / \mathrm{g}$ & $<$ & 24 & $<$ & 25 & & $<$ & 51 & & $<$ & 34 & -. & $100 \%$ \\
\hline Semi-Volatiles & Benzoic acid & SW 8270 & $\mathrm{ng} / \mathrm{g}$ & $<$ & 196 & $<$ & 205 & & $<$ & 1,940 & & $<$ & 780 & .. & $100 \%$ \\
\hline Semi-Volatiles & Benzyl alcohol & SW 8270 & $\mathrm{ng} / \mathrm{g}$ & $<$ & 53 & $<$ & 56 & & $<$ & 31 & & $<$ & 47 & -. & $100 \%$ \\
\hline Semi-Volatiles & Butylbenzy/phthalate & SW 8270 & $\mathrm{ng} / \mathrm{g}$ & $<$ & 19 & $<$ & 20 & & $<$ & 31 & & $<$ & 24 & -. & $100 \%$ \\
\hline Semi-Volallles & Chrysene & SW 8270 & $\mathrm{ng} / \mathrm{g}$ & $<$ & 33 & $<$ & 35 & & $<$ & 27 & & $<$ & 32 & -. & $100 \%$ \\
\hline Semi-Volatiles & Di-n-octylphthalate & SW 8270 & $\mathrm{ng} / \mathrm{g}$ & $<$ & 45 & $<$ & 47 & & $<$ & 18 & & $<$ & 37 & -. & $100 \%$ \\
\hline Semi-Volatiles & Dibenz $(a, h)$ anthracene & SW 8270 & $\mathrm{ng} / \mathrm{g}$ & $<$ & 23 & $<$ & 25 & & $<$ & 41 & & $<$ & 30 & $\cdots$ & $100 \%$ \\
\hline Semi-Volatiles & Dibenz $(a, j)$ acridine & SW 8270 & $\mathrm{ng} / \mathrm{g}$ & $<$ & 29 & $<$ & 30 & & $<$ & 42 & & $<$ & 34 & $\cdots$ & $100 \%$ \\
\hline Semi-Volatiles & Dibenzofuran & SW 8270 & $\mathrm{ng} / \mathrm{g}$ & $<$ & 20 & $<$ & 21 & & $<$ & 27 & & $<$ & 23 & -. & $100 \%$ \\
\hline Semi-Volatiles & Dlethylphthalate & SW 8270 & $\mathrm{ng} / \mathrm{g}$ & $<$ & 17 & $<$ & 17 & & $<$ & 26 & & $<$ & 20 & - & $100 \%$ \\
\hline Semi-Volatlles & Dimethylphenethylamine & SW 8270 & $\mathrm{ng} / \mathrm{g}$ & $<$ & 120 & $<$ & 120 & & $<$ & 120 & & $<$ & 120 & $\cdots$ & $100 \%$ \\
\hline Semi-Volatiles & Dimethyiphthalate & SW 8270 & $\mathrm{ng} / \mathrm{g}$ & $<$ & 14 & $<$ & 15 & & $<$ & 17 & & $<$ & 15 & -. & $100 \%$ \\
\hline Semi-Volatiles & Diphenylamine & SW 8270 & $\mathrm{ng} / \mathrm{g}$ & $<$ & 26 & $<$ & 27 & & $<$ & 14 & & $<$ & 22 & -. & $100 \%$ \\
\hline Semi-Volatiles & Ethyl methanesulfonate & SW 8270 & $\mathrm{ng} / \mathrm{g}$ & $<$ & 25 & $<$ & 26 & & $<$ & 34 & & $<$ & 28 & $\cdots$ & $100 \%$ \\
\hline Semi-Volatiles & Fluoranthene & SW 8270 & $\mathrm{ng} / \mathrm{g}$ & $<$ & 32 & $<$ & 33 & & $<$ & 24 & & $<$ & 29 & .. & $100 \%$ \\
\hline Semi-Volatiles & Fluorene & SW 8270 & $\mathrm{ng} / \mathrm{g}$ & $<$ & 17 & $<$ & 17 & & $<$ & 19 & & $<$ & 18 & $\cdots$ & $100 \%$ \\
\hline Semi-Volatiles & Hexachlorobenzene & SW 8270 & $\mathrm{ng} / \mathrm{g}$ & $<$ & 12 & $<$ & 12 & & $<$ & 16 & & $<$ & 13 & .. & $100 \%$ \\
\hline Semi-Volatiles & Hexachlorobuladiene & sW 8270 & $\mathrm{ng} / \mathrm{g}$ & $<$ & 35 & $<$ & 36 & & $<$ & 26 & & $<$ & 32 & $\ldots$ & $100 \%$ \\
\hline Semi-Volatiles & Hexachlorocyclopentadiene & SW 8270 & $\mathrm{ng} / \mathrm{g}$ & $<$ & 441 & $<$ & 462 & & $<$ & 296 & & $<$ & 400 & $\cdots$ & $100 \%$ \\
\hline Semi-Volatiles & Hexachloroethane & SW 8270 & $\mathrm{ng} / \mathrm{g}$ & $<$ & 29 & $<$ & 31 & & $<$ & 32 & & $<$ & 31 & .. & $100 \%$ \\
\hline Semi-Volatiles & Indeno(1,2,3-cd)pyrene & sW 8270 & $\mathrm{ng} / \mathrm{g}$ & $<$ & 26 & $<$ & 27 & & $<$ & 67 & & $<$ & 40 & -. & $100 \%$ \\
\hline Semi-Volatiles & Isophorone & SW 8270 & $\mathrm{ng} / \mathrm{g}$ & $<$ & 14 & $<$ & 15 & & $<$ & 31 & & $<$ & 20 & -. & $100 \%$ \\
\hline Semi-Volatiles & Methyl methanesulfonate & SW 8270 & $\mathrm{ng} / \mathrm{g}$ & $<$ & 50 & $<$ & 50 & & $<$ & 50 & & $<$ & 50 & $\cdots$ & $100 \%$ \\
\hline Semi-Volatiles & N-Nitroso-di-n-butylamine & SW 8270 & $\mathrm{ng} / \mathrm{g}$ & $<$ & 65 & $<$ & 68 & & $<$ & 32 & & $<$ & 55 & -. & $100 \%$ \\
\hline Semi-Volatiles & N-Nitrosodimelhylamine & SW 8270 & $\mathrm{ng} / \mathrm{g}$ & $<$ & 66 & $<$ & 69 & & $<$ & 40 & & $<$ & 58 & -. & $100 \%$ \\
\hline
\end{tabular}

JBR Underflow Slurry Solids - Page 4 
Solid Stream Data

Sample Stream: JBR Underflow Slurry Solids

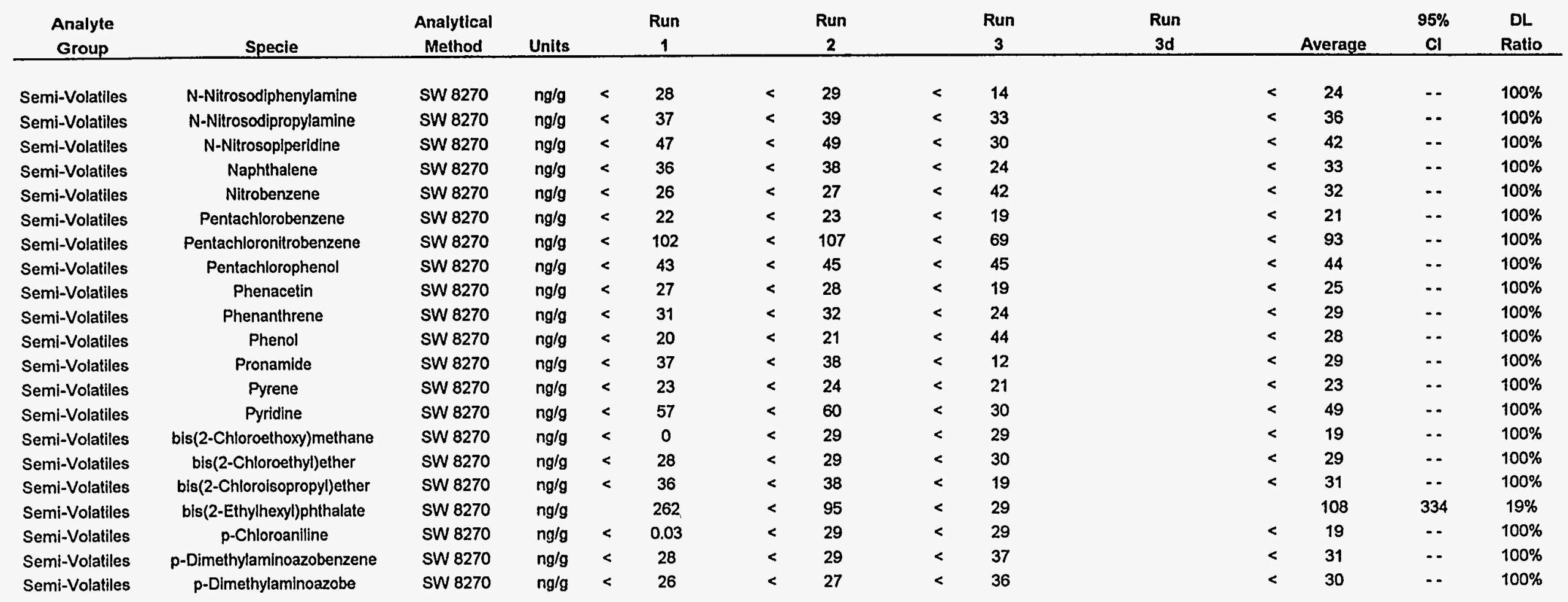

ND $=$ Not Detected, (no detection limit specified). 



\section{Liquid Stream Data Summary}

Sample Stream: Ash Pond Water

\begin{tabular}{|c|c|}
\hline $\begin{array}{l}\text { Analyte } \\
\text { Group }\end{array}$ & Specie \\
\hline Reduced Specles & Cyanide \\
\hline Reduced Species & Ammonia as $\mathrm{N}$ \\
\hline Anions & Chloride \\
\hline Anions & Fluoride \\
\hline Anlons & Phosphate \\
\hline Anions & Sulfate \\
\hline Metals, Soluble & Aluminum \\
\hline Metals, Soluble & Antimony \\
\hline Metals, Soluble & Arsenic \\
\hline Metals, Soluble & Barium \\
\hline Metals, Soluble & Beryllium \\
\hline Metals, Soluble & Boron \\
\hline Metals, Soluble & Cadmlum \\
\hline Metals, Soluble & Calclum \\
\hline Metals, Soluble & Chromium \\
\hline Metals, Soluble & Cobalt \\
\hline Metals, Soluble & Copper \\
\hline Metals, Soluble & Iron \\
\hline Metals, Soluble & Lead \\
\hline Metals, Soluble & Magnesium \\
\hline Metals, Soluble & Manganese \\
\hline Metals, Soluble & Mercury \\
\hline Metals, Soluble & Molybdenum \\
\hline Metals, Soluble & Nickel \\
\hline Metals, Soluble & Phosphorus \\
\hline Metals, Soluble & Potasslum \\
\hline Metals, Soluble & Selenium \\
\hline Metals, Soluble & Sillicon \\
\hline Metals, Soluble & Sodlum \\
\hline Metals, Soluble & Strontium \\
\hline
\end{tabular}

Tin

\begin{tabular}{|c|c|}
\hline $\begin{array}{l}\text { Analytical } \\
\text { Method }\end{array}$ & \\
\hline SW 9012 & \\
\hline EPA 350.1 & \\
\hline EPA 300 & \\
\hline EPA 340.2 & \\
\hline EPA 365.2 & \\
\hline EPA 300.0 & \\
\hline SW 6010 & \\
\hline SW 6010 & \\
\hline SW 7060 & \\
\hline SW 6010 & \\
\hline SW 6010 & \\
\hline SW 6010 & \\
\hline SW 7131 & \\
\hline SW 6010 & \\
\hline SW 6010 & \\
\hline SW 6010 & \\
\hline SW 6010 & \\
\hline SW 6010 & \\
\hline SW 7421 & \\
\hline SW 6010 & \\
\hline SW 6010 & \\
\hline SW 7470 & \\
\hline SW 6010 & \\
\hline SW 6010 & \\
\hline SW 6010 & \\
\hline SW 6010 & \\
\hline SW 7740 & \\
\hline SW 6010 & \\
\hline SW 6010 & \\
\hline SW 6010 & \\
\hline SW 6010 & \\
\hline
\end{tabular}

I

\begin{tabular}{|c|c|c|c|c|c|c|c|c|c|c|c|c|c|c|}
\hline Run & & & Run & & & Run & & & Run & & & & $95 \%$ & DL \\
\hline 1 & & & 2 & & & $3 a$ & & & $3 d$ & & & Average & Cl & Ratio \\
\hline 0.0024 & $J$ & & 0.0026 & J & & 0.00084 & $J$ & & 0.0015 & $J$ & & 0.0019 & 0.0024 & \\
\hline 0.194 & & & 0.255 & & & 0.164 & & & 0.151 & & & 0.204 & 0.115 & \\
\hline 9.28 & & & 9.37 & & & 7.99 & & & 9 & & & 8.88 & 1.92 & \\
\hline 0.377 & & & 0.461 & & & 0.443 & & & 0.441 & & & 0.427 & 0.110 & \\
\hline 0.02 & & $<$ & 0.002 & & $<$ & 0.02 & & & 0.00176 & J & $<$ & 0.014 & -- & $100 \%$ \\
\hline 108 & & & 115 & & & 117 & & & 120 & & & 113 & 12 & \\
\hline 0.0167 & J & & 0.0172 & $J$ & & 0.00881 & $J$ & & 0.00481 & J & & 0.014 & 0.012 & \\
\hline 0.0241 & & $<$ & 0.0241 & & $<$ & 0.0241 & & $<$ & 0.0241 & & $<$ & 0.024 & $\cdots$ & $100 \%$ \\
\hline 0.000657 & & $<$ & 0.000657 & & $<$ & 0.000657 & & $<$ & 0.000657 & & $<$ & 0.00066 & -- & $100 \%$ \\
\hline 0.147 & & & 0.168 & & & 0.151 & & & 0.15 & & & 0.155 & 0.028 & \\
\hline 0.000554 & & & 0.00058 & & & 0.00005 & $J$ & & 0.00018 & J & $<$ & 0.00055 & -- & $31 \%$ \\
\hline 1.14 & & & 0.97 & & & 1.12 & & & 1.06 & & & 1.08 & 0.23 & \\
\hline 0.0012 & & & 0.00058 & & & 0.00137 & & & 0.00196 & & & 0.0011 & 0.0010 & \\
\hline 31.4 & & & 32.8 & & & 34.2 & & & 33.6 & & & 32.8 & 3.478 & \\
\hline 0.00249 & & $<$ & 0.00249 & & & 0.00218 & $\mathrm{~J}$ & $<$ & 0.00249 & & $<$ & 0.0025 & - - & $53 \%$ \\
\hline 0.0034 & & $<$ & 0.0034 & & & 0.00228 & $J$ & & 0.00164 & J & $<$ & 0.0034 & - & $60 \%$ \\
\hline 0.00364 & $J$ & & 0.00297 & $J$ & & 0.00667 & & & 0.00397 & & & 0.0044 & 0.0049 & \\
\hline 3.76 & & & 5.63 & & & 6.75 & & & 6.67 & & & 5.38 & 3.75 & \\
\hline 0.0115 & & & 0.0035 & & & 0.0098 & & & 0.0132 & & & 0.0083 & 0.010 & \\
\hline 3.06 & & & 3.09 & & & 3.19 & & & 3.15 & & & 3.11 & 0.17 & \\
\hline 0.458 & & & 0.606 & & & 0.603 & & & 0.593 & & & 0.556 & 0.210 & \\
\hline 0.00005 & & & 0.00008 & & & 0.00005 & & & 0.00002 & J & & 0.00006 & 0.00004 & \\
\hline 0.0447 & & & 0.0319 & & & 0.0284 & & & 0.0248 & & & 0.035 & 0.021 & \\
\hline 0.0213 & & & 0.0172 & & & 0.0207 & & & 0.0191 & & & 0.020 & 0.0055 & \\
\hline 0.147 & & $<$ & 0.061 & & & 0.0179 & J & $<$ & 0.061 & & & 0.065 & 0.177 & $16 \%$ \\
\hline 5.29 & & & 5.06 & & & 5.68 & & & 5.38 & & & 5.34 & 0.78 & \\
\hline 0.0003 & $J$ & & 0.002 & & & 0.0033 & & & 0.0016 & & & 0.0019 & 0.0037 & \\
\hline 3.77 & & & 3.34 & & & 3.24 & & & 3.2 & & & 3.45 & 0.70 & \\
\hline 12.7 & & & 12.4 & & & 12.1 & & & 12 & & & 12.4 & 0.7 & \\
\hline 0.334 & & & 0.343 & & & 0.35 & & & 0.346 & & & 0.342 & 0.020 & \\
\hline 0.0144 & & & 0.0028 & J & $<$ & 0.0144 & & $<$ & 0.0144 & & $<$ & 0.014 & - & $84 \%$ \\
\hline
\end{tabular}

Ash Pond Water - Page 1 


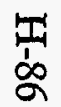

Sample Stream: Ash Pond Water

Analyte

Group

Metals, Soluble

Metals, Soluble

Metals, Soluble

Metals, Total

Metals, Total

Metals, Total

Metals, Total

Metals, Total

Metals, Total

Metals, Total

Metals, Total

Metals, Total

Metals, Total

Metals, Total

Metals, Total

Metals, Total

Metals, Total

Metals, Total

Metals, Total

Metals, Total

Metals, Total

Metals, Tolal

Metals, Tolal

Metals, Total

Metals, Total

Metals, Total

Metals, Total

Metals, Total

Metals, Total

Metals, Total

Metals, Total

Specie
Titanium
Vanadium
Zinc
Aluminum
Antimony
Arsenic
Barium
Beryllum
Boron
Cadmium
Calclum
Chromium
Cobalt
Copper
Iron
Lead
Magneslum
Manganese
Mercury
Molybdenum
Nickel
Phosphorus
Potassium
Selenium
Sillcon
Sodium
Strontium
Tin
Titanium
Vanadlum
Zinc

\begin{tabular}{|c|c|}
\hline $\begin{array}{l}\text { Analytical } \\
\text { Method }\end{array}$ & Units \\
\hline SW 6010 & $\mathrm{ug} / \mathrm{ml}$ \\
\hline SW 6010 & ug/m! \\
\hline SW 6010 & $\mathrm{ug} / \mathrm{ml}$ \\
\hline SW 6010 & $\mathrm{ug} / \mathrm{ml}$ \\
\hline SW 6010 & $\mathrm{ug} / \mathrm{ml}$ \\
\hline SW 7060 & $\mathrm{ug} / \mathrm{ml}$ \\
\hline SW 6010 & $u g / m l$ \\
\hline SW 6010 & $\mathrm{ug} / \mathrm{ml}$ \\
\hline SW 6010 & $\mathrm{ug} / \mathrm{ml}$ \\
\hline SW 7131 & $\mathrm{ug} / \mathrm{ml}$ \\
\hline SW 6010 & $\mathrm{ug} / \mathrm{ml}$ \\
\hline SW 6010 & ugiml \\
\hline SW 6010 & $\mathrm{ug} / \mathrm{ml}$ \\
\hline sw 6010 & $u g / m l$ \\
\hline SW 6010 & $\mathrm{ug} / \mathrm{ml}$ \\
\hline SW 7421 & $u g / m l$ \\
\hline SW 6010 & $\mathrm{ug} / \mathrm{ml}$ \\
\hline SW 6010 & $\mathrm{ug} / \mathrm{ml}$ \\
\hline SW 7470 & ug/ml \\
\hline SW 6010 & $\mathrm{ug} / \mathrm{ml}$ \\
\hline SW 6010 & $\mathrm{ug} / \mathrm{ml}$ \\
\hline SW 6010 & $\mathrm{ug} / \mathrm{ml}$ \\
\hline sW 6010 & $\mathrm{ug} / \mathrm{ml}$ \\
\hline SW 7740 & $\mathrm{ug} / \mathrm{ml}$ \\
\hline SW 6010 & $\mathrm{ug} / \mathrm{ml}$ \\
\hline SW 6010 & $\mathrm{ug} / \mathrm{ml}$ \\
\hline SW 6010 & $\mathrm{ug} / \mathrm{ml}$ \\
\hline SW 6010 & $\mathrm{ug} / \mathrm{ml}$ \\
\hline SW 6010 & $\mathrm{ug} / \mathrm{ml}$ \\
\hline SW 6010 & $\mathrm{ug} / \mathrm{ml}$ \\
\hline SW 6010 & $\mathrm{ug} / \mathrm{ml}$ \\
\hline
\end{tabular}

\section{Liquid Stream Data Summary}

\begin{tabular}{|c|c|c|c|c|c|c|c|c|c|c|c|c|c|}
\hline $\begin{array}{c}\text { Run } \\
1\end{array}$ & & & $\begin{array}{c}\text { Run } \\
2\end{array}$ & & $\begin{array}{c}\text { Run } \\
\text { 3a }\end{array}$ & & & $\begin{array}{c}\text { Run } \\
\text { 3d }\end{array}$ & & & Average & $\begin{array}{c}95 \% \\
\mathrm{Cl}\end{array}$ & $\underset{\text { Ratio }}{\mathrm{DL}}$ \\
\hline 0.00042 & $J$ & $<$ & 0.00236 & & 0.00031 & $\mathbf{J}$ & & 0.00024 & $\mathrm{~J}$ & $<$ & 0.0024 & .. & $62 \%$ \\
\hline 0.00019 & $J$ & & 0.0118 & & 0.00167 & $J$ & & 0.00116 & $\mathbf{J}$ & & 0.0046 & 0.016 & \\
\hline 0.0109 & & & 0.00881 & $\mathbf{J}$ & 0.00995 & & & 0.0102 & & & 0.010 & 0.0026 & \\
\hline 0.0708 & & & 0.355 & & 0.102 & & & 0.123 & & & 0.176 & 0.387 & \\
\hline 0.0146 & $\mathbf{J}$ & & 0.0166 & $J$ & 0.0241 & & & 0.0131 & $\mathbf{J}$ & & 0.018 & 0.012 & \\
\hline 0.0004 & $\mathbf{J}$ & & 0.0004 & $\mathbf{J}$ & 0.0014 & & & 0.0014 & & & 0.00073 & 0.0014 & \\
\hline 0.144 & & & 0.168 & & 0.148 & & & 0.144 & & & 0.153 & 0.032 & \\
\hline 0.00013 & $J$ & & $9 \mathrm{E}-05$ & $J$ & 0.000554 & & $<$ & 0.000554 & & & 0.00026 & 0.000639 & \\
\hline 0.976 & & & 1.02 & & 1.1 & & & 0.996 & & & 1.03 & 0.16 & \\
\hline 0.00079 & & & 0.0036 & & 0.00105 & & & 0.00083 & & & 0.0018 & 0.0039 & \\
\hline 32.6 & & & 34.8 & & 33.8 & 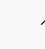 & & 32.7 & & & 33.7 & 2.7 & \\
\hline 0.00111 & $\mathbf{J}$ & & 0.0018 & $J$ & 0.00194 & $J$ & & 0.00175 & $J$ & & 0.0016 & 0.0011 & \\
\hline 0.00674 & & & 0.00622 & & 0.00619 & & & 0.00411 & 、 & & 0.0064 & 0.00077 & \\
\hline 0.00832 & & & 0.00866 & & 0.00493 & & & 0.00869 & & & 0.0073 & 0.0051 & \\
\hline 8.28 & & & 12.6 & & 9.8 & & & 9.71 & & & 10.2 & 5.4 & \\
\hline 0.0008 & & & 0.0435 & & 0.0079 & & & 0.0039 & & & 0.017 & 0.057 & $1 \%$ \\
\hline 3.11 & & & 3.26 & & 3.13 & & & 3.02 & & & 3.17 & 0.20 & \\
\hline 0.487 & & & 0.647 & & 0.531 & & & 0.497 & & & 0.555 & 0.205 & \\
\hline 7E-05 & & & 6E-05 & & $2 E-05$ & $\mathbf{J}$ & & 1E-05 & $\mathbf{J}$ & & 5E-05 & 7E-05 & \\
\hline 0.0761 & & & 0.1 & & 0.0761 & & & 0.0736 & & & 0.084 & 0.034 & \\
\hline 0.0296 & & & 0.0195 & & 0.022 & & & 0.0269 & & & 0.024 & 0.013 & \\
\hline 0.0038 & $\mathbf{J}$ & & 0.0326 & $\mathbf{J}$ & 0.0446 & $\mathbf{J}$ & $<$ & 0.061 & & & 0.027 & 0.052 & \\
\hline 5.87 & & & 5.99 & & 5.36 & & & 5.4 & & & 5.74 & 0.83 & \\
\hline 0.006 & & & 0.0043 & & 0.0041 & & & 0.0042 & & & 0.0048 & 0.0026 & \\
\hline 4.03 & & & 3.58 & & 3.48 & & & 3.34 & & & 3.697 & 0.728 & \\
\hline 13 & & & 13.5 & & 12 & & & 11.7 & & & 12.8 & 1.9 & \\
\hline 0.329 & & & 0.35 & & 0.337 & & & 0.326 & & & 0.339 & 0.026 & \\
\hline 0.0144 & & $<$ & 0.0144 & & 0.0144 & & $<$ & 0.0144 & & $<$ & 0.014 & - & $50 \%$ \\
\hline 0.00024 & $\mathrm{~J}$ & & 0.0008 & $J$ & 0.001 & $\mathbf{J}$ & & 0.00041 & J & & 0.00068 & 0.0010 & \\
\hline 0.0286 & & & 0.0227 & & 0.0202 & & & 0.0239 & & & 0.024 & 0.011 & \\
\hline 0.0128 & & & 0.0124 & & 0.0107 & & & 0.011 & & & 0.012 & 0.0028 & \\
\hline
\end{tabular}

Ash Pond Water - Page 2 


\section{Liquid Stream Data Summary}

Sample Stream: Ash Pond Water

\begin{tabular}{|c|c|c|c|c|c|c|c|}
\hline $\begin{array}{l}\text { Analyte } \\
\text { Group }\end{array}$ & Specie & $\begin{array}{c}\text { Analytical } \\
\text { Method }\end{array}$ & Units & & $\begin{array}{c}\text { Run } \\
1\end{array}$ & & $\begin{array}{c}\text { Run } \\
2\end{array}$ \\
\hline Aldehydes & Acetaldehyde & SW 8315 & $\mathrm{ug} / \mathrm{ml}$ & & 0.006 & & 0.102 \\
\hline Aldehydes & Formaldehyde & SW 8315 & $\mathrm{ug} / \mathrm{ml}$ & & 0.006 & & 0.018 \\
\hline Organics, Seml-volatile & 1,2,4,5-Tetrachlorobenzene & SW 8270 & ug/L & $<$ & 0.561 & $<$ & 0.556 \\
\hline Organics, Semi-volatile & 1,2,4-Trichlorobenzene & SW 8270 & $u g / L$ & $<$ & 0.574 & $<$ & 0.568 \\
\hline Organics, Semi-volatile & 1,2-Dichlorobenzene & SW 8270 & ug/L & $<$ & 0.756 & $<$ & 0.749 \\
\hline Organics, Semi-volatile & 1,2-Diphenylhydrazine & SW 8270 & $u g / L$ & $<$ & 100 & $<$ & 100 \\
\hline Organics, Semi-volatlle & 1,3-Dichlorobenzene & SW 8270 & $u g / L$ & $<$ & 0.384 & $<$ & 0.381 \\
\hline Organics, Semi-volatile & 1,4-Dichlorobenzene & SW 8270 & $\mathrm{ug} / \mathrm{L}$ & $<$ & 0.784 & $<$ & 0.777 \\
\hline Organics, Semi-volatile & 1-Chloronaphthalene & SW 8270 & ug/L & $<$ & 0.625 & $<$ & 0.619 \\
\hline Organics, Semi-volatile & 1-Naphthylamine & SW 8270 & ug/L & $<$ & 1.51 & $<$ & 1.5 \\
\hline Organics, Semi-volatlle & 2,3,4,6-Tetrachlorophenol & SW 8270 & ug/L & $<$ & 0.488 & $<$ & 0.484 \\
\hline Organics, Semi-volatile & 2,4,5-Trichlorophenol & SW 8270 & ug/L & $<$ & 0.32 & $<$ & 0.317 \\
\hline Organics, Semi-volatile & 2,4,6-Trichlorophenol & SW 8270 & ug/L & $<$ & 0.339 & $<$ & 0.336 \\
\hline Organics, Semi-volatile & 2,4-Dichlorophenol & SW 8270 & $\mathrm{ug} / \mathrm{L}$ & $<$ & 0.43 & $<$ & 0.426 \\
\hline Organics, Semi-volatile & 2,4-Dimethylphenol & SW 8270 & $\mathrm{ug} / \mathrm{L}$ & $<$ & 1.07 & $<$ & 1.06 \\
\hline Organics, Semi-volatile & 2,4-Dinitrophenol & SW 8270 & $\mathrm{ug} / \mathrm{L}$ & $<$ & 6.8 & $<$ & 6.73 \\
\hline Organics, Semi-volatile & 2,4-Dinitrotoluene & SW 8270 & $\mathrm{ug} / \mathrm{L}$ & $<$ & 0.534 & $<$ & 0.529 \\
\hline Organics, Semi-volatile & 2,6-Dichlorophenol & SW 8270 & ug/L & $<$ & 0.702 & $<$ & 0.695 \\
\hline Organics, Semi-volatile & 2,6-Dinitrotoluene & SW 8270 & ug/L & $<$ & 0.336 & $<$ & 0.333 \\
\hline Organics, Semi-volatile & 2-Chloronaphthalene & SW 8270 & ug/L & $<$ & 0.315 & $<$ & 0.312 \\
\hline Organics, Semi-volatile & 2-Chlorophenol & SW 8270 & ug/L & $<$ & 0.742 & $<$ & 0.735 \\
\hline Organics, Semi-volatile & 2-Methylnaphthalene & SW 8270 & ug/L & $<$ & 0.641 & $<$ & 0.635 \\
\hline Organics, Semi-volatile & 2-Methylphenol(o-cresol) & SW 8270 & $\mathrm{ug} / \mathrm{L}$ & $<$ & 0.518 & $<$ & 0.513 \\
\hline Organics, Semi-volatile & 2-Naphthylamine & SW 8270 & $\mathrm{ug} / \mathrm{L}$ & $<$ & 1.89 & $<$ & 1.87 \\
\hline Organics, Seml-volatlle & 2-Nitroanilline & SW 8270 & $u g / L$ & $<$ & 0.39 & $<$ & 0.387 \\
\hline Organics, Semi-volatile & 2-Nitrophenol & SW 8270 & ug/L & $<$ & 0.427 & $<$ & 0.423 \\
\hline Organics, Semi-volatile & 2-Picoline & SW 8270 & ug/L & $<$ & 1.06 & $<$ & 1.05 \\
\hline Organics, Semi-volatile & 3,3'-Dlchlorobenzidine & SW 8270 & ug/L & $<$ & 0.476 & $<$ & 0.471 \\
\hline Organics, Semi-volatile & 3-Methyicholanthrene & SW 8270 & ug/L & $<$ & 0.76 & $<$ & 0.753 \\
\hline Organics, Semi-volatile & 3-Nitroaniline & SW 8270 & ug/L & $<$ & 0.494 & $<$ & 0.489 \\
\hline Organics, Semi-volatile & 4,6-Dinitro-2-methylphenol & SW 8270 & ug/L & $<$ & 0.769 & $<$ & 0.762 \\
\hline Organics, Semi-volatile & 4-Aminoblphenyl & SW 8270 & ug/L & $<$ & 0.726 & $<$ & 0.719 \\
\hline
\end{tabular}

Ash Pond Water - Page 3

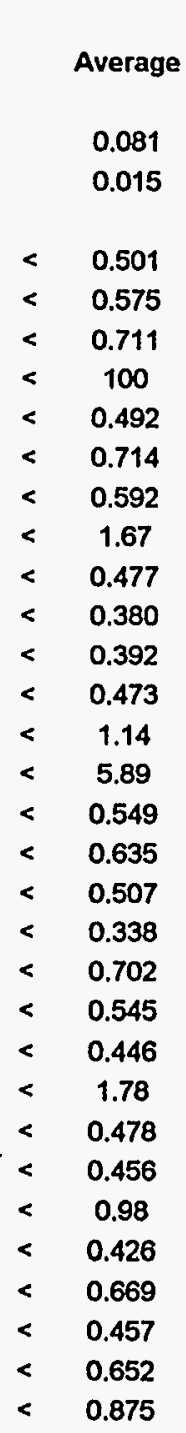

0.165

0.021

\begin{tabular}{cr}
\hline- & $100 \%$ \\
\hline- & $100 \%$ \\
\hline- & $100 \%$ \\
\hline- & $100 \%$ \\
\hline- & $100 \%$ \\
\hline- & $100 \%$ \\
\hline- & $100 \%$ \\
\hline- & $100 \%$ \\
\hline- & $100 \%$ \\
\hline- & $100 \%$ \\
\hline- & $100 \%$ \\
\hline- & $100 \%$ \\
\hline- & $100 \%$ \\
\hline- & $100 \%$ \\
\hline- & $100 \%$ \\
\hline- & $100 \%$ \\
\hline- & $100 \%$ \\
\hline- & $100 \%$ \\
\hline- & $100 \%$ \\
\hline- & $100 \%$ \\
\hline- & $100 \%$ \\
\hline- & $100 \%$ \\
\hline- & $100 \%$ \\
\hline- & $100 \%$ \\
\hline- & $100 \%$ \\
\hline- & $100 \%$ \\
\hline- & $100 \%$ \\
\hline & $100 \%$ \\
\hline
\end{tabular}


Sample Stream: Ash Pond Water

Analyte
Group
Organics, Semi-volatile
Organics, Semi-volatile
Organics, Semi-volatile
Organics, Semi-volatile
Organics, Semi-volatile
Organics, Semi-volatile
Organics, Semi-volatile
Organics, Semi-volatile
Organics, Semi-volatile
Organics, Semi-volatile
Organics, Semi-volatile
Organics, Semi-volatile
Organics, Semi-volatile
Organics, Semi-volatile
Organics, Semi-volatile
Organics, Semi-volatile
Organics, Semi-volatile
Organics, Seml-volatile
Organics, Semi-volatile
Organics, Semi-volatile
Organics, Semi-volatile
Organics, Semi-volatile
Organics, Semi-volatile
Organics, Semi-volatile
Organics, Semi-volatile
Organics, Semi-volatile
Organics, Semi-volatile
Organics, Semi-volatile
Organics, Semi-volatile
Organics, Semi-volatile
Organics, Semi-volatile
Organics, Semi-volatile
Organics, Semi-volatile

\begin{tabular}{|c|c|}
\hline Specie & $\begin{array}{l}\text { Analytica } \\
\text { Method }\end{array}$ \\
\hline 4-Bromophenyl phenyl & SW 8270 \\
\hline 4-Chloro-3-methylphenol & SW 8270 \\
\hline 4-Chlorophenyl phenyl ether & SW 8270 \\
\hline 4-Methylphenol(p-cresol) & SW 8270 \\
\hline 4-Nitroanlline & SW 8270 \\
\hline 4-Nitrophenol & SW 8270 \\
\hline 7,12-Dimethylbenz(a)anthracene & SW 8270 \\
\hline Acenaphthene & SW 8270 \\
\hline Acenaphthylene & SW 8270 \\
\hline Acetophenone & SW 8270 \\
\hline Aniline & SW 8270 \\
\hline Anthracene & SW 8270 \\
\hline Benzidine & SW 8270 \\
\hline Benzo(a)anthracene & SW 8270 \\
\hline Benzo(a)pyrene & SW 8270 \\
\hline Benzo(b)fluoranthene & SW 8270 \\
\hline Benzo $(g, h, i)$ perylene & SW 8270 \\
\hline Benzo(k)fluoranthene & SW 8270 \\
\hline Benzolc acid & SW 8270 \\
\hline Benzyl alcohol & SW 8270 \\
\hline Butylbenzylphthalate & SW 8270 \\
\hline Chrysene & SW 8270 \\
\hline Dl-n-octylphthalate & SW 8270 \\
\hline Dibenz(a,h)anthracene & SW 8270 \\
\hline Dibenz $\left(a_{1}\right)$ )acridine & SW 8270 \\
\hline Dibenzofuran & SW 8270 \\
\hline Dibutyiphthalate & SW 8270 \\
\hline Diethyiphthalate & SW 8270 \\
\hline Dimethylphenethylamine & SW 8270 \\
\hline Dimethytphthalate & SW 8270 \\
\hline Diphenylamine & SW 8270 \\
\hline Ethyl methanesulfonate & Swi 8270 \\
\hline Fluoranthene & SW 8270 \\
\hline
\end{tabular}

\begin{tabular}{|c|c|c|}
\hline & & Run \\
\hline Units & & 1 \\
\hline$u g / L$ & $<$ & 0.443 \\
\hline $\mathrm{ug} / \mathrm{L}$ & $<$ & 0.702 \\
\hline ug/L & $<$ & 0.513 \\
\hline ug/L & $<$ & 0.558 \\
\hline ug/L & $<$ & 0.47 \\
\hline ug/L & $<$ & 0.671 \\
\hline ug/L. & $<$ & 1.86 \\
\hline ug/L. & $<$ & 0.464 \\
\hline ug/L. & $<$ & 0.219 \\
\hline ug/L. & $<$ & 0.446 \\
\hline ug/L & $<$ & 0.906 \\
\hline ug/L & $<$ & 0.564 \\
\hline ug/L & $<$ & 20 \\
\hline ug/L & $<$ & 0.5 \\
\hline ug/L & $<$ & 0.372 \\
\hline ug/L & $<$ & 0.552 \\
\hline ug/L & $<$ & 0.473 \\
\hline ug/L & $<$ & 0.94 \\
\hline ug/L. & $<$ & 3.84 \\
\hline ug/L & $<$ & 1.05 \\
\hline ug/L & & 0.305 \\
\hline$u g / L$ & $<$ & 0.65 \\
\hline$u g / L$ & $<$ & 0.884 \\
\hline ug/L & $<$ & 0.46 \\
\hline ug/L. & $<$ & 0.564 \\
\hline ug/L & $<$ & 0.396 \\
\hline ug/L & $<$ & 0.479 \\
\hline ug/L. & $<$ & 0.326 \\
\hline$u g / h$ & $<$ & 120 \\
\hline$u g / h$ & $<$ & 0.272 \\
\hline ug/L & $<$ & 0.513 \\
\hline ug/h & $<$ & 0.488 \\
\hline
\end{tabular}

\begin{tabular}{|c|c|c|c|c|}
\hline & $\begin{array}{c}\text { Run } \\
2\end{array}$ & & & $\begin{array}{c}\text { Run } \\
3 a\end{array}$ \\
\hline$<$ & 0.438 & & $<$ & 0.479 \\
\hline$<$ & 0.695 & & $<$ & 0.51 \\
\hline$<$ & 0.508 & & $<$ & 0.417 \\
\hline$<$ & 0.553 & & $<$ & 0.454 \\
\hline$<$ & 0.465 & & $<$ & 0.6 \\
\hline$<$ & 0.664 & & $<$ & 0.928 \\
\hline$<$ & 1.85 & & $<$ & 1.32 \\
\hline$<$ & 0.46 & & $<$ & 0.269 \\
\hline$<$ & 0.217 & & $<$ & 0.414 \\
\hline$<$ & 0.441 & & $<$ & 0.553 \\
\hline$<$ & 0.897 & & $<$ & 0.61 \\
\hline$<$ & 0.559 & & $<$ & 0.364 \\
\hline$<$ & 20 & & $<$ & 20 \\
\hline$<$ & 0.495 & & $<$ & 0.445 \\
\hline$<$ & 0.368 & & $<$ & 0.513 \\
\hline$<$ & 0.547 & & $<$ & 0.899 \\
\hline$<$ & 0.468 & & $<$ & 1.01 \\
\hline$<$ & 0.931 & & $<$ & 0.989 \\
\hline$<$ & 3.81 & & $<$ & 38.2 \\
\hline$<$ & 1.04 & & $<$ & 0.604 \\
\hline & 0.292 & J & $<$ & 0.619 \\
\hline$<$ & 0.643 & & $<$ & 0.532 \\
\hline$<$ & 0.876 & & $<$ & 0.349 \\
\hline$<$ & 0.456 & & $<$ & 0.803 \\
\hline$<$ & 0.559 & & $<$ & 0.834 \\
\hline 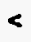 & 0.392 & & $<$ & 0.532 \\
\hline$<$ & 0.474 & & $<$ & 0.321 \\
\hline$<$ & 0.323 & & $<$ & 0.51 \\
\hline$<$ & 120 & & $<$ & 120 \\
\hline$<$ & 0.269 & & $<$ & 0.333 \\
\hline$<$ & 0.508 & & $<$ & 0.274 \\
\hline$<$ & 0.484 & & $<$ & 0.672 \\
\hline & 0.613 & & $<$ & 0.466 \\
\hline
\end{tabular}

$\begin{array}{cc} & \text { Run } \\ & 3 d \\ & \\ < & 0.461 \\ < & 0.49 \\ < & 0.401 \\ < & 0.437 \\ < & 0.577 \\ < & 0.892 \\ < & 1.27 \\ < & 0.259 \\ < & 0.398 \\ < & 0.532 \\ < & 0.587 \\ < & 0.35 \\ < & 20 \\ < & 0.428 \\ < & 0.493 \\ < & 0.865 \\ < & 0.971 \\ < & 0.951 \\ < & 36.8 \\ < & 0.581 \\ < & 0.595 \\ < & 0.511 \\ < & 0.335 \\ < & 0.772 \\ < & 0.802 \\ < & 0.511 \\ < & 0.309 \\ < & 0.49 \\ < & 120 \\ < & 0.32 \\ < & 0.264 \\ < & 0.647 \\ < & 0.449 \\ & <\end{array}$

Ash Pond Water - Page 4

\begin{tabular}{|c|c|c|c|}
\hline & Average & $\begin{array}{c}95 \% \\
\mathrm{Cl}\end{array}$ & $\underset{\text { Ratio }}{\mathrm{DL}}$ \\
\hline$<$ & 0.453 & -. & $100 \%$ \\
\hline$<$ & 0.636 & -. & $100 \%$ \\
\hline$<$ & 0.479 & $\ldots$ & $100 \%$ \\
\hline$<$ & 0.522 & $\cdots$ & $100 \%$ \\
\hline$<$ & 0.512 & 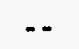 & $100 \%$ \\
\hline$<$ & 0.754 & $\cdots$ & $100 \%$ \\
\hline$<$ & 1.68 & - & $100 \%$ \\
\hline$<$ & 0.398 & -. & $100 \%$ \\
\hline$<$ & 0.283 & $\ldots$ & $100 \%$ \\
\hline$<$ & 0.480 & -. & $100 \%$ \\
\hline$<$ & 0.804 & - & $100 \%$ \\
\hline$<$ & 0.496 & -. & $100 \%$ \\
\hline$<$ & 20 & $\cdots$ & $100 \%$ \\
\hline$<$ & 0.480 & -. & $100 \%$ \\
\hline$<$ & 0.418 & -. & $100 \%$ \\
\hline$<$ & 0.666 & -. & $100 \%$ \\
\hline$<$ & 0.650 & -. & $100 \%$ \\
\hline$<$ & 0.953 & -. & $100 \%$ \\
\hline$<$ & 15.3 & $\cdots$ & $100 \%$ \\
\hline$<$ & 0.898 & $\ldots$ & $100 \%$ \\
\hline$<$ & 0.619 & $\cdots$ & $34 \%$ \\
\hline$<$ & 0.608 & -. & $100 \%$ \\
\hline$<$ & 0.703 & -. & $100 \%$ \\
\hline$<$ & 0.573 & $\cdots$ & $100 \%$ \\
\hline$<$ & 0.652 & -. & $100 \%$ \\
\hline$<$ & 0.440 & -. & $100 \%$ \\
\hline$<$ & 0.425 & $\cdots$ & $100 \%$ \\
\hline$<$ & 0.39 & $\cdots$ & $100 \%$ \\
\hline$<$ & 120 & $\cdots$ & $100 \%$ \\
\hline$<$ & 0.291 & $\cdots$ & $100 \%$ \\
\hline$<$ & 0.432 & $\cdots$ & $100 \%$ \\
\hline$<$ & 0.548 & -. & $100 \%$ \\
\hline$<$ & 0.566 & -. & $100 \%$ \\
\hline
\end{tabular}




\section{Liquid Stream Data Summary}

Sample Stream: Ash Pond Water

\begin{tabular}{|c|c|c|c|c|c|c|c|c|c|c|c|c|c|c|c|c|}
\hline $\begin{array}{l}\text { Anaiyte } \\
\text { Group }\end{array}$ & Specie & $\begin{array}{l}\text { Analytical } \\
\text { Method }\end{array}$ & Units & & $\begin{array}{c}\text { Run } \\
1\end{array}$ & & $\begin{array}{c}\text { Run } \\
2\end{array}$ & & $\begin{array}{c}\text { Run } \\
\mathbf{3 a}\end{array}$ & & & $\begin{array}{c}\text { Run } \\
3 d\end{array}$ & & Average & $\begin{array}{c}95 \% \\
\mathrm{Cl}\end{array}$ & $\begin{array}{c}\text { DL } \\
\text { Ratio }\end{array}$ \\
\hline Organics, Semi-volatile & Fluorene & SW 8270 & $u g / L$ & $<$ & 0.326 & $<$ & 0.323 & $<$ & 0.376 & & $<$ & 0.362 & $<$ & 0.342 & - & $100 \%$ \\
\hline Organics, Semi-volatile & Hexachlorobenzene & SW 8270 & ug/L & $<$ & 0.227 & $<$ & 0.225 & $<$ & 0.311 & & $<$ & 0.299 & $<$ & 0.254 & - & $100 \%$ \\
\hline Organics, Semi-volatile & Hexachlorobutadiene & SW 8270 & $u g / L$ & $<$ & 0.678 & $<$ & 0.671 & $<$ & 0.507 & & $<$ & 0.488 & $<$ & 0.619 & - & $100 \%$ \\
\hline Organics, Semi-volatile & Hexachlorocyclopentadiene & SW 8270 & ug/L & $<$ & 8.66 & $<$ & 8.58 & $<$ & 5.83 & & $<$ & 5.61 & $<$ & 7.69 & -. & $100 \%$ \\
\hline Organics, Semi-volatile & Hexachloroethane & SW 8270 & ug/L & $<$ & 0.577 & $<$ & 0.571 & $<$ & 0.629 & & $<$ & 0.605 & $<$ & 0.592 & -- & $100 \%$ \\
\hline Organics, Semi-volatile & Indeno(1,2,3-cd)pyrene & SW 8270 & ug/L & $<$ & 0.51 & $<$ & 0.505 & $<$ & 1.32 & , & $<$ & 1.27 & $<$ & 0.78 & - & $100 \%$ \\
\hline Organics, Semi-volatile & Isophorone & SW 8270 & ug/L & $<$ & 0.279 & $<$ & 0.276 & $<$ & 0.61 & & $<$ & 0.587 & $<$ & 0.388 & -- & $100 \%$ \\
\hline Organics, Semi-volatile & Methyl methanesulfonate & SW 8270 & $u g / L$ & $<$ & 50 & $<$ & 50 & $<$ & 50 & & $<$ & 50 & $<$ & 50 & - & $100 \%$ \\
\hline Organics, Semi-volatile & N-Nitroso-di-n-butylamine & SW 8270 & ug/L & $<$ & 1.27 & $<$ & 1.26 & $<$ & 0.623 & & $<$ & 0.599 & $<$ & 1.051 & -- & $100 \%$ \\
\hline Organics, Semi-volatile & N-Nitrosodimethylamine & SW 8270 & $u g / h$ & $<$ & 1.29 & $<$ & 1.28 & $<$ & 0.778 & & $<$ & 0.749 & $<$ & 1.116 & - & $100 \%$ \\
\hline Organics, Semi-volatile & N-Nitrosodiphenylamine & SW 8270 & $u g / L$ & $<$ & 0.55 & $<$ & 0.544 & $<$ & 0.266 & & $<$ & 0.256 & $<$ & 0.453 & - & $100 \%$ \\
\hline Organics, Semi-volatile & N-Nitrosodipropylamine & SW 8270 & ug $/ \mathrm{L}$ & $<$ & 0.729 & $<$ & 0.722 & $<$ & 0.648 & & $<$ & 0.623 & $<$ & 0.700 & - & $100 \%$ \\
\hline Organics, Semi-volatile & N-Nitrosopiperidine & SW 8270 & $u g / L$ & $<$ & 0.916 & $<$ & 0.907 & $<$ & 0.591 & & $<$ & 0.569 & $<$ & 0.805 & - & $100 \%$ \\
\hline Organics, Semi-volatile & Naphthalene & sW 8270 & $u g / L$ & $<$ & 0.708 & $<$ & 0.701 & $<$ & 0.473 & & $<$ & 0.455 & $<$ & 0.627 & - & $100 \%$ \\
\hline Organics, Semi-volatile & Nitrobenzene & SW 8270 & ug/L. & $<$ & 0.513 & $<$ & 0.508 & $<$ & 0.834 & & $<$ & 0.802 & $<$ & 0.618 & - & $100 \%$ \\
\hline Organics, Semi-volatile & Pentachlorobenzene & SW 8270 & ug/h & $<$ & 0.43 & $<$ & 0.426 & $<$ & 0.37 & & $<$ & 0.356 & $<$ & 0.409 & .. & $100 \%$ \\
\hline Organics, Semi-volatile & Pentachloronitrobenzene & SW 8270 & $u g / \mathrm{h}$ & $<$ & 2.01 & $<$ & 1.99 & $<$ & 1.37 & & $<$ & 1.31 & $<$ & 1.79 & -. & $100 \%$ \\
\hline Organics, Semi-volatile & Pentachlorophenol & sW 8270 & ug/L & $<$ & 0.839 & $<$ & 0.831 & $<$ & 0.88 & & $<$ & 0.847 & $<$ & 0.850 & - & $100 \%$ \\
\hline Organics, Semi-volatile & Phenacetin & SW 8270 & ug/L & $<$ & 0.524 & $<$ & 0.519 & $<$ & 0.382 & & $<$ & 0.368 & $<$ & 0.475 & $\ldots$ & $100 \%$ \\
\hline Organics, Semi-volatile & Phenanthrene & SW 8270 & $u g / L$ & $<$ & 0.604 & $<$ & 0.598 & $<$ & 0.463 & & $<$ & 0.446 & $<$ & 0.555 & -- & $100 \%$ \\
\hline Organics, Semi-volatile & Phenol & sW 8270 & $u g / L$ & $<$ & 0.387 & $<$ & 0.384 & $<$ & 0.874 & & $<$ & 0.841 & $<$ & 0.548 & -- & $100 \%$ \\
\hline Organics, Semi-volatile & Pronamide & SW 8270 & $u g / L$ & $<$ & 0.717 & $<$ & 0.711 & $<$ & 0.239 & & $<$ & 0.23 & $<$ & 0.556 & -. & $100 \%$ \\
\hline Organics, Semi-volatile & Pyrene & SW 8270 & ug/L & $<$ & 0.454 & $<$ & 0.45 & $<$ & 0.404 & & $<$ & 0.389 & $<$ & 0.436 & -. & $100 \%$ \\
\hline Organics, Semi-volatile & Pyridine & SW 8270 & $u g / L$ & $<$ & 1.13 & $<$ & 1.12 & $<$ & 0.582 & & $<$ & 0.56 & $<$ & 0.944 & .. & $100 \%$ \\
\hline Organics, Semi-volatile & bis(2-Chloroethoxy)methane & SW 8270 & $u g / L$ & $<$ & 0.546 & $<$ & 0.54 & $<$ & 0.6 & & $<$ & 0.577 & $<$ & 0.56 & -- & $100 \%$ \\
\hline Organics, Semi-volatile & bis(2-Chloroethyl)ether & SW 8270 & $u g / L$ & $<$ & 0.711 & $<$ & 0.704 & $<$ & 0.379 & & $<$ & 0.365 & $<$ & 0.598 & - & $100 \%$ \\
\hline Organics, Semi-volatile & bis(2-Chloroisopropyl)ether & SW 8270 & $u g / h$ & $<$ & 0.705 & $<$ & 0.698 & $<$ & 0.79 & & $<$ & 0.76 & $<$ & 0.731 & -. & $100 \%$ \\
\hline Organics, Semi-volatile & bis(2-Ethylhexyl)phthalate & SW 8270 & $u g / L$ & $<$ & 1.78 & $<$ & 1.76 & $<$ & 0.575 & & & 447 & $<$ & 1.37 & -. & $100 \%$ \\
\hline Organics, Semi-volatile & p-Chloroaniline & SW 8270 & $u g / L$ & $<$ & 0.543 & $<$ & 0.537 & $<$ & 0.738 & & $<$ & 0.71 & $<$ & 0.606 & - & $100 \%$ \\
\hline Organics, Semi-volatile & p-Dimethylaminoazobenzene & SW 8270 & $u g / L$ & $<$ & 0.5 & $<$ & 0.495 & $<$ & 0.719 & & $<$ & 0.691 & $<$ & 0.571 & -- & $100 \%$ \\
\hline Organics. Volatlle & 1,1,1-Trichloroethane & SW 8240 & $u g / h$ & $<$ & 5 & $<$ & 5 & $<$ & 5 & & $<$ & 5 & $<$ & 5 & -- & $100 \%$ \\
\hline Organics, Volatile & $1,1,2,2$-Tetrachloroethane & SW 8240 & $u g / \mathrm{h}$ & $<$ & 5 & $<$ & 5 & $<$ & 5 & & $<$ & 5 & $<$ & 5 & $-\cdot$ & $100 \%$ \\
\hline \multicolumn{17}{|c|}{ Ash Pond Water - Page 5} \\
\hline
\end{tabular}




\section{Liquid Stream Data Summary}

sample Stream: Ash Pond Water

Analyte
Group

Organics, Volatile

Organics, Volatile

Organics, Volatile

Organics, Volatile

Organics, Volatile

Organics, Volatile

Organics, Volatile

Organics, Volatlle

Organics, Volatile

Organics, Volatile

Organics, Volatile

Organics, Volatile

Organics, Volatile

Organics, Volatile

Organics, Volatile

Organics, Volatile

Organics, Volatile

Organics, Volatile

Organics, Volatile

Organics, Volatile

Organics, Volatile

Organics, Volatile

Organics, Volatile

Organics, Volatile

Organics, Volatile

Organics, Volatile

Organics, Volatile

Organics, Volatile

Organics, Volatile

Organics, Volatile

Organics, Volatile

Organics, Volatile

\begin{tabular}{|c|c|c|c|c|}
\hline Specie & $\begin{array}{l}\text { Analytical } \\
\text { Method }\end{array}$ & Units & & $\begin{array}{c}\text { Run } \\
1\end{array}$ \\
\hline 1,1,2-Trichloroethane & SW 8240 & ug/L & $<$ & 5 \\
\hline 1,1-Dichloroethane & SW 8240 & ug/L & $<$ & 5 \\
\hline 1,1-Dichloroethene & SW 8240 & $u g / L$ & $<$ & 5 \\
\hline 1,2-Dichloroethane & SW 8240 & ug/L & $<$ & 5 \\
\hline 1,2-Dichloroethene (total) & SW 8240 & $u g / L$ & $<$ & 5 \\
\hline 1,2-Dichloropropane & SW 8240 & $\mathrm{ug} / \mathrm{L}$ & $<$ & 5 \\
\hline 2-Butanone (MEK) & SW 8240 & ug/L & $<$ & 10 \\
\hline 2-Hexanone & SW 8240 & $u g / L$ & $<$ & 10 \\
\hline 4-Methyl-2-pentanone (MIBK) & SW 8240 & $u g / L$ & $<$ & 10 \\
\hline Acetone & SW 8240 & $u g / L$ & $<$ & 10 \\
\hline Benzene & SW 8240 & $u g / L$ & $<$ & 5 \\
\hline Bromodichloromethane & SW 8240 & $\mathrm{ug} / \mathrm{L}$ & $<$ & 5 \\
\hline Bromoform & SW 8240 & ug/L & $<$ & 5 \\
\hline Bromomethane & SW 8240 & $u g / L$ & $<$ & 10 \\
\hline Carbon Disulfide & SW 8240 & $\mathrm{ug} / \mathrm{L}$ & $<$ & 5 \\
\hline Carbon Tetrachloride & SW 8240 & $\mathrm{ug} / \mathrm{L}$ & $<$ & 5 \\
\hline Chlorobenzene & SW 8240 & $\mathrm{ug} / \mathrm{L}$ & $<$ & 5 \\
\hline Chloroethane & SW 8240 & ug/L. & $<$ & 10 \\
\hline Chloroform & SW 8240 & $u g / L$ & $<$ & 5 \\
\hline Chloromethane & SW 8240 & $u g / L$ & $<$ & 10 \\
\hline Dibromochloromethane & SW 8240 & ug/h. & $<$ & 5 \\
\hline Ethylbenzene & SW 8240 & ug/L & $<$ & 5 \\
\hline Methylene Chloride & SW 8240 & $\mathrm{ug} / \mathrm{L}$ & $<$ & 5 \\
\hline Styrene & SW 8240 & $\mathrm{ug} / \mathrm{L}$ & $<$ & 5 \\
\hline Tetrachloroethene & SW 8240 & $\mathrm{ug} / \mathrm{L}$ & $<$ & 5 \\
\hline Toluene & SW 8240 & ug/L & $<$ & 5 \\
\hline Trichloroethene & SW 8240 & ug/L & $<$ & 5 \\
\hline Vinyl acetate & SW 8240 & ug/L & $<$ & 10 \\
\hline Vinyl chloride & SW 8240 & ug/L & $<$ & 10 \\
\hline Xylenes & SW 8240 & ug/L & $<$ & 5 \\
\hline cis-1,3-Dichloropropene & SW 8240 & ug/L & $<$ & 5 \\
\hline trans-1,3-Dichloropropene & SW 8240 & ug/L. & $<$ & 5 \\
\hline
\end{tabular}

Run

Run

5

$\begin{array}{ll}< & 5 \\ < & 5 \\ < & 5 \\ < & 5 \\ < & 5 \\ < & 5 \\ < & 10 \\ < & 10 \\ < & 10 \\ & 6 \\ < & 5 \\ < & 5 \\ < & 5 \\ < & 10 \\ < & 5 \\ < & 5 \\ < & 5 \\ < & 10 \\ < & 5 \\ < & 10 \\ < & 5 \\ < & 5\end{array}$
Average

cl

DL

-. $\quad 100 \%$

-. $\quad 100 \%$

.. $\quad 100 \%$

.. $\quad 100 \%$

-. $100 \%$

-. $\quad 100 \%$

$\therefore \quad 100 \%$

-. $100 \%$

-. $100 \%$

-. $\quad 28 \%$

-. $100 \%$

- $\quad 100 \%$

-. $100 \%$

-. $100 \%$

-. $100 \%$

-. $100 \%$

.. $100 \%$

-. $100 \%$

-. $100 \%$

-. $100 \%$

- $\quad 100 \%$

-. $100 \%$

-. $19 \%$

-. $100 \%$

-. $100 \%$

-. $100 \%$

-. $\quad 100 \%$

- $\quad 100 \%$

-. $100 \%$

-. $100 \%$

-. $\quad 100 \%$

-. $100 \%$

Ash Pond Water - Page 6 


\section{Liquid Stream Data Summary}

Sample Stream: Bottom Ash Sluice Filtrate

\begin{tabular}{|c|c|c|c|c|c|c|c|c|c|c|c|c|c|c|c|c|c|c|c|}
\hline $\begin{array}{c}\text { Analyte } \\
\text { Group }\end{array}$ & Specie & $\begin{array}{c}\text { Analytical } \\
\text { Method }\end{array}$ & Units & & $\begin{array}{c}\text { Run } \\
1 \\
\end{array}$ & & & $\begin{array}{c}\text { Run } \\
2 \\
\end{array}$ & & & $\begin{array}{c}\text { Run } \\
3 a\end{array}$ & & & $\begin{array}{c}\text { Run } \\
3 d\end{array}$ & & & Average & $\begin{array}{c}95 \% \\
\mathrm{Cl} \\
\end{array}$ & $\begin{array}{c}\text { DL } \\
\text { Ratio }\end{array}$ \\
\hline Reduced Species & Cyanide & SW 9012 & $\mathrm{ug} / \mathrm{ml}$ & & 0.0025 & $J$ & & 0.0017 & $\mathbf{J}$ & & 0.0017 & $J$ & & 0.0025 & $\mathrm{~J}$ & & 0.0020 & 0.0011 & \\
\hline Reduced Species & Ammonia as $\mathrm{N}$ & EPA 350.1 & $\mathrm{ug} / \mathrm{ml}$ & & 0.293 & & & 0.421 & & & 0.638 & & & 0.402 & & & 0.451 & 0.433 & \\
\hline Anions & Chloride & EPA 300 & $\mathrm{ug} / \mathrm{ml}$ & & 8.39 & & & 7.74 & & & 7.55 & & & 7.62 & & & 7.89 & 1.09 & \\
\hline Anlons & Fluoride & EPA 340.2 & $\mathrm{ug} / \mathrm{ml}$ & & 0.272 & & & 0.268 & & & 0.302 & & & 0.302 & & & 0.281 & 0.046 & \\
\hline Anions & Phosphate & EPA 365.2 & $\mathrm{ug} / \mathrm{ml}$ & & 0.0396 & & $<$ & 0.02 & & & 0.0264 & & & 0.0235 & & & 0.0253 & 0.0368 & $13 \%$ \\
\hline Anions & Sulfate & EPA 300.0 & $\mathrm{ug} / \mathrm{ml}$ & & 67.5 & & & 95.1 & & & 79 & & & 79.1 & & & 80.5 & 34.4 & \\
\hline Metals, Soluble & Aluminum & SW 6010 & $\mathrm{ug} / \mathrm{ml}$ & & 0.182 & & & 0.302 & & & 0.431 & & & 0.399 & & & 0.305 & 0.309 & \\
\hline Metals, Soluble & Antimony & SW 6010 & $\mathrm{ug} / \mathrm{ml}$ & $<$ & 0.0241 & & $<$ & 0.0241 & & $<$ & 0.0241 & & $<$ & 0.0241 & & $<$ & 0.0241 & $\cdots$ & $100 \%$ \\
\hline Metals, Soluble & Arsenic & SW 7060 & $u g / m l$ & & 0.0028 & & & 0.0646 & & & 0.0031 & & & 0.004 & & & 0.024 & 0.088 & \\
\hline Metals, Soluble & Barium & SW 6010 & $\mathrm{ug} / \mathrm{ml}$ & & 0.0744 & & & 0.14 & & & 0.0927 & & & 0.0919 & & & 0.102 & 0.084 & \\
\hline Metals, Soluble & Beryllium & SW 6010 & $\mathrm{ug} / \mathrm{ml}$ & $<$ & 0.000554 & & $<$ & 0.000554 & & $<$ & 0.000554 & & $<$ & 0.000554 & & $<$ & 0.000554 & . & $100 \%$ \\
\hline Metals, Soluble & Boron & SW 6010 & $\mathrm{ug} / \mathrm{ml}$ & & 0.624 & & & 1.14 & & & 0.849 & & & 0.936 & & & 0.871 & 0.643 & \\
\hline Metals, Soluble & Cadmium & SW 7131 & $\mathrm{ug} / \mathrm{ml}$ & $<$ & 0.000237 & & & 0.00173 & & & 0.00131 & & & 0.00179 & & & 0.00105 & 0.00208 & $4 \%$ \\
\hline Metals, Soluble & Calcium & SW 6010 & $\mathrm{ug} / \mathrm{ml}$ & & 29.1 & & & 39 & & & 47.4 & & & 44.5 & & & 38.5 & 22.8 & \\
\hline Metals, Soluble & Chromlum & SW 6010 & $\mathrm{ug} / \mathrm{ml}$ & & 0.00211 & $J$ & & 0.00419 & & & 0.00301 & & & 0.00318 & & & 0.00310 & 0.00259 & \\
\hline Metals, Soluble & Cobalt & SW 6010 & $\mathrm{ug} / \mathrm{ml}$ & $<$ & 0.0034 & & $<$ & 0.0034 & & $<$ & 0.0034 & & $<$ & 0.0034 & & $<$ & 0.0034 & .. & $100 \%$ \\
\hline Metals, Soluble & Copper & SW 6010 & $\mathrm{ug} / \mathrm{ml}$ & & 0.00355 & $J$ & & 0.0116 & & & 0.0393 & & & 0.00533 & & & 0.0182 & 0.0466 & \\
\hline Metals, Soluble & Iron & SW 6010 & $\mathrm{ug} / \mathrm{ml}$ & & 0.0199 & & & 0.0439 & & & 0.0212 & & & 0.0059 & $J$ & & 0.0283 & 0.0335 & \\
\hline Metals, Soluble & Lead & SW 7421 & $u g / m l$ & & 0.009 & & & 0.006 & & & 0.016 & & & 0.017 & & & 0.010 & 0.013 & \\
\hline Metals, Soluble & Magnesium & SW 6010 & $\mathrm{ug} / \mathrm{ml}$ & & 2.07 & & & 2.98 & & & 1.71 & & & 1.8 & & & 2.25 & 1.63 & \\
\hline Metals, Soluble & Manganese & SW 6010 & $u g / m l$ & & 0.07 & & & 0.0918 & & & 0.00172 & & & 0.00257 & & & 0.0545 & 0.1168 & \\
\hline Metals, Soluble & Mercury & sW 7470 & $u g / m !$ & & 0.00007 & & & 0.00002 & $J$ & & 0.00003 & $J$ & & 0.00007 & & & 0.00004 & 0.00007 & \\
\hline Metals, Soluble & Molybdenum & SW 6010 & $u g / m l$ & & 0.0472 & & & 0.11 & & & 0.0587 & & & 0.0593 & & & 0.0720 & 0.0831 & \\
\hline Metals, Soluble & Nickel & SW 6010 & $\mathrm{ug} / \mathrm{ml}$ & & 0.00016 & $J$ & & 0.011 & & & 0.00466 & $J$ & & 0.0026 & J & & 0.0053 & 0.0135 & \\
\hline Metals, Soluble & Phosphorus & SW 6010 & $u g / m l$ & & 0.0872 & & & 0.172 & & & 0.0791 & & & 0.197 & & & 0.113 & 0.128 & \\
\hline Metals, Soluble & Potasslum & SW 6010 & $\mathrm{ug} / \mathrm{ml}$ & & 3.67 & & & 5.64 & & & 3.85 & & & 3.83 & & & 4.39 & 2.71 & \\
\hline Metals, Soluble & Selenium & SW 7740 & $\mathrm{ug} / \mathrm{ml}$ & & 0.0038 & & & 0.0036 & & & 0.0043 & & & 0.0035 & & & 0.0039 & 0.0009 & \\
\hline Metals, Soluble & Silicon & SW 6010 & $\mathrm{ug} / \mathrm{ml}$ & & 4.63 & & & 4.61 & & & 4.97 & & & 4.8 & & & 4.74 & 0.50 & \\
\hline Metals, Soluble & Sodium & SW 6010 & $\mathrm{ug} / \mathrm{ml}$ & & 9.05 & & & 10.4 & & & 8.69 & & & 8.69 & & & 9.38 & 2.24 & \\
\hline Metals, Soluble & Strontlum & SW 6010 & $\mathrm{ug} / \mathrm{ml}$ & & 0.194 & & & 0.423 & & & 0.225 & & & 0.22 & & & 0.281 & 0.309 & \\
\hline Metals, Soluble & $\operatorname{Tin}$ & SW 6010 & $\mathrm{ug} / \mathrm{ml}$ & & 0.00499 & J & $<$ & 0.0144 & & & 0.00446 & J & & 0.00236 & J & $<$ & 0.0144 & .. & $43 \%$ \\
\hline
\end{tabular}

Bottom Ash Sluice Filtrate - Page 1 


\section{Liquid Stream Data Summary}

Sample Stream: Bottom Ash Sluice Filtrate

\begin{tabular}{|c|c|c|c|c|c|c|c|c|c|c|c|c|c|c|c|}
\hline $\begin{array}{c}\text { Analyte } \\
\text { Group } \\
\end{array}$ & Specle & $\begin{array}{c}\text { Analytical } \\
\text { Method }\end{array}$ & Units & & $\begin{array}{c}\text { Run } \\
1 \\
\end{array}$ & & $\begin{array}{c}\text { Run } \\
2 \\
\end{array}$ & & $\begin{array}{c}\text { Run } \\
\text { 3a }\end{array}$ & & $\begin{array}{c}\text { Run } \\
3 d\end{array}$ & & Average & $\begin{array}{c}95 \% \\
\mathrm{Cl} \\
\end{array}$ & $\begin{array}{c}\text { DL } \\
\text { Ratio }\end{array}$ \\
\hline Metals, Soluble & Tilanium & SW 6010 & $\mathrm{ug} / \mathrm{ml}$ & & 0.00101 & $J$ & 0.00226 & $<$ & 0.00102 & & 0.00076 & $J$ & 0.0013 & 0.0022 & $13 \%$ \\
\hline Metals, Soluble & Vanadlum & SW 6010 & $\mathrm{ug} / \mathrm{ml}$ & & 0.0349 & & 0.00712 & & 0.0453 & & 0.0444 & & 0.0291 & 0.0490 & \\
\hline Metals, Soluble & Zinc & SW 6010 & $u g / m l$ & & 0.00339 & & 0.0162 & & 0.00565 & & 0.00342 & & 0.0084 & 0.0170 & \\
\hline Aldehydes & Acetaldehyde & SW 8315 & $\mathrm{ug} / \mathrm{ml}$ & & 0.006 & & 0.09 & & 0.134 & & 0.09 & & 0.077 & 0.162 & \\
\hline Aldehydes & Formaldehyde & SW 8315 & $\mathrm{ug} / \mathrm{ml}$ & & 0.006 & & 0.032 & & 0.03 & & 0.026 & & 0.023 & 0.036 & \\
\hline Organics, Semi-volatile & 1,2,4,5-Tetrachlorobenzene & SW 8270 & $u g / L$ & $<$ & 0.556 & $<$ & 0.578 & $<$ & 0.402 & $<$ & 0.373 & $<$ & 0.512 & $\cdots$ & $100 \%$ \\
\hline Organics, Semi-volatile & 1,2,4-Trichlorobenzene & sw 8270 & $u g / L$ & $<$ & 0.568 & $<$ & 0.591 & $<$ & 0.606 & $<$ & 0.563 & $<$ & 0.588 & $\cdots$ & $100 \%$ \\
\hline Organics, Semi-volatile & 1,2-Dichlorobenzene & SW 8270 & $u g / h$ & $<$ & 0.749 & $<$ & 0.779 & $<$ & 0.655 & $<$ & 0.608 & $<$ & 0.728 & $\cdots$ & $100 \%$ \\
\hline Organics, Semi-volatile & 1,2-Diphenylhydrazine & SW 8270 & $u g / h$ & $<$ & 100 & $<$ & 100 & $<$ & 100 & $<$ & 100 & $<$ & 100 & -- & $100 \%$ \\
\hline Organics, Semi-volatile & 1,3-Dichlorobenzene & SW 8270 & $u g / L$ & $<$ & 0.381 & $<$ & 0.396 & $<$ & 0.739 & $<$ & 0.686 & $<$ & 0.505 & -. & $100 \%$ \\
\hline Organics, Semi-volatile & 1,4-Dichlorobenzene & SW 8270 & $u g / L$ & $<$ & 0.777 & $<$ & 0.808 & $<$ & 0.606 & $<$ & 0.563 & $<$ & 0.730 & -. & $100 \%$ \\
\hline Organics, Semi-volatile & 1-Chloronaphthalene & SW 8270 & $u g / L$ & $<$ & 0.619 & $<$ & 0.644 & $<$ & 0.554 & $<$ & 0.514 & $<$ & 0.606 & -. & $100 \%$ \\
\hline Organics, Semi-volatile & 1-Naphthylamine & SW 8270 & $u g / L$ & $<$ & 1.5 & $<$ & 1.56 & $<$ & 2.09 & $<$ & 1.94 & $<$ & 1.72 & $\cdots$ & $100 \%$ \\
\hline Organics, Semi-volatile & 2,4,5-Trichlorophenol & SW 8270 & $u g / L$ & $<$ & 0.317 & $<$ & 0.33 & $<$ & 0.525 & $<$ & 0.487 & $<$ & 0.391 & $\cdots$ & $100 \%$ \\
\hline Organics, Semi-volatile & 2,4,6-Trichlorophenol & SW 8270 & $u g / L$ & $<$ & 0.336 & $<$ & 0.349 & $<$ & 0.522 & $<$ & 0.484 & $<$ & 0.402 & $\cdots$ & $100 \%$ \\
\hline Organics, Semi-volatile & 2,4-Dichlorophenol & SW 8270 & ug/L & $<$ & 0.426 & $<$ & 0.443 & $<$ & 0.587 & $<$ & 0.544 & $<$ & 0.485 & $\ldots$ & $100 \%$ \\
\hline Organics, Semi-volatile & 2,4-Dimelhylphenol & SW 8270 & $u g / L$ & $<$ & 1.06 & $<$ & 1.1 & $<$ & 1.34 & $<$ & 1.24 & $<$ & 1.17 & $\cdots$ & $100 \%$ \\
\hline Organics, Semi-volatile & 2,4-Dinitrophenol & SW 8270 & $u g / L$. & $<$ & 6.73 & $<$ & 7 & $<$ & 4.31 & $<$ & 4 & $<$ & 6.01 & $\cdots$ & $100 \%$ \\
\hline Organics, Semi-volatile & 2,4-Dinitrotoluene & sw 8270 & $u g / L$ & $<$ & 0.529 & $<$ & 0.55 & $<$ & 0.609 & $<$ & 0.566 & $<$ & 0.563 & - & $100 \%$ \\
\hline Organics, Semi-volatile & 2,6-Dichlorophenol & SW 8270 & $u g / L$ & $<$ & 0.695 & $<$ & 0.723 & $<$ & 0.528 & $<$ & 0.49 & $<$ & 0.649 & -. & $100 \%$ \\
\hline Organics, Semi-volatile & 2,6-Dinitrotoluene & SW 8270 & ug/L & $<$ & 0.333 & $<$ & 0.346 & $<$ & 0.888 & $<$ & 0.824 & $<$ & 0.522 & -. & $100 \%$ \\
\hline Organics, Semi-volatile & 2-Chloronaphthalene & SW 8270 & $\mathrm{ug} / \mathrm{L}$ & $<$ & 0.312 & $<$ & 0.324 & $<$ & 0.404 & $<$ & 0.375 & $<$ & 0.347 & $-\cdot$ & $100 \%$ \\
\hline Organics, Semi-volatile & 2-Chlorophenol & SW 8270 & $\mathrm{ug} / \mathrm{L}$ & $<$ & 0.735 & $<$ & 0.764 & $<$ & 0.655 & $<$ & 0.608 & $<$ & 0.718 & $\cdots$ & $100 \%$ \\
\hline Organics, Semi-volatile & 2-Methyinaphthalene & SW 8270 & $u g / L$ & $<$ & 0.635 & $<$ & 0.66 & $<$ & 0.375 & $<$ & 0.348 & $<$ & 0.557 & $\cdots$ & $100 \%$ \\
\hline Organics, Semi-volatile & 2-Methylphenol(o-cresol) & SW 8270 & $\mathrm{ug} / \mathrm{L}$ & $<$ & 0.513 & $<$ & 0.534 & $<$ & 0.32 & $<$ & 0.297 & $<$ & 0.456 & -. & $100 \%$ \\
\hline Organics, Semi-volatile & 2-Naphthylamine & SW 8270 & $u g / L$ & $<$ & 1.87 & $<$ & 1.95 & $<$ & 1.65 & $<$ & 1.53 & $<$ & 1.82 & -. & $100 \%$ \\
\hline Organics, Semi-volatile & 2-Nitroaniline & SW 8270 & $\mathrm{ug} / \mathrm{L}$ & $<$ & 0.387 & $<$ & 0.402 & $<$ & 0.684 & $<$ & 0.634 & $<$ & 0.491 & $-\cdot$ & $100 \%$ \\
\hline Organics, Semi-volalile & 2-Nitrophenol & SW 8270 & ug/L & $<$ & 0.423 & $<$ & 0.44 & ¿ & 0.538 & $<$ & 0.5 & $<$ & 0.467 & $-\cdot$ & $100 \%$ \\
\hline Organics, Semi-volatile & 2-Picoline & SW 8270 & ug/L & $<$ & 1.05 & $<$ & 1.09 & $<$ & 0.853 & $<$ & 0.791 & $<$ & 0.998 & .. & $100 \%$ \\
\hline Organics, Semi-volatile & 3,3'-Dichlorobenzidine & SW 8270 & ug/L & $<$ & 0.471 & $<$ & 0.49 & $<$ & 0.343 & $<$ & 0.319 & $<$ & 0.435 & .. & $100 \%$ \\
\hline
\end{tabular}

Bottom Ash Sluice Filtrate - Page 2 


\section{Liquid Stream Data Summary}

Sample Stream: Bottom Ash Sluice Filtrate

\begin{tabular}{|c|c|c|c|c|c|c|c|c|c|c|c|c|c|c|c|}
\hline $\begin{array}{c}\text { Analyte } \\
\text { Group }\end{array}$ & Specie & $\begin{array}{l}\text { Analytical } \\
\text { Method }\end{array}$ & Units & & $\begin{array}{c}\text { Run } \\
1 \\
\end{array}$ & & $\begin{array}{c}\text { Run } \\
2 \\
\end{array}$ & & $\begin{array}{c}\text { Run } \\
\text { 3a }\end{array}$ & & $\begin{array}{c}\text { Run } \\
\text { 3d }\end{array}$ & & Average & $\begin{array}{c}95 \% \\
\mathrm{Cl}\end{array}$ & $\begin{array}{c}\text { DL } \\
\text { Ratio }\end{array}$ \\
\hline Organics, Semi-volatile & 3-Methylcholanthrene & SW 8270 & ug/L & $<$ & 0.753 & $<$ & 0.783 & $<$ & 0.515 & $<$ & 0.478 & $<$ & 0.684 & $-\cdot$ & $100 \%$ \\
\hline Organics, Semi-volatile & 3-Nitroanilline & SW 8270 & $\mathrm{ug} / \mathrm{L}$ & $<$ & 0.489 & $<$ & 0.509 & $<$ & 0.405 & $<$ & 0.376 & $<$ & 0.468 & $\cdots$ & $100 \%$ \\
\hline Organics, Semi-volatile & 4,6-DInitro-2-methylphenol & SW 8270 & ug/L & $<$ & 0.762 & $<$ & 0.792 & $<$ & 0.443 & $<$ & 0.411 & $<$ & 0.666 & -- & $100 \%$ \\
\hline Organics, Semi-volatile & 4-Aminobiphenyl & SW 8270 & ug/L & $<$ & 0.719 & $<$ & 0.748 & $<$ & 1.23 & $<$ & 1.14 & $<$ & 0.899 & -- & $100 \%$ \\
\hline Organics, Semi-volatile & 4-Bromophenyi phenyl & SW 8270 & ug/L & $<$ & 0.438 & $<$ & 0.456 & $<$ & 0.499 & $<$ & 0.463 & $<$ & 0.464 & -- & $100 \%$ \\
\hline Organics, Semi-volatile & 4-Chloro-3-methylphenol & SW 8270 & ug/L & $<$ & 0.695 & $<$ & 0.723 & $<$ & 0.531 & $<$ & 0.493 & $<$ & 0.650 & -- & $100 \%$ \\
\hline Organics, Semi-volatile & 4-Chlorophenyl phenyl ether & SW 8270 & $u g / L$ & $<$ & 0.508 & $<$ & 0.528 & $<$ & 0.434 & $<$ & 0.403 & $<$ & 0.490 & - & $100 \%$ \\
\hline Organics, Semi-volatile & 4-Methylphenol(p-cresol) & SW 8270 & $u g / L$ & $<$ & 0.553 & $<$ & 0.575 & $<$ & 0.473 & $<$ & 0.439 & $<$ & 0.534 & - & $100 \%$ \\
\hline Organics, Semi-volatile & 4-Nitroanilline & SW 8270 & $\mathrm{ug} / \mathrm{L}$ & $<$ & 0.465 & $<$ & 0.484 & $<$ & 0.625 & $<$ & 0.58 & $<$ & 0.525 & -- & $100 \%$ \\
\hline Organics, Semi-volatile & 4-Nitrophenol & SW 8270 & $\mathrm{ug} / \mathrm{L}$ & $<$ & 0.664 & $<$ & 0.691 & $<$ & 0.966 & $<$ & 0.897 & $<$ & 0.774 & - & $100 \%$ \\
\hline Organics, Semi-volatile & 7,12-Dimethylbenz(a)anthracene & SW 8270 & ug/L & $<$ & 1.85 & $<$ & 1.92 & $<$ & 1.37 & $<$ & 1.27 & $<$ & 1.71 & -- & $100 \%$ \\
\hline Organics, Semi-volatile & Acenaphthene & SW 8270 & ug/L & $<$ & 0.46 & $<$ & 0.478 & $<$ & 0.28 & $<$ & 0.26 & $<$ & 0.406 & -- & $100 \%$ \\
\hline Organics, Semi-volatile & Acenaphthylene & SW 8270 & $\mathrm{ug} / \mathrm{h}$ & $<$ & 0.217 & $<$ & 0.226 & $<$ & 0.431 & $<$ & 0.4 & $<$ & 0.291 & - & $100 \%$ \\
\hline Organics, Semi-volatile & Acetophenone & SW 8270 & $u g / h$ & $<$ & 0.441 & $<$ & 0.459 & $<$ & 0.576 & $<$ & 0.535 & $<$ & 0.492 & - & $100 \%$ \\
\hline Organics, Semi-volatile & Aniline & SW 8270 & ug/h & $<$ & 0.897 & $<$ & 0.933 & $<$ & 0.635 & $<$ & 0.589 & $<$ & 0.822 & - & $100 \%$ \\
\hline Organics, Semi-volatile & Anthracene & SW 8270 & ug/L & $<$ & 0.559 & $<$ & 0.581 & $<$ & 0.379 & $<$ & 0.352 & $<$ & 0.506 & $\cdots$ & $100 \%$ \\
\hline Organics, Semi-volatile & Benzidine & SW 8270 & $u g / L$ & $<$ & 20 & $<$ & 20 & $<$ & 20 & $<$ & 20 & $<$ & 20 & - & $100 \%$ \\
\hline Organics, Semi-volatile & Benzo(a)anthraceno & SW 8270 & ug/L & $<$ & 0.495 & $<$ & 0.515 & $<$ & 0.463 & $<$ & 0.43 & $<$ & 0.491 & $\cdots$ & $100 \%$ \\
\hline Organics, Semi-volatile & Benzo(a)pyrene & SW 8270 & $u g / L$ & $<$ & 0.368 & $<$ & 0.383 & $<$ & 0.534 & $<$ & 0.496 & $<$ & 0.428 & -- & $100 \%$ \\
\hline Organics, Semi-volatile & Benzo(b)fluoranthene & SW 8270 & $u g / L$ & $<$ & 0.547 & $<$ & 0.569 & $<$ & 0.936 & $<$ & 0.869 & $<$ & 0.684 & -- & $100 \%$ \\
\hline Organics, Semi-volatile & Benzo $(g, h, l)$ perylene & SW 8270 & $u g / L$ & $<$ & 0.468 & $<$ & 0.487 & $<$ & 1.05 & $<$ & 0.976 & $<$ & 0.668 & -- & $100 \%$ \\
\hline Organics, Semi-volatile & Benzo(k)fluoranthene & sw 8270 & $u g / L$ & $<$ & 0.931 & $<$ & 0.968 & $<$ & 1.03 & $<$ & 0.956 & $<$ & 0.976 &.- & $100 \%$ \\
\hline Organics, Semi-volatile & Benzoic acid & SW 8270 & $u g / L$ & $<$ & 3.81 & $<$ & 3.96 & $<$ & 39.8 & $<$ & 36.9 & $<$ & 15.86 & -- & $100 \%$ \\
\hline Organics, Semi-volatile & Benzyl alcohol & SW 8270 & ug/L & $<$ & 1.04 & $<$ & 1.08 & $<$ & 0.629 & $<$ & 0.584 & $<$ & 0.916 & - & $100 \%$ \\
\hline Organics, Seml-volatile & Butylbenzylphthalate & SW 8270 & $u g / L$ & $<$ & 0.378 & $<$ & 0.393 & $<$ & 0.644 & $<$ & 0.598 & $<$ & 0.472 & -- & $100 \%$ \\
\hline Organics, Semi-volatile & Chrysene & SW 8270 & $u g / L$ & $<$ & 0.643 & $<$ & 0.669 & $<$ & 0.554 & $<$ & 0.514 & $<$ & 0.622 & - & $100 \%$ \\
\hline Organies, Semi-volatile & Di-n-octylphthalate & SW 8270 & $u g / L$. & $<$ & 0.876 & $<$ & 0.911 & $<$ & 0.363 & $<$ & 0.337 & $<$ & 0.717 & -- & $100 \%$ \\
\hline Organics, Semi-volatile & Dibenz $(a, h)$ anthracene & SW 8270 & $u g / L$ & $<$ & 0.456 & $<$ & 0.474 & $<$ & 0.836 & $<$ & 0.776 & $<$ & 0.589 & - & $100 \%$ \\
\hline Organics, Semi-volatile & Dibenz $\left(\mathrm{a}_{1}\right)$ )acridine & SW 8270 & $u g / L$ & $<$ & 0.559 & $<$ & 0.581 & $<$ & 0.868 & $<$ & 0.806 & $<$ & 0.669 & -- & $100 \%$ \\
\hline Organics, Semi-volatile & Dibenzofuran & SW 8270 & ug/L & $<$ & 0.392 & $<$ & 0.408 & $<$ & 0.554 & $<$ & 0.514 & $<$ & 0.451 & -- & $100 \%$ \\
\hline Organics, Semi-volatile & Dibutyiphthalate & SW 8270 & $u g / L$ & $<$ & 0.474 & $<$ & 0.493 & $<$ & 0.334 & $<$ & 0.31 & $<$ & 0.434 & $\cdots$ & $100 \%$ \\
\hline Organics, Semi-volatilo & Diethyiphthalate & SW 8270 & $u g / L$ & $<$ & 0.323 & $<$ & 0.336 & & 1.06 & $<$ & 0.493 & & 0.463 & 1.2841 & $24 \%$ \\
\hline Organics, Semi-volatile & Dimethylphenethylamine & sW 8270 & $u g / L$ & $<$ & 120 & $<$ & 120 & $<$ & 120 & $<$ & 120 & $<$ & 120 & -- & $100 \%$ \\
\hline
\end{tabular}


Sample Stream: Bottom Ash Sluice Filtrate

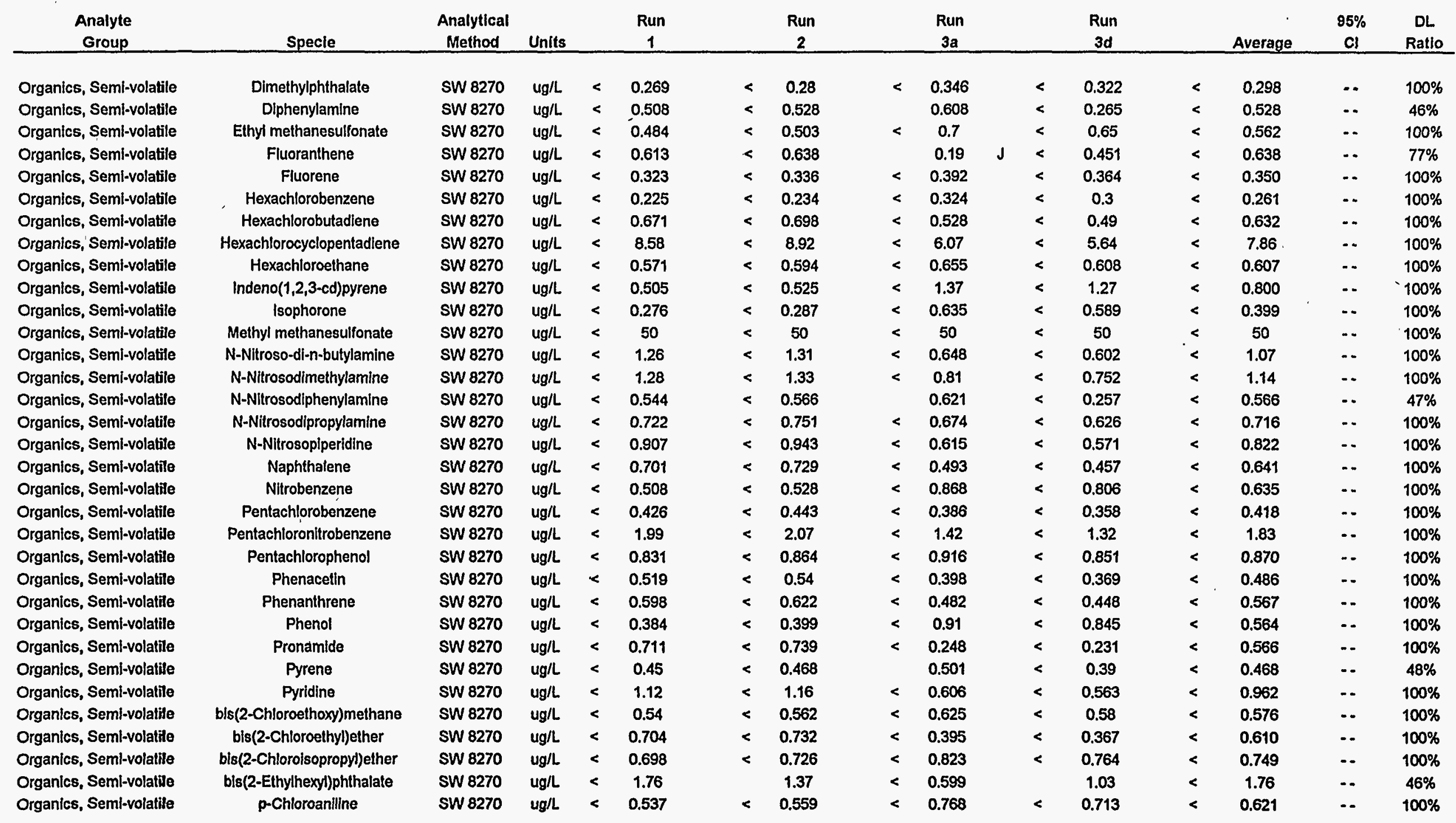




\section{Liquid Stream Data Summary}

Sample Stream: Bottom Ash Sluice Filtrate

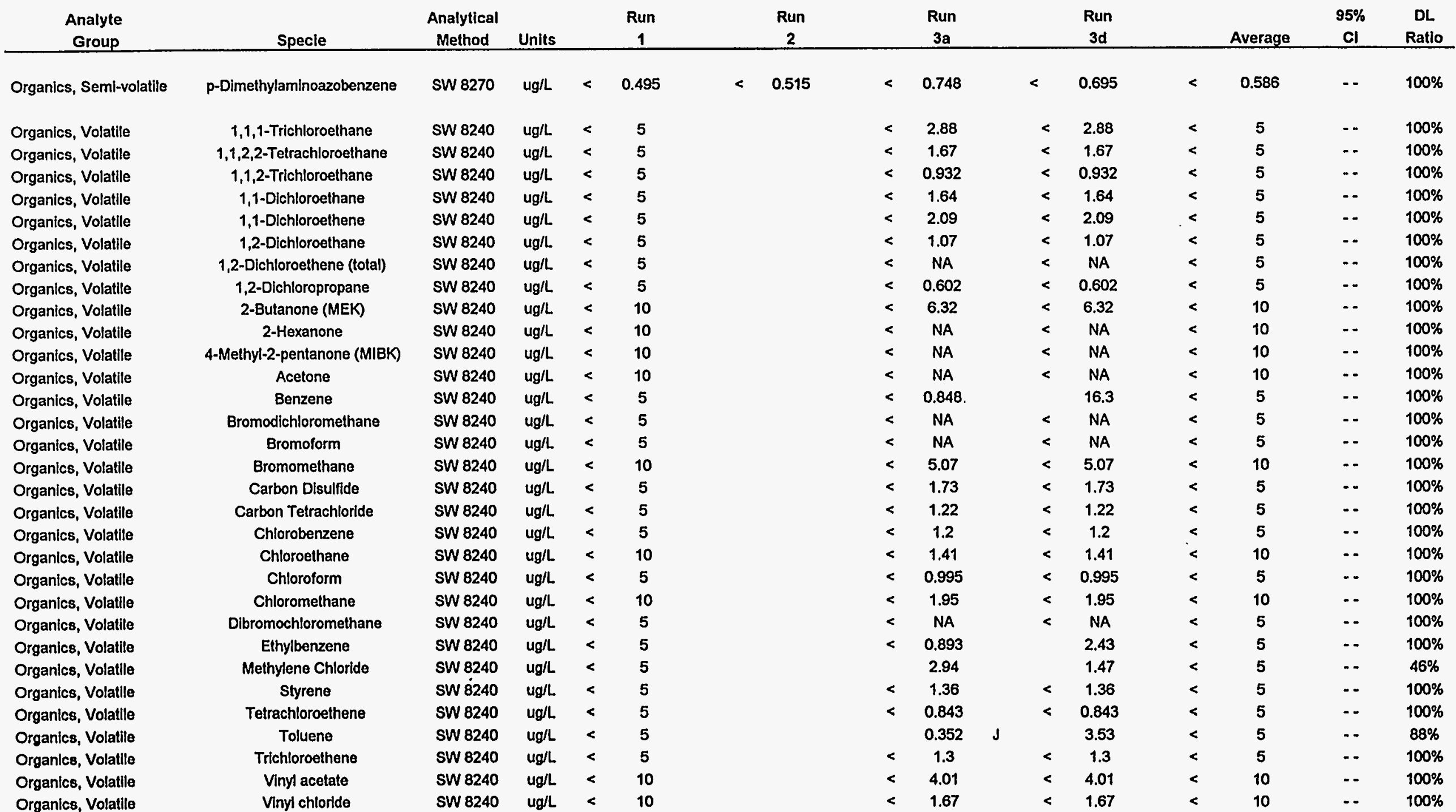




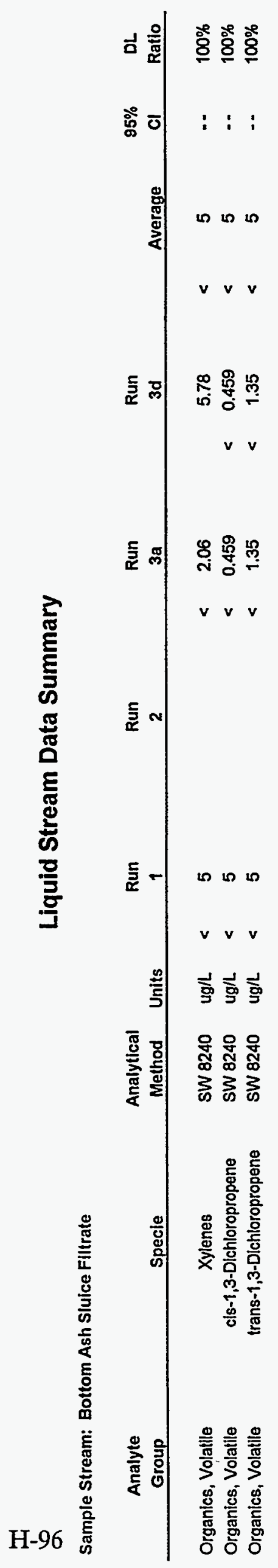

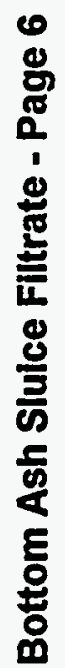




\section{Liquid Stream Data Summary}

Sample Stream: ESP Fly Ash Sluice Filtrate

\begin{tabular}{|c|c|c|c|c|c|c|c|c|c|c|c|c|c|c|c|c|c|c|c|}
\hline $\begin{array}{l}\text { Analyte } \\
\text { Group }\end{array}$ & Specie & $\begin{array}{l}\text { Analytical } \\
\text { Method }\end{array}$ & Units & & $\begin{array}{c}\text { Run } \\
1\end{array}$ & & & $\begin{array}{c}\text { Run } \\
2 \\
\end{array}$ & & & $\begin{array}{c}\text { Run } \\
\text { 3a }\end{array}$ & & & $\begin{array}{r}\text { Run } \\
\text { 3d } \\
\end{array}$ & & & Average & $\begin{array}{c}95 \% \\
\mathrm{Cl} \\
\end{array}$ & $\begin{array}{c}\text { DL } \\
\text { Ratio }\end{array}$ \\
\hline Reduced Species & Cyanide & SW 9012 & $\mathrm{ug} / \mathrm{ml}$ & & 0.0014 & $\mathbf{J}$ & & 0.0009 & $\mathbf{J}$ & & 0.0022 & $\mathbf{J}$ & $<$ & 0.01 & & & 0.0015 & 0.0016 & \\
\hline Reduced Species & Ammonia as $N$ & EPA 350.1 & $\mathrm{ug} / \mathrm{ml}$ & & 0.379 & & & 0.419 & & & 0.355 & & & 0.438 & & & 0.3843 & 0.0803 & \\
\hline Anions & Chloride & EPA 300 & $\mathrm{ug} / \mathrm{ml}$ & & 10.9 & & & 10.7 & & & 9.71 & & & 10.1 & & & 10.4 & 1.6 & \\
\hline Anions & Fluoride & EPA 340.2 & $\mathrm{ug} / \mathrm{ml}$ & & 0.633 & & & 1 & & & 0.576 & & & 0.698 & & & 0.736 & 0.572 & \\
\hline Anions & Phosphate & EPA 365.2 & $u g / m l$ & & 0.015 & J & & 0.0453 & & $<$ & 0.02 & & $<$ & 0.02 & & & 0.023 & 0.047 & $14 \%$ \\
\hline Anions & Sulfate & EPA 300.0 & $\mathrm{ug} / \mathrm{ml}$ & & 238 & & & 582 & & & 210 & & & 236 & & & 343 & 515 & \\
\hline Metals, Soluble & Aluminum & SW 6010 & $\mathrm{ug} / \mathrm{ml}$ & & 0.381 & & & 2.48 & & & 0.0307 & & & 0.204 & & & 0.964 & 3.291 & \\
\hline Metals, Soluble & Antimony & SW 6010 & $\mathrm{ug} / \mathrm{ml}$ & & 0.0118 & $J$ & $<$ & 0.0241 & & $<$ & 0.0241 & & $<$ & 0.0241 & & $<$ & 0.024 & - & $67 \%$ \\
\hline Motals, Soluble & Arsenic & SW 7060 & $\mathrm{ug} / \mathrm{ml}$ & & 0.0108 & & & 0.0387 & & & 0.0004 & $J$ & & 0.0127 & & & 0.017 & 0.049 & \\
\hline Metals, Soluble & Barium & SW 6010 & $\mathrm{ug} / \mathrm{ml}$ & & 0.198 & & & 0.314 & & & 0.213 & & & 0.226 & & & 0.242 & 0.157 & \\
\hline Motals, Soluble & Beryllium & SW 6010 & $\mathrm{ug} / \mathrm{ml}$ & $<$ & 0.000554 & & $<$ & 0.000554 & & $<$ & 0.000554 & & $<$ & 0.000554 & & $<$ & 0.000554 & $\cdots$ & $100 \%$ \\
\hline Metals, Soluble & Boron & SW 6010 & $\mathrm{ug} / \mathrm{ml}$ & & 7.03 & & & 17 & & & 5.73 & & & 6.16 & & & 9.92 & 15.32 & \\
\hline Metals, Soluble & Cadmium & SW 7131 & $\mathrm{ug} / \mathrm{ml}$ & & 0.00275 & & & 0.00108 & & & 0.00426 & & & 0.00269 & & & 0.0027 & 0.0040 & \\
\hline Metals, Soluble & Calcium & SW 6010 & $\mathrm{ug} / \mathrm{ml}$ & & 104 & & & 219 & & & 93.6 & & & 99.2 & & & 138.9 & 172.9 & \\
\hline Metals, Soluble & Chromium & SW 6010 & ug/ml & & 0.0582 & & & 0.0619 & & & 0.0244 & & & 0.0329 & & & 0.0482 & 0.0513 & \\
\hline Metals, Soluble & Cobalt & SW 6010 & $\mathrm{ug} / \mathrm{ml}$ & $<$ & 0.0034 & & $<$ & 0.0034 & & & 0.00008 & $J$ & & 0.00042 & $J$ & $<$ & 0.0034 & .. & $98 \%$ \\
\hline Metals, Soluble & Copper & SW 6010 & $u g / m l$ & & 0.00332 & $J$ & & 0.00236 & $J$ & & 0.00226 & $J$ & & 0.00209 & $\mathrm{~J}$ & & 0.0026 & 0.0015 & \\
\hline Metals, Soluble & Iron & SW 6010 & $\mathrm{ug} / \mathrm{ml}$ & & 0.0131 & & & 0.00277 & $J$ & & 0.00289 & $J$ & & 0.00444 & $\mathrm{~J}$ & & 0.0063 & 0.0147 & \\
\hline Metals, Soluble & Lead & SW 7421 & $\mathrm{ug} / \mathrm{ml}$ & & 0.0065 & & & 0.004 & & & 0.004 & & & 0.004 & & & 0.0048 & 0.0036 & \\
\hline Metals, Soluble & Magnesium & SW 6010 & $\mathrm{ug} / \mathrm{ml}$ & & 3.9 & & & 5.39 & & & 4.08 & & & 3.85 & & & 4.46 & 2.02 & \\
\hline Metals, Soluble & Manganese & SW 6010 & $\mathrm{ug} / \mathrm{ml}$ & & 0.00372 & & & 0.0394 & & & 0.0173 & & & 0.00213 & & & 0.0201 & 0.0447 & \\
\hline Metals, Soluble & Mercury & SW 7470 & $\mathrm{ug} / \mathrm{ml}$ & $<$ & 0.00005 & & & 0.00008 & & $<$ & 0.00005 & & $<$ & 0.00005 & & $<$ & 0.00005 & -. & $38 \%$ \\
\hline Metals, Soluble & Molybdenum & SW 6010 & $\mathrm{ug} / \mathrm{ml}$ & & 0.513 & & & 1.06 & & & 0.29 & & & 0.425 & & & 0.62 & 0.98 & \\
\hline Motals, Soluble & Nickel & SW 6010 & $\mathrm{ug} / \mathrm{ml}$ & & 0.0272 & & & 0.0122 & & & 0.032 & & & 0.0273 & & & 0.0238 & 0.0257 & \\
\hline Metals, Soluble & Phosphorus & SW 6010 & $\mathrm{ug} / \mathrm{ml}$ & $<$ & 0.061 & & & 0.243 & & & 0.149 & & & 0.13 & & & 0.14 & 0.26 & $7 \%$ \\
\hline Metals, Soluble & Potasslum & SW 6010 & $u g / m l$ & & 8.73 & & & 19.4 & & & 6.98 & & & 8.27 & & & 11.70 & 16.70 & \\
\hline Metals, Soluble & Selenium & SW 7740 & $\mathrm{ug} / \mathrm{ml}$ & & 0.0331 & & & 0.0518 & & & 0.0198 & & & 0.0259 & & & 0.0349 & 0.0399 & \\
\hline Metals, Soluble & Sillicon & SW 6010 & $\mathrm{ug} / \mathrm{m} /$ & & 4.64 & & & 2.78 & & & 4.74 & & & 4.67 & & & 4.05 & 2.74 & \\
\hline Metals, Soluble & Sodium & SW 6010 & $\mathrm{ug} / \mathrm{ml}$ & & 17.7 & & & 32.8 & & & 14.1 & & & 16.2 & & & 21.5 & 24.6 & \\
\hline Metals, Soluble & Strontium & SW 6010 & $\mathrm{ug} / \mathrm{ml}$ & & 0.488 & & & 0.926 & & & 0.45 & & & 0.514 & & & 0.621 & 0.657 & \\
\hline Metals, Soluble & Tin & SW 6010 & $\mathrm{ug} / \mathrm{ml}$ & & 0.0111 & $J$ & & 0.00125 & $J$ & & 0.00021 & $J$ & $<$ & 0.0144 & & & 0.0042 & 0.0149 & \\
\hline Metais, Soluble & Titanium & SW 6010 & $\mathrm{ug} / \mathrm{ml}$ & & 0.00095 & $J$ & & 0.00058 & $J$ & & 0.0475 & & & 0.00055 & $J$ & & 0.0163 & 0.0670 & \\
\hline Metals, Soluble & Vanadlum & SW 6010 & $\mathrm{ug} / \mathrm{ml}$ & & 0.0634 & & & 0.12 & & & 0.0224 & & & 0.0681 & & & 0.0686 & 0.1218 & \\
\hline
\end{tabular}

ESP Fly Ash Sluice Filtrate - Page 1 


\section{Liquid Stream Data Summary}

Sample Stream: ESP Fly Ash Sluice Filtrate

\begin{tabular}{|c|c|c|c|c|c|c|c|c|c|c|c|c|c|c|c|c|}
\hline $\begin{array}{l}\text { Analyte } \\
\text { Group }\end{array}$ & Specle & $\begin{array}{c}\text { Analytical } \\
\text { Method }\end{array}$ & Units & & $\begin{array}{c}\text { Run } \\
1 \\
\end{array}$ & & $\begin{array}{c}\text { Run } \\
2 \\
\end{array}$ & & & $\begin{array}{c}\text { Run } \\
3 \mathrm{a}\end{array}$ & & $\begin{array}{r}\text { Run } \\
\text { 3d }\end{array}$ & & Average & $\begin{array}{c}95 \% \\
\mathrm{Cl} \\
\end{array}$ & $\begin{array}{c}\text { DL } \\
\text { Ratio }\end{array}$ \\
\hline Metals, Soluble & Zinc & SW 6010 & $\mathrm{ug} / \mathrm{ml}$ & & 0.00659 & & 9E-05 & $\mathbf{J}$ & & 0.204 & & 0.00605 & & 0.0702 & 0.2879 & \\
\hline Aldehydes & Acetaldehydo & SW 8315 & $\mathrm{ug} / \mathrm{ml}$ & & 0.014 & & 0.088 & & & 0.012 & & 0.086 & & 0.038 & 0.108 & \\
\hline Aldehydes & Formaldehyde & SW 8315 & $u g / m l$ & & 0.016 & & 0.052 & & & 0.022 & & 0.034 & & 0.030 & 0.048 & \\
\hline Organics, Semi-volatile & 1,2,4,5-Tetrachlorobenzene & SW 8270 & ugh & $<$ & 0.55 & $<$ & 0.578 & & $<$ & 0.375 & $<$ & 0.375 & $<$ & 0.501 & $\cdots$ & $100 \%$ \\
\hline Organics, Semi-volatile & 1,2,4-Trichlorobenzene & SW 8270 & ugh & $<$ & 0.563 & $<$ & 0.591 & & $<$ & 0.565 & $<$ & 0.565 & $<$ & 0.573 & $\cdots$ & $100 \%$ \\
\hline Organics, Semi-volatile & 1,2-Dichlorobenzene & SW 8270 & ugh & $<$ & 0.742 & $<$ & 0.779 & & $<$ & 0.611 & $<$ & 0.611 & $<$ & 0.711 & $\cdots$ & $100 \%$ \\
\hline Organics, Semi-volatile & 1,2-Diphenylhydrazine & SW 8270 & ug/L & $<$ & 100 & $<$ & 100 & & $<$ & 100 & $<$ & 100 & $<$ & 100 & $\cdots$ & $100 \%$ \\
\hline Organics, Semi-volatlle & 1,3-Dichlorobenzene & SW 8270 & ug $h$ & $<$ & 0.377 & $<$ & 0.396 & & $<$ & 0.689 & $<$ & 0.689 & $<$ & 0.487 & $\cdots$ & $100 \%$ \\
\hline Organics, Semi-volatile & 1,4-Dichlorobenzene & SW 8270 & $u g / h$ & $<$ & 0.77 & $<$ & 0.808 & & $<$ & 0.565 & $<$ & 0.565 & $<$ & 0.714 & $\cdots$ & $100 \%$ \\
\hline Organics, Semi-volatile & 1-Chloronaphthalene & SW 8270 & $\mathrm{ug} / \mathrm{h}$ & $<$ & 0.613 & $<$ & 0.644 & & $<$ & 0.516 & $<$ & 0.516 & $<$ & 0.591 & $\cdots$ & $100 \%$ \\
\hline Organics, Semi-volatile & 1-Naphthylamine & SW 8270 & $u g / L$ & $<$ & 1.49 & $<$ & 1.56 & & $<$ & 1.95 & $<$ & 1.95 & $<$ & 1.67 & -. & $100 \%$ \\
\hline Organics, Semi-volatile & 2,3,4,6. Tetrachlorophenol & SW 8270 & ugh & $<$ & 0.479 & $<$ & 0.503 & & $<$ & 0.447 & $<$ & 0.447 & $<$ & 0.476 & $\cdots$ & $100 \%$ \\
\hline Organics, Semi-volatile & 2,4,5-Trichlorophenol & SW 8270 & $\mathrm{ug} / \mathrm{L}$ & $<$ & 0.314 & $<$ & 0.33 & & $<$ & 0.489 & $<$ & 0.489 & $<$ & 0.378 & $\cdots$ & $100 \%$ \\
\hline Organics, Semi-volatile & 2,4,6-Trichlorophenol & SW 8270 & ugh & $<$ & 0.332 & $<$ & 0.349 & & $<$ & 0.487 & $<$ & 0.487 & $<$ & 0.389 & $\cdots$ & $100 \%$ \\
\hline Organics, Semi-volatile & 2,4-Dichlorophenol & SW 8270 & $\mathrm{ug} / \mathrm{L}$ & $<$ & 0.422 & $<$ & 0.443 & & $<$ & 0.547 & $<$ & 0.547 & $<$ & 0.471 & $\cdots$ & $100 \%$ \\
\hline Organics, Semi-volatile & 2.4-Dimethylphenol & SW 8270 & ug/L & $<$ & 1.05 & $<$ & 1.1 & & $<$ & 1.25 & $<$ & 1.25 & $<$ & 1.13 & $\cdots$ & $100 \%$ \\
\hline Organics, Semi-volatile & 2,4-Dinitrophenol & SW 8270 & ug/h & $<$ & 6.67 & $<$ & 7 & & $<$ & 4.02 & $<$ & 4.02 & $<$ & 5.90 & $\cdots$ & $100 \%$ \\
\hline Organics, Semi-volatile & 2.4-Dinitrotoluene & SW 8270 & ug/h & $<$ & 0.524 & $<$ & 0.55 & & $<$ & 0.568 & $<$ & 0.568 & $<$ & 0.547 & $\cdots$ & $100 \%$ \\
\hline Organics, Semi-volatile & 2,6-Dlchlorophenol & SW 8270 & ugh. & $<$ & 0.689 & $<$ & 0.723 & & $<$ & 0.492 & $<$ & 0.492 & $<$ & 0.635 & $\cdots$ & $100 \%$ \\
\hline Organics, Semi-volatile & 2,6-Dinitrotoluene & SW 8270 & ugil & $<$ & 0.33 & $<$ & 0.346 & & $<$ & 0.828 & $<$ & 0.828 & $<$ & 0.501 & $\cdots$ & $100 \%$ \\
\hline Organics, Semi-volatile & 2.Chloronaphthalene & SW 8270 & ug/L & $<$ & 0.309 & $<$ & 0.324 & & $<$ & 0.377 & $<$ & 0.377 & $<$ & 0.337 & $\cdots$ & $100 \%$ \\
\hline Organics, Semi-volatile & 2.Chlorophenol & SW 8270 & $u g h$ & $<$ & 0.728 & $<$ & 0.764 & & $<$ & 0.611 & $<$ & 0.611 & $<$ & 0.701 & $\cdots$ & $100 \%$ \\
\hline Organics, Semi-volatile & 2-Methylnaphthalene & SW 8270 & $u g / L$ & $<$ & 0.629 & $<$ & 0.66 & & $<$ & 0.35 & $<$ & 0.35 & $<$ & 0.55 & $\cdots$ & $100 \%$ \\
\hline Organics, Semi-volatlle & 2-Methyiphenol(o-cresol) & SW 8270 & $u g / L$ & $<$ & 0.509 & $<$ & 0.534 & & $<$ & 0.298 & $<$ & 0.298 & $<$ & 0.447 & -. & $100 \%$ \\
\hline Organics, Semi-volatile & 2-Naphthylamine & SW 8270 & ug/L & $<$ & 1.86 & $<$ & 1.95 & & $<$ & 1.54 & $<$ & 1.54 & $<$ & 1.78 & $\cdots$ & $100 \%$ \\
\hline Organics, Semi-volatile & 2-Nitroanlline & SW 8270 & ugh & $<$ & 0.383 & $<$ & 0.402 & & $<$ & 0.637 & $<$ & 0.637 & $<$ & 0.474 & $\cdots$ & $100 \%$ \\
\hline Organics, Semi-volatile & 2-Nitrophenol & SW 8270 & ug/L & $<$ & 0.419 & $<$ & 0.44 & & $<$ & 0.502 & $<$ & 0.502 & $<$ & 0.454 & $\cdots$ & $100 \%$ \\
\hline Organics, Semi-volatile & 2-Picoline & SW 8270 & ugh & $<$ & 1.04 & $<$ & 1.09 & & $<$ & 0.795 & $<$ & 0.795 & $<$ & 0.975 & $\cdots$ & $100 \%$ \\
\hline Organics, Semi-volatile & 3,3'-Dichlorobenzidine & SW 8270 & ugh & $<$ & 0.467 & $<$ & 0.49 & & $<$ & 0.32 & $<$ & 0.32 & $<$ & 0.43 & $\cdots$ & $100 \%$ \\
\hline Organics, Seml-volatile & 3-Methylcholanthrene & SW 8270 & $u g / L$ & $<$ & 0.746 & $<$ & 0.783 & & $<$ & 0.481 & $<$ & 0.481 & $<$ & 0.670 & $\cdots$ & $100 \%$ \\
\hline Organics, Semi-volatile & 3-Nitroaniline & SW 8270 & ug/L & $<$ & 0.485 & $<$ & 0.509 & & $<$ & 0.378 & $<$ & 0.378 & $<$ & 0.457 & .. & $100 \%$ \\
\hline Organics, Semi-volatile & 4,6-Dinitro-2-methylphenol & SW 8270 & ug/L & $<$ & 0.754 & $<$ & 0.792 & & $<$ & 0.413 & $<$ & 0.413 & $<$ & 0.653 & $\cdots$ & $100 \%$ \\
\hline Organics, Semi-volatile & 4-Aminobiphenyl & SW 8270 & ug $\Omega$ & $<$ & 0.712 & $<$ & 0.748 & & $<$ & 1.14 & $<$ & 1.14 & $<$ & 0.867 & .. & $100 \%$ \\
\hline
\end{tabular}

ESP Fly Ash Sluice Filtrate - Page 2 
Liquid Stream Data Summary

Sample Stream: ESP Fly Ash Sluice Filtrate

\begin{tabular}{|c|c|c|c|c|c|c|c|c|c|c|c|c|c|c|c|}
\hline $\begin{array}{l}\text { Analyte } \\
\text { Group }\end{array}$ & Specie & $\begin{array}{c}\text { Analytical } \\
\text { Method }\end{array}$ & Units & & $\begin{array}{c}\text { Run } \\
1 \\
\end{array}$ & & $\begin{array}{c}\text { Run } \\
2 \\
\end{array}$ & & $\begin{array}{c}\text { Run } \\
3 a\end{array}$ & & $\begin{array}{r}\text { Run } \\
3 d \\
\end{array}$ & & Average & $\begin{array}{c}95 \% \\
\mathrm{Cl} \\
\end{array}$ & $\begin{array}{c}\text { DL } \\
\text { Ratio }\end{array}$ \\
\hline Organics, Semi-volatilo & 4-Bromophenyl phenyl ether & SW 8270 & ug $/$. & $<$ & 0.434 & $<$ & 0.456 & $<$ & 0.465 & $<$ & 0.465 & $<$ & 0.452 & $\cdots$ & $100 \%$ \\
\hline Organics, Semi-volatile & 4-Chloro-3-methylphenol & SW 8270 & ugh & $<$ & 0.689 & $<$ & 0.723 & $<$ & 0.495 & $<$ & 0.495 & $<$ & 0.636 & $\cdots$ & $100 \%$ \\
\hline Organics, Seml-volatile & 4-Chlorophenyl phenyl ether & SW 8270 & ug $/$. & $<$ & 0.503 & $<$ & 0.528 & $<$ & 0.405 & $<$ & 0.405 & $<$ & 0.479 & $\cdots$ & $100 \%$ \\
\hline Organics, Semi-volatilo & 4-Methylphenol(p-cresol) & SW 8270 & ugh/L & $<$ & 0.548 & $<$ & 0.575 & $<$ & 0.441 & $<$ & 0.441 & $<$ & 0.521 & $\cdots$ & $100 \%$ \\
\hline Organics, Semi-volatile & 4-Nitroaniline & SW 8270 & $u g / L$ & $<$ & 0.461 & $<$ & 0.484 & $<$ & 0.583 & $<$ & 0.583 & $<$ & 0.509 & $\cdots$ & $100 \%$ \\
\hline Organics, Semi-volatile & 4-Nitrophenol & SW 8270 & ug/L & $<$ & 0.658 & $<$ & 0.691 & $<$ & 0.901 & $<$ & 0.901 & $<$ & 0.750 & $\cdots$ & $100 \%$ \\
\hline Organics, Semi-volatile & 7.12-Dimethylbenz(a)anthracene & SW 8270 & ug/L & $<$ & 1.83 & $<$ & 1.92 & $<$ & 1.28 & $<$ & 1.28 & $<$ & 1.68 & $\cdots$ & $100 \%$ \\
\hline Organics, Semi-volatile & Acenaphthene & SW 8270 & ughl & $<$ & 0.455 & $<$ & 0.478 & $<$ & 0.262 & $<$ & 0.262 & $<$ & 0.398 & $\cdots$ & $100 \%$ \\
\hline Organics, Seml-volatile & Acenaphthylene & SW 8270 & ugh & $<$ & 0.215 & $<$ & 0.226 & $<$ & 0.402 & $<$ & 0.402 & $<$ & 0.281 & $-\cdot$ & $100 \%$ \\
\hline Organics, Semi-volatlie & Acetophenone & SW 8270 & ug/L & $<$ & 0.437 & $<$ & 0.459 & $<$ & 0.537 & $<$ & 0.537 & $<$ & 0.478 & $-\cdot$ & $100 \%$ \\
\hline Organics, Semi-volatile & Aniline & SW 8270 & ug $/ \mathrm{h}$ & $<$ & 0.889 & $<$ & 0.933 & $<$ & 0.592 & $<$ & 0.592 & $<$ & 0.805 & $\cdots$ & $100 \%$ \\
\hline Organics, Semi-volatlle & Anthracene & SW 8270 & ug/L & $<$ & 0.553 & $<$ & 0.581 & $<$ & 0.354 & $<$ & 0.354 & $<$ & 0.496 & $\cdots$ & $100 \%$ \\
\hline Organics, Seml-volatile & Benzidine & SW 8270 & ug/L & $<$ & 20 & $<$ & 20 & $<$ & 20 & $<$ & 20 & $<$ & 20 & $\cdots$ & $100 \%$ \\
\hline Organics, Semi-volatile & Benzo(a)anthracene & SW 8270 & ug/L & $<$ & 0.49 & $<$ & 0.515 & $<$ & 0.432 & $<$ & 0.432 & $<$ & 0.479 & $\cdots$ & $100 \%$ \\
\hline Organics, Semi-volatile & Benzo(a)pyrene & SW 8270 & ug/L & $<$ & 0.365 & $<$ & 0.383 & $<$ & 0.498 & $<$ & 0.498 & $<$ & 0.415 & .. & $100 \%$ \\
\hline Organics, Semi-volatile & Benzo(b)fluoranthene & SW 8270 & ug/L & $<$ & 0.542 & $<$ & 0.569 & $<$ & 0.873 & $<$ & 0.873 & $<$ & 0.661 & -. & $100 \%$ \\
\hline Organics, Semi-volatile & Benzo(g,h,i)perylene & SW 8270 & ug/L & $<$ & 0.464 & $<$ & 0.467 & $<$ & 0.981 & $<$ & 0.981 & $<$ & 0.644 & $-\cdot$ & $100 \%$ \\
\hline Organics, Semi-volatile & Benzo(k)fluoranthene & SW 8270 & ug/L & $<$ & 0.922 & $<$ & 0.968 & $<$ & 0.961 & $<$ & 0.961 & $<$ & 0.950 & $\cdots$ & $100 \%$ \\
\hline Organics, Semi-volatilo & Benzoic acid & SW 8270 & ugh & $<$ & 3.77 & $<$ & 3.96 & $<$ & 37.1 & $<$ & 37.1 & $<$ & 14.9 & $\cdots$ & $100 \%$ \\
\hline Organics, Semi-volatilo & Benzyl alcohol & SW 8270 & ug/L & $<$ & 1.03 & $<$ & 1.08 & $<$ & 0.587 & $<$ & 0.587 & $<$ & 0.899 & .. & $100 \%$ \\
\hline Organics, Semi-volatile & Butylbenzyiphthalate & SW 8270 & ugh & $<$ & 0.374 & $<$ & 0.393 & $<$ & 0.601 & $<$ & 0.601 & $<$ & 0.456 & -. & $100 \%$ \\
\hline Organics, Semi-volatilo & Chrysene & SW 8270 & ug/h & $<$ & 0.637 & $<$ & 0.669 & $<$ & 0.516 & $<$ & 0.516 & $<$ & 0.607 & $\cdots$ & $100 \%$ \\
\hline Organics, Semi-volatile & Di-n-octylphthalate & SW 8270 & ug/L & $<$ & 0.868 & $<$ & 0.911 & $<$ & 0.338 & $<$ & 0.338 & $<$ & 0.706 & $\cdots$ & $100 \%$ \\
\hline Organics, Semi-volatilo & Dibenz $(a, h)$ anthracene & SW 8270 & ug/L & $<$ & 0.451 & $<$ & 0.474 & $<$ & 0.78 & $<$ & 0.78 & $<$ & 0.568 & .. & $100 \%$ \\
\hline Organics, Semi-volatile & Dibenz $(\mathrm{a}, \mathrm{j})$ acridine & SW 8270 & ug/L & $<$ & 0.553 & $<$ & 0.581 & $<$ & 0.81 & $<$ & 0.81 & $<$ & 0.648 & $\cdots$ & $100 \%$ \\
\hline Organics, Somi-volatilo & Dibenzofuran & SW 8270 & ug/L. & $<$ & 0.389 & $<$ & 0.408 & $<$ & 0.516 & $<$ & 0.516 & $<$ & 0.438 & $\cdots$ & $100 \%$ \\
\hline Organics, Semi-volatile & Dibutylphthalate & SW 8270 & ug/L & $<$ & 0.47 & $<$ & 0.493 & $<$ & 0.312 & $<$ & 0.312 & $<$ & 0.425 & $\cdots$ & $100 \%$ \\
\hline Organics, Semi-volatilo & Diethylphthalato & SW 8270 & ug/L & $<$ & 0.32 & $<$ & 0.336 & $<$ & 0.495 & $<$ & 0.495 & $<$ & 0.384 & .. & $100 \%$ \\
\hline Organics, Semi-volatile & Dimethylphenethylamine & SW 8270 & $u g / L$ & $<$ & 120 & $<$ & 120 & $<$ & 120 & $<$ & 120 & $<$ & 120 & -. & $100 \%$ \\
\hline Organics, Semi-volatile & Dimethyiphthalate & SW 8270 & ug/L & $<$ & 0.267 & $<$ & 0.28 & $<$ & 0.323 & $<$ & 0.323 & $<$ & 0.290 & $\cdots$ & $100 \%$ \\
\hline Organics, Semi-volatile & Diphenylamine & SW 8270 & ug/h & $<$ & 0.503 & $<$ & 0.528 & $<$ & 0.266 & $<$ & 0.266 & $<$ & 0.432 & . & $100 \%$ \\
\hline Organics, Semi-volatile & Ethyl methanesulfonate & SW 8270 & $u g / L$ & $<$ & 0.479 & $<$ & 0.503 & $<$ & 0.653 & $<$ & 0.653 & $<$ & 0.545 & -. & $100 \%$ \\
\hline Organics, Semi-volatilo & Fluoranthene & SW 8270 & ug/L & $<$ & 0.608 & $<$ & 0.638 & $<$ & 0.453 & $<$ & 0.453 & $<$ & 0.566 & $\cdots$ & $100 \%$ \\
\hline Organics, Semi-volatile & Fluorene & SW 8270 & $u g / L$ & $<$ & 0.32 & $<$ & 0.336 & $<$ & 0.365 & $<$ & 0.365 & $<$ & 0.340 & .. & $100 \%$ \\
\hline Organics, Semi-volatilo & Hexachlorobenzene & SW 8270 & ugh & $<$ & 0.223 & $<$ & 0.234 & $<$ & 0.302 & $<$ & 0.302 & $<$ & 0.253 & . & $100 \%$ \\
\hline
\end{tabular}




\section{Liquid Stream Data Summary}

Sample Stream: ESP Fly Ash Sluice Filtrate

\begin{tabular}{|c|c|c|c|c|c|c|c|c|c|c|c|c|c|c|c|c|}
\hline $\begin{array}{l}\text { Analyte } \\
\text { Group }\end{array}$ & Specie & $\begin{array}{l}\text { Analytical } \\
\text { Method }\end{array}$ & Units & & $\begin{array}{c}\text { Run } \\
1 \\
\end{array}$ & & $\begin{array}{c}\text { Run } \\
2 \\
\end{array}$ & & $\begin{array}{c}\text { Run } \\
3 a\end{array}$ & & $\begin{array}{r}\text { Run } \\
\text { 3d } \\
\end{array}$ & & & Average & $\begin{array}{c}96 \% \\
\mathrm{Cl} \\
\end{array}$ & $\begin{array}{c}\text { DL } \\
\text { Ratio }\end{array}$ \\
\hline Organics, Seml-volatile & Hexachlorobutadiene & SW 8270 & ugh & $<$ & 0.665 & $<$ & 0.698 & $<$ & 0.492 & $<$ & 0.492 & & $<$ & 0.618 & $\cdots$ & $100 \%$ \\
\hline Organics, Seml-volatilo & Hexachlorocyclopentadieno & SW 8270 & ug/L & $<$ & 8.5 & $<$ & 8.92 & $<$ & 5.66 & $<$ & 5.66 & ' & $<$ & 7.69 & $\cdots$ & $100 \%$ \\
\hline Organics, Seml-volatile & Hexachloroethane & SW 8270 & ugh & $<$ & 0.566 & $<$ & 0.594 & $<$ & 0.611 & $<$ & 0.611 & & $<$ & 0.590 & .. & $100 \%$ \\
\hline Organics, Semi-volatile & Indeno(1,2,3-çd)pyrene & SW 8270 & ugh & $<$ & 0.5 & $<$ & 0.525 & $<$ & 1.28 & $<$ & 1.28 & & $<$ & 0.768 & $\cdots$ & $100 \%$ \\
\hline Organics, Semi-volatile & Isophorone & SW 8270 & ugh & $<$ & 0.273 & $<$ & 0.287 & $<$ & 0.592 & $<$ & 0.592 . & & $<$ & 0.384 & -. & $100 \%$ \\
\hline Organics, Semi-volatile & Methyl methanesulfonate & SW 8270 & ug/L & $<$ & 50 & $<$ & 50 & $<$ & 50 & $<$ & 50 & & $<$ & 50 & .. & $100 \%$ \\
\hline Organics, Semi-volatile & N-Nitroso-di-n-butylamine & SW 8270 & ugh & $<$ & 1.25 & $<$ & 1.31 & $<$ & 0.605 & $<$ & 0.605 & & $<$ & 1.055 & .. & $100 \%$ \\
\hline Organies, Semi-volatile & N-Nitrosodimethylamine & SW 8270 & ug/h & $<$ & 1.27 & $<$ & 1.33 & $<$ & 0.756 & $<$ & 0.756 & & $<$ & 1.119 & .. & $100 \%$ \\
\hline Organics, Semi-volatile & N-Nitrosodiphenylamine & SW 8270 & ug/L & $<$ & 0.539 & $<$ & 0.566 & $<$ & 0.259 & $<$ & 0.259 & & $<$ & 0.455 & $\cdots$ & $100 \%$ \\
\hline Organics, Semi-volatile & N-Nitrosodipropylamine & SW 8270 & ug/L & $<$ & 0.715 & $<$ & 0.751 & $<$ & 0.629 & $<$ & 0.629 & & $<$ & 0.698 & -. & $100 \%$ \\
\hline Organics, Semi-volatile & N.Nitrosopiperidine & SW 8270 & ug/L & $<$ & 0.898 & $<$ & 0.943 & $<$ & 0.574 & $<$ & 0.574 & & $<$ & 0.805 & -. & $100 \%$ \\
\hline Organics, Seml-volatile & Naphthalene & SW 8270 & ug/L & $<$ & 0.694 & $<$ & 0.729 & $<$ & 0.46 & $<$ & 0.46 & & $<$ & 0.628 & .. & $100 \%$ \\
\hline Organics, Semi-volatile & Nitrobenzene & sw 8270 & ug/L & $<$ & 0.503 & $<$ & 0.528 & $<$ & 0.81 & $<$ & 0.81 & & $<$ & 0.614 & -. & $100 \%$ \\
\hline Organics, Semi-volatile & Pentachlorobenzene & SW 8270 & ug/L & $<$ & 0.422 & $<$ & 0.443 & $<$ & 0.36 & $<$ & 0.36 & & $<$ & 0.408 & .. & $100 \%$ \\
\hline Organics, Semi-volatile & Pentachloronitrobenzene & SW 8270 & ugh & $<$ & 1.97 & $<$ & 2.07 & $<$ & 1.33 & $<$ & 1.33 & & $<$ & 1.79 & $\cdots$ & $100 \%$ \\
\hline Organics, Semi-volatile & Pentachlorophenol & SW 8270 & ug/L & $<$ & 0.823 & $<$ & 0.864 & $<$ & 0.855 & $<$ & 0.855 & & $<$ & 0.847 & $\cdots$ & $100 \%$ \\
\hline Organics, Semi-volatile & Phenacetin & SW 8270 & ugh & $<$ & 0.514 & $<$ & 0.54 & $<$ & 0.371 & $<$ & 0.371 & & $<$ & 0.475 & $\cdots$ & $100 \%$ \\
\hline Organics, Seml-volatile & Phenanthrene & SW 8270 & ug/L. & $<$ & 0.592 & $<$ & 0.622 & $<$ & 0.45 & $<$ & 0.45 & & $<$ & 0.555 & $\cdots$ & $100 \%$ \\
\hline Organics, Semi-volatile & Phenol & SW 8270 & ug/L & $<$ & 0.38 & $<$ & 0.399 & $<$ & 0.849 & $<$ & 0.849 & & $<$ & 0.543 & -. & $100 \%$ \\
\hline Organics, Semi-volatile & Pronamide & SW 8270 & ug/L. & $<$ & 0.704 & $<$ & 0.739 & $<$ & 0.232 & $<$ & 0.232 & & $<$ & 0.558 & $\cdots$ & $100 \%$ \\
\hline Organics, Semi-volatile & Pyrene & SW 8270 & ug/L & $<$ & 0.446 & $<$ & 0.468 & $<$ & 0.392 & $<$ & 0.392 & & $<$ & 0.435 & .. & $100 \%$ \\
\hline Organics, Semi-volatile & Pyridine & SW 8270 & ug/L & $<$ & 1.1 & $<$ & 1.16 & $<$ & 0.565 & $<$ & 0.565 & & $<$ & 0.942 & $\cdots$ & $100 \%$ \\
\hline Organics, Semi-volatile & bis(2-Chloroethoxy)methane & SW 8270 & ugh & $<$ & 0.535 & $<$ & 0.562 & $<$ & 0.583 & $<$ & 0.583 & & $<$ & 0.560 & -. & $100 \%$ \\
\hline Organics, Semi-volatile & bls(2-Chloroethyi)ether & SW 8270 & ugh & $<$ & 0.697 & $<$ & 0.732 & $<$ & 0.368 & $<$ & 0.368 & & $<$ & 0.599 & -. & $100 \%$ \\
\hline Organics, Semi-volatile & bis(2-Chioroisopropyl)ether & SW 8270 & ugh & $<$ & 0.691 & $<$ & 0.726 & $<$ & 0.767 & $<$ & 0.767 & & $<$ & 0.728 & -. & $100 \%$ \\
\hline Organics, Semi-volatile & bis(2-Ethylhexyl)phthalate & SW 8270 & ug/L & $<$ & 1.74 & & 2.35 & $<$ & 0.559 & $<$ & 0.559 & & $<$ & 1.740 & $\cdots$ & $33 \%$ \\
\hline Organics, Semi-volatile & p-Chloroaniline & SW 8270 & ug/L & $<$ & 0.532 & $<$ & 0.559 & $<$ & 0.716 & $<$ & 0.716 & & $<$ & 0.602 & $\cdots$ & $100 \%$ \\
\hline Organics, Semi-volatile & p-Dimethylaminoazobenzene & SW 8270 & ugh & $<$ & 0.49 & $<$ & 0.515 & $<$ & 0.698 & $<$ & 0.698 & & $<$ & 0.568 & $\cdots$ & $100 \%$ \\
\hline Organics, Volatile & 1,1,1-Trichloroethane & SW 8240 & ugh & $<$ & 5 & $<$ & 5 & $<$ & 5 & $<$ & 5 & & $<$ & 5 & $\cdots$ & $100 \%$ \\
\hline Organics, Volatile & 1,1,2,2-Tetrachloroethane & SW 8240 & ugh & $<$ & 5 & $<$ & 5 & $<$ & 5 & $<$ & 5 & & $<$ & 5 & -. & $100 \%$ \\
\hline Organics, Volatile & 1,1,2-Trichloroethane & SW 8240 & ugh & $<$ & 5 & $<$ & 5 & $<$ & 5 & $<$ & 5 & & $<$ & 5 & -. & $100 \%$ \\
\hline Organics, Volatile & 1,1-Dichloroethane & SW 8240 & ug/h & $<$ & 5 & $<$ & 5 & $<$ & 5 & $<$ & 5 & & $<$ & 5 & $\cdots$ & $100 \%$ \\
\hline Organics, Volatile & 1,1-Dichloroethene & SW 8240 & ugh & $<$ & 5 & $<$ & 5 & $<$ & 5 & $<$ & 5 & & $<$ & 5 & .. & $100 \%$ \\
\hline Organics, Volatile & 1,2-Dichloroethane & SW 8240 & ug $/$ & $<$ & 5 & $<$ & 5 & $<$ & 5 & $<$ & 5 & & $<$ & 5 & - & $100 \%$ \\
\hline
\end{tabular}




\section{Liquid Stream Data Summary}

Sample Stream: ESP Fly Ash Sluice Filtrate

\begin{tabular}{|c|c|c|c|c|c|c|c|c|c|c|c|c|c|c|c|}
\hline $\begin{array}{l}\text { Analyte } \\
\text { Group }\end{array}$ & Specie & $\begin{array}{c}\text { Analytical } \\
\text { Method }\end{array}$ & Units & & $\begin{array}{c}\text { Run } \\
1 \\
\end{array}$ & & $\begin{array}{c}\text { Run } \\
2 \\
\end{array}$ & & $\begin{array}{c}\text { Run } \\
3 a\end{array}$ & & $\begin{array}{r}\text { Run } \\
\text { 3d } \\
\end{array}$ & & Average & $\begin{array}{c}95 \% \\
\mathrm{Cl} \\
\end{array}$ & $\begin{array}{c}\mathrm{DL} \\
\text { Ratio }\end{array}$ \\
\hline Organics, Volatile & 1,2-Dichloroethene (total) & SW 8240 & ugh & $<$ & 5 & $<$ & 5 & $<$ & 5 & $<$ & 5 & $<$ & 5 & -. & $100 \%$ \\
\hline Organics, Volatile & 1,2-Dichloropropane & SW 8240 & ugh & $<$ & 5 & $<$ & 5 & $<$ & 5 & $<$ & 5 & $<$ & 5 & -. & $100 \%$ \\
\hline Organics, Volatile & 2-Butanone (MEK) & SW 8240 & ugh & $<$ & 10 & $<$ & 10 & $<$ & 10 & $<$ & 10 & $<$ & 10 & -. & $100 \%$ \\
\hline Organics, Volatile & 2-Hexanone & SW 8240 & ug/ & $<$ & 10 & $<$ & 10 & $<$ & 10 & $<$ & 10 & $<$ & 10 & -. & $100 \%$ \\
\hline Organics, Volatile & 4-Methyl-2-pentanone (MIBK) & SW 8240 & ugh & $<$ & 10 & $<$ & 10 & $<$ & 10 & $<$ & 10 & $<$ & 10 & $\cdots$ & $100 \%$ \\
\hline Organics, Volatile & Acetone & SW 8240 & ug/L & $<$ & 10 & $<$ & 10 & & 13 & $<$ & 10 & $<$ & 10 &.- & $43 \%$ \\
\hline Organics, Volatile & Benzene & SW 8240 & ugh & $<$ & 5 & $<$ & 5 & $<$ & 5 & $<$ & 5 & $<$ & 5 & $\cdots$ & $100 \%$ \\
\hline Organics, Volatilo & Bromodichloromethane & SW 8240 & ugh & $<$ & 5 & $<$ & 5 & $<$ & 5 & $<$ & 5 & $<$ & 5 & $\cdots$ & $100 \%$ \\
\hline Organics, Volatile & Bromoform & SW 8240 & ug/L & $<$ & 5 & $<$ & 5 & $<$ & 5 & $<$ & 5 & $<$ & 5 & -. & $100 \%$ \\
\hline Organics, Volatile & Bromomethane & SW 8240 & $u g / L$ & $<$ & 10 & $<$ & 10 & $<$ & 10 & $<$ & 10 & $<$ & 10 & $\cdots$ & $100 \%$ \\
\hline Organics, Volatilo & Carbon Disulfido & SW 8240 & ug/L & $<$ & 5 & $<$ & 5 & $<$ & 5 & $<$ & 5 & $<$ & 5 & $\cdots$ & $100 \%$ \\
\hline Organics, Volatile & Carbon Tetrachloride & SW 8240 & ug/L & $<$ & 5 & $<$ & 5 & $<$ & 5 & $<$ & 5 & $<$ & 5 & -. & $100 \%$ \\
\hline Organics, Volatile & Chlorobenzene & SW 8240 & ug/L & $<$ & 5 & $<$ & 5 & $<$ & 5 & $<$ & 5 & $<$ & 5 & $\cdots$ & $100 \%$ \\
\hline Organics, Volatile & Chloroethane & SW 8240 & ug/L & $<$ & 10 & $<$ & 10 & $<$ & 10 & $<$ & 10 & $<$ & 10 & .. & $100 \%$ \\
\hline Organics, Volatile & Chloroform & SW 8240 & ug/ & $<$ & 5 & $<$ & 5 & $<$ & 5 & $<$ & 5 & $<$ & 5 & $\cdots$ & $100 \%$ \\
\hline Organics, Volatilo & Chloromethane & SW 8240 & $\mathrm{ug} / \mathrm{L}$ & $<$ & 10 & $<$ & 10 & $<$ & 10 & $<$ & 10 & $<$ & 10 & $\cdots$ & $100 \%$ \\
\hline Organics, Volatilo & Dibromochloromethano & SW 8240 & ug $/ \mathrm{L}$ & $<$ & 5 & $<$ & 5 & $<$ & 5 & $<$ & 5 & $<$ & 5 & -. & $100 \%$ \\
\hline Organics, Volatile & Ethylbenzene & SW 8240 & ugil & $<$ & 5 & $<$ & 5 & $<$ & 5 & $<$ & 5 & $<$ & 5 & - & $100 \%$ \\
\hline Organics, Volatile & Methylene Chloride & SW 8240 & ug $/ L$ & & 5.5 & & 3.6 & & 5.7 & & 6.5 & & 4.9 & 2.8 & \\
\hline Organics, Volatile & Styrene & SW 8240 & ug/L & $<$ & 5 & $<$ & 5 & $<$ & 5 & $<$ & 5 & $<$ & 5 & $\cdots$ & $100 \%$ \\
\hline Organics, Volatile & Tetrachloroethene & SW 8240 & $\operatorname{lgg} / \mathrm{L}$ & $<$ & 5 & $<$ & 5 & $<$ & 5 & $<$ & 5 & $<$ & 5 & $\cdots$ & $100 \%$ \\
\hline Organics, Volatile & Toluene & SW 8240 & ug/L & $<$ & 5 & $<$ & 5 & $<$ & 5 & $<$ & 5 & $<$ & 5 & - & $100 \%$ \\
\hline Organics, Volatlle & Trichloroethene & SW 8240 & ug/L & $<$ & 5 & $<$ & 5 & $<$ & 5 & $<$ & 5 & $<$ & 5 & $\cdots$ & $100 \%$ \\
\hline Organics, Volatile & Vinyl acetate & SW 8240 & ugh & $<$ & 10 & $<$ & 10 & $<$ & 10 & $<$ & 10 & $<$ & 10 & $\cdots$ & $100 \%$ \\
\hline Organics, Volatile & Vinyl chloride & SW 8240 & ug/L & $<$ & 10 & $<$ & 10 & $<$ & 10 & $<$ & 10 & $<$ & 10 &.- & $100 \%$ \\
\hline Organics, Volatile & Xylenes & SW 8240 & ug/L & $<$ & 5 & $<$ & 5 & $<$ & 5 & $<$ & 5 & $<$ & 5 & $\cdots$ & $100 \%$ \\
\hline Organics, Volatile & cis-1,3-Dichloropropene & SW 8240 & ugh & $<$ & 5 & $<$ & 5 & $<$ & 5 & $<$ & 5 & $<$ & 5 & $\cdots$ & $100 \%$ \\
\hline Organics, Volatile & trans-1,3-Dlchloropropene & SW 8240 & ug/L & $<$ & 5 & $<$ & 5 & $<$ & 5 & $<$ & $\mathbf{5}$ & $<$ & 5 & $\cdots$ & $100 \%$ \\
\hline
\end{tabular}




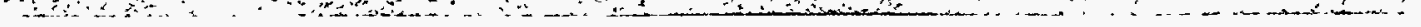




\section{Liquid Stream Data Summary}

Sample Stream: Gypsum Pond Water

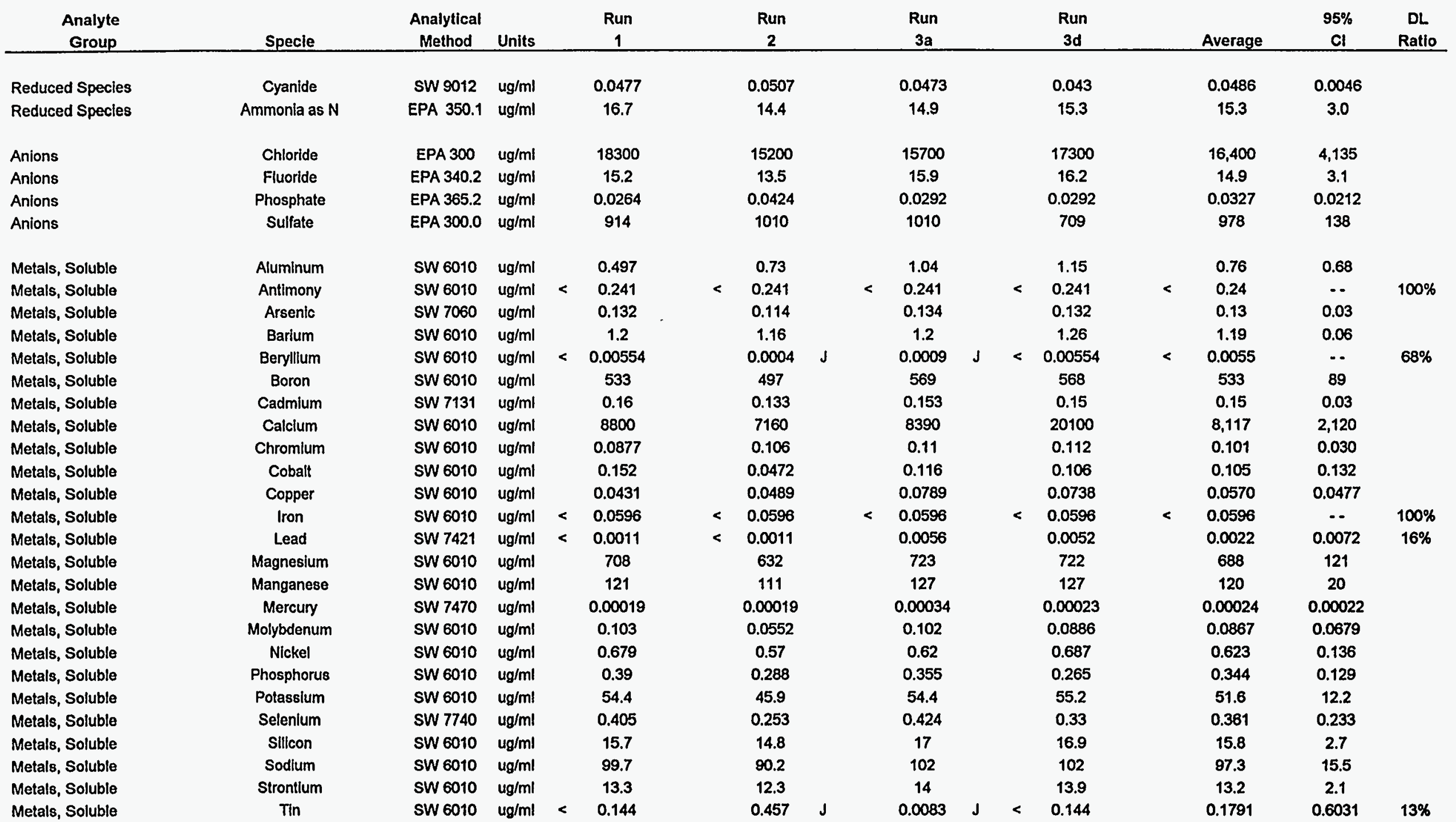

\section{Gypsum Pond Water - Page 1}


Sample Stream: Gypsum Pond Water

\begin{tabular}{|c|c|c|c|c|c|c|c|c|c|c|c|c|c|c|c|c|c|}
\hline $\begin{array}{c}\text { Analyte } \\
\text { Group }\end{array}$ & Specie & $\begin{array}{l}\text { Analytical } \\
\text { Method }\end{array}$ & Units & & $\begin{array}{c}\text { Run } \\
1 \\
\end{array}$ & & $\begin{array}{c}\text { Run } \\
2 \\
\end{array}$ & & & $\begin{array}{c}\text { Run } \\
3 a\end{array}$ & & $\begin{array}{c}\text { Run } \\
3 d\end{array}$ & & & Average & $\begin{array}{c}95 \% \\
\mathrm{Cl} \\
\end{array}$ & $\begin{array}{c}\text { DL } \\
\text { Ratio }\end{array}$ \\
\hline Metals, Soluble & Tilanium & SW 6010 & $\mathrm{ug} / \mathrm{ml}$ & & 2.39 & & 2.14 & & & 2.04 & & 2.04 & & & 2.190 & 0.448 & \\
\hline Metals, Soluble & Vanadium & SW 6010 & $\mathrm{ug} / \mathrm{ml}$ & & 0.348 & & 0.296 & & & 0.323 & & 0.342 & & & 0.322 & 0.065 & \\
\hline Metals, Soluble & Zinc & SW 6010 & $\mathrm{ug} / \mathrm{ml}$ & & 0.81 & & 0.739 & & & 0.868 & & 0.865 & & & 0.806 & 0.161 & \\
\hline Metals, Total & Aluminum & SW 6010 & $\mathrm{ug} / \mathrm{ml}$ & & 1.91 & & 1.85 & & & 2.36 & & 2.83 & & & 2.04 & 0.69 & \\
\hline Metals, Totai & Antimony & SW 6010 & $u g / m l$ & $<$ & 0.0964 & $<$ & 0.0964 & & $<$ & 0.241 & $<$ & 0.241 & & $<$ & 0.1446 & $\cdots$ & $100 \%$ \\
\hline Metals, Total & Arsenic & SW 7060 & $\mathrm{ug} / \mathrm{ml}$ & & 0.121 & & 0.118 & & & 0.141 & & 0.127 & & & 0.127 & 0.031 & \\
\hline Metals, Total & Barium & SW 6010 & ug/mi & & 1.28 & & 1.08 & & & 1.21 & & 1.06 & & & 1.19 & 0.25 & \\
\hline Metals, Total & Beryllium & SW 6010 & $\mathrm{ug} / \mathrm{ml}$ & & 0.00396 & & 0.00116 & $\mathbf{J}$ & $<$ & 0.00554 & & 0.0012 & $J$ & $<$ & 0.0055 & -- & $35 \%$ \\
\hline Metals, Total & Boron & SW 6010 & ug/ml & & 589 & & 472 & & & 566 & & 512 & & & 542 & 154 & \\
\hline Metals, Total & Calcium & SW 6010 & $\mathrm{ug} / \mathrm{ml}$ & & 12200 & & 7720 & & & 8470 & & 8340 & & & 9,463 & 5,961 & \\
\hline Metals, Total & Cadmilum & sw 7131 & $\mathrm{ug} / \mathrm{ml}$ & & 0.174 & & 0.185 & & & 0.171 & & 0.168 & & & 0.177 & 0.018 & \\
\hline Metals, Total & Chromium & SW 6010 & $\mathrm{ug} / \mathrm{ml}$ & & 0.0586 & & 0.047 .6 & & & 0.118 & & 0.0646 & & & 0.075 & 0.094 & \\
\hline Metals, Total & Cobalt & SW 6010 & $\mathrm{ug} / \mathrm{ml}$ & & 0.163 & & 0.113 & & & 0.152 & & 0.143 & & & 0.143 & 0.065 & \\
\hline Metals, Total & Copper & sW 6010 & $\mathrm{ug} / \mathrm{ml}$ & & 0.0633 & & 0.0403 & & & 0.0563 & & 0.0824 & & & 0.0533 & 0.0293 & \\
\hline Metals, Total & Iron & SW 6010 & $\mathrm{ug} / \mathrm{ml}$ & & 0.557 & & 1.01 & & & 0.462 & & 0.451 & & & 0.676 & 0.728 & \\
\hline Metals, Total & Lead & SW 7421 & $\mathrm{ug} / \mathrm{ml}$ & & 0.0022 & & 0.0027 & & & 0.0058 & & 0.0043 & & & 0.0036 & 0.0048 & \\
\hline Metals, Total & Magnesium & SW 6010 & $\mathrm{ug} / \mathrm{ml}$ & & 784 & & 620 & & & 744 & & 668 & & & 716 & 212 & \\
\hline Metals, Total & Manganese & sw 6010 & $\mathrm{ug} / \mathrm{ml}$ & & 135 & & 105 & & & 129 & & 116 & & & 123 & 39 & \\
\hline Metals, Total & Mercury & SW 7470 & $\mathrm{ug} / \mathrm{ml}$ & & 0.00028 & & 0.00031 & & & 0.0003 & & 0.00036 & & & 0.00030 & 0.00004 & \\
\hline Metals, Total & Molybdenum & SW 6010 & $\mathrm{ug} / \mathrm{ml}$ & & 0.0816 & & 0.0749 & & & 0.0718 & & 0.0565 & & & 0.0761 & 0.0124 & \\
\hline Metals, Total & Nickel & SW 6010 & $u g / m l$ & & 0.668 & & 0.545 & & & 0.678 & & 0.638 & & & 0.630 & 0.184 & \\
\hline Metals, Total & Phosphorus & SW 6010 & $u g / m l$ & & 0.227 & & 0.235 & & & 0.246 & & 0.322 & & & 0.236 & 0.024 & \\
\hline Metals, Total & Potassium & SW 6010 & $u g / m l$ & & 53.2 & & 45.9 & & & 56 & & 52.2 & & & 51.7 & 13.0 & \\
\hline Metals, Total & Selenium & SW 7740 & $\mathrm{ug} / \mathrm{ml}$ & & 0.242 & & 0.343 & & & 0.212 & & 0.0462 & & & 0.2657 & 0.1705 & \\
\hline Metals, Total & Sillicon & SW 6010 & $\mathrm{ug} / \mathrm{ml}$ & & 19.2 & & 16.9 & & & 19 & & 17.1 & & & 18.4 & 3.2 & \\
\hline Metals, Total & Sodium & SW6010 & $u g / m !$ & & 109 & & 91 & & & 107 & & 95.5 & & & 102.3 & 24.5 & \\
\hline Metals, Total & Strontlum & SW 6010 & $\mathrm{ug} / \mathrm{ml}$ & & 15.3 & & 11.7 & & & 14.1 & & 12.6 & & & 13.7 & 4.6 & \\
\hline Metals, Total & $\operatorname{Tin}$ & SW 6010 & $\mathrm{ug} / \mathrm{ml}$ & $<$ & 0.0576 & $<$ & 0.0576 & & $<$ & 0.144 & $<$ & 0.144 & & $<$ & 0.086 & $\cdots$ & $100 \%$ \\
\hline Metals, Total & Titanium & SW 6010 & $\mathrm{ug} / \mathrm{ml}$ & & 0.351 & & 0.566 & & & 2.38 & & 0.855 & & & 1.099 & 2.769 & \\
\hline Metals, Total & Vanadium & SW 6010 & $\mathrm{ug} / \mathrm{ml}$ & & 0.158 & & 0.145 & & & 0.346 & & 0.163 & & & 0.216 & 0.279 & \\
\hline Metals, Total & Zlnc & SW 6010 & $u g / m l$ & & 0.841 & & 0.715 & & & 0.884 & & 0.81 & & & 0.813 & 0.218 & \\
\hline
\end{tabular}

Gypsum Pond Water - Page 2 


\section{Liquid Stream Data Summary}

Sample Stream: Gypsum Pond Water

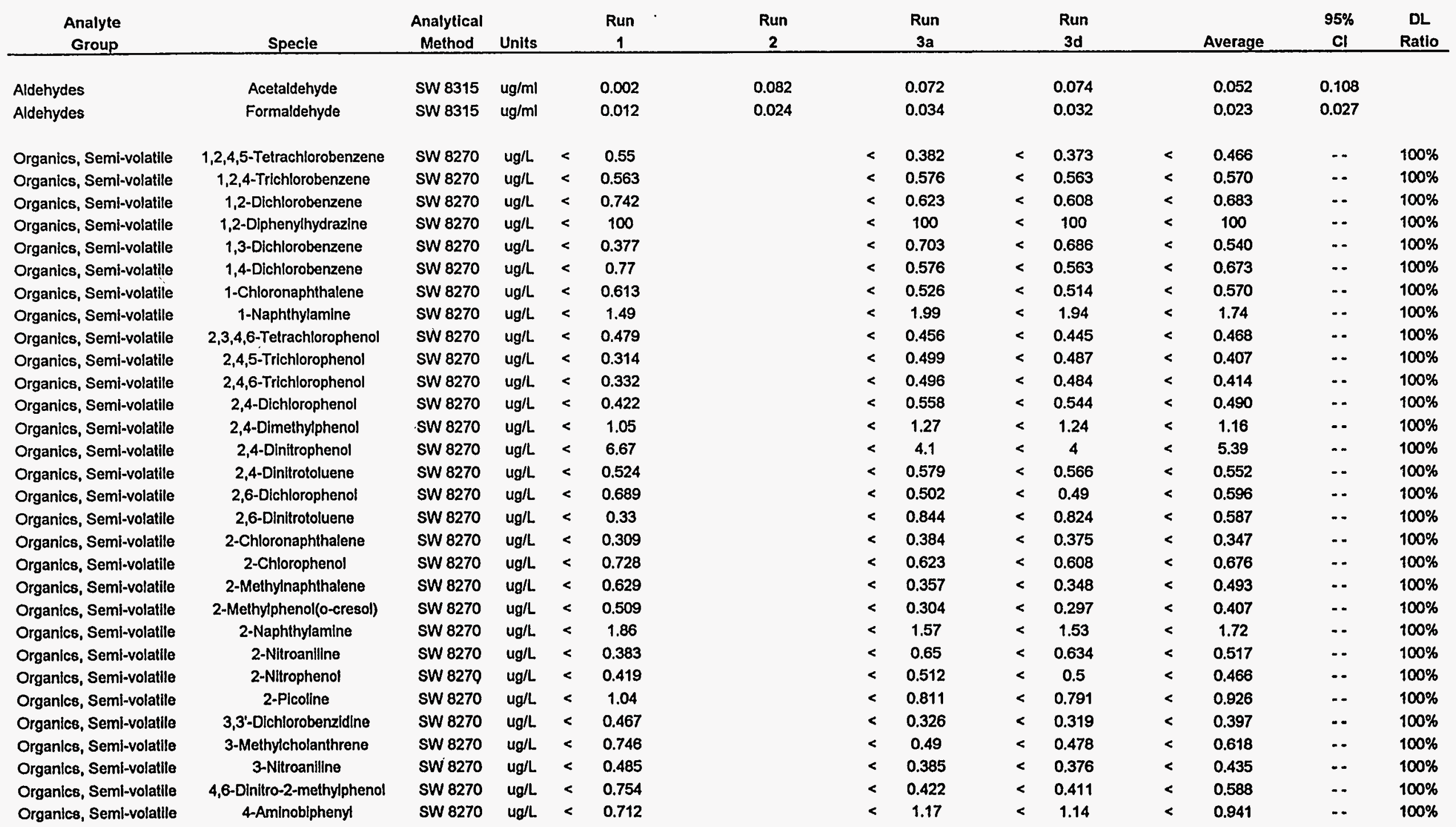


Sample Stream: Gypsum Pond Water

\section{Liquid Stream Data Summary}

\begin{tabular}{|c|c|c|c|c|c|c|c|c|c|c|c|c|c|c|}
\hline $\begin{array}{c}\text { Analyte } \\
\text { Group }\end{array}$ & Specie & $\begin{array}{c}\text { Analytical } \\
\text { Method }\end{array}$ & Units & & $\begin{array}{c}\text { Run } \\
1 \\
\end{array}$ & $\begin{array}{c}\text { Run } \\
2 \\
\end{array}$ & & $\begin{array}{c}\text { Run } \\
3 \mathbf{a}\end{array}$ & & $\begin{array}{c}\text { Run } \\
3 d\end{array}$ & & Average & $\begin{array}{c}95 \% \\
\mathrm{Cl} \\
\end{array}$ & $\begin{array}{c}\mathrm{DL} \\
\text { Ratio }\end{array}$ \\
\hline Organics, Semi-volatile & 4-Bromophenyl phenyl & SW 8270 & ug/L & $<$ & 0.434 & & $<$ & 0.475 & $<$ & 0.463 & $<$ & 0.455 & - & $100 \%$ \\
\hline Organics, Semi-volatile & 4-Chlora-3-methylphenol & SW 8270 & $\mathrm{ug} / \mathrm{L}$ & $<$ & 0.689 & & $<$ & 0.505 & $<$ & 0,493 & $<$ & 0.597 & - & $100 \%$ \\
\hline Organics, Semi-volatile & 4-Chlorophenyl phenyl ether & SW 8270 & ug/L & $<$ & 0.503 & & $<$ & 0.413 & $<$ & 0.403 & $<$ & 0.458 & - & $100 \%$ \\
\hline Organics, Semi-volatile & 4-Methylphenol(p-cresol) & SW 8270 & ug/L & $<$ & 0.548 & & $<$ & 0.45 & $<$ & 0.439 & $<$ & 0.499 & $\cdots$ & $100 \%$ \\
\hline Organics, Semi-volatile & 4-Nitroaniline & SW 8270 & ug/L & $<$ & 0.461 & & $<$ & 0.594 & $<$ & 0.58 & $<$ & 0.528 & $\cdots$ & $100 \%$ \\
\hline Organics, Seml-volatile & 4-Nitrophenol & SW 8270 & ug/L & $<$ & 0.658 & & $<$ & 0.919 & $<$ & 0.897 & $<$ & 0.789 & $\cdots$ & $100 \%$ \\
\hline Organics, Semi-volatile & 7,12-Dimethylbenz(a)anthracen & SW 8270 & ug/L & $<$ & 1.83 & & $<$ & 1.3 & $<$ & 1.27 & $<$ & 1.57 & $\cdots$ & $100 \%$ \\
\hline Organics, Semi-volatile & Acenaphthene & SW 8270 & $\mathrm{ug} / \mathrm{L}$ & $<$ & 0.455 & & $<$ & 0.267 & $<$ & 0.26 & $<$ & 0.361 & - & $100 \%$ \\
\hline Organics, Semi-volatile & Acenaphthylene & SW 8270 & ug/L & $<$ & 0.215 & & $<$ & 0.41 & $<$ & 0.4 & $<$ & 0.313 & $\cdots$ & $100 \%$ \\
\hline Organics, Semi-volatile & Acetophenone & SW 8270 & $\mathrm{ug} / \mathrm{L}$ & $<$ & 0.437 & & $<$ & 0.548 & $<$ & 0.535 & $<$ & 0.493 & $\cdots$ & $100 \%$ \\
\hline Organies, Semi-volatile & Aniline & SW 8270 & ug/L. & $<$ & 0.889 & & $<$ & 0.604 & $<$ & 0.589 & $<$ & 0.747 & $\cdots$ & $100 \%$ \\
\hline Organics, Semi-volatile & Anthracene & SW 8270 & ug/L. & $<$ & 0.553 & & $<$ & 0.361 & $<$ & 0.352 & $<$ & 0.457 & -- & $100 \%$ \\
\hline Organics, Semi-volatile & Benzidine & SW 8270 & ug/L & $<$ & $20^{\circ}$ & & $<$ & 20 & $<$ & 20 & $<$ & 20 &.- & $100 \%$ \\
\hline Organics, Semi-volatile & Benzo(a)anthracene & SW 8270 & ug/L & $<$ & 0.49 & & $<$ & 0.44 & $<$ & 0.43 & $<$ & 0.47 & $\cdots$ & $100 \%$ \\
\hline Organics, Semi-volatile & Benzo(a)pyrene & SW 8270 & ug/L & $<$ & 0.365 & & $<$ & 0.508 & $<$ & 0.496 & $<$ & 0.437 & -- & $100 \%$ \\
\hline Organics, Semi-volatile & Benzo(b)fluoranthene & SW 8270 & ug/L & $<$ & 0.542 & & $<$ & 0.89 & $<$ & 0.869 & $<$ & 0.716 & $\cdots$ & $100 \%$ \\
\hline Organics, Semi-volatile & Benzo $(g, h, i)$ perylene & SW 8270 & ug/L & $<$ & 0.464 & & $<$ & 1 & $<$ & 0.976 & $<$ & 0.732 &.- & $100 \%$ \\
\hline Organics, Semi-volatile & Benzo(k)fluoranthene & SW 8270 & ug/L. & $<$ & 0.922 & & $<$ & 0.979 & $<$ & 0.956 & $<$ & 0.951 & $-\cdot$ & $100 \%$ \\
\hline Organics, Semi-volatile & Benzolc acid & SW 8270 & ug/L & $<$ & 3.77 & & $<$ & 37.8 & $<$ & 36.9 & $<$ & 20.79 & - & $100 \%$ \\
\hline Organics, Semi-volatile & Benzyl alcohol & SW 8270 & ug/L & $<$ & 1.03 & & $<$ & 0.598 & $<$ & 0.584 & $<$ & 0.814 & $\ldots$ & $100 \%$ \\
\hline Organics, Semi-volatlle & Butylbenzyiphthalate & SW 8270 & ug/L & & 0.296 & J & $<$ & 0.613 & $<$ & 0.598 & $<$ & 0.613 & $\cdots$ & $51 \%$ \\
\hline Organics, Semi-volatile & Chrysene & SW 8270 & ug/L & $<$ & 0.637 & & $<$ & 0.526 & $<$ & 0.514 & $<$ & 0.582 & - & $100 \%$ \\
\hline Organics, Semi-volatile & Di-n-octylphthalate & SW 8270 & ug/L & $<$ & 0.868 & & $<$ & 0.345 & $<$ & 0.337 & $<$ & 0.607 & -- & $100 \%$ \\
\hline Organics, Semi-volatile & Dibenz $(a, h)$ anthracene & SW 8270 & ug/L & $<$ & 0.451 & & $<$ & 0.795 & $<$ & 0.776 & $<$ & 0.623 & $\cdots$ & $100 \%$ \\
\hline Organics, Semi-volatile & Dibenz $(a, j)$ acridine & SW 8270 & ug/L & $<$ & 0.553 & & $<$ & 0.825 & $<$ & 0.806 & $<$ & 0.689 & -. & $100 \%$ \\
\hline Organics, Semi-volatile & Dibenzofuran & SW 8270 & ug/L & $<$ & 0.389 & & $<$ & 0.526 & $<$ & 0.514 & $<$ & 0.458 & -- & $100 \%$ \\
\hline Organics, Seml-volatile & Dibutylphthalate & SW 8270 & ug/L & $<$ & 0.47 & & $<$ & 0.318 & $<$ & 0.31 & $<$ & 0.394 & $\cdots$ & $100 \%$ \\
\hline Organics, Semi-volatile & Diethylphthalate & SW 8270 & ug/L. & $<$ & 0.32 & & $<$ & 0.505 & $<$ & 0.493 & $<$ & 0.413 & -. & $100 \%$ \\
\hline Organics, Semi-volatile & Dimethylphenethylamine & SW 8270 & Ug $/ L$ & $<$ & 120 & & $<$ & 120 & $<$ & 120 & $<$ & 120 & -. & $100 \%$ \\
\hline Organics, Semi-volatile & Dimethylphthalate & SW 8270 & ugh & & 1.44 & & & 1.09 & & 1.02 & & 1.27 & 2.22 & \\
\hline Organics, Semi-volattle & Dlphenylamine & sw 8270 & ug/L & $<$ & 0.503 & & $<$ & 0.272 & $<$ & 0.265 & $<$ & 0.388 & -- & $100 \%$ \\
\hline Organics, Semi-volatile & Ethyl methanesulfonate & SW 8270 & ug/L & $<$ & 0.479 & & $<$ & 0.666 & $<$ & 0.65 & $<$ & 0.573 & -. & $100 \%$ \\
\hline Organics, Semi-volatlle & Fluoranthene & SW 8270 & ug/h & $<$ & 0.608 & & $<$ & 0.462 & $<$ & 0.451 & $<$ & 0.535 & $\cdots$ & $100 \%$ \\
\hline
\end{tabular}

\footnotetext{
Gypsum Pond Water - Page 4
} 


\section{Liquid Stream Data Summary}

Sample Stream: Gypsum Pond Water

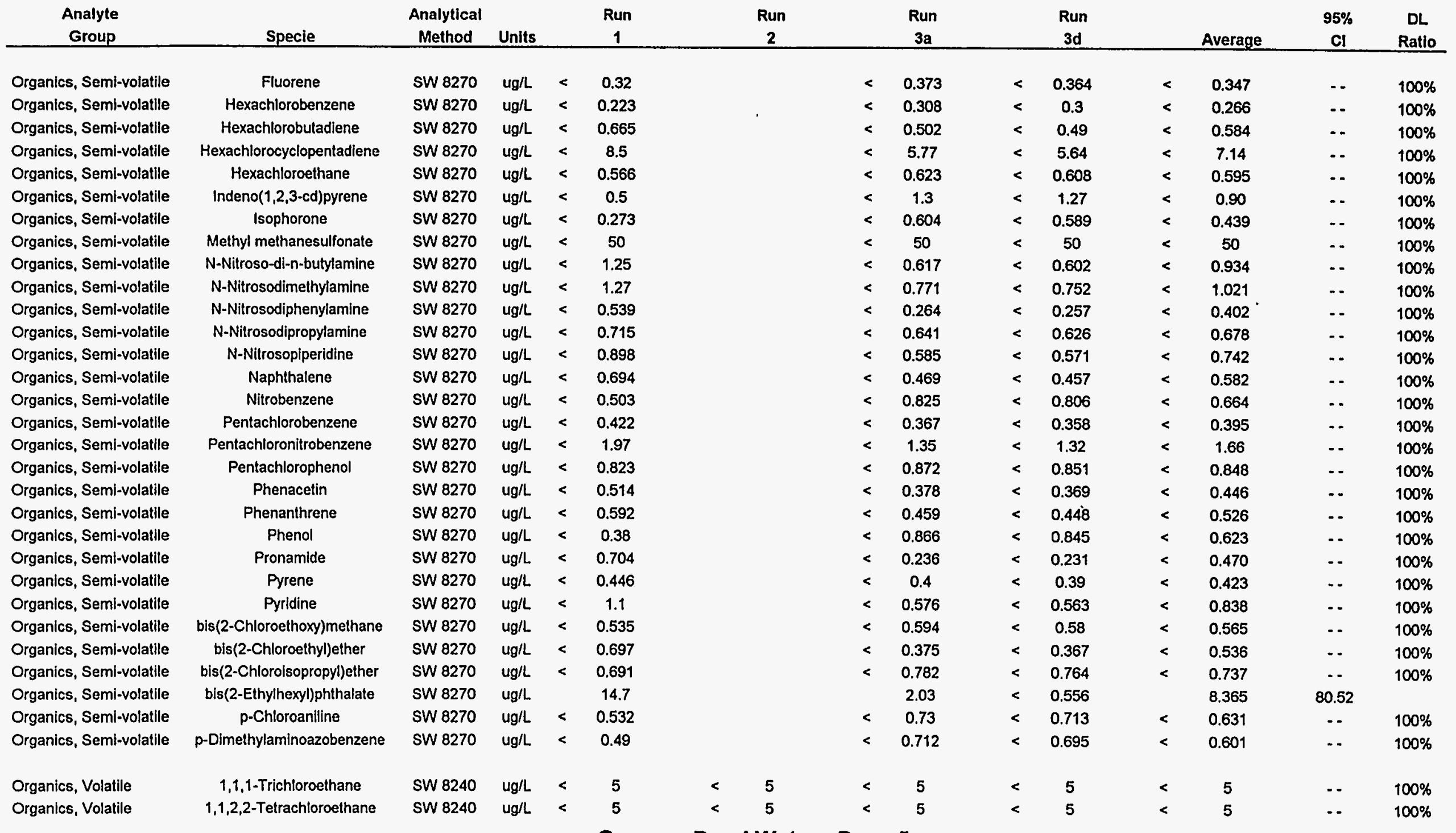

Gypsum Pond Water - Page 5 


\section{Liquid Stream Data Summary}

Sample Stream: Gypsum Pond Water

\begin{tabular}{|c|c|c|c|c|c|c|c|c|c|c|c|c|c|c|c|c|c|}
\hline $\begin{array}{c}\text { Analyte } \\
\text { Group }\end{array}$ & Specie & $\begin{array}{l}\text { Analytical } \\
\text { Method }\end{array}$ & Units & & $\begin{array}{c}\text { Run } \\
1 \\
\end{array}$ & & $\begin{array}{c}\text { Run } \\
2 \\
\end{array}$ & & & $\begin{array}{c}\text { Run } \\
3 \mathbf{a}\end{array}$ & & & $\begin{array}{c}\text { Run } \\
3 d \\
\end{array}$ & & Average & $\begin{array}{c}95 \% \\
\text { CI }\end{array}$ & $\begin{array}{c}\mathrm{DL} \\
\text { Ratio }\end{array}$ \\
\hline Organics, Volatile & 1,1,2-Trichloroethane & SW 8240 & $\mathrm{ug} / \mathrm{L}$ & $<$ & 5 & $<$ & 5 & & $<$ & 5 & & $<$ & 5 & $<$ & 5 & .. & $100 \%$ \\
\hline Organics, Volatile & 1,1-Dichloroelhane & SW 8240 & ug/L & $<$ & 5 & $<$ & 5 & & $<$ & 5 & & $<$ & 5 & $<$ & 5 & -. & $100 \%$ \\
\hline Organics, Volatile & 1,1-Dichtoroéthene & SW 8240 & ug/L & $<$ & 5 & $<$ & 5 & & $<$ & 5 & & $<$ & 5 & $<$ & 5 & $\cdots$ & $100 \%$ \\
\hline Organics, Volatile & 1,2-Dichloroethane & SW 8240 & ug/L & $<$ & 5 & $<$ & 5 & & $<$ & 5 & & $<$ & 5 & $<$ & 5 & $\cdots$ & $100 \%$ \\
\hline Organics, Volatile & 1,2-Dichloroethene (tolal) & SW 8240 & ug/L & $<$ & 5 & $<$ & 5 & & $<$ & 5 & & $<$ & 5 & $<$ & 5 &.- & $100 \%$ \\
\hline Organics, Volatile & 1,2-Dichloropropane & SW 8240 & ug/L & $<$ & 5 & $<$ & 5 & & $<$ & 5 & & $<$ & 5 & $<$ & 5 & -. & $100 \%$ \\
\hline Organics, Volatile & 2-Butanone (MEK) & SW 8240 & ug/L & $<$ & 10 & $<$ & 10 & & $<$ & 10 & & $<$ & 10 & $<$ & 10 & $-\cdot$ & $100 \%$ \\
\hline Organics, Volatile & 2-Hexanone & SW 8240 & ug/L & $<$ & 10 & $<$ & 10 & & $<$ & 10 & & $<$ & 10 & $<$ & 10 & $\ldots$ & $100 \%$ \\
\hline Organics, Volatile & 4-Methyl-2-pentanone (MIBK) & SW 8240 & ug/L & $<$ & 10 & $<$ & 10 & & $<$ & 10 & & $<$ & 10 & $<$ & 10 & -- & $100 \%$ \\
\hline Organics, Volatile & Acetone & SW 8240 & ug/L & $<$ & 10 & & 6.8 & $\mathbf{J}$ & & 7.1 & $\mathrm{~J}$ & & 11 & $<$ & 10 & - & $26 \%$ \\
\hline Organics, Volatile & Benzene & SW 8240 & ug/L & $<$ & 5 & $<$ & 5 & & $<$ & 5 & & $<$ & 5 & $<$ & 5 & $\cdots$ & $100 \%$ \\
\hline Organics, Volatile & Bromodichloromethane & SW 8240 & ug/L & $<$ & 5 & $<$ & 5 & & $<$ & 5 & & $<$ & 5 & $<$ & 5 & $-\cdot$ & $100 \%$ \\
\hline Organics, Volatile & Bromoform & SW 8240 & ug/L & $<$ & 5 & $<$ & 5 & & $<$ & 5 & & $<$ & 5 & $<$ & 5 & $\cdots$ & $100 \%$ \\
\hline Organics, Volatile & Bromomethane & SW 8240 & $\mathrm{ug} / \mathrm{L}$ & $<$ & 10 & $<$ & 10 & & $<$ & 10 & & $<$ & 10 & $<$ & 10 & $\cdots$ & $100 \%$ \\
\hline Organics, Volatile & Carbon Disulfide & SW 8240 & ug/L & $<$ & 5 & $<$ & 5 & & $<$ & 5 & & $<$ & 5 & $<$ & 5 & $\cdots$ & $100 \%$ \\
\hline Organics, Volatile & Carbon Tetrachloride & SW 8240 & ug/L & $<$ & 5 & $<$ & 5 & & $<$ & 5 & & $<$ & 5 & $<$ & 5 & $\cdots$ & $100 \%$ \\
\hline Organics, Volatile & Chlorobenzene & SW 8240 & ug/L & $<$ & 5 & $<$ & 5 & & $<$ & 5 & & $<$ & 5 & $<$ & 5 & $\cdots$ & $100 \%$ \\
\hline Organics, Volatile. & Chloroethane & SW 8240 & $u g / h$ & $<$ & 10 & $<$ & 10 & & $<$ & 10 & & $<$ & 10 & $<$ & 10 & $\cdots$ & $100 \%$ \\
\hline Organics, Volatile & Chloroform & SW 8240 & ug/L & $<$ & 5 & $<$ & 5 & & $<$ & 5 & & $<$ & 5 & $<$ & 5 & - & $100 \%$ \\
\hline Organics, Volatile & Chloromethane & SW 8240 & ug/L & $<$ & 10 & $<$ & 10 & & $<$ & 10 & & $<$ & 10 & $<$ & 10 & -. & $100 \%$ \\
\hline Organics, Volatile & Dibromochloromethane & SW 8240 & ug/L & $<$ & 5 & $<$ & 5 & & $<$ & 5 & & $<$ & 5 & $<$ & 5 & - & $100 \%$ \\
\hline Organics, Volatlle & Ethylbenzene & SW 8240 & ug/L & $<$ & 5 & $<$ & 5 & & $<$ & 5 & & $<$ & 5 & $<$ & 5 & $\cdots$ & $100 \%$ \\
\hline Organics, Volatile & Methylene Chloride & SW 8240 & $u g / L$ & $<$ & 5 & & 3.8 & $\mathrm{~J}$ & & 4.9 & $\mathbf{J}$ & & 7 & $<$ & 5 & $\cdots$ & $22 \%$ \\
\hline Organics, Volatile & Styrene & SW 8240 & ug/L & $<$ & 5 & $<$ & 5 & & $<$ & 5 & & $<$ & 5 & $<$ & 5 & $\cdots$ & $100 \%$ \\
\hline Organics, Volatile & Tetrachloroethene & SW 8240 & ug/L & $<$ & 5 & $<$ & 5 & & $<$ & 5 & & $<$ & 5 & $<$ & 5 & - & $100 \%$ \\
\hline Organics, Volatile & Toluene & SW 8240 & ug/L & $<$ & 5 & $<$ & 5 & & $<$ & 5 & & $<$ & 5 & $<$ & 5 & $\cdots$ & $100 \%$ \\
\hline Organics, Volatile & Trichloroethene & SW 8240 & ug/L & $<$ & 5 & $<$ & 5 & & $<$ & 5 & & $<$ & 5 & $<$ & 5 & -- & $100 \%$ \\
\hline Organics, Volatile & Vinyl acetate & SW 8240 & ug/L & $<$ & 10 & $<$ & 10 & & $<$ & 10 & & $<$ & 10 & $<$ & 10 & $\cdots$ & $100 \%$ \\
\hline Organics, Volatile & Vinyl chloride & SW 8240 & $u g / L$ & $<$ & 10 & $<$ & 10 & & $<$ & 10 & & $<$ & 10 & $<$ & 10 & $\cdots$ & $100 \%$ \\
\hline Organics, Volatile & Xylenes & SW 8240 & ug/L & $<$ & 5 & $<$ & 5 & & $<$ & 5 & & $<$ & 5 & $<$ & 5 & $\cdots$ & $100 \%$ \\
\hline Organics, Volatile & cis-1,3-Dichloropropene & SW 8240 & $\mathrm{ug} / \mathrm{L}$ & $<$ & 5 & $<$ & 5 & & $<$ & 5 & & $<$ & 5 & $<$ & 5 & $\cdots$ & $100 \%$ \\
\hline Organics, Volatile & trans-1,3-Dichloropropene & SW 8240 & $u g / L$ & $<$ & 5 & $<$ & 5 & & $<$ & 5 & & $<$ & 5 & $<$ & 5 & $\cdots$ & $100 \%$ \\
\hline
\end{tabular}

\section{Gypsum Pond Water - Page 6}




\section{Liquid Stream Data Summary}

Sample Stream: JBR Underflow Slurry Filtrate

\begin{tabular}{|c|c|c|c|c|c|c|c|c|c|c|c|c|c|c|c|c|c|}
\hline $\begin{array}{c}\text { Analyte } \\
\text { Group }\end{array}$ & Specie & $\begin{array}{c}\text { Analytical } \\
\text { Method }\end{array}$ & Units & & $\begin{array}{c}\text { Run } \\
1 \\
\end{array}$ & & $\begin{array}{c}\text { Run } \\
2 \\
\end{array}$ & & & $\begin{array}{r}\text { Run } \\
3 a\end{array}$ & & & $\begin{array}{c}\text { Run } \\
\text { 3d }\end{array}$ & & Average & $\begin{array}{c}95 \% \\
\mathrm{Cl} \\
\end{array}$ & $\begin{array}{c}\text { DL } \\
\text { Ratio } \\
\end{array}$ \\
\hline Reduced Specles & Cyanide & SW 9012 & ug/ml & & 0.114 & & 0.0372 & & & 0.0959 & & & 0.0205 & & 0.0824 & 0.0997 & \\
\hline Reduced Specles & Ammonia as $\mathrm{N}$ & EPA 350.1 & $\mathrm{ug} / \mathrm{ml}$ & & 43.9 & & 43 & & $<$ & 40.2 & & & 41.6 & $<$ & 40.2 & -. & $19 \%$ \\
\hline Anions & Chloride & EPA 300 & $\mathrm{ug} / \mathrm{ml}$ & & 27,200 & & 24,100 & & & 26,900 & & & 25,600 & & 26,067 & 4,248 & \\
\hline Anions & Fluoride & EPA 340.2 & $\mathrm{ug} / \mathrm{ml}$ & & 23.8 & & 35.1 & & & 34.1 & & & 34.1 & & 31.0 & 15.5 & \\
\hline Anlons & Phosphate & EPA 365.2 & $\mathrm{ug} / \mathrm{ml}$ & $<$ & 0.02 & & 0.118 & & & 0.0122 & $J$ & $<$ & 0.02 & & 0.047 & 0.153 & $7 \%$ \\
\hline Anions & Sulfate & EPA 300.0 & $\mathrm{ug} / \mathrm{ml}$ & & 740 & & 688 & & & 709 & & & 709 & & 712 & 65 & \\
\hline Anions & Sulfite & EPRI-FGD-M2 & $\mathrm{ug} / \mathrm{ml}$ & & 4 & & 1.6 & & & 2.4 & & & 1.6 & & 2.67 & 3.04 & \\
\hline Metals, Soluble & Aluminum & SW 6010 & $\mathrm{ug} / \mathrm{ml}$ & & 10.7 & & 14.4 & & & 11.9 & & & 12.4 & & 12.3 & 4.7 & \\
\hline Metals, Soluble & Antimony & SW 6010 & $\mathrm{ug} / \mathrm{ml}$ & $<$ & 0.241 & $<$ & 0.241 & & $<$ & 0.0964 & & $<$ & 0.241 & $<$ & 0.1928 & - & $100 \%$ \\
\hline Metals, Soluble & Arsenic & SW 7060 & $\mathrm{ug} / \mathrm{ml}$ & & 0.315 & & 0.157 & & & 0.121 & & & 0.352 & & 0.198 & 0.256 & \\
\hline Metals, Soluble & Barium & SW 6010 & $\mathrm{ug} / \mathrm{ml}$ & & 3.33 & & 3.52 & & & 3.31 & & & 3.99 & & 3.39 & 0.29 & \\
\hline Metals, Soluble & Beryllium & SW 6010 & $\mathrm{ug} / \mathrm{ml}$ & & 0.0085 & & 0.0048 & J & & 0.00728 & & & 0.0042 & $J$ & 0.0069 & 0.0047 & \\
\hline Metals, Soluble & Boron & SW 6010 & $\mathrm{ug} / \mathrm{ml}$ & & 1450 & & 1430 & & & 1310 & & & 1480 & & 1,397 & 188 & \\
\hline Metals, Soluble & Cadmium & SW 7131 & $\mathrm{ug} / \mathrm{ml}$ & & 0.473 & & 0.47 & & & 0.426 & & & 0.467 & & 0.456 & 0.065 & \\
\hline Metals, Soluble & Calcium & SW 6010 & $\mathrm{ug} / \mathrm{ml}$ & & 20,100 & & 19,300 & & & 12,600 & & & 19,000 & & 17,333 & 10,232 & \\
\hline Metals, Soluble & Chromium & SW 6010 & $\mathrm{ug} / \mathrm{ml}$ & & 0.096 & & 0.0851 & & & 0.0277 & & & 0.0791 & & 0.0696 & 0.0912 & \\
\hline Metals, Soluble & Cobalt & SW 6010 & $\mathrm{ug} / \mathrm{ml}$ & & 0.303 & & 0.303 & & & 0.305 & & & 0.316 & & 0.304 & 0.003 & \\
\hline Metals, Soluble & Copper & SW 6010 & $\mathrm{ug} / \mathrm{ml}$ & & 0.242 & & 0.272 & & & 0.203 & & & 0.234 & & 0.239 & 0.086 & \\
\hline Metals, Soluble & Iron & SW 6010 & $\mathrm{ug} / \mathrm{ml}$ & $<$ & 0.0596 & $<$ & 0.0596 & & $<$ & 0.0238 & & $<$ & 0.0596 & $<$ & 0.0477 & -. & $100 \%$ \\
\hline Metals, Soluble & Lead & SW 7421 & $\mathrm{ug} / \mathrm{ml}$ & & 0.0139 & & 0.016 & & & 0.009 & & & 0.012 & & 0.013 & 0.009 & \\
\hline Metals, Soluble & Magnesium & SW 6010 & $\mathrm{ug} / \mathrm{ml}$ & & 1830 & & 1810 & & & 1750 & & & 1870 & & 1,797 & 103 & \\
\hline Metals, Soluble & Manganese & SW 6010 & $\mathrm{ug} / \mathrm{ml}$ & & 318 & & 315 & & & 288 & & & 326 & & 307 & 41 & \\
\hline Metals, Soluble & Mercury & SW 7470 & $\mathrm{ug} / \mathrm{ml}$ & & 0.00056 & & 0.0014 & & & 0.00111 & & & 0.00125 & & 0.00102 & 0.00106 & \\
\hline Metals, Soluble & Molybdenum & SW 6010 & $\mathrm{ug} / \mathrm{ml}$ & & 0.0571 & & 0.0659 & & & 0.0695 & & & 0.0619 & & 0.0642 & 0.0158 & \\
\hline Metals, Soluble & Nickel & SW 6010 & $\mathrm{ug} / \mathrm{ml}$ & & 1.57 & & 1.61 & & & 1.37 & & & 1.61 & & 1.52 & 0.32 & \\
\hline Metals, Soluble & Phosphorus & SW 6010 & $\mathrm{ug} / \mathrm{ml}$ & & 0.675 & & 0.777 & & & 0.703 & & & 0.916 & & 0.718 & 0.131 & \\
\hline Metals, Soluble & Potasslum & SW 6010 & $\mathrm{ug} / \mathrm{ml}$ & & 125 & & 125 & & & 119 & & & 126 & & 123 & 9 & \\
\hline Metals, Soluble & Selenium & SW 7740 & $\mathrm{ug} / \mathrm{ml}$ & $<$ & 0.00288 & & 0.734 & & & 0.728 & & & 0.814 & & 0.488 & 1.046 & $0.1 \%$ \\
\hline Metals, Soluble & Silicon & SW 6010 & $\mathrm{ug} / \mathrm{ml}$ & & 39.7 & & 44.3 & & & 43.3 & & & 45.4 & & 42.4 & 6.0 & \\
\hline
\end{tabular}




\section{Liquid Stream Data Summary}

Sample Stream: JBR Underflow Slurry Filtrate

\begin{tabular}{|c|c|c|c|c|c|c|c|c|c|c|c|c|c|c|c|c|}
\hline $\begin{array}{c}\text { Analyte } \\
\text { Group }\end{array}$ & Specie & $\begin{array}{c}\text { Analytical } \\
\text { Method }\end{array}$ & Units & & $\begin{array}{c}\text { Run } \\
1 \\
\end{array}$ & & $\begin{array}{c}\text { Run } \\
2 \\
\end{array}$ & & & $\begin{array}{c}\text { Run } \\
3 \mathbf{a} \\
\end{array}$ & & $\begin{array}{c}\text { Run } \\
3 d\end{array}$ & & Average & $\begin{array}{c}95 \% \\
\mathrm{Cl} \\
\end{array}$ & $\begin{array}{c}\text { DL } \\
\text { Ratio }\end{array}$ \\
\hline Metals, Soluble & Sodium & SW 6010 & $\mathrm{ug} / \mathrm{ml}$ & & 244 & & 242 & & & 246 & & 256 & & 244 & 5 & \\
\hline Metals, Soluble & Strontium & SW 6010 & $\mathrm{ug} / \mathrm{ml}$ & - & 34.1 & & 33.6 & & & 30.9 & & 35 & & 32.9 & 4.3 & \\
\hline Metals, Soluble & Tin & SW 6010 & $u g / m l$ & $<$ & 0.144 & & 0.0007 & J & $<$ & 0.144 & $<$ & 0.144 & $<$ & 0.144 & - & $100 \%$ \\
\hline Metals, Soluble & Tilanium & SW 6010 & $\mathrm{ug} / \mathrm{ml}$ & & 0.762 & & 0.817 & & & 0.868 & & 0.739 & & 0.816 & 0.132 & \\
\hline Metals, Soluble & Vanadlum & SW 6010 & ug/ml & & 0.296 & & 0.29 & & & 0.138 & & 0.288 & & 0.241 & 0.222 & \\
\hline Metals, Soluble & Zinc & SW 6010 & $\mathrm{ug} / \mathrm{ml}$ & & 2.34 & & 2.43 & & & 2.18 & & 2.52 & & 2.32 & 0.31 & \\
\hline Aldehydes & Acetaldehyde & SW 8315 & $u g / m l$ & & 0.008 & & 0.078 & & & 0.096 & & 0.072 & & 0.061 & 0.115 & \\
\hline Aldehydes & Formaldehyde & SW 8315 & $\mathrm{ug} / \mathrm{ml}$ & & 0.004 & & 0.048 & & & 0.2 & & 0.152 & & 0.084 & 0.255 & \\
\hline Organics, Semi-volatile & 1,2,4,5-Tetrachlorobenzene & SW 8270 & ug/L & $<$ & 0.625 & $<$ & 0.567 & & $<$ & 0.561 & $<$ & 0.456 & $<$ & 0.584 & -- & $100 \%$ \\
\hline Organics, Semi-volatile & 1,2,4-Trichlorobenzene & SW 8270 & ug/L & $<$ & 0.639 & $<$ & 0.579 & & $<$ & 0.846 & $<$ & 0.688 & $<$ & 0.688 & -- & $100 \%$ \\
\hline Organics, Seml-volatile & 1,2-Dichlorobenzene & SW 8270 & ug/L & $<$ & 0.842 & $<$ & 0.764 & & $<$ & 0.914 & $<$ & 0.743 & $<$ & 0.840 & -- & $100 \%$ \\
\hline Organics, Seml-volatile & 1,2-Diphenylhydrazine & SW 8270 & $u g / L$ & $<$ & 100 & $<$ & 100 & & $<$ & 100 & $<$ & 100 & $<$ & 100 & -- & $100 \%$ \\
\hline Organics, Semi-volatile & 1,3-Dichlorobenzene & SW 8270 & ug/L & $<$ & 0.428 & $<$ & 0.388 & & $<$ & 1.03 & $<$ & 0.839 & $<$ & 0.615 & - & $100 \%$ \\
\hline Organics, Semi-volatile & 1,4-Dichlorobenzene & SW 8270 & ug/L & $<$ & 0.874 & $<$ & 0.792 & & $<$ & 0.846 & $<$ & 0.688 & $<$ & 0.837 & $-\infty$ & $100 \%$ \\
\hline Organics, Semi-volatile & 1-Chloronaphthalene & SW 8270 & $\mathrm{ug} / \mathrm{L}$ & $<$ & 0.696 & $<$ & 0.631 & & $<$ & 0.773 & $<$ & 0.628 & $<$ & 0.700 & $\cdots$ & $100 \%$ \\
\hline Organics, Semi-volatile & 1-Naphlhylamine & SW 8270 & $u g / L$ & $<$ & 1.69 & $<$ & 1.53 & & $<$ & 2.92 & $<$ & 2.37 & $<$ & 2.05 & $\cdots$ & $100 \%$ \\
\hline Organics, Semi-volatlle & 2,3,4,6-Tetrachlorophenol & SW 8270 & ug/L & $<$ & 0.544 & $<$ & 0.493 & & $<$ & 0.669 & $<$ & 0.544 & $<$ & 0.569 & $\cdots$ & $100 \%$ \\
\hline Organics, Semi-volatlle & 2,4,5-Trichloropheno! & SW 8270 & $u g / L$ & $<$ & 0.357 & $<$ & 0.324 & & $<$ & 0.732 & $<$ & 0.595 & $<$ & 0.471 & $\cdots$ & $100 \%$ \\
\hline Organics, Semi-volatile & 2,4,6-Trichlorophenol & SW 8270 & ug/L. & $<$ & 0.377 & $<$ & 0.342 & & $<$ & 0.728 & $<$ & 0.592 & $<$ & 0.482 & $\cdots$ & $100 \%$ \\
\hline Organics, Semi-volatile & 2,4-Dichlorophenol & SW 8270 & $u g / L$ & $<$ & 0.479 & $<$ & 0.434 & & $<$ & 0.819 & $<$ & 0.665 & $<$ & 0.577 & $-\cdots$ & $100 \%$ \\
\hline Organics, Semi-volatile & 2,4-Dimethylphenol & SW 8270 & $u g / L$ & $<$ & 1.19 & $<$ & 1.08 & & $<$ & 1.87 & $<$ & 1.52 & $<$ & 1.38 & -- & $100 \%$ \\
\hline Organics, Semi-volatile & 2,4-Dinitrophenol & SW 8270 & ug/L & $<$ & 7.57 & $<$ & 6.86 & & $<$ & 6.01 & $<$ & 4.89 & $<$ & 6.81 & $\cdots$ & $100 \%$ \\
\hline Organics, Semi-volatile & 2,4-Dinitrotoluene & SW 8270 & ug/L & $<$ & 0.595 & $<$ & 0.539 & & $<$ & 0.85 & $<$ & 0.691 & $<$ & 0.661 & -. & $100 \%$ \\
\hline Organics, Semi-volatile & 2,6-Dichlorophenol & SW 8270 & ug/L & $<$ & 0.782 & $<$ & 0.709 & & $<$ & 0.737 & $<$ & 0.599 & $<$ & 0.743 & $\cdots$ & $100 \%$ \\
\hline Organics, Semi-volatile & 2,6-Dinitrotoluene & SW 8270 & ug/L & $<$ & 0.374 & $<$ & 0.339 & & $<$ & 1.24 & $<$ & 1.01 & $<$ & 0.651 & $-\cdot$ & $100 \%$ \\
\hline Organics, Semi-volatile & 2-Chloronaphthalene & SW 8270 & ug/L & $<$ & 0.35 & $<$ & 0.318 & & $<$ & 0.564 & $<$ & 0.458 & $<$ & 0.411 & -- & $100 \%$ \\
\hline Organics, Semi-volatile & 2-Chlorophenol & SW 8270 & ug/L & $<$ & 0.826 & $<$ & 0.749 & & $<$ & 0.914 & $<$ & 0.743 & $<$ & 0.830 & - & $100 \%$ \\
\hline Organics, Semi-volatile & 2-Methylnaphthalene & SW 8270 & $\mathrm{ug} / \mathrm{L}$ & $<$ & 0.714 & $<$ & 0.647 & & $<$ & 0.524 & $<$ & 0.426 & $<$ & 0.628 & - & $100 \%$ \\
\hline Organics, Semi-volatile & 2-Methylphenol(a-cresol) & SW 8270 & ug/L & $<$ & 0.577 & $<$ & 0.524 & & $<$ & 0.446 & $<$ & 0.363 & $<$ & 0.516 & $\cdots$ & $100 \%$ \\
\hline
\end{tabular}




\section{Liquid Stream Data Summary}

Sample Stream: JBR Underflow Slurry Filtrate

\begin{tabular}{|c|c|c|c|c|c|c|c|c|c|c|c|c|c|c|c|}
\hline $\begin{array}{c}\text { Analyte } \\
\text { Group }\end{array}$ & Specie & $\begin{array}{l}\text { Analytical } \\
\text { Method }\end{array}$ & Units & & $\begin{array}{c}\text { Run } \\
1\end{array}$ & & $\begin{array}{c}\text { Run } \\
2\end{array}$ & & $\begin{array}{r}\text { Run } \\
\mathbf{3 a}\end{array}$ & & $\begin{array}{c}\text { Run } \\
3 d\end{array}$ & & Average & $\begin{array}{c}95 \% \\
\text { Cl }\end{array}$ & $\begin{array}{c}\text { DL } \\
\text { Ratio }\end{array}$ \\
\hline Organics, Semi-volatile & 2-Naphthylamine & SW 8270 & ug/L & $<$ & 2.11 & $<$ & 1.91 & $<$ & 2.3 & $<$ & 1.87 & $<$ & 2.11 & -. & $100 \%$ \\
\hline Organics, Seml-volatile & 2-Nitroaniline & SW 8270 & ug/L & $<$ & 0.435 & $<$ & 0.394 & $<$ & 0.954 & $<$ & 0.775 & $<$ & 0.594 & $\cdots$ & $100 \%$ \\
\hline Organles, Seml-volatile & 2-Nitrophenol & SW 8270 & ug/L & $<$ & 0.476 & $<$ & 0.431 & $<$ & 0.751 & $<$ & 0.611 & $<$ & 0.553 & -. & $100 \%$ \\
\hline Organics, Semi-volatile & 2-Picoline & SW 8270 & ug/L & $<$ & 1.18 & $<$ & 1.07 & $<$ & 1.19 & $<$ & 0.967 & $<$ & 1.15 & - & $100 \%$ \\
\hline Organics, Semi-volatile & 3,3'-Dichlorobenzidine & SW 8270 & ug/L & $<$ & 0.53 & $<$ & 0.48 & $<$ & 0.479 & $<$ & 0.389 & $<$ & 0.496 & $\cdots$ & $100 \%$ \\
\hline Organics, Semi-volatile & 3-Methylcholanthrene & SW 8270 & ug/L & $<$ & 0.846 & $<$ & 0.768 & $<$ & 0.719 & $<$ & 0.585 & $<$ & 0.778 & - & $100 \%$ \\
\hline Organics, Semi-volatile & 3-Nitroaniline & SW 8270 & ug/L & $<$ & 0.55 & $<$ & 0.499 & $<$ & 0.565 & $<$ & 0.46 & $<$ & 0.538 & - & $100 \%$ \\
\hline Organics, Semi-volatile & 4,6-Dinitro-2-methylphenol & SW 8270 & ug/L. & $<$ & 0.856 & $<$ & 0.776 & $<$ & 0.619 & i & 0.503 & $<$ & 0.750 & $\cdots$ & $100 \%$ \\
\hline Organics, Semi-volatile & 4-Aminoblphenyl & SW 8270 & ug/L & $<$ & 0.809 & $<$ & 0.733 & $<$ & 1.71 & $<$ & 1.39 & $<$ & 1.084 & $\cdots$ & $100 \%$ \\
\hline Organics, Semi-volatile & 4-Bromophenyl phenyl & SW 8270 & ug/L & $<$ & 0.493 & $<$ & 0.447 & $<$ & 0.696 & $<$ & 0.566 & $<$ & 0.545 & . & $100 \%$ \\
\hline Organics, Semi-volatile & 4-Chloro-3-methylphenol & SW 8270 & ug/L & $<$ & 0.782 & $<$ & 0.709 & $<$ & 0.741 & $<$ & 0.602 & $<$ & 0.744 & $\cdots$ & $100 \%$ \\
\hline Organics, Seml-volatile & 4-Chlorophenyl phenyl ether & SW 8270 & ug/L & $<$ & 0.571 & $<$ & 0.518 & $<$ & 0.606 & $<$ & 0.492 & $<$ & 0.565 & - & $100 \%$ \\
\hline Organics, Semi-volatile & 4-Methyiphenol(p-cresol) & SW 8270 & ug/L & $<$ & 0.622 & $<$ & 0.564 & $<$ & 0.66 & $<$ & 0.537 & $<$ & 0.615 & - & $100 \%$ \\
\hline Organics, Semi-volatile & 4-Nitroaniline & SW 8270 & ug/L. & $<$ & 0.523 & $<$ & 0.475 & $<$ & 0.872 & $<$ & 0.709 & $<$ & 0.623 & $\cdots$ & $100 \%$ \\
\hline Organics, Semi-volatile & 4-Nitrophenol & SW 8270 & ug/L & $<$ & 0.747 & $<$ & 0.677 & $<$ & 1.35 & $<$ & 1.1 & $<$ & 0.925 & - & $100 \%$ \\
\hline Organics, Semi-volatile & 7,12-Dimethylbenz(a)anthracene & sW 8270 & ug/L & $<$ & 2.08 & $<$ & 1.88 & $<$ & 1.91 & $<$ & 1.56 & $<$ & 1.96 & $\cdots$ & $100 \%$ \\
\hline Organics, Semi-volatile & Acenaphthene & SW 8270 & ug/L & $<$ & 0.517 & $<$ & 0.469 & $<$ & 0.391 & $<$ & 0.318 & $<$ & 0.459 & - & $100 \%$ \\
\hline Organics, Semi-volatile & Acenaphthylene & SW 8270 & ug/L & $<$ & 0.244 & $<$ & 0.222 & $<$ & 0.601 & $<$ & 0.489 & $<$ & 0.356 & .. & $100 \%$ \\
\hline Organics, Semi-volatile & Acelophenone & SW 8270 & ug/L & $<$ & 0.496 & $<$ & 0.45 & $<$ & 0.804 & $<$ & 0.654 & $<$ & 0.583 & $\ldots$ & $100 \%$ \\
\hline Organics, Semi-volatile & Anlline & SW 8270 & ug/L & $<$ & 1.01 & $<$ & 0.915 & & 1.57 & $<$ & 0.72 & $<$ & 1.010 & - & $38 \%$ \\
\hline Organics, Semi-volatile & Anthracene & SW 8270 & $u g / L$ & $<$ & 0.628 & $<$ & 0.57 & $<$ & 0.529 & $<$ & 0.43 & $<$ & 0.576 & - & $100 \%$ \\
\hline Organics, Semi-volatile & Benzidine & SW 8270 & ug/L & $<$ & 20 & $<$ & 20 & $<$ & 20 & $<$ & 20 & $<$ & 20 & - & $100 \%$ \\
\hline Organics, Semi-volatile & Benzo(a)anthracene & SW 8270 & ug/L & $<$ & 0.557 & $<$ & 0.505 & $<$ & 0.646 & $<$ & 0.525 & $<$ & 0.569 & -- & $100 \%$ \\
\hline Organics, Seml-volatile & Benzo(a)pyrene & SW 8270 & ug/L & $<$ & 0.414 & $<$ & 0.375 & $<$ & 0.745 & $<$ & 0.606 & $<$ & 0.511 & -- & $100 \%$ \\
\hline Organics, Semi-volatile & Benzo(b)fluoranthene & SW 8270 & ug/L & $<$ & 0.615 & $<$ & 0.558 & $<$ & 1.31 & $<$ & 1.06 & $<$ & 0.828 & $\cdots$ & $100 \%$ \\
\hline Organics, Semi-volatile & Benzo $(g, h, l)$ perylens & SW 8270 & $u g / L$ & $<$ & 0.526 & $<$ & 0.477 & $<$ & 1.47 & $<$ & 1.19 & $<$ & 0.824 & -- & $100 \%$ \\
\hline Organics, Seml-volatile & Benzo(k)fluoranthene & SW 8270 & ught & $<$ & 1.05 & $<$ & 0.949 & $<$ & 1.44 & $<$ & 1.17 & $<$ & 1.146 & - & $100 \%$ \\
\hline Organics, Seml-volatile & Benzolc acld & sW 8270 & ug/L. & $<$ & 4.28 & & 4.73 & $<$ & 55.5 & $<$ & 45.1 & $<$ & 55.50 & - & $86 \%$ \\
\hline Organics, Seml-volatile & Benzyl alcohol & SW 8270 & $u g / L$ & $<$ & 1.17 & $<$ & 1.06 & $<$ & 0.878 & $<$ & 0.713 & $<$ & 1.036 & -. & $100 \%$ \\
\hline Organics, Seml-volatile & Butylbenzylphthalate & SW 8270 & ug/l & $<$ & 0.425 & $<$ & 0.385 & $<$ & 0.899 & $<$ & 0.731 & $<$ & 0.570 & - & $100 \%$ \\
\hline Organics, Semi-volatile & Chrysene & SW 8270 & ug/L & $<$ & 0.723 & $<$ & 0.656 & $<$ & 0.773 & $<$ & 0.628 & $<$ & 0.717 & $\cdots$ & $100 \%$ \\
\hline
\end{tabular}

壳 


\section{Liquid Stream Data Summary}

Sample Stream: JBR Underflow Slurry Filtrate

\begin{tabular}{|c|c|c|c|c|c|c|c|c|c|c|c|c|c|c|c|}
\hline $\begin{array}{c}\text { Analyte } \\
\text { Group }\end{array}$ & Specie & $\begin{array}{c}\text { Analytical } \\
\text { Method }\end{array}$ & Units & & $\begin{array}{c}\text { Run } \\
1 \\
\end{array}$ & & $\begin{array}{c}\text { Run } \\
2 \\
\end{array}$ & & $\begin{array}{c}\text { Run } \\
\mathbf{3 a} \\
\end{array}$ & & $\begin{array}{c}\text { Run } \\
3 d\end{array}$ & & Average & $\begin{array}{c}95 \% \\
\mathrm{Cl} \\
\end{array}$ & $\begin{array}{c}\text { DL } \\
\text { Ratio }\end{array}$ \\
\hline Organics, Semi-volatile & Di-n-octylphthalate & SW 8270 & ug/L. & $<$ & 0.985 & $<$ & 0.893 & $<$ & 0.506 & $<$ & 0.412 & $<$ & 0.795 & - & $100 \%$ \\
\hline Organics, Semi-volatile & Dlbenz(a,h)anthracene & SW 8270 & Ug/L & $<$ & 0.512 & $<$ & 0.465 & $<$ & 1.17 & $<$ & 0.949 & $<$ & 0.716 & - & $100 \%$ \\
\hline Organics, Semi-volatile & Dibenz(a,j)acridine & SW 8270 & ug/L. & $<$ & 0.628 & $<$ & 0.57 & $<$ & 1.21 & $<$ & 0.985 & $<$ & 0.803 & $\cdots$ & $100 \%$ \\
\hline Organics, Semi-volatile & Dibenzofuran & SW 8270 & $u g / L$ & $<$ & 0.441 & $<$ & 0.4 & $<$ & 0.773 & $<$ & 0.628 & $<$ & 0.538 & $-\cdot$ & $100 \%$ \\
\hline Organics, Semi-volatile & Dlbutylphthalate & SW 8270 & $\mathrm{ug} / \mathrm{L}$ & $<$ & 0.533 & $<$ & 0.483 & $<$ & 0.466 & $<$ & 0.379 & $<$ & 0.494 & - & $100 \%$ \\
\hline Organics, Semi-volatile & Dlethylphthalate & SW 8270 & $u g / L$ & $<$ & 0.363 & $<$ & 0.329 & $<$ & 0.741 & $<$ & 0.602 & $<$ & 0.478 & - & $100 \%$ \\
\hline Organics, Semi-volatile & Dimethylphenethylamine & SW 8270 & ug/L & $<$ & 120 & $<$ & 120 & $<$ & 120 & $<$ & 120 & $<$ & 120 & $\cdots$ & $100 \%$ \\
\hline Organics, Semi-volatile & Dimethyiphthalate & SW 8270 & ug/L & $<$ & 0.303 & & 3.09 & & 3.04 & & 2.65 & & 2.094 & 4.18 & $2 \%$ \\
\hline Organics, Semi-volatlle & Diphenylamine & SW 8270 & $u g / L$ & $<$ & 0.571 & $<$ & 0.518 & $<$ & 0.399 & $<$ & 0.324 & $<$ & 0.496 & $\cdots$ & $100 \%$ \\
\hline Organics, Semi-volatlle & Ethyl methanesulfonate & SW 8270 & ug/L & $<$ & 0.544 & $<$ & 0.493 & $<$ & 0.977 & $<$ & 0.794 & $<$ & 0.671 & $\cdots$ & $100 \%$ \\
\hline Organics, Semi-volatile & Fluoranthene & SW 8270 & $u g / L$ & $<$ & 0.69 & $<$ & 0.625 & $<$ & 0.678 & $<$ & 0.551 & $<$ & 0.664 & - & $100 \%$ \\
\hline Organics, Semi-volatile & Fluorene & SW 8270 & $u g / L$ & $<$ & 0.363 & $<$ & 0.329 & $<$ & 0.547 & $<$ & 0.444 & $<$ & 0.413 & $\cdots$ & $100 \%$ \\
\hline Organics, Semi-volatile & Hexachlorobenzene & SW 8270 & ug/L & $<$ & 0.253 & $<$ & 0.229 & $<$ & 0.452 & $<$ & 0.367 & $<$ & 0.311 & $\cdots$ & $100 \%$ \\
\hline Organics, Semi-volatile & Hexachlorobutadiene & SW 8270 & $u g / L$ & $<$ & 0.755 & $<$ & 0.684 & $<$ & 0.737 & $<$ & 0.599 & $<$ & 0.725 & $\cdots$ & $100 \%$ \\
\hline Organics, Semi-volatile & Hexachlorocyclopentadiene & SW 8270 & $u g / L$ & $<$ & 9.64 & $<$ & 8.75 & $<$ & 8.47 & $<$ & 6.89 & $<$ & 8.95 & -- & $100 \%$ \\
\hline Organics, Semi-volatile & Hexachloroethane & SW 8270 & $\mathrm{ug} / \mathrm{L}$ & $<$ & 0.642 & $<$ & 0.582 & $<$ & 0.914 & $<$ & 0.743 & $<$ & 0.713 & $\cdots$ & $100 \%$ \\
\hline Organics, Semi-volatile & Indeno(1,2,3-cd)pyrene & SW 8270 & $u g / L$ & $<$ & 0.568 & $<$ & 0.515 & $<$ & 1.91 & $<$ & 1.56 & $<$ & 0.998 & $\cdots$ & $100 \%$ \\
\hline Organics, Seml-volatile & Isophorone & SW 8270 & $u g / L$ & $<$ & 0.31 & $<$ & 0.281 & $<$ & 0.886 & $<$ & 0.72 & $<$ & 0.492 & -- & $100 \%$ \\
\hline Organics, Semi-volatile & Methyl methanesulfonate & SW 8270 & ug/L & $<$ & 50 & $<$ & 50 & $<$ & 50 & $<$ & 50 & $<$ & 50 & - & $100 \%$ \\
\hline Organics, Semi-volatile & N-Nitroso-dl-n-butylamine & SW 8270 & $u g / L$ & $<$ & 1.42 & $<$ & 1.28 & $<$ & 0.905 & $<$ & 0.736 & $<$ & 1.20 & $\cdots$ & $100 \%$ \\
\hline Organics, Seml-volatile & N-Nitrosodimethylamine & SW 8270 & $u g / L$ & $<$ & 1.44 & $<$ & 1.3 & $<$ & 1.13 & $<$ & 0.919 & $<$ & 1.29 & -. & $100 \%$ \\
\hline Organics, Semi-volatile & N-Nitrosodiphenylamine & SW 8270 & ug/L. & $<$ & 0.612 & $<$ & 0.555 & $<$ & 0.387 & $<$ & 0.315 & $<$ & 0.518 & - & $100 \%$ \\
\hline Organics, Semi-volatile & N-Nitrosodipropylamine & SW 8270 & $\mathrm{ug} / \mathrm{L}$ & $<$ & 0.812 & $<$ & 0.736 & $<$ & 0.941 & $<$ & 0.765 & $<$ & 0.830 & $\cdots$ & $100 \%$ \\
\hline Organics, Semi-volatile & N-Nitrosopiperidine & SW 8270 & $u g / L$ & $<$ & 1.02 & $<$ & 0.925 & $<$ & 0.859 & $<$ & 0.698 & $<$ & 0.935 & $\cdots$ & $100 \%$ \\
\hline Organics, Semi-volatile & Naphthaiene & SW 8270 & ug/L & $<$ & 0.788 & $<$ & 0.715 & $<$ & 0.688 & $<$ & 0.559 & $<$ & 0.730 & $\cdots$ & $100 \%$ \\
\hline Organics, Seml-volatlle & Nitrobenzene & SW 8270 & ug/L & $<$ & 0.571 & $<$ & 0.518 & $<$ & 1.21 & $<$ & 0.985 & $<$ & 0.766 & $\cdots$ & $100 \%$ \\
\hline Organics, Seml-volatlle & Pentachlorobenzene & SW 8270 & $u g / L$ & $<$ & 0.479 & $<$ & 0.434 & $<$ & 0.538 & $<$ & 0.437 & $<$ & 0.484 & $\cdots$ & $100 \%$ \\
\hline Organics, Semi-volatile & Pentachloronitrobenzene & SW 8270 & ug/L & $<$ & 2.24 & $<$ & 2.03 & $<$ & 1.99 & $<$ & 1.61 & $<$ & 2.09 & - & $100 \%$ \\
\hline Organics, Semi-volatile & Pentachlorophenol & SW 8270 & $u g / L$ & $<$ & 0.934 & $<$ & 0.847 & $<$ & 1.28 & $<$ & 1.04 & $<$ & 1.020 & $\cdots$ & $100 \%$ \\
\hline Organics, Seml-volatile & Phenacetin & SW 8270 & ug/L & $<$ & 0.584 & $<$ & 0.529 & $<$ & 0.555 & $<$ & 0.451 & $<$ & 0.556 & $-\cdot$ & $100 \%$ \\
\hline Organics, Semi-volatile & Phenanthrene & SW 8270 & ug/L. & $<$ & 0.672 & $<$ & 0.61 & $<$ & 0.673 & $<$ & 0.547 & $<$ & 0.652 & $\cdots$ & $100 \%$ \\
\hline
\end{tabular}

JBR Underflow Slurry Filtrate - Page 4 


\section{Liquid Stream Data Summary}

Sample Stream: JBR Underflow Slurry Filtrate

\begin{tabular}{|c|c|c|c|c|c|c|c|c|c|c|c|c|c|c|c|c|}
\hline $\begin{array}{c}\text { Analyte } \\
\text { Group }\end{array}$ & Specie & $\begin{array}{l}\text { Analytical } \\
\text { Method }\end{array}$ & Units & & $\begin{array}{c}\text { Run } \\
1 \\
\end{array}$ & & $\begin{array}{c}\text { Run } \\
2 \\
\end{array}$ & & & $\begin{array}{r}\text { Run } \\
\text { 3a }\end{array}$ & & $\begin{array}{c}\text { Run } \\
\text { 3d }\end{array}$ & & Average & $\begin{array}{c}95 \% \\
\mathrm{Cl} \\
\end{array}$ & $\begin{array}{c}\text { DL } \\
\text { Ratio }\end{array}$ \\
\hline Organics, Semi-volatile & Phenol & SW 8270 & $u g / L$ & $<$ & 0.431 & $<$ & 0.391 & & $<$ & 1.27 & $<$ & 1.03 & $<$ & 0.697 & $\cdots$ & $100 \%$ \\
\hline Organics, Semi-volatile & Pronamide & SW 8270 & ug/L & $<$ & 0.799 & $<$ & 0.725 & & $<$ & 0.347 & $<$ & 0.282 & $<$ & 0.624 & - & $100 \%$ \\
\hline Organics, Semi-volatile & Pyrene & SW 8270 & $u g / L$ & $<$ & 0.506 & $<$ & 0.459 & & $<$ & 0.587 & $<$ & 0.477 & $<$ & 0.517 & $\cdots$ & $100 \%$ \\
\hline Organics, Semi-volatile & Pyridine & SW 8270 & ug/L & $<$ & 1.25 & $<$ & 1.14 & & $<$ & 0.846 & $<$ & 0.688 & $<$ & 1.079 & -. & $100 \%$ \\
\hline Organics, Semi-volatile & bis(2-Chloroethoxy)methane & SW 8270 & ug/L & $<$ & 0.608 & $<$ & 0.551 & & $<$ & 0.872 & $<$ & 0.709 & $<$ & 0.677 & -. & $100 \%$ \\
\hline Organics, Semi-volatile & bis(2-Chloroethy) )ether & SW 8270 & $u g / L$ & $<$ & 0.791 & $<$ & 0.718 & & $<$ & 0.551 & $<$ & 0.448 & $<$ & 0.687 & - & $100 \%$ \\
\hline Organics, Semi-volatile & bis(2-Chlorolsopropyl)ether & SW 8270 & $u g / L$ & $<$ & 0.785 & $<$ & 0.712 & & $<$ & 1.15 & $<$ & 0.933 & $<$ & 0.882 & -- & $100 \%$ \\
\hline Organics, Semi-volatile & bis(2-Ethylhexyl)phthalate & SW 8270 & $u g / L$ & & 4 & & 5.11 & & & 4.16 & & 2.98 & & 4.42 & 1.49 & \\
\hline Organics, Semi-volatile & p-Chloroanilline & SW 8270 & $u g / L$ & $<$ & 0.604 & $<$ & 0.548 & & $<$ & 1.07 & $<$ & 0.871 & $<$ & 0.741 & -- & $100 \%$ \\
\hline Organics, Semi-volatile & p-Dimethylaminoazobenzene & SW 8270 & $u g / L$ & $<$ & 0.557 & $<$ & 0.505 & & $<$ & 1.04 & $<$ & 0.849 & $<$ & 0.701 & $\cdots$ & $100 \%$ \\
\hline Organics, Volatlle & 1,1,1-Trichloroethane & SW 8240 & ug/L. & $<$ & 5 & $<$ & 5 & & $<$ & 5 & $<$ & 5 & $<$ & 5 & - & $100 \%$ \\
\hline Organics, Volatlle & 1,1,2,2-Tetrachloroethane & SW 8240 & $u g / L$ & $<$ & 5 & $<$ & 5 & & $<$ & 5 & $<$ & 5 & $<$ & 5 & $\cdots$ & $100 \%$ \\
\hline Organics, Volatile & 1,1,2-Trichloroethane & SW 8240 & $u g / L$ & $<$ & 5 & $<$ & 5 & & $<$ & 5 & $<$ & 5 & $<$ & 5 & -. & $100 \%$ \\
\hline Organics, Volatile & 1.1-Dichloroethane & SW 8240 & $u g / L$ & $<$ & 5 & $<$ & 5 & & $<$ & 5 & $<$ & 5 & $<$ & 5 & $-\cdot$ & $100 \%$ \\
\hline Organics, Volatile & 1,1-Dlchloroethene & SW 8240 & ug/L & $<$ & 5 & $<$ & 5 & & $<$ & 5 & $<$ & 5 & $<$ & 5 & $\cdots$ & $100 \%$ \\
\hline Organics, Volatile & 1,2-Dichloroethane & SW 8240 & ug/L & $<$ & 5 & $<$ & 5 & & $<$ & 5 & $<$ & 5 & $<$ & 5 & -- & $100 \%$ \\
\hline Organics, Volatile & 1,2-Dichloroethene (total) & SW 8240 & ug/L & $<$ & 5 & $<$ & 5 & & $<$ & 5 & $<$ & 5 & $<$ & 5 & -- & $100 \%$ \\
\hline Organics, Volatile & 1,2-Dlchloropropane & SW 8240 & ug/L & $<$ & 5 & $<$ & 5 & & $<$ & 5 & $<$ & 5 & $<$ & 5 & -. & $100 \%$ \\
\hline Organics, Volatile & 2-Butanone (MEK) & SW 8240 & ug/L & $<$ & 10 & $<$ & 10 & & $<$ & 10 & $<$ & 10 & $<$ & 10 & -- & $100 \%$ \\
\hline Organics, Volatile & 2-Hexanone & SW 8240 & ug/L & $<$ & 10 & $<$ & 10 & & $<$ & 10 & $<$ & 10 & $<$ & 10 & -. & $100 \%$ \\
\hline Organics, Volatile & 4Methyl-2-pentanone (MIBK) & SW 8240 & ug/L & $<$ & 10 & $<$ & 10 & & $<$ & 10 & $<$ & 10 & $<$ & 10 & $-\cdot$ & $100 \%$ \\
\hline Organics, Volatile & Acetone & SW 8240 & ug/L & $<$ & 10 & & 6.8 & $\mathrm{~J}$ & $<$ & 10 & $<$ & 10 & $<$ & 10 & $\cdots$ & $60 \%$ \\
\hline Organlcs, Volatile & Benzene & SW 8240 & ug/L & $<$ & 5 & $<$ & 5 & & $<$ & 5 & $<$ & 5 & $<$ & 5 & -. & $100 \%$ \\
\hline Organics, Volatlle & Bromodichloromethane & SW 8240 & ug/L & $<$ & 5 & $<$ & 5 & & $<$ & 5 & $<$ & 5 & $<$ & 5 & $\cdots$ & $100 \%$ \\
\hline Organics, Volatile & Bromoform & SW 8240 & ug/L & $<$ & 5 & $<$ & 5 & & $<$ & 5 & $<$ & 5 & $<$ & 5 & $\cdots$ & $100 \%$ \\
\hline Organics, Volatile & Bromomethane & SW 8240 & ug/L & $<$ & 10 & $<$ & 10 & & $<$ & 10 & $<$ & 10 & $<$ & 10 & -- & $100 \%$ \\
\hline Organics, Volatlle & Carbon Disulfide & SW 8240 & $u g / L$ & $<$ & 5 & $<$ & 5 & & $<$ & 5 & $<$ & 5 & $<$ & 5 & $\cdots$ & $100 \%$ \\
\hline Organics, Volatile & Carbon Tetrachloride & SW 8240 & $u g / L$ & $<$ & 5 & $<$ & 5 & & $<$ & 5 & $<$ & 5 & $<$ & 5 & - & $100 \%$ \\
\hline Organics, Volatile & Chlorobenzene & SW 8240 & ug/L & $<$ & 5 & $<$ & 5 & & $<$ & 5 & $<$ & 5 & $<$ & 5 & -- & $100 \%$ \\
\hline Organlcs, Volatlle & Chloroethane & SW 8240 & $\mathrm{ug} / \mathrm{L}$ & $<$ & 10 & $<$ & 10 & & $<$ & 10 & $<$ & 10 & $<$ & 10 & $\cdots$ & $100 \%$ \\
\hline
\end{tabular}




\section{Liquid Stream Data Summary}

Sample Stream: JBR Underflow Slurry Filtrate

\begin{tabular}{|c|c|c|c|c|c|c|c|c|c|c|c|c|c|c|c|c|}
\hline $\begin{array}{c}\text { Analyte } \\
\text { Group }\end{array}$ & Specie & $\begin{array}{c}\text { Analytical } \\
\text { Method }\end{array}$ & Units & & $\begin{array}{c}\text { Run } \\
1 \\
\end{array}$ & & $\begin{array}{c}\text { Run } \\
2 \\
\end{array}$ & & & $\begin{array}{c}\text { Run } \\
3 \mathbf{a} \\
\end{array}$ & & $\begin{array}{r}\text { Run } \\
3 d \\
\end{array}$ & & Average & $\begin{array}{c}85 \% \\
\mathrm{Cl} \\
\end{array}$ & $\begin{array}{r}\text { DL } \\
\text { Ratio }\end{array}$ \\
\hline Organics, Volatile & Chloroform & SW 8240 & $\mathrm{ug} / \mathrm{L}$ & $<$ & 5 & $<$ & 5 & & $<$ & 5 & $<$ & 5 & $<$ & 5 & $\cdots$ & $100 \%$ \\
\hline Organlcs, Volatile & Chloromethane & SW 8240 & $u g / L$ & $<$ & 10 & $<$ & 10 & & $<$ & 10 & $<$ & 10 & $<$ & 10 & $\cdots$ & $100 \%$ \\
\hline Organics, Volatile & Dibromochloromethane & SW 8240 & $u g / L$ & $<$ & 5 & $<$ & 5 & & $<$ & 5 & $<$ & 5 & $<$ & 5 & - & $100 \%$ \\
\hline Organics, Volatile & Elhylbenzene & SW 8240 & $u g / L$ & $<$ & 5 & $<$ & 5 & & $<$ & 5 & $<$ & 5 & $<$ & 5 & $\cdots$ & $100 \%$ \\
\hline Organics, Volatile & Methylene Chloride & SW 8240 & ug/L & $<$ & 5 & & 4.6 & J & & 5.7 & & 5 & $<$ & 5 & - & $20 \%$ \\
\hline Organics, Volatile & Styrene & SW 8240 & $\mathrm{ug} / \mathrm{L}$ & $<$ & 5 & $<$ & 5 & & $<$ & 5 & $<$ & 5 & $<$ & 5 & - & $100 \%$ \\
\hline Organics, Volatile & Tetrachloroethene & SW 8240 & $\mathrm{ug} / \mathrm{L}$ & $<$ & 5 & $<$ & 5 & & $<$ & 5 & $<$ & 5 & $<$ & 5 & $\cdots$ & $100 \%$ \\
\hline Organics, Volatile & Toluene & SW 8240 & $u g / L$ & $<$ & 5 & & 2 & $J$ & $<$ & 5 & $<$ & 5 & $<$ & $\cdot 5$ & $\cdots$ & $71 \%$ \\
\hline Organics, Volalile & Trichloroethene & SW 8240 & ug/L & $<$ & 5 & $<$ & 5 & & $<$ & 5 & $<$ & 5 & $<$ & 5 & $\cdots$ & $100 \%$ \\
\hline Organics, Volatile & Vinyl acetate & SW 8240 & ug/L & $<$ & 10 & $<$ & 10 & & $<$ & 10 & $<$ & 10 & $<$ & 10 & $\cdots$ & $100 \%$ \\
\hline Organics, Volatile & Vinyl chloride & SW 8240 & ug/L & $<$ & 10 & $<$ & 10 & & $<$ & 10 & $<$ & 10 & $<$ & 10 & $\cdots$ & $100 \%$ \\
\hline Organics, Volatile & Xylenes & SW 8240 & $\mathrm{ug} / \mathrm{L}$ & $<$ & 5 & $<$ & 5 & & $<$ & 5 & $<$ & 5 & $<$ & 5 & $\cdots$ & $100 \%$ \\
\hline Organics, Volatile & cis-1,3-Dichloropropene & SW 8240 & ugg/L & $<$ & 5 & $<$ & 5 & & $<$ & 5 & $<$ & 5 & $<$ & 5 & $\cdots$ & $100 \%$ \\
\hline Organics, Volatile & trans-1,3-Dichloropropene & SW 8240 & ug/L & $<$ & 5 & $<$ & 5 & & $<$ & 5 & $<$ & 5 & $<$ & 5 & $\cdots$ & $100 \%$ \\
\hline
\end{tabular}




\section{Liquid Stream Data Summary}

Sample Stream: Limestone Slurry Filtrate

\begin{tabular}{|c|c|c|c|c|c|c|c|c|c|c|c|c|c|c|c|c|c|}
\hline $\begin{array}{c}\text { Analyte } \\
\text { Group }\end{array}$ & Specie & $\begin{array}{c}\text { Analytical } \\
\text { Method }\end{array}$ & Units & & $\begin{array}{c}\text { Run } \\
1 \\
\end{array}$ & & & $\begin{array}{c}\text { Run } \\
2 \\
\end{array}$ & & $\begin{array}{r}\text { Run } \\
\text { 3a } \\
\end{array}$ & & & $\begin{array}{c}\text { Run } \\
3 d\end{array}$ & & Average & $\begin{array}{c}95 \% \\
\mathrm{Cl} \\
\end{array}$ & $\begin{array}{c}\text { DL } \\
\text { Ratio }\end{array}$ \\
\hline Reduced Species & Cyanide & SW 9012 & $\mathrm{ug} / \mathrm{ml}$ & & 0.0593 & & & 0.0834 & & 0.003 & J & & 0.0786 & & 0.0486 & 0.1025 & \\
\hline Reduced Species & Ammonia as $\mathrm{N}$ & EPA 350.1 & $\mathrm{ug} / \mathrm{ml}$ & & 13.9 & & & 15.2 & & 13.3 & & & 13.8 & & 14.1 & 2.4 & \\
\hline Anions & Chloride & EPA 300 & $\mathrm{ug} / \mathrm{ml}$ & & 14,000 & & & 12,900 & & 12,300 & & & 13,700 & & 13,067 & 2,142 & \\
\hline Anions & Fluoride & EPA 340.2 & $\mathrm{ug} / \mathrm{ml}$ & & 2.1 & & & 2.02 & & 1.4 & & & 1.46 & & 1.84 & 0.95 & \\
\hline Anions & Phosphate & EPA 365.2 & $\mathrm{ug} / \mathrm{ml}$ & $<$ & 0.02 & & $<$ & 0.02 & $<$ & 0.02 & & $<$ & 0.02 & $<$ & 0.02 & -. & $100 \%$ \\
\hline Anions & Sulfate & EPA 300.0 & $u g / m l$ & & 827 & & & 818 & & 709 & & & 709 & & 785 & 163 & \\
\hline Metals, Soluble & Aluminum & SW 6010 & $\mathrm{ug} / \mathrm{ml}$ & & 0.089 & J & & 0.0418 & $J$ & 0.654 & & & 0.0725 & J & 0.2616 & 0.8463 & \\
\hline Metals, Soluble & Antimony & SW 6010 & $\mathrm{ug} / \mathrm{ml}$ & $<$ & 0.241 & & $<$ & 0.241 & $<$ & 0.241 & & $<$ & 0.241 & $<$ & 0.241 & $\cdots$ & $100 \%$ \\
\hline Metals, Soluble & Arsenic & SW 7060 & $\mathrm{ug} / \mathrm{ml}$ & & 0.105 & & & 0.089 & & 0.0068 & & & 0.09 & & 0.067 & 0.131 & \\
\hline Metals, Soluble & Barium & SW 6010 & $\mathrm{ug} / \mathrm{ml}$ & & 1.08 & & & 1.13 & & 8.48 & & & 1.09 & & 3.56 & 10.58 & \\
\hline Metals, Soluble & Beryllium & SW 6010 & $\mathrm{ug} / \mathrm{ml}$ & & 0.0005 & $J$ & $<$ & 0.00554 & & 0.0017 & J & $<$ & 0.00554 & $<$ & 0.0055 & -. & $56 \%$ \\
\hline Metals, Soluble & Boron & SW 6010 & $\mathrm{ug} / \mathrm{ml}$ & & 443 & & & 449 & & 3330 & & & 432 & & 1,407 & 4,137 & \\
\hline Metals, Soluble & Calcium & SW 6010 & $u g / m l$ & & 7,160 & & & 7,030 & & 7,030 & & & 6,470 & & 7,073 & 186 & \\
\hline Metals, Soluble & Chromium & SW 6010 & $\mathrm{ug} / \mathrm{ml}$ & & 0.0515 & & & 0.0523 & & 0.0848 & & & 0.0361 & & 0.0629 & 0.0472 & \\
\hline Metals, Soluble & Cobalt & sW 6010 & $\mathrm{ug} / \mathrm{ml}$ & & 0.0347 & & & 0.0108 & J & 0.23 & & & 0.0207 & J & 0.0918 & 0.2987 & \\
\hline Metals, Soluble & Copper & SW 6010 & $\mathrm{ug} / \mathrm{ml}$ & & 0.0255 & $J$ & & 0.0132 & J & 0.0923 & & & 0.0273 & J & 0.0437 & 0.1057 & \\
\hline Metals, Soluble & Iron & SW 6010 & $\mathrm{ug} / \mathrm{ml}$ & $<$ & 0.0596 & & $<$ & 0.0596 & $<$ & 0.0596 & & $<$ & 0.0596 & $<$ & 0.0596 & - & $100 \%$ \\
\hline Metals, Soluble & Lead & SW 7421 & $\mathrm{ug} / \mathrm{ml}$ & & 0.0011 & & & 0.002 & & 0.002 & & & 0.005 & & 0.0017 & 0.0013 & \\
\hline Metals, Soluble & Magneslum & SW 6010 & $\mathrm{ug} / \mathrm{ml}$ & & 583 & & & 592 & & 4470 & & & 568 & & 1,882 & 5,569 & \\
\hline Metals, Soluble & Manganese & SW 6010 & $\mathrm{ug} / \mathrm{ml}$ & & 17.2 & & & 15.5 & & 90.6 & & & 12.5 & & 41.1 & 106.5 & \\
\hline Metals, Soluble & Mercury & SW 7470 & $\mathrm{ug} / \mathrm{ml}$ & & 0.00006 & & & 0.00006 & & 0.00005 & & & 0.00006 & & 0.00006 & 0.00001 & \\
\hline Metals, Soluble & Molybdenum & SW 6010 & $\mathrm{ug} / \mathrm{ml}$ & & 0.0671 & & & 0.0698 & & 0.506 & & & 0.102 & & 0.214 & 0.628 & \\
\hline Metals, Soluble & Nickel & SW 6010 & $\mathrm{ug} / \mathrm{ml}$ & & 0.303 & & & 0.32 & & 1.91 & & & 0.302 & & 0.844 & 2.293 & \\
\hline Metals, Soluble & Phosphorus & SW 6010 & $\mathrm{ug} / \mathrm{ml}$ & & 0.104 & & & 0.246 & & 0.118 & & & 0.711 & & 0.156 & 0.194 & \\
\hline Metals, Soluble & Potassium & SW 6010 & $u g / m l$ & & 41.3 & & & 40.9 & & 333 & & & 43.7 & & 138.4 & 418.7 & \\
\hline Metals, Soluble & Selenium & SW 7740 & $\mathrm{ug} / \mathrm{ml}$ & & 0.105 & & & 0.141 & & 0.137 & & & 0.157 & & 0.128 & 0.049 & \\
\hline Metals, Soluble & Sillicon & SW 6010 & $\mathrm{ug} / \mathrm{ml}$ & & 2.38 & & & 2.3 & & 16.9 & & & 2.38 & & 7.2 & 20.9 & \\
\hline Metals, Soluble & Sodium & SW 6010 & $\mathrm{ug} / \mathrm{ml}$ & & 83.3 & & & 84.7 & & 687 & & & 82.9 & & 285.0 & 864.9 & \\
\hline
\end{tabular}




\section{Liquid Stream Data Summary}

Sample Stream: Limestone Slurry Filtrate

\begin{tabular}{|c|c|c|c|c|c|c|c|c|c|c|c|c|c|c|c|c|c|}
\hline $\begin{array}{c}\text { Analyte } \\
\text { Group }\end{array}$ & Specie & $\begin{array}{c}\text { Analytical } \\
\text { Method }\end{array}$ & Units & & $\begin{array}{c}\text { Run } \\
1 \\
\end{array}$ & & & $\begin{array}{c}\text { Run } \\
2 \\
\end{array}$ & & $\begin{array}{r}\text { Run } \\
\text { 3a }\end{array}$ & & $\begin{array}{c}\text { Run } \\
\text { 3d } \\
\end{array}$ & & & Average & $\begin{array}{c}95 \% \\
\text { CI } \\
\end{array}$ & $\begin{array}{c}\text { DL } \\
\text { Ratio }\end{array}$ \\
\hline Metals, Soluble & Strontlum & SW 6010 & $\mathrm{ug} / \mathrm{ml}$ & & 11.3 & & & 11.4 & & 85.1 & & 10.9 & & & 35.9 & 105.8 & \\
\hline Metals, Soluble & Tin & SW 6010 & $\mathrm{ug} / \mathrm{ml}$ & & 0.007 & $\mathrm{~J}$ & $<$ & 0.144 & $<$ & 0.144 & & 0.109 & $\mathrm{~J}$ & $<$ & 0.144 & -. & $95 \%$ \\
\hline Metals, Soluble & Tiltanium & SW 6010 & $\mathrm{ug} / \mathrm{ml}$ & & 0.725 & & & 0.731 & $<$ & 0.0102 & & 0.0059 & $\mathrm{~J}$ & & 0.4870 & 1.0369 & $0.3 \%$ \\
\hline Metals, Soluble & Vanadium & SW 6010 & $\mathrm{ug} / \mathrm{ml}$ & & 0.137 & & & 0.128 & & 0.29 & & 0.063 & & & 0.185 & 0.226 & \\
\hline Metals, Soluble & Zinc & SW 6010 & $\mathrm{ug} / \mathrm{ml}$ & & 0.0133 & $J$ & & 0.0307 & & 0.0765 & & 0.0195 & & & 0.0402 & 0.0811 & \\
\hline Aldehydes & Acetaldehyde & SW 8315 & $\mathrm{ug} / \mathrm{ml}$ & & 0.0042 & & & 0.068 & & 0.08 & & 0.076 & & & 0.051 & 0.101 & \\
\hline Aldehydes & Formaldèhyde & SW 8315 & $\mathrm{ug} / \mathrm{ml}$ & & 0.01 & & & 0.022 & & 0.03 & & 0.026 & & & 0.021 & 0.025 & \\
\hline Organics, Semi-volatile & 1,2,4,5-Tetrachlorobenzene & SW 8270 & ug/L & $<$ & 0.578 & & $<$ & 0.593 & $<$ & 0.6 & $<$ & 0.531 & & $<$ & 0.590 & $\cdots$ & $100 \%$ \\
\hline Organics, Semi-volatile & 1,2,4-Trichlorobenzene & SW 8270 & $\mathrm{ug} / \mathrm{h}$ & $<$ & 0.591 & & $<$ & 0.606 & $<$ & 0.905 & $<$ & 0.8 & & $<$ & 0.701 & .. & $100 \%$ \\
\hline Organics, Semi-volatile & 1,2-Dlchlorobenzene & SW 8270 & $u g / L$ & $<$ & 0.779 & & $<$ & 0.799 & $<$ & 0.977 & $<$ & 0.864 & & $<$ & 0.852 & -. & $100 \%$ \\
\hline Organics, Semi-volatile & 1,2-Diphenylhydrazine & SW 8270 & $u g / L$ & $<$ & 100 & & $<$ & 100 & $<$ & 100 & $<$ & 100 & & $<$ & 100 &.- & $100 \%$ \\
\hline Organics, Semi-volatile & 1,3-Dichlorobenzene & SW 8270 & $\mathrm{ug} / \mathrm{L}$ & $<$ & 0.396 & & $<$ & 0.406 & $<$ & 1.1 & $<$ & 0.976 & & $<$ & 0.634 & - & $100 \%$ \\
\hline Organics, Semi-volatile & 1,4-Dichlorobenzene & SW 8270 & $\mathrm{ug} / \mathrm{L}$ & $<$ & 0.808 & & $<$ & 0.829 & $<$ & 0.905 & $<$ & 0.8 & & $<$ & 0.847 & $-\cdot$ & $100 \%$ \\
\hline Organics, Semi-volatile & 1-Chloronaphthalene & SW 8270 & $\mathrm{ug} / \mathrm{h}$ & $<$ & 0.644 & & $<$ & 0.661 & $<$ & 0.826 & $<$ & 0.731 & & $<$ & 0.710 & $\cdots$ & $100 \%$ \\
\hline Organics, Seml-volatile & 1-Naphthylamine & SW 8270 & ug/L & $<$ & 1.56 & & $<$ & 1.6 & $<$ & 3.12 & $<$ & 2.76 & & $<$ & 2.09 & $-\cdot$ & $100 \%$ \\
\hline Organics, Semi-volatile & 2,3,4,6-Tetrachlorophenol & SW 8270 & ug/h & $<$ & 0.503 & & $<$ & 0.516 & $<$ & 0.715 & $<$ & 0.633 & & $<$ & 0.578 & -. & $100 \%$ \\
\hline Organics, Semi-volatile & 2,4,5-Trichlorophenol & SW 8270 & $u g / L$ & $<$ & 0.33 & & $<$ & 0.338 & $<$ & 0.783 & $<$ & 0.693 & & $<$ & 0.484 & $\cdots$ & $100 \%$ \\
\hline Organics, Semi-volatile & 2,4,6-Trichlorophenol & SW 8270 & ug/L & $<$ & 0.349 & & $<$ & 0.358 & $<$ & 0.778 & $<$ & 0.688 & & $<$ & 0.495 & $-\cdot$ & $100 \%$ \\
\hline Organics, Seml-volatile & 2,4-Dichlorophenol & SW 8270 & ug/L & $<$ & 0.443 & & $<$ & 0.454 & $<$ & 0.875 & $<$ & 0.774 & & $<$ & 0.591 & $\cdots$ & $100 \%$ \\
\hline Organics, Semi-volatile & 2,4-Dimethylphenol & SW 8270 & ug/L & $<$ & 1.1 & & $<$ & 1.13 & $<$ & 2 & $<$ & 1.77 & & $<$ & 1.41 & $\cdots$ & $100 \%$ \\
\hline Organics, Semi-volatile & 2,4-Dinitrophenol & SW 8270 & ug/L & $<$ & 7 & & $<$ & 7.18 & $<$ & 6.43 & $<$ & 5.69 & & $<$ & 6.87 & $-\cdot$ & $100 \%$ \\
\hline Organics, Semi-volatile & 2,4-Dinitrololuene & SW 8270 & $\mathrm{ug} / \mathrm{L}$ & $<$ & 0.55 & & $<$ & 0.564 & $<$ & 0.909 & $<$ & 0.804 & & $<$ & 0.674 & -. & $100 \%$ \\
\hline Organics, Semi-volatile & 2,6-Dichlorophenol & SW 8270 & ug/L & $<$ & 0.723 & & $<$ & 0.742 & $<$ & 0.788 & $<$ & 0.697 & & $<$ & 0.751 & -- & $100 \%$ \\
\hline Organics, Semi-volatile & 2,6-Dinitrotoluene & SW 8270 & $u g / L$ & $<$ & 0.346 & & $<$ & 0355 & $<$ & 1.32 & $<$ & 1.17 & & $<$ & 0.674 & -. & $100 \%$ \\
\hline Organics, Semi-volatile & 2-Chloronaphithalene & SW 8270 & $\mathrm{ug} / \mathrm{L}$ & $<$ & 0.324 & & $<$ & 0.332 & $<$ & 0.603 & $<$ & 0.533 & & $<$ & 0.420 & -- & $100 \%$ \\
\hline Organics, Seml-volatile & 2-Chlorophenol & SW 8270 & $u g / L$ & $<$ & 0.764 & & $<$ & 0.784 & $<$ & 0.977 & $<$ & 0.864 & & $<$ & 0.842 & $\cdots$ & $100 \%$ \\
\hline Organics, Semi-volatile & 2-Methylnaphthalene & SW 8270 & $\mathrm{ug} / \mathrm{L}$ & $<$ & 0.66 & & $<$ & 0.677 & $<$ & 0.56 & $<$ & 0.495 & & $<$ & 0.632 & -. & $100 \%$ \\
\hline Organics, Semi-volatile & 2-Methylphenol(o-cresol) & SW 8270 & $u g / L$ & $<$ & 0.534 & & $<$ & 0.548 & $<$ & 0.477 & $<$ & 0.422 & & $<$ & 0.520 & -. & $100 \%$ \\
\hline Organics, Semi-volatile & 2-Naphthylamine & SW 8270 & $u g / L$ & $<$ & 1.95 & & $<$ & 2 & $<$ & 2.46 & $<$ & 2.18 & & $<$ & 2.14 & -. & $100 \%$ \\
\hline
\end{tabular}

Limestone Slurry Filtrate - Page 2 


\section{Liquid Stream Data Summary}

Sample Stream: Limestone Slurry Filtrate

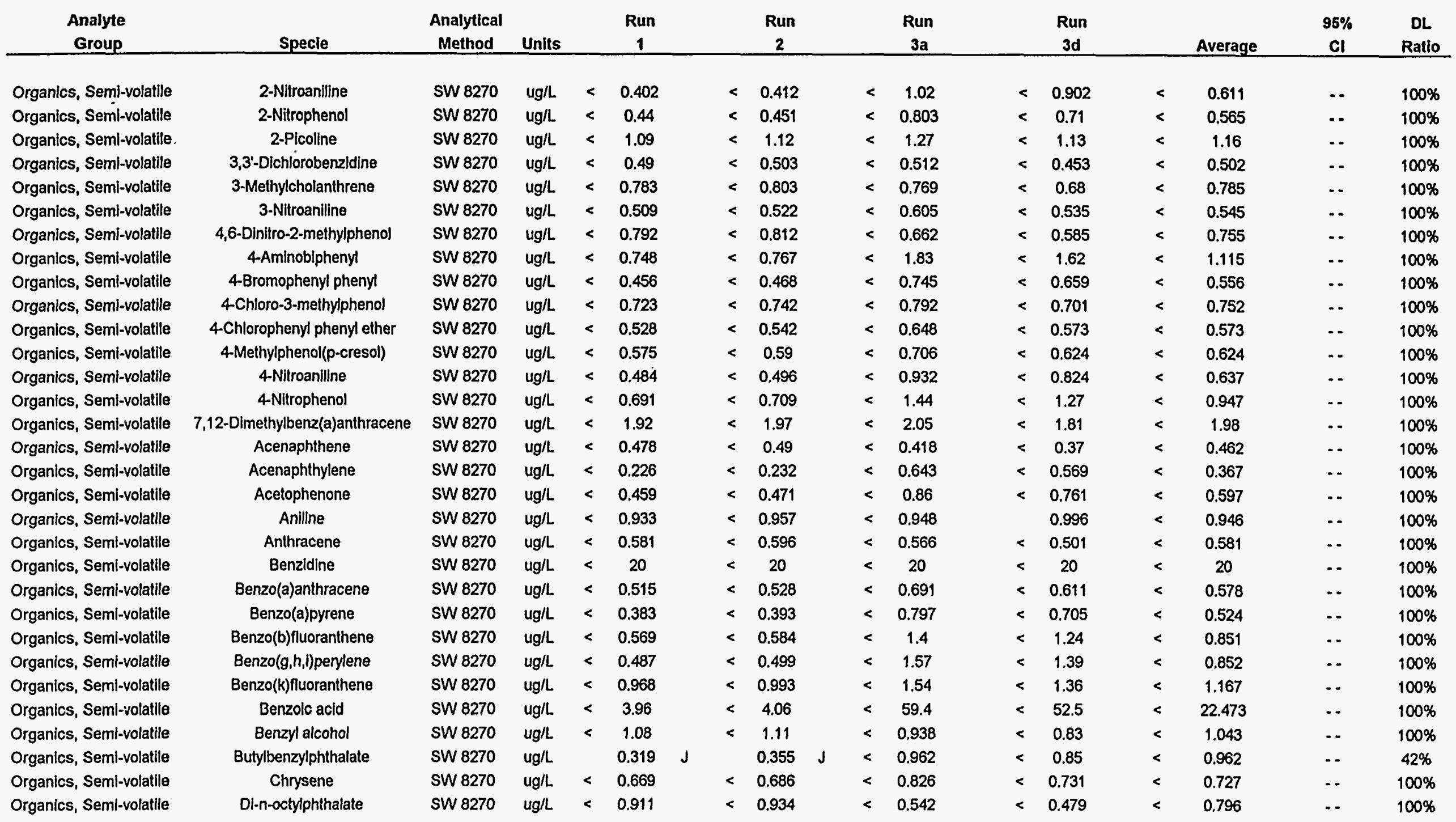




\section{Liquid Stream Data Summary}

Sample Stream: Limestone Slurry Filtrate

\begin{tabular}{|c|c|c|c|c|c|c|c|c|c|c|c|c|c|c|c|c|c|}
\hline $\begin{array}{c}\text { Analyte } \\
\text { Group }\end{array}$ & Specie & $\begin{array}{c}\text { Analytical } \\
\text { Method }\end{array}$ & Units & & $\begin{array}{c}\text { Run } \\
1 \\
\end{array}$ & & $\begin{array}{c}\text { Run } \\
2 \\
\end{array}$ & & & $\begin{array}{r}\text { Run } \\
\text { 3a } \\
\end{array}$ & & & $\begin{array}{c}\text { Run } \\
3 d\end{array}$ & & Average & $\begin{array}{c}95 \% \\
\mathrm{Cl} \\
\end{array}$ & $\begin{array}{c}\mathrm{DL} \\
\text { Ratio }\end{array}$ \\
\hline Organics, Semi-volatile & Dibenz $(a, h)$ anthracene & SW 8270 & ug/L & $<$ & 0.474 & $<$ & 0.486 & & $<$ & 1.25 & & $<$ & 1.1 & $<$ & 0.737 & $\cdots$ & $100 \%$ \\
\hline Organics, Semi-volatile & Dibenzofuran & SW 8270 & $u g / L$ & $<$ & 0.408 & $<$ & 0.418 & & $<$ & 0.826 & & $<$ & 0.731 & $<$ & 0.551 & $\cdots$ & $100 \%$ \\
\hline Organics, Semi-volatile & Dibutylphthalate & SW 8270 & ug/L & $<$ & 0.493 & $<$ & 0.506 & & & 0.769 & & $<$ & 0.441 & $<$ & 0.506 & -. & $39 \%$ \\
\hline Organics, Semi-volatile & Diethylphthalate & SW 8270 & ug/L & $<$ & 0.336 & $<$ & 0.345 & & & 0.482 & J & $<$ & 0.701 & $<$ & 0.345 & .. & $41 \%$ \\
\hline Organics, Semi-volátile & Dimethylphenethylamine & SW 8270 & $u g / L$ & $<$ & 120 & $<$ & 120 & & $<$ & 120 & & $<$ & 120 & $<$ & 120 & -. & $100 \%$ \\
\hline Organics, Semi-volatile & Dimethylphthalate & SW 8270 & ug/L. & $<$ & 0.28 & $<$ & 0.287 & & $<$ & 0.517 & & $<$ & 0.457 & $<$ & 0.361 & - & $100 \%$ \\
\hline Organics, Semi-volatile & Diphenylamine & SW 8270 & ug/h & $<$ & 0.528 & $<$ & 0.542 & & $<$ & 0.426 & & $<$ & 0.377 & $<$ & 0.499 & -. & $100 \%$ \\
\hline Organics, Semi-volatile & Ethyl methanesulfonate & SW 8270 & ug/L & $<$ & 0.503 & $<$ & 0.516 & & $<$ & 1.04 & & $<$ & 0.924 & $<$ & 0.686 & $\cdots$ & $100 \%$ \\
\hline Organics, Semi-volatile & Fluoranthene & SW 8270 & ug/L & $<$ & 0.638 & $<$ & 0.654 & & $<$ & 0.725 & & $<$ & 0.641 & $<$ & 0.672 & $\cdots$ & $100 \%$ \\
\hline Organics, Semi-volatile & Fluorene & SW 8270 & ug/L & $<$ & 0.336 & $<$ & 0.345 & & $<$ & 0.585 & & $<$ & 0.517 & $<$ & 0.422 & $\cdots$ & $100 \%$ \\
\hline Organics, Semi-volatile & Hexachlorobenzene & SW 8270 & $u g / L$ & $<$ & 0.234 & $<$ & 0.24 & & $<$ & 0.483 & & $<$ & 0.427 & $<$ & 0.319 & -. & $100 \%$ \\
\hline Organics, Semi-volatile & Hexachlorobutadlene & SW 8270 & ug/L & $<$ & 0.698 & $<$ & 0.716 & & $<$ & 0.788 & & $<$ & 0.697 & $<$ & 0.734 & $\cdots$ & $100 \%$ \\
\hline Organics, Semi-volatile & Hexachlorocyclopentadiene & SW 8270 & ug/L & $<$ & 8.92 & $<$ & 9.15 & & $<$ & 9.06 & & $<$ & 8.01 & $<$ & 9.04 & -. & $100 \%$ \\
\hline Organics, Semi-volatile & Indeno(1,2,3-cd)pyrene & SW 8270 & $u g / L$ & $<$ & 0.525 & $<$ & 0.538 & & $<$ & 2.05 & & $<$ & 1.81 & $<$ & 1.038 & $\cdots$ & $100 \%$ \\
\hline Organics, Semi-volatile & Isophorone & SW 8270 & $u g / L$ & $<$ & 0.287 & $<$ & 0.294 & & $<$ & 0.948 & & $<$ & 0.838 & $<$ & 0.510 & $\cdots$ & $100 \%$ \\
\hline Organics, Semi-volatile & Methyl methanesulfonate & SW 8270 & ug/L & $<$ & 50 & $<$ & 50 & & $<$ & 50 & & $<$ & 50 & $<$ & 50 & $\cdots$ & $100 \%$ \\
\hline Organics, Semi-volatile & N-Nitroso-dl-n-butylamine & SW 8270 & $u g / L$ & $<$ & 1.31 & $<$ & 1.34 & & $<$ & 0.968 & & $<$ & 0.856 & $<$ & 1.21 &.- & $100 \%$ \\
\hline Organics, Semi-volatile & N-Nitrosodimethylamine & SW 8270 & $\mathrm{ug} / \mathrm{L}$ & $<$ & 1.33 & $<$ & 1.36 & & $<$ & 1.21 & & $<$ & 1.07 & $<$ & 1.30 & $\cdots$ & $100 \%$ \\
\hline Organics, Semi-volatile & N-Nitrosodiphenylamine & SW 8270 & $\mathrm{ug} / \mathrm{L}$ & $<$ & 0.566 & $<$ & 0.581 & & $<$ & 0.414 & & $<$ & 0.366 & $<$ & 0.520 & $\cdots$ & $100 \%$ \\
\hline Organics, Semi-volatile & N-Nitrosodipropylamine & SW 8270 & ug/L & $<$ & 0.751 & $<$ & 0.77 & & $<$ & 1.01 & & $<$ & 0.89 & $<$ & 0.84 & $\cdots$ & $100 \%$ \\
\hline Organics, Semi-volatile & N-Nitrosopiperidine & SW 8270 & ug/L & $<$ & 0.943 & $<$ & 0.967 & & $<$ & 0.918 & & $<$ & 0.812 & $<$ & 0.943 & .. & $100 \%$ \\
\hline Organics, Semi-volatile & Naphthalene & SW 8270 & ug/L & $<$ & 0.729 & & 0.206 & J & $<$ & 0.735 & & $<$ & 0.65 & $<$ & 0.735 & $\cdots$ & $78 \%$ \\
\hline Organics, Semi-volatile & Nitrobenzene & SW 8270 & $u g / L$ & $<$ & 0.528 & $<$ & 0.542 & & $<$ & 1.3 & & $<$ & 1.15 & $<$ & 0.790 & $\cdots$ & $100 \%$ \\
\hline Organics, Semi-volatile & Pentachlorobenzene & SW 8270 & $u g / L$ & $<$ & 0.443 & $<$ & 0.454 & & $<$ & 0.575 & & $<$ & 0.509 & $<$ & 0.491 & $\cdots$ & $100 \%$ \\
\hline Organics, Semi-volatile & Pentachloronitrobenzene & SW 8270 & ug/L & $<$ & 2.07 & $<$ & 2.12 & & $<$ & 2.12 & & $<$ & 1.88 & $<$ & 2.10 & $\cdots$ & $100 \%$ \\
\hline Organics, Semi-volatile & Pentachlorophenol & SW 8270 & $u g / L$ & $<$ & 0.864 & $<$ & 0.886 & & $<$ & 1.37 & & $<$ & 1.21 & $<$ & 1.040 & $\cdots$ & $100 \%$ \\
\hline Organics, Semi-volatile & Phenacetln & SW 8270 & ug/L & $<$ & 0.54 & $<$ & 0.554 & & $<$ & 0.594 & & $<$ & 0.525 & $<$ & 0.563 & $\cdots$ & $100 \%$ \\
\hline Organics, Semi-volatile & Phenanthrene & SW 8270 & ug/L & $<$ & 0.622 & $<$ & 0.638 & & $<$ & 0.72 & & $<$ & 0.637 & $<$ & 0.660 & $\cdots$ & $100 \%$ \\
\hline Organics, Semi-volatile & Phenol & SW 8270 & ug/L & $<$ & 0.399 & $<$ & 0.409 & & $<$ & 1.36 & & $<$ & 1.2 & $<$ & 0.723 & $\cdots$ & $100 \%$ \\
\hline
\end{tabular}

Limestone Slurry Filtrate - Page 4 


\section{Liquid Stream Data Summary}

Sample Stream: Limestone Slurry Filtrate

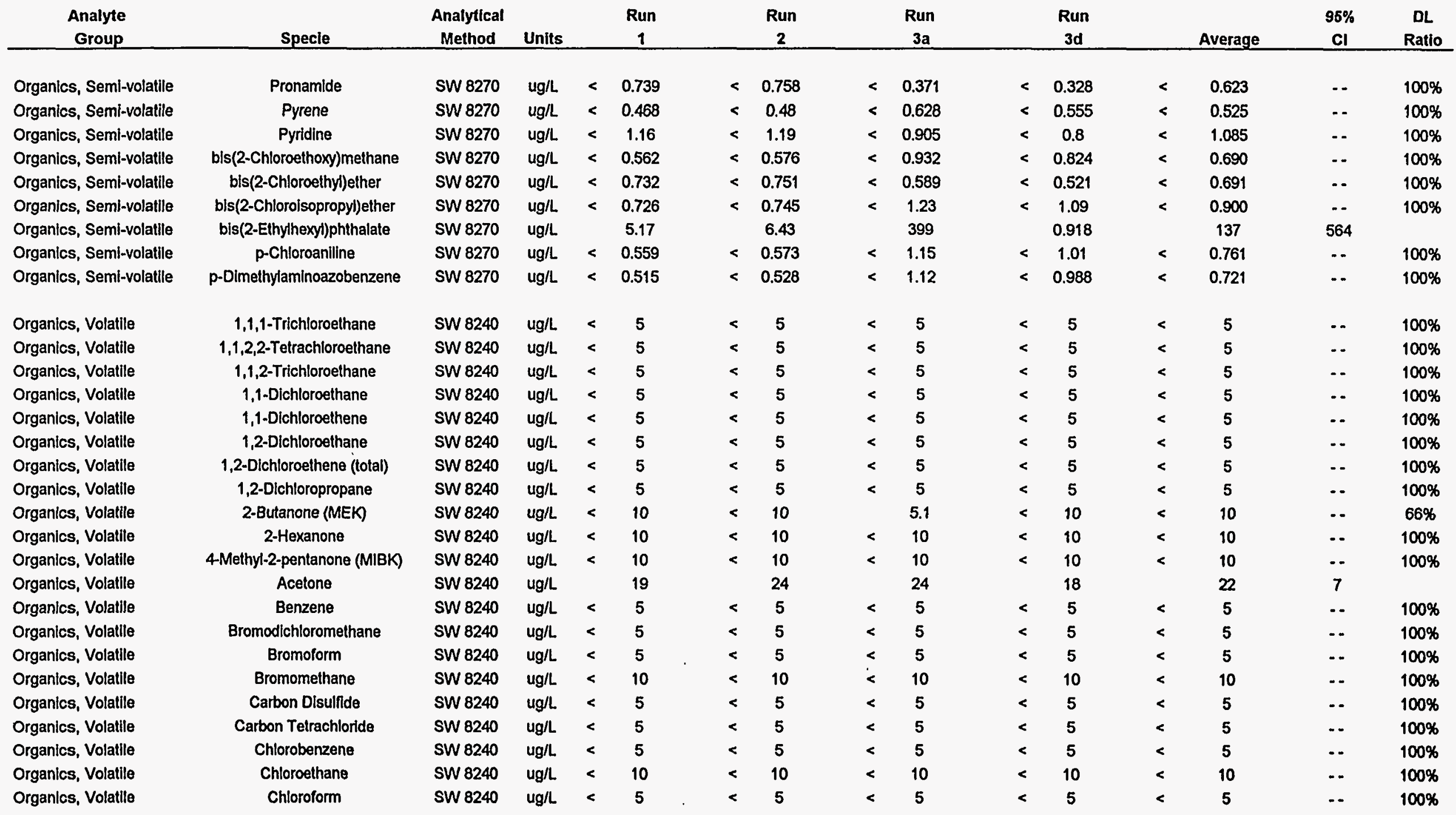




\section{Liquid Stream Data Summary}

Sample Stream: Limestone Slurry Filtrate

\begin{tabular}{|c|c|c|c|c|c|c|c|c|c|c|c|c|c|c|c|c|}
\hline $\begin{array}{c}\text { Analyte } \\
\text { Group }\end{array}$ & Specie & $\begin{array}{c}\text { Analytical } \\
\text { Method }\end{array}$ & Units & & $\begin{array}{c}\text { Run } \\
1 \\
\end{array}$ & & $\begin{array}{c}\text { Run } \\
2 \\
\end{array}$ & & $\begin{array}{c}\text { Run } \\
3 \mathbf{a} \\
\end{array}$ & & $\begin{array}{r}\text { Run } \\
3 \mathrm{~d} \\
\end{array}$ & & & Average & $\begin{array}{c}86 \% \\
\mathrm{Cl} \\
\end{array}$ & $\begin{array}{c}\text { DL } \\
\text { Ratio }\end{array}$ \\
\hline Organics, Volatile & Chloromethane & SW 8240 & $u g / L$ & $<$ & 10 & $<$ & 10 & $<$ & 10 & $<$ & 10 & & $<$ & 10 &.- & $100 \%$ \\
\hline Organics, Volatlle & Dibromochloromethane & SW 8240 & ug/L & $<$ & 5 & $<$ & 5 & $<$ & 5 & $<$ & 5 & & $<$ & 5 & $\cdots$ & $100 \%$ \\
\hline Organics, Volatile & Ethylbenzene & SW 8240 & $u g / L$ & $<$ & 5 & $<$ & 5 & $<$ & 5 & $<$ & 5 & & $<$ & 5 & $\cdots$ & $100 \%$ \\
\hline Organics, Volatile & Methylene Chloride & SW 8240 & ug/L & $<$ & 5 & & 5 & & 5 & & 4.8 & J & $<$ & 5 & $\cdots$ & $20 \%$ \\
\hline Organics, Volatile & Styrene & SW 8240 & ug/L & $<$ & 5 & $<$ & 5 & $<$ & 5 & $<$ & 5 & & $<$ & 5 & $\cdots$ & $100 \%$ \\
\hline Organics, Volatile & Tetrachioroethene & SW 8240 & ug/L. & $<$ & 5 & $<$ & 5 & $<$ & 5 & $<$ & 5 & & $<$ & 5 & $\cdots$ & $100 \%$ \\
\hline Organics, Volatile & Toluene & SW 8240 & ug/L & $<$ & 5 & $<$ & 5 & $<$ & 5 & $<$ & 5 & & $<$ & 5 & $-\cdot$ & $100 \%$ \\
\hline Organics, Volatile & Trichloroethene & SW 8240 & ug/L & $<$ & 5 & $<$ & 5 & $<$ & 5 & $<$ & 5 & & $<$ & 5 & $-\cdot$ & $100 \%$ \\
\hline Organics, Volatile & Vinyl acetate & SW 8240 & $u g / L$ & $<$ & 10 & $<$ & 10 & $<$ & 10 & $<$ & 10 & & $<$ & 10 & $\cdots$ & $100 \%$ \\
\hline Organics, Volatile & Vinyl chloride & SW 8240 & ug/L & $<$ & 10 & $<$ & 10 & $<$ & 10 & $<$ & 10 & & $<$ & 10 & $\cdots$ & $100 \%$ \\
\hline Organics, Volatile & Xylenes & SW 8240 & ug/L & $<$ & 5 & $<$ & 5 & $<$ & 5 & $<$ & 5 & & $<$ & 5 & $\cdots$ & $100 \%$ \\
\hline Organics, Volatile & cis-1,3-Dichloropropene & SW 8240 & ug/L & $<$ & 5 & $<$ & 5 & $<$ & 5 & $<$ & 5 & & $<$ & 5 & $\cdots$ & $100 \%$ \\
\hline Organies, Volatile & trans-1,3-Dichloropropene & SW 8240 & ug/L & $<$ & 5 & $<$ & 5 & $<$ & 5 & $<$ & 5 & & $<$ & 5 & $\cdots$ & $100 \%$ \\
\hline
\end{tabular}

Limestone Slurry Filtrate - Page 6 


\section{Liquid Stream Data Summary}

Sample Stream: Cooling Water

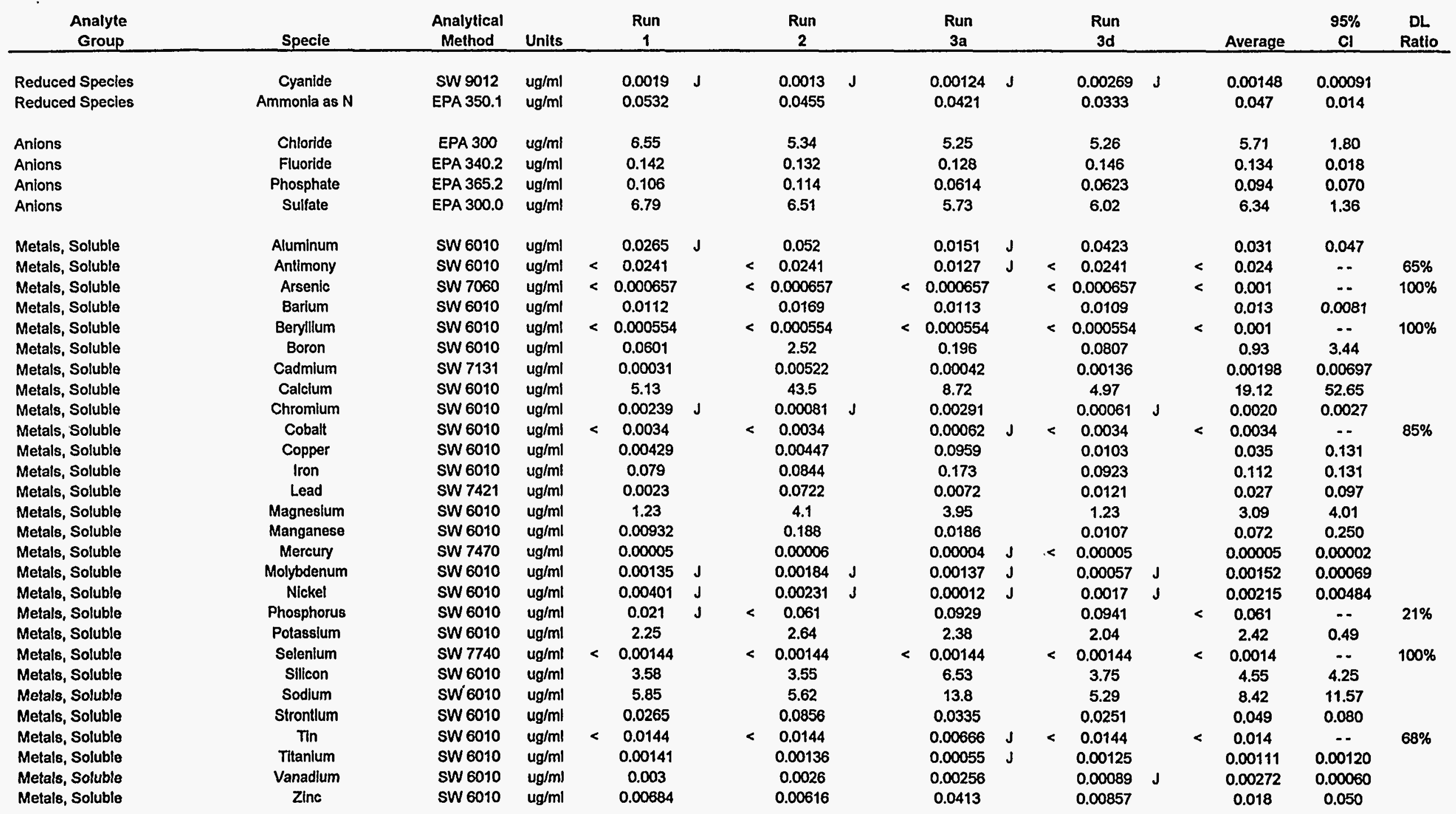

\section{Cooling Water - Page 1}


Sample Stream: Cooling Water

\begin{tabular}{|c|c|c|c|c|c|c|c|c|c|c|c|c|c|c|c|c|c|c|c|}
\hline $\begin{array}{c}\text { Analyte } \\
\text { Group }\end{array}$ & Specie & $\begin{array}{l}\text { Analytical } \\
\text { Method }\end{array}$ & Units & & $\begin{array}{c}\text { Run } \\
1 \\
\end{array}$ & & & $\begin{array}{c}\text { Run } \\
2 \\
\end{array}$ & & & $\begin{array}{c}\text { Run } \\
3 a\end{array}$ & & & $\begin{array}{c}\text { Run } \\
\text { 3d }\end{array}$ & & & Average & $\begin{array}{c}95 \% \\
\mathrm{Cl}\end{array}$ & $\begin{array}{c}\text { DL } \\
\text { Ratio }\end{array}$ \\
\hline Metals, Total & Aluminum & SW 6010 & $\mathrm{ug} / \mathrm{ml}$ & & 2.98 & & & 4.6 & & & 1.03 & & & 1.15 & & & 2.87 & 4.44 & \\
\hline Metals, Total & Antimony & sW 6010 & $\mathrm{ug} / \mathrm{ml}$ & & 0.036 & & & 0.0219 & $J$ & & 0.00859 & $J$ & & 0.0346 & & & 0.022 & 0.034 & \\
\hline Metals, Total & Arsenic & sw 7060 & $\mathrm{ug} / \mathrm{ml}$ & & 0.0216 & & $<$ & 0.000657 & & $<$ & 0.000657 & & $<$ & 0.000657 & & & 0.0074 & 0.0305 & $3 \%$ \\
\hline Metals, Total & Barium & SW 6010 & $\mathrm{ug} / \mathrm{ml}$ & & 0.0322 & & & 0.0409 & & & 0.0188 & & & 0.0181 & & & 0.031 & 0.028 & \\
\hline Metals, Total & Beryllium & SW 6010 & $\mathrm{ug} / \mathrm{ml}$ & & $9 E-05$ & $\mathbf{J}$ & & 0.00014 & $J$ & $<$ & 0.000554 & & $<$ & 0.000554 & & $<$ & 0.00055 & $\ldots$ & $55 \%$ \\
\hline Metals, Total & Boron & SW 6010 & $\mathrm{ug} / \mathrm{ml}$ & & 0.247 & & & 0.488 & & & 0.236 & & & 0.0846 & & & 0.324 & 0.354 & \\
\hline Metals, Total & Cadmium & sW 7131 & $\mathrm{ug} / \mathrm{ml}$ & & 0.00023 & $\mathbf{J}$ & & 0.00209 & & & 0.00064 & & & 0.00031 & & & 0.00099 & 0.00243 & \\
\hline Metals, Total & Calcium & sW 6010 & ug/ml & & 5.91 & & & 6.54 & & & 5.28 & & & 4.62 & & & 5.91 & 1.57 & \\
\hline Metals, Total & Chromium & SW 6010 & $\mathrm{ug} / \mathrm{ml}$ & & 0.00566 & & & 0.00634 & & & 0.00283 & & & 0.00449 & & & 0.00494 & 0.00462 & \\
\hline Metals, Total & Cobalt & SW 6010 & $\mathrm{ug} / \mathrm{ml}$ & & 0.00453 & & & 0.00682 & & & 0.00368 & & & 0.00622 & & & 0.00501 & 0.00403 & \\
\hline Metals, Total & Copper & SW 6010 & $\mathrm{ug} / \mathrm{ml}$ & & 0.0112 & & & 0.0132 & & & 0.00682 & & & 0.00552 & & & 0.010 & 0.00811 & \\
\hline Metals, Total & Iron & SW 6010 & $\mathrm{ug} / \mathrm{ml}$ & & 4.12 & & & 6.21 & & & 1.87 & & & 1.94 & & & 4.07 & 5.39 & \\
\hline Metals, Total & Lead & SW 7421 & $\mathrm{ug} / \mathrm{ml}$ & & 0.0163 & & & 0.0572 & & & 0.0173 & & & 0.0092 & & & 0.030 & 0.058 & \\
\hline Metals, Total & Magnesium & SW 6010 & $\mathrm{ug} / \mathrm{ml}$ & & 1.81 & & & 1.89 & & & 1.36 & & & 1.28 & & & 1.69 & 0.71 & \\
\hline Metals, Total & Manganese & SW 6010 & $\mathrm{ug} / \mathrm{ml}$ & & 0.193 & & & 0.237 & & & 0.104 & & & 0.0934 & & & 0.178 & 0.168 & \\
\hline Metals, Total & Nickel & SW 6010 & $\mathrm{ug} / \mathrm{ml}$ & & 0.00524 & $\mathrm{~J}$ & & 0.00445 & $\mathbf{J}$ & $<$ & 0.00986 & & & 0.00078 & $\mathbf{J}$ & $<$ & 0.010 & .. & $34 \%$ \\
\hline Metals, Total & Phosphorus & SW 6010 & $\mathrm{ug} / \mathrm{ml}$ & & 0.138 & & & 0.184 & & $<$ & 0.061 & & $<$ & 0.061 & & & 0.118 & 0.196 & $9 \%$ \\
\hline Metals, Total & Potassium & SW 6010 & $\mathrm{ug} / \mathrm{ml}$ & & 3.1 & & & 2.84 & & & 2.33 & & & 2.43 & & & 2.76 & 0.97 & \\
\hline Metals, Total & Selenlum & SW 7740 & $\mathrm{ug} / \mathrm{ml}$ & & 0.0214 & & $<$ & 0.00144 & & $<$ & 0.00144 & & $<$ & 0.00144 & & & 0.008 & 0.030 & $6 \%$ \\
\hline Metals, Total & Sillicon & sW 6010 & $\mathrm{ug} / \mathrm{ml}$ & & 7.01 & & & 8.22 & & & 4.47 & & & 4.56 & & & 6.57 & 4.75 & \\
\hline Metals, Total & Sodium & sw 6010 & uig/ml & & 6.27 & & & 5.1 & & & 4.81 & & & 4.7 & & & 5.39 & 1.92 & \\
\hline Metals, Total & Strontlum & SW 6010 & ug/ml & & 0.0295 & & & 0.0293 & & & 0.0241 & & & 0.0224 & & & 0.028 & 0.0076 & \\
\hline Metals, Total & Tin & SW 6010 & $\mathrm{ug} / \mathrm{ml}$ & $<$ & 0.0144 & & $<$ & 0.0144 & & $<$ & 0.0144 & & $<$ & 0.0144 & & $<$ & 0.014 & -. & $100 \%$ \\
\hline Metals, Total & Titanium & SW 6010 & $\mathrm{ug} / \mathrm{ml}$ & & 0.167 & & & 0.235 & & & 0.0677 & & & 0.069 & & & 0.157 & 0.209 & \\
\hline Metals, Total & Vanadium & SW 6010 & ug/ml & & 0.00881 & & & 0.0119 & & & 0.00427 & & & 0.00629 & & & 0.00833 & 0.010 & \\
\hline Metals, Total & Zinc & SW 6010 & $\mathrm{ug} / \mathrm{ml}$ & & 0.0275 & & & 0.0382 & & & 0.0136 & & & 0.0136 & & & 0.026 & 0.031 & \\
\hline Aldehydes & Acetaldehyde & SW 8315 & $\mathrm{ug} / \mathrm{ml}$ & & 0.004 & & & 0.066 & & & 0.096 & & & 0.09 & & & 0.055 & 0.117 & \\
\hline Aldehydes & Formaldehyde & SW 8315 & $\mathrm{ug} / \mathrm{ml}$ & & 0.0054 & & & 0.044 & & & 0.03 & & & 0.026 & & & 0.026 & 0.049 & \\
\hline Organics, Seml-volatile & 1,2,4,5-Telrachlorobenzene & SW 8270 & ught & $<$ & 0.55 & & $<$ & 0.556 & & $<$ & 0.371 & & $<$ & 0.375 & & $<$ & 0.492 & $\ldots$ & $100 \%$ \\
\hline Organics, Semi-volatile & 1,2,4-Trichlorobenzene & SW 8270 & ug/L & $<$ & 0.563 & & $<$ & 0.568 & & $<$ & 0.56 & & $<$ & 0.565 & & $<$ & 0.564 & $\ldots$ & $100 \%$ \\
\hline Organics, Semi-volatile & 1,2-Dichlorobenzeno & SW 8270 & ug/L & $<$ & 0.742 & & $<$ & 0.749 & & $<$ & 0.605 & & $<$ & 0.611 & & $<$ & 0.699 & - & $100 \%$ \\
\hline
\end{tabular}

Cooling Water - Page 2 


\section{Liquid Stream Data Summary}

Sample Stream: Cooling Water

\begin{tabular}{|c|c|c|c|c|c|c|c|c|c|c|c|c|c|c|c|}
\hline $\begin{array}{c}\text { Analyte } \\
\text { Group }\end{array}$ & Specle & $\begin{array}{c}\text { Analytical } \\
\text { Method }\end{array}$ & Units & & $\begin{array}{c}\text { Run } \\
1 \\
\end{array}$ & & $\begin{array}{c}\text { Run } \\
2 \\
\end{array}$ & & $\begin{array}{c}\text { Run } \\
3 \mathbf{a} \\
\end{array}$ & & $\begin{array}{c}\text { Run } \\
\text { 3d }\end{array}$ & & Average & $\begin{array}{c}95 \% \\
\mathrm{Cl} \\
\end{array}$ & $\begin{array}{c}\text { DL } \\
\text { Ratio }\end{array}$ \\
\hline Organics, Semi-volatile & 1,2-Diphenylhydrazine & SW 8270 & $u g / L$ & $<$ & 100 & $<$ & 100 & $<$ & 100 & $<$ & 100 & $<$ & 100 & -. & $100 \%$ \\
\hline Organics, Semi-volatile & 1,3-Dichlorobenzene & SW 8270 & ug/L & $<$ & 0.377 & $<$ & 0.381 & $<$ & 0.683 & $<$ & 0.689 & $<$ & 0.480 & -- & $100 \%$ \\
\hline Organics, Semi-volatile & 1,4-Dichlorobenzene & SW 8270 & ug/L & $<$ & 0.77 & $<$ & 0.777 & $<$ & 0.56 & $<$ & 0.565 & $<$ & 0.702 & -- & $100 \%$ \\
\hline Organics, Semi-volatile & 1-Chloronaphthalene & SW 8270 & ug/L & $<$ & 0.613 & $<$ & 0.619 & $<$ & 0.511 & $<$ & 0.516 & $<$ & 0.581 & $-\cdot$ & $100 \%$ \\
\hline Organics, Semi-volatile & 1-Naphthylamine & SW 8270 & ug/L & $<$ & 1.49 & $<$ & 1.5 & $<$ & 1.93 & $<$ & 1.95 & $<$ & 1.64 & -. & $100 \%$ \\
\hline Organics, Semi-volatile & 2,3,4,6-Tetrachlorophenol & SW 8270 & ug/L & $<$ & 0.479 & $<$ & 0.484 & $<$ & 0.443 & $<$ & 0.447 & $<$ & 0.469 & $\cdots$ & $100 \%$ \\
\hline Organics, Semi-volatile & 2,4,5-Trichlorophenol & SW 8270 & ug/L & $<$ & 0.314 & $<<$ & 0.317 & $<$ & 0.485 & $<$ & 0.489 & $<$ & 0.372 & $\cdots$ & $100 \%$ \\
\hline Organics; Semi-volatile & 2,4,6-Trichlorophenol & SW 8270 & ug/L & $<$ & 0.332 & $<$ & 0.336 & $<$ & 0.482 & $<$ & 0.487 & $<$ & 0.383 & -- & $100 \%$ \\
\hline Organics, Semi-volatile & 2,4-Dichlorophenol & SW 8270 & $u g / L$ & $<$ & 0.422 & $<$ & 0.426 & $<$ & 0.542 & $<$ & 0.547 & $<$ & 0.463 & $-\cdot$ & $100 \%$ \\
\hline Organics, Semi-volatile & 2,4-Dimethylphenol & SW 8270 & $u g / L$ & $<$ & 1.05 & $<$ & 1.06 & $<$ & 1.24 & $<$ & 1.25 & $<$ & 1.12 & -- & $100 \%$ \\
\hline Organics, Semi-volatile & 2,4-Dinitrophenol & SW 8270 & ug/L & $<$ & 6.67 & $<$ & 6.73 & $<$ & 3.98 & $<$ & 4.02 & $<$ & 5.79 & $-\cdot$ & $100 \%$ \\
\hline Organics, Semi-volatile & 2,4-Dinitrotoluene & SW 8270 & $\mathrm{ug} / \mathrm{L}$ & $<$ & 0.524 & $<$ & 0.529 & $<$ & 0.563 & $<$ & 0.568 & $<$ & 0.539 & -- & $100 \%$ \\
\hline Organics, Semi-volatile & 2,6-Dichlorophenol & SW 8270 & ug/L & $<$ & 0.689 & $<$ & 0.695 & $<$ & 0.488 & $<$ & 0.492 & $<$ & 0.624 & -- & $100 \%$ \\
\hline Organics, Semi-volatile & 2,6-Dinitrotoluene & SW 8270 & ug/L & $<$ & 0.33 & $<$ & 0.333 & $<$ & 0.82 & $<$ & 0.828 & $<$ & 0.494 & $-\cdot$ & $100 \%$ \\
\hline Organics, Semi-volatile & 2-Chloronaphthalene & SW 8270 & $u g / L$ & $<$ & 0.309 & $<$ & 0.312 & $<$ & 0.373 & $<$ & 0.377 & $<$ & 0.331 & -. & $100 \%$ \\
\hline Organics, Semi-volatile & 2-Chlorophenol & SW 8270 & ug/L & $<$ & 0.728 & $<$ & 0.735 & $<$ & 0.605 & $<$ & 0.611 & $<$ & 0.689 & $\cdots$ & $100 \%$ \\
\hline Organics, Semi-volatile & 2-Methyinaphthalene & SW 8270 & $u g / L$ & $<$ & 0.629 & $<$ & 0.635 & $<$ & 0.347 & $<$ & 0.35 & $<$ & 0.54 & - & $100 \%$ \\
\hline Organics, Semi-volatile & 2-Methylphenol(o-cresol) & SW 8270 & ug/L & $<$ & 0.509 & $<$ & 0.513 & $<$ & 0.295 & $<$ & 0.298 & $<$ & 0.439 & -. & $100 \%$ \\
\hline Organics, Semi-volattle & 2-Naphthylamine & SW 8270 & $u g / L$ & $<$ & 1.86 & $<$ & 1.87 & $<$ & 1.52 & $<$ & 1.54 & $<$ & 1.75 & -. & $100 \%$ \\
\hline Organics, Semi-volatile & 2-Nitroaniline & SW 8270 & $u g / h$ & $<$ & 0.383 & $<$ & 0.387 & $<$ & 0.631 & $<$ & 0.637 & $<$ & 0.467 & -- & $100 \%$ \\
\hline Organics, Semi-volatile & 2-Nitrophenol & SW 8270 & $u g / L$ & $<$ & 0.419 & $<$ & 0.423 & $<$ & 0.497 & $<$ & 0.502 & $<$ & 0.446 & -. & $100 \%$ \\
\hline Organics, Semi-volatile & 2-Picoline & SW 8270 & ug/L & $<$ & 1.04 & $<$ & 1.05 & $<$ & 0.788 & $<$ & 0.795 & $<$ & 0.959 & -. & $100 \%$ \\
\hline Organics, Semi-volatlle & 3,3'-Dichlorobenzidine & SW 8270 & $u g / L$ & $<$ & 0.467 & $<$ & 0.471 & $<$ & 0.317 & $<$ & 0.32 & $<$ & 0.418 & - & $100 \%$ \\
\hline Organics, Semi-volatile & 3-Methylcholanthrene & SW 8270 & $u g / L$ & $<$ & 0.746 & $<$ & 0.753 & $<$ & 0.476 & $<$ & 0.481 & $<$ & 0.658 & $-\cdot$ & $100 \%$ \\
\hline Organics, Semi-volatile & 3-Nitroaniline & SW 8270 & $u g / h$ & $<$ & 0.485 & $<$ & 0.489 & $<$ & 0.374 & $<$ & 0.378 & $<$ & 0.449 & -. & $100 \%$ \\
\hline Organics, Semi-volatile & 4,6-Dinitro-2-methylphenol & SW 8270 & $u g / L$ & $<$ & 0.754 & $<$ & 0.762 & $<$ & 0.41 & $<$ & 0.413 & $<$ & 0.642 & - & $100 \%$ \\
\hline Organics, Semi-volatile & 4-Aminobiphenyl & SW 8270 & $\mathrm{ug} / \mathrm{L}$ & $<$ & 0.712 & $<$ & 0.719 & $<$ & 1.13 & $<$ & 1.14 & $<$ & 0.854 & $-\cdot$ & $100 \%$ \\
\hline Organics, Semi-volatile & 4-Bromophenyl phenyl & SW 8270 & $u g / L$ & $<$ & 0.434 & $<$ & 0.438 & $<$ & 0.461 & $<$ & 0.465 & $<$ & 0.444 & -. & $100 \%$ \\
\hline Organics, Semi-volatile & 4-Chloro-3-methylphenol & SW 8270 & ug/L & $<$ & 0.689 & $<$ & 0.695 & $<$ & 0.49 & $<$ & 0.495 & $<$ & 0.625 & $\cdots$ & $100 \%$ \\
\hline Organics, Semi-volatile & 4-Chlorophenyl phenyl ether & SW 8270 & $\mathrm{ug} / \mathrm{h}$ & $<$ & 0.503 & $<$ & 0.508 & $<$ & 0.401 & $<$ & 0.405 & $<$ & 0.471 & $-\cdot$ & $100 \%$ \\
\hline Organics, Semi-volatile & 4-Methylphenol(p-cresol) & SW 8270 & ug/h. & $<$ & 0.548 & $<$ & 0.553 & $<$ & 0.437 & $<$ & 0.441 & $<$ & 0.513 & -. & $100 \%$ \\
\hline Organics, Semi-volatile & 4-Nitroanlline & SW 8270 & $\mathrm{ug} / \mathrm{L}$ & $<$ & 0.461 & $<$ & 0.465 & $<$ & 0.577 & $<$ & 0.583 & $<$ & 0.501 & -. & $100 \%$ \\
\hline Organics, Semi-volatile & 4-Nitrophenol & SW 8270 & $\mathrm{ug} / \mathrm{h}$ & $<$ & 0.658 & $<$ & 0.664 & $<$ & 0.892 & $<$ & 0.901 & $<$ & 0.738 & - & $100 \%$ \\
\hline Organics, Semi-volatile & 7,12-Dimethylbenz(a)anthracene & SW 8270 & ug/L & $<$ & 1.83 & $<$ & 1.85 & $<$ & 1.27 & $<$ & 1.28 & $<$ & 1.65 & $-\cdot$ & $100 \%$ \\
\hline Organics, Semi-volatile & Acenaphthene & SW 8270 & $\mathrm{ug} / \mathrm{L}$ & $<$ & 0.455 & $<$ & 0.46 & $<$ & 0.259 & $<$ & 0.262 & $<$ & 0.391 & -. & $100 \%$ \\
\hline Organics, Semi-volatile & Acenaphthylene & SW 8270 & ug/h. & $<$ & 0.215 & $<$ & 0.217 & $<$ & 0.398 & $<$ & 0.402 & $<$ & 0.277 & - & $100 \%$ \\
\hline
\end{tabular}

Cooling Water - Page 3 
Sample Stream: Cooling Water

\section{Liquid Stream Data Summary}

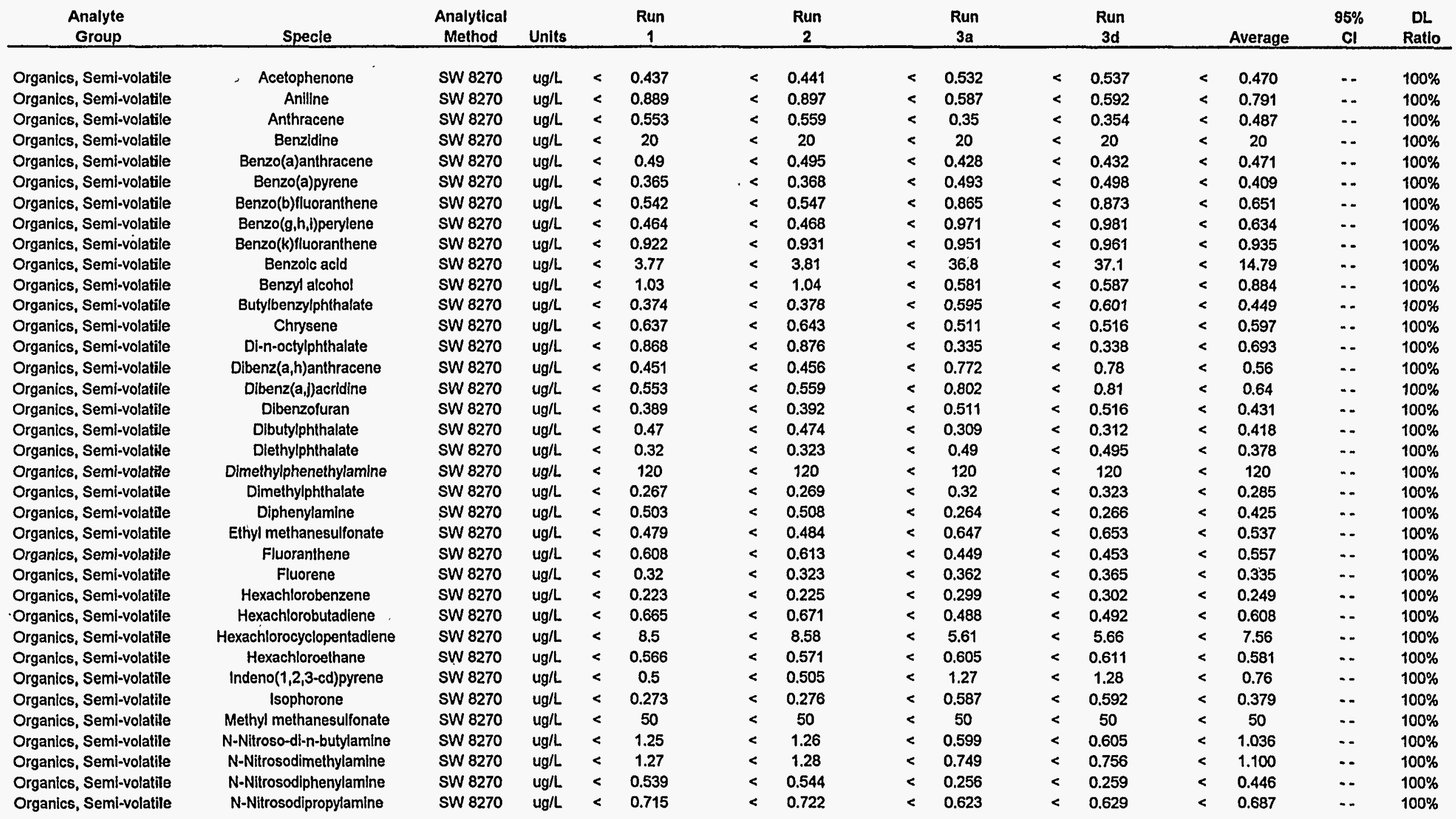

\section{Cooling Water - Page 4}




\section{Liquid Stream Data Summary}

Sample Stream: Cooling Water

\begin{tabular}{|c|c|c|c|c|c|c|c|c|c|c|c|c|c|c|c|c|}
\hline $\begin{array}{c}\text { Analyte } \\
\text { Group }\end{array}$ & Specie & $\begin{array}{c}\text { Analytical } \\
\text { Method }\end{array}$ & Units & & $\begin{array}{c}\text { Run } \\
1 \\
\end{array}$ & & $\begin{array}{c}\text { Run } \\
2 \\
\end{array}$ & & $\begin{array}{c}\text { Run } \\
\mathbf{3 a} \\
\end{array}$ & & $\begin{array}{c}\text { Run } \\
3 d\end{array}$ & & & Average & $\begin{array}{c}95 \% \\
\mathrm{CI} \\
\end{array}$ & $\begin{array}{c}\text { DL } \\
\text { Ratio }\end{array}$ \\
\hline Organics, Semi-volatile & N-Nitrosopiperidine & SW 8270 & $\mathrm{ug} / \mathrm{L}$ & $<$ & 0.898 & $<$ & 0.907 & $<$ & 0.569 & $<$ & 0.574 & & $<$ & 0.791 & - & $100 \%$ \\
\hline Organics, Semi-volatile & Naphthalene & SW 8270 & $u g / L$ & $<$ & 0.694 & $<$ & 0.701 & $<$ & 0.455 & $<$ & 0.46 & & $<$ & 0.62 & $\cdots$ & $100 \%$ \\
\hline Organics, Semi-volatile & Nitrobenzene & SW 8270 & ug/L & $<$ & 0.503 & $<$ & 0.508 & $<$ & 0.802 & $<$ & 0.81 & & $<$ & 0.604 & $\cdots$ & $100 \%$ \\
\hline Organics, Semi-volatile & Pentachlorobenzene & SW 8270 & ug/L & $<$ & 0.422 & $<$ & 0.426 & $<$ & 0.356 & $<$ & 0.36 & & $<$ & 0.401 & -- & $100 \%$ \\
\hline Organics, Semi-volatile & Pentachloronitrobenzene & SW 8270 & $\mathrm{ug} / \mathrm{L}$ & $<$ & 1.97 & $<$ & 1.99 & $<$ & 1.31 & $<$ & 1.33 & & $<$ & 1.76 & -- & $100 \%$ \\
\hline Organics, Semi-volatile & Pentachlorophenol & SW 8270 & $u g / L$ & $<$ & 0.823 & $<$ & 0.831 & $<$ & 0.847 & $<$ & 0.855 & & $<$ & 0.834 & $-\cdot$ & $100 \%$ \\
\hline Organics, Semi-volatile & Phenacetin & SW 8270 & $u g / L$ & $<$ & 0.514 & $<$ & 0.519 & $<$ & 0.368 & $<$ & 0.371 & & $<$ & 0.467 & - & $100 \%$ \\
\hline Organics, Semi-volatile & Phenanthrene & SW 8270 & $\mathrm{ug} / \mathrm{L}$ & $<$ & 0.592 & $<$ & 0.598 & $<$ & 0.446 & $<$ & 0.45 & & $<$ & 0.545 & $\cdots$ & $100 \%$ \\
\hline Organics, Semi-volatile & Phenol & SW 8270 & $\mathrm{ug} / \mathrm{L}$ & $<$ & 0.38 & $<$ & 0.384 & $<$ & 0.841 & $<$ & 0.849 & & $<$ & 0.535 & $-\cdot$ & $100 \%$ \\
\hline Organics, Semi-volatile & Pronamide & SW 8270 & $\mathrm{ug} / \mathrm{L}$ & $<$ & 0.704 & $<$ & 0.711 & $<$ & 0.23 & $<$ & 0.232 & & $<$ & 0.548 & - & $100 \%$ \\
\hline Organics, Semi-volatile & Pyrene & SW 8270 & ug/L & $<$ & 0.446 & $<$ & 0.45 & $<$ & 0.389 & $<$ & 0.392 & & $<$ & 0.428 & $\cdots$ & $100 \%$ \\
\hline Organics, Semi-volatile & Pyridine & SW 8270 & ug/L & $<$ & 1.1 & $<$ & 1.12 & $<$ & 0.56 & $<$ & 0.565 & & $<$ & 0.93 & - & $100 \%$ \\
\hline Organics, Semi-volatile & bis(2-Chloroethoxy)methane & SW 8270 & ug/L & $<$ & 0.535 & $<$ & 0.54 & $<$ & 0.577 & $<$ & 0.583 & & $<$ & 0.551 & - & $100 \%$ \\
\hline Organics, Semi-volatile & bis(2-Chloroethyl)ether & SW 8270 & $\mathrm{ug} / \mathrm{L}$ & $<$ & 0.697 & $<$ & 0.704 & $<$ & 0.365 & $<$ & 0.368 & & $<$ & 0.589 & $-\cdot$ & $100 \%$ \\
\hline Organics, Semi-volatile & bis(2-Chloroisopropyl)ether & SW 8270 & ug/L & $<$ & 0.691 & $<$ & 0.698 & $<$ & 0.76 & $<$ & 0.767 & & $<$ & 0.716 & -- & $100 \%$ \\
\hline Organics, Semi-volatile & bis(2-Ethylhexyl)phthalate & SW 8270 & ug/L & & 4.56 & & 5.8 & $<$ & 0.553 & $<$ & 0.559 & & & 3.55 & 7.2 & $3 \%$ \\
\hline Organics, Semi-volatile & p-Chloroaniline & SW 8270 & $\mathrm{ug} / \mathrm{L}$ & $<$ & 0.532 & $<$ & 0.537 & $<$ & 0.71 & $<$ & 0.716 & & $<$ & 0.593 & $\cdots$ & $100 \%$ \\
\hline Organics, Seml-volatile & p-Dimethylaminoazobenzene & SW 8270 & $\mathrm{ug} / \mathrm{L}$ & $<$ & 0.49 & $<$ & 0.495 & $<$ & 0.691 & $<$ & 0.698 & & $<$ & 0.559 & $\cdots$ & $100 \%$ \\
\hline Organics, Volatile & 1,1,1-Trichloroethane & SW 8240 & $u g / L$ & $<$ & 5 & $<$ & 5 & $<$ & 5 & $<$ & 5 & & $<$ & 5 & -. & $100 \%$ \\
\hline Organics, Volatile & 1,1,2,2-Tetrachloroethane & SW 8240 & $\mathrm{ug} / \mathrm{L}$ & $<$ & 5 & $<$ & 5 & $<$ & 5 & $<$ & 5 & & $<$ & 5 & -- & $100 \%$ \\
\hline Organics, Volatile & 1,1,2-Trichloroethane & SW 8240 & $\mathrm{ug} / \mathrm{L}$ & $<$ & 5 & $<$ & 5 & $<$ & 5 & $<$ & 5 & & $<$ & 5 & $\cdots$ & $100 \%$ \\
\hline Organics, Volatile & 1,1-Dichloroethane & SW 8240 & $\mathrm{ug} / \mathrm{L}$ & $<$ & 5 & $<$ & 5 & $<$ & 5 & $<$ & 5 & & $<$ & 5 & $-\cdot$ & $100 \%$ \\
\hline Organics, Volatile & 1,1-Dichloroethene & SW 8240 & ug/L & $<$ & 5 & $<$ & 5 & $<$ & 5 & $<$ & 5 & & $<$ & 5 & $-\cdot$ & $100 \%$ \\
\hline Organics, Volatile & 1,2-Dichloroethane & SW 8240 & $\mathrm{ug} / \mathrm{L}$ & $<$ & 5 & $<$ & 5 & $<$ & 5 & $<$ & 5 & & $<$ & 5 & -- & $100 \%$ \\
\hline Organics, Volatile & 1,2-Dichloroethene (total) & SW 8240 & $u g / L$ & $<$ & 5 & $<$ & 5 & $<$ & 5 & $<$ & 5 & & $<$ & 5 & $-\cdot$ & $100 \%$ \\
\hline Organics, Volatile & 1,2-Dichloropropane & SW 8240 & $\mathrm{ug} / \mathrm{L}$ & $<$ & 5 & $<$ & 5 & $<$ & 5 & $<$ & 5 & & $<$ & 5 & $\cdots$ & $100 \%$ \\
\hline Organics, Volatile & 2-Butanone (MEK) & SW 8240 & $\mathrm{ug} / \mathrm{L}$ & $<$ & 10 & $<$ & 10 & $<$ & 10 & $<$ & 10 & & $<$ & 10 & $\cdots$ & $100 \%$ \\
\hline Organics, Volatile & 2-Hexanone & SW 8240 & $\mathrm{ug} / \mathrm{L}$ & $<$ & 10 & $<$ & 10 & $<$ & 10 & $<$ & 10 & & $<$ & 10 & $\cdots$ & $100 \%$ \\
\hline Organics, Volatile & 4-Methyl-2-pentanone (MIBK) & SW 8240 & $\mathrm{ug} / \mathrm{L}$ & $<$ & 10 & $<$ & 10 & $<$ & 10 & $<$ & 10 & & $<$ & 10 & $\cdots$ & $100 \%$ \\
\hline Organics, Volatile & Acetone & SW 8240 & $u g / L$ & $<$ & 10 & $<$ & 10 & & 12 & & 8 & J & $<$ & 10 & $\cdots$ & $45 \%$ \\
\hline Organics, Volatile & Benzene & SW 8240 & $u g / L$ & $<$ & 5 & $<$ & 5 & $<$ & 5 & $<$ & 5 & & $<$ & 5 & - & $100 \%$ \\
\hline Organlcs, Volatile & Bromodlchloromethane & SW 8240 & $\mathrm{ug} / \mathrm{L}$ & $<$ & 5 & $<$ & 5 & $<$ & 5 & $<$ & 5 & & $<$ & 5 & $\cdots$ & $100 \%$ \\
\hline Organics, Volatile & Bromoform & SW 8240 & $u g / L$ & $<$ & 5 & $<$ & 5 & $<$ & 5 & $<$ & 5 & & $<$ & 5 & $\cdots$ & $100 \%$ \\
\hline Organics, Volatile & Bromomethane & SW 8240 & $\mathrm{ug} / \mathrm{L}$ & $<$ & 10 & $<$ & 10 & $<$ & 10 & $<$ & 10 & & $<$ & 10 & - & $100 \%$ \\
\hline Organics, Volatile & Carbon Disulfide & SW 8240 & $\mathrm{ug} / \mathrm{L}$ & $<$ & 5 & $<$ & 5 & $<$ & 5 & $<$ & 5 & & $<$ & 5 & . & $100 \%$ \\
\hline
\end{tabular}

\section{Cooling Water - Page 5}




\section{Liquid Stream Data Summary}

Sample Stream: Cooling Water

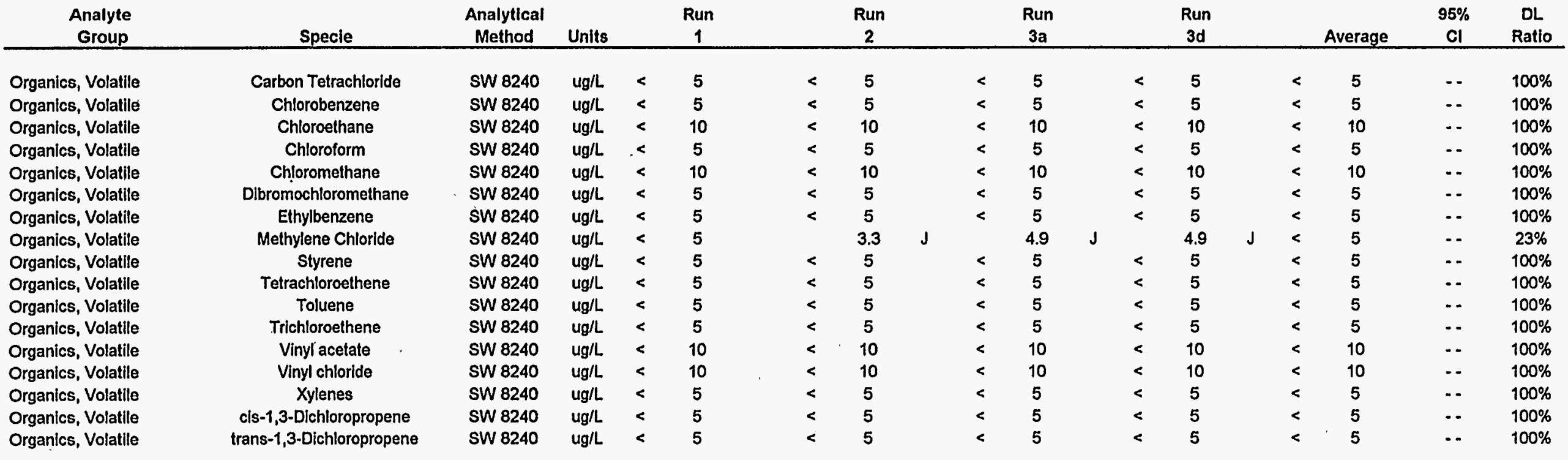

\footnotetext{
Cooling Water - Page 6
} 


\section{Liquid Stream Data Summary}

Sample Stream: Coal Pile Run-off

\begin{tabular}{|c|c|c|c|c|c|c|c|c|c|c|}
\hline $\begin{array}{c}\text { Analyte } \\
\text { Group }\end{array}$ & Specie & $\begin{array}{c}\text { Analytical } \\
\text { Method }\end{array}$ & Units & & $\begin{array}{c}\text { Run } \\
1 \\
\end{array}$ & $\begin{array}{c}\text { Run } \\
2 \\
\end{array}$ & & Average & $\begin{array}{c}95 \% \\
\mathbf{C l} \\
\end{array}$ & $\begin{array}{c}\text { DL } \\
\text { Ratio }\end{array}$ \\
\hline Aldehydes & Acetaldehyde & SW 8315 & $\mathrm{ug} / \mathrm{ml}$ & & 0.07 & 0.112 & & 0.091 & 0.267 & \\
\hline Aldehydes & Formaldehyde & SW 8315 & $\mathrm{ug} / \mathrm{ml}$ & & 0.026 & 0.088 & & 0.057 & 0.394 & \\
\hline Organics, Semi-volatile & $1,2,4,5-$ Tetrachlorobenzene & SW 8270 & $u g / L$ & $<$ & 0.709 & & $<$ & 0.709 & -- & $100 \%$ \\
\hline Organics, Semi-volatile & 1,2,4-Trichlorobenzene & SW 8270 & ug/L & $<$ & 0.725 & & $<$ & 0.725 & - - & $100 \%$ \\
\hline Organics, Semi-volatile & 1,2-Dlchlorobenzene & SW 8270 & $u g / L$ & $<$ & 0.956 & & $<$ & 0.956 & $\cdots$ & $100 \%$ \\
\hline Organics, Seml-volatile & 1,2-Diphenylhydrazine & SW 8270 & ug/h & $<$ & 100 & & $<$ & 100 & -. & $100 \%$ \\
\hline Organics, Semi-volatile & 1,3-Dichlorobenzene & SW 8270 & $\mathrm{ug} / \mathrm{L}$ & $<$ & 0.486 & & $<$ & 0.486 & -- & $100 \%$ \\
\hline Organics, Semi-volatile & 1,4-Dichlorobenzene & SW 8270 & ug/L & $<$ & 0.991 & & $<$ & 0.991 & $\cdots$ & $100 \%$ \\
\hline Organics, Semi-volatile & 1.Chloronaphthalene & SW 8270 & ug/L & $<$ & 0.79 & & $<$ & 0.79 & - & $100 \%$ \\
\hline Organics, Semi-volatile & 1-Naphthylamine & SW 8270 & ug/h & $<$ & 1.91 & & $<$ & 1.91 & $\cdots$ & $100 \%$ \\
\hline Organics, Semi-volatile & $2,3,4,6$-Tetrachlorophenol & SW 8270 & $\mathrm{ug} / \mathrm{L}$ & $<$ & 0.617 & & $<$ & 0.617 & -. & $100 \%$ \\
\hline Organics, Semi-volatile & 2,4,5-Trichlorophenol & SW 8270 & ug/L & $<$ & 0.405 & & $<$ & 0.405 & -. & $100 \%$ \\
\hline Organics, Semi-volatile & 2,4,6-Trichlorophenol & SW 8270 & ug/L & $<$ & 0.428 & & $<$ & 0.428 & -- & $100 \%$ \\
\hline Organics, Semi-volatile & 2,4-Dichlorophenol & SW 8270 & ug/L & $<$ & 0.544 & & $<$ & 0.544 & -- & $100 \%$ \\
\hline Organics, Seml-volatile & 2,4-Dimethyiphenol & SW 8270 & $u g / L$ & $<$ & 1.35 & & $<$ & 1.35 & 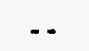 & $100 \%$ \\
\hline Organics, Semi-volatile & 2,4-Dinitrophenol & SW 8270 & ug/L & $<$ & 8.59 & & $<$ & 8.59 &.- & $100 \%$ \\
\hline Organics, Semi-volatile & 2,4-Dinitrotoluene & SW 8270 & $u g / L$ & $<$ & 0.675 & & $<$ & 0.675 & -- & $100 \%$ \\
\hline Organics, Semi-volatile & 2,6-Dichlorophenol & SW 8270 & ug/h & $<$ & 0.887 & & $<$ & 0.887 & $\cdots$ & $100 \%$ \\
\hline Organics, Semi-volatile & 2,6-Dinitrotoluene & SW 8270 & $u g / L$ & $<$ & 0.425 & & $<$ & 0.425 & -. & $100 \%$ \\
\hline Organics, Semi-volatile & 2-Chloronaphthalene & SW 8270 & ug/L & $<$ & 0.398 & & $<$ & 0.398 & - & $100 \%$ \\
\hline Organics, Semi-volatile & 2-Chlorophenol & SW 8270 & ug/L & $<$ & 0.937 & & $<$ & 0.937 & -. & $100 \%$ \\
\hline Organics, Semi-volatlle & 2-Methylnaphthalene & SW 8270 & $u g / L$ & $<$ & 0.81 & & $<$ & 0.81 & -. & $100 \%$ \\
\hline Organics, Seml-volatlle & 2-Methylphenol(o-cresol) & SW 8270 & ug/L & $<$ & 0.655 & & $<$ & 0.655 & - & $100 \%$ \\
\hline Organics, Semi-volatile & 2-Naphthylamine & SW 8270 & $u g / L$ & $<$ & 2.39 & & $<$ & 2.39 & - & $100 \%$ \\
\hline Organics, Semi-volatile & 2-Nitroaniline & SW 8270 & $u g / L$ & $<$ & 0.493 & & $<$ & 0.493 & - & $100 \%$ \\
\hline Organics, Semi-volatile & 2-Nitrophenol & SW 8270 & ugill & $<$ & 0.54 & & $<$ & 0.54 & -- & $100 \%$ \\
\hline Organics, Semi-volatile & 2-Plcolline & SW 8270 & ug/L & $<$ & 1.34 & & $<$ & 1.34 & -- & $100 \%$ \\
\hline Organics, Semi-volatile & 3,3'-Dichlorobenzidine & SW 8270 & ug/L & $<$ & 0.601 & & $<$ & 0.601 & $\cdots$ & $100 \%$ \\
\hline Organics, Semi-volatlle & 3-Methylcholanthrene & SW 8270 & $u g / L$ & $<$ & 0.961 & & $<$ & 0.961 & -. & $100 \%$ \\
\hline Organics, Seml-volatile & 3-Nitroanlline & SW 8270 & $u g / L$ & $<$ & 0.625 & & $<$ & 0.625 & $\cdots$ & $100 \%$ \\
\hline
\end{tabular}

Coal Pile Run-off - Page 1 


\section{Liquid Stream Data Summary}

Sample Stream: Coal Pile Run-off

\begin{tabular}{|c|c|c|c|c|c|c|c|c|c|c|}
\hline $\begin{array}{c}\text { Analyte } \\
\text { Group }\end{array}$ & Specie & $\begin{array}{c}\text { Analytical } \\
\text { Method }\end{array}$ & Units & & $\begin{array}{c}\text { Run } \\
1 \\
\end{array}$ & $\begin{array}{c}\text { Run } \\
2 \\
\end{array}$ & & Average & $\begin{array}{c}96 \% \\
\mathrm{Cl} \\
\end{array}$ & $\begin{array}{c}\text { DL } \\
\text { Ratio }\end{array}$ \\
\hline Organics, Semi-volatile & 4,6-Dinitro-2-methylphenol & SW 8270 & ug/L & $<$ & 0.972 & & $<$ & 0.972 & -- & $100 \%$ \\
\hline Organics, Semi-volatile & 4-Aminoblphenyl & SW 8270 & ug/L. & $<$ & 0.918 & & $<$ & 0.918 & $\cdots$ & $100 \%$ \\
\hline Organics, Semi-volatile & 4-Bromophenyl phenyl & SW 8270 & ug/L & $<$ & 0.56 & & $<$ & 0.56 & $\cdots$ & $100 \%$ \\
\hline Organics, Semi-volatlle & 4-Chloro-3-methylphenol & SW 8270 & ug/L. & $<$ & 0.887 & & $<$ & 0.887 & $\cdots$ & $100 \%$ \\
\hline Organics, Semi-volatile & 4-Chlorophenyl phenyl ether & SW 8270 & ug/L & $<$ & 0.648 & & $<$ & 0.648 & $\cdots$ & $100 \%$ \\
\hline Organics, Semi-volatile & 4-Methylphenol(p-cresol) & SW 8270 & ug/L & $<$ & 0.706 & & $<$ & 0.706 & -- & $100 \%$ \\
\hline Organics, Semi-volatile & 4Nitroanilline & SW 8270 & ug/L & $<$ & 0.594 & & $<$ & 0.594 & $\cdots$ & $100 \%$ \\
\hline Organics, Semi-volatile & 4-Nitrophenol & SW 8270 & ug/L & $<$ & 0.848 & & $<$ & 0.848 & $\cdots$ & $100 \%$ \\
\hline Organics, Seml-volatile & 7,12-Dimelhylbenz(a)anthracene & SW 8270 & ug/L & $<$ & 2.36 & & $<$ & 2.36 & $\cdots$ & $100 \%$ \\
\hline Organics, Seml-volatile & Acenaphthene & SW 8270 & ug/L. & $<$ & 0.587 & & $<$ & 0.587 & $-\cdot$ & $100 \%$ \\
\hline Organics, Seml-volatile & Acenaphthylene & SW 8270 & $u g / L$ & $<$ & 0.277 & & $<$ & 0.277 & $\cdots$ & $100 \%$ \\
\hline Organics, Semi-volatile & Acetophenone & SW 8270 & ug/L & $<$ & 0.563 & & $<$ & 0.563 & $\cdots$ & $100 \%$ \\
\hline Organics, Seml-volatile & Anilline & SW 8270 & ug/h & $<$ & 1.14 & & $<$ & 1.14 & -- & $100 \%$ \\
\hline Organics, Semi-volatile & Anthracene & SW 8270 & ug/L & $<$ & 0.713 & & $<$ & 0.713 & $\cdots$ & $100 \%$ \\
\hline Organics, Semi-volatile & Benzidine & SW 8270 & ug/L & $<$ & 20 & & $<$ & 20 & $\cdots$ & $100 \%$ \\
\hline Organics, Semi-volatile & Benzo(a)anthracene & SW 8270 & ug/L. & $<$ & 0.632 & & $<$ & 0.632 & $\cdots$ & $100 \%$ \\
\hline Organics, Semi-volatlle & Benzo(a)pyrene & SW 8270 & ug/L. & $<$ & 0.47 & & $<$ & 0.47 & $\therefore$ & $100 \%$ \\
\hline Organics, Semi-volatile & Benzo(b)fiuoranthene & SW 8270 & ug/L & $<$ & 0.698 & & $<$ & 0.698 & $\cdots$ & $100 \%$ \\
\hline Organics, Semi-volatlle & Benzo(g,h,l)perylene & SW 8270 & ug/L & $<$ & 0.598 & & $<$ & 0.598 & -- & $100 \%$ \\
\hline Organics, Semi-volatile & Benzo(k)fluoranthene & SW 8270 & ug/L & $<$ & 1.19 & & $<$ & 1.19 & $\cdots$ & $100 \%$ \\
\hline Organics, Semi-volatile & Benzolc acid & SW 8270 & ug/L & $<$ & 4.86 & & $<$ & 4.86 & $\cdots$ & $100 \%$ \\
\hline Organles, Semi-volatile & Benzyl alcohol & SW 8270 & ug/L. & $<$ & 1.33 & & $<$ & 1.33 & $-\cdot$ & $100 \%$ \\
\hline Organios, Semi-volatlle & Buty/benzylphthalate & SW 8270 & ug/L & & 0.539 & & & 0.539 & $\cdots$ & \\
\hline Organies, Semi-volatile & Chrysene & SW 8270 & ug/L & $<$ & 0.821 & & $<$ & 0.821 & $\cdots$ & $100 \%$ \\
\hline Organics, Semi-volatile & Di-n-octylphthalate & SW 8270 & $\mathrm{ug} / \mathrm{L}$ & $<$ & 1.12 & & $<$ & 1.12 & $\because$ & $100 \%$ \\
\hline Organios, Semi-volatlle & Dlbenz(a,h)anthracene & SW 8270 & ug/L. & $<$ & 0.582 & & $<$ & 0.582 & $\cdots$ & $100 \%$ \\
\hline Organics, Seml-volatile & Dibenz $\left(\mathrm{a}_{1}\right)$ )acridine & SW 8270 & $u g / L$ & $<$ & 0.713 & & $<$ & 0.713 & $\cdots$ & $100 \%$ \\
\hline Organics, Seml-volatile & Dibenzofuran & SW 8270 & ug/L & $<$ & 0.501 & & $<$ & 0.501 & -- & $100 \%$ \\
\hline Organlos, Seml-volatile & Dibutylphthalate & SW 8270 & ug/L & $<$ & 0.605 & & $<$ & 0.605 & $\cdots$ & $100 \%$ \\
\hline Organios, Seml-volatile & Dielhylphthalate & SW 8270 & ug/L & $<$ & 0.412 & & $<$ & 0.412 & -- & $100 \%$ \\
\hline Organios, Seml-volatile & Dimethylphenethylamine & SW 8270 & $u g / L$ & $<$ & 120 & & $<$ & 120 & $\cdots$ & $100 \%$ \\
\hline
\end{tabular}

Coal Pile Run-off - Page 2 


\section{Liquid Stream Data Summary}

Sample Stream: Coal Pile Run-off

\begin{tabular}{|c|c|c|c|c|c|c|c|c|c|c|}
\hline $\begin{array}{c}\text { Analyte } \\
\text { Group }\end{array}$ & Specie & $\begin{array}{c}\text { Analytical } \\
\text { Method }\end{array}$ & Units & & $\begin{array}{c}\text { Run } \\
1 \\
\end{array}$ & $\begin{array}{c}\text { Run } \\
2 \\
\end{array}$ & & Average & $\begin{array}{c}95 \% \\
\text { Cl }\end{array}$ & $\begin{array}{c}\text { DL } \\
\text { Ratio } \\
\end{array}$ \\
\hline Organics, Semi-volatlle & Dimethylphthalate & SW 8270 & $u g / L$ & $<$ & 0.344 & & $<$ & 0.344 & - & $100 \%$ \\
\hline Organics, Semi-volatile & Diphenylamine & SW 8270 & ug/L & $<$ & 0.648 & & $<$ & 0.648 & -. & $100 \%$ \\
\hline Organics, Semi-volatile & Ethyl methanesulfonate & SW 8270 & ug/L & $<$ & 0.617 & & $<$ & 0.617 & -. & $100 \%$ \\
\hline Organics, Semi-volatile & Fluoranthene & SW 8270 & ug/L. & $<$ & 0.783 & & $<$ & 0.783 & - & $100 \%$ \\
\hline Organics, Semi-volatile & Fluorene & SW 8270 & ug/L & $<$ & 0.412 & & $<$ & 0.412 & -. & $100 \%$ \\
\hline Organics, Semi-volatlle & Hexachlorobenzene & SW 8270 & ug/h & $<$ & 0.287 & & $<$ & 0.287 & -. & $100 \%$ \\
\hline Organics, Semi-volatile & Hexachlorobutadiene & SW 8270 & ug/l & $<$ & 0.856 & & $<$ & 0.856 & - & $100 \%$ \\
\hline Organics, Semi-volatile & Hexachlorocyclopentadiene & SW 8270 & ug/h & $<$ & 10.9 & & $<$ & 10.9 & $\ldots$ & $100 \%$ \\
\hline Organics, Semi-volatile & Hexachloroethane & SW 8270 & $u g / L$ & $<$ & 0.729 & & $<$ & 0.729 & -- & $100 \%$ \\
\hline Organics, Semi-volatile & Indeno(1,2,3-cd)pyrene & SW 8270 & ug/L & $<$ & 0.644 & & $<$ & 0.644 & - & $100 \%$ \\
\hline Organics, Semi-volatile & Isophorone & SW 8270 & $u g / h$ & $<$ & 0.352 & & $<$ & 0.352 &.- & $100 \%$ \\
\hline Organics, Semi-volatile & Methyl melhanesulfonate & SW 8270 & $u g / L$ & $<$ & 50 & & $<$ & 50 & - & $100 \%$ \\
\hline Organics, Semi-volatile & N-Nitroso-dl-n-butylamine & SW 8270 & ug/L & $<$ & 1.61 & & $<$ & 1.61 & -- & $100 \%$ \\
\hline Organics, Semi-volatile & N-Nitrosodimethylamine & SW 8270 & $u g / L$ & $<$ & 1.63 & & $<$ & 1.63 & -. & $100 \%$ \\
\hline Organics, Semi-volatile & N-Nitrosodiphenylamine & SW 8270 & ug/h & $<$ & 0.694 & & $<$ & 0.694 & - - & $100 \%$ \\
\hline Organics, Semi-volatile & N-Nitrosodipropylamine & SW 8270 & $u g / L$ & $<$ & 0.921 & & $<$ & 0.921 & -- & $100 \%$ \\
\hline Organics, Semi-volatile & N-Nitrosopiperidine & SW 8270 & $u g / L$ & $<$ & 1.16 & & $<$ & 1.16 & -- & $100 \%$ \\
\hline Organics, Semi-volatile & Naphthalene & SW 8270 & ug/L & $<$ & 0.894 & & $<$ & 0.894 & $\cdots$ & $100 \%$ \\
\hline Organics, Semi-volatile & Nitrobenzene & SW 8270 & ug $/ \mathrm{L}$ & $<$ & 0.648 & & $<$ & 0.648 & $\ldots$ & $100 \%$ \\
\hline Organics, Semi-volatile & Pentachlorobenzene & SW 8270 & ug $/ \mathrm{L}$ & $<$ & 0.544 & & $<$ & 0.544 & - & $100 \%$ \\
\hline Organics, Semi-volatile & Pentachloronitrobenzene & SW 8270 & ug/L & $<$ & 2.54 & & $<$ & 2.54 & -. & $100 \%$ \\
\hline Organics, Semi-volatile & Pentachlorophenol & SW 8270 & ug/L & $<$ & 1.06 & & $<$ & 1.06 & $\cdots$ & $100 \%$ \\
\hline Organics, Semi-volatlle & Phenacetin & SW 8270 & $u g / L$ & $<$ & 0.663 & & $<$ & 0.663 & -- & $100 \%$ \\
\hline Organics, Semi-volatile & Phenanthrene & SW 8270 & $u g / L$ & $<$ & 0.763 & & $<$ & 0.763 & $\cdots$ & $100 \%$ \\
\hline Organics, Seml-volatile & Phenol & SW 8270 & ug/L & $<$ & 0.49 & & $<$ & 0.49 & $\cdots$ & $100 \%$ \\
\hline Organics, Semi-volalile & Pronamide & SW 8270 & ug/L & $<$ & 0.907 & & $<$ & 0.907 & - & $100 \%$ \\
\hline Organics, Semi-volatile & Pyrene & SW 8270 & ug/L & $<$ & 0.574 & & $<$ & 0.574 & $\cdots$ & $100 \%$ \\
\hline Organics, Semi-volatile & Pyridine & SW 8270 & $u g / L$ & $<$ & 1.42 & & $<$ & 1.42 & - & $100 \%$ \\
\hline Organics, Semi-volatile & bis(2-Chloroethoxy)methane & SW 8270 & ug/L & $<$ & 0.69 & & $<$ & 0.69 & $\cdots$ & $100 \%$ \\
\hline Organics, Seml-volatile & bis(2-Chloroethyl)ether & SW 8270 & ug/L & $<$ & 0.898 & & $<$ & 0.898 & - & $100 \%$ \\
\hline Organics, Semi-volatlle & bis(2-Chlorolsopropy)ether & SW 8270 & $u g / L$ & $<$ & 0.891 & & $<$ & 0.891 & $\ldots$ & $100 \%$ \\
\hline
\end{tabular}

Coal Pile Run-off - Page 3 


\section{Liquid Stream Data Summary}

Sample Stream: Coal Pile Run-off

\begin{tabular}{|c|c|c|c|c|c|c|c|c|c|c|c|c|}
\hline $\begin{array}{c}\text { Analyte } \\
\text { Group }\end{array}$ & Specle & $\begin{array}{c}\text { Analytical } \\
\text { Method }\end{array}$ & Units & & $\begin{array}{c}\text { Run } \\
1 \\
\end{array}$ & & $\begin{array}{c}\text { Run } \\
2 \\
\end{array}$ & & & Average & $\begin{array}{c}95 \% \\
\mathrm{Cl} \\
\end{array}$ & $\begin{array}{c}\text { DL } \\
\text { Ratio }\end{array}$ \\
\hline Organics, Semi-volatile & bls(2-Ethylhexyl)phthalate & SW 8270 & $u g / L$ & & 3.3 & & & & & 3.3 & $\cdots$ & \\
\hline Organics, Semi-volatile & p-Chloroanillne & SW 8270 & $u g / L$ & $<$ & 0.686 & & & & $<$ & 0.686 & $\cdots$ & $100 \%$ \\
\hline Organics, Semi-volatile & p-Dimethylaminoazobenzene & SW 8270 & ug/L & $<$ & 0.632 & & & & $<$ & 0.632 & -- & $100 \%$ \\
\hline Organics, Volatile & 1,1,1-Trichloroethane & SW 8240 & ug/L & $<$ & 5 & $<$ & 5 & & $<$ & 5 & - & $100 \%$ \\
\hline Organics, Volatile & 1,1,2,2-Tetrachloroethane & SW 8240 & ug/L & $<$ & 5 & $<$ & 5 & & $<$ & 5 & -- & $100 \%$ \\
\hline Organics, Volatile & 1,1,2-Trichloroelhane & SW 8240 & ug/L & $<$ & 5 & $<$ & 5 & & $<$ & 5 & $\cdots$ & $100 \%$ \\
\hline Organics, Volatile & 1,1-Dlchloroethane & SW 8240 & $u g / L$ & $<$ & 5 & $<$ & 5 & & $<$ & 5 & $\cdots$ & $100 \%$ \\
\hline Organics, Volatile & 1,1-Dichloroethene & SW 8240 & ug/L & $<$ & 5 & $<$ & 5 & & $<$ & 5 & -- & $100 \%$ \\
\hline Organics, Volatile & 1,2-Dichloroethane & SW 8240 & ug/L. & $<$ & 5 & $<$ & 5 & & $<$ & 5 & -. & $100 \%$ \\
\hline Organics, Volatlle & 1,2-Dichloroethene (total) & SW 8240 & ug/L & $<$ & 5 & $<$ & 5 & & $<$ & 5 & -. & $100 \%$ \\
\hline Organics, Volatile & 1,2-Dichloropropane & SW 8240 & ug/L & $<$ & 5 & $<$ & 5 & & $<$ & 5 & - & $100 \%$ \\
\hline Organics, Volatile & 2-Butanone (MEK) & SW 8240 & ug/L & $<$ & 10 & $<$ & 10 & & $<$ & 10 & -- & $100 \%$ \\
\hline Organics, Volatile & 2-Hexanone & SW 8240 & ug/L. & $<$ & 10 & $<$ & 10 & & $\leq$ & 10 & -- & $100 \%$ \\
\hline Organics, Volatile & 4-Methyl-2-pentanone (MIBK) & SW 8240 & ug/L & $<$ & 10 & $<$ & 10 & & $<$ & 10 & $\cdots$ & $100 \%$ \\
\hline Organics, Volatile & Acetone & SW 8240 & ug/L & & 60 & & 20 & & & 40 & 254 & \\
\hline Organics, Volatile & Benzene & SW 8240 & ug/L & $<$ & 5 & $<$ & 5 & & $<$ & 5 & -- & $100 \%$ \\
\hline Organics, Volatlle & Bromodichloromethane & SW 8240 & ug/L. & $<$ & 5 & $<$ & 5 & & $<$ & 5 & $\ldots$ & $100 \%$ \\
\hline Organics, Volatile & Bromoform & SW 8240 & ug/L & $<$ & 5 & $<$ & 5 & & $<$ & 5 & - & $100 \%$ \\
\hline Organics, Volatile & Bromomethane & SW 8240 & ug/L & $<$ & 10 & $<$ & 10 & & $<$ & 10 & $-\cdot$ & $100 \%$ \\
\hline Organics, Volatile & Carbon Disulfide & SW 8240 & ug/L & $<$ & 5 & $<$ & 5 & & $<$ & 5 & - & $100 \%$ \\
\hline Organics, Volatile & Carbon Tetrachloride & SW 8240 & ug/L & $<$ & 5 & $<$ & 5 & & $<$ & 5 & - & $100 \%$ \\
\hline Organics, Volatile & Chlorobenzene & siw 8240 & ug/h & $<$ & 5 & $<$ & 5 & & $<$ & 5 & -. & $100 \%$ \\
\hline Organics; Volatile & Chloroethane & SW 8240 & $\mathrm{ug} / \mathrm{L}$ & $<$ & 10 & $<$ & 10 & & $<$ & 10 & -. & $100 \%$ \\
\hline Organics, Volatlle & Chloroform & SW 8240 & ug/L & $<$ & 5 & $<$ & 5 & & $<$ & 5 & -- & $100 \%$ \\
\hline Organics, Volatile & Chloromethane. & SW 8240 & ug/h. & $<$ & 10 & $<$ & 10 & & $<$ & 10 & -. & $100 \%$ \\
\hline Organics, Volatile & Dibromochloromethane & SW 8240 & ug/L & $<$ & 5 & $<$ & 5 & & $<$ & 5 & - & $100 \%$ \\
\hline Organics, Volatile & Ethylbenzene & SW 8240 & ug/L. & $<$ & 5 & $<$ & 5 & & $<$ & 5 & $\cdots$ & $100 \%$ \\
\hline Organics, Volatile & Methylene Chloride & SW 8240 & ug/L & $<$ & 5 & & 3.5 & J & $<$ & 5 & - & $71 \%$ \\
\hline Organics, Volatile & Styrene & SW 8240 & $u g / L$ & $<$ & 5 & $<$ & 5 & & $<$ & 5 & - & $100 \%$ \\
\hline Organics, Volatile & Tetrachloroethene & SW 8240 & ug/L & $<$ & 5 & $<$ & 5 & & $<$ & 5 & -- & $100 \%$ \\
\hline
\end{tabular}

Coal Pile Run-off - Page 4 


\section{Liquid Stream Data Summary}

Sample Stream: Coal Pile Run-off

\begin{tabular}{|c|c|c|c|c|c|c|c|c|c|c|}
\hline $\begin{array}{l}\text { Analyte } \\
\text { Group }\end{array}$ & Specie & $\begin{array}{c}\text { Analytical } \\
\text { Method }\end{array}$ & Units & & $\begin{array}{c}\text { Run } \\
1 \\
\end{array}$ & $\begin{array}{c}\text { Run } \\
2 \\
\end{array}$ & & Average & $\begin{array}{c}95 \% \\
\mathrm{Cl} \\
\end{array}$ & $\begin{array}{c}\text { DL } \\
\text { Ratio }\end{array}$ \\
\hline Organics, Volatile & Toluene & SW 8240 & ug/L & $<$ & 5 & $<$ & $<$ & 5 & $\cdots$ & $100 \%$ \\
\hline Organics, Volatile & Trichloroethene & SW 8240 & $u g / L$ & $<$ & 5 & $<$ & $<$ & 5 & -- & $100 \%$ \\
\hline Organics, Volatile & Vinyl acetate & SW 8240 & ug/L & $<$ & 10 & $<10$ & $<$ & 10 & $\cdots$ & $100 \%$ \\
\hline Organics, Volatile & Vinyl chloride & SW 8240 & ug/L & $<$ & 10 & $<10$ & $<$ & 10 & - & $100 \%$ \\
\hline Organics, Volatile & Xylenes & SW 8240 & ug/L & $<$ & 5 & $<5$ & $<$ & 5 & $\cdots$ & $100 \%$ \\
\hline Organics, Volatile & cls-1,3-Dichloropropene & SW 8240 & $u g / L$ & $<$ & 5 & $<$ & $<$ & 5 & $\cdots$ & $100 \%$ \\
\hline Organics, Volatile & trans-1,3-Dlchloropropene & SW 8240 & ug/L & $<$ & 5 & $<$ & $<$ & 5 & -- & $100 \%$ \\
\hline
\end{tabular}




\section{APPENDIX I: DEVELOPMENT OF MASS BALANCE EQUATIONS AND EXAMPLE CALCULATIONS}

\section{Mass Balances}

Mass balances for ash and trace metals around Plant Yates power generation and emission control systems were calculated as a check on data consistency. Mass balances were calculated for the following processes: boiler, ESP, JBR, and total plant. The mathematical expressions used are developed in the paragraphs below.

A general mass balance equation which applies to any system is:

$$
\left[\begin{array}{l}
\text { Accumulation of } \\
\text { Mass in System }
\end{array}\right]=\left[\begin{array}{c}
\text { Mass into } \\
\text { System }
\end{array}\right]-\left[\begin{array}{l}
\text { Mass out } \\
\text { of System }
\end{array}\right]+\left[\begin{array}{c}
\text { Mass Generated } \\
\text { in System }
\end{array}\right]
$$

For all species, the generation term in Equation I- 1 is equal to zero. Ash is considered to be a component of coal and not to be generated. Mass balance closure is defined by the following expression:

$$
\text { \% Closure }=100 * \frac{\text { Out }}{\text { In-Accumulation }}
$$

Uncertainties for mass balance closures (95\% confidence intervals) were calculated using an error propagation analysis method based on ANSI/SME PTC 19.1-1985, "Measurement Uncertainty." The development of this method is treated in Appendix F.

The following sections detail the development of mass balances for the boiler, ESP, JBR and total plant (power generation and emission control systems). The equations are developed from Equation I-1 above. The purpose of this development is to present the variables considered in each mass balance. The equations presented below are simplified for clarity. The exact equations, which are more complex, are presented in Table I-1. 
Appendix l: Development of Mass Balance Equations \& Example Calculations

Table I-1

Detailed Mass Balance Equations

Mass Balance About Boiler:

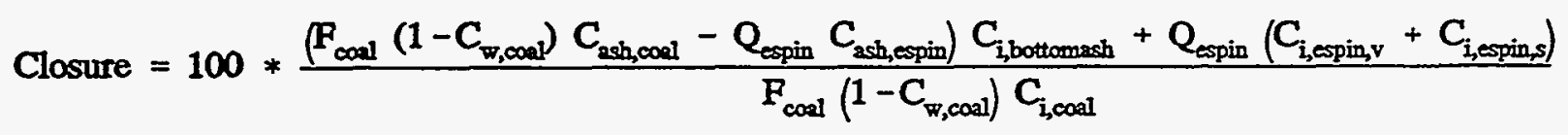

Mass Balance About ESP:

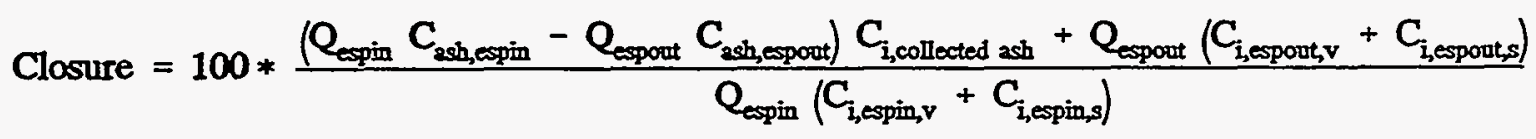

Mass Balance About JBR:

$$
\text { Closure }=100 * \frac{O_{\mathrm{JBR}}}{\mathrm{I}_{\mathrm{JBR}}}
$$

where,

$$
\begin{aligned}
& I_{\text {BR }}=-\frac{\Delta M_{i}}{\Delta t}+Q_{\text {spot }}\left(C_{i, \text { spout }, v}+C_{i, \text { spouts, }}\right)+\left(F_{\text {return,FT128 }}+F_{\text {return, FT142 }}+F_{\text {teturo,FT150B }}\right)
\end{aligned}
$$

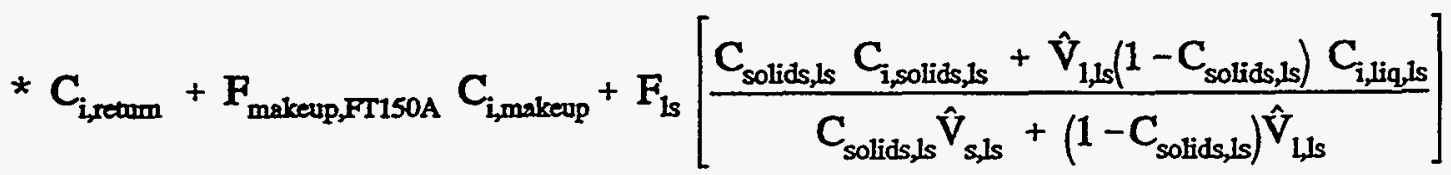

$$
\begin{aligned}
& O_{\text {BR }}=F_{\text {bdwn FT162A }}\left[\frac{C_{\text {solids,bdwn }} C_{i, s o l i d s, b d w n}+\hat{V}_{1, b d w n}\left(1-C_{\text {solids,bdwn }}\right) C_{i, i q, b d w n}}{C_{\text {solids,bdwn }} \hat{V}_{s, b d w n}+\left(1-C_{\text {solids }}\right) \hat{V}_{1, b d w n}}\right] \\
& +Q_{\text {stackgas }}\left(C_{i, s t a c k g a s, v}+C_{i, s t a c k g a s, s}\right)
\end{aligned}
$$

II 


\section{Table I-1 (Continued)}

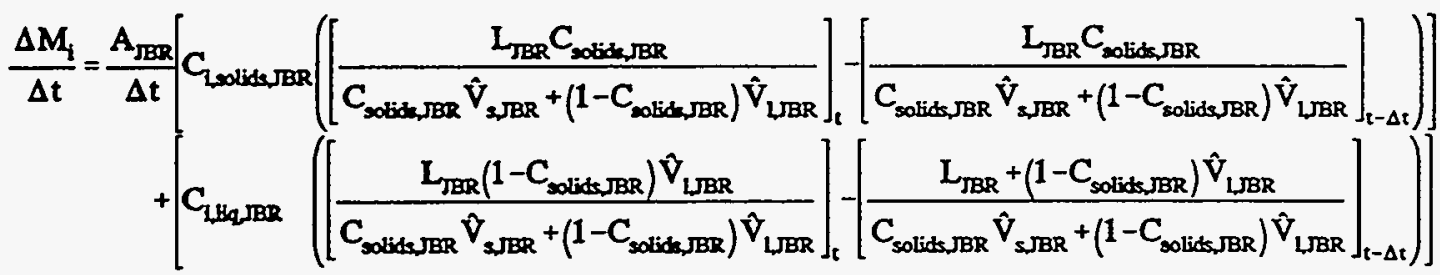

\section{Mass Balance About Entire Plant}

$$
\text { Closure }=100 * \frac{O_{\text {plant }}}{I_{\text {plant }}}
$$

where,

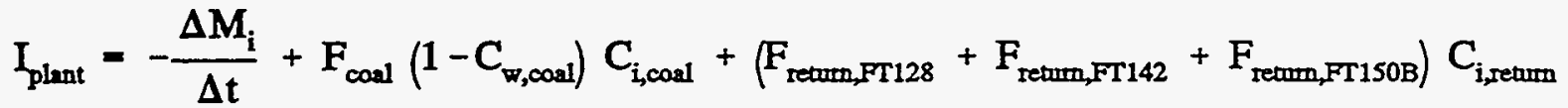

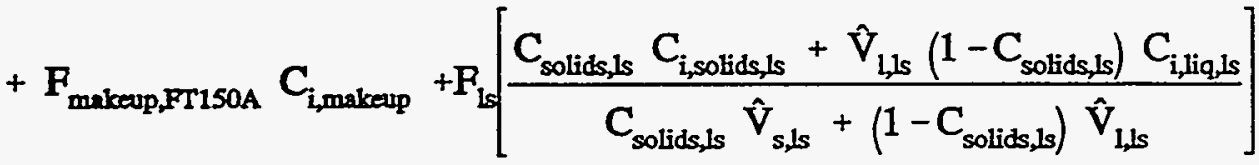

$$
\begin{aligned}
O_{\text {plent }} & =Q_{\text {stackges }}\left(C_{i, s t a c k g a s, v}+C_{i, s t a c k g a s, s}\right) \\
& +F_{\text {bdwn,FT162A }}\left[\frac{C_{\text {solids,bdwn }} C_{i, \text { solids,bdwn }}+\hat{V}_{1, \text { bdwn }}\left(1-C_{\text {solids,bdwn }}\right) C_{i, \text { liq,bdwn }}}{C_{\text {solids,bdwn }} \hat{V}_{s, \text { bdwn }}+\left(1-C_{\text {solids,bdwn }}\right) \hat{V}_{1, \text { bdwn }}}\right] \\
& +\left[F_{\text {coul }}\left(1-C_{w, \text { coul }}\right) C_{\text {esh, coal }}-Q_{\text {espin }} C_{\text {ssh,espin }}\right] C_{i, b o t t o m a s h} \\
& +\left[Q_{\text {espin }} C_{\text {esh,espin }}-Q_{\text {espout }} C_{\text {esh,espout }}\right] C_{i, \text { collectedash }}
\end{aligned}
$$


Appendix l: Development of Mass Balance Equations \& Example Calculations

\section{Boiler}

The following form of Equation I-1 applies to the boiler:

$$
\text { Feed Coal }+ \text { Air }=\text { Bottom Ash + } \begin{gathered}
\text { ESP Inlet Gas } \\
\text { (including entrained particulates) }
\end{gathered}
$$

The accumulation term for ash and trace metal species in the boiler is small and was neglected. For ash, Equation I-3 is expressed mathematically as:

$$
F_{\text {coal }} C_{\text {ash,coal }}=F_{\text {bottomash }}+Q_{\text {espin }} C_{\text {ash,espin }}
$$

Since the bottom ash flow rate could not be measured accurately, Equation I-4 was used to calculate it. The concentrations of trace metal species in combustion air are very low and were neglected. Applied to a trace metal species, Equation I-3 becomes:

$$
F_{\text {coel }} C_{i, \text { cosal }}=F_{\text {botromash }} C_{i, \text { bottomash }}+Q_{\text {espin }} C_{i, \text { espin }}
$$

The exact equation used in calculating the data presented in Table 6-2 in Section 6 was obtained by substituting Equation I-4 into Equation I-5 and rewriting in closure format. This equation is located in Table I-1.

\section{ESP}

The following form of Equation I-1 applies to the ESP:

$$
\text { ESP Inlet Gas = ESP Outlet Gas + ESP Collected Fly Ash }
$$

The accumulation term for solids and trace metals is small and was neglected. For ash, Equation I-6, expressed mathematically, becomes:

$$
Q_{\text {espin }} C_{\text {ash,espin }}=Q_{\text {espout }} C_{\text {ash,espout }}+F_{\text {collectedash }}
$$

Since the collected fly ash flow rate could not be measured, Equation I-7 was used to solve for it. Applied for a trace species, Equation I-6 becomes: 


$$
Q_{\text {capin }} C_{i, \text { espin }}=Q_{\text {expout }} C_{i, \text { espout }}+F_{\text {collectedash }} C_{i, \text { collectedash }}
$$

The exact equation used in calculating the data presented in Table 6-2 of Section 6 was obtained by substituting Equation I-7 into Equation I-8 and rewriting in closure format. This equation is located in Table I-1.

$J B R$

The following form of Equation 1 applies to the JBR:

$$
\underset{\text { Accumulation }}{\text { JBR }}=\underset{\text { Outlet Gas }}{\text { ESP }}+\underset{\text { Water }}{\text { Makeup }}+\frac{\text { Return }}{\text { Water }}+\frac{\text { Limestone }}{\text { Slurry }}+\underset{\text { Oxidation }}{\text { Air }}-\left(\begin{array}{l}
\text { JBR Slurry } \\
\text { Blowdown }
\end{array}+\begin{array}{c}
\text { Stack } \\
\text { Gas }
\end{array}\right)
$$

In the JBR, because of potential changes in volume or slurry solids concentration, the accumulation of solids and trace metals was not considered to be negligible over the test period. Mass flows of trace metal species in oxidation air are very low and were neglected. For a trace metal species, Equation I-1 becomes:

$$
\begin{aligned}
& \frac{d M_{i}}{d t}=Q_{\text {espout }} C_{i, \text { espout }}+F_{\text {makeup }} C_{i, \text { makeup }}+F_{\text {retum }} C_{i \text { retum }} \\
& +\left[\mathrm{F}_{\mathrm{is}} \mathrm{C}_{\text {solids,ls }}+\mathrm{F}_{\mathrm{ls}} \mathrm{C}_{\text {liq,is }} \mathrm{C}_{\mathrm{i}, \mathrm{iq}, \mathrm{ls}}\right] \\
& \left.-\left[F_{\text {bdwn }} C_{\text {solids }} C_{i, s o l i d s}+F_{b d w n} C_{\text {liq,bdwn }} C_{i, l i q, b d w n}\right)+Q_{\text {stackgas }} C_{i, s t a c k g a s}\right]
\end{aligned}
$$

The accumulation term in Equation I-10 was approximated:

$$
\frac{d M_{i}}{d t} \approx \frac{\Delta M_{i}}{\Delta t}
$$

$\Delta \mathrm{M}_{\mathrm{i}}$, the change in the mass of a species in the JBR over a test period, was calculated with the following equation: 
Appendix I: Development of Mass Balance Equations \& Example Calculations

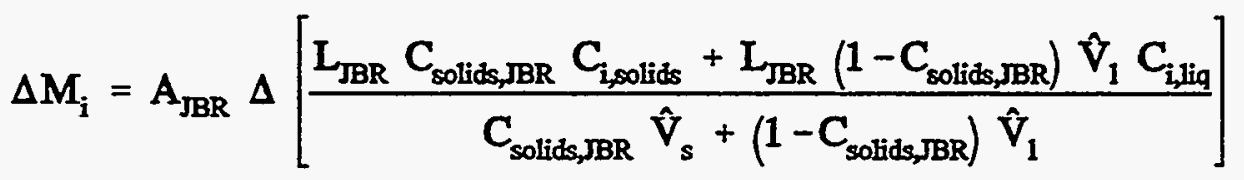

The exact equation used in calculating the data presented in Table 6-2 of Section 6 was obtained by substituting Equation I-12 into Equation I-10 and rewriting in closure format. This equation is located in Table I-1. Densities used in making the above calculations are as follows: JBR solids (gypsum), $2.32 \mathrm{~g} / \mathrm{cc}$; limestone solids $\left(\mathrm{CaCO}_{3}\right), 2.72 \mathrm{~g} / \mathrm{cc} ; \mathrm{JBR}$ and limestone liquid phase, $1.00 \mathrm{~g} / \mathrm{cc}$.

\section{Total Plant}

Equation I-1, applied to the combined power generation/emission control system is:

$$
\begin{aligned}
& \underset{\text { in Each Vessel }}{\sum_{\text {Accumulation }}}=\underset{\text { Air }}{\text { Comb. }}+\underset{\text { Coal }}{\text { Feed }}+\underset{\text { Water }}{\text { Return }}+\underset{\text { Water }}{\text { Makeup }}+\underset{\text { Air }}{\text { Oxidated }}+\underset{\text { Slurry }}{\text { Limestone }} \\
& -\left(\begin{array}{c}
\text { Stack } \\
\text { Gas }
\end{array}+\underset{\text { Slurry }}{\text { Blowdown }}+\underset{\text { Fly Ash }}{\text { ESP Collected }}+\underset{\text { Ash }}{\text { Aottom }}\right)
\end{aligned}
$$

Since most trace metal species will be removed with the bottom and fly ash, the accumulation term in the JBR will be relatively small in the total plant balance. Accumulations in other vessels have been neglected in previous equations and are also neglected in Equation I-13. Trace metals concentrations in the combustion and oxidation air streams are very low and assumed negligible. Expressed mathematically for a trace species, Equation I-13 becomes:

$$
\begin{aligned}
& \frac{\Delta M_{i, \text { DRR }}}{\Delta t}=F_{\text {coal }} C_{i, \text { coal }}+F_{\text {retum }} C_{i, r \text { teum }}+F_{\text {makeup }} C_{i, \text { makedp }} \\
& +\left[\mathrm{F}_{\mathrm{LS}} \mathrm{C}_{\text {solids,Ls }} \mathrm{C}_{\mathrm{i}, \text { solids,LS}}+\mathrm{F}_{\mathrm{LS}} \mathrm{C}_{\mathrm{liq}, \mathrm{LS}} \mathrm{C}_{\mathrm{i}, \mathrm{i} \text { iqLS }}\right] \\
& \text { - }\left[\mathbf{Q}_{\text {stackges }} \mathbf{C}_{\text {stackgas }}+\mathbf{F}_{\text {bdwn }} C_{\text {solids, bdwn }} C_{i, s o l i d s, b d w n}\right] \\
& \text { - [F } \mathrm{F}_{\mathrm{bdwn}} \mathrm{C}_{\mathrm{liq}, \mathrm{bdwn}} \mathrm{C}_{\mathrm{i}, \mathrm{liq}, \mathrm{bdwn}]} \\
& \text { - [ } \left.F_{\text {collectedash }} C_{i, \text { collectedesh }}+F_{\text {bottomash }} C_{i, b o t t o m a s h}\right]
\end{aligned}
$$

The exact equation used in calculating the data presented in Table 6-2 of Section 6 was obtained by substituting Equations I-4 and I-7 into Equation I-14 and rewriting in closure format. This equation is located in Table I-1. 


\section{Example Calculations}

\section{Emission Factor}

The unit-energy-based emission factors were determined by dividing the mass flow rate of a substance being emitted by the heat input to the boiler during testing. Mathematically, Equation 6-3 of Section 6 can be expressed as:

$$
\text { Emission Factor for Species } i=\frac{Q_{\text {stackgas }}\left(C_{i, s t a c k g a s, s}+C_{i, s t a c k g a s, v}\right)}{H_{c o a l} F_{\text {coal }}\left(1-C_{w, \text { coal }}\right)}
$$

Lead will be used for the following example calculation. The following data were taken from tables in Sections 3 and 5.

$$
\begin{aligned}
& Q_{\text {suck gas }}=456,000 \mathrm{Nm}^{3} / \mathrm{hr} \\
& C_{i, \text { stackgas,s }}=0.50 \mu \mathrm{g} / \mathrm{Nm}^{3} \\
& C_{i, \text { stackgas,v }}=<0.22 \mu \mathrm{g} / \mathrm{Nm}^{3} ; \text { for calculations, use } 0.11 \mu \mathrm{g} / \mathrm{Nm}^{3} \\
& \mathrm{H}_{\text {caal }}=12,700 \mathrm{Btu} / \mathrm{lb} \\
& \mathrm{F}_{\text {coal }}=91,000 \mathrm{lb} / \mathrm{hr} \text { (coal rejects subtracted) } \\
& C_{\mathrm{w}, \text { coal }}=0.117 \mathrm{lb} \text { water } / \mathrm{lb} \text { coal }
\end{aligned}
$$

The emission factor for lead is calculated directly from Equation I-15.

$$
\text { Emission Factor, } \mathrm{Pb}=2202.6 * \frac{456,000(0.50+0.11)}{12,700 * 91,000(1-0.117)}=0.6 \frac{\mathrm{lb}}{10^{12} \mathrm{Btu}}
$$

\section{Mass Balance}

An example calculation for each of the mass balance equations presented in Table I- 1 follows:

In this appendix, aluminum mass balance sample calculations are shown using equations and data from the report. The four sample calculations include boiler closure, ESP closure, JBR closure, and total plant closure. 
Appendix l: Development of Mass Balance Equations \& Example Calculations

Boiler Closure. The data required and the location of the data found in the report are shown below:

$$
\begin{aligned}
& C_{i, \text { cosl }}=1.45 \times 10^{7} \mu \mathrm{g} / \mathrm{kg} \\
& F_{\text {cos }}=4.13 \times 10^{4} \mathrm{~kg} / \mathrm{hr}\left(9.1 \times 10^{4} \mathrm{lb} / \mathrm{hr}\right) \\
& \mathrm{C}_{\mathrm{w}, \text { cool }}=0.117 \mathrm{~kg} / \mathrm{kg} \\
& \mathrm{C}_{\text {ash,coal }}=0.111 \mathrm{~kg} / \mathrm{kg} \\
& Q_{\text {espin }}=2.84 \times 10^{5} \mathrm{dscfm}\left(4.5 \times 10^{5} \mathrm{Nm}^{3} / \mathrm{hr}\right) \\
& \mathrm{C}_{\text {ash,espin }}=3.64 \mathrm{gr} / \mathrm{dscf}\left(0.00896 \mathrm{~kg} / \mathrm{Nm}^{3}\right) \\
& \mathrm{C}_{\mathrm{i} \text {,bottomash }}=7.61 \times 10^{7} \mu \mathrm{g} / \mathrm{kg} \\
& \mathrm{C}_{\mathrm{i}, \text { espin, } \mathrm{s}}=8.7 \times 10^{5} \mu \mathrm{g} / \mathrm{Nm}^{3} \\
& \mathrm{C}_{\mathrm{i}, \text { espin,v }}=146 \mu \mathrm{g} / \mathrm{Nm}^{3}
\end{aligned}
$$

The material balance around the boiler is represented by the following equation:

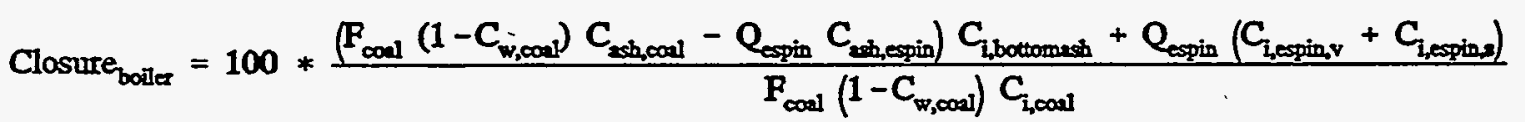

Substitution of the values listed above results in the following boiler closure for aluminum:

Closure $_{\text {boiler }}=74 \%$

ESP Closure. The data used in calculating the material balance closure around the ESP are shown as follows:

$$
\begin{aligned}
& Q_{\text {espin }}=2.84 \times 10^{5} \mathrm{dscfm}\left(4.5 \times 10^{5} \mathrm{Nm}^{3} / \mathrm{hr}\right) \\
& C_{i, \text { espin,s }}=8.7 \times 10^{5} \mu \mathrm{g} / \mathrm{Nm}^{3} \\
& C_{i, \text { espin, }}=146 \mu \mathrm{g} / \mathrm{Nm}^{3} \\
& Q_{\text {espout }}=Q_{\text {espin }}\left(4.5 \times 10^{5} \mathrm{Nm}^{3} / \mathrm{hr}\right) \\
& C_{i, \text { spout }, \mathrm{s}}=1.21 \times 10^{4} \mu \mathrm{g} / \mathrm{Nm}^{3} \\
& C_{i, \text { espout }, v}=57.5 \mu \mathrm{g} / \mathrm{Nm}^{3}
\end{aligned}
$$


Appendix l: Development of Mass Balance Equations \& Example Calculations

$$
\begin{aligned}
& C_{\text {ash,espin }}=3.64 \mathrm{gr} / \mathrm{dscf}\left(8.96 \times 10^{-3} \mathrm{~kg} / \mathrm{Nm}^{3}\right) \\
& C_{\text {est,espout }}=0.0577 \mathrm{gr} / \mathrm{dscf}\left(1.42 \times 10^{-4} \mathrm{~kg} / \mathrm{Nm}^{3}\right) \\
& C_{i, \text { collectedash }}=9.8 \times 10^{7} \mu \mathrm{g} / \mathrm{kg}
\end{aligned}
$$

The material balance closure equation for the ESP is represented by the following equation:

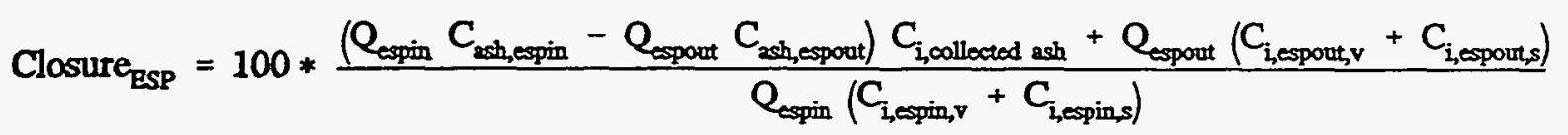

After substitution of the data presented above into this equation, the material balance closure for aluminum around the ESP is calculated to be:

Closure $_{\text {exp }}=101 \%$

JBR Closure. Unlike the other unit operations considered at Plant Yates, the accumulation term for the JBR could be important in the material balance calculations. This is because the residence time of the slurry in the JBR is much greater than any of the sampling times. The first step shown is the calculation for one of the runs in Test Period 1. An average accumulation rate was calculated for each test period; the average of these was then used in the mass balance calculations.

Data required to calculate accumulation are as follows:

$$
\begin{aligned}
& C_{i, \mathrm{iq}, \mathrm{SBR}}=10.7 \mathrm{mg} / \mathrm{L}\left(1.07 \times 10^{7} \mu \mathrm{g} / \mathrm{m}^{3}\right) \\
& \mathrm{A}_{\mathrm{JBR}}=127 \mathrm{~m}^{2} \\
& \Delta \mathrm{t}=8 \mathrm{hr} \\
& C_{i, \text { solids, , BRR }}=1.03 \times 10^{6} \mu \mathrm{g} / \mathrm{kg} \\
& \mathrm{L}_{\mathrm{JBR}, \mathrm{t}-\Delta \mathrm{t}}=4.29 \mathrm{~m} \\
& \mathrm{~V}_{\mathrm{s}, \mathrm{JBR}}=0.000431 \mathrm{~m}^{3} / \mathrm{kg}(\mathrm{Sp} . \mathrm{Gr} .=2.32) \\
& \mathrm{V}_{\mathrm{LJBR}}=0.001 \mathrm{~m}^{3} / \mathrm{kg}(\mathrm{Sp} . \mathrm{Gr} .=1.0) \\
& \mathrm{C}_{\text {solids, }, \mathrm{BR}, \mathrm{L}-\mathrm{At}}=0.222 \mathrm{~kg} / \mathrm{kg} \\
& \mathrm{C}_{\text {solids, } \mathrm{BRR}, \mathrm{L}}=0.223 \mathrm{~kg} / \mathrm{kg} \\
& \mathrm{L}_{\mathrm{JBR}, \mathrm{l}}=4.3 \mathrm{~m}
\end{aligned}
$$

(App. H, Run 1) (Average in Table 6-1) (App. I, p. 6) (Average \% solids in Table 6-1) (Average \% solids in Table 6-1) (Average level in Table 6-1) 
Appendix l: Development of Mass Balance Equations \& Example Calculations

The accumulation term $\left(\Delta \mathrm{m}_{\mathrm{i}} / \Delta \mathrm{t}\right)$ is represented by the following equations. The change in mass of aluminum contained in the JBR during the run is calculated:

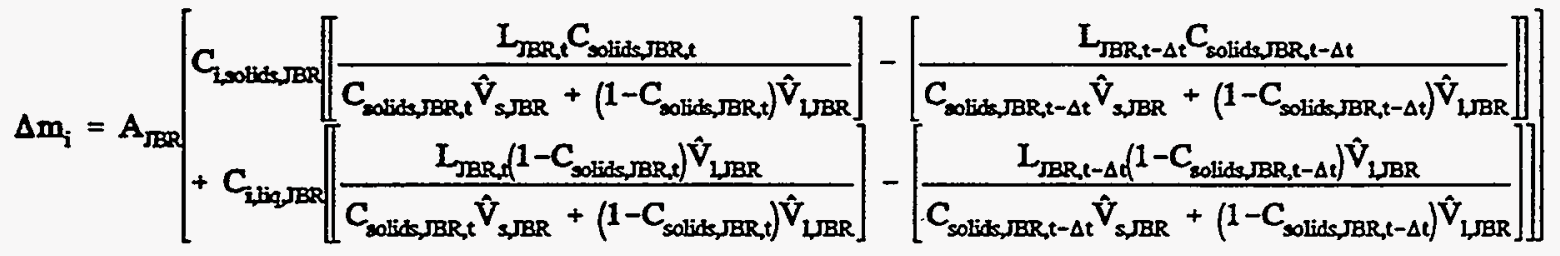

The accumulation of aluminum in the JBR during Run 1 is the change in mass divided by the length of the run and is calculated to be:

$$
\text { acc }=\Delta \mathrm{m}_{\mathrm{i}} / \Delta \mathrm{t} \quad \mathrm{acc}=1.37 \times 10^{8} \mu \mathrm{g} / \mathrm{hr}
$$

In a similar manner, the accumulations in Runs 2 and 3 were calculated and when combined with the accumulation from Run 1 , an average accumulation of $1.42 \times 10^{8} \mu \mathrm{g} / \mathrm{hr}$ was calculated. This average accumulation is used with the following data to calculate mass balance closure around the JBR:

$$
\begin{aligned}
& \operatorname{acc}_{\text {xvg }}=1.42 \times 10^{8} \mu \mathrm{g} / \mathrm{hr} \\
& Q_{\text {espout }}=2.84 \times 10^{5} \mathrm{dscfm}\left(4.5 \times 10^{5} \mathrm{Nm}^{3} / \mathrm{hr}\right) \\
& C_{i, \text { copout, }}=1.21 \times 10^{4} \mu \mathrm{g} / \mathrm{Nm}^{3} \\
& C_{i, \text { espout, }}=57.5 \mu \mathrm{g} / \mathrm{Nm}^{3} \\
& F_{\text {makeup,FT150A }}=26.8 \mathrm{gal} / \mathrm{min}\left(6.09 \mathrm{~m}^{3} / \mathrm{hr}\right) \\
& C_{i, \text { mukeup }}=0.176 \mathrm{mg} / \mathrm{L}\left(1.76 \times 10^{5} \mu \mathrm{g} / \mathrm{m}^{3}\right) \\
& F_{\text {return,FT128 }}=78.9 \mathrm{gal} / \mathrm{min}\left(17.9 \mathrm{~m}^{3} / \mathrm{hr}\right)
\end{aligned}
$$$$
F_{\text {retur, FT142 }}=39.9 \mathrm{gal} / \mathrm{min}(9.06 \mathrm{~m} / \mathrm{hr})
$$$$
F_{\text {return,FT150B }}=6.39 \mathrm{gal} / \mathrm{min}\left(1.45 \mathrm{~m}^{3} / \mathrm{hr}\right)
$$$$
\mathrm{C}_{\mathrm{i}, \text { returm }}=2.04 \mathrm{mg} / \mathrm{L}\left(2.04 \times 10^{6} \mu \mathrm{g} / \mathrm{m}^{3}\right)
$$$$
\mathrm{F}_{\mathrm{ls}}=36.5 \mathrm{gal} / \mathrm{min}\left(8.29 \mathrm{~m}^{3} / \mathrm{hr}\right)
$$

(Mat'l bal. average in Table 6-1 Mist Elim/Deck Wash [Ash Pond Return])

(Table 5-10) Transition Duct PW Flow [Gypsum Pond Return]) (Mat'l bal. average in Table 6-1) (Mat'l bal. average in Table 6-1) (Table 5-10) (Mat'l bal. average in Table 6-1 Reagent Flow) 
$\mathrm{C}_{\text {solids, }, \mathrm{s}}=0.361 \mathrm{~kg} / \mathrm{kg}$

$\mathrm{C}_{\mathrm{i}, \mathrm{liq}, \mathrm{ls}}=6.78 \times 10^{-2} \mathrm{mg} / \mathrm{L}\left(6.78 \times 10^{4} \mu \mathrm{g} / \mathrm{m}^{3}\right)$

$\mathrm{F}_{\mathrm{bdwn}, \mathrm{FT} 162 \mathrm{~A}}=78.4 \mathrm{gal} / \mathrm{min}\left(17.8 \mathrm{~m}^{3} / \mathrm{hr}\right)$

$C_{\text {solds,bdwn }}=0.229 \mathrm{~kg} / \mathrm{kg}$

$C_{i, \text { solids,bdwn }}=1.1 \times 10^{3} \mu \mathrm{g} / \mathrm{gm}\left(1.1 \times 10^{6} \mu \mathrm{g} / \mathrm{kg}\right)$

$\mathrm{V}_{\mathrm{s}, \mathrm{ls}}=0.000367 \mathrm{~m}^{3} / \mathrm{kg}$

$\mathrm{V}_{\mathrm{L}, \mathrm{L}}=0.001 \mathrm{~m}^{3} / \mathrm{kg}$

$\mathrm{V}_{\mathrm{s}, \mathrm{bdwn}}=0.00431 \mathrm{~m}^{3} / \mathrm{kg}(\mathrm{Sp}$. Gr. $=2.32)$

$\mathrm{V}_{\mathrm{L} \text { bdwn }}=0.001 \mathrm{~m}^{3} / \mathrm{kg}(\mathrm{Sp} . \mathrm{Gr} .=1.0)$

$\mathrm{C}_{\mathrm{i}, \text { solids,ls }}=756 \mu \mathrm{g} / \mathrm{gm}\left(7.56 \times 10^{5} \mu \mathrm{g} / \mathrm{kg}\right)$

$\mathrm{C}_{\mathrm{i}, \mathrm{iq}, \mathrm{bdwm}}=12.3 \mathrm{mg} / \mathrm{L}\left(1.23 \times 10^{7} \mu \mathrm{g} / \mathrm{m}^{3}\right)$

$\mathrm{Q}_{\text {sucackges }}=2.88 \times 10^{5} \mathrm{dscfm}\left(4.56 \times 10^{5} \mathrm{Nm}^{3} / \mathrm{hr}\right)$

$\mathrm{C}_{\mathrm{i}, \text { steckgas,s }}=191 \mu \mathrm{g} / \mathrm{Nm}^{3}$

$\mathrm{C}_{\mathrm{i}, \text { steckgas, },}=4.35 \mu \mathrm{g} / \mathrm{Nm}^{3}$
(Mat'l bal. average in Table 6-1)

(App. H, Run 3d substituted for Run 3)

(JBR blowdown in Table 6-1) (JBR density, mat'l bal. average in Table 6-1)

(Table 5-9) (App. I, p. 6) (App. I, p. 6) (App. I, p. 6) (App. I, p. 6) (Table 5-9)

With these input values, the terms $\mathrm{I}_{\mathrm{SBR}}$ and $\mathrm{O}_{\mathrm{JBR}}$ can be calculated as shown below:

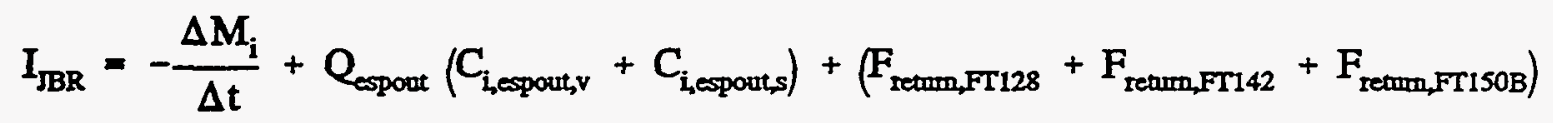

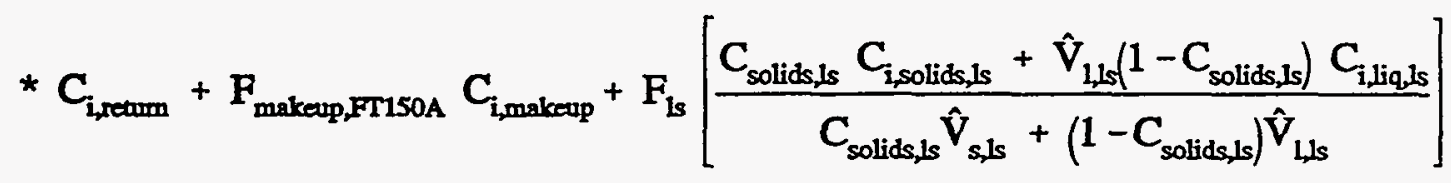

$$
\begin{aligned}
& \mathrm{I}_{\mathrm{BR}}=8.32 \times 10^{9} \mu \mathrm{g} / \mathrm{hr}
\end{aligned}
$$


Appendix I: Development of Mass Balance Equations \& Example Calculations

$$
\begin{aligned}
O_{\mathrm{JBR}} & =F_{\text {bdwn FT162A }}\left[\frac{C_{\text {solids,bdwn }} C_{i, \text { solids,bdwn }}+\hat{V}_{1, b d w n}\left(1-C_{\text {solids,bdwn }}\right) C_{i, l i q, b d w n}}{C_{\text {solids,bdwn }} \hat{V}_{s, b d w n}+\left(1-C_{\text {solids }}\right) \hat{V}_{1, b d w n}}\right] \\
& +Q_{\text {stackgas }}\left(C_{i, \text { stackgas, }, v}+C_{i, s t a c k g a s, s}\right) \\
O_{\mathrm{JBR}} & =5.44 \times 10^{9} \mu \mathrm{g} / \mathrm{hr}
\end{aligned}
$$

Mass balance closure for aluminum around the JBR is calculated to be:

Closure $_{\mathrm{JBR}}=100 * \mathrm{O}_{\mathrm{JBR}} / \mathrm{I}_{\mathrm{JBR}}=65 \%$

Note that the accumulation of aluminum in the JBR $\left(1.42 \times 10^{8} \mu \mathrm{g} / \mathrm{hr}\right)$ is small relative to the throughput (outlet equals $5.5 \times 10^{9} \mu \mathrm{g} / \mathrm{hr}$ ). However, the accumulation calculations are based on a single concentration and only reflect changes in the JBR density and level.

Total Plant Closure. All of the data required for the total plant calculations have been specified in previous calculations. The total flow of aluminum into the plant (minus JBR accumulation) is calculated according to the following equation:

$$
\begin{aligned}
& I_{\text {plant }}=-\frac{\Delta M_{i}}{\Delta t}+F_{\text {coal }}\left(1-C_{w, c o s l}\right) C_{i, c 0 a l}+\left(F_{\text {retum, FT128 }}+F_{\text {retum,FT142 }}+F_{\text {retum, FT150B }}\right) C_{i, \text { retumn }} \\
& +F_{\text {makeup,FT150A }} C_{i, \text { makeur }}+F_{i s}\left[\frac{C_{\text {solids,1s }} C_{i, \text { solids,ls }}+\hat{V}_{1,1 s}\left(1-C_{\text {solids,1s }}\right) C_{i, 1 i q, 1 s}}{C_{\text {solids,ls }} \hat{V}_{s, 1 s}+\left(1-C_{\text {solids, }, 1 s}\right) \hat{V}_{1,1 s}}\right]
\end{aligned}
$$

Substituting values defined above, the mass flow of aluminum into the plant becomes:

$\mathrm{I}_{\mathrm{plent}}=5.32 \times 10^{11} \mu \mathrm{g} / \mathrm{hr}$

The total flow of aluminum exiting the plant is calculated with the following equation:

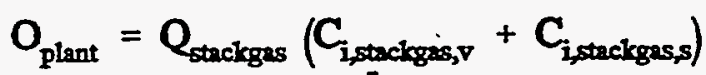

$$
\begin{aligned}
& +F_{\text {bdwn,FT162A }}\left[\frac{C_{\text {solids,bdwn }} C_{i, \text { solids,bdwn }}+\hat{V}_{1, b d w n}\left(1-C_{\text {solids,bdwn }}\right) C_{i, l i q, b d w n}}{C_{\text {solids bdwn }} \hat{V}_{\text {s,bdwn }}+\left(1-C_{\text {solids,bdwn }}\right) \hat{V}_{1, b d w n}}\right] \\
& +\left[F_{\text {coal }}\left(1-C_{w, \text { coal }}\right) C_{\text {ash,coal }}-Q_{\text {espin }} C_{\text {ash,espin }}\right] C_{i, \text { bottomash }} \\
& +\left[Q_{\text {espin }} C_{\text {ash,espin }}-Q_{\text {espout }} C_{\text {ash,espout }}\right] C_{i, \text { collectedash }}
\end{aligned}
$$

Again, values previously given are substituted, which results in the outlet mass flow for aluminum being: 
$\mathrm{O}_{\text {plant }}=3.95 \times 10^{11} \mu \mathrm{g} / \mathrm{hr}$

Using the mass flows inlet and outlet, the overall plant closure for aluminum is calculated:

Closure $_{\text {plant }}=100 * \mathrm{O}_{\text {plant }} / \mathrm{I}_{\text {plant }}=75 \%$

\section{Removal Efficiencies}

An example will be developed for lead removal in the JBR. Equation 6-4 applied to the JBR becomes:

$$
\text { \% Removal }=\left[\frac{1-Q_{\text {stackgas }}\left(C_{i, \text { stackgas,s }}+C_{i, \text { stackgas, } v}\right)}{Q_{\text {espout }}\left(C_{i, \text { espouts }}+C_{i, \text { espout,v }}\right)}\right] * 100
$$

The following data were obtained from tables in Sections 3 and 5.

$$
\begin{aligned}
& \mathrm{Q}_{\text {stackgas }}=456,000 \mathrm{Nm}^{3} / \mathrm{hr} \\
& \mathrm{C}_{\mathrm{i}, \text { stackgas, } \mathrm{s}}=0.50 \mu \mathrm{g} / \mathrm{Nm}^{3} \\
& \mathrm{C}_{\mathrm{i}, \text { stackgas,v }}=<0.22 \mu \mathrm{g} / \mathrm{Nm}^{3} \text {; for calculations use } 0.11 \mu \mathrm{g} / \mathrm{Nm}^{3} \\
& \mathrm{Q}_{\text {ESPout }}=450,000 \mathrm{Nm}^{3} / \mathrm{hr} \\
& \mathrm{C}_{\mathrm{i}, \text { ESPout,s }}=18 \mu \mathrm{g} / \mathrm{Nm}^{3} \\
& \mathrm{C}_{\mathrm{i}, \mathrm{ESPOut}, \mathrm{v}}=0.4 \mu \mathrm{g} / \mathrm{Nm}^{3}
\end{aligned}
$$

The removal efficiency for lead is calculated directly from Equation I-17.

$$
\text { Removal Efficiency of JBR for } \mathrm{Pb}=\left[1-\frac{456,000(0.50+0.11)}{450,000(18+0.4)}\right] * 100=96.7 \%
$$

\section{Nomenclature}
A Cross-sectional area, $\mathrm{m}^{2}$
C Concentration $\mu \mathrm{g} / \mathrm{Nm}^{3}$ (gas), $\mu \mathrm{g} / \mathrm{L}$ (liquid), $\mu \mathrm{g} / \mathrm{kg}$ (solid), or weight fraction (ash or water fraction)
F Coal flow rate, $\mathrm{kg} / \mathrm{hr}$ or water/slurry flow rate, $\mathrm{m}^{3} / \mathrm{hr}$
L Level, $\mathrm{m}$ 
Appendix l: Development of Mass Balance Equations \& Example Calculations

$\begin{array}{ll}\text { Q } & \text { Gas flow rate, } \mathrm{Nm}^{3} / \mathrm{hr} \\ \hat{\mathrm{V}}, \mathrm{V} & \text { Specific volume, } \mathrm{m}^{3} / \mathrm{kg}\end{array}$

Subscripts

bdwn JBR blowdown slurry

bottomash Bottom ash

coal Feed coal

collectedash ESP sluiced ash

espin ESP inlet

espout ESP outlet

FTx As indicated by flow transmitter $\dot{x}$ (flow from data acquisition system)

i Species, i

JBR JBR

1, liq Liquid

1s Limestone slurry

makeup FGD makeup water (ash pond.return)

return Gypsum pond return

s Solid phase

solids Solids

stackgas Stack gas

v Vapor phase

w Water 